\title{
Difusão da Arquitetura Neocolonial no Interior Paulista, 1920-1950
}

\author{
Luciana Pelaes Mascaro
}

Tese apresentada à Escola de Engenharia de São Carlos da Universidade de São Paulo, como parte dos requisitos para obtenção do título de Doutor em Arquitetura e Urbanismo.

Área de Concentração: Tecnologia do Ambiente Construído

Orientadora: Profa. Dra. Maria Ângela Pereira de Castro e Silva Bortolucci

V. 1

São Carlos

2008 
AUTORIZO A REPRODUÇÃO E DIVULGAÇÃO TOTAL OU PARCIAL DESTE TRABALHO, POR QUALQUER MEIO CONVENCIONAL OU ELETRÔNICO, PARA FINS DE ESTUDO E PESQUISA, DESDE QUE CITADA A FONTE.

Ficha catalográfica preparada pela Seção de Tratamento da Informação do Serviço de Biblioteca - EESC/USP

Mascaro, Luciana Pelaes
M395d Difusão da arquitetura neocolonial no interior paulista, 1920-1950 / Luciana Pelaes Mascaro; orientadora Maria Ângela Pereira de Castro e Silva Bortolucci. -- São Carlos, 2008.

Tese (Doutorado-Programa de Pós-Graduação em Arquitetura e Urbanismo e Área de Concentração em Teoria e História da Arquitetura e do Urbanismo) -- Escola de Engenharia de São Carlos da Universidade de São Paulo, 2008 .

1. Arquitetura neo-colonial. 2. Arquitetura paulista. 3. Difusão. 4. Escolas práticas de agricultura.

5. Arquitetura oficial. 6. Arquitetura institucional.

7. Arquitetura residencial. I. Título. 


\section{AGRADECIMENTOS}

Agradecemos aos pesquisadores, professores e profissionais que consultamos, sempre atenciosos nas nossas solicitações, nos facilitando contactos, indicando referências indispensáveis, adicionando informações importantes e fornecendo material de interesse. Aos funcionários da Universidade de São Paulo, da Universidade do Minho, das bibliotecas e arquivos visitados, pelo pronto atendimento e pelos esclarecimentos.

Gostaríamos de lembrar a contribuição de Alessandra F. de Souza, Ana Barbosa, Benigno Gomez, Camila C. Ferreira, Cristina Danko, Daniela Fantoni, Denize Quinsler, Denis W. Esteves, Família Lino, Família Herfer, Família Paolillo, F. Sales Trajano Filho, Gilcilene S. de Paulo, Gláucia E. M. Dotta, Liseane Fontes, Jandira Teixeira, Luzia Novais, Marco A. Pelaes, Marcus V. D. de Queiroz, Maria do Carmo C. Pelaes, Mateus Rosada, Michele Flores, Miguel Costa e Moura, Neide Prato, Régis De Bel, Thais Cruz, Valéria Garcia, Vladimir Benincasa, família e amigos.

Agradecemos, especialmente, à Profa. Dra. Maria Ângela Pereira de Castro e Silva Bortolucci e à Profa. Dra. Júlia Maria Brandão Barbosa Lourenço, pela inestimável orientação e incentivo.

À Coordenação de Aperfeiçoamento de Pessoal de Nível Superior (CAPES), cujo apoio foi imprescindível para tornar possível a realização desse trabalho. À Fundação Calosute Gulbenkian pela disponibilidade de acesso ao seu valioso acervo e apoio financeiro. Ao Santander-Banespa pelo apoio financeiro.

Finalmente, agradecemos a todos os que contribuíram, direta e indiretamente, com o desenvolvimento e finalização deste trabalho. 
Quando uma pessoa treina uma vez, nada acontece. Quando uma pessoa força a si mesma fazer algo centenas ou milhares de vezes, então certamente ela se desenvolverá de maneiras diferentes além da física. Está chovendo? Isso não importa. Estou cansado? Isso não importa também. Neste ponto, vontade não será um problema

(Emil Zátopek)

Deus criou este mundo de maneira a que ele pudesse ser visto; em seguida deu-nos a palavra para que pudéssemos comunicar entre nós, falar do que vemos; mas com todas essas palavras fabricámos histórias, $e$ acabámos por acreditar que a pintura servia para as ilustrar. Ora, na verdade a pintura é antes a procura das memórias de Deus, com a finalidade de se ver o universo tal como Ele o vê.

(Orhan Pamuk)

Uma carta não se exprime apenas pelas palavras escritas. Para ler uma carta, assim como um livro, é preciso também senti-la, tocá-la, manipulála. É por isso que os mais hábeis dizem: «Ora vejamos o que me diz esta carta», e os imbecis contentam-se me dizer: "Vejamos o que está aqui escrito». A arte de saber ler não é só a escrita, mas o que vem com ela. Portanto, escutai o que diz também a carta de Shekuré... 


\section{RESUMO}

As manifestações da arquitetura neocolonial em várias cidades do interior paulista, no período de 1920 a 1950, é o tema central desta tese. Realiza pesquisas e reflexões acerca da ascendência do movimento neocolonial, tomando Ricardo Severo como intelectual que recebeu grande influência do ambiente cultural português. Explora a ocorrência dessa arquitetura na esfera institucional e particular, em obras oficiais, institucionais, religiosas, assistenciais, educativas, recreativas, residenciais $e$ comerciais. Verifica que a difusão se deu, em grande medida, pela atuação de profissionais que estavam em contato com os debates que se desenrolavam na capital paulista e pela implantação de obras emblemáticas em cidades do interior do estado. Verifica também que parte significativa da produção de baixo padrão - ou simplificada - da arquitetura que pretendia expressar a tendência neocolonial foi de responsabilidade de profissionais diplomados. Utiliza o método de levantamento de processos de aprovação de obras, arquivados em prefeituras municipais, levantamento de dados em museus e outras instituições e levantamentos fotográficos para registrar e analisar a produção de interesse. Representa uma contribuição para o conhecimento da arquitetura neocolonial fora da capital paulista.

Palavras-chave: arquitetura neocolonial - arquitetura paulista - difusão - Escolas Práticas de Agricultura - arquitetura oficial - arquitetura institucional - arquitetura residencial 


\begin{abstract}
This thesis investigates expressions of the neo-colonial architecture, in several cities within the State of São Paulo during the period of 1920 to 1950. The research takes into account the intellectual influence of Ricardo Severo in the rise of neo-colonial movement, nevertheless inspired by the Portuguese cultural atmosphere. The diffusion of this architectural style is explored through private exemplars, such as homes, offices and shops along with institutional materializations; public and religious buildings, schools, social welfare bureaus and recreational facilities. The research reveals a link between the hinterland spread of this architecture, empowered by a symbolic drive, and the effort of professionals that were in contact with the intellectual debates taking place at the State capital. By analysing the construction licenses approved by Municipal Halls, we have verified that a significant part of the simplified and low standard production was made under certified professionals' responsibility. In addition, we have expanded the investigation by data collected in museums and other institutions plus photographic surveys to record and analyse this architectonic production. This thesis represents a contribution to the comprehension of the neocolonial architecture outside the city of São Paulo.
\end{abstract}

Key-words: Neo-colonial architecture - São Paulo's Architectureagriculture colleges - public architecture -institutional architecture - residential architecture - spread 


\section{LISTA DE FIGURAS}

\section{CAPÍTULO 1 - ASCENDÊNCIA DO MOVIMENTO TRADICONALISTA NO BRASIL}

Figura 1 - Francisco Martins Sarmento. Cliché de Ricardo Severo tirado na casa da Ponte, em Briteiros, em Junho de 1897.

Figura 2 - Lista de obras que haviam pertencido ao engenheiro Ricardo Severo, incluindo obras do próprio engenheiro.

Figura 3 - Processo para requerimento de licença para construção. Casa do engenheiro Ricardo Severo, localizada à Rua do Conde (atual Rua Ricardo Severo), Porto, Portugal, 1902.

Figura 4 - Fotos da casa do engenheiro Ricardo Severo tiradas por ele, provavelmente, logo que a construção ficou pronta, pois foram publicadas na versão revisada do artigo de Rocha Peixoto "A Casa Portugueza”

Figura 5 - Fotos da arquitetura portuguesa vernacular, tiradas por Rocha Peixoto, por volta de 1905, e publicadas no seu mesmo artigo "A Casa Portugueza" onde foram publicadas as fotos da casa de Severo.

Figura 6 - Aspecto geral da cidade do Porto, com suas tradicionais construções "em banda" (geminadas).

Figura 7a-Cartaz do Museu de Fafe mostrando as casas dos "brasileiros".

Figura 7b - Exemplo de uma casa de "brasileiro" construída em Fafe em 1882. Notar os azulejos aplicados na fachada e a influência da arquitetura eclética

Figura 8 - Prancha 42 de Jean-Baptiste Debret mostrando a planta de uma casa colonial. Notar a semelhança com a planta da casa de Severo no Porto.

Figura 9 - Projeto do Escriptório Technico "Ramos de Azevedo” Severo \& Villares para o hospital a Sociedade Portugueza de Beneficência de Santos, de 1936.

Figura 10a - Em muitos casos os Solares Portugueses dos séculos XVII e XVIII são exemplos da aplicação da arquitetura barroca na arquitetura civil. São possíveis referências para a arquitetura de Ricardo Severo. Notar os pináculos no telhado e os beirais de telha capa e canal. Exemplar "Casas Novas", localizado em Baião, Santa Maria do Zêzere.

Figura 10b - Neste exemplar vemos a simetria da fachada, os pináculos e o frontão, muito comuns em edifícios neocoloniais. "Casa dos Calainhos", localizada em Valpaços, Fornos do Pinhal.

Figura 10c - Exemplar que tem as arcadas como elemento marcante, além dos telhados em ponta, muito usados pelo arquiteto Raul Lino e também encontrados na difusão dos movimentos tradicionalistas. "Casa da Bacalhoa", Setúbal, Azeitão.

Figura 10d - Notar as arcadas e a aplicação de azulejos no "Palácio dos Marqueses de Fronteira", em Lisboa.

Figura 10e - Frontão, pináculos, beirais entre outras características na "Casa de Campo de Besteiros", Tondela, Campo de Besteiros. 
Figura 11 - Casa "Monsalvat", do arquiteto Raul Lino, construída em Monte Estoril para o pianista Alexandre Rey Colaço, em 1901. Beirais, arcos e azulejos em associação com elementos da arquitetura árabe.

Figura 12 - Casa do Conde Armand, do arquiteto Raul Lino, construída na Quinta da Comenda, Setúbal, no início do século XX. A integração na paisagem é uma forte característica dessa edificação e é uma das quais Lino vai priorizar durante toda sua carreira. Arcadas e terraço à moda árabe também são recorrentes nas obras do arquiteto.

Figura 13 - Duas edificações na cidade de Évora. Notar como algumas das características se repetem na arquitetura de Raul Lino e outras, anônimas.

Figura 14 - Vista do Palácio Nacional de Sintra na paisagem, com suas grandes chaminés, e entrada do palácio, com arcos ogivais e traços da arquitetura manuelina. Notar a semelhança com a arquitetura de Évora e com a produzida por Raul Lino.

Figura 15 - Entrada e vista do pátio interno da "Casa do Cipreste". Notar semelhança do frontão da entrada com o da "Casa de Campos de Besteiros" (Figura 10a) e das aberturas triangulares, como na edificação em Évora (Figura 13).

Figura 16 - Casa do Sr. Albino Caetano da Silva, cujo projeto, de Raul Lino, foi publicado em 1909. Construída em Coimbra. Mesmo numa fachada estreita, vemos os traços da arquitetura tradicionalista.

\section{CAPÍTULO 2 - UM PARALELO: DIFUSÃO EM PORTUGAL}

Figura 17a - Plano Diretor da Costa do Sol. Alfred Agache, 1936.

Figura 17b - Plano de Remodelação do Estoril. Alfred Agache, 1936.

Figura 18a - Plano de Urbanização da Costa do Sol, Cascais. Etienne de Gröer, 1948.

Figura 18b - Plano de Urbanização de Lisboa, Cascais. Etienne de Gröer, 1948

Figura 19a - Fachada da edificação ganhadora do Prêmio Valmor de 1910, do arquiteto Ernesto Korrodi. Frontão e beirais que remetem à arquitetura barroca civil dos solares portugueses.

Figura 19b - Processo para requerimento de licença para construção da casa projetada por Ernesto Korrodi (Figura 20a).

Figura 20 - Vista da edificação projetada pelo arquiteto Álvaro Machado e ganhadora do Prêmio Valmor de 1914. Notar as várias características da arquitetura tradicionalista, especialmente, da janela de canto, envidraçada.

Figura 21 - Vista da casa projetada por Raul Lino e ganhadora do Prêmio Valmor em 1930. Notar a abundante decoração que remete à arquitetura barroca.

Figura 22 - Processo para requerimento de licença para construção da casa projetada pelo arquiteto Tertuliano de Lacerda Marques, em 1930, em Lisboa, à Avenida Columbano Bordalo Pinheiro, 50.

Figura 23a - Vista da obra que recebeu o Prêmio Valmor em 1939. Os arquitetos foram os irmãos Carlos e Guilherme Rebelo de Andrade, inspirados na arquitetura da época de $D$. João $V$. 
Figura 23b - Processo para requerimento de licença para construção da casa projetada pelos irmãos Rebelo de Andrade e vencedora do Prêmio Valmor de 1939.

Figura 24 - Vista da obra de Carlos Chambers Ramos, vencedora do Prêmio Valmor de 1946. A fachada foi alterada para receber a Embaixada da Argélia.

Figura 25 - Processo para requerimento de licença para reforma de uma casa no Porto, em 1921, cujo projeto é de Carlos Chambers Ramos. Mantém a mesma estética da casa portuguesa.

Figura 26a - Placa informativa do histórico do atual Pavilhão Carlos Lopes - originalmente Palácio das Indústrias de Portugal da Exposição Internacional de 1922, RJ reconstruído no Parque Carlos VII, Lisboa. O histórico informa que o projeto é de autoria dos irmãos Carlos e Guilherme Rebelo de Andrade.

Figura 26b - Vista do Palácio das Indústrias de Portugal na Exposição Internacional do Rio de Janeiro em 1922. Notar a mesma inspiração dos irmãos arquitetos para a concepção do pavilhão na arquitetura da época de $D$. João $V$.

Figura 27 - Aspecto recente do Pavilhão Carlos Lopes - originalmente Palácio das Indústrias de Portugal da Exposição Internacional de 1922, RJ. Notar a decoração, os painéis de azulejo e o estado geral da obra, que denota o abandono. Não consta como imóvel protegido pelo Instituto Português do Património Arquitectónico (IPPAR). Na Direcção Geral dos Monumentos e Edifícios Nacionais (DGEMN) não havia mais informações disponíveis.

Figura 28 - Capa do Guia Oficial da Exposição Portuguesa em Sevilha, com vista e planta do Pavilhão Português projetado pelos irmãos Rebelo de Andrade.

Figura 29 - Fachada do Colégio Pedro II, em Belo Horizonte. Notar semelhança com o Pavilhão das Indústrias de Portugal da Exposição Internacional do Rio de Janeiro, 1922.

Figura 30 - Projeto do arquiteto Vasco de Moraes Palmeiro (Regaleira) publicado em 1937 na revista Aquitetura. Permanecem traços da arquitetura tradicionalista portuguesa, embora a volumetria e as linhas marcadamente horizontais pertençam à estética modernista.

Figura 31 - Duas edificações, na Avenida de Berna, Lisboa, com características da arquitetura tradicionalista. Possivelmente, tenham existido, nessa avenida, vários outros exemplares de mesma tendência arquitetônica.

Figura 32 - Processo para requerimento de licença para construção da casa projetada pelo arquiteto Sérgio Botelho de Andrade Gomes, em 1949. Mais um exemplo de edificação que mistura elementos da linguagem tradicionalista e modernista.

Figura 33 - Projeto de Raul Lino no Porto, 1930.

Figura 34 - Processo para requerimento de licença para construção de uma casa no Porto, sob a responsabilidade do mestre-de-obras Antonio Rodrigues de Carvalho. Notar a abundante decoração inspirada na arquitetura tradicionalista.

Figura 35 - Processo de 1922, para requerimento de licença para construção de uma casa no Porto, à antiga Rua do Conde, mesma rua onde está localizada a casa de Ricardo Severo.

Figura 36 - Processo de 1922, para requerimento de licença para construção de uma casa no Porto. Notar semelhança com a arquitetura produzida pelo arquiteto Raul Lino. 
Figura 37 - Processo de 1922, para requerimento de licença para construção de um "pequeno bairro operário", no Porto. Segue a estética da casa portuguesa.

Figura 38 - Um dos dois processos de 1929, para requerimento de licença para construção de uma residência no Porto, de autoria do arquiteto Serafim Martins de Sousa.

Figura 39 - Processo de 1938, para requerimento de licença para construção de uma residência no Porto, de autoria do arquiteto Manuel Marques. Floreiras, beirais, frontões entre outras características da arquitetura tradicionalista.

Figura 40 - Vistas de residências em Parede e no Estoril, mostrando grande diversidade na utilização dos elementos que marcam a arquitetura tradicionalista portuguesas das primeiras décadas do século XX. A primeira figura se assemelha muito a alguns exemplares da arquitetura neocolonial; a segunda, certamente, foi é um chalet "re-aportuguesado"; as últimas apresentam características que remetem à arquitetura barroca e àquela produzida por Raul Lino.

Figura 41 - Processo de 1930, para requerimento de licença para reforma de um chalet, cujo projeto é do arquiteto Tertuliano de Lacerda Marques. Transformou os beirais para deixá-los "à antiga", como registrado no memorial descritivo.

Figura 42 - Projeto do arquiteto Tertuliano de Lacerda Marques para uma residência em Cascais, publicado numa revista de arquitetura em 1928.

Figura 43 - Parecer da Comissão de Estética de Cascais, sugerindo modificações a fim de tornar a edificação mais de acordo com os preceitos da arquitetura tradicionalista portuguesa, e assinado pelo arquiteto Tertuliano de Lacerda Marques: "substituição da varando ou sacada de forma a dar-lhe o caráter português (...). Com estas modificações, julga esta Comissão melhorar o aspecto artístico não só com economia para o proprietário, mas ainda com vantagem estética".

CAPÍTULO 3 - Este capítulo não contém figuras.

\section{CAPÍTULO 4 - ARQUITETURA NEOCOLONIAL PAULISTA: IMAGEM OFICIAL}

Figura 44 - Fotografia do agrônomo Fernando Costa. Fonte: Álbum Comemorativo do TriCentenário de Taubaté (1945).

Figura 45 - Escultura do personagem Jeca Tatu, de Monteiro Lobato. Situada em Taubaté, em frente à praça da Estação Ferroviária.

Figura 46 - Vista do prédio principal da Escola Nacional de Agronomia, atual Universidade Federal Rural do Rio de Janeiro.

Figura 47 - Painel de azulejos, encontrado na Escola Nacional de Agronomia, de autoria da artista plástica portuguesa Maria Helena Vieira da Silva (1908-1992).

Figura 48 - Aspecto atual da Escola Agrícola de Barbacena, notar as linhas ecléticas 264

Figura 49 - Imagens dos prédios do Instituto Agronômico do Norte, atual Universidade Federal Rural da Amazônia. Notar que a imagem recente mostra que um dos prédios da escola exibe linhas neocoloniais.

Figura 50 - Exemplos de reportagens de jornais referentes à nomeação de Fernando Costa para Interventor do Estado de São Paulo e à sua política relacionada à educação agrícola 
Figura 51 - Mapa do Estado de São Paulo com a localização das cidades que, segundo o projeto do interventor Fernando Costa, receberiam as Escolas Práticas Agrícolas em 1942

Figura 52 - Fotos da Escola Prática de Agricultura "Paulo de Lima Correia", de Guaratinguetá, tiradas em dezembro de 1949

Figura 53 - Fotos da Escola Prática de Agricultura "Paulo de Lima Correia", antes de sua transformação em Escola de Especialistas de Aeronáutica.

Figura 54 - Vários aspectos da recém construída Escola Prática Agrícola "Dr. Fernando Costa" de, Pirassununga. Podemos ver o portal de acesso, o edifício principal ainda com pouca vegetação em seu entorno, o salão social, casas de professores e funcionários, estábulo e alunos trabalhando em meados de 1940.

Figura 55 - Registros do evento de lançamento da pedra fundamental da Escola Prática de Agricultura "Gustavo Capanema" de Bauru, no dia 19 de abril de 1942, com a presença do interventor Fernando Costa e outras autoridades.

Figura 56 - Prédio do Instituto Biológico, na cidade de São Paulo, de autoria do engenheiro Mario Whately

Figura 57 - Imagem do prédio do Instituto Penal Agrícola “Dr. Javert de Andrade”, de São José do Rio Preto

Figura 58 - Fotografias da formatura da primeira turma da Escola Prática de Agricultura "Gustavo Capanema", de Bauru, em 26 de junho de 1949. Foram encontradas no mesmo antigo álbum sobre a escola.

Figura 59 - Projeto da Diretoria de Obras Públicas, realizado pelo arquiteto Hernani do Val Penteado, em 1939, para a Escola Profissional "Joaquim Ferraz do Amaral”, de Jaú.

Figura 60 - Projeto para a implantação do campus da Universidade Federal Rural do Rio de Janeiro, realizado em 1938, pelo arquiteto Ângelo Murgel

Figura 61 - Exemplos de jardins ingleses, com seu traçado irregular e sinuoso e vista de um recanto de um jardim inglês. Presença do espírito romântico na paisagem pitoresca.....

Figura 62 - Projeto do jardim da Escola Superior de Agricultura Luiz de Queiroz, em Piracicaba, concebido pelo arquiteto paisagista belga Arsenio Puttemans e implantado em 1907. Notar a semelhança com os jardins ingleses

Figura 63 - Barreiras de acesso, necessárias ao atual presídio, desconfiguraram o projeto original do ajardinamento e arruamento definido para a Escola Prática de Agricultura "Gustavo Capanema", de Bauru. Vemos o projeto das barreiras, de 1976, e vistas atuais das mesmas

Figura 64 - Projeto original do ajardinamento e arruamento da Escola Prática de Agricultura "Gustavo Capanema", de Bauru, realizado pelo escritório "Construtora de Jardins São Paulo", na época da construção da escola

Figura 65 - As duas primeiras pranchas são do projeto de Hernani do Val Pentedao para o primeiro andar do prédio de "escola e administração" da Escola Prática de Agricultura "Gustavo Capanema”, de Bauru. As demais pranchas são de levantamentos posteriores feito pelo Instituto Penal Agrícola e de outros equipamentos da época da Escola. 
Figura 66 - Foto aérea do atual Instituto Penal Agrícola "Prof. Noé de Azevedo", de Bauru. Também vemos claramente as barreiras impostas ao projeto original de ajardinamento da antiga Escola Prática de Agricultura "Gustavo Capanema".

Figura 67 - Imagens da construção da Escola Prática de Agricultura “Gustavo Capanema”, de Bauru, em 1944. Podemos ver alguns dos materiais e técnicas de construção empregados.

Figura 68 - Alojamento para operários da construção da Escola Prática de Agricultura

"Gustavo Capanema" e paiol, ambos em madeira

Figura 69 - Portão de entrada da Escola Prática de Agricultura "Gustavo Capanema", Bauru. Mesmo projeto que para o portão da Escola Prática de Agricultura "Getúlio Vargas", Ribeirão Preto

Figura 70 - Vistas da fachada do prédio principal da Escola Prática de Agricultura "Gustavo Capanema”, Bauru. Semelhança com a Escola Prática de Agricultura "Getúlio Vargas", Ribeirão Preto.

Figura 71 - Fotos do interior da Escola Prática de Agricultura "Gustavo Capanema", Bauru. Podemos ver que alguns móveis originais ainda se conservam no local e que as proporções de alguns elementos, como decoração de bandeiras de portas e corrimãos de escada, são exagerados

Figura 72 - Aspectos externos e internos da antiga casa do diretor da Escola Prática de Agricultura "Gustavo Capanema". Muita madeira foi utilizada nos acabamentos internos. Também podemos ver que os vidros das portas são decorados com motivos agrícolas

Figura 73 - Outras casas para funcionários e professores da Escola Prática de Agricultura "Gustavo Capanema", Bauru. Todas exibem traços neocoloniais ....

Figura 74 - Prédios próximos ao prédio principal da Escola Prática de Agricultura

"Gustavo Capanema", atualmente utilizados como presídio, pelo aproveitamento das alas de dormitórios

Figura 75 - Caixa d'água próxima às residências para funcionários e professores da da Escola Prática de Agricultura "Gustavo Capanema”. Mesmo esse edifício não prescindiu de um frentão sobre a porta de acesso

Figura 76 - Prédios destinados a estábulos, matadouros, criadouros de porcos ou bezerros da Escola Prática de Agricultura "Gustavo Capanema”. Notar a presença de estilemas neocoloniais.

Figura 77 - Planta de situação geral da Escola Prática de Agricultura "Getúlio Vargas”, Ribeirão Preto, mostrando ajardinamento e arruamento e planta de situação do prédio principal, do arquiteto Hernani do Val Penteado

Figura 78 - Fotos aéreas da Escola Prática de Agricultura "Getúlio Vargas”, Ribeirão Preto, mostrando o partido do prédio principal e o acesso a um prédio próximo.

Figura 79 - Projeto do portão de entrada da Escola Prática de Agricultura "Getúlio Vargas", Ribeirão Preto, também de autoria de Hernani do Val Penteado, com data de 1943. Notar semelhança com portão da escola de Bauru. Fonte: Arquivo da C.P.O.S.

Figura 80 - Vários projetos para a Escola Prática de Agricultura “Getúlio Vargas”, Ribeirão Preto: projeto para um mirante, para placa de entrada decorada com azulejos, para detalhes de janelas e outros elementos decorativos e para uma das residências de professores. 
Figura 81 - Projeto para o Centro de Educação Física da Escola Prática de Agricultura "Getúlio Vargas", Ribeirão Preto. Notar a simetria da edificação. Projeto de Hernani do Val Penteado

Figura 82 - Fachada e outros aspectos do prédio principal da Escola Prática de Agricultura "Getúlio Vargas", Ribeirão Preto. Como em outros prédios dessa escola e de outras escolas práticas de agricultura, a simetria é característica marcante

Figura 83 - Aspectos atuais do Centro de Educação Física da Escola Prática de Agricultura "Getúlio Vargas", Ribeirão Preto

Figura 84 - Vistas aéreas da Escola Prática de Agricultura "Paulo de Lima Correia", Guaratinguetá. Podemos ver a volumetria do prédio principal em forma de uma cruz com quatro travessas. Vemos também uma situação geral e prédios novos, além, da alameda de entrada, onde, tradicionalmente, a cada ano se coloca um painel comemorativo de azulejos.

Figura 85 - Implantação das casas para os funcionários da Escola Prática de Agricultura "Paulo de Lima Correia", Guaratinguetá, de maneira semelhante às da escola de Bauru

Figura 86 - Fachada do prédio principal da Escola Prática de Agricultura "Paulo de Lima Correia", Guaratinguetá, e de outros prédios construídos na década de 1940, e da capela

Figura 87 - Fotos dos arcos e dos guarda-corpos fechados com meias-luas sobrepostas da Escola Prática de Agricultura "Paulo de Lima Correia", Guaratinguetá

Figura 88 - Vista do prédio construído na Escola de Especialistas de Aeronáutica, antiga Escola Prática de Agricultura "Paulo de Lima Correia", Guaratinguetá, seguindo a tendência neocolonial. Imagens de outros prédios construídos posteriormente.

Figura 89 - Imagens da Escola de Especialistas de Aeronáutica, quando recém instalada nas estruturas da Escola Prática de Agricultura "Paulo de Lima Correia". Frontão de azulejos do prédio principal coberto por pintura......

Figura 90 - Fotos aéreas da Escola Prática de Agricultura "Fernando Costa", Pirassununga, mostrando o arruamento e ajardinamento bem como a implantação do prédio principal. Fonte: Arquivo da USPFZEA. Fotos do lago frontal ao prédio......

Figura 91 - Fotos aéreas do prédio principal da Escola Prática de Agricultura "Fernando Costa", Pirassununga. Vemos a volumetria do prédio, em forma de cruz com várias travessas, como as escolas de Itapetininga e Guaratinguetá.....

Figura 92 - Fotos da construção da caixa d'água da Escola Prática de Agricultura "Fernando Costa", Pirassununga e de algumas residências para funcionários e professores, utilizando a tendência neocolonial.

Figura 93 - Portão de entrada da Escola Prática de Agricultura "Fernando Costa", Pirassununga, com elementos decorativos quadrilobados, e placa de inauguração da escola. Portão construído recentemente para a FZEA, antiga Escola Prática de Agricultura "Fernando Costa", exibindo telhados com beirais e $\operatorname{arcos}$

Figura 94 - Fotos do prédio principal da Escola Prática de Agricultura "Fernando Costa", Pirassununga. Projeto deste exemplar segue a tipologia de um pavimento. Vemos detalhes decorativos em azulejos da fachada, arcadas e telhados. 
Figura 95 - Imagens das alas de dois pavimentos com arcos fechados por meias-luas sobrepostas, muito semelhantes às arcadas de outras Escolas Prática de Agricultura

Figura 96 - Vistas internas do prédio principal da Escola Prática de Agricultura "Fernando Costa", Pirassununga. Vemos os acabamentos em madeira e detalhes do corrimão e dos guarda-corpos de dimensões monumentais

Figura 97 - Casas construídas para funcionários e professores da antiga Escola Prática de Agricultura "Fernando Costa", Pirassununga. Notar o emprego de estilemas neocoloniais

Figura 98 - Vistas do campo de futebol com a arquibancada protegida da Escola Prática de Agricultura "Fernando Costa", Pirassununga. Cachorros nos beirais, volutas e janelas quadrilobadas

Figura 99 - Caixa d'água, em seu aspecto atual, e outras edificações não identificadas da Escola Prática de Agricultura "Fernando Costa", Pirassununga. Como os demais prédios da escola, segue a tendência neocolonial

Figura 100 - Atual Edifício "Prof. Dr. João Soares Veiga" da FZEAUSP. Anteriormente, mais um edifício da Escola Prática de Agricultura "Fernando Costa", Pirassununga. Neocolonial

Figura 101 - Várias outras instalações da antiga Escola Prática de Agricultura "Fernando Costa" que, atualmente, servem de estábulo, matadouro, laticínio, laboratórios, fábrica de ração e equideocultura da FZEAUSP

Figura 102 - Foto aérea do Centro de Eventos da Escola Prática de Agricultura "Fernando Costa". Telhados movimentados e volumetria simétrica Fonte: Arquivo da USPFZEA. Outras fotos do exterior e interior do prédio mostram estilemas neocoloniais.

Figura 103 - Painéis de azulejo no frontão de entrada e no marco comemorativo de inauguração da Escola Prática de Agricultura "Fernando Costa", Pirassununga.

Figura 104 - Projeto de levantamento da antiga Escola Prática de Agricultura "Dr. Carlos Botelho", realizado pela C.P.O.S. em fevereiro de 2002 para fins de reforma. Prancha de situação, de plantas e de fachada do prédio principal.

Figura 105 - Acesso ao prédio principal da Escola Prática de Agricultura "Dr. Carlos Botelho". Notar o pequeno canteiro e as vias de forma arredondada

Figura 106 - Fotos das placas comemorativas de inauguração da Escola Prática de Agricultura "Dr. Carlos Botelho", Itapetininga. Fachada, detalhes internos e externos do prédio principal.

Figura 107 - Arcadas das alas de dois pavimentos da antiga Escola Prática de Agricultura "Dr. Carlos Botelho", Itapetininga. Notar a utilização dos guarda-corpos fechados por meias-luas sobrepostas, tal como em outras escolas analisadas. Nessa caso, essas alas parecem não utilizadas atualmente.

Figura 108 - Frontão do prédio principal com painel de azulejos azul e branco mostrando uma cena agrícola, realizado pelo Liceu de Artes e Ofícios.

Figura 109 - Observação na prancha de projeto para a Escola Prática de Agricultura de Bauru, cuja autoria é do Hernani do Val Penteado, informando que o mesmo é 
uma adaptação do projeto dos Engenheiros Mario Whately \& Cia, que acreditamos ser o projeto para a Escola Nacional de Agronomia do Rio de Janeiro.

Figura 110 - Vários projetos para a Diretoria de Obras Públicas para grupos escolares, de autoria de do arquiteto José Maria da Silva Neves, da década de 1930. Todos de linhas modernistas.

Figura 111 - Projeto para o Fórum de Taubaté, de 1944, de autoria do arquiteto Vicente Leme Zammataro. Obra da Diretoria de Obras Públicas

Figura 112 - Imagens atuais do Fórum de Taubaté

Figura 113 - Imagens da Casa da Lavoura de Taubaté na época de sua inauguração e atuais.

Obra da Diretoria de Obras Públicas.

Figura 114 - Projeto da fachada da Escola de Cadetes de Campinas, de autoria de Hernani do Val Penteado. Obra da Diretoria de Obras Públicas.

Figura 115 - Projetos para a torre de vigia e para o portão da Escola de Cadetes de Campinas, este último realizado em 1970, por Hernani do Val Penteado

Figura 116 - Fotos da construção da Escola de Cadetes de Campinas, por volta de 1944.

Figura 117 - Fotos atuais da Escola de Cadetes de Campinas. Vemos a implantação, onde aparece o pátio interno, similar a um claustro, e a fachada que apresenta características neocoloniais.

Figura 118 - Edifício antigo da instituição Escolástica Rosa, em Santos, projetada pelo escritório Ramos de Azevedo, de linhas ecléticas.

Figura 119 - Fotos atuais da escola Escolástica Rosa, em Santos, depois da reforma que atribuiu a ela o aspecto neocolonial. Fonte: fotos V. Benincasa, fevereiro de 2005

Figura 120 - Vistas do interior da capela da escola Escolástica Rosa, em Santos. A capela foi construída durante as reformas. Notar o retábulo neocolonial.

Figura 121 - Projeto para o prédio da administração da Escola de São Manoel, desenvolvido pelo arquiteto Hernani do Val Penteado.

Figura 122 - Projeto do arquiteto Hernani do Val Penteado para sua residência na Praia do Boqueirão, em São Vicente. Ausência de decoração neocolonial, mas manutenção de beirais tradicionalistas

Figura 123 - Projeto do arquiteto Hernani do Val Penteado para Hospital de Guarantã. Também mantém os beirais tradicionalistas.

Figura 124 - Casa da administração da Fazenda Santa Helena, em Pindamonhangaba, de 1960, projetada pelo arquiteto Hernani do Val Penteado. Beirais no telhado e pedras no muro e na chaminé marcam a tendência tradicionalista, mas não se encontram estilemas neocoloniais

Figura 125 - Perspectiva de Hernani do Val Penteado para o prédio da Santa Casa de Jaú, de características já totalmente modernistas.. 


\section{CAPÍTULO 5 - APROPRIAÇÃO, RECRIAÇÃO E DIFUSÃO DA ARQUITETURA NEOCOLONIAL PAULISTA}

Figura 126 - Fotos antigas do Seminário "Frei Galvão", em Guaratinguetá. Notar, no lado direito do prédio, a ausência do muro em curva já existente nos registros fotográficos atuais

Figura 127 - Fotos aéreas do Seminário "Frei Galvão", em Guaratinguetá. Notar a presença de dois claustros laterais à igreja.

Figura 128 - Vistas do lado externo do Seminário "Frei Galvão", em Guaratinguetá. O portão de entrada também ostenta linhas curvas.

Figura 129 - Vistas do lado interno do Seminário "Frei Galvão". Notar, num dos claustros, as arcadas que parecem ter sido fechadas e revestidas com pedras em reforma. No outro claustro, ausência de arcadas e simplicidade da estrutura da cobertura da galeria interna.

Figura 130 - Vista interna da igreja do Seminário "Frei Galvão" que se mostra bastante despojada: os adornos principais são os vitrais e parte do piso, que se conservou original após reforma

Figura 131 - Fotos da época da construção do Seminário "Santo Antonio", de Agudos. Vemos várias fases de construção: primeiro, as alas posteriores; em seguida, os claustros já fechados e as torres da igreja em construção; e, finalmente, o seminário terminado.

Figura 132 - Perspectiva do arquiteto Joaquim Bezerra da Silva para o prédio do Seminário "Santo Antonio", de Agudos. Vemos no projeto que o nome do seminário está equivocado

Figura 133 - Várias fotos da mostrando a construção do Seminário "Santo Antonio", de Agudos, mostrando também um pouco dos materiais de construção utilizados.

Figura 134 - Fotos de 1955, provavelmente, publicadas em 1975 na revista "Vida Franciscana".

Figura 135 - Aspectos do lado externo do Seminário "Santo Antonio", de Agudos. Destaque para o portão de entrada decorado por várias pequenas volutas e pedras aplicadas aos muros. A igreja no eixo de simetria. Vemos também outros aspectos das fachadas anteriores e posteriores.

Figura 136 - Aspectos do lado interno do Seminário "Santo Antonio". Notar as arcadas dos claustros, muito semelhantes às arcadas das Escolas Práticas de Agricultura. Vemos as torres da igreja e os jardins dos claustros com piso de mosaico português. Notar também os corrimãos da escada do salão nobre, de dimensões pouco monumentais, e as portas de ferro trabalhado.

Figura 137 - O interior da igreja do Seminário "Santo Antonio" se apresenta pouco decorado, com janelas de vidros coloridos e piso de mosaico de mármore e granito. Vemos também o órgão construído por um dos freis, na década de 1940

Figura 138 - Aqui vemos os vários painéis de azulejos encontrados no Seminário "Santo Antonio". O painel com cenas da vida do santo a quem o seminário é dedicado, projetado pelo professor do Liceu de Artes e Ofício de São Paulo, A. Oliani e executado por C.Mancini. O painel da fachada da igreja, provavelmente, do mesmo período e, outros painéis, realizados mais recentemente. 
Figura 139 - Igreja de Jesus, em Roma, que teve parte do projeto realizado por Vignola em fins do século XVI e fachada construída por Giacomo della Porta no mesmo período.

Figura 140 - Três arcos comuns na arquitetura neocolonial de toda a América Latina.

Figura 141 - Convento Santo Antonio, localizado no Largo da carioca, no Rio de Janeiro, construído entre 1748 e 1780

Figura 142 - Mosteiro da Luz, São Paulo

Figura 143 - Fotos Convento Nossa Senhora do Amparo, São Sebastião, século XVII

Figura 145 - Antiga capela da paróquia de Santo Antonio em Agudos. Em seu lugar foi construída a atual igreja da paróquia de Santo Antonio.

Figura 146 - Construção de um anexo posterior à atual igreja da paróquia de Santo Antonio....

Figura 147 - Fotos atuais da igreja da paróquia de Santo Antonio, em Agudos. Notar semelhança com a igreja do Seminário "Santo Antonio".

Figura 148 - Fotos antigas da igreja de Nossa Senhora das Graças, de Guaratinguetá.

Figura 149 - Foto aérea da igreja de Nossa Senhora das Graças, de Guaratinguetá, com o claustro lateral e o pátio frontal.

Figura 150 - Interior da igreja de Nossa Senhora das Graças, efusivamente decorada com pinturas, frisos, forro, vitrais, iluminação e retábulo ricos em detalhes.

Figura 151 - Painel pintado por trás da imagem de São Francisco de Assis no pátio frontal da igreja de Nossa Senhora das Graças, Guaratinguetá.

Figura 152 - Algumas imagens do claustro da igreja de Nossa Senhora das Graças.

Figura 153 - Projeto do engenheiro João Maurício Sampaio para a capela do Cemitério dos Passos, de Guaratinguetá

Figura 154 - Fotos da construção e da fachada da capela do Cemitério dos Passos, de Guaratinguetá.

Figura 155 - Levantamento métrico da igreja da Paróquia de Santo António, de São Carlos. Projeto original do engenheiro Durval Duarte, 1943.

Figura 156 - Igreja da Paróquia de Santo António, São Carlos. Notar características da vertente missões da arquitetura neocolonial e a porta principal, em madeira entalhada

Figura 157 - Aspectos internos da igreja da Paróquia de Santo António. Vemos a antiga pintura exposta, os vitrais, a envazadura da porta de arco trilobado e porta em ferro com motivos decorativos.

Figura 158 - Igreja do Rosário, de Santos. Primeira foto de 1926, anterior a sua reforma. Segunda foto, outubro de 1930, ano e mês de sua inauguração.

Figura 159 - Registros da Igreja do Rosário de Santos em seu aspecto atual. 385

Figura 160 - Aspecto interno da Igreja do Rosário de Santos e detalhes dos forros e do piso. 386 
Figura 162 - Interior da igreja do Santuário de Santo Antonio do Valongo, com seus retábulos barrocos, pinturas de estêncil e painel de azulejos azul e branco, de 1940, de autoria do pintor Cândido da Silva Júnior

Figura 163 - Uma imagem da antiga Igreja Matriz de Taubaté.

Figura 164 - Fachada principal e outros detalhes do exterior da Catedral Diocesana de São Francisco das Chagas, de Taubaté.

Figura 165 - Registro fotográfico do interior da Catedral Diocesana de São Francisco das Chagas. Vemos a riqueza da decoração neocolonial neste exemplar.

Figura 166 - Fachada da Sede do Hospital da Beneficência Portuguesa, em Bauru, inaugurado em 1928. Projeto de Ricardo Severo. Notamos elementos vazados no muro e nos corrimãos da escada similares às meias-luas sobrepostas.

Figura 167 - Aspectos externos do prédio da Maternidade Gota de Leite, de Araraquara, cujo projeto é atribuído ao arquiteto José Maia da Silva Neves. Vemos algumas estilemas neocoloniais como os telhados, os guarda-corpos com elementos vazados em forma de meias-luas e as janelas de arcos abatidos.

Figura 168 - Fachada do Hospital da Irmandade Santa Casa de Misericórdia, de Itapetininga. Frontão neocolonial sobre a entrada principal.

Figura 169 - Fachada do Hospital e Maternidade Frei Galvão, de Guaratinguetá, em 1999.

Figura 170 - Imagem do primeiro prédio do Orfanato Santa Verônica, em Taubaté, com sua capela central, inaugurado em 1927. Arquitetura de tendência eclética no final da década de 1920 .

Figura 171 - Fachada do pavilhão "Patronato Cardoso Ribeiro" do Orfanato Santa Verônica, em Taubaté. Inaugurado em 1940 segundo projeto neocolonial realizado pela Companhia Predial de Taubaté.

Figura 172 - Prédio que abriga o Centro Cultural e Histórico de Itapetininga, localizado na Praça Marechal Deodoro da Fonseca, à direita, na esquina. Vemos a volumetria simples, o telhado de quatro águas e o frontão em destaque sobre a entrada principal.

Figura 173 - Exterior do Centro Cultural e Histórico de Itapetininga. Notar os elementos decorativos aplicados à fachada e as paredes revestidas com acabamento de aspecto rústico. Sobre a porta a data de 1878

Figura 174 - Painéis de azulejos com motivos pitorescos aplicados à fachada do Centro Cultural e Histórico de Itapetininga.

Figura 175 - Interior do Centro Cultural e Histórico de Itapetininga, com suas portas e pilares de proporções exageradas e decoração em madeira.

Figura 176 - Projeto do arquiteto Hernani do Val Penteado, de 1949, para um Colégio de Freiras, que se localizaria na Ponta da Praia, em Santos. Provavelmente demolido ou não construído.

Figura 177 - Foto do prédio da Creche Anita Costa, em São Carlos. Destaque para o torreão circular no centro da edificação

Figura 178 - Fonte com três quedas revestida de pedras e com painel de azulejos azul e branco na Creche Anita Costa. 
Figura 179 - Projeto, de 1922, do Escritório Técnico "Sampaio \& Machado" para o edifício do Araraquara College. A aplicação de pedras nos cunhais, na base e nas fachadas, de forma esparsa, mostra a influência da tendência neocolonial.

Figura 180 - A primeira foto é de 1934 e mostra a construção da Piscina Municipal de São Carlos; a segunda mostra as instalações já prontas em 1940; e, a terceira, de 1957, mostra que as características do prédio já estão diferentes da foto anterior, indicando que passou por reforma na qual adquiriu feições neocoloniais.

Figura 181 - Aspecto atual da Piscina Municipal de São Carlos. Telhados com beirais e telhas capa e canal, arcos com paredes laterais alargadas na base, pedras esparsas nas fachadas entre outros estilemas remetam à influência da vertente missões nesse prédio.

Figura 182 - Alguns detalhes do interior do prédio da Piscina Municipal: aberturas em arco, portas de ferro com motivos decorativos, balcão em madeira.

Figura 183 - Detalhes do prédio e da área externa da Piscina Municipal de São Carlos, mostrando volutas, estrutura aparente do telhado, espaços de estar com caramanchão, muros e escadas revestidos com pedras.

Figura 184 - Imagens de 1945 do Taubaté Country Club. Ao fundo vemos um muro de linhas curvas e telhas capa e canal assentadas no topo como decoração. Vemos também parte do prédio com parte do telhado com beiral, janelas redondas e sacada com mísulas.

Figura 185 - Vista da fachada do Tubaté Country Club nos anos de 1940 e foto recente do interior do prédio mostrando arco e decoração com pedras na fachada e colunas salomônicas na janela.

Figura 186 - Foto, provavelmente da década de 1940, mostrando o prédio principal do atual Itaguará Country Clube de Guaratinguetá. As demais fotos mostram o mesmo prédio na década de 1990, antes das últimas obras de restauro.

Figura 187 - Levantamento métrico da planta do prédio principal do Itaguará Country Clube de Guaratinguetá realizado pelos arquitetos Regina Maia Galvão e Renato Guimarães para realização de projeto de restauro, na década de 1990. 410

Figura 188 - Projeto para a Estação e Passageiros do Aeroclube de Rio Claro, de 1948, realizado pelo engenheiro Minton Silveira. O desenho é assinado, mas está ilegível. Talvez se deva ao autor do desenho o aspecto neocolonial da construção.

Figura 189 - Imagens de outras instalações do Aeroclube de Rio Claro

Figura 190 - Vista dos atuais alojamentos do Aeroclube de Rio Claro, provavelmente, utilizados com outro uso nas décadas de 1940 e 1950. Suas linhas neocoloniais sugerem que foram construídas na mesma época em que o foi a Estação de Passgeiros.

Figura 191 - Fachadas do prédio do Clube Ararense, no centro da cidade de Araras. Exibe traços neocoloniais marcantes.

Figura 192 - Mapa de Taubaté publicado no Relatório de Contas da Companhia Predial de Taubaté de 1938 mostrando os prédios construídos pela companhia na cidade até aquele ano.

Figura 193 - A primeira foto mostra a residência de Eleozippo S. Pinto, construída pela Companhia Predial de Taubaté, nessa mesma cidade. A segunda, a residência 
de Alberto Pedrosa, em Caçapava. Notar como a volumetria das edificações se assemelha à volumetria de algumas obras de Ricardo Severo.

Figura 194 - Outra residência construída pela Companhia Predial de Taubaté, mas esta com estilemas neocoloniais misturados aos da vertente missões.

Figura 195 - Várias residências construídas pela Companhia Predial de Taubaté nas cidades da região, durante as décadas de 1930 e 1940, segundo tendências neocoloniais

Figura 196 - Várias residências construídas pela Companhia Predial de Taubaté nas cidades da região, durante as décadas de 1930 e 1940, segundo tendências art déco, eclética e modernista

Figura 197 - Anúncio da Vila Brasil no Jornal "O Comércio do Jaú”, de 25 de dezembro de 1947. Notar as características dos modelos de residências anunciados: neocoloniais e missões.

Figura 198 - Imagem do Cine Boa Vista, na vila da Companhia Fabril de Juta

Figura 199 - Projeto do Grupo Escolar na vila da Companhia Fabril de Juta.

Figura 200 - Residências para os operários da Companhia Fabril de Juta.

Figura 201 - Estátua de um índio Tamoio, situada junto à chaminé, na entrada da Usina Tamoio, em Araraquara.

Figura 202 - Exemplos de painéis de azulejos produzidos durantes as décadas de 1930 e 1940, para a arquitetura neocolonial, retratando motivos indígenas. Fonte do primeiro painel: foto da autora, abril de 2008. Segundo painel, Bica do Bugre, Taubaté.

Figura 203 - Templo de São Pedro, construído na vila operária da Usina Tamoio, Araraquara.

Figura 204 - Fotos do Estádio “Comendador Freitas”, na Usina Tamoio.

Figura 205 - Várias imagens da vila operária da Usina Tamoio, mostrando residências e outros equipamentos.

Figura 206 - Projeto de linhas art déco para uma usina de beneficiar arroz, de autoria do construtor Flávio Santomauro, a ser construído em Rio Claro, em 1943.

Figura 207 - Em Taubaté, a “Casa Miranda”, também de linhas art déco para um estabelecimento comercial e de serviços. Construída pela Companhia Predial de Taubaté em 1935.

Figura 208 - Posto de gasolina neocolonial, da marca “Atlantic” construído em Taubaté. 430

Figura 209 - Projeto de autoria do escritório Sampaio \& Ferraz Ltda para um posto de gasolina neocolonial, também da marca "Atlantic", a ser construído na cidade de Jaú, em 1938.

Figura 210 - Projeto para um posto de gasolina em Rio Claro, de autoria do engenheiro Augusto Schmidt Filho e do desenhista Henrique Cristofani, com data de 1937.

Figura 211 - Projeto, de 1939, para um posto de gasolina em Santa Gertrudes, distrito de Rio Claro, também de autoria do engenheiro Augusto Schmidt Filho. Exibe estilemas de não apenas da tendência neocolonial. 
Figura 212 - Projeto para duas residências e uma fábrica de móveis em São Carlos, de autoria do engenheiro civil Djalma Ferraz Kehl, de 1948, retratando um caso de edificação destinado ao uso industrial e de características neocoloniais.

Figura 213 - Foto atual da fábrica de móveis em São Carlos, de autoria do engenheiro civil Djalma Ferraz Kehl.

Figura 214 - Residência da senhora Nara Herfer, construída na cidade de Catanduva, a Rua Aracajú esquina com a Rua Ceará, em 1946, pelo construtor Elias Nechar. Notar a presença de armário embutido e decoração em madeira no interior da casa.

Figura 215 - Residência inspirada na da senhora Nara Herfer, construída pelo mesmo construtor Elias Nechar, em Catanduva

Figura 216 - Projeto para a residência do senhor Geraldo Paolillo, construída na Vila Nery, São Carlos. Notar as linhas arquitetônicas da vertente missões.

Figura 217 - Foto da residência do senhor Geraldo Paolillo, onde se vê a substituição da torre circular por um ambiente de planta retangular.

Figura 218 - Projeto do arquiteto Ângelo Murgel para a residência do engenheiro Djalma Ferraz Kehl, que data de 1944, situada a Rua São Sebastião, em São Carlos.

Figura 219 - Fotos atuais da residência do engenheiro Djalma Ferraz Kehl, projetada por Ângelo Murgel.

Figura 220 - Projeto, de 1944, do engenheiro Djalma Ferraz Kehl para residência para Alberto Martins, a Rua Marechal Deodoro, em São Carlos. Nesse e nos próximos projetos podemos verificar a influência do arquiteto Ângelo Murgel sobre a produção do engenheiro sãocarlense

Figura 221 - Projeto de reforma da residência de Jorge Angelino, de 1946, pelo engenheiro Djalma Ferraz Kehl, a rua D. Pedro II, em São Carlos. Adição de estilemas neocoloniais.

Figura 222 - Projeto para a residência para Vicente Gagliardi, de 1946, a Rua XV de Novembro, São Carlos, de autoria do engenheiro Djalma Ferraz Kehl. Notar semelhança dessa residência com a própria residência do engenheiro.

Figura 223 - Projeto do engenheiro Djalma Ferraz Kehl, também de 1946, para a residência de Samuel de Oliveira, a Rua 9 de Julho, em São Carlos.

Figura 224 - Mais um projeto de Djalma Ferraz Kehl com características que evidenciam sua adesão à arquitetura neocolonial após a construção de sua própria casa. Trata-se da residência para Luiz Valentie de Oliveira, também a rua 9 de Julho, em São Carlos, que também data de 1946. 448

Figura 225 - Projeto do engenheiro Djalma Ferraz Kehl, de 1940, ou seja, anterior à construção de sua casa, mostrando que o profissional já havia tomado conhecimento da tendência neocolonial, possivelmente, antes de se radicar em São Carlos.

Figura 226 - Algumas fachadas, projetadas pelo engenheiro Augusto Schmidt Filho, em 1947, para um conjunto de sete casas de sua propriedade, situadas em Rio Claro, provavelmente para aluguel.

Figura 227 - Projeto para seis residências, de autoria do engenheiro Rodolpho Fehr para o proprietário Gelsomino Saia, em São Carlos, que data de 1940. Três tem fachadas de tendência art déco e três, de tendência neocolonial, demonstrando 
que as opções eram questão de gosto. São, também, casas para aluguel, provavelmente.

Figura 228 - Projeto para duas casas de padrão médio, de 1938, também de autoria e propriedade do engenheiro Augusto Schmidt Filho, provavelmente para aluguel ou venda, situadas em Rio Claro

Figura 229 - Conjunto de três casas formando uma pequena vila, de autoria do engenheiro Augusto Schmidt Filho, para o proprietário Fernando Guerreiro, a serem construídas em Rio Claro, em 1941. São residências de médio padrão, provavelmente, destinadas à venda ou aluguel.

Figura 230 - Projeto de reforma de autoria do construtor Octávio Daltro, que data de 1950, para a fachada da residência de Eugenio Ruegger, na cidade de Araras. Notar o acréscimo de um frontão que evoca a tendência neocolonial.

Figura 231 - Projeto de reforma de autoria do construtor Flávio Santomauro, de 1943, para uma residência, em Rio Claro, construída ainda no alinhamento da calçada como a maior parte das edificações ecléticas anteriores aos códigos sanitaristas. Na reforma, foram anexados estilemas neocoloniais.

Figura 232 - Projeto de reforma, de 1950, de autoria do engenheiro Abrahão Schevz executado pelo construtor Humberto Sorregotti, em São Carlos. Essa edificação também ganhou frontões e volutas, mostrando mais uma vez que a tendência neocolonial nessas décadas de 1930 e 1940 era bastante usual.

\section{LISTA DE TABELAS}

Tabela 1 - Processos de Aprovação de Obras por Data - Comparação natureza e padrão da obra.

Tabela 2 - Profissionais Encontrados, por Cidade. 


\section{SUMÁRIO}

Volume 1

INTRODUÇÃO $i$

CAPÍULO 1 - ASCENDÊNCIA DO MOVIMENTO TRADICONALISTA NO BRASIL 1

1.1. Ricardo Severo, a Casa Portuguesa e o Neocolonial ............................. 3

1.2. Raul Lino no Contexto do Movimento Tradicionalista Português........... 9

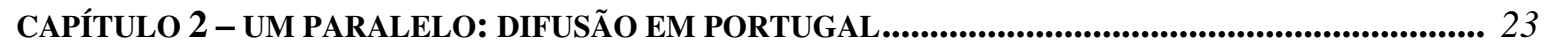

2.1. Circunstâncias Gerais, 1933-1950......................................................... 24

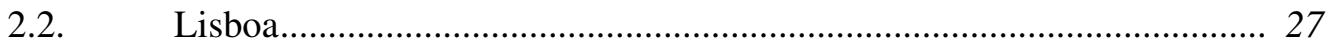

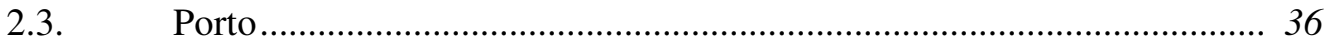

2.4. Cascais, Parede e Estoril …................................................................... 38

CAPÍTULO 3 - O NEOCOLONIAL NA HISTORIOGRAFIA................................................................... 41

3.1. Até os Anos 30: Os Primeiros Debates .................................................... 43

3.2. Os Anos 40 e 50: Afirmação de uma Linha Historiográfica .................... 49

3.3. Os Anos 60 e 70: Escassez de trabalhos sobre o tema ............................ 52

3.4. Os Anos 80 e 90: Abertura para Outros Enfoques .................................. 56

3.5. Trabalhos Recentes: Ajustes na linha historiográfica ............................ 76

CAPÍTULO 4 - ARQUITETURA NEOCOLONIAL PAULISTA: IMAGEM OFICIAL .............................. 87

4.1. A Elaboração de Uma Imagem ......................................................... 91

4.2. Fernando Costa combate o Jeca Tatu .................................................. 94

4.3. Obras Oficiais - Eruditas (Análise da Arquitetura) ................................. 110

CAPÍTULO 5 - APROPRIAÇÃO, RECRIAÇÃO E DIFUSÃo DA ARQUITETURA

NEOCOLONIAL PAULISTA ..................................................................................................... 129

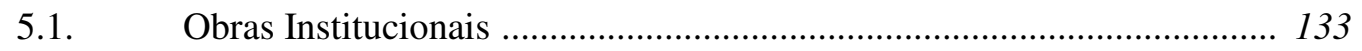

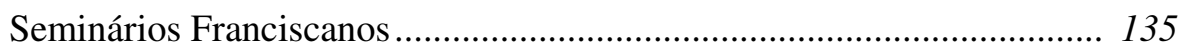

Igrejas, Santuários e Catedrais ........................................................ 148

Edifícios Assistenciais ................................................................... 157

Edifícios para Atividades Educativas .................................................... 160

Edifícios para Atividades Recreativas .............................................. 162

5.2. Obras Particulares .......................................................................... 167

Companhias Construtoras ........................................................ 172

Vilas Operárias ………………......................................................... 174

Edificações Comerciais .................................................................. 176

Edificações Residenciais ................................................................... 179

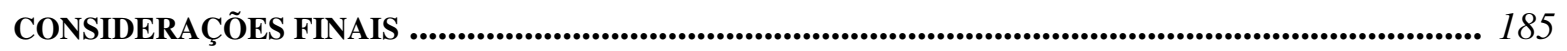


Volume 2

CAPÍULO 1 - IMAGENS

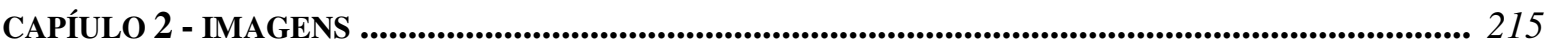

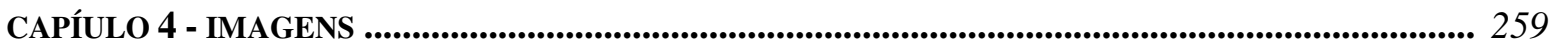

CAPÍULO 5 - IMAGENS ...................................................................................................................................... 355

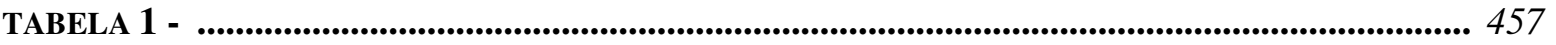

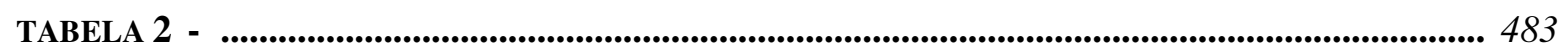

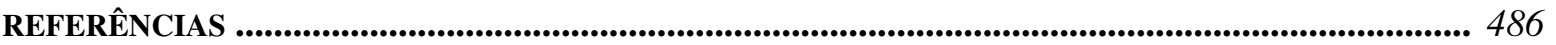

ANEXos - Levantamentos nos Arquivos Municipais e Fotografias (CD-ROM) 


\section{INTRODUÇÃO}

\footnotetext{
"Toda tentativa de modernização implica a passadistização da coisa que a gente quer modernizar" (Mário de Andrade, 1925)
}

\section{A Trajetória da Pesquisa até o Objeto de Estudo}

O nosso interesse pela arquitetura neocolonial começou durante o mestrado, através do estudo de um objeto localizado no interior do Estado de São Paulo, no município de Araraquara - numa área rural - que exibia traços marcantes dessa arquitetura. Na ocasião, realizamos uma abordagem sobre a transformação da arquitetura, na área, desde o final do século XIX até a atualidade, passando pela década de 1940, período em que ali se desenvolveu uma das maiores usinas de cana-de-açúcar da América Latina, a Usina Tamoio. Toda a estrutura construída, da vila operária principal da usina, exibia ${ }^{1}$ características neocoloniais, incluindo-se, aí, as casas dos operários - com beirais nos telhados, arcos nas fachadas, telhas capa e canal, pequenas volutas etc. -; o portal de entrada do campo de futebol; a igreja - reprodução do barroco mineiro, com mistura de características arquitetônicas de várias igrejas -; além do próprio nome - Tamoio - e do símbolo da usina - um índio, ao qual foi erigida uma estátua, colocada na entrada principal.

Pareceu bastante significativo encontrar, numa área rural do interior paulista, um conjunto arquitetônico tão expressivo, fruto do movimento neocolonial - movimento surgido entre as décadas de 1910 e 1920 na capital paulista e também em outras capitais - e que tinha sido implantado na década de 1940, quando vários exemplares importantes da arquitetura moderna estavam construídos, como o Ministério da Educação e Saúde, inaugurado em 1945. A arquitetura da usina parecia uma manifestação tardia, face ao conhecimento que tínhamos sobre a história da arquitetura brasileira. Assim, uma pergunta se impôs com vivacidade, especialmente pela escassez de referências bibliográficas e publicações sobre o tema, na região que abordávamos: como se havia dado, então, a repercussão do movimento neocolonial nas cidades do interior paulista? A observação do espaço urbano com tal preocupação, desde fins de 2002, indicou que havia abundante material para investigação. Os passos seguintes foram o

\footnotetext{
${ }^{1}$ Nem todo o conjunto está preservado; muitas construções foram já demolidas. Na última visita ao local, em 2003, a igreja estava em boas condições, bem como portal do campo de futebol.
} 
desenvolvimento de um plano de pesquisa voltado para a arquitetura neocolonial no interior paulista, e o desenvolvimento desta pesquisa de doutorado, pelo Programa de Pós-Graduação em Arquitetura e Urbanismo da EESC-USP.

Hipótese e Delimitações Iniciais

Nossa hipótese geral, desenvolvida em nosso plano de pesquisa, estava embasada em indícios de que a influência do movimento lançado pelo engenheiro Ricardo Severo em meados de 1910, na capital, tinha alcançado o interior do Estado de São Paulo. Os principais indicativos eram os numerosos exemplares que encontrávamos, a princípio, nas cidades de São Carlos e de Araraquara, e que poderiam ser interpretados como parte da difusão da tendência neocolonial. Assim, para dar início à pesquisa, fez-se necessário delimitar uma região do interior do Estado, dentro da qual realizaríamos, principalmente, levantamento de dados, em documentação pertencente aos arquivos municipais, e levantamento fotográfico.

Detivemos-nos, principalmente, nas cidades que se desenvolveram ao longo da Companhia Paulista de Estradas de Ferro. A ferrovia foi tomada como elemento de seleção da região a ser estudada, pois além de se constituir no fator que mais estimulou o seu desenvolvimento econômico e social, nas primeiras décadas do século $\mathrm{XX}$, era o elo com a capital do Estado, por onde fluíam as notícias, idéias, além de ser, naturalmente, o veículo através do qual se tinha acesso a vários tipos de mercadoria, inclusive material de construção, que se tornou escasso, durante o entre-guerras, obrigando a arquitetura a adaptar-se. Delimitamos um triângulo, na região geográfica central do Estado de São Paulo, que abrangia a cidade de São Carlos - cujos vértices eram constituídos pelas cidades de Rio Claro, Araraquara e Bauru. Além disso, eram cidades localizadas em pontos importantes, com relação às ferrovias: Rio Claro estava na extensão da linha da Companhia Paulista de Estradas de Ferro; Araraquara, no encontro entre as linhas da Companhia Paulista e da Araraquarense; e Bauru, no entroncamento entre as linhas da Companhia Paulista, da Sorocabana e da Noroeste do Brasil.

Outra delimitação estabelecida desde o início e que se fortaleceu, no decorrer da pesquisa, foi a de dar primazia ao estudo de Ricardo Severo como precursor do movimento neocolonial. Embora se saiba que, no Rio de Janeiro, José Mariano Filho defendia uma ideologia semelhante, que impulsionou o movimento e a decorrente produção arquitetônica, tendo sido, também, uma personalidade importante no processo, 
decidimos trabalhar predominantemente com Severo devido à sua área de atuação, que coincide com a área de interesse da pesquisa: o Estado de São Paulo. Assim, dentro desses limites, iniciamos os primeiros levantamentos de campo, em conjunto com a revisão bibliográfica.

\section{Novas Necessidades e Novas Perspectivas}

No decorrer da primeira fase dos nossos trabalhos, anteriormente descrita, duas novas necessidades se impuseram. Uma, dizia respeito à ampliação da área delimitada no início, pois esta não contemplava cidades em que sabíamos existir exemplares muito significativos da tendência neocolonial do interior paulista, como Pirassununga e Ribeirão Preto. Nesse momento, compreendemos que, apesar de a delimitação estar, já, pré-definida, não poderíamos deixar de incluir, no âmbito de nossa pesquisa, os prédios da Faculdade de Zootecnia e Engenharia de Alimentos, e os da Faculdade de Medicina - ambas da Universidade de São Paulo -, o que, pouco mais tarde, levou-nos ao estudo das Escolas Práticas de Agricultura, implantadas pelo Interventor do Estado, Fernando Costa, em 1942. Dessa forma, incluímos, em nosso trabalho, também as cidades de Pirassununga, Ribeirão Preto, Bauru, Guaratinguetá e Itapetininga, a fim de podermos analisar exemplares fundamentais, na difusão da arquitetura neocolonial no interior paulista. O estudo de tais exemplares, mesmo que situados em cidades externas ao recorte inicial, mostrou-se indispensável, pois nos despertou para aspectos não previstos, da difusão neocolonial, e de extrema importância.

Outra necessidade, especialmente ligada ao campo teórico, dizia respeito a uma compreensão mais ampla do movimento neocolonial. Na trajetória do português Ricardo Severo, que defendia o resgate da tradição brasileira, em termos de arquitetura, havia uma ligação muito forte com questões arqueológicas, etnográficas e outras, a elas relacionadas, as quais ele, evidentemente, não havia abordado apenas no Brasil. Também tínhamos conhecimento sobre o arquiteto português Raul Lino, representante de um movimento similar e contemporâneo ao neocolonial em Portugal. Perguntamonos, então, o que haveria em comum entre esses profissionais. E, mais, o que haveria, no movimento neocolonial, em comum com o momento cultural português? Seria possível encontrar mais esclarecimentos sobre o nosso movimento arquitetônico, conhecendo mais do contexto português onde Severo e Lino formaram seus pensamentos? Essas inquietações nos levaram a Portugal, onde, como esperávamos, conseguimos situar o movimento neocolonial num contexto mais amplo, o que 
consideramos, também, de fundamental importância para nossa pesquisa, como mostramos em seguida.

\section{A "Casa Nacional" como "Fenômeno Internacional"}

Desde a Renascença, a Europa tem se reconhecido como herdeira cultural da civilização greco-romana, principalmente. Já no século XIX, muitos fatores contribuíram para reflexões, ainda no contexto europeu, sobre origens, tradições, cultura e nacionalidade. Com o desenvolvimento das técnicas e da arqueologia, o ritmo das escavações cresceu sobremaneira, fornecendo abundante material para as interpretações dos intelectuais e dos artistas, em suas obras. Os processos de unificações de vários países europeus alimentaram sentimentos nacionalistas, e a indústria supriu o mercado com os produtos necessários para expressar - artística e arquitetonicamente - essas novas preocupações sobre identidade. Além disso, cresceu a facilidade de circulação de informações, permitindo aos arquitetos mais acesso ao conhecimento de arquiteturas do passado e de arquiteturas exóticas, permitindo variadas inspirações, em suas obras, e mostrando o espírito liberal do período. A arquitetura européia se expressou sob as influências desse contexto histórico, mostrando diferentes nuances, de acordo com os locais onde floresceram, tendo sido especialmente estimuladas pelo Movimento Romântico que emergiu no Oeste da Europa, como mostramos a seguir, onde nossa principal referência foi ROSMANINHO (2003).

Durante as últimas décadas do século XIX e o início do século XX, a Europa viveu um período de retomada de várias tendências arquitetônicas, como as de matrizes clássicas - góticas e barrocas - e as de matrizes regionais - os cottages, os chalets alpinos e outras referências vernaculares -, interpretadas como repositórios de autenticidade, associadas à idealização da vida no ambiente rural e à integridade do homem do campo, em oposição à vida urbana, corrompida pela presença da indústria e suas exigências, numa clara postura romântica. Ainda em fins do século XIX, as idéias românticas motivaram movimentos nacionalistas que tiveram reflexos na arquitetura, em processos que avançaram os limites europeus, atingindo vários países americanos do Norte, do Centro e do Sul.

$\mathrm{Na}$ Inglaterra, a valorização de tendências arquitetônicas pertencentes à Idade Média, ao período vitoriano, aos tradicionais cottages e aos terraced houses, podem ser identificadas na arquitetura produzida sob a influência do movimento Arts and Crafts, 
bem como nos trabalhos de William Morris, Richard Norman Shaw, John Ruskin, entre outros. Essa arquitetura foi construída nos subúrbios de Londres e em distritos industriais, desde os finais do século XIX até a atualidade, em novas versões inspiradas, ainda, na tendência citada. Na França, o espírito Beaux-Arts produziu conjuntos arquitetônicos que podem ser associados às reformas haussmannianas e à arquitetura eclética, que abarca diversas referências históricas, incluindo as manor houses e os chaletts alpinos, que se tornaram uma das mais populares referências para a arquitetura residencial, e continua a ser reproduzida em vários e diferentes locais. Na Alemanha, as referências arquitetônicas foram retiradas principalmente dos períodos medievais Gótico e Românico. Na Hungria, desde o início do século XIX, a busca por uma casa típica húngara estava presente nas publicações dos intelectuais. Na Polônia, no mesmo período de passagem do século, surgiu um movimento similar, baseado em duas fontes diferentes: a vernacular e a erudita. A última, representada pela arquitetura gótica, e a primeira pela tipologia das manor houses, difundida como um modelo suburbano de habitação, cercado por jardim. O nome desse movimento, Vístula Báltico, associava uma região geográfica a determinadas características vernaculares. Outros exemplos de movimentos similares podem ser citados, como o que ocorreu na Finlândia, chamado "Romantismo Nacional”, ou como o movimento Basco. Outras expressões, no mesmo sentido de afirmação de identidades, podem ser verificadas em pavilhões de diversos países, desenhados e construídos para as Exposições Internacionais da época. Em Portugal, desde os primeiros anos do século XX ensaiava-se o que seria a "casa portuguesa", com a construção da casa de Ricardo Severo, no Porto, e, posteriormente, com a emergência de Raul Lino como representante máximo desse movimento. Fora da Europa, nos Estados Unidos da América- e também no mesmo período- ocorreu um movimento similar, motivado, principalmente, pela busca de um "vernaculismo pioneiro mítico". Tal característica estava associada à imagem dos camponeses que se aventuraram na conquista das terras selvagens americanas, e ao seu modo de vida rústico. De fato, a "rusticidade" como referência a uma arquitetura ideal - ou, uma rusticidade romantizada - começou a aparecer na produção do arquiteto Kirtland Cutter (1860-1939), principal representante do movimento americano.

No contexto latino-americano, especificamente no Brasil, verificamos que a influência do romantismo, na formação dos intelectuais e dos profissionais da arquitetura, também foi decisiva. Ricardo Severo, com a componente romântica em sua 
formação e em seu pensamento, reuniu as condições favoráveis à emergência do movimento neocolonial. Além do ambiente propício que encontrou em São Paulo formado por fatores diversos, tais como a necessidade de afirmação da identidade da elite paulistana; a comemoração dos centenários de independência dos países latinoamericanos; a escassez de material de construção importado, para a arquitetura eclética, devido à guerra; entre outras - Severo foi o veículo dos desdobramentos do Romantismo europeu que repercutiram no Brasil. Nesse sentido, a arquitetura neocolonial é parte de uma movimentação muito mais geral e difusa - um "fenômeno internacional" - de busca pela expressão tradicional da arquitetura de vários países, neste texto, representada pela "casa nacional".

\section{Metodologia}

Durante os anos em que desenvolvemos a pesquisa trabalhamos, especialmente, com levantamento de documentação de interesse em arquivos, tanto no Brasil como em Portugal. Podemos dizer que as primeiras observações e levantamentos fotográficos realizados em São Carlos e Araraquara constituíram uma aplicação preliminar de um método de pesquisa, que foi o levantamento de campo. Esse método foi igualmente importante no decorrer da pesquisa. Também fez parte dos métodos, a revisão bibliográfica.

Em diversos casos, pudemos cruzar os dados dos levantamentos fotográficos e de documentação em arquivos, o que nos permitiu identificar exemplares ainda existentes e preservados; permitiu identificar também, por outro lado, que parte da produção foi demolida e/ou alterada. Em outros casos, não foi possível reconhecer o documento correspondente ao exemplar devido a alterações dos nomes de ruas, falta de dados em projeto ou inexistência do projeto em arquivo.

A seguir, antes de apresentar uma relação dos arquivos visitados, das bibliotecas onde realizamos revisão bibliográfica e dos locais onde fizemos levantamentos de campo, vamos descrever como foi necessário realizar diferentes abordagens em diferentes arquivos.

Nossa pesquisa se iniciou por arquivos municipais das cidades paulistas que fariam parte da pesquisa. Nesses casos, encontramos diferentes condições em cada um, tanto de organização quanto de material que detinham, mas todos organizavam os processos de aprovação de obras pela data em que deram entrada na prefeitura. Assim, 
em alguns desses arquivos, fizemos uma varredura nos processos de 1920 a 1950, a princípio. Depois dos primeiros levantamentos, percebemos que entre 1920 e 1930, prevalecia ainda a produção eclética e, portanto, nos concentramos nos processos de 1930 a 1950. Em outros desses arquivos, como no de Araras, encontramos dificuldades tais como a inexistência de documentação preservada anterior a 1949 - perdidas durante uma enchente, segundo o funcionário que nos atendeu - e a preservação de poucos processos referentes ao período por nós estudado, como no de Jaú e de Araraquara. Devido à extensão da pesquisa, algumas vezes, funcionários dos arquivos nos solicitavam que especificássemos quais os processos gostaríamos de consultar, através do fornecimento dos endereços das respectivas obras, como nos arquivos municipais de São Carlos e Rio Claro. Essa não foi uma estratégia que adotamos, pois nos interessava observar o conjunto da produção neocolonial, embora soubéssemos de antemão que especificamente algumas iriam nos interessar. O levantamento extensivo tomou bastante tempo e foi muito trabalhoso para nós e para os funcionários - que tiraram das prateleiras e deslocaram até o local de consulta, caixas e caixas de documentos -, o que gerou alguma dificuldade, porém o resultado dele foi precioso. Houve casos em que necessitamos fazer uma espécie de perseguição por determinados projetos, como no caso de projetos produzidos pela Diretoria de Obras Públicas (D.O.P.) de São Paulo. Por exemplo, depois de constatar que os projetos originais não se encontravam nas dependências do que haviam sido as Escolas Práticas de Agricultura (com exceção dos projetos encontrados na antiga Escola Prática de Agricultura "Gustavo Capanema" de Bauru), nos dirigimos ao Arquivo Público do Estado de São Paulo, que também não detinha esses projetos. Por indicação de um funcionário, soubemos que, possivelmente, os projetos estariam na Companhia Paulista de Obras e Serviços (C.P.O.S.), em São Paulo, detentora de parte do espólio da antiga D.O.P. Finalmente, lá encontramos projetos originais importantíssimos para nossa pesquisa, embora não todos os que esperávamos.

Aplicamos a mesma estratégia de busca por data nos arquivos municipais visitados em Portugal, como os do Porto e de Cascais, nos quais a dificuldade foi a mesma: o volume de processos a serem consultados. Devido ao nosso tempo - mais restrito em Portugal, pois os estágios lá realizados foram relativamente curtos - no Arquivo Municipal de Cascais, trabalhamos por amostragem, ou seja, consultamos as caixas de processos de aprovação de obra referentes ao início da década, ao meio da 
década e ao final da década: 1925, 1930, 1935, 1940 e 1945. Aplicamos a mesma estratégia no Arquivo Municipal do Porto, combinando a busca por nomes de arquitetos também, pois o arquivo possibilitava esse recurso (parte do índice de documentos, já disponível em forma digital, permitia a busca por nome de autor). Nossa grande dificuldade foi a pesquisa no Arquivo Intermédio - parte do Arquivo Municipal de Lisboa que guarda os processos de aprovação de obras. Nesse local, o acervo não está organizado por data, mas por endereço, o que impossibilitou a aplicação de nossa estratégia principal. A cada endereço correspondem todos os processos de obras, desde a primeira edificação até a mais recente, o que significava ser necessário consultar vários pacotes de documentos até encontrarmos aquele referente à data que nos interessava, e que, possivelmente, não era de interesse para a pesquisa. Através do sistema de busca eletrônico do arquivo, selecionamos, então, algumas ruas e ruas de bairros nos quais sabíamos existirem obras relevantes para a pesquisa. Nessas ruas, selecionamos a numeração de endereço que englobava determinada obra de interesse e solicitávamos as caixas dos processos. Essa estratégia foi combinada também com a busca no sistema por nomes de arquitetos. Assim, conseguimos contornar a impossibilidade da aplicação de nossa estratégia de pesquisa principal e localizamos projetos de grande interesse para o estudo. Por fim, a pesquisa no espólio do arquiteto Raul Lino, guardada pela Fundação Calouste Gulbenkian, foi mais controlada no sentido de que já sabíamos onde estavam os projetos, porém, foi mais exigente. Pela grande quantidade de projetos deixados pelo arquiteto - mais de 630 - foi necessário que fizéssemos uma seleção. Eliminamos os projetos de pequenas obras (bancos de parca, portões, caixas d’água, túmulos etc.) e os projetos de reformas, pois nos interessava analisar determinados aspectos da linguagem desenvolvida e utilizada por Lino. Depois, fizemos uma classificação por uso (comercial, residencial, misto, institucional, religioso etc.) e por data para proceder à análise. Mesmo depois da eliminação e classificação, a quantidade de projetos a serem analisados era extensa e, portanto, deveríamos ser ágeis na leitura dos mesmos, que se deu através de uma máquina leitora de microfilmes (espólio totalmente microfilmado). A fim de agilizar a leitura, desenvolvemos uma tabela de registros de características, onde constava a data do projeto, características de fachada, planta, relação com a paisagem e vocabulário arquitetônico relativo à arquitetura tradicional, barroca, árabe etc. Essa foi, portanto, uma estratégia de abordagem de um arquivo diferente da que vínhamos fazendo: já sabíamos onde se encontravam os projetos que buscávamos, foi apenas necessário fazer 
uma seleção. Além disso, a estratégia se mostrou bastante eficiente na rapidez do registro dos dados e esteve adequada aos nossos objetivos que foi analisar a linguagem arquitetônica de Raul Lino.

Relação dos Arquivos e Bibliotecas Visitados no Brasil

\begin{tabular}{|c|c|c|c|}
\hline $\begin{array}{c}\text { Tipo de } \\
\text { Levantamento }\end{array}$ & Instituição Pesquisada & Local & Material Encontrado \\
\hline \multirow{7}{*}{$\begin{array}{c}\text { Revisão } \\
\text { Bibliográfica }\end{array}$} & Biblioteca Central da EESC-USP & $\begin{array}{l}\text { Campus USP São } \\
\text { Carlos }\end{array}$ & $\begin{array}{l}\text { Referências e periódicos relacionados ao } \\
\text { tema do neocolonial }\end{array}$ \\
\hline & $\begin{array}{c}\text { Centro de Documentação do } \\
\text { Depto. de Arquitetura e } \\
\text { Urbanismo da EESC-USP }\end{array}$ & $\begin{array}{l}\text { Campus USP São } \\
\text { Carlos }\end{array}$ & Pouco material relevante \\
\hline & $\begin{array}{l}\text { Acervo Particular da Prof. Dra. } \\
\text { Ângela Bortolucci }\end{array}$ & São Carlos & $\begin{array}{l}\text { Referências relacionados ao tema do } \\
\text { neocolonial }\end{array}$ \\
\hline & Biblioteca da FZEA-USP & $\begin{array}{l}\text { Campus USP } \\
\text { Pirassununga }\end{array}$ & $\begin{array}{c}\text { Uma referência sobre a história do } \\
\text { Campus Universitário }\end{array}$ \\
\hline & Biblioteca da FFLCH - USP & $\begin{array}{l}\text { Campus USP São } \\
\text { Paulo }\end{array}$ & $\begin{array}{c}\text { Referências relacionados ao tema do } \\
\text { neocolonial }\end{array}$ \\
\hline & Biblioteca da FAU - USP & $\begin{array}{l}\text { Campus USP São } \\
\text { Paulo }\end{array}$ & $\begin{array}{l}\text { Referências relacionados ao tema do } \\
\text { neocolonial, }\end{array}$ \\
\hline & $\begin{array}{l}\text { Bibl. da Univ. Federal de S. } \\
\text { Carlos }\end{array}$ & $\begin{array}{c}\text { Campus UFSCar São } \\
\text { Carlos }\end{array}$ & Pouco material relevante \\
\hline \multirow{12}{*}{$\begin{array}{l}\text { Levantamento } \\
\text { em Fontes } \\
\text { Primárias }\end{array}$} & Assessoria Cult. FZEA-USP & $\begin{array}{l}\text { Campus USP } \\
\text { Pirassununga }\end{array}$ & $\begin{array}{l}\text { Fotografias do Campus, incluindo da } \\
\text { época de construção }\end{array}$ \\
\hline & Arq. Municipal de São Carlos & São Carlos - SP & $\begin{array}{l}\text { Diversos processos de aprovação de } \\
\text { projetos neocoloniais }\end{array}$ \\
\hline & Arquivo Municipal de Araras & Araras - SP & Processos de aprovação \\
\hline & Arq. Público Municipal de Jaú & Jaú - SP & Processos de aprovação \\
\hline & Arq. Público Mun. de R.Claro & Rio Claro - SP & Processos de aprovação \\
\hline & Arq. Público Mun. de Araraquara & Araraquara - SP & Proc. de aprov. e artigo de jornal \\
\hline & $\begin{array}{c}\text { Acervo do Seminário Santo } \\
\text { Antonio }\end{array}$ & Agudos - SP & Revista do Seminário, sobre a construção \\
\hline & Museu Municipal de Agudos & Agudos - SP & $\begin{array}{l}\text { Documentos sobre o Seminário Sto. } \\
\text { António e sobre edificações da cidade. }\end{array}$ \\
\hline & Arquivo Municipal de Taubaté & Taubaté - SP & $\begin{array}{l}\text { Documentos: Álbum comemorativo do } \\
\text { Tricentenário de Taubaté; Publicaçaõ } \\
\text { sobre construtora Cia. Predial }\end{array}$ \\
\hline & $\begin{array}{c}\text { Museu da Imagem e do Som de } \\
\text { Taubaté }\end{array}$ & Taubaté - SP & Fotos antigas e artigo de jornal \\
\hline & $\begin{array}{c}\text { Arquivo da Escola de } \\
\text { Especialistas aa Aeronática }\end{array}$ & Guaratinguetá - SP & Fotos atuais e antigas da Escola \\
\hline & $\begin{array}{l}\text { Arquivo Municipal de } \\
\text { Guaratinguetá }\end{array}$ & Guaratinguetá - SP & $\begin{array}{l}\text { Documentos do Seminário Frei Galvão; } \\
\text { Fotos da cidade; Documentos do Itaguará }\end{array}$ \\
\hline
\end{tabular}




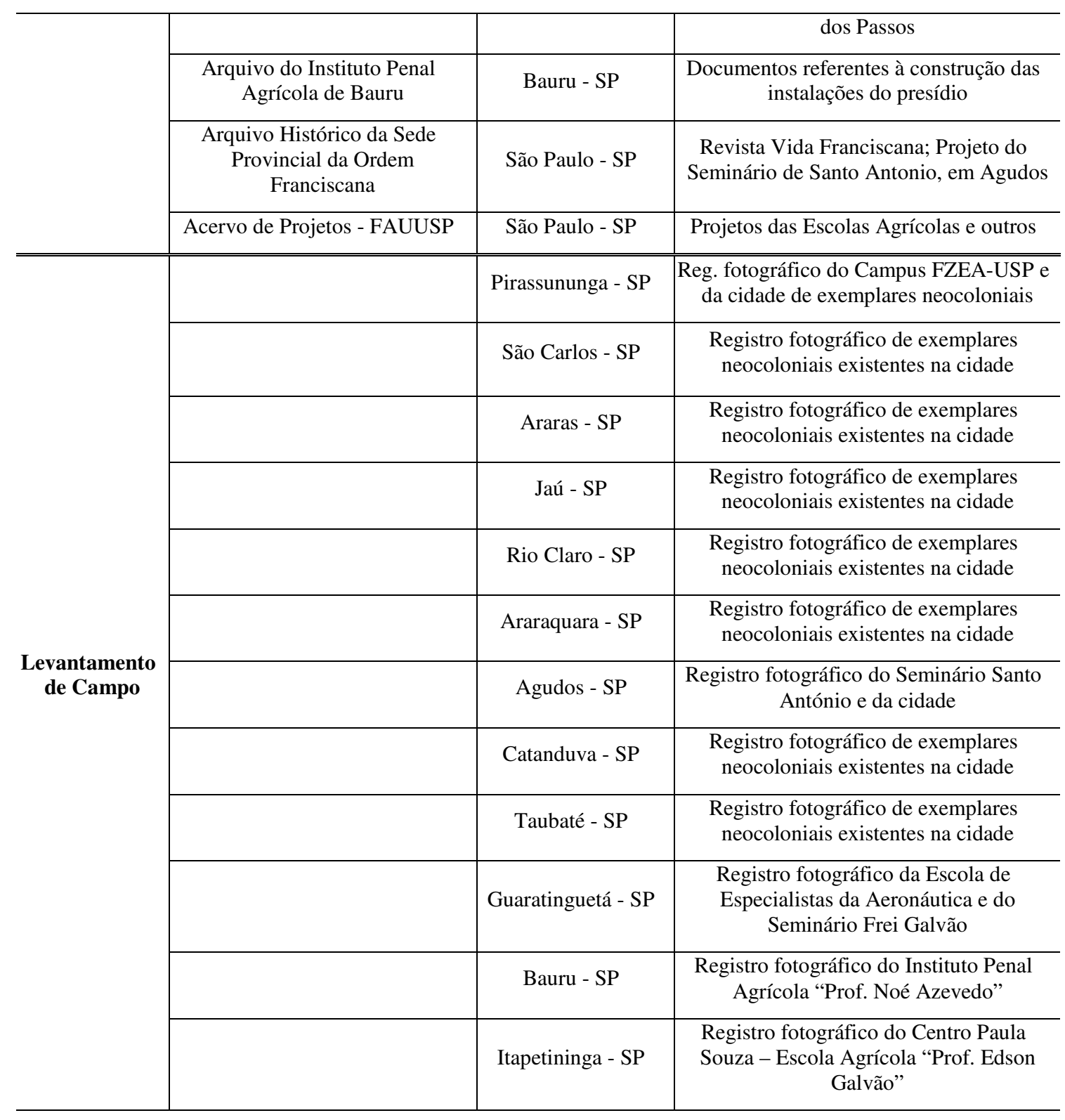


Relação dos Arquivos e Bibliotecas Visitados em Portugal

\begin{tabular}{|c|c|c|c|}
\hline $\begin{array}{c}\text { Tipo de } \\
\text { Levantamento }\end{array}$ & Instituição Pesquisada & Local & Material Encontrado \\
\hline \multirow{6}{*}{$\begin{array}{c}\text { Revisão } \\
\text { Bibliográfica }\end{array}$} & $\begin{array}{c}\text { Biblioteca da Universidade do } \\
\text { Minho }\end{array}$ & Guimarães - PT & $\begin{array}{c}\text { Referências relacionados à pesquisa sobre } \\
\text { Raul Lino }\end{array}$ \\
\hline & Biblioteca Pública de Braga & Braga - PT & $\begin{array}{c}\text { Referências relacionados à pesquisa sobre } \\
\text { Raul Lino e ao Barroco }\end{array}$ \\
\hline & $\begin{array}{l}\text { Biblioteca da Sociedade } \\
\text { Martins Sarmento }\end{array}$ & Guimarães - PT & Pouco material relevante \\
\hline & Biblioteca Nacional - BN & Lisboa - PT & $\begin{array}{l}\text { Referências relacionadas ao tema do } \\
\text { neocolonial, em especial ao Pavilhão } \\
\text { Carlos Lopes }\end{array}$ \\
\hline & $\begin{array}{l}\text { Biblioteca da Fundação } \\
\text { Calouste Gulbenkian }\end{array}$ & Lisboa - PT & $\begin{array}{c}\text { Referências relacionados à pesquisa sobre } \\
\text { Raul Lino }\end{array}$ \\
\hline & Acervo da Família Lino & Lisboa - PT & Pouco material relevante \\
\hline \multirow{7}{*}{$\begin{array}{l}\text { Levantamento } \\
\text { em Fontes } \\
\text { Primárias }\end{array}$} & Arquivo Municipal do Porto & Porto - PT & Processo de aprovação da Casa R. Severo \\
\hline & $\begin{array}{c}\text { Arquivo da Fundação Calouste } \\
\text { Gulbenkian }\end{array}$ & Lisboa - PT & Espólio de Projetos de Raul Lino \\
\hline & $\begin{array}{c}\text { Setor de Periódicos da } \\
\text { Biblioteca Pública de Braga }\end{array}$ & Braga - PT & $\begin{array}{c}\text { Artigos de jornais, sobre R. Severo e sobre } \\
\text { o Pavilhão Carlos Lopes }\end{array}$ \\
\hline & $\begin{array}{l}\text { Acervo Particular da Família } \\
\text { Lino }\end{array}$ & Lisboa - PT & $\begin{array}{c}\text { Manuscritos do livro "Auriverde Jornada" } \\
\text { R. Lino }\end{array}$ \\
\hline & $\begin{array}{l}\text { Biblioteca da Sociedade } \\
\text { Martins Sarmento }\end{array}$ & Guimarães - PT & $\begin{array}{c}\text { Correspondência entre R. Severo e M. } \\
\text { Sarmento }\end{array}$ \\
\hline & $\begin{array}{c}\text { Arquivo Intermédio - Arquivo } \\
\text { Municipal de Lisboa }\end{array}$ & Lisboa - PT & Processos de Licenças de Obras \\
\hline & Arquivo Municipal de Cascais & Cascais - PT & $\begin{array}{c}\text { Licenças de Obras referentes às cidades de } \\
\text { Cascais, dos Estoris e Parede }\end{array}$ \\
\hline \multirow{11}{*}{$\begin{array}{l}\text { Levantamento } \\
\text { de Campo }\end{array}$} & & Porto - PT & $\begin{array}{l}\text { Registro fotográfico de exemplares } \\
\text { barrocos, da Casa R. Severo e vizinhança; } \\
\text { Casa da Música (ref. ao barroco) }\end{array}$ \\
\hline & & Braga - PT & $\begin{array}{c}\text { Registro fotográfico da arquitetura barroca } \\
\text { e do Santuário B. Jesus (barroco) }\end{array}$ \\
\hline & & $\begin{array}{c}\text { Santuário da Peneda } \\
\text { Gerês PT }\end{array}$ & $\begin{array}{l}\text { Registro fotográfico da Santuário do } \\
\text { século XIX (ref. ao barroco) }\end{array}$ \\
\hline & & Guimarães - PT & Registro fotográfico da arquitetura barroca \\
\hline & & Arcos de Valdevez - PT & Registro fotográfico da arquitetura barroca \\
\hline & & Coimbra - PT & Idem e de uma obra de R. Lino \\
\hline & & Fátima - PT & $\begin{array}{l}\text { Registro fotográfico da arquitetura que faz } \\
\text { referência a R. Lino e ao barroco }\end{array}$ \\
\hline & & Aveiro - PT & $\begin{array}{l}\text { Registro fotográfico da Estação } \\
\text { Ferroviária e outras }\end{array}$ \\
\hline & & Mafra, Alcobaça - PT & $\begin{array}{l}\text { Registro fotográfico da arquitetura } \\
\text { barroca/gótica }\end{array}$ \\
\hline & & Lisboa - PT & $\begin{array}{c}\text { Registro fotográfico do Pavilhão C. Lopes, } \\
\text { da arquitetura que faz referência ao } \\
\text { barroco e de obras de R. Lino }\end{array}$ \\
\hline & & $\begin{array}{c}\text { Sintra, Estoril, Parede - } \\
\text { PT }\end{array}$ & $\begin{array}{c}\text { Registro fotográfico de obras de R. Lino e } \\
\text { da arquitetura nacionalista }\end{array}$ \\
\hline
\end{tabular}




\section{O Conteúdo da Tese}

Dessa maneira, deparamo-nos com um aspecto da pesquisa, mais ampliado, que procurou situar o movimento neocolonial num enquadramento que considerou as contribuições do Romantismo e, por essa via, suas conexões com o ambiente cultural português, e com um aspecto mais centralizado, que buscou conhecer a difusão da arquitetura neocolonial no interior paulista, e explorar seu significado. Assim, nosso primeiro capítulo - Ascendência do Movimento Tradicionalista do Brasil - trata da atuação de Ricardo Severo e de Raul Lino em Portugal, das relações entre os movimentos brasileiro e português. No segundo capítulo - Um Paralelo: Difusão em Portugal - tratamos de evidências de que houve, assim como no Brasil, especificamente no interior paulista, difusão da arquitetura tradicionalista portuguesa, produzida no mesmo período, sob as mesmas circunstâncias. No terceiro capítulo - O Neocolonial na Historiografia - fizemos uma revisão dos autores que trataram sobre o tema do movimento e da arquitetura neocolonial, por períodos, desde seu aparecimento até a atualidade, procurando evidenciar aspectos sobre a complexidade cultural das primeiras duas décadas do século XX, investigando se a esfera da oficialidade dessa arquitetura já havia sido anteriormente abordada, e pesquisando, ainda, sobre a tratada difusão. Emergiu, dessa revisão, que não poderíamos continuar interpretando o neocolonial segundo premissas modernistas e que, atualmente, existe uma abertura bem maior, na historiografia, para a inclusão de temas antes preteridos. No quarto capítulo Arquitetura Neocolonial Paulista: Imagem Oficial - tratamos da apropriação, pelo Estado, da linguagem da arquitetura neocolonial para a construção de obras oficiais, especialmente das Escolas Práticas de Agricultura, já mencionadas. No quinto e último capítulo - Apropriação e Recriação da Arquitetura Neocolonial na Difusão Paulista abordamos a difusão da arquitetura neocolonial em obras institucionais e particulares, em suas versões comerciais e residenciais. Procuramos interpretar se o conteúdo ideológico do movimento ainda se fazia presente nessas esferas, e mostramos que mesmo parte da difusão mais simplificada, muitas vezes foi realizada por profissionais eruditos, ou seja, diplomados, e não por profissionais sem formação. Finalmente, procuramos mostrar imagens e projetos que encontramos em diversos arquivos municipais, e fotos onde registramos exemplares de interesse. 
No decorrer desses anos de trabalho, deparamo-nos com algumas dificuldades que nem sempre nos permitiram chegar aos resultados idealizados; porém, acreditamos ter alcançado dimensões positivas, no que diz respeito à nossa meta principal: a investigação da difusão neocolonial no interior paulista. Acreditamos, ainda, que as reflexões contidas em nosso trabalho contribuíram para uma compreensão maior do neocolonial no Brasil. Além disso, esperamos que sejam úteis para eventuais futuras pesquisas, para o reconhecimento de que a arquitetura neocolonial foi representativa de uma fase importante - e complexa - da história da nossa arquitetura e para a preservação de exemplares situados no interior do Estado de São Paulo. 


\section{Capítulo 1}

\section{ASCENDÊNCIA DO MOVIMENTO \\ TRADICONALISTA NO BRASIL}


Esse primeiro capítulo de nossa tese resulta de uma parte da pesquisa realizada em Portugal. Em certa altura do trabalho, motivados pela necessidade de visualizar o movimento neocolonial num âmbito maior, que nos permitisse dimensionar o significado da figura de seu principal precursor - Ricardo Severo -, conectando-o às condicionantes de seu país de origem, realizamos um estudo sobre temáticas pouco comuns, na nossa historiografia. Assim, nosso interesse voltou-se para o contexto do qual emergiu esse engenheiro português, sob a perspectiva de que, provavelmente, Portugal também experimentasse, no mesmo período, uma ânsia de busca de identidade e de elementos culturais e tradicionais que, então, caracterizavam sua nacionalidade. Algumas referências confirmaram essa suposição e indicaram o arquiteto português Raul Lino como um "pensador nacionalista da arquitetura" (KESSEL, 2002; RIBEIRO, 1994; LINO, 1972; LINO, 1933). Assim, foram encontrados dois profissionais da arquitetura, de mesma nacionalidade, de mesmo viés de pensamento - a preocupação com as origens - e mesma fonte de inspiração - a arquitetura tradicional portuguesa - atuando, contemporaneamente, um em Portugal e outro no Brasil. Portanto, as evidências apontavam uma origem comum para o movimento neocolonial e para o movimento da casa portuguesa, que é o que vamos explorar a seguir. Além disso, procuramos observar se em Portugal, tal como no Brasil, ter-se-ia dado a difusão da arquitetura nascida do movimento da casa portuguesa. A suspeita foi confirmada e pudemos apurar um processo de "reaportuguesamento" da arquitetura (de onde surgiram exemplares neobarrocos e outras vertentes tradicionalistas) e, além das identificações entre traçados urbanos com influência da teoria cidade-jardim e casas tradicionalistas, tivemos também a oportunidade de levantar exemplares semelhantes aos neocoloniais brasileiros.

Observamos qual o papel do engenheiro português Ricardo Severo na origem dos movimentos tradicionalistas brasileiro e português que repercutiram na produção arquitetônica daquelas décadas, assim como o do arquiteto de mesma nacionalidade, Raul Lino, na liderança do movimento português. Assim, cientes da existência de estudos mais profundos sobre a biografia de ambos, vamos, aqui, traçar apenas algumas linhas, em função do assunto que nos interessa. 


\subsection{Ricardo Severo, a Casa Portuguesa e o Neocolonial}

Ricardo Severo da Fonseca Costa nasceu em Lisboa, em 1869. Ainda criança, mudou-se com a família para a cidade do Porto, onde cresceu e formou-se Engenheiro Civil de Obras Públicas (1890), e de Minas (1891), pela Academia Politécnica do Porto. Durante o curso na universidade teve estreito contato com Rocha Peixoto ${ }^{1}$, que havia sido redator da Revista Portugália desde 1889, e organizador do Gabinete de Mineralogia, Geologia e Paleontologia dessa escola, em 1891, ano em que Severo completou sua formação. Essa ligação com Rocha Peixoto mostra que ambos tinham, de fato, interesses afins. Severo esteve, também, bastante ligado a Martins Sarmento², natural da cidade de Guimarães, primeiro arqueólogo e etnógrafo português reconhecido internacionalmente, muito envolvido na pesquisa sobre questões antropológicas portuguesas (FIGURA 1). Severo publicou um de seus primeiros artigos sobre o assunto na Revista de Guimarães ${ }^{3}$, quando era ainda muito jovem, aos 17 anos, em co-autoria com Fonseca Cardoso ${ }^{4}$. De 1899 a 1908, publica a Revista Portugália ${ }^{5}$, que tratava de temas relacionados à antropologia, porém a publicação foi interrompida pelo seu retorno ao Brasil, onde já criara sólidos laços, desde que aqui estivera pela primeira vez, exilado, em decorrência de seu envolvimento em questões políticas, em Portugal.

Ricardo Severo foi um homem engajado em pesquisas etnográficas (Matos, 2002, p. 131) e no movimento republicano português, inserindo-se perfeitamente na geração de homens cultos de 1890 (Silva, 2005, p. 44), da qual faziam parte intelectuais, cientistas e artistas, envolvidos com a valorização do mundo português e com a definição dos principais símbolos, instituições e personagens que davam identidade a Portugal. Esse republicanismo estava, por um lado, sob a influência iluminista e, por

\footnotetext{
${ }^{1}$ António Augusto da Rocha Peixoto (1866-1909). Naturalista, etnólogo e arqueólogo, foi uma das figuras marcantes na vida cultural portuguesa na transição do século XIX para o nosso século. Em 1891 secretaria a "Revista de Portugal" fundada por Eça de Queiroz e onde já colaborava. Organizou o Gabinete de Mineralogia, Geologia e Paleontologia da Academia Politécnica do Porto. Colaborou nos jornais "O Século" e "O Primeiro de Janeiro" e em 1889, como redator chefe, é um dos impulsionadores da revista "Portugália", conhecida pela sua alta erudição nos domínios da arqueologia, da história, da antropologia e da etnografia. Foi diretor da Biblioteca Pública e Museu Municipal do Porto. http://www.cm-pvarzim.pt/Turismo/HistoriaTradicoes/Poveiros\%20Ilustres.htm. Acesso: 13/04/2006.

${ }^{2}$ Francisco Martins Sarmento (1833-1899). Disponível em: http://www.csarmento.uminho.pt/sms_41.asp Acesso: 03/07/2006.

${ }^{3}$ Revista de Guimarães, Órgão da Sociedade Martins Sarmento, fundada em 1884, sendo uma das mais antigas e prestigiadas publicações, de caráter científico, portuguesas.

http://www.csarmento.uminho.pt/sms.asp - Acesso: 03/07/2006.

${ }^{4}$ Severo, R., Cardoso, A. F. "Notícia arqueológica sobre o Monte da Cividade". In: Revista de Guimarães, Guimarães: Martins Sarmento, v. 3, p. 137-145, 1886.

5 "Portugália: materiais para o estudo do povo português. Ao contrário da primeira iniciativa editorial, nesta nova revista o vínculo imediato entre o propósito científico e o ideal nacionalista em Portugal era claramente assumido no seu próprio subtítulo”. (Silva, 2005, p.44).
} 
outro, sob uma vertente romântica que justifica o interesse pelas tradições, pela etnia e pelo nacionalismo. Esse interesse pode

ser identificado no trabalho de Severo ou de seus contemporâneos, fosse tratando de arqueologia, história ou arquitectura (...). Tratava-se de voltar para as origens da nação e de seu povo, para suas tradições, para a partir dela projetar um futuro radiante promissor (MATOS, p.39, 2005).

Encontramos, em um alfarrabista do Porto ${ }^{6}$, livros da biblioteca pessoal do engenheiro que também ajudam a compor o panorama de seus interesses. Os exemplares localizados tratam de antiguidades, culturas e povos antigos como, por exemplo: Villenoisy, F. \& Blanchet, A. Guide Pratique de Lántiquaire; Lenormant, F. Histoire des Peuples Orientaux; Arbois de Jubainville, H. Celtes; Nicolay, F. Histoire des Croyances Superstitions Moeurs Usages et Cotumes (FIGURA 2).

Severo veio, pela primeira vez, o Brasil, em $1892^{7}$, e aí permaneceu até 1897 , período em que mais se empenhou na produção escrita sobre a República, envolveu-se no setor da construção civil, e se casou (SILVA, 2005, p.55). Já outra vez no Porto, inicia, em 1899, a publicação da Revista Portugália, mas em 1908 tem de voltar ao Brasil, devido a dificuldades financeiras, aí permanecendo até a data de seu falecimento, em 1940.

Assim, o engenheiro teve dois aspectos marcantes, em sua carreira. Em Portugal é reconhecido, principalmente, pela sua produção escrita sobre antropologia e arqueologia, e pela publicação da Portugália. No Brasil, principalmente pelo seu trabalho como engenheiro e difusor das idéias que fomentaram um movimento de renascimento arquitetônico, que buscava empregar as raízes da arquitetura colonial e barroca, o posteriormente chamado "movimento neocolonial".

O movimento da casa portuguesa surgiu como um dos desdobramentos do debate sobre questões ligadas a origens, tradições, raízes culturais e nacionalismo, em Portugal, desencadeado pelo Ultimato Inglês, ocorrido em 11 de Janeiro de 1890, e que foi um duro golpe no sentimento nacionalista português e no regime monárquico, acusado de ser incapaz de defender os interesses da Nação (LABOURDETTE, 2003, p. 523). Esse

\footnotetext{
${ }^{6}$ Exemplares encontrados num Alfarrabista do Porto: Livraria Manuel Ferreira, que afirma ter comprado os livros da biblioteca de Ricardo Severo.

${ }^{7}$ Não há consenso se o engenheiro teria chegado em 1891 ou 1892, no Rio de Janeiro ou em São Paulo, porém é certo que já se encontra na cidade de São Paulo em 1892. (Silva, 2005, p.54).

${ }^{8}$ Segundo Segawa (1997, p.36), José Mariano Filho (1881-1946), médico e historiador de arte, foi o "responsável pela denominação "neocolonial” ao movimento".
} 
fato estimulou fortemente o crescimento do movimento republicano. Nesse novo contexto de sentimentos exacerbados, a classe intelectual debatia questões relacionadas à nacionalidade $\mathrm{e}$, assim, criaram-se as condições favoráveis para novas expressões nas artes, incluindo a arquitetura. A discussão sobre o que viria a ser a casa portuguesa já comparecia entre as preocupações da intelectualidade (LEAL, 2000).

A primeira obra de arquitetura de Ricardo Severo foi construída em Portugal, no Porto, à Rua do Conde ${ }^{9}$, a partir de 1902. Essa é a data de registro do processo de aprovação da obra junto à Câmara Municipal do Porto (FIGURAS 3 e 4). Naquele contexto de agitação em busca da arquitetura genuinamente portuguesa, em que raros exemplares da novíssima tendência haviam sido ensaiados ${ }^{10}$, essa casa foi objeto de um debate $^{11}$, fortalecido a partir do artigo de Rocha Peixoto, A Casa Portugueza, publicado em 1904 no jornal Primeiro de Janeiro. Na segunda publicação desse artigo, na revista Serões, em 1905, o autor junta 14 fotografias de habitações autóctones portuguesas, denotando um interesse prévio pelo assunto (FIGURA 5).

$\mathrm{O}$ aspecto geral dessa edificação é de uma casa urbana do início do século XX: isolada no terreno, planta com espaços compartimentados e especializados. Destacou-se por exibir uma tipologia diferenciada, em relação às tradicionais construções "em banda" (geminadas), muito comuns no Porto, que são alinhadas pelo estreito limite frontal do terreno e se desenvolvem na vertical (FIGURA 6). Era diferente, também, em relação aos “chalés” e à arquitetura de inspiração eclética, então em voga.

Por sua feição incomum e por pertencer a um português que tinha vivido no Brasil, a obra várias vezes foi interpretada, equivocadamente, como de influência brasileira. Com relação a esse detalhe, já nos alerta Milheiro (2005, p. 165), dizendo que “a casa do engenheiro Ricardo Severo (...) que retorna do Brasil na década de 90 (...) é correntemente confundida com um exemplar da «arquitetura brasileira»”. Essa arquitetura brasileira, a que a autora se refere, são as casas construídas pelos portugueses "torna-viagem", aqueles que imigraram para o Brasil durante o final do século XIX e começo do XX, enriqueceram, voltaram a Portugal e construíram edificações residenciais e institucionais, via de regra, muito ostensivas e ricas, com

\footnotetext{
${ }^{9}$ Atualmente, Rua Ricardo Severo.

${ }^{10}$ Considera-se a casa de propriedade dos senhores O Neill (1900), projeto de Francisco Vilaça, em Cascais e M. Gomes, no Estoril, como exemplos desses ensaios. Viterbo (1912, p. 567).

${ }^{11}$ Outros artigos que localizamos e que discutem a casa de Severo e a temática envolvida são: Viterbo (1912); Carvalho (1901a) (1901b).
} 
influências ecléticas brasileiras. Esses exemplares são comuns na região do Minho, especialmente na cidade de Fafe ${ }^{12}$ (FIGURA 7a e 7b).

Contudo, a casa de Severo foge às interpretações mais comuns, pois sustenta um ar tradicionalista e remete, principalmente, à arquitetura da região Norte de Portugal - o uso da pedra, a escada, a varanda, os beirais, a constituição pesada - ainda que faça referências a variados detalhes que podem ser associados à arquitetura de outras regiões de Portugal, como analisado por Peixoto (1905, p.163-165). Embora o autor já afirmasse que não "há lugar para o destaque duma casa ou casas de indefectível estilo nacional" (PEIXOTO, 1905, p. 161), ele próprio, no mesmo artigo, publicado em 1904, faz a defesa do espírito nacionalista do exemplar em questão, traduzido através do emprego de diversas outras características:

esta casa, pois, (...) constitui um verdadeiro Museu de pormenores e de motivos que resume épocas, estilos e influências (...) ficam patentes os recursos de que nos é lícito dispor para a edificação duma «casa portuguesa» (PEIXOTO, 1905, p. 165).

Conforme podemos verificar pelo projeto e pelas fotos, estão presentes, nela, elementos tais como balcão com muxarabi, nicho para santo e chaminés pronunciadas, como as do Sul do país, que fazem da casa uma reunião de características da arquitetura portuguesa, um “museu de pormenores”, como foi descrito (FIGURAS 3 e 4).

Entretanto, dentre todas as características da casa, a que mais se destaca é a planta, pois existe uma clara semelhança com a planta da casa registrada por JeanBaptiste Debret (1768-1848) em sua Prancha 42 (FIGURA 8). Quem chama a atenção para o fato de esse artista francês ter-se tornado uma fonte de informações é Pinheiro (2005, p.7):

A despeito de suas breves análises arquitetônicas, o fato é que Debret (...) pela escassez de outros estudos a respeito - tornou-se referência para todos aqueles que voltaram seus olhos para a arquitetura colonial brasileira (...), a começar por Ricardo Severo e José Mariano Filho, passando por Alexandre Albuquerque e tantos outros.

\footnotetext{
12 Sobre o assunto ver: Monteiro, Miguel. 1991. Fafe dos "Brasileiros"- (1860-1930) - Perspectiva Histórica e Patrimonial. Fafe, Ed. Autor; Lima, Roberto Pastana Teixeira. 2001. Modelos Portugueses e a Arquitetura Brasileira: catálogo e análise das formas arquiteturais paulistanas e lusitanas no oitocentos. Tese (Instituto de Filosofia e Ciências Humanas) - Universidade Estadual de Campinas, p.175-188
} 
Assim, é possível aventar duas possibilidades: a primeira é que Severo tenha entrado em contato com a obra de Debret durante sua primeira estada no Brasil e tenha, através dessa inspiração, desenvolvido a planta para sua casa no Porto; a segunda é que essa planta tenha sido fruto das pesquisas de cunho arqueológico levadas a cabo por Severo. De acordo, ainda, com Pinheiro (2005, Figura 1), referindo-se à casa em questão, "Debret relaciona cada cômodo (...) com seu correspondente pompeiano". Significa que a matriz utilizada por Severo tem origem na arquitetura residencial romana, o que possivelmente não the tenha passado despercebido, em suas investigações sobre as origens do povo português. De acordo com o primeiro caso, então, temos uma influência da arquitetura colonial brasileira já na primeira casa construída por Severo; de acordo com o segundo, essa seria mais uma característica ancestral - da arquitetura tradicional portuguesa, acrescentada ao "museu de pormenores”. Peixoto (1905, p. 163) julga que o arranjo espacial em torno do pátio, pode ainda, ser de origem árabe, além de romano: "à reminiscência árabe ou romana, tão pouco comum entre nós e tão freqüente na Espanha, liga-se a adopção dum pátio interior". De qualquer forma, a casa de Severo no Porto é, seguramente, a primeira obra a materializar, de maneira satisfatória, os anseios de debates teóricos quanto à arquitetura genuinamente portuguesa. Depois de sua construção, as intenções de "reaportuguesar" a moradia se acentuaram, e passa a ser possível encontrar, nas revistas de arquitetura da época - como na A Arquitectura Portuguesa ou A Construção Moderna numerosos projetos com características, e nomes alusivos, tais como casa regionalista, tradicionalista ou portuguesa, que fazem menção às tradições, e cuja autoria nos remete a vários arquitetos que já haviam aderido à tendência (LEAL, 2000, p.112). Esse se configurou, pois, como um momento mais voltado à divulgação das idéias de um movimento que vinha se consolidando, diferentemente do debate anterior, onde as discussões eram teóricas e se davam na esfera do público intelectual.

A produção arquitetônica de Ricardo Severo no Brasil, embora guarde, inegavelmente, uma identidade com a referida casa do Porto, caracteriza-se por uma maior expressividade e liberdade, na maneira de utilização da linguagem de ornamentação e no emprego das referências tradicionalistas, marcando uma dicotomia, também, no que se refere à sua obra, construída nos dois países. Em planta, de acordo com a análise realizada por Silva (2005), as residências criadas pelo engenheiro no Brasil aproximam-se dos palacetes ecléticos. Contudo, nas elevações o apelo às 
referências tradicionalistas e barroquizantes é bastante mais efusivo, se comparado com sua casa no Porto, como facilmente se verifica em exemplares tais como a Casa Numa de Oliveira (1916), a Casa Praiana (1920-24), a Casa Rui Nogueira (1939-40), a Casa Júlio de Mesquita (1910) e a Casa Lusa (1920-24) ${ }^{13}$. Severo empregou painéis de azulejos, frontões e volutas barrocas, chaminés à portuguesa, beirais revirados, e até mesmo elementos de demolições, entre os quais peças originárias do período barroco, tendo procedido, portanto, de um modo atualmente inaceitável. Nesse sentido, a reforma da Faculdade de Direito do Largo São Francisco é a obra mais questionável de sua carreira, segundo podemos verificar em Pinheiro (2005, p. 123-127), pois o engenheiro não teria apresentado nenhuma preocupação preservacionista com relação à obra original Pelo contrário, segundo a autora, "os dois maiores expoentes da tendência neocolonial (...) José Mariano Filho e Ricardo Severo - estavam entre os maiores colecionadores do período" (PINHEIRO, 2005, p.16), pois utilizaram vários elementos coloniais originais, na composição de suas casas neocoloniais. Em contrapartida, Silva (2005, p. 64) vê no “discurso «Culto à Tradição» (...) [que] não trata especificamente de arquitetura (...) uma preocupação em Severo com relação à destruição das construções do passado colonial, como ameaça de desagregação do laço tradicional”. Seja como for, talvez tenhamos que considerar a contradição do pensamento desses homens que atuaram no período como um aspecto intrínseco, invisível à ponderação da época. Retornando aos projetos de sua autoria, também podem ser citados, devido à profusão ornamental que apresentam, principalmente barroquizante, embora não sejam residenciais, os prédios da Beneficência Portuguesa de Santos (1936), Campinas (1926) e Bauru (1914), cidades do interior do Estado de São Paulo, incluindo a intervenção realizada no prédio da Faculdade de Direito, na cidade de São Paulo (1939). (FIGURA 9).

Tendo sido um profissional que viveu e estudou na região Norte de Portugal, pode-se dizer que ele esteve mais ligado à tradição arquitetônica dessa região, lugar onde a arquitetura barroca foi bastante mais expressiva que em outras regiões do país, e onde se concentram os antigos solares portugueses, do século VIII, principais exemplares do barroco não religioso (FIGURAS 10a a 10e). Além disso, quando esteve no Brasil, entrou em contato com a arquitetura do período colonial, da qual se destaca a barroca, julgando serem, essas, as raízes da arquitetura brasileira, as quais deveriam

${ }^{13}$ Quando volta ao Brasil, em 1908, Severo torna-se sócio do escritório Ramos de Azevedo em São Paulo, de maneira que todos os projetos aqui citados são posteriores a essa data. 
orientar a produção vindoura ${ }^{14}$. Devido, portanto, ao seu repertório e à sua nacionalidade, encontramos o engenheiro no Brasil produzindo obras que apresentam uma relação mais direta com o barroco, mas que se inserem totalmente no debate sobre a casa portuguesa. Possivelmente a maior expressividade de Severo, em terras brasileiras, se tenha dado no intuito de relembrar, na ex-colônia, o veio português de sua arquitetura, inclusive relembrando a origem da arquitetura colonial barroca. Afinal, é o cariz tradicional português e barroco que vai distinguir a arquitetura, lançada por Severo, das influências neocoloniais hispânicas. Como desdobramento de sua atuação veremos, após o lançamento de suas idéias e a construção de suas obras, a disseminação de uma linguagem de traços "barroquizantes" que se estende até meados de 1940, o que também afirma Milheiro (2005, p.178 e 180): “o tempo neocolonial invade o tempo moderno, mesmo enfrentando uma desaprovação crescente. (...) a idéia de uma casa brasileira prolonga-se, assim, do neocolonial para o moderno”. Adiante vamos tratar dessa difusão, que se estendeu para além da cidade de São Paulo, no interior do Estado.

\subsection{Raul Lino no Contexto do Movimento Tradicionalista Português}

Raul Lino nasceu em Lisboa, no ano de 1879, numa família relativamente abastada. Seu pai foi um bem sucedido comerciante do ramo de materiais de construção, de onde provém, possivelmente, o interesse em mandar os filhos estudarem assuntos relacionados a esse setor de atividades. Assim, quando Raul Lino tinha apenas 10 anos, em 1890, embarca, com o irmão, para Windsor, Inglaterra, a fim de cumprir o equivalente aos estudos secundários. Em 1893, vai para Hannover, na Alemanha, para cursar a Escola de Artes Decorativas (PIMENTEL, 2006). É importante destacar que nas últimas décadas do século XIX o curso de arquitetura, em Portugal, não tinha estatuto de curso superior, ao contrário dos de engenharia. Trata-se de um período de instabilidade no país e de conseqüentes mudanças na área política (crise do regime monárquico), principalmente, o que vai se refletir nos aspectos sócio econômicos e culturais; (LEAL, 2000; CATROGA, 1991; RAMOS, 1994). Dessa forma, as famílias mais abastadas, que podiam proporcionar melhor formação para seus filhos, ou os mandavam para as engenharias, em Portugal, ou para o exterior, via de regra para a França, onde recebiam a influência cultural desse país. A própria Academia de Belas Artes de Lisboa - que

\footnotetext{
${ }^{14}$ É “claro para Severo que outras raízes - também plausíveis, como as indígenas - não são exactamente tradicionais; ou seja, não geraram verdadeiros estilos arquitectónicos ou artísticos, reportando-se a um uso decorativo: o ser autóctone não se confunde com o ser tradicional, constituindo assim um primeiro argumento que afasta, da fonte nacional brasileira, as manifestações artísticas anteriores à colonização" (Milheiro, 2005, p.181).
} 
passa a ser Academia Real, em 1862, tendo nascido como Casa do Risco, em 1755 envia a Paris, em 1865, os primeiros bolsistas, o que significa que o ensino em Portugal seguia a escola francesa ${ }^{15}$. Contrariando a tendência corrente do momento, Lino foi mandado para a Inglaterra e para a Alemanha, provavelmente em decorrência, como já dissemos, da área de atuação do pai, que também intencionava estimular, nos filhos, o desenvolvimento das habilidades artísticas. Na Alemanha, contudo, Lino não vai para um curso superior, mas freqüenta cursos livres, que não lhe dão o grau acadêmico de arquiteto. Ou seja, Lino não vai para a academia, mas vai para o exterior, outro fator indicativo da preocupação das famílias ricas em conseguir para os filhos uma formação melhor que aquela existente em Portugal, na época. $\mathrm{O}$ arquiteto somente recebe seu título em 1926, “de uma forma quase honorífica” (RIBEIRO, 1994, p.27).

Essa trajetória diferenciada marcou, do início ao fim, o trabalho de Raul Lino. Sua formação cultural e profissional tem raízes no centro da Europa, no ambiente cultural e nas idéias que circulavam nessa região, na virada do século. Recebeu grande influência do movimento Arts and Crafts, à qual se pode atribuir sua postura em defesa do artesanato e contra a standatização e a industrialização. Em outras palavras, defendia o "amor pelo fazer" (PIMENTEL, 2006). À influência desse movimento também se podem atribuir suas idéias acerca da recuperação e da valorização de certos aspectos da arquitetura tradicional e vernacular. Em sua biblioteca podem ser encontrados livros tais como os de Mackintosh, de Ruskin e de Bailey Scott $^{16}$ - e revistas de artes e arquitetura - como Deutsch Kunst Deco, Racion, Studio e publicações sobre a Sesseção Vienense (PIMENTEL, 2006). Encontra-se no trabalho de Vogliazzo (1988) uma aproximação entre as obras de Muthesius, Das Englische Haus (1904), e Lino, A Nossa Casa (1918), concluindo-se que o último teria, muito provavelmente, lido o primeiro, devido às características presentes nas idéias e no trabalho do arquiteto português. Foi marcado também pela cultura alemã de fins do século XIX e início do XX: pelo Jugendstil, pela obra global, quando, em Hannover, trabalhou com o professor Albrecht Haupt $^{17}$, estudioso da arquitetura portuguesa dos séculos XIII ao XVII, a quem dedicou

15 Nota Histórica sobre a Faculdade de Belas-Artes de Lisboa. Cronologia adaptada de Calado, Margarida. Tábua Cronológica 1755-1983 in "O Caderno de Desenho". Catálogo da Exposição "O Risco Inadiável”, ESBAL, 1988. http://www.fba.ul.pt/001.html

${ }^{16}$ Lord George Bailey-Scott (radicado em Portugal no séc. XIX) desenvolveu intensa atividade na área da botânica e da imortalidade humana, no Alentejo rural.

17 “Karl Albrecht Haupt nasceu a 18 de Março de 1852 em Büdingen. Faleceu a 27 de Outubro de 1932, em Hannover. Frequentou a Universidade de Giessen e as escolas técnicas de Hannover e Karlsruhe; graduou-se em Filosofia e habilitou-se, em 1880, na escola técnica da Hannover; foi arquitecto de 
grande estima e a quem se referia como "querido mestre"18. Sua inclinação pela música o fez grande admirador de Wagner e das grandes encenações, o que acabou por se refletir em suas obras arquitetônicas mais significativas, nas quais se verifica um grande cuidado com os sons dos ambientes.

Essa sua formação deriva da cultura romântica, bem como sua tendência à busca das tradições e da identidade nacional, embora se tenha mantido sempre longe da política. Ribeiro afirma que, além de todas essas características de sua formação, também teve influências da literatura e da música portuguesa, formando

o seu próprio modelo de romantismo, afinal um dos vectores estruturais da sua personalidade, intuitiva, intimista e diletante, de alguma forma paternalista e aristocrática, dentro desse contexto cultural de nacionalismo quase mítico (RIBEIRO, 1994, p.31).

Seu perfil contrasta, portanto, com o da maioria dos portugueses eruditos e o dos arquitetos que se formavam no período, e que produziam a arquitetura eclética dos revivalismos historicistas e dos "chalés" (RIBEIRO, 1994, p. 28).

De volta a Portugal em 1897, Lino sem demora inicia seu trabalho. Uma de suas primeiras obras, e também uma das mais conhecidas, é a casa "Monsalvat", de 1901, construída no Monte Estoril para o pianista Alexandre Rey Colaço (FIGURA 11). Sua bagagem cultural adquirida no exterior, na qual estão as principais convicções que nortearam seu trabalho, associada às inquietações acerca de seu país, especialmente no que diz respeito à arquitetura, levaram-no a realizar outras viagens e a tomar uma postura própria. Assim, Lino desenvolveu um posicionamento diferenciado, com relação a várias correntes de pensamento que caracterizaram a produção arquitetônica dos princípios do século $\mathrm{XX}$, e que acabou florescendo devido às condições propícias do período, já aqui citadas, e que foram os debates intelectuais por uma arquitetura genuinamente portuguesa. Por um lado se opunha ao academicismo "afrancesado" e ao ecletismo - que considerava como influências estranhas às raízes portuguesas - e, por

castelos ao modo de seu tempo, construiu casas municipais e restaurou igrejas na Alemanha. Foi viajador por toda a Europa e escreveu mais de uma dezena de livros sobre arte. Quedou-se em Portugal durante alguns anos, percorreu-o quase todo à procura de nossa arte sobre a qual publicou dois volumes: Die Baukunst der Renaissance in Portugal, Ester Band, Frankfurt A.M., Heinrich Keller, 1890; idem, Zweiter Band, 1895 (158 pp. E 171pp.)" Esta rápida biografia foi tirada da "Introdução Crítica” que acompanha a edição portuguesa: Haupt, A. A Arquitectura do Renascimento em Portugal. Tradução: Margarida Morgado, Introdução crítica e revisão de texto: M. C. Mendes Atanázio. Lisboa: Ed. Presença, 1986.

${ }^{18}$ Tratamento retirado da correspondência trocada entre Lino e Haupt (Documentos encontrados no Acervo da Família Lino). 
outro, à industrialização da arquitetura, à era da velocidade e às idéias modernistas, percorrendo um terceiro caminho motivado pela busca da arquitetura ideal. Lino trabalhou em função da valorização de qualidades arquitetônicas tais como a implantação, a paisagem, a proporção, além de buscar, incessantemente, as componentes e a essência do que seria a casa portuguesa (FIGURA 12). Segundo Ribeiro (1994, p.102), Lino desenvolve, ao longo de sua produção, características ligadas às idéias de natureza e tradição e, dessa forma, mantém uma linguagem ao mesmo tempo histórica, porém sem o barroquismo ${ }^{19}$ do historicismo eclético. Esta autora situa Lino, segundo sua formação e segundo as influências que recebeu, numa posição particular, que não era moderna e também não era eclética:

Apaixonadamente, contraria a lógica abstracta de um geometrismo apolíneo, que considera desumano - o modernismo, mas enjeita também, na sua demanda de tranquilidade, os excessos decorativos e cenográficos de um barroquismo dionisíaco - o ecletismo (RIBEIRO, 1994, p. 189).

Nesse caminho muito próprio que Raul Lino traçou - que não seguia nenhuma das tendências predominantes da época, mas coincidia com o movimento tradicionalista que se fortalecia, e do qual ele viria a ser a figura mais importante - é possível identificar algumas vertentes arquitetônicas que faziam parte do que ele considerava como componentes da arquitetura portuguesa, tais como a árabe, a manuelina e a barroca.

Pode-se considerar que foi o "mestre Haupt", através de seu trabalho e de seu convívio, quem despertou em Lino o interesse pela busca dos componentes culturais da arquitetura de seu país. É importante, aqui, nos demorarmos um pouco mais sobre a influência de Haupt em Lino, lembrando que esse estudioso alemão, como já foi mencionado, viajou por toda a Europa, principalmente por Portugal, durante o final da década de 1880, inclusive, saliente-se, pelo Norte português (Haupt, 1986, p. III, IV e V). Na "Introdução Crítica” que se encontra na edição portuguesa do livro do "mestre", “Baunkunst Der Renaissance in Portugal”, de 1986, há informações pertinentes à compreensão dessa influência.

Em primeiro lugar, Atanázio - autor da introdução crítica e da revisão de texto da edição citada - esclarece que, embora a obra e seu título queiram se referir à

\footnotetext{
${ }^{19}$ O "barroquismo", neste caso, significa que Lino se absteve dos excessos, da profusão de decorações.
} 
arquitetura do renascimento em Portugal, "para ele [Haupt], tal conceito vai do séc. XIV, ou XIII, pelo séc. XVI e até XVII, misturando Barroco e Maneirismo, e ContraReforma” (Haupt, 1986, p. II). Analisando a obra, o crítico afirma que Haupt

deu muito valor aos trabalhos em talha, sobretudo quando os encontrou nos coros das igrejas, catedrais, armários de sacristia, retábulos de altar, nos tectos e nalgumas superfícies murária em "decoração escultórica luxuosa, toda dourada (HAUPT, 1986, p. II).

Esta descrição aponta para estudos sobre o Barroco, ao contrário do que é sugerido no título da obra. Isso indica que, muito provavelmente, as referências acerca do que seria a arquitetura que Lino procurava em seu país - considerando-se que ele via o mundo um pouco pelas lentes do "mestre" - não se restringem ao Renascimento, abrangendo um universo bastante mais amplo, onde esteve, inclusive, o Barroco.

Em segundo, Atanázio mostra a faceta de Haupt interessada pela cultura que fosse distante e estranha a ele, que começava em Portugal e se estendia até o Oriente, ou seja,

ao lermos a obra de Haupt, devemos entendê-lo ao nível de um estrangeiro tocado por algo de aventura, que veio aqui à busca do estranho mundo que ele pensou ser Portugal, e em cuja arte e cultura misturou quanto e quando pôde uma mezinha exótica de orientalismo e arabismo. (...) A visão e interesses de Haupt pelo exótico e antiquariado é que o terão levado a não só falar da arquitectura, como o título de seu livro exigia, mas também das nossas artes ornamentais, desde os azulejos, até aos móveis de madeira, bordados e ourivesaria. (...) É aceitável no que disse sobre a influência mourisca, seja na arquitectura mudéjar, seja nos revestimentos de azulejos e "desenhos dos entrelaçados geométricos", sem esquecer a olaria $e$ marcenaria (HAUPT, 1986, p.II e III).

Desse modo, é possível conjecturar que a percepção de Lino para com a contribuição do veio árabe ou mourisco na cultura portuguesa foi despertada por Haupt. Assim, logo que volta a Portugal, viaja pelo país, agora com uma nova visão, no intuito de reconhecê-lo. E, então, o que mais lhe interessou foi a arquitetura alentejana, principalmente da cidade de Évora (FIGURA 13), na qual identificou as origens árabes (PIMENTEL; 2006). Mas por que vai para Évora? Possivelmente, também por indicação de Haupt. Em sua obra já citada, junto a um desenho do Palácio Real de Sintra 
- atual Palácio Nacional de Sintra (FIGURA 14) - o texto do "mestre" associa o trabalho aos construtores mouros, Sintra e Évora, como se pode ler no trecho:

a maior parte do edifício se deve aos reinados de D. João I e em especial aos de D. Afonso V e de D. João II, tendo os trabalhos de construção sido executados até o reinado de D. Manuel sobretudo por artífices mouros, provavelmente os mesmos que trabalhavam para o rei em Évora. Todo o Palácio Real de Sintra mostra uma marcada e estranha semelhança com os edifícios daquela velha cidade distante, mas nenhuma com os de Lisboa e arredores (HAUPT, 1986, p.113).

Compreende-se, assim, um pouco do interesse de Lino por Sintra, pelo Palácio Real e por Évora: ele começa, por esses lugares, a encontrar uma das raízes da arquitetura portuguesa, a árabe. Mais tarde, em 1902, viaja a Marrocos, talvez como conseqüência da ida ao Alentejo, em busca de raízes mais profundas. E, tal como Haupt, encontra-se Lino viajando a fim de observar, conhecer e registrar aspectos culturais, principalmente da arquitetura. $\mathrm{O}$ próprio arquiteto afirma que essa viagem a Marrocos foi bastante importante para o exercício de sua profissão. No seu projeto de pavilhão para a Exposição Universal de Paris, 1900, aparecem "reminiscências amouriscadas do nosso Alentejo" (LINO, 1969), tal como em outros projetos aparecem características marroquinas, por exemplo, nas casas Rey Colaço, Silva Gomes, Jorge O`Neill, Vila Tânger (Ribeiro, 1994, p.29, 20, 35).

Raul Lino põe em causa e trabalha sempre, durante toda sua trajetória profissional, como arquiteto e como teórico, o problema da expressão da tradição e das origens culturais. Assim, segundo Ribeiro (p.99, 1994), para ele a casa portuguesa definiu-se no segundo quartel do século XVII, "dentro de um estilo barroco dominante”. Esta autora afirma que o arquiteto considerava também o Manuelino como o primeiro estilo português (RIBEIRO, 1994, p.86).

É, portanto, muito significativo que sua produção pareça, por vezes, uma colagem de vários estilos; afinal, no seu pensamento a arquitetura portuguesa era uma mistura de muitas influências. Contudo, o próprio arquiteto defende-se desse tipo de crítica na sua obra teórica. Em Casas Portuguesas: Alguns Apontamentos sobre o Arquitectar das Casas Simples, de 1933, ele mostra que a mera junção de alguns detalhes ou ornamentos não qualificam devidamente o edifício e seu espaço, nem o 
caracterizam como sendo próprio de uma nação, como se pode deduzir pelo trecho de sua autoria:

o autor tendo ouvido alomear que o arco de ferradura é autenticamente árabe, à última hora resolve imprimir um par de ferraduras no meio da fachada, para que de arqueologia não deixe de haver também sua pitadinha... Bravo! Está terminada a obra; só lhe falta falar. Mas a obra não diz nada, parecendo tudo consentir. Saxa loquuntur é mentira como todas as figuras de retórica (LINO, 1993, p.69).

Pelo exposto, nota-se que a intenção de Lino, enquanto arquiteto, é ampla. Esteve sempre preocupado - além de sua inquietação acerca das origens culturais - com a qualidade do espaço. Segundo seu neto, o também arquiteto Diogo Lino Pimentel, Raul Lino não buscava um "estilo" e não propalava, em suas obras teóricas, que o "estilo" era importante. Ao contrário, seu intuito era o de indicar "o que era importante numa casa, para se viver de maneira agradável". Nunca quis disseminar receitas, pois para ele importava a expressão cultural própria de cada época e, mais que tudo, a qualidade do espaço. No desenvolvimento dos seus projetos, ainda segundo as palavras de Diogo Lino Pimentel, fossem de edificações ou de objetos, as características não eram as da forma pela forma, mas da forma que nascia de dentro, das necessidades internas ${ }^{20}$. Alguns autores ${ }^{21}$ entendem que a atitude projetual do arquiteto era, já, um tanto moderna, como menciona o Professor Engenheiro Costa Lobo, quando relembra a postura "sempre aberta ao novo e muito modernista" 22 de Lino, nas reuniões da Junta Nacional de Educação ${ }^{23}$. Nesse mesmo sentido, recordamos que o último inquérito à arquitetura portuguesa afirma que Lino "valoriza uma postura teórica tão inovadora quanto moderna, baseada no entendimento do sítio, na reinvenção dos materiais tradicionais e na importância da vivência doméstica” (TOSTÕES, 2006, p. 18).

Como essa característica era compatível com seu tradicionalismo? Aqui, mais uma vez se evidencia o aspecto ambíguo dos pensamentos desses intelectuais das

\footnotetext{
${ }^{20}$ Entrevista com o arquiteto Diogo Lino Pimentel, neto do arquiteto Raul Lino, realizada em 28/01/2006, na Casa do Cipreste, projetada por Raul Lino em Sintra.

${ }^{21}$ Almeida, Pedro Vieira de. Raul Lino ensina a Olhar. Mesa Redonda: 28/10/2005, 17h - Palácio Vilaças, Sintra.

${ }^{22}$ Conversa com o Professor Engenheiro Costa Lobo no dia 28/01/2006.

${ }^{23}$ O Prof. Dr. Costa Lobo esclareceu que a Junta Nacional de Educação (4 ${ }^{a}$. Subsecção da $2^{a}$. Secção) foi a instituição que deu origem ao IPPC - Instituto Português do Património Cultural - que, mais tarde, se transformou no atual IPPAR - Instituto Português do Património Arquitectónico. Acrescentou que lá - na Junta - o arquiteto Carlos Ramos trabalhou com Raul Lino e eram, os dois, as principais figuras das reuniões, mas o primeiro não era seguidor ou discípulo do segundo. Informações retiradas também da nota 10 .
} 
primeiras décadas do século XX, que viveram entre a necessidade de afirmação de uma identidade e o avanço da modernidade, que pretendia se desligar da tradição cultural e olhar para o futuro. Os descendentes de Lino argumentam que ele defendia "não deitar fora o que fosse bom da «casa portuguesa»" e conjugar essas qualidades com as "boas novidades", no seu entender. O Dr. Martinho Pimentel - bisneto de Raul Lino exemplifica que

a Casa do Cipreste não é exactamente uma casa portuguesa, mas os elementos que a ela podem ser atribuídos lá estão presentes”. Afirma também que a preocupação do bisavô era a "de não perder as raízes, ou melhor, perceber as raízes para não esquecer do ponto de partida, mas sem deixar de andar para a frente; não estava pensando em buscar a identidade nacional (PIMENTEL, 2006) (FIGURA 15).

É claro que este vem a ser um ponto bastante discutível, embora seja também um dos que fazem de Raul Lino uma figura de grande interesse, para se compreender a arquitetura do período e, inclusive, de períodos posteriores, tanto que um dos trabalhos mais completos sobre o arquiteto e seu pensamento, de autoria de Irene Ribeiro, leva o nome de "Raul Lino, pensador nacionalista da arquitectura” (RIBEIRO, 1994).

É certo que sua sensibilidade para produzir uma arquitetura de qualidade, a despeito das críticas de que foi alvo, pode ser atribuída à sua formação romântica, ao seu convívio com Haupt - que desenhou e fotografou enorme quantidade (mais de 300) de objetos e edificações portuguesas de várias épocas - e, claro, à sua tendência natural. Seus descendentes asseguram que estava sempre atento, dava muito valor ao sentido da observação e desenhava assiduamente. Lino recusou-se ao uso da máquina fotográfica, preferindo desenhar, sobretudo, a fim de conhecer, compreender e aprender sobre a construção, além de preocupar-se com o registro e com o domínio das dimensões. Como exemplo de seu estudo através da observação e do desenho, o arquiteto Diogo Pimentel conta que foi olhando e desenhando inúmeras janelas, portuguesas, mouriscas, alemãs, entre outras, que Lino descobriu a origem genovesa dos cogumelos das janelas do Palácio Real de Sintra (PIMENTEL, 2006). Além disso, os descendentes falam também em reinterpretação pelo desenho. Dessa maneira, não podia haver "colagem" ou cópia nas obras de Lino: ele observava, desenhava, reinterpretava e se expressava. É assim que, mesmo que se possa identificar as suas referências ou influências, em suas criações se nota, sempre, a sua "maneira de fazer". Como exemplo disso, seu neto menciona as 
curvas, que são características dos trabalhos de Lino: seja nos telhados, nos candelabros ou em outros objetos, são sempre curvas suaves. Afirma, inclusive, que entre seus estudos, deixados no arquivo da família, é possível encontrar desenhos de características barrocas, especialmente de objetos, mas que eram feitos com o mesmo intuito, o de conhecer. E salienta que Lino não produziu nada que se referisse a tal "estilo" (PIMENTEL, 2006) ${ }^{24}$. Foi fundamental, portanto, para sua expressão e seu raciocínio, essa experiência proporcionada pelo desenho e, ao certo, daí provém a importância que Lino atribuía à proporção, que é uma das características marcantes dos seus projetos e de suas recomendações teóricas. Associada a outros componentes de sua forma de projetar, a proporção ajudava a compor um aspecto especial, em suas obras, para cuja definição Ribeiro (1994, p.37 e 38) emprega o termo "cenográfico". Lino também chegou a estudar Botânica, o que lhe serviu para “aprender com a natureza”, especialmente nas pequenas viagens que fazia pelo interior da serra de Sintra (PIMENTEL, 2006). Certamente, essa atenção ao entorno natural inspirou a grande importância que dava à relação de suas obras com a paisagem, com os elementos vegetais e o modo como resolvia a implantação.

Ainda relacionada à questão da proporção está a relação de Lino com a música. A visita à Casa do Cipreste, para entrevista com os descendentes do arquiteto, foi valiosa, pois proporcionou a percepção de como Lino trazia seu conhecimento musical para a arquitetura (PIMENTEL, 2006). Seu bisneto Martinho Pimentel, que atualmente é quem vive na casa, descreveu suas impressões com relação aos sons da mesma. De início, contou que para Raul Lino o barulho da porta de entrada é importantíssimo, numa moradia: seria como um aviso, que transmite ou não segurança, e dá a conhecer aos moradores quem chega, pelo modo como um ou outro abre e fecha a porta. Mencionou, ainda, como sente que a proporção e a escala são extremamente importantes para dar a noção de espaço - uma vez que essa noção está ligada aos sons dentro dos ambientes que transmite a sensação de segurança, de conforto, de interioridade, e até mesmo de calor. Depois mostrou, na Casa do Cipreste, que a sala de estar tem uma acústica excelente e está totalmente adequada aos recitais, como os que aconteciam na casa, na época em que lá vivia Raul Lino. As paredes não são paralelas; o forro apresenta vários

\footnotetext{
${ }^{24}$ Notou-se, durante a conversa, certa recusa em aceitar que Raul Lino tenha posto em suas obras, caracteres que remetam ao Barroco. Talvez devido ao fato de ser, este "estilo", muito criticado, especialmente pela geração modernista, em Portugal (da mesma forma que, no Brasil, a mesma geração negou tudo o que se referia ao Ecletismo).
} 
planos inclinados; e, finalmente, o ambiente possui uma caixa de ressonância - uma sala semelhante, no piso de baixo, que, quando as portas estão fechadas, proporciona à sala de cima um desempenho acústico ótimo. Não existe reverberação de som nessa sala, de modo que uma conversa pode se manter clara, mesmo num tom baixo. Em contraste, na sala de jantar o trabalho com os sons é diferente. Nessa sala acha-se uma única e grande mesa, ao redor da qual se espera que as pessoas se reúnam para as refeições. Segundo Martinho Pimentel, a intenção do arquiteto, nesse espaço, é a de que todos participassem da mesma conversa. Trata-se de um ambiente oval, em planta, cujas paredes acompanham a forma, fazendo com que os sons se propaguem de maneira que tudo o que se diz de um lado é audível do outro. Na entrada, no hall, uma canalização de água, que provém da Serra de Sintra, foi concebida para formar uma "bica" que faz constantemente barulho de água corrente (PIMENTEL, 2006). No mais, a casa apresenta outras características próprias de Lino, como, por exemplo, a ligação com o movimento Arts and Crafts, visível na forma como comparecem os traços da arquitetura tradicional portuguesa, os nichos, os armários embutidos, também presentes, e a preocupação com a inserção na paisagem e com o usufruto da mesma. A sala de estar tem uma parede com aberturas que oferecem uma visão privilegiada do Palácio Real de Sintra, tão caro ao arquiteto. Assim, a formação e as convicções de Lino traduziram-se numa linguagem muito particular e rica, na qual podem ser lidas diversas influências.

Por seu profundo envolvimento na prática da arquitetura ${ }^{25}$, assim como pela produção de uma obra teórica cujo intuito era orientar a construção de edifícios residenciais dentro dos cânones da "boa" arquitetura portuguesa, Lino foi reconhecido como o precursor e líder do movimento da casa portuguesa. Ribeiro (1994, p.93) mostra a importância de seu papel nesse processo e, ao mesmo tempo, afirma que seus esforços foram engolidos pelos novos e modernos tempos, que já se anunciavam: “ $A$ «casa portuguesa» não passava afinal de uma ficção. Raul Lino tinha dado vida a um sonho”.

\subsection{Síntese das Trajetórias de Severo e Lino}

Como síntese dessa breve descrição das trajetórias de Severo e Lino, vamos estabelecer uma linha de análise a partir de Silva (2005). Essa autora levanta a

$25 \mathrm{O}$ arquiteto também produziu obras institucionais e comerciais, além das residenciais, muito desconhecidas. Encontramos em seu espólio, na Fundação Calouste Gulbenkian, 39 projetos comerciais/industriais; 20 religiosos e 46 institucionais, entre outros de outras naturezas. 
possibilidade de Severo ter sido influenciado por Lino e pelo movimento da casa portuguesa, quando retorna a Portugal, em 1897:

o retorno [de Severo] ao Porto coincidiu com o surgimento em Portugal de um movimento nacionalista de revivescência da casa portuguesa, capitaneada pelo arquiteto Raul Lino (...): O movimento arquitetônico, que se opunha ao ecletismo ao propor a retomada de uma «arquitetura autóctone», pode ter de algum modo influenciado Severo, que anos depois encetaria uma campanha semelhante no Brasil (SILVA, 2005, p. 56).

E continua, conjeturando que a casa no Porto teria sido a "primeira vez [em que o engenheiro] experimentou o desafio de «harmonizar» as referências da arquitetura portuguesa com as exigências de conforto da casa moderna” (SILVA, 2005, p. 56). Segundo nossa análise anterior, Lino havia saído do país ainda muito jovem e teria retornado a Portugal, coincidentemente, no mesmo ano em que o fez Severo, 1897. Nesse momento, como vimos, a inquietação intelectual em favor do fortalecimento da nacionalidade, das tradições e do republicanismo já havia sido deflagrada, e vinha amadurecendo desde 1890, data do Ultimato Inglês. Severo esteve muito envolvido nesse processo, portanto acreditamos que estava, já, completamente imbuído de um espírito capaz de mover um movimento relativo à arquitetura, além do que, tinha 27 anos de idade e, provavelmente, idéias muito amadurecidas sobre seus interesses. Ao contrário, Lino não participara de tais movimentações. Quando retorna a Portugal tem apenas 17 anos e uma bagagem cultural que abrangia Ruskin e o movimento Arts and Crafts. Começou logo a realizar suas obras, mas ainda não era o notável arquiteto de casas "verdadeiramente" pertencentes à cultura de seu país. Em 1902, quando Severo começa a construir sua casa no Porto, Lino está em digressão pelo Marrocos, ainda em busca de afirmação quanto aos aspectos formadores da arquitetura tradicional portuguesa. A publicação de um projeto seu para uma residência em Coimbra, na revista A Architectura Portuguesa, de 1909, dá mais força à idéia de que Lino começa a ganhar visibilidade, ao final dessa década: “apezar de Raul Lino ser um artista novo, estes esforços [busca de elementos originais para compor arquitetura portuguesa] já são antigos; pois elles lhe teem consumido patrioticamente toda a actividade artística. (...). A Raul Lino se deve uma creação artística nova - a casa portugueza” (A Casa..., 1909, p.29). (FIGURA 16). O arquiteto passou a ser reconhecido como expoente do movimento da casa portuguesa somente depois da publicação das suas obras, a partir de 
$1918^{26}$, as quais cumpriram um papel de divulgação e orientação para quem queria construir segundo a boa arquitetura portuguesa (LEAL, 2000, p.112).

Assim, estamos de acordo com Silva (2005) quando afirma que a casa de Severo, no Porto, com suas características, é a primeira experiência do engenheiro nesse sentido, motivada por uma movimentação intelectual propícia, que vinha se desenvolvendo desde o final do século XIX. Porém divergimos quanto a considerar que Severo tenha sido influenciado por Lino, pois o arquiteto vai se afirmar como a figura mais relevante do movimento da casa portuguesa aproximadamente quinze anos depois do início da construção da casa no Porto. Isso fortalece a hipótese de que Severo tenha sido pioneiro tanto do movimento brasileiro como do português, como Peixoto (1905, p.153) já teria registrado: “O novo prédio que um engenheiro ilustre edificou (...) no Porto, a rua do Conde, veio a dilatar (...) o débil movimento promovido pela aspiração ainda indecisa da nacionalização do domicílio português”. O engenheiro português foi, assim, o realizador das primeiras obras emblemáticas, frutos de tais campanhas tradicionalistas, tanto num país como no outro.

Procuramos também saber se Severo e Lino chegaram a se conhecer e a trocar idéias sobre os aspectos comuns ao trabalho de ambos. Segundo o arquiteto Pimentel (2006), seu avô Raul Lino e o engenheiro Ricardo Severo não mantinham relações e é provável que nunca tenham se encontrado, pois Diogo não tem nenhuma notícia de que o engenheiro tenha frequientado a casa da família Lino. Em nossa visita ao arquivo particular do arquiteto $^{27}$ não encontramos, entre as correspondências, nada que se referisse a Ricardo Severo. Talvez a maior aproximação entre as duas personalidades tenha sido a que foi descrita pelo próprio Lino em seu livro "Auriverde Jornada", quando faz menção às palestras que realizara, em 1935, em São Paulo, na Escola de Engenharia Mackenzie, no Instituto de Engenharia e no Instituto Histórico e Geográfico, as quais teriam sido organizadas por Morales de los Rios e por Ricardo Severo:

\footnotetext{
${ }^{26}$ A Nossa Casa: Apontamentos sobre o Bom Gosto na Construção das Casas Simples (1918); A Casa Portuguesa (1929); A Casa Portuguesa: Alguns Apontamentos sobre o Arquitectar das Casas Simples (1933)

${ }^{27}$ Bernardo Lino Pimentel, bisneto do arquiteto Raul Lino, e sua esposa, Madalena Pimentel, guardam parte do espólio deixado por Raul Lino, onde estão os seus desenhos e estudos de artes decorativas e as suas correspondências pessoais, em sua residência em Lisboa. Foi-nos gentilmente permitida uma visita a esse arquivo em Fevereiro de 2006.
} 
Mal parecia guardar silêncio sobre algumas destas rápidas impressões colhidas na capital paulistana onde o incansável Prof. Morales de los RiosPresidente do Conselho Federal de Engenharia e Arquitectura - por um lado, e o grande português Ricardo Severo, (a-pesar-de ausente), com o seu enorme prestígio, pelo lado da nossa Colónia, tudo haviam previsto para que tivéssemos uma esplêndida recepção sancionada pelo Exmo. Prefeito Municipal, Dr. Fábio Prado (LINO, 1937, p. 107). 
Capítulo 2

UM PARALELO: DIFUSÃO EM PORTUGAL 
Durante a pesquisa em Portugal, pudemos observar a ocorrência de difusões de linguagens arquitetônicas relativas àquela atmosfera propícia aos debates e à construção do que se pensava ser a arquitetura portuguesa. Por uma questão de prioridade e tempo, deixamos de aprofundar as pesquisas nesse sentido, mas conseguimos levantar um bom material em alguns arquivos municipais, que dão bons indicativos sobre essa difusão. De início, verificamos que, tal como no Brasil, onde, no bojo do movimento neocolonial, floresceram vertentes diversas - muitas vezes misturando estilemas da arquitetura portuguesa, de Severo; da missões; da Marajoara -, em Portugal também foram geradas variações, dentro do contexto de reflexões sobre o que seria a "verdadeira" arquitetura portuguesa, tais como o movimento da casa portuguesa e o florescimento do gosto neobarroco. Pudemos observar a difusão devida a algumas variáveis (certos atores e adventos) que funcionaram como catalisadores para a proliferação de edificações que, pelas suas características, podem ser identificadas com os movimentos e tendências anteriormente citados. São elas a interferência do Estado Novo (1933-1974), através da atuação de um de seus ministros, e o histórico do Prêmio Valmor $^{1}$. Essa estratégia não fazia parte de nosso método de pesquisa original, mas fezse necessária, ao longo de nosso estudo sobre o material levantado em Portugal. Primeiro apresentamos as circunstâncias gerais ligadas ao Ministro Duarte Pacheco, depois os resultados dos levantamentos realizados em arquivos das cidades de Lisboa, Porto, Cascais / Parede / Estoril. Na análise sobre Lisboa, incluímos uma leitura sobre os Prêmios Valmor e algumas observações sobre o Pavilhão das Indústrias Portuguesas para a Exposição internacional de 1922, no Rio de Janeiro.

\subsection{Circunstâncias Gerais, 1933-1950}

Em Portugal, até o início do Estado Novo, em 1933, apesar do movimento em prol de uma arquitetura tradicionalista, que já vinha se desenvolvendo desde o início de 1900, essa arquitetura não figurava como arquitetura oficial. Isso vai acontecer somente durante o intervalo havido no decurso do estabelecimento da arquitetura modernista no

\footnotetext{
${ }^{1} \mathrm{O}$ "Prêmio Valmor" é um prêmio pecuniário a ser dividido entre o arquiteto e o proprietário da obra, concedido anualmente pela Câmara Municipal de Lisboa. Os fundos para o prêmio foram deixados em testamento pelo "Visconde Valmor" Fausto Queiroz Guedes. É atribuído por um júri de três arquitetos nomeados pela Câmara Municipal e foi associado, a partir de 1982, ao Prêmio Municipal de Arquitetura.
} 
país, que corresponde à década de 1940. A partir do final da década de 1930, o Estado entra na sua fase mais alinhada ao fascismo, diminuindo as possibilidades de modernização da arquitetura portuguesa. Deu-se um retorno às características preconizadas pelo movimento da casa portuguesa, e uma simpatia pela arquitetura neoclássica fascista (TOSTÕES, 2002, p.350). As orientações oficiais para a construção instruíam que os grandes edifícios públicos deveriam aproximar-se da arquitetura clássica e da sua monumentalidade - claramente, uma orientação que se coadunava com a arquitetura fascista. Os edifícios menores, situados nas pequenas localidades, deveriam empregar elementos de raiz cultural rural e regional e, quanto aos médios, estes deveriam apresentar um aspecto híbrido entre os dois primeiros (Pereira, 2000, p.33-39); estes híbridos resultaram no chamado português suave (FERNANDES, 2003, As características mais comuns dessa linha arquitetônica são a monumentalidade, a simetria e o ritmo dos corpos e das fachadas associados a pináculos nos telhados, telhas capa e canal e beirais tradicionalistas. $\mathrm{O}$ arquiteto que mais produziu durante esse período, em Portugal, e que desenvolveu uma linguagem dentro dessa tendência, foi Luís Cristino da Silva.

As pesquisas nos Arquivos Municipais de Lisboa e do Porto mostraram haver uma coincidência entre planos de urbanizações das décadas de 1930 e 1940 e as edificações neles construídas - em geral habitações - de feições tradicionalistas, na freguesia de Santa Maria de Belém, Lisboa, e na freguesia de Lordelo do Ouro, no Porto, para citar alguns exemplos. Um paralelo pode ser realizado com o bairro Jardim América, em São Paulo, onde verificamos o mesmo fenômeno de associação entre o traçado cidade-jardim com edificações tradicionalistas e pitorescas, como podemos observar pelo trabalho de Wolff (2001). Sob o mandato do Ministro de Obras Públicas e Comunicações, o engenheiro Duarte Pacheco - no poder durante os anos de 1932 a 1936 e de 1938 a 1943, durante o governo de Salazar -, foram realizadas importantes obras de modernização da infra-estrutura do país, entre as quais planos urbanísticos. Alguns urbanistas de renome, como Donat-Alfred Agache e Etienne de Gröer, atuaram em Portugal a convite de Duarte Pacheco e foram os principais responsáveis pela introdução e aplicação da teoria cidade-jardim no país, já um pouco tardiamente. 
Donat-Alfred Agache trabalhou na expansão da região Oeste de Lisboa, ao longo da chamada Costa do Sol, em 1935 e 1936, depois de já ter feito o plano para o Rio de Janeiro (1928-1930). É importante notar que o urbanista já havia assimilado os ideais da cidade-jardim e passava a uma concepção mais modernista, valorizando os espaços públicos e as áreas verdes. Primeiro traçou um projeto à escala de Plano Diretor para a região, e depois continuou com Planos de Urbanização para os aglomerados da costa, de Algés e de Cascais e com Estudos de Pormenores de saídas da cidade de Lisboa (LÔBO, 1995, p.61).

Etienne de Gröer foi adepto da teoria da cidade-jardim, conceito que se refletiu fortemente no trabalho que desenvolveu em terras portuguesas, principalmente a partir de 1938 (LÔBO, 1995, p.75). Além disso, foi um grande defensor das habitações unifamiliares, pois visualizava no adensamento e no alto gabarito das edificações sérios problemas, inclusive os de ordem sanitária e de segurança. Trabalhou ativamente para Portugal, realizando Planos de Urbanização para as cidades de Coimbra, Braga, Évora, Costa do Sol (Carcavelos e Cascais), Lisboa, Sintra e Luanda, Angola. Em seus projetos urbanísticos para a Costa do Sol, Gröer definiu zonas em que o tecido urbano foi constituído por um traçado orgânico e adaptado ao relevo, e por edificações baixas e rodeadas por jardim, permitindo, apenas em alguns lugares, edifícios de, no máximo, três pavimentos. No seu projeto para Sintra, o urbanista critica duramente os chalets encontrados no local, sugerindo até a sua demolição e, ao mesmo tempo, faz a apologia da arquitetura tradicional portuguesa (LÔBO, 1995, p.100). Talvez isso explique a existência de vários processos de licenças de obras, cujo projeto mostra transformações de chalets em edifícios cujos telhados seriam refeitos "à moda portuguesa", com beirais revirados e telhas capa e canal ou de canudo, numa clara intenção de "re-aportuguesar" a habitação, ou ir ao encontro da identidade nacional. Segundo Lôbo (1995, p.89),

dentro do espírito restauracionista da época, estabelece a ligação do paradigma da cidade-jardim com a tradição (...), embora se invoquem as tradições locais, a tipologia proposta (...) com habitação descontínua rodeada por jardim não se assemelhava à tipologia tradicional de construções em banda, alinhadas pelo limite da parcela. 
A extensão do conceito de cidade-jardim para subúrbio-jardim, primeiro na Inglaterra, permitiu a identificação deste com as moradias isoladas nos lotes, com seus próprios jardins, com baixa densidade e inequívoca construção de um ambiente pitoresco, associado às idéias românticas do ideal de vida não-urbana. Assim, explica-se a localização de habitações cuja linguagem arquitetônica está visivelmente ligada a esses preceitos e também a uma busca do que fosse a "casa portuguesa", como acontece em Cascais, Parede, Estoril, Santa Maria de Belém, Sintra e no Porto, por exemplo. Assim, pode-se dizer que os trabalhos de Agache e Gröer, especialmente o que se aplicou à zona Leste de Lisboa, até Cascais, contribuíram sobremaneira para configurações urbanas de feições românticas, que evoca os ideais da cidade-jardim e da “casa portuguesa”. (FIGURA17a e 017b; 018a e 018b)

\subsection{Lisboa}

\section{Os Prêmios Valmor}

A análise das obras ganhadoras dos Prémios Valmor mostrou que durante um longo período, que vai de 1910 a 1946 - período de interesse para nossa pesquisa - a tendência oficial era a de incentivar a produção de uma arquitetura tradicionalista na cidade de Lisboa, o que acaba se refletindo em municipalidades próximas, devido à atuação dos mesmos profissionais em diversas localidades.

Em 1910 e 1919 o ganhador do Prêmio Valmor foi Ernesto Korrodi, um arquiteto de origem suíça, naturalizado português. Foi autor de obras de características românticas e ecléticas, e também de restaurações de palácios e castelos. Entre 1921 e 1934 exerceu a função de diretor de obras de uma comissão subordinada à DirecçãoGeral dos Edifícios e Monumentos Nacionais (DGMN), um dos principais órgãos de preservação do patrimônio português. Ganhou também Menção Honrosa, do prêmio, no ano de 1917, com uma obra de telhados tradicionalistas, situada à Rua Viriato, 5. Pudemos localizar, no Arquivo Intermédio, os projetos referentes à sua obra premiada em 1910, situada na Avenida Fontes Pereira de Melo, 30, Lisboa, a qual apresenta características ecléticas, com gradis tendentes ao Art Nouveau, e um telhado com beiral em curva. No memorial descritivo do processo submetido à Câmara Municicpal, o arquiteto faz o seguinte comentário sobre a linguagem da casa: 
quanto ao exterior do prédio as formas architectonicas adoptadas são as tradicionaes do fim do século XVIII, embora com propositada interpretação moderna. Para este effeito e como trecho característico haverá um beiral em telhões vidrados, mas este como indica o detalhe (...) puramente decorativo (FIGURA 19a a 19c).

Em 1914, o Prêmio Valmor foi atribuído ao arquiteto português Álvaro Machado, pela obra situada no Campo Grande, 382, Lisboa, onde atualmente funciona o Museu Rafael Bordalo Pinheiro ${ }^{2}$. O parecer do júri considerou que "duas fachadas de estilização portuguesa recomendam-se” (CÂMARA MUNICIPAL DE LISBOA, 2007) (FIGURA 20).

Em 1921 o Prêmio Valmor foi atribuído, pela primeira vez, a uma obra de restauro, projetada pelo arquiteto português Tertuliano de Lacerda Marques ${ }^{3}$. Não casualmente, tratava-se do restauro de um palácio setecentista, situado a Cova da Moura, $\mathrm{n}^{\mathrm{o}} 1$, cujo projeto foi considerado, pelo júri, merecedor do prêmio por "por se desenvolver dentro de uma arquitectura tradicionalista portuguesa das mais belas" (CÂMARA MUNICIPAL DE LISBOA, 2007). O mencionado arquiteto parece ter sido atuante, no sentido de incentivar a construção de edificações alinhadas ao que se entendia por "arquitetura portuguesa". Foi autor de outras obras em Lisboa e encontramos os projetos de duas delas no Arquivo Intermédio: uma, a habitação na Avenida Columbano Bordalo Pinheiro, 50, construída em 1930, cuja linguagem está totalmente dentro dos preceitos do movimento da casa portuguesa, com volumetria simples, telhado de telhas tipo "marselha", beiral revirado com telhas tipo "portuguesa", decoração com telhas sobre as janelas, painel de azulejos azuis e amarelos, floreiras, arcos e chaminé pronunciada, decorada com telhas, foi demolida em 1991 (FIGURA 22). Outra, uma igreja para a "Congregação Evangélica Alemã”, de 1934, apresenta as mesmas características arquitetônicas, porém é menos ornamentada, e tem pedras na decoração das fachadas. $\mathrm{O}$ arquiteto Tertuliano de Lacerda Marques assumiu cargo público junto à Câmara Municipal de Cascais, nos anos de 1920, e assinava os pareceres da Comissão de Estética do município. Lá também realizou projetos.

\footnotetext{
${ }^{2}$ Desenhista, aquarelista, caricaturista, ilustrador, jornalista, ceramista e professor português (1846-1905). ${ }^{3}$ Sobre o arquiteto ver: Jornal "Diário de Lisboa", 11 de Novembro de 1933. Entrevista com o arquiteto ver: Revista "A Arquitectura Portuguesa", Julho e Agosto de 1911 e Janeiro de 1928.
} 
Em 1930, o ganhador do Prêmio Valmor foi o arquiteto Raul Lino, com a moradia situada à Rua Castilho, 64-66. Curiosamente, o arquiteto recusou-se a recebê-lo pois, segundo consta, a aparência eleita pelo cliente para a casa era demasiado "barroca", apesar de que nela poderiam ser encontrados vários elementos da arquitetura portuguesa (PIMENTEL, 2006). Demolida em 1982, atualmente existe, no local, um estacionamento (FIGURA 21).

Em 1939 o Prêmio Valmor foi para os irmãos arquitetos Carlos e Guilherme Rebelo de Andrade, que venceram o concurso com o projeto de uma residência localizada à Avenida Columbano Bordalo Pinheiro, 52 e 52a , Lisboa, no qual empregam a inspiração $D$. João $V$, que vai estar presente em vários de seus projetos como, por exemplo, no Pavilhão das Indústrias Portuguesas para a Exposição Internacional do Rio de Janeiro de 1922, atual Pavilhão Carlos Lopes, situado no Parque Eduardo VII, Lisboa, do qual vamos tratar a seguir (FIGURA 23a e 23b).

Finalmente, em 1946, no elenco de obras selecionadas para prêmios daquela época, destacamos que o Prêmio Municipal de Arquitetura, de Lisboa, foi concedido ao arquiteto Carlos Chambers Ramos, pela obra situada à Rua D. Francisco de Almeida, 9. Igualmente, apresenta características da casa portuguesa, apesar das modifições atuais (FIGURA 24). Desse mesmo arquiteto foi localizado um projeto, de 1921, de uma reforma no Arquivo Municipal do Porto, que atribuiu à edificação características da casa portuguesa (FIGURA 25).

\section{O Pavilhão das Indústrias Portuguesas, 1922}

No decorrer do levantamento de dados em Portugal, apuramos algumas informações acerca de uma das obras dos irmãos arquitetos Carlos e Guilherme Rebelo de Andrade: o Pavilhão das Indústrias Portuguesas para a Exposição Internacional do Rio de Janeiro de 1922. Uma dessas informações trata da autoria do projeto do Pavilhão, que na historiografia brasileira consta como sendo de Ricardo Severo, embora na historiografia portuguesa não haja dúvidas de que pertence aos irmãos arquitetos acima citados. Detivemos-nos nessa questão por entendermos que interessa diretamente à pesquisa sobre o neocolonial e sobre o seu precursor: o prédio serviu de inspiração para edifícios neocoloniais no Brasil. 
Outras informações estão relacionadas ao renascimento de um gosto pelo barroco, que o Pavilhão teria ajudado a disseminar em obras portuguesas, embora tenham sido criticadas, mais tarde, pelo seu caráter historicista. Assim, como algumas referências são comuns, naturalmente, às produções arquitetônicas brasileiras e portuguesas do período, por vezes assemelham-se. Notamos a existência de uma troca de informações entre Brasil e Portugal acerca da questão maior que preocupava os arquitetos, engenheiros, construtores e intelectuais das primeiras décadas do século XX, que era a de encontrar a arquitetura ideal, ao mesmo tempo genuinamente nacional e moderna. Uma vez mais, as revistas de arquitetura atuaram na divulgação dessas informações, como podemos notar pelo artigo publicado na Arquitectura Portuguesa, de 1937:

Lima Júnior (...)nos contou como tomava impulso o estilo arquitectónico lá [no Brasil] chamado «colonial», preferido e imposto em construções oficiais, estudado e enriquecido pelos mais modernos arquitectos, erguido à categoria de cunho arquitectónico brasileiro. (...) se esta atonia do gosto português (...) se propagar (...) os nossos netos terão de ir ao Brasil para (...) aprenderem a amar e a servir o que resta do espírito português (COLAÇO, 1937, p.8).

Além do conhecimento e do elogio ao movimento neocolonial, podemos verificar, também, que os portugueses reconheciam o seu legado na arquitetura brasileira que se procurava fazer então, aspecto do qual Ricardo Severo ficaria, certamente, orgulhoso.

Os irmãos Carlos e Guilherme Rebelo de Andrade atuaram a partir da década de 1920, principalmente em Lisboa. Realizaram projetos de inspiração no chamado "estilo D. João V" - associado à manifestação do barroco em diversos produtos culturais como móveis, azulejos e arquitetura -, entre os quais se destaca o projeto para o Pavilhão das Indústrias de Portugal, construído na Exposição Internacional do Rio de Janeiro de 1922, e reconstruído no Parque Eduardo VII ${ }^{4}$, Lisboa, dez anos mais tarde.

\footnotetext{
${ }^{4}$ Atualmente Pavilhão Carlos Lopes. "Carlos Alberto de Sousa Lopes" foi um importante atleta olímpico português, tendo se destacado em corridas de longa distância, nas décadas de 1970 e 1980.
} 
Ao contrário do que consta na historiografia brasileira ${ }^{5}$, a autoria desse pavilhão não é do engenheiro Ricardo Severo, que foi apenas o responsável pela sua construção no Brasil (LIVRO..., 1923, p. 314) (FIGURA 26a e 26b). O próprio engenheiro declara, em entrevista, que

os inventores do projecto do Pavilhão [foram] os Srs. Assumpção Santos e Rebello de Andrade" e que "acompanharam o movimento nacional de renascença das artes portuguezas; e bem andaram projectando para a representação de Portugal no centenário brasileiro um espécimen monumental de architectura nossa, do tempo em que brilhou no velho reino a opulência do ouro e das pedrarias do Brasil (LIVRO..., 1923, p. 313).

Severo atribui ainda o "estilo" do pavilhão à inspiração dos claustros dos conventos portugueses, com seus pátios internos, e dos "palácios solarengos do século XVII” (LIVRO..., 1923, p. 314) ${ }^{6}$, que são exemplos de arquitetura barroca portuguesa na construção civil (FIGURA 10). Ao final da entrevista, Severo faz um agradecimento aos trabalhadores responsáveis pela realização técnica e artística do Pavilhão das Indústrias de Portugal, o que pode indicar que ele esteve, de fato, presente na construção do mesmo, na Exposição do Rio de Janeiro.

Outra entrevista que vem comprovar a autoria do Pavilhão pelos Rebelo de Andrade foi dada por eles próprios, na ocasião em que o prédio foi construído pela segunda vez, no Parque Eduardo VII, Lisboa, em 1932. Queixam-se os autores de que não foram chamados para trabalhar na reconstrução, o que qualificam de um "abuso de autoridade" e, portanto, não reconhecem como de sua autoria o que foi reconstruído (UM GRANDE..., 1932). Porém, a entrevista queixosa (UM GRANDE..., 1932) dos autores nos comprova que o mesmo pavilhão foi desmontado no Brasil e montado em Lisboa, dez anos mais tarde, na ocasião da Exposição Industrial Portuguesa. Existiram alterações com as quais os autores não estavam de acordo, quando da remontagem, porém o pavilhão é o mesmo. Encontramos identificação em Kessel (2002, p. 101) com

\footnotetext{
${ }^{5}$ Azevedo, R. M. Las ideas de Ricardo Severo y la relación com el cademicismo. In: Amaral (1994, p 249-258), este autor não afirma que o projeto do Pavilhão seja de Severo, mas inclui uma imagem do mesmo em meio a vários outros projetos de autoria do engenheiro; já Silva (2005, p.66) afirma a autoria do Pavilhão por Severo.

${ }^{6}$ Nesta mesma página, Severo dá mais detalhes sobre os detalhes ornamentais do Pavilhão das Indústria, citando a autoria e descrevendo as cenas dos painéis de azulejo empregados no edifício, Jorge Colaço.
} 
nossa posição, quando afirma que Severo apenas acompanhou a construção do Pavilhão e, por conseguinte, está mais alinhado à postura de que a autoria não é necessariamente desse engenheiro, mas dos irmãos Rebelo de Andrade, como afirmam os pesquisadores portugueses: “O Pavilhão das Grandes Indústrias de Portugal, que só foi aberto à visitação às vésperas do encerramento da Exposição, teve a fase final da sua construção supervisionada por Ricardo Severo, e evocava a época de D. João IV”. (FIGURA 27).

José Augusto França (1981) alerta-nos para o fenômeno do aparecimento de um gosto barroquizante, na década de 1920. Esse autor faz duras reflexões ao gosto pelas características da arquitetura barroca que reaparecem fora de seu tempo, através do trabalho de vários arquitetos:

não valerá a pena certamente nomear aqueles que contribuíram para isso dezenas de arquitectos mediocres que outra coisa não seriam capazes de fazer. O caminho ficara juncado de milhares de moradias baratas - e de algumas construções mais caras, como este palácio reconstruído em “símile” D. João V, à Cova Moura, encomendado por um financeiro Ulrich e Tertuliano Marques em 21 e Prémio Valmor; ou como as duas moradias do conde de Monte Real, à Lapa e em Cascais, obras de 17 e 19, verdadeiras caricaturas do género, a de Lisboa tocando as raias do absurdo "kitsch", com o seu arzinho de miniatura de feira turística... (FRANÇA, 1981, p.337).

No desenrolar do texto, observamos que também os pavilhões das Exposições Internacionais, bem como seus autores, não passaram despercebidos aos olhos aguçados e às palavras críticas do autor:

Para pavilhões de feira de resto se indicava esta estilização cenográfica: já em 1889 vimos levantar um pavilhão assim, na feira parisiense, e em 1922 os irmãos Rebelo de Andrade repetiam a receita na feira do Rio de Janeiro (FRANÇA, 1981, p. 338). 
França ainda dedica algumas linhas à reconstrução do pavilhão do Rio de Janeiro em Lisboa, denotando a aprovação do poder público municipal a tal tipo de arquitetura: "e tanto ele agradou à Câmara que dez anos depois o primeiro pavilhão foi repetido no Parque Eduardo VII, para uma Exposição Industrial, e promovido finalmente a Palácio Municipal de Festas ou de Exposições” (FRANÇA, 1981, p.338). Assim, segundo França (1981, p.338), verificamos que houve em Lisboa, principalmente nas três primeiras décadas do século XX, um "revivalismo barroco", que se difundiu, tendo por importantes propagadores algumas obras públicas. Esse renovado gosto se verifica quando o autor mostra - além da menção já feita às habitações que se espalharam pelo país - que outros pavilhões foram realizados na mesma linha, como segue:

outro do mesmo tipo, e dos mesmos arquitectos, ter sido construído na Exposição de Sevilha de 30. Também no Rio, um pavilhão de Honra foi devido aos jovens Cottinelli Telmo e Carlos Ramos, que sacrificaram ao mesmo gosto (...). Nuns e noutros o "estilo D. João V” reinou, com misturas de Luís XV; no pavilhão que perdurou no Parque, torreões, portal com sacada de gala a coroá-lo, no gosto romano, joanino, balaústres e elementos rococó, painéis de Azulejo de Colaço e de Battistini, duas estátuas posteriores, da Arte e da Ciência, de Raul Xavier (1935) dão um conjunto que traduz como propositadamente a falsidade de um espírito de "pastiche", posto à solta em obra pública (FRANÇA, 1981, p.338) (FIGURA 28).

Esses dois últimos pavilhões citados também se utilizaram da evocação à linguagem barroca, demonstrando que a lembrança do período D. João $V$ era reconhecida, pelos arquitetos, pelo poder público e pelo público em geral, como representativos da arquitetura portuguesa. E, sem dúvida, como também já foi citado, tal gosto foi assumido pela população e pelas "dezenas de arquitectos medíocres que outra coisa não seriam capazes de fazer", difundindo uma arquitetura repleta de elementos barroquizantes. Curiosamente, tais pavilhões, que foram para a exposição do Rio de Janeiro de 1922, estiveram ao lado de outros, brasileiros, igualmente plenos de referências à arquitetura barroca. Mais curioso foi constatar que, em Portugal, a crítica preconceituosa - baseada em premissas modernistas, da qual França (1981) é um dos 
responsáveis - volta-se, antes, a essas manifestações neobarrocas, mais do que à eclética de influência européia. Isso talvez se deva à profusão decorativa, contrária à limpeza e à racionalidade modernista, e ao fato de que a própria arquitetura barroca portuguesa foi, e ainda é, alvo de desvalorização pela historiografia ${ }^{7}$.

Esse neo-barroco das exposições internacionais, então em voga, português ou brasileiro, parece ter se disseminado largamente e se misturado com manifestações do nosso neocolonial. Pinheiro (2005, p. 57), por exemplo, flagra a "influência direta do pavilhão português no corpo central e na fachada" do Colégio Pedro II, localizado à Avenida Alfredo Balena, Belo Horizonte, Minas Gerais e, “ao mesmo tempo, o correr de janelas nas alas laterais remete ao pavilhão mexicano" ${ }^{\prime 8}$ da exposição de 1922, no Rio de Janeiro. Segundo consta, a escola foi inaugurada em 1926, e a autoria do projeto é do arquiteto Carlos Santos, que ainda foi responsável pelos trabalhos de ornamentação do hall, salão de festas e porta principal (SILVEIRA ${ }^{9}, 1926$ apud COLÉGIO..., 2003) (FIGURA 29).

\section{Levantamento no Arquivo Intermédio}

Fizemos um levantamento de processos de aprovação de obras no Arquivo Intermédio, que é o setor do Arquivo Municipal de Lisboa onde ficam depositados os documentos dessa natureza. $\mathrm{O}$ sistema de busca do arquivo permite que se façam buscas por endereço da obra, por autor e por assunto, mas não por data. Isso dificultou nosso trabalho, mas, afinal, encontramos vários processos de interesse. Selecionamos, primeiro, os Prêmios Valmor e, em seguida, obras dos mesmos arquitetos ganhadores dos prêmios. Finalmente, verificamos alguns processos localizados nos arredores daqueles já identificados, e que apresentaram as características que buscávamos. Infelizmente, pelo alto custo das cópias, tivemos que escolher algumas, das que receberam os prêmios (já mostradas), e uma do arquiteto Sérgio Botelho de Andrade

\footnotetext{
${ }^{7}$ Ao analisarmos a obras de Raul Lino, por exemplo, muitas vezes nos deparamos com desenhos e elementos que, claramente, fazem referência à arquitetura barroca, como nas FIGURAS 010c e 015. Essa idéia de associar Lino à arquitetura barroca, porém, não foi bem aceita nem pelos pesquisadores nem pelos descendentes do arquiteto, com os quais conversamos. Lino também foi alvo de duras críticas provenientes de postura modernista, mas recentemente tem sido reabilitado e reconhecido como um importante arquiteto de produção profícua; ver na sua obra características barrocas não contribui para sua valorização, talvez porque a própria arquitetura barroca portuguesa ainda careça de reconhecimento.

${ }^{8}$ Destacamos a legenda das fotos dos prédios do pavilhão português e do edifício escolar, na FIGURA 25, sem número de página. (Pinheiro, 2005).

${ }^{9}$ SILVEIRA, Victor. (1926). Minas Gerias. Belo Horizonte: Imprensa Oficial. P543/4.
} 
Gomes, que mostra certo hibridismo entre o apego às tradições e a reserva em apostar, inteiramente, na estética modernista. A esse meio caminho recorriam vários profissionais, como se pode ver, por exemplo, pelo projeto publicado na revista Aquitectura, de 1937, do arquiteto Vasco de Moraes Palmeiro (Regaleira): “o tipo arquitectónico desta casa é absolutamente moderno, sem contudo perder o carácter nacionalista” (COLAÇO, 1937, p.170-171) (FIGURA 30).

Lisboa, como uma cidade muito antiga, apresenta um panorama arquitetônico diversificado, com obras que testemunham vários períodos históricos, como as da região da Baixa Pombalina, do século XVIII; o Mosteiro dos Jerónimos, importante exemplar da arquitetura manuelina, iniciado em 1502; o palácio Nacional de Sintra, iniciado pelos mouros; e, o Castelo de São Jorge, provavelmente, do século II a. C., para citar alguns exemplos emblemáticos. Assim como em outras cidades portuguesas, pudemos verificar que as edificações cuja linguagem está ligada ao movimento da casa portuguesa e outras vertentes tradicionalistas começam a aparecer com maior freqüência a partir de 1930. Isso ficou mais claro com os levantamentos de processos de licenças para construção no Arquivo Intermédio. Antes, desde fins do século XIX, é muito comum encontrarmos conjuntos e exemplares importantes da arquitetura eclética, que convivem na paisagem com as construções altas, de fachada estreita e "em banda" (geminadas). Os chalets ecléticos, também desse período, se diferenciavam por estarem isolados nos lotes. Na Avenida de Berna, nas proximidades do local onde foram fotografados alguns exemplares de interesse (FIGURA 32), encontramos um projeto de 1945, no número 22 , referente à Central Telefónica do Campo Pequeno (Anglo Portuguese Telephone Co. Lda.), do arquiteto Fernando de Castro Freire, com todas as características do movimento da casa portuguesa, já mencionado.

A maior concentração de projetos de interesse está na Rua D. Francisco de Almeida, situada nas proximidades da Torre de Belém, já no limite oeste de Lisboa, região de habitações de alto padrão, onde atualmente se encontram embaixadas e outros edifícios oficiais, como, aliás, também ocorreu no Jardim América, em São Paulo. Essa Rua D. Francisco de Almeida é parte de um plano urbanístico da década de 1940 e teve influência das idéias do urbanista Etienne de Gröer. A maior parte dos projetos aí localizados segue a estética da casa portuguesa, incluindo o Prêmio Municipal de 1946, do arquiteto Carlos Chambers Ramos. Algumas de suas características mais comuns são as telhas de "marselha" com beirais revirados em telhas "portuguesas" para efeito 
decorativo, arcos, vergas retas nas janelas, chaminés pronunciadas, painéis de azulejos, floreiras. Outros arquitetos, autores de habitações de mesmas características, nessa localidade, são:

Sérgio Botelho de Andrade Gomes: é de sua autoria a obra localizada à Rua D. Francisco de Almeida, 25, cujo processo de aprovação de obras é datado de 1949. A edificação apresenta telhados com beirais e chaminés tradicionalistas, associados a linhas retas. Os guarda-corpos das varandas, com seu desenho retilíneo e limpo, conferem horizontalidade ao conjunto da obra e já remetem à estética modernista. Utilizou-se concreto armado na construção (FIGURA 31).

Luís Bevilaqua e Eurico Pinto (projeto de 1939); Luís Mateus Júnior (projeto da década de 1940, em cujo memorial descritivo há um trecho que demonstra uma preocupação com o “aspecto rústico” da obra); José Almeida Segurado (projeto de 1949); Raul Tojal, (projeto de 1942); João Simões (dois projetos de 1943); Jorge Segurado (projeto de 1944); Luís Mateus Júnior (projeto de 1948); Luís Xavier (projeto de 1949). O memorial descritivo deste último projeto diz que o arquiteto lançou mão de "alguns elementos da construção rústica, tais como um pouco de movimento no telhado, umas varandas, tapa-luzes nas janelas e um soco rústico”; também está descrito que o telhado leva telha de "Marselha" com "beiral à portuguesa".

Encontramos uma exceção a esse padrão que se estabeleceu na região da Rua D. Francisco de Almeida, que é o projeto para a própria casa do arquiteto Inácio Ramon Tomás Peres Fernandes, modernista. Isso sugere que, apesar da tendência e apesar, até, das orientações oficiais para se construir "à portuguesa", foi possível o uso de outras orientações estilísticas. A opção por um determinado "estilo" era uma questão que envolvia diversas motivações, que iam desde o gosto dos clientes - talvez, mais predispostos a aceitar um aspecto tradicional para suas residências - até aconselhamentos oficiais, possibilidades técnicas etc.

\subsection{Porto}

A paisagem predominante na região mais antiga da cidade do Porto é composta pelas edificações "em banda", de fachadas estreitas a altas (três a quatro pisos), configurando um espaço de alta densidade, como já foi mencionado (FIGURA 6). Essa também é a paisagem que se vê a partir do Rio Douro. São marcantes, também, as 
igrejas, em geral localizadas em largos que aliviam a densidade, sendo, muitas delas, barrocas, e dentre as quais algumas são obras do mais importante construtor e arquiteto do século XVIII, no local, Nicolau Nasoni, um italiano. Assim, quando, no início do século XIX, Severo constrói sua casa, as características que mais a diferenciam são o isolamento no lote e a linguagem diferente da eclética.

A pesquisa no Arquivo Municipal indicou que até, aproximadamente, 1930, a tradicional configuração "em banda" permaneceu, associada ou não a uma linguagem eclética, como no caso de outras cidades. Dentre os arquitetos mais conhecidos e que trabalharam com a tendência tradicionalista, encontramos, no arquivo do Porto, um projeto de Raul Lino, que data de 1930 - e, naturalmente, apresenta a linguagem do movimento da casa portuguesa (FIGURA 33) - e um de Carlos Chambers Ramos - para a reforma de uma habitação, que data de 1921 (FIGURA 25). Existe a possibilidade de haver mais projetos cujos autores trabalharam, também, no Sul do país, mas no período e regiões do Porto pesquisadas por nós, localizamos apenas os dois, acima citados.

Os processos de interesse, anteriores a 1925 são, em sua maioria, de autoria de mestres-de-obras. O maior número de processos cujos projetos apresentam a tendência tradicionalista são os de Francisco do Santos Silva, Manoel Francisco Rodrigues e Antonio Rodrigues de Carvalho (FIGURA 34). Um projeto, do mestre José Francisco Duarte, de 1925, destina-se a uma edificação geminada, de fachada estreita, diferentemente dos demais projetos encontrados, porém com decorações "à portuguesa”. Um arquiteto, Aucindio Ferreira dos Santos, aparece, nessa época, com projetos de mesma tendência. Três processos que datam de 1922, mas cuja autoria não foi possível identificar, também estão alinhados à estética da casa portuguesa. Um deles está localizado na mesma rua onde Severo construiu sua casa (FIGURA 35) e tem algumas características que a ela se assemelham, como os recuos e os telhados. Outro, que pode ser considerado como difusão da linguagem de Lino (FIGURA 36), tem telhado em ponta e janelas em forma de ferradura, de tendência "arabizante". O terceiro é um projeto para um bairro operário, que se constitui de um "grupo de "casas portuguesas" pitorescas", como consta na memória descritiva, de dois pavimentos, geminadas e com telhados “à portuguesa” (FIGURA 37).

A partir de 1926, aumentou o número de processos de interesse para a pesquisa De alguns deles não foi possível identificar a autoria. Dentre os projetos de autoria identificada, os arquitetos que mais aparecem são: Serafim Martins de Sousa, com dois 
projetos de 1929 (FIGURA 38); Manuel Marques, com projetos nos anos de 1934, 1937 e 1938 (FIGURA 39); e João Queirós, com projeto de 1943, na freguesia de Lordelo do Ouro, no Porto, região onde várias edificações apresentam a estética da casa portuguesa.

No Porto, existiu uma “Comissão de Estética”, desde 1917, cujas atribuições eram as de emitir pareceres sobre projetos a construir ou reformar, sobre o valor histórico e/ou artísticos de edificações, monumentos ou espaços públicos, decidindo-se, a partir daí, sobre a permissão para demolição, e promovendo a conservação dos mesmos (Regulamento da Comissão de Estética da Cidade). Em 1938 já tinha passado a ser "Conselho de Estética e Urbanização do Porto" e aprovava projetos “à portuguesa", como foi observado no processo 579/1938, referente a uma obra localizada à Rua Fonte da Arcada, no qual se encontrou um parecer aprovando o projeto, cuja descrição é semelhante à casa de Ricardo Severo.

\subsection{Cascais, Parede e Estoril}

O Concelho de Cascais, que engloba as freguesias de Cascais, Parede e Estoril, entre outras, é uma região de vocação turística, localizada a oeste de Lisboa, junto à costa, escolhida para construções de "segundas moradias" ou moradias para final de semana e férias. A região apresenta acentuada influência da teoria cidade-jardim, como já exposto anteriormente. Predomina na paisagem a casa isolada no lote, com jardins e muros baixos (FIGURA 40). Tal conjunto de características permitiu que a manifestação arquitetônica ali surgida nas primeiras décadas do século XX estivesse bastante ligada ao movimento da casa portuguesa. Embora a influência eclética também se tenha dado, ocorreu de maneira mais amena que nas demais cidades pesquisadas. Ou, possivelmente, o número de reformas realizadas a fim de "re-aportuguesar" as edificações tenha sido muito expressivo. Nos anos de 1920, diferentemente dos outros locais, não foi encontrado nenhum projeto de cariz eclético, o que indica ter sido, essa estética, pouco freqüente nesses anos. Encontramos alguns projetos de reformas de “chalets", levadas a cabo, na década de 1930, para "re-aportuguesá-los”, dos quais temos exemplos realizados pelo arquiteto Tertuliano de Lacerda Marques. Um de seus projetos foi localizado no arquivo de Cascais, no setor de Parede, e mostra a reforma da 
fachada, a fim de fazê-la "à portuguesa" (FIGURA 41). Outro projeto para reforma, de sua autoria, publicado na revista A Arquitetura Portuguesa, fez surgir, de uma

primitiva casa onde o sopro da arte jamais passara, teve [o proprietário] $o$ louvável tino e intuição de transformar esse «monstro» numa aprazível vivenda" "a linda casinha em estilo tradicionalista (...) era um desses barracões inestéticos que o lápis primoroso do arquiteto Tertuliano Marques, fez renascer no seu aspecto agradável e correcto que agora apresenta (CASA..., 1928, p.2) (FIGURA 42).

Durante os anos de 1920 e 1930, os processos de aprovação de obras apresentam pareceres das "Comissão de Estética", assinados pelo mesmo arquiteto Tertuliano de Lacerda Marques. Nota-se, pelos documentos, a tendência à aprovação da estética tradicionalista para as edificações, especialmente habitações (FIGURA 43).

A partir de 1930, começam a aparecer edificações de linhas mais retas e tendentes à estética Art Déco e modernista, como, por exemplo, o projeto para o "Royal Cine de Parede", de 1945, e o "Rink de Patinagem" de Estoril, do mesmo ano. Contudo, a partir da década de 1940, os pareceres do Plano de Urbanização da Costa do Sol, que também registra questões de cunho estético, continuam aprovando a presença de características da casa portuguesa nos projetos a serem construídos ou reformados.

Pelo fato de Cascais, Parede e Estoril serem freguesias muito próximas, e por estarem próximas, também, de Lisboa, foi comum encontrar os mesmos profissionais atuando tanto em uma localidade quanto em outra, no período determinado para nossa pesquisa, que foi de 1925 até 1945. Assim, durante a década de 1920, a maior parte dos processos pesquisados foi requerida por mestres-de-obras, sendo que o profissional mais freqüente é o mestre Domingos Teixeira Dos Santos. Os profissionais eruditos encontrados em processos desses anos foram os arquitetos Joaquim Moreira de Lemos e João Antunes (formado pela Escola de Belas Artes de Lisboa), e o engenheiro Luiz Ernesto Ruprano.

$\mathrm{Na}$ década de 1930, os profissionais eruditos mais freqüentes foram os engenheiros Artur José Nobre e Alberto Villaça e os arquitetos Vasco Regaleira que, como vimos, atuou também em Lisboa, e Adelino A. Nunes. Entre os mestres-de-obras, 
António Ferreira Meirinha, Francisco Nunes Vicente e Domingos Ribeiro. A partir de 1940, os mestres José Afonso Vilar Júnior e Alfredo Antonio de Figueiredo, e os arquitetos Dario Silva Vieira, Filipe Nobre De Figueiredo e Vasco Pereira de Lacerda Marques, talvez descendente do arquiteto Tertuliano de Lacerda Marques. Esse quadro mostra que a atuação dos arquitetos foi maior a partir de 1940, mas, mesmo antes, tanto mestres-de-obras como engenheiros freqüentemente adotavam, para suas obras, a estética da casa portuguesa

As características comumente encontradas nas obras - tanto de Lisboa, como do Concelho de Cascais e do Porto - são a volumetria com algum movimento, telhados movimentados com beirais revirados de telhas capa-canal (tipo "portuguesa" ou tipo “canudo"), janelas de vergas retas, arcadas nas varandas, chaminés pronunciadas e, por vezes, decoradas nos cimos com ornamentos em forma de navios ou galos, fechamento das janelas com folhas de madeira treliçada, floreiras nas janelas, nichos para santos, painéis de azulejos com motivos religiosos, da vida comum ou de desenhos em padrões não figurativos. Algumas vezes, a expressividade de algum ornamento evoca com maior força características da arquitetura barroca, o que aproxima essa produção nacionalista portuguesa do neocolonial brasileiro. É recorrente a presença de fontes de água com painéis de azulejos. Em geral, são semelhantes à casa Ricardo Severo, no Porto, no que toca, principalmente, à volumetria e aos recuos. Alguma variação nesse aspecto está mais relacionada à linguagem desenvolvida por Raul Lino, como terraços "à mourisca", arcos ogivais e abertura tipo "ferradura", trabalho com tijolos formando vedações vazadas em formas triangulares, torreões, formas arredondadas, utilização do branco nas paredes exteriores, entre outras. A ocorrência dessas tendências se dá, em todos os locais pesquisados, principalmente a partir de 1930. Trata-se de uma difusão, em muitos casos, desenvolvida por profissionais eruditos, que começam a aparecer em maior número, nos processos, também a partir dessa data. 
Capítulo 3

O NEOCOLONIAL NA HISTORIOGRAFIA 
De acordo com os objetivos propostos no início de nosso trabalho, além das tradicionais interpretações que consideram o movimento neocolonial, e a arquitetura que lhe corresponde, como transição, disputa, oposição, contradição e ruptura, procuramos observar na historiografia sobre arquitetura brasileira, especialmente, referências à sua difusão e à sua oficialidade. Aspectos relacionados à apropriação, à recriação e à difusão da arquitetura neocolonial e sua linguagem envolveram a observação de qual teria sido o período aproximado em que se considerou superado o movimento, e a permanência ou não do seu conteúdo ideológico em difusões mais tardias. Observamos, também, se os autores registraram a adoção pelo Estado do neocolonial como linguagem oficial, em determinados momentos. Também procuramos detectar interpretações sobre a complexidade cultural do período em que o neocolonial ocorreu, pois encontramos arquitetos reconhecidos pela sua produção modernista e que praticaram o neocolonial no interior paulista, o que de certa forma desmistifica a ortodoxia a eles atribuída e expõe que a fase foi de transição, contradições e conflitos, que só podem ficar mais claros com o distanciamento temporal e estudos baseados em premissas adequadas.

Percebemos também, em nossa revisão bibliográfica, que, grande parte dos autores apresenta abordagens sobre o movimento e a arquitetura neocolonial, mas com notável diversidade no enfoque principal dos trabalhos. De fato, até um dado momento da historiografia, é comum encontrarmos pesquisas que abarcam um longo período da produção arquitetônica brasileira e que tratam da arquitetura modernista. O exercício de revisão, aqui apresentado, mostrou-nos, porém, que o neocolonial só passa a ser tema central da historiografia a partir da década de 1990. Fizemos uma periodização, no intuito de captar as características principais que marcam os períodos, porém percebemos que algumas obras fogem a essas categorias gerais, mostrando-se mais avançadas ou conservadoras, com relação à época em que apareceram. Assim, em linhas gerais, interessou-nos compreender a percepção registrada em décadas de produção para, posteriormente, sob essa luz, estudar a documentação encontrada, como projetos, textos e processos, entre outros. 


\subsection{Até os Anos 30: Os Primeiros Debates}

Deveríamos nos furtar ao recorrente início o marco inicial do movimento neocolonial foi a conferência intitulada "A Arte Tradicional no Brasil”, proferida pelo engenheiro português Ricardo Severo, na Sociedade de Cultura Artística, no ano de $1914^{1}$ ? Não saberíamos responder, e não seria fácil fugir a essa "regra" - como não o fizemos -, mas o certo é que mesmo a história da arquitetura parece ter-se tornado tradicional, ao menos no que diz respeito a esse assunto. Pretendemos, com essa observação, prevenir sobre o fato de que nos empenhamos, aqui, tanto no sentido de identificar na historiografia idéias repetidas incessantemente e que, por isso, cristalizaram-se, como também para localizar abordagens novas, capazes de abrir horizontes interpretativos para o movimento.

De volta à conferência de Severo, identificamos, desde esse evento até, aproximadamente, 1930, nos textos dos intelectuais que se referem à arquitetura neocolonial, uma postura de aprovação às movimentações em favor da tradição e da identidade nacional. A aceitação de idéias relacionadas a esses temas se explica devido às intenções de afirmação de uma nacionalidade brasileira, que vinham amadurecendo desde o século XVIII, e que desencadearam uma série de acontecimentos, muito apropriadamente destacados por PINHEIRO (2003, p.166), como por exemplo, a Inconfidência Mineira, em 1789. No início do século seguinte, a Independência (1822) já era um fato e, ao final do século implantou-se a República (1889), acontecimentos fundamentais para o processo de afirmação da "brasilidade". Particularmente no Estado de São Paulo, a intensa imigração que se desencadeou a partir de 1888, com a libertação dos escravos, acirrou os ânimos dos paulistas "quatrocentões" no sentido da afirmação de sua posição de elite na sociedade, baseados em argumentos como origem e tradição (PINHEIRO, 1998, p.22). Por todos esses motivos, a produção artística e intelectual do início do século XX, não só de São Paulo, mas do Brasil, pôs em pauta as questões relacionadas ao assunto, como é notável nas obras de Gilberto Freyre (1900-1987), Câmara Cascudo (1898-1986), Oswald de Andrade (1890-1954), Mário de Andrade (1893-1945) e Monteiro Lobato (1882-1948), entre outros, apenas para citar algumas das figuras relevantes desse cenário.

\footnotetext{
${ }^{1}$ Sociedade de Cultura Artística. Conferências 1914 - 1916. São Paulo, Tipografia Levi, 1916, p. 46-47.
} 
Na produção desses autores interessou-nos verificar as posturas a respeito do movimento neocolonial, que vinham sendo inspirado por Mariano Filho e Ricardo Severo. Apesar de ser precoce analisar os aspectos que mais nos interessaram nessa década de 1930 - oficialidade e difusão -, vale mencionar, apenas como ilustração, que nesse momento de surgimento a postura geral era de oposição ao ecletismo e de indefinição quanto ao movimento neocolonial, pois se no início os intelectuais identificaram-se com a causa da valorização da tradição e da brasilidade, ao mesmo tempo também se sentiram atraídos pelas propostas da arquitetura modernista.

De acordo com Lemos (1994, p.151), “el primer intelectual que escribió sobre nuestro assunto en la prensa fue Moneiro Lobato (...) era leído avidamente por la clase media, de la cual era en realidad portavoz”. Seus primeiros artigos escritos e publicados, a partir de 1917, no jornal O Estado de São Paulo, faziam a defesa de um "estilo" nacional e abriram o debate público acerca do tema, com as respostas do, provavelmente, primeiro opositor à campanha neocolonial, o arquiteto Christiano Stockler das Neves ${ }^{2}$. O debate se alongou durante dez anos, quando então José Mariano Filho $^{3}$ entraria em cena em defesa do neocolonial. Esse ambiente de ânimos exaltados em torno da causa de uma arquitetura brasileira levou o citado jornal a publicar uma série de entrevistas com vários profissionais da construção civil, entre 13 e 29 de Abril de 1926, organizadas pelo advogado, professor e praticante do jornalismo Fernando de Azevedo, que escreve o primeiro dos nove artigos publicados (KESSEL, 2002, p. 135). Esse artigo mostra bem o clima de indefinição que vigorava, em relação à modernidade e à tradição:

a arquitetura no Brasil (...) não está, de fato, nem com os reformadores revolucionários que procuram na arquitetura um jogo de formas geométricas primárias ordenadas no espaço virtual e de um caráter social marcado; nem com os tradicionalistas que a querem encarada sob uma ótica local, em todos os aspectos que toma ao seu ambiente. Nem se orienta no sentido de uma 'arte mundial'... nem tenta vincular a arte às tradições locais

\footnotetext{
${ }^{2}$ Christiano Stockler das Neves (1889-1982). Arquiteto brasileiro formado na Pennsylvania State University, nos Estados Unidos da América. Foi o fundador da Faculdade de Arquitetura e Urbanismo Mackenzie, em 1947, e foi também prefeito de São Paulo no mesmo ano.

${ }^{3}$ José Marianno Carneiro da Cunha Filho (1881-1946). Médico e intelectual nascido no Recife e radicado no Rio de Janeiro. Interessado por artes plásticas e arquitetura, principalmente, do período colonial. Principal expoente da campanha neocolonial no Rio de Janeiro. Sobre sua trajetória, ver: Kessel (2002).
} 
e ao espírito da raça. Em uma palavra nem é tradicionalista nem antitradicionalista. (AZEVEDO ${ }^{4}, 1926$ apud KESSEL, 2002).

Em seguida, foram chamados às entrevistas Ricardo Severo, José Wasth Rodrigues, Alexandre Albuquerque ${ }^{5}$, Adolfo Pinto Filho e, finalmente, José Mariano Filho (Lemos, 1994). Nesses artigos foi discutido, inclusive, o nome mais adequado ao "estilo": "combateu-se o «estilo colonial»", cogitou-se "estilo jesuítico" e "estilo tradicional português”, pois "estava mais que implicitada e aceita a participação dominante da cultura portuguesa em nossa formação” (LEMOS, 1985, p.168). Assim, durante o período de pouco mais de uma década, desde que Severo realizou sua famosa conferência inaugural, em 1914, muitos intelectuais envolveram-se nos debates mais acalorados em defesa dessa arquitetura brasileira, enquanto as primeiras obras alinhadas à campanha foram construídas em São Paulo, no Rio de Janeiro e também em Santos ${ }^{6}$.

Foi nesse clima que se constituiu a gênese do movimento neocolonial que, como é evidente, nasceu entre os núcleos de São Paulo e Rio, e envolveu outras figuras do cenário intelectual. Depois dessa fase de maior agitação, o tema continuou a ser contemplado por vários autores, na imprensa e nas revistas, até 1930, aproximadamente, num tom mais brando, mas com a mesma tendência de combate ao ecletismo.

Quando a arquitetura modernista começou a tomar vulto, em fins dos anos 20, o debate sobre a arquitetura neocolonial ganhou novo fôlego, permanecendo mais tempo na berlinda como principal oponente da arquitetura promovida por Le Corbusier. Bom exemplo da continuidade da disputa deu-se entre o arquiteto Lucio Costa e José Mariano Filho, depois da entrada do primeiro na direção da Escola Nacional de Belas Artes (ENBA), em 1930. A célebre mudança de orientação de Lucio Costa - de tradicionalista para adicto da arquitetura "ultramoderna", como a chamou Mariano Filho -, foi motivo da permanência do tema na imprensa, tendo sido, talvez, a fase mais agressiva desse debate, como se verifica pelo trecho:

Quando o ilustre sr. dr. Francisco Campos entregou inesperadamente a direção da Escola de Belas Artes ao jovem arquiteto Lucio Costa, considerado até então o mais valoroso cadete da esquadra tradicionalista,

\footnotetext{
${ }^{4}$ AZEVEDO, F. O Estado de São Paulo, 13.4.1926.

${ }^{5}$ A ele Lemos (1994) atribui uma posição mais equilibrada pois, "en la entrevista, reconoció que São Paulo, ente todo constituía un crisol de razas y que el eclecticismo era totalmente valido entre nosostros" (Lemos, 1994, p. 153).

6 "entre 1914 y 1916 el arquitecto Victor Dubugras ya había construido en Santos empleando en la composición de las fachadas elementos de la arquitectura tradicional” (Lemos, 1994, p. 155).
} 
eu exultei sinceramente com a escolha, considerando-a legítima vitória da causa que defendo... O cadete Lucio Costa, que até a véspera de sua nomeação, fazia praça de seu credo nacionalista, ingressava a capacho nas hostes da corrente ultra-moderna... o paladino da arquitetura de fundo nacional... se fizera do dia para a noite agente secreto do nacionalismo judaico... E abriu sem demora as portas aos artistas que iriam dentro da propria Escola trabalhar contra o sentimento nacional", (MARIANO FILHO $^{8}, 1931$, apud KESSEL, 2002, p.181).

Esse debate continuou durante mais de nove meses, período em que Lucio Costa permaneceu na diretoria da ENBA, envolvendo, inclusive, manifestações de Mário de Andrade e Manuel Bandeira, em apoio a Lucio Costa (KESSEL, 2002, p.179184).

Em 1931, portanto, ainda se discutia, na esfera erudita, qual das correntes iria se estabelecer, sinal de que, como movimento, o neocolonial ainda transmitia enfaticamente seus valores e idéias, ao menos no Rio de Janeiro e através de Mariano Filho, muito embora a sensibilidade de alguns, como Lucio Costa, já estivesse inclinada a reconhecer as limitações do "estilo" tradicionalista. Em meio ao debate, entre esclarecimentos e reconhecimentos, Lucio Costa "aconselha insistentemente" a Mariano Filho que desistisse "do propósito de ficar sozinho pregando o seu evangelho no deserto, atitude excessivamente melodramática"9 (COSTA $^{10}, 1931$ apud KESSEL, 2002, p.183). Enquanto isso, inúmeras obras neocoloniais continuaram a ser construídas no Rio, em São Paulo e em muitas outras localidades brasileiras; eruditas ou não, tais obras iam contribuindo para a difusão do "estilo".

Para exemplificar as duas fases do debate público em torno do neocolonial, uma em oposição ao ecletismo e outra, mais tardia, em oposição à arquitetura modernista, tomamos Mário de Andrade, em fins da década de 1920 e de 1930. Em sua crônica, intitulada $O$ Grande Arquiteto, de 1927, o autor faz uma crítica bem-humorada à arquitetura eclética, mostrando um diálogo com um arquiteto que se considera muito competente, mas que, ao longo do texto, expõe suas limitações e, mesmo, sua "cegueira" em relação às novas tendências que se impunham e já superavam o ecletismo. Ao final, o arquiteto conta como conseguira fazer um material como a

\footnotetext{
${ }^{7}$ Marianno Filho, José. Escola Nacional de Arte Futurista. O Jornal, 22.7.1931

${ }^{8}$ MARIANO FILHO, J. (1931). Escola Nacional de Arte Futurista. O Jornal, 22.7.

${ }^{9}$ Costa, Lucio. Uma Escola Viva de Belas Artes. O Jornal, 31.7.31

${ }^{10}$ COSTA, L. (1931) Uma Escola Viva de Belas Artes. O Jornal, 31.7.310
} 
madeira ser tomada pelo nobre mármore e declara, expondo um resumo do seu pensamento:

- Nisso é que está a fantasia. Não é fazer essas loucuras que os arquitetos futuristas estão fazendo. Aliás nem sei o que eles estão fazendo porque não tenho nenhuma dessas revistas nem livros de agora. Aprendi arquitetura em Roma e em Paris. Tenho muito boa escola para estar perdendo tempo com essas bobagens dos moços de hoje. Eles só querem ser originais e não conseguem! Originalidade o senhor vai ver mais é neste "hall"! E o grande arquiteto abriu a porta que comunicava com o "hall". Gritei: - Santa Maria, que é isso? - Ah!... meu caro, este "hall" é a reprodução exatinha da gruta de Fingal! (ANDRADE, 1976, p.69-71).

Nessa fase, Mario de Andrade andava refletindo sobre a validade da campanha neocolonial e sobre as possibilidades da arquitetura modernista, impressões retratadas na sua conhecida série Arquitetura Colonial, de 1928. Nesse momento, não toma partido nem de uma nem de outra tendência, afirmando que a última só havia, até então, materializado

a fábrica e o arranha-céu”, e a “neocolonial ou o que diabo se chame, estão funcionando em relação à atualidade nacional. A função deles [dos arquitetos envolvidos nesse movimento] é pois, perfeitamente justificável e mesmo justa. O que resta saber é se estão funcionando bem (ANDRADE, 1985, p.14).

Uma década depois, em 1937, esse mesmo autor deixa mais evidente o seu pensamento sobre o neocolonial, numa carta que envia a Paulo Duarte, também analisada por Pinheiro (2005, p.113). A autora destaca que Mário de Andrade fazia um balanço do neocolonial, apontando seu lado pouco positivo, mas também o seu mérito: o de ter iniciado a campanha pelo registro e documentação da arquitetura colonial:

Além disso creio que os mais verdadeiramente culpados de descaso serão os leigos. Alguns anos atrás, ninguém ignora a campanha tão convincente que se fez em prol de uma arquitetura brasileira. Disso resultou o bem menos convincente "neo-colonial”. Mas o espantoso é que ninguém cuidasse então, organizadamente, de preservar o colonial verdadeiro... Despargiu-se no corpo das nossas colinas paulistanas uma quantidade de... de "chalets" decorados à colonial, desvirtuando profunda, intimamente o espírito, a expressão, a "necessidade" dos tipos coloniais da nossa arquitetura. O que 
havia de essencial nessa arquitetura, a sua monumentalidade lógica, nascida diretamente de formas lógicas em que, a tradição portuguêsa se acomodava e regia por nossa natureza e economia, isso se destruiu. E se destrói ainda. Não será vandalismo maior, êsse desvirtuamento, do que a venda de uma porta de jacarandá?...Parece que nessa corrente, em que, aliás, há duas ou três exceções respeitáveis, ao menos uma coisa valiosa se fez. A documentação ajuntada. Quando uma arquitetura histórica, um desenho rupestre de primitivos, uma casa de taipa e outros elementos frágeis, não podem ser guardados através do tempo, a tradição se preserve pela iconografia. Não será o caso da campanha agora empreendida, tratar imediatamente de se dar a si mesma uma feição energicamente prática? Fazer leis, reunir mecenas, iconografar os restos e as ruinas? Sei, pois tenha a felicidade de participar da atividade do Instituto e de você, que isso já se está fazendo. Se aludi ao fato, é que me parece de necessidade imediata reunir-se a documentação ajuntada por engenheiros e artistas diligentes, durante a campanha do neo-colonial, defendendo êsses documentos da dispersão. E publicá-los de maneira racional” (DUARTE, 1985, p.150$151)$.

Além do julgamento feito por Mário de Andrade nesta carta, podemos observar também que, segundo as considerações do escritor, em 1937 o movimento neocolonial já tinha cessado, pois afirma que a convincente campanha tinha sido realizada "há alguns anos atrás”.

Segundo nos parece, esse é um indicativo de que na década de 1930, e até alguns anos antes, mesmo na capital paulista a proliferação do "estilo" já se dava sem considerar o conteúdo ideológico do movimento, salvo, talvez, em alguns casos eruditos e no das obras do próprio Severo. Há que se considerar, inclusive, que a difusão descomprometida tenha sido desencadeada pelas obras de Felizberto Ranzini ${ }^{11}$ (1927) e de José Wasth Rodrigues ${ }^{12}$ (1944), a última já bastante tardia em relação à campanha ideológica, primeiras obras que fizeram circular, entre profissionais da construção civil e entre leigos, as características da arquitetura colonial. Azevedo (1994, p.252) concorda que especialmente o trabalho de Wasth Rodrigues

fue utilizado como catálogo o repertorio de motivos o elementos aptos a ser colocados sin critério ni distinción en contrucciones que, de esse modo,

\footnotetext{
${ }^{11}$ Ranzini, Felisberto. 1927. Estylo Colonial Brasileiro. São Paulo: Amadeu de Barros Saraiva.

12 Rodrigues, José Wasth. 1944. Documentário Arquitetônico. São Paulo: Livraria Martins Editora.
} 
llegaban a configurarse em un montaje heterogêneo de fragmentos: los perros del alero tomados de un determinado ejemplo, ventanas de outro, balcones de um tercero y así sucesivamente (Azevedo, 1994,).

Assim, com essas duas obras e com a publicação de revistas de arquitetura, a adesão formal ao neocolonial e sua difusão foram facilitadas enormemente.

\subsection{Os Anos 40 e 50: Afirmação de uma linha historiográfica}

Em 1952, em seu Depoimento de um Arquiteto Carioca, Lucio Costa compara Oscar Niemeyer ao Aleijadinho, afirmando que "êle é a chave do enigma que intriga a quantos se detêm na admiração dessa obra esplêndida e numerosa" (COSTA, 1952, p.36), ao referir-se ao conjunto da Pampulha. Anteriormente, em seu artigo de 1929, o autor contraditoriamente valoriza a arquitetura colonial anônima e não as "obras de exceção", como as do escultor e arquiteto mineiro, como veremos mais adiante. O que teria mudado no pensamento de Lucio Costa, em duas décadas, para valer-se de uma referência criticada por ele próprio ${ }^{13}$ para validar a obra de um arquiteto que começava a despontar no cenário da arquitetura brasileira modernista como um talento promissor, além de ter sido justamente essa uma das referências mais importantes para o movimento neocolonial? Ao que parece, nesse momento Lucio Costa manifestava abertamente sua postura contrária ao neocolonial, apoiado nas evidências de que a arquitetura modernista estava definitivamente estabelecida e, ao mesmo tempo, já teria se convencido do valor da obra de Aleijadinho no conjunto da arquitetura colonial.

$\mathrm{Na}$ mesma obra Lucio Costa faz uma crítica curta e aberta à arquitetura neocolonial, enfatizando a idéia de que se tratava de mais um "tipo", mais uma alternativa para a decoração eclética. Ressalta a "irrelevância da querela entre o falso colonial e o ecletismo dos falsos estilos europeus" (COSTA, 1952, p.22), através da afirmação de que ambas teriam sido "equivocados pseudos-estilos". Como se poderá observar mais adiante, essa postura teve conseqüências ao longo da construção da historiografia da arquitetura brasileira. Apesar do teor depreciativo da avaliação de Lucio Costa sobre a arquitetura neocolonial - e, por extensão, também sobre a eclética -

\footnotetext{
13 "Em 1929, é a vez de Lucio Costa publicar o artigo "O Aleijadinho e a arquitetura tradicional” em O Jornal, edição especial dedicada a Minas Gerais. Nessa oportunidade, Costa procurou ressaltar as características genéricas essenciais da arquitetura brasileira, em detrimento da excepcionalidade virtuosística da obra do Aleijadinho" (Pinheiro, 2006, p. 66).
} 
consideramos que ao chamá-la "retardado ruskinismo" (COSTA, 1952, p.22), o autor foi bastante preciso, não fosse a carga pejorativa que emana da expressão. Verificamos que a influência romântica esteve presente no pensamento e nos ideais de Ricardo Severo (SILVA, 2005, p.47), do arquiteto português Raul Lino, estreitamente identificado com o movimento Arts and Crafts (Ribeiro, 1994; Pinheiro \& D’Agostinho, 2004), e de outros intelectuais formados no final do século XIX, incluindo outros líderes de movimentos arquitetônicos semelhantes, ocorridos em vários países da Europa e da América (ROSMANINHO, 2003). Se quisermos ser mais precisos, podemos questionar se realmente a influência do espírito romântico foi "retardada", ou seja, se deveria ter ocorrido mais cedo. Várias manifestações arquitetônicas do final do século podem a ela ser associadas, como mostra Paulo Santos, lembrando-nos da "evasão para longe e para o passado (...) tudo em choque com a inelutável presença da Revolução Industrial” (SANTOS, 1981, p. 66) que se manifestou no Brasil com as primeiras evocações aos jardins franceses e chineses, à arquitetura portuguesa Manuelina ou à arquitetura árabe. Talvez mais acertado seja reconhecer que várias tendências de arquitetura tiveram um viés de inspiração ligado a esse espírito romântico que permaneceu por muito tempo, durante as décadas próximas à virada do século XIX para o XX, inclusive a neocolonial.

Relacionado ao espírito romântico está o conceito de pitoresco, que também entra no debate sobre a arquitetura neocolonial e modernista. Devemos relembrar que Ruskin (1819-1900) identificou pitoresco com arquitetura vernácula e com aquilo que teria “aptidão para tornar-se tema de pintura” (PINHEIRO; D’AGOSTINHO, 2004, p.122), noções em oposição à verticalização das habitações e à estética da máquina. Em Considerações sobre Arte Contemporânea, também publicado em 1952, Lucio Costa aborda a questão do pitoresco, destacada no trecho:

monumentalidade não exclui a graça, e da qual participarão as árvores, os arbustos e o próprio descampado como complementos naturais, porquanto o que caracteriza o conceito moderno de urbanismo, que se estende da cidade aos arredores e à própria zona rural, é, precisamente, a abolição do "pitoresco", graças à incorporação efetiva do bucólico ao monumental (COSTA, 1952, p.34).

Em suas palavras notamos que, numa situação ideal, a lógica modernista, nesse caso aplicada ao urbanismo, superaria facilmente os conflitos gerados pelo choque com 
o espírito romântico. O pitoresco, aqui colocado como um problema, seria absorvido e resolvido. Assim, o trecho destacado pode ser entendido como mais uma "das investidas contra o pittoresco lançadas pelos modernos” (PINHEIRO; D’AGOSTINHO, 2004, p.122) que, não sendo, embora, uma crítica direta, atingiu a arquitetura neocolonial em seus traços e intenções pitorescas.

Luiz Saia publicou as suas Notas sôbre a Evolução da Morada Paulista em 1957. Nessa contribuição à historiografia, o autor abrange um grande período, que se estende desde a casa bandeirista até a arquitetura moderna, mas o importante é sua firme postura crítica, evidenciada pela afirmação de que

é um engano (...) pensar que a arquitetura possa ser tratada como um assunto estanque; e engano maior pretender individualizá-la com base na análise formal, desvinculando-a de seus fundamentos econômicos, políticos e sociais (Saia, 1957).

Dentro dessa óptica, afirma que os profissionais da construção civil foram incapazes de apresentar uma solução para as cidades que experimentavam um boom de crescimento a partir do início do século XX. Teria sido justamente por essa ausência de um projeto geral que foram aceitas as mais variadas feições nas habitações burguesas, uma das quais, a feição tradicionalista, ou neocolonial: "nem mesmo aquele que pretendeu fazê-lo procurando nas tradições uma âncora justificativa para a cópia indevida, que realizou, de alguns aspectos decorativos da nossa arquitetura tradicional" (SAIA, 1957, p.24). Saia (1957) deixa entrever, no trecho destacado, que também compartilhava da tradicional interpretação de que o neocolonial não repetiu fielmente a arquitetura colonial - esta sim, merecedora de respeito - e, portanto, foi uma manifestação menor. Além disso, ao incluir a arquitetura neocolonial no conjunto dos “diferentes estilos, importados através de arquitetos estrangeiros (...) e pela consulta viciosa de publicações estrangeiras” (SAIA, 1957, p.24), mostra que também considerava a arquitetura de Severo como mais uma opção eclética, contribuindo para a continuidade da idéia de que não eram objetos dignos de estudo. Porém, a despeito disso, é importante relembrar a mensagem maior que emana dessas suas Notas, mesmo não sendo, este, nosso foco principal:

a natureza peculiar dos problemas de arquitetura não permite sejam as soluções procuradas exclusivamente a partir da intervenção individualista, 
exigindo uma colaboração de várias especialidades e a soma de esforços esparsos e sucessivos (SAIA, 1957, p.35);

ou seja, o que o autor defende é a existência de um projeto que considere as relações da arquitetura com os aspectos econômicos, políticos e sociais.

\subsection{Os Anos 60 e 70: Escassez de Trabalhos sobre o Tema}

Publicada originalmente em $1965^{14}$, segundo Puppi (1998), a obra de Paulo Santos, Quatro Séculos de Arquitetura, é "fruto do clima cultural dos anos 1930-50" (PUPPI, 1998, p.57, nota 33). De acordo, ainda, com Puppi (1998), o escritor Paulo Santos, na sua segunda fase produtiva, correspondente aos anos 60, ao "reconhecer características (...) comuns ao ecletismo e à arquitetura moderna”, tornou-se o primeiro estudioso a atribuir à primeira “um lugar na história” (PUPPI, 1998, p.62) e, assim, contribuir com uma dose de isenção no trato historiográfico das fases arquitetônicas que se sucederam entre fins do século XIX e início do XX, incluindo-se aí a neocolonial. A citada obra de Paulo Santos coloca o movimento neocolonial e sua arquitetura como mais uma manifestação, no vasto panorama dos 400 anos da cidade do Rio de Janeiro, o que dá ao tratamento dispensado ao "estilo" um teor de imparcialidade, permitindo até que o autor destaque o seu "saldo positivo". Da mesma maneira que outros autores, Santos evidencia que a campanha neocolonial teria criado "as condições propícias ao estudo de questões de raça, costumes, economia e vida social e artística de nosso povo”, e incentivado as pesquisas histórico-artísticas que, mais tarde, foram publicadas pelo Departamento do Patrimônio Histórico e Artístico Nacional (DPHAN) (SANTOS, 1981, p.95). Interessou-nos observar que, quando trata dos Concursos de Projetos, o autor indica a disposição do poder público em adotar uma linguagem oficial, mostrando a influência de José Mariano Filho “junto ao Governo para que constasse do edital a obrigatoriedade do estilo" neocolonial na década de 1920 (SANTOS, 1981, p.90). Dentre os projetos vencedores estavam vários pavilhões para exposições internacionais e o Edifício da Escola Normal (1928), do arquiteto Ângelo Brunhs, em parceria com José Cortez. Santos (1981). Esse autor situa, ainda, o apogeu do movimento neocolonial, no Rio de Janeiro, entre as décadas de 1920 e 1930,

\footnotetext{
${ }^{14}$ Palestra proferida por Paulo Santos, na Universidade do Brasil (atual Universidade Federal do Rio de Janeiro), em comemoração ao $4^{\circ}$ Centenário da Cidade do Rio de Janeiro, posteriormente transcrita e publicada em 1965. As outras duas edições datam de 1977 e 1981. Utilizamos a edição de 1981.
} 
época na qual ocorreu a Exposição do Centenário (1922), com vários pavilhões alinhados às prerrogativas do movimento, os vários concursos de projetos, o patrocínio das viagens para investigação da arquitetura colonial, e a adesão de vários arquitetos ao movimento, com a conseqüente proliferação de obras do gênero, pela cidade. E, afinal, sobre Paulo Santos, não podemos deixar de relembrar que interpretou o neocolonial como ligação, transição da arquitetura do século XIX para a modernista, apesar dos enfrentamentos e debates de seus mentores.

Observamos também que até a década de 1970 a resistência intelectual e historiográfica ao neocolonial (e também ao ecletismo) foi acentuada, pois ainda são escassos os trabalhos desse período a contemplarem o tema ${ }^{15}$, fator que se refletiu no que o SPHAN considerou digno de preservação: tradicionalmente, a arquitetura colonial. O parecer de Lucio Costa sobre o Solar Monjope ${ }^{16}$ é muito significativo e expõe contradição, em seu pensamento, ainda relacionada à complexidade e às exaltadas disputas das primeiras décadas do século:

O chamado "Solar Monjope" é um falso testemunho, exemplo de como uma casa brasileira nunca foi. A tarefa inicial do antigo Serviço do Patrimônio Histórico e Artístico Nacional constitui em desfazer o equívoco que levou a essa pseudo-reconstituição. Deve-se considerar, pois, contraditório, para não dizer chocante, que se insinue agora a conveniência do tombamento dessa elaborada cenografia como “documento histórico”. Parecerá mesmo um desrespeito à memória de Rodrigo M. F. de Andrade na luta que enfrentou, com todos nós, seus colaboradores, para repor nas suas legítimas bases apoiado em documentação e exemplares autênticos o conhecimento de várias fases e modalidades da nossa arquitetura do tempo da Colônia e do Império. Sem dúvida, a edificação abriga peças e azulejos de valiosos

\footnotetext{
15 Gonçalves, Ana Maria do Carmo Rossi (1977). A Obra de Ricardo Severo. São Paulo: FAUUSP; Costa, Jose Horacio de Almeida Nascimento (1978). Sobre o Neocolonial. São Paulo: FAUUSP.

16 "Prêmio Heitor de Mello", para o projeto de um "solar brasileiro em dois pavimentos para centro de grande parque". Nele José Mariano fez constar também a obrigatoriedade de inspiração das "linhas gerais do projeto e todos os motivos e detalhes na arquitetura tradicional (colonial) sacra ou civil. $O$ projeto vencedor de Ângelo Bruhns atendia ao programa luxuoso, que Mariano pretendia materializar para sua própria moradia no extenso terreno que adquirira anos antes às margens da Lagoa Rodrigo de Freitas, e onde plantara dezenas de árvores de espécies nativas. Entretanto, a construção pautou-se pelas próprias idéias do proprietário, que aproveitou também soluções criadas pelos concorrentes classificados em segundo e terceiro lugar (respectivamente, Lúcio Costa e Nereu de Sampaio) e com o auxílio de um desenhista deu forma final ao que chamou de "Solar Monjope", homenageando a antiga propriedade familiar em Pernambuco” (Kessel, 2002, p.110). Grifo nosso.
} 
monumentos, como, por exemplo, da bela igreja franciscana das margens do Paraguaçu, material que deverá ser evidentemente, em caso extremo, recuperado. Esclarecido este ponto fundamental, ou seja, a impossibilidade de considerar-se tal edifício "monumento nacional”, digno de tombamento pelo IPHAN, o caso muda de figura quando encarado do ponto de vista da cidade e do seu patrimônio ambiental. É de todo interesse que o estado preserve o conjunto, não só porque o prédio se insere na última área onde a vegetação da encosta do Corcovado, ainda preservada pelo Parque Lage, atinge a lagoa, constituindo-se assim na única mancha verde do lado esquerdo da via, como porque representa o fruto de um apaixonado e generoso esforço pessoal que, conquanto equivocado, merece a devida proteção. Assim, portanto, o tombamento pelo estado não é apenas justificado, mas se impõe. Não faltarão instituições ou empresas que se possam ali condignamente instalar, uma vez que o valor da transação seja reconsiderado à vista do impedimento de qualquer iniciativa de caráter imobiliário local (COSTA, 1973).

Verificamos que, antes, Lucio Costa nega qualquer valor que possa ser atribuído ao solar e, ao final, acrescenta que sua proteção se justifica por seu valor local, a vegetação, a paisagem e pelo conjunto, ou seja, por diversos motivos, mas não pelo que de fato foi, historicamente, o prédio, e pelo que representava. Seriam necessários mais 20 anos, aproximadamente, para que o solar fosse reconhecido como patrimônio com valor de preservação, infelizmente tarde demais, pois mesmo com o parecer favorável de Lucio Costa, sua demolição foi levada a termo. Nos anos 90, Lemos (1994, p.158) concorda que o Solar deveria ter sido protegido pelo SPHAN "como construcción representativa de um instante plenamente justificado de nuestro proceso cultural que estaba insertado em el complejo ideario de América Latina”.

Mesmo em trabalhos que reconheciam, já no início dessa década de 1970, o fato de o Ecletismo ter funcionado "como um veículo estético eficiente para a assimilação de inovações tecnológicas" e a conseqüente necessidade de um "reexame crítico” (REIS FILHO, 1970, p.178), havia o cuidado em deixar evidente que essa cultura do século XIX havia pecado por questões de gosto, excesso decorativo, arquitetura de fachada e ausência de compromisso com a "verdade dos materiais". 
Permanece, assim, a postura de análise do Ecletismo com base em premissas modernas. Fugindo a essa interpretação geral, Reis Filho (1970), em sua publicação Quadro da Arquitetura no Brasil, propõe uma "crítica do ecletismo", no qual o autor não aborda a questão do neocolonial, mas destaca pontos de interesse para possíveis - e necessárias novas abordagens sobre o ecletismo. Um dos mais importantes é a clara renovação e modernização da construção - que vai de aspectos da formação da mão de obra até a utilização de novas tecnologias, passando por opções estéticas - que ocorreu atrelada ao período eclético (REIS FILHO, 1970, p.180). Outro ponto diz respeito às políticas de preservação do patrimônio que, por falta de recursos, "tende a concentrar seus esforços em áreas como Bahia, Pernambuco e Minas Gerais”, preterindo regiões como São Paulo, onde se deram "manifestações culturais de interesse nacional, como as que se referem à história do café e à origem da industrialização no Brasil (...), pois as ocorrências dos séculos coloniais tendem a ser mais valorizadas" (Reis Filho, 1970, p.194). Assim, podemos vislumbrar já nessa época o germe da abertura para novas interpretações históricas, que se daria aproximadamente duas décadas depois.

Entretanto, os anos de 1970 e 1980 ainda foram bastante rígidos, em tal aspecto, tendo sido, mesmo, uma fase de recrudescimento da oposição da historiografia ao ecletismo e, em conseqüência, ao neocolonial. Possivelmente esse endurecimento tenha ocorrido, em parte, devido ao surgimento da obra de Yves Bruand, em 1971, embora sua tradução brasileira tenha sido publicada uma década mais tarde ${ }^{17}$. Certamente esse fato teve seu impacto, pois contribuiu para consolidar a idéia de desqualificação do ecletismo, numa época em que a atmosfera intelectual já se preparava para abordagens mais ajustadas. Bruand (1981, p.52) inicia sua análise com uma visão pré-formulada sobre o neocolonial, tratando-o meramente como uma moda - conseqüente, admite mas apenas isso. E na seqüência estão, uma após outra, todas as idéias cristalizadas, sobre o movimento, até o momento do lançamento do referido livro, reditas e autorizadas pela importância atribuída à obra: principal publicação sobre arquitetura contemporânea brasileira lançada até 1970 e intensamente adotada nos cursos de graduação do país. Bruand (1981, p.52) considera, por exemplo, uma “anomalia” o fato de os precursores do movimento terem sido estrangeiros. Afirma ainda que Severo e Dubrugras, já em suas primeiras obras neocoloniais, faziam uma arquitetura diferente da arquitetura colonial e portuguesa; que, por isso, em especial no caso de Dubrugras,

\footnotetext{
${ }^{17}$ Bruan, Yves. (1981). Arquitetura Contemporânea no Brasil. São Paulo: Perspectiva. Tradução da tese de doutorado do mesmo autor L'architecture Contemporaine au Brésil, Paris, 1971.
} 
eram "mistura de estilos" e "fantasia pitoresca” (BRUAND, 1981, p.53), e que esse arquiteto teria sofrido um "retrocesso patente", devido à sua personalidade "muito influenciável e (...) mentalidade muito eclética” (BRUAND, 1981, p.54). Atualmente, podemos perceber a clara desqualificação do arquiteto e sua obra, por pertencerem à cultura eclética e, mais que isso, uma interpretação do neocolonial como sinônimo de ecletismo pois, sob tal perspectiva, somente mentes ecléticas poderiam tê-lo praticado. O autor argumenta, ainda, que apesar de ter-se iniciado em São Paulo, o movimento e a produção neocolonial aqui "não alcançou grande expansão e importância em termos históricos” (BRUAND, 1981, p.54), pois, entre outros fatores, não existia nessa cidade uma elite intelectual sensível ao estudo do passado. Mário de Andrade, Monteiro Lobato e o próprio Severo não seriam alguns exemplos de representantes dessa elite intelectual? Não foi um jornal paulista - O Estado de São Paulo - que publicou um debate em série sobre o tema, em 1926 - com textos escritos por outros representantes da intelectualidade paulista - ao qual já nos referimos? Sobre isso, Pinheiro (2005) também nos reafirma o equívoco de Bruand (1981) mostrando um indicativo da importância da elite intelectual de São Paulo: a realização, em 1922, da Semana de Arte Moderna, "solenemente ignorada no Rio de Janeiro, na ocasião" e que "é um fato amplamente comprovado pelo exame da imprensa da época que a intelligentsia carioca via-se a si mesma como o próprio sol irradiando para o restante do país” (PINHEIRO, 2005, p.46).

Essa argumentação de Bruand (1981), portanto, se opõe justamente aos propósitos da investigação que apresentamos, ou seja, os de mostrar que a arquitetura neocolonial em terras paulistas foi muito expressiva, inclusive no interior do Estado, e com relevante significado histórico. Retomando, para o autor em questão as vicissitudes pelas quais passou a arquitetura brasileira desde o período eclético, tendo sido uma delas o neocolonial, só começaram a ser superadas com as primeiras obras modernistas, a partir de 1930.

Em 1979, aparece a obra de Carlos Lemos, Arquitetura Brasileira ${ }^{18}$. Da mesma forma que Bruand (1981), Lemos (1979, p. 130) entra num impasse classificando o neocolonial como vertente eclética e, ao mesmo tempo, colocando-o no capítulo intitulado Tempos Recentes, que trata da arquitetura do século XX, ou seja, da arquitetura moderna. Isso denota o conflito dos autores ao considerarem o neocolonial:

${ }^{18}$ Lemos, Carlos Alberto Cerqueira. (1979). Arquitetura Brasileira. São Paulo: Melhoramentos. 
ainda vinculado à arquitetura eclética - alvo de críticas -, porém com características que se podem considerar modernas.

\subsection{Os Anos 80 e 90: Abertura para Outros Enfoques}

$\mathrm{Na}$ década de 1980 percebemos as primeiras preocupações em estudar e preservar a produção arquitetônica anônima ou, como poderíamos também chamá-las, difusões popularizadas de diversos "estilos", produzidas pelas classes médias e baixas, exceção feita, talvez, à preocupação precocemente manifestada por Lucio Costa, em seu artigo “O Aleijadinho e a Arquitetura Colonial Tradicional”, de $1929^{19}$, no qual o arquiteto destaca o valor da arquitetura colonial não barroca (apud Pinheiro, 2006, p.66), embora, neste último caso, o arquiteto trate, antes, de uma arquitetura vernácula, e não de difusões de estilos. Essa exceção será também observada por Puppi (1998, p.21), no final dos anos 90, acrescida de outro aspecto que só poderia ter sido identificado por um trabalho mais recente da historiografia, como é o caso deste, e que será detalhado mais adiante.

Em 1994, Aracy Amaral coordena e publica uma das mais importantes referências sobre o fenômeno neocolonial na América: "Arquitectura Neocolonial: América Latina, Caribe, Estados Unidos" ${ }^{20}$. Além da coleção de artigos de historiadores de arquitetura de vários países americanos sobre o tema, encontramos, como texto de abertura, o artigo "La invención de un pasado" (AMARAL, 1994) que salienta, como o próprio nome sugere, aspectos equivocados do movimento, tanto os relacionados ao vocabulário utilizado, que não estava baseado numa arquitetura colonial de fato - por falta de conhecimento desta, argumenta -, como aqueles relacionados à "neocolonização", presentes em reconstruções, reformas e restaurações, de edificações originalmente coloniais. A autora atribui à internacionalização do movimento, não só ao espírito romântico, ainda presente nas primeiras décadas do século XX e que motivou movimentos semelhantes na Europa ${ }^{21}$, mas, principalmente, à forte influência dos

\footnotetext{
19 É necessário considerar que talvez o texto tenha sido publicado anteriormente, como alerta o autor Marcelo Puppi na nota ${ }^{\circ}$ 3, da página 20, de sua publicação de 1998, "Por uma história não moderna da arquitetura brasileira”.

20 Amaral, Aracy (coord.). (1994). “Arquitectura Neocolonial: América Latina, Caribe, Estados Unidos". São Paulo: Memorial, Fondo de Cultural Econômica

${ }^{21}$ Nicola Gordon Bowe (ed.), Art and the National Dream. The search for vernacular expression in turnof-the century design. Dublin, Irish Academic Press, 1993 (copyright), pp. 69-80. Rosmaninho, Nuno.
} 
Estados Unidos "país que ya desde princípios del siglo era un exportador vigoroso de las modas arquitectónicas de ciertas regiones de su territorio de clima agradable" (AMARAL, 1994, p.14). Afirma que essa influência era exercida através das revistas de arquitetura e filmes norteamericanos "que difundían ampliamente el estilo del ócio, la escenografía del turismo y de la fantasia” (AMARAL, 1994, p.13). Assim, realça o tom de modismo como impulsionador da disseminação da arquitetura neocolonial ,desde muito cedo, em detrimento da ideologia de recuperação da tradição e afirmação da identidade, apenas atribuindo valor aos esforços de reconhecimento e registro da produção colonial, no caso do Brasil, como, ademais, é a postura de vários autores durante várias décadas de historiografia. Além disso há, no texto da autora, uma atenção especial à mudança de eixo de influência sobre os países americanos, que se desloca da Europa para a América do Norte, apoiada pela observação de Ramón Gutiérrez de que "el neocolonial es, em realidad, la primera señal de que los modelos que inspiraban a los arquitectos de nuestro continente se desplazan de Europa para los Estados Unidos” (AMARAL, 1994, p.15). Acrescentando a esta postura que, ao menos no Brasil, a campanha de Ricardo Severo representou ainda uma continuidade da influência européia, uma vez que ele defendia que a tradição da arquitetura brasileira descendia da portuguesa. Ao final do texto, relembrando que

la arquitectura moderna na Brasil haya surgido solo em los años 20, para afirmarse em los años 30, em la mayor parte de los países latinoamericanos, después de la oleada del neocolonial, el estilo de la modernidad (...), sólo prenetraría en los años 50 (AMARAL, 1994, p.15),

indica que a partir de 1940 o movimento neocolonial brasileiro já havia sido superado, e não aborda possíveis difusões posteriores.

A publicação acima contou com a contribuição de Carlos Alberto Cerqueira Lemos, autor do famoso capítulo “El Estilo que Nunca Existió” (LEMOS, 1994, p.147164). Além do que o próprio nome sugere - que a arquitetura neocolonial foi fruto de um conhecimento precário sobre a arquitetura colonial e, portanto, fantasiosa - , fato muitas vezes repetido pela historiografia ${ }^{22}$, o autor faz uma detalhada revisão das

(2003). A «Casa Portuguesa» e Outras «Casas Nacionais». Revista da Universidade de Aveiro. Letras, Aveiro, n. 19-20, 2002-2003, pp. 225-250.

22 Podemos citar, por exemplo: Amaral, Aracy (coord.). (1994). La Invención de un Pasado. In: “Arquitectura Neocolonial: América Latina, Caribe, Estados Unidos”. São Paulo: Memorial, Fondo de Cultural Econômica, p. 11-18; Pinheiro, Maria Lucia Bressan. (1998). Ricardo Severo e o "Estilo Tradicional Brasileiro”. In: Revista D'Arte, São Paulo, n.3, p. 22-28. 
publicações que fomentaram a campanha iniciada por Severo ${ }^{23}$. Pudemos verificar também que, na opinião de Lemos, as obras de Victor Dubugras para o Caminho do Mar, realizadas em 1922, constituem

el apogeo de la arquitectura necolonial em Brasil. El Pouso Paranapiacaba, el Rancho da Maioridade, el Padrão do Lorena, el Belvedere y la Cruz. Quinhentista son construcciones magníficamente implantadas y ambientadas en las escarpadas cuestas de la sierra (LEMOS, 1994, p.156).

Considera esta obra como um marco e fonte de inspiração para "los neocolonialistas para inundar nuestras calles en los años 20 con casas supuestamente tradicionales", e também como a primeira obra pública alinhada ao estilo tradicionalista (LEMOS, 1985, p.163). A partir de então, assistiu-se a uma difusão pelo interior paulista e outras cidades do Brasil do "estilo" neocolonial até os anos 30, quando o art déco passa a dominar a paisagem, ao menos na cidade de São Paulo (LEMOS, 1994, p.160). Lemos aborda, ainda, a questão da oficialidade da linguagem, nesse mesmo texto, lembrando que a influência de José Mariano Filho junto ao governo, na década de 1920, fez do neocolonial uma obrigatoriedade, em determinados concursos, em concordância com o anteriormente dito por Paulo Santos (1981) na década de 1970. Acrescenta que o Rio de Janeiro, como capital da República, era exportador de ordens, modelos, usos e costumes e, juntamente com São Paulo, foi o pólo responsável pela divulgação do estilo em outros estados (LEMOS, 1994, p.158159). A Obra de Amaral (1994) foi, em que pese a visão ainda um pouco rígida, talvez a primeira a tomar o neocolonial como tema principal, indicando, assim, certa disposição a aberturas.

Retomando a produção historiográfica desses anos, podemos verificar que vários autores salientaram que, com relação à arquitetura neocolonial, mesmo os primeiros exemplares e os exemplares eruditos exibiam um vocabulário desvinculado daquele empregado para a arquitetura colonial. Isso se teria dado por falta de conhecimento do que foi, de fato, a principal arquitetura inspiradora do movimento, o que é muito procedente pois, como mostram as pesquisas, os primeiros arquitetos praticantes do neocolonial eram estrangeiros ${ }^{24}$ e não poderiam ter nem conhecimento

\footnotetext{
${ }^{23}$ Ver neste capítulo, o item: “Até a Década de 1930”.

${ }^{24}$ A propósito, outra idéia repetida pela historiografia sobre o neocolonial é esse fato de serem os seus precursores profissionais estrangeiros. Idéia que, nesse caso, assume sempre um tom negativo. Podemos observar que, desde a grande inovação tecnológica no âmbito das construções, permitida pela Revolução
} 
nem vivência da arquitetura colonial. Uma ressalva, nesse sentido, deve ser feita a Severo, pois tinha amplo conhecimento da arquitetura portuguesa. E, mesmo que esses arquitetos conhecessem muito bem a arquitetura produzida no período colonial, ainda assim, sua produção não seria autêntica colonial. Além disso, essa arquitetura colonial tinha sido banida, por representar um passado pobre em relação às novidades européias que inundaram os principais centros urbanos do país a partir do início do século XIX. Podemos citar alguns autores que trabalharam essa questão como, por exemplo, Lemos (1985, p.160): “Realmente acreditamos que devemos repartir entre Ricardo Severo e Victor Dubugras o mérito de introdução do novo estilo entre nós, embora nenhum dos dois, na verdade, tenha se inspirado em nossa verdadeira arquitetura colonial"; Amaral (1994, p.11-18), em seu artigo “la invención de un pasado”, cujo título, por si só, é bastante esclarecedor, mas do qual podemos destacar o trecho:

la arquitectura de prácticamente todos los países de América Latina, com el objetivo de rememorar un pasado muchas veces inexistente, a través de la manipulación nostálgica de un mundo remoto (...) com el cual resta poca afinidad a princípios del siglo XX (AMARAL, 1994, p.11);

e Pinheiro (1998, p.24): “o mais interessante é que as obras neocoloniais de ambos - Dubrugras e Severo - praticamente nada tinham a ver com a verdadeira arquitetura colonial brasileira (...). E nem poderia ser de outro modo, uma vez que nossa arquitetura colonial, suposta matriz do novo estilo, era até então pouquíssimo conhecida e estudada”. Embora incontestável, o enfoque na desvinculação entre a arquitetura autêntica da colônia e a que se praticava, supostamente baseada na primeira, acentuou a aura de "falsidade" criada e alimentada à volta da última, contribuindo para aumentar-lhe o demérito, no âmbito historiográfico. Acaso as obras neocoloniais seriam valiosas, do ponto de vista artístico, se fossem idênticas às coloniais? Cremos que não, pois de qualquer forma estariam fora de seu tempo: seriam somente cópias. O que significa, então, a insistência da historiografia nesse aspecto "inventado" da arquitetura neocolonial? Verificamos que, além de se constituir num reconhecimento sobre um de

Industrial, registrou-se a presença de profissionais estrangeiros - vindos dos países já industrializados em países da Península Ibérica e da América, encarregados da construção de pontes, elevadores, ferrovias e obras de grande porte. Da mesma forma, temos a presença do próprio Le Corbusier e de Gregori Warchavchik no germe da arquitetura modernista brasileira. Acreditamos que o que pesa para o neocolonial a qualidade de estrangeiros de seus iniciadores é justamente o fato de tratarem de um objeto que não poderiam conhecer: a tradição da arquitetura local. Porém, se o objeto era desconhecido, a idéia de retomá-lo para afirmação de uma identidade era bastante dominada, especialmente por Severo, que tinha sérios interesses arqueológicos e antropológicos, e tinha raízes no estrangeiro - na Europa - e no Romantismo. 
seus equívocos ${ }^{25}$, tal insistência também pretende exaltar a liberdade que, naquele momento, podia ser exercida no ato de projetar e construir, liberdade que estava ligada à idéia de modernidade e, por isso, obteve grande aceitação. Nas palavras de Lemos (1985, p.163) "a modernidade estaria na libertação do jugo vignolesco em favor de uma prática improvisativa em que, por acaso, os elementos vocabulares eram os tradicionais, não os do Brasil, mas aqueles de uma semântica portuguesa barroca, ou então aqueles outros simplesmente inventados”. Assim é necessário, ao se investigar as várias facetas do neocolonial, considerar que todas elas são parte do contexto complexo que permitiu a esse movimento expressar a modernidade através da liberdade com que trabalhava um passado imaginário, não um passado real. Como, devemos relembrar, o ecletismo já havia feito. Nesse sentido, a produção foi legítima, bem como sua difusão.

Ao final da década de 1980 surgiu a dissertação de mestrado de Carlos Alberto Ferreira Martins, intitulada Arquitetura e Estado no Brasil, que trata da obra de Lucio Costa e dedica um capítulo às questões relacionadas com o movimento neocolonial. Assim como outros autores, Martins (1987) considera que a arquitetura neocolonial não estava embasada fielmente no passado, como demonstram suas palavras ao descrever, por exemplo, as primeiras obras de Ricardo Severo no Brasil:

ficam claros ao mesmo tempo sua preocupação com uma leitura "arqueológica" da tradição construtiva brasileira e a liberdade com que articula plantas livres e recursos compositivos (...) que a simplicidade estrutural da arquitetura tradicional não podia permitir (MARTINS, 1987, p.132).

Essa postura do autor é ainda reforçada quando descreve as impressões de Lucio Costa ao conhecer a arquitetura colonial de Minas Gerais, em sua viagem patrocinada por Mariano Filho: segundo Martins (1987, p.138-139), Lucio Costa verifica que o neocolonial que se fazia era artificial, "de estufa”, em suas palavras, pois não era exatamente a arquitetura que havia encontrado em Minas, embora estivesse ligada a ela.

Tal postura pode ser tomada como natural, já que suas fontes foram as primeiras a formular esse argumento depreciativo para analisar a produção neocolonial;

\footnotetext{
${ }^{25}$ Demolições e reformas de edifícios autênticos coloniais para substituição por neocoloniais, o que representou a destruição de exemplares significativos, como por exemplo, a Faculdade de Direito de São Paulo, episódio já estudado por PINHEIRO (2005); linguagem decorativa que não inovou no programa ou na técnica; pastiche; entre outros equívocos descritos pela historiografia.
} 
além disso, trata-se de uma obra essencialmente voltada ao estudo da arquitetura modernista, no qual importa, antes, aprofundar o estudo desta e não o de questões periféricas. Apesar disso, o autor reconhece que "o neocolonial surgia, de certa maneira, associado à idéia de modernidade” (MARTINS, 1987, p.132), por ter sido a tendência arquitetônica escolhida para celebrar a importância da primeira estrada de rodagem pavimentada em concreto latino-americana, o Caminho do Mar, obra de Victor Dubugras. Apenas cita, de passagem, que a modernidade do movimento neocolonial estava, especialmente, na liberdade de expressão que se permitia, como já observado por Lemos (1985, p.163). Afinal, Martins (1987, p.137) não assume nem que o neocolonial pudesse ser enquadrado como ecletismo, nem que tivesse sido a transição entre a arquitetura eclética e a moderna, como autores anteriores afirmaram, o que significa uma abertura importante para um trabalho do final dos anos 1980. Porém, ainda deixa transparecer uma postura um tanto rígida, calcada na construção historiográfica de que seria necessário ter "uma visão crítica dos procedimentos compositivos do ecletismo" (MARTINS, 1987, p.141).

Ainda nesse período, embora a historiografia mencione diversas vezes a existência da difusão neocolonial, não se verificam indicações de que esta seja um objeto de pesquisa importante para o reconhecimento da conformação espacial das cidades, e para o próprio conhecimento do processo histórico que se desenvolveu desde o início do século XX, exceto pelos trabalhos de Amaral (1994) e de Carlos Lemos, já citados, que, já em 1985, estudava o que denominava "neocolonial simplificado" (LEMOS, 1985, p.173-189), na cidade de São Paulo. O autor defende o valor da arquitetura "sem arquitetos", afirmando que

constituem um elo de uma longa cadeia infelizmente interrompida em vários lugares devido ao descaso de muita gente preconceituosa que confundia Patrimônio Histórico e Artístico com alguns patrimônios setoriais da classe dirigente, a incentivadora dos grandes artistas e responsáveis por obras de exceção que justamente por serem excepcionais não são representativas da nossa sociedade (LEMOS, 1985, p.180).

Além de apontar o valor do processo de apropriação e de difusão pelo qual passaram vários "estilos" arquitetônicos, em especial o neocolonial, Lemos foi, certamente, um dos primeiros pesquisadores a indicarem o interior do Estado como importante objeto de estudo, quando, ao final do capítulo, abre novas possibilidades de 
investigação: “nossa esperança salvaguardadora também está nas cidades do interior, aquelas crescidas sob a égide do café, que até certo ponto, constituíram verdadeiras projeções da capital” (LEMOS, 1985, p.180). Contudo, preferencialmente existe, nas pesquisas sobre história da arquitetura, a tendência de se privilegiar a arquitetura de autor, ou seja, a arquitetura erudita, e não se atribuir valor à arquitetura anônima, como se verifica pelo trecho:

Sin embargo, salvo las obras de Victor Dubugras, arquitecto excepcional y com raro domínio de los médios disciplinares de su oficio, las construcciones "neocoloniales" constituyen muchas veces um agregado poco coherente (...). Em breve aparecieron remedos de esos proyectos en edifícios más simples (...). Y luego se llegó a las reducciones (...). Hoy en día, principalmente en el interior del estado de São Paulo, aún se construye una cosa denominada "estilo colonial" para familias de clase media o ricas (...) que se caracterizan casi siempre por una enorme falta de preparación intelectual y sedimentadas referencias estéticas (AZEVEDO, 1994, p.252253).

Essa resistência se explica como herança das disputas e das lutas pela conquista de um espaço hegemônico, entre as várias correntes da arquitetura, afinal ocupado pela corrente modernista, essencialmente erudita. O clima de combate atravessou décadas de história, apenas permitindo olhares mais isentos, para as diversas produções arquitetônicas - fossem ecléticas, neocoloniais, anônimas ou outra qualquer, produzida nas primeiras décadas do século XX - em fins dos anos 80 e início dos 90 .

Referimo-nos à inusitada dissertação de mestrado produzida, em 1985, por Rodrigues, As Fachadas na Arquitetura Paulistana: O Estilo Missões. A leitura das primeiras páginas do trabalho revela uma postura ainda totalmente alinhada à historiografia dominante. O autor, ao reproduzir uma entrevista com o arquiteto Eduardo Kneese de Mello, em que este é questionado sobre a fase em que produzia arquitetura neocolonial e "missões", expressa sua impressão ao afirmar que

há uma grande preocupação por parte dos arquitetos em esconder um período de mais de trinta anos de produção arquitetônica, apenas pelo fato dessa produção ter sido inconseqüente e leviana em face da arquitetura contemporânea (RODRIGUES, 1985). 
Notamos aí que, mesmo se propondo a estudar um objeto externo ao arcabouço modernista, o autor continua muito contaminado pela postura herdada da historiografia. Certamente, porque não havia alternativas. As lições dos livros sobre história da arquitetura brasileira, salvo raras exceções, legaram uma única interpretação aos seus leitores, que tenderam a olhar para o passado e para o futuro de uma forma restrita, como nos mostra, ainda, esse mesmo autor, na seqüência:

a arquitetura de estilo [categoria na qual inclui tanto ecletismo como neocolonial, missões etc.] espelhou (...) o ideário da classe dominante da época, o que não pode ser considerado muito diferente do ideário da burguesia atual (...). Tal não fosse, não estaríamos assistindo com pesar a transição do gosto da burguesia de uma arquitetura contemporânea para um movimento pós-moderno, como é chamada essa arquitetura tão espúria e obsoleta, que conceitualmente nada difere de todos os "neos" edificados na primeira metade deste século (Rodrigues, 1985).

As palavras falam por si e, constatamos assim que um trabalho sobre a tendência "missões" foi realizado por um autor de postura ortodoxamente modernista. Apesar disso, a simples existência do interesse por um assunto omitido, e a realização de um estudo sobre ele, em plenos anos de 1980, acabou por representar um avanço. O trabalho vale também pelo esforço de registro de uma coleção de exemplares ligados ao “missões" e ao neocolonial. Vale também por uma passagem onde o autor afirma que os elementos em meia-lua, atribuídos por Lemos (1985, p.166) à inventividade de Victor Dubugras, "pertenceu ao repertório de todos os coloniais americanos" (RODRIGUES, 1985). Para sustentar sua afirmação, o autor apenas mostra uma foto de uma casa colonial em Cuernavaca, México, a empregar esse motivo nos guarda-corpos, mas sem quaisquer referências. Dessa maneira, permanece a dúvida, já que Lemos (1985) afirma ser criação de Dubugras.

Referimo-nos também e, principalmente, ao trabalho de Fabris (1987), Ecletismo na Arquitetura Brasileira, surgido no mesmo período, que reúne artigos de vários autores sobre a arquitetura eclética. Abre o livro um artigo do pesquisador italiano Luciano Patetta, esclarecendo as principais motivações que despertaram a necessidade de reavaliar a produção eclética na Europa:

por um lado, a implantação do problema da proteção e restauração do patrimônio histórico-monumental para as estruturas urbanas e edifícios do 
século XIX; por outro, a crise do Urbanismo do Movimento Moderno que levou a uma revisão dos princípios desta disciplina e a uma reflexão crítica, em cujo alicerce se encontram, exatamente, a cultura e a cidade do século passado (PATETTA, 1987, p.10).

Em vários capítulos, podemos encontrar referências ao neocolonial, em razão do seu reconhecimento como uma manifestação eclética. No texto de Lemos (1987, p.91), encontramos um trecho no qual, baseado em palavras de Ricardo Severo, o autor mostra que "as honras de introdutor do Neocolonial" são divididas entre "Severo, Washington Luiz e Victor Dubugras. O primeiro teorizou, o segundo deu o impulso inicial com suas encomendas e o terceiro executou-as". É comum, na historiografia, considerar Severo, principalmente, como um teórico e como um engenheiro pouco afeito ao desenho, como sabemos. Porém temos em conta que ele construiu vários edifícios, no Estado de São Paulo e um, também, de grande importância, na cidade do Porto. Como vimos no capítulo anterior, esse edifício representou a primeira manifestação de um movimento arquitetônico tradicionalista, similar ao movimento neocolonial, em Portugal. No artigo de Salgueiro (1987, p.105-145), encontramos boas indicações da ocorrência do neocolonial fora do Estado de São Paulo e do Rio de Janeiro. Uma dessas indicações, importantes para nosso trabalho, é a atuação do estado para a oficialização, disseminação e atribuição de caráter nacionalista à linguagem neocolonial mineira. A autora afirma que o governo do Estado de Minas Gerais manda fotografar a arquitetura colonial de cidades como Ouro Preto e Mariana "para catalogação de «motivos»e «ornatos» a serem utilizados nas construções novas e na remodelação de edifícios públicos” (SALGUEIRO, 1987, p.132). Menciona, também, a realização de um filme-documentário para divulgação de Minas antiga em grupos escolares (SALGUEIRO, 1987, p.132). Temos notícias, ainda, através do artigo de Castro (1987, p.209-255), da adoção, pelo Estado Cearense, do estilo tradicionalista de Severo, para os "Grupos Escolares Visconde do Rio Branco e Fernandes Vieira" (CASTRO, 1987, p.231), projetados pelo arquiteto carioca Armando Oliveira. E, além ser a tendência escolhida para as escolas, foi utilizada, em 1922, para a

completa reforma do Parque da Liberdade, ocasião em que o logradouro ficou cercado por um gradil de ferro apoiado numa mureta de alvenaria de tijolos decorada com volutas compostas ingenuamente, dando um toque supostamente colonial. O grande portão de entrada da Rua Pedro I também recebia tratamento idêntico, com a aplicação de uma barra de azulejos 
estampilhados, portugueses, azuis e brancos (...) no alto do frontão (...) um índio que partia os grilhões da submissão colonial (CASTRO, 1987, p.231).

Temos, assim, registradas ocorrências de obras neocoloniais oficiais, espalhadas por diversas regiões do país.

O último artigo é da própria organizadora da obra, e seu título indica um tema polêmico: O Ecletismo à Luz do Modernismo. Fabris (1985, p.281) o inicia mostrando a ferrenha oposição dos intelectuais da época - Mário de Andrade, Alcântara Machado e Monteiro Lobato - à cidade eclética que era São Paulo, naquele tempo. No desenvolvimento do texto percebemos que o aspecto modernizador do ecletismo é considerado, o que coloca o texto no conjunto dos trabalhos que busca a reavaliação do período eclético. Sobre o neocolonial, a postura da autora é participante da idéia de que “a campanha de Severo em prol do "estilo colonial brasileiro", tanto em suas reflexões teóricas, quanto em sua prática arquitetônica, representa, na verdade, uma atitude tão eclética quanto a daqueles profissionais contra os quais reagia” (FABRIS, 1987, p.287). Relembrando, não pretendemos aqui decidir se o neocolonial foi ou não uma opção a mais, disponível para no repertório eclético, mas cremos ser necessário ter sempre em mente que a aproximação entre essas tendências foi um fator que muito contribuiu para atribuir àquele movimento a mesma reserva e desinteresse direcionada a este último. Além disso, quando o fenômeno neocolonial aconteceu, as modernizações implementadas na arquitetura eclética já haviam acontecido, e o neocolonial se fazia sem alguns desses recursos. Em poucas palavras, o Ecletismo na Arquitetura Brasileira representa uma intenção inaugural de se discutir a arquitetura produzida desde fins do século XIX até os anos vinte do século seguinte, sem excluir posições contraditórias e polêmicas, mas com importante foco nas questões da industrialização e modernização da construção. Além disso, por ter sido fruto de um congresso ${ }^{26}$ dedicado ao neoclassicismo e ao ecletismo, podemos vê-lo como mais um sinal de flexibilidade dos tempos.

Na mesma linha, podemos mencionar os trabalhos de Lemos (1985), Alvenaria Burguêsa, já citado e, principalmente, outros trabalhos desenvolvidos sob sua orientação, como o de Bortolucci (1991), Moradias Urbanas Construídas em São Carlos no Período Cafeeiro, o de Homem (1996), O Palacete Paulistano, e o de Wolff (1998), Jardim América: o Primeiro Bairro Jardim de São Paulo e sua Arquitetura. O

${ }^{26}$ II Congresso Nacional de História da Arte, Rio de Janeiro, setembro de 1984. (Fabris, 1987). 
trabalho de Homem (1996) trata da residência da burguesia da cidade de São Paulo no período em que o ecletismo lá floresceu em sua expressão mais rica, dando enfoque, também, ao modo de vida dessa elite. Wolff (1998) mostra a ocorrência da arquitetura neocolonial no Jardim América, e afirma que residências cuja arquitetura seguiu essa tendência começaram a ser construídas desde que o empreendimento imobiliário fora lançado, na segunda metade da década de 1910, até, aproximadamente, 1945, considerando-se as derivações da tendência, como o "missões" e o "mexicano" (WOLFF, 1998, p.220-221), mostrando, mais uma vez, que a arquitetura neocolonial perdurou por mais tempo do que se admite. A autora faz uma observação fundamental, na análise do conjunto arquitetônico do bairro paulistano, que é a impossibilidade de avaliá-lo "sob os princípios críticos esboçados pelo arcabouço teórico da arquitetura moderna (...). Não se pode buscar verdade dos materiais e funcionalismo em produção que não se fazia segundo tais premissas. Essa vertente de análise ou de crítica impede o reconhecimento de qualquer valor nessa produção” (WOLFF, 1998, p.267). Numa extensão desse raciocínio, podemos nos perguntar, agora, se existiria alguma outra tendência arquitetônica que pudesse ser avaliada segundo as premissas modernistas, se não ela própria. Dessa maneira, verificamos que tal questionamento, presente nesse trabalho de 1998, representa uma abertura significativa da tradicional interpretação historiográfica, e que a autora leva até a apreciação dos critérios adotados pelos órgãos de preservação do patrimônio, calcados na visão modernista:

como é possivel valorizar a contribuição do bairro à imagem da cidade, como têm feito as políticas preservacionistas, desprezando o que deu vida a ele, as casas de seus moradores? A observação dos efeitos da preservação oficial do Jardim América nos últimos dez anos, que protegeu seu parcelamento do solo, suas árvores e o traçado de suas ruas, desconectados de suas edificações, permite verificar que essa política tem-se mostrado absolutamente limitada (...), se não mesmo ineficaz (WOLFF, 1998, p.269).

Por último, pode-se depreender desse trabalho que existiu uma associação entre traçados urbanos referentes à teoria cidade-jardim e o estabelecimento, neles, de uma arquitetura ciosa da relação com a paisagem, onde o ajardinamento é um elemento importante e onde se busca, deliberadamente, a qualidade de "pitoresco". Certamente, essa associação é dada pela influência das teorias urbanísticas inglesas do período que, além do traçado levavam em consideração, também, os elementos da envolvente, para 
criar um ambiente integrado. Em última instância, essa associação é dada também por mais uma manifestação da influência do espírito romântico na arquitetura.

O trabalho de Bortolucci (1991) contribuiu com, pelo menos, três aspectos inéditos, que são os seguintes: a) tratar do ecletismo, b) tratar do ecletismo no interior do Estado de São Paulo e c) registrar a ocorrência da arquitetura neocolonial fora dos grandes centros. Nos últimos dois aspectos, o autor aborda a questão da difusão de linguagens, o que também foi inédito, no contexto que privilegiava o estudo de obras eruditas. Além disso, põe em evidência a contribuição da mão-de-obra imigrante, especialmente a italiana, na construção de um espaço urbano que se caracterizou pela linguagem eclética que, apesar de não ter sido suntuosa, na região, foi a que caracterizou o período:

as manifestações ecléticas sãocarlenses se apresentaram de forma tardia e superficial. Sem maiores considerações de ordem filosófica, por exemplo, as diversas tendências estilísticas puderam se exprimir, bastando para isso a justaposição, aos mesmos arcabouços construtivos, de uma "decoração" classicizante, art-nouveau ou até neocolonial (BORTOLUCCI, 1991, p.379).

Dessa forma, a autora admitiu, ao menos no âmbito do seu objeto de estudo, no momento em que o realizou e no que diz respeito à difusão da arquitetura neocolonial, assim como Lemos (1985) e outros autores, que o neocolonial foi uma opção decorativa "eclética". Porém, nesse caso, o fato de tomar o neocolonial como um "tipo" de ecletismo não traz prejuízo para sua interpretação, pois o trabalho tem como tema central o ecletismo. Trata-se, antes, de um sintoma da assimilação da linha historiográfica predominante, que preteriu a manifestação eclética, e a neocolonial por associação. A crítica realizada pela própria autora, além da opção pela pesquisa de um assunto desconsiderado até quase um século depois de sua ocorrência, deixa claro o seu posicionamento dissonante do estabelecido:

A arquitetura do século XIX tem sido, nos últimos anos, objeto freqüente de estudos e passa, evidentemente, por um cuidadoso processo de reavaliação, que não exclui a quebra de preconceitos. As reações pejorativas dos modernos dificultaram, para as gerações posteriores, o conhecimento da verdadeira contribuição deste período (...). Dificultaram também a conservação de exemplares desta produção arquitetônica, inclusive no Brasil, onde até os órgãos de preservação privilegiaram apenas o período colonial". E termina: "pode-se afirmar que, de alguma forma, estas 
manifestações ainda não morreram. Nem os modernistas conseguiram impedir o aparecimento dessas expressões extemporâneas, produto do saudosismo e da excentricidade da classe burguesa, que continuou, na execução de suas moradias, a demonstrar a admiração e a preferência pelos “neos”, principalmente o neocolonial (BORTOLUCCI, 1991, p.379).

Enfim, embora não se trate de um trabalho especificamente sobre o neocolonial, deixa explícita a necessidade de dar continuidade às pesquisas por essa via, já que identifica uma ocorrência significativa de obras dessa tendência em São Carlos.

Verificamos que ao final da década de 1990 deu-se uma maior abertura para enfoques inéditos sobre a historiografia construída. Uma profunda revisão dos principais autores é evidente na proposta de Puppi (1998), e é anunciada já no título de sua obra - Por uma História Não Moderna da Arquitetura Brasileira - que visa o ecletismo no Rio de Janeiro. Ao fazer uma revisão das contribuições dos principais autores da nossa história da arquitetura, Puppi (1998) coloca em cheque a interpretação tradicional construída, ao longo dos anos, sob a forte influência que as idéias da modernidade exerceram sobre gerações de estudiosos. Assim, o autor traz à luz uma análise polêmica e complexa, mas de fundamental interesse para quem pretenda olhar a mesma questão por ângulos diferentes. Por exemplo, com base no argumento da "tradição", também adotado pelos primeiros intelectuais modernistas, o autor mostra como a arquitetura colonial - não barroca - foi valorizada, enquanto aquela que não tinha tradição - a eclética - foi ignorada, inclusive pelos pesquisadores e historiadores, como se fosse objeto "invisível", ou seja:

a abordagem, enfim, pretende instaurar uma antropologia da arquitetura; esta, não por acaso, torna desnecessário o conhecimento efetivo da própria história disciplinar: a «história» antropológica elimina a história «histórica» (PUPPI, 1998, p.24).

Somando-se a isso o fato de que a arquitetura neocolonial já tinha sido definida como mais uma opção de decoração eclética desde os anos 70, a sua exclusão da historiografia foi um processo lógico. Podemos ainda identificar outra passagem na obra de Puppi (1998) que mostra como o neocolonial - movimento e arquitetura - foi, desde o seu surgimento, desmerecedor de um lugar na história. Ao analisar o já mencionado artigo de Lucio Costa sobre o Aleijadinho, o autor registra que o arquiteto considerou como "representativas não as obras de exceção, mas sim a arquitetura dos «mestres 
anônimos»” (Puppi, 1998, p.21), fazendo, dessa maneira, uma crítica sutil, mas eficiente, ao movimento neocolonial. Ao elogiar arquitetura anônima colonial em detrimento da obra de Aleijadinho, e ao condená-la como decorativa, Lucio Costa ao mesmo tempo validava as razões da arquitetura modernista e atingia o cerne do movimento neocolonial, pois este movimento "havia revalorizado a arte $e$ a arquitetura coloniais, reservando ao Aleijadinho um lugar de destaque. A decoração de origem barroca e rococó era a mais concorrida, no meio da qual o artista mineiro sobressaía-se” (PUPPI, 1998, p.21). Assim, Lucio Costa, em 1929, quando ainda não havia abandonado sua posição a favor da campanha tradicionalista, já havia lançado mais uma boa razão para a historiografia considerar o fenômeno neocolonial com muitas reservas. Se a própria fonte inspiradora da campanha era criticada como decorativa, restaria algum valor ao produto de sua inspiração?

Mais um ponto muito importante levantado por Puppi (1998), e que só poderia ter sido apresentado numa interpretação de fins dos anos 90, é que, ao fim e ao cabo, o problema-chave enfrentado tanto pela arquitetura neocolonial como pela modernista era o mesmo, e estava relacionado à questão de sintetizar tradição e modernidade. $\mathrm{O}$ problema foi resolvido favoravelmente pela arquitetura modernista, ao se evitar repetir formas pertencentes ao passado - pelo que o neocolonial foi duramente criticado, embora se afirmasse repetidamente que os arquitetos não conheciam o passado ao qual se referiam, como já dissemos -, o que não evitou, contudo, que o problema permanecesse no momento da realização arquitetônica. O autor recorre a Paulo Santos para demonstrar que, para neutralizar a ambiência fria das formas industriais eleitas para a arquitetura modernista e, ainda, casá-las à tradição, muitas vezes, os arquitetos recorreram aos mesmos recursos empregados na arquitetura neocolonial:

móveis, prataria, porcelanas, tapetes, azulejos e portas de almofadadas obtidas em demolições (uma delas usada por Alcides Rocha Miranda na capelinha da casa Almeida Braga à Rua Icatú), telhões de louça esmaltada (empregados por Lucio Costa na casa da baronesa de Saavedra em Itaipava) (SANTOS, 1981, p.94).

$\mathrm{E}$ acrescenta que tal "reutilização de materiais originais (...) não era desconhecida, nem tampouco privilégio da nova geração" (PUPPI, 1998, p.67), pois Mariano Filho, Ricardo Severo e outros, já haviam procedido da mesma maneira. Assim, o autor mostra que o movimento neocolonial foi importante para o movimento 
moderno, também no que tange às técnicas, e não apenas ao "espírito tradicional". Por essa via, evidencia também que não devemos esquecer, por ter sido negado, o legado academicista presente na arquitetura modernista. Além disso, é importante notar que, embora Puppi (1998) admita a arquitetura neocolonial e a modernista como sucessivas continuidades da arquitetura do século XIX - fato admitido também por Paulo Santos -, não enquadra a primeira como eclética, evitando perpetuar sua condenação à invisibilidade histórica. Para Puppi (1998), Paulo Santos é, talvez, o único autor cuja visão escapou à tradicional historiografia, fruto do esquema desenvolvido e plantado por Lucio Costa - e que Puppi (1998, p.17-55) analisa em profundidade em seu primeiro capítulo -, o que podemos notar quando ele afirma que Paulo Santos "escreve de fato uma outra história do movimento neocolonial” (PUPPI, 1998, p.87). Por conseqüência, fica sugerido nas entrelinhas que, se o raciocínio de Paulo Santos tivesse sido seguido pela historiografia - de que “a superioridade do neocolonial é devida mais à sua vitória sobre os demais estilos (...) que propriamente a qualidades especiais: a vitória desencadeia o resgate da «sensibilidade nacional»" (PUPPI, 1998, p.87) -, certamente o conhecimento sobre o movimento neocolonial e sobre o ecletismo estaria bastante mais desenvolvido.

Na continuidade, Puppi (1998) faz, ainda, a revisão do trabalho de Bruand (1981), já abordado - Arquitetura Contemporânea no Brasil. O principal ponto destacado é que o autor francês

não apenas reduz a teoria do brasileiro [Lucio Costa] aos aspectos funcionais mais visíveis, como atribui-lhe valor de verdade histórica. $O$ roteiro fortemente esquemático da arquitetura nacional do primeiro Lucio Costa ganha novo fôlego para ser assim definitivamente incorporado à historiografia (PUPPI, 1998, p.105).

Esse ponto, associado ao conteúdo de crítica ao ecletismo dos anos de 1900 a 1930, e por constar numa das mais destacadas obras sobre a arquitetura brasileira, segundo o autor, perpetua no Brasil a desvalorização da produção do período. Quanto ao neocolonial, o autor interpreta que Bruand (1981) deu um passo à frente ao “considerá-lo parte essencial na criação da nova arquitetura, e sobretudo na ênfase do papel formador do movimento" Puppi (1998, p.109); porém, “o avanço crítico no final das contas, é mais aparente que real, e não tem desenvolvimento” Puppi (1998, p.110), já que Braund (1981) considera o neocolonial como ecletismo, condenado 
anteriormente pelo autor, na primeira parte de seu trabalho. Esse, porém, é um problema intrincado, capaz de revelar a complexidade do quadro que estamos abordando. Como já foi evidenciado, a historiografia, ao considerar o neocolonial como uma vertente eclética, prejudicou o aprofundamento de sua compreensão, pois atirou-a para o campo da produção arquitetônica desprezível. Ao considerarmos as palavras de Puppi (1998, p.126), notamos que Bruand (1981) foi contraditório e simplificador, pois mesmo limitando-se a situar o neocolonial no ecletismo, acabou por escrever

uma história do estilo tão heróica quanto deformada: de um lado o neocolonial é desmedidamente alçado a um movimento com ares de vanguarda; de outro, o ecletismo tido como estrangeiro, é reduzido a um fato meramente «negativo» (PUPPI, 1998, p.126).

O autor francês criou, assim, um impasse em que o neocolonial não poderia ter virtudes, uma vez que foi eclético, mas, ao mesmo tempo, pelo fato de ter suplantado os estrangeirismos, atribuiu-lhe uma supervalorização. Por ter produzido uma obra de importância, no cenário historiográfico, Bruand (1981) deixa para os próximos autores a tarefa de encarar esse problema. Em todo caso, em sua análise, Puppi (1998, p.121) nos apresenta outra contribuição, quando diz que Bruand (1981), assim como Santos (1981), também considera o neocolonial como uma transição para a arquitetura modernista.

Ainda na revisão sobre Bruand (1981), Puppi (1998) deixa entrever rapidamente a sua avaliação sobre o neocolonial, quando afirma que o autor em análise tem a dura tarefa de mostrar que "o estilo tem um apelo nacionalista inquestionável $e$ um valor cultural efetivo, sem esgotar-se numa moda passageira” que só consegue forçando uma situação e "passando por cima de todas as evidências em contrário" (PUPPI, 1998, p.123). Essa última frase confirma o entendimento de Puppi (1998) de que o neocolonial foi uma moda que passou rapidamente. Nossas pesquisas no interior paulista entram justamente em conflito com tal afirmação, primeiro pelo fato de que pudemos verificar que essa arquitetura de inspiração tradicionalista continuou a ser produzida e reproduzida até, aproximadamente, 1950. Depois disso, como já foi apontado por alguns autores, e, evidentemente, fora do âmbito da discussão aqui colocada, continua a ser reproduzida até os dias atuais, motivada, talvez, por uma associação de nostalgia com falta de conhecimento histórico-estético. Por isso, discordamos de que tenha sido passageira. Segundo - e esse é um ponto a ser discutido adiante - discordamos também da idéia de que, por ter sido esvaziada ideologicamente, 
deixou de ter valor arquitetônico, ou seja, que seja desprovida de importância no que se refere à construção do espaço e à representação de um período histórico.

Retomando, Puppi (1998) analisa, por fim, outros três autores, quais sejam Carlos Lemos, Mario Barata e Giovanna del Brenna. Sua visão sobre Lemos ${ }^{27}$ é que o autor é totalmente filiado ao esquema de pensamento de Lucio Costa, ou, em outras palavras, para ele "a arquitetura eclética é um puro intervalo estrangeirizante entre momentos da entre momentos [colonial e moderno] de produção artística genuinamente local” (PUPPI, 1998, p.131). Isso, porém, não impediu que Lemos fosse o responsável por várias pesquisas importantes sobre o ecletismo e sobre o neocolonial, principalmente em São Paulo, tanto as de sua própria autoria como as realizadas sob sua orientação $^{28}$, algumas das quais já abordamos aqui, e outras mais recentes, que vamos discutir adiante. De algum modo, portanto, consideramos que a atuação de Lemos proporcionou também a realização do nosso trabalho, cujo enfoque segue a mesma linha de desdobramentos.

O trabalho de Mário Barata, como destaca Puppi (1998), traz a mesma visão negativa do ecletismo, mas, por ser um historiador da arte, não interpreta o seu objeto da maneira determinista como fariam os arquitetos teóricos (PUPPI, 1998, p.145), acabando por atribuir o valor de renovação a essa manifestação arquitetônica, pois ela "correspondia perfeitamente às demandas do insipiente progresso nacional, entre os anos de 1890 e 1930, e dele é parte constitutiva e inseparável” (PUPPI, 1998, p.155). Uma visão de grande interesse, pois atrela a produção da arquitetura ao desenvolvimento de um quadro mais amplo, onde atuam variáveis como os aspectos históricos, sociais e econômicos. Puppi (1998) não identifica nos textos que analisa, desse autor - A Arquitetura Brasileira dos Séculos XIX e XX ${ }^{29}$, As Artes Plásticas de 1808 a $1899^{30}$ e Século XIX. Transição e Início do Século XX $X^{31}$ - nenhuma consideração importante sobre o neocolonial. Tampouco Giovanna del Brenna, segundo a revisão de Puppi (1998, p.157), escapa "à sedução das grandes linhas interpretativas do pensamento nacional, as quais são também incorporadas às suas reflexões históricas”,

\footnotetext{
27 "Afora algumas diferenças" (Puppi, 1998, p.130), a opinião é sobre a postura do autor Carlos Alberto Cerqueira Lemos, embora em sua obra Puppi (1998) analise somente o Arquitetura Brasileira, de 1979.

${ }^{28}$ Lista de alguns: Lemos (1985, 1987, 1994); Bortolucci (1991); D’Alambert (2003); Homem (1996); Wolff (1998).

${ }^{29}$ Jornal do Comércio, Rio de Janeiro, 1952.

${ }^{30}$ In: História Geral da Civilização Brasileira. São Paulo: Difel, 1967, t.2, v.3, p. 409-424.

${ }^{31}$ In: Zanini, W. (1983). História Geral da Arte no Brasil. São Paulo: Inst. Moreira Salles, 2 v., p.377451.
} 
realizando um trabalho que contribuiu para perpetuar o desprestígio da fase eclética, muito embora tenha pesquisado sobre o ecletismo no Rio de Janeiro, durante a primeira metade dos anos de 1980. Abordou o neocolonial de passagem, situando-o no fim do período de seu interesse (Puppi, 1998, p.157-174). Um ponto de destaque, em seu trabalho, levantado pelo autor aqui mencionado, é sobre a questão da "tipificação $e$ serialização" (PUPPI, 1998, p.172) que os arquitetos do século XIX e início do XX punham em prática, demonstrando antes "sua clara consciência do novo papel do objeto arquitetônico na construção da cidade, que uma limitação de suas atividades" (PUPPI, 1998, p.170). Veremos, depois, que muitos dos projetos encontrados nos arquivos municipais pesquisados eram repetidos, mostrando que também a idéia da produção em série se difundiu, como representativa de um recurso da modernidade sem carga pejorativa - e, certamente, fez parte da rotina dos escritórios de arquitetura e engenharia. Talvez por esse motivo não houvesse constrangimentos em "copiar", dentro da medida do possível, um edifício famoso ou um projeto veiculado por revistas de arquitetura. Em suma, a revisão de Puppi (1998) representa a vontade de ver superada a "predisposição anti-eclética", como o autor assim chamou a tendência historiográfica tradicional, esforço que contribuiu - e contribui -, conseqüentemente, para o estudo do fenômeno neocolonial.

Um ano antes da publicação de Puppi (1998), Hugo Segawa lançava Arquiteturas no Brasil, 1900-1990. Trata-se também de uma obra cujo tema é muito abrangente, na qual o neocolonial comparece como parte de um longo processo, que o autor analisa através de uma óptica que busca identificar a modernidade em cada momento. Podemos conferir na obra, pelo próprio título do capítulo referente ao período neocolonial, que Segawa (1997, p.29-40) junta, na mesma ânsia de modernidade, a fase eclética e a neocolonial, apenas polarizando cada uma delas, em relação ao colonial; assim: "Do Anticolonial ao Neocolonial: Busca de Alguma Modernidade: 1880-1926”. De certo modo, o autor mostra, com essa estratégia, que também percebe a arquitetura de Ricardo Severo como opção eclética. Isso se confirma ao final do capítulo, onde Segawa (1997, p.38) diz que é possível "situar o neocolonialismo numa posição simétrica ao sistema Beaux-arts: ambos se sustentam e se legitimam no passado, com discursos tautológicos - demonstram teses repetindo-as com palavras diferentes. (...) o neocolonial, na prática concreta, afigurou-se como uma variação do ecletismo”. O autor também partilha da tradicional idéia de que no Rio de Janeiro o neocolonial teve 
maior repercussão e maiores conseqüências, porém atribui esse fato não ao ambiente intelectual das cidades, mas à atuação de seus precursores (SEGAWA, 1997, p.36). O autor afirma que "a última obra neocolonial importante executada no Brasil foi o edifício da Faculdade de Direito de São Paulo, projeto de Ricardo Severo inaugurado em 1939” (SEGAWA, 1997, p.38), ponto com o qual não estamos de acordo, pois o conjunto das Escolas Práticas Agrícolas, realizadas a partir de 1942, é de enorme valor e é erudito, embora não seja uma realização de primeira hora. A novidade da obra de Segawa (1997) é que deixa exposta a complexidade daquelas décadas, mostrando que, mesmo antes da conferência de 1914, feita pelo engenheiro português, mesmo antes de o debate sobre identidade cultural chegar à esfera da arquitetura, "a questão era latente, e, ao menos isoladamente, arquitetos manifestavam-se a respeito na esteira da discussão mais ampla” (SEGAWA, 1997, p.32). O autor também adota uma visão mais aberta sobre a figura de Severo, afirmando que o engenheiro "não defendia uma postura propriamente conservadora" (SEGAWA, 1997, p.35), ressaltando a defesa que ele fazia do regime republicano e destacando, ainda, que a parcela da arquitetura que deveria ser recuperada no Brasil era a de origem Portuguesa. O fato de recordarmos, através de Segawa (1997) que fazer a defesa do regime republicano era, naqueles dias, uma atitude progressista, contribui para o ajuste da imagem construída pela historiografia sobre o engenheiro português. O capítulo também nos chama a atenção para a difusão do neocolonial, que teria ocorrido por todo o Brasil, nas reproduções de elementos ornamentais, em edifícios residenciais e comerciais (e aqui cita os postos de gasolina, dos quais encontramos alguns projetos).

Podemos dizer que, nessa fase, o neocolonial começa a ser considerado como objeto de interesse para as pesquisas, embora ainda haja reservas em observá-lo, bem como ao ecletismo, sem a carga pejorativa estabelecida na historiografia, devido ao seguinte esquema, consolidado após os trabalhos de Goodwin (1943) ${ }^{32}$ e Mindlin $(1956)^{33}$ :

a dominância da produção eclética, nas últimas décadas do século XIX e nas duas primeiras deste século [XX], representa uma interrupção, um desvio, e a constituição do grupo carioca, especialmente a partir da vinda de Le Corbusier e da experiência do edifício do Ministério, a reconstituição do fio condutor (MARTINS, 1987, p.30).

\footnotetext{
${ }^{32}$ Goodwin, Philip L. 1943. Brazil Builds. Architecture Old and New: 1652/1942. New York: MMA.

${ }^{33}$ Mindlin, Henrique E. 1956. Modern architecture in Brazil. New York: Reinhold Pub. Corp.
} 
De certa forma, deu-se uma reabilitação da arquitetura do século XIX que permitirá estudos mais aprofundados sobre o movimento neocolonial a partir do final do século XX. No mais, até a década de 1990, aproximadamente, os trabalhos que tratam de assuntos que abordam o movimento neocolonial tendem a repetir e reforçar o que já vinha sendo dito.

\subsection{Trabalhos Recentes: Ajustesna Linha Historiográfica}

A tendência da historiografia, hoje, nos parece mais ampla, uma vez que procura compreender o período em questão de maneira contextualizada, considerando a complexidade em que estiveram envolvidos, principalmente, os arquitetos que obtiveram destaque na produção arquitetônica do início do século XX. Essa maior abertura e maior ramificação de investigações se devem, também, à revisão dos parâmetros utilizados para a interpretação da produção cultural de fins do século XIX e início do XX e, especificamente, à reconsideração da arquitetura eclética, que pertence a esse contexto.

Assim, continuaram a despontar trabalhos sobre o ecletismo, como o realizado por Lima (2001), intitulado Modelos Portugueses e a Arquitetura Brasileira: catálogo e análise das formas arquiteturais paulistanas e lusitanas no oitocentos, doutorado orientado por Jorge Sidney Coli Junior, o mesmo pesquisador a orientar Puppi (1998). Nessa pesquisa, o autor trata da difusão de um gosto, através de manuais, que vai culminar com a arquitetura eclética no século XIX, tanto em Portugal como no Brasil. O objeto é a arquitetura anônima, realizada por "construtores, pedreiros e mestres de obras que estiveram em ação, tanto em Portugal como no interior paulista, por quase dois séculos” (LIMA, 2001, p.445). A partir de sua pesquisa, o autor levanta uma questão importante para o aprofundamento da compreensão da arquitetura eclética paulista: depois de ter mostrado as relações entre legislações urbanas e práticas arquitetônicas brasileiras e portuguesas, o autor pergunta se "sob esse aspecto, as influências na arquitetura paulista, tanto da missão francesa como dos imigrantes italianos, podem ser repensadas" (LIMA, 2001, p.444). Vemos serem desenvolvidos, assim, um núcleo de estudos, no âmbito da História da Arte, que vai contribuindo para alargar o leque de temas historiográficos sobre a arquitetura brasileira. Certamente haverá outros núcleos a tratarem de ecletismo e de outras vertentes preteridas. 
Ainda no âmbito da História, foi desenvolvida, sob orientação de Etelvina Maria de Castro Trindade, da Universidade Federal do Paraná, a tese de doutorado Beirais e platibandas; arquitetura de Curitiba na primeira metade do século XX, no ano de 2003, de autoria de Marcelo Saldanha Sutil. O trabalho trata da arquitetura neocolonial e art déco na cidade de Curitiba, no período de 1920 a 1950, de suas difusões e da difusão de um gosto popular dessas tendências. Segundo o autor, um dos objetivos da obra é reafirmar a importância desse período "que, em nome da hegemonia de uma escola modernista influenciada por Le Corbusier, foi desqualificado pela própria historiografia da arquitetura" (SUTIL, 2003), demonstrando um ponto de alargamento na tradicional visão historiográfica. Outro estudo sob a mesma orientação, da mesma instituição e, também, mesma autoria, porém ainda da década de 1990, é $O$ Espelho e a Miragem: Ecletismo, Moradia e Modernidade na Curitiba no Início do Século, dissertação de mestrado que contempla as "transformações ocorridas na arquitetura curitibana durante a passagem do século XIX para o XX” e as possíveis influências dos imigrantes na construção do ecletismo desse período (SUTIL, 1996).

Outro texto que evidencia a complexidade cultural das primeiras décadas do século XX é o artigo publicado por Farès El-DahDah, “A Arqueologia da Modernidade de Lucio Costa" (NOBRE, 2004) traz a contribuição de explorar contradições na trajetória do arquiteto, tais como o fato de ter sido chamado, em 1937, para projetar o novo prédio do Ministério da Educação e Saúde e, também, ter recebido o cargo de diretor da Divisão de Tombamentos do IPHAN. Tal fenômeno deu-se também com outros intelectuais modernistas que trabalharam para o IPHAN, como é o caso de Mário de Andrade $^{34}$. O artigo explora, inclusive, a maneira como o arquiteto trata, em seus projetos, as referências vernáculas, alcançando como resultado ora a arquitetura modernista tão almejada, ora “puro simulacro” (EL-DAHDAH, 2004, p.290).

Ainda no mesmo sentido, é fundamental a diferenciação que Pinheiro (2004, p.299-304) faz, em seu artigo "Enigmas de Lucio Costa”, entre as arquiteturas ditas "modernas", entre as décadas de 1930 e 1940, que englobavam várias vertentes "modernizantes" e, que "mesmo quando denominada "moderna" - continua a ser entendida exclusivamente como um fenômeno de fachada” (PINHEIRO, 2004, p.302). Não menos importante é o olhar que a autora lança sobre o arquiteto Lucio Costa,

\footnotetext{
34 Ver a esse respeito: Andrade, Mário de (1981). Mário de Andrade, cartas de trabalho: correspondência com Rodrigo Mello Franco de Andrade (1936-1945). Brasília: Ministério da Educação e Cultura, Secretaria do Patrimônio Histórico e Artístico Nacional, Fundação Nacional Pró-Memória.
} 
procurando compreender os seus "enigmas", dentro do contexto ambíguo em que desenvolveu a sua obra - e não como figura isolada e destacada, como tradicionalmente o vinha tratando a historiografia - e que nos ajuda a melhor compreender, também, outros arquitetos, seus contemporâneos, que certamente tiveram de lidar com a mesma complexidade, dentre os quais podemos citar Hernani do Val Penteado, Ângelo Alberto Murgel, Ícaro de Castro Mello, José Maria da Silva Neves e Eduardo Kneese de Mello.

A esse propósito, devemos voltar à obra de Puppi (1998) que, embora não pertença aos últimos trabalhos realizados sobre o assunto, parece ter sido o mais contundente, na sua posição questionadora, no âmbito de um desenvolvimento historiográfico, que se abre ao admitir novos enfoques. A nossa alusão à complexidade vivida nos tempos da campanha neocolonial é também considerada pelo autor, de uma forma com a qual estamos de pleno acordo. $\mathrm{O}$ autor, ao afirmar que o movimento neocolonial teve "duas faces inseparáveis (...) a ideológica (o conflito dos estilos «nacional»e «estrangeiros») e a profissional (a convivência entre eles)" (PUPPI, 1998, p.91) chama a atenção para aquilo que também vamos demonstrar neste trabalho, que é o fato de que vários profissionais praticaram concomitantemente a arquitetura eclética, a neocolonial, a art déco e a modernista, em vários graus de erudição, como havia feito nos primórdios o arquiteto carioca Heitor de Mello (SANTOS, 1981, p.90). Entre o conteúdo ideológico e a prática já havia uma distância, desde o princípio, e essa distância foi crescendo, com o decorrer do tempo e com a difusão da arquitetura (de origem) neocolonial no espaço construído, principalmente o urbano.

Podemos citar aqui, também, como pertencentes a essa fase, trabalhos produzidos no Rio de Janeiro, e que são os de Kessel (2002), Entre o Pastiche e a Modernidade: Arquitetura Neocolonial no Brasil, e de Silveira (2002), Arquitetura Neocolonial e o Pensamento Nacionalista. O primeiro trata da produção textual, elaborada pelos intelectuais que mais se destacaram no lançamento, debate e implementação do movimento neocolonial e, se propõe a reavaliar algumas questões relacionadas que, segundo o autor, estão em aberto, com os novos estudos acerca do tema:

os trabalhos mais recentes, de pesquisa e de análise, refletem uma conjuntura em que se debate o esgotamento dos modelos funcionalistas $e$ racionalistas, no que se refere à produção construída dos arquitetos, e em que se coloca em cheque também a necessidade de reavaliação de todo o 
arcabouço sobre o qual assenta a história da nossa arquitetura (KESSEL, 2002, p.21).

As "questões em aberto" que o autor vai abordar são várias, três delas aqui já mencionadas. Uma é o combate do neocolonial ao ecletismo - já aventado por Puppi (1998), que teria sido uma motivação inflamada por Mariano Filho, após o ponto de partida de o movimento ter sido a retomada da tradição arquitetônica -, considerado pelo autor como reação inicial para a constituição do movimento (KESSEL, 2002, p.239). Outra é a tomada da arquitetura neocolonial por mais uma opção eclética, bem descrita pelo autor como:

inegavelmente, é a relação do Neocolonial com o ecletismo, na medida em que o seu surgimento estaria ligado ao esgotamento dos modelos historicistas importados da École des Beaux Arts parisiense, e se constituiria numa reação ao fazer arquitetônico do início do século. Ao mesmo tempo, como vimos, difundiu-se a noção de que esta reação teria terminado por amalgamar-se com o próprio objeto de oposição, criando mais um estilo (ou pseudo-estilo) historicista, mero revival destituído de densidade (KESSEL, 2002, p.22).

E, ainda outra, é a distância existente entre a proposta do movimento e a arquitetura realizada a partir dela. Sobre esta última questão, perguntamo-nos se também ela não seria uma construção da historiografia. Existiria, de fato, uma distância, se os mentores do movimento tivessem clareza absoluta do se deveria construir como arquitetura brasileira. Ao que nos consta, eles pregavam que os arquitetos se inspirassem na tradição arquitetônica do país para desenvolverem seus projetos, e, o exemplo mais próximo desse modelo ideal era a arquitetura colonial e barroca, com raízes portuguesas. Tanto assim que Kessel (2002, p.240) afirma que "Severo e Marianno (...) ressaltam a importância de evitar a cópia acrítica da ornamentação da época colonial”. Tanto assim que, ainda segundo o autor (Kessel, 2002, p.216) ao afirmar que "a tentativa de estabelecer um dicionário e uma gramática da arquitetura colonial brasileira, esforço totalizante para criar uma linguagem nova e controlada, havia fracassado”, não considera que esse suposto dicionário era justamente sobre o modelo de inspiração - o colonial - e não sobre o neocolonial. Tanto assim que Mariano Filho, médico, tinha em mente uma idéia para seu Solar Monjope que nenhum arquiteto conseguiu traduzir. Ele próprio, orientando seus construtores, conseguiu expressar satisfatoriamente a arquitetura que professava. Por todas essas razões, 
poderíamos considerar que muitos exemplares construídos se aproximaram dos ideais propostos, ou, por outro lado, considerar que todos estiveram distantes. Acreditamos que houve um "distanciamento" entre ideal e prática, na reprodução da linguagem, de maneira despreocupada, por modismo, mas esse é o campo da difusão. A arquitetura neocolonial esteve sim, longe de ser igual à colonial/barroca, mas isso não foi uma premissa do movimento. Portanto, há que se avaliar se, de fato, houve distância entre ideal e produção nos exemplares que não devemos considerar como difusão. Nessas obras neocoloniais de primeira hora houve a tentativa de associar inspiração colonial e necessidades programáticas/recursos tecnológicos atuais, sendo essa síntese o ideal buscado. Naturalmente, o produto da tentativa de síntese seria diferente da arquitetura colonial, mas não teria se aproximado do ideal buscado?

Para Kessel (2002, p.210), por fim, 1940 é a data da morte do movimento neocolonial, mas

não significou, em absoluto, o seu fim na produção construída. Duas décadas de esforços haviam sido suficientes para estabelecer o estilo como um dos mais requisitados aos arquitetos e construtores. (...) os ornamentos característicos da arquitetura colonial brasileira (...) seriam reutilizados $e$ reapropriados pelas décadas de 30, 40 e 50 afora. Marcam esta fase as casas e sobrados que surgem nos arrabaldes paulistanos; no Rio de Janeiro, principalmente em Botafogo, na Tijuca, em Copacabana e na Urca, mas também nos subúrbios; e nos bairros de classe média das principais cidades brasileiras (KESSEL, 2002, p.214)

e, acrescentamos aqui, também pelas cidades do interior paulista.

Também de 2002 é a dissertação de mestrado de Edis Evandro Teixeira de Carvalho, orientado por Paulo Ormindo David de Azevedo, na Faculdade de Arquitetura da Universidade Federal da Bahia, intitulada A Arquitetura Neocolonial: A Arquitetura como Afirmação de Nacionalidade. A pesquisa traça "relações entre a Arquitetura Neocolonial encontrada em diversas partes do país, demonstrando seu alcance territorial e temporal, seus valores ideológicos e artísticos” (CARVALHO, 2002) e faz uma revisão crítica da historiografia pois aponta para a valorização, nela, prioritariamente, da arquitetura colonial e da modernista.

Nesse universo dos trabalhos mais recentes podemos incluir a, por assim dizer, "segunda geração de descendentes" do professor Carlos Lemos como, por exemplo, a 
tese de doutorado de D’Alambert (2003), que investigou as Manifestações da Arquitetura Residencial Paulistana entre as Grandes Guerras. É nessa geração também que irá se inserir a nossa tese. Em sua pesquisa, a autora aborda várias tendências estilísticas identificáveis na arquitetura da capital paulista, dentre as quais a neocolonial é uma das principais. Segundo nosso entendimento, a grande inovação deste trabalho é o fato de seu enfoque principal centrar-se na análise do objeto arquitetônico propriamente dito - ou seja, técnicas construtivas, programas, repertórios estilísticos para posterior defesa de uma linguagem estilística própria da cidade de São Paulo, ocorrida no período abordado. Dessa maneira, D’Alambert (2003) supera, com informações novas na pesquisa do tema neocolonial, as discussões de confronto sobre a validade do objeto, tendo sido o conjunto da obra bastante inspirador, pois percorre um caminho diverso. Uma dessas novidades que a autora traz à luz é, por exemplo, a evidência de que

algumas obras neocoloniais (...) sob a óptica atual podem ser consideradas excepcionais pela sua complexidade volumétrica (...) resultante de plantas minuciosamente elaboradas, só possíveis de ser executadas graças ao emprego da nova técnica construtiva do concreto armado (D’ALAMBERT, 2003, p.49).

Por outro lado, não se valeu da oportunidade de realizar o trabalho para se estender na discussão teórica sobre o movimento neocolonial, repetindo alguns lugares comuns estabelecidos pela linha historiográfica dominante como quando, com apoio nas palavras de Bruand (1981), afirma que em São Paulo “o movimento tradicionalista tivesse (...) uma penetração e uma aceitação limitadas, quando comparado com o Rio de Janeiro" (D’ALAMBERT, 2003, p.49). Observamos também que a autora considera a década de 1920 como o apogeu do neocolonial no Rio de Janeiro, o que, em São Paulo ocorre entre os anos 20 e 30, aí tendo sido definitivamente superado apenas no segundo pós-guerra (D’ALAMBERT, 2003, p.50, 54 e 64). Apuramos que no interior paulista o neocolonial persistiu também até mais ou menos essa época, sendo que os exemplares mais tardios que pudemos localizar datam de 1950.

José Maurício Saldanha Alvarez foi orientador da pesquisa de mestrado de Maria de Lourdes Rumbelsperger, em 2004, cujo título é A Arquitetua Neocolonial e sua Poética: das origens do movimento ao projeto da Universidade Federal Rural do Rio de Janeiro. O trabalho se propõe a “investigar o estilo Neocolonial e seu contexto 
de modernidade" (RUMBELSPERGER, 2004) tendo o prédio da UFRJ como objeto de análise. Do mesmo ano é o mestrado de Renato Guimarães Pereira, do Mackenzie: Documentário Necessário: Contribuição de José Wasth Rodrigues para a Arquitetura Brasileira entre 1914 e 1944. Como o nome informa, a pesquisa trata de um dos artistas mais comprometidos nas viagens de reconhecimento da arquitetura colonial, patrocinadas pelos seus precursores. $\mathrm{O}$ autor afirma que, além do registro que fez de nossa arquitetura, Wasth Rodrigues contribuiu com "um enorme legado entre desenhos, pinturas e textos documentais nas áreas de arquitetura, mobiliária, heráldica e trajes militares" (PEREIRA; 2004).

O ano de 2005 trouxe várias contribuições importantes para o melhor delineamento dos rumos historiográficos, em especial no que tange ao movimento neocolonial. Pinheiro (2005), em sua tese de livre docência, Neocolonial, Modernismo e Preservação do Patrimônio no Debate Cultural dos Anos 1920 no Brasil, destaca “a ascensão da capital paulista não só do ponto de vista econômico, mas também artístico e cultural" (PINHEIRO, 2005, p.45-50) nos anos de lançamento do movimento neocolonial, mostrando que a cidade já alcançara desenvolvimento suficiente para acolher idéias de vanguarda, colaborando para que o estigma de atraso cultural e intelectual, com que costumava ser laureada, fosse desfeito ${ }^{35}$, colaborando, em conseqüência, para entendermos porque obras neocoloniais eruditas - como o prédio da Beneficência Portuguesa, de Severo, em Bauru, por exemplo - pulularam pelo interior do Estado. A autora também sustenta que a explosão neocolonial no Rio de Janeiro se deu impulsionada pela Exposição Internacional do Centenário da Independência, onde se instalou o impressionante Pavilhão do México, já devidamente caracterizado dentro da nova tendência neocolonial hispânica, abrindo caminho para essa vertente em terras cariocas, e outras regiões brasileiras (PINHEIRO, 2005, p.56-57). Em São Paulo, porém, devido à “orientação lusa impressa por Ricardo Severo ao neocolonial paulista foi inicialmente menos permeável à influência do Mission Style ou do «Renascença Espanhola»" (PINHEIRO, 2005, p.59). De fato, veremos que, com a difusão pelo interior paulista, as influências se misturaram, e pudemos localizar diversos exemplares ligados, mesmo que de forma tênue, às vertentes missões e espanholas. Outra abordagem esclarecedora, nesse trabalho, é sobre o ensino de arquitetura durante os anos em que o neocolonial floresceu e se estabeleceu. Esse aspecto nos dá a

\footnotetext{
35 Novamente, lembramos aqui a postura de Bruan (1981), que ajuda a propagar a idéia do atraso intelectual e artístico da sociedade paulista, já anteriormente discutida.
} 
compreender alguns motivos que levaram tantos profissionais a praticarem várias tendências arquitetônicas em seus projetos. Esse ponto muito nos interessou, visto que encontramos projetos neocoloniais de profissionais reconhecidamente modernistas na área de abrangência de nossa pesquisa e, também, inúmeros profissionais - eruditos, embora não renomados - a produzirem e reproduzirem variadas tendências estilísticas sem discriminação, inclusive misturando suas características. A autora destaca, ao tratar dos pavilhões brasileiros para a Exposição de 1922, “a inexistência de quaisquer pretensões de exclusividade estilística por parte dos autores dos projetos, que transitavam livremente do neocolonial para o Luís XVI, e vice-versa” (PINHEIRO, 2005, p.56). Ainda de acordo com a autora, Victor Dubugras costumava levar seus projetos, certamente neocoloniais, para serem copiados por seus alunos (PINHEIRO, 2005, p.62) e, em iniciativas oficiais, já que realizadas pela Escola Politécnica, o engenheiro-arquiteto Alexandre Albuquerque realizava “"excursões técnicas» com seus alunos, levando-os a cidades como Itanhaém, Ouro Preto, Tiradentes e Congonhas do Campo" (PINHEIRO, 2005, p.63), para estudarem a arquitetura colonial. Assim como Silva (2005), Pinheiro (2005) vai destacar a influência de Ruskin e do romantismo na formação e no pensamento de Ricardo Severo, trazendo à luz, por essa via, o caráter romântico do movimento neocolonial, do da Casa Portuguesa e de outros movimentos similares, que ficam ligados por uma ideologia comum. Sob esse ponto de vista que considera a influência do espírito romântico no pensamento das figuras mais importantes de tais movimentos, elas passam a fazer sentido, deixando de ser satisfatórias as interpretações que as reduzem a meras mentalidades que não compreendiam ou não aceitavam se render às "incontestáveis" razões da modernidade. Pinheiro (2005, p. 129-167) finaliza fazendo uma análise da "biografia de Lúcio Costa (...) [no que diz respeito a] sua proximidade do neocolonial no Rio de Janeiro, e inegável proximidade com sua figura de proa, José Mariano Filho” (PINHEIRO, 2005, p.129), contribuindo para uma melhor compreensão da relação neocolonial-modernismo e também do pensamento de Lúcio Costa.

A Presença da Arquitetura Neocolonial na Cidade do Salvador é o título de uma dissertação de mestrado, também de 2005, realizada por Silvia Becher Breitembach, sob orientação de Odete Dourado Silva. A pesquisa, que nos informa sobre a ocorrência da tendência nessa cidade do Nordeste mostra também haver interesse específico nesse objeto por parte da Escola de Arquitetura e Urbanismo da 
Universidade Federal da Bahia. A autora diz que foi "nas décadas de 20 e 30 que floresce a maior parte da produção construída, adotado em residências, escolas, clubes e outros projetos públicos" (BREITEMBACH, 2005), evidenciando o aspecto oficial do neocolonial baiano e considerando também a esfera da difusão, ao dizer que foi “interpretado e contextualizado” (BREITEMBACH, 2005).

É também de 2005 a dissertação de mestrado Nacionalismo e Arquitetura em Ricardo Severo, Porto 1869 - São Paulo 1940, de Joana Mello de Carvalho e Silva. Nessa investigação encontramos um vasto levantamento sobre a figura de Ricardo Severo, contemplando diversos aspectos de sua trajetória, como o de sua formação erudita, de seus interesses e de seu papel no movimento neocolonial. Tem como um de seus principais objetivos desmistificar a "imagem histórica" construída a seu respeito, geralmente, em relação ao arquiteto Victor Dubugras, como descreve a autora:

a falta de originalidade e de expressão da arquitetura de Severo era explicada, de um lado, pelo fato do engenheiro não gostar de desenhar nem possuir atributos excepcionais como arquiteto (...) por outro lado, a preocupação quase obsessiva e xenófoba de Severo em realizar "projetos que nada mais eram que estilizações do mais puro barroco lusitano das casas solarengas do norte de Portugal» (SILVA, 2005, p.28).

Consegue mostrar que Severo foi um homem comprometido com questões políticas, científicas e artísticas, levado, por seus interesses, a uma produção tanto teórica como prática, em sua terral natal e no Brasil. Contempla a atuação de Severo considerando o contexto político e social de seu país, como um fator que, sem dúvida, foi determinante para seu pensamento e sua obra. É um trabalho que busca, assim como o de Pinheiro (2005) e o de Milheiro $(2005)^{36}$, vislumbrar, nas relações entre certos aspectos da cultura portuguesa e da brasileira, alguns esclarecimentos, no âmbito da arquitetura. E seria nesse mesmo sentido que, acreditamos, o nosso trabalho vai se alinhar. Ou seja, dessa maneira, o movimento neocolonial deixa de ser apenas uma manifestação "americana" - ligada, por um lado, às novas influências da propaganda, cinema e revistas americanas para divulgar a vertente hispânica e, por outro, a uma busca de identidade nacional, motivada pelas emancipações culturais dos países latinoamericanos - para encontrar um sentido maior, sendo além de tudo, mais um efeito do "espírito romântico", das influências de Ruskin e das relações com a modernidade.

36 Milheiro, Ana Vaz. 2005. A Construção do Brasil: Relações com a Cultura Arquitectónica Portuguesa. Porto: FAUP Publicações. Sobre Ricardo Severo, Raul Lino e o Neocolonial ver: p. 133-229. 
Sobre o mesmo assunto específico, e do ano anterior (2004), discorre a dissertação de mestrado orientada pelo professor Cândido Malta Campos Neto, O Discurso de Ricardo Severo e o Neocolonial Brasileiro, realizado no Mackenzie por André Henrique Quintanilha Ronzani.

Ao final desse enquadramento teórico, situamos nossa pesquisa como uma contribuição para o entendimento da abrangência, no tempo e no espaço, da chamada arquitetura neocolonial. Foram encontradas obras eruditas e difusões "anônimas", pelo interior paulista, mostrando que essa produção avançou muito os limites da cidade de São Paulo ou da do Rio de Janeiro, abrindo um campo inédito para pesquisas futuras. Embora as viagens de reconhecimento da arquitetura brasileira, patrocinadas por Mariano Filho e pelo SPHAN, tenham sido as primeiras a se preocuparem com a arquitetura realizada fora das capitais e dos centros mais desenvolvidos, esses esforços não tiveram continuidade no âmbito do interior paulista, reforçando a teoria da desvalorização, pela historiografia, do que não fosse colonial ou modernista.

Quanto à contribuição para a historiografia, procuramos fugir aos enfoques mais comuns, apontados em nossa revisão bibliográfica, e dar um testemunho, tanto quanto possível, isento de idéias cristalizadas. Concordamos com vários autores em muitos aspectos e nos utilizamos largamente de suas informações - o que não poderia deixar de ocorrer -, particularmente, para observar o problema da difusão das características formais do movimento sem conteúdo ideológico e para identificar se a arquitetura neocolonial tinha sido registrada como oficial em plena década de 1940. Deparamos-nos também com algumas suspeitas que pesquisas futuras poderão (ou não) confirmar, como por exemplo, a existência de uma inclinação a associar o neocolonial ao ambiente rural, como se verifica em algumas obras do arquiteto Ângelo Murgel e em alguns edifícios que atualmente ainda são utilizados como institutos penais agrícolas. Outra hipótese é sobre a tipologia pré-escolhida para determinados usos dos edifícios. Acreditamos que, num primeiro momento, o neocolonial rompeu com esse "historicismo tipológico", como chamado por Patetta (1987, p.14), sendo, essa, mais uma característica modernizadora do movimento. Sabemos de edifícios religiosos, escolares, públicos e residenciais que empregaram o estilo tradicionalista, abolindo a rigidez do neogótico para igrejas, neoclássicos para edifícios públicos, exóticos para jardins ou praças públicas (PATETTA, 1987, p.14-15). Num segundo momento, ou durante a difusão, verificamos uma tendência ao uso da linguagem preferencialmente 
para moradias, enquanto os edifícios comerciais adotavam o art déco, para comunicar um desejo de progresso (FERRAZ, 2003, p.47).

Como pano de fundo, mas não menos importante, coloca-se a convergência de nosso entendimento sobre o movimento neocolonial com a interpretação de Puppi (1998). A parte I desta pesquisa, realizada em Portugal, como vários outros trabalhos, indica que o movimento brasileiro foi uma manifestação conectada a outras semelhantes, e que suas motivações foram, também, fruto de idéias românticas, como aconteceu com outros movimentos semelhantes, surgidos por toda a Europa. Curiosamente, o romantismo foi associado apenas a tendências arquitetônicas anteriores, como o fez Santos (1981, p.65-69) e outros pesquisadores. Diferentemente, Puppi (1998, p. 91) afirma que "o estilo tinha clara conotação nacionalista desde cedo, mas ela estava associada mais ao pitoresco que a uma grande causa”. Essa grande causa seria o combate ferrenho ao ecletismo, que teria sido despertado por Mariano Filho (PUPPI, 1998, p.91), mas que não estava na base da valorização da cultura tradicional e, portanto, não nasceu com o movimento. Essa idéia é reforçada pelo fato de Ricardo Severo - bem como outros profissionais envolvidos em outros movimentos tradicionalistas, como Raul Lino, por exemplo - ter recebido, em sua formação, a herança da cultura romântica, como mostram respectivamente Silva (2005) e Ribeiro (1994), em seus trabalhos sobre as personalidades citadas, e é ratificada, também, pelo próprio Severo, ao recomendar que “não se revoltem os profissionais do ecletismo artístico, supondo que esta orientação injustamente condena as suas obras; pelo contrário, louva-as quando são expressões perfeitas de real beleza estética" (SEVERO $^{37}, 1917$ apud FABRIS, 1987, p. 287).

\footnotetext{
${ }^{37}$ SEVERO, R. Da Arquitetura Colonial no Brasil. Arqueologia e Arte. O Estado de São Paulo, 7 set. 1922.
} 
Capítulo 4

ARQUITETURA NEOCOLONIAL PAULISTA: IMAGEM OFICIAL 
A história da ocupação e do desenvolvimento do Estado de São Paulo está envolvida com diversos fatores, entre os quais se sobressai o ciclo do café, ocorrido no século XIX e início do século XX. Esse tema é objeto de muitas pesquisas, o que nos desobriga, aqui, de uma repetição detalhada. Vários estudiosos do assunto mostram que o vulto tomado pela produção cafeeira em terras paulistas acelerou, na mesma proporção, o desenvolvimento de todos os aspectos da sociedade. Antes disso, a ocupação do território, a exploração agropecuária, e consideráveis relações sociais e econômicas, já eram praticadas, porém não de forma tão notável.

A estrada de ferro, trazida no encalço dos interesses da produção cafeeira, foi o elemento primordial de ligação entre as cidades paulistas, e destas com o mundo. Em virtude desse intercâmbio, grande parte das cidades que se consolidaram durante o ciclo cafeeiro, no Estado de São Paulo, exibia uma arquitetura estreitamente ligada aos preceitos do ecletismo, e uma "preferência marcada pelo traçado ortogonal de ruas $e$ praças" (BORTOLUCCI, 1991, p.26). Com as novas facilidades de comunicação, a arquitetura produzida no século XIX, e mesmo depois, foi paulatinamente alterada e substituída pela eclética, tanto na área urbana como na rural, quando os recursos financeiros se avultaram, em decorrência do comércio do café. Naturalmente, a arquitetura tradicional foi associada ao atraso e ao passado, pois a cultura eclética passou a representar a prosperidade e a modernidade. Como já se sabe, fatores como materiais facilmente trazidos através das estradas de ferro, assim como mão-de-obra experiente, no ramo da construção, representada pelos imigrantes europeus, especialmente os italianos, propiciaram o florescimento dessa arquitetura europeizada, no interior paulista.

Importa, para nossa pesquisa, notar que por volta de 1930 esse quadro começa a se transformar, e novas variáveis determinam o desenvolvimento, a estagnação e/ou o retrocesso das cidades do interior paulista, bem como seu espaço arquitetônico. $\mathrm{O}$ ciclo do café em decadência, o início do processo de industrialização, o processo de migração do campo para as cidades, o forte investimento em rodovias, em detrimento da ferrovia, foram algumas das novas condicionantes da arquitetura. Dentre as cidades paulistas cujo desenvolvimento esteve associado ao ciclo do café, algumas mantiveram e outras estancaram seu ritmo de crescimento, diante desses novos fatores. Cidades próximas às linhas-férreas principais e, posteriormente, às rodovias principais, não sofreram o mesmo retraimento que outras, localizadas menos favoravelmente com relação às vias 
de transporte (NUNES, 2005). Assim, cidades hoje pequenas, ou de médio porte - de 10mil habitantes a 80mil, aproximadamente -, via de regra, não acompanharam as mesmas fases de desenvolvimento de cidades maiores e, por conseguinte, não apresentam as mesmas manifestações arquitetônicas. Por isso, grande parte das cidades pequenas e médias do interior do Estado apresenta configuração arquitetônica predominantemente eclética, como se tivessem parado no tempo. Para ilustrar, podemos citar algumas cidades localizadas mais a nordeste do Estado e que foram fundadas ainda no século XIX - como Casa Branca (1872), Mococa (1871), São José do Rio Pardo (1867) e Santa Cruz das Palmeiras (1870) - e, mais ao centro - como Boa Esperança do Sul (1880), Ribeirão Bonito (1872), Dourado (1880) e Bocaina (1890) ${ }^{1}$.

Essa região central, formada pelas últimas quatro cidades citadas, e outras que eram atendidas pela Estrada de Ferro Douradense, é um bom exemplo, não apenas para este estudo sobre arquitetura, mas também para outros, sobre urbanização, desenvolvimento sócio-econômico e cultural, à luz da crise do café e do abandono do modelo de transportes baseado na ferrovia. Como nos mostra Nunes (2005), essas cidades passaram por um processo de estagnação e até retrocesso, em vista da interrupção dos investimentos na rede ferroviária e do seu desmonte, a partir do decreto de 1955 que, "entre outras providências estabelecia a substituição de ferrovias reconhecidamente deficitárias por rodovias" (NUNES, 2005, p.20). Segundo esse mesmo autor, houve um

desequilíbrio socioeconômico ocorrido com o processo de erradicação dos trilhos [e que] foi inevitável em toda [a sua] área de influência, destacandose a paralisação de fluxos de escoamento da produção de pequenos produtores e da população em geral (NUNES, 2005, p.20).

Essas cidades sofreram um processo de redução nas possibilidades de deslocamento populacional, de oportunidade de empregos, de movimentação econômica e cultural. Os deslocamentos na região chegaram praticamente à metade, e a população chegou a reduzir-se de 35\% a 15\% (NUNES, 2005, p.180-181). Junto com o efeito de migração do campo para as cidades, as decisões políticas das décadas de 1930, 1940 e 1950, causaram também a migração de algumas cidades para outras, que centralizaram melhores oportunidades de emprego, lazer, educação etc. No geral, as cidades cuja

\footnotetext{
${ }^{1}$ Dados sobre as cidades retirados da IBGE (1957 a 1964). Enciclopédia dos Municípios Brasileiros. Ed. IBGE, DVD (2000).
} 
vitalidade estava ligada apenas à ferrovia empobreceram-se em vários aspectos, pois perderam para cidades melhor localizadas com relação às rodovias, no que se refere a itens como acesso à saúde, à educação, à cultura, ao emprego, passando a fícar cada vez mais dependentes das cidades polarizadoras ${ }^{2}$ (SÃO PAULO (ESTADO). SECRETARIA DE ECONOMIA E PLANEJAMENTO (1978).

Em contraste, até a década de 1930 foram construídos, mesmo nas pequenas e médias cidades do interior paulista, muitos prédios que se destacam pela qualidade e expressividade, como as escolas construídas durante a Primeira República e tombadas pelo CONDEPHAAT desde 2002 (CORRÊA, 1991). Grande parte desses prédios escolares ainda é eclética, sendo, alguns, neocoloniais. Outros exemplos são igrejas, habitações, edifícios públicos e até obras de arte, como as produzidas por Benedito Calixto $^{3}$, existentes ainda na Igreja da cidade de Bocaina. A própria Bocaina é um exemplo do resultado do isolamento ao qual foi destinada: sua arquitetura está quase intacta, constituindo-se num patrimônio eclético bem preservado.

Como resultado, no que diz respeito à arquitetura podemos observar que não foram erigidos exemplares ou conjuntos arquitetônicos muito significativos, nas cidades desfavorecidas pela decadência do modelo de produção café / transporte ferroviário. Ressentidas dos efeitos da crise, durante as décadas de 1940 e 1950, essas cidades dispunham de poucos recursos para manter seu desenvolvimento e para ostentar novas construções, como a neocolonial e a modernista, por exemplo. Essa foi uma tendência geral para as cidades menores, mas, especificamente, fatores diversos agiram em cada uma, gerando situações diferenciadas, razão pela qual é possível encontrar, em alguns municípios, produções e/ou exemplares neocoloniais importantes. Um exemplo é a cidade de Pirassununga $(1879)^{4}$, que recebeu uma Escola Prática de Agricultura, em 1942, cujas edificações foram construídas segundo os preceitos do neocolonial.

Por outro lado, nas cidades que continuaram a crescer a produção neocolonial é expressiva, como pudemos verificar naquelas que fizeram parte de nossa pesquisa. A

\footnotetext{
${ }^{2}$ Verificamos, entre outros dados relevantes, que em 1947, no governo estadual de Adhemar de Barros (1947-51), foi dada atenção maior para o Departamento de Imigração e Colonização, que passa para a Secretaria da Agricultura. Nesse momento, "a ênfase do discurso [político] é dada às migrações, que deveriam suprir a carência de mão-de-obra na cidade”. .

3 Benedito Calixto (1853-1927) foi um importante pintor paulista, atuante entre fins do século XIX e início do XX em várias cidades do Estado de São Paulo. http://pt.wikipedia.org/w/index.php?title=Benedito_Calixto\&oldid=4552319. Acessado em 26/03/2007. 4 Ainda hoje sua população é de $70 \mathrm{mil}$ habitantes, aproximadamente (IBGE, http://www.ibge.gov.br/cidadesat/default.php, consulta 28/03/2007).
} 
cidade de Bauru, por exemplo, continuou seu desenvolvimento, tendo passado por uma produção arquitetônica que contempla a tendência art déco, neocolonial e modernista, como mostra Ferraz (2003).

Assim, em linhas gerais, esse é o panorama arquitetônico do interior paulista até 1950, aproximadamente: nas cidades pequenas e médias é menos provável encontrarmos uma produção neocolonial expressiva, a não ser naquelas em que houve condições especiais para o seu desenvolvimento; nas cidades maiores que superaram a crise café-ferrovia, certamente a produção neocolonial foi importante. De acordo com o recorte aplicado à nossa pesquisa, já exposto anteriormente, contemplamos as cidades de nossa região e aquelas que apresentaram as condições especiais - a implantação de obras importantes, públicas e neocoloniais - para o florescimento da arquitetura tradicionalista de Severo, fossem de pequeno ou médio porte. Para a análise das edificações que encontramos nas cidades abordadas pela nossa investigação, o critério foi agrupá-las por grau de erudição e função ao qual o espaço se destinou, a fim de, posteriormente, passar à análise das obras de difusão.

\subsection{A Elaboração de Uma Imagem}

Como verificamos através da revisão das referências bibliográficas utilizadas para esta pesquisa, a campanha neocolonial frutificou e chegou a ser uma importante opção do poder público para edifícios oficiais. Tomou grande visibilidade e foi rapidamente identificada pelo governo e pela população em geral como representação de modernidade, de originalidade, de tradicionalismo, de status e, por certo, de outras qualificações.

Num primeiro momento, os principais precursores do movimento neocolonial deram corpo e sintetizaram, com a construção das primeiras obras, os preceitos que o movimento defendia, idealizava e imaginava. Ricardo Severo e Victor Dubugras foram os primeiros realizadores do neocolonial na cidade de São Paulo (LEMOS, 1994, p.155). Essa arquitetura recém plasmada nos primeiros exemplares foi reproduzida, a princípio, para clientes particulares e, especialmente, para as obras residenciais das famílias paulistanas mais abastadas que, como nos mostra Pinheiro (1998, p.22), formavam 
um meio sócio-cultural bastante conservador, ansioso por encontrar argumentos que reafirmassem as origens nacionais das elites paulistas diante da ameaça representada pela maciça migração européia, principalmente italiana, que inundara a cidade naquele período.

Assim, a arquitetura neocolonial começou a tomar forma numa versão erudita, para responder a algumas demandas dos estratos mais ricos da sociedade, que pretendiam ver em suas próprias casas a expressão de sua origem e, por extensão, de seus direitos sobre o local que a eles, primeiro, pertencia. Lemos (1985, p.168) também está de acordo com esse ponto de partida e afirma que "o neocolonial expressou-se entre nós a partir da vertente «erudita» formulada por arquitetos categorizados". Mesmo que estivesse longe de corresponder à arquitetura tradicional brasileira, interpretada como sendo a colonial, barroca ou não, a arquitetura neocolonial de primeira hora estava validada pelos profissionais que as realizaram e, portanto, satisfaziam aos anseios dos seus clientes. Devemos lembrar que exceções importantes a essa tendência de responder às demandas particulares foram a reforma do Largo da Memória, construído por volta de 1919, e os monumentos do Caminho do Mar, “visando às comemorações do Centenário da Independência”, ambos por Dubugras, a encargo do prefeito paulista Washington Luís (LEMOS, 1985, p.160; 166).

Num momento seguinte, nos anos de 1920, o movimento neocolonial havia ganhado grande repercussão e seduzido “vários dos mais importantes personagens dos meios artísticos e culturais paulistanos (...) entre os quais destaca-se Mário de Andrade" (PINHEIRO, 1998, p.25) e, por conseqüência, a arquitetura dele proveniente alcançara grande visibilidade. Nesse ponto específico, estamos de acordo com Lemos (1985, p.169) em que da "vertente elitista decorreu toda a produção popular receptadora sem maiores indagações", mas acreditamos que a "vertente elitista" é mais abrangente que a produção arquitetônica da classe mais alta da cidade de São Paulo, representada por uma produção majoritariamente residencial, projetada por profissionais eruditos. Nossa proposta consiste em considerar um alargamento do que se entende por "vertente elitista": corresponde a uma difusão não residencial, não está restrita à capital paulista, mas continua a ser erudita. Trata-se da arquitetura neocolonial produzida pelo poder público.

Assim, por ser oficial, acreditamos que tal produção não esteve desprovida de reflexão sobre o conteúdo ideológico que o neocolonial carregou a princípio. A "grande 
visibilidade" alcançada pela arquitetura neocolonial, e já amadurecida numa imagem identificável, não passou despercebida aos olhos do Estado. Durante as décadas de 1920, 1930 e 1940, diversos edifícios públicos foram construídos seguindo a estética neocolonial, entre os quais escolas e fóruns, não só na cidade e no Estado de São Paulo, como em outros lugares do país. Nesses casos, havia uma identificação entre os propósitos do Estado e a imagem da arquitetura neocolonial, que foi apropriada e reproduzida na esfera oficial, ainda numa forma erudita repleta de conteúdo ideológico. Assim, devemos nos lembrar de que, de acordo com Alvarez ${ }^{5}$ (1992, p.133 apud RUMBELAPAGER, 2005, p.91),

a parte mais expressiva da simbólica arte estadonovista achava-se representada pela arquitetura. É através da produção espacial que a linguagem triunfal fica assegurada e expressa seus ideais político-sociais (...). Na produção arquitetônica estava presente o espírito de «compromisso» assumido pela política nacional.

Certamente, o conteúdo ideológico original do movimento foi reinterpretado, mas ele veio a favorecer, especialmente, aspectos referentes aos interesses do momento histórico por que passava a Nação. Nesse âmbito, consideramos que o neocolonial foi uma arquitetura nacionalista. Assim, através da Diretoria de Obras Públicas do Estado de São Paulo (DOP), muitos engenheiros e arquitetos trabalharam na difusão da arquitetura neocolonial, ainda numa forma erudita e provida de ideologia, inclusive pelo interior do Estado e, especialmente, na década de 1940. Provavelmente, essa ideologia já era diferente da original, mas alimentou uma produção importante.

Tais obras oficiais, realizadas pela Diretoria de Obras Públicas - em conjunto com as obras neocoloniais da "vertente elitista", a que se refere Lemos (1985, p.169) também contribuíram para a difusão do gosto pelo neocolonial, ou seja, uma difusão vazia do conteúdo original do movimento ou de pretensões nacionalistas e, em grande parte, não eruditas. Consideramos, portanto, que esse seja um terceiro momento do fenômeno neocolonial e que coincide com aquele ao qual Lemos (1985, p.169) se refere. Apropriação, reinterpretação e recriação resultaram em uma produção variada, por vezes "verdadeiros exemplares representativos de uma criação arquitetônica popular autóctone" (LEMOS, 1985, p.169), na qual a presença de apenas uma característica ou um elemento remete à imagem elaborada nos primeiros tempos do

\footnotetext{
${ }^{5}$ ÁLVAREZ, J.M.S. (1992). Este sólido e imponente edifício. Niterói: Cromos.
} 
movimento neocolonial. Neste capítulo, tratamos do segundo momento de difusão no interior paulista, ou seja, aquele ocorrido por meio das obras oficiais. No próximo capítulo, tratamos da difusão generalizada e não necessariamente erudita.

\subsection{Fernando Costa combate o Jeca Tatu}

Em algumas cidades do interior paulista, como Pirassununga, Bauru, Guaratinguetá, Itapetininga, Ribeirão Preto e São José do Rio Preto, a manifestação da arquitetura neocolonial - ou, antes, de um dos conjuntos mais expressivos do "estilo", nessas cidades - deu-se por intervenção do poder público e, por isso, sua manifestação dependeu menos da disponibilidade de recursos privados e do momento em que se encontrava o desenvolvimento da cidade, como no caso de outras cidades paulistas. No início dos anos de 1940, o governo do Estado de São Paulo planejou a implantação de dez Escolas Práticas Agrícolas (EPAs) em seu território e, ao que indicam as pesquisas, seis delas foram construídas nas cidades citadas. A arquitetura de todas elas estava alinhada à tendência neocolonial.

A figura chave no planejamento e implantação de escolas agrícolas no Brasil e no Estado de São Paulo, naquele ínterim, foi o agrônomo Fernando Costa (FIGURA 44), que ocupou vários cargos públicos - como o de vereador e de prefeito de Pirassununga -, tendo chegado a Ministro da Agricultura durante a era Vargas ${ }^{6}$. Assumiu, a convite de Getúlio Vargas, em 1937, o cargo de Presidente do Departamento Nacional do Café, nele ficando por seis meses. Em 1938, foi indicado para Ministro da Agricultura, onde permaneceu por três anos, antes de ocupar o cargo de Interventor do Estado de São Paulo, de 1941 a 1945.

A partir da presença de Fernando Costa nos assuntos do governo relacionados à agricultura, a política mudou de enfoque, o que foi muito bem interpretado por Teles \& Iokoi (2005, p.63), através da metáfora do Jeca Tatu que, aqui, tomamos emprestada, para enfatizá-la:

era inconcebível no projeto de Fernando Costa e de Moraes Mello (...) a imagem criada por Monteiro Lobato do Homem do campo. A figura do Jeca Tatu preocupava esses dirigentes, de um lado, por considerá-la preconceituosa, e, de outro, por perceberem que de fato a monocultura e o

\footnotetext{
${ }^{6}$ Teles \& Iokoi (2005) traçam a trajetória política de Fernando Costa.
} 
latifúndio haviam apartado o camponês, o trabalho rural e o pequeno sitiante dos benefícios que os fazendeiros obtinham do fundo público do país.

A preocupação, naquela altura, era, pois, combater a imagem do camponês esquecido pelo poder público e abandonado à sua própria sorte, em meio às doenças e falta de recursos para produzir (FIGURA 45). Passou a ser importante levar a instrução aos trabalhadores do campo, através de instituições que foram implantadas em localidades por vezes distantes dos centros mais desenvolvidos e das capitais, no Brasil, enquanto Fernando Costa foi o Ministro da Agricultura, e no Estado de São Paulo, quando ele se tornou o interventor desse Estado. Logo após sua nomeação como Interventor, em 23 de julho de 1941, os jornais noticiaram uma reunião da Secretaria da Agricultura com os representantes dos lavradores de 45 municípios paulistas, para a discussão dos principais problemas, como as vias de comunicação, crédito agrícola, assistência técnica, redução de impostos, educação e assistência sanitária. Sobre os últimos dois itens publicou-se, respectivamente, que era pretensão do governo

tornar o homem do campo apto a encontrar no meio em que vive elementos para o seu progresso econômico e para sua perfeita estabilização social e que lhe possa proporcionar uma existência digna e feliz" e que se fazia necessário combater "as endemias reinantes em diversas regiões, como a maleita (...). O sr. Fernando Costa declarou que está disposto a tomar todas as providências necessárias, aplaudindo a franqueza com que os lavradores estão expondo ao governo os problemas que os interessa (REUNIÃO..., 1941).

O Estado parecia, finalmente, ter voltado os olhos e os cuidados para o Jeca Tatu. Na região paulista, essa nova linha política foi, sem dúvida, sinal do esgotamento do esquema de produção cafeeira. Foi preciso diversificar a produção para procurar manter o produtor rural no campo, proporcionando-lhe melhores meios para isso.

Assim, sob o mandato de Fernando Costa no Ministério da Agricultura, projetos para construção de escolas e de instituições ligadas à agricultura, pecuária e veterinária tomaram novo impulso. Houve investimentos no setor, reformas e reorganização das instituições, como podemos verificar pelas palavras do Ministro:

desde há muitos anos constitui objeto de preocupação nos meios técnicos o aparelhamento e articulação dos trabalhos de pesquisa e experimentação 
agrícolas, (...) para maior eficácia e preparo do pessoal técnico (...). Reformando-se o Ministério da Agricultura foi possível atender-se a esse imperativo com a criação do Centro Nacional de Ensino e Pesquisas Agronômicas, subordinando-se a um só órgão coordenador a Escola Nacional de Agronomia e os Institutos de Química, Ecologia e Experimentação (COSTA, 1939a, p.141).

Foi nesse período, também, que apareceram as primeiras ações do poder público em relação à conservação dos recursos naturais e à criação das primeiras reservas florestais e parques regionais (COSTA, 1939a, p.434). A rigor, as primeiras preocupações, no sentido de registrar as potencialidades dos recursos no Brasil, ainda sem vistas à proteção dos mesmos, mas como legado que colaborou para a formação de um pensamento preservacionista, vêm de longa data e têm suas raízes nos séculos

XVI e XVII [que] foram marcados pela produção literária das ordens religiosas (...) na medida em que os religiosos constituíam o contingente mais intelectualizado que aqui se estabelecera. (...) Vindas de autores jesuítas, franciscanos, carmelitas e capuchinhos, muitas foram as obras através das quais foi possivel posteriormente conhecer (...) aspectos da natureza local e as formas de sua apropriação (SANTOS, 1999, p.78).

No século XIX encontramos algumas das mentes que se destacaram na preocupação com a manutenção e preservação, principalmente das matas, como José Bonifácio de Andrada e Silva (Santos, 1999, p.132), e no início do século XX temos as manifestações sobre a conservação das florestas da cidade do Rio de Janeiro, do nosso, por outros motivos, tão conhecido, médico e intelectual José Mariano Filho (Santos, 1999, p.195-197). De acordo com Santos (1999, p.195-196) o médico,

já em 1915, havia proposto que o Rio de Janeiro se tornasse uma «cidade floresta», conservando-se «maciços florestais» na área urbana e seu entorno", tendo se sobressaído "entre os conservacionistas das primeiras décadas do século XX pela sua abordagem ecológica da questão florestal.

Dessa maneira, Santos (1999) nos mostra um longo processo, que culminou com as primeiras medidas do governo no sentido de preservar os recursos naturais, com muito atraso, na década de 1930:

outra vez o pensamento preservacionista se anteciparia à ação do Estado, sempre moroso em relação às propostas que implementassem uma política 
de conservação da natureza no Brasil, pois o Parque Nacional de Itatiaia só seria criado em 1937,

embora a proposta de criação desse parque date de 1913 e tenha sido novamente enfatizada como necessária em 1922 (Santos, 1999, p.171). Assim, fez parte da política de Vargas a concretização de medidas para a criação de parques nacionais de preservação da natureza. Em 1939 foi criado o Parque Nacional da Serra dos Órgãos. Dois anos depois da entrada de Fernando Costa no Ministério da Agricultura foi criado o parque nacional de Iguassú e, em 1948, o de Paulo Afonso (SANTOS, 1999, p.208; COSTA, 1941, p.27).

E foi a partir desse novo impulso que vemos vários prédios, que serviram de sede à educação e às pesquisas na área, tomarem o aspecto neocolonial, até mesmo no Parque Nacional do Itatiaia, onde edificações neocoloniais foram levantadas segundo o desenho do arquiteto Ângelo Murgel. Talvez esteja nesse momento a raiz da associação entre o ambiente rural e a arquitetura neocolonial, através do conceito desenvolvido por Murgel, a partir de 1937, quando foi contratado como servidor do Ministério da Agricultura e teve de desenvolver projetos para “implantação de núcleos urbanos em áreas rurais” (LIMA, 2005, p.12). Segundo esse autor, o conceito se constituía na busca de "adaptação às circunstâncias locais, tendo em vista as imposições da natureza, pelo uso de tecnologias e materiais disponíveis na região” (LIMA, 2005, p.15-16).

A Escola Nacional de Agronomia tem suas origens em $1910^{7}$, mas teve sua instalação definitiva no prédio atual da Universidade Federal Rural do Rio de Janeiro. O local foi "finalmente, escolhido à margem da estrada Rio - São Paulo" (COSTA, 1939a, p.141) em 1938; no ano seguinte foi iniciada a construção do prédio (FIGURA 46 e 47). No relatório de 1940, do Ministério da Agricultura ao Presidente da República, Fernando Costa refere-se à Escola Nacional de Agronomia nos seguintes termos:

A Escola Nacional de Agronomia, que está sendo construída em Santa Cruz, no quilômetro 47 da estrada de rodagem Rio - São Paulo, é uma das maiores realizações do Ministério da Agricultura, por isso que se trata de um estabelecimento básico para formação de valores indispensáveis ao desenvolvimento racional das nossas riquezas naturais. Obra grandiosa, já

\footnotetext{
${ }^{7}$ Decreto 8.319 de 20 de Outubro de 1910: Cria o ensino agronômico e aprova o respectivo regulamento Disponível em: http://www6.senado.gov.br/sicon/ExecutaPesquisaLegislacao.action Acesso em: 07/01/2008.
} 
pelo seu aspecto arquitetônico, já pelas instalações que foram projetadas tendo em vista os progressos do ensino agronômico, ela há de marcar uma época nesta fase de renovação econômica do país (COSTA, 1941, p.17).

Mais adiante continua, com algumas menções às construções, dizendo que o projeto das instalações fora aprovado pelo chefe da Nação:
êsse plano, organizado segundo as exigências da técnica moderna, compreendia numerosos edifícios dispostos em zonas distintas, ligadas por um grande parque paisagístico (...). Obras de grandes proporções, ela será um centro irradiador de ensinamentos agrícola" (COSTA, 1941, p.59-61).

Em nenhum dos relatórios do Ministro foi possível encontrar referências ao estilo arquitetônico eleito para tais instituições, mas sabemos que o arquiteto Ângelo Murgel também fez parte da equipe que projetou essa escola, e que a tendência arquitetônica adotada por ele para essa obra foi, igualmente, a neocolonial. Esse arquiteto tem, pelo menos, mais um projeto que segue a tendência neocolonial e que é “o aeroporto do Parque Nacional de Iguaçú, no Paraná” (KESSEL, 2002, p.215).

Em 1937, o então Presidente da República, em seu pronunciamento anual, comunica que "os edifícios da Escola Agrícola de Barbacena passaram por uma reforma completa, sendo ampliados os dormitórios e refeitórios, melhoradas as instalações internas, reaparelhados os laboratórios e gabinetes" (VARGAS, 1937, p.334). Porém, o ensino agrícola, nesse local, data do início do século XX ${ }^{8}$. Em 1940, "nessa escola foram [continuaram as] obras de readaptação" (COSTA, 1940, p.18). Possivelmente por ter sido criada em 1910, a linha arquitetônica predominante nos prédios da escola é a eclética e, apesar das várias reformas pelas quais passou, não exibe aparência neocolonial (FIGURA 48).

Em 1939 foi fundado o Instituto Agronômico do Norte, em Belém do Pará, na fazenda Murutucu, com área de 3185 hectares, e "é o primeiro dos cinco, que serão convenientemente organizados e instalados no Brasil, com o fim de atender a todos os interesses de pesquisas agronômicas para o seguro desenvolvimento agrícola do país" (COSTA, 1939b, p.121). No ano de 1939 seus prédios principais estavam concluídos e "os restantes deverão ter a construção realizada em 1940, total ou parcialmente" (COSTA, 1939b, p.123). A qualidade das fotos não permite afirmar que os edifícios

\footnotetext{
${ }^{8}$ Decreto $^{\circ}$. 8.358, de 09 de novembro de 1910: Cria um aprendizado agrícola na cidade de Barbacena, Estado de Minas Gerais. Disponível em:

http://www6.senado.gov.br/sicon/ExecutaPesquisaLegislacao.action Acesso em: 07/01/2008
} 
construídos em 1939 sejam neocoloniais; porém, em reforma posterior tomaram esse aspecto (FIGURA 49). Este instituto originou a Embrapa Amazônia Oriental ${ }^{9}$ e, atualmente, abriga parte do Campus da Universidade Federal Rural da Amazônia.

Em 1940 foi instalado o Instituto Agronômico do Nordeste (Costa, 1940, p.9), situado a 18 km do Recife, no bairro de Curado; em 1942 já funcionava, tendo a pesquisa sobre cultura canavieira como principal atividade (Salles, 1943, p.43), porém não conseguimos localizar informações sobre suas instalações.

O aparecimento de tais instituições no período em que Fernando Costa esteve no ministério são indicadores que demonstram, também, além da necessidade de implementação de um sistema produtivo mais diversificado, a tendência política em expandir a ocupação do território e em potencializar a exploração de recursos naturais e agropecuários. Indica também a importância atribuída por esse ministro à educação agrícola para o desenvolvimento do país (TELES \& IOKOI, 2005), em associação à educação nacionalista - uma característica do período, verificada no governo Vargas, como sabemos -, efetivada, inclusive, através da linguagem arquitetônica. Constatamos essa estratégia ao verificarmos que, das instituições federais criadas e reformuladas naqueles anos, várias empregaram, em seus edifícios, a arquitetura fruto do movimento iniciado por Ricardo Severo, como, por exemplo, a escola do Rio de Janeiro e o instituto de Belém do Pará.

Assim, apesar de o neocolonial não ser uma linguagem exclusiva, adotada pelo Ministério da Agricultura para suas edificações, verificamos que, entre os anos de 1938 e 1945, aproximadamente, configurou-se mais um momento de contato entre o Estado e uma expressão arquitetônica que se propunha tradicional brasileira, ou antes, uma arquitetura que, na interpretação do Estado, serviria aos seus propósitos nacionalistas. Esse momento é tardio, em relação à campanha neocolonial, que teve início nos anos de 1910 e cujo último debate tinha sido levado a cabo no início da década de 1930. Contudo, é relevante relembrar que, sob o governo de Getúlio Vargas e sob a influência dos regimes totalitários vividos na Europa, o nacionalismo brasileiro passou a ser trabalhado por uma "máquina de propaganda", que envolvia a divulgação de preceitos pelo rádio, pela música, pela Igreja e pela educação oficial (CAPELATO, 1998). O principal dos preceitos implicava na homogeneização das idéias e dos símbolos nacionais com os quais a massa popular passava a se identificar, relegando para

\footnotetext{
9 Informação disponível em: http://www.cpatu.embrapa.br/a-unidade/unidade/historico/ Acesso em: $05 / 01 / 2008$.
} 
segundo plano as particularidades dos traços culturais regionais e as diferentes identidades locais. Dessa forma, a adoção da arquitetura neocolonial como oficial está relacionada aos propósitos do Estado. As instituições oficiais cujos prédios foram construídos segundo os preceitos neocoloniais podem ser encontradas em diferentes regiões do país, mostrando-nos que o poder público também ajudou na difusão da arquitetura preconizada por Ricardo Severo.

Anteriormente ao governo Vargas, ainda na década de 1920, já havia existido uma aproximação entre o Estado e a arquitetura neocolonial, o que fica patente com a construção de estabelecimentos de ensino no Rio de Janeiro. Naquela década - no mandato de António Prado Jr., que assumiu a prefeitura do Rio de Janeiro em 1926, e de seu Instrutor Geral de Instrução Pública, Fernando Azevedo - foi posta em prática uma estratégia para a transmissão de valores ideológicos através da arquitetura, que seria usada como meio. A construção de novos prédios escolares era parte de uma

reforma, exemplar acabado do tipo de intervenção posteriormente identificado com o movimento batizado de "Escola Nova” (...), e se inscreve no ambiente de discussão e renovação pontuado pelos congressos promovidos pela Associação Brasileira de Educação (ABE), fundada em 1924, que congregava professores, administradores escolares e intelectuais (KESSEL, 2002, p.149).

Nesse ensejo, já devido às campanhas de Ricardo Severo e José Mariano Filho, o movimento neocolonial defendia modelos e características do que deveria ser a arquitetura brasileira. Essa definição foi muito conveniente a um poder que procurava, pela educação, transformar a população “em cidadãos, inculcando valores cívícos elementares e funcionando como instrumento de diluição das origens étnicas e culturais diferenciadas" (KESSEL, 2002, p.149-151). A recomendação de Mariano Filho segue a mesma linha, segundo sua argumentação no II $^{\circ}$ Congresso Brasileiro de Educação:

contra as conseqüências de serem erigidos prédios escolares segundo estilos arquitetônicos que não se referenciassem na tradição do país, pelo risco que correriam os alunos ao conviverem com elementos estéticos estrangeiros. A escola, caracterizada como a instituição que propiciava o primeiro contato do brasileiro com a nacionalidade, deveria ser plasmada numa arquitetura de fundo nacional (KESSEL, 2002, p.154). 
Foram lançados concursos para a construção das novas escolas, cuja principal exigência era que o "estilo" arquitetônico do projeto inscrito seguisse os preceitos neocoloniais, sob pena de serem eliminados do concurso (KESSEL, 2002). Assim, foram construídas nove escolas, das quais

se destacam as Escolas Argentina, Uruguai, Prado Júnior, Estados Unidos e Soares Pereira. Todas - com a exceção da última, projetada por José Amaral Nieddermeyer em terreno doado à prefeitura - de autoria dos arquitetos Nereu Sampaio e Gabriel Fernandes.

Um pequeno número, considerando-se que a intenção inicial era a de atingir 100 unidades escolares construídas dentro do planejamento do instrutor Azevedo (KESSEL, 2002, p.152), mas demonstrativo de que a arquitetura neocolonial se tornou oficial uma década depois de ter surgido ${ }^{10}$. Fernando Costa, como Ministro da Agricultura e como Interventor do Estado, manteve e estendeu a oficialidade dessa arquitetura por, aproximadamente, mais uma década, a partir de 1938, contribuindo, assim, para que a linguagem neocolonial tenha avançado por longo período, no interior paulista.

Devido à sua importante atuação como ministro e à necessidade de afastar Adhemar de Barros, em 1941, Fernando Costa foi nomeado, pelo presidente Vargas, Interventor do Estado de São Paulo. Com a sua nomeação, os jornais demonstram uma ansiedade em trazer para o Estado paulista a mesma política do Ministério da Agricultura, de implantação de escolas para especialização da mão-de-obra rural, de investimentos nesse setor, e de incentivos para a fixação da população em seus locais de origem, para evitar a corrida para as grandes cidades. Tanto jornais locais, de cidades do interior, como jornais da cidade de São Paulo, após a nomeação do novo interventor, em cinco de junho de 1941, abordavam assuntos relacionados ao seu novo programa de governo, nos quais, invariavelmente, o tema do ensino agrícola era trazido à baila ${ }^{11}$ (FIGURA 50). Foi um quadro sintomático, num período em que o sistema de produção do café já havia decaído e era preciso encontrar alternativas viáveis para produtores e

\footnotetext{
10 Lembrar que o discurso de Ricardo Severo, em 1914, é tido como marco inicial do movimento neocolonial.

${ }^{11}$ Amaral Jr, Amadeu. Uma Escola Profissional em Cada Cidade. In: O Dia. São Paulo, 06/06/1941.

Folha da Noite. O Ensino Rural será Objeto de Espacial Atenção. São Paulo, 12/06/1941.

O Estado de São Paulo. O Programa de Governo do Interventor Fernando Costa. "Instrução Pública e Ensino Rural - O Financiamento da Produção Agropecuária e a Reforma do Banco do Estado". São Paulo, 17/06/1941.

Folha da Noite. Assistência Técnica aos Lavradores - Formação do Operariado Rural - Uma Escola Profissional para Cada Cinco Municípios. São Paulo, 23/06/1941.
} 
trabalhadores rurais. Agrônomos... (1941), retrata as expectativas quanto ao assunto, como se vê:

a presença do Sr. Fernando Costa no governo de S. Paulo acendeu as esperanças de que agora se intensificará (...) a campanha de racionalização agrícola que dará às nossas terras fertilidade permanente e que fixará as populações (...) cessando enfim a era do nomadismo económico que caracteriza o Brasil e S. Paulo". Continua sugerindo uma política de descentralização, que deveria instalar o "agrónomo de zona" que, por sua vez, seria "o elemento de ligação entre esses institutos [os centrais] e os lavradores de cada região (...). Seja qual for o ramo agrícola, todos se dirigirão ao agrónomo local e este, com suas luzes próprias ou com as que pedir à organização estadual, será o ponto de concentração de toda ação técnica a ser desenvolvida no seu setor.

E o artigo finaliza prenunciando o que seria feito, no próximo ano, pelo novo interventor: "dividindo-se o Estado em blocos de cinco ou seis municípios, bastariam cinqüenta agrônomos para formar uma rede completa”. No ano seguinte, Fernando Costa lança um projeto que dividiria o Estado em regiões e instalaria, em cada uma, uma escola agrícola.

Essa nova estratégia de desenvolvimento da zona rural contrastou com a que era utilizada para a monocultura cafeeira. Como é sabido, o governo Vargas foi voltado à industrialização do país, e esse foi, inclusive, o momento em que a influência norteamericana passa a ser mais significativa, sendo que tais aspectos atingiram e começaram a mudar, também, as condições da zona rural. Segundo Vieira (2005), a nova estratégia política voltada para o campo

visava superar as condições de atraso da agricultura (...). Para tanto, havia a necessidade de "educar" o povo rural para que ele passasse a adquirir equipamentos e insumos industrializados necessários à industrialização de sua atividade agropecuária, passando com isso do atraso para a modernidade. (...) modelo "tecnicista”, isto é, com estratégias de desenvolvimento e intervenção que levam em conta apenas os aspectos técnicos da produção, sem observar as questões culturais, sociais ou ambientais (VIEIRA, 2005, p.6).

Esse traço esteve, inclusive, alinhado à intenção da propaganda nacionalista do governo, que pretendia apagar vicissitudes culturais locais, em favor da construção da 
imagem de um tipo brasileiro generalizado. Dois autores, Vieira (2005, p.5) e Caporal (1991, p.41), concordam em que o marco inicial desse processo - de influência norteamericana no esquema de produção rural brasileira - foi a Escola Superior de Agricultura e Veterinária do Estado de Minas Gerais, em Viçosa, inaugurada em 28 de agosto de 1926, pelo então Presidente da República, Arthur Bernardes. A direção da escola ficou a cargo do norte-americano, bacharel em agricultura e professor, Peter Henry Rolfs, que implantou a filosofia dos "Land Grant Colleges", que associava teoria, ciência e prática. Desenvolveram-se, a partir de então, especialmente na Era Vargas, dois parâmetros que orientam a atuação de Fernando Costa com relação à implantação das escolas agrícolas, primeiro no Brasil, quando Ministro da Agricultura e, depois, pelo território paulista, quando Interventor do Estado: a necessidade de educar o camponês supostamente atrasado e de disseminar o nacionalismo forjado pela máquina oficial de propaganda. COSTA (p.4, 2001) confirma essa política: “nos países latino-americanos, a extensão rural começou a se desenvolver na década de 40, tendo maior ênfase na década de 50”. Além da implantação das Escolas Práticas de Agricultura, ainda na década de 1940, o Ministério da Agricultura e as Secretarias de Agricultura dos Estados construíram também Casas da Lavoura, promoveram as Semanas Ruralistas e implantaram os Postos Agropecuários, medidas tomadas para orientar os produtores, e que atestam a política mais abrangente do Estado no sentido de desenvolver a zona rural, agora sob novos parâmetros.

No dia três de junho de 1942, portanto, o Decreto-Lei Estadual n ${ }^{\circ} 12742$ determinou a criação das Escolas Práticas de Agricultura ${ }^{12}$. Fernando Costa colocou em prática seu projeto, seguindo a intenção de estabelecer uma escola em cada uma das zonas administrativas nas quais o Estado de São Paulo foi dividido, zonas que contavam com uma média de cinco municípios cada (FIGURA 51). Em 1945, cinco das Escolas Práticas de Agricultura foram inauguradas: as de Bauru, de Guaratinguetá, de Itapetininga, de Pirassununga e de Ribeirão Preto. Embora Teles \& Iokoi (p.64, 2005) afirmem que as demais não chegaram a ser construídas, em parte pelos problemas relacionados à Segunda Guerra Mundial e à crise do Estado Novo, consta que, em 18 de

\footnotetext{
${ }^{12}$ Decreto-Lei 12742, de 03.06.1942: Dispõe sobre a criação de Escolas Práticas de Agricultura. Fonte: Assembléia Legislativa do Estado de São Paulo. Acesso em 03.04.2007. Disponível em: http://www.al.sp.gov.br/portal/site/alesp/menuitem.f737045a72a1eec53700aa5cf20041ca/?inicio=0\&fim $=10 \&$ texto=\&idTpLei=\&nrLei=12742\&dtLei=\&nrAnoLei=1942\&tipoBusca=avancada\#noWhere
} 
Agosto de 1944, através de um novo decreto, $\mathrm{n}^{\circ} 14.139^{13}$, o interventor estadual criou a EPA de São José do Rio Preto ${ }^{14}$, já prevista pelo primeiro decreto. Sobre as outras quatro Escolas Práticas de Agricultura - as de Amparo, Araçatuba, Marília e Presidente Prudente - não foram encontradas informações, indicador de que deixaram de ser construídas, como afirmam as autoras anteriormente citadas.

Ao observar essas escolas, constatamos que o projeto de "construção da nacionalidade", implantado por Vargas, beneficiou-se das idéias lançadas, quase duas décadas antes, por Severo e Mariano Filho, pois todas elas foram construídas segundo os preceitos da arquitetura neocolonial. Teles \& Iokoi (2005) descrevem rapidamente como deveriam ser as estruturas das Escolas Práticas Agrícolas:

As plantas seguiam rigorosamente o estilo colonial brasileiro, em perfeita harmonia com as paisagens onde seriam instaladas. Os espaços planejados separavam áreas distintas para administração, aulas, laboratórios, auditório, biblioteca, salas de jogos cobertos, controle de alimentação, instalação sanitária. As oficinas de carpintaria, mecânica, ferraria etc. deveriam preparar os alunos para serviços necessários às atividades da fazenda (TELES \& IOKOI, p.74, 2005).

Observamos também que o discurso nacionalista associado à arquitetura seguiu desde 1926, com a criação dos estabelecimentos de ensino cariocas anteriormente citados, como mostra o trecho de Teles \& Iokoi (2005, p.64):

A festa de inauguração [da EPA de Pirassununga] foi uma atividade cívica e ufanista, com pompas militares, desfiles, hasteamento do Pavilhão Nacional, hino e apresentação da Banda da Força Policial e da Guarda Civil de São Paulo. Evidentemente, essas manifestações, bem ao gosto do regime, faziam parte de todo um aparato destinado ao engrandecimento das figuras políticas e do nacionalismo, que vinha sendo despertado em diferentes países desde o final da Primeira Guerra Mundial.

Assim, observamos que toda a criação e construção das escolas agrícolas, nas décadas de 1930 e 1940, está envolvida pela ideologia nacionalista, que se refletiu,

\footnotetext{
${ }^{13}$ Decreto-Lei 14139, de 18.08.1944: Dispõe sobre desapropriação de imóveis, situados em Rio Preto, necessários às instalações da Escola Prática de Agricultura. Fonte: Assembléia Legislativa do Estado de São Paulo. Acesso em 03.04.2007. Disponível em: http://www.al.sp.gov.br/portal/site/alesp/menuitem.f737045a72a1eec53700aa5cf20041ca/?inicio=0\&fim $=10 \&$ texto=\&idTpLei $=\&$ nrLei $=14139 \& d t L e i=\&$ nrAnoLei $=1944 \&$ tipoBusca $=$ avancada

${ }^{14}$ Informação retirada de (consulta: 13 de Março de 2007): http://www.sap.sp.gov.br/common/unidprisionais/ipa/sao_jose_da_rio_preto_dr_javert_de_andrade.html
} 
inclusive com muita expressividade, na arquitetura, visto que para a totalidade delas foi adotada a linguagem neocolonial, certamente escolhida por ser a mais adequada aos propósitos oficiais da época. O interventor Fernando Costa havia lançado um grande projeto, para o qual foram necessários os trabalhos da antiga Diretoria de Obras Públicas do Estado de São Paulo.

Segundo Lourenço (1999, p.192,) esse foi o órgão responsável pela construção das instalações da Escola Prática de Agricultura "Getúlio Vargas", de Ribeirão Preto, atual Campus da Universidade de São Paulo, cujo projeto é do arquiteto Hernâni do Val Penteado. O processo de extinção da Escola Prática de Agricultura de Ribeirão Preto deu-se entre 1952 e 1954 . Inicialmente ${ }^{15}$, parte do prédio da escola agrícola foi cedida para uso da Universidade de São Paulo e, finalmente ${ }^{16}$, dois anos mais tarde, recebeu a Faculdade de Medicina desta universidade, criada antes da extinção da Escola Prática de Agricultura, em $1948^{17}$.

A Escola Prática de Agricultura "Paulo de Lima Correia"18, de Guaratinguetá, foi inaugurada em 1945. Foi doada à União em $1950^{19} \mathrm{e}$, posteriormente, transformada na Escola de Especialistas de Aeronáutica. O processo de mudança, porém, ocorreu sob protestos dos moradores da cidade, como mostra o artigo do jornal Diário de São Paulo, de 29 de outubro de 1949. O artigo, intitulado Contrários à Transferência da Escola Prática de Agricultura, traz a notícia de que a população se organizou e realizou um abaixo-assinado de 450 assinaturas, pedindo à Assembléia Legislativa do Estado "que não prive esta localidade, e mesmo toda a zona, de tão útil, valioso e necessário

\footnotetext{
${ }^{15}$ Lei 2029, de 24.12.1952: Cessão, à Universidade de São Paulo, do uso de parte do imóvel onde funciona a Escola Prática de Agricultura de Ribeirão Preto. Fonte: Assembléia Legislativa do Estado de São Paulo. Acesso em 04.04.2007. Disponível em:

http://www.al.sp.gov.br/portal/site/alesp/menuitem.f737045a72a1eec53700aa5cf20041 ca/?inicio=0\&fim $=10 \&$ texto $=\&$ idTpLei $=\& n r L e i=2029 \&$ dtLei $=\& n r$ AnoLei $=1952 \&$ tipoBusca=avancada

${ }^{16}$ Lei 2844, de 07.12.1954: Inclui, no quadro da Universidade de São Paulo, cargos da Secretaria da Agricultura (Escola Prática de Agricultura de Ribeirão Preto, extinta). Fonte: Assembléia Legislativa do Estado de São Paulo. Acesso em 04.04.2007. Disponível em: http://www.al.sp.gov.br/portal/site/alesp/menuitem.f737045a72a1eec53700aa5cf20041 ca/?inicio=0\&fim $=10 \&$ texto $=\&$ idTpLei $=\& n r L e i=2844 \& d t L e i=\& n r$ AnoLei $=1954 \&$ tipoBusca=avancada

${ }^{17}$ Lei 161, de 24.09.1948: Dispõe sobre a criação de estabelecimentos de ensino superior no interior do estado. Ensino superior / Universidade de São Paulo - USP / Escola de Engenharia de São Carlos / Faculdade de Farmácia e Odontologia de Bauru / Faculdade de Farmácia e Odontologia de Taubaté / Faculdade de Medicina de Ribeirão Preto / Faculdade de Direito de Campinas / Faculdade de Filosofia, Ciências e Letras de Limeira. Fonte: Assembléia Legislativa do Estado de São Paulo. Disponível em: http://www.al.sp.gov.br/portal/geral/ddilei/DdiLeiListaDetalhe.jsp?idLgLei=30284\&textoBusca Acesso em 04.04.2007

${ }^{18}$ Paulo de Lima Correia foi Secretário da Agricultura quando Fernando Costa era Interventor do Estado.

${ }^{19}$ Lei 696, de 05.05.1950: Autoriza a doação da escola prática de agricultura de Guaratinguetá à União. Fonte: Assembléia Legislativa do Estado de São Paulo. Acesso em 03.04.2007. Disponível em: http://www.al.sp.gov.br/portal/site/alesp/menuitem.f737045a72a1eec53700aa5cf20041 ca/?inicio=0\&fim $=10 \&$ texto=\&idTpLei $=\&$ nrLei $=696 \&$ dtLei $=\& n r$ AnoLei $=1950 \&$ tipoBusca $=$ avancada
} 
estabelecimento de ensino agrícola, que tantos benefícios vêm prestando em prol do reerguimento agropecuário da região”. Notícias de teor equivalente encontram-se no jornal Correio Paulistano, com os títulos "Protesta a População de Guaratinguetá contra a pretendida transferência”, e "É contra a cessão da Escola Prática de Agricultura de Guaratinguetá à Aviação”, respectivamente dos dias 29 de outubro de 1949 e 05 de novembro de 1949. Apesar de toda a movimentação em favor da manutenção da escola de Agricultura, no mês de dezembro do mesmo ano, segundo documento localizado no Museu Frei Galvão, foi realizado um levantamento fotográfico para analisar se a situação e o entorno da escola eram adequados às necessidades da nova escola de Aeronáutica, que o governo pretendia instalar ali. Do relatório, com o levantamento de 29 fotos, restaram apenas cinco que foram doadas ao museu por Myrthis M. Machado Dias (FIGURA 52). No ano seguinte, em 1950, foi iniciado o processo de transformação daquela instituição de ensino na atual Escola de Especialistas de Aeronáutica. Em 1954, essa escola de aeronáutica já estava em pleno funcionamento (FIGURA 53).

A Escola Prática Agrícola "Dr. Fernando Costa", de Pirassununga, foi inaugurada no dia 05 de junho de 1945. Seu projeto e execução estavam a cargo da Diretoria de Obras Públicas do Estado de São Paulo. Provavelmente, o autor do projeto foi o arquiteto Hernani do Val Penteado. Em 1956 foi fechada e em cinco de novembro de 1957, “o governador Jânio Quadros cedeu às pressões contrárias dos políticos e das associações rurais de Pirassununga" e criou o Izip - Instituto de Zootécnica e Indústrias Pecuárias -, através da Lei ${ }^{\circ} 1.763$ (TELES \& IOKOI, 2005, p.89). As palavras das autoras mostram que, também nessa cidade, houve resistência à transformação da Escola Prática Agrícola, ainda que ela se tornasse uma outra instituição de ensino, anexa à Universidade de São Paulo. Atualmente, como sabemos, suas instalações são ocupadas pela Faculdade de Zootecnia e Engenharia de Alimentos da USP (FIGURA 54).

A Escola Prática de Agricultura "Gustavo Capanema", de Bauru, foi, igualmente, criada em 1942. No dia 19 de abril desse mesmo ano, o Interventor Fernando Costa assina a ata de lançamento da pedra fundamental (FIGURA 55). Desde 12 de junho de 1955, é utilizada como Instituto Penal Agrícola "Prof. Noé Azevedo", um presídio de regime semi-aberto para detentos de bom comportamento ou em 
cumprimento final de pena, segundo nos informou o funcionário Sr. Sílvio Padim ${ }^{20}$. Encontramos, no arquivo do atual presídio, a planta do primeiro andar do prédio de "escola e administração", projetada pelo arquiteto Hernani do Val Penteado, com uma observação importante, ao final da prancha: “adaptação do projeto dos Eng ${ }^{o s}$ Mario Whately \& Cia." (FIGURA 65). Segundo nos consta, o engenheiro Mario Whately foi professor da Escola Politécnica da Universidade de São Paulo, ministrando a cadeira de Pontes e Grandes Estruturas, desde $1935^{21}$; foi, também, autor dos projetos dos edifícios do Parque da Água Branca ${ }^{22}$ e do Instituto Biológico, em São Paulo, este último, um projeto art déco (FIGURA 56) (REBOUÇAS, 2006, p.65). Encontramos, ainda, nos arquivos do instituto penal, o projeto de paisagismo da antiga Escola Prática de Agricultura, realizado pelo escritório “Construtora de Jardins São Paulo”. Por ser um escritório situado na cidade de São Paulo, e não em Bauru, local da escola, talvez tenha realizado projetos para outras Escolas Práticas Agrícolas, o que não foi possível confirmar (FIGURA 64).

A Escola Prática Agrícola "Dr. Javert de Andrade”, de São José do Rio Preto, foi apenas parcialmente construída, pois em 1949 suas instalações foram finalizadas pelo então governador Adhemar de $\operatorname{Barros}^{23}$; porém, ao que parece, nunca chegou a funcionar. No Diário Oficial do Estado de São Paulo, do dia 28 de novembro de 1951, encontramos o protesto do deputado Alberto Andaló, natural de São José do Rio Preto, contra a instalação de um presídio agrícola nas dependências do que deveria ter sido a Escola Prática Agrícola daquela cidade:

verificamos o caso como realmente ele se apresenta. Existem 3 prédios semi-construídos pelo interventor Fernando Costa, nos terrenos da Escola Prática de Agricultura. (...) Agora vai ser reformado o prédio - o último prédio como nós o chamamos - e, então, irão para lá (...) trinta ou quarenta condenados [que] posteriormente irão reformar o outro prédio (...) situação «maravilhosa»: Rio Preto perdeu os terrenos; perdeu aquilo que era produção imediata para o consumo da cidade, perdeu a Escola Prática de

\footnotetext{
${ }^{20}$ Visita realizada ao Instituto Penal Agrícola "Prof. Noé Azevedo" em 02/05/2007 e informações colhidas com os funcionários Silvio Padim e Roberval Cervantes Doro.

21 Disponível em: http://www.poli.usp.br/Organizacao/Historia/Historico/1941-1950.asp Acesso em: $13 / 03 / 2008$.

${ }^{22}$ Disponível em: http://www.parqueaguabranca.sp.gov.br/historico.dwt.asp Acesso em: 13/03/2008.

23 "Foi realizada a conclusão de cobertura dos edifícios principais da Escola Prática de Agricultura de São José do Rio Preto, e do Pavilhão para isolamento de animais, no Instituto Biológico". Disponível em: http://www.adhemar.debarros.nom.br/desenvolvimento/agrointe.htm Acesso em 05.04.2007.
} 
Agricultura e recebeu, em compensação, os presos que irão (...) cultivar a terra (SÃO PAULO (ESTADO), 1951, p.30).

Afinal, o instituto penal agrícola foi instalado, e continua em funcionamento (FIGURA 57).

A Escola Prática de Agricultura "Carlos Botelho", de Itapetininga, também foi criada em $1942^{24}$, mas foi inaugurada no dia cinco de junho de 1945 , com o nome de "Escola Técnica no Bairro Capão Alto". De 1955 a 1959, durante o governo de Jânio Quadros, foi fechada e utilizada como instituto penal, fato desaprovado pela população, que reivindicava o retorno da escola. Em 1969, foi finalmente re-inaugurada como "Escola Técnica Agropecuária Estadual Prof. Edson Galvão"25, uma das escolas dos Centros de Educação Tecnológica Paula Souza (Ceeteps) (FIGURAS 88 e 89).

Fernando Costa permaneceu como Interventor do Estado de São Paulo até 27 de outubro de 1945. A partir de então, seus sucessores não mantêm a mesma política de interesse no projeto das Escolas Práticas de Agricultura. José Carlos Macedo Soares (1945-1947) e Adhemar de Barros (1947-1951) não investiram na continuidade do projeto. A partir de 1950, os usos aos quais foram destinados os prédios das Escolas Práticas de Arquitetura foram alterados. A morte de Fernando Costa, em 1946, anunciaria uma fase de decadência que, associada às condições políticas e históricas, levou ao esgotamento do projeto de ensino agrícola nos moldes então implantados. Essa fase de declínio aparece na crítica do deputado Aníbal Furlan, registradas também no Diário Oficial do dia 28 de novembro de 1951:

“quero (...) dar o meu testemunho pessoal a respeito das chamadas Escolas Práticas de Agricultura. Em Ribeirão Preto há uma Escola Prática de Agricultura suntuosa, um verdadeiro monumento que honra o Estado de São Paulo. Acontece que, na prática, é o mais retumbante fracasso que já vi. $O$ indivíduo sai da fazenda, entra na Escola e fica vagabundo, porque durante os três anos de permanência na Escola, se acostuma com água quente, com cinema, teatro, etc. Nunca mais voltará para a fazenda de onde saiu filho de colono. Dessa forma penso que o problema da Escola Prática de

\footnotetext{
${ }^{24}$ Decreto-Lei n ${ }^{\circ} 12.912$, de 28 de Agosto de 1942. Dispõe sobre a desapropriação de imóveis necessários à Escola Prática de Agricultura de Itapetininga. Disponível em: http://www.al.sp.gov.br/web/portal/08_documentacao_informacao/decretos_leis_pl77_\%202006.pdf Acesso em: 13/04/2007.

${ }^{25}$ Disponível em: http://www.ceeteps.br/Ete/Escolas/Sorocaba/Itapetininga_ETE_Prof_Edson.html Acesso em: 17/03/2007.
} 
Agricultura, como se situa hoje, é um problema superado. Não dá, absolutamente, resultado algum” (SÃO PAULO (ESTADO), 1951, p.30).

Descontando o enfoque pejorativo do discurso do deputado, observamos que o projeto do interventor Fernando Costa não frutificou conforme o esperado. Mais adiante, na mesma fala, é possível notar que, no caso da Escola Prática de Agricultura de Ribeirão Preto, havia cursos sem demanda suficiente. O debate entre deputados continua pondo em causa a ociosidade e os grandes custos que as instalações das Escolas Práticas de Agricultura passaram a gerar para os cofres do Estado, considerando, portanto, que seria melhor destiná-las a outros usos do que manter seu uso original (SÃO PAULO (ESTADO), 1951, p.30). Isso viria a acontecer, de fato, a partir de 1950, com todas as cinco escolas construídas.

Por fim, sobre as Escolas Práticas de Agricultura, podemos dizer que foi um projeto ambicioso. Suas unidades contaram com estruturas de grandes dimensões e com capacidade para receber muitos alunos, conforme afirmam Teles \& Iokoi (2005, p.69): “cada escola receberia trezentos alunos internos e 150 semi-internos, capacidade que poderia ampliar-se, pois o projeto previa a ampliação das instalações”. Porém, já de início esse grande projeto foi implantado apenas parcialmente, uma vez que das dez unidades planejadas somente foi realizada a metade. Cada escola levou aproximadamente três anos para ser concluída - de 1942 a 1945 todas estavam em obras e formaram as primeiras turmas por volta do final da década de 1950, quando os grupos dirigentes haviam sido mudados e, com eles, a política para essas escolas rurais, que entraram, então, em processo de extinção. A formatura da primeira turma da Escola Prática de Agricultura "Gustavo Capanema", de Bauru, por exemplo, aconteceu em junho de 1949 (FIGURA 58). Portanto, o que deveria ter sido um projeto de longo prazo, pelos altos recursos e tempo investidos, e pelas variáveis envolvidas, agonizou em, praticamente, cinco anos. Como disseram Teles \& Iokoi (2005, p.84), "Retornava a metáfora do Jeca Tatu”. Em resumo, duas escolas foram transformadas em campi de universidade, duas em institutos penais, e uma, após ter sido instituto penal por um tempo, tornou-se escola técnica. Todavia as construções foram preservadas e nos dão um testemunho eloqüente da adoção da linguagem arquitetônica neocolonial naquele período.

Apesar do desfecho pouco feliz, a trajetória histórica do projeto para as Escolas Práticas de Agricultura nos forneceu indicações sobre a relação do poder público do 
Estado de São Paulo com as linguagens arquitetônicas disponíveis na época. Além desses prédios escolares em linguagem neocolonial, encontramos também três outros tipos de edificações oficiais que seguiram a mesma tendência arquitetônica e, da mesma maneira, foram construídas pela Diretoria de Obras Públicas. Essas edificações são a Casa da Lavoura de Taubaté (FIGURA 113), inaugurada em 1945, o Fórum de Taubaté, “instalada em 3 de fevereiro de 1944” (ÁLBUM..., 1945, p.183) (FIGURA 111 e 112) e a Escola Preparatória de Cadetes, em Campinas, criada em 17 de setembro de $1940^{26}$ (FIGURA 114). Encontramos, em Jaú, a Escola Profissional "Joaquim Ferraz do Amaral", de 1939, também obra da Diretoria de Obras Públicas e, também, de autoria do arquiteto Hernani do Val Pentado. É uma edificação de pouca decoração, mas com telhados e frontão neocoloniais (FIGURA 59). Inclusive as casas da vila exibem traços neocoloniais. A existência dessas obras nos faz pensar que seria conveniente uma pesquisa sobre os projetos oriundos da Diretoria de Obras Públicas, entre 1940 e 1950, para cidades do interior paulista. É possível que seja mais ampla a adoção da tendência e se tenham construído obras semelhantes - neocoloniais - em várias outras localidades. Tentamos localizar projetos de fóruns e casas da lavoura do período concernente, e das mesmas cidades onde foram implantadas as Escolas Práticas de Agricultura, junto à Companhia Paulista de Obras e Serviços, onde estariam arquivados os projetos da antiga Diretoria de Obras Públicas, porém sem sucesso. Apenas conseguimos encontrar o projeto para o fórum de Pirassununga, que segue a estética modernista. Os demais não constavam no arquivo consultado.

\subsection{Obras Oficiais}

Analisamos, neste item, alguns aspectos arquitetônicos das obras oficiais que pudemos localizar, construídas pela Diretoria de Obras Públicas, na década de 1940, no interior do Estado de São Paulo, cuja arquitetura é de tendência neocolonial. São elas: as Escolas Práticas de Agricultura, o Fórum e a Casa da Lavoura, de Taubaté. Observamos, também, quem foram os arquitetos envolvidos em tais projetos, e procuramos compreender, na sua trajetória profissional, o significado de obras (ou obra) neocoloniais. A opção desses profissionais por essa linguagem arquitetônica, tão combatida em tempos de estabelecimento da arquitetura modernista, ter- se- ia dado por intervenção do Estado, através da Diretoria de Obras Públicas, órgão para o qual

\footnotetext{
26 Decreto-Lei n. 2584, de 17 de setembro de 1940. Disponível em: http://terra.espcex.ensino.eb.br/nova_internet/escola.php?w=232 Acesso em: 30/03/2008.
} 
trabalhavam, ou teria sido opção pessoal? As respostas nos remetem, novamente, para a questão da complexidade que fez parte do pensamento e do ambiente cultural das primeiras décadas do século XX. Afinal, como vimos, existiu um mal estar, entre os arquitetos, em admitir que tivessem aderido ao movimento neocolonial durante certo tempo, mas, por outro lado, existiam outros motivos para continuar aplicando essa linguagem em determinadas obras. Procuramos, assim, identificar alguma dessas causas, de forma a obter maior clareza sobre a fase intermediária de difusão do neocolonial, uma fase oficial e nacionalista.

\section{Escolas Práticas de Agricultura}

Acreditamos que o modelo para as Escolas Práticas de Agricultura foi o projeto desenvolvido pelo arquiteto Ângelo Murgel para a Escola Nacional de Agronomia, atual Universidade Federal Rural do Rio de Janeiro (FIGURA 46 e 47), tanto no uso da linguagem neocolonial para os prédios, como no modo de inserção de núcleos urbanos em áreas rurais (LIMA, 2005, p.12). Aqui, referimo-nos, antes, ao modelo arquitetônico, pois já vimos que a política de desenvolvimento agrário permeou tanto a esfera federal como as estaduais, durante o governo Vargas. Embora, como já sinalizamos anteriormente, Fernando Costa, como Ministro da Agricultura, não tenha se pronunciado especificamente sobre a arquitetura que seria empregada na Escola Nacional de Agronomia - pelo menos segundo os documentos que encontramos ${ }^{27}$ sustentamos a hipótese de que foi através dele que esse modelo chegou às Escolas Práticas de Agricultura paulistas. Provavelmente, no âmbito federal, a escola do Rio de Janeiro tenha correspondido mais que satisfatoriamente às expectativas oficiais, e, assim, o modelo arquitetônico foi trazido para o âmbito estadual pelo próprio Fernando Costa, quando ele passou a ser o interventor do Estado de São Paulo.

As informações levantadas sobre as Escolas Práticas de Agricultura nos permitem ter uma idéia aproximada das circunstâncias que envolveram sua implantação e construção. Por estarem localizadas em áreas rurais, certamente, houve exigências de toda ordem a serem cumpridas, e dificuldades a serem vencidas, desde a abertura e adequação dos terrenos aos projetos, passando pela ligação das unidades com centros maiores através de meios de transporte para trabalhadores, materiais de construção e, posteriormente, alunos e funcionários, até o abastecimento de energia elétrica e água,

\footnotetext{
${ }^{27}$ Relatórios (Costa, 1939a, 1939b) e conferência (Costa, 1941).
} 
que, quando não podiam ser trazidos de redes próximas, deviam ser produzidos no local, através de geradores e poços. Assim, podemos deduzir que a construção do projeto das Escolas Práticas de Agricultura demandou grandes esforços e recursos, de forma alguma condizentes com o tempo em que funcionaram a contento. Perguntamonos se o projeto foi mal dimensionado pelo interventor do Estado, que precisava responder às exigências da população, como mostravam os jornais da época, e de um governo voltado ao desenvolvimento a qualquer custo, ou se aos seus sucessores não interessava dar continuidade a tal obra. Possivelmente, havia os dois motivos e outros mais, porém não vamos nos alongar nessa questão que foge ao escopo da nossa pesquisa.

As instalações das Escolas Práticas de Agricultura, além de incluírem campos para cultivo, criação de animais e represas, eram formadas por um conjunto de edificações, entre as quais as destinadas ao prédio principal, aos alojamentos, ao ginásio de esportes, ao salão social, aos laboratórios, aos estábulos, ao laticínio, ao matadouro, às casas para funcionários e professores etc. É possível que em algumas das escolas nem toda a estrutura prevista tenha sido construída, como no caso da de São José do Rio Preto, onde a função original nunca foi implantada, e a de Itapetininga que, pelo que nos mostram as informações que levantamos, possui apenas o prédio principal com os alojamentos e alguns outros poucos edifícios (FIGURA 88).

Essa estrutura, em cada unidade, era envolvida por um planejamento paisagístico que se assemelha ao projeto de Murgel para a Escola Nacional de Agronomia que, de acordo com Lima (2005, p.17), definiu para as áreas de implantação assimétricas um "traçado de bairro-jardim" (FIGURA 60). Porém, nos projetos paisagísticos para as Escolas Práticas de Agricultura e, inclusive, naquele para a Escola Nacional de Agronomia, podemos identificar, também, elementos dos jardins ingleses pitorescos, fruto de "um movimento marcante na Inglaterra a partir do século 16" que passou a valorizar o campo e a paisagem - em versões distantes das "agruras concretas do cotidiano campesino" - em detrimento do novo e impactante aspecto urbano gerado pelo crescimento e industrialização de Londres (SEGAWA, 1996, p.28). Trata-se, portanto, da construção de uma paisagem onde está presente o espírito romântico e o conceito de pitoresco, tendo, este último traço, sido trazido pelo precursor dos jardins ingleses, William Kent. Segundo Mercadal (1949, p.160), o gênio criador de Kent "procede de su formación de pintor y de su compresión pictórica del paisaje" e 
“impresionado por las descripciones literarias de Addison y de Pope, intenta crear sus parques como pinta sus cuadros”. Assim, enquanto o jardim francês era marcado por "su planimetria, su rectitude, siendo todo regular y digno como en fachada de un edifico" (Mercadal, 1949, p.148), o inglês “se compone de paseos sinuosos, arroyos describiendo meandros y estanques de bordes irregulares” (MERCADAL, 1949, p.160) (FIGURA 61). Um dos jardins realizados no Estado de São Paulo segundo as premissas dos jardins ingleses é o da Escola Superior de Agricultura Luiz de Queiroz, em Piracicaba, concebido pelo arquiteto paisagista belga Arsenio Puttemans ${ }^{28}$, com auxílio do professor dessa mesma instituição, Luiz Teixeira Mendes, e implantado em 1907 (LIMA, 1987, p.21) (FIGURA 62). Assim, esse e outros jardins da tradição inglesa podem ser tomados como referências para os projetos paisagísticos das Escolas Práticas de Agricultura. Características como as de grandes gramados, tanques de água, traçados sinuosos e caminhos com bifurcações para favorecer certas visuais são encontradas nos projetos paisagísticos para as Escolas Práticas Agrícolas. Um traço recorrente é o acesso por caminhos que nunca vão diretamente até a edificação principal, mas, num dado momento, abrem-se e circundam pelas laterais de um gramado frontal, em formas ovais ou elípticas (FIGURAS 64, 77, 90).

Os traçados paisagísticos para as Escolas Práticas de Agricultura diferem, porém, dos jardins ingleses, no emprego de alguma simetria, como no caso da Escola Prática de Agricultura "Dr. Fernando Costa", de Pirassununga, que exibe um eixo frontal à edificação principal, embora, de uma perspectiva mais ampla, os traçados de cada lado do eixo sejam diferentes (FIGURA 90). No caso da Escola Prática de Agricultura "Gustavo Capanema", de Bauru, existe simetria em frente a cada edificação, mas o traçado geral é assimétrico e sinuoso. O responsável por esse projeto foi João Schmid, vinculado à Construtora de Jardins «São Paulo», que ficava à Rua Tutoya, 343, como se verifica na prancha de projeto (FIGURA 64). Atualmente, parte do traçado está descaracterizada. Desde que passou a ser utilizada como instituto penal, houve a necessidade de fazer adaptações. Encontramos um projeto, da década de 1970,

\footnotetext{
28 Arsenio Puttemans também foi responsável pelo "projeto do jardim do Ipiranga, o da Praça da República e da Várzea do Braz, em São Paulo, bem como aquele da Praça de São Bento em Niterói, o do Parque Philippe Westin Cabral de Vasconcelos é hoje a única que permanece praticamente inalterada" (Lima, 1987, p. 22). Este último parque é o parque da Esalq. Os jardins do Museu do Ipiranga foram ampliados em 1922, segundo o projeto de Reynaldo Dierberg, paisagista ascendência alemã, muito atuante no estado de São Paulo nas décadas de 1920 e 1930. Dierberger, Reynaldo. Arte e jardim. São Paulo: Dierberg, 1928. Dierberger foi ainda responsável pelos jardins do claustro da Escola Nacional de Agronomia, RJ (Rumbelapager, 2005, p.105).
} 
para instalação de alambrados ao redor de três dos principais prédios para, naturalmente, impedir a circulação. A disposição dessas barreiras não respeitou o arruamento do projeto original, constituindo-se de uma forma irregular de sete lados retilíneos que desfiguraram por completo o ajardinamento anterior (FIGURA 63 e 66). Assim como as anteriores, a Escola Prática de Agricultura "Getúlio Vargas", de Ribeirão Preto, recebeu um projeto paisagístico que se identifica com os jardins ingleses, mas com traçado simétrico à volta do prédio principal. Sobre as três demais escolas - de Guaratinguetá, de Itapetininga e de São José do Rio Preto - não foi possível realizar uma análise mais apurada de seus projetos paisagísticos, devido à insuficiência de informações sobre o assunto. As fotos aéreas da Escola de Especialistas de Aeronáutica, de Guaratinguetá, antiga Escola Prática de Agricultura "Paulo de Lima Correia”, mostram que, no decurso de transformação de uma instituição para outra, a taxa de ocupação do sítio onde está instalada cresceu consideravelmente, fazendo com que o traçado original se extinguisse. Apesar disso, ainda é possível distinguir alguns elementos que indicam a semelhança do projeto paisagístico original com os das outras escolas, que é o acesso por um ponto lateral ao prédio principal, o acesso por vias sinuosas à casa principal do conjunto e uma rua curva que leva às casas que, anteriormente, deveriam ser as casas dos funcionários. Essas casas estão implantadas de maneira semelhante às casas dos funcionários da unidade de Bauru (FIGURA 64 e 85). Como não nos foi possível localizar o projeto original, as dúvidas permanecem. Localizamos um levantamento do conjunto de edificações da Escola Técnica Agropecuária Estadual "Prof. Edson Galvão", antiga Escola Prática de Agricultura "Dr. Carlos Botelho", de Itapetininga, realizado pela Companhia Paulista de Obras e Serviços, que data do ano de 2002. O levantamento e novos projetos destinaram-se a reformas realizadas na instituição a partir daquele ano. Não foi possível localizar o projeto original da escola, e tal levantamento apenas considera as vias existentes, de maneira que também não foi possível analisar o projeto paisagístico original dessa unidade. Apesar disso, pelas fotos podemos perceber que a via de acesso ao prédio principal se faz por uma curva que chega a um pequeno canteiro de forma arredondada, o que nos indica que o paisagismo original se identifica com aquele realizado para a escola de Bauru (FIGURA 105). Sobre a Escola Prática de Agricultura de São José do Rio Preto, atual Instituto Penal Agrícola "Dr. Javert de Andrade", apenas encontramos uma foto que não permite maiores análises. Seu projeto não consta no arquivo da Companhia Paulista de Obras e Serviços (FIGURA 57). 
Apesar da clara referência à arquitetura barroca, feita nos prédios das Escolas Práticas de Agricultura, o mesmo não se deu em seus projetos paisagísticos. Poderíamos supor, seguindo a mesma lógica, que o traçado para esses espaços fosse inspirado na simetria e no emprego de desenhos geométricos dos jardins franceses que coincidem com o período Barroco ${ }^{29}$. Porém, a identidade com o aspecto romântico e pitoresco prevaleceu na composição geral dos traçados para os entornos dessas escolas, implantadas em meio a projetos que remetem ao jardim inglês e à teoria cidade-jardim. Talvez isso se tenha dado, inclusive, pelo fato de as escolas se situarem em áreas rurais, condicionante ligada à idéia romântica de idealização do campo, além do que os prédios, em sua concepção neocolonial, também estão associados ao espírito romântico e pitoresco.

Uma característica comum a todos os prédios principais das Escolas Práticas de Agricultura é a simetria, mas cada um deles possui suas particularidades. Essa característica também aparece em outros prédios importantes da escola, como o prédio para o Centro de Educação Física da escola de Ribeirão Preto (FIGURA 81 e 83). Pudemos identificar dois tipos de projetos, entre as Escolas Práticas de Agricultura: aqueles cujos prédios principais possuem dois pavimentos, e aqueles em que possuem apenas um. Bauru e Ribeirão Preto receberam o projeto com dois pavimentos e assemelham-se no destaque do volume central, que avança em relação à fachada, por onde se dá o acesso principal (FIGURA 70 e 82). No prédio principal da escola de Bauru, um grande frontão tripartido, com volutas e coruchéus nas laterais, sobrepõe-se a três aberturas de arco abatido e a três arcos plenos. Uma das aberturas é uma portabalcão, cuja sacada semicircular possui uma balaustrada com elementos que evocam as madeiras torneadas, itens muito utilizados nas manifestações arquitetônicas neohispânicas. As duas laterais da fachada são marcadas por duas grandes seqüências de janelas, no piso superior de arco abatido e no inferior de vergas retas. Esse prédio possui decoração escassa, sem painel de azulejos na fachada. Na Escola de Ribeirão Preto, diferentemente, o frontão do antecorpo em destaque na fachada é triangular, mas, de maneira similar, apresenta três aberturas: três janelas no piso superior e duas janelas elípticas e uma portada central decorada com motivos evocativos da arquitetura

\footnotetext{
29 "Por haber nascido en Inglaterra se le conoce [ao jardim paisagístico, de traçado irregular] por jerdín inglés, reservando la denominación de jardín fracés, al de trazado regular del siglo XVII" Mercadal (1949, p. 161).
} 
barroca $^{30}$. As laterais do prédio são compostas por arcadas no pavimento inferior, e uma seqüência de janelas de arcos abatidos no superior, que chegam, dos dois lados, a outros dois volumes destacados. Em planta, os prédios das duas unidades, de Bauru e de Ribeirão Preto, são em forma de "E", com três alas partindo perpendicularmente à fachada principal (FIGURA 66 e 78). Os portões de entrada das unidades de Bauru e Ribeirão Preto seguem o mesmo projeto e são praticamente iguais, com rusticação nas pilastras de entrada, arco pleno e janelas elípticas (FIGURA 69 e 79).

As Escolas Práticas de Agricultura "Paulo de Lima Correia", de Guaratinguetá, "Dr. Fernando Costa", de Pirassununga, e "Dr. Carlos Botelho", de Itapetininga, foram construídas segundo o tipo de projeto em que os prédios principais têm apenas um pavimento. (FIGURA 86, 94 e 106). Os prédios principais das duas primeiras escolas têm a fachada simétrica e também possuem um antecorpo central destacado, por onde se faz o acesso através de três arcos encimados por um grande frontão, curvo e abatido, decorado por telhas capa e canal, e um painel de azulejos mostrando uma cena rural. A fachada continua, para a esquerda e para a direita, com um ritmo de abertura marcado por três janelas de vergas retas de cada lado. O prédio principal da escola de Itapetininga é quase idêntico, mas difere levemente na forma do frontão e do painel de azulejos, na ausência de telhas sobre a cimalha desse elemento, e no ritmo de abertura das laterais da fachada, que possui três janelas pequenas e agrupadas, e uma maior, de arco pleno a cada lado. Esse prédio e o de Guaratinguetá têm cunhais decorados com aplicação em pedra. Todos os prédios principais dessas três unidades assemelham-se em planta, cuja forma pode ser descrita como uma cruz de quatro travessas (FIGURA 84, 91 e 104), ou seja, possuem um eixo principal de onde partem, perpendicularmente, alas simétricas, tanto para um lado como para o outro. As alas intermediárias possuem dois pavimentos compostos por arcos alongados, em que a curva fica apenas na fachada do pavimento superior; aí, os guarda-corpos empregam as meias-luas decorativas, tão utilizadas em exemplares neocoloniais (FIGURAS 87, 95 e 107). Nessas alas estavam localizados os dormitórios.

Diversos estilemas são recorrentes em prédios de várias escolas, como portadas decoradas; cartelas $^{31}$; volutas; coruchéus; arcadas; telhados de telha capa e canal, beirais revirados e telhas de ponta; e outros mais. É importante conjecturar que, muito

\footnotetext{
${ }^{30}$ Segundo Koch (1994, p. 187), também chamado "nastros volteados".

${ }^{31}$ Segundo Koch (1994, p. 51), também chamada “cártula de rolos”, na arquitetura barroca.
} 
provavelmente, a Diretoria de Obras Públicas desenvolveu projetos tipo para as Escolas Práticas de Agricultura que, dependendo de determinadas condições, eram destinados a uma ou outra unidade. Mais que isso, provavelmente, os projetos tipo são uma derivação simplificada da arquitetura do edifício da Escola Nacional de Agronomia. Observando esse prédio, verificamos que possui imponência e dimensões maiores, e que muitas de suas características se repetem nos prédios das Escolas Práticas de Agricultura, sendo que algumas merecem ser, aqui, analisadas, para melhor visualizarmos o parentesco existente entre tais obras. Especialmente, é na compleição dos acessos principais que verificamos uma grande semelhança: a entrada principal da Escola Nacional de Agronomia se faz por um antecorpo destacado e um pórtico. O antecorpo é composto por um grande frontão curvo e interrompido, com coruchéus laterais, uma janela falsa central elíptica preenchida por um painel de azulejos e três portas-balcão que dão para uma sacada em forma de taça e de guarda-corpo maciço. $\mathrm{O}$ pórtico, igualmente, apresenta grande frontão curvo com ornamento em painel de azulejos, coruchéus sobre três grandes arcos (FIGURA 46). Detendo-nos na análise, notaremos que o projeto tipo um - o de dois pavimentos - das Escolas Práticas de Agricultura, é muito semelhante à descrição acima, embora sem o espaço que forma o pórtico; o projeto tipo dois - de um pavimento - também é muito semelhante, porém, por sua vez, sem o espaço que forma o antecorpo. No mais, outras componentes do partido, como a seqüência de janelas laterais nos três pavimentos, alas que partem perpendicularmente à fachada principal, e a simetria, são traços que tornam evidentes as semelhanças entre os prédios. Além desses traços, podemos ainda citar os telhados, as arcadas, os azulejos e os adornos, como elementos de construção que foram empregados tanto em uma, como noutras obras oficiais.

Já havíamos citado que num dos projetos para a Escola Prática de Agricultura de Bauru, cuja autoria é do Hernani do Val Penteado, há uma anotação informando que o mesmo havia sido adaptado de um projeto de Mario Whately \& Cia. o qual cremos ser, justamente, o projeto da Escola Nacional de Agronomia (FIGURA 109). Uma informação que, definitivamente, comprova nossa hipótese, é a de que a Escola Nacional de Agronomia foi elaborada

por Mario Whately \& Cia, sob a supervisão do engenheiro-arquiteto Ângelo Murgel (da Divisão de Obras do Ministério da Agricultura) nomeado pelo então ministro Fernando Costa (e com a contribuição dos arquitetos 
Eduardo da Veiga Soares e José Theodoro da Silva) (RUMBELAPAGER, 2005, p.102).

As Escolas Práticas de Agricultura foram implantadas naturalmente, de diferentes formas, tendo diversos prédios destinados a diversas funções, localizados segundo a conveniência local. A escola de Guaratinguetá possui um prédio alocado em frente ao prédio principal que parece ter sido, devido às suas características, construído quando ali já funcionava a Escola de Especialistas de Aeronáutica. Esse é o prédio do Comando e denota, embora de maneira enviesada, certo cuidado com o patrimônio arquitetônico legado pela escola de agricultura, pois seu aspecto reproduz vários estilemas do neocolonial ali implantado. Observamos os arcos, as meias-luas, o frontão curvo, as telhas capa e canal e, por outro lado, também, principalmente, as proporções, os telhados que findam em beirais demasiadamente retos, as vigas e os pilares de concreto, que permitem uma clara distinção entre esse, e os prédios oriundos da antiga escola dos tempos de Fernando Costa. Estamos diante de um exemplar "neoneocolonial", ou diante de uma permanência da linguagem que se deu dentro da própria escola (FIGURA 88). Assim, prédios da época do interventor, qualificados como pastiche e, por isso, muito criticados, nesse contexto passam a ter uma conotação de originalidade, o que nos lembra que algumas interpretações são relativas. Ao caminharmos pela atual escola, podemos identificar outros prédios, provavelmente construídos no mesmo período em que o foi o prédio do Comando, pois vemos a reprodução, porém com características próprias, dos estilemas anteriormente citados e das meias-luas que se transformaram em círculos completos (FIGURA 88).

Apesar das particularidades, todos os prédios dos conjuntos construídos para as Escolas Práticas de Agricultura, quaisquer que fossem as funções às quais eram destinados, podem ser caracterizados como neocoloniais devido ao seu aspecto geral. Por exemplo, mesmo prédios destinados a estábulos, matadouros, criadouros de porcos ou bezerros, e caixas d'água, não prescindiram de decorações e traços neocoloniais, o que destaca a preocupação em qualificar todo o conjunto das instalações da escola dentro da mesma unidade estilística (FIGURAS 72, 73, 74, 75, 76, 97, 98, 99, 100, 101 e 102).

Algumas fotos da época de construção nos mostram que o sistema construtivo utilizado foi, basicamente, a alvenaria de tijolos. É possível que se tenha usado o concreto, em alguma parte das edificações, pois as escolas foram construídas já nos 
anos de 1940, porém, não é perceptível. A madeira foi um material usado principalmente nos telhados e em acabamentos internos - portas, janelas, lustres, decoração para paredes, pisos de áreas nobres - além de ter sido usada na construção de paióis e alojamentos para operários da construção. Nesses casos, quando utilizadas para construir os alojamentos, foram consideradas, "anti-higiências" (Álbum de Inauguração da Escola Prática de Agricultura "Gustavo Capanema”, Bauru) (FIGURA 67 e 68). Outros materiais como pisos cerâmicos em áreas externas, vidros nas janelas e portas e azulejos decorativos foram muito utilizados.

Merecem destaque, nessa descrição, alguns detalhes decorativos que ajudaram a constituir a linguagem neocolonial dos prédios das escolas. Evidentemente, a ocorrência de tais detalhes é mais intensa nos prédios principais. Uma dessas ocorrências consiste nas proporções, que tendem a ser maiores do que o esperado para diversos elementos, para as fachadas e entradas principais. Podemos observar que os frontões das fachadas têm grandes dimensões e ganham muito destaque, principalmente quando se trata do prédio de apenas um pavimento; alguns dos pilares passam a sensação de que poderiam ser mais esbeltos; desenhos decorativos das bandeiras das portas são simples e grandes; as quartilhas dos corrimãos são volumosas, assim como as volutas que os adornam; guarnições de janelas e portas são de dimensões exageradas (FIGURA 71 e 96). Essa arquitetura pouco esbelta foi fruto de uma intenção, por parte do Estado paulista, de fazer impressionante o projeto das Escolas Práticas de Agricultura. Nesse sentido de busca por certa monumentalidade, a arquitetura neocolonial foi adequada, posto que uma de suas características foi a reinterpretação das proporções originais da arquitetura barroca colonial, como nos mostra Perichi (1994, p.142 e 146), ao descrever algumas colunas de edifícios neocoloniais, na Venezuela, como "panzudas".

Outro detalhe que pode ser citado é o emprego dos azulejos, em alguns dos prédios das Escolas Práticas de Agricultura. Os painéis decorativos compostos por azulejos são mais uma referência da arquitetura neocolonial à arquitetura barroca e à portuguesa. Nesse sentido, vale ressaltar que, a partir do fim do século XVII, Portugal se torna independente da importação de azulejos holandeses, pois aflora uma produção nacional consistente, conduzida por mestres que passaram a dominar a técnica da azulejaria, sendo o mais importante deles Gabril del Barco (MECO, 1986, p.19). Esse período coincide com o auge da arquitetura barroca, que empregou painéis de azulejos, tanto em manifestações religiosas, como nas civis, dessa arquitetura. Segundo Pereira 
(1989, p.67), foi com Barco que a arte do azulejo se ligou à arquitetura barroca em Portugal: “Com a produção figurativa de Barco, o azulejo alcançou uma teatralidade barroca através da grandiosidade de algumas concepções, reforçadas pelas paisagens distantes, os elementos de arquitectura monumentais, cortinados e outros acessórios". A utilização do azulejo nesse país também está ligada à tradição islâmica (BACKHEUSER, 2006). Os temas geométricos eram oriundos, justamente, dessa tradição, enquanto os das cenas e das paisagens estiveram presentes desde os tempos dos azulejos holandeses, enquanto as figuras tornaram-se mais populares no século XVIII. Ora, desde o século XVI até o XIX, o Brasil importou os azulejos portugueses, sendo que até o século XVIII "os navios que partiam vazios das terras lusitanas, para voltarem carregados de produtos locais, costumavam levar grandes quantidades destes azulejos para servir de lastro (BACKHEUSER, 2006). O período também coincidiu com a produção barroca e colonial brasileira e, logo, se tornou um elemento apropriado pelos construtores brasileiros. Como nos mostra Backheuser (2006), o azulejo consistiu num exemplo da "efetiva transculturação e numa curiosa inversão de influências na utilização de um material de construção tão português que também se provou muito brasileiro”. Assim, sua utilização como decoração, especialmente em painéis retratando cenas e figuras, muitas vezes numa atitude romântica, nacionalista e/ou pitoresca, reaparece na produção arquitetônica neocolonial, inclusive na arquitetura neocolonial oficial, como é o caso das escolas aqui tratadas. Antes de sua utilização nas Escolas Práticas de Agricultura, temos notícia do emprego de um painel decorativo de azulejos na Universidade Federal Rural do Rio de Janeiro, obra de autoria da artista plástica Vieira da Silva ${ }^{32}$ (KESSEL, 2002, p.215) (FIGURA 47). Comprovadamente, receberam painéis e outros detalhes decorativos em azulejos, produzidos pelo Liceu de Artes e Ofícios de São Paulo, as escolas de Pirassununga e Itapetininga, em cujos elementos pudemos verificar a marca de origem. Na escola de Pirassununga, um grande painel, de aproximadamente nove metros de largura, preenche o frontão de entrada do prédio principal, mostrando uma cena bucólica, em que um trabalhador conduz uma parelha de bois a arar a terra, nas cores azul e branco (FIGURA 103). Abaixo, entre os pilares, outros adornos quadrilobados também são preenchidos com azulejos; esse tipo de detalhe decorativo se repete em vários outros prédios da escola, como o do Centro de Eventos e habitações, e no portão de entrada, ora como decoração, ora como forma das

\footnotetext{
32 Maria Helena Vieira da Silva (1908 - 1992) foi uma pintora portuguesa, naturalizada francesa em 1956; viveu no Brasil durante e no pós Segunda Guerra Mundial.
} 
molduras das janelas. Repete-se também em outras unidades, como na escola de Itapetininga, por exemplo (FIGURA 93). No obelisco comemorativo da inauguração do parque dessa escola, igualmente encontramos painéis de azulejos, retratando cenas nas quais comparecem homens no trabalho do campo, casas rurais simples e animais como galinhas, cavalos, vacas e ovelhas, destacando uma ambiência pitoresca e buscando valorizar a vida rural. A escola de Itapetininga ganhou também um painel de azulejos no grande frontão da entrada principal, de origem do Liceu de Artes e Ofícios, mostrando, novamente, o ato de lavrar a terra, mas por uma parelha de burros, guiados por um trabalhador (FIGURA 108). Parece bastante significativo colocar em evidência tais cenas, simbolicamente ligadas à produtividade da terra trabalhada. Nesses casos, a arquitetura é suporte para a mensagem de que é preciso aprender a trabalhar a terra, e de que está ali a escola que o ensina. Na unidade de Guaratinguetá também encontramos um frontão azulejado na entrada, que mostra vacas e bezerros saudáveis, situados num campo tranqüilo (FIGURA 86). Esse painel aparece totalmente coberto por uma pintura lisa, numa foto de 1954, portanto quatro anos depois de a escola ter sido doada à União. Certamente, foi pintado quando da implantação da Escola de Especialistas de Aeronáutica, cujas atividades - aéreas - pareciam condizer muito pouco com as evocações ao mundo telúrico (FIGURA 89). Felizmente, a negação daquele passado imediato foi apenas superficial: a camada de tinta conservou os azulejos e evitou a atitude mais drástica, de retirada dos mesmos. Desconhecemos a data em que os azulejos foram redescobertos, mas certamente o conflito terra/ar foi superado, pois a história da Escola Prática de Agricultura é conhecida pelos oficiais que nos atenderam, na ocasião de nossa visita ao local ${ }^{33}$. Mais que isso, curiosamente, foi implantada uma "tradição azulejista", na atual Escola de Especialistas de Aeronáutica, que consiste em que cada turma de formandos manda erigir um painel, ao longo da alameda de entrada, com cenas relativas ao curso que realizaram (FIGURA 84). Na unidade de Bauru não encontramos azulejos; na de Ribeirão Preto, existe um painel ao menos no marco de entrada (FIGURA 80).

\section{Fórum de Taubaté}

O prédio do fórum de Taubaté, em plena construção no ano de 1945, é mais um exemplo de obras neocoloniais realizadas pela Diretoria de Obras Públicas do Estado de

\footnotetext{
${ }^{33}$ Visita realizada em 18/04/2007.
} 
São Paulo (FIGURA 111 E 112). Constitui-se, também, em mais um exemplo de como a tendência arquitetônica neocolonial esteve associada à idéia de modernização, segundo o registro no Álbum... (1945, p.295):

uma das esplêndidas realidades deste surto de progresso que Taubaté revela é, sem dúvida, o novo Fórum cuja construção já vai adiantada. (...) pelo progresso que revela (...), pela vida urbana moderna que toma, mudando aos poucos sua feição de cidade antiga, necessitava mesmo de um edifício forense (...) moderno, amplo, bem localizado.

A cidade, assim, mudava seu aspecto antigo - atrasado - através da construção de um aspecto antigo renovado - neocolonial. Contradição aos nossos olhos, tal iniciativa, entretanto, esteve plena de sentido, naquela época, e marcava a presença de um Estado nacionalista. O edifício é composto por um volume de dois pavimentos e planta em forma de "E", com fileiras de janelas de arco abatido nas fachadas, em cujas bandeiras vemos as mesmas decorações utilizadas em algumas janelas das Escolas Práticas de Agricultura. Na fachada principal, simetria e leve destaque da porção central, por onde se faz o acesso através de um pórtico que sustenta a sacada retangular da porta-balcão do segundo piso. O guarda-corpo da sacada é composto por balaustrada semelhante a outras encontradas nas Escolas Práticas de Agricultura, com coruchéus marcando os vértices. A porta-balcão é de arco curvo encimada por um frontão curvo tripartido, decorado com volutas e concha; situa-se entre duas janelas elípticas e dois pares de janelas de arcos curvos, e cimalhas decoradas por pequenas cártulas de rolo. Os pontos mais altos dos telhados de telhas capa e canal levam pináculos e têm beirais largos e simples, de estuque. Os cunhais do edifício são marcados por rusticação, bem como a base, onde é feita com a aplicação de pedras. Essa composição remete, antes, à arquitetura colonial civil, que à barroca. As pranchas de arquitetura dessa obra são assinadas pelo engenheiro-arquiteto Vicente Leme Zammataro, diplomado pela escola Politécnica em 1938, e cuja "principal atividade profissional foi na Diretoria de Obras Públicas, onde entrou ainda estudante e se aposentou em 1974” (FICHER, 2005, p.308). É possível que existam, pelo interior paulista, outros prédios de fóruns construídos no mesmo período e cuja arquitetura seja neocolonial.

\section{Casa da Lavoura de Taubaté}

Como parte da política de desenvolvimento agrícola da gestão Fernando Costa, foi implantada ao menos uma Casa da Lavoura em estilo neocolonial no interior 
paulista, a de Taubaté "que é uma organização que tem por finalidade prestar assistência técnica e material à lavoura da extensa região do Vale do Paraíba" (ÁLBUM..., 1945, p.183) (FIGURA 113). Foi inaugurada no dia 3 de fevereiro de 1944, no local onde anteriormente havia existido o Teatro São João, na atual Praça 08 de Maio, e funcionou até $1979^{34}$. A volumetria da edificação é paralelepipédica, com um volume central de dois pavimentos. Assemelha-se às Escolas Práticas de Agricultura de apenas um pavimento, pois é simétrica e possui destaque na porção central, embora esta não avance como um antecorpo, como nas escolas. Possui também um grande frontão curvo com volutas e coruchéus nas laterais, onde sentimos a falta do painel de azulejos, que neste prédio está ausente. Os três arcos abaixo do frontão, por onde se faz o acesso, e os cunhais, são decorados com aplicação de pedras. Três janelas de vergas retas e adornadas com frisos, localizadas a cada lado da fachada, e também nas fachadas laterais, completam a simetria do conjunto. Os telhados são de telhas capa e canal com beirais levemente revirados. Pode-se supor que tenha sido mais uma obra realizada pela Diretoria de Obras Públicas em cujo projeto esteve envolvido o arquiteto Hernani do Val Penteado, devido à data de sua implantação e às características neocoloniais de sua arquitetura. É possível que existam outras Casas da Lavoura, em outras regiões do interior paulista, que tenham sido implantadas no mesmo período, e cuja arquitetura seja semelhante. Procuramos, no arquivo da Companhia Paulista de Obras e Serviços, por esses projetos, que talvez tivessem sido implantados nas mesmas cidades onde foram implantadas as Escolas Práticas de Agricultura, porém nada encontramos, o que leva a pensar que isso não ocorreu. Pesquisas futuras podem trazer mais informações.

\section{Escola Preparatória de Cadetes de Campinas}

Outro prédio oficial, construído no interior do Estado paulista pela Diretoria de Obras Públicas, durante o mandato de Fernando Costa como interventor do Estado, segundo projeto do arquiteto Hernani do Val Penteado, foi a Escola Preparatória de Cadetes de São Paulo ${ }^{35}$. Segundo consta na prancha de desenho da fachada da escola, o projeto data do ano de 1944 (FIGURAS 114 a 117). Além desse desenho, encontramos projetos da adaptação de alguns espaços, do ano de 1955, e o projeto para uma torre de vigia, elaborado mais tarde, já em 1970, todos realizados, ainda, pelo mesmo arquiteto,

\footnotetext{
${ }^{34}$ Informações anotadas no verso da foto da Casa da Lavoura, de 1944, quando estava recém-inaugurada. Foto localizada no Museu da Imagem e do Som de Taubaté, em 17/04/2007.

35 "No dia 23 de janeiro de 1959, a sede da Escola era transferida para a cidade de Campinas, passando a se chamar Escola Preparatória de Cadetes de Campinas". Disponível em: http://terra.espcex.ensino.eb.br/nova_internet/escola.php?w=232 Acesso em: 30/03/2008.
} 
e com características arquitetônicas que o integram ao restante do conjunto (FIGURA 115). A fachada do grande prédio da Escola Preparatória de Cadetes segue os mesmos padrões dos prédios das Escolas Práticas de Agricultura de Bauru e de Ribeirão Preto, ou seja, constitui-se de um bloco simétrico de dois pavimentos, com destaque no antecorpo central, por onde se faz o acesso principal. Esse antecorpo central possui um grande frontão curvo com arco interrompido, mostrando uma evocação ao barroco espanhol, com coruchéus laterais e decoração com concha sobre a porta-balcão com sacada e guarda-corpo com balaústres de formas torneadas. Abaixo, um grande arco abatido. Possui duas alas laterais formadas por arcadas e um ritmo dado pelas aberturas das janelas. A simetria é quebrada por uma torre localizada próxima ao frontão, do lado esquerdo. Em planta, o desenho da edificação conforma um grande quadrado aberto e gramado, como um pátio, onde são realizados exercícios militares e solenidades comemorativas. Esse pátio é rodeado por arcadas que formam galerias, como num claustro. Do lado direito do quadrado partem quatro alas de dois pavimentos. Faz parte do conjunto de prédios uma capela, também neocolonial, feita à semelhança do corpo central do prédio principal (FIGURAS 117). Pelo material levantado sobre essa escola, não é possível afirmar se houve emprego de painéis de azulejos, em sua decoração. As telhas utilizadas são capa e canal. Algumas fotos da época de construção mostram a utilização de alvenaria de tijolos e concreto nas vigas e pilares da torre da fachada (FIGURA 116).

\section{Instituto "Dona Escolástica Rosa", de Santos}

A atual Escola Técnica do Centro Paula Sousa nasceu como Instituto "Dona Escolástica Rosa", em 1908, com a missão de acolher e educar órfãos da cidade de Santos. Os recursos para a construção do instituto vieram da fortuna de João Octávio dos Santos - filho da ex-escrava do Conselheiro João Octávio Nébias, Escolástica Rosa - conseguida no comércio de exportação de bananas e trigo. A obra, de linhas ecléticas, foi projetada pelo escritório Ramos de Azevedo numa das propriedades de João Octávio dos Santos, localizada na orla marítima da cidade (FIGURA 118). Em 1933, foi realizado um convênio entre a Santa Casa de Santos - administradora da manutenção do orfanato - e o Governo do Estado de São Paulo, por um período de 50 anos. Nessa fase, mais especificamente entre 1936 e 1951, passou por transformações que lhe conferiram o atual aspecto neocolonial, tendo ganhado os frontões, o painel de azulejos, as arcadas internas e outros estilemas característicos (FIGURA 119); ganhou também, na mesma 
ocasião, em 1939, uma capela neocolonial (FIGURA 120). Nesse caso, não podemos afirmar que a reforma tenha sido de responsabilidade da Diretoria de Obras Públicas do Estado de São Paulo, porém, devido ao convênio, à data em que o mesmo se firmou e à tendência arquitetônica empregada - a neocolonial -, acreditamos haver a possibilidade de, também essa reforma, ter sido realizada pela diretoria citada. Na década de 1980, o instituto foi fechado, e suas instalações foram alugadas pelo Estado. Em 2004, o prédio

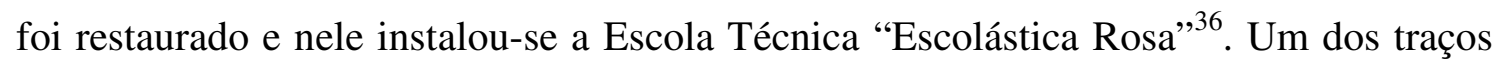
neocoloniais do prédio da Escola Técnica "Escolástica Rosa", muito semelhante aos encontrados em outras obras oficiais, é o grande frontão central ornamentado com o painel de azulejos brancos e azuis, retratando uma cena relacionada à função do edifício: uma mulher com duas crianças a caminho de um edifício, presumidamente, um orfanato. A reforma preservou a simetria, volumetria, o número de pavimentos e o ritmo de aberturas do prédio original de Ramos de Azevedo; acrescentou-lhe uma cobertura, diante do acesso principal, que avança até a calçada e é encimada por um frontão curvo, volutas e coruchéus laterais, e também, nas laterais do frontão de azulejos, dois outros frontões curvos menores e, em cada extremidade da fachada do prédio, um frontão semelhante. As janelas ganharam arcos abatidos com cimalhas e lembram as janelas do Fórum de Taubaté; os telhados foram acrescidos de beirais pronunciados, com cachorros e coruchéus sobre os cunhais. Um muro baixo, revestido com pedras, cerca a edificação (FIGURA 119). Infelizmente, não pudemos ter acesso aos projetos da reforma da década de 1930, pois, ao contrário do projeto original, de Ramos de Azevedo - que está sob os cuidados do Centro de Memória da escola - os posteriores já não constam em seu acervo. Assim, não nos foi possível confirmar se a autoria foi, realmente, do Departamento de Obras Públicas.

Muitos dos desenhos para os edifícios oficiais estudados, que foram elaborados e construídos pela Diretoria de Obras Públicas do Estado de São Paulo, levam a assinatura do arquiteto Hernani do Val Penteado. Assim, o arquiteto esteve envolvido no desenvolvimento de muitos projetos neocoloniais oficiais que foram implantados pelo inteiro paulista, como vimos e, também, por outros de mesma tendência estética,

\footnotetext{
${ }^{36}$ As informações foram fornecidas, em entrevista telefônica, pela coordenadora do Centro de Memória da Escola Técnica "Escolástica Rosa", senhora Deisy Rodrigues de Lima Simões, em 16/04/2008. Maiores informações estão disponíveis em: http://www.escolasticarosa.com.br/Hist,\%20Dep\%20Pasta/hist\%20pag.htm Acesso em 15/04/2008.
} 
mas não oficiais, como o do Colégio de Freiras da Ponta da Praia, em Santos, a pedido da Madre Maria Diomira do Santíssimo Sacramento, em 1949 ${ }^{37}$. Possivelmente, o projeto da Escola Profissional de São Manoel seja, também, desse arquiteto, pois localizamos o projeto do prédio da Administração da escola, que leva sua assinatura. Trata-se de uma edificação simples, mas de uma arquitetura que se aproxima à tendência neocolonial (FIGURA 121). Apesar de ter sido autor desses vários projetos, frutos do movimento iniciado por Ricardo Severo, o arquiteto Hernani do Val Penteado é mais conhecido por seus projetos para os prédios escolares na cidade de São Paulo, da década de 1930, e para o Aeroporto de Congonhas, de 1949, projetos de tendências art déco e modernistas (FICHER, 2005, p.354-355). Considerando-se que também as escolas de cariz modernista foram construídas pela Diretoria de Obras Públicas, cabe uma investigação que aponte os motivos de o Estado empregar tanto a tendência neocolonial como a modernista, em prédios escolares construídos nas décadas de 1930 e 1940. Em uma publicação sobre um estudo da Diretoria de Ensino e da Diretoria de Obras Públicas de 1937, acha-se uma argumentação do arquiteto José Maria da Silva Neves $^{38}$ sobre os motivos pelos quais as escolas não deveriam utilizar fachadas neocoloniais. Nessa sua explanação, Neves mostra-se já totalmente adepto da arquitetura modernista, afirmando que “o colonial só tem dado bôas producções artísticas quando applicado a vivendas residenciaes, pittorescas, elegantes e, sobretudo caprichosas” (SÃO PAULO (Estado). Secretaria dos Negócios da Educação e Saúde Pública, 1936, p.63) e continua mostrando a razão pela qual essa arquitetura não seria adequada às escolas a serem construídas pelo Departamento de Obras Públicas:

os prédios de grandes proporções se tornam ridículos quando de architectura ingênua e desproporcionada. A architectura escolar é quasi sempre de grandes proporções. É uma architectura que não admitte symetrias, com o sacrifício da collocação forçada de portas ou janellas. $O$ colonial exige riqueza de ornamentação interna e externa, o que não é admissível num prédio escolar, que deve ser simples, harmonioso e de fácil asseio (SECRETARIA DOS NEGÓCIOS DA EDUCAÇÃO E SAÚDE PÚBLICA, 1936, p.63).

\footnotetext{
${ }^{37}$ Ver capítulo seguinte (Capítulo 5, p. 160).

${ }^{38}$ Autor da Maternidade Gota de Leite de Araraquara. Mais informações sobre o arquiteo: Ficher (2005).
} 
E abre uma exceção que vem bem a calhar, parecendo, mesmo, uma justificativa ao prédio da Escola Nacional de $\operatorname{Agronomia}^{39}$ e às futuras Escolas Práticas de Agricultura: “sómente nas escolas isoladas, perdidas nas fazendas poderíamos adoptalo, fazendo o pittoresco e ingenuo á decoração «luxuosa e freiratica»” (SÃO PAULO (Estado). Secretaria dos Negócios da Educação e Saúde Pública, 1936, p.63). Não obstante a posição de alguns arquitetos, como a de Neves, na Diretoria de Obras Públicas, o neocolonial continuou a ser utilizado, tanto nas escolas rurais como em prédios públicos, como o fóruns e as casas da lavoura (FIGURA 110).

Voltando ao arquiteto Hernani do Val Penteado, a transição entre "estilos" parece ter acontecido durante um tempo significativo de sua carreira, que vai até 1950 , aproximadamente. A partir de fins dos anos de 1940, o arquiteto parece abandonar o neocolonial, passando para uma linguagem modernista, como mostram os seus projetos, inclusive um para a sua própria residência, em São Vicente, na praia do Boqueirão, que data de 1950. Neste projeto, mantém grandes beirais e cachorros aparentes, mas não existe decoração semelhante à do neocolonial (FIGURA 122); já para o Hospital de Guarantã, são projetadas linhas mais simples e retas, porém com beirais, 1954 (FIGURA 123); para a casa da administração da Fazenda Santa Helena, em Pindamonhangaba, que data de 1960, continua utilizando pedras e beirais. É significativo esse projeto, já que a associação entre a arquitetura colonial e o ambiente rural desaparece (FIGURA 124). Finalmente, percebemos a predominância da tendência modernista, numa fase mais tardia da carreira do arquiteto, com um projeto para a Santa Casa de Jaú, também de sua autoria, cuja data, certamente, é posterior a 1950, pois o desenho já segue totalmente os preceitos modernistas, com linhas retas, marquise, terraço-jardim, janelas corridas e jardins de traçado orgânico (FIGURA 125). Apesar disso, percebemos que para conjuntos arquitetônicos neocoloniais o arquiteto daria preferência a seguir essa mesma linha de arquitetura - neocolonial - em prédios adicionais, como o fez na Escola Preparatória de Cadetes de Campinas, mesmo mais de duas décadas depois, em 1970, como vimos. Verificamos, assim, observando a trajetória profissional de Hernani do Val Penteado, que as tendências neocolonial e modernista eram praticadas concomitantemente, por motivos como exigências de uma orientação oficial e/ou opção pessoal, mesmo no interior do Estado de São Paulo, e através dos anos de 1930 e 1940, período que pode ser considerado tardio, com relação ao

\footnotetext{
${ }^{39}$ O projeto para a Escola Nacional de Agronomia foi aprovado pelo presidente Getúlio Vargas em 18 de dezembro de 1948 e a construção foi iniciada no ano seguinte. (Rumbelapager, 2005, p. 94)
} 
lançamento da campanha neocolonial. Certamente, o estudo das trajetórias de outros arquitetos vai nos mostrar uma circunstância semelhante, de complexidade, como já dissemos. Por exemplo, algumas indicações de como a lógica que permitia esse trânsito entre tendências se dava para os arquitetos daquela época, sem que isso fosse percebido por alguns ${ }^{40}$ como atitude contraditória, podem ser notadas na leitura que Lima (2005, p.21 e 22) faz sobre a produção do arquiteto Ângelo Murgel:

de início, aderiu aos princípios difundidos pelo Movimento Moderno na sua vertente germânica, em particular as idéias de racionalização e padronização de Walter Gropius. Ao mesmo tempo, não desprezava outros referenciais, como a visão de Frank Lloyd Wright, no sentido de uma arquitetura adaptada às especificidades locais. Neste sentido, sempre se mostrou contrário a uma arquitetura ou mesmo a um estilo internacionais. (...) a adoção de princípios modernos configurou um processo marcado por contradições, em que as teorias não se evidenciavam plenamente nas suas propostas. A modernidade anunciada, no período em que manteve o seu escritório em Belo Horizonte, deu lugar à tradição, quando da sua transferência para o Rio de Janeiro.

Veremos ainda que, mesmo fora do âmbito oficial, arquitetos e engenheiros vão transitar entre tendências arquitetônicas, demonstrando vários motivos para isso, como adequação à função do edifício, gosto próprio ou do cliente, e modismo.

Procuramos mostrar, neste capítulo, que a arquitetura neocolonial foi apropriada pela esfera oficial e, através dessa produção que, nesse caso, pode ser interpretada como nacionalista, difundiu-se enormemente pelas cidades do interior paulista, estimulando uma produção neocolonial não oficial, da qual trataremos em seguida.

\footnotetext{
${ }^{40}$ Para outros tantos - como Eduardo Kneese de Mello como vimos no capítulo 3 (Rodrigues, 1985) - era inconcebível continuar produzindo qualquer outra linha depois de terem tomado contato com a lógica modernista. Assim, abandonavam o neocolonial como uma fase "vergonhosa" de suas carreiras. Talvez, a complexidade continuasse a se expressar de maneira sutil em alguns projetos, mas a reação primeira era de rejeição, pois não era simples lidar de maneira coerente com tendências tão opostas. Essa é uma questão que demanda estudos mais aprofundados.
} 


\section{Capítulo 5}

\section{APROPRIAÇÃO E RECRIAÇÃO DA ARQUITETURA NEOCOLONIAL NA DIFUSÃO PAULISTA}


A despeito de todas as críticas sofridas, a manifestação arquitetônica neocolonial deu mostras de ter sido muito atraente. Em parte, essa identificação foi devida ao arcabouço ideológico do movimento, que tratava de temas ligados à história, à colônia e à tradição, presentes no repertório da população em geral. Por mais distante que estivesse da arquitetura colonial, a neocolonial, ainda assim, conseguia ser legível em sua intenção de mostrar-se como representante de algo conectado ao passado. E neste sentido, estamos de acordo com a consideração de Rumbelspager (2005, p.110), segundo a qual "a bagagem cultural do indivíduo é o ponto fundamental para a mensagem se fazer entender" e que nos ajuda a compreender que se a arquitetura neocolonial encontrou larga aceitação é porque, de alguma forma, ela "falava" aos seus adeptos, rememorava, neles, algo da sua bagagem cultural. Por esses motivos, entre outros, a arquitetura tradicionalista lançada por Severo, materializada pelos arquitetos que, primeiro, aderiram ao movimento, e utilizada pelo poder público, foi apropriada, recriada, reproduzida, sincretizada e difundida, até aproximadamente 1950, em boa parte do território paulista, e não somente na capital e em Santos, onde estão localizadas as conhecidas obras inaugurais da tendência. Os resultados são os mais diversos e sempre carregam alguma característica ligada, em última instância, à produção neocolonial dos primeiros anos. Tal manifestação, localizada na cidade de São Paulo, foi chamada por D’Alambert (2003, p.146) de “Maneirismo Paulistano", e

pode ser interpretada como uma recriação, e, em alguns casos, como uma apropriação e simplificação da arquitetura «tradicionalista» de Victor Dubugras" e "também equivaleu integralmente ao que o professor Carlos A. C. Lemos chamou de Neocolonial Simplificado (D’ALAMBERT, 2003, p.147).

Nossas pesquisas mostram que no interior paulista houve uma difusão da arquitetura neocolonial num território maior do que era suposto e com grande número de nuances - desde as mais emblemáticas até as mais simplificadas -, contrariando o senso geral, baseado na maior visibilidade da produção paulistana. De certa forma, contribuímos para o alargamento da noção de que manifestações como as que são chamadas "neocolonial simplificado" ou "maneirismo paulistano" tenham sido restritivamente "um fenômeno típico da cidade de São Paulo", pois "até o momento só temos conhecimento da ocorrência de casos esporádicos fora da capital paulista" (D’ALAMBERT, 2003, p.146). Isso significa que muitas pesquisas ainda serão 
necessárias, para termos um conhecimento mais amplo sobre a abrangência e o significado do movimento.

O fenômeno "neocolonial simplificado", identificado por Lemos (1985, p.173189), pressupõe uma hierarquização da produção arquitetônica de tendência neocolonial segundo classes sociais. Lemos (1985), em sua obra “Alvenaria Burguesa”, usou o conceito de classes para interpretar a arquitetura da sociedade paulista, e especialmente paulistana, no início do século XX pois, como ele explica:

Tudo ficou confuso. De repente, um barão de café é guiado às alturas, deixando irmãos e primos vivendo na média abastança e até mesmo na pobreza (...). Paralelamente, o café introduziu outra classe de brancos imigrantes, os quais trataram logo de ajudar o desenvolvimento de outra atividade: a indústria e, a seguir, deram oportunidade ao alto comércio (LEMOS, 1985, p.8).

Nessa altura, surge também a arquitetura industrial e operária. Assim, a variedade arquitetônica, para efeitos de pesquisa, foi dividida em classes correspondentes, classificação pela qual Lemos (1985, p.7) se desculpa, pois, segundo ele, em sua disciplina, que está relacionada a muitas outras, não pode seguir o rigor do “«sociologuês» dos especialistas”. E, assim, alguns trabalhos feitos sob sua orientação ${ }^{1}$ também se pautam na classificação da produção arquitetônica em função de sua correspondente classe social.

Quando decidimos abordar a questão da difusão da arquitetura neocolonial, a hipótese era a de que obras de autoria erudita teriam ajudado a divulgar a linguagem e reproduzi-la anonimamente, ou seja, difusão e obra de autoria desconhecida eram idéias associadas. Isso se mostrou uma meia verdade, já que, na maior parte dos casos, descobrimos os nomes dos autores que trabalharam na difusão do neocolonial, alguns até reconhecidos arquitetos da capital. Eram, assim, desconhecidos, mas não anônimos.

Outra hipótese era a de que obras eruditas eram uma exclusividade da classe social dominante. Mais coerente é pensar que isso depende do que chamamos "obra erudita". Seria aquela realizada pelo profissional que possui "erudição"2? Erudito seria

\footnotetext{
${ }^{1}$ Por exemplo: Bortolucci, Maria Ângela P. C. S. (1991). Moradias Urbanas Construídas em São Carlos no Período Cafeeiro. Tese (Doutorado) FAUUSP; D’Alambert, Clara Correia (2003). Manifestações da Arquitetura Residencial Paulista entre as Grandes Guerras. Tese (Doutorado) FAUUSP.

2 "Instrução, conhecimento ou cultura variada, adquiridos especialmente por meio da leitura". INSTITUTO ANTÔNIO HOUAISS DE LEXICOGRAFIA (2001).
} 
o profissional diplomado? Assumimos que sim, mas não excluímos o profissional autodidata, a quem se reconhece determinado nível de erudição e, portanto, o título de engenheiro ou arquiteto (embora não tenhamos podido identificar esses casos especiais). Assim, "obra erudita" está ligada à autoria da mesma, enquanto o "padrão da obra" está ligado ao conceito de classes sociais. Esse critério, baseado na formação do autor e no padrão da obra, foge ao utilizado primeiramente por Lemos (1985), e nos mostra que profissionais diplomados também atuaram na difusão neocolonial de baixo padrão além de abrir a possibilidade de que uma obra emblemática da tendência possa ter sido realizada por profissionais da construção civil - construtores licenciados, mestres-deobras, artesãos e outros - que detinham o saber prático. Dessa maneira, verificamos que a simplificação e a fuga aos cânones do movimento, também foram praticadas por eruditos; e, por conseqüência, a produção vazia de conteúdo ideológico não deve ser associada unicamente a profissionais supostamente sem formação (TABELA 1).

Cabe também, agora, uma explicação sobre o que entendemos por difusão da arquitetura neocolonial. Voltando rapidamente a Lemos (1985), parece-nos que seu trabalho considera as obras neocoloniais eruditas como aquelas que foram pioneiras, e as que fazem parte do universo da difusão, como as populares. Aqui, procuramos considerar também as emblemáticas, cuja força de influência depende do contexto onde se encontram. Como nossa região de estudo está fora dos núcleos onde surgiram a campanha e a arquitetura neocolonial, consideramos obras eruditas e não eruditas, de alto, médio e baixo padrões, como difusão. Nesse amplo universo, desde os exemplares mais elaborados até os mais simplificados foram considerados, contanto que neles existisse uma "intenção plástica" identificável, um "querer ser", expresso através do emprego de "elementos conhecidos originados de um único vocabulário estilístico erudito" e também da mistura de elementos de vários vocabulários, que expressaria um sincretismo de "estilos" (D’ALAMBERT, 2003, p.145). Essa nossa definição se relaciona ao que Paulo Santos (1981, p.94-95), chamou “constantes de sensibilidade nacional", que se traduz como "um não sei quê de indefinivelmente brasileiro a provar que mais do que a forma o que importa à tradição é o espírito". Verificamos que a ligação entre as duas esferas - matéria/espírito - expressou-se através de uma linguagem formal, através do "querer ser" que, bem ou mal, ajudou a conformar certo gosto arquitetônico no interior paulista, ligado ao movimento neocolonial. 
Na seqüência, apresentamos uma amostra da produção neocolonial difundida pelo interior paulista, agrupada por natureza da obra, ou seja, conforme fossem institucionais ou particulares. Identificamos engenheiros, arquitetos e construtores responsáveis por projetos nos quais pode ser identificada a influência do movimento neocolonial. Identificamos também datas dos projetos e proprietários. Com esses dados, verificamos, por exemplo, que a produção levantada é tardia, ocorrendo com maior freqüência a partir de 1930 e avançando pela década de 1950, em todas as cidades pesquisadas. Verificamos que os mesmos engenheiros, arquitetos e construtores desenvolviam, concomitantemente, projetos de várias linhas arquitetônicas, ligados tanto ao neocolonial, como ao Art Déco. Empregavam também misturas de características de várias tendências, num mesmo edifício. Porém, observamos que a partir dos anos 30 o distanciamento da linguagem eclética é um fato. Notamos também que, ao mesmo tempo em que certas características se repetem, outras são absolutamente únicas, possivelmente devido a fatores como o domínio e assimilação da linguagem pela mão-de-obra construtora, que poderia introduzir adaptações, alterações e a própria manifestação de sua expressividade em detalhes, soluções e ornamentações.

\subsection{Obras Institucionais}

Encontramos, no interior paulista, muitas obras institucionais cuja arquitetura segue os preceitos neocoloniais. Foi-nos possível também identificar os autores de algumas dessas obras. Esses exemplares, juntamente com os exemplares oficiais, demonstram a presença, na região de nossa pesquisa, da interpretação erudita do movimento neocolonial funcionando como fator de difusão, mas não só. São, também, uma evidência de que fora da cidade de São Paulo não proliferou apenas o "neocolonial simplificado" (Lemos, 1985) ou o neocolonial oficial, mas também floresceu um conjunto de obras institucionais, como seminários, igrejas, hospitais, orfanatos e clubes, representativos do movimento lançado por Ricardo Severo e de um gosto que se alastrou por diversos setores sociais.

Procuramos verificar, nessa produção institucional, se o conteúdo ideológico do movimento neocolonial ainda existe, se foi modificado ou se esvaziou-se por completo. Como tratamos, nessa parte do trabalho, de uma arquitetura religiosa, a suposição inicial era a de que existe um conteúdo ideológico, na opção pelo neocolonial, talvez já modificado, em relação àquele lançado por Severo, mas um conteúdo ligado, antes, à rememoração de períodos importantes para a Igreja, no que diz respeito à conquista dos 
fiéis, e nos quais a arquitetura foi utilizada como recurso de persuasão. Evidentemente, estamos aqui nos referindo à arquitetura barroca religiosa, que floresceu dentro das "fronteiras criadas por esse grande movimento eclesiástico pós-tridentino que se chama (...) Contra-Reforma” (CARPEAUAX, 1990, p.8-9). Segundo Carpeuax (1990, p.8-9), "as fronteiras geográficas do estilo barroco parecem coincidir com as fronteiras das religiões no século XVII” e de acordo com Pevsner (1982, p.273)

nem a França nem a Inglaterra (e tampouco o Norte da Alemanha, Holanda, Dinamarca e Escandinávia) jamais aceitaram o barroco com todas as suas implicações. Seu mundo - e, em certo sentido, o mundo moderno - pertence ao protestantismo.

O Brasil, como extensão do mundo católico, desenvolveu também a arquitetura barroca. Assim, podemos constatar a força da relação barroco-igreja e supor que, mesmo no século XX, a arquitetura religiosa que evoque o barroco está, antes, referindo-se a um período muito significativo da Igreja, mais do que a um modo de expressão que pretenda recuperar as raízes tradicionais ou culturais do país. E, portanto, mais uma vez, podemos considerar que a difusão da arquitetura neocolonial, na esfera religiosa, foi motivada por idéias ligadas ao passado da própria Igreja, no que está embutido um conceito básico do movimento lançado por Severo, a rememoração do passado. Acreditamos que referências diversas - do barroco europeu, do barroco brasileiro, da arquitetura jesuítica e de outras ordens - confluíram para o florescimento da arquitetura religiosa neocolonial nas primeiras décadas do século XX. Assim, temos um conteúdo ideológico transformado, mas associado ao original, que nos impede de considerar a difusão do neocolonial, nesse âmbito religioso, apenas como modismo vazio. De certa forma, instituições assistenciais, como orfanatos e hospitais, têm uma relação próxima com a religião, sendo plausível admitir que, nesses casos, o emprego de uma linguagem neocolonial para seus prédios procurasse, além de outras motivações, fornecer elementos de linguagem passíveis de serem interpretados como "pontes" entre seus usuários e a Igreja, a fé, a esperança. Por último, o emprego da arquitetura neocolonial em edifícios institucionais recreativos e de lazer pode estar associado às idéias de pertencimento e de afirmação de uma identidade, que são idéias mais próximas ao conteúdo ideológico original do movimento neocolonial. Reconhecemos que a difusão da arquitetura neocolonial na esfera institucional foi devida às suas próprias motivações - como a forte ligação com períodos significativos de sua história, 
em que uma determinada tendência arquitetônica predominou - mas, ao mesmo tempo, foi devida ao próprio movimento neocolonial, que incentivou um modo de pensar e o uso de um grande espectro de características referentes ao passado arquitetônico. Acreditamos, até, que isso se tenha dado, em maior ou menor grau, nas várias esferas estudadas, como pretendemos mostrar neste trabalho.

\section{Seminários Franciscanos}

Devido à pesquisa realizada sobre a Escola Prática de Agricultura "Paulo de Lima Correia”, de Guaratinguetá (FIGURAS 84 a 89), verificamos a existência, nessa cidade, de um seminário franciscano cuja arquitetura exibe uma linguagem neocolonial muito expressiva. Já através de nossa pesquisa em Bauru e também em Jaú, tivemos notícia de um seminário, pertencente também à Ordem Franciscana, localizado na cidade de Agudos, a $25 \mathrm{~km}$ de Bauru; uma rápida pesquisa sobre esse último confirmou que, também ele, fora construído segundo a tendência neocolonial e, assim, concluímos que ambos os Seminários, encontrados em Guaratinguetá e em Agudos, poderiam ter grande significado, no contexto que estamos abordando, o da produção neocolonial no interior paulista. Portanto, incluímos as cidades onde estão localizados, no programa de pesquisa que, a princípio, não contemplava essa, por assim dizer, surpresa. Encontramos informações em visita aos próprios seminários e, principalmente, na Sede Provincial da Ordem Franciscana, em São Paulo, onde está localizado o arquivo de documentos da ordem.

O Seminário "Frei Galvão", de Guaratinguetá, começou a ser construído em 1941 - e levou três anos para ser finalizado (SANSÃO, 1961, p.50) - para atender os interessados no estudo religioso, não só os da região, mas também os de outros estados (FIGURA 126). Situado no perímetro urbano e a três quilômetros do centro da cidade, no bairro de São Bento,

o terreno está com as frentes para a antiga estrada São Paulo-Rio, e seus fundos alcançam o rio Paraíba; de permeio à chácara passa e Estrada de Ferro Central do Brasil. A área é de 6 alqueires, num total de 144.000 metros quadrados (SANSÃO, 1961, p.60).

A área prevista para o prédio é de considerável capacidade, contando com uma 
área de construção (...) de 3.250 metros quadrados, incluindo-se o claustro e os dois pátios internos do Seminário. Estando os fundamentos do edifício num terreno em declive, resultou ficar parte do prédio com um só andar e outra com três (SANSÃO, 1961, p.50) (FIGURA 127).

O programa previa cinco amplas salas para estudos, aulas, leitura, música e recreio, capela, enfermaria, dormitórios, refeitório, reitoria, prefeitura, galerias, corredores, dependências sanitárias, lavatórios e lava-pés, ocupando dois terços da edificação, sendo o terço faltante ocupado pelo convento, com celas, claustro, biblioteca e outras acomodações necessárias (FIGURAS 128 a 130). Seu projeto original, provavelmente da autoria de certo "Dr. Arantes", sofreu modificações, em planta, no ato da construção, realizadas pelo construtor Frei Edgar (SANSÃO, 1961, p.50). Aproximadamente 15 anos depois da construção do seminário, mas antes de 1961, o edifício passou por uma reforma, tendo sido realizada

grande melhoria na cozinha e no refeitório dos padres, bem como no dos alunos. Os ladrilhos do piso foram substituídos por cerâmica, removidas as mesas de marmorite e colocadas treze mesas forradas de fórmica. Remodelaram-se os sanitários de tôda a casa, fazendo-se outro tanto com os lavatórios, lava-pés e chuveiros com capacidade para 14 duchas (SANSÃO, 1961, p.51).

Uma descrição rápida registra a cor das paredes externas e das janelas, por volta de 1960 , e a vista que se tem a partir da rodovia:

O telhado do edifício parece emergir do verdor acariciante das folhagens, enquanto a ramaria do arvoredo procura abraçar as paredes côr de ocre (...). De longe, ao passar pela via Dutra, o caminhoneiro se defronta (...) com a fachada do Seminário. As três janelas de frente, de ombreiras pintadas de branco, lembram olhares sorrindo de aceno para uma visita (SANSÃO, 1961, p.53).

É recorrente, nos registros da revista Vida Franciscana, a referência ao prédio do seminário como um lugar aconchegante e familiar, onde está presente certa ambiência que atrai e conforta as pessoas. Nesse caso, é possível que a evocação do barroco religioso, plasmada no corpo do prédio, falasse à memória - ou à bagagem cultural - das pessoas que ali procuravam refúgio, segundo comentário do autor de uma

\footnotetext{
${ }^{3}$ Não conseguimos identificar quem foi o Dr. Arantes mencionado no documento escrito por SANSÃO, 1961.
} 
reportagem na referida revista: "na alma de muita gente calha bem essa linguagem muda do prédio" (SANSÃO, 1961, p.53). Talvez tenha sido esse um dos motivos pelos quais a linguagem neocolonial foi escolhida para esse seminário e para o de Agudos. Verificamos que é alta a ocorrência da arquitetura neocolonial em edifícios religiosos, especialmente num período em que era muito comum lançar mão da linguagem eclética - na versão neogótica - para a aplicação em igrejas. Pareceu-nos que a referência à arquitetura barroca seria algo inerente a tais prédios, uma vez que a ela foi majoritariamente religiosa. Porém, nos questionamos sobre a possibilidade de essa predileção ter sido, também, devida a uma nostalgia da arquitetura jesuítica, ou seja, de um período muito significativo da presença da Igreja no Brasil. Devemos recordar também que Severo, em sua conferência de 1914, ratifica a arquitetura jesuítica como uma das primeiras arquiteturas tradicionais a se estabelecerem no Brasil:

os jesuítas missionários, que se espalháram pelo vasto domínio colonial portuguez se devem os principaes edifícios religiosos que se encontram nas possessões da Índia, da África e do Brasil (SEVERO, 1914, p.50)

e, continua citando Debret: o autor

referindo-se á obras dos jesuítas, diz que elles propagaram no Brasil a architectura portuguesa com seus caractéres e estylo. Há uma nota de Debret que pretendo frisar, a qual é, referindo-se a esses architectos «que elles respeitaram judiciosamente em suas obras as exigências do clima e dos materiaes próprios do país» (SEVERO, 1914, p.51).

Lembremos ainda Mariano Filho, em seu mandamento número III:

O espírito clássico... A ordem implantada pelos Jesuitas entre nós, a toscana, é a única que convém ás composições do estylo neo-colonial. Os seus elementos eminentemente latinos são, a um tempo, fortes, simples e decorativos (MARIANO FILHO ${ }^{4}, 1923$ apud Amaral, 1994, p.18)

Além disso, uma pergunta se coloca: por quais motivos o chamado "estilo missões" ou "californiano" é associado somente às evocações da arquitetura missionária a que emergiu na Califórnia e no México? Vamos retomar essa questão adiante, na análise do partido dos seminários aqui apresentados.

\footnotetext{
${ }^{4}$ MARIANO FILHO, José. Os Dez Mandamentos do Estylo Neo-Colonial - Revista Architectura no Brasil. 1923 M.4 (p.161/63)
} 
Devemos recordar que, em 1940, já estava em plena construção a Escola Nacional de Agronomia (FIGURA 46), situada na mesma estrada Rio-São Paulo, sendo provável que a arquitetura do seminário também tenha recebido influência da arquitetura dessa escola. Levantamos a hipótese de a obra ter recebido influência, também, de uma das unidades das Escolas Práticas de Agricultura $^{5}$ situada em Guaratinguetá (FIGURAS 84 a 89), porém esta começou a ser construída em 1942, depois da inauguração do seminário, em 01 de Março de $1942^{6}$.

A possibilidade de influências das idéias sobre arquitetura neocolonial, que circulavam nos órgãos públicos responsáveis por obras oficiais, sobre a arquitetura do Seminário Seráfico "Frei Galvão", é fortalecida quando verificamos que existiu um contato dos religiosos com profissionais da construção que atuaram nesses órgãos. Esse contato ter-se-ia dado através do arquiteto Joaquim Bezerra da Silva, que foi "funcionário da Secretaria de Agricultura e autor de vários projetos para Escolas Agrícolas do Estado" (PRIM, 1975, p.7), e esteve também envolvido no desenvolvimento do projeto do Seminário Seráfico "Frei Galvão", provavelmente, na citada reforma anterior a 1961, tal como comprovam duas pranchas de projeto para instalações de chuveiros e lava-pés, assinadas pelo arquiteto. Nos dados que levantamos, sobre as Escolas Práticas de Agricultura, não verificamos nenhuma referência ao arquiteto acima citado, mas é provável que as "Escolas Agrícolas do Estado" sejam as Escolas Práticas de Agricultura. A despeito da imprecisão das informações, o que se verifica, sem dúvida, é que no início da década de 1940, o arquiteto Joaquim Bezerra da Silva, que trabalhava para um órgão público, projetou também obras particulares institucionais de linguagem neocolonial no interior do Estado de São Paulo.

A relação profissional do arquiteto Joaquim Bezerra da Silva com a Ordem Franciscana parece ter sido profícua, pois ele foi também o autor do projeto para o Seminário Santo Antonio, em Agudos - SP, embora na perspectiva, por ele assinada, o nome conste como Seminário de São Francisco, certamente, um equívoco (FIGURA 132). Segundo Agudos... (1999), por volta de 1940 era grande a demanda pelos ensinamentos da Ordem, devido ao grande número de vocações no Brasil e a

\footnotetext{
${ }^{5}$ O decreto que cria as Escolas Práticas de Agricultura é do dia 03/06/1942, como verificado no capítulo anterior.

${ }^{6}$ Disponível em: http://www.franciscanos.org.br/fraternidades/casas/guara_post/historia.php Acesso em: 17/01/2008.
} 
impossibilidade de se contar com o "Colégio Missionário de vocações para o Brasil, em Garnstock, na Bélgica [que] foi fechado" “durante a II guerra Mundial em 1943”. Diante dessa necessidade, em 1943, resolveram transferir o Seminário - e ampliar suas dependências - para a cidade de Piraí do Sul-PR, onde "Frei Edgar Loers, que construíra o Seminário de Guaratinguetá, foi escolhido para enfrentar o projeto" (PRIM, 1975, p.7). Depois de iniciadas, verificou-se que nem o terreno nem o clima eram ideais para as obras, que foram, então, paralisadas, e o local do Seminário novamente transferido. Em Agudos-SP, os freis Heliodoro Mueller e Damaso Venker encontraram condições propícias, como o entusiasmo do Padre João Batista de Aquino - que era também o prefeito da cidade, naqueles anos -, a sede das Irmãs Franciscanas de Siessen, e os atributos do local. Um frei registra a boa localização em que estaria o Seminário, descrevendo que

em 10 minutos andando a pé atingimos a estação de Taperão que margeia justo o terreno da Fazenda S. Antônio, donde, em bitola estreita, o trem nos leva, dentro de 60 minutos e fumaça, até Pederneiras, onde baldeamos para o elétrico da Companhia Paulista (WILTGEN, 1950, p.47).

A proprietária da fazenda Santo Antonio,

viúva Maria Ornellas de Barros, (...) queria vendê-la. O terreno oferecia lucro de café (...), possibilidades de criação e pomares, tinha água, luz (na fazenda havia casa de força), terreno plano para construção (...). Fechou-se o negócio e a fazenda foi comprada em duas prestações de Cr\$ 2.000.000,00, no ano de 1945 (PRIM, 1975, p.7).

Frei Ruffino Ueter foi o responsável por acompanhar a construção, Frei Heliodoro foi quem procurou o arquiteto Joaquim Bezerra da Silva para realizar o projeto e o Sr. Armando Carrara foi contratado como mestre-de-obras, tendo, por isso, se mudado para Agudos. As obras começaram em Agosto de 1947 (WILTGEN, 1950, p.46) e, durante os dias 19 e 20 de Fevereiro de 1950, deram-se as cerimônias de inauguração do Seminário Santo Antonio, contando com a presença de autoridades da 
cidade e também a do arquiteto responsável pelo projeto, Joaquim Bezerra da Silva (AGUDOS..., 1999) (FIGURAS 133 e 134).

$\mathrm{Na}$ data da inauguração, somente um terço dos $31.500 \mathrm{~m} 2$ de área construída estava pronto; projeto bastante audacioso, se considerarmos que é quase dez vezes maior que o Seminário construído em Guarantinguetá, e com capacidade para 300 alunos (PRIM, 1975, p.13). Em 1952, começou-se a construir o campo de esportes “dentro de uma planta pré-estabelecida, em harmonia com parques e jardins" (PRIM, 1975, p.10). Somente em 1955 se deu a benção da Igreja “adiada meia dúzia de vezes, porque o mármore parecia nunca mais chegar da Itália e o cimento era difícil de se encontrar"; em 1959, o Frei Friedrich Scherle começou a construir o órgão de tubos que ainda se encontra na Igreja (FIGURA 137) e que foi inaugurado em 8 de Dezembro de 1961. Em 1960 a piscina estava pronta (PRIM, 1975, p.10) (FIGURAS 134 a 136).

É preciso notar também que, próximo dali, em Bauru, no ano em que as terras para a instalação do Seminário Santo Antonio foram compradas, 1945, a Escola Prática de Agricultura "Prof. Gustavo Capanema" (FIGURA 70 e 71), estava sendo inaugurada. Uma obra neocolonial e oficial, construída pela Diretoria de Obras Públicas de São Paulo, tal como em Guaratinguetá. É possível que a presença de funcionários (engenheiros-arquitetos entre outros), nas cidades destinadas a receber obras oficiais, tenha colaborado para a difusão da arquitetura neocolonial, pois talvez esses profissionais tenham atuado em outras obras não oficiais, como foi o caso do arquiteto Joaquim Bezerra da Silva.

Da mesma maneira que as Escolas Práticas de Agricultura, a construção desses seminários significou a inserção de grandes instalações que, não chegando a ser urbanas, exigiram um plano de organização do espaço, de fornecimento de materiais e mão-de-obra, de cumprimento de etapas de trabalho, de transportes, de abastecimento de energia e água, de disponibilidade e geração de recursos, entre outras, que só teriam sido possíveis numa época em que a demanda de alunos justificasse tamanhos esforços e empenhos. Esses esforços ficaram registrados em episódios como o que aconteceu em "maio de 1953 [quando] perfurou-se o poço artesiano, porque a água vinda das nascentes atrás da fazenda se tornara insuficiente. Só em janeiro de 1954 a água jorrou de mais de 100 metros de profundidade à razão de 700 litros por hora” (PRIM, 1975, p.10). Desde a década de 1940, quando os seminários de Guaratinguetá e de Agudos foram construídos, até meados da década de 1960, a procura pelos estudos nessas 
instituições era grande. Por exemplo, a capacidade do Seminário "Santo Antonio", de Agudos, estava completa:

em 1964 tínhamos 333 seminaristas (...) em 1966 o seminário bateu o recorde em número de seminaristas: 355 no mês de fevereiro ao serem abertas as aulas (...). Fomos obrigados a soluções de emergência nos dormitórios, na igreja, nas salas de aula (PRIM, 1975, p.13).

Mas, na mesma década de 1960, começaram a ocorrer transformações na sociedade em geral, e mesmo na própria Igreja, que levaram a uma inadequação dos moldes em que estavam assentados os seminários, até então. Assim foi retratada essa fase de transformação: "ninguém mais duvida de que a década de 60 foram os anos de transição na Igreja inteira. De 1962 a 1965 se realizou o Concílio do Vaticano II. Depois vieram longas e continuadas discussões em torno dos documentos conciliares" (PRIM, 1975, p.15). Associada a essa mudança interna, os freis acreditavam que a influência do mundo exterior também ajudara a desencadear a falta de interesse que se anunciava:

os alunos passaram primeiro a ter férias em casa de dois em dois anos, depois todo ano e, agora, até mesmo durante o mês de julho. Os padres orientadores tiveram que fechar os olhos aos cabelos compridos e elogiar as vestes coloridas dos adolescentes (PRIM, 1975, p.17).

Foram então tentadas diferentes estratégias para evitar uma evasão drástica do número de "vocações":

por esse tempo também se falou muito que a melhor vocação seria a adulta, isto é, aquela que surgisse depois do homem maduro, já profissionalizado e experimentado no mundo (...). Nossa Província transformou o seminário de Guaratinguetá e o reservou para as chamadas «vocações adultas»(PRIM, 1975, p.18). 
O resultado desse processo foi o esvaziamento de alunos e, em alguns casos, o fechamento de instituições semelhantes. Na década de 1970, o seminário de Agudos luta para não fechar as portas, pois, além da crise, não se tornou auto-suficiente, como foi previsto quando da escolha do local para sua implantação. Atualmente, o seminário é alugado para eventos tais como congressos e outros encontros, o que ajuda na manutenção do mesmo ${ }^{7}$. Assim, um período de decadência sobreveio a essas instituições franciscanas, tal como aconteceu às Escolas Práticas de Agricultura, obrigando-as a fecharem as portas ou se adaptarem.

Por outro lado, voltando à questão da influência, sobre esses edifícios religiosos, da arquitetura das missões jesuíticas não necessariamente californianas, é plausível que o resultado arquitetônico a que se chegou nesses seminários não tenha sido fruto apenas da proximidade - espacial e temporal - das Escolas Práticas de Agricultura e da Escola Nacional de Agronomia. O que nos leva a considerar tal aspecto são dois motivos. O primeiro é a procedência do seminário de Agudos. Essa instituição resultou de sucessivas transferências que vêm do Sul do país em direção ao Estado de São Paulo. O processo se inicia em Blumenau, passa pela construção de um seminário em Rio Negro, na fronteira do Paraná com Santa Catarina, depois por Piraí do Sul, no Paraná e, finalmente, em Agudos, no interior paulista (PRIM, 1975, p.5-7). Assim, originalmente, os franciscanos estiveram bastante próximos às reduções missionárias do Sul, o que poderia tê-los também inspirado na construção de suas instalações do início do século XX. O segundo e principal motivo é o partido arquitetônico e a implantação adotada para os referidos prédios. Observando a perspectiva de autoria de Joaquim Bezerra da Silva para o Seminário "Santo Antonio", de Agudos, e uma foto aérea do Seminário "Frei Galvão", de Guaratinguetá, podemos verificar que ambas as edificações se constituem de um corpo principal, onde se situa a igreja, e dois claustros laterais (FIGURA 132 e 127). No caso do primeiro, observamos também a existência de alas que estruturam os espaços e, do segundo, edificações complementares independentes. Afora esses anexos, o partido principal é o mesmo que o utilizado em missões jesuíticas do Sul do país: "fórmula repetida no mínimo em trinta casos, junto aos Guaranis e dez, entre os Chiquitanos (...) esta tipologia é plenamente reconhecível como a do espaço missioneiro” (CUSTÓDIO, 2006, p.21). Essa fórmula é descrita como

\footnotetext{
7 Informação concedida pelo Frei Rafael Spricigo em visita ao Seminário "Santo Antonio" em 04/04/2007.
} 
uma grande estrutura com a igreja ao centro, e de um lado o cemitério e do outro, o claustro e as oficinas e depósitos ao redor de dois pátios. No primeiro pátio ficava a residência dos padres. Atrás desse bloco e cercada por um muro de pedra, localizava-se a quinta dos padres, com pomar, horta e jardim. Era uma estrutura fechada, organizada sobre um mesmo alinhamento frontal, com poucos e definidos acessos em relação à praça e ao restante do espaço público. Apenas o pórtico da igreja avançava sobre a praça e se sobressaia em relação ao alinhamento do conjunto. A enorme igreja era o principal marco morfológico e funcional da redução, constituindo-se no coração da mesma (CUSTÓDIO, 2006, p.21) (FIGURA 139).

Excetuando-se apenas alguns espaços, como a localização do cemitério, do pomar e horta - cuja localização não nos foi possível definir - e a inexistência de uma grande praça frontal - no caso dos seminários, substituída por espaços amplos de chegada, o que inclui vias de acesso e ajardinamento - o partido, no qual a igreja é o elemento mais importante, e os claustros definidores de espaços internos de acesso controlado, é muito semelhante na constituição dos seminários franciscanos. Especialmente as fachadas das igrejas, que avançam com relação ao restante do corpo construído, é um recurso da arquitetura jesuítica que reaparece nos colégios franciscanos de Guaratinguetá e Agudos. Essa característica aparece também, como vimos, nos prédios da Escola Nacional de Agronomia (FIGURA 46) e das Escolas Práticas de Agricultura (FIGURAS 70, 82, 86, 94, 106), mas nesses casos não existem os claustros, apenas alas que partem dos corpos principais. No caso da primeira, podemos considerar a influência da arquitetura das missões da Ordem Jesuíta, característica já observada por Rumbelapager (2005, p.102):

todo o prédio envolve um pátio interno central (...) este pátio é circundado por galerias que funcionam como circulação do edifício - em arcos plenos ritmados, o que faz lembrar os antigos claustros dos colégios e conventos jesuítas. 
Um detalhe que podemos observar, no seminário de Agudos, é que ele não segue exatamente a perspectiva de Joaquim Bezerra da Silva. Em uma foto aérea, podemos ver que as alas do prédio construído se estendem à esquerda da igreja, enquanto no desenho as alas estão à direita e não formam pátios fechados como vemos na foto (FIGURA 131 e 132). Em contrapartida, a linguagem arquitetônica refere-se, antes, à barroca, do que à das missões. A principal referência para a linguagem arquitetônica das reduções jesuíticas é a Igreja de Jesus, em Roma, que teve parte do projeto realizado por Vignola em fins do século XVI, e fachada construída por Giacomo della Porta, no mesmo período (CUSTÓDIO, 2006, p.20) (FIGURA 139). A filiação da arquitetura jesuítica a essa igreja italiana pode ser percebida em características da linguagem maneirista, especialmente nos frontões triangulares, que contrastam com os frontões curvos barrocos.

A fachada principal do Seminário "Frei Galvão", de Guaratinguetá, é simétrica, de dois pavimentos, e composta pelo já citado avanço do corpo central que corresponde à entrada da igreja e à sua fachada. Essa fachada é imponente e apresenta um grande frontão abatido e tripartido, formado por pequenas volutas e cimalha na porção mais alta; a decoração contempla coruchéus nos lados do frontão e rusticação nos cunhais. Abaixo do frontão, três janelas de vergas retas e decoradas com molduras, volutas e cimalhas finalizadas por telhas capa e canal. Abaixo, a porta principal da igreja, larga e de arco abatido, também com cimalha e telhas, e quadro com volutas; duas janelas laterais completam o ritmo da fachada. A cada lado desse corpo central, corre uma galeria de apenas um pavimento e três arcos plenos, sendo que a da direita dá acesso, por uma pequena escada, à entrada do seminário. Fileiras de janelas de vergas retas e sem decoração seguem pelos corpos laterais que compõem a fachada. Em cada extremidade apresenta num volume em destaque, de apenas um pavimento, que também é decorado por pequenos frontões à semelhança do frontal principal. Abaixo de um dos volumes está uma janela, devido à altura que se encontra do piso, e, do outro, uma porta. Ambas as aberturas são encimadas por cimalhas decoradas por telhas capa e canal (FIGURA 128 a 130).

O Seminário "Santo Antonio", em Agudos, é diferente, quanto às características de fachada, do Seminário "Frei Galvão", embora alguns aspectos sejam semelhantes, como a simetria, o avanço do corpo central em relação ao alinhamento, e o partido, como já mencionado. As alas laterais da fachada principal são de dois pavimentos, que 
ficam baixos em ralação à altura da fachada da igreja. Esta é composta por duas torres de bases quadradas e encimadas por cúpulas de cebola. São mais altas que o frontão central e conferem a essa fachada uma horizontalidade acentuada, ainda, pela marcação dos cunhais e pelas janelas alongadas (FIGURA 135). Trata-se uma característica que remete, de certa forma, à arquitetura de inspiração maneirista das missões jesuítas, porém, "a maior parte das igrejas missioneiras possuía apenas uma torre ou campanário, que se localizava independentemente no lado oposto ao batistério" (CUSTÓDIO, 2006, p.16). O frontão curvo tripartido possui cimalhas e volutas e um painel de azulejos no centro. Abaixo, uma porta-balcão de arco abatido com portal de cimalha interrompida, onde foi aplicada uma cártula de rolos e uma pequena abertura com curvas; possui sacada e guarda-corpo com balaústres. Nas laterais, duas janelas de arco abatido e quadros decorados. Ao nível do chão, três arcos plenos dão acesso à porta de entrada da igreja. As alas laterais apresentam duas seqüências de janelas de vergas retas no primeiro e segundo pisos. A não ser pelas torres laterais e os três arcos de entrada, encimados pelo frontão, é semelhante à tipologia destinada às Escolas Práticas de Agricultura de Bauru e Ribeirão Preto (FIGURA 70 e 81). Tal combinação de elementos de linguagem é recorrente na arquitetura neocolonial de toda a América Latina, como vemos em Amaral (1994) (FIGURA 140). As fachadas dos dois seminários citados também evocam a arquitetura do Convento Santo Antonio, localizado no Largo da carioca, no Rio de Janeiro, construído entre 1748 e $1780^{8}$ (FIGURA 141). O Mosteiro da Luz, em São Paulo, que tem ligações com o seminário de Guaratinguetá, pois foi erguido em fins do século XVIII e inaugurado em 1774 (TOLEDO, 2007, p.49) pelo frei que deu nome à instituição do Vale do Paraíba, é mais uma possível referência inspiradora para edifícios franciscanos construídos no início do século XX (FIGURA 142). Mesmo o Convento de Nossa Senhora do Amparo ${ }^{9}$, da Ordem Franciscana, localizado em São Sebastião, fundado no século XVII e tombado pelo CONDEPHAAT, pode ter sido referência para edificações posteriores, como veremos a seguir (FIGURA 143). E, certamente, se continuássemos a observar esse aspecto, outros edifícios religiosos do período colonial poderiam surgir para reforçar a idéia de que foram recorrentemente utilizados como inspiração.

8 Mais informações sobre o Convento "Santo Antonio" estão disponíveis em: http://www.franciscanos.org.br/noticias/noticias_especiais/conventorio_08/ Acesso em: 14/04/2007.

9 Disponível em: http://www.franciscanos.org.br/fraternidades/casas/saosebastiao/historia.php Acesso em: 24/06/2007. 
Sobre os sistemas construtivos e materiais utilizados na construção dos seminários, temos algumas indicações, incluindo algumas fotos do período da construção do seminário de Agudos. Alvenaria de tijolos, madeira e telhas de barro tipo capa e canal nas coberturas, constituem o sistema principal dos prédios (FIGURA 133). Nos acabamentos, encontramos grande variedade de materiais. Nos pisos interiores, cerâmica sextavada, nas cores vermelha e preta, e assoalhos de madeira (FIGURAS 136). Nos pisos das igrejas, ladrilhos hidráulicos, granito e mármore (FIGURAS 137). Nos pisos exteriores, cerâmicas, pedras e mosaico português (FIGURAS 135). No Seminário "Frei Galvão", encontramos janelas guilhotina de madeira, com gradis de ferro decorado na fachada principal; outras, na igreja, basculantes de ferro e com vidros pintados, e um vitral colorido com motivos que lembram as volutas barrocas; portas de madeira (FIGURA 126). A igreja foi reformada e o forro original substituído por um de PVC, mas manteve os pisos e bancos também em madeira (FIGURA 130). No Seminário "Santo Antonio" foram usadas portas de perfis de ferro decorativos fechadas com vidros, e também portas de madeira, sendo a do salão nobre decorada com gradis de ferro (FIGURA 136). Algumas bandeiras de portas têm decoração semelhante às bandeiras encontradas na Escola Prática de Agricultura de Bauru. Na igreja, janelas com vidros coloridos; nas alas, janelas de madeira tipo veneziana, inclusive nas torres da igreja (FIGURA 137 e 135). No seminário de Guaratinguetá não encontramos painéis de azulejos. No de Agudos, por outro lado, encontramos, no alto do primeiro patamar da escada do Salão Nobre, um painel decorativo de azulejos azuis e brancos, que fazem uma grande moldura para uma imagem de Santo Antonio, em madeira, pousada sobre uma base sustentada por uma mísula com volutas (FIGURA 138). Esse painel, que mostra sete cenas da vida do santo, data de 13 de Junho de 1954. Foi produzido no Liceu de Artes e Ofícios de São Paulo, segundo o desenho do professor Alfredo Oliani $^{10}$, e executado por Carlos Mancini (FIGURA 138). Existe ainda, nesse seminário, o painel de azulejos do frontão da igreja, igualmente nas cores azul e branco, mostrando uma cena da santa Imaculada Conceição, a quem "a Igreja foi dedicada (...), padroeira da Ordem Franciscana e patrona da Província" (PRIM, 1975, p.10); contudo, não nos foi possível identificar-lhe a autoria (FIGURA 138). Outros pequenos painéis de azulejos podem ser vistos na edificação, os quais, provavelmente, foram aplicados em

\footnotetext{
${ }^{10}$ Alfredo Oliani é o autor (1906 - 1988). Escultor e gravador. É de sua autoria a escultura O 'Ultimo Adeus', situada no Cemitério São Paulo, em São Paulo. Mais sobre Oliani em: Pontual, R. (1969). Dicionário das artes plásticas no Brasil. Rio de Janeiro: Civilização Brasileira.
} 
tempos posteriores à construção da mesma, pois exibem outras cores, além do azul e do branco, e também traços diferentes de desenho (FIGURA 138). Como nas Escolas Práticas de Agricultura, os painéis de azulejos foram utilizados não só como ornamento, mas para retratar cenas relacionadas às suas atividades, ou seja, como elementos passíveis de sustentar representações simbólicas.

Outros aspectos das edificações dos seminários "Frei Galvão" e "Santo Antonio" devem ser, aqui, citados, pelo valor que têm no contexto da arquitetura neocolonial e pela semelhança que apresentam em relação aos prédios que são nossas principais referências, ou seja, o da Escola Nacional de Agronomia e os das Escolas Práticas de Agricultura, como já deixamos claro. Os telhados do seminário "Frei Galvão", por exemplo, possuem beirais, mas são retos em sua maior extensão. Na fachada principal, nas partes visíveis, ganhou certa curvatura, e nos cantos recebeu tratamento decorativo com telhas rabo de andorinha (FIGURA 128), o que remete diretamente aos solares portugueses e à arquitetura construída por Ricardo Severo. Ao observarmos as águas dos telhados vemos que, certamente, as telhas foram substituídas em etapas, em obras de reforma ou manutenção do prédio, pois existem três tipos de telhas em utilização: a tipo capa e canal, utilizada originalmente; a tipo romana; e a tipo francesa, embora esta esteja aplicada apenas no telhado de um prédio anexo (FIGURA 128). No seminário "Santo Antonio", de Agudos, originalmente foram utilizadas telhas capa e canal e, ao que parece, foram substituídas em algumas partes, mas pelo mesmo tipo de telhas. As águas dos telhados têm beirais retos e guarnecidos por calhas e condutores; nos finais dos espigões dos telhados que dão para a fachada foram empregadas também telhas rabo de andorinha (FIGURA 35 e 136).

Outros elementos construtivos e ornamentos que compõem a linguagem da arquitetura dos seminários de Guaratinguetá e Agudos podem ser, ainda, observados. Por exemplo, no caso do Seminário "Frei Galvão" a ornamentação geral do edifício é de pequenas dimensões, quando comparada com a das Escolas Práticas de Agricultura, onde ocorrem elementos exagerados propositadamente para alcançar um efeito monumental para os prédios (FIGURA 128). O mesmo se dá para o Seminário "Santo Antonio" onde, por exemplo, o corrimão da escadaria do saguão do Salão Nobre é muito menos exagerado, quando comparado aos corrimãos da Escola Prática de Agricultura de Pirassununga (FIGURA 136). De maneira geral, a ornamentação dos 
seminários é de proporções mais leves e elegantes, embora nas fachadas as dimensões das volutas e dos frontões sejam bastante expressivas.

As arcadas dos claustros dos seminários são muito semelhantes às das Escolas Práticas de Agricultura (FIGURAS 87 e 95). Encontramos, no claustro menor do Seminário "Frei Galvão", arcadas da altura de dois pavimentos, compostas por arcos plenos e, conquanto lembrem muito as arcadas das Escolas Práticas de Agricultura, parecem ter passado por reforma, pois são fechadas desde o piso até a altura do início dos arcos, que coincide com a altura dos guarda-corpos de quem estivesse circulando por dentro. Os guarda-corpos são completamente fechados e pintados de branco, e as paredes, pelo lado de dentro do claustro, são revestidas por pedras de quartzito ${ }^{11} \mathrm{em}$ cacos, o que manifesta terem sido aplicadas muito depois da construção do edifício, em reforma de décadas depois dos anos de 1940 (FIGURA 129). O claustro maior não apresenta arcadas, apenas tem uma cobertura simples, para proteção do piso que contorna o pátio interno, sustentada por pilares muito esbeltos (FIGURA 129). No caso do Seminário "Santo Antonio", a semelhança entre as arcadas é muito maior. Nas alas principais, paralelas à igreja, as arcadas têm dois pavimentos, sendo cada arco localizado no pavimento superior e fechado por guarda-corpos com balaustrada. Esse detalhe é o que faz a diferença com as arcadas das Escolas Práticas de Agricultura: nelas os guarda-copos são fechados por meias-luas (FIGURA 136). Mas, esse elemento da arquitetura neocolonial não deixou de ser utilizado: foram aplicados nas sacadas da fachada posterior da última ala perpendicular à igreja (FIGURA 135).

Em síntese, verificamos que os seminários "Frei Galvão", de Guaratinguetá, e o "Santo Antonio", de Agudos, são semelhantes entre si e também têm várias características em comum com as Escolas Práticas de Agricultura e, mesmo, com a Escola Nacional de Agronomia. Podemos dizer que a arquitetura neocolonial que se manifestou nesses prédios foi fruto da atuação do arquiteto Joaquim Bezerra da Silva envolvido na construção de obras públicas neocoloniais, provavelmente as Escolas Práticas de Agricultura - além da influência de obras de mesma tendência, localizadas em locais próximos, e da inspiração em obras religiosas do período colonial. Devido à expressividade de sua linguagem arquitetônica, ao porte e ao significado desses edifícios, consideramos que desempenharam papel importante, na difusão da arquitetura neocolonial pelo interior do Estado de São Paulo, em suas formas mais simples,

${ }^{11}$ Também conhecidas por Pedras São Tomé ou Pedras Mineiras. 
embora, muitas vezes, de autoria erudita, e na esfera particular, ou seja, na arquitetura residencial e comercial.

\section{Igrejas, Santuários e Catedrais}

O contato com a Ordem Franciscana, para a pesquisa sobre os seminários de Guaratinguetá e de Agudos despertou nosso interesse para o fato de que poderia haver igrejas construídas ou reformadas entre 1920 e 1950, segundo a tendência neocolonial, da mesma ordem religiosa ou não, espalhadas pelo interior paulista - nas cidades onde encontramos as Escolas Práticas de Agricultura e os Seminários, e em outras, onde pesquisamos sobre a difusão da arquitetura. Aqui, vamos analisar alguns exemplares localizados em cidades paulistas sobre as quais conseguimos levantar dados importantes, como projeto ou história e autoria da construção.

Igreja da Paróquia Santo Antonio, de Agudos

Ainda em Agudos, encontramos a Igreja da Paróquia Santo Antonio, situada na Praça Santo Antônio, próxima ao centro da cidade, e também atendida pelos Frades Franciscanos desde 1968 (FRANCISCANOS, Paróquia Santo Antonio, 2008). Sua aparência atual é devida a uma reforma realizada em 1951, pelo construtor Sr. Arcângelo Napoleone, em uma pequena capela, construída, em 1919, pelo mesmo construtor, segundo consta numa publicação comemorativa da criação da paróquia, no ano de 2000, o que transformou a igreja em Sede Paroquial. A publicação leva o nome de Criação de Uma Paróquia no Século XXI ${ }^{12}$ e é de autoria do Frei Mario Brunetta, frei da paróquia na ocasião (FIGURA 145). A reforma da capela deu-se no ano seguinte ao da inauguração do Seminário Santo Antônio (1950), acontecimento de grande importância para a cidade, não só pelas dimensões e significado da obra, mas também porque o prefeito da cidade era, naqueles anos, um cônego. A julgar pelo aspecto da torre, construída numa das laterais da igreja que substituiu a antiga capela, e pelo frontão, observamos que a igreja do seminário recém construído foi sua fonte de inspiração, uma vez que, certamente, também foi a principal referência de construção religiosa do período, naquelas imediações (FIGURA 146 e 147). A torre da Igreja da Paróquia de Santo Antonio também possui base quadrada e é guarnecida com

\footnotetext{
${ }^{12}$ Brunetta, Mario. (2000). Criação de Uma Paróquia no Século XXI. Agudos-SP: Gráfica Agudos.
} 
balaustrada, mas, ao contrário das torres do Seminário Santo Antonio, que têm balaústres torneados, nesta foram empregadas as meias-luas disseminadas largamente na arquitetura neocolonial. Possui quatro coruchéus nos vértices e cúpula de cebola; o frontão é uma simplificação do frontão da igreja do seminário, mantendo, inclusive, a moldura central, onde poderia ser colocado um painel de azulejos, como no caso da edificação inspiradora (FIGUA 135). A entrada se faz por um pequeno pórtico em arcos plenos, como as janelas, também de arcos plenos. Esse modelo de torre, com janelas em arco pleno ou abatido, ao lado da entrada principal, com frontão e três arcos plenos, faz lembrar o Convento de Nossa Senhora do Amparo, em São Sebastião, já citado (FIGURA 43).

Igreja da Paróquia de Nossa Senhora das Graças de Guaratinguetá

Em 1926, os freis Franciscanos conseguem autorização do Bispo para a construção da Igreja de Nossa Senhora das Graças e do convento, na chácara comprada, pelo Vigário Martiniano, do senhor Israel Guimarães, lugar esse que ficava mais próximo ao centro da cidade de Guaratinguetá. Em 1934 foi lançada a pedra fundamental, e em 21 de maio de 1936 a igreja foi inaugurada (FIGURA 148). Em setembro desse mesmo ano, uma imagem de Nossa Senhora do Rosário - barroca - que pertencia à Igreja do Rosário, atualmente demolida, foi levada à então nova Igreja de Nossa Senhora das Graças lá permanecendo até os dias atuais, sob proteção contra roubo. Em 1938, o engenheiro Antonio Filippo cedeu projeto e construção do muro que fecha o pátio externo, seguindo a tendência neocolonial. Em 1940, foram encomendados o altar e a imagem da santa padroeira da igreja. A citada igreja, de fachada estreita, segue o modelo composto por corpo principal e apenas uma torre lateral, de base quadrada e aberturas do campanário de arcos plenos, tal como na Igreja de Nossa Senhora do Amparo de São Sebastião, já anteriormente citada. O corpo principal avança levemente sobre o pátio frontal, é simétrico e possui portal de entrada simples, mas bem ao gosto neocolonial, com cimalha sobreposta por telhas de barro capa e canal e, nas pontas, arrematadas por telhas rabo de andorinha; um único central coruchéu arremata a cimalha. Sobre o portal, duas janelas, sendo uma alongada e de arco abatido, com moldura ornamentada por volutas e fechada por um vitral colorido e, outra, acima desta, quadrilobada e fechada também por vitral. Possui um grande frontão superior, curvo e tripartido, também decorado por telhas semelhantes às que adornam a 
porta; acima, um cruzeiro e, nas laterais, coruchéus. Os cunhais são feitos como pilastras com capitéis decorados (FIGURA 149). Anexo à torre lateral está o claustro, repetindo o exemplo das construções religiosas tradicionais, no interior do qual se encontram arcos plenos formando galerias protegidas. No centro do claustro, um cruzeiro: "obra em cimento branco de Ângelo Lucchesi"13 (FRANCISCANOS, Província Franciscana da Imaculada Conceição, 2007) (FIGURA 152). No pátio externo, frontal à entrada da igreja, no muro lateral direito, encontramos também um painel pintado e emoldurado por um frontão curvo com telhas. Junto ao piso, abaixo do painel, um pequeno jardim que poderia ter sido originalmente uma pequena fonte, à maneira de outras comumente encontradas em exemplares neocoloniais. O painel retrata uma paisagem com pássaros e em sua frente, na borda do pequeno jardim, uma estátua de São Francisco de Assis (FIGURA 151). O interior da igreja é rico em decorações, tendo nas paredes muitas pinturas de imagens, cenas e paisagens religiosas e, também, pinturas de estêncil (FIGURA 150). Frei Ricardo Backes, atual padre da igreja, afirma que as pinturas ainda existem devido a uma postura de oposição, sua, a uma prática surgida em fins da década de 1960, e que pretendia "limpar" as igrejas, realizando por cima da pintura original uma pintura lisa e simples (Informação verbal) ${ }^{14}$. Essa nova prática talvez estivesse relacionada a uma interpretação dos documentos lançados pelo Concílio do Vaticano II (1961-1965) que recomendava às instituições, por exemplo, que “tenham direito a possuir o que é necessário à vida temporal e às próprias obras, evitem, contudo, toda a aparência de luxo, de lucro exagerado e de acumulação de bens". (DECRETO..., 1965). É também possível que estivesse relacionada ao Código... (19--?), segundo o qual

debe conservarse firmemente el uso de exponer a la veneración de los fieles imágenes sagradas en las iglesias; pero ha de hacerse en número moderado y guardando el orden debido, para que no provoquen extrañeza en el pueblo cristiano ni den lugar a una devoción desviada,

pois recomenda a parcimônia, qualidade pouco condizente com a arquitetura barroca ou com a neocolonial. Por outro lado, tal prática pode também estar relacionada

13 Disponível em: http://www.franciscanos.org.br/fraternidades/casas/gracas/historia.php Acesso: 25/04/2007. Ângelo Lucchesi deve ter sido uma personalidade reconhecida na região, pois uma das ruas da cidade de Guaratinguetá leva seu nome.

${ }^{14}$ Informações conseguidas junto ao Frei Ricardo Backes, que nos atendeu numa visita à Igreja de Nossa Senhora das Graças em 21/04/2007. 
a uma perda do domínio da técnica do estêncil e outras técnicas de pintura das paredes. Assim, quando as pinturas passaram a precisar de manutenção, pela ação do tempo, tornou-se mais fácil e mais barato recobrir a igreja com uma pintura simples, que encontrar mão-de-obra que soubesse recuperá-la por preço acessível ${ }^{15}$.

Provavelmente na mesma época em que se pretendeu encobrir as pinturas, fez-se a troca do piso original, que atualmente é constituído por pedaços irregulares de granito. Muita madeira foi utilizada nos bancos, nas portas e no forro. Todas as janelas possuem vitrais coloridos. Em 1940,

Frei Henrique encomendou ao escultor Arthur Perdezoli, de São Paulo, o novo altar, medindo 8 metros de altura por 6,25 de largura, em imbuia e com a parte ornamental em ouro velho. Na mesma data, foi encomendada ao aludido escultor a imagem de Nossa Senhora das Graças para o novo altar, tendo 2 metros de altura, de madeira trabalhada, colorida (FRANCISCANOS, Província Franciscana da Imaculada Conceição, 2007).

Esse altar é também uma obra neocolonial, pois as proporções nele utilizadas são exageradas: possui um grande frontão curvo com coruchéus nas laterais, um grande nicho central com arco curvo, onde está a imagem da santa e, apesar de suas linhas predominantemente retas, a profusão de detalhes, típica da arquitetura barroca, é representada por pinturas douradas nas pilastras, formando uma linha de motivos curvilíneos (FIGURA 150). No coro, dois órgãos completam a decoração.

Aqui, vamos citar também o Cemitério dos Passos, de Guaratinguetá que, conquanto não seja uma igreja, é também um espaço arquitetônico de cunho institucional e religioso. Existente desde o final do século XIX, faz parte da "Irmandade do Nosso Senhor dos Passos", que detém o patrimônio do cemitério e do hospital. A licença para a construção do cemitério data de 12 de Setembro de 19855 (Livro de Tombo da Igreja Matriz de Guaratinguetá, folha 157); a licença para construção de uma capela, no cemitério, foi concedida em 18 de Agosto de $1865^{16}$. Não temos informações sobre a primeira capela, mas uma nova capela foi construída na década de 1990,

\footnotetext{
${ }^{15}$ Colaboraram para que pudéssemos verificar essas possibilidades os colegas Valéria Garcia e Mateus Rosada, cujas pesquisas são referentes à arquitetura e às igrejas paulistas.

${ }^{16}$ Informação tirada de um documento disponível no arquivo do Museu Frei Galvão, em Guaratinguetá.
} 
segundo um projeto do engenheiro João Maurício Sampaio, elaborado em 1988 (FIGURA 153). A capela foi inaugurada em 1994. Certamente, não podemos caracterizar sua arquitetura como neocolonial. Contudo, poderia se tratar de um exemplar erudito muito tardio, exibindo uma simplificação do vocabulário do movimento, como podemos observar no projeto e nas imagens (FIGURA 154).

\section{Santuário de Nossa Senhora Aparecida da Babilónia, São Carlos}

O santuário fica localizado na Estrada Municipal Leôncio Zambel, cujo acesso se faz pela SP-215, Rodovia Dr. Paulo Lauro, no quilômetro 136. Segundo consta no inventário da igreja, realizado pelo Arquivo Municipal de São Carlos, a romaria ao local do santuário teve início quando, entre 1860 e 1870, foi encontrada uma imagem de Nossa Senhora da Conceição aos pés da única árvore que não havia sido consumida por um terrível incêndio. Construiu-se, então, a primeira capela, que permaneceu em funcionamento até, aproximadamente, 1920. Nesse mesmo ano, foi iniciada a construção de uma nova igreja, mas as obras pararam e somente recomeçaram em 1944. Não localizamos, no Arquivo Municipal, o autor do projeto, mas uma pequena descrição, constante do inventário, informa-nos sobre suas características: foi construída

segundo a corrente neocolonial. A planta possui formato de cruz latina. A fachada apresenta um alprendre de proteção à entrada; e muitos ornamentos: frontão com volutas interrompidas, quadrifólios, coruchéus, pilastras, colunas, florões, a tradicional concha estilizada (rocaille). Está localizada a meia encosta, tendo sua fachada voltada para o vale. Ao lado da capela há uma torre sineira isolada (BENINCASA, 2004).

\section{Igreja da Paróquia de Santo Antônio de São Carlos}

Localizada no bairro Vila Prado, essa igreja teve sua pedra fundamental lançada em 13 de Junho de 1943, tornando-se, então, a segunda paróquia do município. O projeto e construção foram da responsabilidade do engenheiro Durval Duarte. Na década de 1990, a igreja foi reformada, segundo orientações do Padre José Carlos Frederici, e teve o telhado trocado, as fundações fortalecidas e o espaço ampliado com a 
anexação de um novo batistério e uma nova capela, dedicada ao Santíssimo Sacramento $^{17}$. Está implantada numa praça, com a frente voltada para uma das principais avenidas do bairro. Possui planta em cruz e uma linguagem arquitetônica de tendência neocolonial (FIGURA 155). Tal como muitos outros exemplos de arquitetura religiosa, aqui citados, apresenta fachada principal simétrica e uma torre sineira à esquerda. Possui um portal de entrada destacado do alinhamento da construção, constituído por arcos plenos simples e colunas salomônicas que emolduram uma porta de madeira almofadada e entalhada com motivos religiosos; acima um frontão reto, interrompido, adornado por pequenas volutas e uma cruz. Sobre o portal, uma janela tripartida de arcos plenos, cujas partes são separadas por colunas solomônicas e adornadas por uma moldura com pequeno frontão interrompido, volutas e florões; sobre a janela, uma pequena janela quadrilobada e uma cruz adornam o grande frontão principal da fachada, que é tripartido e arredondado. Nas laterais, coruchéus sobre as pilastras marcadas por rusticação. A cada lado dos cunhais, uma janela de arco pleno em cuja moldura está um adorno em forma de concha; sobre cada janela, uma espécie de platibanda com volutas faz a concordância dessas porções laterais com a fachada principal. A torre é de base quadrada, arrematada por uma cúpula ogival que leva um cruzeiro; possui uma entrada de acesso independente da entrada da igreja e uma série de janelas de várias formas ao longo da altura; tem os cunhais como os da fachada principal, arrematados por coruchéus. Não possui beirais e quase nada se vê do telhado. É importante notar que, embora a edificação não seja profusamente decorada, todas as fachadas dessa igreja receberam um tratamento igualitário, nesse aspecto. $\mathrm{O}$ alargamento da base de algumas paredes, a presença de colunas salomônicas, os frontões arredondados e o aspecto de uma massa compacta bem assentada no solo denotam, nesse exemplar da arquitetura neocolonial, a influência da tendência estilística "missões", mas nesse caso, de origem espanhola e californiana (FIGURA 156). No interior, a decoração da Igreja de Santo Antonio segue a mesma tendência neocolonial, principalmente empregada no retábulo que leva colunas salomônicas e moldura com volutas, dentro do qual está a imagem do santo padroeiro da igreja. A exemplo da tendência dos anos de 1970, que encobriu as pinturas originais de algumas igrejas com camadas de tinta lisa, verificamos que o mesmo aconteceu à igreja em questão. Durante a reforma por que passou, a pintura original foi redescoberta, e deixada exposta em

\footnotetext{
${ }^{17}$ Informações contidas no inventário da igreja, realizado pelo Arquivo Municipal de São Carlos.
} 
alguns trechos, principalmente do forro, onde não está completamente deteriorada. Apesar de todas as críticas que possam ser realizadas, quanto aos métodos da reforma, a exposição e preservação de partes da pintura demonstram um reconhecimento e uma manifestação de apreço, por parte da comunidade, pelo seu patrimônio arquitetônico. $\mathrm{O}$ piso foi substituído por piso de granito; possui janelas com vitrais e janelas de vidros coloridos. De fato, os vitrais previstos originalmente nunca chegaram a ser feitos. Os bancos antigos, de madeira, foram mantidos (FIGURA 157).

\section{Igreja do Rosário, de Santos}

A origem da Igreja de Nossa Senhora do Rosário, localizada no Largo do Rosário, em Santos, remonta ao século XVII e está ligada a história dos escravos. Tratase de uma igreja muito conhecida, na cidade, devido à sua trajetória histórica e à centralidade de sua localização - na atual Praça Rui Barbosa -, mas aqui nos interessa destacar a transformação pela qual passou no final da década de 1920. Devido às obras de alinhamento do antigo Largo do Rosário, que passou a ser denominado Praça Rui Barbosa, houve um acordo entre a Prefeitura e a Igreja do Rosário em que esta, já necessitando de reformas urgentes (FRANCO, [197-?], p.84), teria sua fachada recuada, em troca "do terreno de dois metros e quinze centímetros de largura por dezenove metros de comprimento" que foi acrescentado ao Jazigo da Irmandade no Cemitério do Paquetá (FRANCO, [197-?], p.84). Assim,

a Igreja do Rosário (...) foi reconstruída, recuaram a fachada para melhor alinhamento da praça e deram-lhe novo aspecto em linhas de estilo colonial, com a torre ao lado esquerdo da igreja, onde colocaram um relógio de grandes proporções (...). No interior da igreja fizeram a ornamentação $e$ decoraram os altares, paredes e abóbada. A imagem de Nossa Senhora recebeu um manto novo (FRANCO, [197-?], p.84) (FIGUA 158).

Essa transformação em "estilo colonial”, ou seja, neocolonial, foi inaugurada no dia 12 de Outubro de 1930. De fato, como podemos observar numa outra descrição sobre a nova fachada construída para a igreja, a inspiração na arquitetura colonial religiosa vem desde longa data, pois o seu exterior "foi reformado no mesmo estilo da 
fachada anterior que já era uma reprodução das linhas da velha e demolida Igreja Matriz na Praça da República, (...) em estilo jesuíta ou barroco” (FRANCO, [197-?], p.84). É de interesse notar que, apesar de toda a intenção de evocar o passado, o que foi conseguido através da aplicação de uma linguagem, na nova fachada, que está claramente baseada não só na fachada anterior, mas também numa igreja mais antiga e já demolida, a idéia de modernidade - que acompanhou a produção neocolonial - está presente também na reforma da Igreja do Rosário, na qual foi preciso realizar "adaptação aos processos modernos da arquitetura, [e ao mesmo tempo] mantém as linhas gerais de outros tempos" (FRANCO, [197-?], p.84). Uma torre baixa, de base quadrada, continuou ocupando a esquina, e tal qual a anterior, possuindo entrada independente, uma sequiência de aberturas na vertical e uma cúpula arrematada por um cruzeiro; os cunhais são igualmente marcados e encimados por coruchéus. A fachada principal possui atualmente um frontão curvo tripartido, com cimalha e cruzeiro ao centro; uma grande janela em curvas sobre três outras janelas, também de linhas curvas, à semelhança das antigas de arco abatido; o portal ficou mais imponente, com cimalha e uma cártula de rolos ao gosto barroco. As proporções da fachada se mantiveram e, portanto, a reforma não causou grande impacto. A lateral da igreja ganhou uma longa seqüência de janelas de linhas curvas, como as da fachada, seguindo, talvez, as aberturas anteriormente existentes (FIGURA 159). Foi decorada internamente por algumas pinturas e adornos, mas o destaque maior está no retábulo, de granito, linhas pouco rebuscadas e volutas, e no forro, que ganhou um trabalho minucioso de "frisos enquadadros que se unem em rosetas" decoradas com pintura (FRANCO, [197-?], p.84) (FIGURA 160). Podemos dizer que a Igreja do Rosário foi mais um exemplar colonial que, durante as primeiras décadas do século $\mathrm{XX}$, foi transformado em neocolonial, por força da necessidade de serviços de manutenção e das idéias então em voga, postas a circular pela movimentação iniciada por Severo.

Outro exemplar da arquitetura religiosa de Santos - o Santuário de Santo Antonio do Valongo - merece, aqui, uma pequena consideração (FIGURA 161). À semelhança do exemplar anterior, foi construído no século XVII e passou por algumas modificações, como a demolição do convento anexo. No interior da igreja do santuário encontramos retábulos, altares e diversos outros adornos barrocos, e grandes painéis de azulejo nas paredes laterais do altar, que datam de 1940 e são de autoria do "pintor português" Cândido da Silva Júnior (FIGURA 162). Esse detalhe mostra que era 
admissível, naquele período, a inserção de uma característica da arquitetura neocolonial - o painel de azulejos - num contexto onde a arquitetura é majoritariamente barroca. Seria, possivelmente, pelo fato de que painéis de azulejo já eram utilizados na arquitetura barroca, não se constituindo, assim, em um elemento estranho? Essa e outras reflexões fazem parte do esforço para um entendimento mais profundo sobre a manifestação neocolonial que, como já sabemos, substituiu exemplares originais por outros, inspirados nos primeiros, e trouxe para construções novas elementos construtivos e peças originais, além do que, como no caso em descrição, acrescentou, em exemplares vetustos, versões modernas de estimadas características do passado colonial, atitudes, estas, aceitáveis naquele período e que, atualmente, são reavaliadas à luz da conservação e proteção do patrimônio arquitetônico, como podemos verificar, especialmente, na obra de Pinheiro (2005, p.123-127), quando a autora analisa o caso da Faculdade de Direito, demolida e reconstruída por Ricardo Severo.

\section{Catedral Diocesana de São Francisco das Chagas, de Taubaté}

Originou-se da reforma, iniciada em 1942, da Igreja Matriz dedicada ao mesmo santo, sendo consagrada Catedral Diocesana em $1950^{18}$. A igreja matriz anterior, que ostentava na fachada traços da arquitetura eclética, como aberturas com arcos ogivais, passou a exibir uma tendência marcadamente neocolonial. Segundo "a vontade firme do apostólico Bispo Diocesano Dom Francisco Borja do Amaral (...) as obras estão a cargo da Cia. Predial de Taubaté” (ÁLBUM..., 1945, p.66) que, conforme veremos adiante, foi responsável por inúmeras obras, em sua maioria residenciais, alinhadas aos preceitos neocoloniais, tanto em Taubaté como em cidades da região (FIGURAS 163). As duas torres laterais de base quadrada foram mantidas e ganharam maior verticalidade com a marcação de seus cunhais, a abertura de uma janela longa e estreita, em cada uma, e a retirada da modinatura eclética; as cúpulas também foram mantidas. A porção central da fachada simétrica ganhou um grande frontão curvo, separado da parte inferior por uma cimalha com curva, e decoração de telhas capa e canal; acima do portal de arcos e molduras decorativas, três aberturas de arco abatido, sendo, a do meio, uma porta-balcão com sacada em forma de taça, sobre a qual está um nicho para o santo padroeiro da igreja. As laterais também ganharam portas e janelas de arcos plenos ou

\footnotetext{
${ }^{18}$ As informações constam no verso de uma foto da reforma tirada em 1944 e localizada no Museu da Imagem e do Som de Taubaté.
} 
abatidos, em substituição aos antigos arcos ogivais. Aos telhados da catedral foram aplicados pequenos beirais, com telhas capa e canal (FIGURA 164). O interior da catedral foi abundantemente decorado com muitos elementos e características que evocam as igrejas barrocas. O retábulo, que vai do forro ao piso, exibe grandes mísulas curvas, sobre as quais pousam colunas decoradas; frontões interrompidos e volutas arrematam a peça, no centro da qual está a imagem de São Francisco das Chagas. Nas paredes laterais, janelas com vitrais coloridos, pinturas de cenas e frisos com motivos de conchas; revestimento e bancos de madeira. Os arcos laterais que dão para as capelas, e os falsos arcos adjacentes, possuem molduras com volutas douradas, florões centrais e cimalha; o coro possui guarda-corpo com balaustrada e dois órgãos. Todas as molduras e frisos são realçados por pintura dourada (FIGURA 165).

De modo geral, o que se verificou, com a pesquisa desses exemplares neocoloniais religiosos localizados em cidades do interior paulista - que representam uma pequena parcela do universo existente -, é que, por um lado, buscaram inspiração em sua própria tradição construtiva religiosa e colonial, que tem origens no século XVI e que, portanto, não se trata apenas de referências barrocas, mas também da cultura arquitetônica de um período anterior, que coincidia com o chamado Maneirismo. Por outro, também retomou a referência barroca, pois esta é parte da tradição arquitetônica religiosa, mas está muito ligada às referências do movimento neocolonial. Por serem edificações de impacto considerável, na paisagem das cidades, e no imaginário da população, por seu significado, acreditamos terem colaborado na difusão de estilemas e características neocoloniais pelo interior do Estado de São Paulo.

\section{Edifícios Assistenciais}

Mostramos, anteriormente, o projeto de Ricardo Severo para o hospital da Beneficência Portuguesa de Santos, mas é sabido que ele também realizou projetos para outros hospitais da mesma instituição, nas cidades de Campinas e de Bauru. Queremos, aqui, destacar a presença da atuação do engenheiro em cidades do interior paulista, e chamar a atenção para o significado dessas obras, especialmente a de Bauru, cidade distante da capital. São obras de autoria erudita, elaboradas pelo principal representante do movimento neocolonial no Estado de São Paulo e que, por isso, não correspondem, propriamente, a uma difusão da arquitetura fruto da campanha. São, antes, exemplares 
da "vertente elitista", lembrando Lemos (1985) uma vez mais, localizadas fora dos centros onde o movimento teve seu início e onde, tradicionalmente, se considera que estejam as obras mais expressivas a ele referentes. Devido ao porte e à novidade que representou a linguagem arquitetônica empregada em tais obras, nos anos em que foram construídas, acreditamos que colaboraram na difusão da arquitetura neocolonial nas regiões onde foram implantadas.

O Hospital da Beneficência Portuguesa de Bauru (1928), e a Maternidade Gota de Leite, de Araraquara, são exemplos de duas edificações de autoria erudita, de tendência neocolonial, situadas em cidades distantes daquela onde emergiu o movimento. Segundo Ghirardello (1992, 149), o Hospital da Beneficência Portuguesa “teve sua pedra fundamental lançada em 1925” e foi projetado por Ricardo Severo, de acordo com as recomendações tradicionais construtivas que ele próprio divulgava: telhados com beirais, frontão curvo, janelas com molduras decorativas, balaustradas e guarda-corpos empregando meias-luas sobrepostas, estão entre os estilemas encontrados nessa edificação e, também, em muitas outras posteriores a elas. Ghirardello (1992, p.152) afirma ainda que "esta obra se constituirá em marco para a cidade, início de uma série de construções dentro das características do estilo, construídas principalmente por imigrantes portugueses" (FIGURA 166 e 284). A Maternidade Gota de Leite, de Araraquara, foi uma instituição instalada com a ajuda do político araraquarense Bento de Abreu. Não pudemos precisar a data em que a maternidade foi projetada e construída, nem confirmar sua autoria - que é atribuída ao engenheiroarquiteto José Maria da Silva Neves - pois o processo de aprovação dessa obra, que constava do acervo do Arquivo Municipal da cidade, está desaparecido. Beirais, janelas de arco abatido, guarda-corpos com meias-luas, também fazem parte das características desse prédio situado à Rua Carlos Gomes, 1610 (FIGURA 167).

Encontramos, ainda, em duas cidades nas quais foram instaladas Escolas Práticas de Agricultura, hospitais de tendência neocolonial, que são o Hospital da Irmandade Santa Casa de Misericórdia, de Itapetininga, e o Hospital e Maternidade Frei Galvão, de Guaratinguetá. Sobre o primeiro, somente temos o levantamento fotográfico, que nos permitiu observar características de sua arquitetura, como o típico frontão curvo com volutas e coruchéus nas laterais, a simetria e os beirais (FIGURA 168). O Hospital e Maternidade Frei Galvão foi idealizado em 1940, quando recebeu um terreno, onde se ergueriam suas futuras instalações, do Sr. Acelino José de Castro; em 1942 tinha 20 
leitos ocupados ${ }^{19}$. Podemos observar, no prédio do Hospital Frei Galvão, através de uma foto do Arquivo Municipal, que a entrada principal se dá por um pequeno pórtico de arcos plenos, sobre o qual está um frontão triangular com volutas, decorado com telhas capa e canal e com uma janela falsa quadrilobada (FIGURA 169). São dois exemplares de linhas simplificadas, mas indicativos da difusão da tendência neocolonial no interior paulista. A sua arquitetura pode não ser, necessariamente, fruto da presença das Escolas Práticas de Agricultura e, justamente por isso, o assunto dos hospitais construídos no interior paulista nas décadas de 1930 e 1940 demanda pesquisas mais aprofundadas.

A história do Orfanato Santa Verônica, de Taubaté, tem origem em 1919, quando foi instalado num prédio provisório e "foi muito pobre em seu início, como geralmente são todas as obras do espírito Franciscano” (ÁLBUM..., 1945, p.83). Logo recebeu, em doação, pela Ordem III de São Francisco, um terreno anexo, onde seriam construídas novas instalações. Em 1927 foi inaugurada a capela do orfanato, cuja arquitetura segue linhas ecléticas (FIGURA 170); em 1937, um novo pavilhão; e, em 1940, o pavilhão chamado Patronato Cardoso Ribeiro, pois “foi mandado construir pela Exma. Sra. D. Eponina Cardoso, cumprindo o caritativo e nobre desejo do saudoso Dr. Cardoso Ribeiro, cujo nome legou ao prédio” (ÁLBUM..., 1945, p.83). Este, sim, segundo a tendência neocolonial (FIGURAS 171). Prédio simples, com beirais nas alas laterais e fileiras de janelas retas, e entrada principal marcada por um frontão curvo tripartido com volutas, três janelas, guilhotina de arco abatido e molduras decoradas com volutas e um portal simples, também, decorado com volutas, tendo, a cada lado, uma janela de forma quadrilobada. Esse corpo saliente de entrada tem os cunhais marcados e encimados por coruchéus. Trata-se de um exemplar neocolonial simples, mas com que se repetem vários dos estilemas encontrados em outros, já citados. Consideramos que seja uma difusão simplificada da tendência, porém de autoria erudita, uma vez que a obra foi realizada pela Companhia Predial de Taubaté, segundo consta em seu relatório de contas, de 1941.

\footnotetext{
${ }^{19}$ Informações retiradas de um documento intitulado "O Hospital e Maternidade Frei Galvão e a sua História” que faz parte do acervo do Museu Frei Galvão, Guaratinguetá. O documento não informa sobre autor, data ou edição; também não traz informações sobre o prédio.
} 


\section{Edifícios para Atividades Educativas}

Vamos, aqui, analisar alguns edifícios também institucionais, voltados para atividades educativas, localizados em cidades que fizeram parte de nossa pesquisa, cuja arquitetura é de tendência neocolonial. Em Itapetininga, encontramos o prédio do Centro Cultural e Histórico, que se localiza na Praça Marechal Deodoro da Fonseca. Nesse caso, uma vez mais nos deparamos com uma reforma "neocolonizadora", embora tenha sido realizada, possivelmente, sobre um exemplar do final do século XIX, e não sobre um colonial original. É possível, até, que esse prédio tenha passado por mais de uma transformação, pois apesar de ostentar na fachada a data de 1878, não tem características de uma construção eclética. Sua volumetria é simples e constituída por um grande paralelepípedo coberto por um telhado de quatro águas, partido que remete às construções do período colonial (FIGURA 172). Depois da reforma, podemos observar-lhe a influência do chamado "estilo missões": beirais com cachorros falsos decorados, frontão curvo arredondado sobre a entrada principal, portal de arco pleno decorado com pedras irregulares, cujo desenho se alarga na base. Sobre a entrada, uma porta-balcão com sacada e moldura com motivo curvilíneo muito incomum, no qual foram aplicadas pedras roliças e pequenas; na fachada, janelas de arcos plenos no pavimento superior e de vergas retas, no inferior (FIGURA 173). Não faltaram entre cada janela do pavimento térreo, protegidos por pequenos telhados de telha capa e canal anexados à parede, dois painéis de azulejos retangulares, nas cores azul e branco, um retratando cenas bucólicas (FIGURA 174). No interior do edifício, o mesmo ar monumental, alcançado pelo exagero nas medidas das proporções das aberturas, dos pilares e dos frisos decorativos. As portas em madeira de arco pleno, e motivos decorativos, em curvas, foram encontrados nas portas das Escolas Práticas de Agricultura, e também serão vistos em residências ditas "mexicanas” (FIGURA 175).

Trata-se de um exemplar que concentra variadas características, exageros e ornamentação invulgar. 
No acervo de projetos do arquiteto Hernani do Val Penteado, da FAUUSP, encontramos um projeto, de 1949, para um Colégio de Freiras, que se localizaria na Ponta da Praia, em Santos. Consta como cliente a Madre Maria Diomira do Santíssimo Sacramento. O edifício, neocolonial, seria implantado em um terreno irregular, formando um grande claustro de quatro lados, fechado por uma entrada monumental. $\mathrm{O}$ projeto previu três pavimentos, e as demais características são aquelas já descritas para edificações religiosas neocoloniais. Provavelmente não foi construído, ou foi demolido (FIGURA 176).

O Clube de Mães - Creche Anita Costa, criada em 11 de Junho de 1952, foi a primeira creche construída na cidade de São Carlos (ZAMBOM, 2007, p.1526). Conforme consta em documento fornecido pelo Arquivo Municipal de São Carlos, a área construída do prédio é de 1498,91m2. Implantada com a fachada principal voltada para a Rua Conde do Pinhal, a volumetria do prédio é composta por quatro alas que fecham um quadrilátero, formando um pátio interno. No centro do pátio, uma torre de base circular toma quase a totalidade do espaço. Esse ambiente, com seu telhado em forma de cone, arrematado por um coruchéu no ponto mais alto, tornou-se muito comum entre residências de inspiração neocolonial, especialmente da vertente missões (D’ALAMBERT, 2003, p.196); em geral, abrigava a caixa de escadas, quando havia dois pavimentos, mas neste caso foi destinado a outro uso. A propósito, Amaral (1994, p.14) afirma ser um equívoco a prática que

incorporaba a la residencia la torre cilíndrica o cuadrangular - elemento falso que no tenía ninguna relacion con el pasado constructivo colonial en Brasil -, (...) los balcones de madera a la manera hispánica, las agujas y ornamentos de hierro forjado, elementos inspirados también en revistas norteamericanas.

Elementos de influência missões, a entrada da creche é marcada por um pórtico de três arcos plenos, que avança em relação ao alinhamento da fachada e é coberto por oitão triangular e beirais com cachorros aparentes. Nas laterais do arco frontal, as paredes sofrem alargamento em direção ao piso, sendo, essa, mais uma característica 
bastante comum, nos prédios de inspiração missões. A base do prédio, bem como o muro que circunda o terreno da creche, é revestido com pedras de formato irregular (FIGURA 177). Junto a um dos lados do muro, possui uma grande fonte de três quedas e o típico painel de azulejos azul e branco (FIGURA 178). Como exemplar construído no início da década de 1950, podemos dizer que é uma manifestação tardia.

No Arquivo Municipal da cidade de Araraquara, encontramos o projeto para o Internato do Araraquara College, desenvolvido pelo escritório do arquiteto Alexandre Ribeiro Marcondes Machado. Nascido em Pindamonhangaba, Machado cursou o ensino primário em Araraquara e formou-se engenheiro-arquiteto pela Escola Politécnica de São Paulo, em 1917, onde estabeleceu seu escritório técnico de construções Sampaio \& Machado, em sociedade com o Otávio Ferraz Sampaio. O arquiteto Alexandre Ribeiro Marcondes Machado escreveu crônicas e poesias sob o pseudônimo de "Juó Bananére", cuja produção literária é associada ao movimento moderno ${ }^{20}$. Seu projeto para o Araraquara College data de 1922 e pode ser considerado um exemplar precoce da tendência neocolonial no interior paulista. Embora não apresente todos os estilemas que poderíamos relacionar à arquitetura neocolonial - não exibe frontões nem arcos plenos - possui outros que o alinham à tendência: beirais, arcadas (de arco abatido), revestimento com pedras irregulares na base do edifício e pedras isoladas, completando a decoração das paredes (FIGURA 179).

\section{Edifícios para Atividades Recreativas}

No ano de 1934 a Piscina Municipal de São Carlos estava em construção. O prédio aparece pronto numa foto de 1940, e o que se vê é uma arquitetura de linhas retas, o que indica ter o prédio passado por uma reforma entre 1940 e 1957 (FIGURA 180). Nesse ano, outra foto mostra banhistas e, ao fundo, o prédio com beirais, onde se divisa os cachorros aparentes e duas janelas redondas, que condizem com seu aspecto atual. Certamente, devido à reforma pelas quais passaram, as dependências da Piscina Municipal ganharam ares da arquitetura de influência missões. A todos os acessos

\footnotetext{
${ }^{20}$ Mais informações em:

http://www.itaucultural.org.br/aplicexternas/enciclopedia/poesia/index.cfm?fuseaction=Detalhe\&CD_Ver bete $=661$ Acesso em: 27/10/2006.
} 
foram acrescentados arcos plenos, incluindo o acesso interno para a piscina, que anteriormente possuía três aberturas retas, sem nenhum adorno. Esse acesso interno ganhou um grande arco pleno principal e, em cada lado, uma porta de arco pleno. As paredes externas do edifício foram revestidas por uma massa rústica, as bases foram decoradas por pedras irregulares - assim como as fachadas que receberam pedras esparsas como ornamentação -, as paredes laterais aos arcos foram alargadas junto ao piso e os telhados ganharam beirais com cachorros aparentes. Observamos também, algumas janelas redondas e algumas volutas (FIGURAS 181). No interior, os arcos também foram realizados nas aberturas, e ainda permanecem móveis de linhas curvas em madeira (FIGURA 182). Cercando as dependências da piscina, um muro baixo, revestido de pedras, e escadas de acesso com corrimão de grandes dimensões, com volutas (FIGURA 183). Observamos que, novamente, o prédio está em obras para se adaptar a um novo uso, mas, felizmente, as intenções da Prefeitura Municipal são no sentido de preservar suas características:

Por meio da Secretaria Municipal de Obras e Serviços Públicos, a Prefeitura iniciou [em 2006] a pintura do prédio da Piscina Municipal, que voltará a ter a cor original, ou seja, amarela. Essa definição é resultado do trabalho de prospecção realizado pela Fundação Pró-Memória. (SÃO CARLOS (MUNICÍPIO). Prefeitura Municipal de São Carlos, 2006).

$\mathrm{Na}$ região do Vale do Paraíba, encontramos dois clubes cujas edificações seguem a tendência neocolonial, o Country Club de Taubaté e o Itaguará Country Clube. O primeiro foi construído em 1938 pela elite da cidade de Taubaté. Podemos observar algumas poucas características de sua arquitetura pelas imagens do Álbum Comemorativo ao Tri-Centenário de Taubaté (1945, p.335 e p.340) (FIGURA 184), por uma imagem da fachada, que mostra arcos no frontão de entrada, e por uma foto que mostra pedras irregulares, distribuídas pela fachada, e sobre um arco ogival (FIGURA 185). Uma notícia do jornal "O Vale Paraibano", de 18 de Janeiro de 1998, informa que

a sede social do TCC (Taubaté Country Club) foi tombada como patrimônio de interesse arquitetônico, histórico e paisagístico do 
município. O tombamento foi decretado pelo prefeito Antonio Mário Ortiz (PSDB), depois de um estudo realizado pelo Conselho Municipal de Defesa do Patrimônio Histórico, Arquitetônico e Paisagístico.

O Itaguará Country Club, de Guaratinguetá, une-se ao conjunto dos edifícios que foram reformados e ganharam aspecto neocolonial. O edifício principal foi construído no final do século XIX, numa propriedade produtora de leite, que foi comprada em 1940 por Aberto Byngton. Depois de sua morte, a chácara foi vendida e transformada no citado clube, no dia quatro de setembro de $1963^{21}$. Possivelmente, enquanto foi propriedade de Byngton passou por uma reforma que alterou o arcabouço eclético original da construção, acrescentando um frontão curvo e coruchéus laterais numa das laterais da entrada principal, de visibilidade privilegiada. Foram acrescentadas também, no guarda-corpo desse trecho do alpendre, as meias-luas sobrepostas; ao pé da escada, um tanque ou jardim com nervuras decorativas, como simulação de uma alvenaria, pedras irregulares ou raízes (FIGURA 186). A restauração, posterior a 1990, realizada pelos arquitetos Regina Maia Galvão e Renato Guimarães, parece ter preservado as características que já se encontravam na edificação (FIGURA 187).

Segundo o Álbum... (1951), o Aeroclube de Rio Claro nasceu em 1938, por iniciativa de Manoel Lopes da Silva Jr., Alcides Gonçalves da Rocha e Orton Floover. Por volta de 1940,

o então prefeito municipal sr. Irineu Penteado, de acordo com Adhemar de Barros, Interventor Federal, construiu o hangar e pistas para o Aéro Clube de Rio Claro (...). Em 1949, graças aos esforços do atual presidente [do clube] sr. Manoel Lopes da Silva Jr., foi conseguida uma estação de passageiros (ÁLBUM..., 1951).

\footnotetext{
${ }^{21}$ Informações retiradas do projeto de restauro, encontrado no Arquivo Municipal de Guaratinguetá, realizado pelos arquitetos Regina Maia Galvão e Renato Guimarães. Não consta data, mas, possivelmente, é posterior a 1990.
} 
O projeto da estação de passageiros deu entrada junto à prefeitura municipal no dia 30 de novembro de 1948, sob a responsabilidade do engenheiro Milton Silveira; o construtor seria Manoel Antonio de Carvalho. Os desenhos das fachadas levam uma assinatura ilegível. A estação é pequena, com cerca de $230 \mathrm{~m} 2$, e abriga um salão de estar, uma sala para piloto, um espaço para administração, um pequeno bar com cozinha e dois sanitários. As linhas arquitetônicas são de influência missões; a fachada é simétrica e o portal de entrada lembra os portais da Creche Anita Costa e os da Piscina Municipal de São Carlos, ou seja, um arco pleno frontal encimado por um oitão triangular, sendo que, a cada lado do frontão, há um alargamento da parede, com arremate em volutas. Sobre o portal, um frontão curvo tripartido, com volutas e coruchéus. Nas laterais da fachada, janelas de vergas retas e janelas de arcos plenos. Possui beirais bem pronunciados, finalizados por telhas rabo de andorinha. A fachada posterior possui uma arcada que forma uma galeria; no telhado, dois frontões pequenos, à semelhança do principal (FIGURA 188). O aeroclube passou a se chamar Aeroporto “Adhemar de Barros"22, certamente em homenagem ao político que teve participação na sua viabilização. $\mathrm{O}$ aeroclube possui, ainda, algumas casas, atualmente utilizadas como alojamentos, que exibem as mesmas linhas arquitetônicas do terminal de passageiros (FIGURA 189 e 190).

Em Araras, cidade próxima de Rio Claro, encontramos o "Clube Ararense", cuja sede atual foi construída em 1952, situado a Rua José Bonifácio, região central da cidade. Não conseguimos apurar maiores informações sobre seu histórico ou sobre o prédio, pois não localizamos seu projeto no arquivo municipal. Porém, como podemos observar pelas figuras (FIGURA 191), trata-se de uma obra emblemática na cidade que, embora tardia, pode ter suscitado inspiração para outras edificações. Possui, assim como outros exemplares neocoloniais, pórtico de entrada com frontão curvo de proporções monumentais, com volutas e coruchéus; possui também cunhais e arcada marcados por revestimento de pedras.

\footnotetext{
${ }^{22}$ Em 1949, Adhemar de Barros elabora o contrato para construção do aeroporto que começa a ser construído no mesmo ano. Disponível em: http://www.adhemar.debarros.nom.br/obras.htm Acesso em: 23/04/2008.
} 
No decorrer da pesquisa, verificamos que a autoria de várias das obras institucionais, no interior paulista, que seguiram a tendência neocolonial, foi de responsabilidade de autores conhecidos, especialmente de engenheiros-arquitetos formados pela Escola Politécnica, como Joaquim Bezerra da Silva, Hernâni do Val Penteado e Alexandre Ribeiro Marcondes Machado. Ou seja, esses e outros profissionais estiveram presentes e atuantes nessa região, fazendo circular, fora das cidades do Rio de Janeiro, de São Paulo e dos centros maiores, as idéias, então em voga, sobre arquitetura, e contribuindo para disseminar certo gosto. Porém, não conseguimos identificar a autoria de várias outras obras. Acreditamos, contudo, que muitas delas, por serem obras institucionais, são de autoria erudita - obra de autor que tenha passado por uma escola - mesmo sendo bastante simplificadas, em alguns casos. Notamos também, no âmbito dos edifícios institucionais, mais que em outros, a alta incidência de reformas destinadas a atribuir características neocoloniais a exemplares construídos em épocas anteriores. Isso pode ser indicativo da força dessa tendência no interior paulista. 


\subsection{Obras Particulares}

Como foi verificado anteriormente, desde muito cedo houve uma diferença entre o movimento neocolonial e a prática arquitetônica fruto dele. Mesmo nos primórdios dessa manifestação, que se deu na cidade de São Paulo e do Rio de Janeiro, a quantidade de edificações, nas quais é possível identificar os cânones restritos da campanha, é significativa, porém muito menor que o número de obras inspiradas na tendência. Ricardo Severo pregava o resgate da tradição arquitetônica brasileira, de raízes portuguesas, mas construiu com liberdade, o que resultou em composições diferentes da arquitetura colonial, que era, e continua sendo, idealizada. Mesmo obras de Victor Dubrugras, reconhecidas como neocoloniais da vertente erudita, ostentaram as tais "invencionices" (LEMOS, 1985, p.160-168; D’ALEMBERT, 2003, p.148) que as distinguiam do colonial original. Assim, afinal, nos perguntamos: qual é a arquitetura que corresponde ao conteúdo ideológico lançado pela campanha neocolonial? Podemos entender que seja aquela que levou em consideração as recomendações de Ricardo Severo, contidas primeiramente em sua conferência de 1914, sobre onde deveriam os arquitetos brasileiros buscar a tradição e sobre a importância do compromisso com o caráter e a verdade da arquitetura (SEVERO, 1916, p.52). Seria, também, aquela que, do mesmo modo, acatou os "Dez Mandamentos do Estylo Neo-Colonial" lançados por Mariano Filho ${ }^{1}$ (1923 apud Amaral, 1994, p.18) e que contempla preocupações do mesmo teor. Além disso, essa arquitetura repleta de conteúdo ideológico teria que levar em conta a atitude de combate ao ecletismo - que foi enxertada ao movimento neocolonial posteriormente ao seu aparecimento, como afirma Puppi (1998, p.91). Assim, diante de tantas exigências, algumas das quais bastante subjetivas - tais sejam a tradução de conceitos como tradição, caráter e verdade, na obra de arquitetura -, acreditamos que mesmo os exemplares de autores engajados no movimento, participantes dos debates e atualizados sobre as idéias, utilizaram características diversas daquelas encontradas na arquitetura colonial.

Isso foi ainda mais explícito no caso dos profissionais que estivessem distante dos centros, para os quais era inviável acompanhar os debates. Além do que, essa prática talvez se constituísse em um detalhe irrelevante na rotina do mercado que

\footnotetext{
${ }^{1}$ MARIANO FILHO, José. Os Dez Mandamentos do Estylo Neo-Colonial. Revista Architectura no Brasil. 1923, M.4 (p.161/63).
} 
buscava (e busca) atender as demandas por determinadas intenções e gostos. Mais natural seria, portanto, relacionar diretamente uma idéia a uma forma ou a um elemento construtivo; por exemplo, uma casa "tradicional" corresponderia a uma casa com beirais ou com frontões.

Por conseguinte, muito mais comuns que exemplares fiéis aos originais coloniais, ou aos neocoloniais mais restritos às idéias do movimento, foram os inúmeros exemplares identificados como frutos do movimento neocolonial através de algumas características, primeiramente empregadas nas obras inaugurais, mas, depois, utilizadas aqui e ali sem restrições, em conjunto ou separadamente, nos centros onde se originou e fora deles. Verificamos que, ao longo das décadas de manifestação da arquitetura neocolonial, o conteúdo ideológico do movimento esteve em transformação, de acordo com diferentes motivações. Assim, na esfera oficial, a ideologia do movimento neocolonial foi adaptada às necessidades de comunicação de determinadas mensagens que o poder público pretendia transmitir; na esfera das instituições religiosas, foi adaptada a um apelo ao passado da Igreja como recurso útil para a conquista dos fiéis, e assim por diante. Desse modo, no âmbito dessas esferas não se pode dizer que a manifestação neocolonial esteve totalmente desprovida de conteúdo ideológico. A pergunta que se faz, agora, é se, na esfera da produção particular - que inclui a produção residencial e comercial - e que é a mais extensa, ainda permaneceu um conteúdo ideológico ligado ao conteúdo original, ou se essa produção se deu apenas movida por um gosto, por uma moda.

Nesse sentido, os dados que levantamos durante a pesquisa, tanto os relativos à arquitetura oficial, institucional, como os referentes à particular, nos levam a admitir que aquele conteúdo ideológico, descrito anteriormente, esteja presente apenas em pequena parte da produção arquitetônica neocolonial que floresceu no interior paulista. Casos como os de companhias construtoras que levantaram muitos prédios, cuja arquitetura está alinhada ao neocolonial, mas que nada mencionam acerca dessa opção, ou exemplos em que a edificação, segundo seu proprietário, foi copiada de uma revista ou de um exemplar visto na cidade de São Paulo, confirmam a limitação de alcance da ideologia do movimento. Todavia, salientamos que, se não foi pelos motivos professados pela campanha neocolonial, foi por outros, que a arquitetura neocolonial se difundiu. Algo no universo daquela linguagem se identificou com o gosto de várias camadas sociais, resultando numa produção variada, na qual "sempre houve uma 
intenção plástica, e sua produção estaria, com toda justiça, inserida dentro daquilo que chamamos de arquitetura”, como assegurou Lemos (1985, p.169) sobre a arquitetura neocolonial difundia na cidade de São Paulo.

Devemos considerar que, também no interior paulista, a questão da difusão, por gosto ou por moda, esteve associada à influência da classe dominante sobre as outras, como já apontaram Lemos (1985) e D’Alembert (2003). Assim,

se por razões financeiras esta[s] classe [s] não podia $[\mathrm{m}]$ construir da mesma forma, pelo menos procurava[m] exibir algum elemento de referência da arquitetura erudita [ou elitista] nas fachadas de suas moradias, que simbolizasse o «status» almejado e personalizasse a edificação (D’ALEMBERT, 2003, p.144).

Nas décadas de 1930 e 1940, a diversificação de classes sociais também foi um fenômeno ocorrido nas cidades do interior do Estado de São Paulo, igualmente estimulado pela decadência do ciclo cafeeiro e pelo estabelecimento de indústrias. A vida urbana foi incrementada pelo crescimento populacional. As pessoas estabelecidas nas cidades agora atuavam como operários, profissionais autônomos, comerciantes, prestadores de serviços entre outros, diversificando a estrutura de classes sociais e gerando maiores oportunidades para a circulação e assimilação de idéias, de novidades e de modismos. Nesse ambiente, a novidade neocolonial - novidade em relação ao ecletismo, que foi a cultura formadora predominante das cidades paulistas - introduzida por grandes obras oficiais ou institucionais e por obras residenciais de elite, repercutiu e refletiu-se nas edificações das mais variadas classes sociais, talvez como maneira de exibir sua modernidade e marcar uma identificação com classes mais abastadas. Era um contexto que "induzia naturalmente à cópia ou imitação" (D’ALEMBERT, 2003, p.144).

Como ilustração para essa tendência de apropriação, reprodução e recriação - e até de "cópia ou imitação" - da linguagem neocolonial, destacamos a atuação de profissionais da construção civil, eruditos ou não, cujos projetos tivemos a oportunidade de analisar, através do acesso a processos de aprovação de obras, arquivados em prefeituras municipais. Já mencionamos que as exigências do mercado da construção, muito provavelmente, foram um apelo mais importante que as razões de um movimento arquitetônico que, ademais, estava distante. É certo que esse movimento elaborou e lançou uma nova estética, e foi justamente esse o aspecto de que se serviram 
profissionais e clientes, sem maiores preocupações do que, talvez, a apreensão de algo indefinido, vindo diretamente do passado, dos tempos coloniais, e que foi traduzido em forma de arcos, pedras, frontões etc. Estava, dessa forma, assegurada a evocação distante de uma memória e, algumas vezes, de um status. Porém, são alegações insuficientes para considerarmos que essa produção arquitetônica esteve imbuída da ideologia do movimento neocolonial. Demonstrativo desse processo é o fato de que vários profissionais, em seus escritórios, praticavam, concomitantemente, várias linhas arquitetônicas. Ao lado de projetos de inspiração arte déco ou eclética, encontramos outros influenciados pelo neocolonial, muitas vezes de autoria do mesmo engenheiro ou mestre-de-obras. Mais uma indicação da ausência do conteúdo ideológico nessa difusão neocolonial é que, nos processos de aprovação de obras, pesquisados, não encontramos, nos memoriais descritivos, menções aos aspectos estéticos, nem definição de determinados materiais, características ou ornamentações por razões de tradição ou identidade.

É importante observar ainda que, durante as décadas de 1930 e 1940, período em que encontramos maior número de obras neocoloniais, nos arquivos municipais das cidades que fizeram parte dessa fase da pesquisa, já havia no mercado um número considerável de profissionais eruditos - ou seja, engenheiros e arquitetos. Em contrapartida, na década de 1920, a maior parte deles era de construtores licenciados e de mestres-de-obras. Assim, pudemos verificar que parte do "neocolonial simplificado" foi construída por profissionais eruditos. Em Araras, dos onze projetos de interesse, referentes aos anos de 1949 e 1950, guardados pelo arquivo municipal, somente um é obra de profissional erudito; em Jaú, dos 24 projetos de interesse, apenas quatro apresentam a mesma característica. Em Rio Claro, dos 94 projetos encontrados, 36 são de profissionais eruditos; em Araraquara, de 31 projetos de interesse, 26. E, finalmente, em São Carlos, dos 79 projetos de interesse, 74 são de profissionais eruditos, sendo, esta, a cidade onde menos encontramos construtores ou mestres de obras responsáveis por obras neocoloniais (TABELA 1). Esses números, que não podem ser tomados como amostra estatística, indicam que uma parte expressiva da difusão neocolonial, mesmo a simplificada, foi realizada por profissionais diplomados. Indicam, ainda, quantidade maior de profissionais diplomados no mercado e, naturalmente, maior presença deles em cidades de maior porte. No caso de São Carlos, segundo mostra Bortolucci (1991, 
p.171-172), as edificações mais importantes foram construídas por engenheiros de São Paulo, sendo que
o restante das construções - mais simples e em maior número -, foi absorvido pelos engenheiros que se fixaram em São Carlos (...) [que] tiveram que dividir esta fatia do mercado de trabalho, principalmente as residências, com os construtores licenciados.

É oportuno, ainda, observarmos que os profissionais diplomados, encontrados, possuíam, provavelmente, a formação de engenheiro-arquiteto, já que as faculdades de Arquitetura, no Brasil, foram criadas a partir da metade da década de 1940, e seus alunos começaram a atuar a partir de 1950, já fora do nosso período de pesquisa ${ }^{2}$. Assim, ainda tomando São Carlos como exemplo, a primeira geração de construtores era de estrangeiros que imigraram, principalmente da Itália, no final do século XIX eram os construtores e mestres-de-obras. A segunda geração era dos filhos dos estrangeiros radicados na cidade e que "realizaram sua formação profissional nas escolas paulistanas, permitindo, desta forma, a continuidade da influência da arquitetura da capital nas construções sãocarlenses” (BORTOLUCCI, 1991, p.172). Esse processo pode ser estendido às demais cidades paulistas que fizeram parte da pesquisa, uma vez que em nenhuma delas havia escolas de engenharia, obrigando os que quisessem formar-se, a procurar a capital ou outros centros, fora do Estado ou do País (TABELA 2).

$\mathrm{Na}$ seqüência, analisamos alguns exemplares ilustrativos do processo de apropriação, recriação e difusão da arquitetura neocolonial, acima descrito. $\mathrm{Na}$ esfera das obras particulares encontramos uma grande variedade de obras que se encaixam, principalmente, na categoria destinada ao uso residencial e ao comercial, tanto de autoria erudita como popular ${ }^{3}$. Encontramos também exemplares rurais, um dos quais conforma um núcleo industrial e, por isso, trata-se de um exemplar incomum. Pelo fato de termos encontrado uma quantidade extensa de processos de aprovação de obras, nos arquivos municipais das cidades visitadas, e por termos também realizado o levantamento fotográfico dos exemplares que ainda permanecem, fizemos uma seleção daqueles que julgamos mais significativos, mostrados nos anexos, e, posteriormente, apresentamos uma lista de todas as obras levantadas, por ano (TABELA 1).

\footnotetext{
${ }^{2} \mathrm{Na}$ tabela em anexo, chamamos "arquiteto" ou "engenheiro" conforme constava nos processos.

3 Segundo INSTITUTO ANTÔNIO HOUAISS DE LEXICOGRAFIA (2001). "Popular: feito pelas pessoas simples, sem muita instrução".
} 


\section{Companhias Construtoras}

Mais um meio, através do qual a linguagem neocolonial se propagou, além daquele representado pelas obras oficiais e institucionais, pelas revistas e por outros meios de comunicação, foi a atuação de companhias construtoras. Essas, a exemplo de alguns engenheiros e arquitetos, trabalharam ao mesmo tempo com várias tendências arquitetônicas, inclusive com a modernista. Em 23 de Agosto de 1931, segundo Andrade (1998, p.5) foi fundada pelo engenheiro Urbano Alves de Souza Pereira (18871955) e seu cunhado José Haroldo de Mattos (1905-1997) e, segundo Ricci (2002, p.2), por acionistas da Companhia Taubaté Industrial, a Companhia Predial de Taubaté, que atuou até fins da década de 1960. Foi uma das mais importantes empresas da cidade naquele período, tendo construído entre 1932 e 1941

cerca de 400 prédios e reformou 50, sendo: 58 casas de alto padrão nas cidades de Taubaté, Pindamonhangaba, Tremembé e Caçapava; prédios comerciais, de escritórios e de apartamentos; cinema; escola; clube; asilo; hospital, entre outros (RICCI, 2002, p.2).

Os relatórios de contas da companhia, dos anos de 1932 a 1941, fornecem-nos uma amostra da produção realizada pela mesma, nessa década, e que engloba tanto edificações destinadas à clientela de alto, quanto a de baixo poder aquisitivo. No relatório de 1938, inclusive, foi publicado um mapa da cidade, com as obras realizadas pela companhia até então, que já eram em número considerável, para uma empresa de seis anos (FIGURA 192). Os relatórios mostram, também, que, a partir de 1934, excetuando-se o relatório de 1935, ao qual não tivemos acesso, constam em todos os relatórios anuais exemplos de edifícios de estética neocolonial construídos pela companhia. Alguns exemplares seguem a tendência portuguesa, de Ricardo Severo, chegando a ser bastante semelhantes às obras do engenheiro, em especial, a casa Numa de Oliveira, onde se destacam, na fachada, dois volumes cúbicos com beirais (FIGURA 193). Outros apresentam uma verdadeira colagem de estilemas de várias tendências, com telhados à portuguesa, colunas solomônicas e frontões (FIGURA 194). Outros, ainda, mesmo que mais simplificados, ostentam volumetria movimentada, painéis de azulejos, meias-luas sobrepostas para fechamento de guarda-corpos, beirais revirados, telhas rabo de andorinha, janelas quadrilobadas, coruchéus, pedras decorando a fachada, floreiras, volutas, arcos e alargamento de paredes laterais de arcos (FIGURA 195). Notamos que a empresa construiu, durante o mesmo período, além de edifícios de linhas 
neocoloniais, também vários exemplares de linhas ecléticas ${ }^{4}$, art déco e modernistas (FIGURA 196).

Na cidade de Jaú, encontramos a "Sociedade Imobiliária e Construtora de Jaú Ltda.", responsável pela venda de "prédios e terrenos, à vista e a prazo, no florescente e magnífico bairro da Vila Brasil" (SOLAR..., 1947). Constam como diretores da empresa, em 1947, Jarbas de Lima Portella, Enoch Amaral Camargo e Paulo Amaral Machado. As imagens que ilustravam os anúncios do jornal Comércio do Jaú, durante a década de 1940, mostram residências de aspecto neocolonial da vertente missões, com beirais, arcos, alargamento das bases das paredes, pedras irregulares como decoração das fachadas e, segundo se verifica pelo anúncio, voltadas para um público de médio poder aquisitivo (FIGURA 197). Entre os dados recolhidos no Arquivo Municipal de Jaú, verificamos que José Arduíno, construtor muito atuante desde a década de 1930, realizou projetos de linhas arquitetônicas predominantemente eclética e art déco, até muito tarde, em 1944. Em 1947, ele passa a trabalhar para a Sociedade Imobiliária e Construtora de Jaú, atuando em obras neocoloniais ${ }^{5}$. Consideramos esse detalhe como indicativo de que as companhias construtoras também tiveram importante papel, na difusão da tendência neocolonial.

O fato de a empresa de Taubaté trabalhar com diversas tendências arquitetônicas denota ausência de preocupação em seguir uma ideologia que estivesse por trás de uma manifestação arquitetônica, qualquer que fosse ela. Aqui não se trata do problema vivenciado por alguns arquitetos que sentiram aquele já mencionado constrangimento, ao admitir que houvessem, por certo tempo, praticado o neocolonial, nem da complexidade do pensamento de alguns outros, própria daqueles anos de muitas transformações, que se sentiam divididos entre as razões da tradição e da modernidade, como já citamos. Se a empresa assim procedeu, em nossa opinião, foi antes em função das razões do mercado que, certamente, estava aberto para tal variedade, entre elas, para a tendência neocolonial. Consideramos também que, embora ambas as empresas construíssem para diversas classes sociais, suas obras eram eruditas, posto que projetadas por companhias estabelecidas e que, necessariamente, deveriam contar com engenheiros e arquitetos, em seus quadros de funcionários.

\footnotetext{
${ }^{4}$ Ecléticas com recuos e com estética que evoca os chalets. As edificações ecléticas alinhadas à calçada já não aparecem entre as obras da Companhia Predial de Taubaté.

${ }_{5}$ Dados retirados das pranchas 23 e 24 , de 1947 , livro 16 , cujo projeto é de responsabilidade do construtor José Arduíno. Arquivo Municipal de Jaú.
} 


\section{Vilas Operárias}

Nosso interesse na arquitetura neocolonial, como já tivemos a oportunidade de mencionar, deu-se pela presença de um núcleo fabril rural em Araraquara, relacionado ao nosso objeto de pesquisa de mestrado, cujas instalações foram realizadas de acordo com essa tendência arquitetônica. Assim, já alertados para a possibilidade de existência de outros núcleos similares, procuramos identificá-los nas cidades em que desenvolvemos nossa pesquisa. Em Taubaté, encontramos a Companhia Fabril de Juta que, segundo Ricci (2002, p.2) “foi fundada em 1927, tendo sido suas instalações ampliadas em 1931, 1933 e 1943. Em 1941, instalou seções de tecelagem em Caçapava, Pindamonhangaba e Tremembé”. Estima-se que a unidade de Taubaté chegou a abrigar dois mil funcionários; passou por uma ampliação, entre os anos de 1943 e 1944, quando foram construídas mais 258 casas, além das já existentes (RICCI, 2002, p.2). A primeira vila teria sido construída nas imediações da fábrica, enquanto a segunda foi implantada aproximadamente a um quilômetro de distância, ambas nas imediações da cidade (RICCI, 2002, p.4). O que verificamos através do Álbum... (1945), é que, além das casas, a vila operária, construída na década de 1940, contava com uma estrutura que incluía escola, parque infantil e cinema e, atualmente, é o bairro denominado Vila São Geraldo. Tanto as escolas como o cinema exibem frontões curvos, arcos, coruchéus e telhas capa e canal, no telhado e nas decorações (FIGURA 198 e 199). O cinema, chamado Cine Boa Vista, tinha capacidade para até mil pessoas e funcionou até a década de $1960^{6}$. As casas são construídas em blocos únicos, geminadas umas às outras, com a água do telhado voltada para a rua; as aberturas são de vergas retas e os principais adornos são os dois frontões curvos com coruchéus nas fachadas principais; possui cada casa, pequenos jardins de entrada, separados dos vizinhos por um muro baixo e curvo e, da rua, por um muro constituído por elementos vazados (tijolos alternados) (FIGURA 200). No geral, os estilemas que nos permitem caracterizar a vila como neocolonial são simples e escassos, mas ainda assim mostram certa preocupação da empresa em oferecer aos seus operários mais que o mínimo. Ainda que parco, ofereceu um sentido de estética que, devido às circunstâncias da época, foi de tendência neocolonial.

${ }_{6}$ Disponível em: http://www.idesa.com.br/idesagora/index.php?cod=354\&edicao=25 Acesso em: 25/04/2008. 
De maneira um pouco diferente, no que diz respeito à intensidade da expressão estética, temos a vila operária da seção Sede da Usina Tamoio, de Araraquara. Seremos breves, nesse item, já que nossa dissertação de mestrado trata detalhadamente do assunto (MASCARO, 2003). Todavia, consideramos esclarecedor destacar alguns aspectos e mostrar algumas imagens, para uma comparação mais imediata, por parte do leitor. Nessa vila operária existem exemplares importantes da arquitetura neocolonial, como sua igreja e o estádio de futebol, além de o próprio nome ser significativo Tamoio. À entrada do complexo industrial foi erigida uma escultura de um índio Tamoio, figura romântica, relacionada ao resgate das raízes identitárias brasileiras (FIGURA 201). Se a arquitetura indígena não serviu de referência ao neocolonial, devido aos argumentos de Severo, logo no lançamento da campanha, por outro lado, a imagem do índio - idealizado, romântico - emergiu em diversos painéis de azulejos utilizados na decoração da arquitetura neocolonial, como referência às origens (FIGURA 202). Emergiu, inclusive, nessa forma inaudita de escultura, e no nome de uma usina paulista. Em 1940, começou a ser construída a igreja da seção Sede da usina, chamada Templo de São Pedro, e configurou-se como um exemplar neocolonial também incomum, devido às suas paredes e curvas, e devido, também, ao frontão principal que, além de curvo e com volutas, é curvo em planta. De acordo com nossa pesquisa anterior, essa característica nos remete diretamente à Igreja do Rosário, da cidade de Ouro Preto. Porém, contrasta com esta, nas proporções de suas torres e de outros elementos, como as das aberturas, do frontão principal e até da imagem de São Pedro sobre o portal de entrada, visível à distância. Tais proporções exageradas conferem à edificação um aspecto pesado. $\mathrm{O}$ interior segue o exagero, com quatro colunas salomônicas e uma moldura efusivamente decorada com florões, friso, cártula de rolo e anjos na entrada para o altar (FIGURAS 203). Outra edificação que faz parte dos equipamentos da vila operária da Tamoio, e que merece destaque, é o estádio de futebol chamado "Comendador Freitas". A entrada do estádio é marcada por um portal simétrico, também de proporções monumentais, com frontão curvo decorado com telhas capa e canal, e com o nome do estádio, com três arcos plenos sustentados por colunas e protegidas por um telhado. Dentro, arquibancadas e dois camarotes para a assistência especial, de plantas ovaladas, pequenos frontões nos acessos, guarda-corpos de meiasluas sobrepostas, telhados com beirais e telhas capa e canal (FIGURA 204). Algumas residências para os operários lembram as casas da Vila Fabril de Juta: geminadas e com pouca decoração; outras são maiores e isoladas nos lotes (FIGURA 205). 
Da mesma forma que para as companhias construtoras, consideramos que a arquitetura das vilas operárias citadas não se constitui em manifestações populares, pois existem, também nesses casos, profissionais eruditos envolvidos no desenvolvimento dos projetos das edificações dos conjuntos operários. Não nos foi possível identificarlhe os nomes, mas, certamente, na década de 1940, empresas do porte das aqui mencionadas - de cerca de dois mil operários - contavam com um departamento de projetos, ou os mandavam realizar em escritórios competentes. Por isso, consideramos que a arquitetura nelas implantada é de autoria erudita, embora algumas vezes,bastante simplificadas. As vilas operárias da Companhia Fabril de Juta, bem como da Usina Tamoio, mostram que o gosto neocolonial ganhou também a classe industrial e atingiu regiões rurais do interior paulista.

\section{Edificações Comerciais}

$\mathrm{Na}$ esfera das obras particulares, a linguagem neocolonial parece ter sido utilizada, preferencialmente, para prédios residenciais, enquanto a art déco destinou-se aos comerciais ou industriais. Esse processo faz parte da descrição de Segawa (1997, p.72), segundo a qual

na segunda metade dos anos de 1930, as arquiteturas «cúbicas»e art déco disseminavam-se entre os profissionais de várias regiões do Brasil. Em (...) revistas surgidas nessa época (...) havia uma convivência pacífica entre circunspectas obras tradicionalistas, exóticas casas neocoloniais e geométricas construções modernizantes em suas ecléticas páginas, com leve predominância das linhas modernas - ampliando-se esse domínio ano a ano, mais nos programas de âmbito coletivo (...) e menos nas obras residenciais.

Possivelmente, essa escolha estivesse ligada a determinada interpretação das linhas arquitetônicas que se divulgavam durante as primeiras décadas do século XX. A tendência art déco e também a modernista, com suas linhas retas e seu despojamento, em associação com os ecos de suas ideologias voltadas para o futuro, talvez tenham sido interpretadas como mais adequadas para edificações nas quais fosse conveniente exibir um potencial de modernidade. Em suma, a opção por esta ou aquela linha arquitetônica, para determinados usos que o prédio viria a ter, continuava a ser feita de acordo com uma interpretação simbólica de sua linguagem. Assim, encontramos, nos arquivos, 
prédios comerciais de inspiração art déco cuja autoria é a mesma de residências neocoloniais. Encontramos também exceções, representadas pelos postos de gasolina de inspiração neocolonial.

Podemos citar exemplos de prédios comerciais de inspiração art déco na cidade de Jaú, e em outras, realizados por vários construtores que praticaram diversas tendências arquitetônicas, inclusive a neocolonial. De autoria do construtor José Arduíno, encontramos o projeto de uma cabine de força, de 1939, para o senhor Jorge de Campos Jacuzzi, à Rua Prudente de Moraes, e um armazém de café, construído a Rua Marechal Bittencourt, em 1938. Do construtor Ângelo José Terreri, a loja de móveis "Jahu Progride", de 1938; e a loja dos Irmãos Cury \& Cia. Ltda, à Rua Paissandu, esquina Edgard Ferraz, de 1939. De responsabilidade do construtor Flávio Santomauro - um dos mais atuantes no mercado da construção de Rio Claro, no período -, encontramos um projeto para um "prédio para instalação de uma usina de beneficiar arroz" - de 1943, segundo consta no processo de aprovação enviado à prefeitura (FIGURA 206); encontramos também uma edificação de uso misto, com armazém e escritório voltados para a rua e uma pequena residência ao fundo, de 9147, de autoria do mesmo construtor. Em São Carlos, sem autoria identificada, encontramos o projeto para a "Firma Abdelnur e Remailli", que seria construída à Rua José Bonifácio, que data de 1944. Em Taubaté, construída pela Companhia Predial de Taubaté, em 1935, o edifício "Miranda", que abrigava, no térreo, o estabelecimento comercial "Casa Miranda", e no pavimento superior, escritórios (FIGURA 207) ${ }^{7}$. Poderíamos continuar a lista de projetos que confirmam essa inclinação para o emprego de influências art déco na arquitetura comercial e industrial, no entanto, importa, antes, mostrarmos algumas exceções à regra.

Nesse âmbito das exceções, interessou-nos, particularmente, os postos de gasolina - estabelecimentos comerciais muito ligados a um novo representante da era da máquina, o automóvel - realizados, surpreendentemente, segundo a tendência arquitetônica neocolonial. Justamente para esse tipo de estabelecimento, linhas arquitetônicas que evocassem o futuro e a modernidade pareceriam mais adequadas, como a art déco. Além do mais, essa linha "foi o suporte formal para inúmeras tipologias arquitetônicas que se afirmaram a partir da década de 1930”, como cinemas, sedes de emissoras de rádio (SEGAWA, 1997, p.61), rodoviárias e, também,

\footnotetext{
${ }^{7}$ Dados levantados nos Arquivos Municipais das respectivas cidades citadas.
} 
postos de gasolina. Ao contrário, a linha neocolonial foi predominantemente utilizada em tipologias há muito, conhecidas, como escolas, igrejas e residências. Não obstante encontramos, em diversas cidades paulistas, postos de gasolina neocoloniais, dificultando os nossos esforços para uma sistematização das razões da difusão dessa tendência arquitetônica, e colaborando para a confirmação de que, muitas vezes, a opção por esta ou aquela tendência era antes questão de gosto que de conteúdo ideológico. Em Taubaté, por exemplo, temos o "Posto de Serviço Atlantic", "fundado em 1925” (ÁLBUM..., 1945), com um grande telhado com beirais abrigando o espaço fechado, de escritório, e o espaço aberto para estacionamento dos automóveis. Possui, também, sobre o telhado, um frontão principal e frontões laterais, todos curvos, com volutas e coruchéus (FIGURA 208). Em Jaú, encontramos um projeto para um posto de gasolina, de autoria do escritório Sampaio \& Ferraz Ltda., que data de 1938. Constam, em seu programa, espaços para lavagem dos carros, oficina, loja e abrigo para estacionamento e abastecimento dos automóveis. Na fachada, molduras decorativas nas aberturas, frontões curvos com volutas e coruchéus; o telhado apresenta beirais com cachorros. O projeto da oficina foi realizado no ano seguinte, em 1939, e recebeu um tratamento mais simplificado (FIGURA 209). Em Rio Claro, encontramos dois exemplares de postos de gasolina neocoloniais - um deles no distrito de Santa Gertrudes. O primeiro, situado à Rua 1, esquina com a Rua 7, é de autoria do engenheiro Augusto Schmidt Filho e do desenhista Henrique Cristofani ,e data de 1937. O programa contempla ampla oficina, loja, escritório, sala de espera e aposentos para um funcionário, além do abrigo para abastecimento de combustível nas bombas. Apresenta linhas arquitetônicas da vertente missões, com colunas salomônicas e frontões arredondados. Possui também um frontão curvo em planta, sobre o telhado da esquina que foi destinada ao estacionamento dos automóveis; esse frontão é decorado com um painel de azulejos. Podemos observar também diversos outros elementos decorativos, como os coruchéus, detalhes quadrilobados nos frontões, telhas rabo de andorinha e gradis rebuscados (FIGURA 210). O posto de gasolina de Santa Gertrudes é um exemplar híbrido: sobre o abrigo para estacionamento, na esquina, ostenta um pequeno frontão com uma curva e com cimalha, sustentado por duas colunas solomônicas; as fachadas laterais não têm aspecto neocolonial, e exibem janelas verticais de vergas retas, e telhado com um pequeno oitão de vértices inferiores triangulares, similar a certas edificações ecléticas. O programa não inclui oficina, sendo, apenas um, posto de abastecimento. É híbrido também no uso, pois numa das laterais 
possui uma pequena casa em anexo. O projeto também é de autoria de Augusto Schmidt Filho e data de setembro de 1939; o processo foi cancelado em janeiro de 1940, pois a edificação não foi construída (FIGURA 211).

Além dos postos de gasolina, existiram outros prédios de estabelecimentos comerciais ou industriais de tendência neocolonial, embora tenham ocorrido em menor número que os de tendência art déco, segundo a amostragem que analisamos. Podemos tomar como exemplo um projeto para uma fábrica de móveis e duas residências para o senhor Aldemar Pícollo, que data de 1948, construídas à Rua Marechal Deodoro, em São Carlos. O projeto é de autoria do engenheiro civil Djalma Ferraz Kehl e, tanto na fachada das casas como na da fábrica, podemos ver estilemas que caracterizam a tendência neocolonial, como frontões e telhados com beirais e telha rabo de andorinha. O aspecto geral é simples e despojado de excesso de adornos (FIGURA 212 e 213).

\section{Edificações Residenciais}

Acreditamos que tenha sido no universo da produção arquitetônica residencial que a difusão da tendência neocolonial apresentou as mais variadas combinações de características e estilemas, incluindo-se aí, traços inventados. Foi também nesse universo que apresentou várias gradações, desde as mais rebuscadas às mais simplificadas. Essas formas de expressão foram sistematizadas por D’Alambert (2003), para o mesmo tipo de manifestação arquitetônica na cidade de São Paulo, ao que a autora chamou "maneirismo paulistano". A seguir, apresentamos um pouco dessa variedade, encontrada nos processos de aprovação de obras dos arquivos municipais e registrada em fotografias de uma série dessas habitações.

Antes, contudo, devemos nos deter na discussão sobre certos aspectos de alguns exemplares, pelo que significam no âmbito de nossa análise. Durante a pesquisa, nos deparamos com alguns casos comprovados de influência da arquitetura neocolonial da capital sobre a do interior, e de um profissional, vindo dos grandes centros urbanos, sobre outro, atuante fora deles. Um desses casos é representado pela residência da senhora Nara Herfer, construída na cidade de Catanduva, à Rua Aracajú, esquina com a Rua Ceará, em 1946, pelo construtor Elias Nechar. Em entrevista com a senhora Nara, ela nos informou que a casa teve por modelo uma casa "mexicana" existente na Lapa, 
em São Paulo, segundo contava seu pai (Informação verbal) ${ }^{8}$. De fato, a casa possui estilemas próprios dessa vertente "mexicana" ou missões, como o telhado movimentado com telhas capa e canal e beirais com cachorros recortados e, principalmente no interior, o forro de madeira rusticada, lembrando dormentes, madeira torneada fazendo o corrimão da escada e a decoração das portas de arco pleno, que lembram lemes. Porém, sua volumetria cúbica, movimentada e assobradada, com janelas de vergas retas, evoca antes a vertente portuguesa do movimento neocolonial, ligada a Ricardo Severo ou Victor Dubugras (FIGURAS 214). A senhora Nara nos contou também que, depois de pronta, a sua casa serviu de inspiração para outra residência na cidade, edificada pelo mesmo construtor. Trata-se também de um sobrado, mas erguido num terreno mais estreito, o que não permitiu movimentação volumétrica. Os demais estilemas, por outro lado, são muito semelhantes, como no emprego das pedras para revestimento da fachada, cunhais e pilares, na utilização de aberturas de vergas retas e molduras decorativas com mesmo motivo (FIGURA 215). Este caso retrata como uma influência vinda da capital proliferou no interior, e como um exemplar popular - ou seja, construído por um profissional não diplomado - no contexto da cidade, tornou-se uma obra emblemática, referencial para outras. Ou seja, foi uma "cadeia” de influências.

Na cidade de São Carlos encontramos mais dois, desses casos de influência, um exercido pela arquitetura - como no caso da casa da senhora Nara - e outro, por um profissional sobre outro. A residência do senhor Geraldo Paolillo foi construída na Vila Nery, à Rua São Sebastião, esquina com Rua Rodrigues Cajado, tal e qual uma casa que havia em São Paulo, como ele nos afirmou (Informação verbal) ${ }^{9}$. Esse é um exemplar típico da vertente missões, com torre circular com telhado cônico, arcos plenos na varanda frontal com decoração de pedras esparsas na moldura, e parede lateral alargada na base, conforme mostra o projeto original. Atualmente, seu aspecto está alterado, talvez devido a uma reforma que eliminou a torre circular e edificou, em seu lugar, um novo ambiente de planta retangular. Alguns ambientes internos também foram ampliados, mas sem prejuízo de seu aspecto exterior (FIGURA 216 e 217). Trata-se de outro caso de exemplar popular de médio padrão, e inspirado num exemplar situado na capital, mas munido de um conjunto de características que o tornam emblemático. $\mathrm{O}$ segundo caso mostra a presença do arquiteto Ângelo Murgel em São Carlos, através da

\footnotetext{
${ }^{8}$ Informações gentilmente concedidas em conversa pela senhora Nara, no dia 11/04/2007, em sua casa em Catanduva.

${ }^{9}$ Visita realizada a residência do senhor Geraldo Paolillo em outubro de 2004.
} 
autoria de uma obra, e sua influência sobre o engenheiro Djalma Ferraz Kehl, autor de diversas obras na cidade. De acordo com Bortolucci (1991, p.169), Djalma Ferraz Kehl

era formado na Escola Politécnica de São Paulo, em 1928, e esteve em São Carlos como diretor técnico da Companhia Paulista de Eletricidade, da qual sua família era a principal acionista. Foi longa sua permanência na cidade, em função de interesses familiares.

Foi casado com Diva Murgel, possivelmente irmã de Ângelo Murgel. Em 1944, Djalma Ferraz Kehl foi o engenheiro responsável pela construção de sua própria casa, situada à Rua São Sebastião, segundo projeto do arquiteto Ângelo Murgel. Esse exemplar assobradado, de volumetria cúbica, telhado movimentado, "telhas de barro typo colonial" ", revestimento de pedras nas paredes externas e janelas de vergas retas, parece inspirado na vertente neocolonial de matriz portuguesa ou de referência na produção de Victor Dubugras. Por outro lado, os beirais generosos, com cachorros aparentes de madeira, decorações com elementos de madeira torneada, e janelas tripartidas de arco pleno, evocam a vertente missões (FIGURA 218 e 219). É um exemplar erudito e emblemático, no contexto da cidade, que exerceu influência através da atuação de Djalma Ferraz Kehl. Essa influência se evidencia na fábrica de móveis, já citada, e em outros projetos, como no da residência para Alberto Martins, à Rua Marechal Deodoro, de 1944 (FIGURA 220); na reforma da residência de Jorge Angelino, à Rua D. Pedro II, de 1946, que acrescentou beirais na fachada com recuo, uma proteção de entrada com arco e telhado de telhas capa e canal e telhas sobre as janelas da fachada com platibanda alinhada à Rua (FIGURA 221); no da residência para Vicente Gagliardi, à Rua XV de Novembro, de 1946, que é quase uma miniatura da sua própria casa (FIGURA 222); no da residência para Samuel de Oliveira, à Rua 9 de Julho, também de 1946, que já exibe muitos estilemas da vertente missões, como o arco de entrada com aplicação de pedras esparsas na moldura, vários arcos plenos e várias colunas salomônicas (FIGURA 223); e no da residência de Luiz Valentie de Oliveira, também à Rua 9 de Julho, e também de 1946, sobrado de arcabouço e estilemas muito semelhantes à sua casa e ao seu projeto anteriormente citado (FIGURA 224).

\footnotetext{
${ }^{10}$ Transcrição de Informação que consta no memorial descritivo do processo de aprovação da referida obra.
} 
Possivelmente, o engenheiro sãocarlense já houvesse tomado contato com a ideologia e a estética do movimento neocolonial, pois esteve em São Paulo pelo menos até 1928, quando terminou os estudos, e seu nome apenas aparece nos livros de impostos de São Carlos a partir de 1935 (BORTOLUCCI, 1991, p.169). Uma evidência dessa possibilidade é um projeto seu, de 1940, que possui beiral e telhas rabo de andorinha (FIGURA 225). Assim, além da predisposição, em Djalma Ferraz Kehl, para se envolver com as questões neocoloniais, e expressar isso em seus trabalhos predisposição provavelmente criada pelo ambiente em que viveu antes de se radicar em São Carlos - existiu, certamente, troca de idéias com Ângelo Murgel, fatores que propiciaram a difusão dessa tendência arquitetônica no mencionado município.

Observamos, nos processos levantados, outro aspecto que, afinal, configurou-se como mais uma maneira pela qual a difusão da arquitetura neocolonial se deu. Essa maneira está relacionada ao marcado da construção e, embora tenha sido, muitas vezes, realizada por profissionais diplomados, trata-se de um procedimento que resultou em exemplares de baixo padrão e, portanto, de características simplificadas: as casas de aluguel. Podemos citar como exemplo as sete casas de propriedade do engenheiro Augusto Schmidt Filho, projetadas por ele próprio em Rio Claro, em 1947. Todas as casas têm uma planta comum e diferem no desenho da fachada, sendo algumas com arcos, algumas com linhas curvas e outras com linhas retas (FIGURA 226). No limite da simplificação, representado por esses prédios, ainda podemos reconhecer uma ligação com a arquitetura neocolonial. Podemos citar também o caso das seis residências projetadas pelo engenheiro Rodolpho Fehr para Gelsomino Saia, em 1940, na cidade de São Carlos. Três das casas possuem telhado com beiral, arco e pedras decorativas, e outras três são casos de difusão da linha art déco (FIGURA 227). Casos parecidos são os das habitações, nas quais proprietário e autor coincidem, mas são de padrão médio, e destinadas ao aluguel ou à venda, como no caso de outros dois exemplares de Augusto Schmidt Filho. Possuem frontões, coruchéus, frisos e pedras na fachada (FIGURA 228). Evidentemente, existem casos semelhantes em que proprietário e autor não são a mesma pessoa, porém são mais difíceis de serem identificados, a menos que o projeto preveja um conjunto de casas iguais, formando vilas, como as de autoria, também, de Augusto Schmidt Filho e propriedade de Fernando Guerreiro, 
construídas à Rua 7, em Rio Claro, em 1941. São três sobrados de médio padrão, com pequenas diferenças nas fachadas, como na decoração e nos arcos (FIGURA 229).

Por último, devemos destacar também os casos de reforma em edificações como especialmente representativos da força que teve a moda neocolonial. Conhecemos alguns casos importantes - tidos atualmente como desastrosos, por terem desfigurado, ou mesmo destruído, obras de patente valor patrimonial - que foram objeto de reforma "neocolonializante". Essa, portanto, parece ter sido uma tendência que também se difundiu, criando, em exemplares da arquitetura comum, feições neocoloniais. Já mencionamos, anteriormente, um trabalho realizado pelo engenheiro Djalma Ferraz Kehl que se insere nesta categoria, mas encontramos vários outros. Em Araras, em 1950, a fachada da residência de Eugenio Ruegger foi reformulada pelo construtor Octávio Daltro e ganhou um pequeno frontão arredondado, decorado com telhas na cimalha (FIGURA 230). Em Rico Claro, segundo projeto do construtor Flávio Santomauro, de 1943, uma pequena edificação, ainda construída no alinhamento da calçada, foi transformada em residência, e ganhou voluta e telhas decorativas sobre a porta, janela e portão lateral (FIGURA 231). Em São Carlos, uma reforma, de 1950, para acrescentar uma sala comercial em anexo a uma residência, atribuiu à fachada, também alinhada à calçada e com entrada lateral, frontões curvos com volutas, conchas, coruchéus; na base, e aplicação de uma faixa de pedras. Sobre a entrada, um arco decorado com telhas e uma coluna salomônica, que se repete numa das janelas. O projeto data de 1950, do engenheiro Abrahão Schevz, executado pelo construtor Humberto Sorregotti (FIGURA 232). Provavelmente, traços e estilemas da linguagem neocolonial foram transmitidos aos construtores através dos projetos dos engenheiros. Os engenheiros diplomados eram uma categoria mais recente de profissionais, que viveram, ao menos por algum tempo, nos centros onde estavam as escolas em que se formaram e, certamente, trouxeram para o interior algumas novidades, ao passo que os construtores, mesmo em contato com as novidades, através dos meios de comunicação, estavam mais habituados ao modo de fazer eclético. Nessas reformas, das quais citamos apenas alguns exemplos, verificamos o estabelecimento do novo gosto, muitas vezes sobre exemplares remanescentes do ecletismo. 
Aqui cabem algumas observações sobre os profissionais identificados em cada cidade. Alguns deles vinham de famílias de construtores que já atuavam nas cidades desde o início do século XX. Caso da família Terreri, de Jaú, que já vinha trabalhando na construção civil desde, pelo menos, 1919, quando aparecem processos cujos responsáveis são Domingos Terreri \& Irmãos. Também é o caso da família Sorregotti, de São Carlos, em que o pai, Umberto, trabalhou no setor da construção civil com seus filhos Olívio, Henrique e Mário (BORTOLUCCI, 1991, p.177). Outros, como já assinalamos, eram os filhos de imigrantes enriquecidos, que conseguiam cursar escolas de engenharia nas capitais. Caso da família Fehr, de São Carlos, em que os irmãos "Rodolpho e Theodoro, filhos do empreiteiro e, posteriormente, grande empresário Germano Fehr" (BORTOLUCCI, 1991, p.171), tornaram-se engenheiros civis. Outros, ainda, se tornaram figuras de relevo, no contexto da cidade, tendo até mesmo se tornado lideranças políticas. É o caso de Augusto Schmidt Filho, de Rio Claro, que se tornou prefeito da cidade nos anos de 1930, e foi homenageado, emprestando seu nome ao Estádio Municipal, inaugurado em 1973, e projetado pelo engenheiro Marco Antonio Padula (TABELA 2). Nos anexos, apresentamos mais projetos e fotos de exemplares significativos encontrados nas cidades onde se realizou a pesquisa. 
CONSIDERAÇÕES FINAIS 
Desde o início desta pesquisa - que trata principalmente da arquitetura neocolonial no interior paulista - quando sentimos a necessidade de ampliar a compreensão sobre o movimento que lhe deu origem e fomos levados a Portugal para conhecer melhor uma figura, por assim dizer, paralela à figura de Ricardo Severo Raul Lino - percebemos que houve um amplo contexto a envolver o fenômeno brasileiro. Atualmente, acreditamos que o movimento neocolonial não pode ser compreendido sem considerarmos o seu aspecto romântico, que muito contribuiu para determinados interesses de seus arautos. $\mathrm{O}$ apelo do passado - sob a forma do interesse pela etnia, pela arqueologia, pela identidade, pela tradição -, durante as últimas décadas do século XIX e as primeiras do XX, exerceu grande influência no espírito da classe intelectual e artística de vários países. No Brasil, essa nostalgia, motivada inclusive por questões de afirmação de identidade, teve expressão no movimento neocolonial e na sua arquitetura. Assim, podemos afirmar que, embora muito motivado pela influência norteamericana, através do cinema e outros meios de comunicação, como já nos havia alertado Amaral (1994), o movimento neocolonial teve sua ascendência no ambiente cultural em que esteve inserido Portugal naquele período.

Nossa hipótese inicial previa a existência de obras emblemáticas nas cidades do interior paulista que faziam parte da pesquisa e que, provavelmente, teriam funcionado como difusoras de uma tendência arquitetônica, o que foi comprovado. Entretanto, tínhamos conhecimento de que os prédios dos campi da Universidade de São Paulo de Ribeirão Preto e de Pirassununga eram neocoloniais, o que nos abriu um novo veio para investigação e, além disso, nos despertou para o fato de que houve uma expressiva produção neocolonial na esfera oficial. Em decorrência, verificamos que a difusão da tendência no interior paulista se deu, além das obras oficiais, através de obras institucionais, o que configurou uma gradação intermediária entre as obras pioneiras e as obras da difusão.

Essas obras da gradação intermediária foram, na maior parte das vezes, emblemáticas e de importância incontestável no que tange à força de influência que tiveram para difundir a linguagem arquitetônica que as constituiu. Nesse sentido, admitimos que, em seu raio de alcance, essas obras tiveram uma conotação de originalidade, pois funcionaram como referência. Em alguns casos, mesmo não sendo oficialmente protegidas por órgãos oficiais de preservação, percebemos que existe por parte da comunidade onde estão inseridas um cuidado para mantê-las. Bons exemplos 
são os casos onde foram construídas edificações mais recentes como parte do conjunto neocolonial original, segundo uma arquitetura inspirada naquela existente em seu entorno. Prescindimos aqui de debater se seriam casos de pastiche, cópia etc., pois nos interessou antes perceber como o conceito de originalidade pode ser relativo.

Entendemos ainda que, especialmente, nas esferas oficial e institucional, e em alguns exemplares da esfera privada, existiu um conteúdo ideológico que, se não era exatamente o mesmo que existiu no caso das obras pioneiras, foi baseado nele e reformulado segundo determinados interesses. Por outro lado, confirmamos que a ideologia neocolonial não atingiu a esfera da difusão generalizada por diversas razões. Dificuldades, por parte dos profissionais, em acompanhar os debates que se desenrolavam na capital paulista e carioca devido à distância; exigências do mercado imobiliário, como escassez de materiais exigidos na prática do ecletismo, anseio da sociedade por modernidade, anseio das camadas menos favorecidas da sociedade em aderir aos modelos das mais favorecidas, circulação de informações facilitada; e, a fácil aceitação da linguagem neocolonial, foram motivos suficientes para impulsionar a difusão da tendência por mais de três décadas no interior paulista, chegando a meados de 1950, prescindindo da retaguarda das idéias iniciais.

Especificamente sobre a arquitetura religiosa neocolonial podemos dizer que a referência não foi apenas a arquitetura barroca, mas uma arquitetura colonial anterior. Tendo chegado ao Brasil muito cedo, já no início do século XVI com o descobrimento, cedo também as ordens religiosas - jesuítica, franciscana e outras - começaram a construir uma arquitetura específica. Via de regra, assumimos que a arquitetura colonial, na qual o movimento de Ricardo Severo procurou se pautar foi a barroca ou a arquitetura civil anônima. Contudo, como sabemos, o período colonial foi longo e a produção arquitetônica durante esse período também passou por adaptações e transformações. Considerá-la com um todo homogêneo é um equívoco, inclusive pelas especificidades regionais que apresenta. Como exemplo, podemos tomar a arquitetura religiosa que, em seus exemplares do século XVI e XVII - primeiros mosteiros, conventos e reduções jesuíticas -, foram construídos ainda segundo alguns parâmetros maneiristas, às vezes, expressando uma transição para a arquitetura barroca. Assim, essa arquitetura também serviu de inspiração para edifícios religiosos construídos no século $\mathrm{XX}$, cuja herança pode ser percebida em alguns traços como os que identificamos nos prédios dos seminários e igrejas neocoloniais analisados. 
Cabe agora, também, esclarecer mais sobre nosso entendimento acerca da arquitetura neocolonial. Acreditamos que o termo neocolonial refere-se a uma produção bastante ampla e que, inclusive, refere-se a produção latino-americana de motivação similar e contemporânea. No Brasil, essa produção apresentou especificidades que se manifestaram em vertentes, tais como a vertente de características portuguesas - como a lançada por Ricardo Severo - e a vertente hispânica, ou missões, vinda através da influência norte-americana e da mexicana. Contudo, é muito difícil definir exemplares puros de uma ou outra vertentes, visto sempre se apresentam miscigenados, especialmente, em obras de difusão.

No decorrer das pesquisas nos arquivos municipais, encontramos variada documentação que colocaram em evidência, principalmente, a partir da década de 1930, o abandono da linguagem eclética em prol de novas tendências arquitetônicas. Os códigos de obras fizeram quase desaparecer as edificações nos alinhamentos das calçadas, induzindo a que as novas estéticas se adaptassem a esse requisito. Talvez, por esse motivo, uma das características da arquitetura neocolonial seja o muro baixo em frente à construção, em geral revestido de pedras. Outro atributo da tendência é que ela se constituiu na opção mais aceitável, na ausência do ecletismo, face o arrojo das linhas retas e do despojamento das correntes art déco e modernista. A arquitetura neocolonial ocupou, portanto, um importante espaço no contexto urbano do período, representando, como se pretendia desde o início da campanha, a opção local - se não brasileira, ao menos paulista - de expressão arquitetônica.

A difusão da arquitetura neocolonial foi produto, entre outros fatores, também de uma conjuntura histórica e social em que filhos de imigrantes radicados no interior do estado paulista alcançaram condições para buscar as escolas que os habilitaria a trabalhar, por vezes, no mesmo setor que seus pais ou avós. Houve, assim, pela primeira vez um incremento do número de engenheiros civis no mercado imobiliário das cidades do interior. Com isso, o conhecimento sobre o movimento neocolonial adquirido pelos engenheiros nas escolas dos grandes centros gerou obras emblemáticas, mas também foi rapidamente neutralizado por limitações de ordem econômica. Assim, foi gerado um sem-número de obras neocoloniais simplificadas, algumas vezes até o extremo, produzidas por profissionais diplomados e não apenas pelos construtores, que ainda resistiam no mercado. Destacamos, dessa forma, que a difusão neocolonial, não foi 
devida somente aos profissionais sem diploma e pudemos distinguir qual foi a contribuição dos diferentes profissionais envolvidos.

Agora, no momento final desta pesquisa, quando olhamos para sua trajetória, nos damos conta de que o nosso objeto se expandiu muito ampla e deixou margem para futuros estudos. A principal continuidade seria o aprofundamento das análises dos prédios, do ponto de vista da arquitetura, pois diante de tantas obras por nós levantadas, nos foi impossível realizar também estudos mais pontuais e detalhados. Outro exemplo de continuidade seria uma pesquisa específica sobre a produção realizada pela Diretoria de Obras Públicas de São Paulo durante 1930 e 1950 pode trazer à luz importantes obras neocoloniais instaladas no interior paulista. Pesquisas sobre a produção de companhias construtoras que aturam no âmbito de determinadas regiões paulistas também podem ser relevantes. Instituições assistenciais, clubes ou postos de gasolina neocoloniais igualmente merecem atenção mais detalhada. Mesmo sobre a arquitetura neocolonial residencial do interior ainda há muito a ser estudado, inclusive abordando o aspecto do alcance que a difusão alcançou, pois temos notícias de várias outras cidades, que não fizeram parte dessa pesquisa, em que a produção neocolonial está presente. Assim, apesar de nossa extensa "varredura" e dos vários campos abertos para pesquisa, certamente, ainda existe muito a ser explorado sobre o tema e na região do interior paulista.

Finalmente, queremos manifestar nossa motivação pelo tema da pesquisa que, assim como o próprio objeto da mesma, foi fruto dessa nostalgia inerente pelo passado, por uma explicação para o que somos, por uma busca pelo início do fio do novelo... Talvez tenha sido esse mesmo sentimento o que promoveu a grande adesão pela estética neocolonial, mostrada nessa pesquisa. $\mathrm{O}$ gosto pelo beiral, pelo arco, pela telha capa e canal, pelo azulejo e pela curva, de alguma forma, responderam às vozes emanadas dos tempos coloniais e que ecoam na bagagem cultural do paulista - talvez, também, na do brasileiro e mesmo na do latino-americano. Não é raro encontrarmos à venda portas e janelas "coloniais" ou nos depararmos com uma casa de "estilo colonial", a nos mostrar que a identidade sempre será questão presente na arquitetura. Por isso, é tempo de direcionar esforços no sentido de conhecer melhor a arquitetura neocolonial e encará-la como patrimônio merecedor de salvaguarda. Antes que se transforme num passado sem testemunhos. Antes que as vozes se calem... 


\title{
Difusão da Arquitetura Neocolonial no Interior Paulista, 1920-1950
}

\author{
Luciana Pelaes Mascaro
}

Tese apresentada à Escola de Engenharia de São Carlos da Universidade de São Paulo, como parte dos requisitos para obtenção do título de Doutor em Arquitetura e Urbanismo.

Área de Concentração: Tecnologia do Ambiente Construído

Orientadora: Profa. Dra. Maria Ângela Pereira de Castro e Silva Bortolucci

V. 2

São Carlos

2008 
AUTORIZO A REPRODUÇÃO E DIVULGAÇÃO TOTAL OU PARCIAL DESTE TRABALHO, POR QUALQUER MEIO CONVENCIONAL OU ELETRÔNICO, PARA FINS DE ESTUDO E PESQUISA, DESDE QUE CITADA A FONTE.

Ficha catalográfica preparada pela Seção de Tratamento da Informação do Serviço de Biblioteca - EESC/USP

Mascaro, Luciana Pelaes
M395d Difusão da arquitetura neocolonial no interior paulista, 1920-1950 / Luciana Pelaes Mascaro; orientadora Maria Ângela Pereira de Castro e Silva Bortolucci. -- São Carlos, 2008.

Tese (Doutorado-Programa de Pós-Graduação em Arquitetura e Urbanismo e Área de Concentração em Teoria e História da Arquitetura e do Urbanismo) -- Escola de Engenharia de São Carlos da Universidade de São Paulo, 2008 .

1. Arquitetura neo-colonial. 2. Arquitetura paulista. 3. Difusão. 4. Escolas práticas de agricultura.

5. Arquitetura oficial. 6. Arquitetura institucional.

7. Arquitetura residencial. I. Título. 


\section{SUMÁRIO}

Volume 1

INTRODUÇÃO $i$

CAPÍULO 1 - ASCENDÊNCIA DO MOVIMENTO TRADICONALISTA NO BRASIL 1

1.1. Ricardo Severo, a Casa Portuguesa e o Neocolonial ............................. 3

1.2. Raul Lino no Contexto do Movimento Tradicionalista Português........... 9

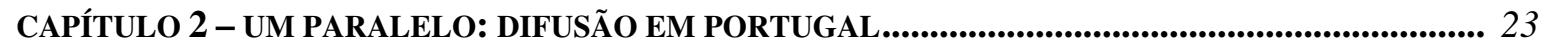

2.1. Circunstâncias Gerais, 1933-1950......................................................... 24

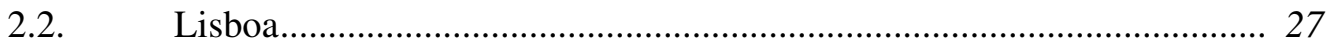

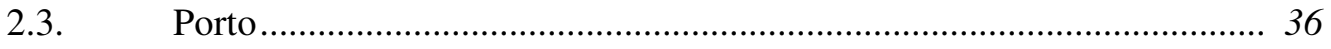

2.4. Cascais, Parede e Estoril …................................................................... 38

CAPÍTULO 3 - O NEOCOLONIAL NA HISTORIOGRAFIA................................................................... 41

3.1. Até os Anos 30: Os Primeiros Debates .................................................... 43

3.2. Os Anos 40 e 50: Afirmação de uma Linha Historiográfica .................... 49

3.3. Os Anos 60 e 70: Escassez de trabalhos sobre o tema ............................ 52

3.4. Os Anos 80 e 90: Abertura para Outros Enfoques .................................. 56

3.5. Trabalhos Recentes: Ajustes na linha historiográfica ............................ 76

CAPÍTULO 4 - ARQUITETURA NEOCOLONIAL PAULISTA: IMAGEM OFICIAL .............................. 87

4.1. A Elaboração de Uma Imagem ......................................................... 91

4.2. Fernando Costa combate o Jeca Tatu .................................................. 94

4.3. Obras Oficiais - Eruditas (Análise da Arquitetura) ................................. 110

CAPÍTULO 5 - APROPRIAÇÃO, RECRIAÇÃO E DIFUSÃo DA ARQUITETURA

NEOCOLONIAL PAULISTA ..................................................................................................... 129

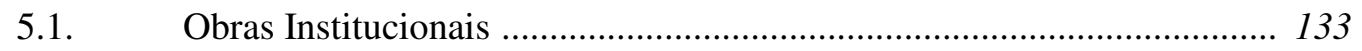

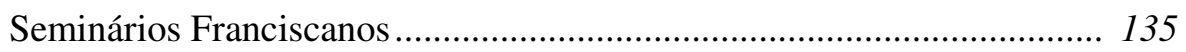

Igrejas, Santuários e Catedrais ........................................................ 148

Edifícios Assistenciais ................................................................... 157

Edifícios para Atividades Educativas .................................................... 160

Edifícios para Atividades Recreativas .............................................. 162

5.2. Obras Particulares .......................................................................... 167

Companhias Construtoras ........................................................ 172

Vilas Operárias ………………......................................................... 174

Edificações Comerciais .................................................................. 176

Edificações Residenciais ................................................................... 179

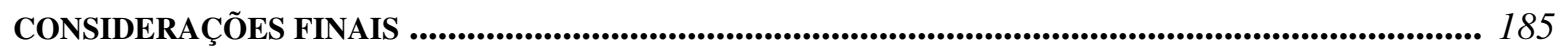


Volume 2

CAPÍULO 1 - IMAGENS

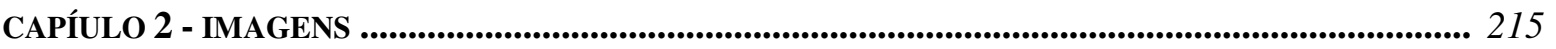

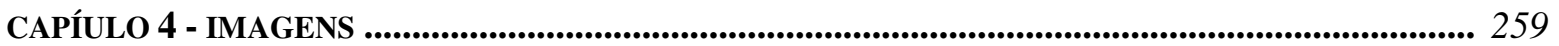

CAPÍULO 5 - IMAGENS ...................................................................................................................................... 355

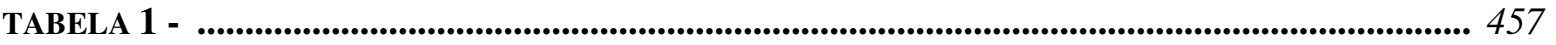

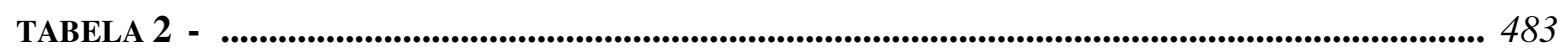

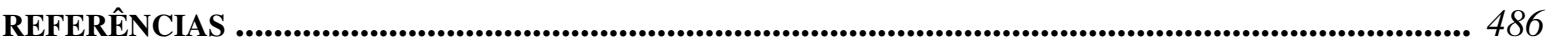

ANEXos - Levantamentos nos Arquivos Municipais e Fotografias (CD-ROM) 


\section{Capítulo 1}

\section{ASCENDÊNCIA DO MOVIMENTO TRADICONALISTA NO BRASIL}





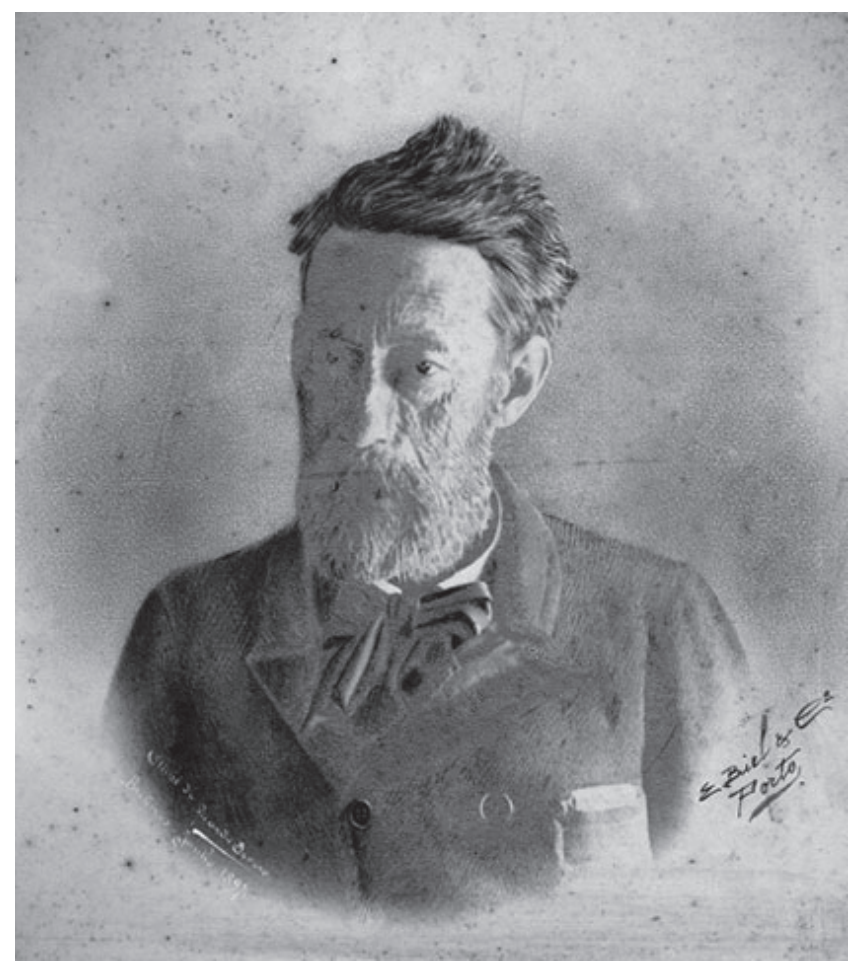

Figura 1 (ao lado) - Francisco Martins Sarmento. Cliché de Ricardo Severo tirado na casa da Ponte, em Briteiros, em Junho de 1897. Fonte: Casa de Sarmento, Centro de Estudos do Patrimônio. Disponível em http:/ / w w w . c s a r m en t o. u min ho.p t/ nephl_211x.asp?tematica $=3 \&$ offset $=60$. Acesso em: 16/02/2006.

Figura 2 (abaixo) - Lista de obras que haviam pertencido ao engenheiro Ricardo Severo, incluindo obras do próprio engenheiro. Fonte: Livraria Manuel Ferreira - Alfarrabista, cidade do Porto.

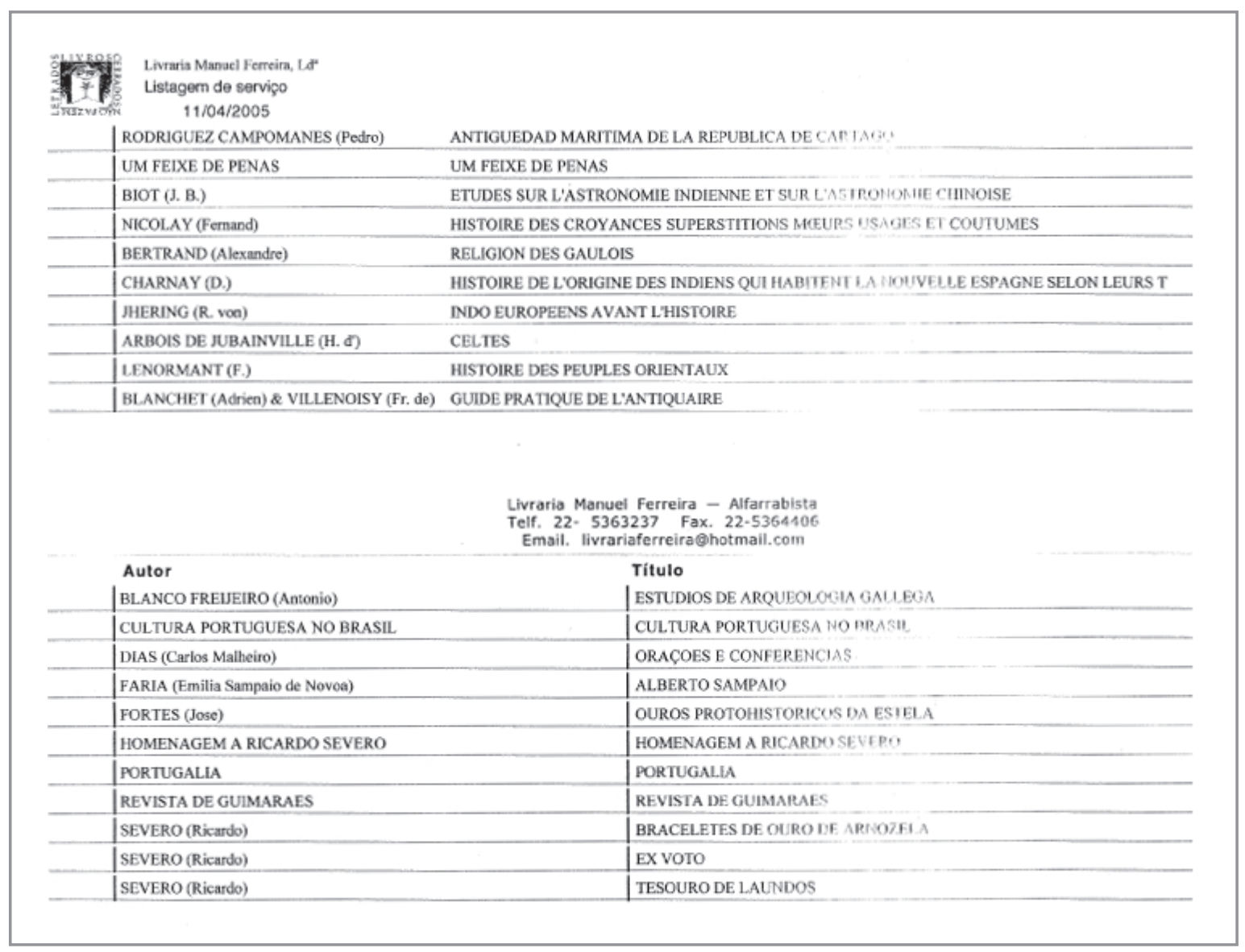



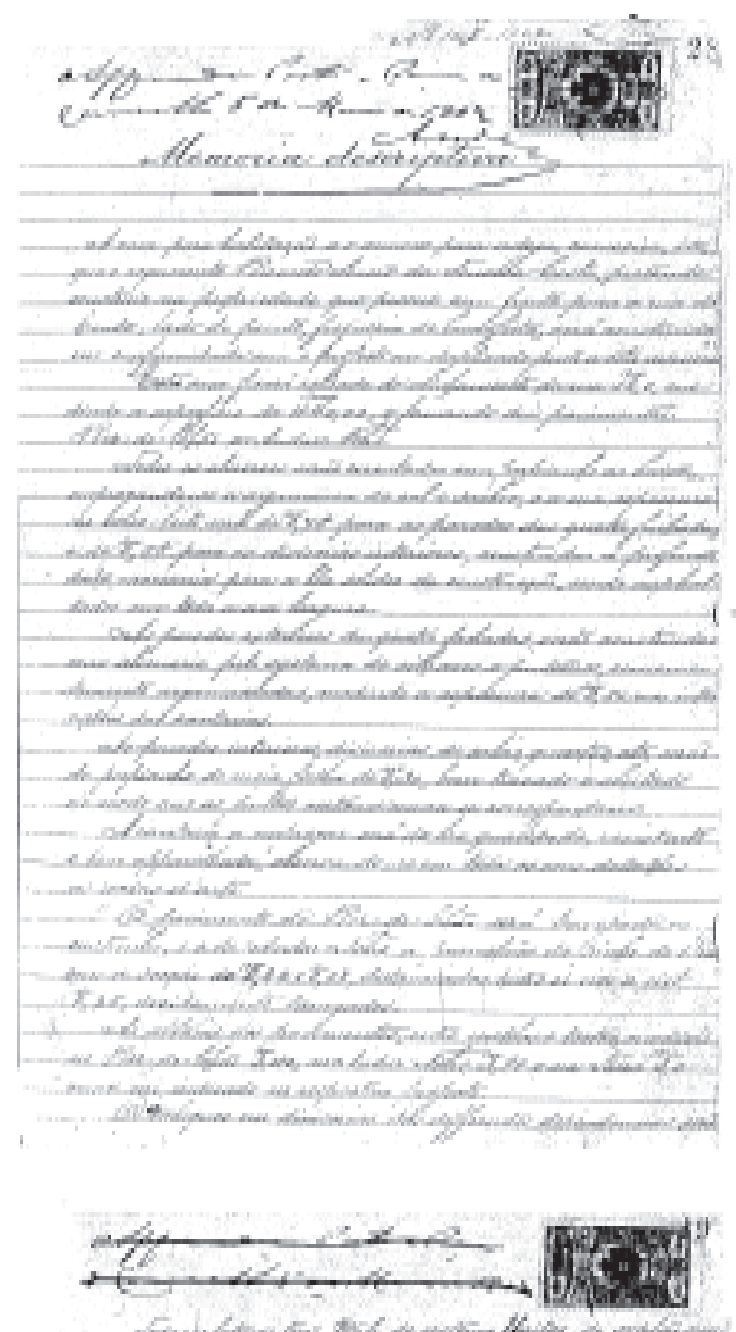

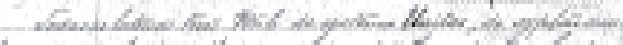

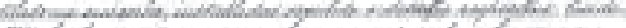

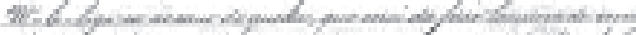

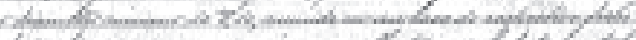

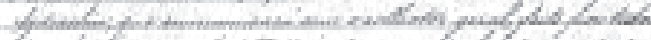

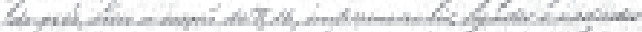
C6.

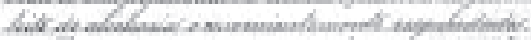

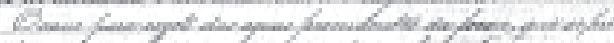

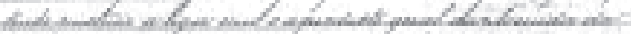

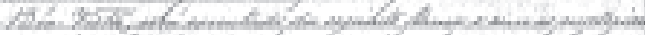

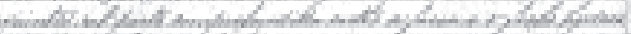

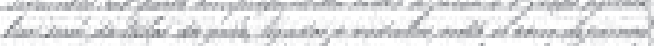

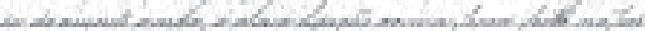

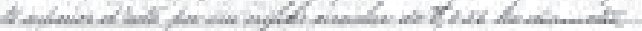

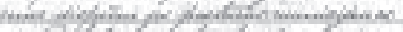

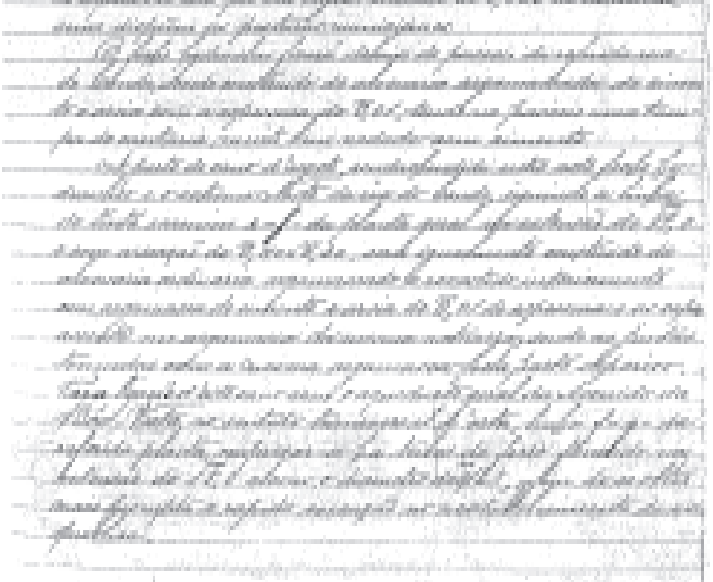

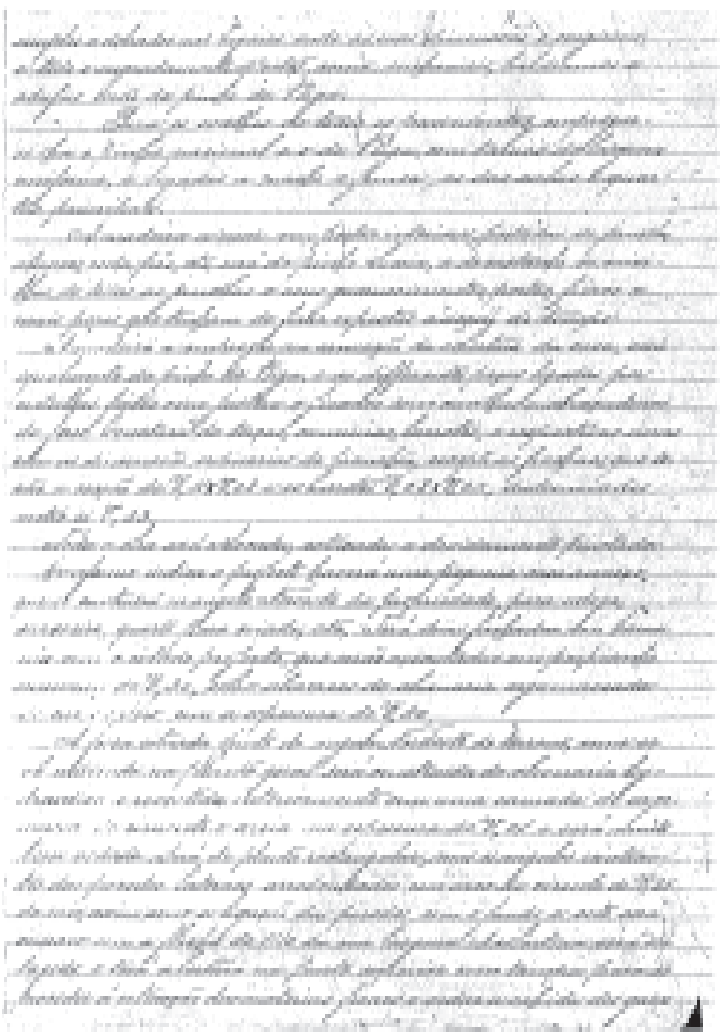

Figura 3 (páginas 194 e 195) - Processo para requerimento de licença para construção. Casa do engenheiro Ricardo Severo, localizada à Rua do Conde (atual Rua Ricardo Severo), Porto, Portugal, 1902. Fonte: Arquivo Municipal do Porto. 

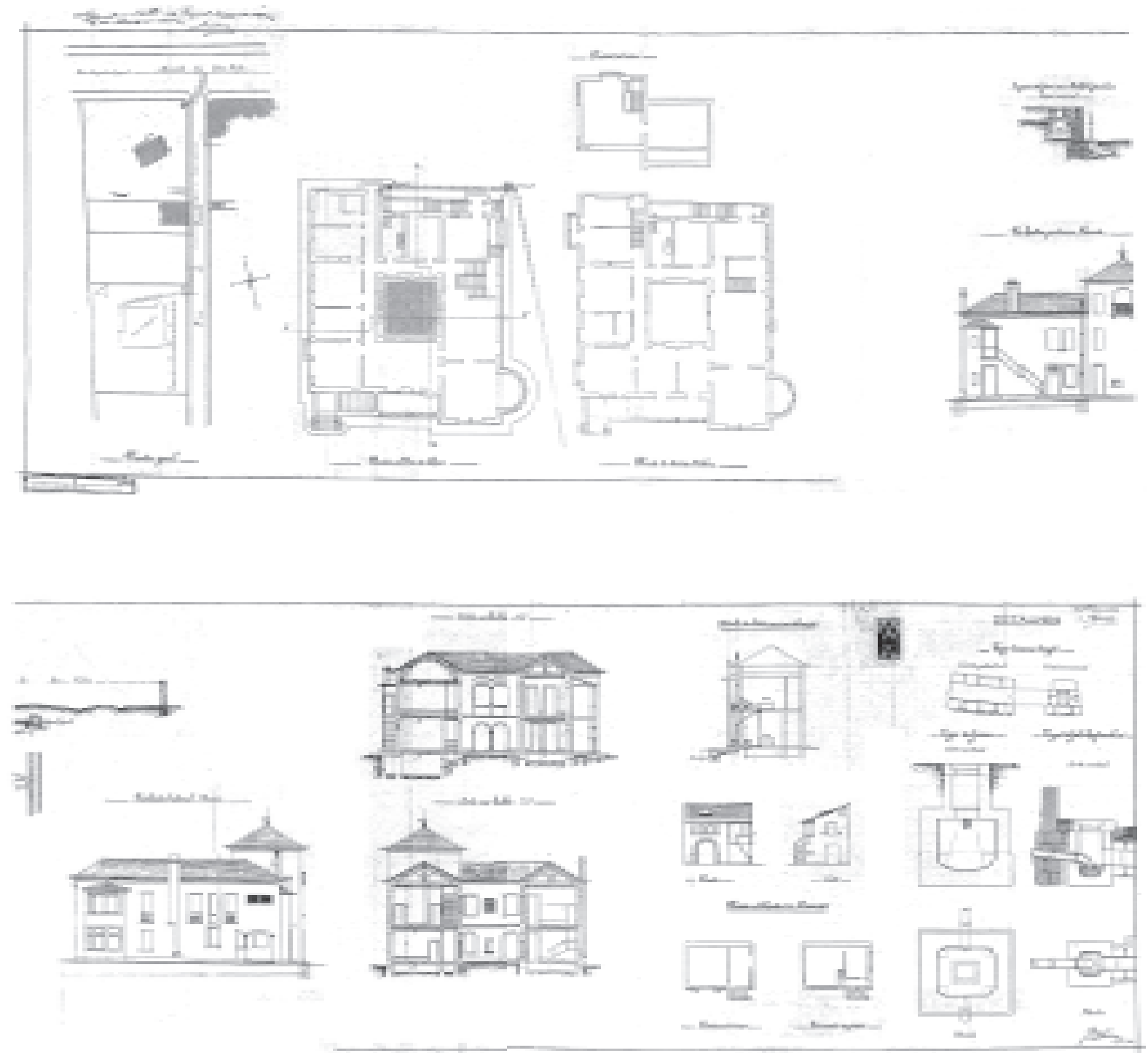

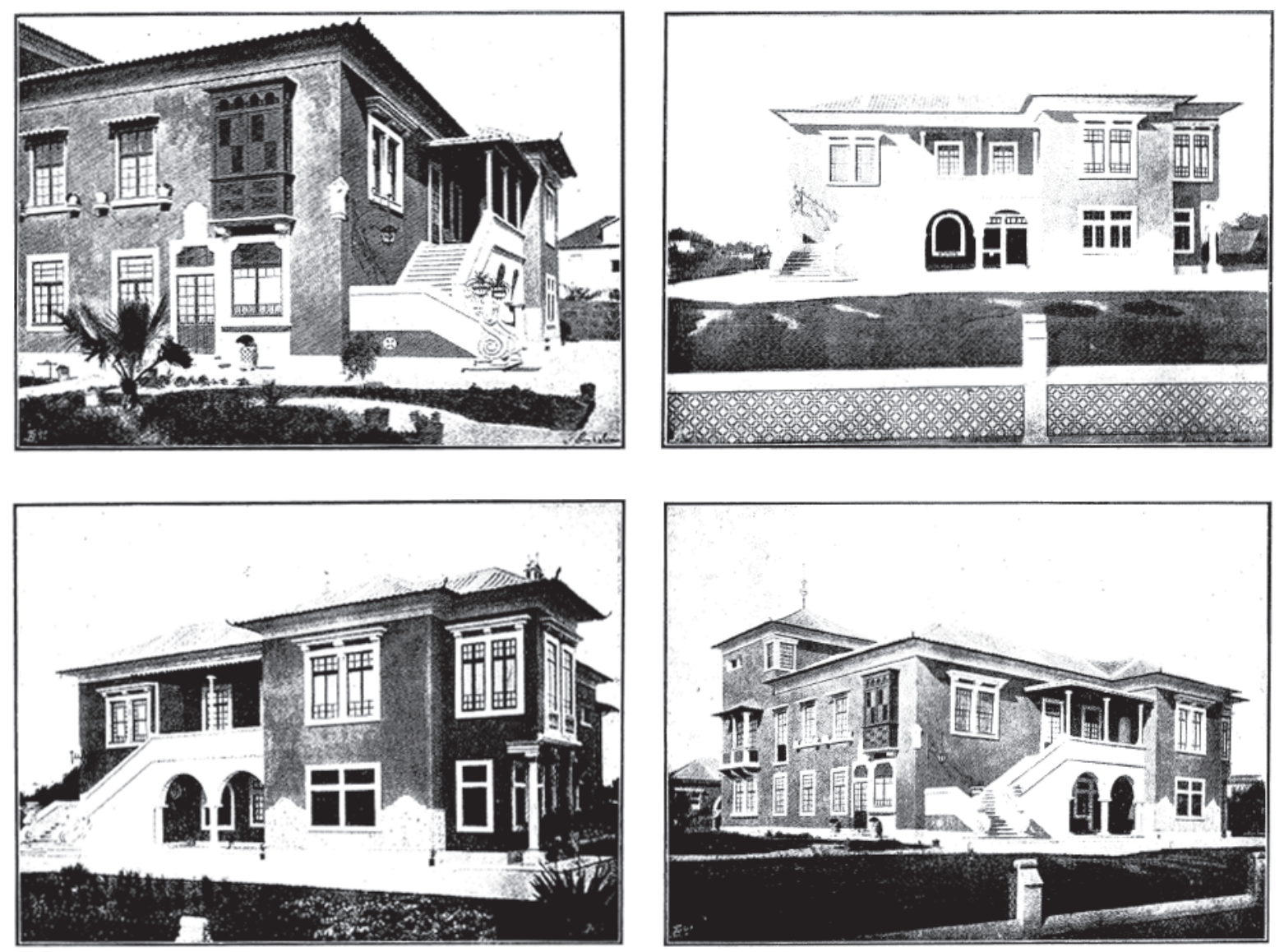

Figura 4 - Fotos da casa do engenheiro Ricardo Severo tiradas por ele, provavelmente, logo que a construção ficou pronta, pois foram publicadas na versão revisada do artigo de Rocha Peixoto "A Casa Portugueza”. Fonte: revista Serões, 1905. 

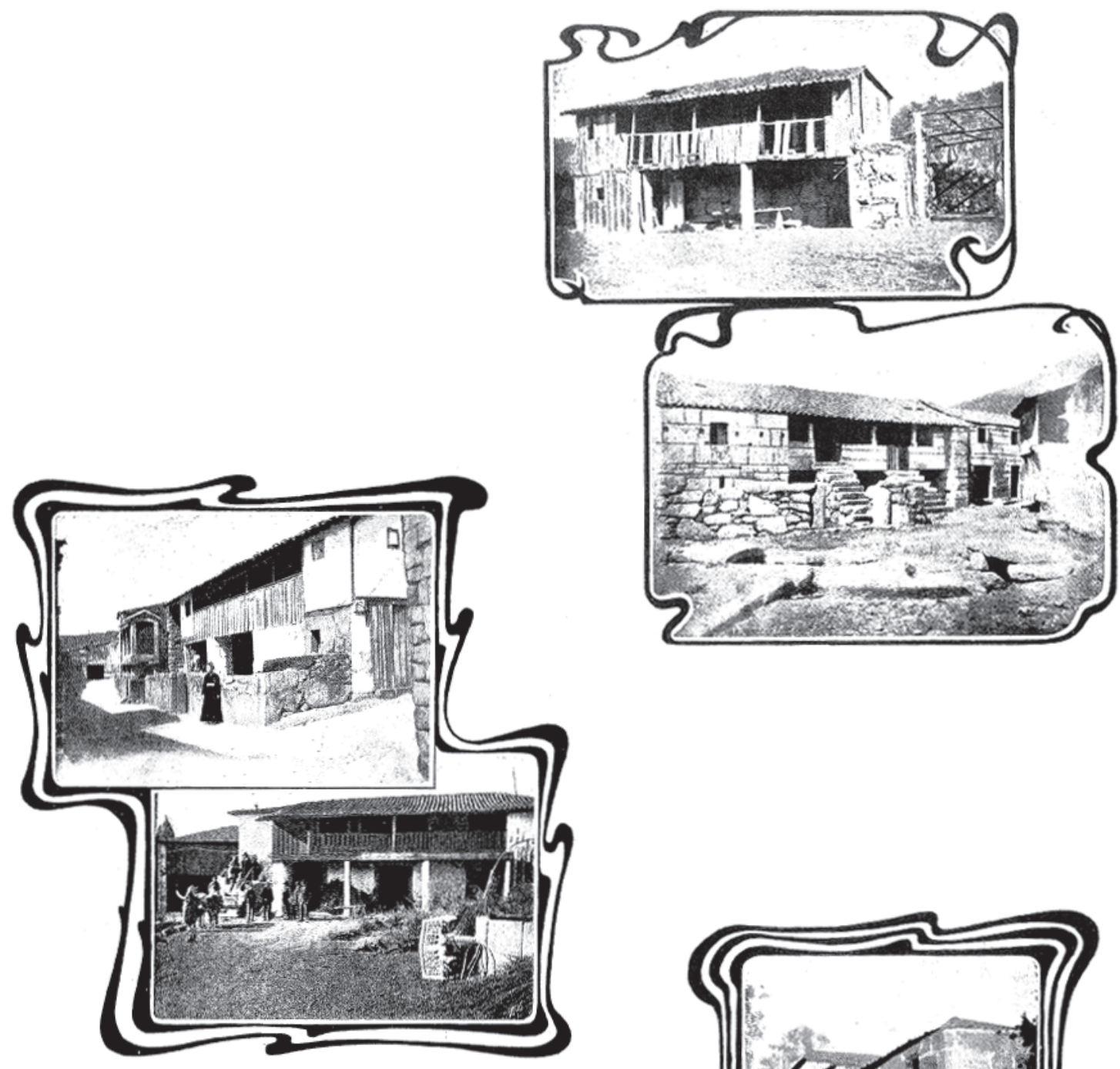

Figura 5 - Fotos da arquitetura portuguesa vernacular, tiradas por Rocha Peixoto, por volta de 1905, e publicadas no seu mesmo artigo "A Casa Portugueza" onde foram publicadas as fotos da casa de Severo. A presença dessas imagens denota a discussão estabelecida no artigo citado, sobre a questão do tradicionalismo na casa de Severo. Fonte: revista Serões, 1905. 


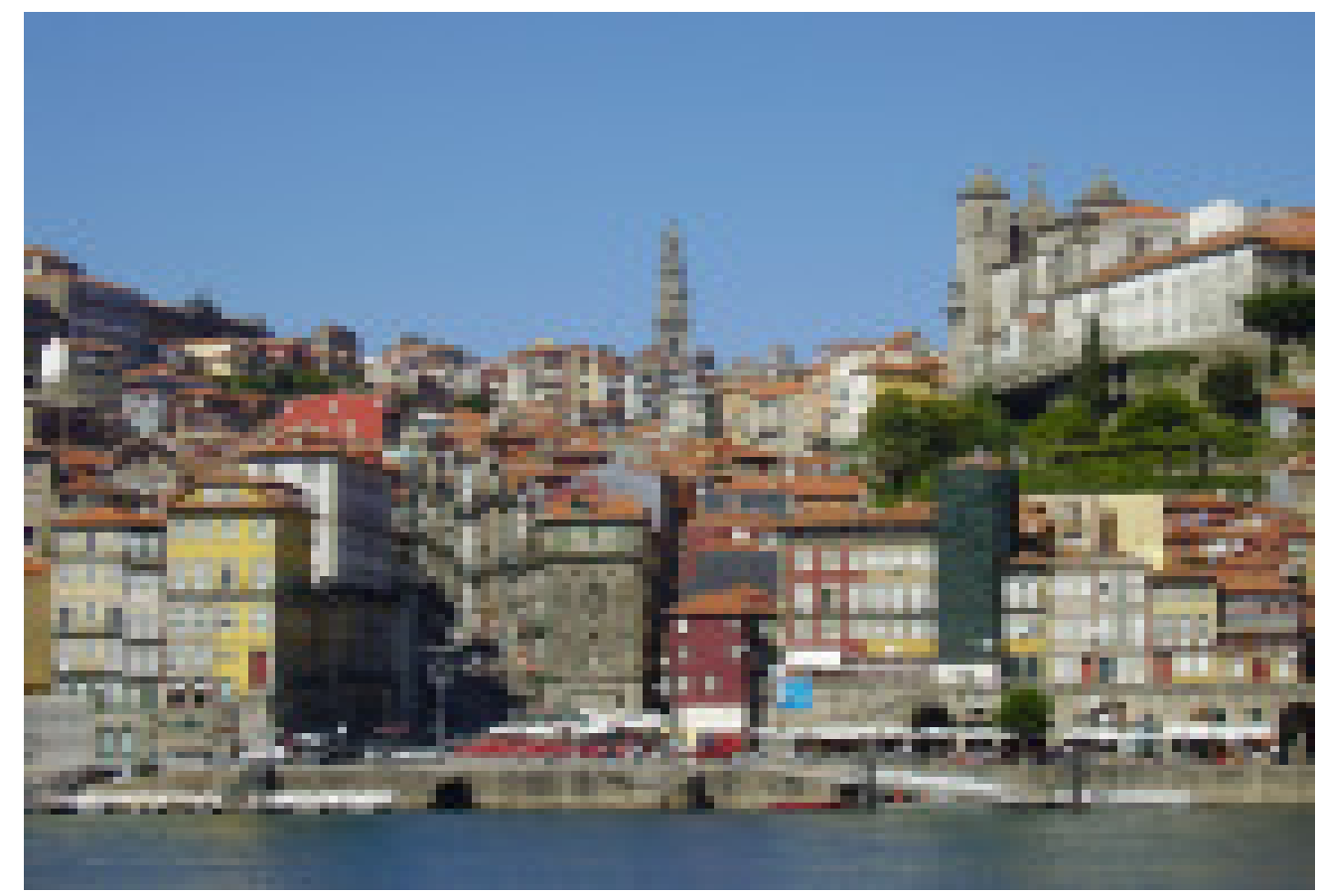

Figura 6 - Aspecto geral da cidade do Porto, com suas tradicionais construções "em banda" (geminadas). Fonte: foto da autora, outubro de 2005.
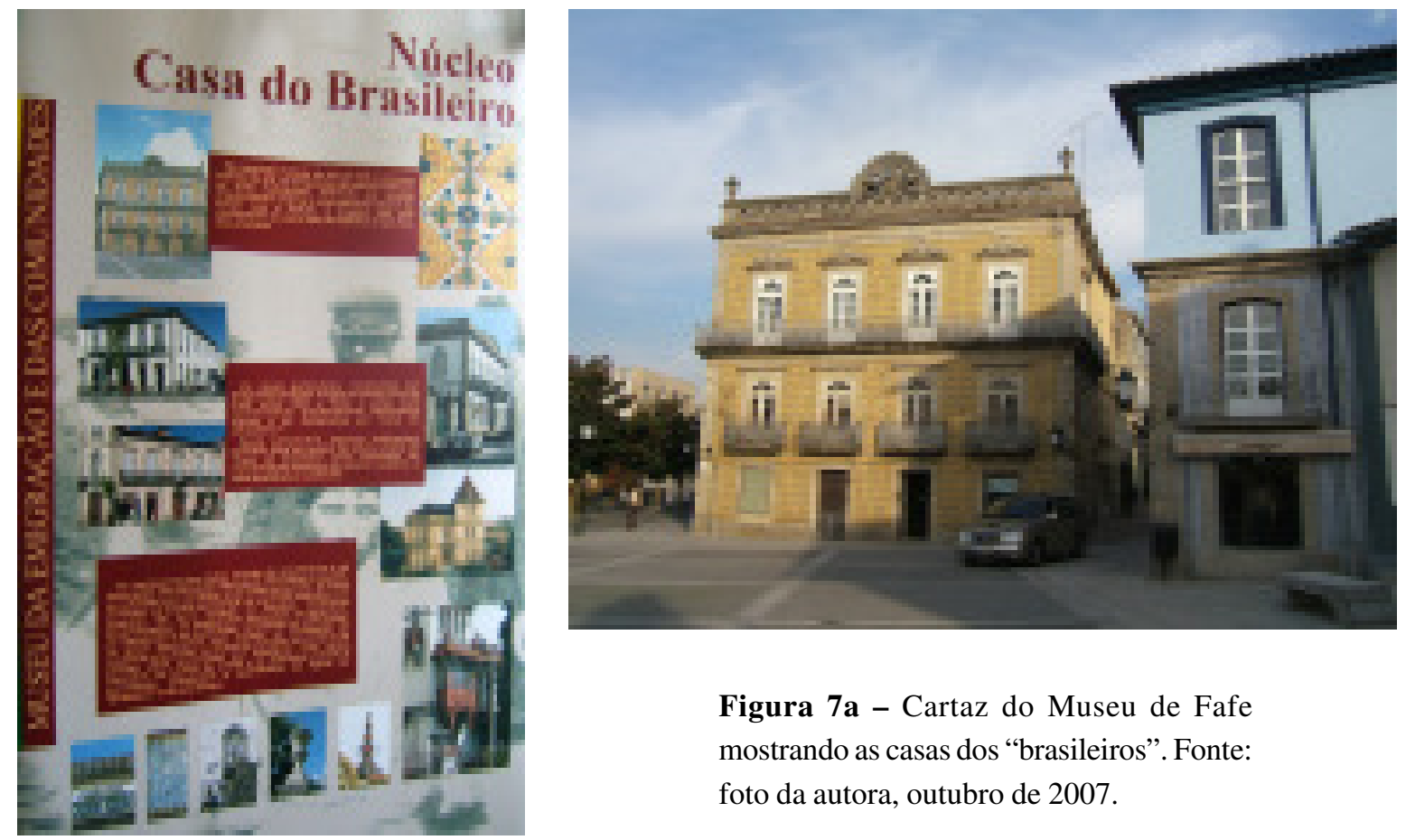

Figura 7a - Cartaz do Museu de Fafe mostrando as casas dos "brasileiros". Fonte: foto da autora, outubro de 2007.

Figura 7b - Exemplo de uma casa de "brasileiro" construída em Fafe em 1882. Notar os azulejos aplicados na fachada e a influência da arquitetura eclética. Fonte: foto da autora, outubro de 2007. 


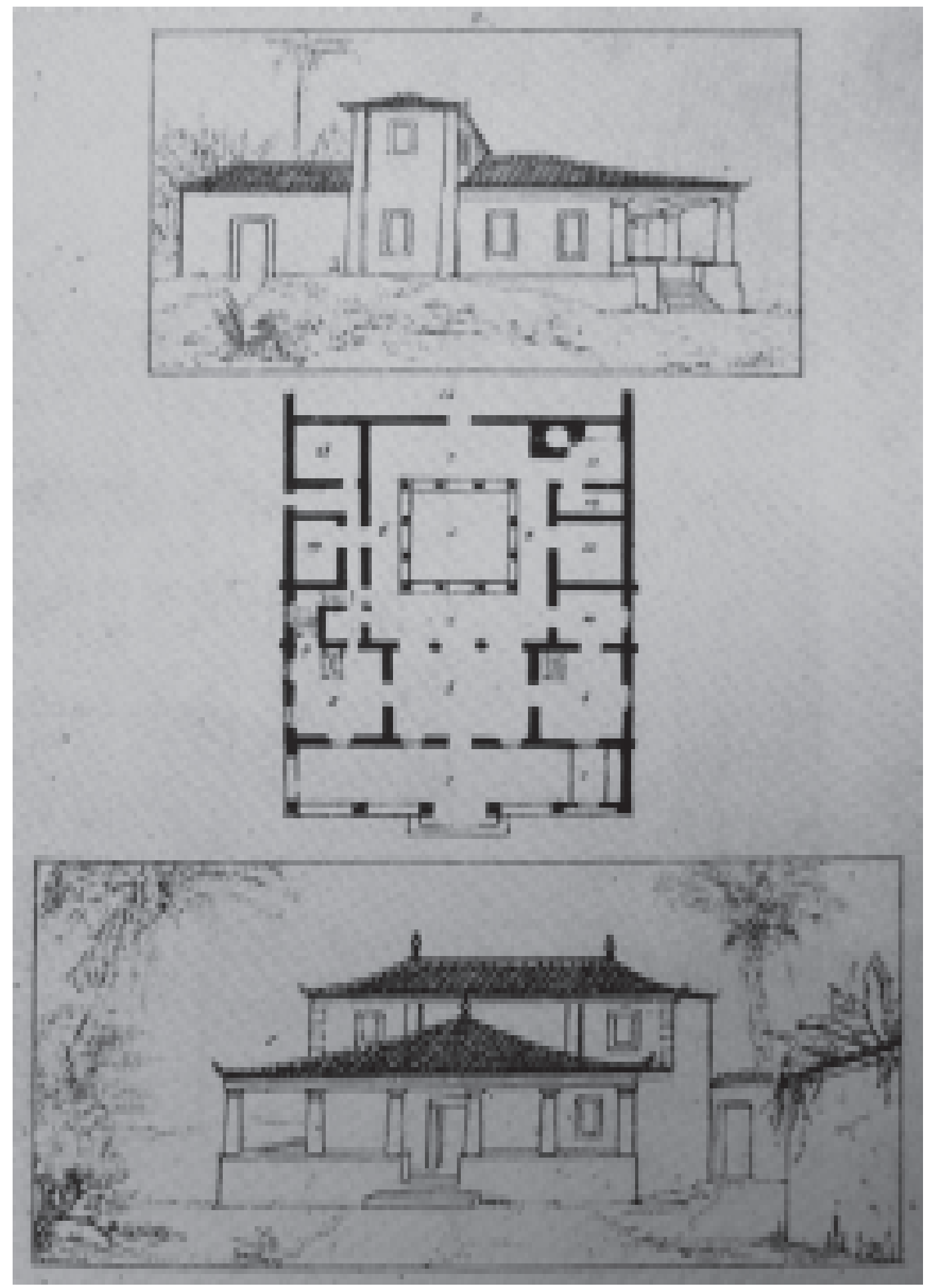

Figura 8 - Prancha 42 de Jean-Baptiste Debret mostrando a planta de uma casa colonial. Notar a semelhança com a planta da casa de Severo no Porto. Fonte: Pinheiro (2005b). 

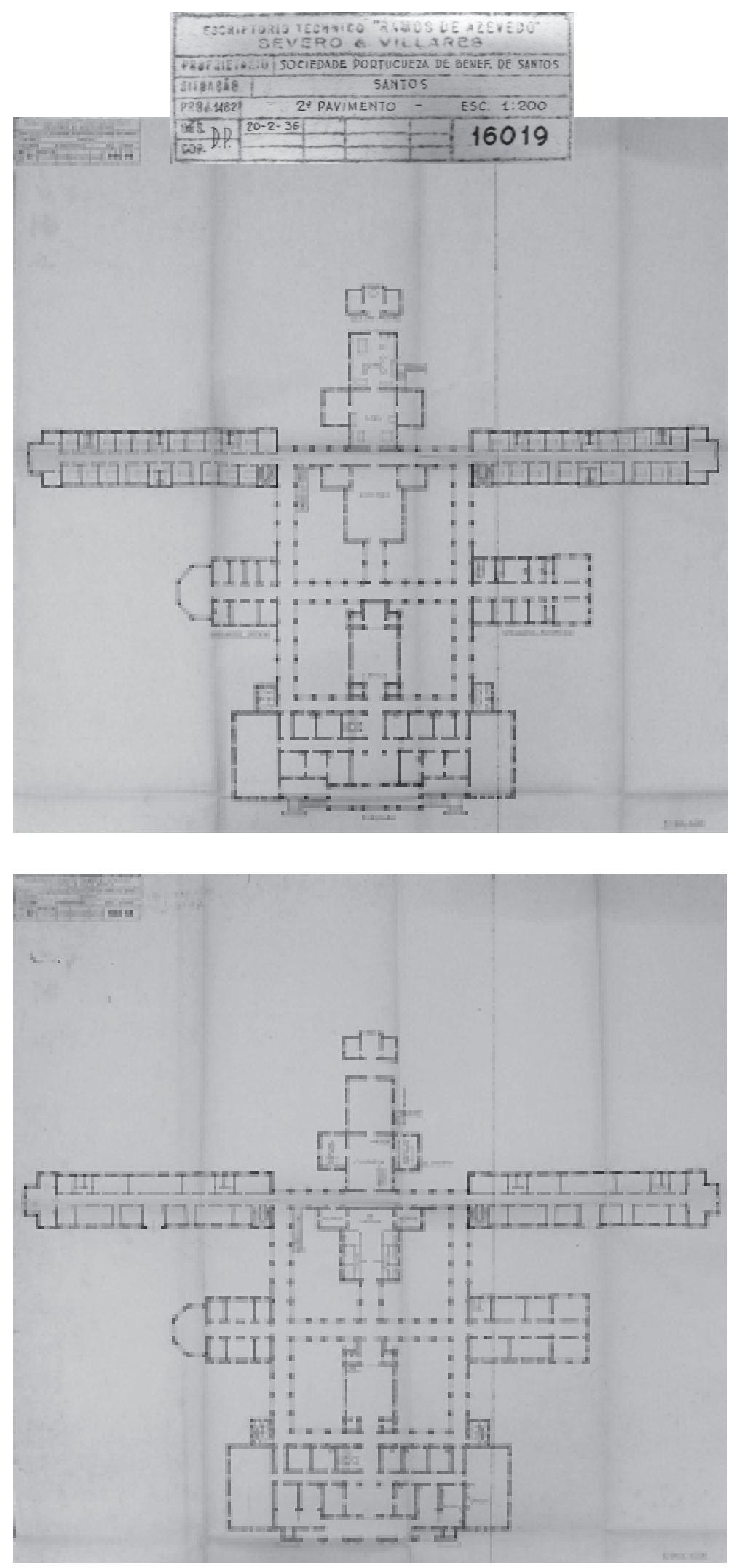

Figura 9 (páginas 200 e 201) - Projeto do Escriptório Technico "Ramos de Azevedo" Severo \& Villares para o hospital a Sociedade Portugueza de Beneficência de Santos, de 1936. Fonte: FAUUSP. Projeto de características diferentes do realizado para a Sociedade Portuguesa Beneficência de Bauru (ver Figura 166). 

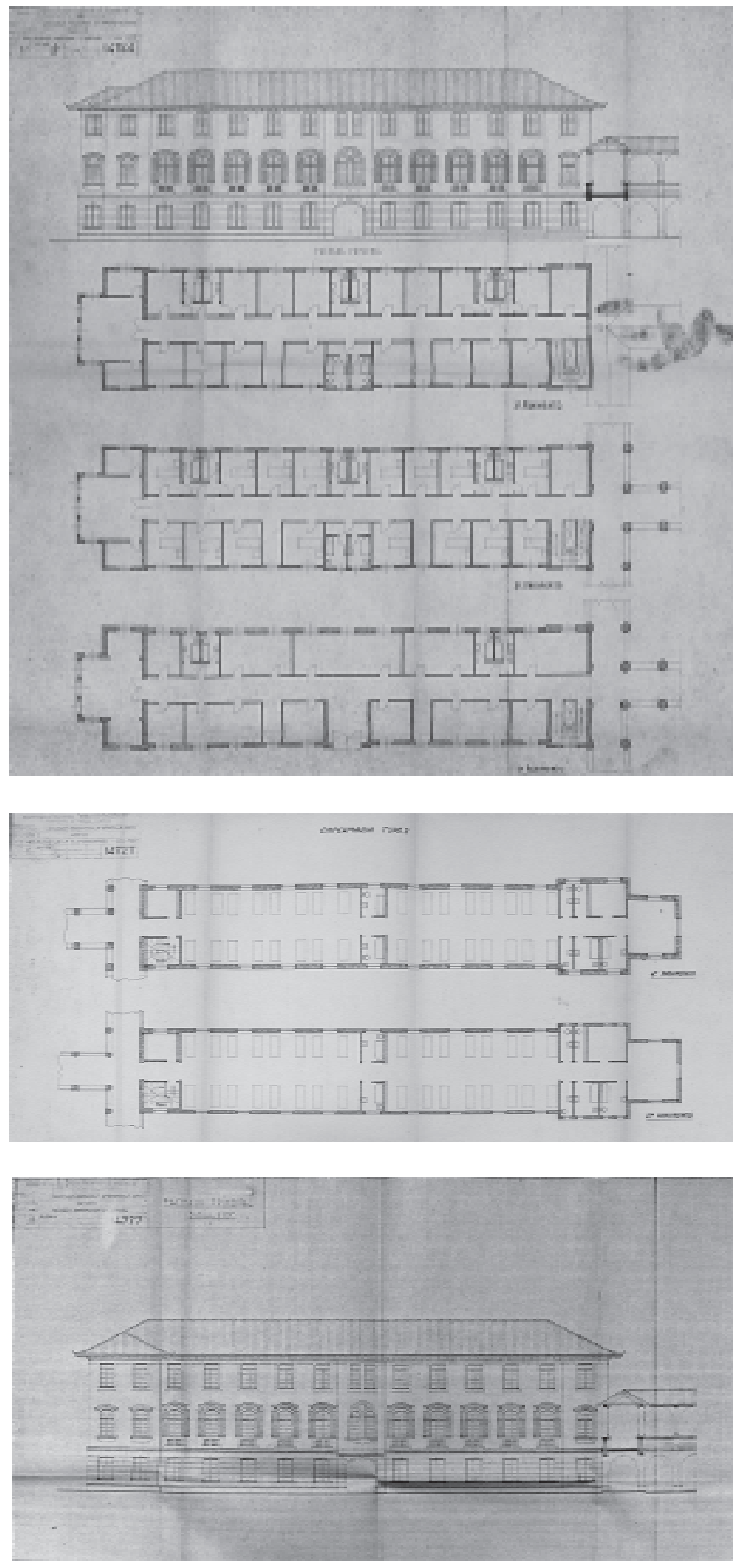


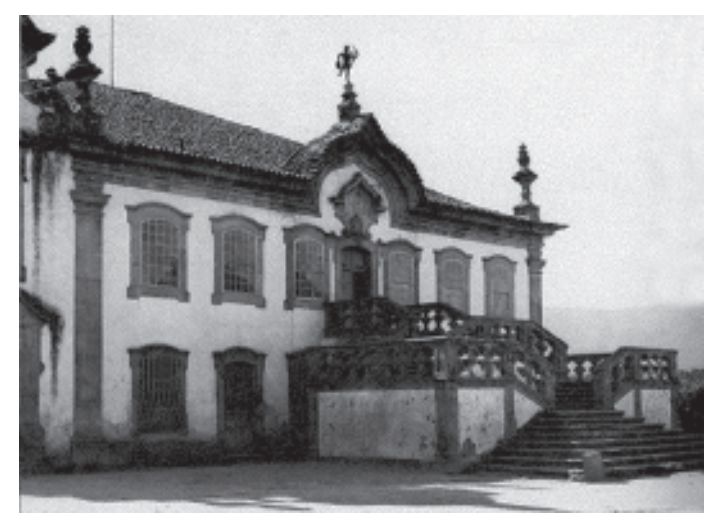

Figura 10a - Em muitos casos os Solares Portugueses dos séculos XVII e XVIII são exemplos da aplicação da arquitetura barroca na arquitetura civil. São possíveis referências para a arquitetura de Ricardo Severo. Notar os pináculos no telhado e os beirais de telha capa e canal. Exemplar "Casas Novas", localizado em Baião, Santa Maria do Zêzere. Fonte: Azevedo (1988, p. 100).

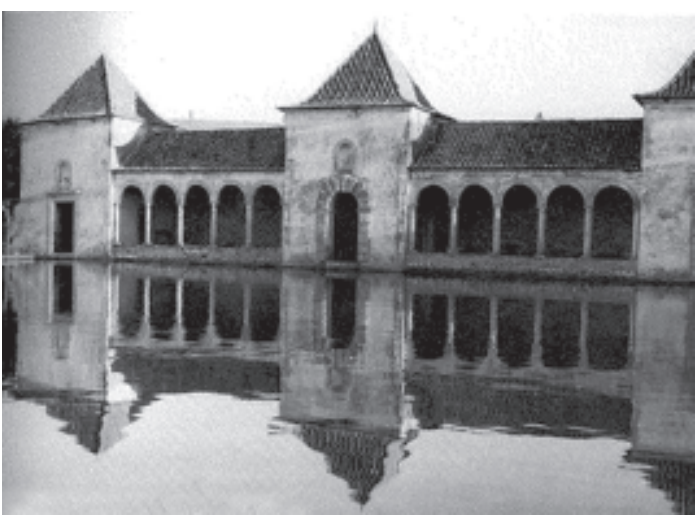

Figura 10b - Exemplar que tem as arcadas como elemento marcante, além dos telhados em ponta, muito usados pelo arquiteto Raul Lino e também encontrados na difusão dos movimentos tradicionalistas. "Casa da Bacalhoa”, Setúbal, Azeitão. Fonte: Azevedo (1988, p. 31).

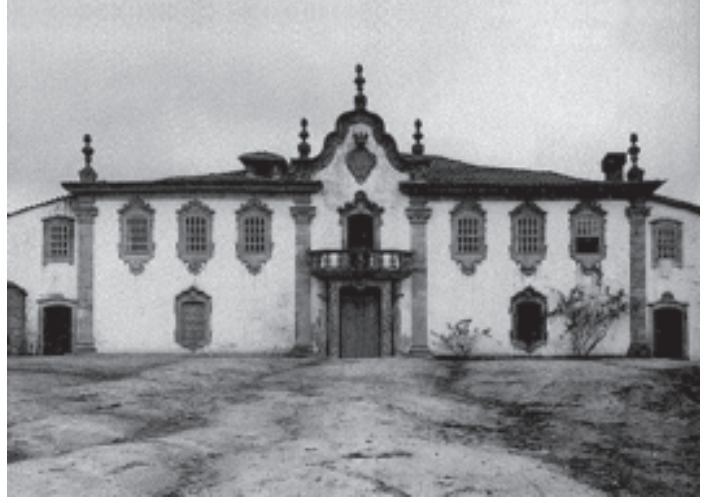

Figura 10c - Neste exemplar vemos a simetria da fachada, os pináculos e o frontão, muito comuns em edifícios neocoloniais. "Casa dos Calainhos", localizada em Valpaços, Fornos do Pinhal. Fonte: Azevedo (1988, p. 117).

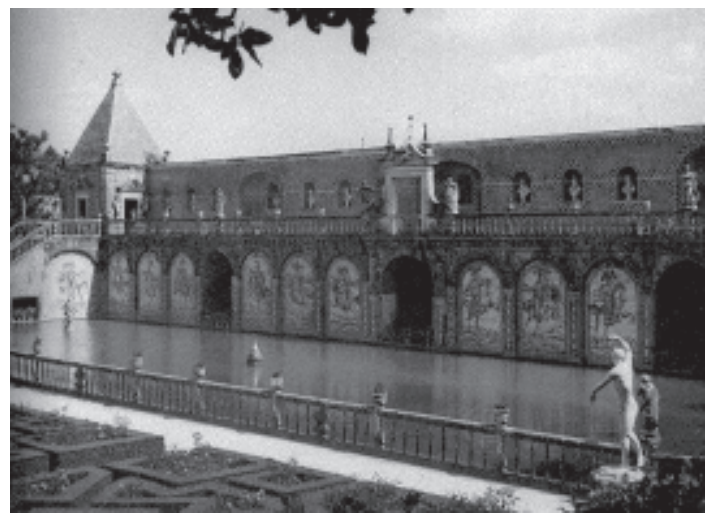

Figura 10d - Notar as arcadas e a aplicação de azulejos no "Palácio dos Marqueses de Fronteira", em Lisboa. Fonte: Azevedo (1988, p. 47).

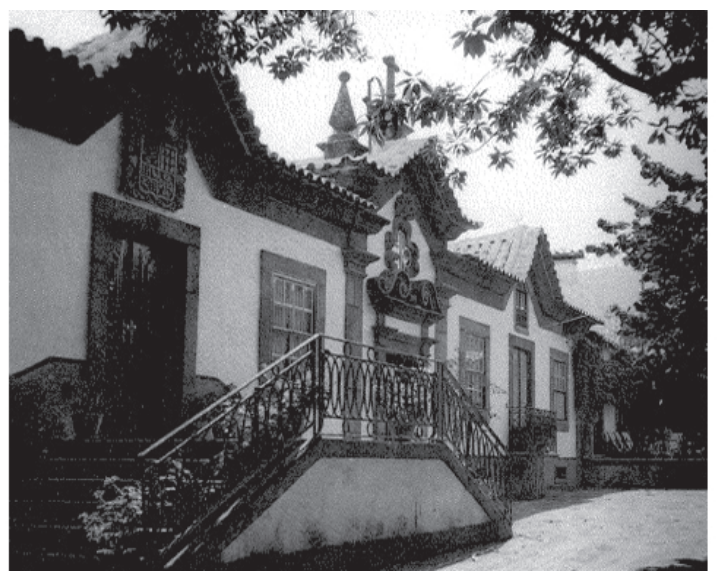

Figura 10e - Frontão, pináculos, beirais entre outras características na "Casa de Campo de Besteiros", Tondela, Campo de Besteiros. Fonte: Azevedo (1988, p. 60). 

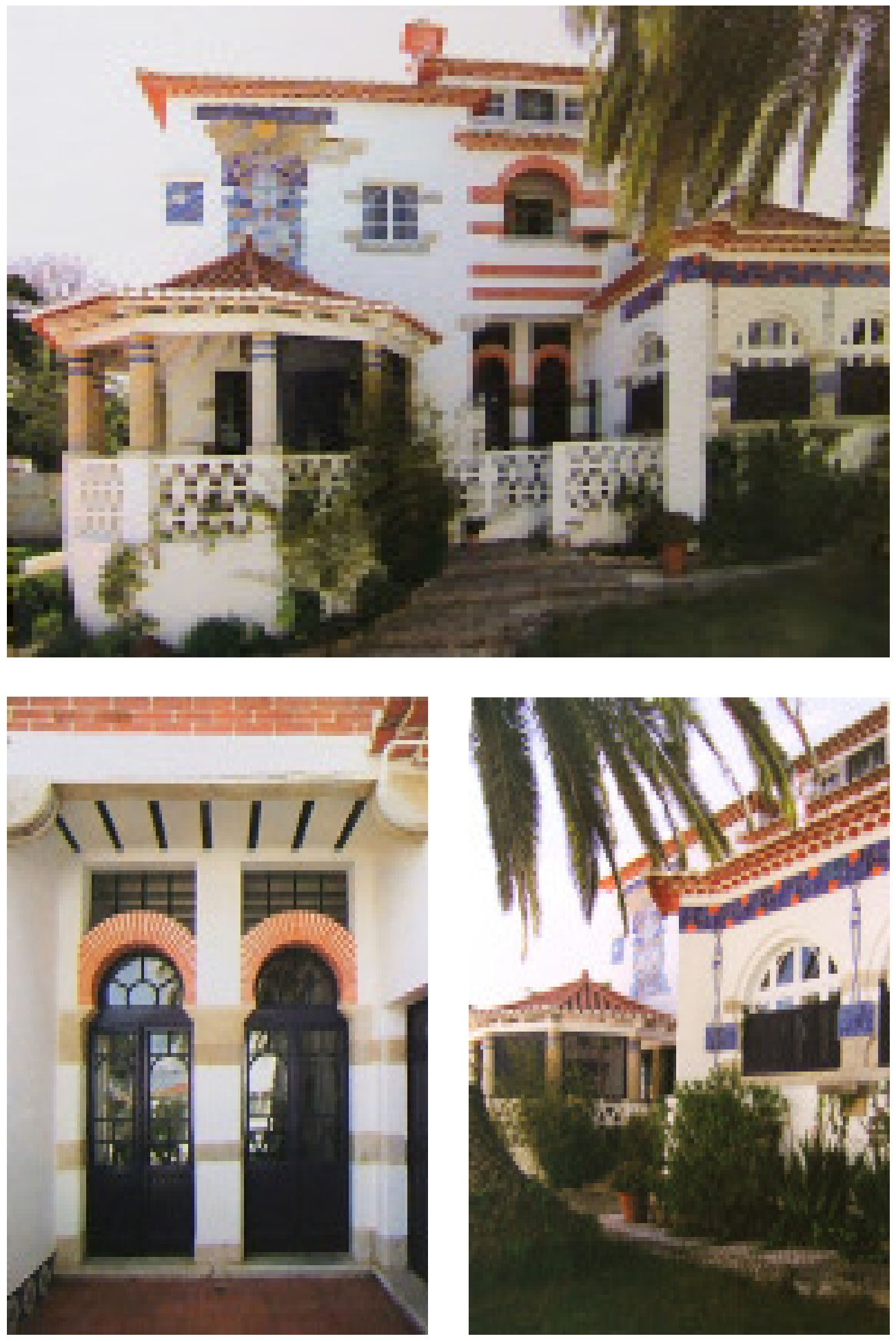

Figura 11 - Casa "Monsalvat", do arquiteto Raul Lino, construída em Monte Estoril para o pianista Alexandre Rey Colaço, em 1901. Beirais, arcos e azulejos em associação com elementos da arquitetura árabe. Fonte: Serrão (2005, p. 29-30). 

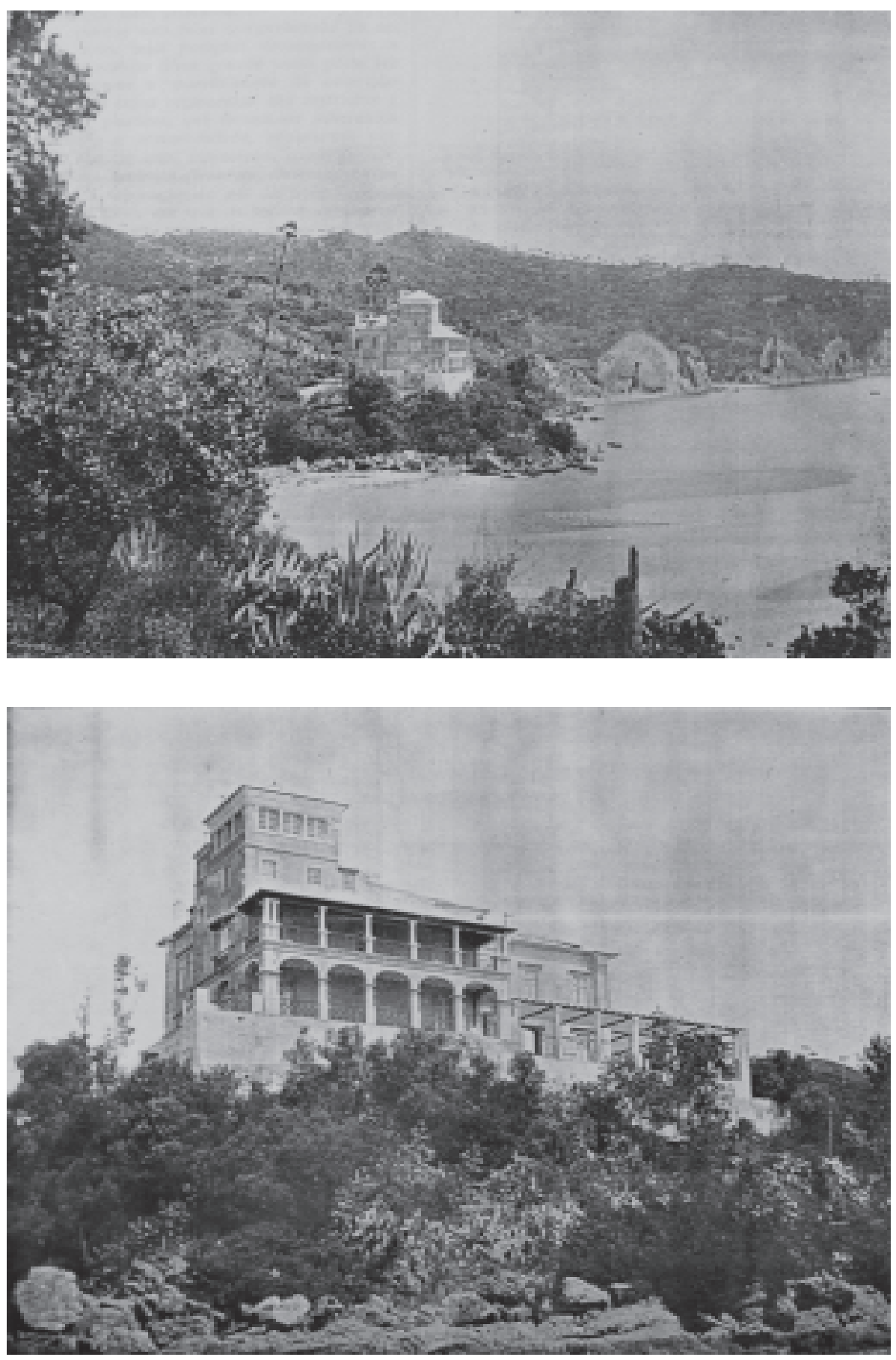

Figura 12 (páginas 204 e 205) - Casa do Conde Armand, do arquiteto Raul Lino, construída na Quinta da Comenda, Setúbal, no início do século XX. A integração na paisagem é uma forte característica dessa edificação e é uma das quais Lino vai priorizar durante toda sua carreira. Arcadas e terraço à moda árabe também são recorrentes nas obras do arquiteto. Fonte: Neves (1908, p. 22-24). 

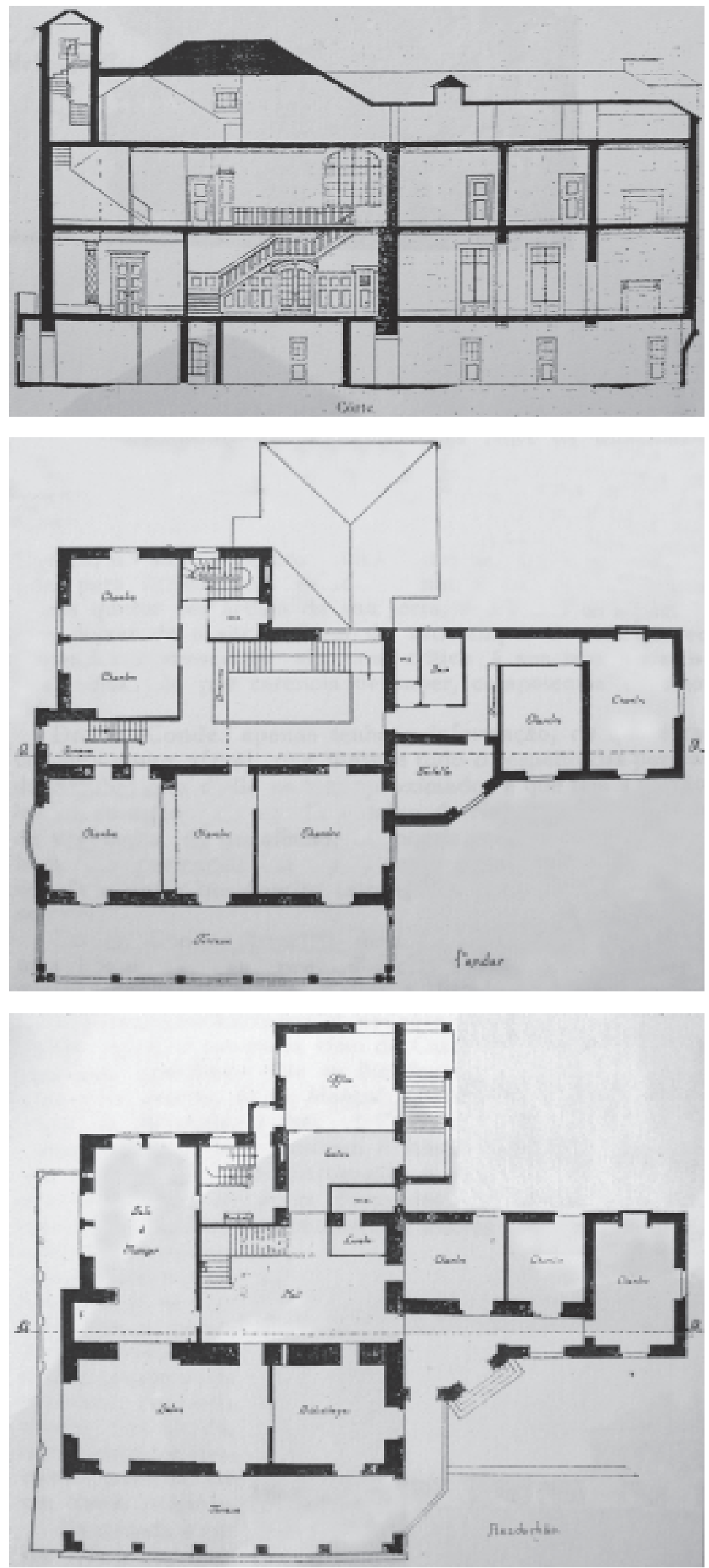

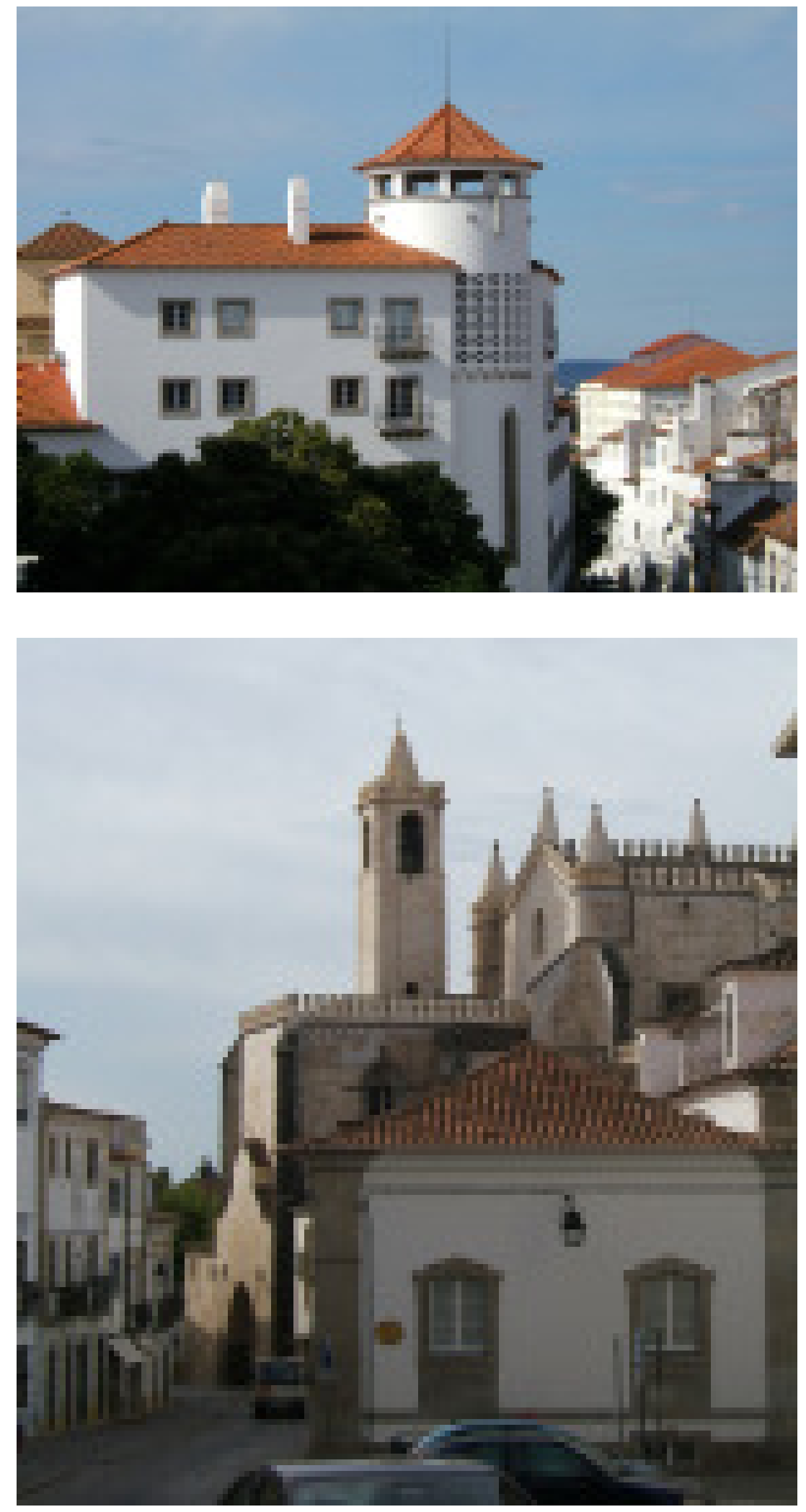

Figura 13 - Duas edificações na cidade de Évora. Notar como algumas das características se repetem na arquitetura de Raul Lino e em outras arquiteturas anônimas. Fonte: fotos da autora, outubro de 2007. 

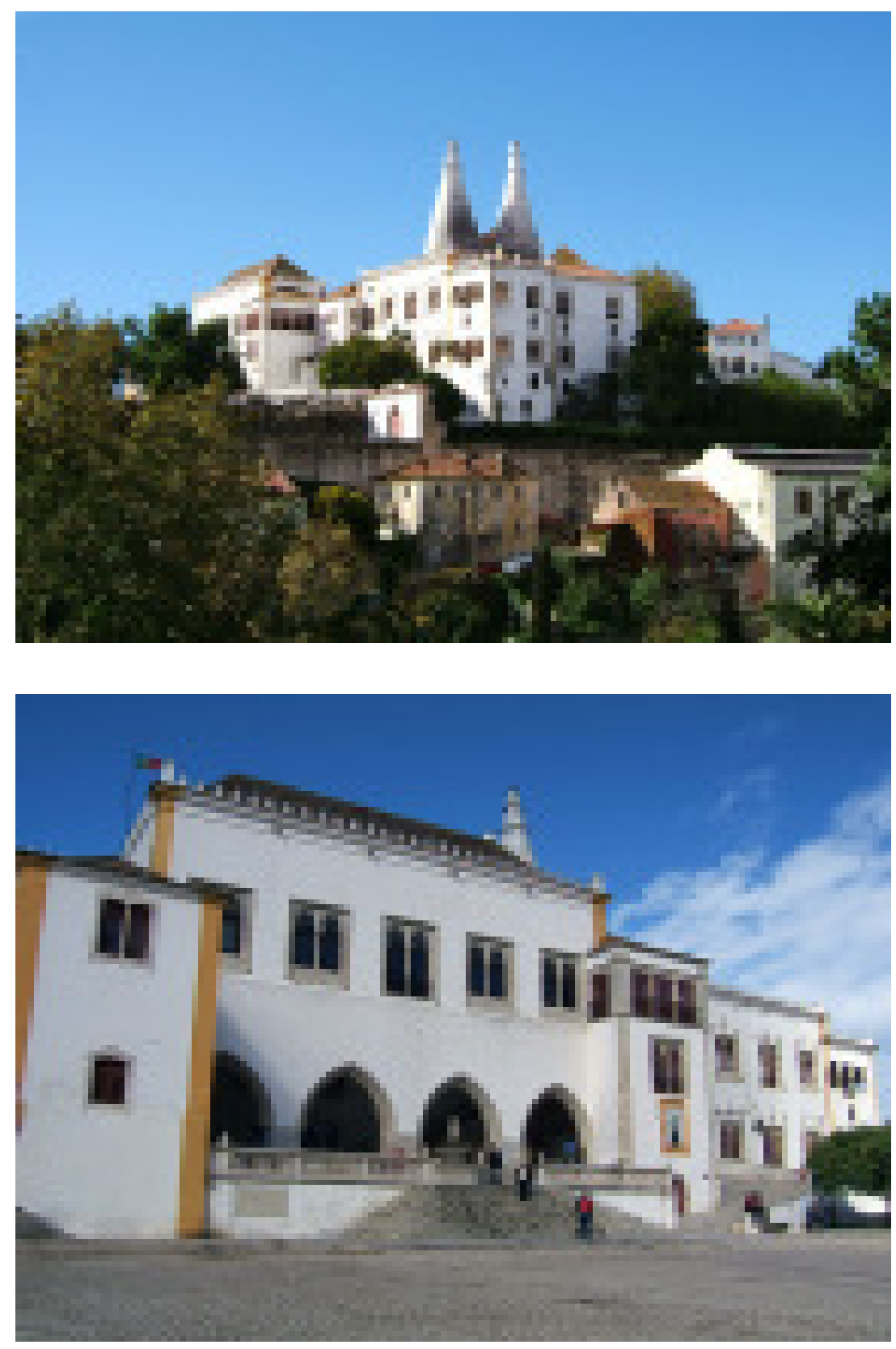

Figura 14 - Vista do Palácio Nacional de Sintra na paisagem, com suas grandes chaminés, e entrada do palácio, com arcos ogivais e traços da arquitetura manuelina. Notar a semelhança com a arquitetura de Évora e com a produzida por Raul Lino. Fonte: fotos da autora, outubro de 2005. 

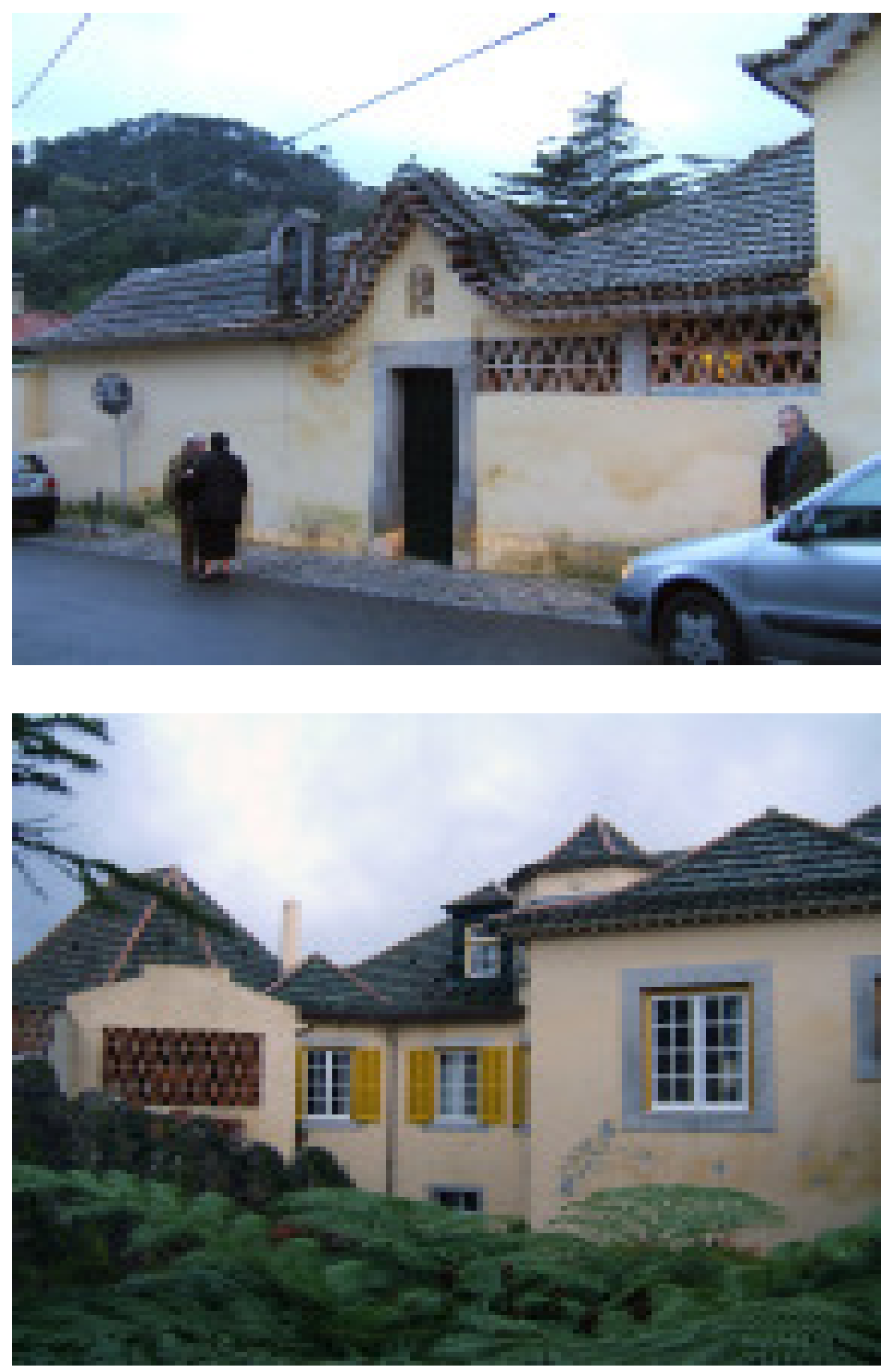

Figura 15 - Entrada e vista do pátio interno da "Casa do Cipreste". Notar semelhança do frontão da entrada com o da "Casa de Campos de Besteiros" (Figura 10a) e das aberturas triangulares, como na edificação em Évora (Figura 13). Fonte: fotos da autora, janeiro de 2006. 

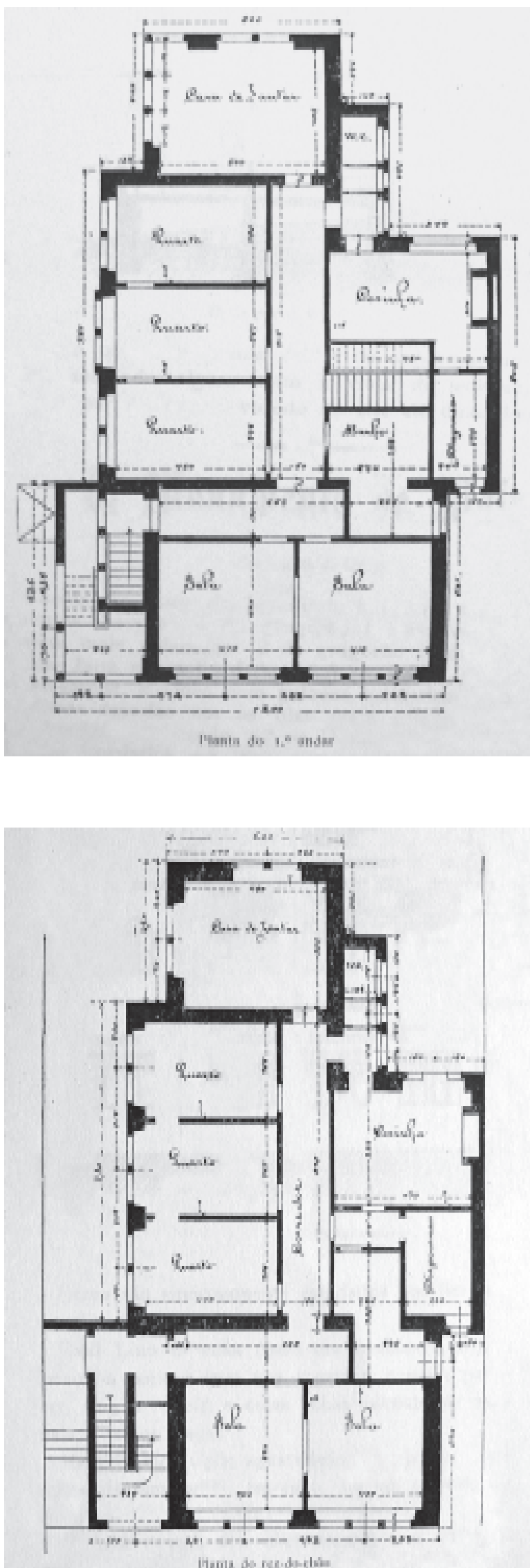
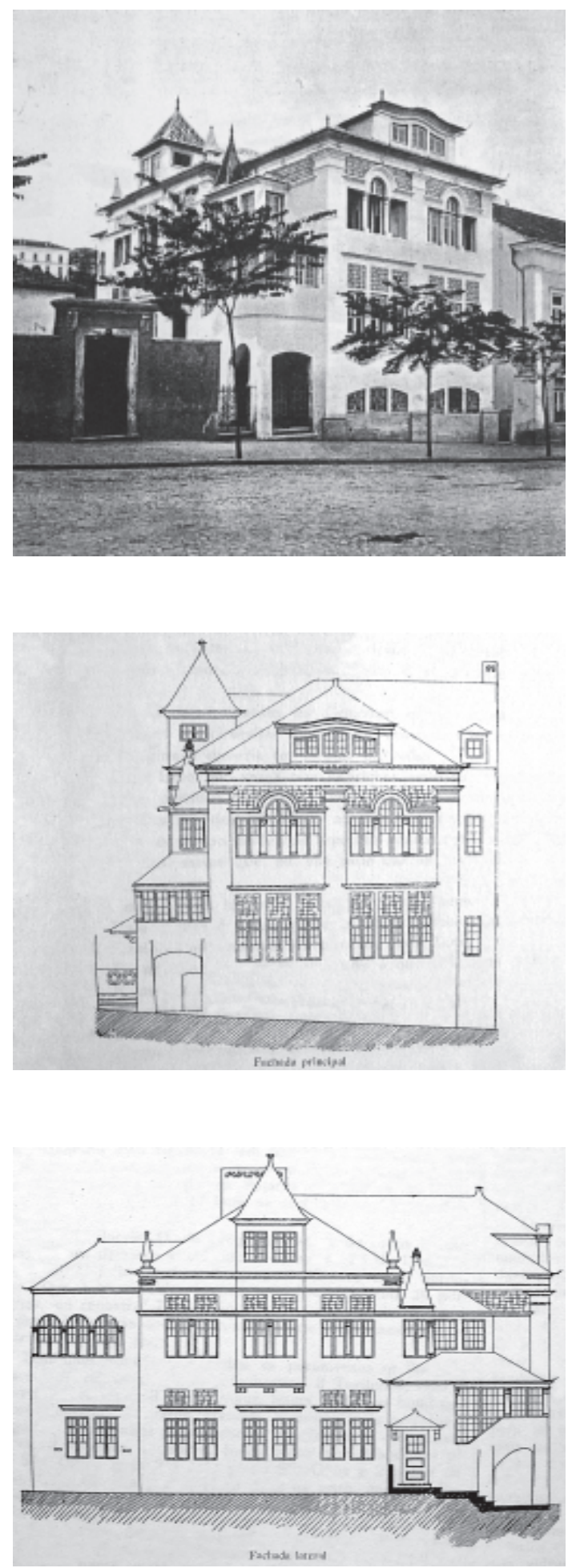

Figura 16 - Casa do Sr. Albino Caetano da Silva, cujo projeto, de Raul Lino, foi publicado em 1909. Construída em Coimbra. Mesmo numa fachada estreita, vemos os traços da arquitetura tradicionalista. Fonte: AArchitetura Portuguesa, 1909. 

Capítulo 2

UM PARALELO: DIFUSÃO EM PORTUGAL

Imagens 


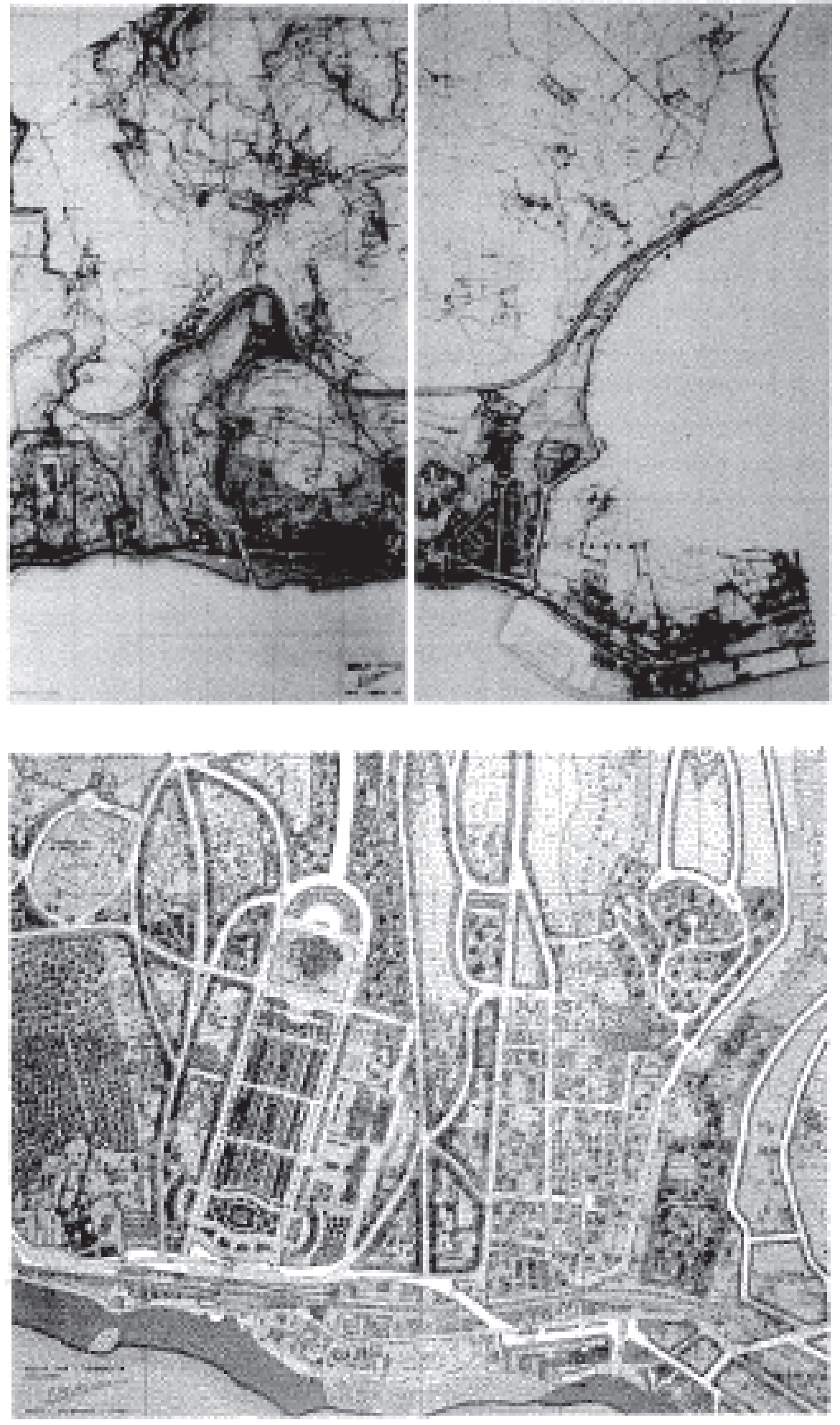

Figura 17a (topo)- Plano Diretor da Costa do Sol. Alfred Agache, 1936. Fonte: Lobo (1995, p. 13).

Figura 17b (acima) - Plano de Remodelação do Estoril. Alfred Agache, 1936. Fonte: Lobo (1995, p. 19). 


\section{AMBMAN \\ MANL IH' BWh \\ MHI THAHI}

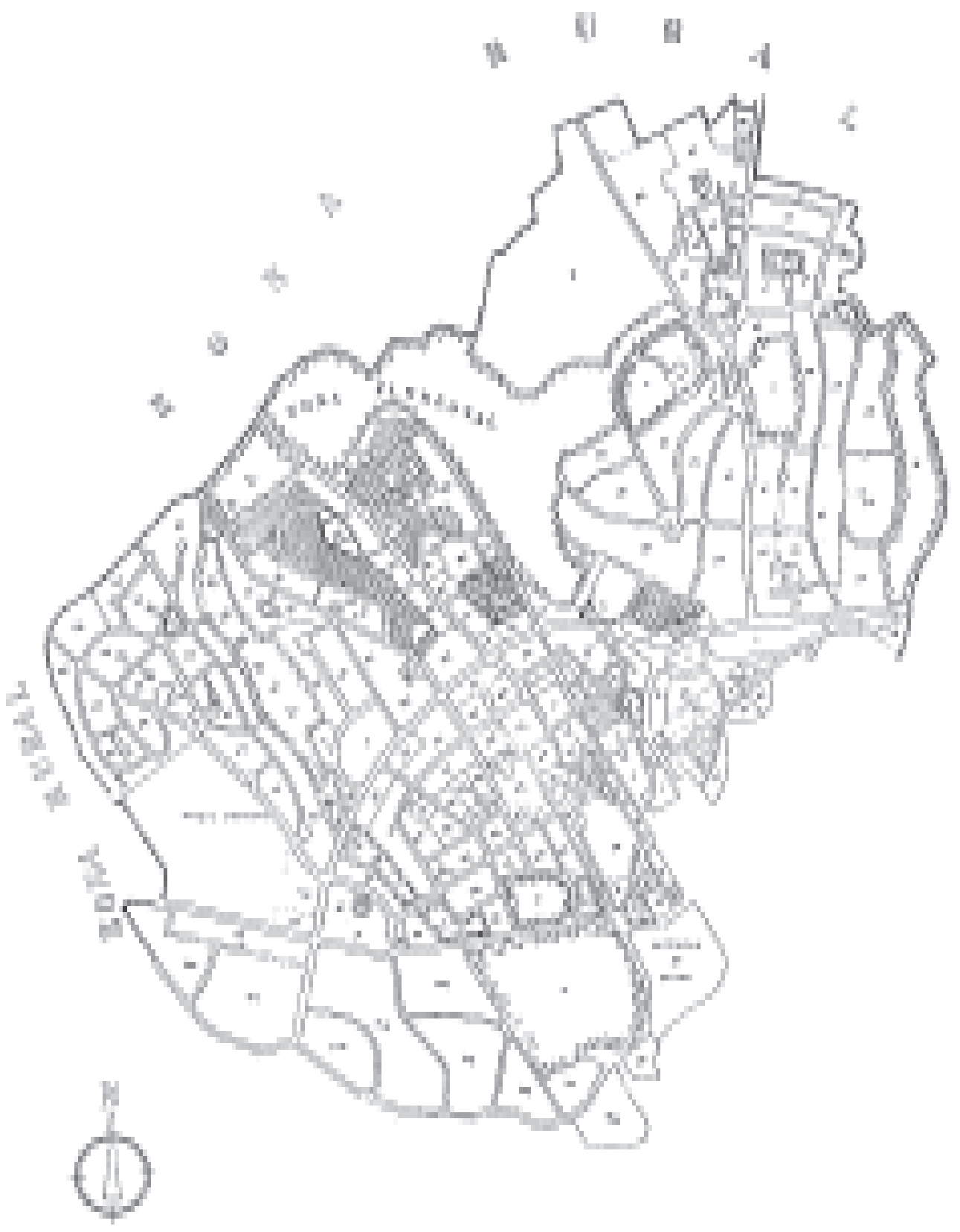

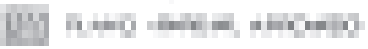

Figura 18a - Plano de Urbanização da Costa do Sol, Cascais. Etienne de Gröer, 1948. Fonte: Lobo (1995, p. 37). 


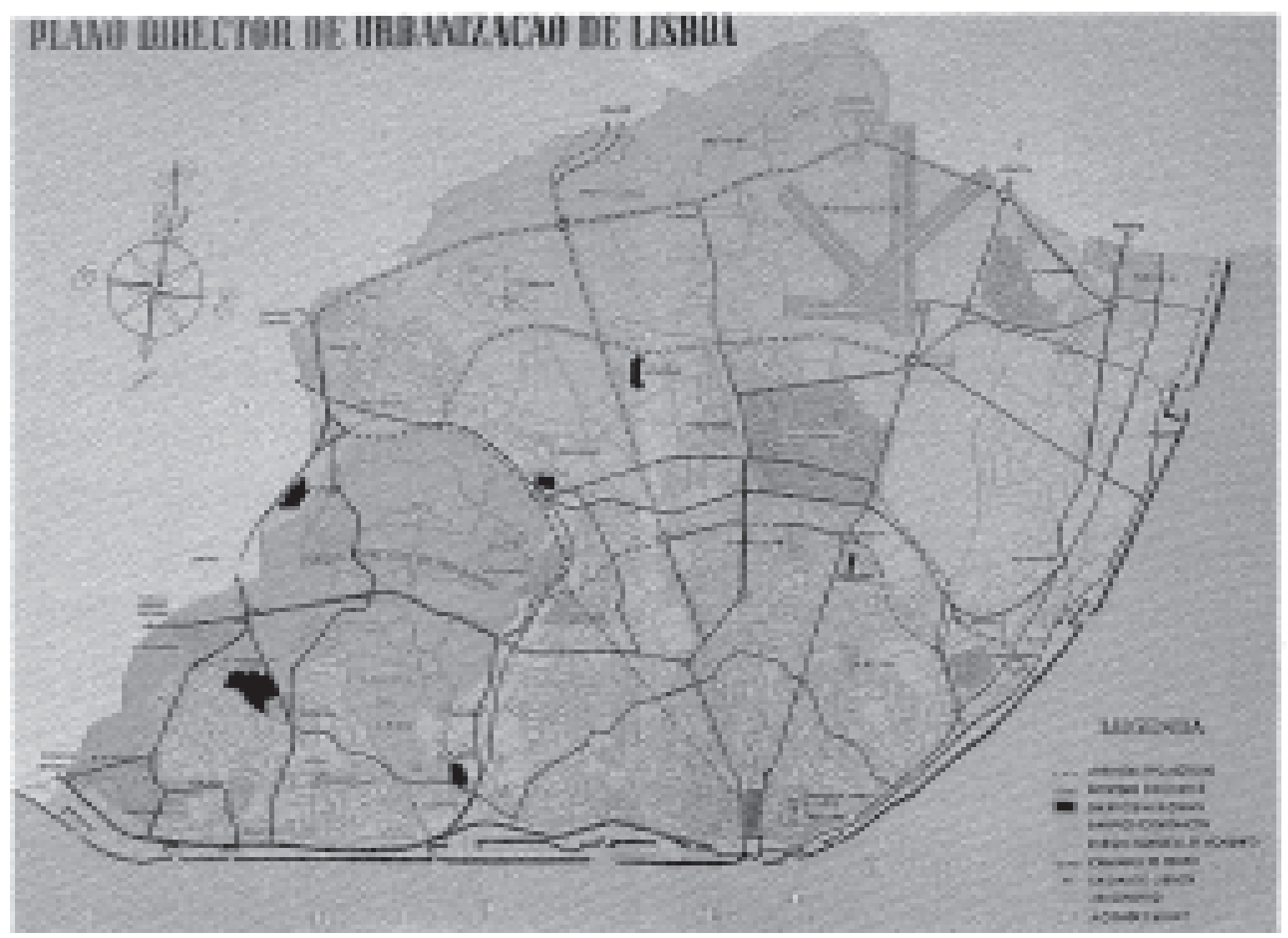

Figura 18b - Plano de Urbanização de Lisboa, Cascais. Etienne de Gröer, 1948. Fonte: Lobo (1995, p. 38). 


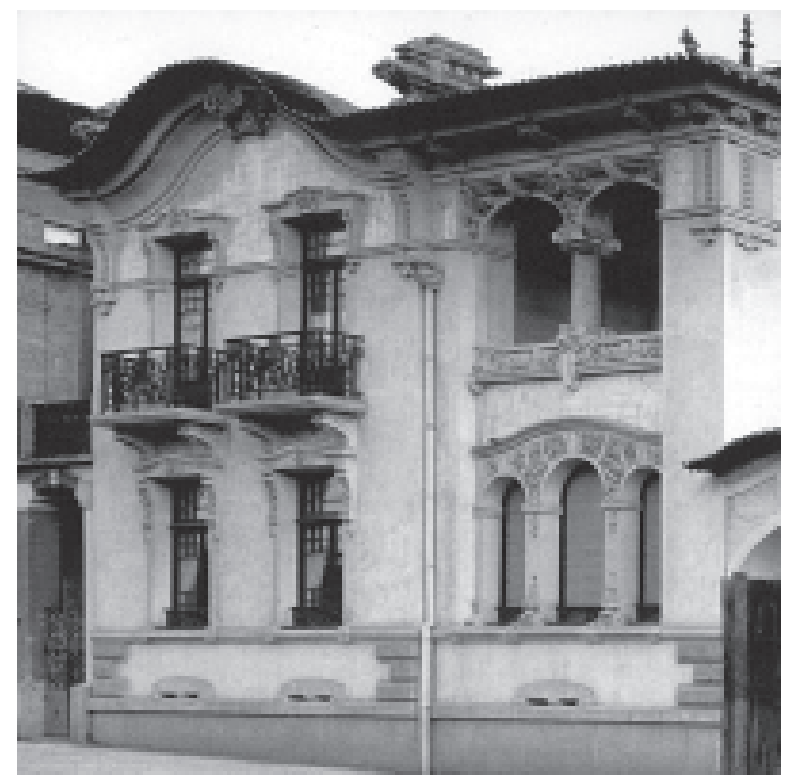

Figura 19a (à esquerda) - Fachada da edificação ganhadora do Prêmio Valmor de 1910, do arquiteto Ernesto Korrodi. Frontão e beirais que remetem à arquitetura barroca civil dos solares portugueses. Disponível em: http://ulisses.cm-lisboa.pt/data/002/ 008/index.php?ml=7\&x=06.xml. Acesso em: maio de 2007.

Figura 19b (abaixo e página 217) - Processo para requerimento de licença para construção da casa projetada por Ernesto Korrodi (Figura 20a). Fonte: Arquivo Intermédio, Lisboa.
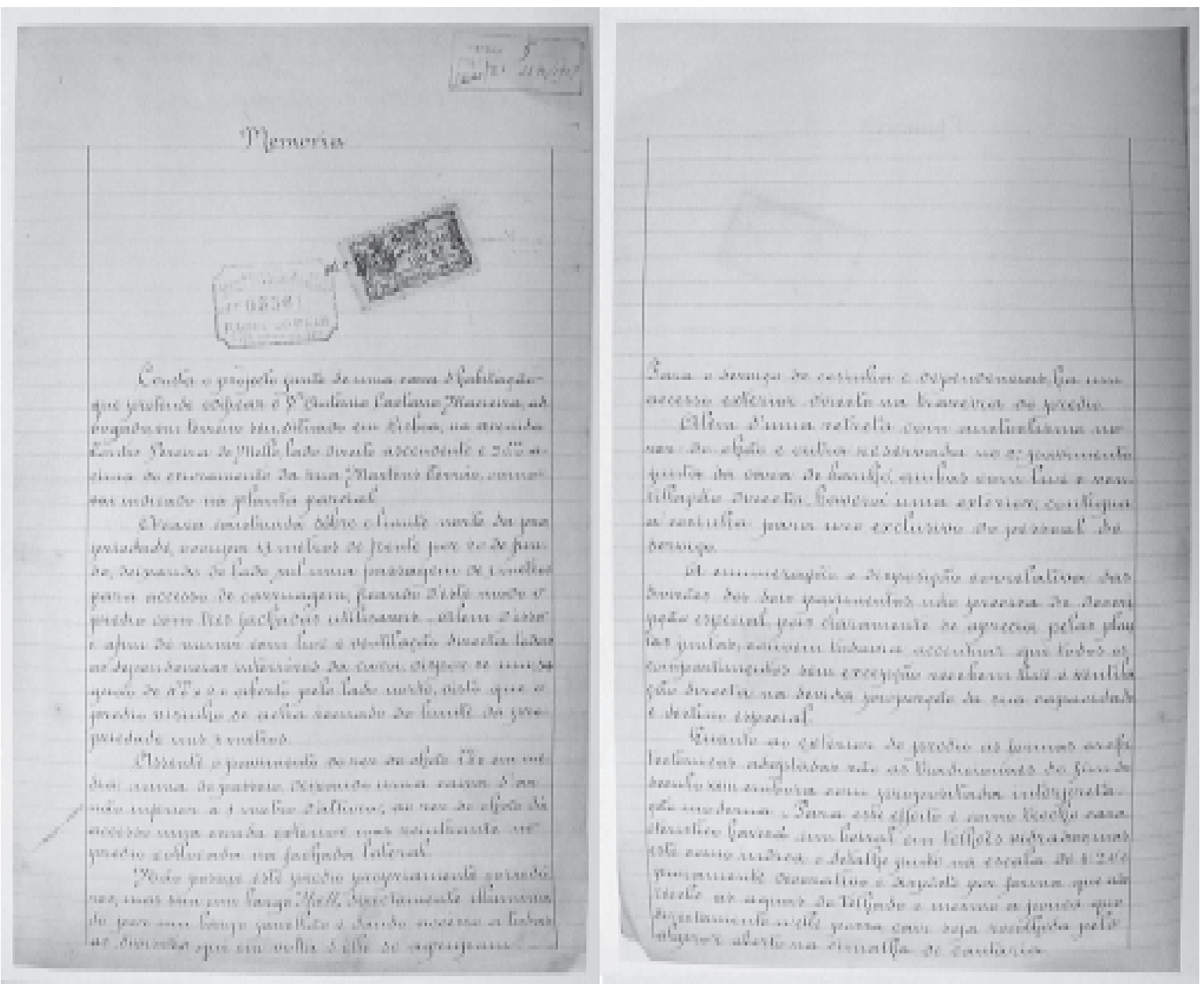

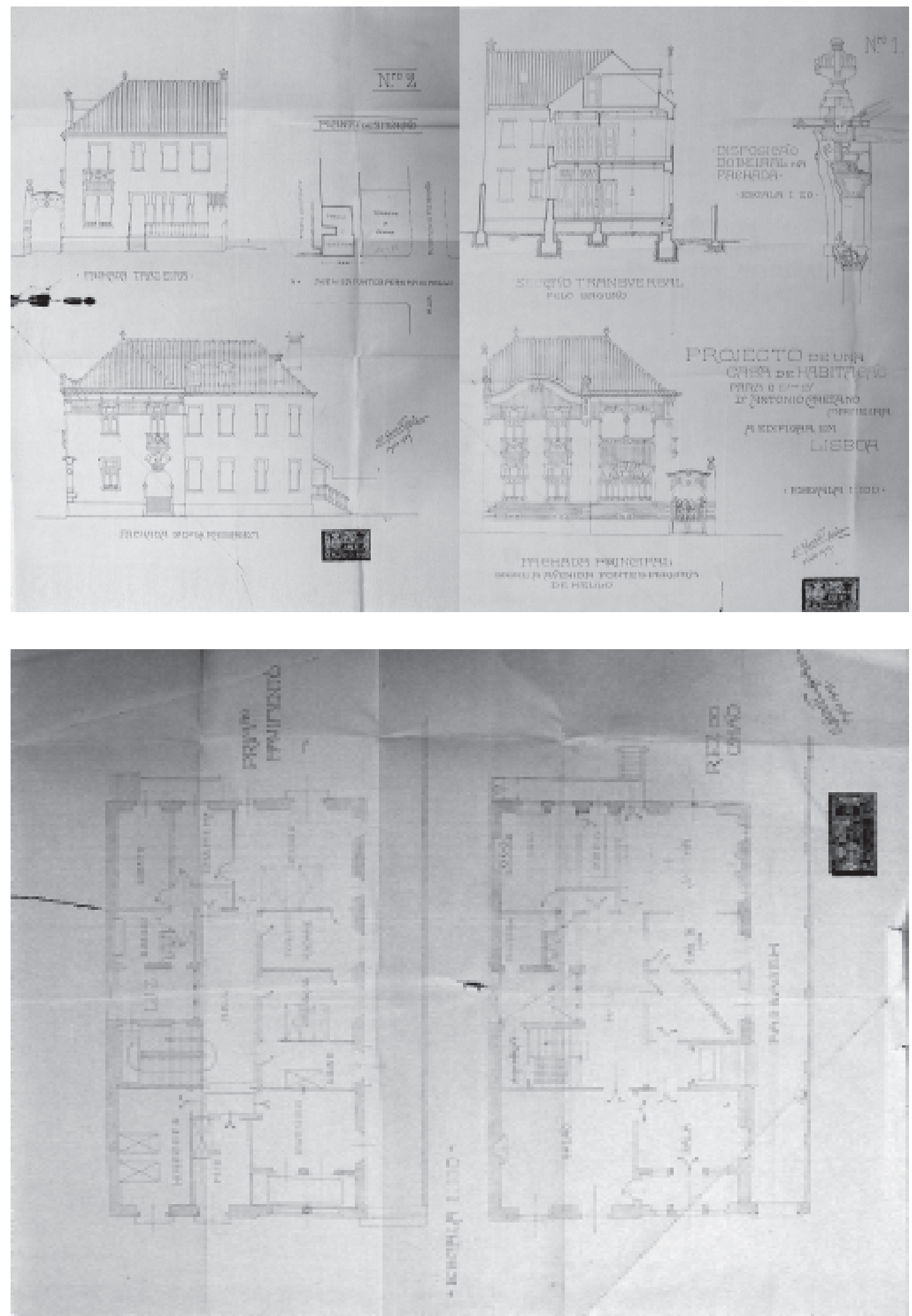


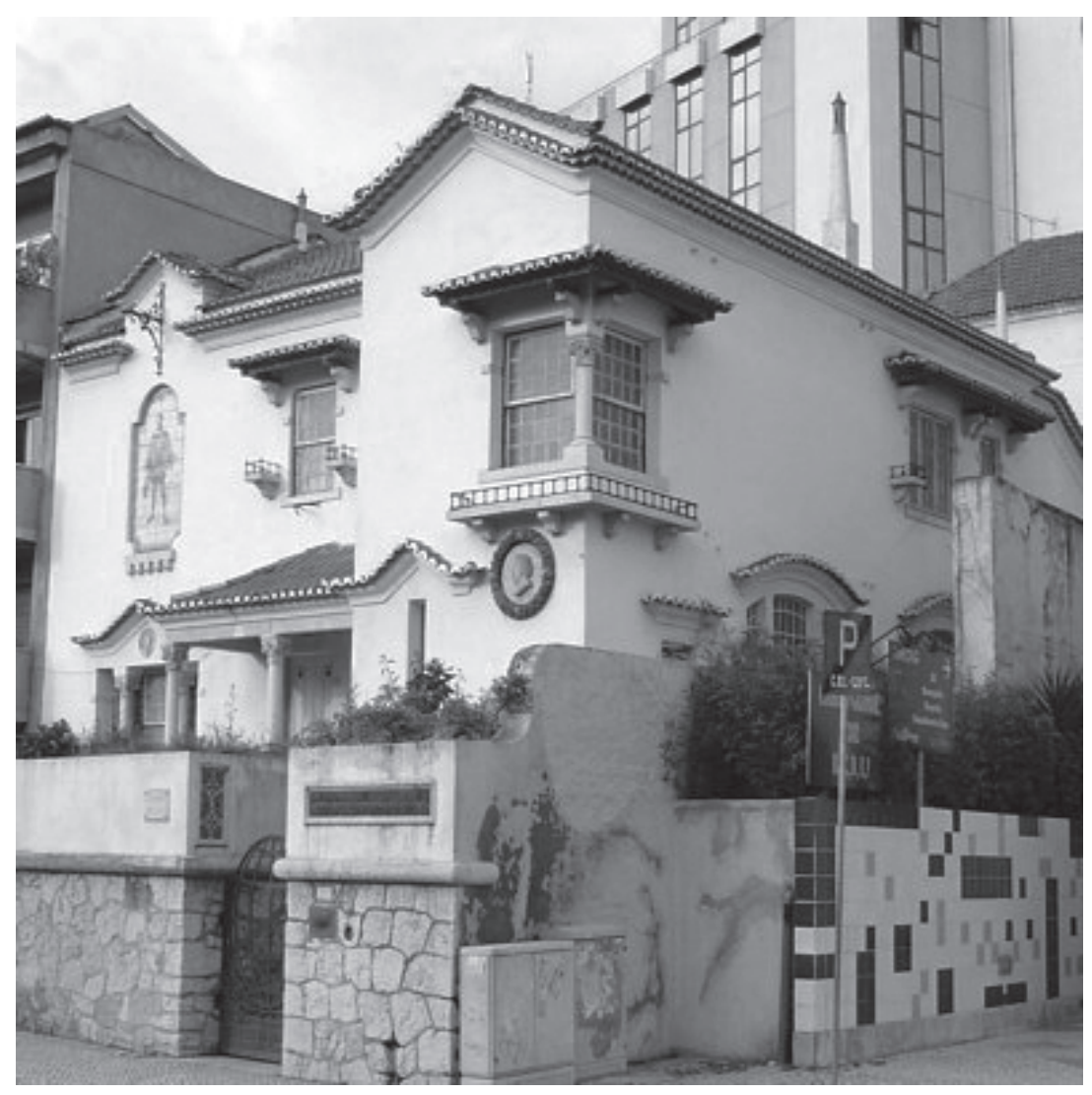

Figura 20 - Vista da edificação projetada pelo arquiteto Álvaro Machado e ganhadora do Prêmio Valmor de 1914. Notar as várias características da arquitetura tradicionalista, especialmente, da janela de canto, envidraçada. Disponível em: http:// ulisses.cm-lisboa.pt/data/002/008/ index.php?ml=7\&x=06.xml. Acesso em: em maio de 2007. 


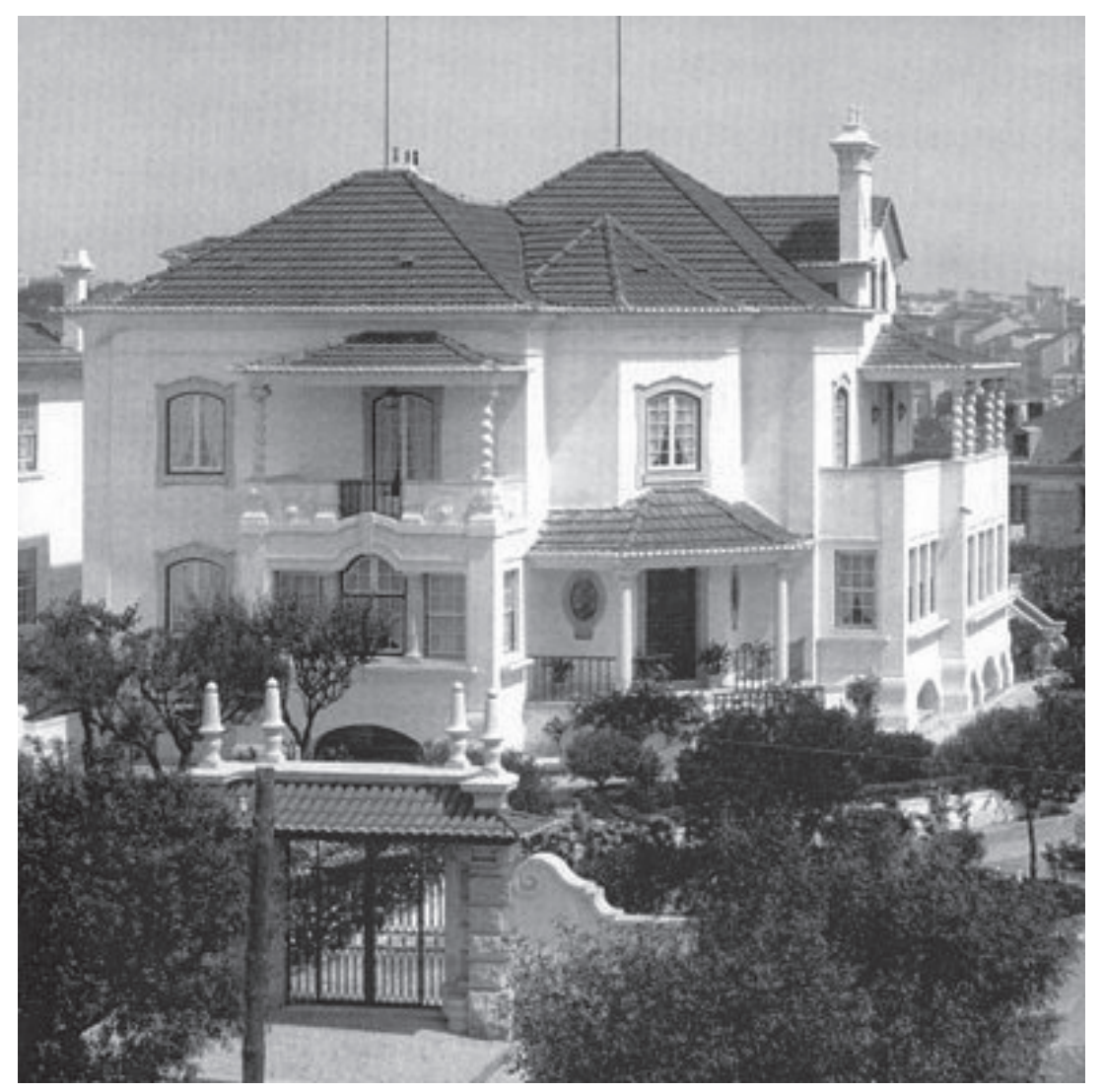

Figura 21 - Vista da casa projetada por Raul Lino e ganhadora do Prêmio Valmor em 1930. Notar a abundante decoração que remete à arquitetura barroca. Disponível em: http:// ulisses.cm-lisboa.pt/data/002/008/ index.php?ml=5\&x=0033.xml. Acesso em: em maio de 2007. 


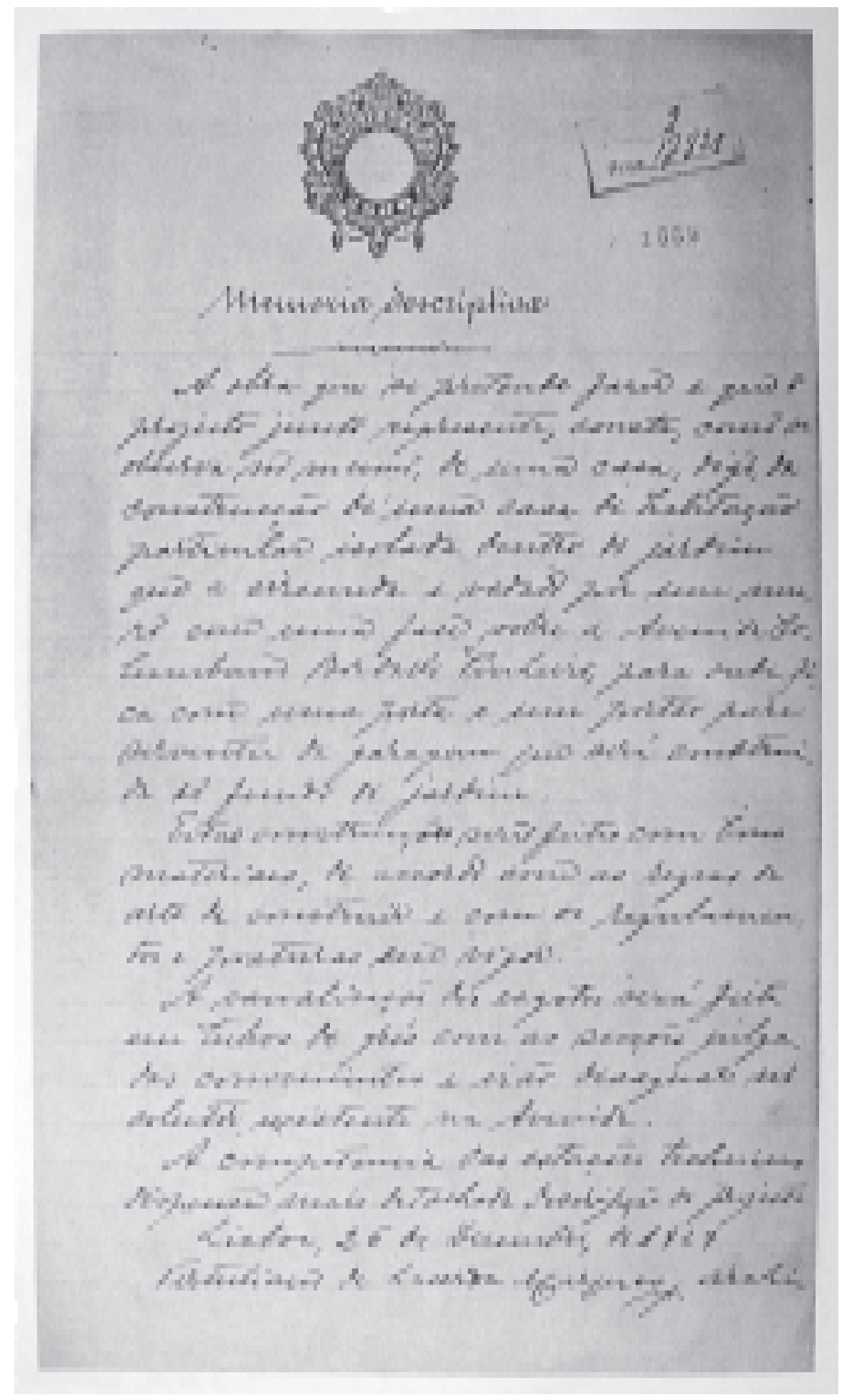

Figura 22 (acima e página 221) - Processo para requerimento de licença para construção da casa projetada pelo arquiteto Tertuliano de Lacerda Marques, em 1930, em Lisboa, à Avenida Columbano Bordalo Pinheiro, 50. Fonte: Arquivo Intermédio, Lisboa. 

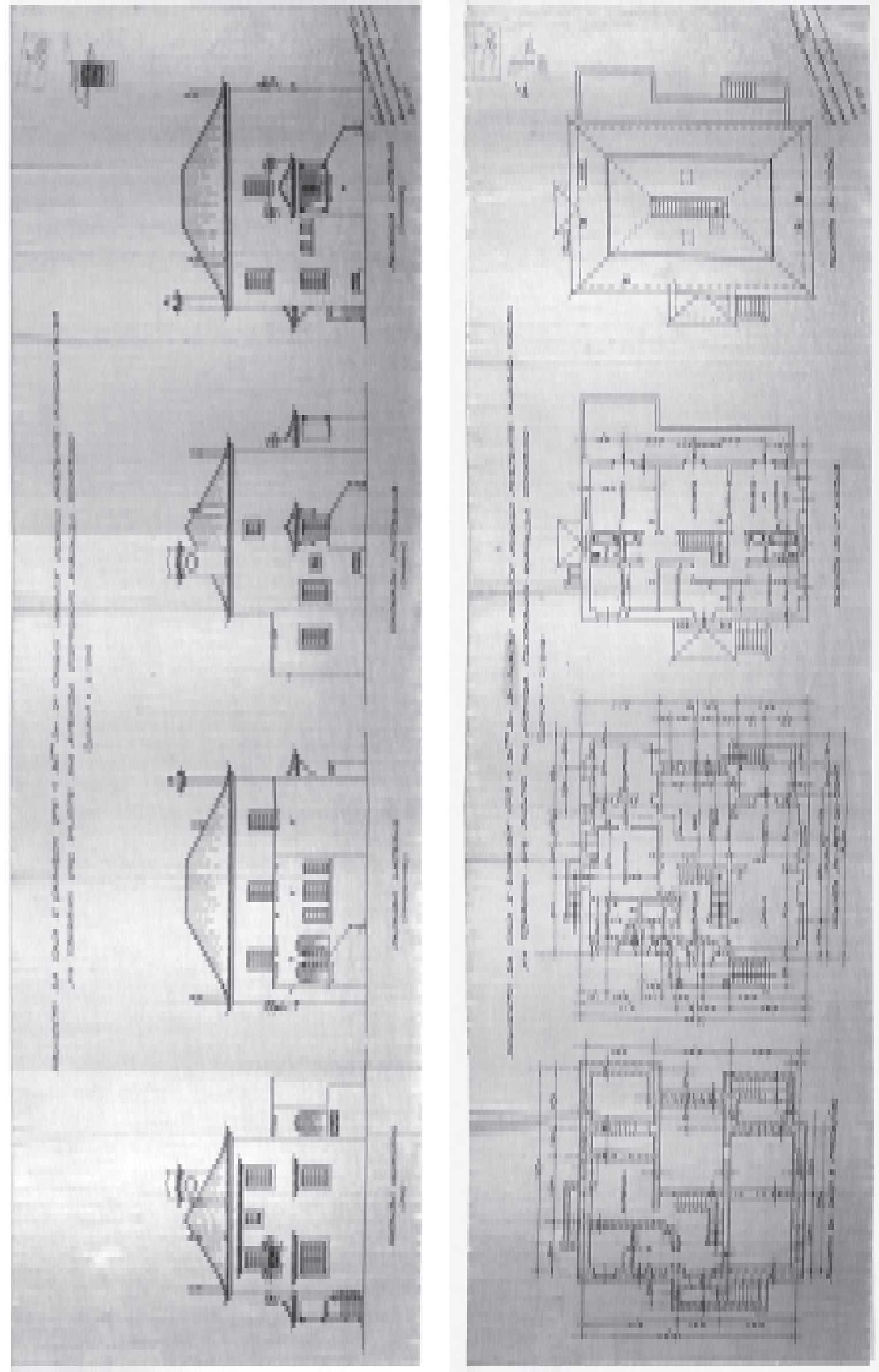


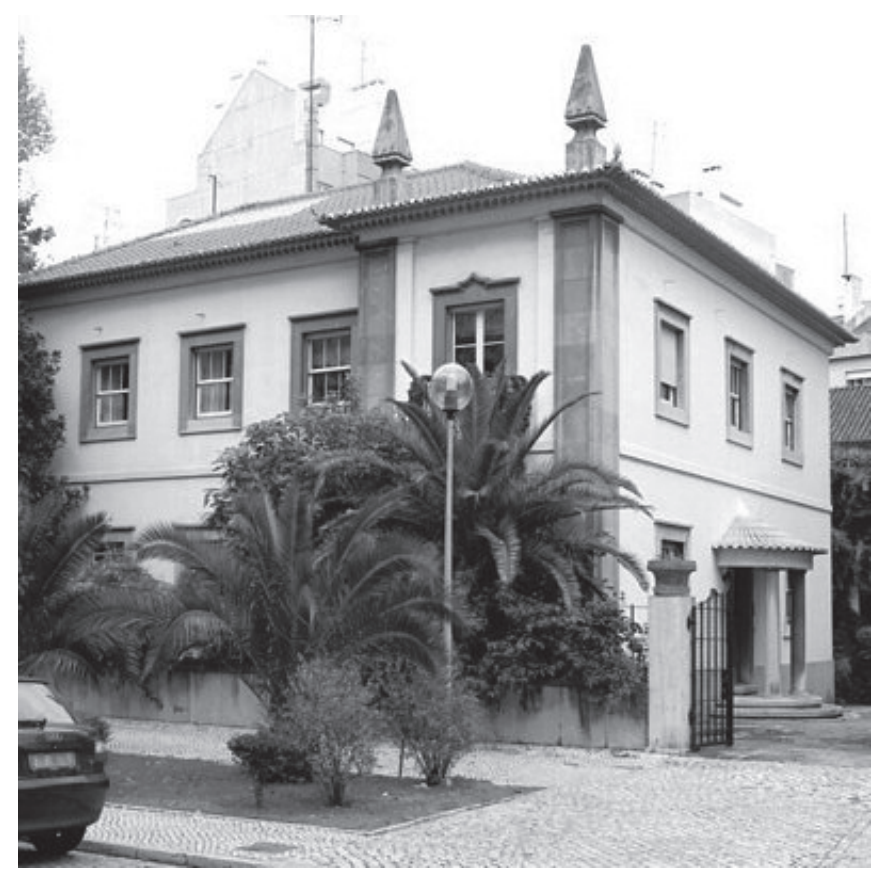

Figura 23a (à esquerda) - Vista da obra que recebeu o Prêmio Valmor em 1939. Os arquitetos foram os irmãos Carlos e Guilherme Rebelo de Andrade, inspirados na arquitetura da época de $D$. João $V$. Disponível em: http://ulisses.cm-lisboa.pt/ data/002/008/index.php?ml=5\&x=0037.xml. Acesso em: em maio de 2007.

Figura 23b (abaixo e páginas 223 a 225) Processo para requerimento de licença para construção da casa projetada pelos irmãos Rebelo de Andrade e vencedora do Prêmio Valmor de 1939. Fonte: Arquivo Intermédio, Lisboa.

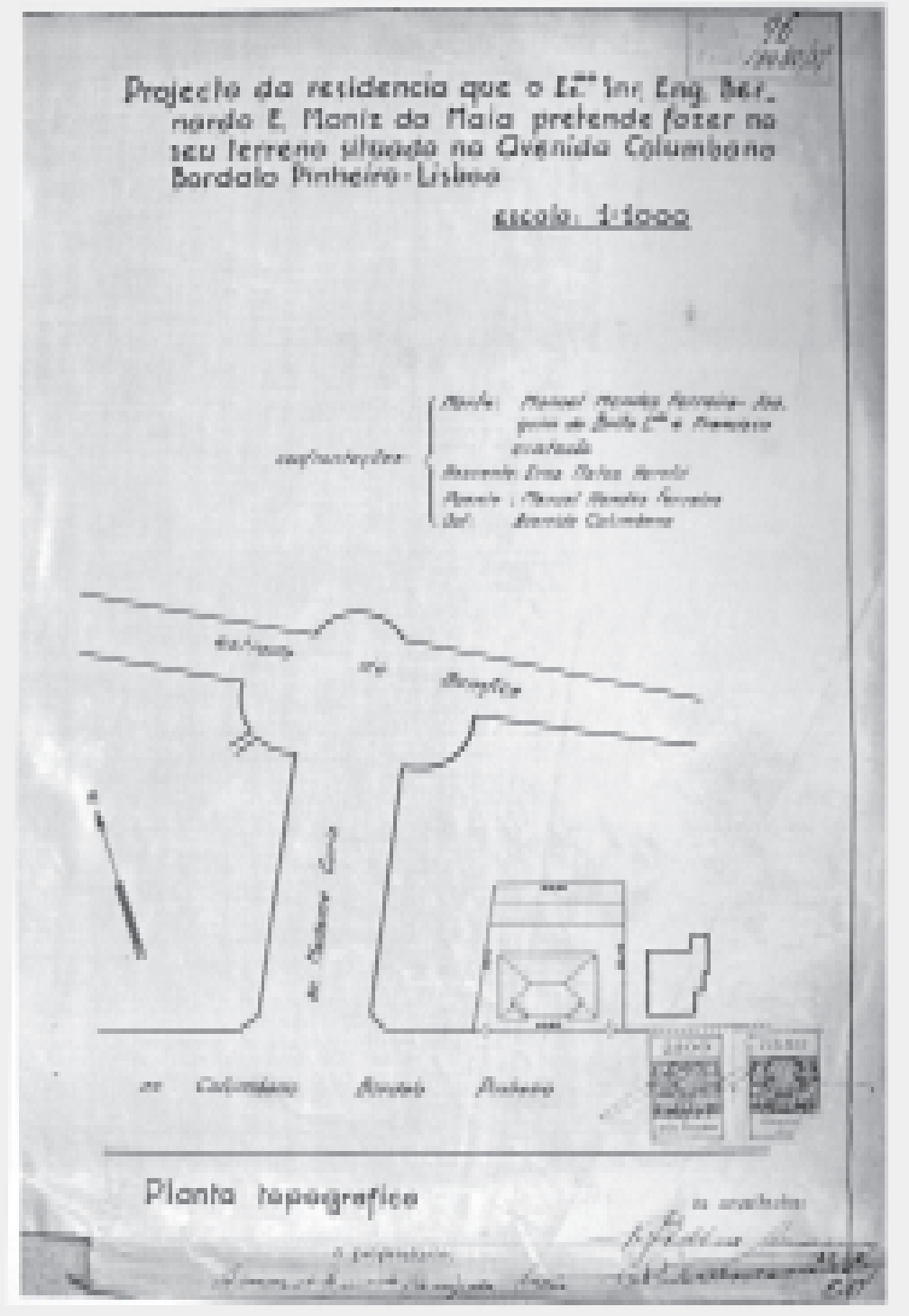




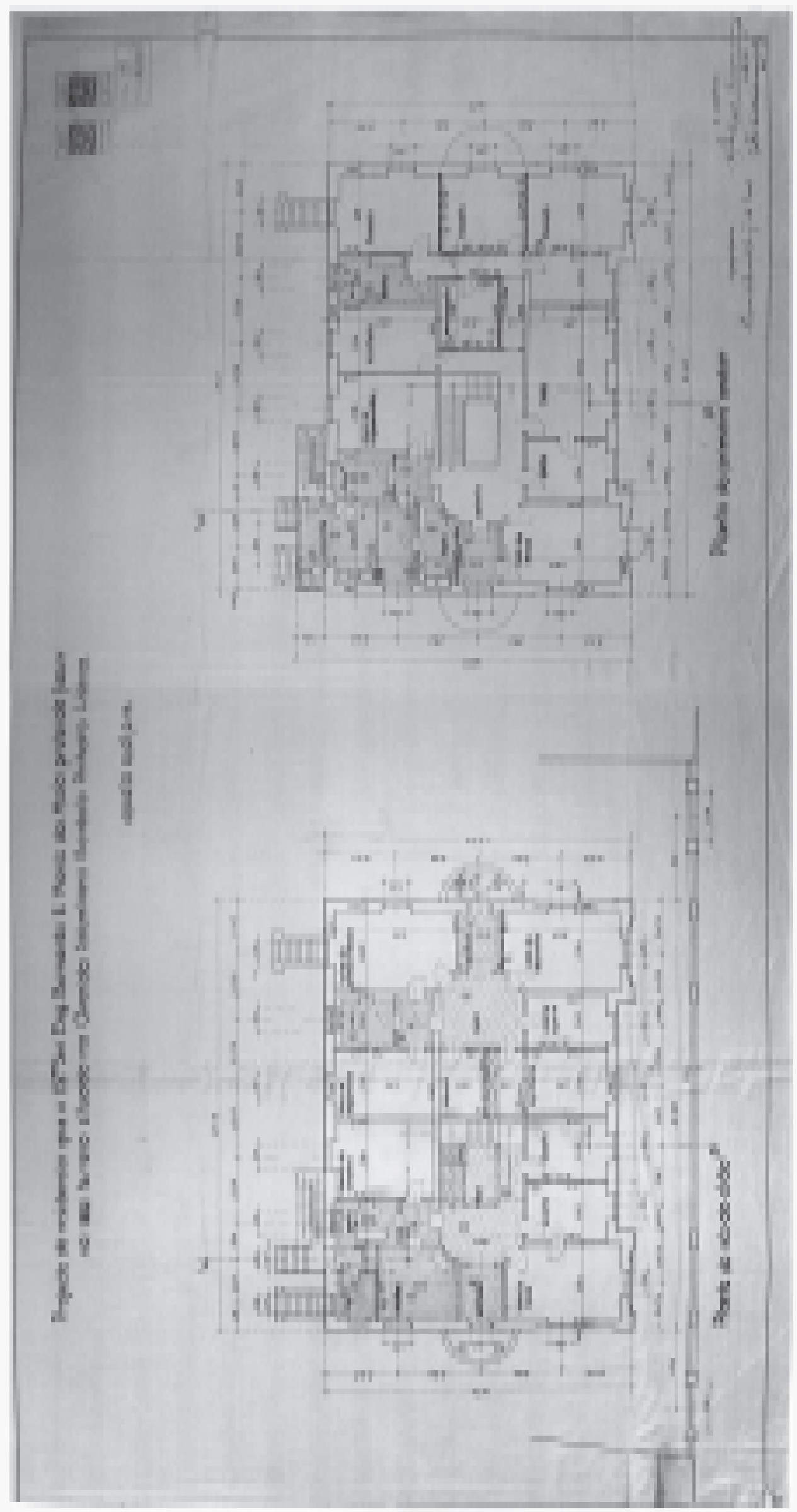




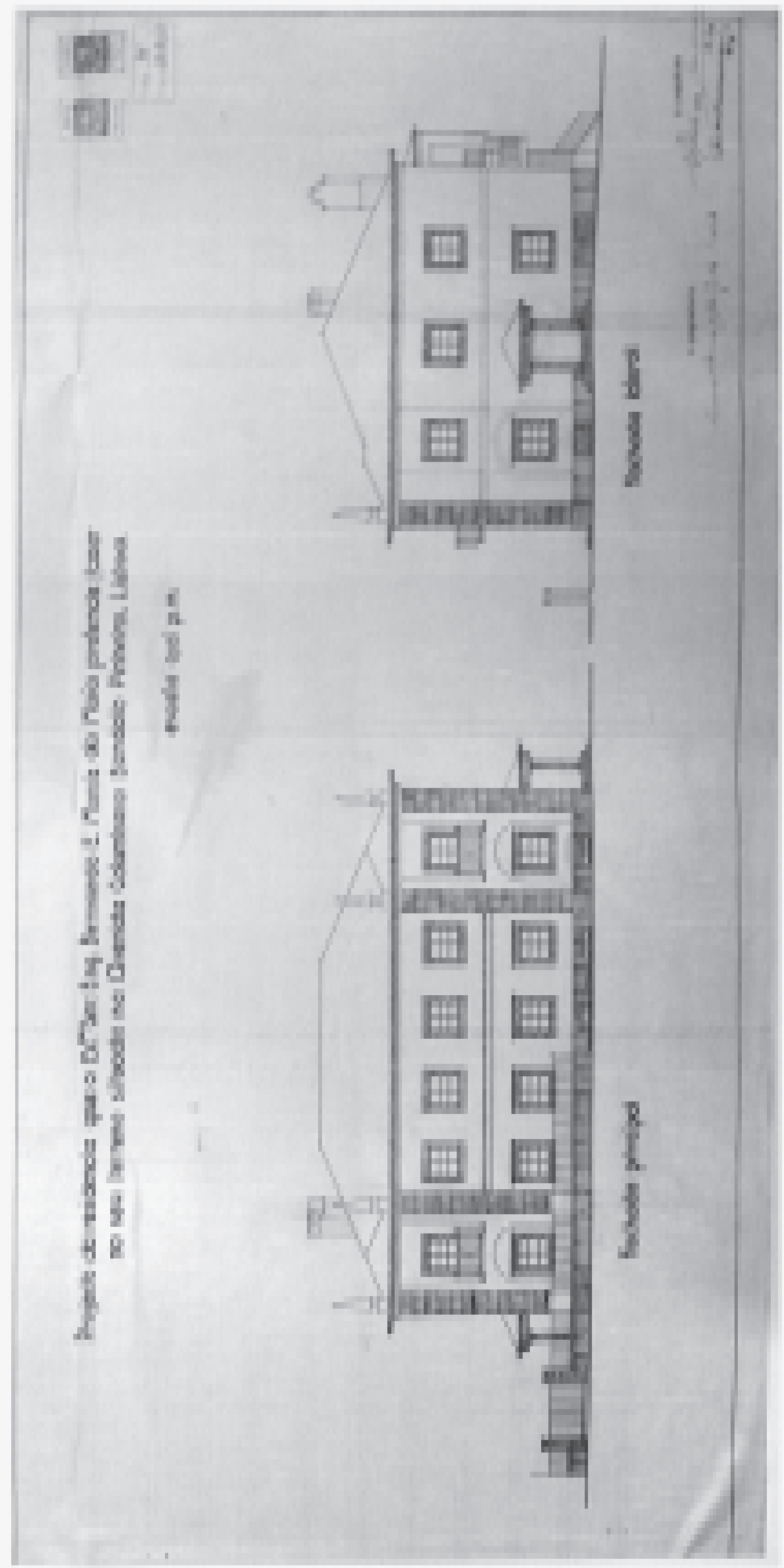




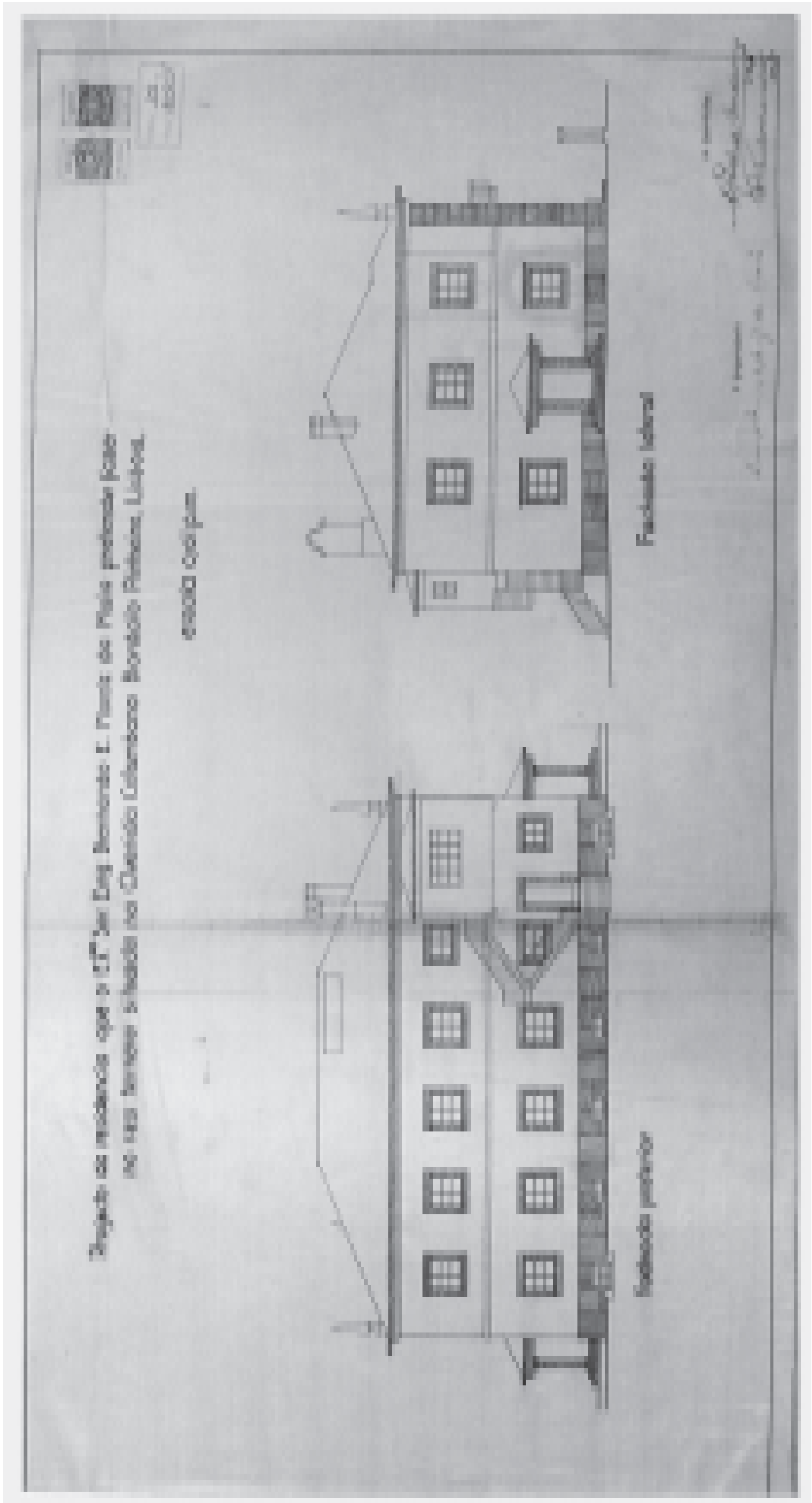




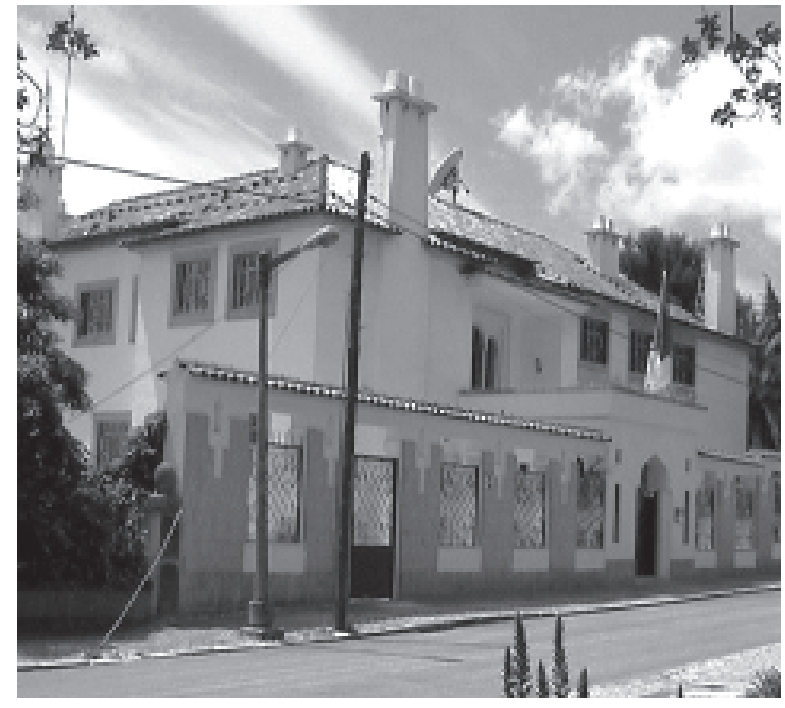

Figura 24 (à esquerda) - Vista da obra de Carlos Chambers Ramos, vencedora do Prêmio Valmor de 1946. A fachada foi alterada para receber a Embaixada da Argélia. Disponível em: http://ulisses.cm-lisboa.pt/ data/002/008/index.php?ml=6\&x=0046.xml. Acesso em: em maio de 2007.

Figura 25 (abaixo e página 227) - Processo para requerimento de licença para reforma de uma casa no Porto, em 1921, cujo projeto é de Carlos Chambers Ramos. Mantém a mesma estética da casa portuguesa. Fonte: Arquivo Municipal do Porto.

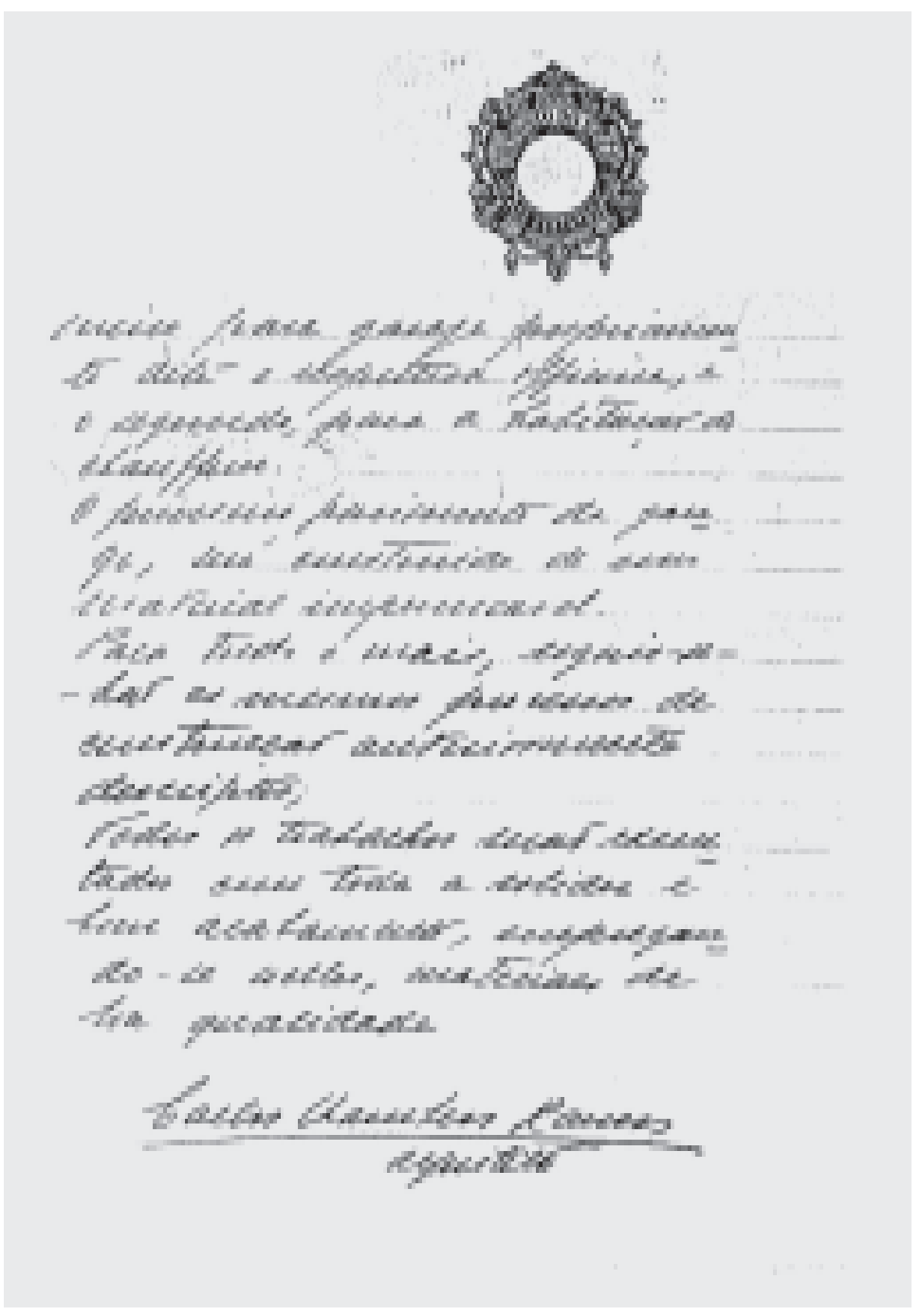



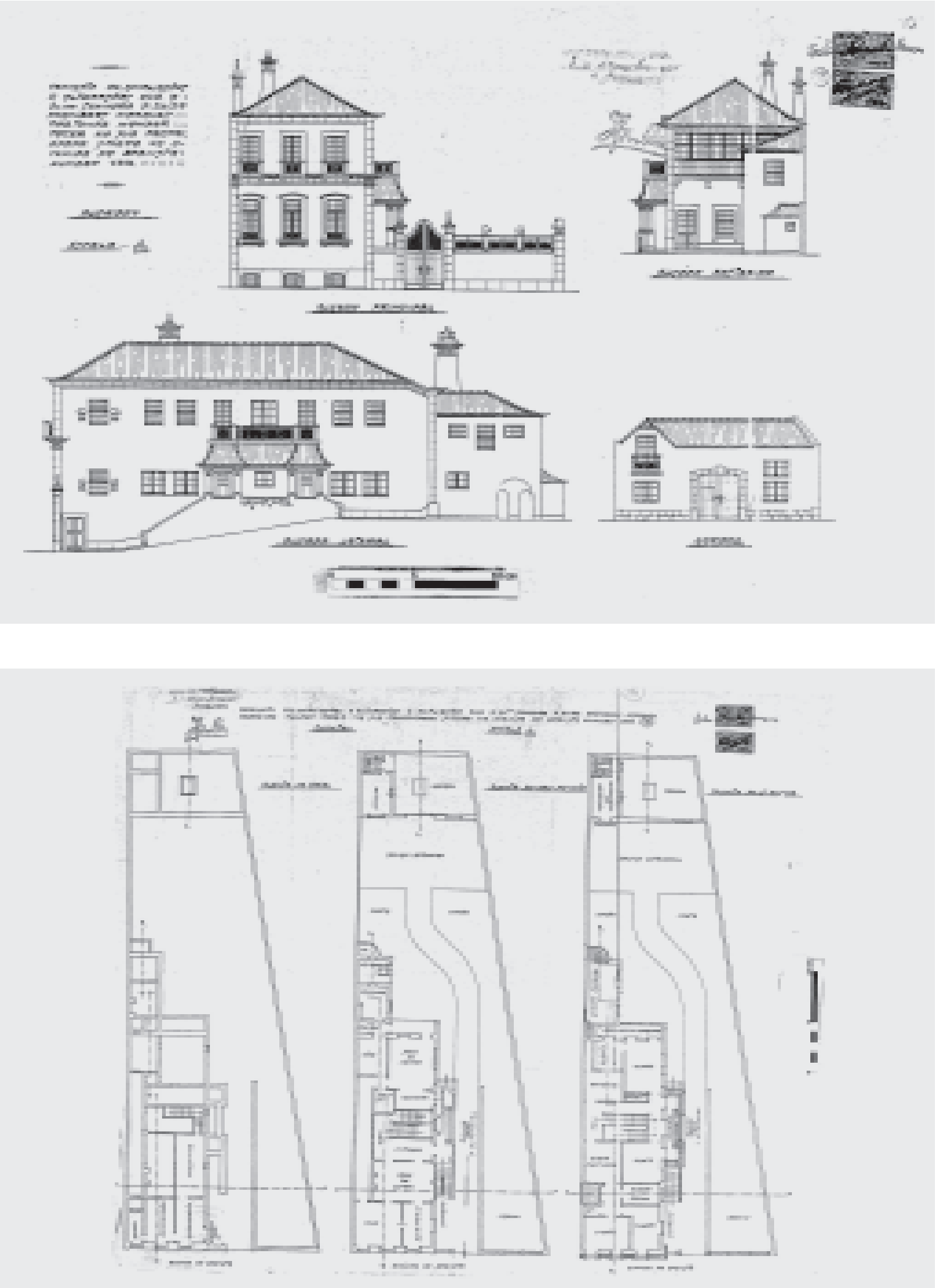


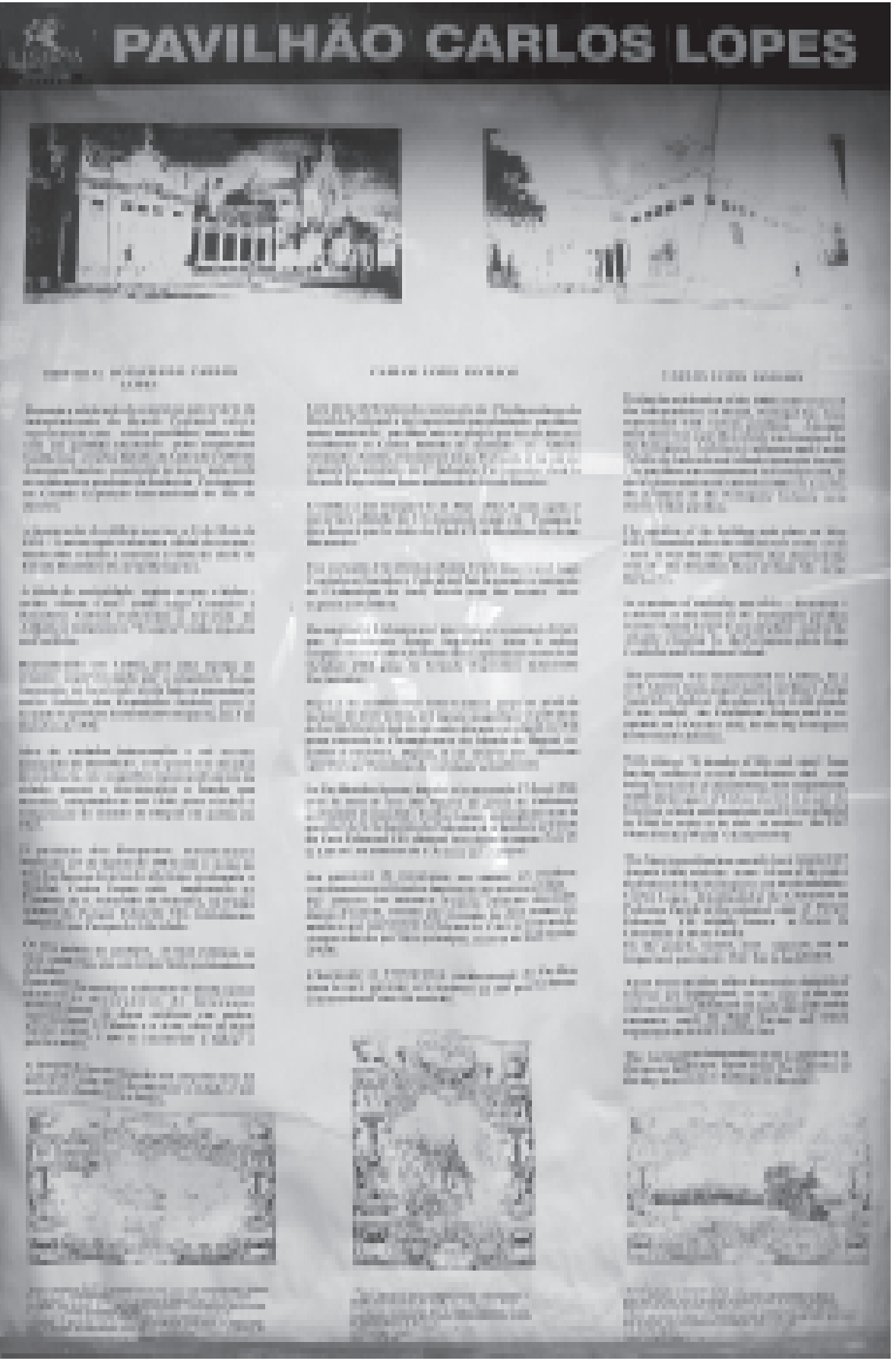

Figura 26a - Placa informativa do histórico do atual Pavilhão Carlos Lopes originalmente Palácio das Indústrias de Portugal da Exposição Internacional de 1922, RJ - reconstruído no Parque Carlos VII, Lisboa. O histórico informa que o projeto é de autoria dos irmãos Carlos e Guilherme Rebelo de Andrade. Fonte: foto da autora, março de 2006. 


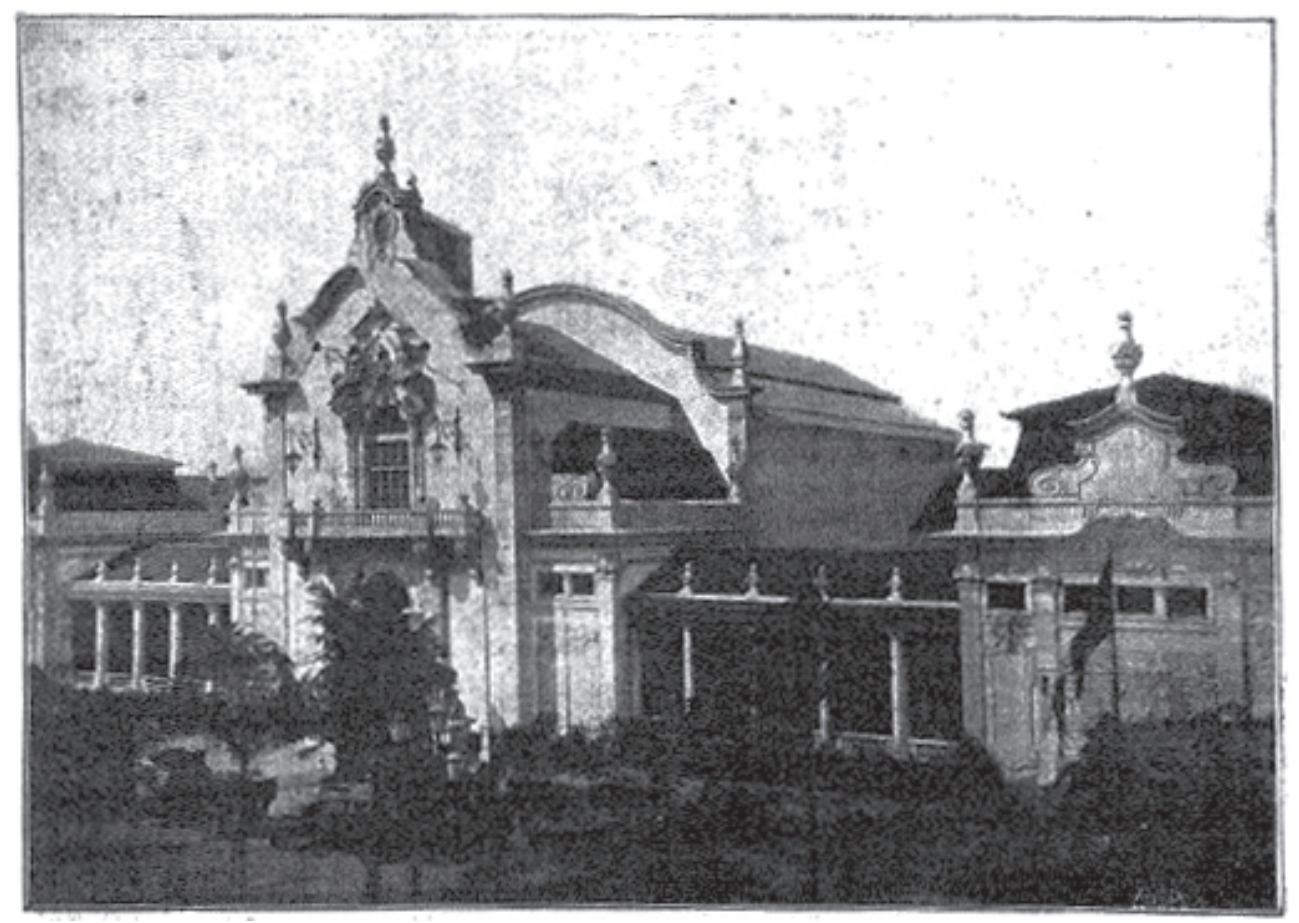

Figura 26b - Vista do Palácio das Indústrias de Portugal na Exposição Internacional do Rio de Janeiro em 1922. Notar a mesma inspiração dos irmãos arquitetos para a concepção do pavilhão na arquitetura da época de $D$. João $V$. Fonte: Livro de Ouro Commemorativo do Centenário da Independência e da Exposição Internacional. 

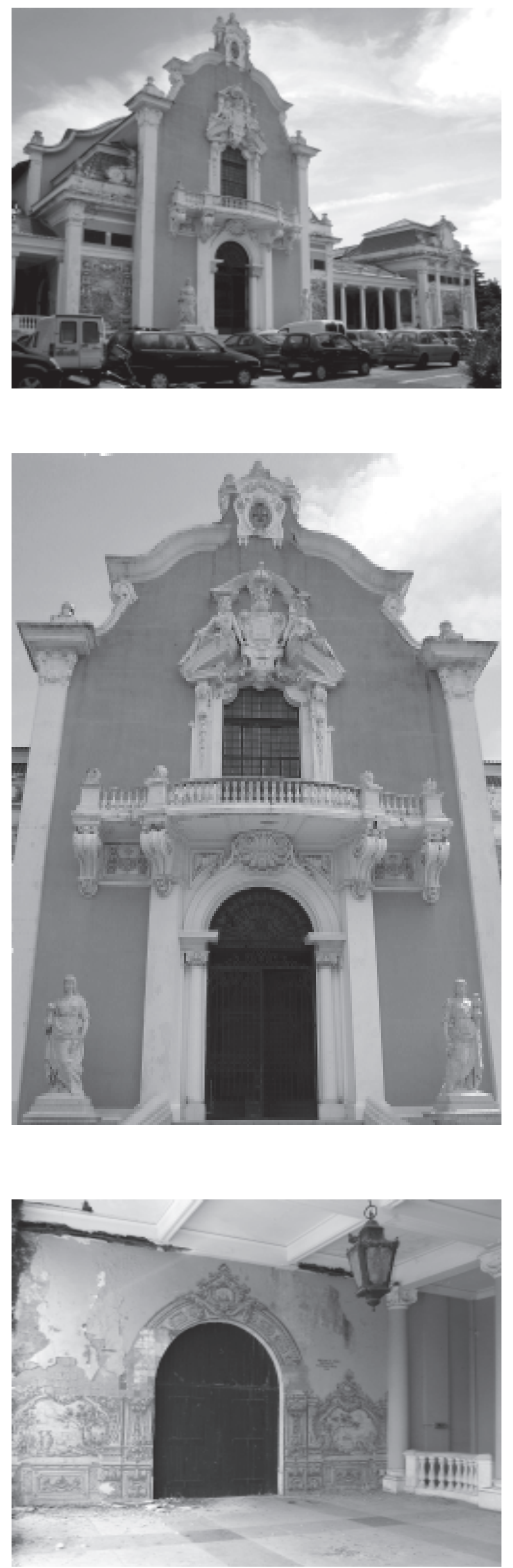

Figura 27 (páginas 230 e 231) - Aspecto recente do Pavilhão Carlos Lopes originalmente Palácio das Indústrias de Portugal da Exposição Internacional de 1922, RJ. Notar a decoração, os painéis de azulejo e o estado geral da obra, que denota o abandono. Não consta como imóvel protegido pelo Instituto Português do Património Arquitectónico (IPPAR). Na Direcção Geral dos Monumentos e Edifícios Nacionais (DGEMN) não havia mais informações disponíveis. Fonte: fotos da autora, junho de 2007. 

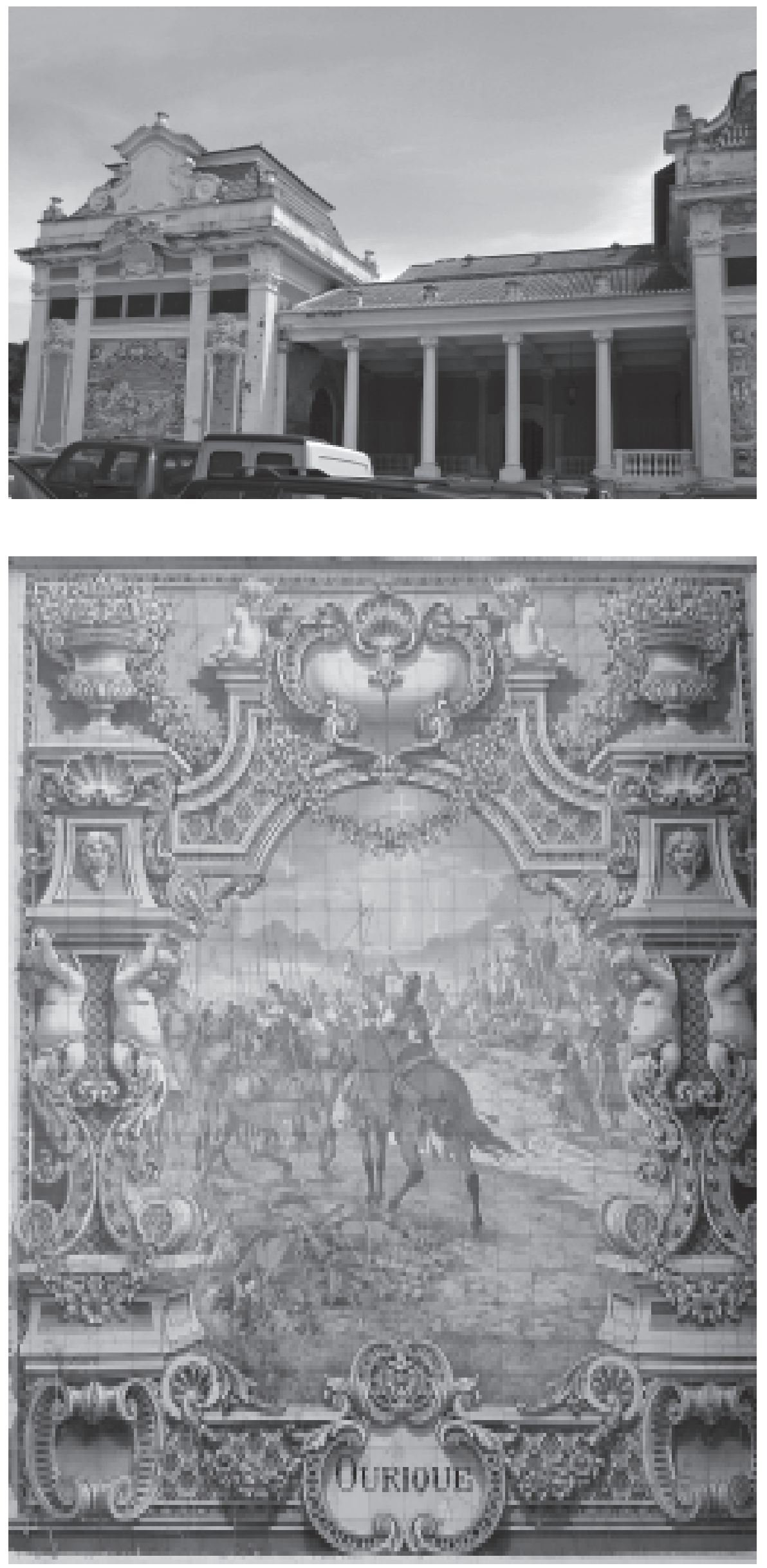


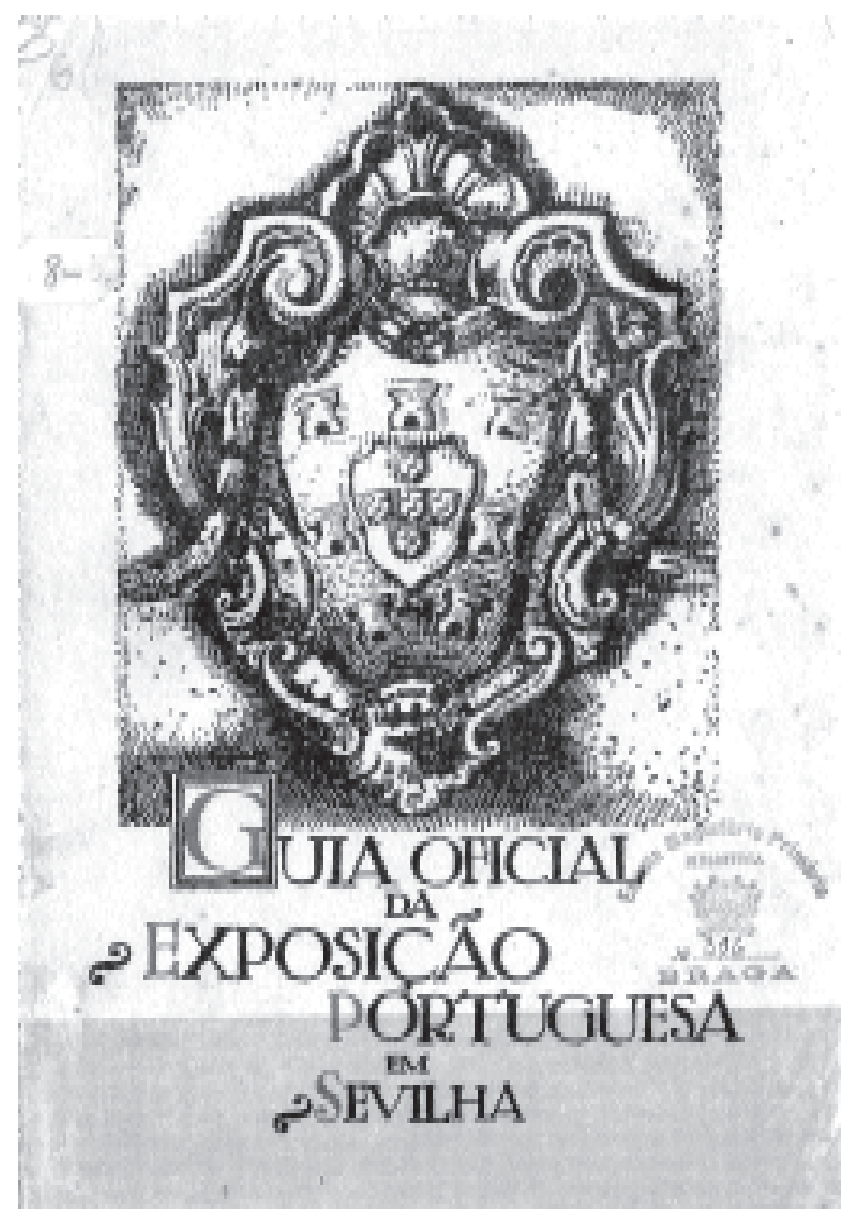

Figura 28 (páginas 232 e 233) - Capa do Guia Oficial da Exposição Portuguesa em Sevilha, com vista e planta do Pavilhão Português projetado pelos irmãos Rebelo de Andrade. Fonte: Guia Oficial da Exposição Portuguesa em Sevilha, 1929.
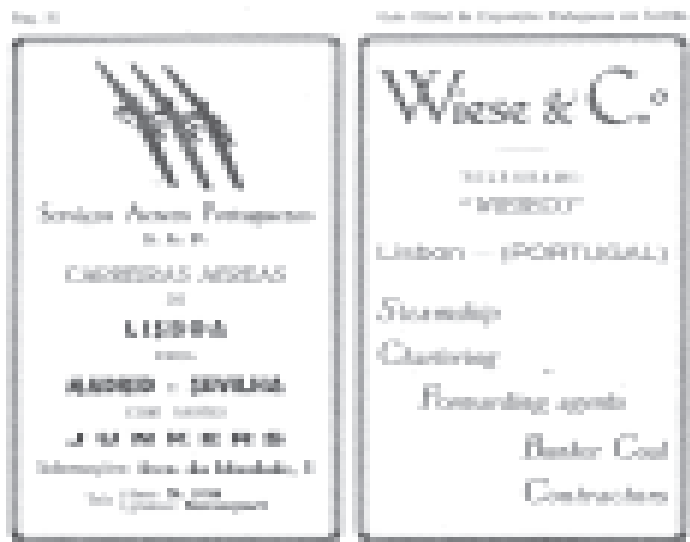

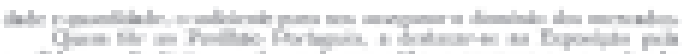

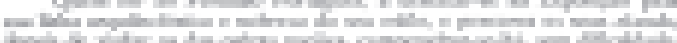

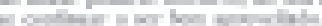

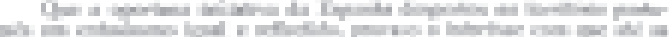

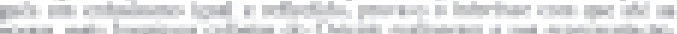

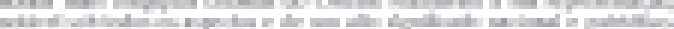

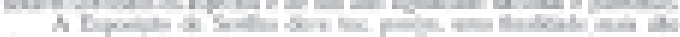
-

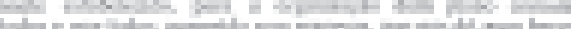

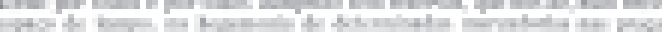

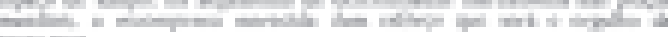
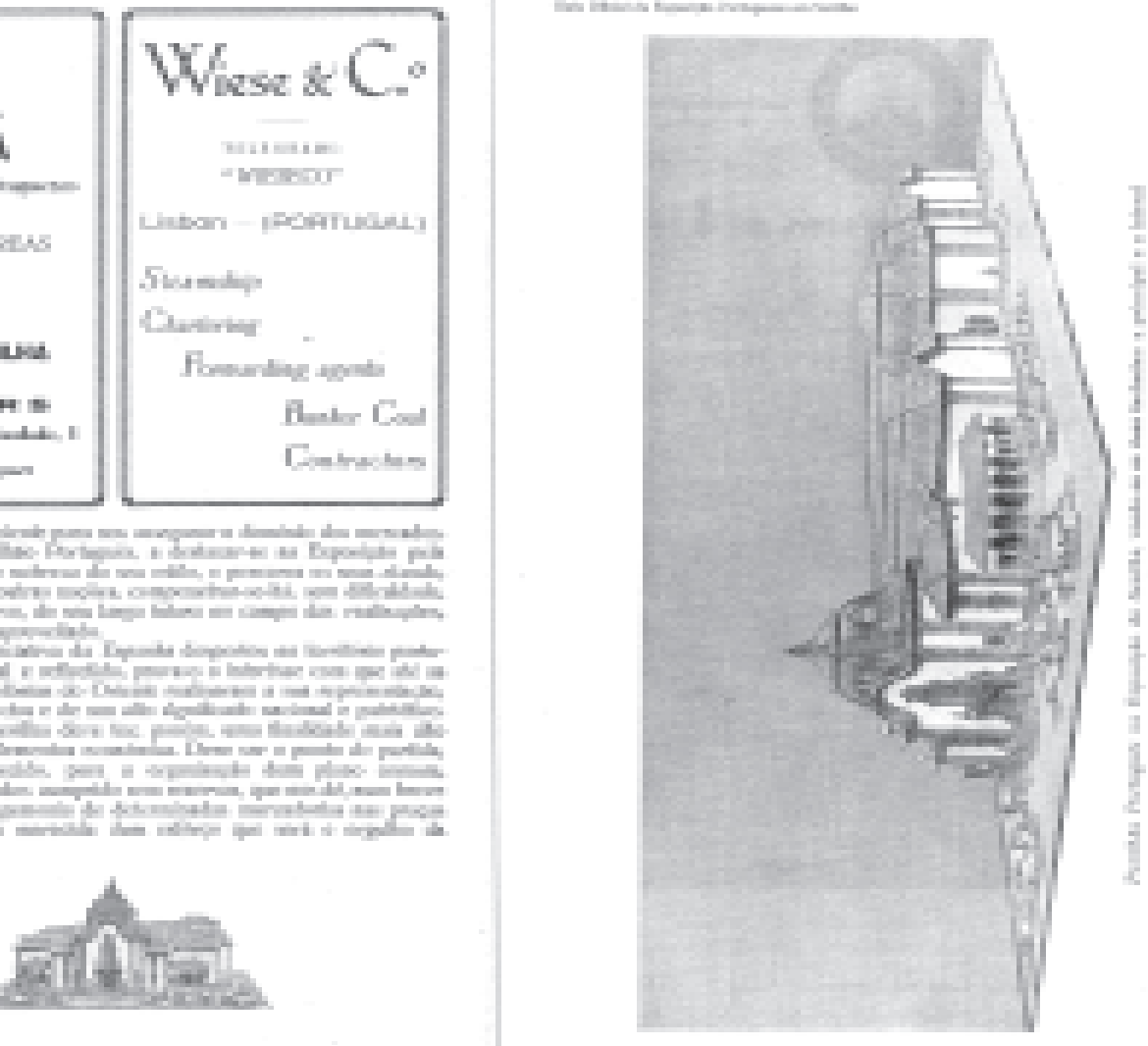


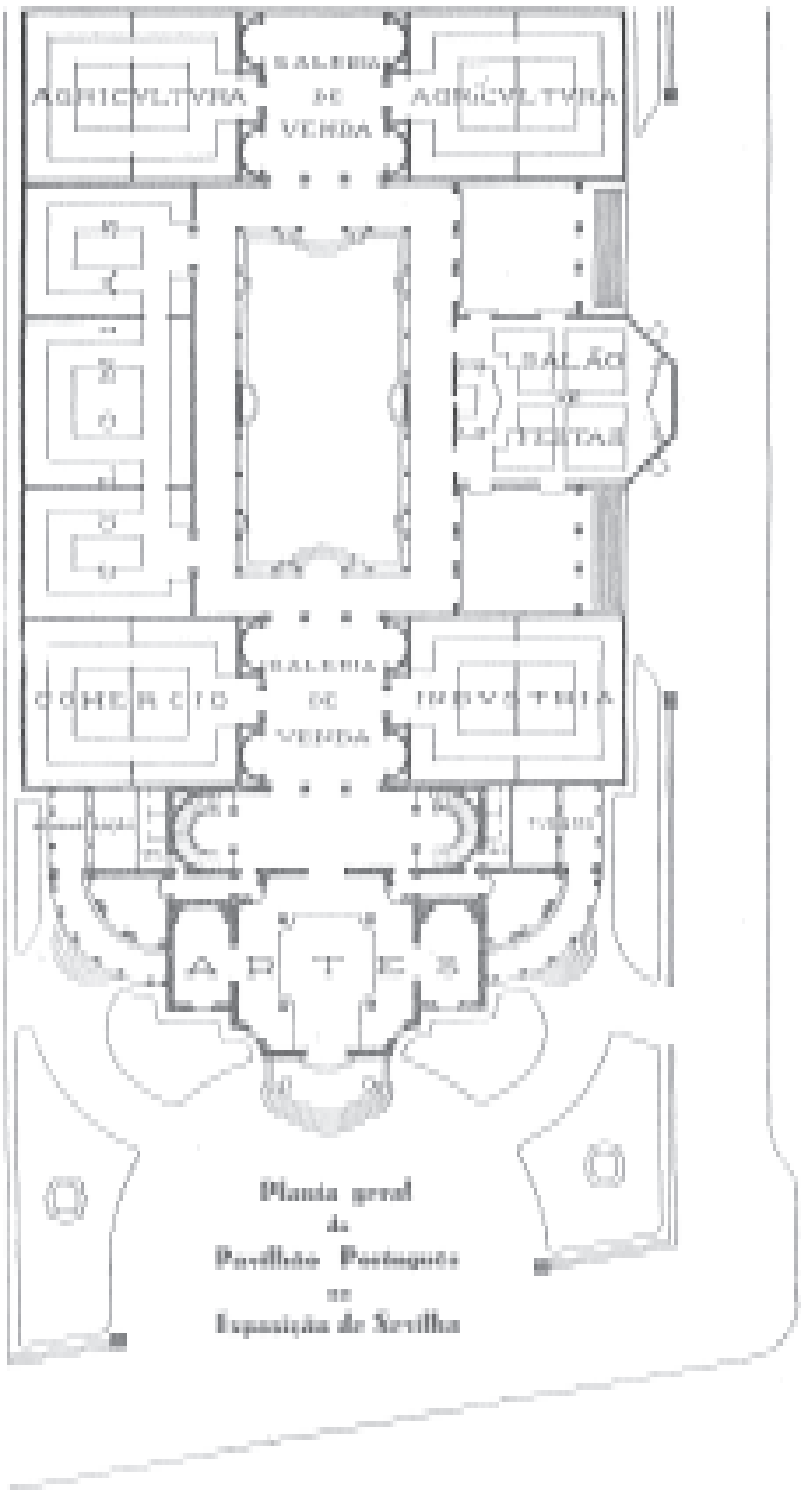




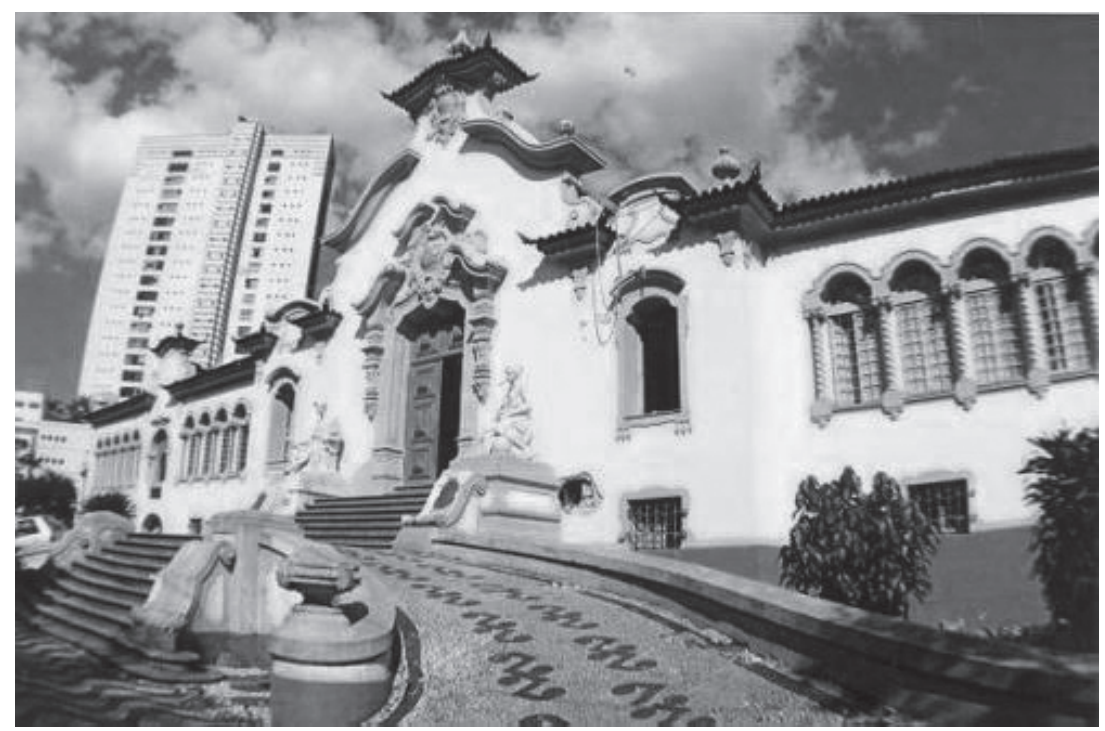

Figura 29 (acima) - Fachada do Colégio Pedro II, em Belo Horizonte. Notar semelhança com o Pavilhão das Indústrias de Portugal da Exposição Internacional do Rio de Janeiro, 1922. Disponível em: http:// pedrosegundo.tripod.com/fotos/index.html. Acesso em: 17/03/2007.
Figura 30 (abaixo e página 235) - Projeto do arquiteto Vasco de Moraes Palmeiro (Regaleira) publicado em 1937 na revista Aquitetura. Permanecem traços da arquitetura tradicionalista portuguesa, embora a volumetria e as linhas marcadamente horizontais pertençam à estética modernista. Fonte: Revista Arquitectura: Revista de Arte e Construção (1937,p. 170-171).

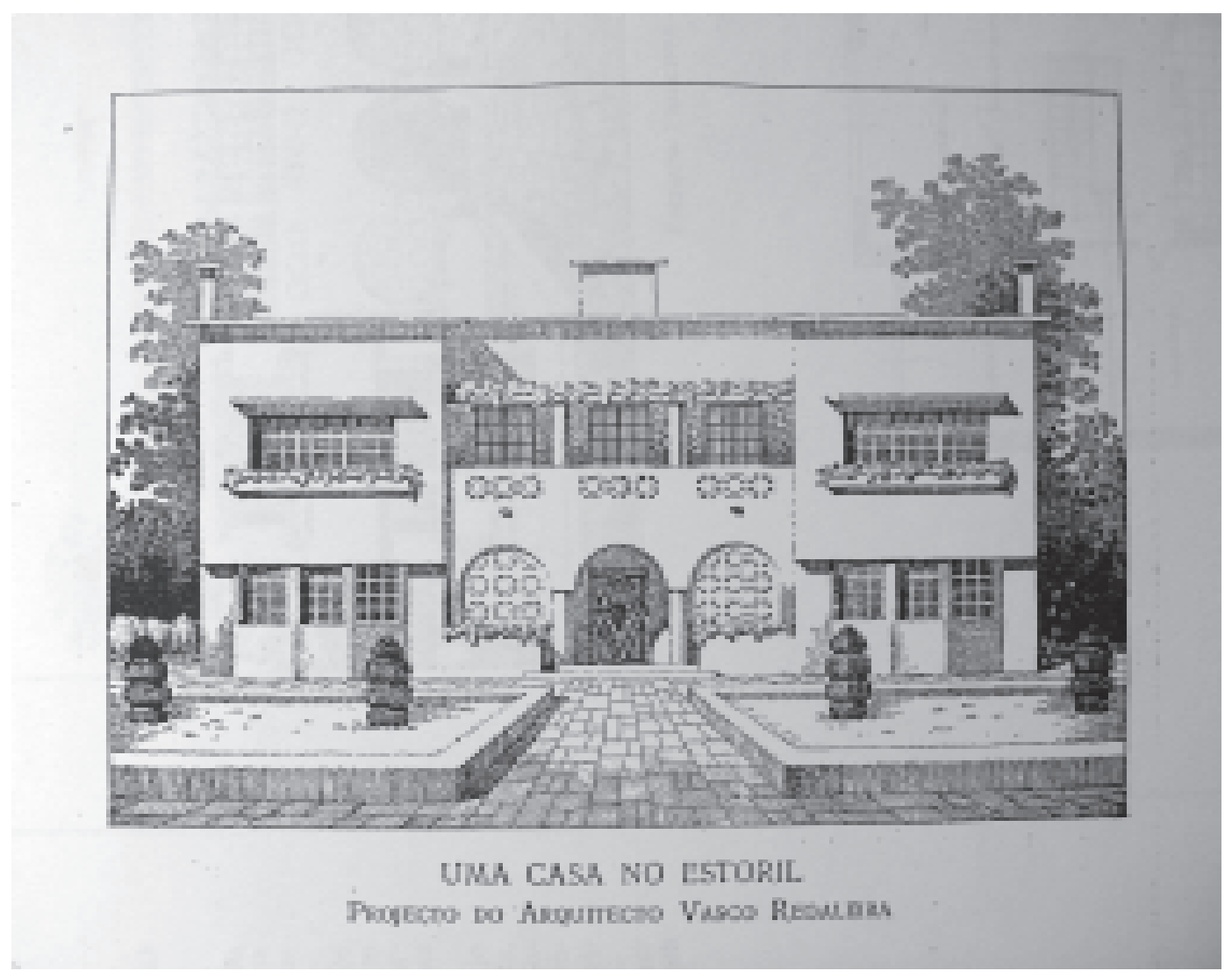



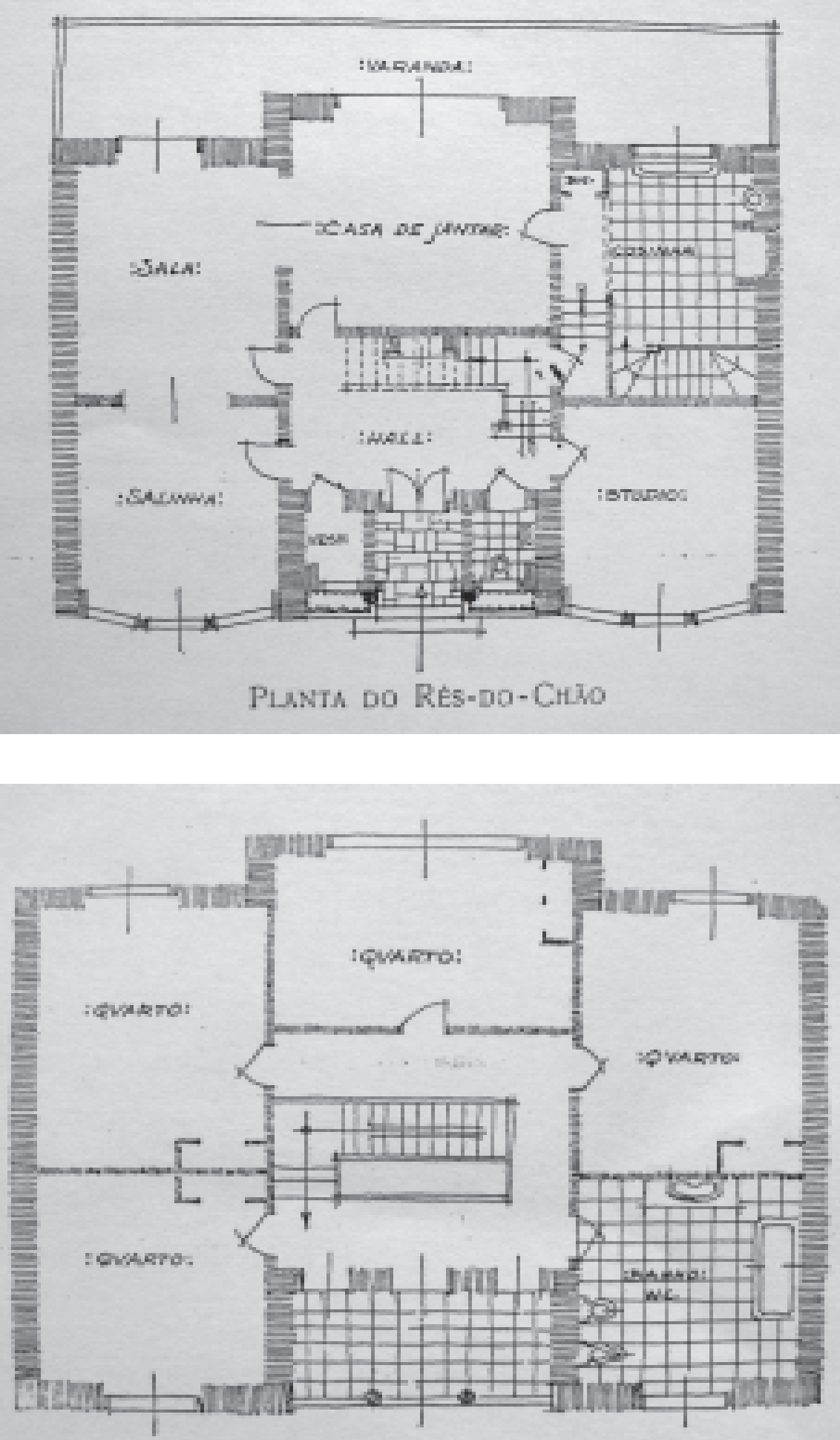

PIanta do L." Andar 


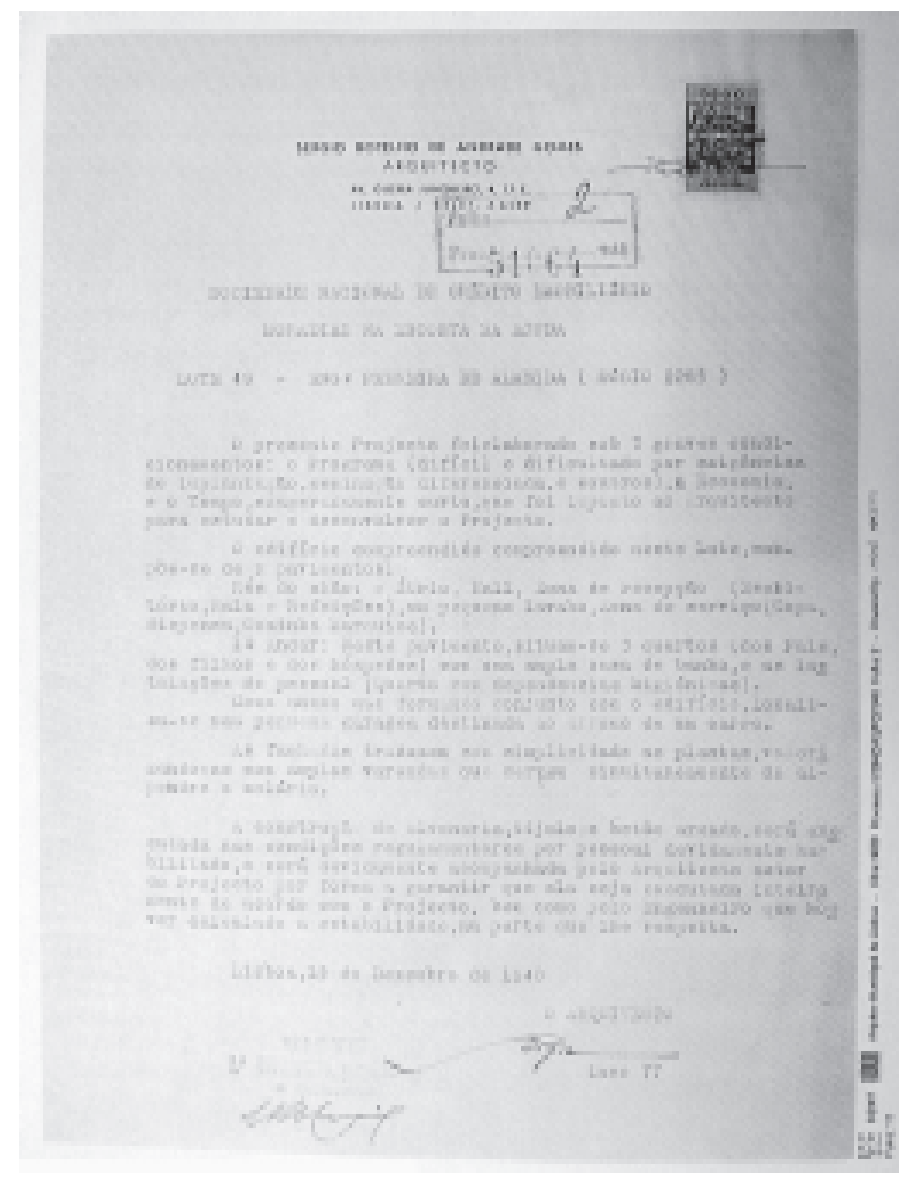

Figura 31 (páginas 236 e 237) - Processo para requerimento de licença para construção da casa projetada pelo arquiteto Sérgio Botelho de Andrade Gomes, em 1949. Mais um exemplo de edificação que mistura elementos da linguagem tradicionalista e modernista. Fonte: Arquivo Intermédio, Lisboa.

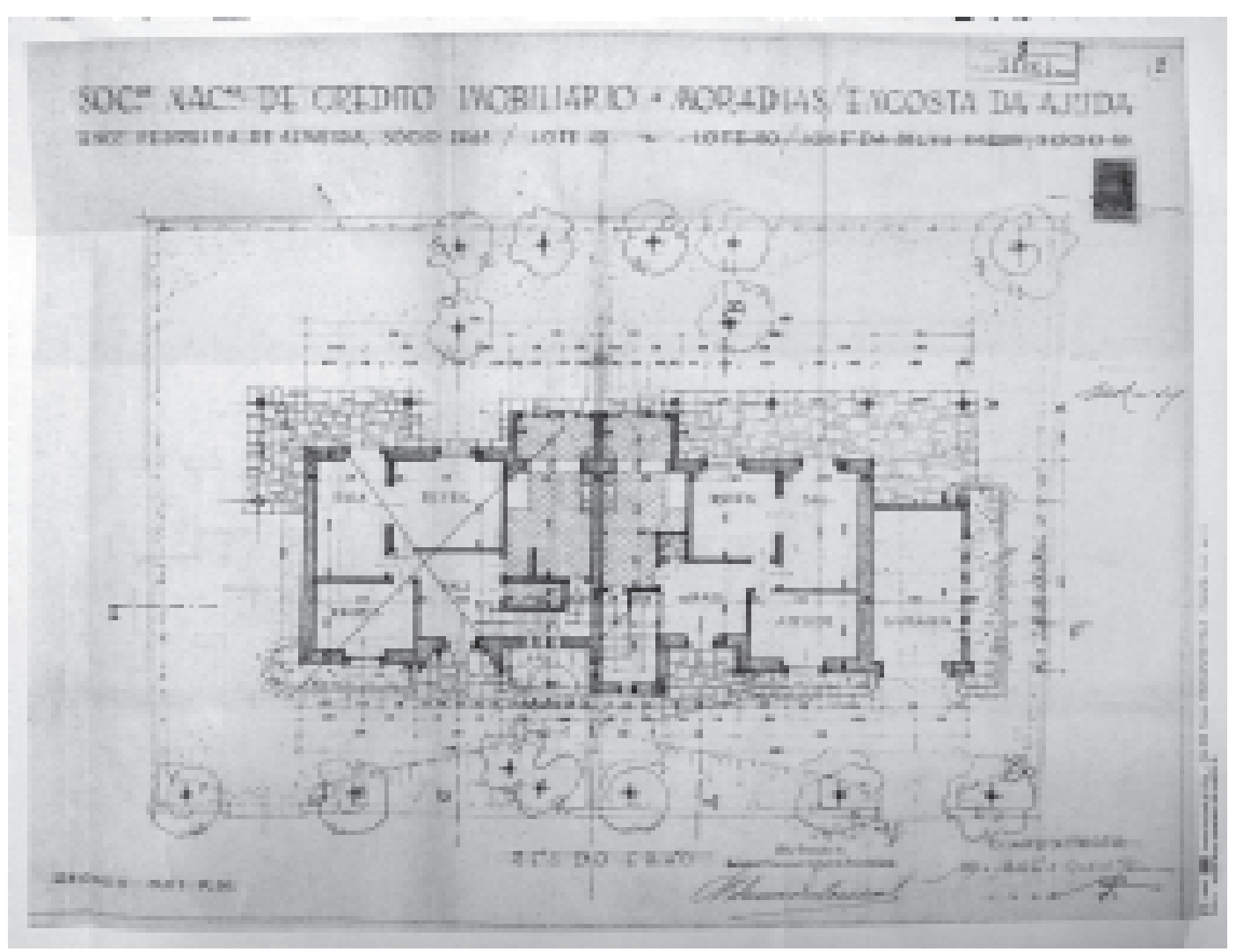



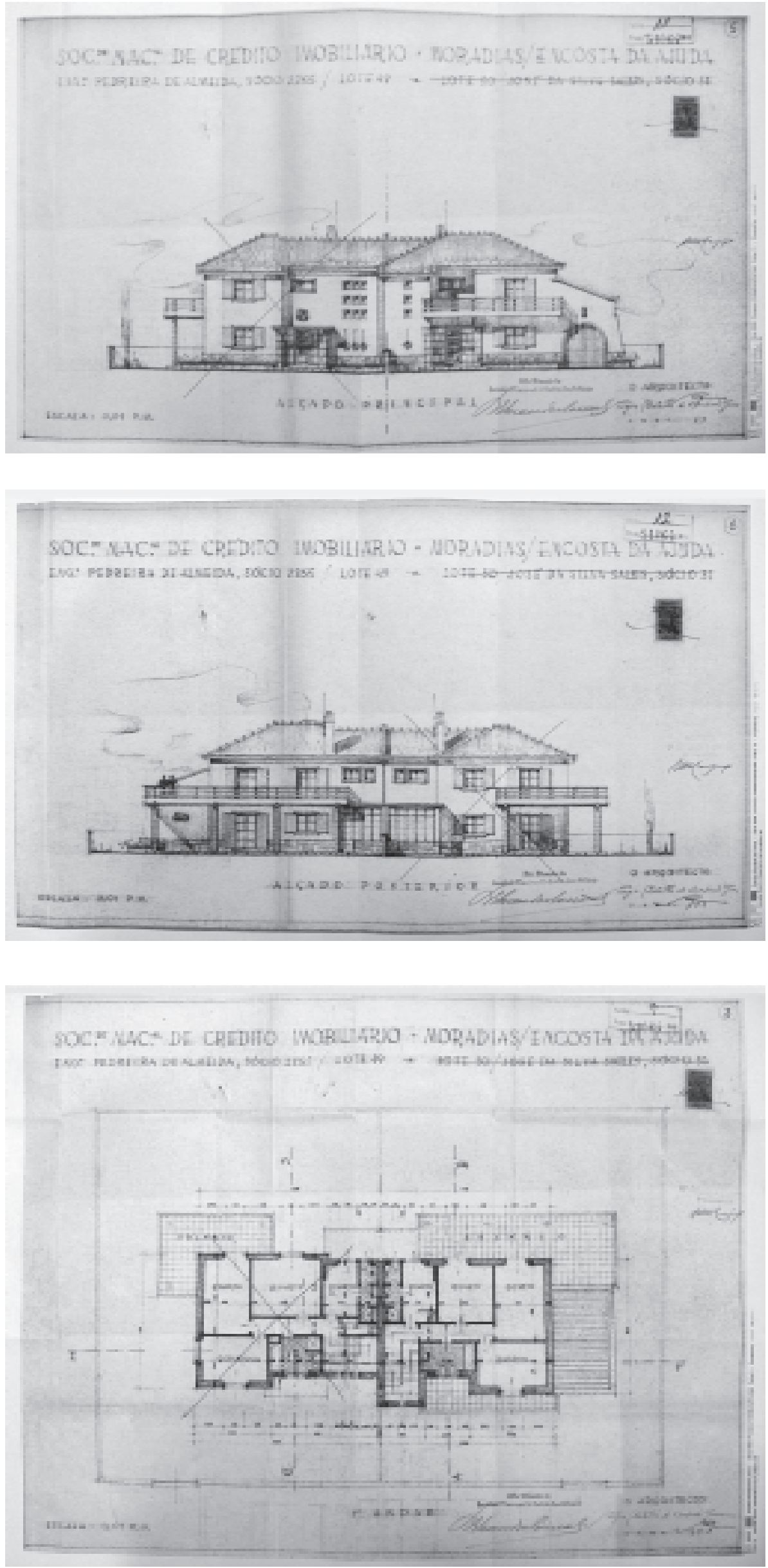

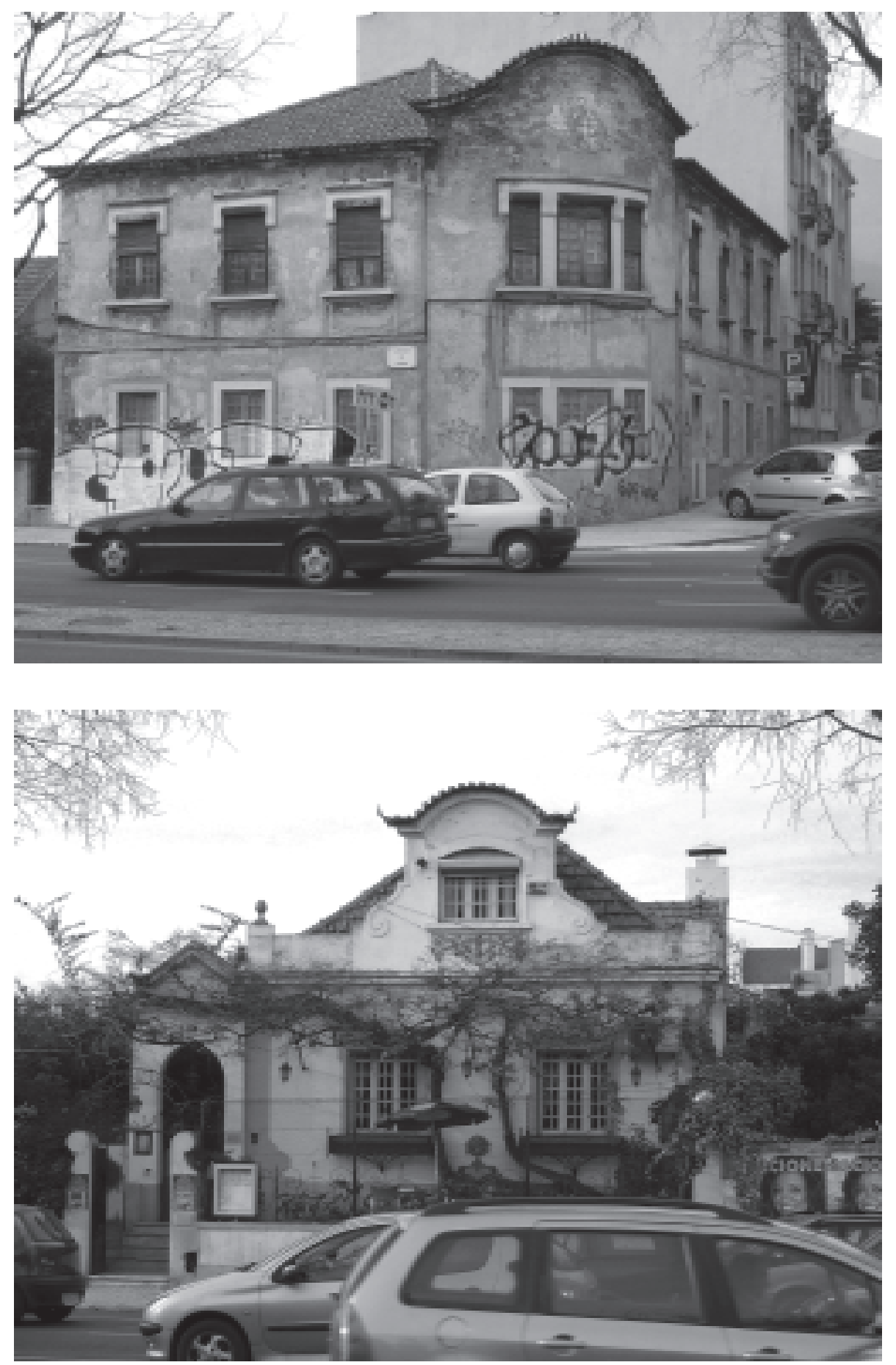

Figura 32 - Duas edificações, na Avenida de Berna, Lisboa, com características da arquitetura tradicionalista. Possivelmente, tenham existido, nessa avenida, vários outros exemplares de mesma tendência arquitetônica. Fonte: fotos da autora, junho de 2006. 


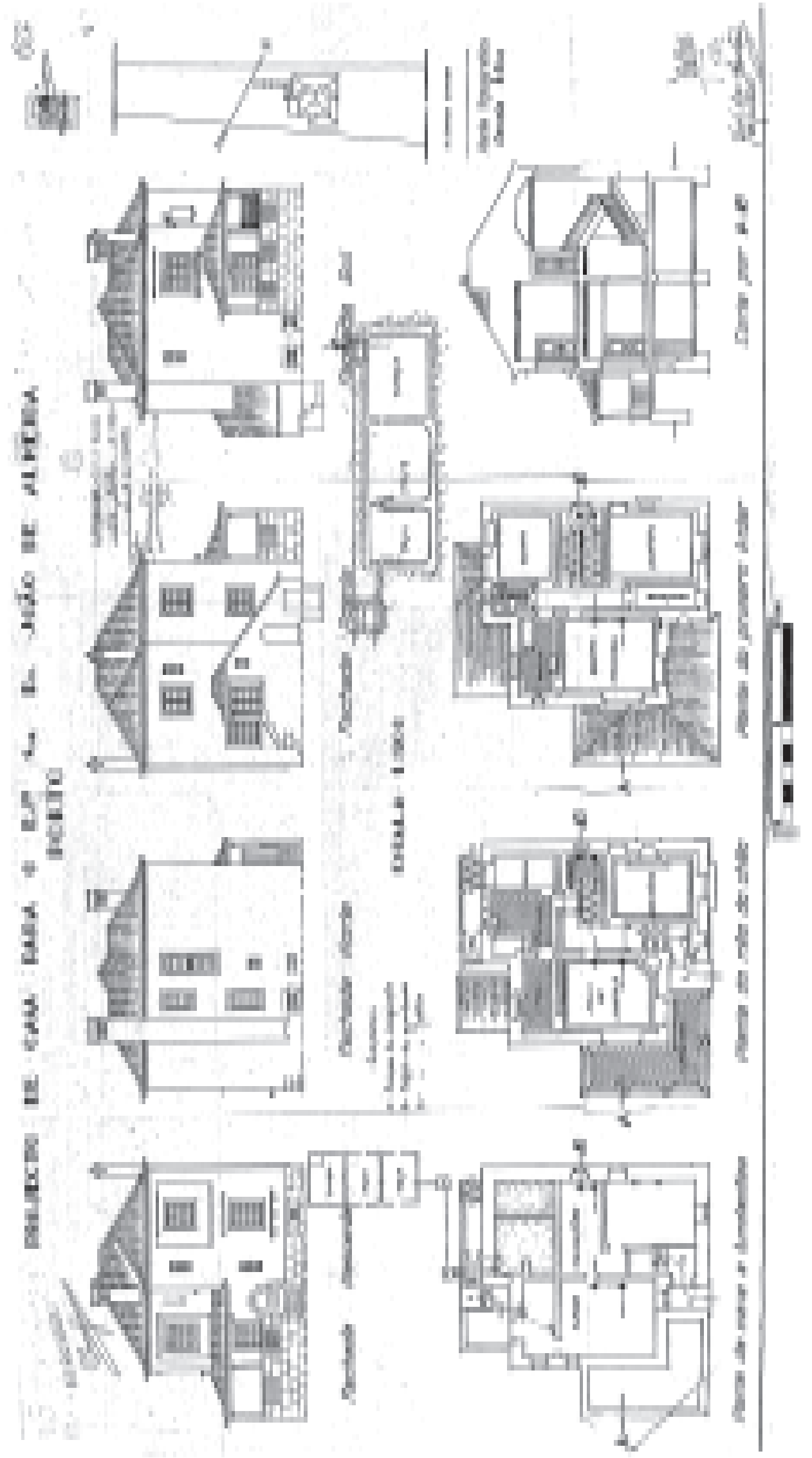

Figura 33 - Projeto de Raul Lino no Porto,

1930. Fonte: Arquivo Municipal do Porto. 


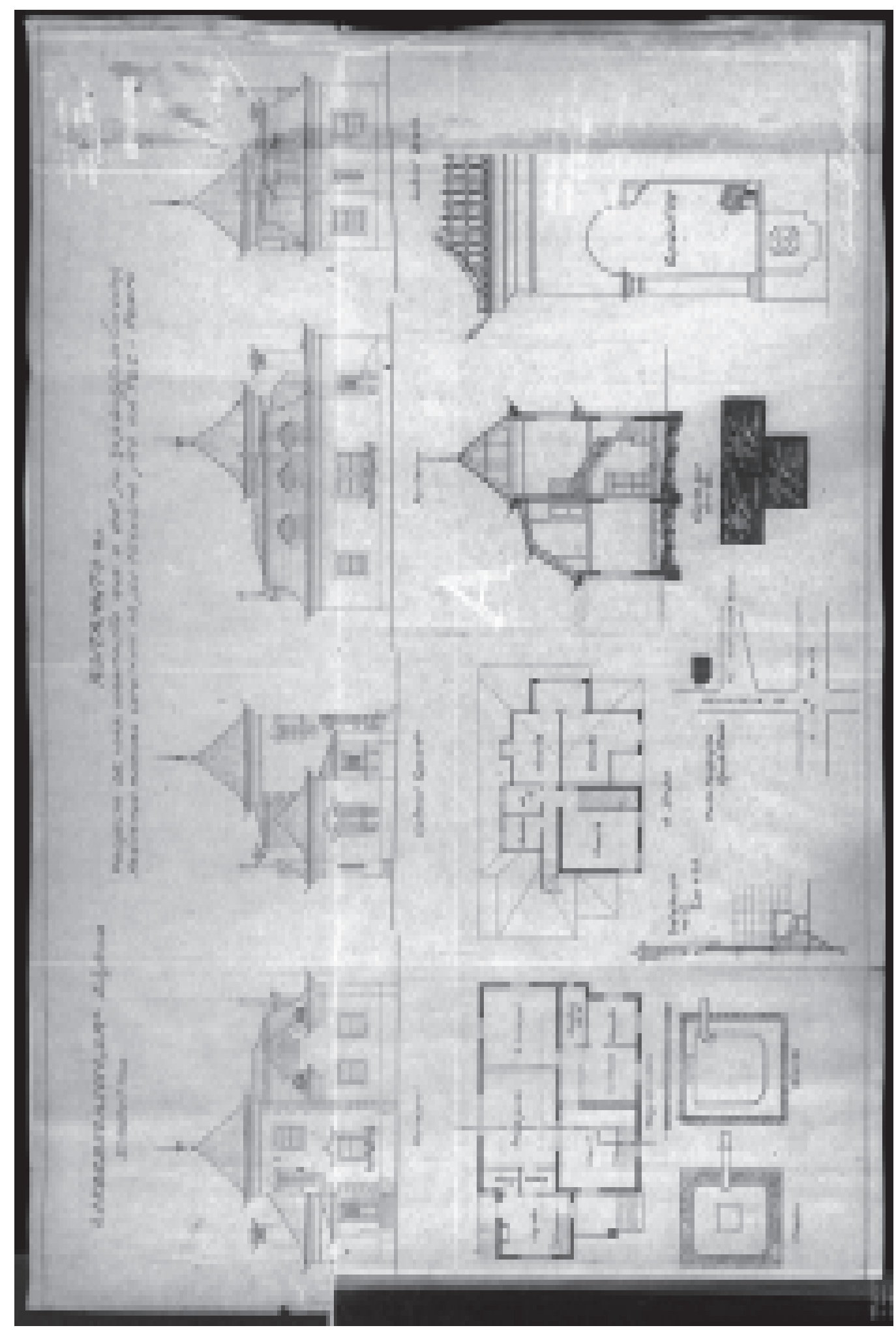

Figura 34 - Processo para requerimento de licença para construção de uma casa no Porto, sob a responsabilidade do mestrede-obras Antonio Rodrigues de Carvalho. Notar a abundante decoração inspirada na arquitetura tradicionalista. Fonte: Arquivo Municipal do Porto. 


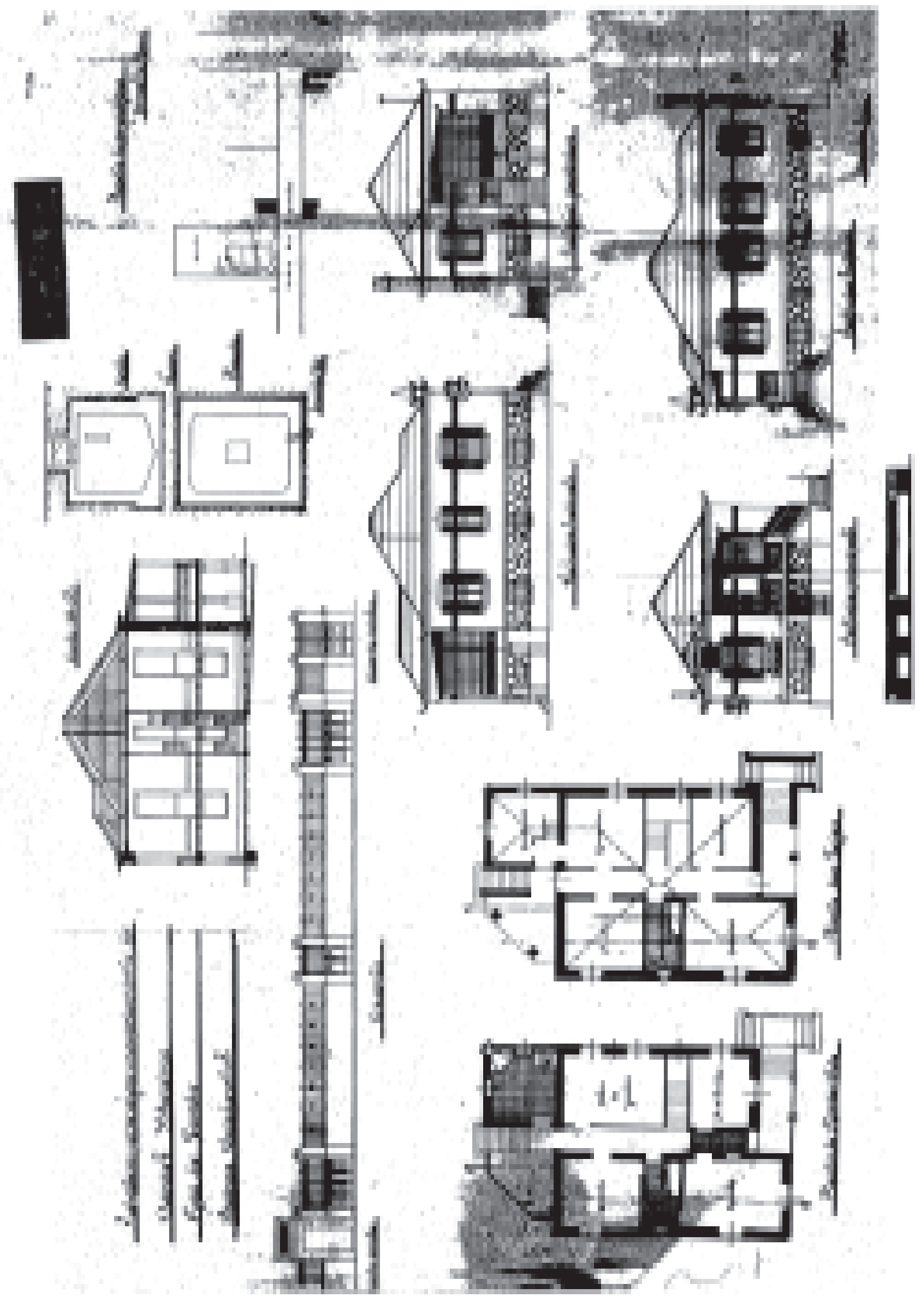

Figura 35 - Processo de 1922, para requerimento de licença para construção de uma casa no Porto, à antiga Rua do Conde, mesma rua onde está localizada a casa de Ricardo Severo. Fonte: Arquivo Municipal do Porto. 


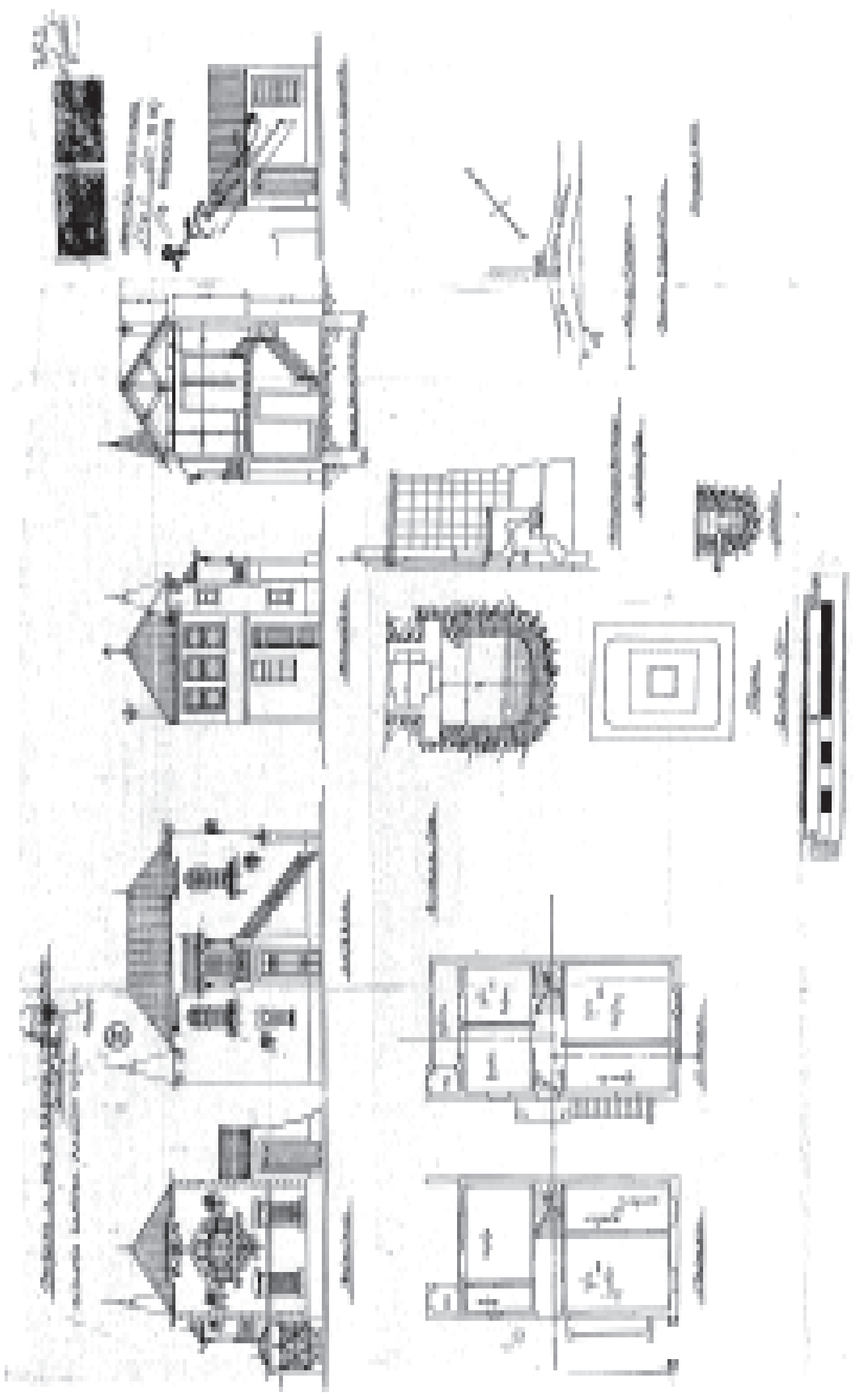

Figura 36 - Processo de 1922, para requerimento de licença para construção de uma casa no Porto. Notar semelhança com a arquitetura produzida pelo arquiteto Raul Lino. Fonte: Arquivo Municipal do Porto. 


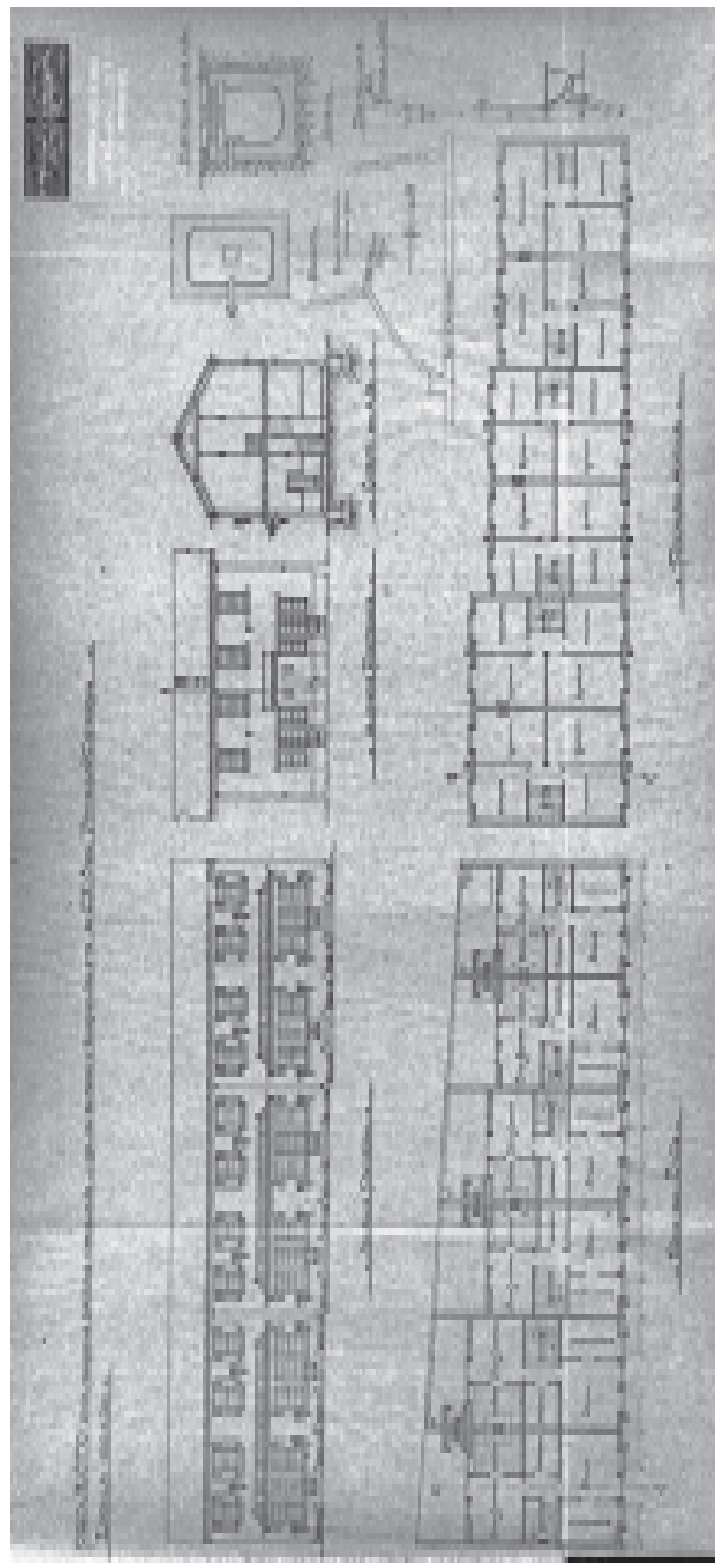

Figura 37 - Processo de 1922, para requerimento de licença para construção de um "pequeno bairro operário", no Porto. Segue a estética da casa portuguesa. Fonte: Arquivo Municipal do Porto. 


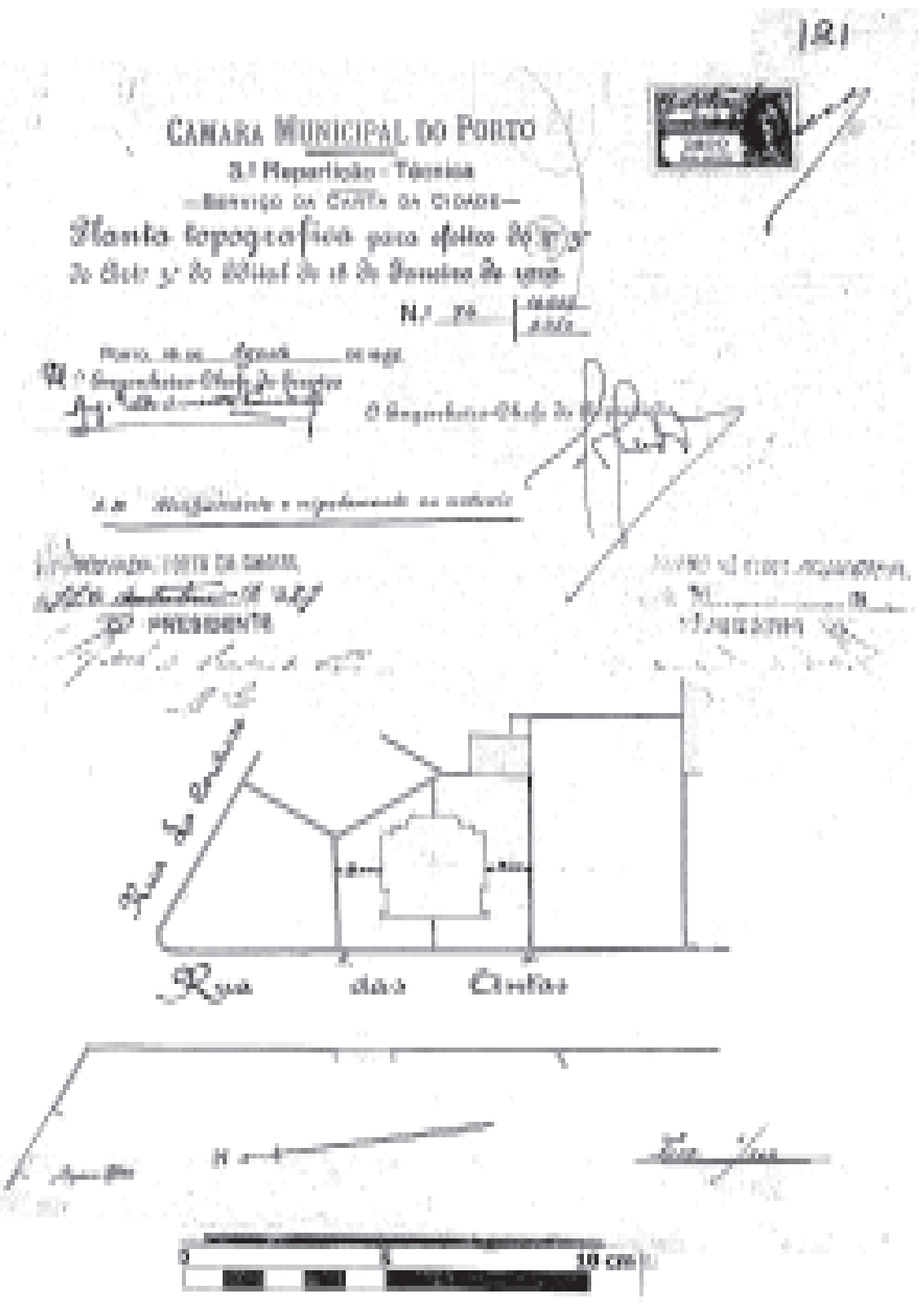

Figura 38 (acima e página 249) - Um dos dois processos de 1929, para requerimento de licença para construção de uma residência no Porto, de autoria do arquiteto Serafim Martins de Sousa. Fonte: Arquivo Municipal do Porto. 


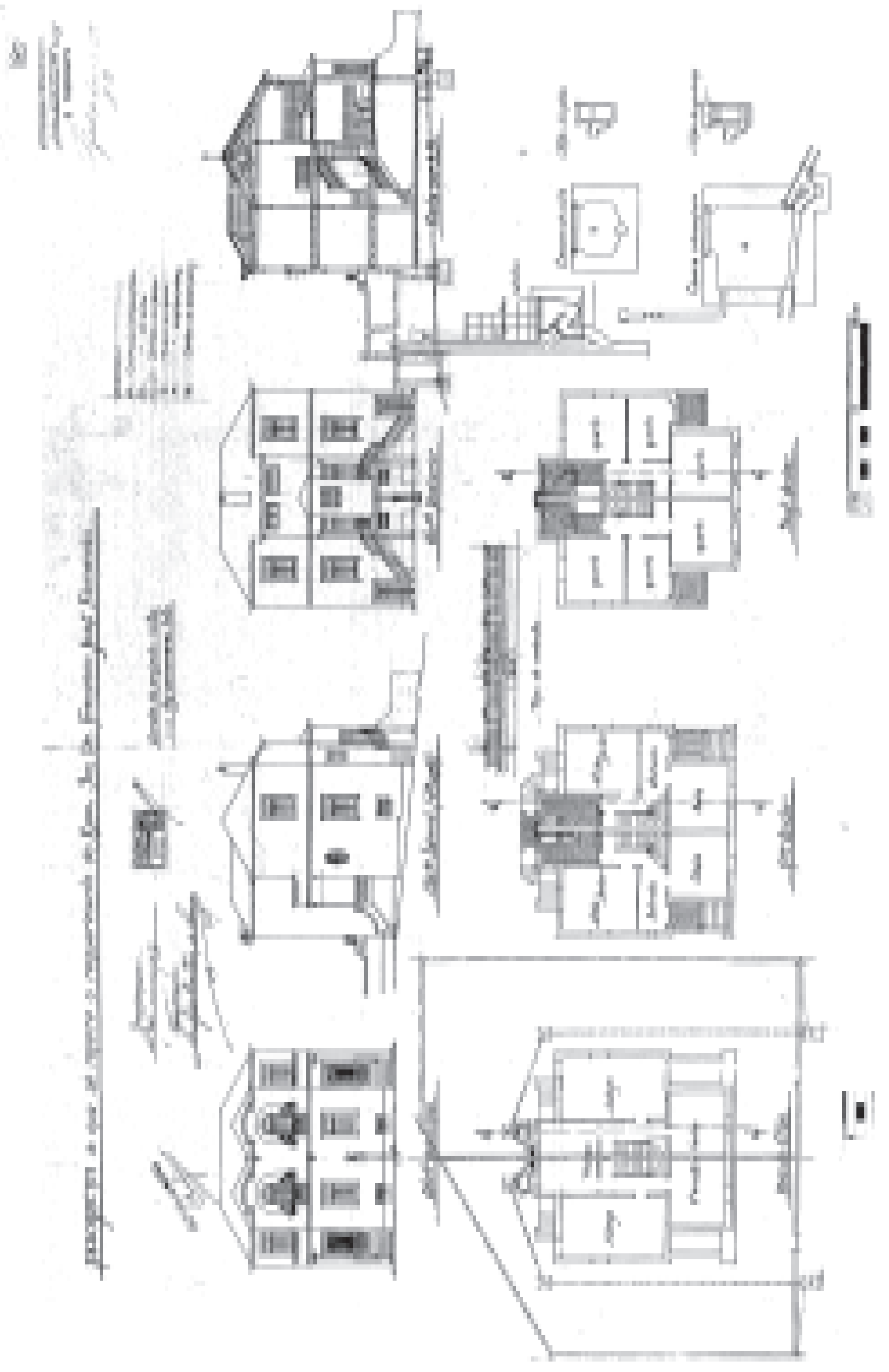




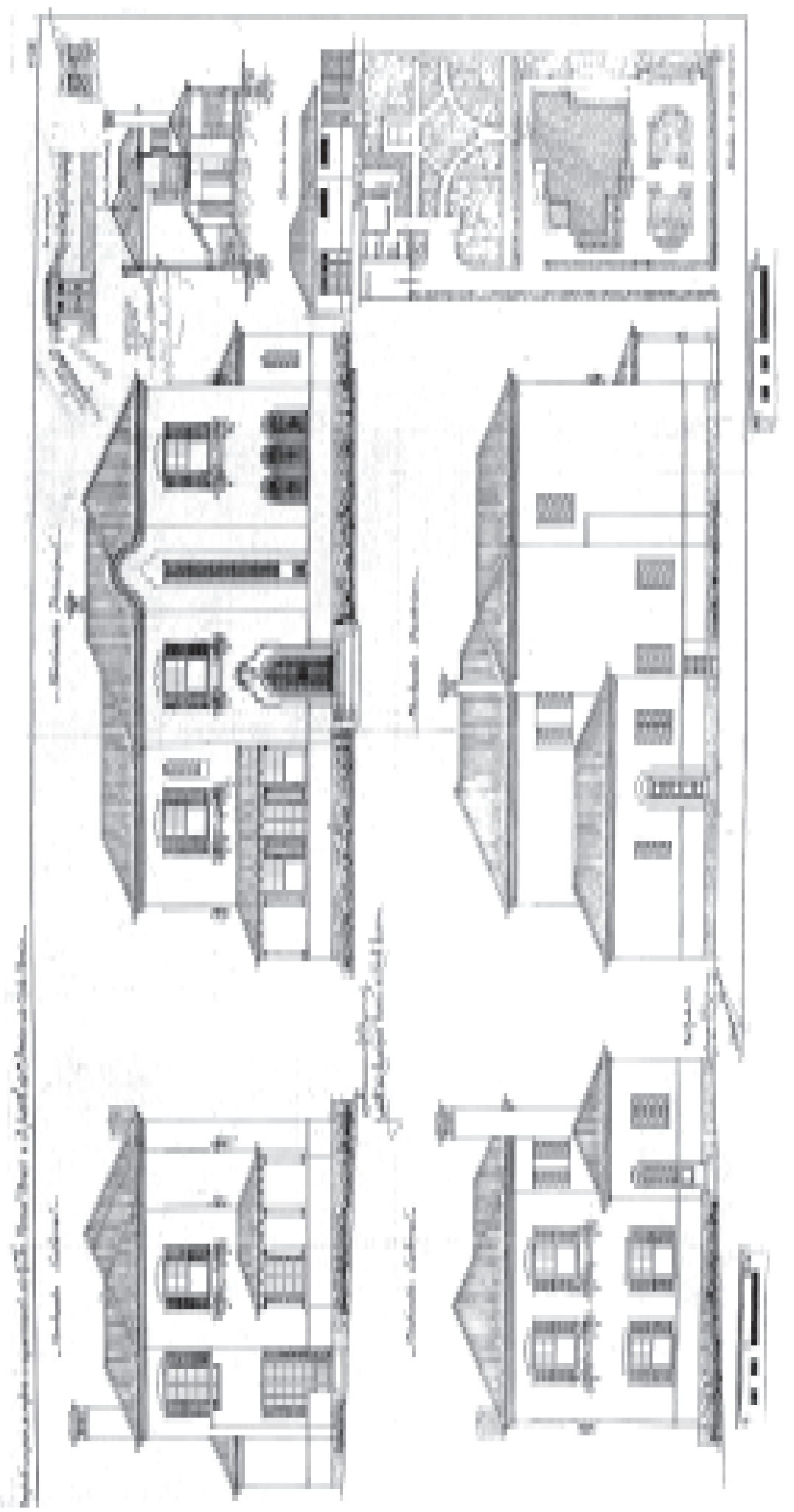

Figura 39 (acima e página 251) - Processo de 1938, para requerimento de licença para construção de uma residência no Porto, de autoria do arquiteto Manuel Marques. Floreiras, beirais, frontões entre outras características da arquitetura tradicionalista. Fonte: Arquivo Municipal do Porto. 
CAPÍTULO 2 - UM PARALELO: DIFUSÃO EM PORTUGAL - IMAGENS

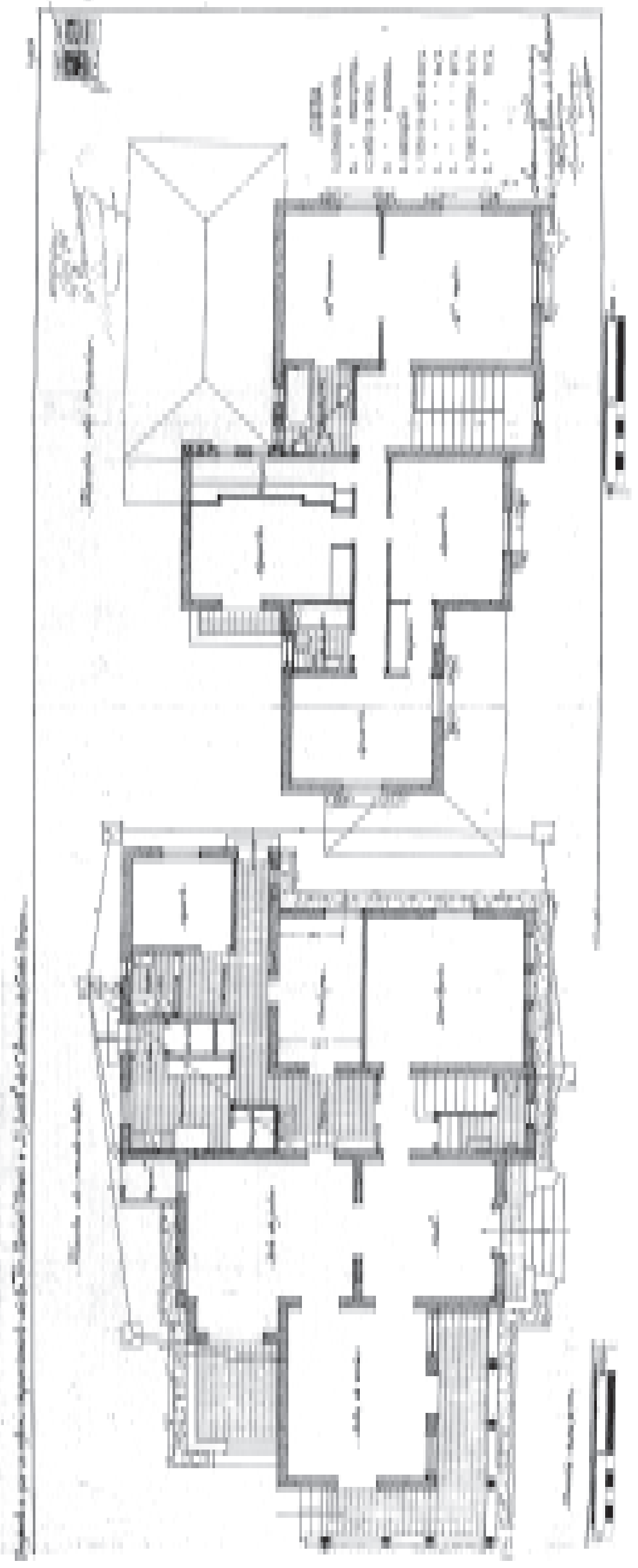



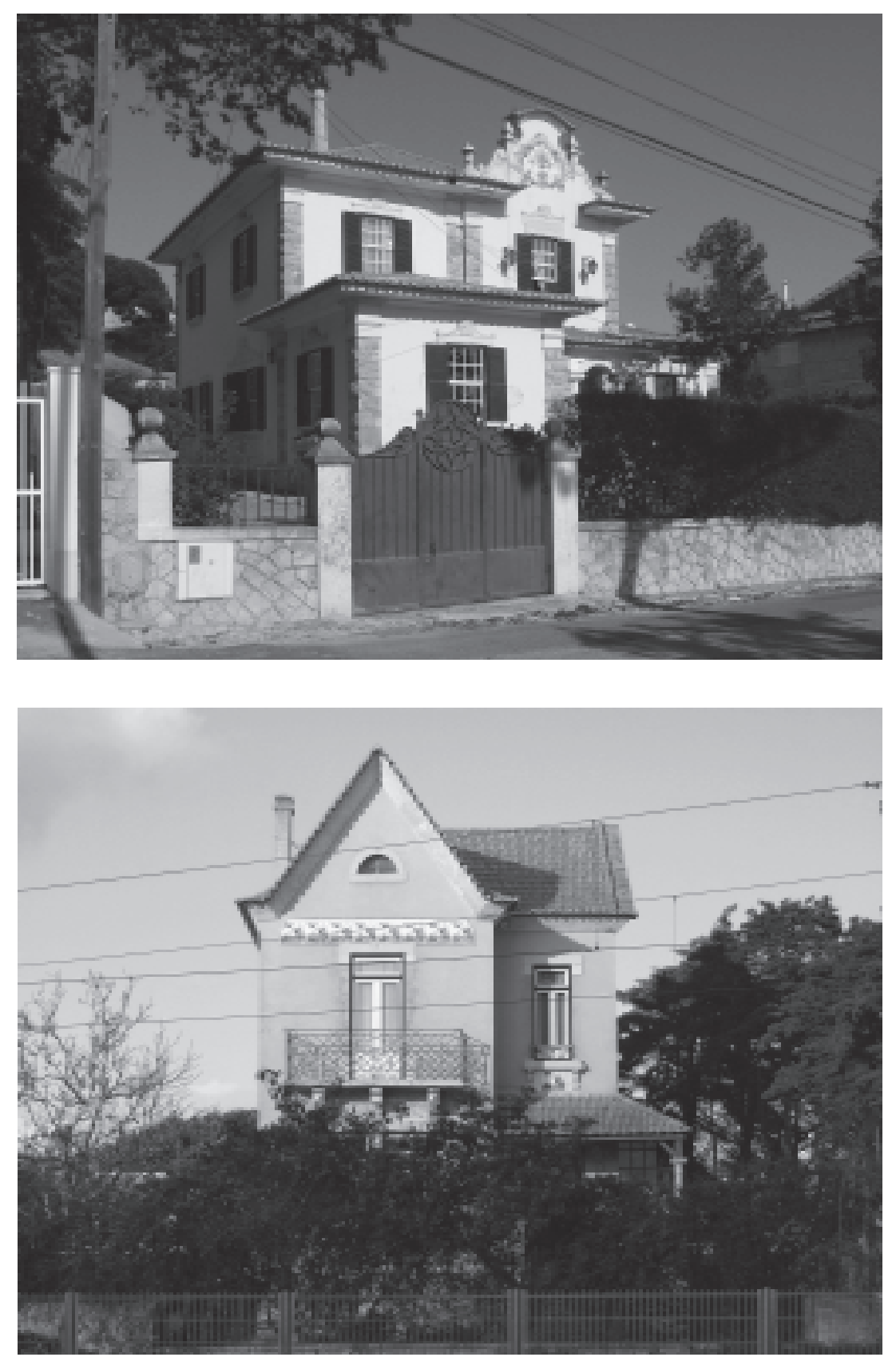

Figura 40 (páginas 252 e 253) - Vistas de residências em Parede e no Estoril, mostrando grande diversidade na utilização dos elementos que marcam a arquitetura tradicionalista portuguesas das primeiras décadas do século XX. A primeira figura se assemelha muito a alguns exemplares da arquitetura neocolonial; a segunda, certamente, foi é um chalet "reaportuguesado"; as últimas apresentam características que remetem à arquitetura barroca e àquela produzida por Raul Lino. Fonte: fotos da autora, janeiro de 2006. 

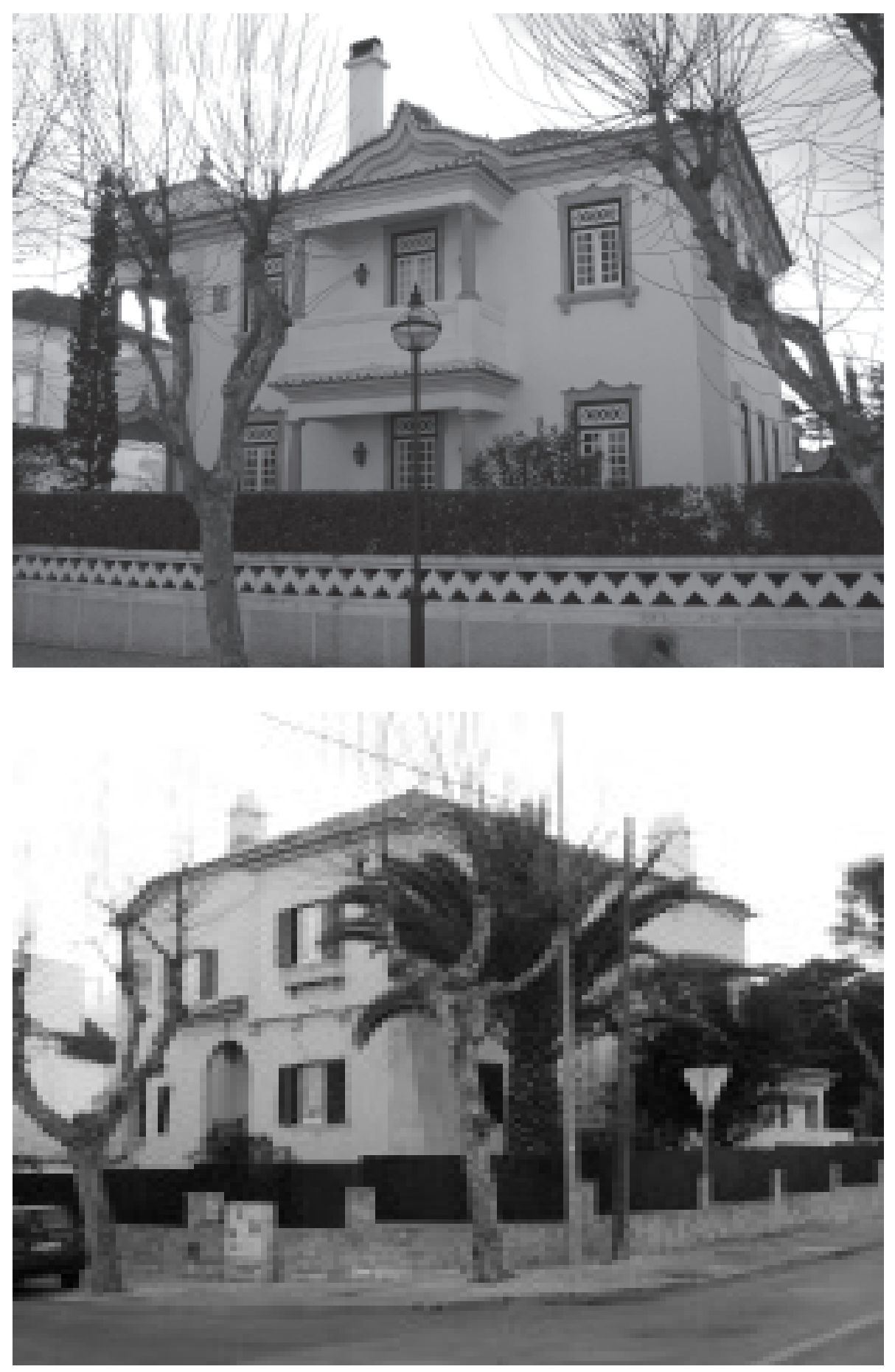


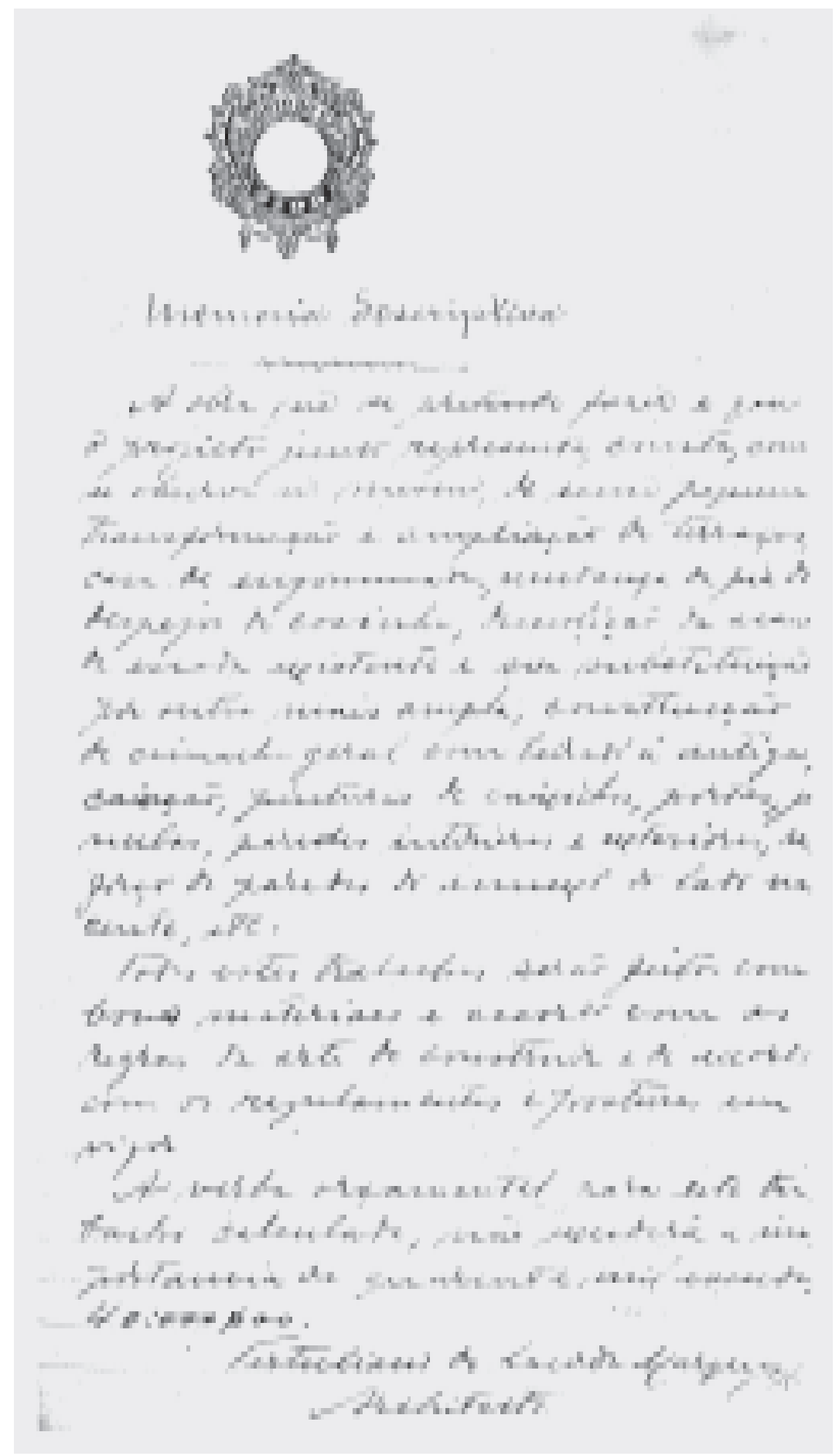

Figura 41 (acima e página 255) - Processo de 1930, para requerimento de licença para reforma de um chalet, cujo projeto é do arquiteto Tertuliano de Lacerda Marques. Transformou os beirais para deixá-los "à antiga", como registrado no memorial descritivo. Fonte: Arquivo Municipal de Cascais. 

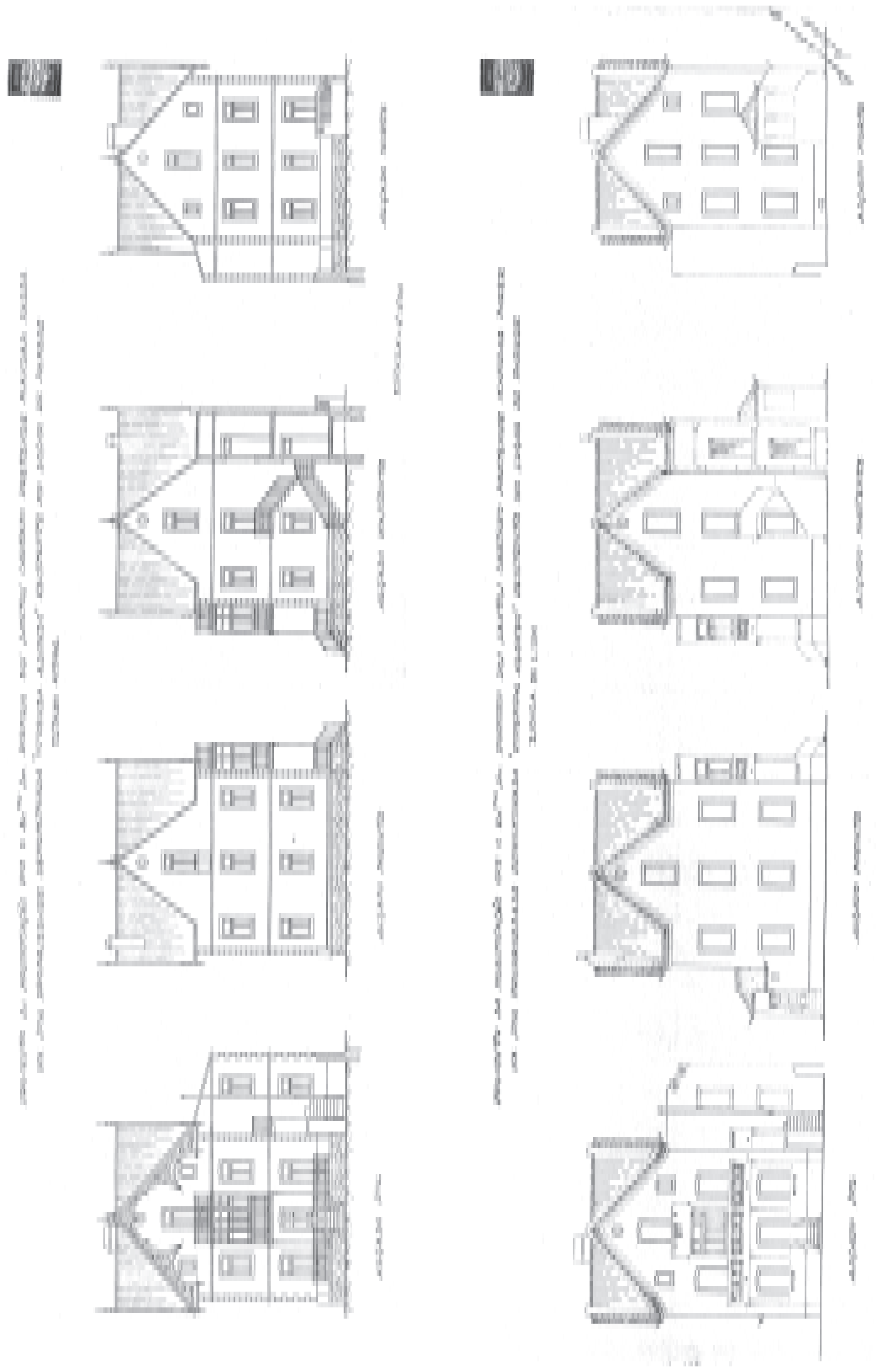

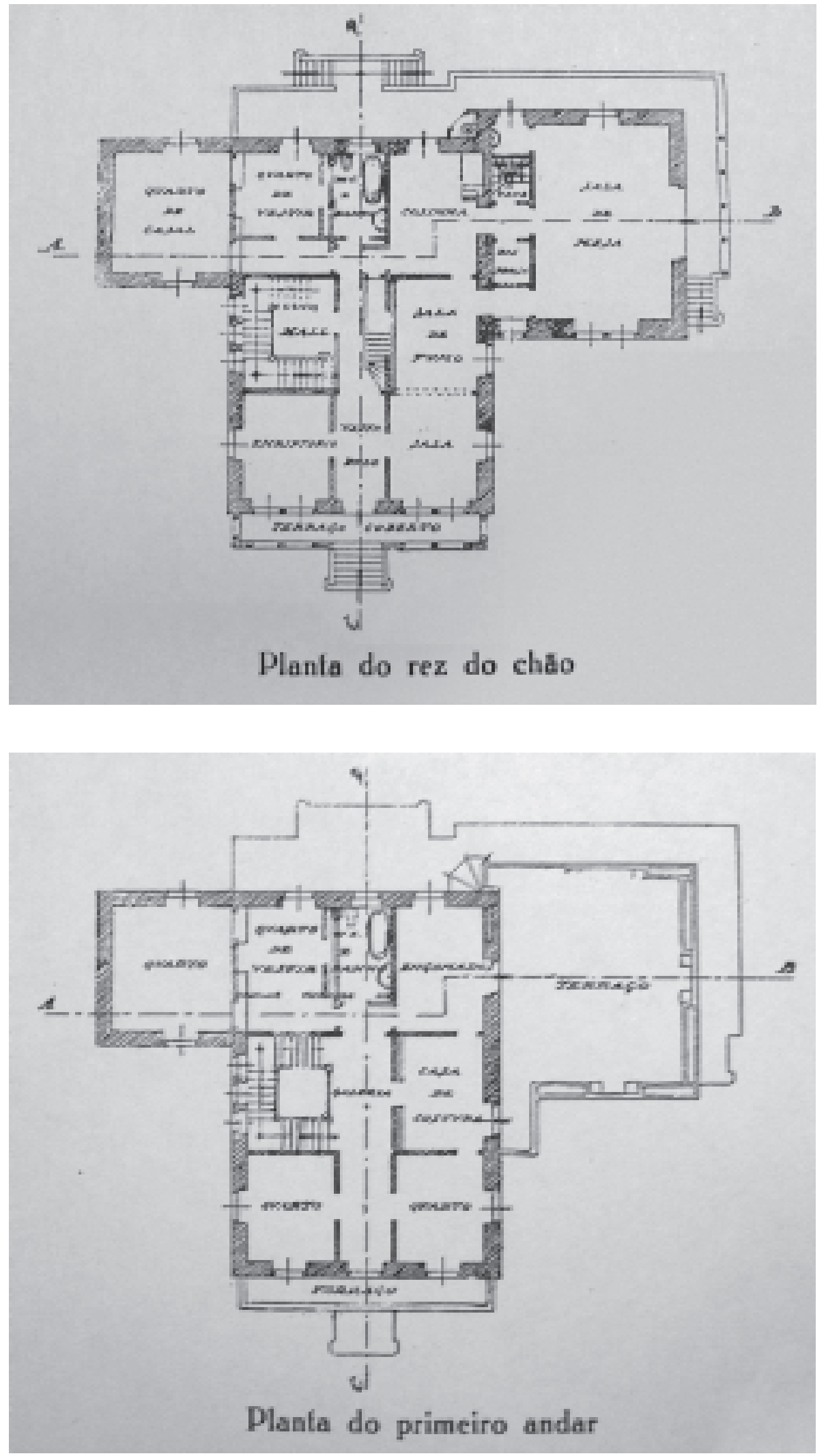

Figura 42 (páginaa 256 e 257) - Projeto do arquiteto Tertuliano de Lacerda Marques para uma residência em Cascais, publicado numa revista de arquitetura em 1928. Fonte: A Arquitetura Portuguesa, (1928). 

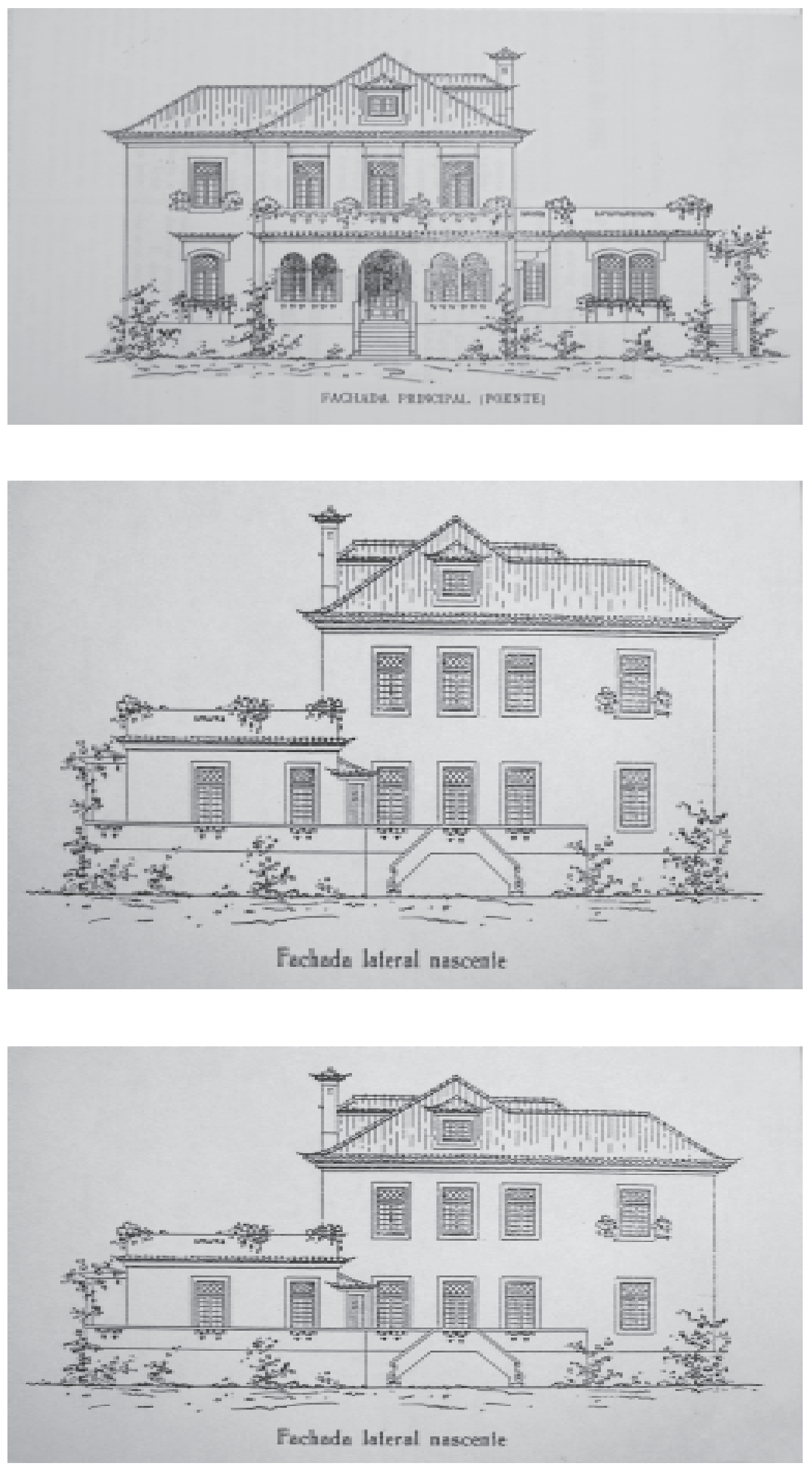


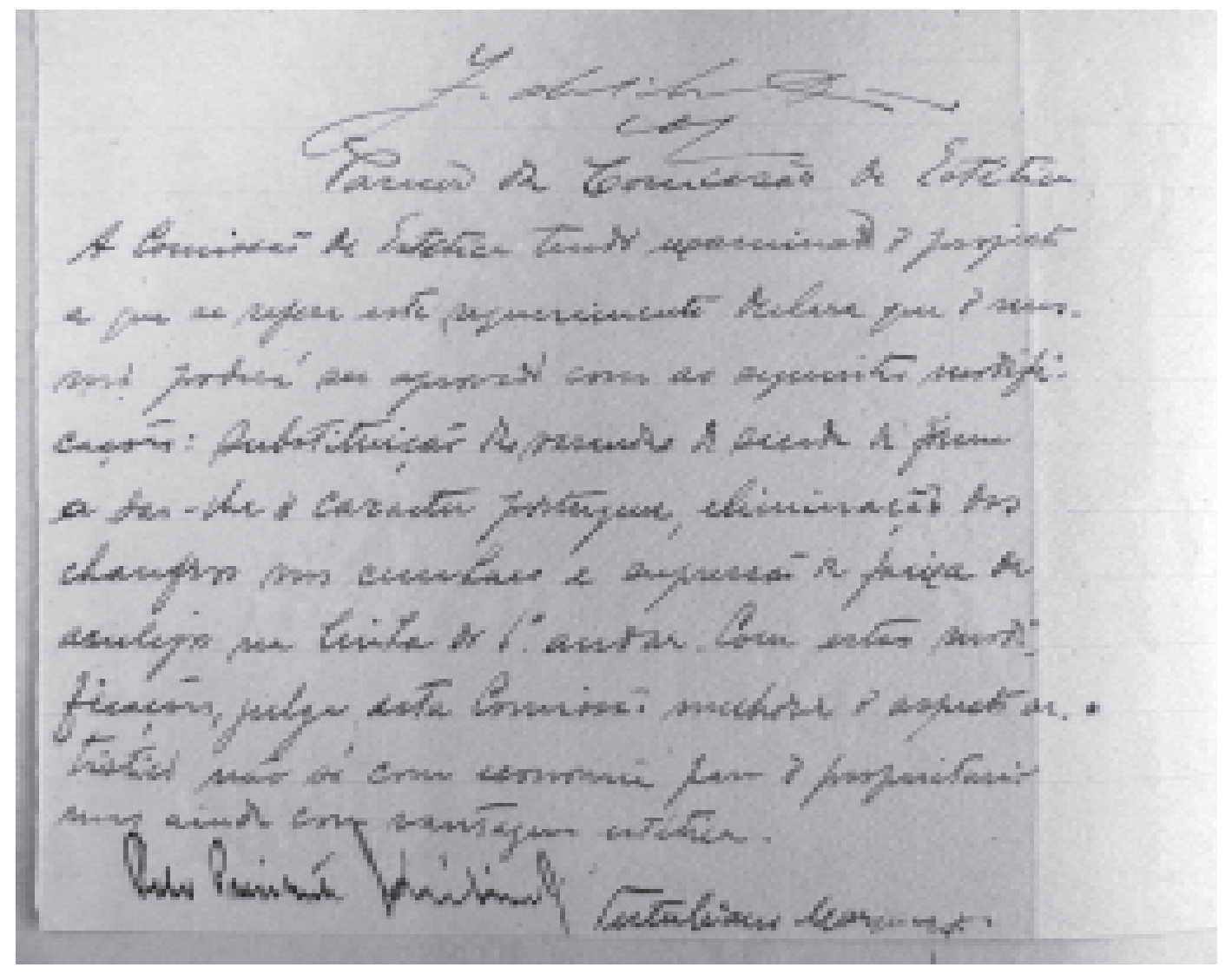

Figura 43 - Parecer da Comissão de Estética de Cascais, sugerindo modificações a fim de tornar a edificação mais de acordo com os preceitos da arquitetura tradicionalista portuguesa, e assinado pelo arquiteto Tertuliano de Lacerda Marques: "substituição da varando ou sacada de forma a dar-lhe o caráter português (...). Com estas modificações, julga esta Comissão melhorar o aspecto artístico não só com economia para o proprietário, mas ainda com vantagem estética”. Fonte: Arquivo Municipal de Cascais. 


\section{Capítulo 4}

\section{ARQUITETURA NEOCOLONIAL PAULISTA: IMAGEM OFICIAL}

Imagens 


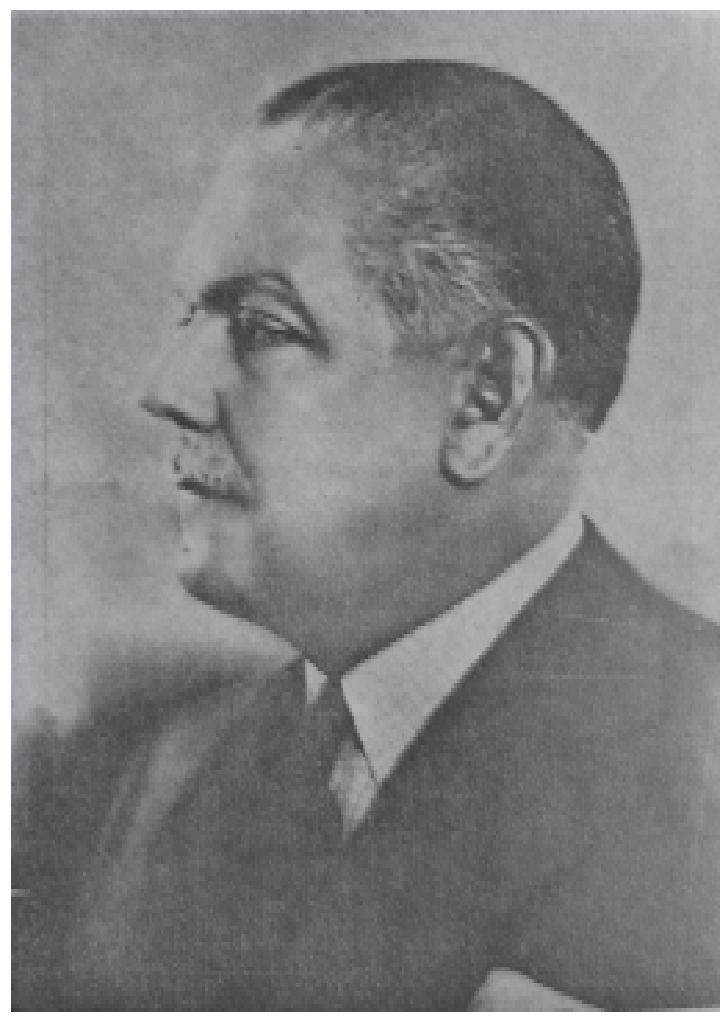

Figura 44 - Fotografia do agrônomo Fernando Costa. Fonte: Álbum Comemorativo do TriCentenário de Taubaté (1945).

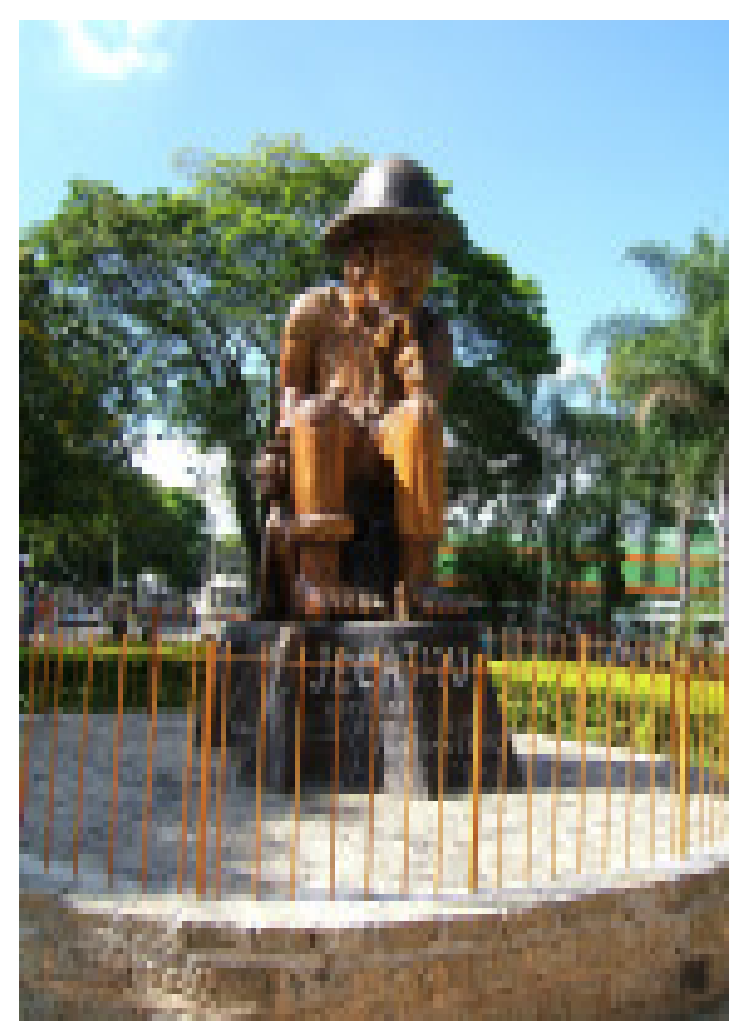

Figura 45 - Escultura do personagem Jeca Tatu, de Monteiro Lobato. Situada em Taubaté, em frente à praça da Estação Ferroviária. Fonte: foto da autora, abril de 2007. 

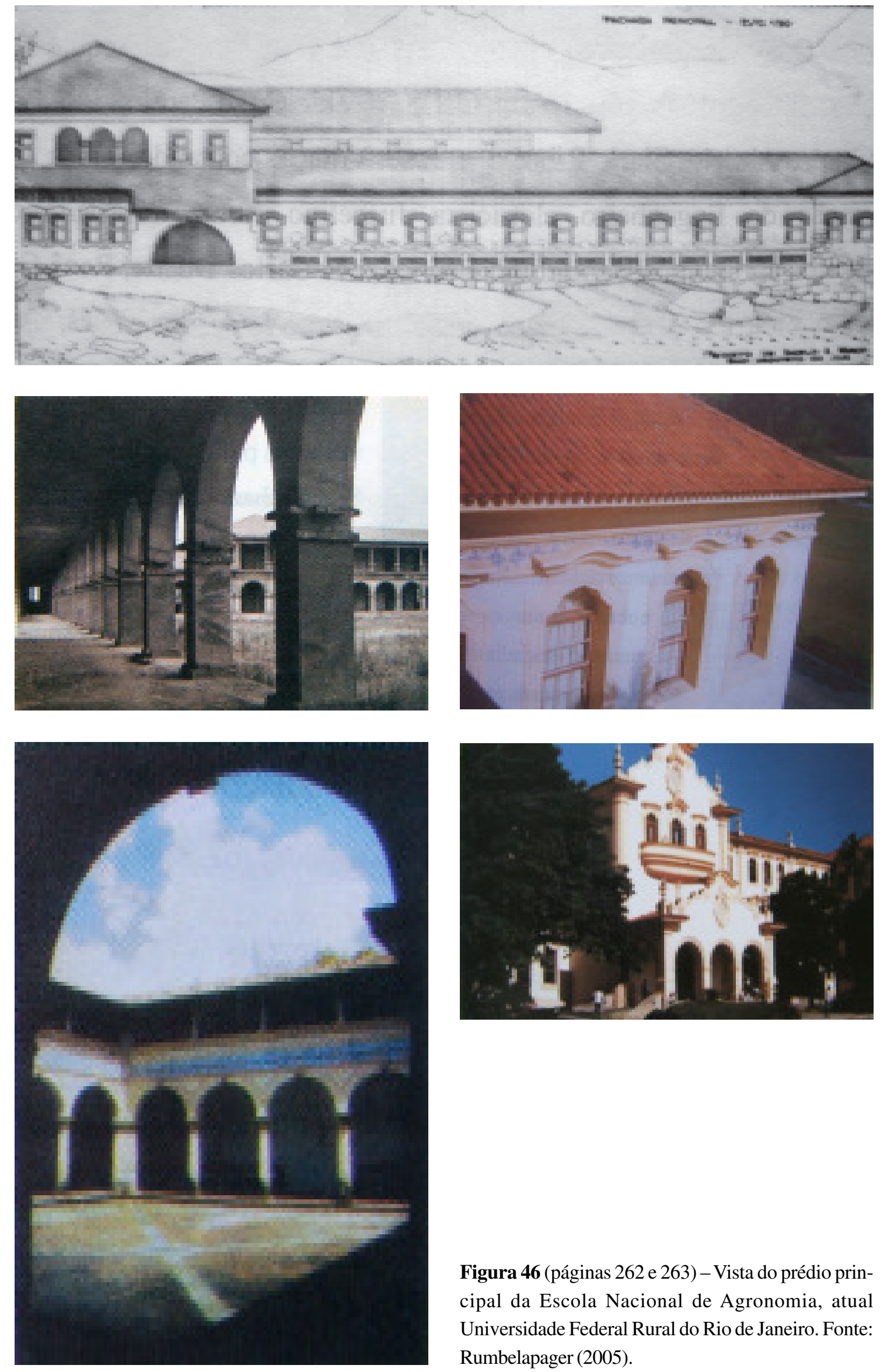

Figura 46 (páginas 262 e 263) - Vista do prédio principal da Escola Nacional de Agronomia, atual Universidade Federal Rural do Rio de Janeiro. Fonte: Rumbelapager (2005). 

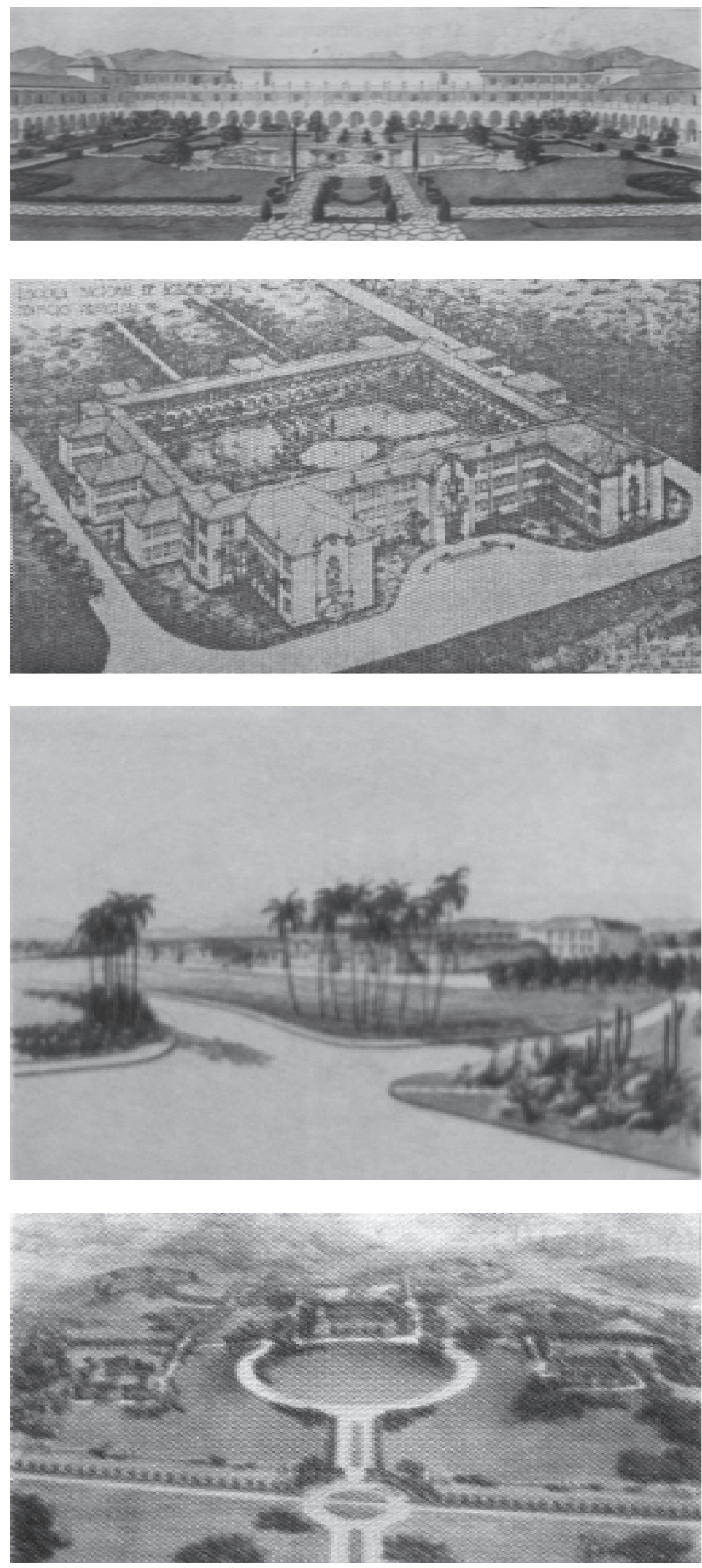


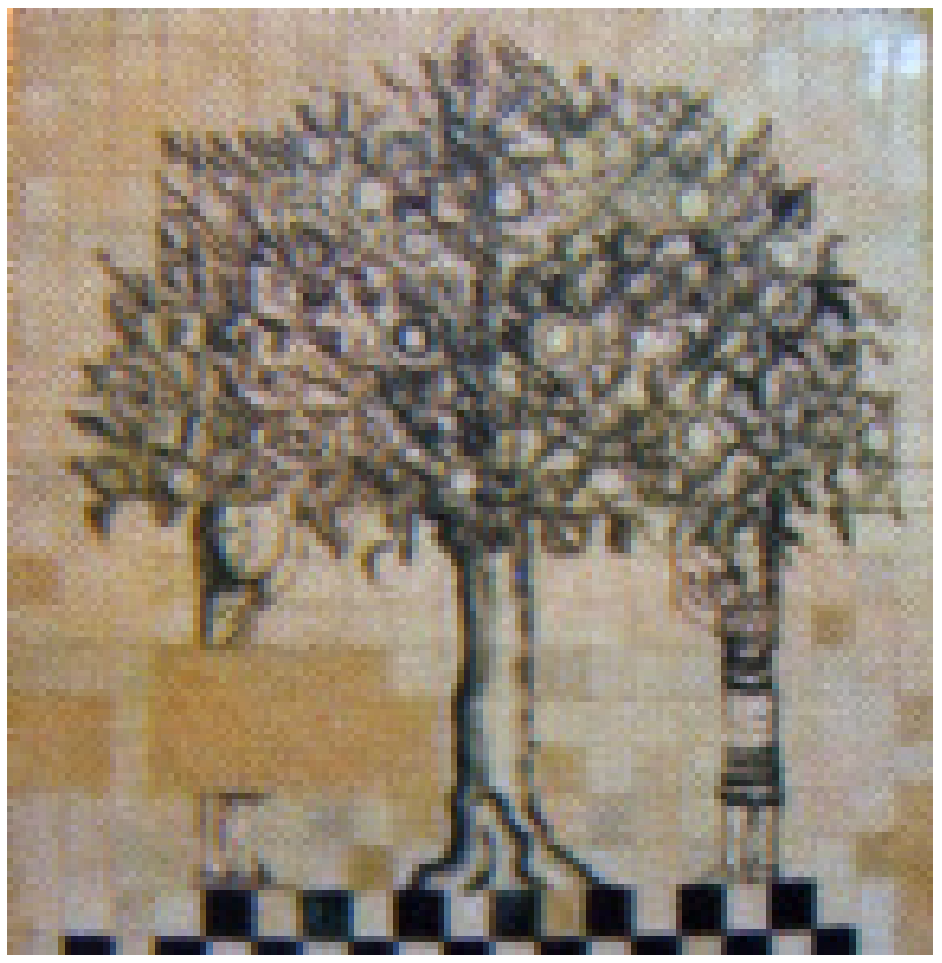

Figura 47 - Painel de azulejos, encontrado na Escola Nacional de Agronomia, de autoria da artista plástica portuguesa Maria Helena Vieira da Silva (1908-1992). Fonte: Rumbelapager (2005, p.106).

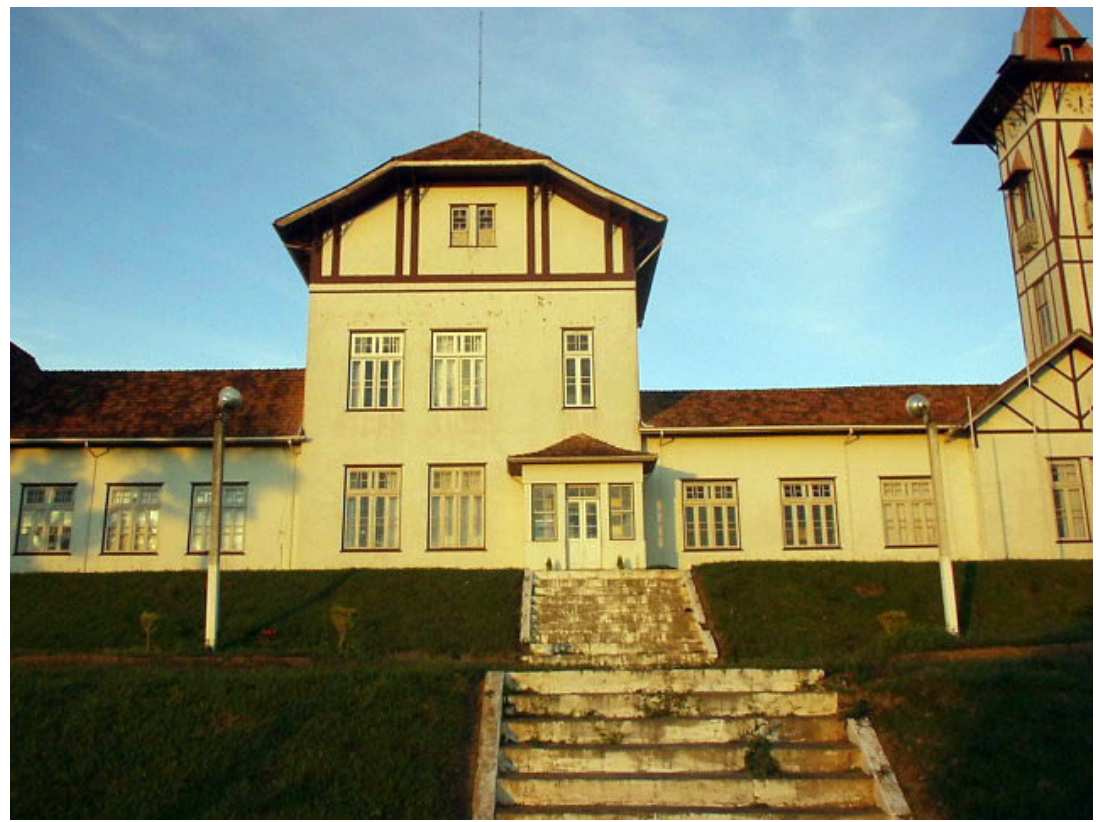

Figura 48 - Aspecto atual da Escola Agrícola de Barbacena, notar as linhas ecléticas. Disponível em: http://www.eafb.org.br/images/albun/index.htm. Acesso em: fevereiro de 2008. 

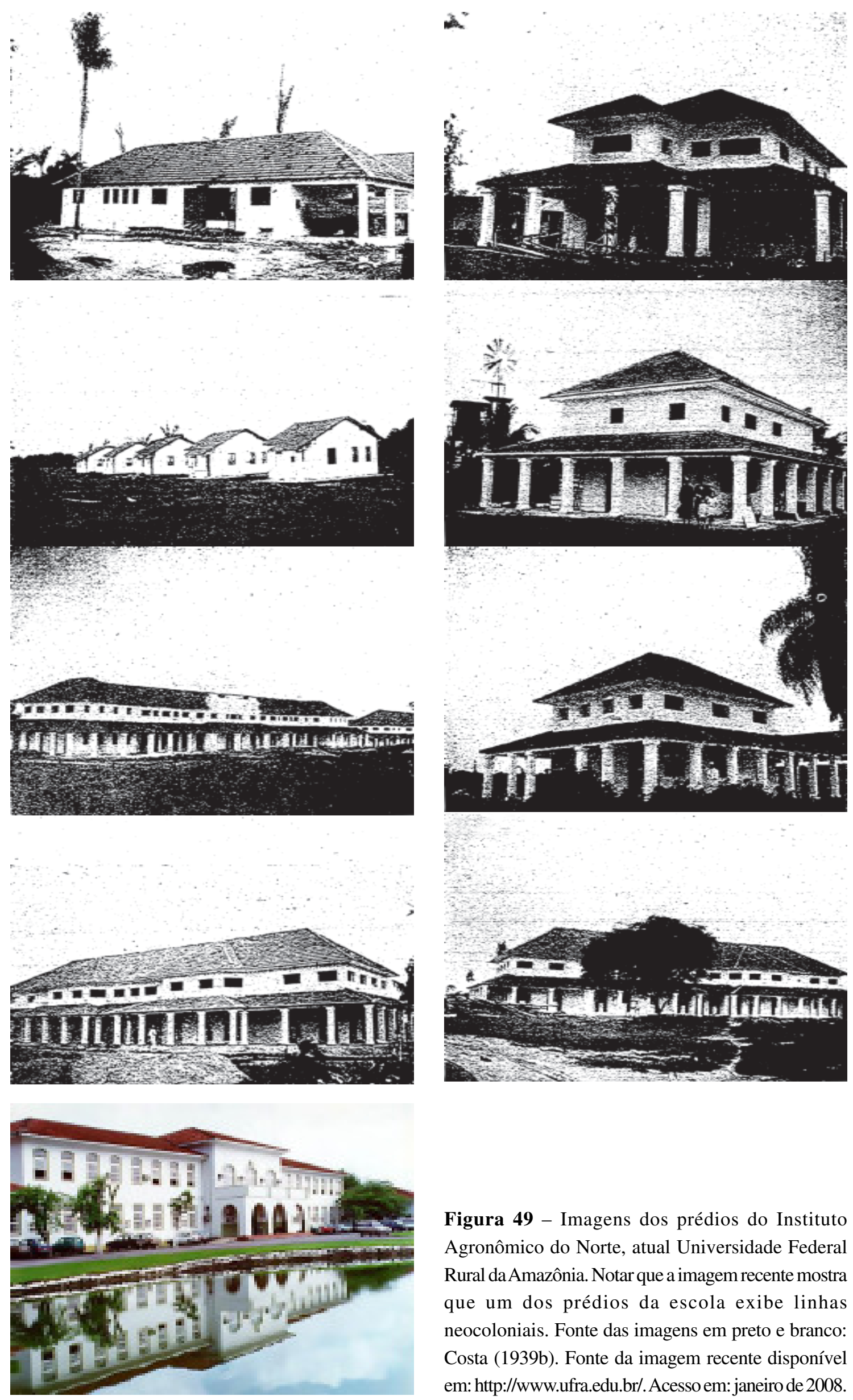

Figura 49 - Imagens dos prédios do Instituto Agronômico do Norte, atual Universidade Federal Rural da Amazônia. Notar que a imagem recente mostra que um dos prédios da escola exibe linhas neocoloniais. Fonte das imagens em preto e branco: Costa (1939b). Fonte da imagem recente disponível em: http://www.ufra.edu.br/.Acesso em: janeiro de 2008. 


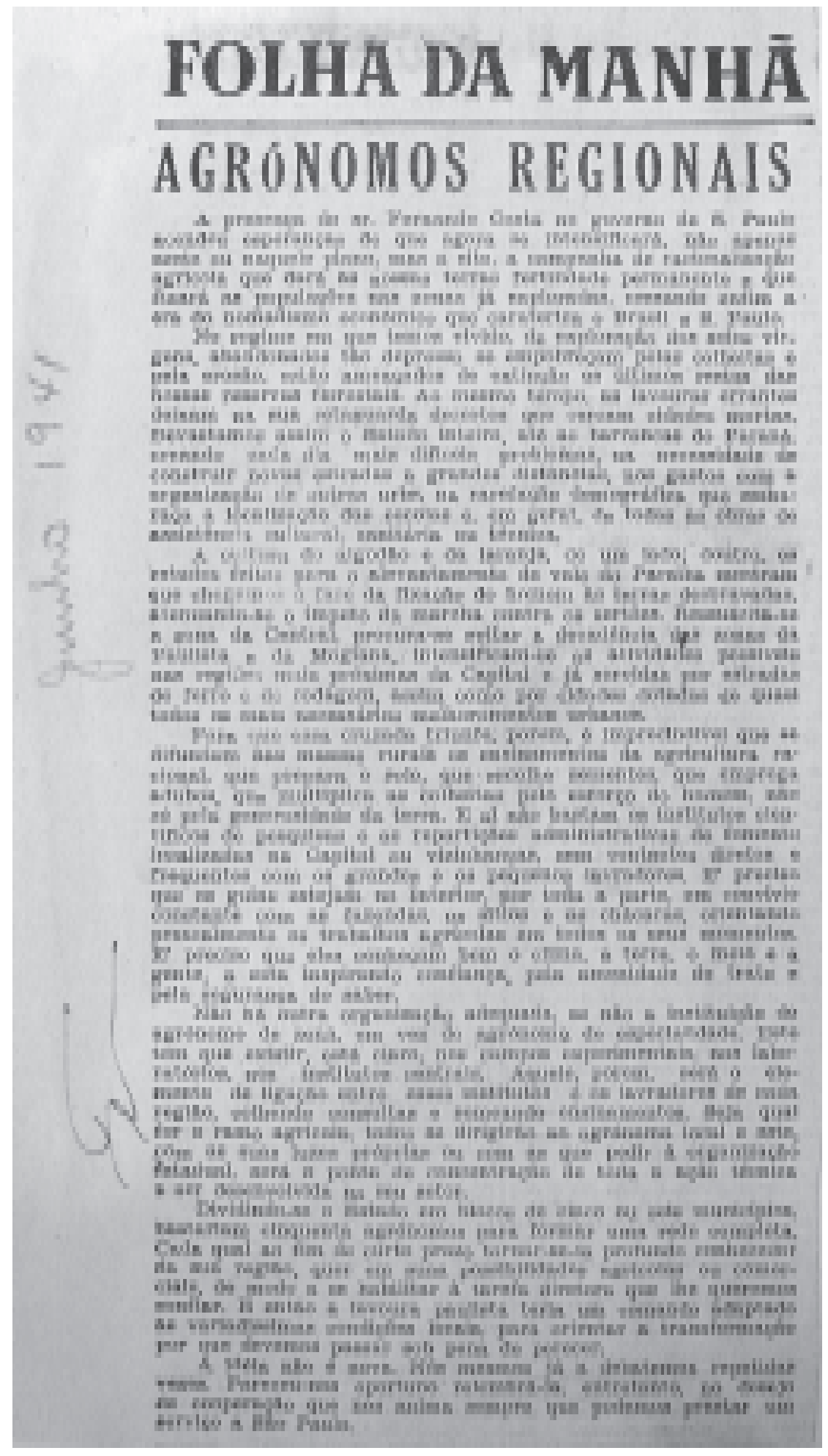

Figura 50 (páginas 266 e 267) - Exemplos de reportagens de jornais referentes à nomeação de Fernando Costa para Interventor do Estado de São Paulo e à sua política relacionada à educação agrícola. Fonte: Arquivo do Estado, São Paulo, SP. 


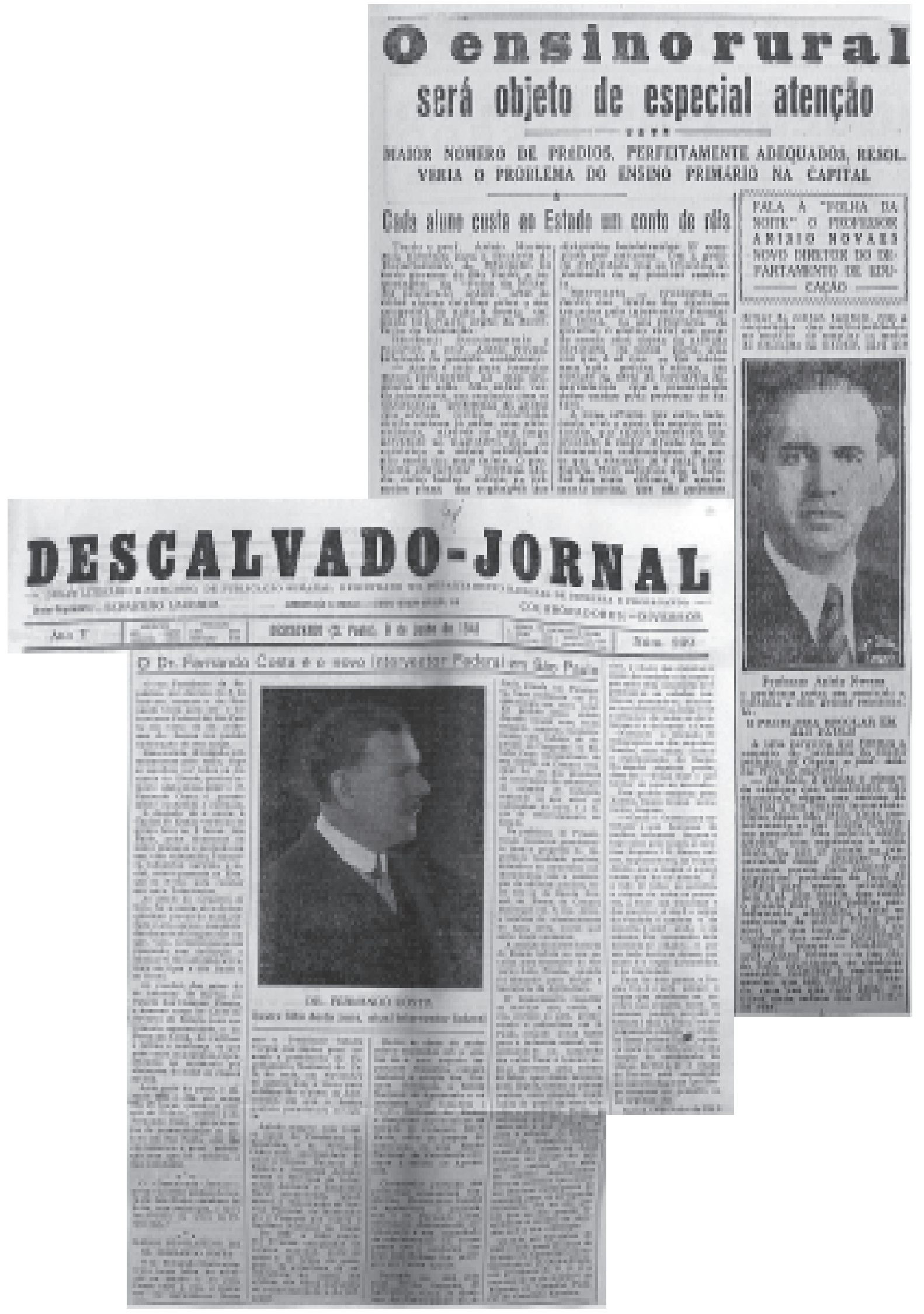




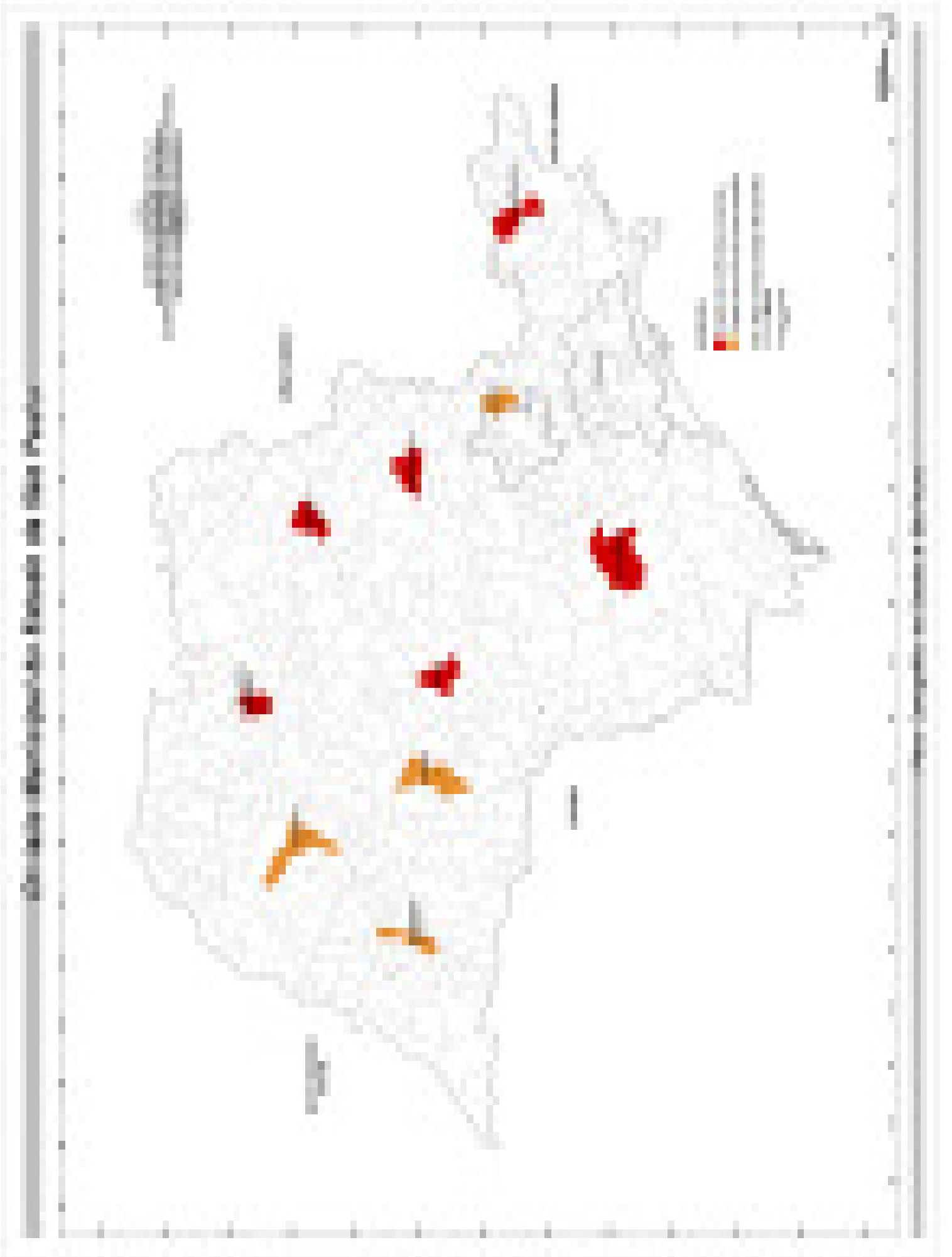

Figura 51 - Mapa do Estado de São Paulo com a localização das cidades que, segundo o projeto do interventor Fernando Costa, receberiam as Escolas Práticas Agrícolas em 1942. Fonte do mapa: Instituto Geográfico e Cartográfico. Marcação das cidades e legenda da autora. 

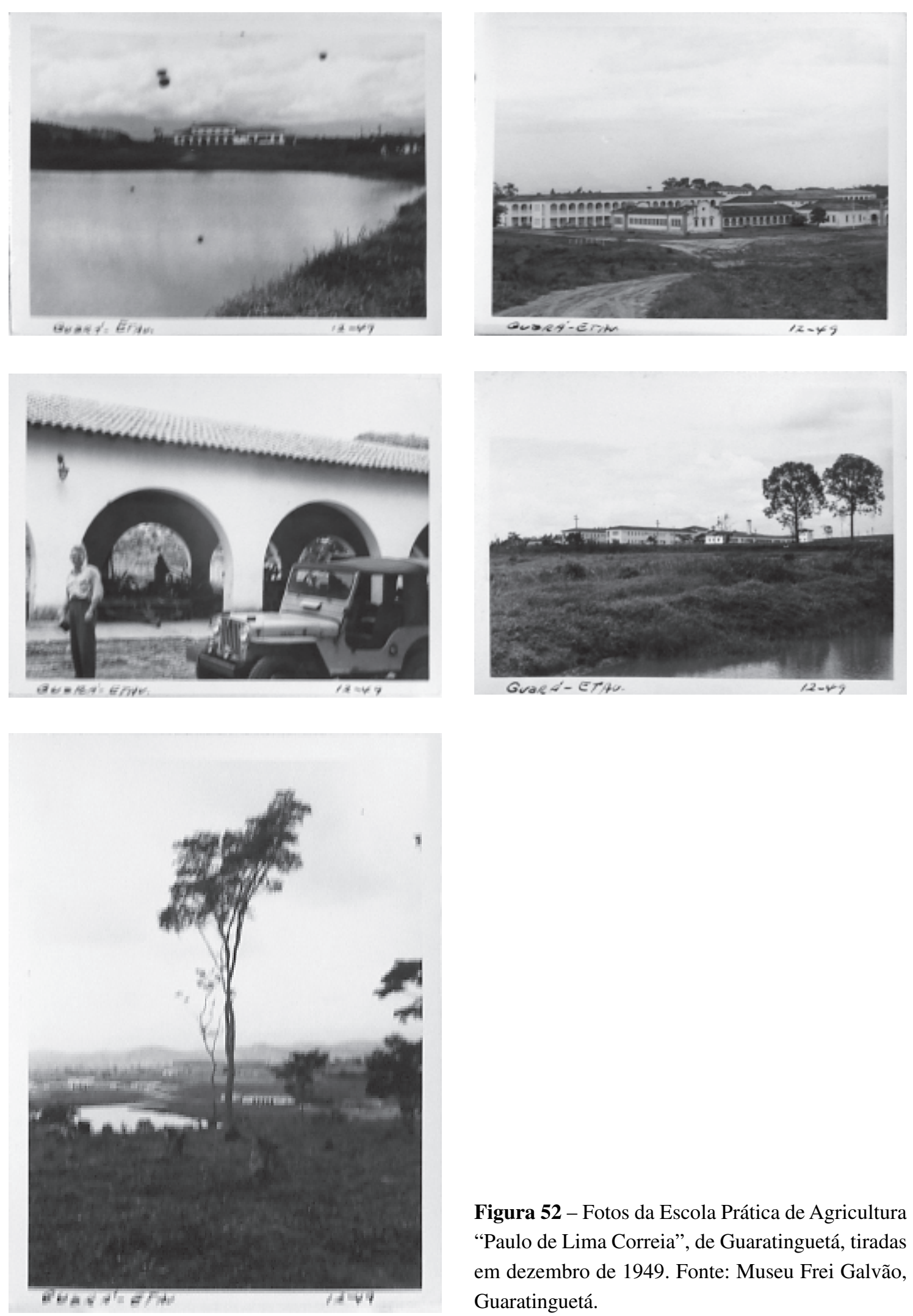

Figura 52 - Fotos da Escola Prática de Agricultura "Paulo de Lima Correia", de Guaratinguetá, tiradas em dezembro de 1949. Fonte: Museu Frei Galvão, Guaratinguetá. 

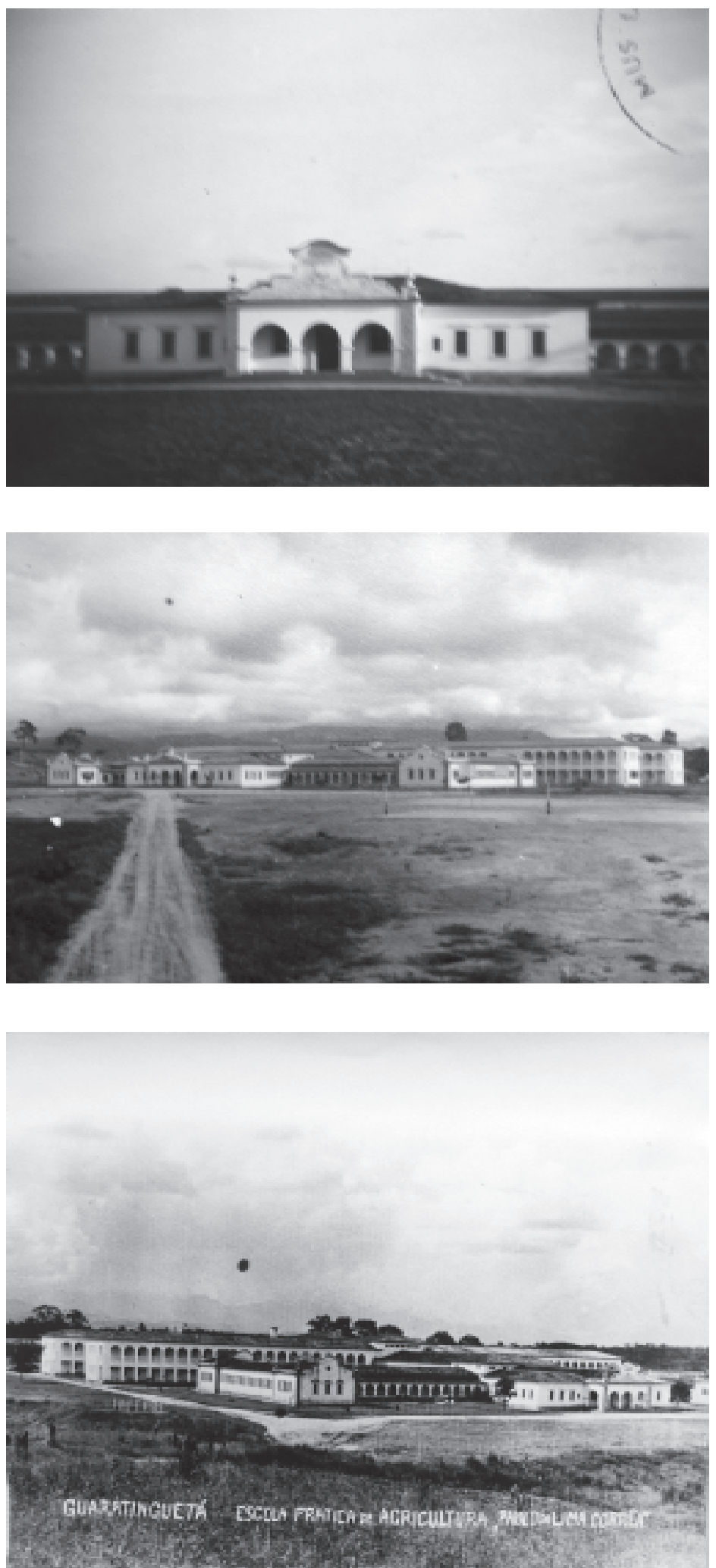

Figura 53 - Fotos da Escola Prática de Agricultura "Paulo de Lima Correia", antes de sua transformação em Escola de Especialistas de Aeronáutica. Fonte: Museu Frei Galvão, Guaratinguetá. 

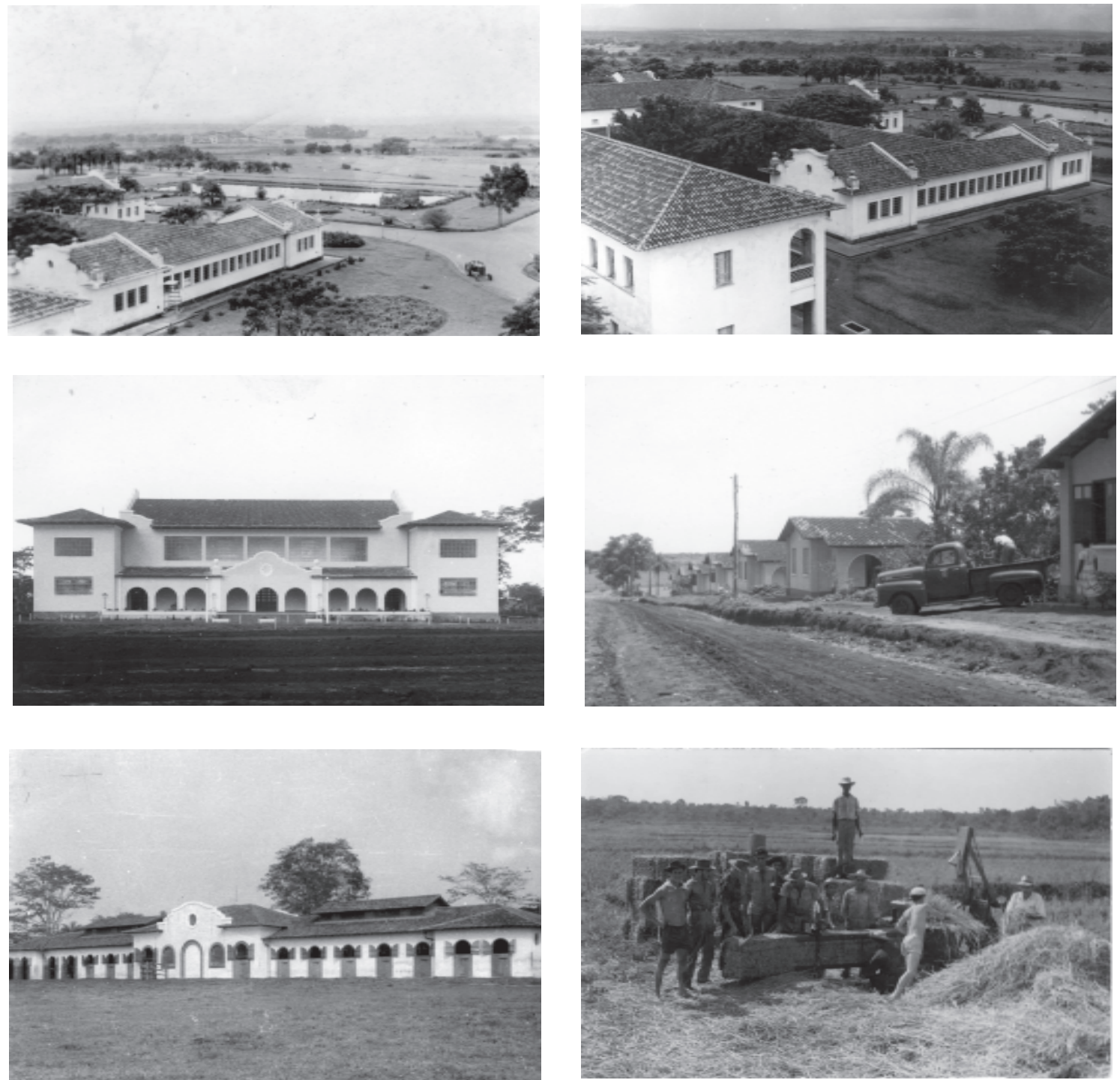

Figura 54 - Vários aspectos da recém construída Escola Prática Agrícola "Dr. Fernando Costa” de, Pirassununga. Podemos ver o edifício principal ainda com pouca vegetação em seu entorno, o salão social, casas de professores e funcionários, estábulo e alunos trabalhando em meados de 1940. Fonte: FZEAUSP, Seção de Eventos. 

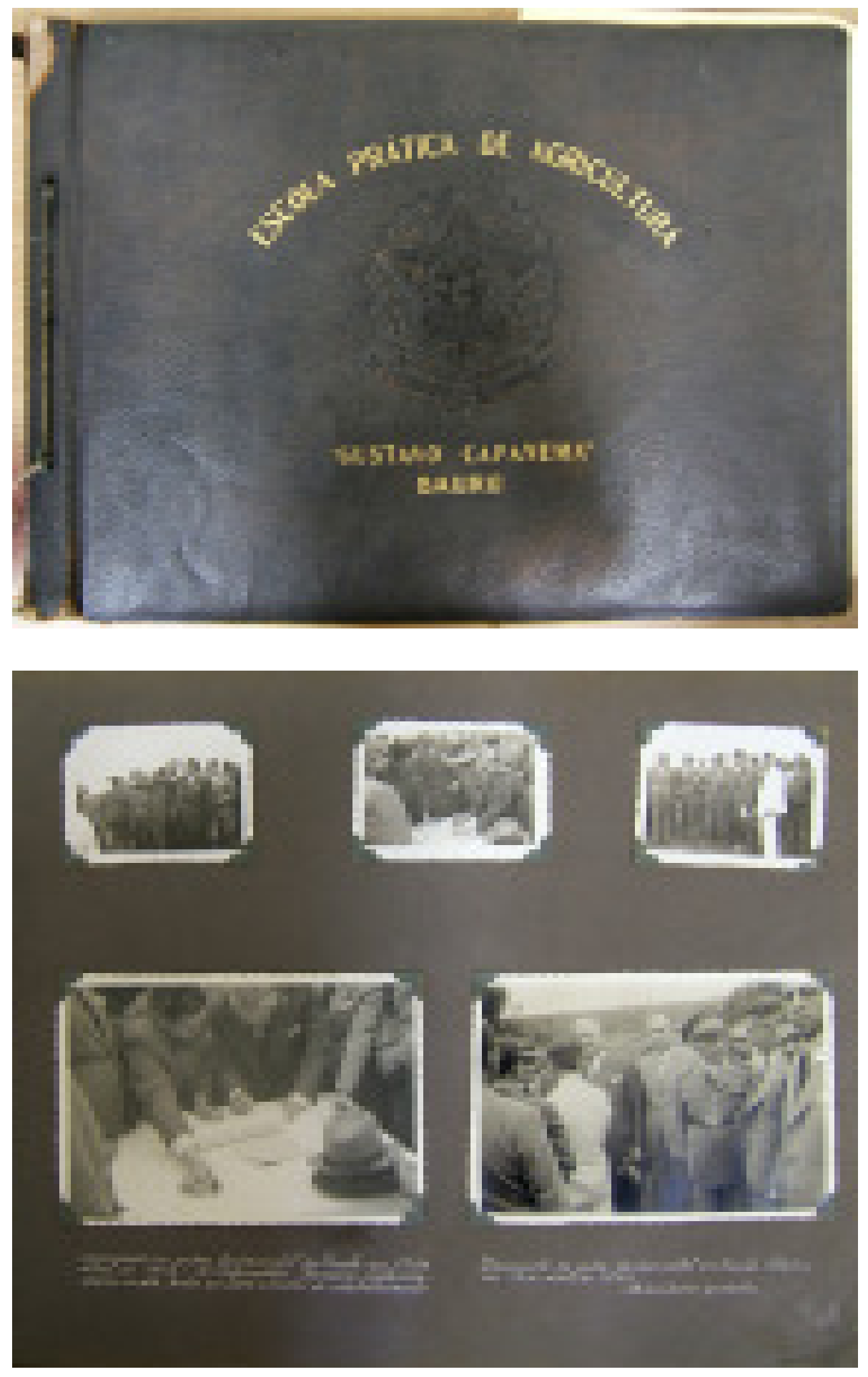

Figura 55 (páginas 272 e 273) - Registros do evento de lançamento da pedra fundamental da Escola Prática de Agricultura "Gustavo Capanema" de Bauru, no dia 19 de abril de 1942, com a presença do interventor Fernando Costa (na foto onde há um chapéu, Fernando Costa é a pessoa que assina o documento) e outras autoridades. O prefeito de Bauru é quem está colocando massa sobre a urna. Fotos encontradas num antigo álbum de fotos sobre a escola, do qual vemos a capa. Fonte: Arquivo do atual Instituto Penal Agrícola "Prof. Noé Azevedo", Bauru. 

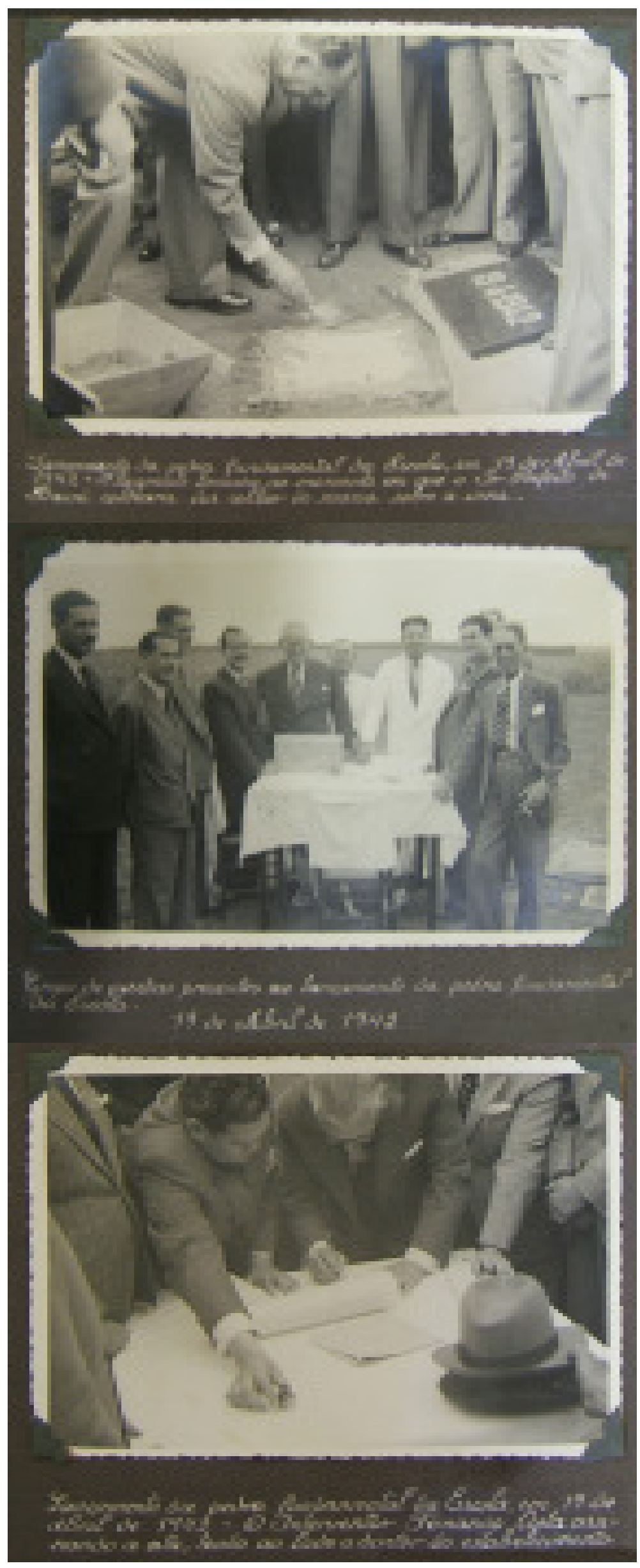


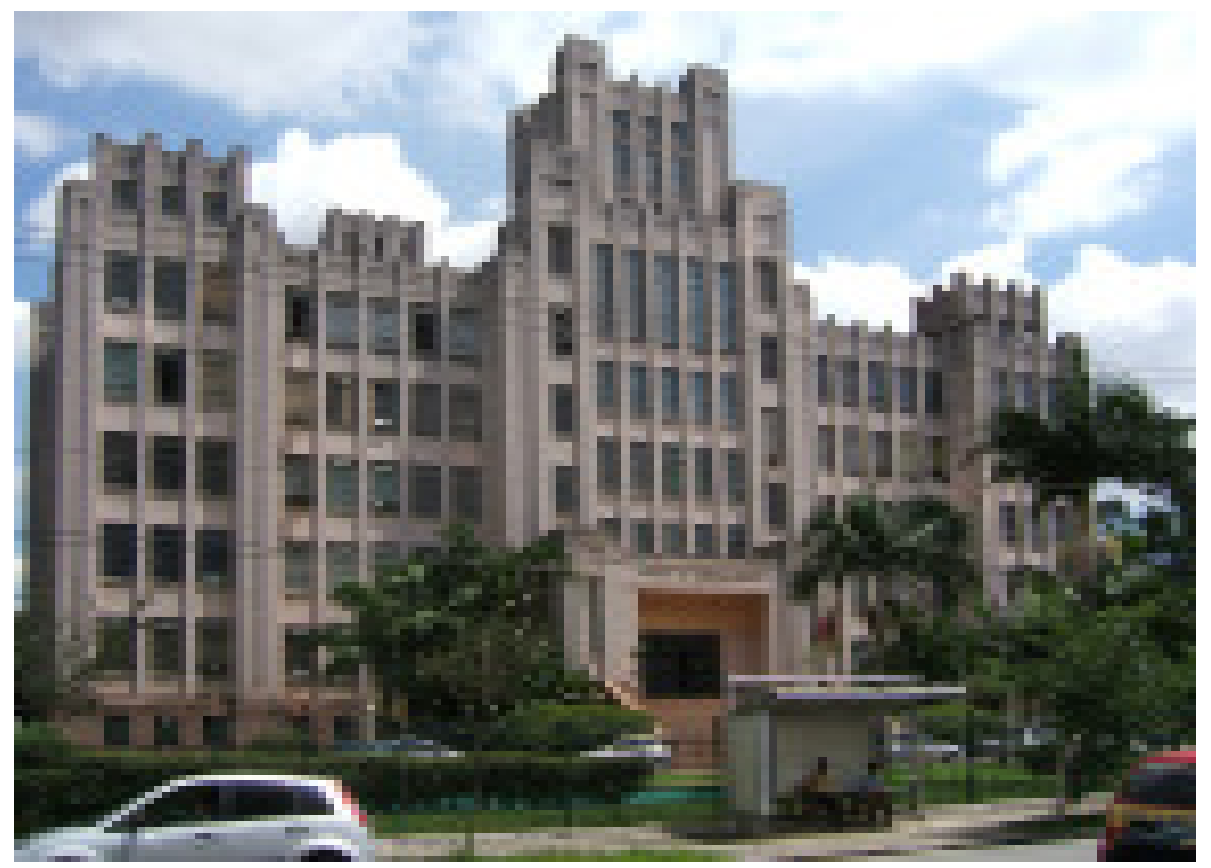

Figura 56 - Prédio do Instituto Biológico, na cidade de São Paulo, de autoria do engenheiro Mario Whately. Fonte: foto da autora, março de 2008.

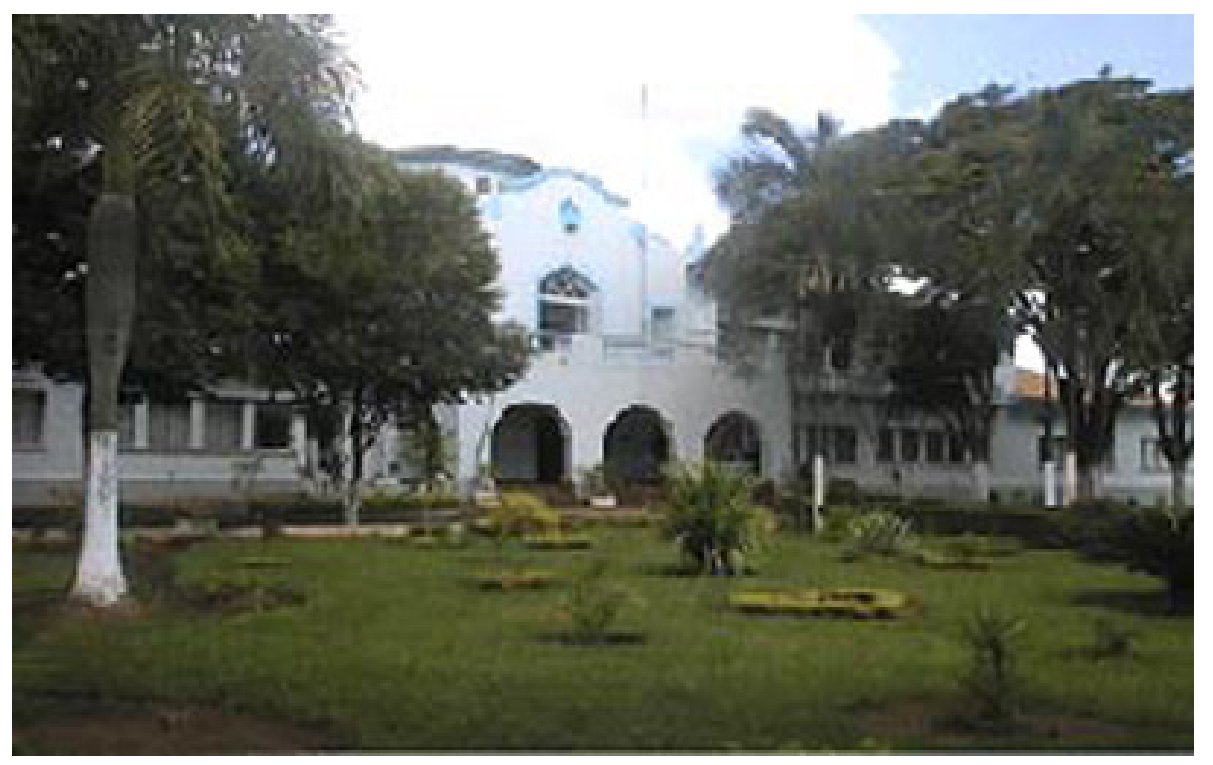

Figura 57 - Imagem do prédio do Instituto Penal Agrícola "Dr. Javert de Andrade", de São José do Rio Preto. Disponível em: http://g1.globo.com/ Noticias/SaoPaulo/0,,MUL10342-5605,00.html Acesso em: março de 2007. 

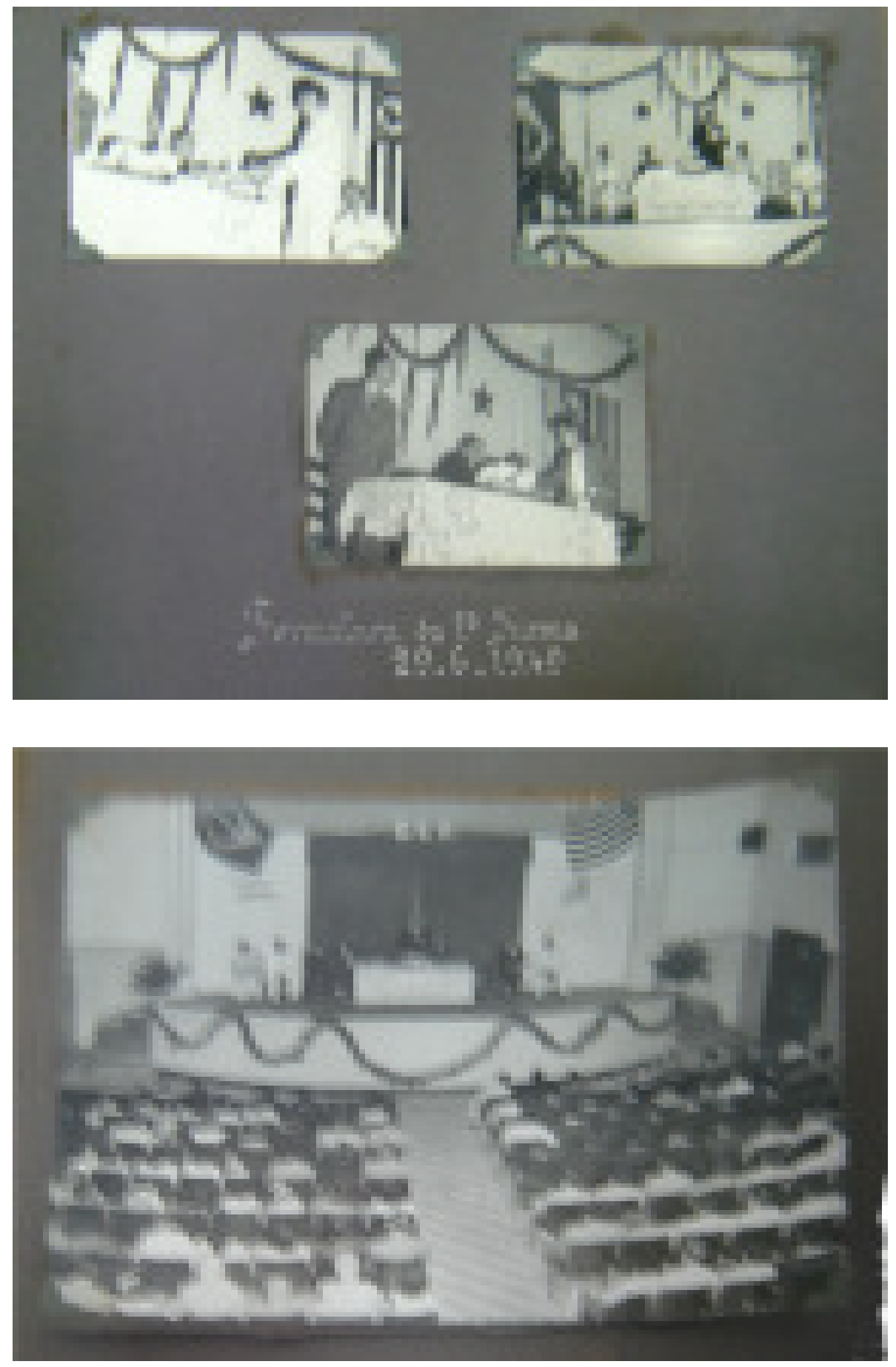

Figura 58 - Fotografias da formatura da primeira turma da Escola Prática de Agricultura "Gustavo Capanema”, de Bauru, em 26 de junho de 1949. Foram encontradas no mesmo antigo álbum sobre a escola. Fonte: Arquivo do atual Instituto Penal Agrícola "Prof. Noé Azevedo", Bauru. 

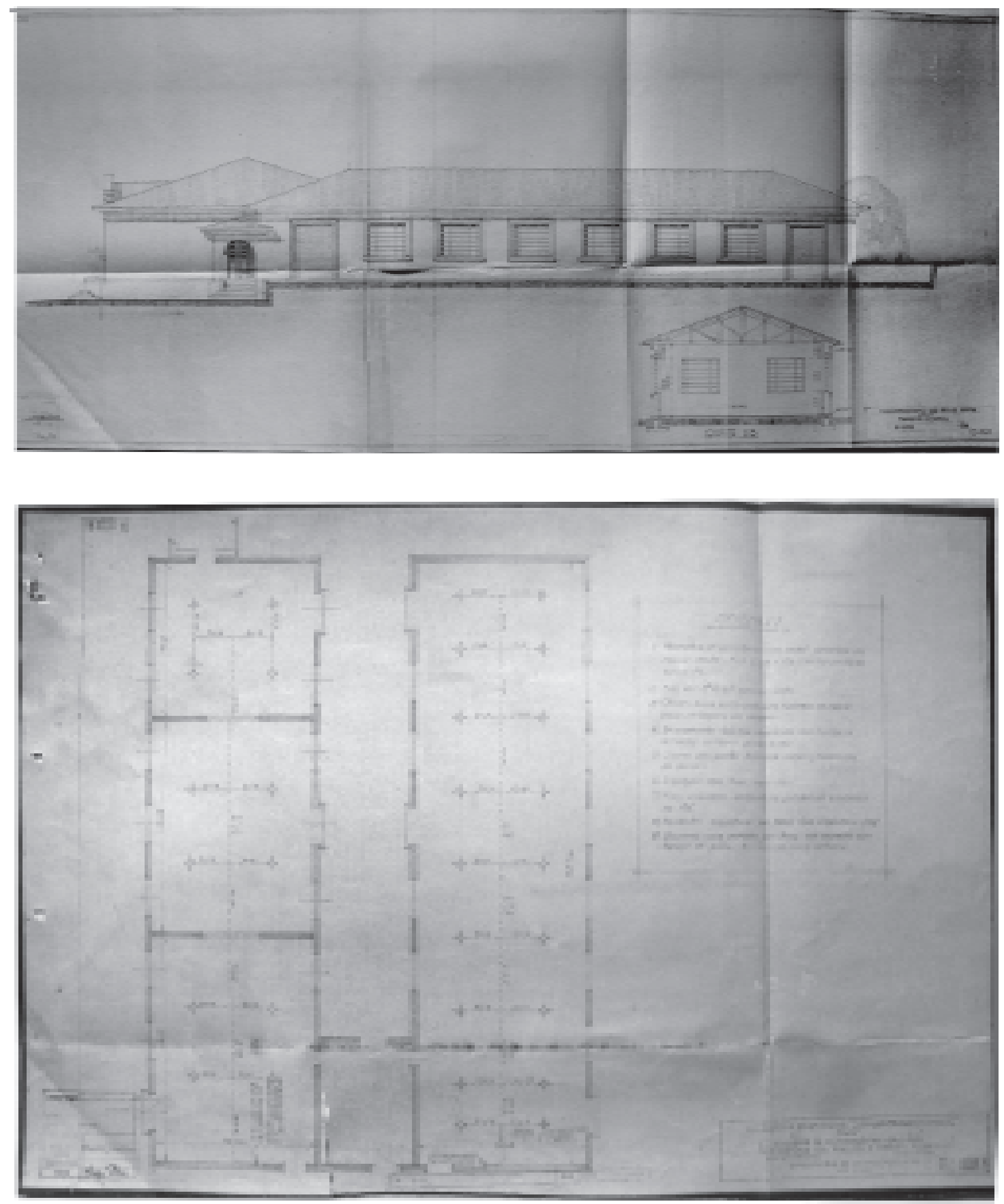

Figura 59 - Projeto da Diretoria de Obras Públicas, realizado pelo arquiteto Hernani do Val Penteado, em 1939, para a Escola Profissional “Joaquim Ferraz do Amaral”, de Jaú. Fonte: Arquivo Municipal de Jaú. 


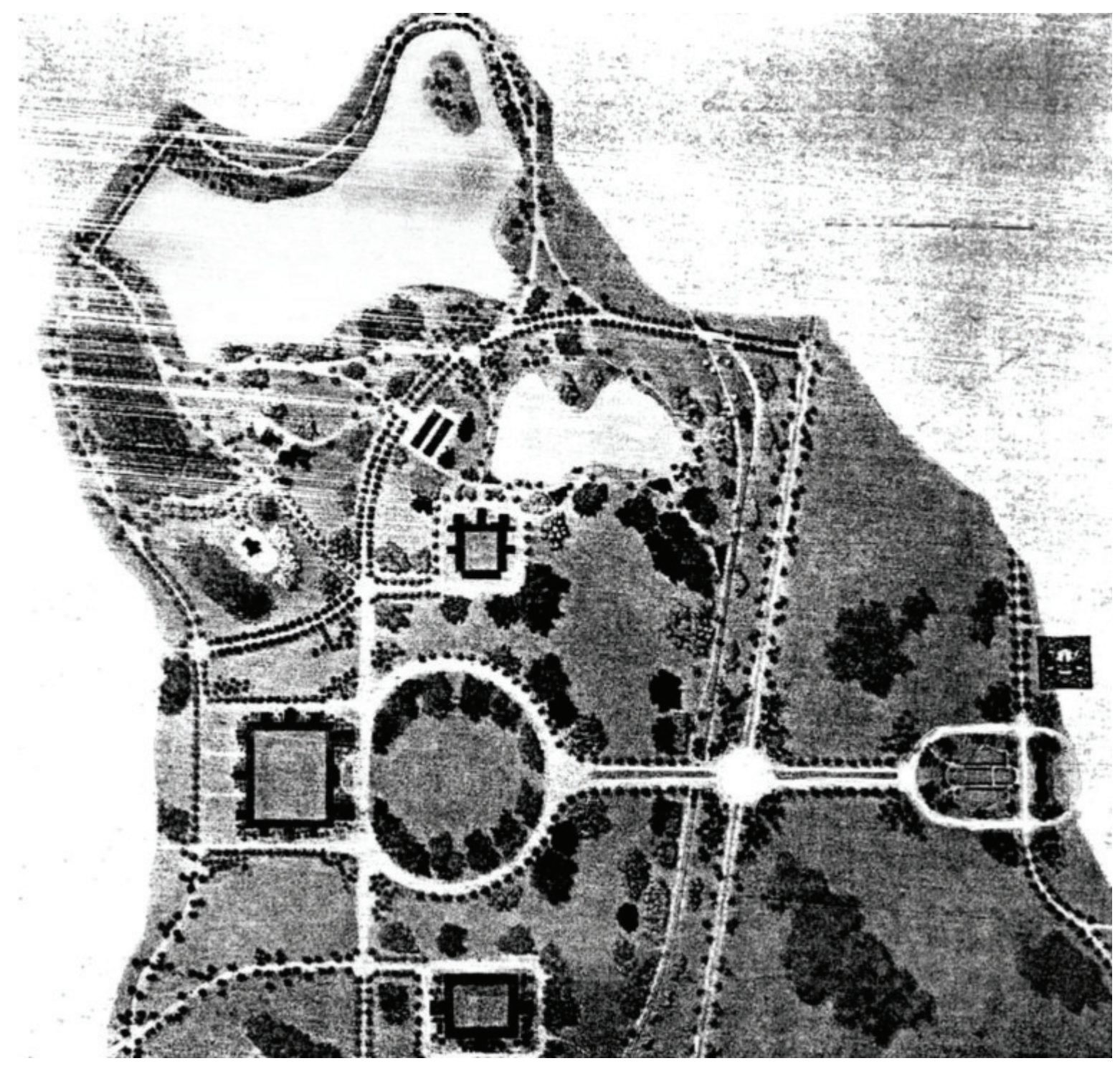

Figura 60 - Projeto para a implantação do campus da Universidade Federal Rural do Rio de Janeiro, realizado em 1938, pelo arquiteto Ângelo Murgel. Fonte: Lima (2005, p.17). 


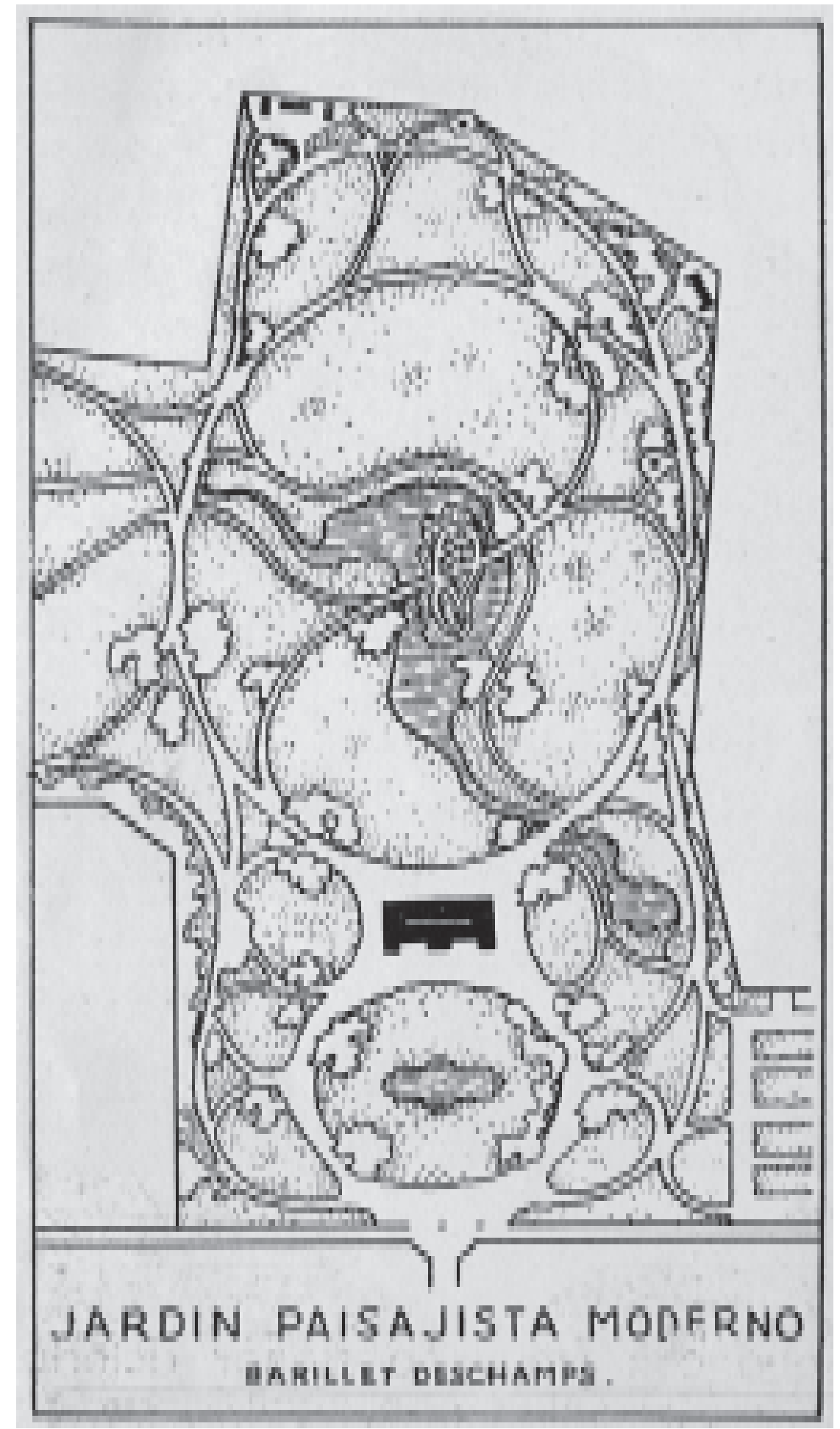

Figura 61 (páginas 278 e 279) - Exemplos de jardins ingleses, com seu traçado irregular e sinuoso e vista de um recanto de um jardim inglês. Presença do espírito romântico na paisagem pitoresca. Fonte: Mercadal (1949). 

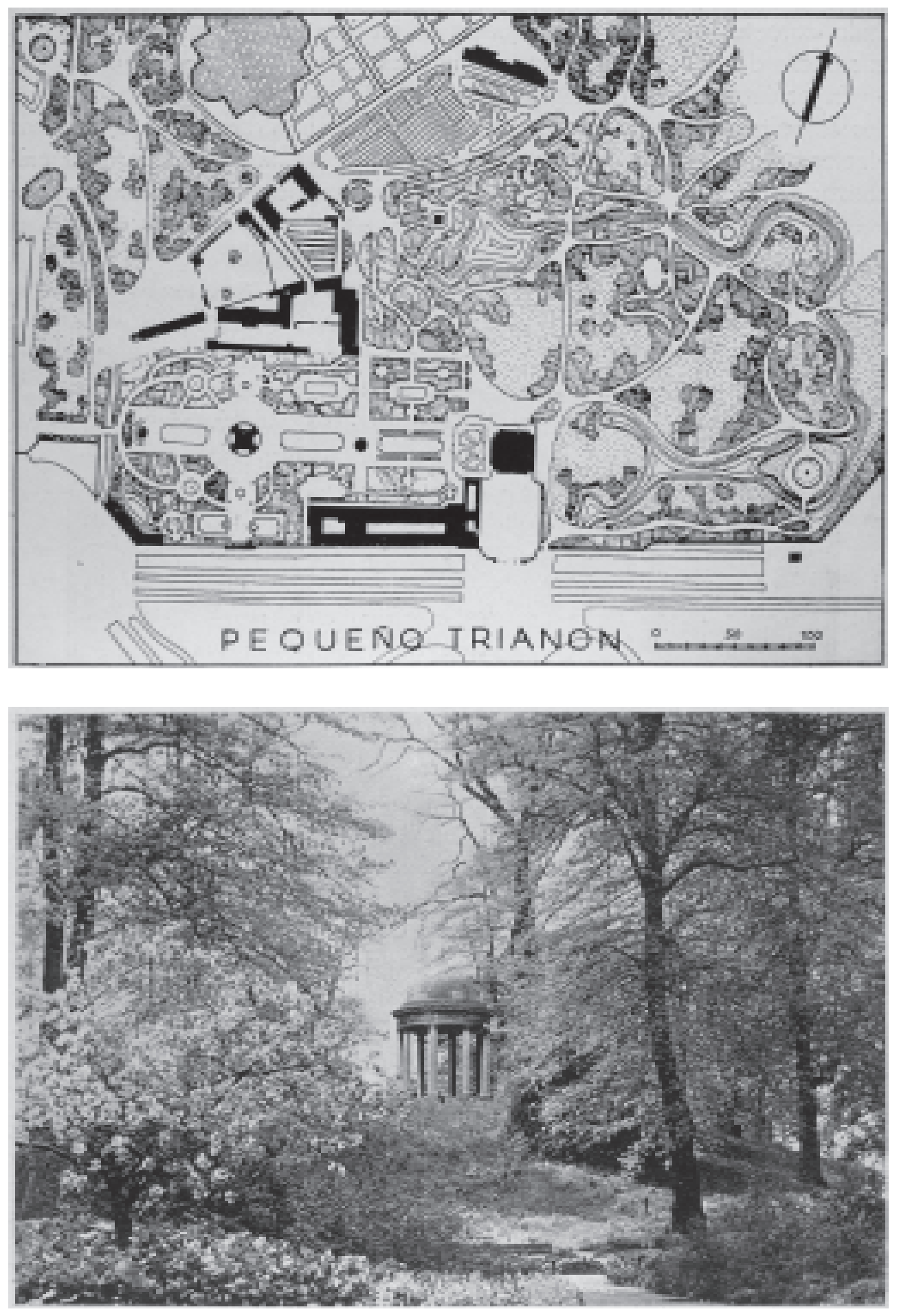


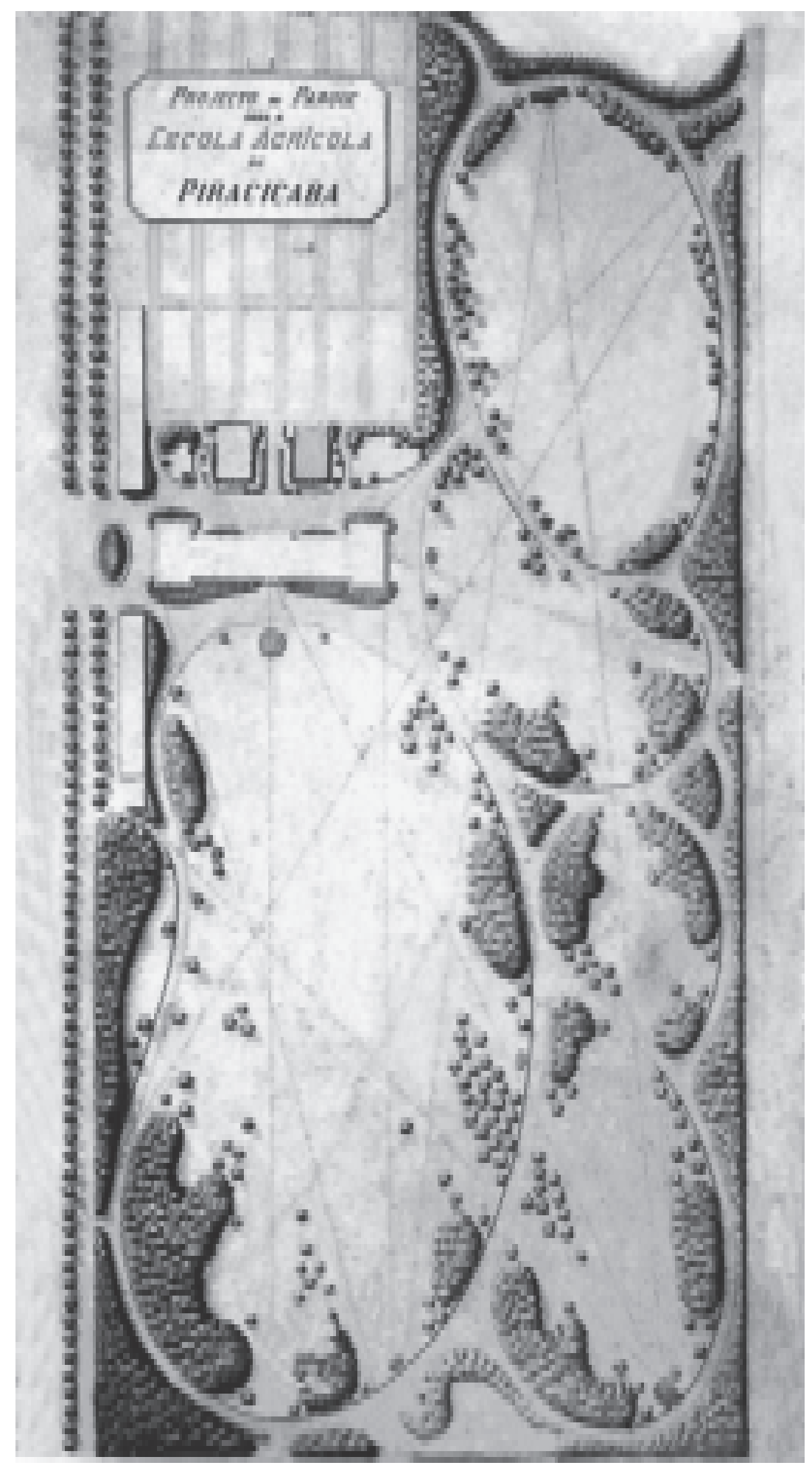

Figura 62 - Projeto do jardim da Escola Superior de Agricultura Luiz de Queiroz, em Piracicaba, concebido pelo arquiteto paisagista belga Arsenio Puttemans e implantado em 1907. Notar a semelhança com os jardins ingleses. Disponível em: http:// www.esalq.usp.br/parque/new_page_1.htm. Acesso em: 18/03/2008. 

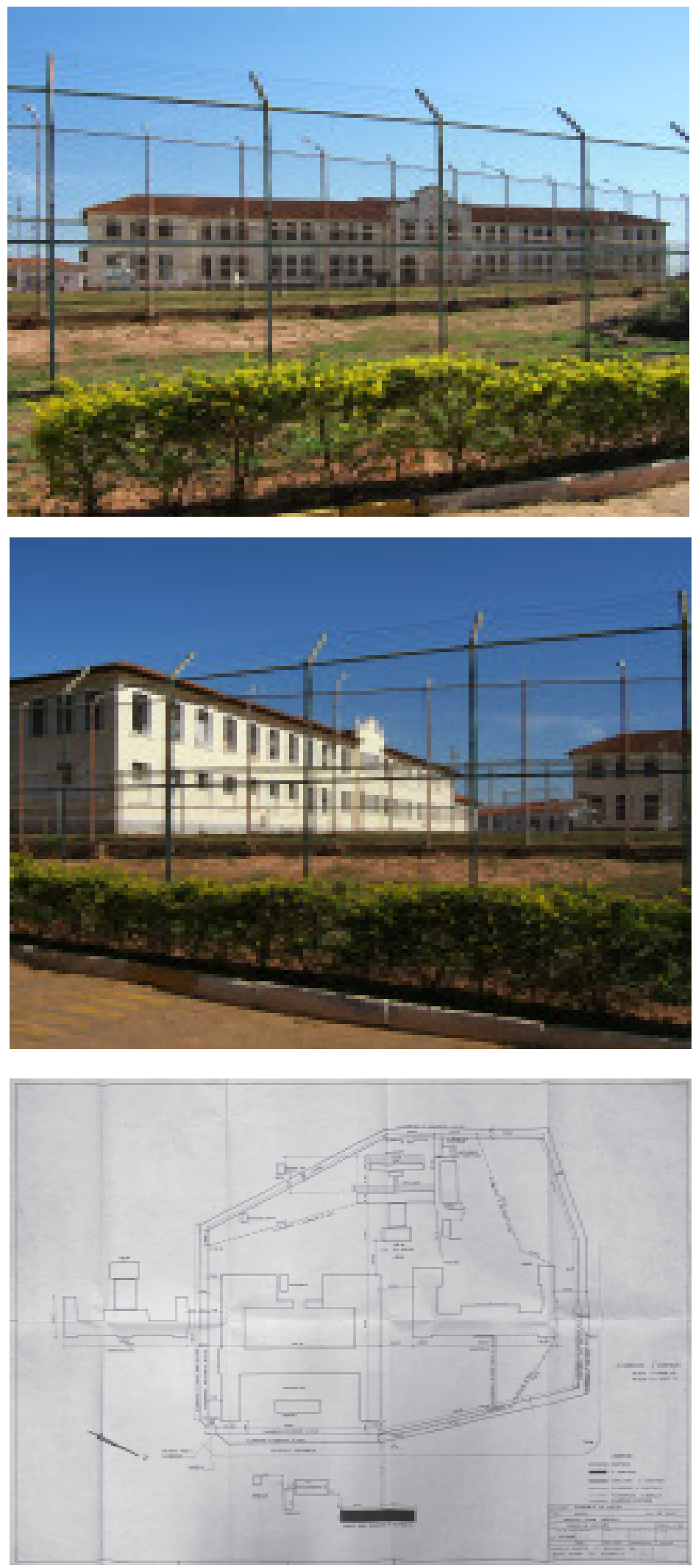

Figura 63 - Barreiras de acesso, necessárias ao atual presídio, desconfiguraram o projeto original do ajardinamento e arruamento definido para a Escola Prática de Agricultura "Gustavo Capanema", de Bauru. Vemos o projeto das barreiras, de 1976, e vistas atuais das mesmas. Fonte: Arquivo do Instituto Penal Agrícola "Prof. Noé de Azevedo" e fotos da autora, abril de 2007. 

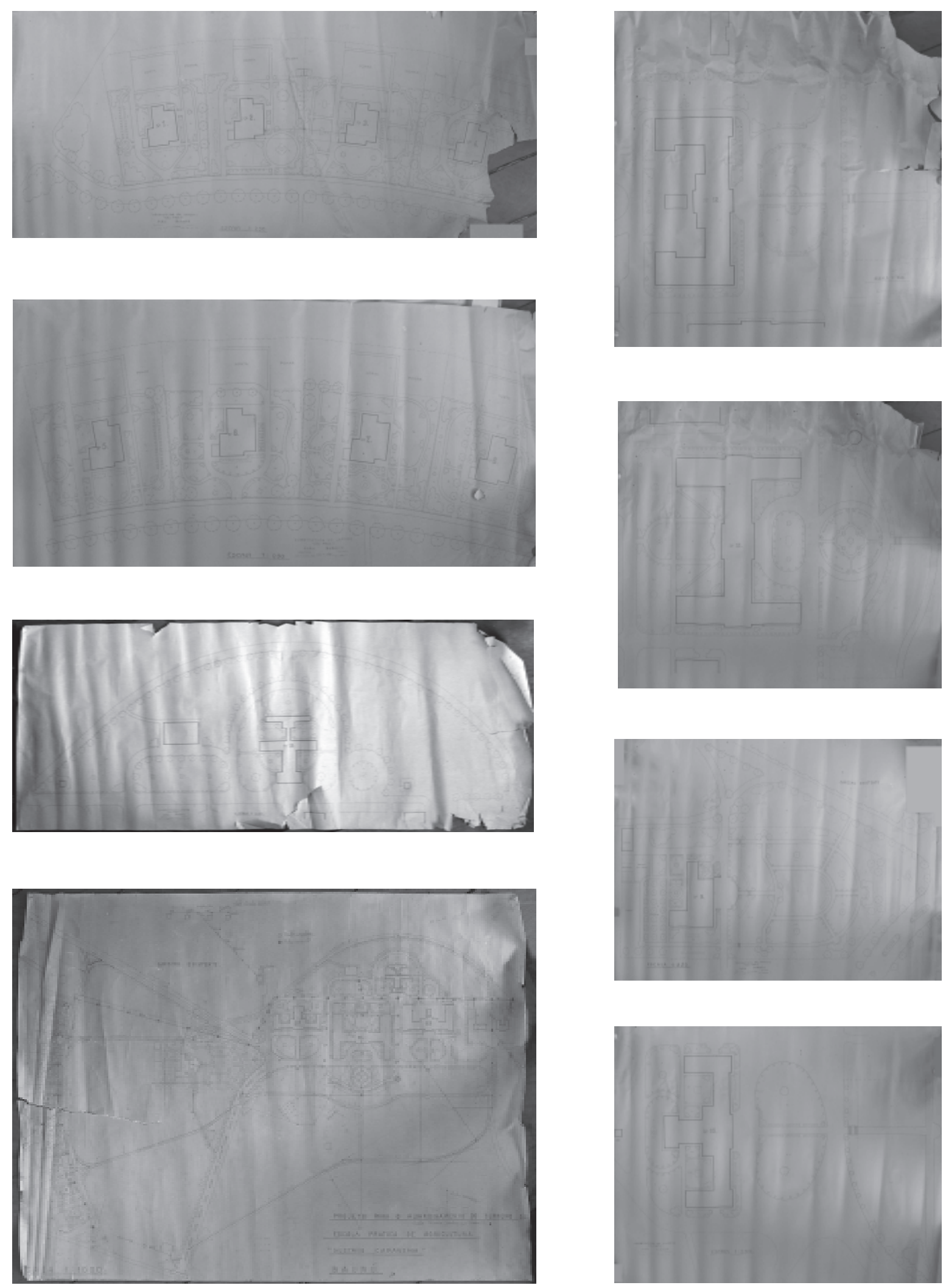

Figura 64 - Projeto original do ajardinamento e arruamento da Escola Prática de Agricultura "Gustavo Capanema”, de Bauru, realizado pelo escritório “Construtora de Jardins São Paulo”, na época da construção da escola. Fonte: Arquivo do Instituto Penal Agrícola "Prof. Noé de Azevedo". 

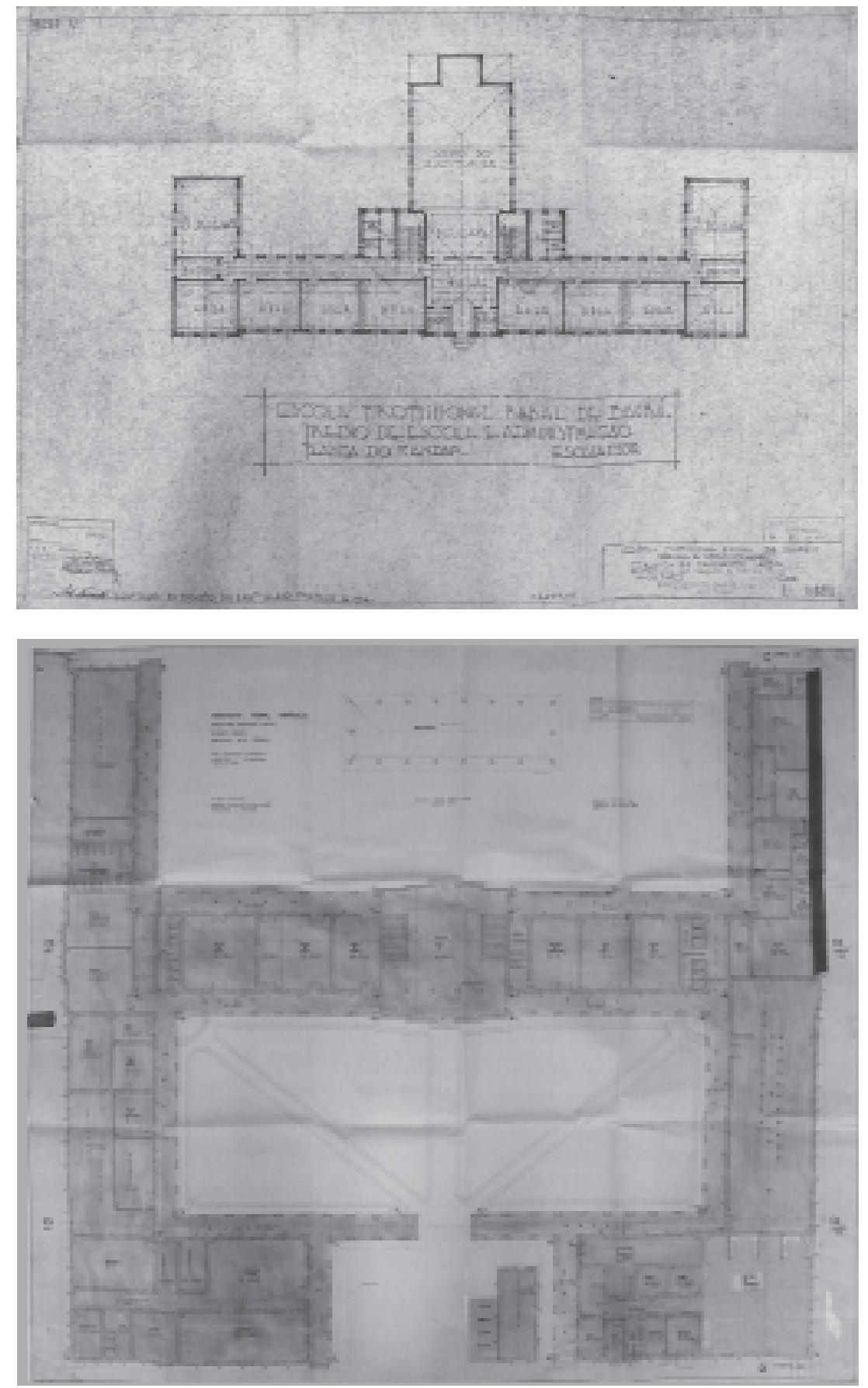

Figura 65 (páginas 283 a 286) - A primeira prancha é do projeto de Hernani do Val Pentedao para o primeiro andar do prédio de "escola e administração" da Escola Prática de Agricultura "Gustavo Capanema", de Bauru. Notar a observação que informa este projeto ter sido adaptado de um projeto do engenheiro Mario Whately, provavelmente, para a Escola nacional de Agronomia do Rio de Janeiro. As demais pranchas são de levantamentos posteriores feito pelo Instituto Penal Agrícola e de outros equipamentos da época da Escola. Fonte: Arquivo do Instituto Penal Agrícola "Prof. Noé de Azevedo". 

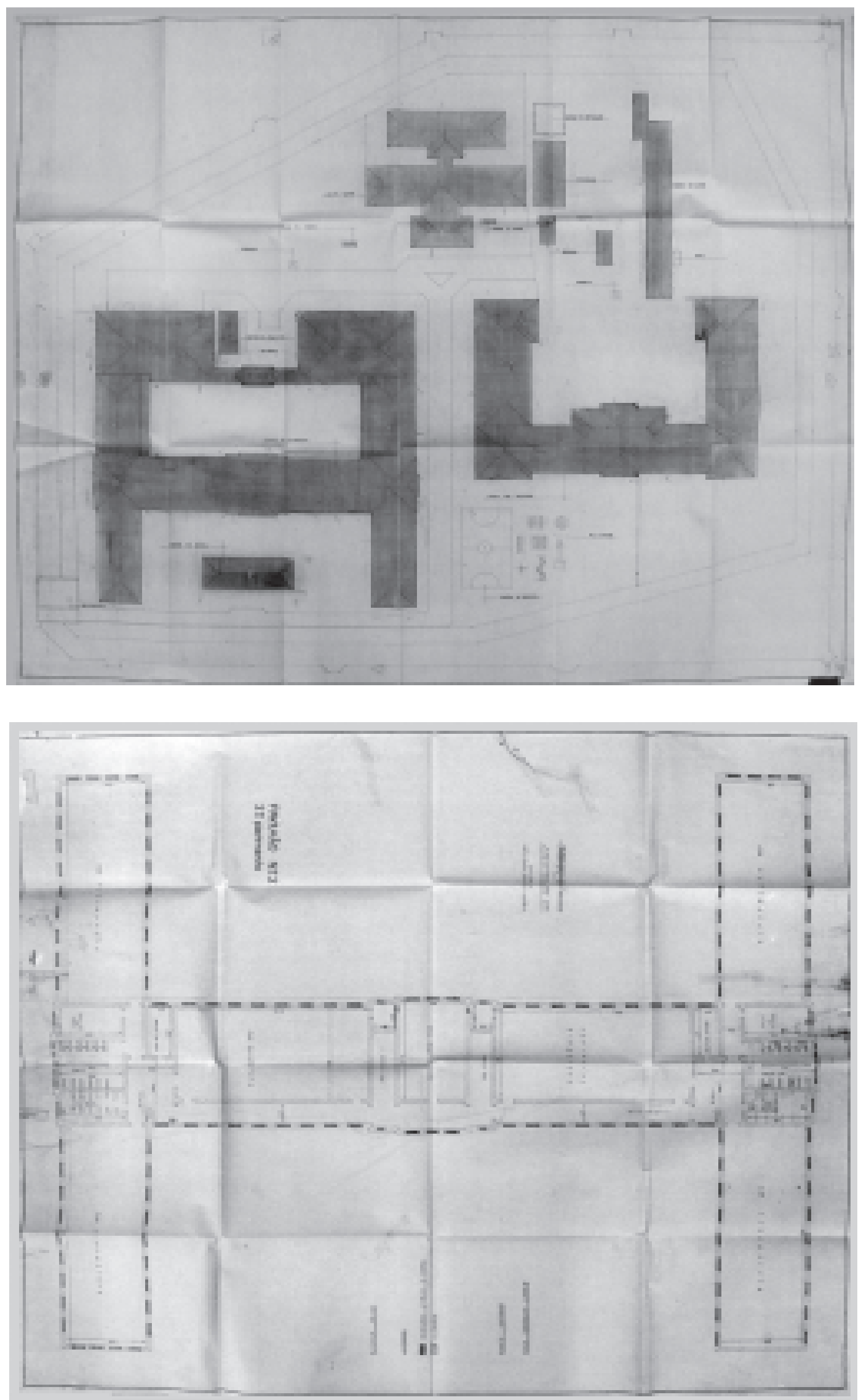

Figura 65 - legenda na página 283. 

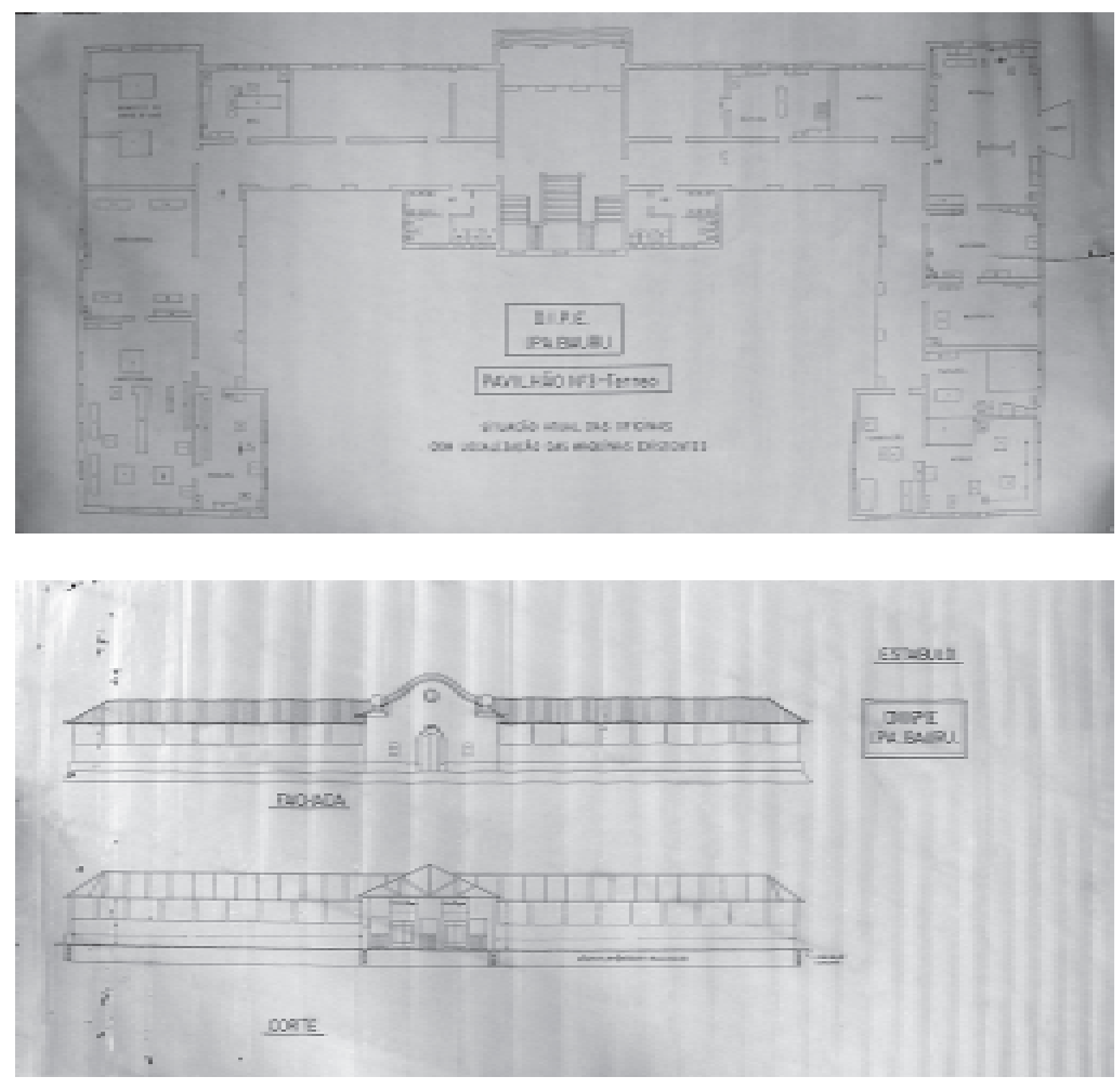

Figura 65 - legenda na página 283. 

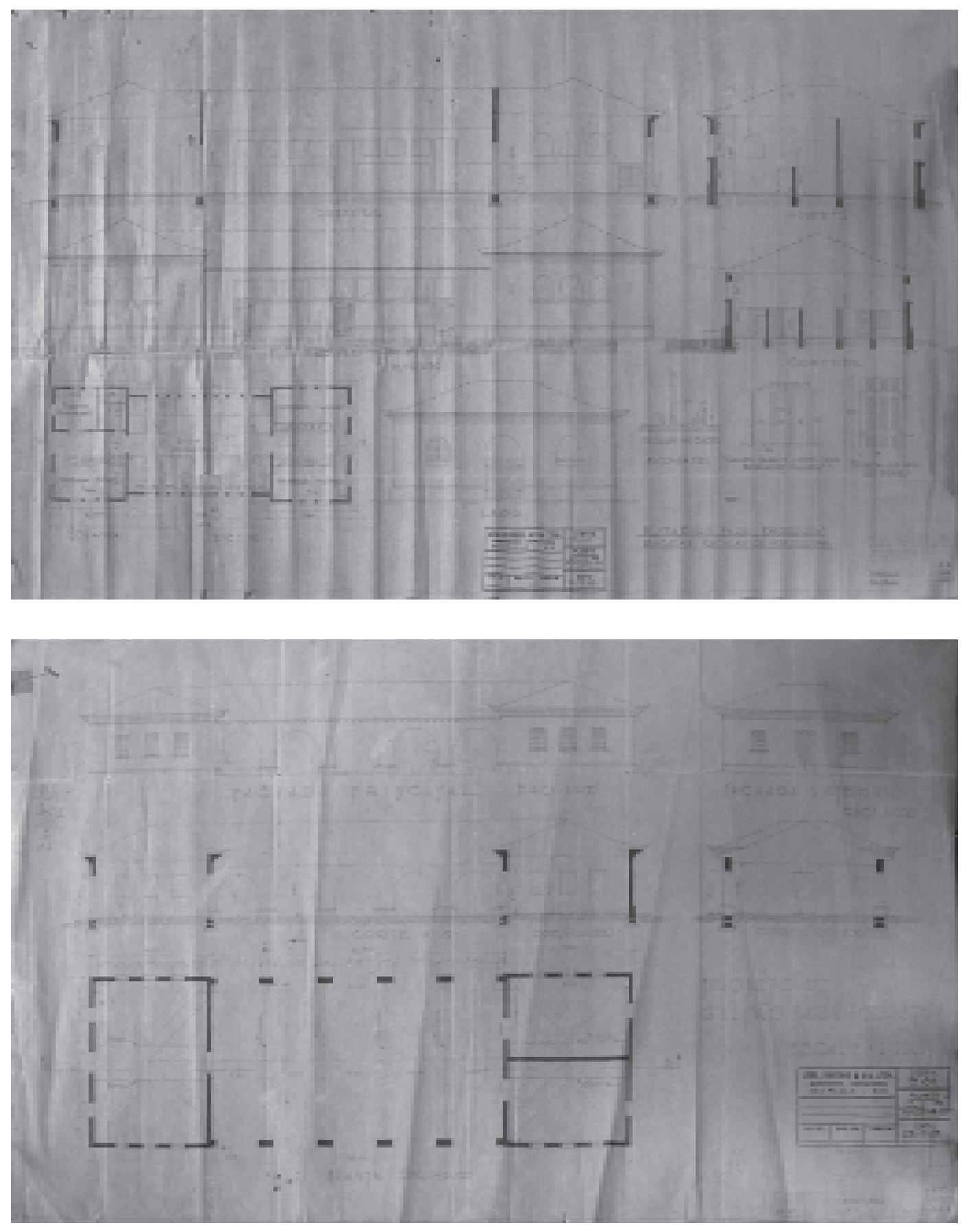

Figura 65 - legenda na página 283. 


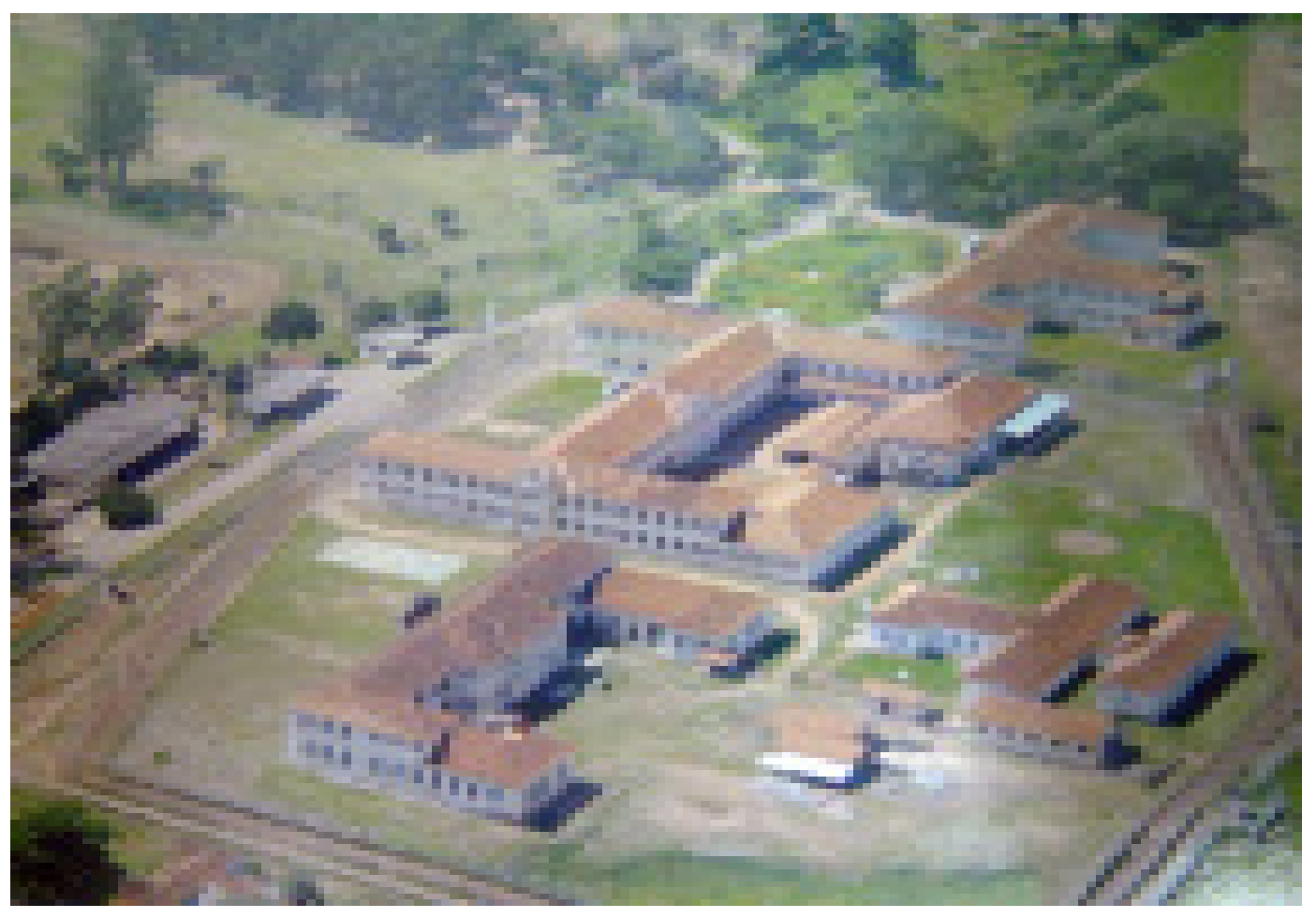

Figura 66 - Foto aérea do atual Instituto Penal Agrícola “Prof. Noé de Azevedo", de Bauru. Também vemos claramente as barreiras impostas ao projeto original de ajardinamento da antiga Escola Prática de Agricultura "Gustavo Capanema". Fonte: Arquivo do Instituto Penal Agrícola "Prof. Noé de Azevedo". 

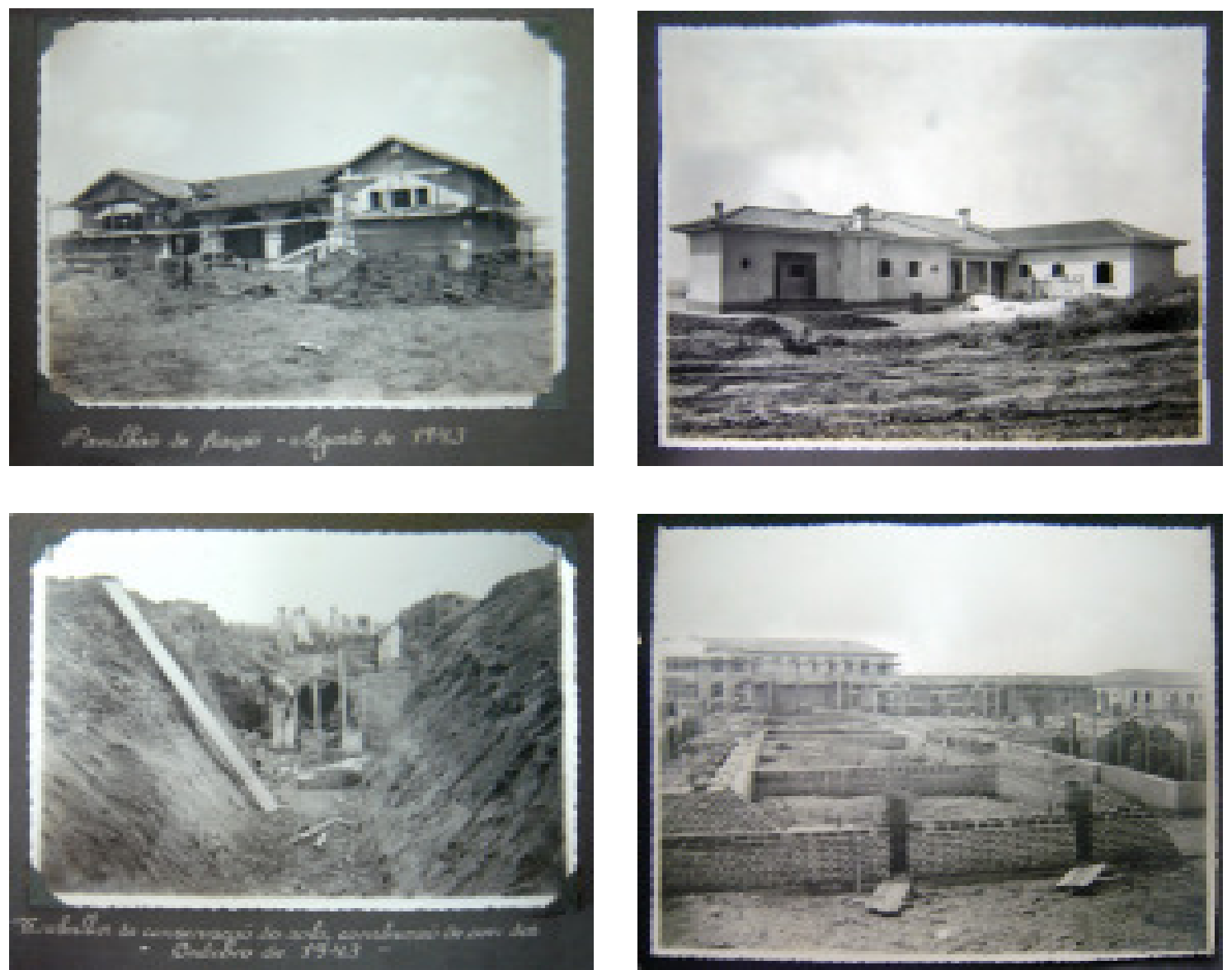

Figura 67 (páginas 288 e 289) - Imagens da construção da Escola Prática de Agricultura "Gustavo Capanema", de Bauru, em 1944. Podemos ver alguns dos materiais e técnicas de construção empregados, como a alvenaria de tijolos. Fonte: Arquivo do Instituto Penal Agrícola "Prof. Noé de Azevedo". 

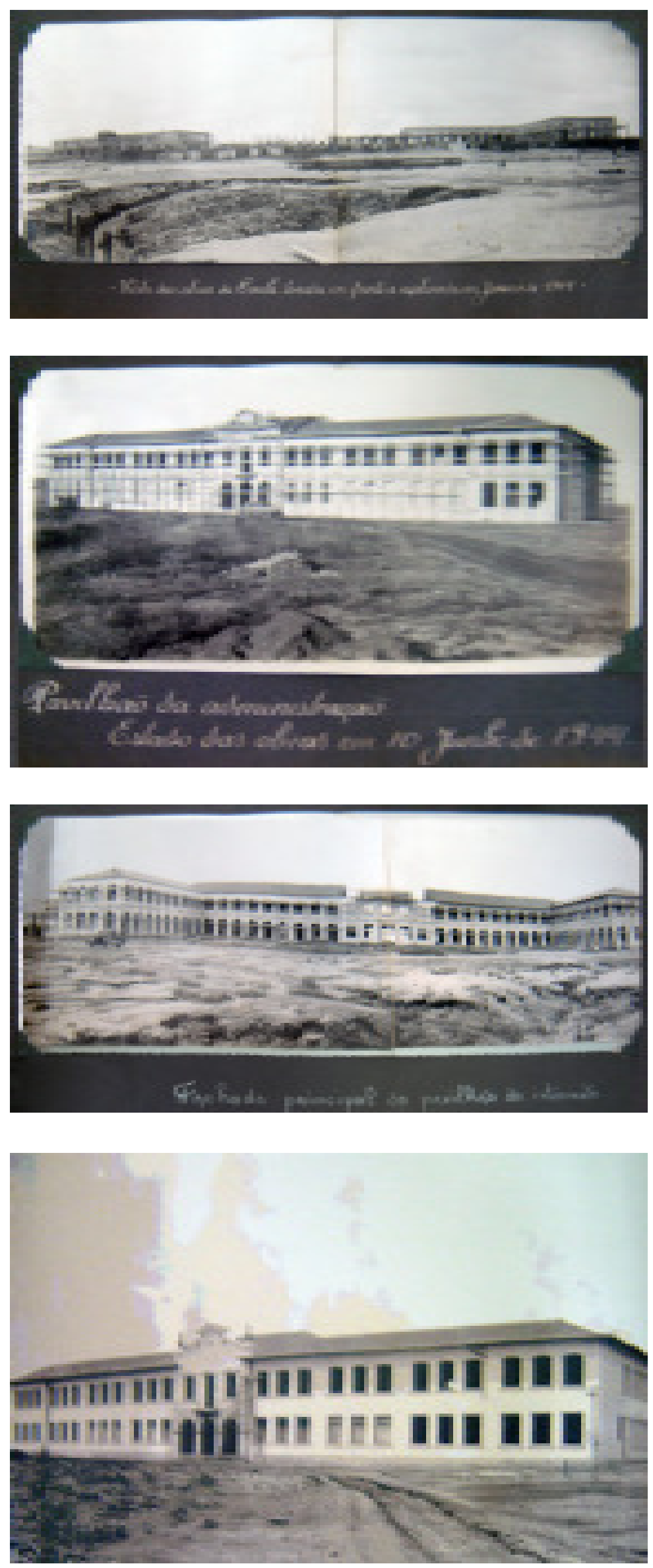

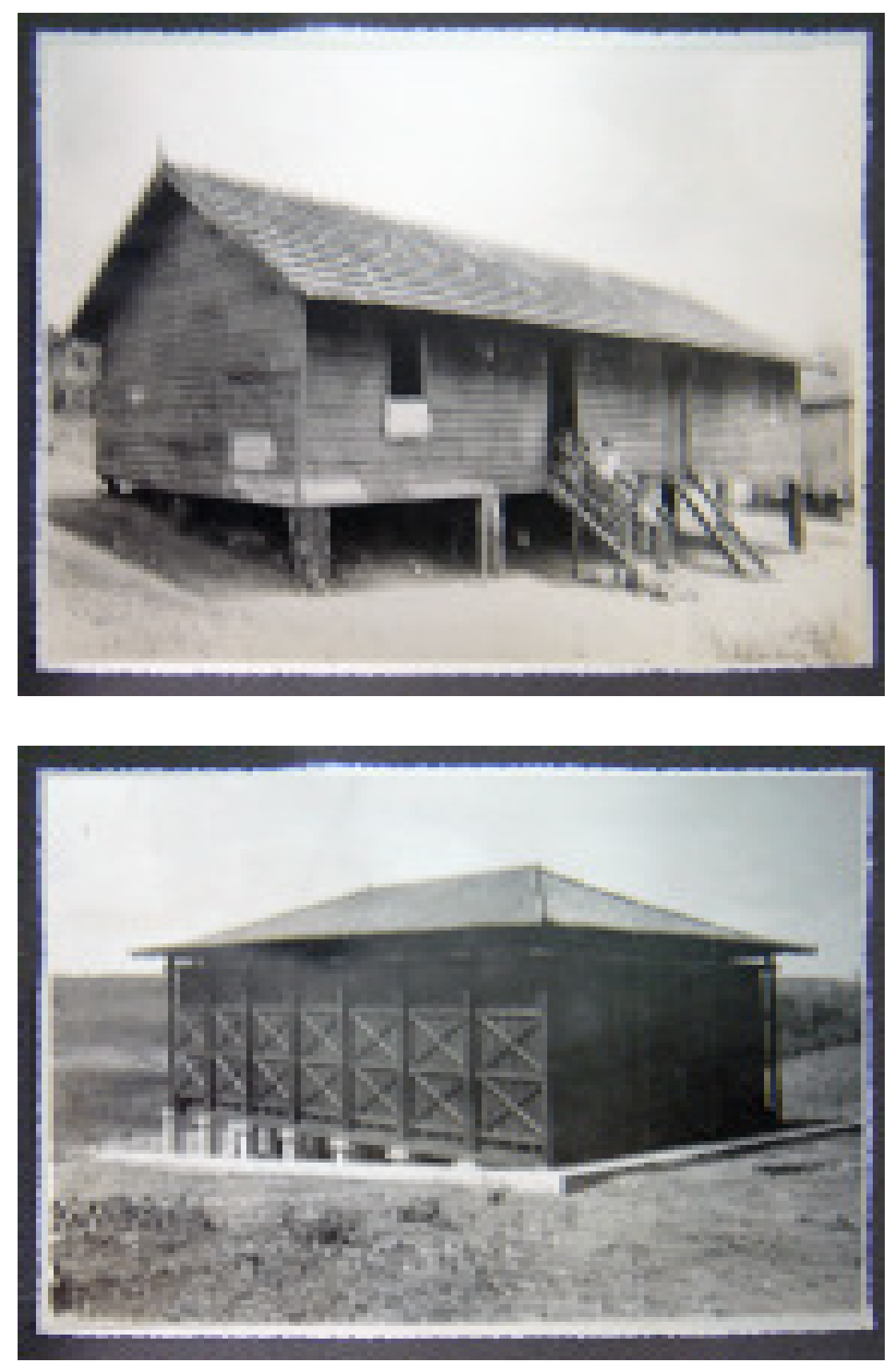

Figura 68 - Alojamento para operários da construção da Escola Prática de Agricultura "Gustavo Capanema" e paiol, ambos em madeira. Fonte: Arquivo do Instituto Penal Agrícola "Prof. Noé de Azevedo". 

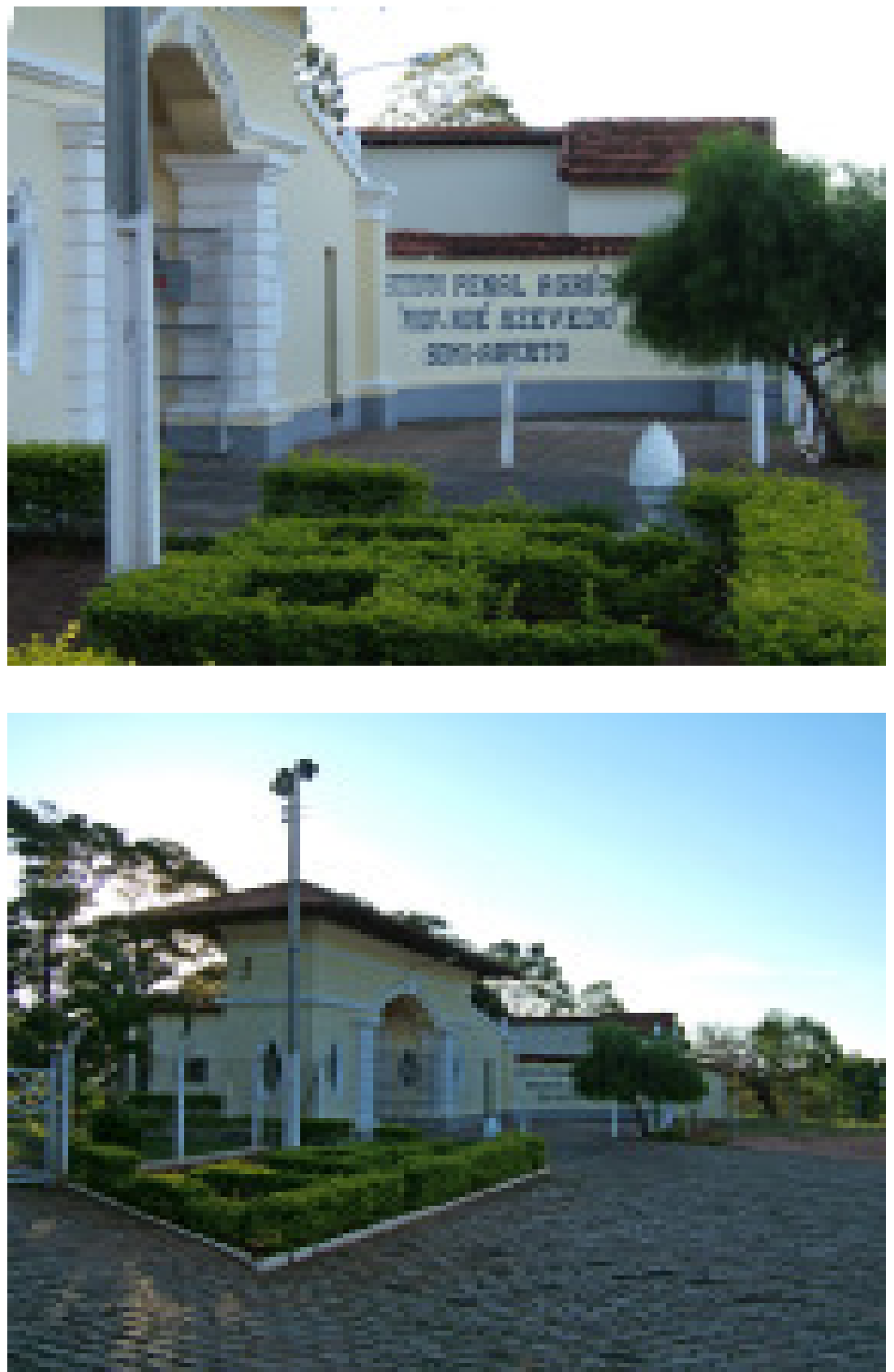

Figura 69 - Portão de entrada da Escola Prática de Agricultura "Gustavo Capanema", Bauru. Mesmo projeto que para o portão da Escola Prática de Agricultura "Getúlio Vargas", Ribeirão Preto. Fonte: fotos da autora, abril de 2007. 

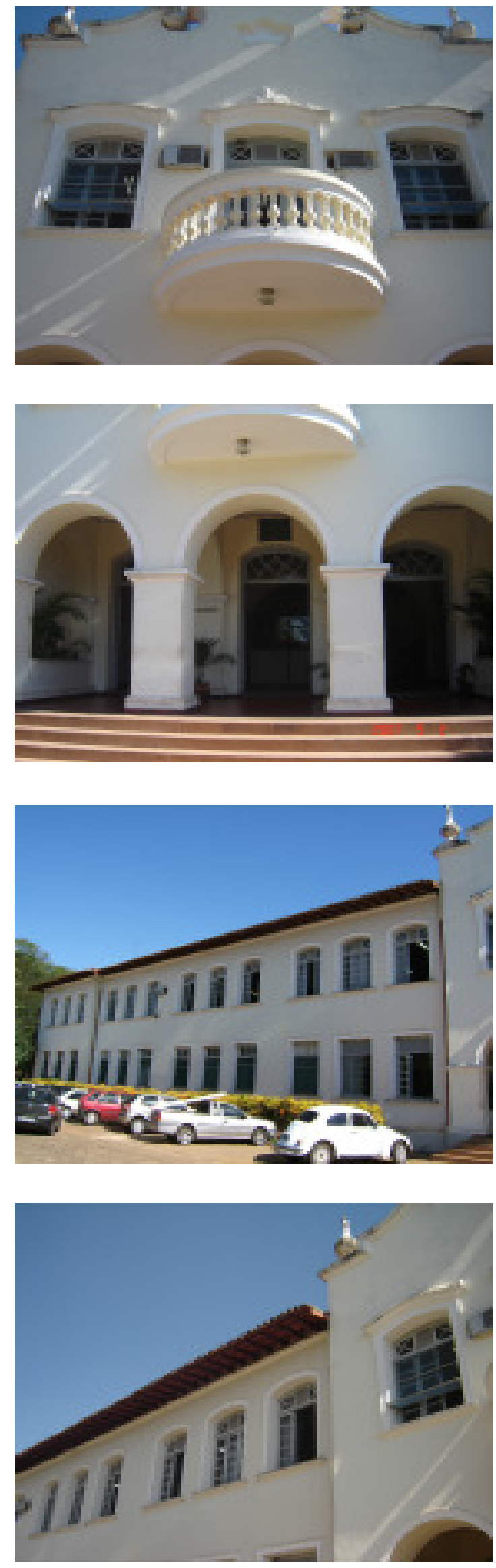
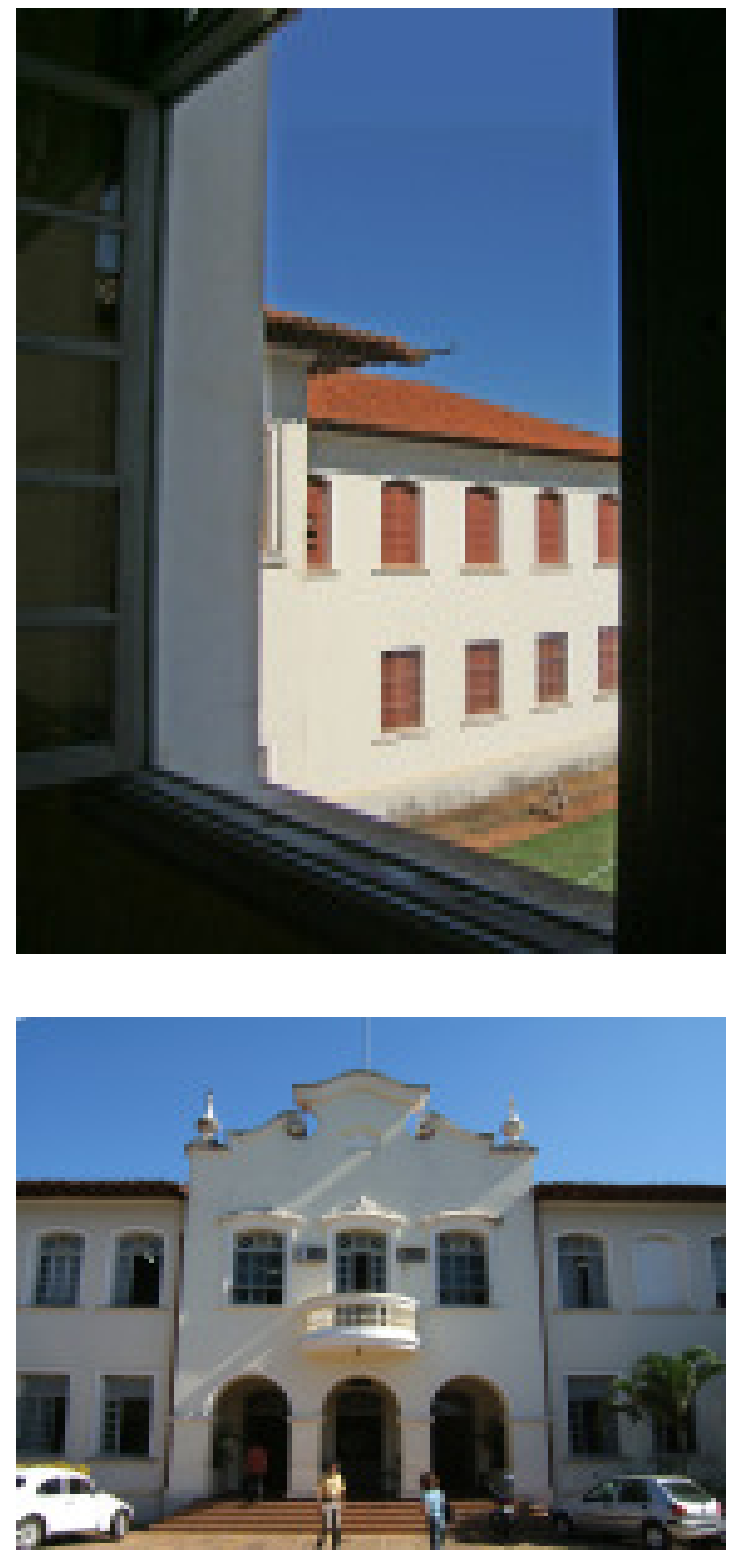

Figura 70 - Vistas da fachada do prédio principal da Escola Prática de Agricultura "Gustavo Capanema”, Bauru. Semelhança com a Escola Prática de Agricultura “Getúlio Vargas”, Ribeirão Preto. Fonte: fotos da autora, abril de 2007. 

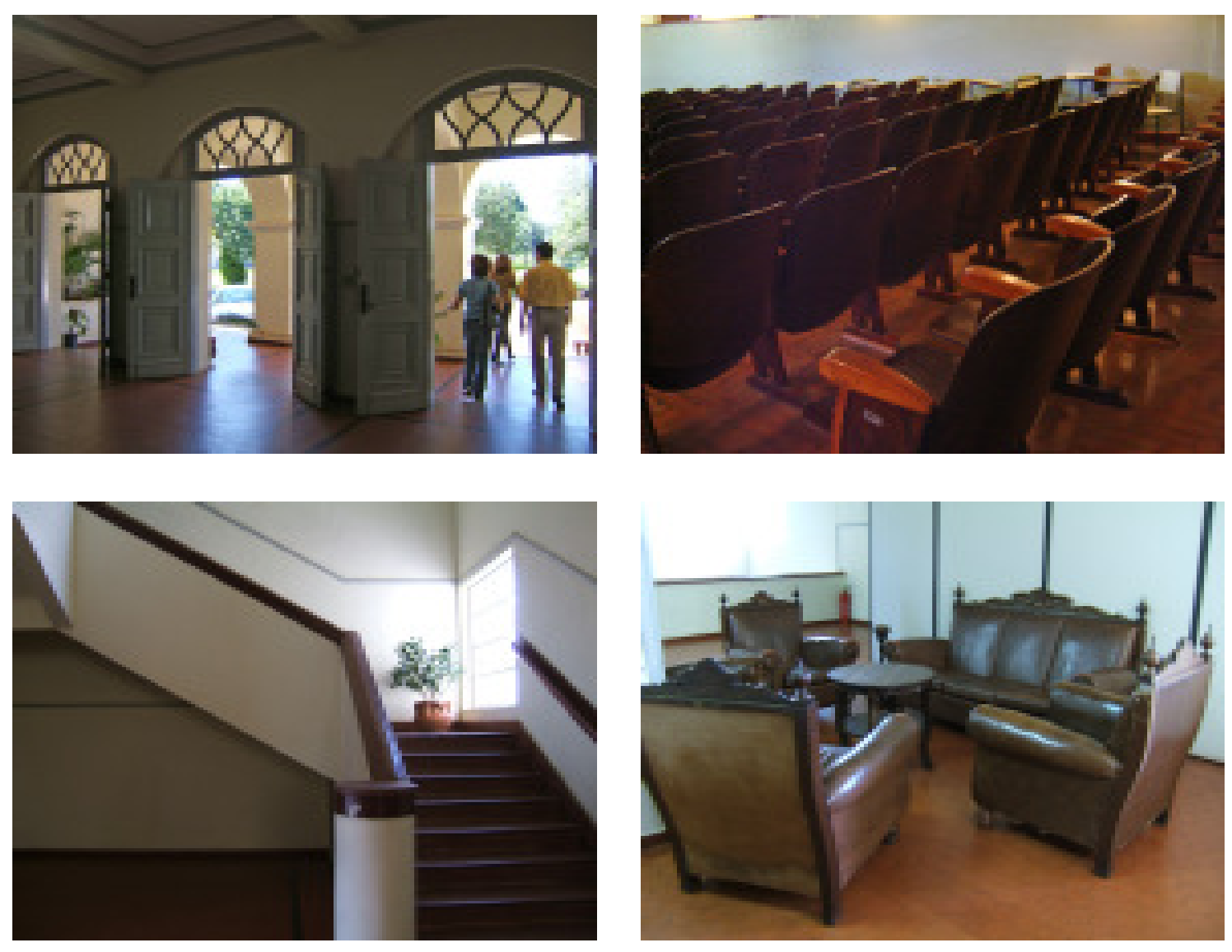

Figura 71 - Fotos do interior da Escola Prática de Agricultura "Gustavo Capanema", Bauru. Podemos ver que alguns móveis originais ainda se conservam no local e que as proporções de alguns elementos, como decoração de bandeiras de portas e corrimãos de escada, são exagerados. Fonte: fotos da autora, abril de 2007. 

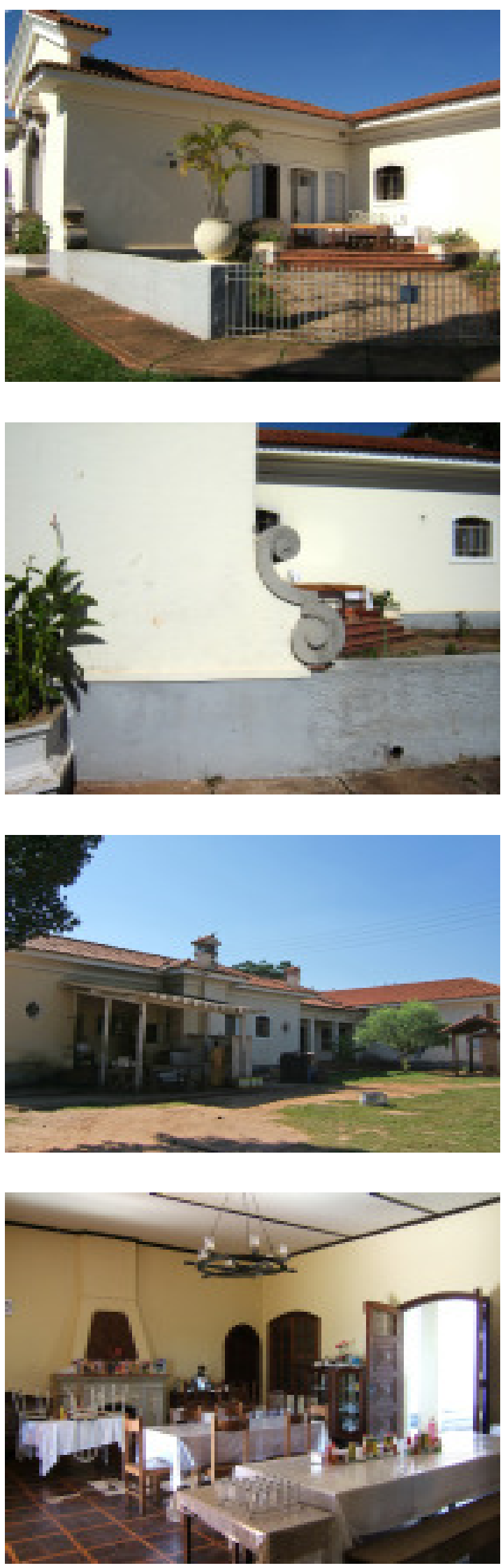
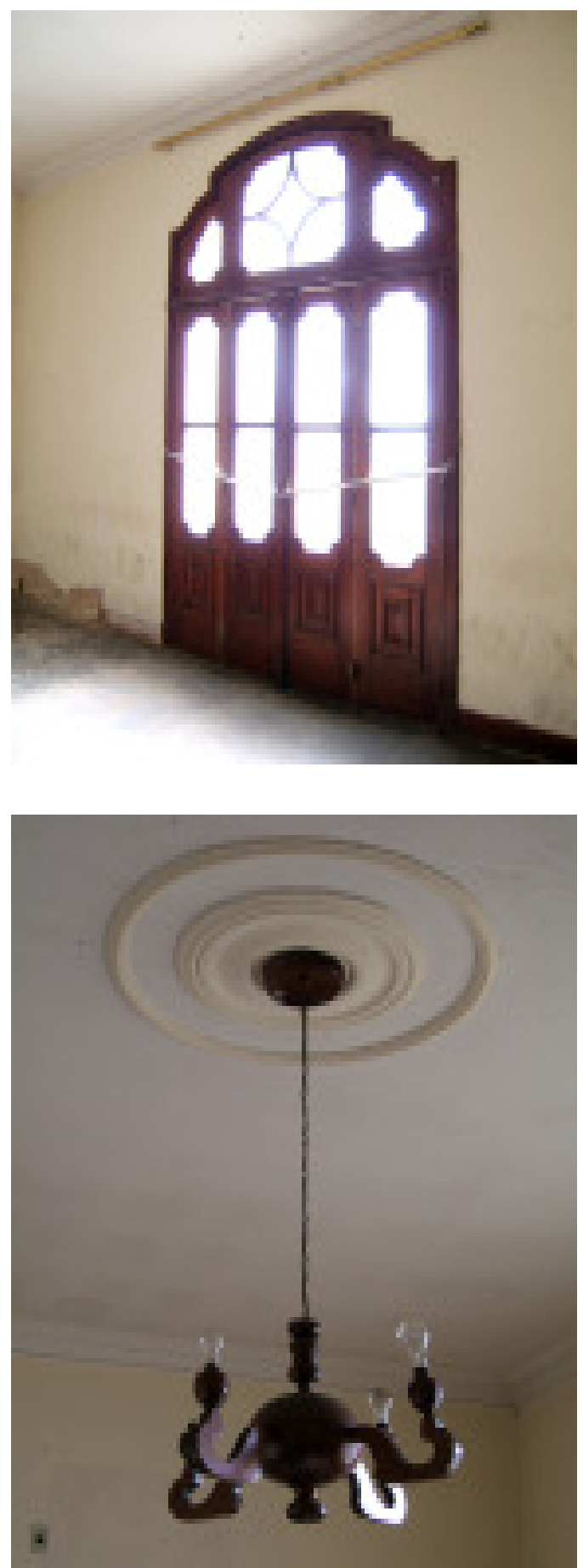

Figura 72 (páginas 294 e 295) - Aspectos externos e internos da antiga casa do diretor da Escola Prática de Agricultura "Gustavo Capanema". Muita madeira foi utilizada nos acabamentos internos. Também podemos ver que os vidros das portas são decorados com motivos agrícolas. Fonte: fotos da autora, abril de 2007. 

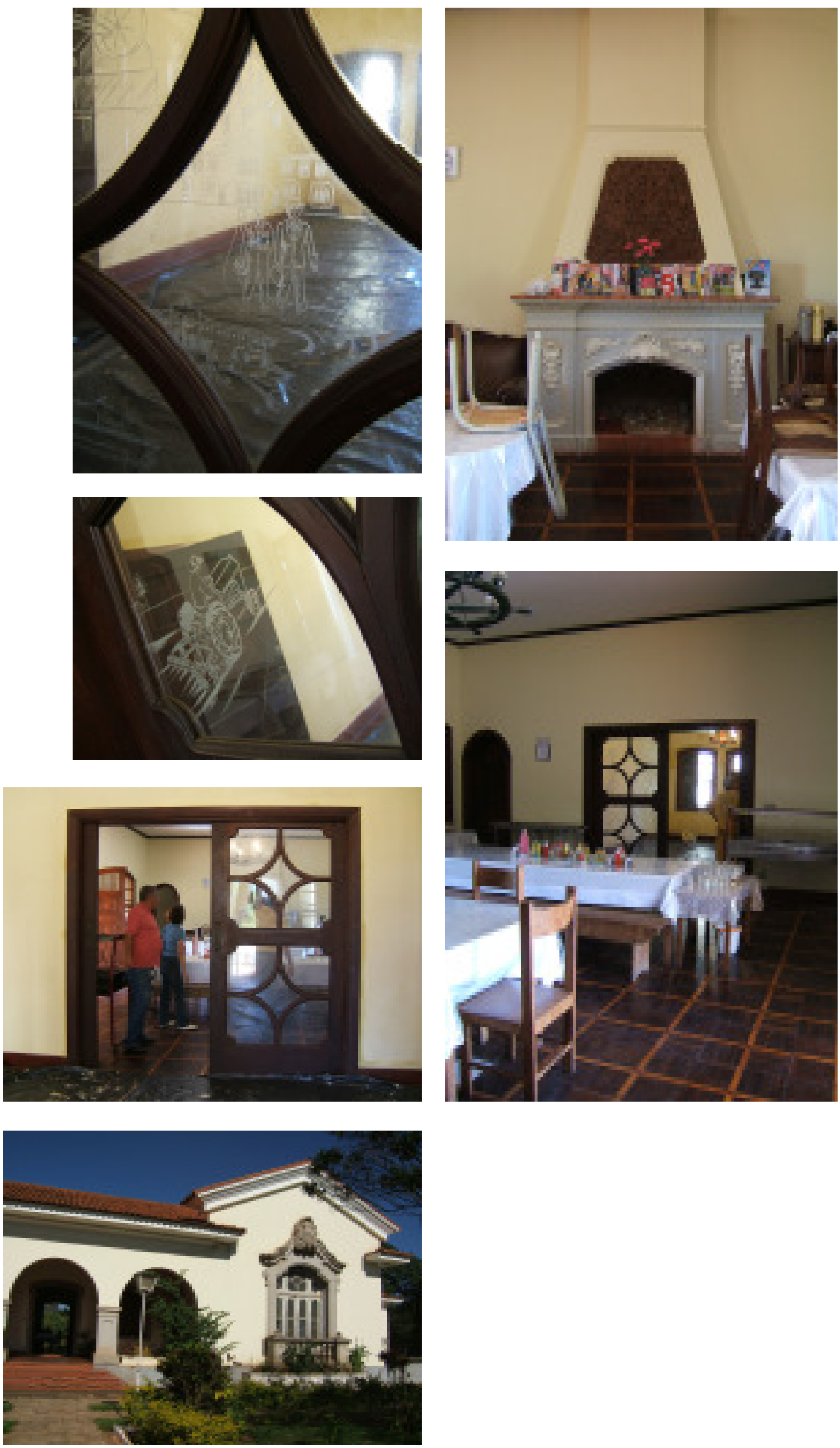

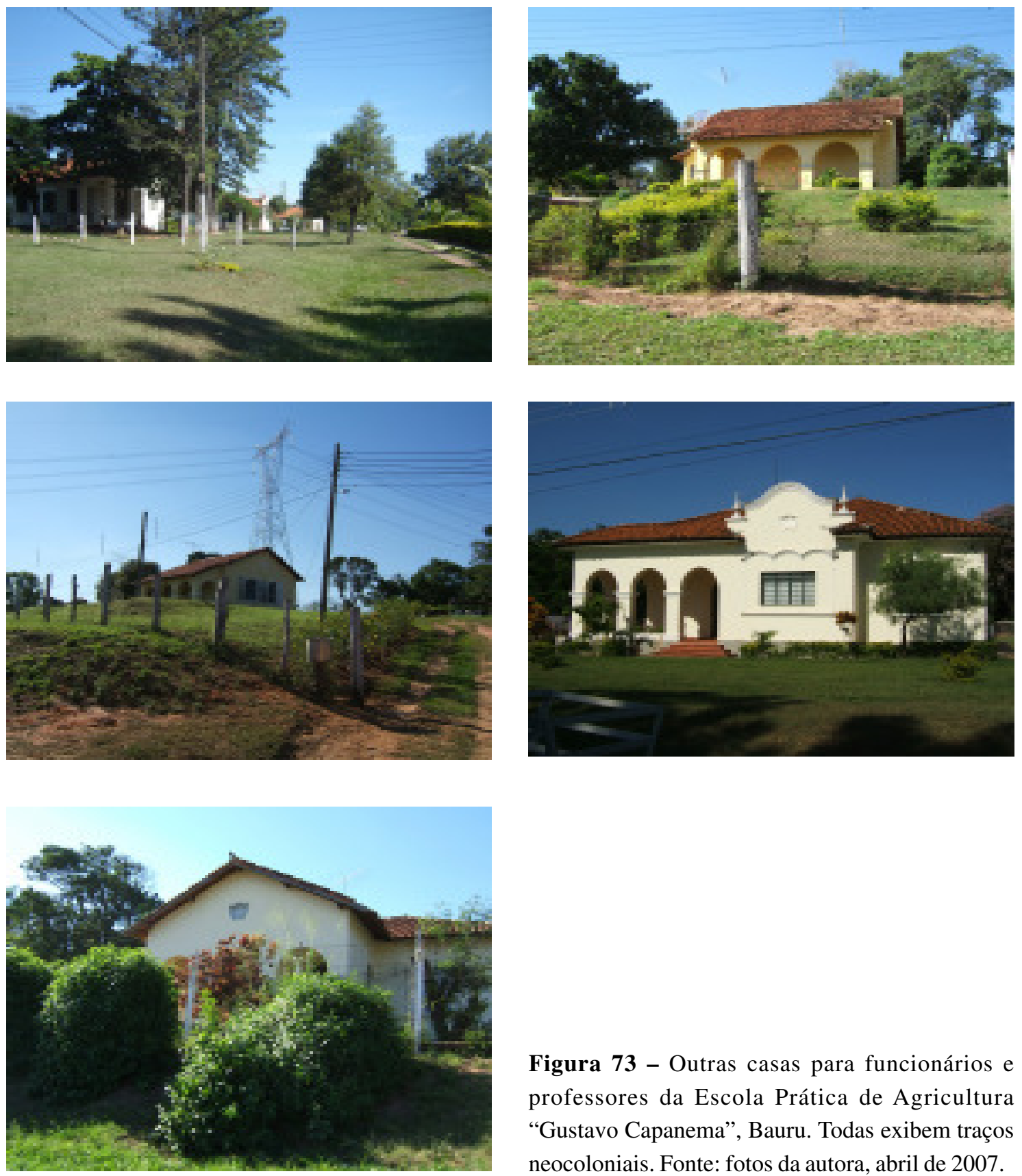

Figura 73 - Outras casas para funcionários e professores da Escola Prática de Agricultura "Gustavo Capanema", Bauru. Todas exibem traços neocoloniais. Fonte: fotos da autora, abril de 2007. 

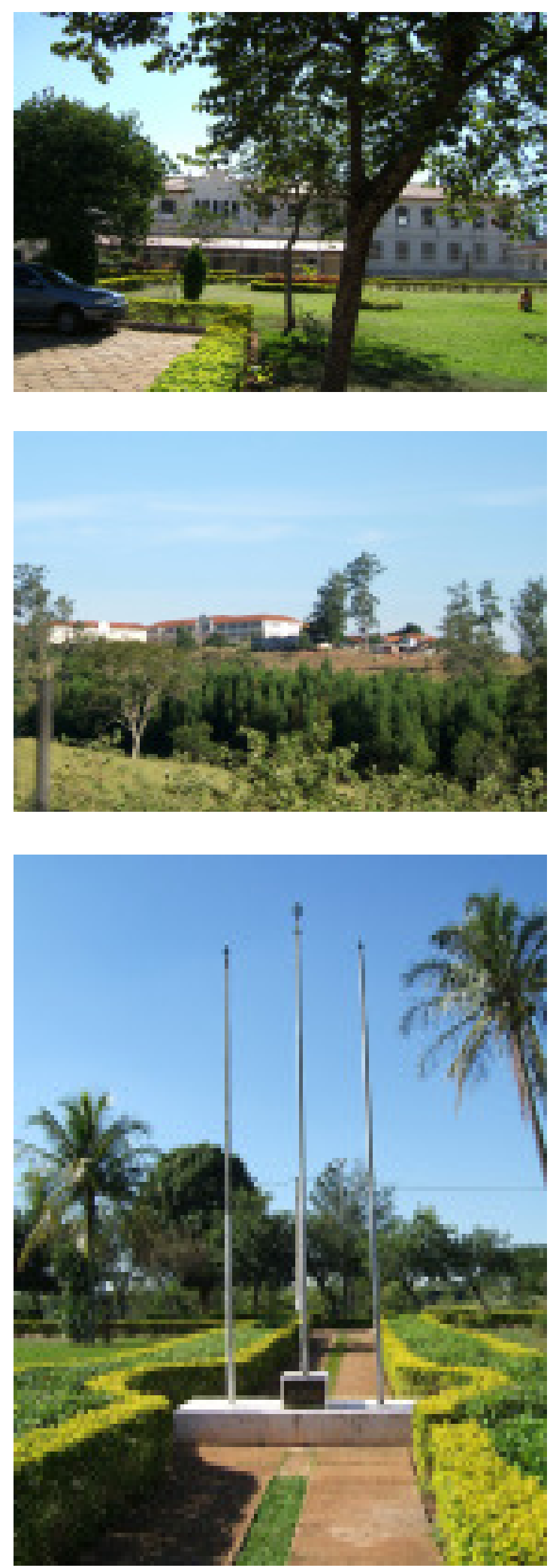

Figura 74 (acima) - Prédios próximos ao prédio principal da Escola Prática de Agricultura "Gustavo Capanema", atualmente utilizados como presídio. Vemos também a placa comemorativa de lançamento da pedra fundamental (19/4/1942) Fonte: fotos da autora, abril de 2007.

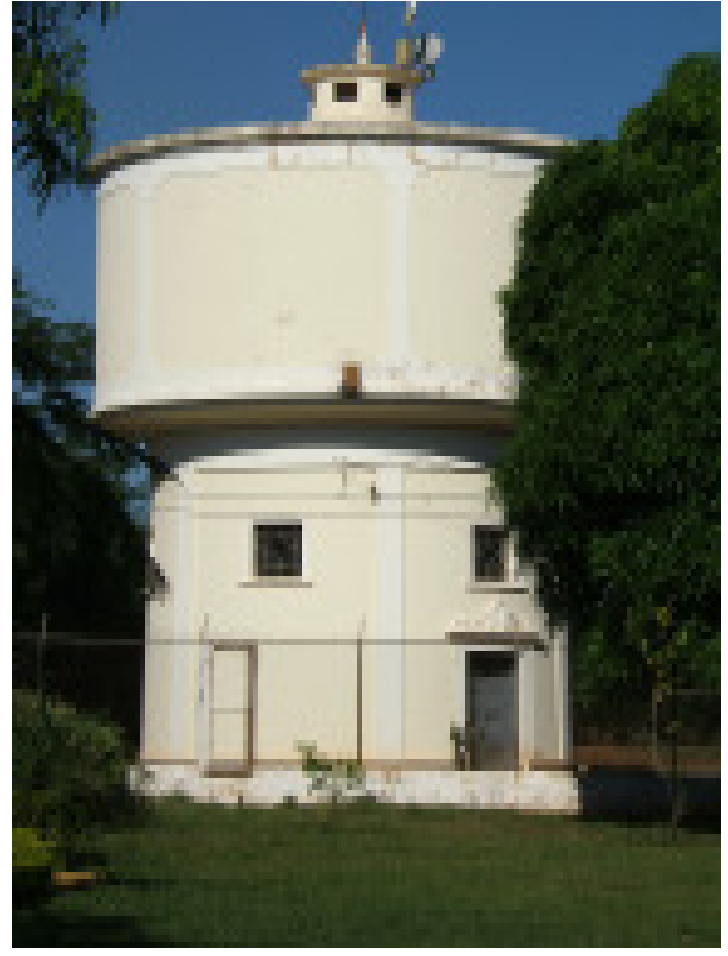

Figura 75 (acima) - Caixa d’água próxima às residências para funcionários e professores da da Escola Prática de Agricultura "Gustavo Capanema”. Mesmo esse edifício não prescindiu de um frentão sobre a porta de acesso. Fonte: fotos da autora, abril de 2007. 

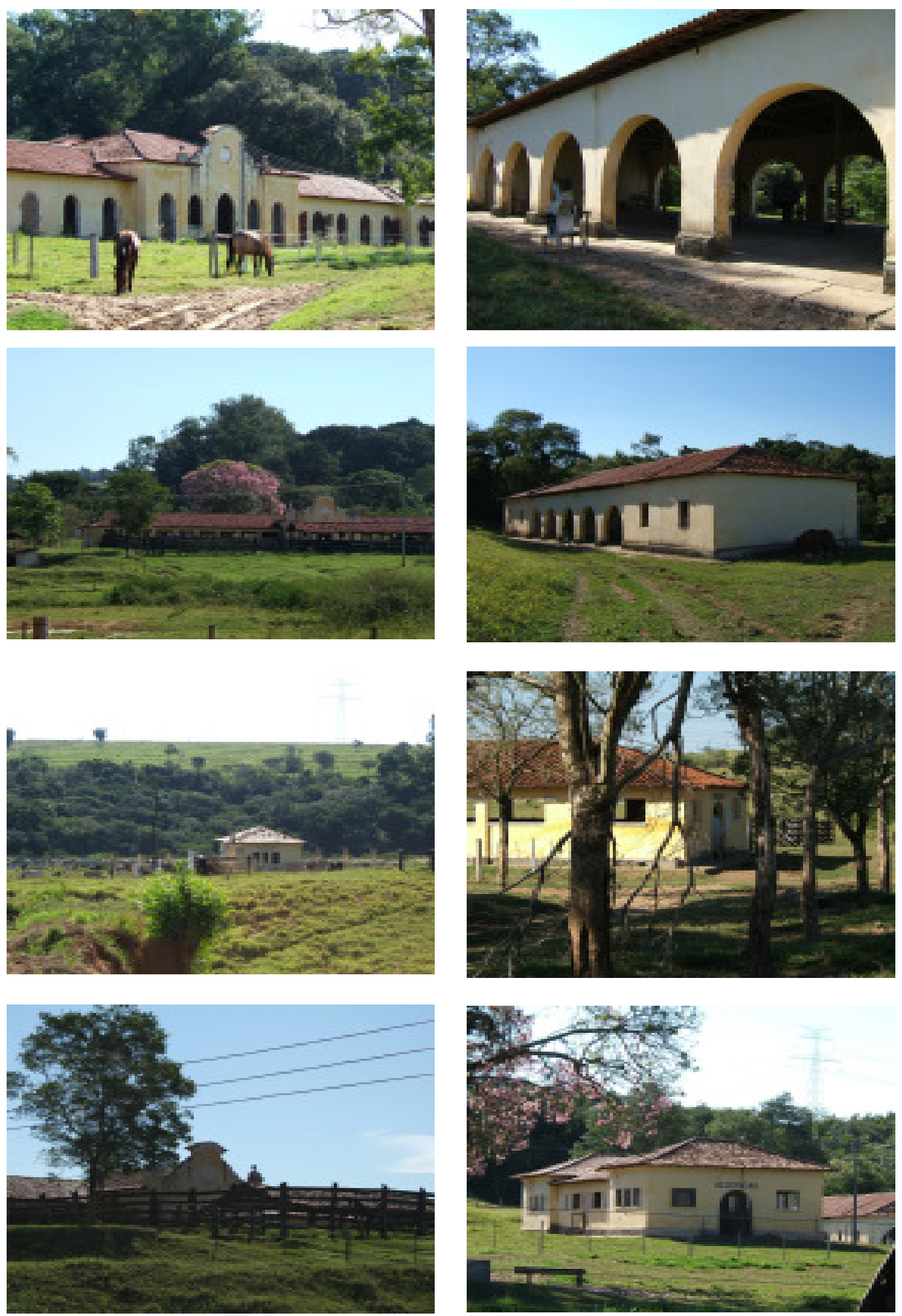

Figura 76 - Prédios destinados a estábulos, matadouros, criadouros de porcos ou bezerros da Escola Prática de Agricultura "Gustavo Capanema". Notar a presença de estilemas neocoloniais. Fonte: fotos da autora, abril de 2007. 

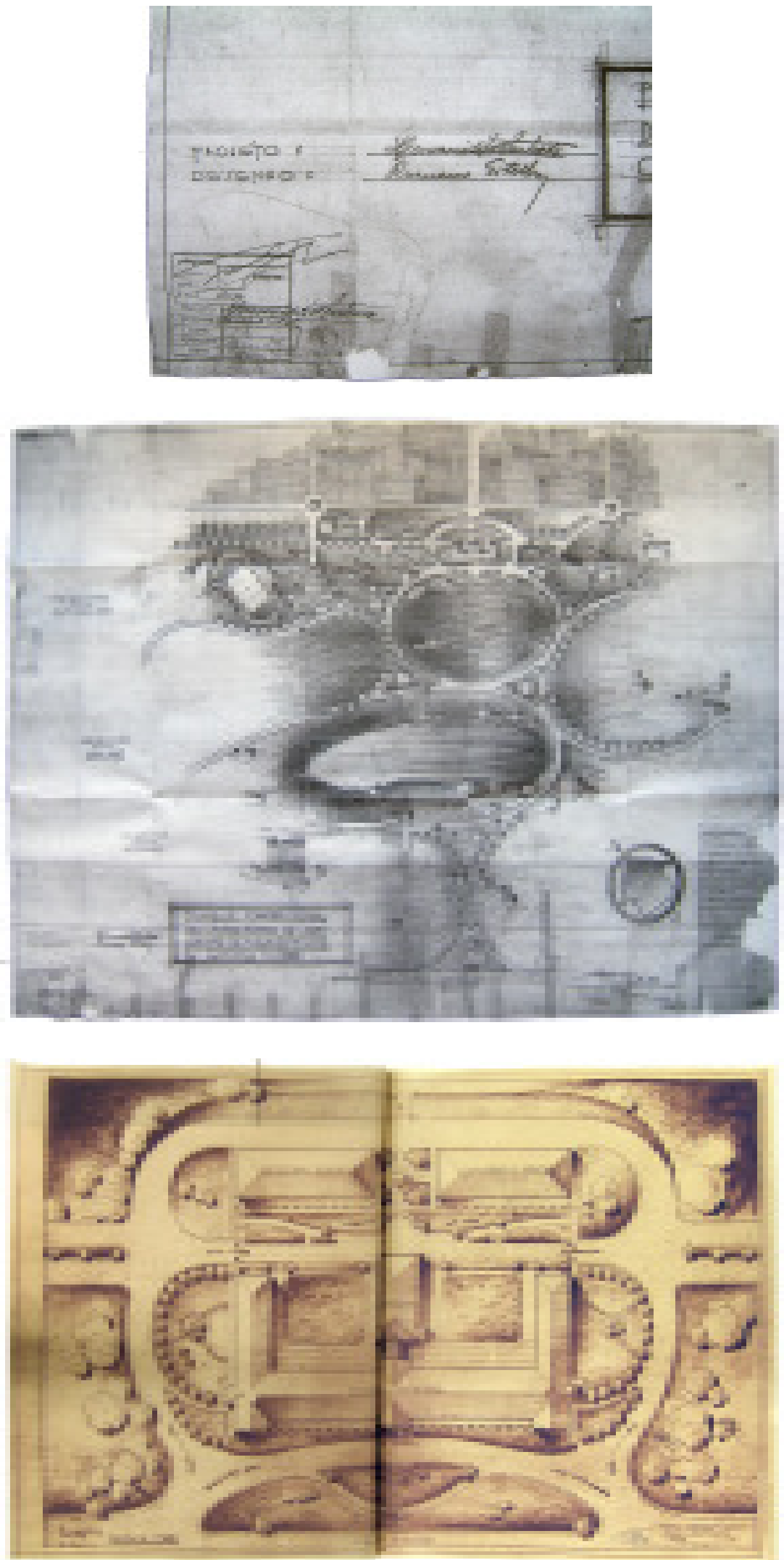

Figura 77 - Planta de situação geral da Escola Prática de Agricultura "Getúlio Vargas", Ribeirão Preto, mostrando ajardinamento e arruamento e planta de situação do prédio principal, do arquiteto Hernani do Val Penteado. Fonte: Arquivo da C.P.O.S. e Acervo de Projetos da FAUUSP. 

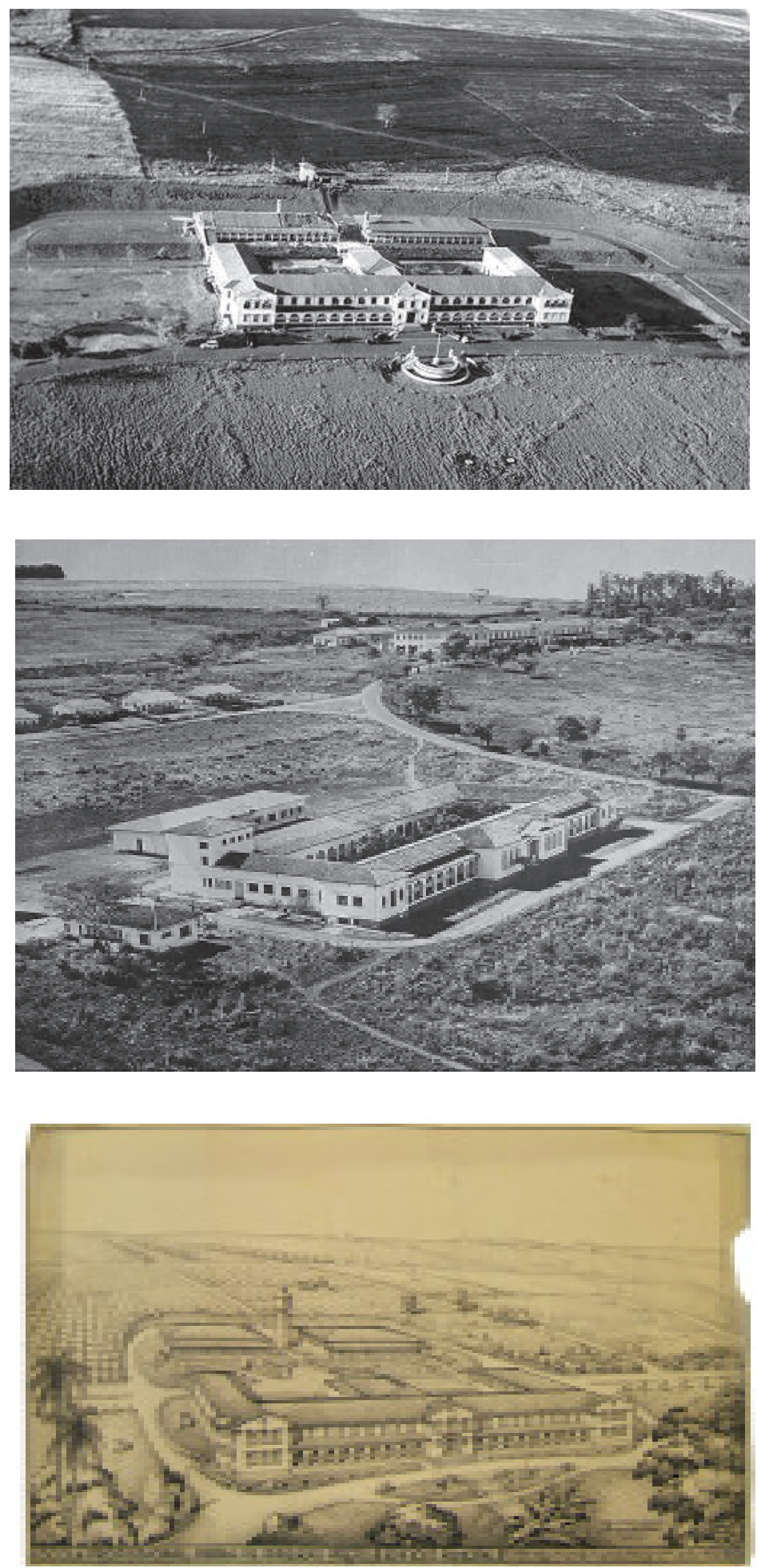

Figura 78 - Fotos aéreas da Escola Prática de Agricultura "Getúlio Vargas", Ribeirão Preto, mostrando o partido do prédio principal e o acesso a um prédio próximo. Disponível em: http://www.fmrp.usp.br/ portal/fotos.php. Acesso em: março de 2007. E, perspectiva do prédio principal, de Hernani do Val Penteado, de 1942. Fonte: Acervo de Projetos da FAUUSP. 


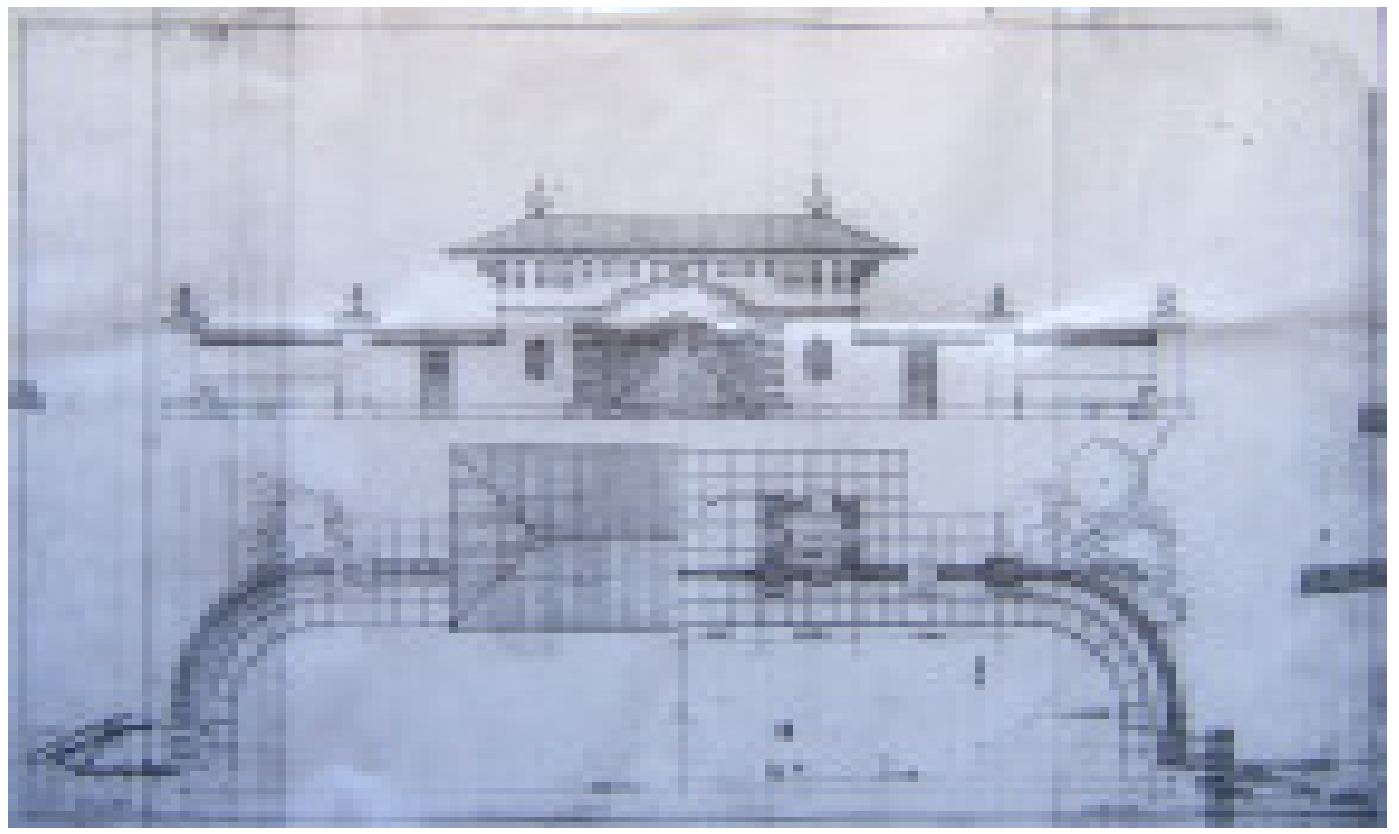

Figura 79 (acima) - Projeto do portão de entrada da Escola Prática de Agricultura "Getúlio Vargas", Ribeirão Preto, também de autoria de Hernani do Val Penteado, com data de 1943. Notar semelhança com portão da escola de Bauru. Fonte: Arquivo da C.P.O.S.

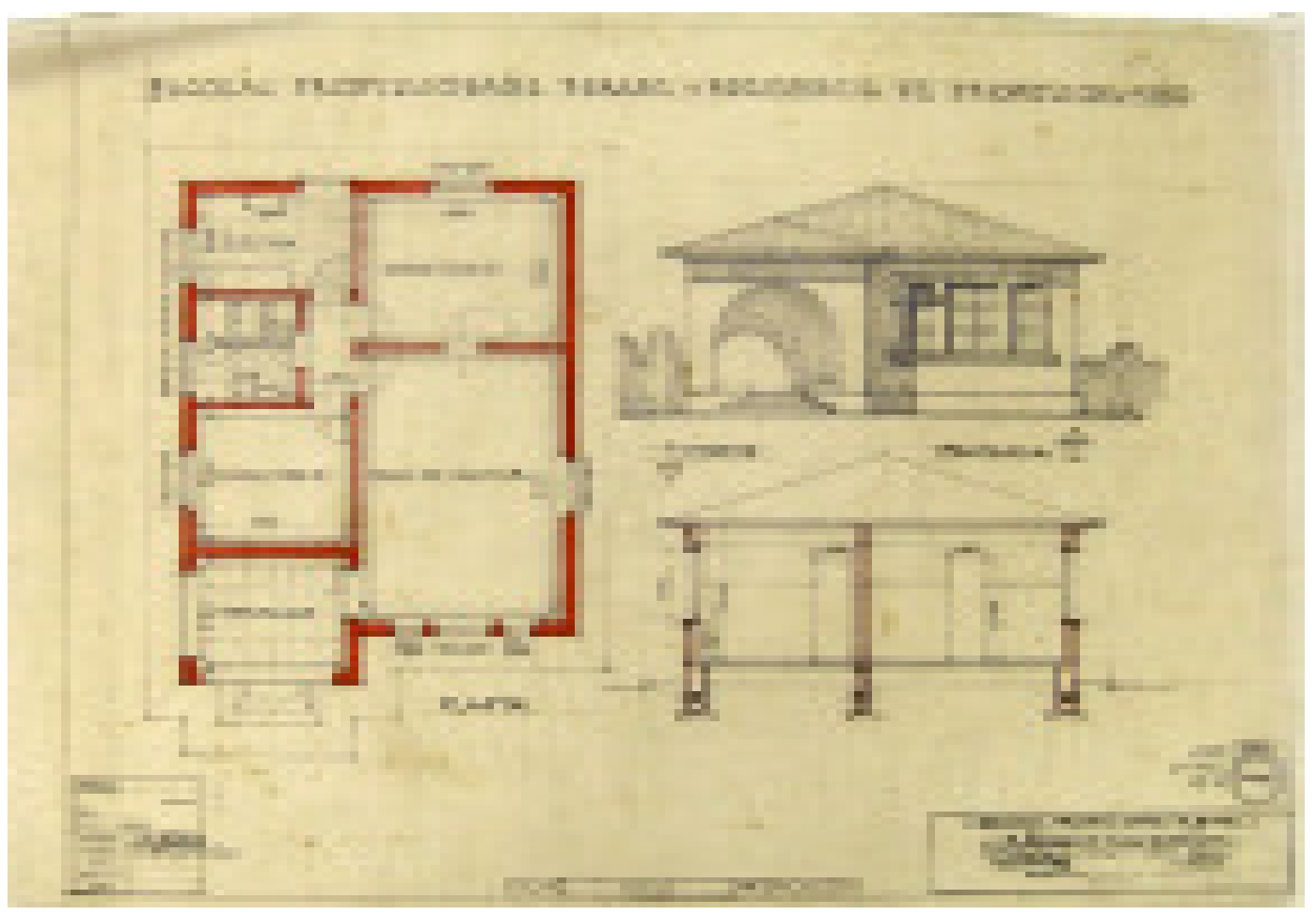

Figura 80 (páginas 301 e 302) - Vários projetos para a Escola Prática de Agricultura "Getúlio Vargas", Ribeirão Preto: projeto para um mirante, para placa de entrada decorada com azulejos, para detalhes de janelas e outros elementos decorativos e para uma das residências de professores. Fonte: Arquivo da C.P.O.S. 

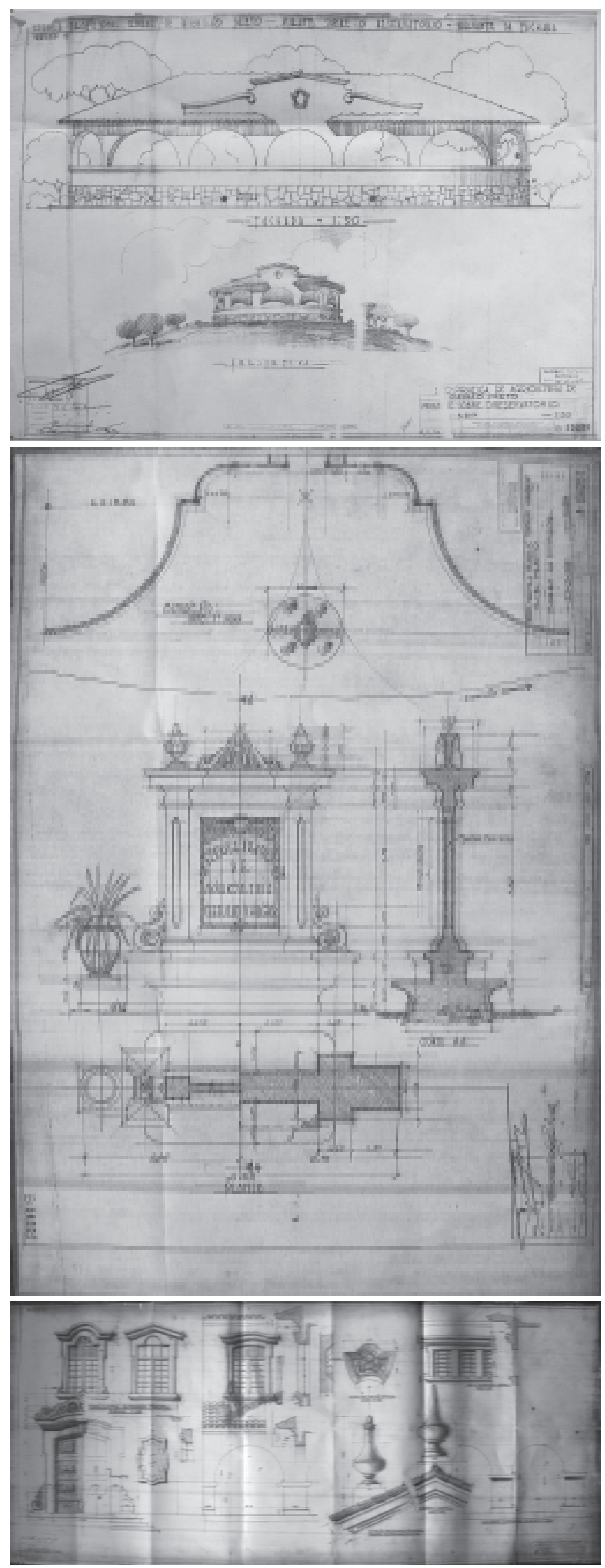


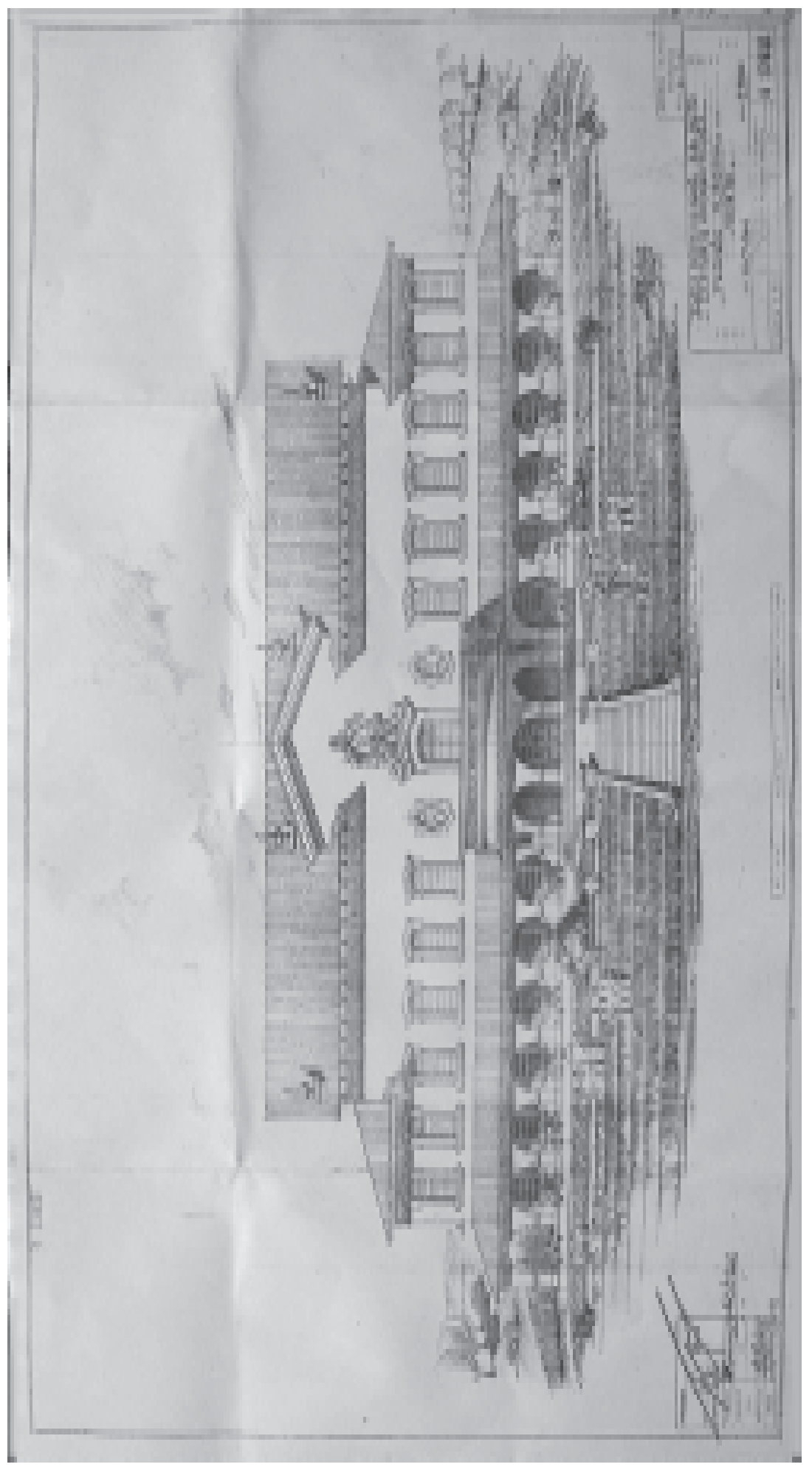

Figura 81 - Projeto para o Centro de Educação Física da Escola Prática de Agricultura "Getúlio Vargas", Ribeirão Preto. Notar a simetria da edificação. Projeto de Hernani do Val Penteado. Fonte: Arquivo da C.P.O.S. 

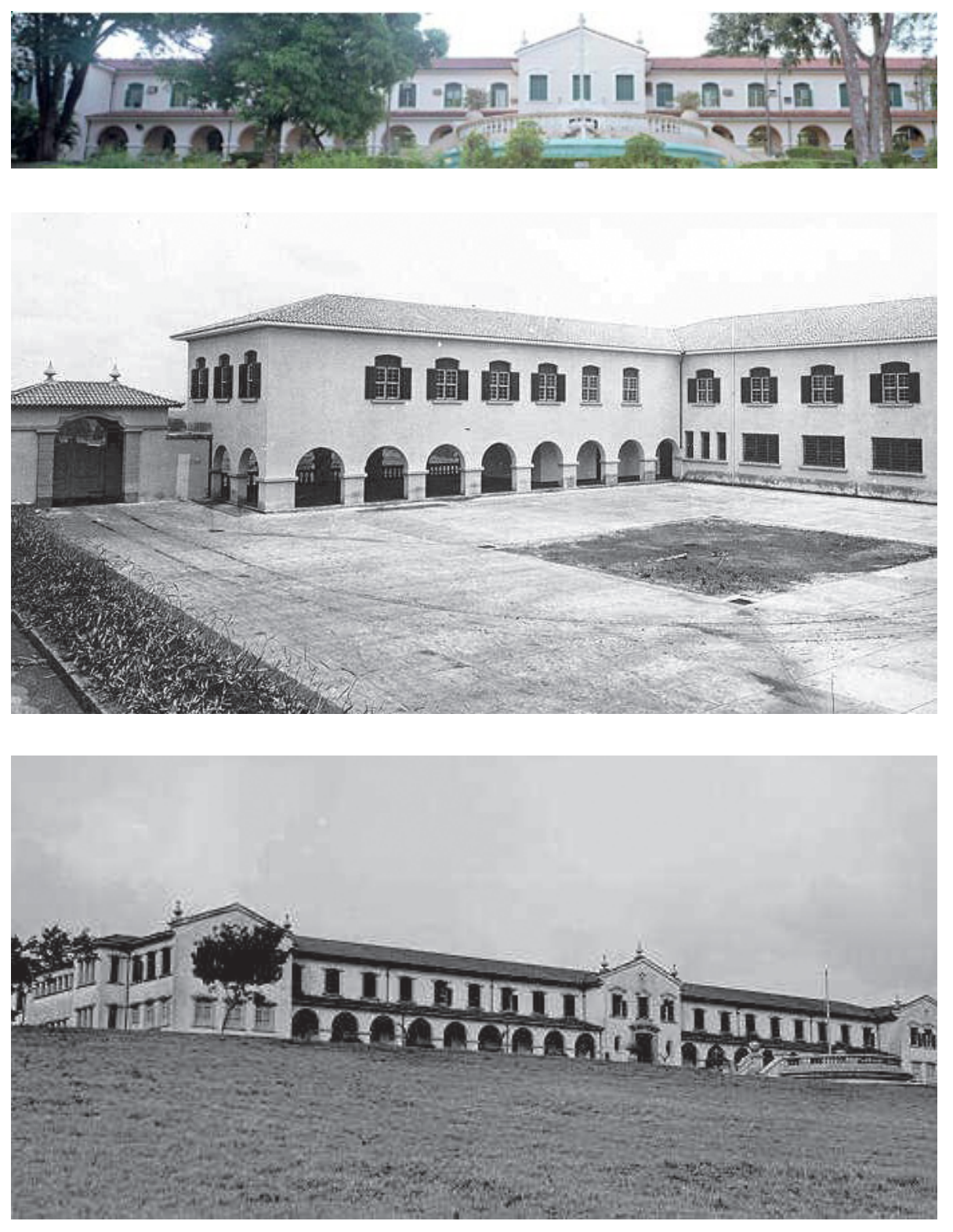

Figura 82 - Fachada e outros aspectos do prédio principal da Escola Prática de Agricultura "Getúlio Vargas", Ribeirão Preto. Como em outros prédios dessa escola e de outras escolas práticas de agricultura, a simetria é característica marcante. Disponível em: http://www.fmrp.usp.br/portal/fotos.php. Acesso em: março de 2007. 

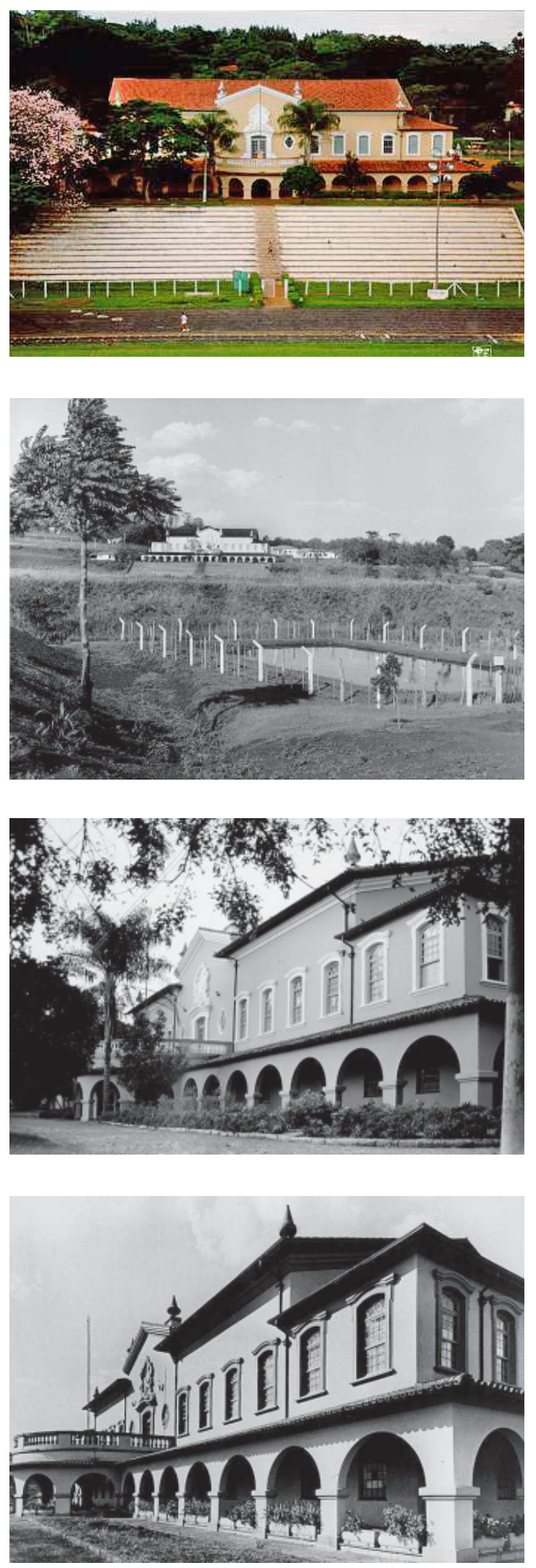
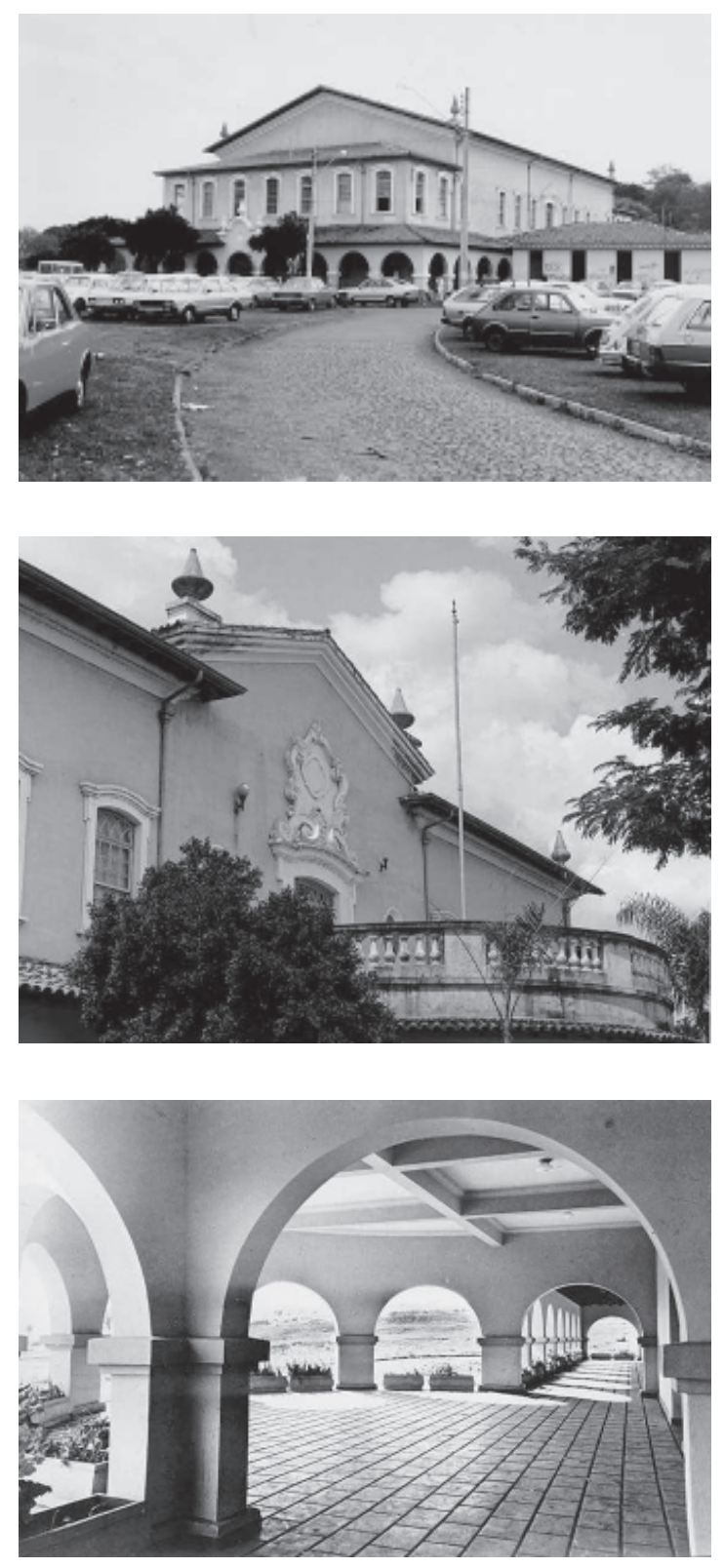

Figura 83 - Aspectos atuais do Centro de Educação Física da Escola Prática de Agricultura "Getúlio Vargas", Ribeirão Preto. Disponível em: http:// www.fmrp.usp.br/portal/fotos.php. Acesso em: março de 2007. 

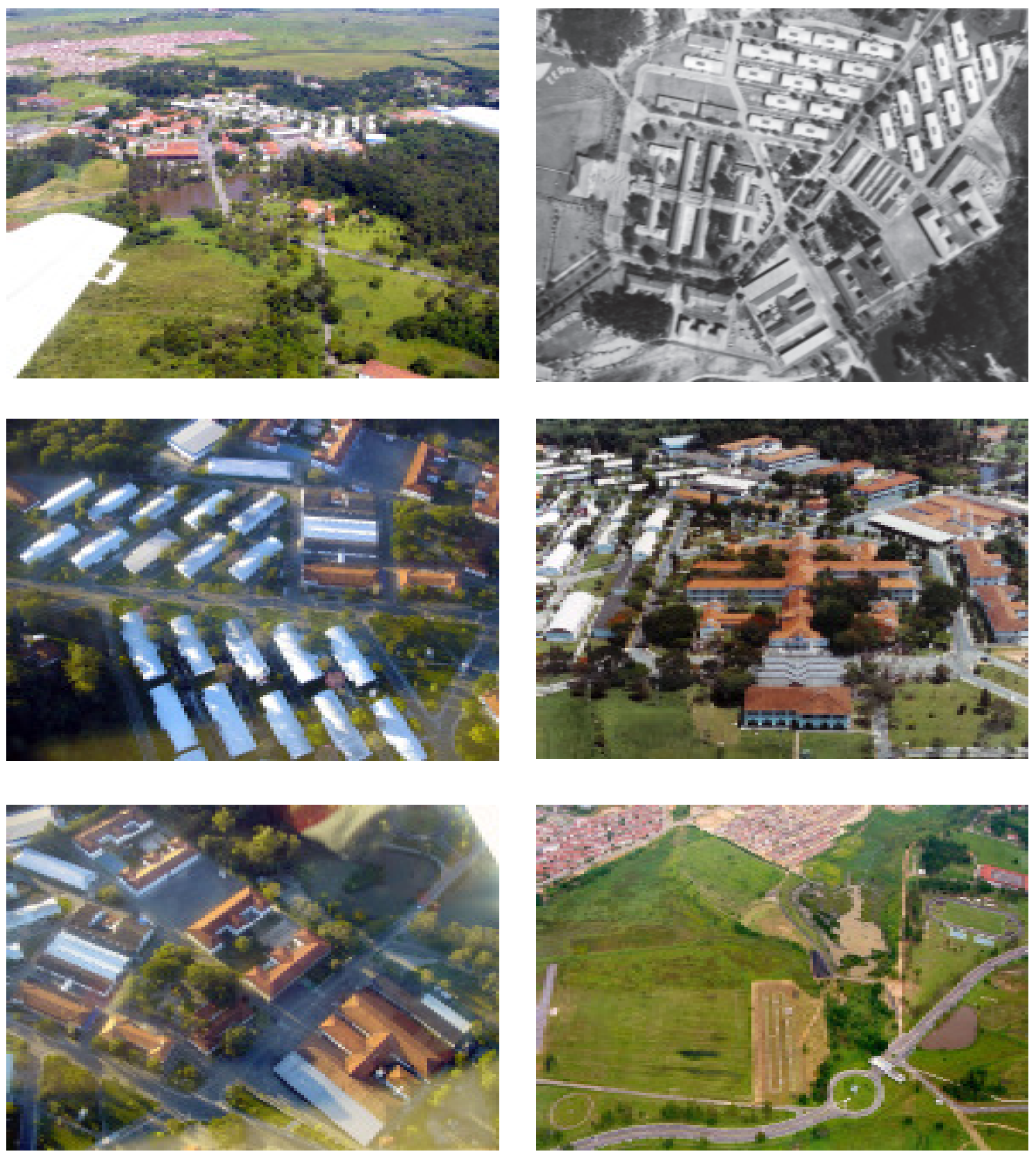

Figura 84 - Vistas aéreas da Escola Prática de Agricultura "Paulo de Lima Correia", Guaratinguetá. Podemos ver a volumetria do prédio principal em forma de uma cruz com quatro travessas. Vemos também uma situação geral e prédios novos, além, da alameda de entrada, onde, tradicionalmente, a cada ano se coloca um painel comemorativo de azulejos (última figura). Fonte: Arquivo da Escola de Especialistas de Aeronáutica. 


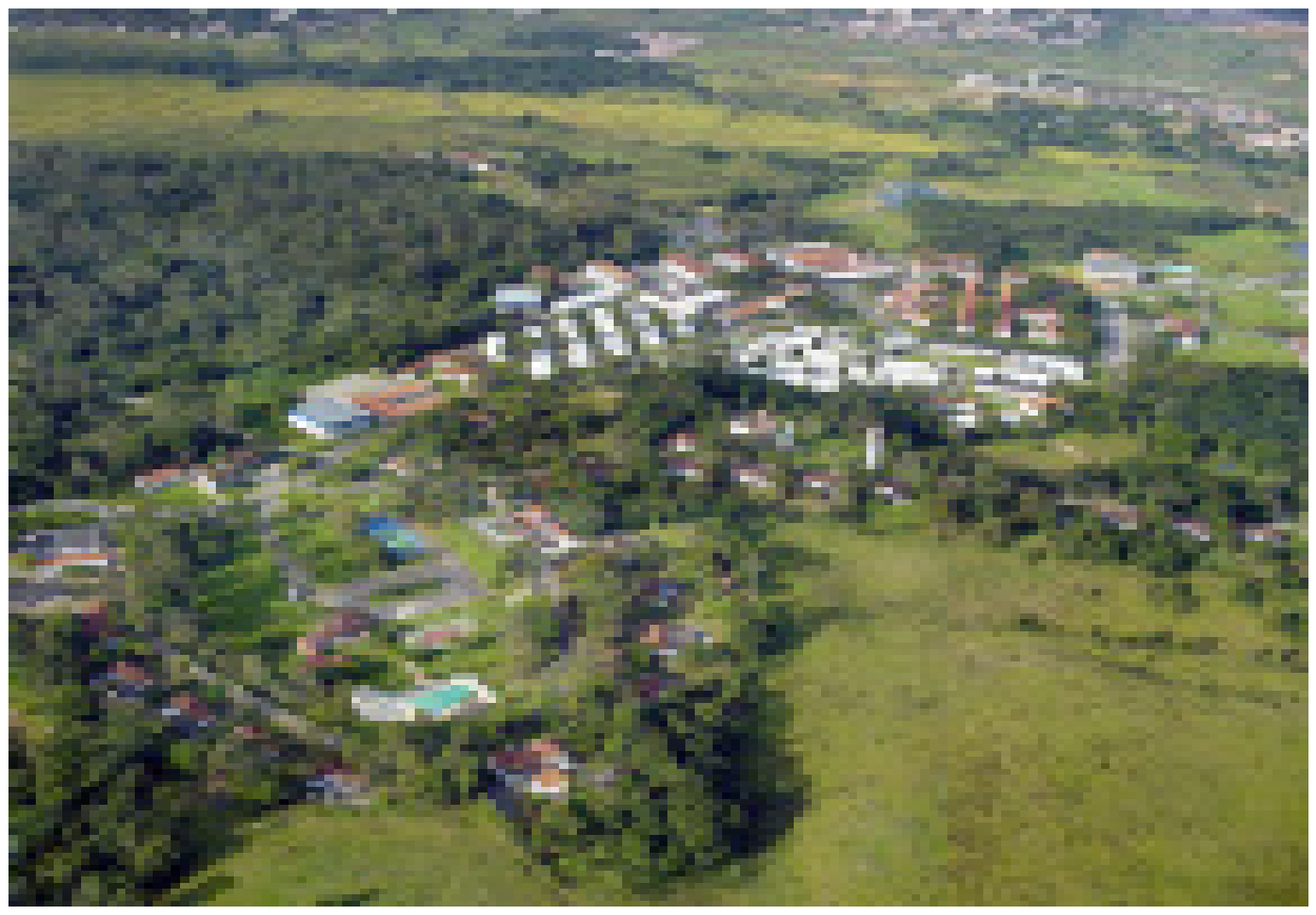

Figura 85 (acima) - Implantação das casas (à esquerda, rua em curva) para os funcionários da Escola Prática de Agricultura "Paulo de Lima Correia", Guaratinguetá, de maneira semelhante às da escola de Bauru (ver FIGURA 64). Fonte: Arquivo da Escola de Especialistas de Aeronáutica. 

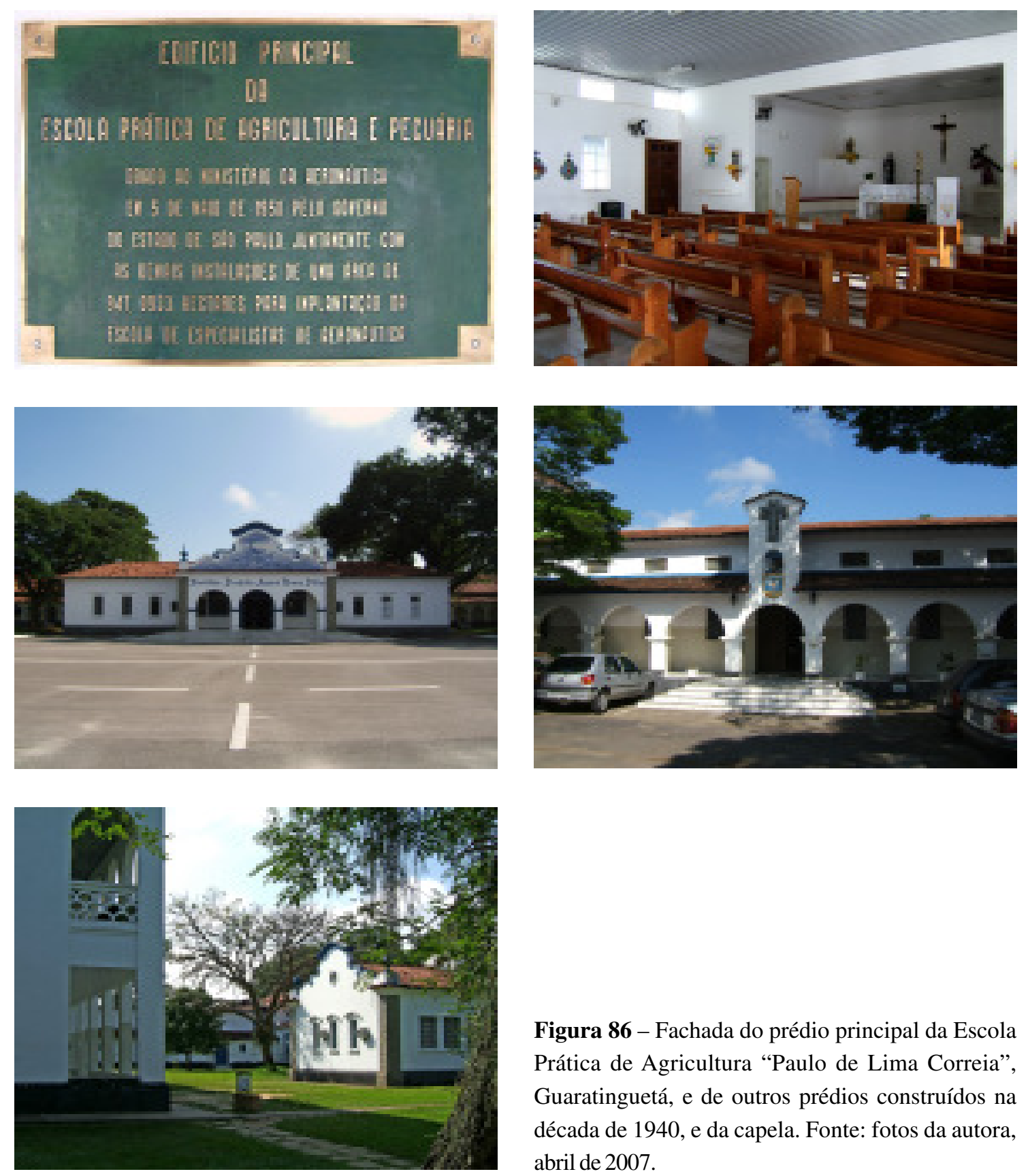

Figura 86 - Fachada do prédio principal da Escola Prática de Agricultura "Paulo de Lima Correia", Guaratinguetá, e de outros prédios construídos na década de 1940, e da capela. Fonte: fotos da autora, abril de 2007. 

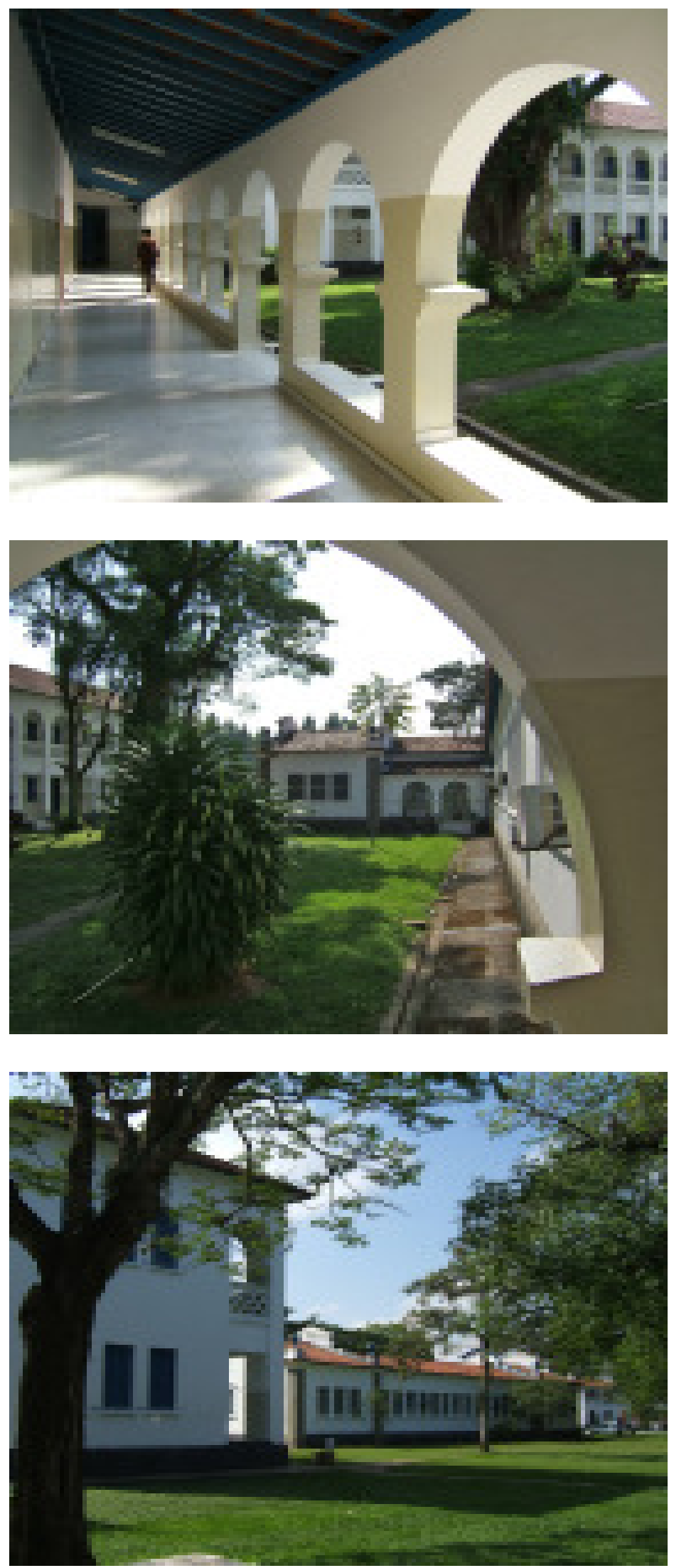

Figura 87 - Fotos dos arcos e dos guarda-corpos fechados com meias-luas sobrepostas da Escola Prática de Agricultura "Paulo de Lima Correia", Guaratinguetá. Fonte: fotos da autora, abril de 2007. 

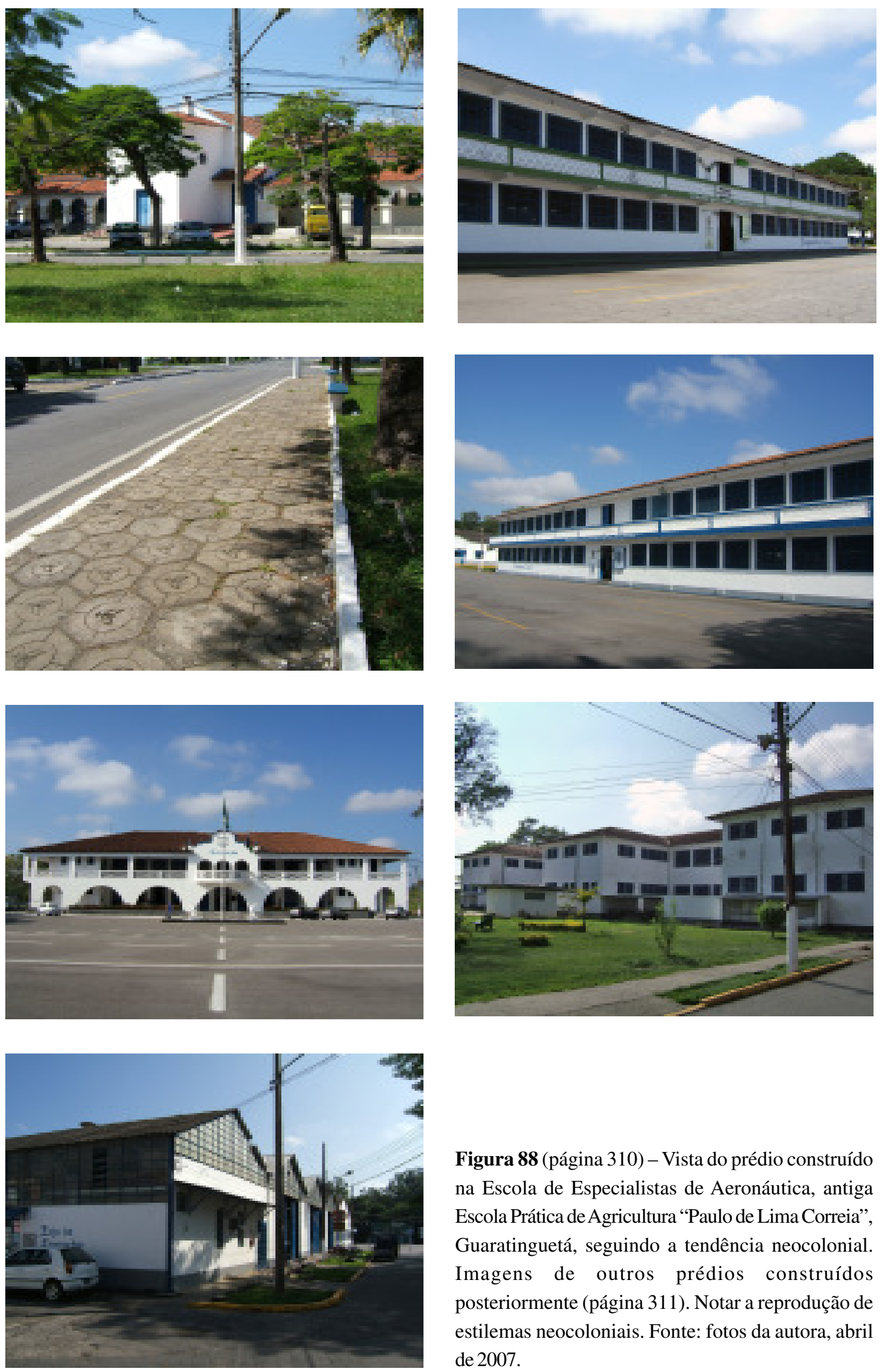

Figura 88 (página 310) - Vista do prédio construído na Escola de Especialistas de Aeronáutica, antiga Escola Prática de Agricultura "Paulo de Lima Correia", Guaratinguetá, seguindo a tendência neocolonial. Imagens de outros prédios construídos posteriormente (página 311). Notar a reprodução de estilemas neocoloniais. Fonte: fotos da autora, abril de 2007. 

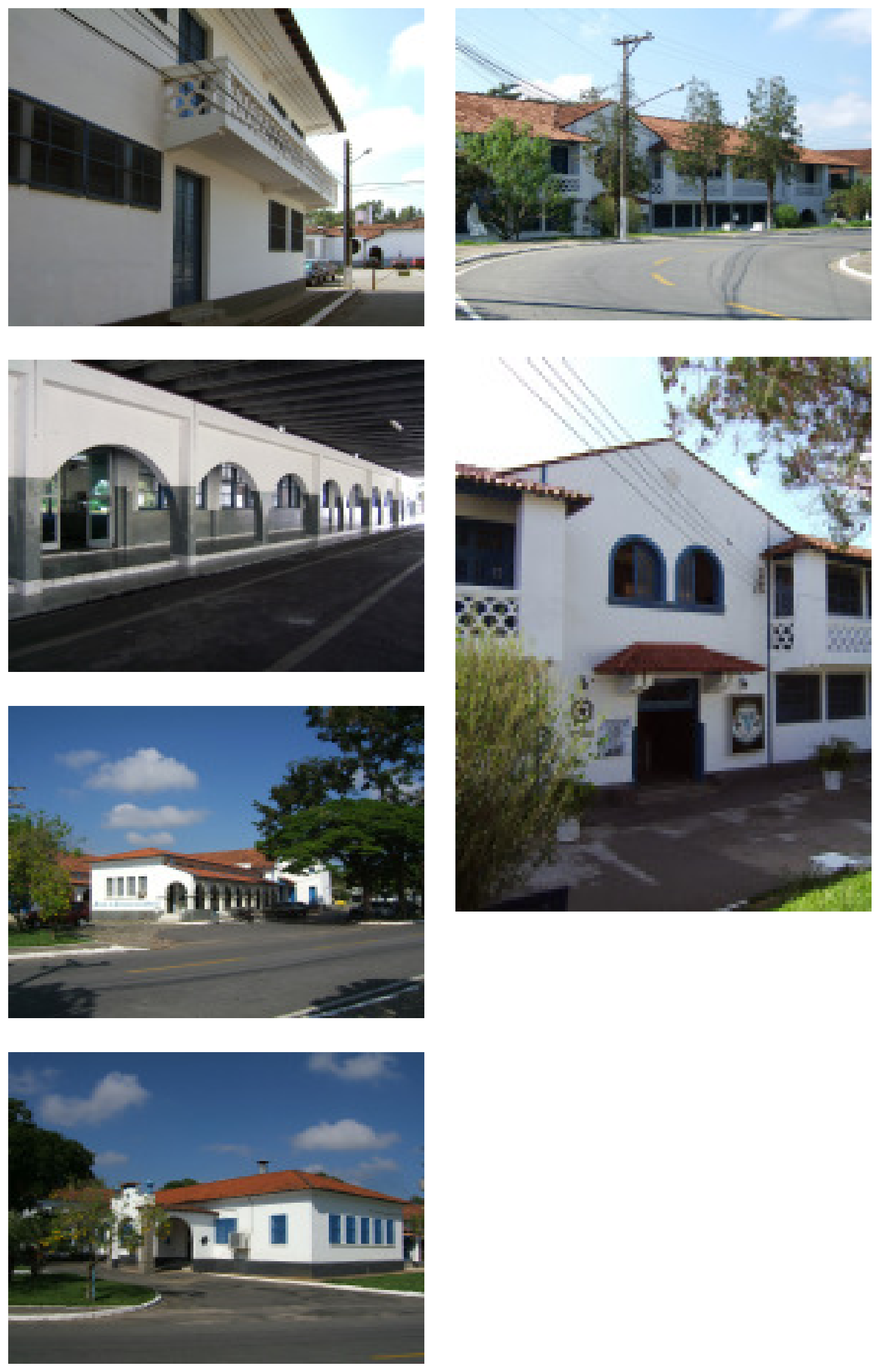

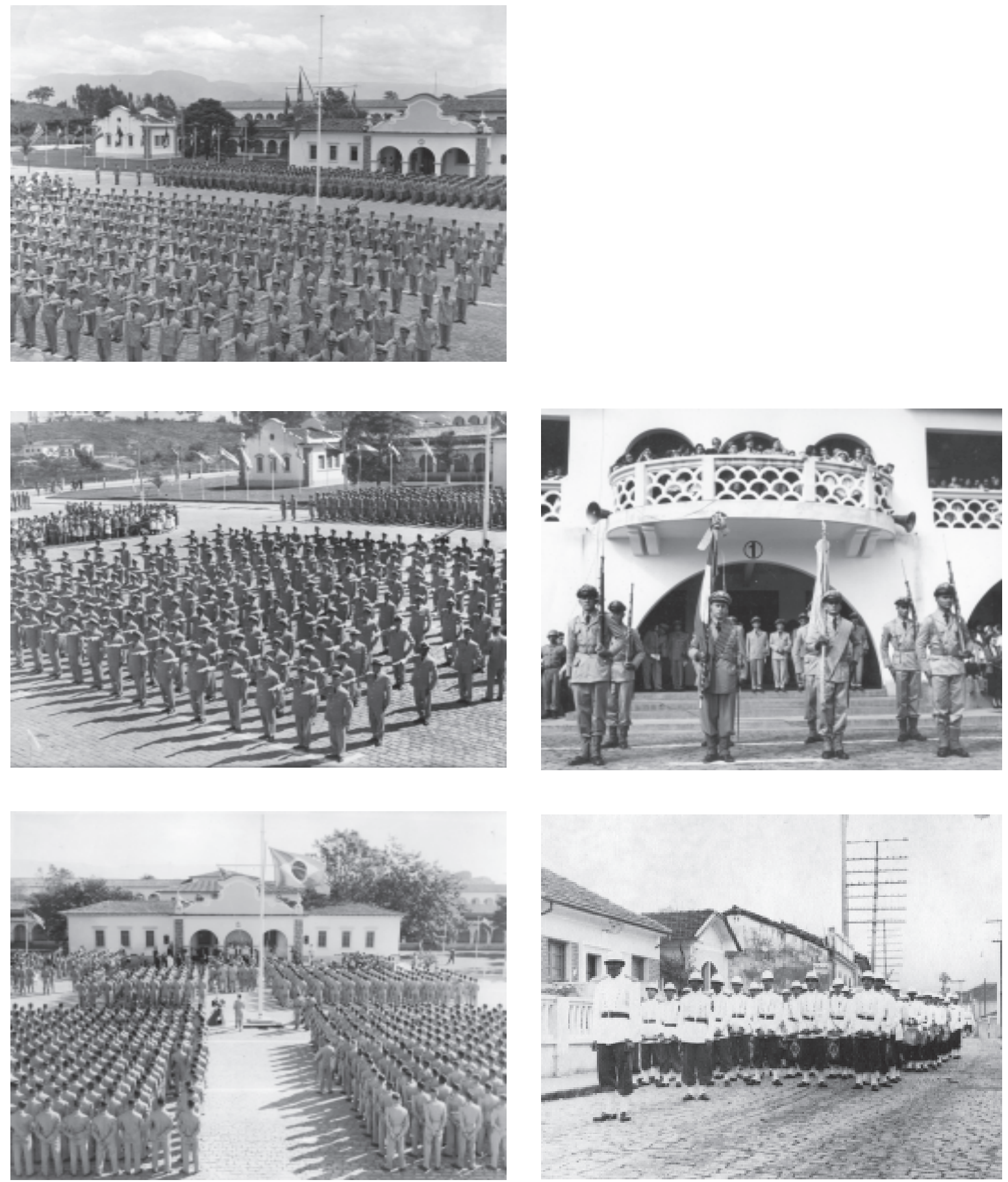

Figura 89 - Imagens da Escola de Especialistas de Aeronáutica, quando recém instalada nas estruturas da Escola Prática de Agricultura "Paulo de Lima Correia". Frontão de azulejos do prédio principal coberto por pintura. Fonte: Arquivo da Escola de Especialistas de Aeronáutica. 

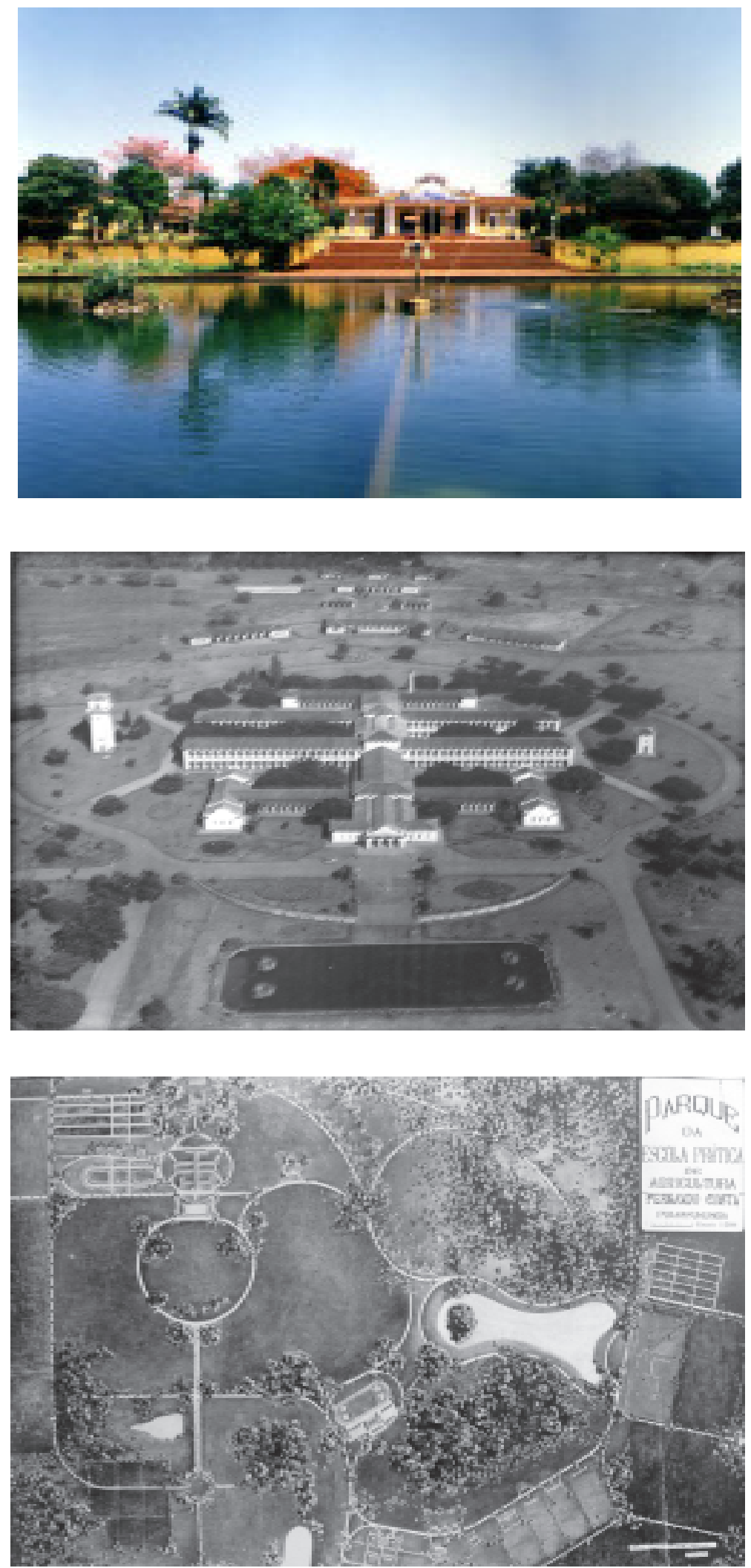

Figura 90 - Fotos aéreas da Escola Prática de Agricultura "Fernando Costa", Pirassununga, mostrando o arruamento e ajardinamento bem como a implantação do prédio principal. Fonte: Arquivo da USPFZEA. Fotos do lago frontal ao prédio. Fonte: foto da autora, dezembro de 2006. 

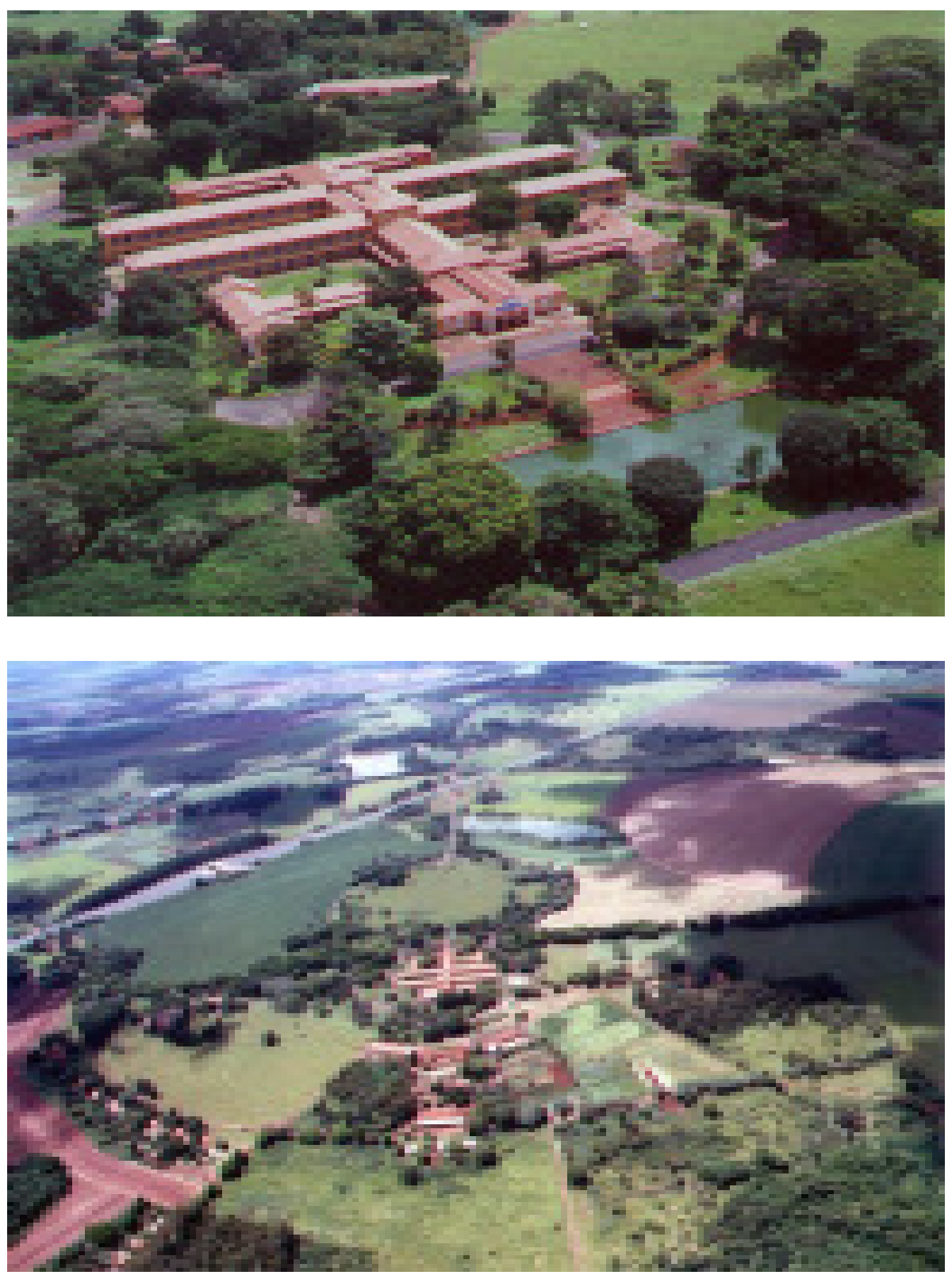

Figura 91 - Fotos aéreas do prédio principal da Escola Prática de Agricultura "Fernando Costa", Pirassununga. Vemos a volumetria do prédio, em forma de cruz com várias travessas, como as escolas de Itapetininga e Guaratinguetá. Fonte: Arquivo da USPFZEA. 

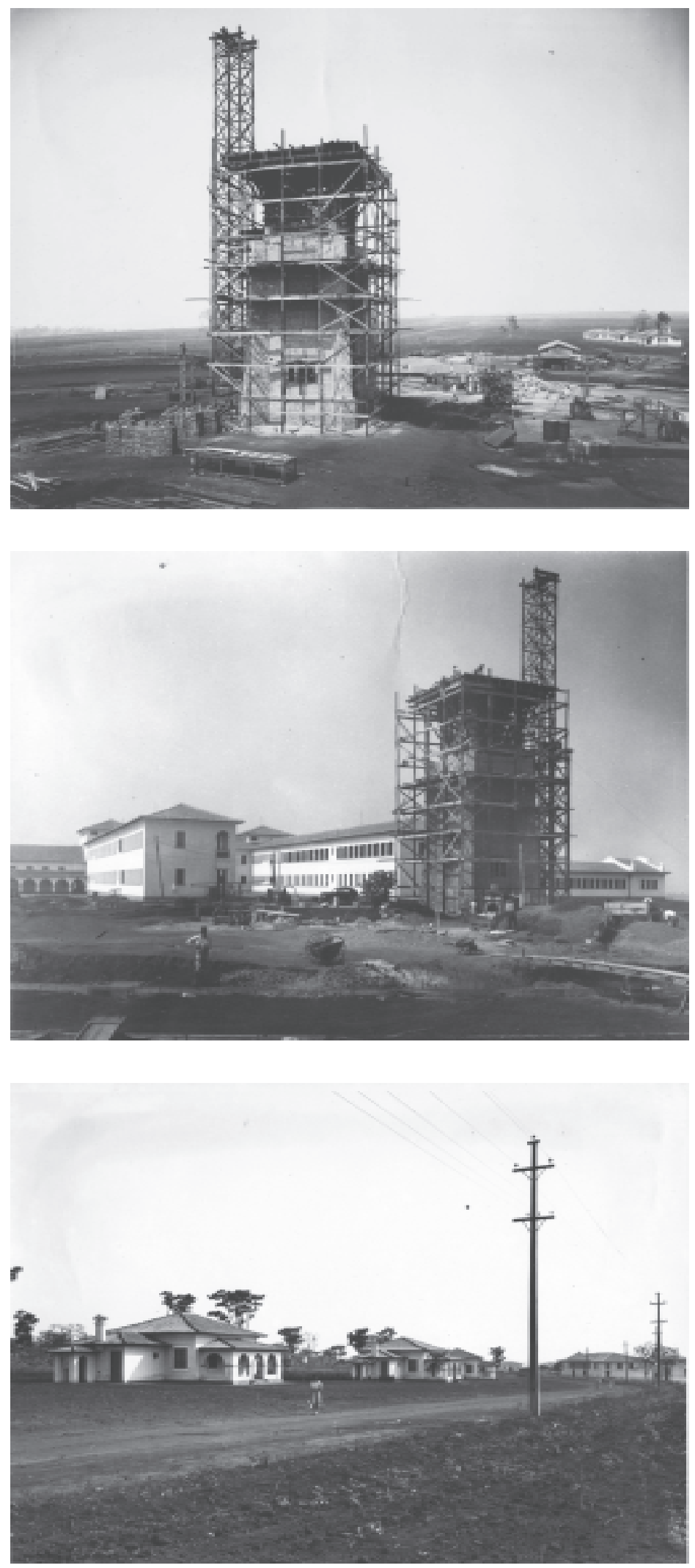

Figura 92 - Fotos da construção da caixa d'água da Escola Prática de Agricultura "Fernando Costa", Pirassununga, e de algumas residências para funcionários e professores, utilizando a tendência neocolonial. Fonte: Arquivo da USPFZEA. 

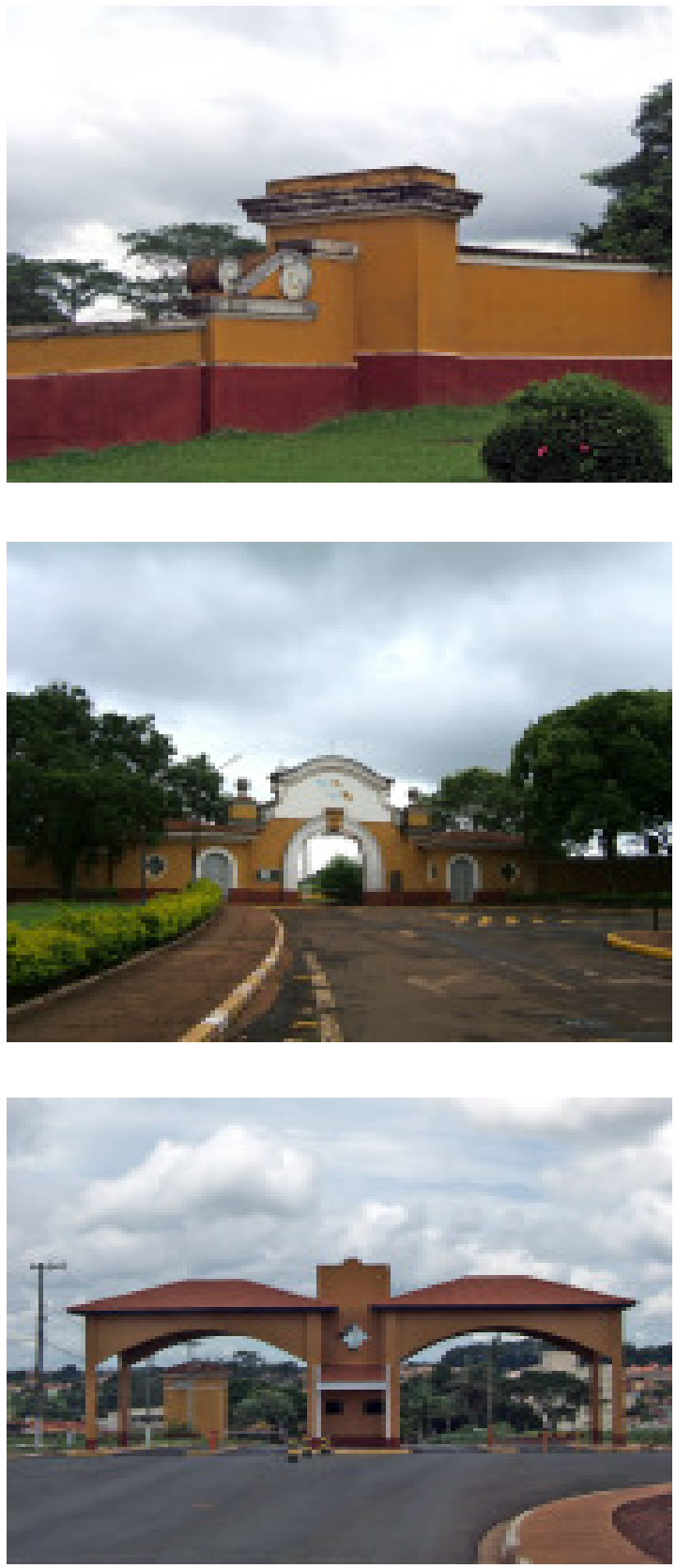

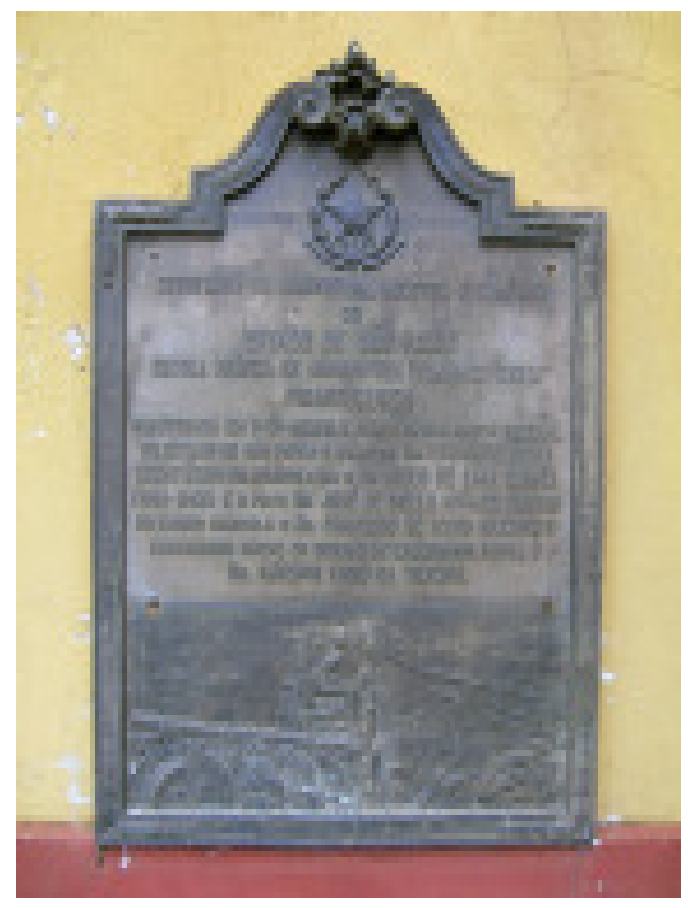

Figura 93 - Portão de entrada da Escola Prática de Agricultura "Fernando Costa", Pirassununga, com elementos decorativos quadrilobados, e placa de inauguração da escola. Portão construído recentemente para a FZEA, antiga Escola Prática de Agricultura "Fernando Costa", exibindo telhados com beirais e arcos. Fonte: foto da autora, dezembro de 2006. 

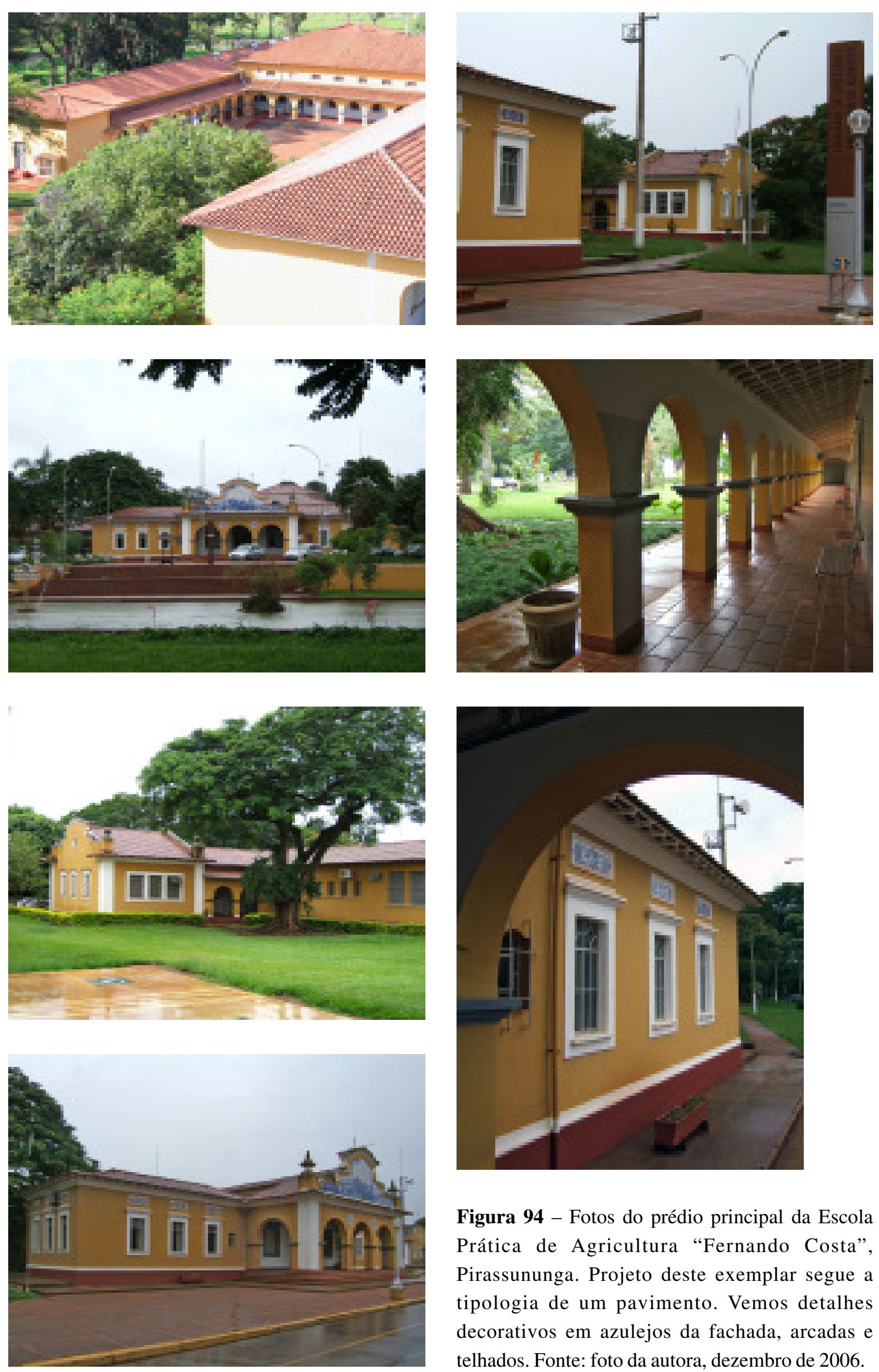

Figura 94 - Fotos do prédio principal da Escola Prática de Agricultura "Fernando Costa", Pirassununga. Projeto deste exemplar segue a tipologia de um pavimento. Vemos detalhes decorativos em azulejos da fachada, arcadas e telhados. Fonte: foto da autora, dezembro de 2006. 

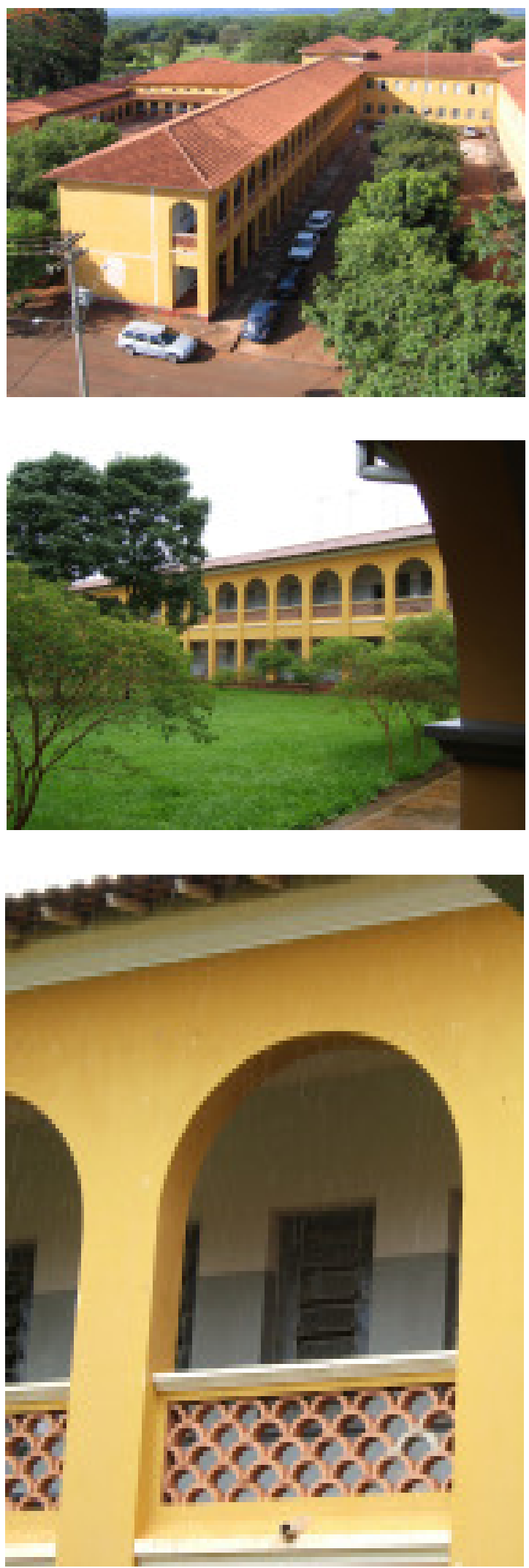

Figura 95 - Imagens das alas de dois pavimentos com arcos fechados por meias-luas sobrepostas, muito semelhantes às arcadas de outras Escolas Prática de Agricultura. Fonte: foto da autora, dezembro de 2006. 

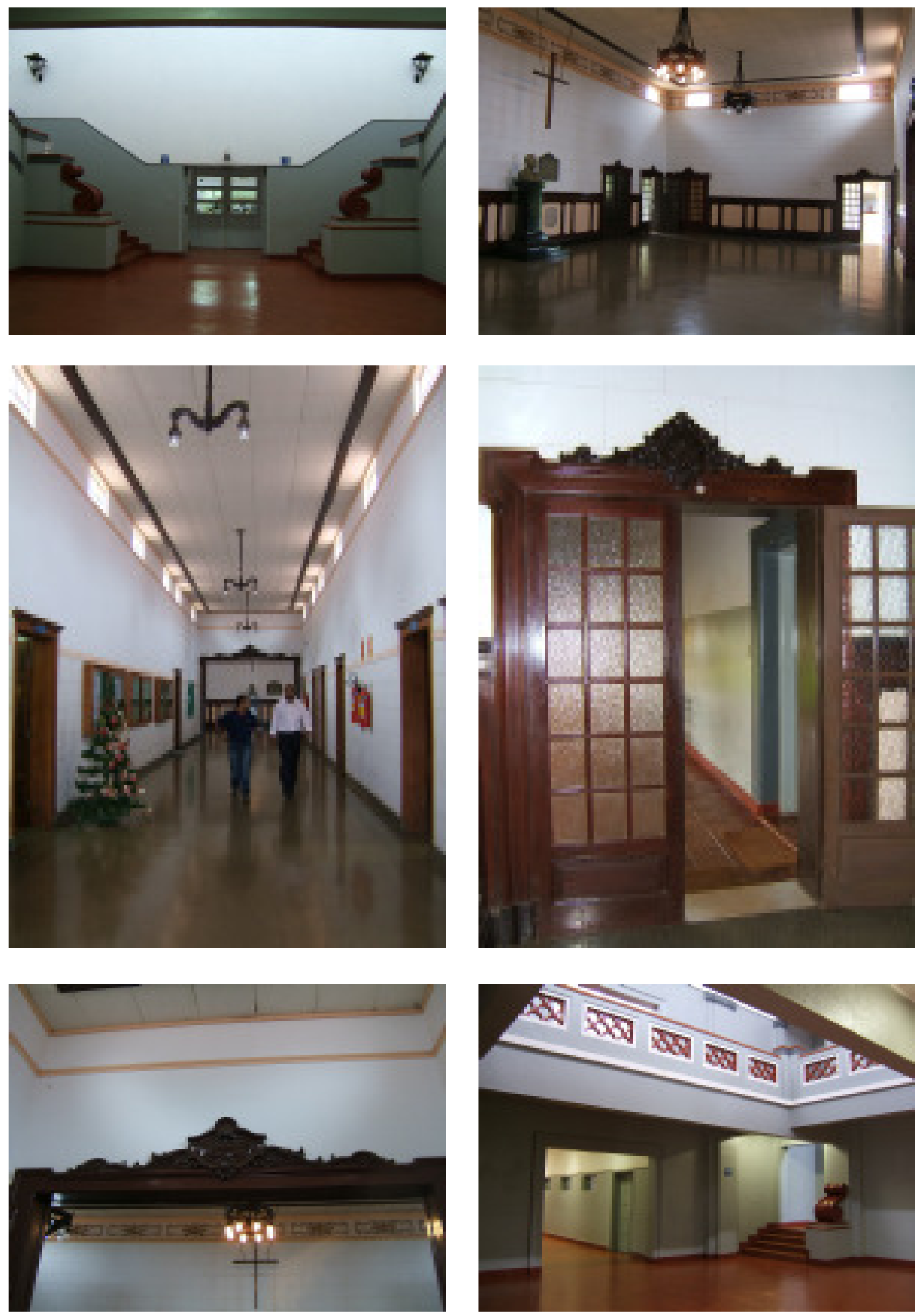

Figura 96 - Vistas internas do prédio principal da Escola Prática de Agricultura "Fernando Costa", Pirassununga. Vemos os acabamentos em madeira e detalhes do corrimão e dos guarda-corpos de dimensões monumentais. Fonte: foto da autora, dezembro de 2006 

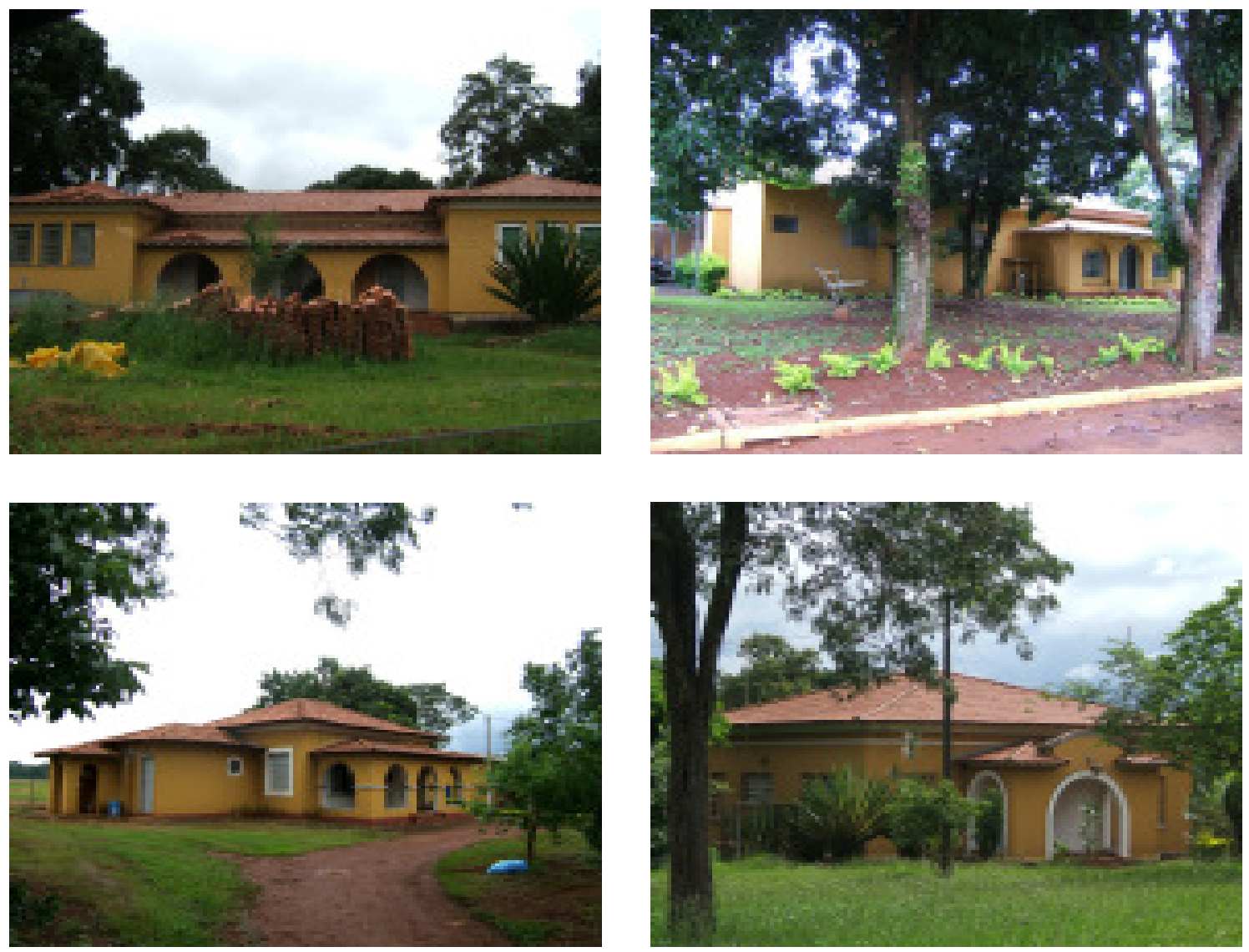

Figura 97 - Casas construídas para funcionários e professores da antiga Escola Prática de Agricultura "Fernando Costa", Pirassununga. Notar o emprego de estilemas neocoloniais. Fonte: foto da autora, dezembro de 2006. 

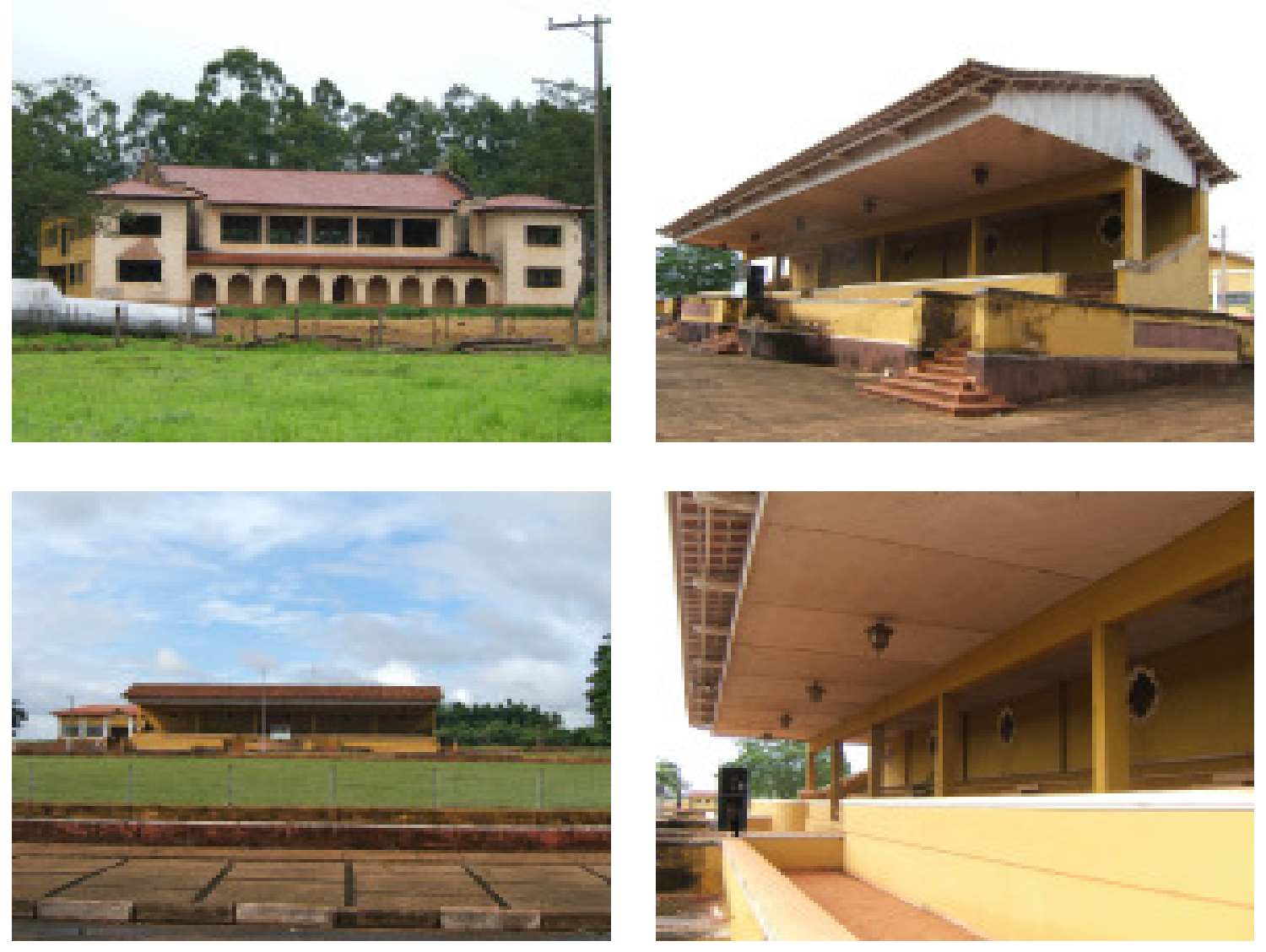

Figura 98 - Vistas do campo de futebol com a arquibancada protegida da Escola Prática de Agricultura "Fernando Costa", Pirassununga. Cachorros nos beirais, volutas e janelas quadrilobadas. Fonte: foto da autora, dezembro de 2006. 

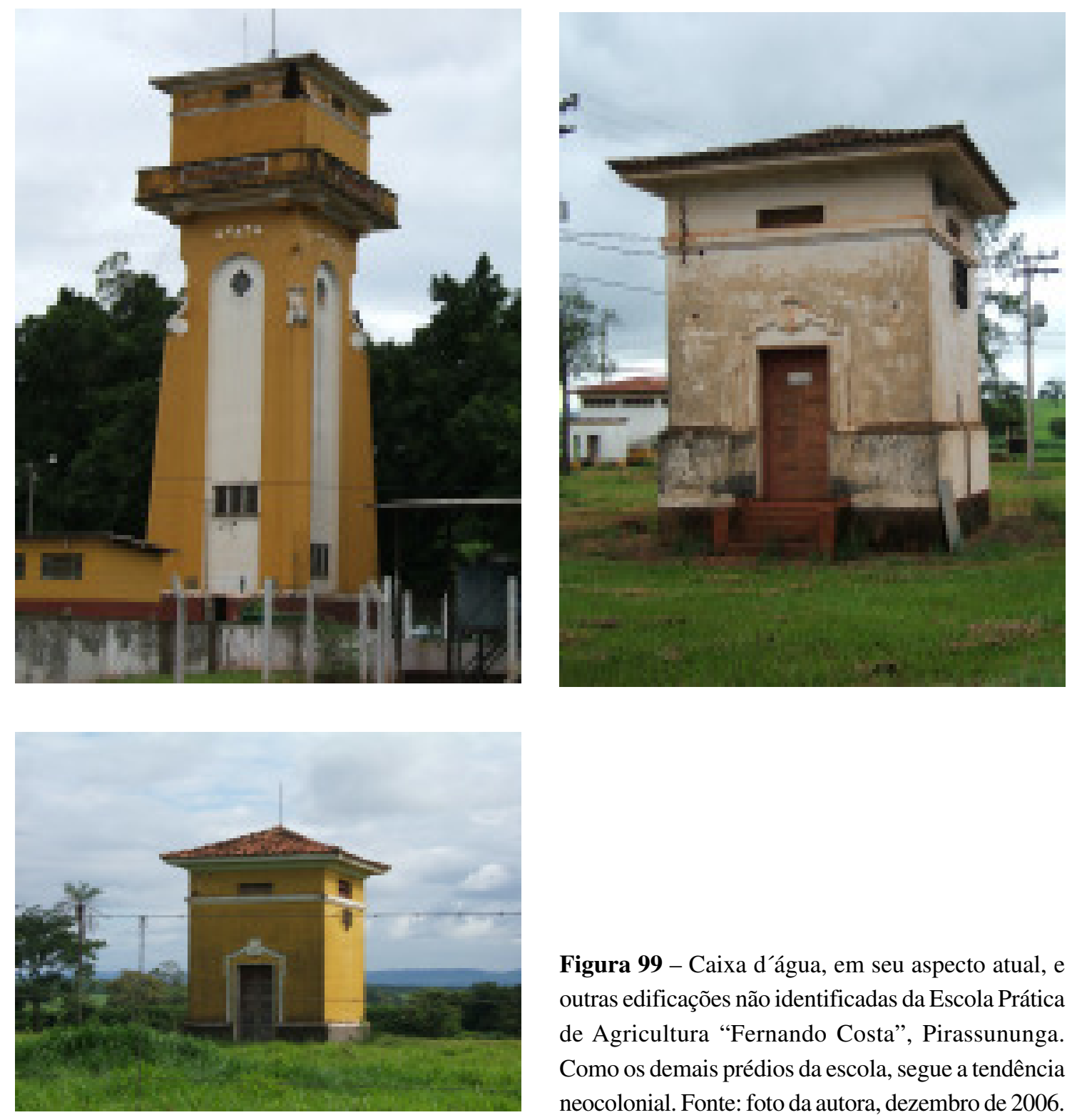

Figura 99 - Caixa d'água, em seu aspecto atual, e outras edificações não identificadas da Escola Prática de Agricultura "Fernando Costa", Pirassununga. Como os demais prédios da escola, segue a tendência neocolonial. Fonte: foto da autora, dezembro de 2006. 

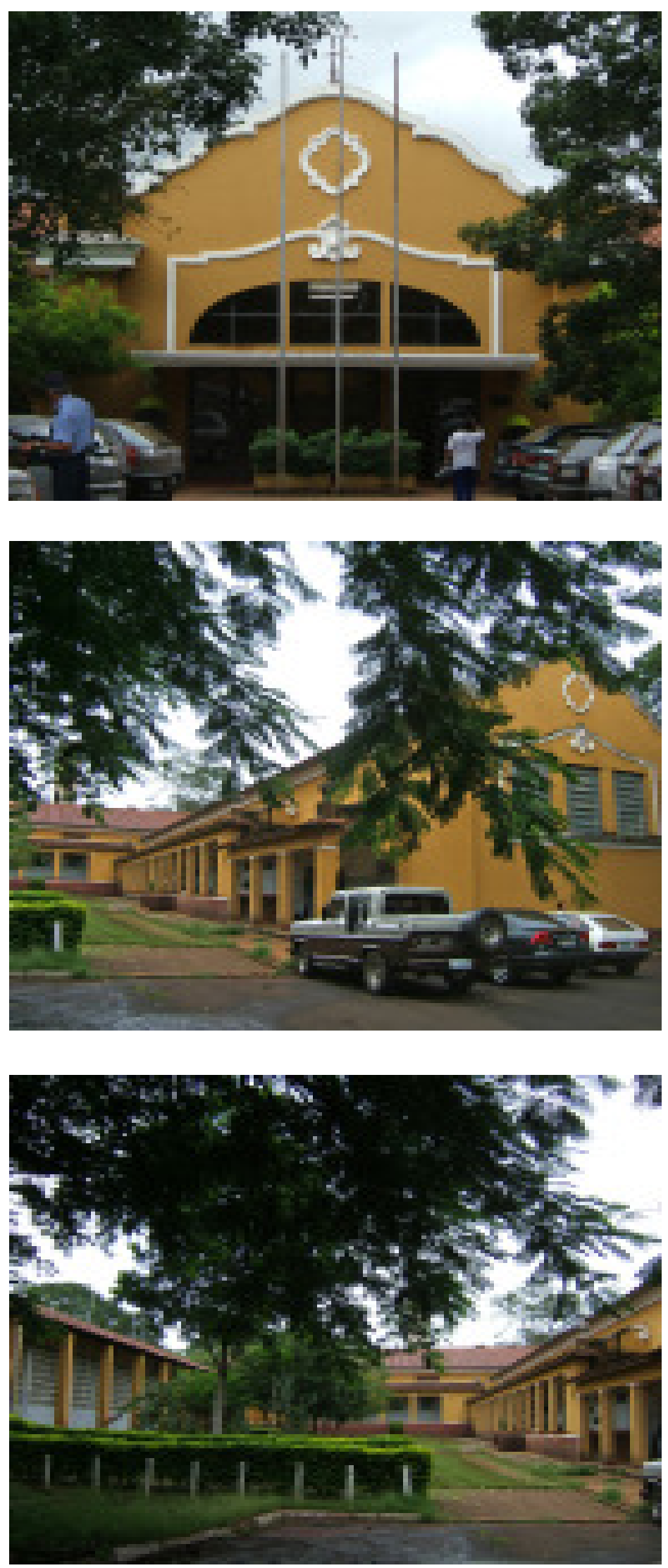

Figura 100 - Atual Edifício "Prof. Dr. João Soares Veiga" da FZEAUSP. Anteriormente, mais um edifício da Escola Prática de Agricultura "Fernando Costa", Pirassununga. Neocolonial. Fonte: foto da autora, dezembro de 2006. 

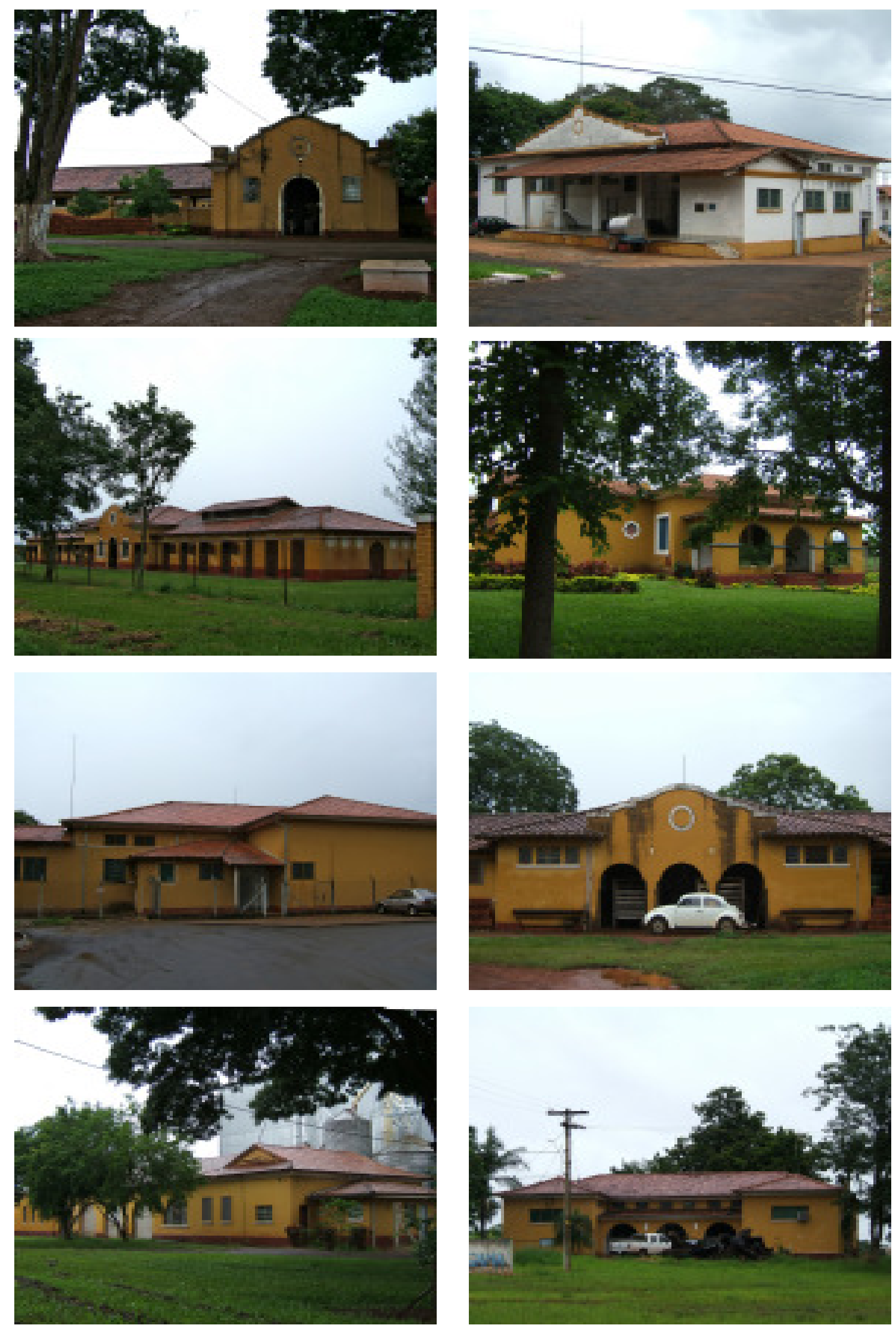

Figura 101 - Várias outras instalações da antiga Escola Prática de Agricultura "Fernando Costa" que, atualmente, servem de estábulo, matadouro, laticínio, laboratórios, fábrica de ração e equideocultura da FZEAUSP. Fonte: foto da autora, dezembro de 2006. 

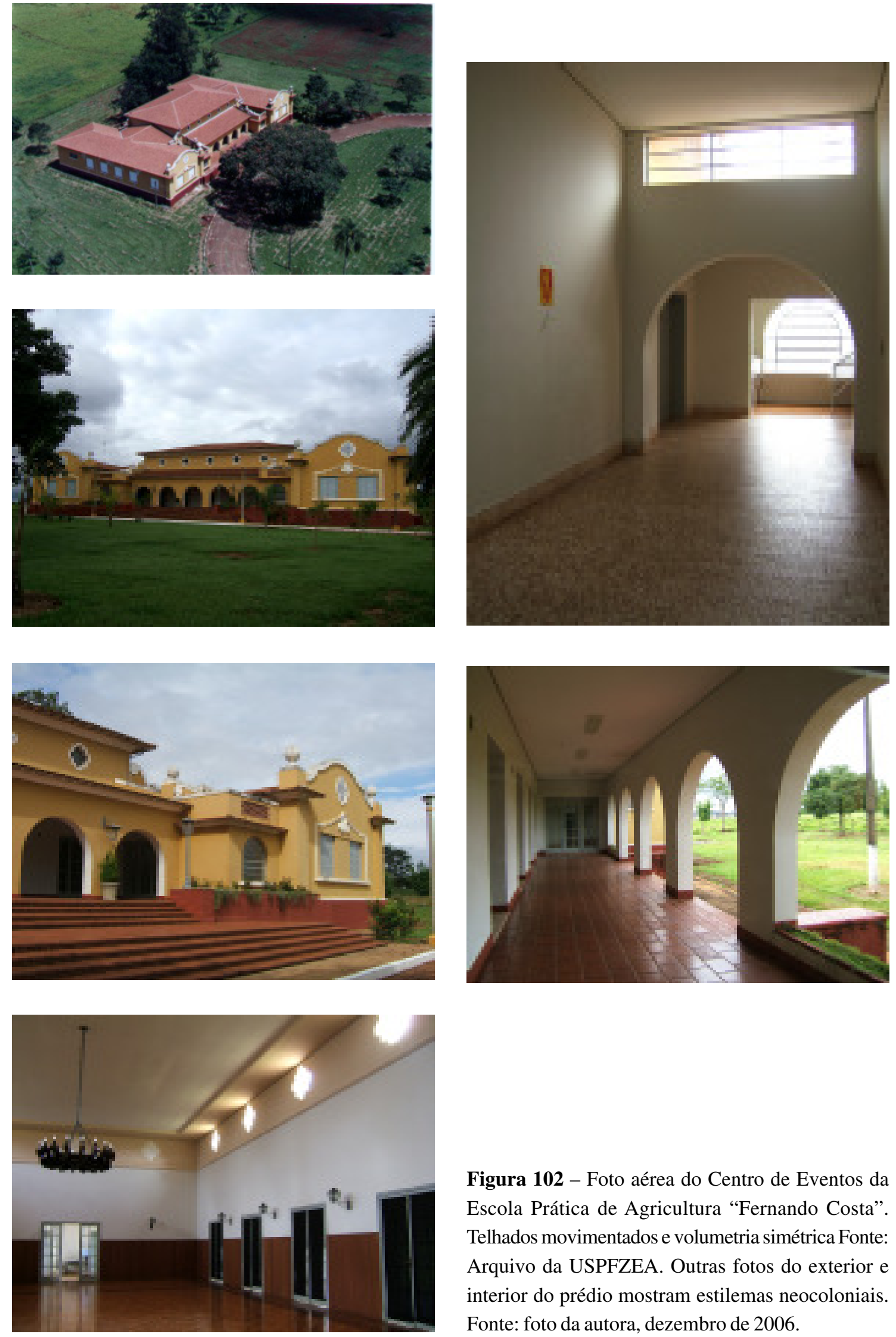

Figura 102 - Foto aérea do Centro de Eventos da Escola Prática de Agricultura "Fernando Costa". Telhados movimentados e volumetria simétrica Fonte: Arquivo da USPFZEA. Outras fotos do exterior e interior do prédio mostram estilemas neocoloniais. Fonte: foto da autora, dezembro de 2006. 

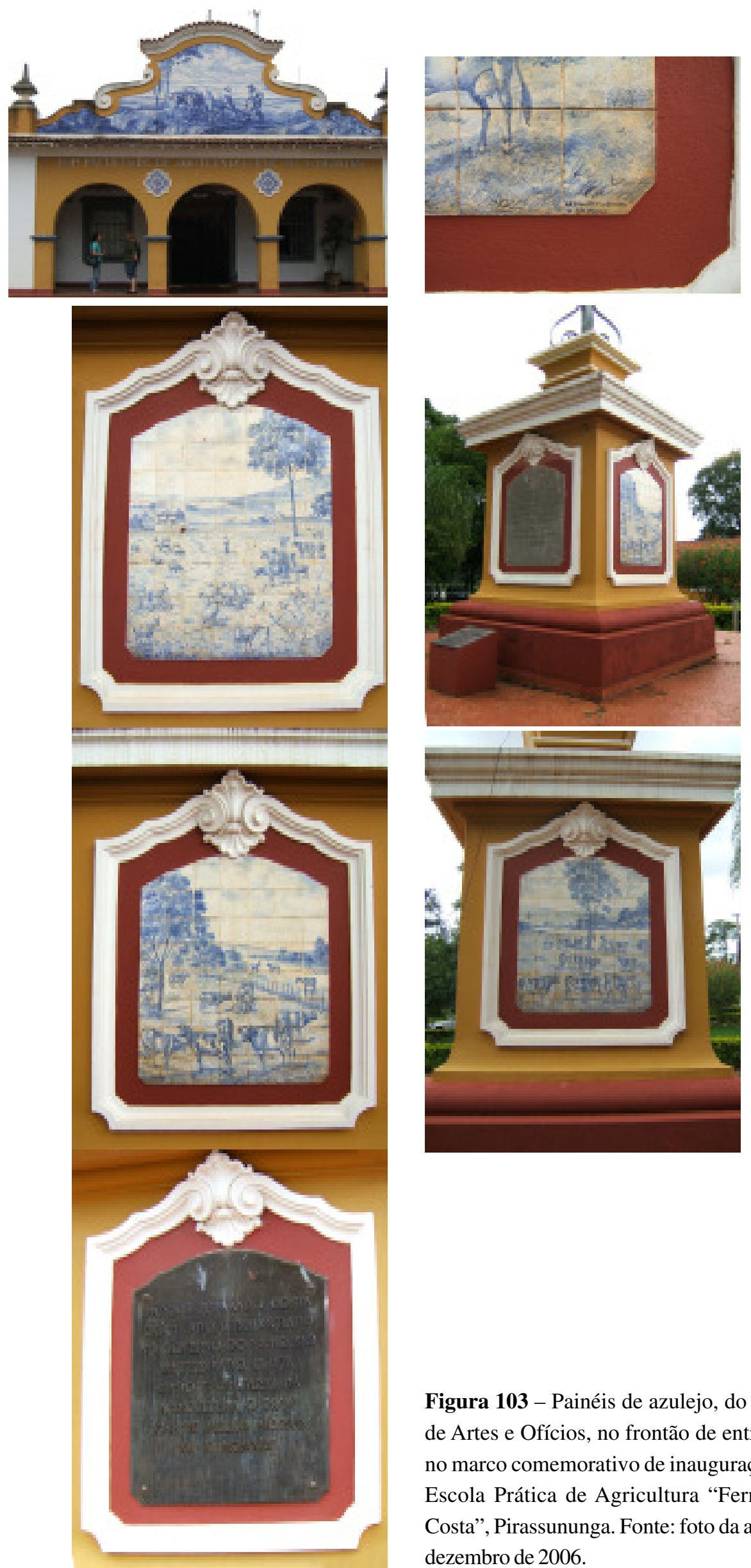

Figura 103 - Painéis de azulejo, do Liceu de Artes e Ofícios, no frontão de entrada e no marco comemorativo de inauguração da Escola Prática de Agricultura "Fernando Costa", Pirassununga. Fonte: foto da autora, dezembro de 2006. 

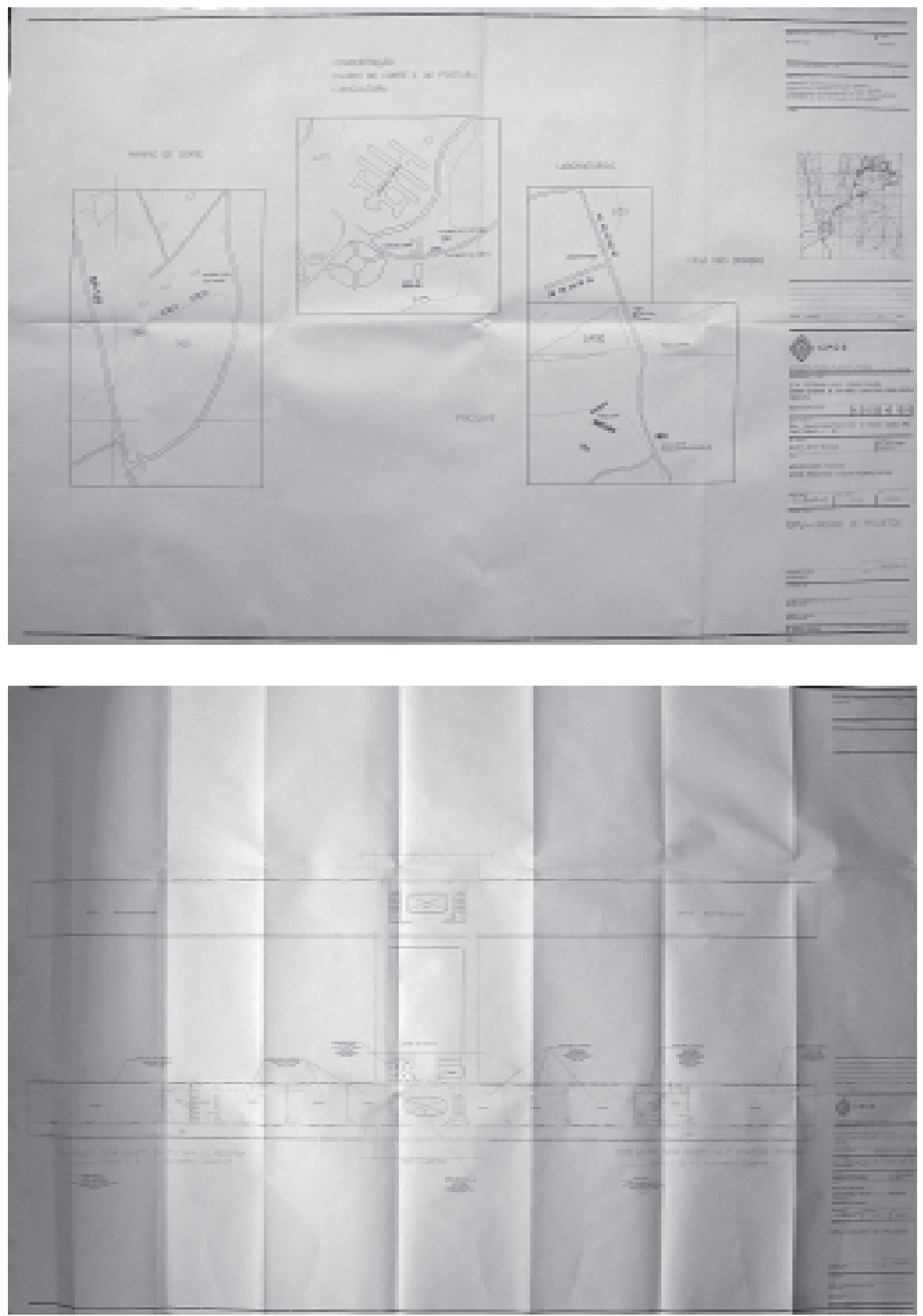

Figura 104 (páginas 327 e 328)- Projeto de levantamento da antiga Escola Prática de Agricultura "Dr. Carlos Botelho", Itapetininga, realizado pela C.P.O.S. em fevereiro de 2002 para fins de reforma. Prancha de situação, de plantas e de fachada do prédio principal. Fonte: Arquivo do C.P.O.S. 

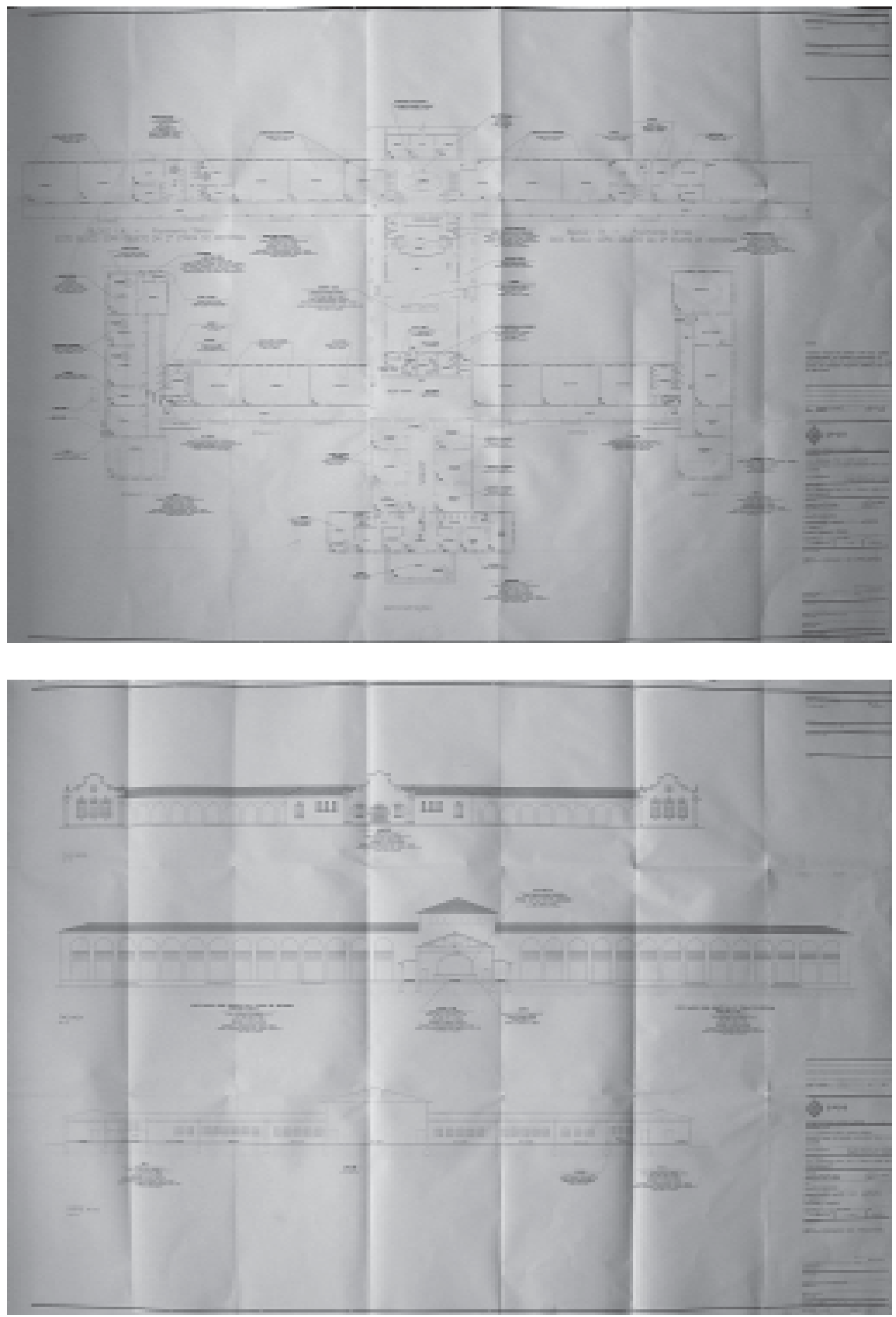

Figura 104 - Legenda da página anterior (327) 


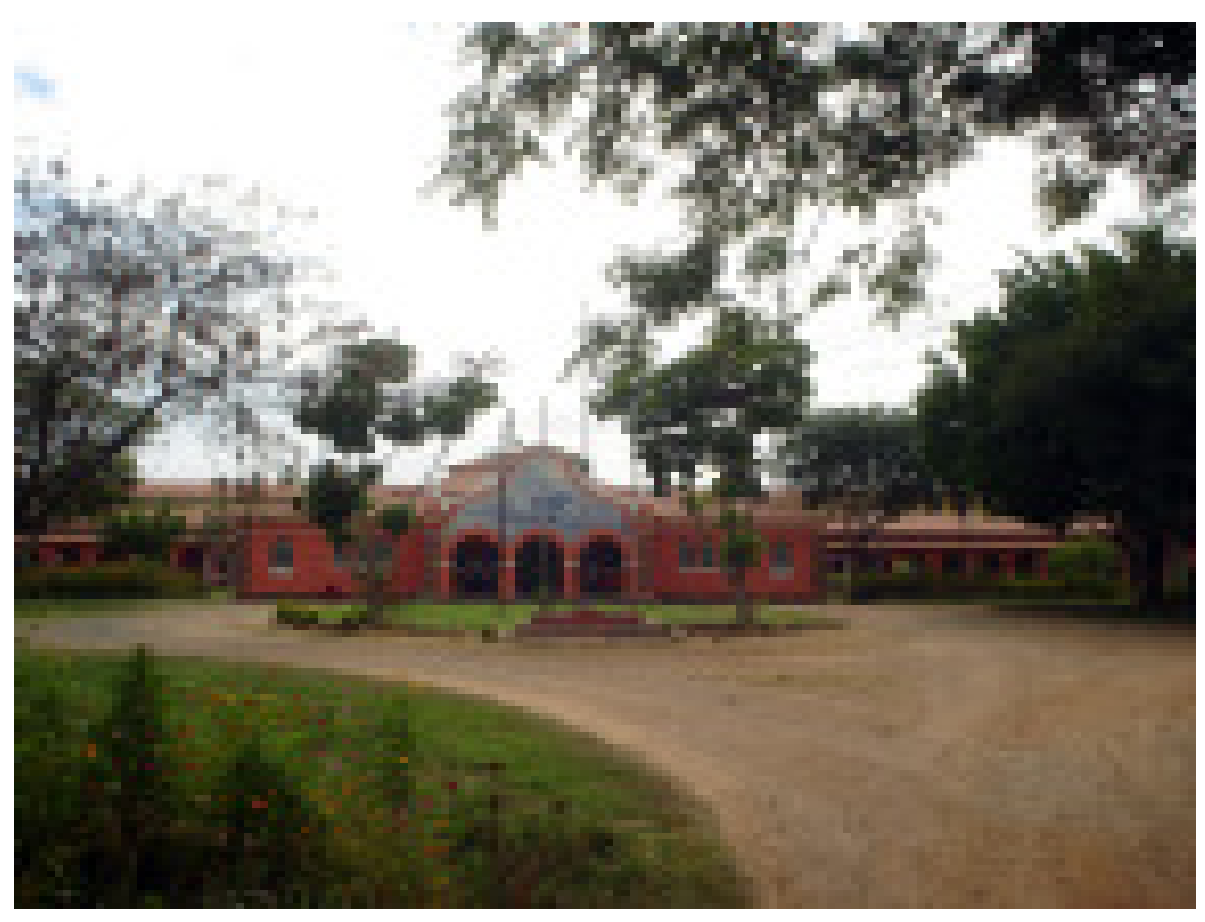

Figura 105 - Acesso ao prédio principal da Escola Prática de Agricultura "Dr. Carlos Botelho", Itapetininga. Notar o pequeno canteiro e as vias de forma arredondada. Fonte: foto A. F. de Souza, abril de 2007. 

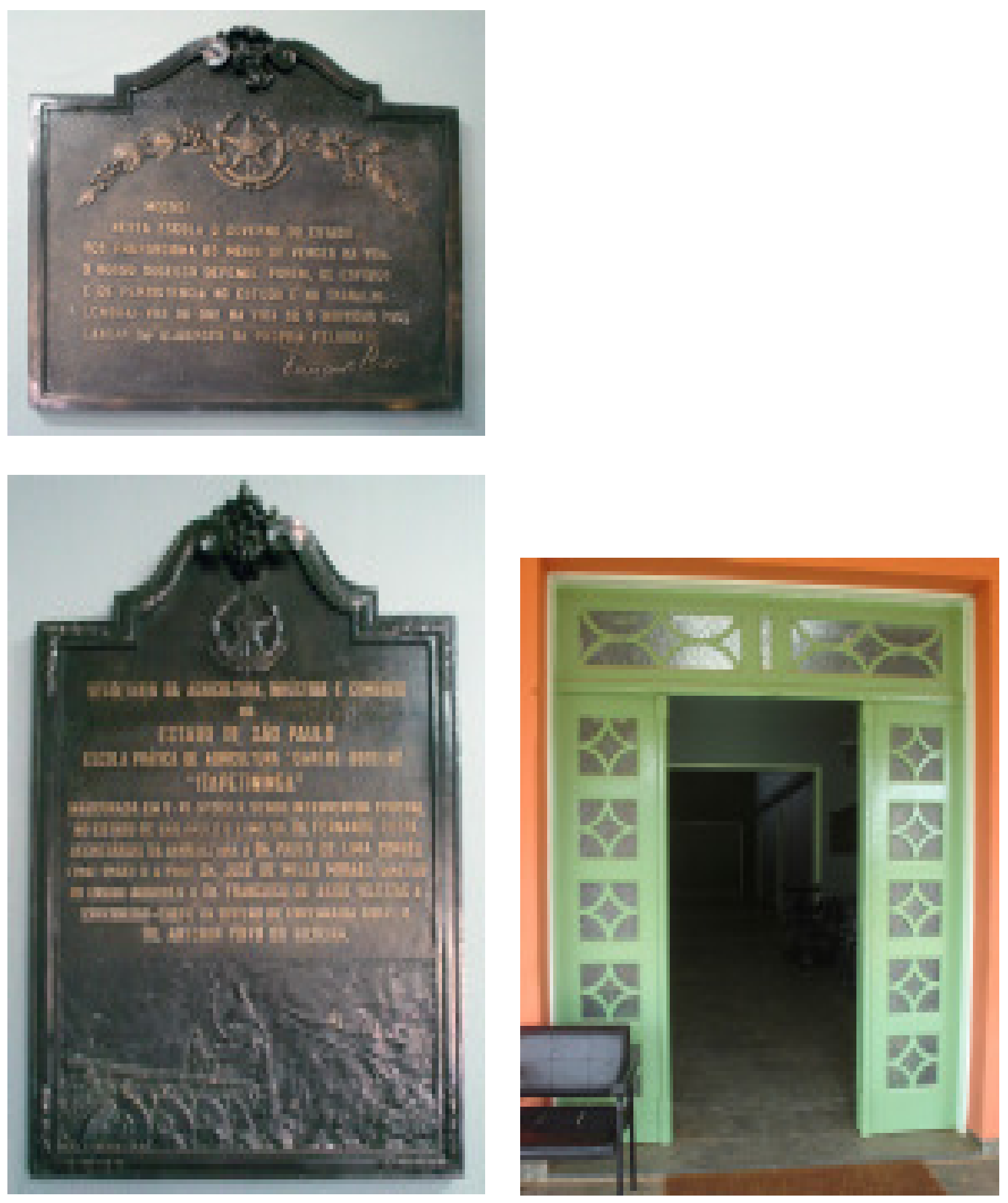

Figura 106 (páginas 330 a 333) - Fotos das placas comemorativas de inauguração da Escola Prática de Agricultura "Dr. Carlos Botelho", Itapetininga. Detalhes externos e internos do prédio principal. Fonte: foto A. F. de Souza, abril de 2007. 

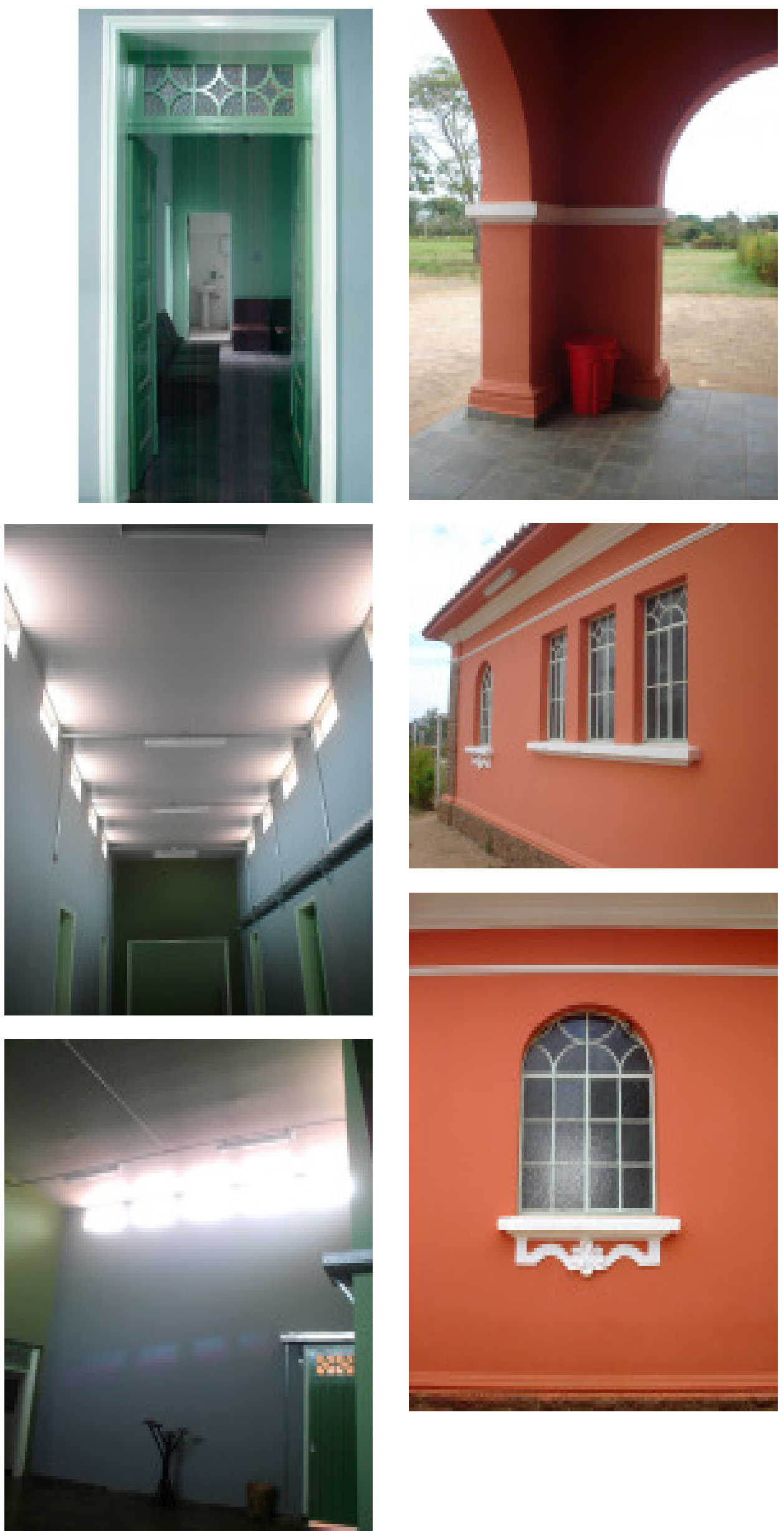

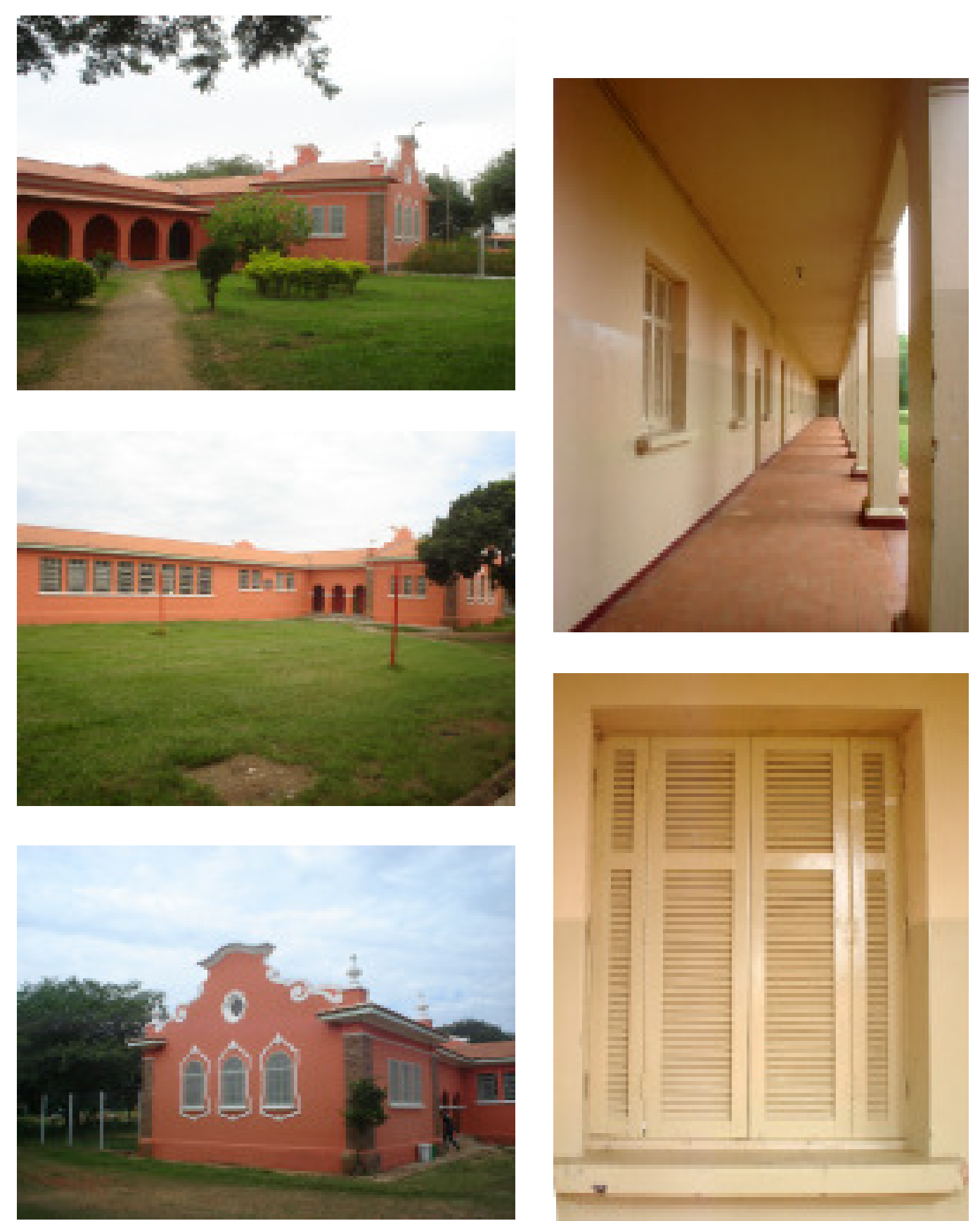

Figura 106 (páginas 330 a 333) - Fotos da Escola Prática de Agricultura "Dr. Carlos Botelho", Itapetininga. Fachada e detalhes externos do prédio principal. Fonte: foto A. F. de Souza, abril de 2007. 

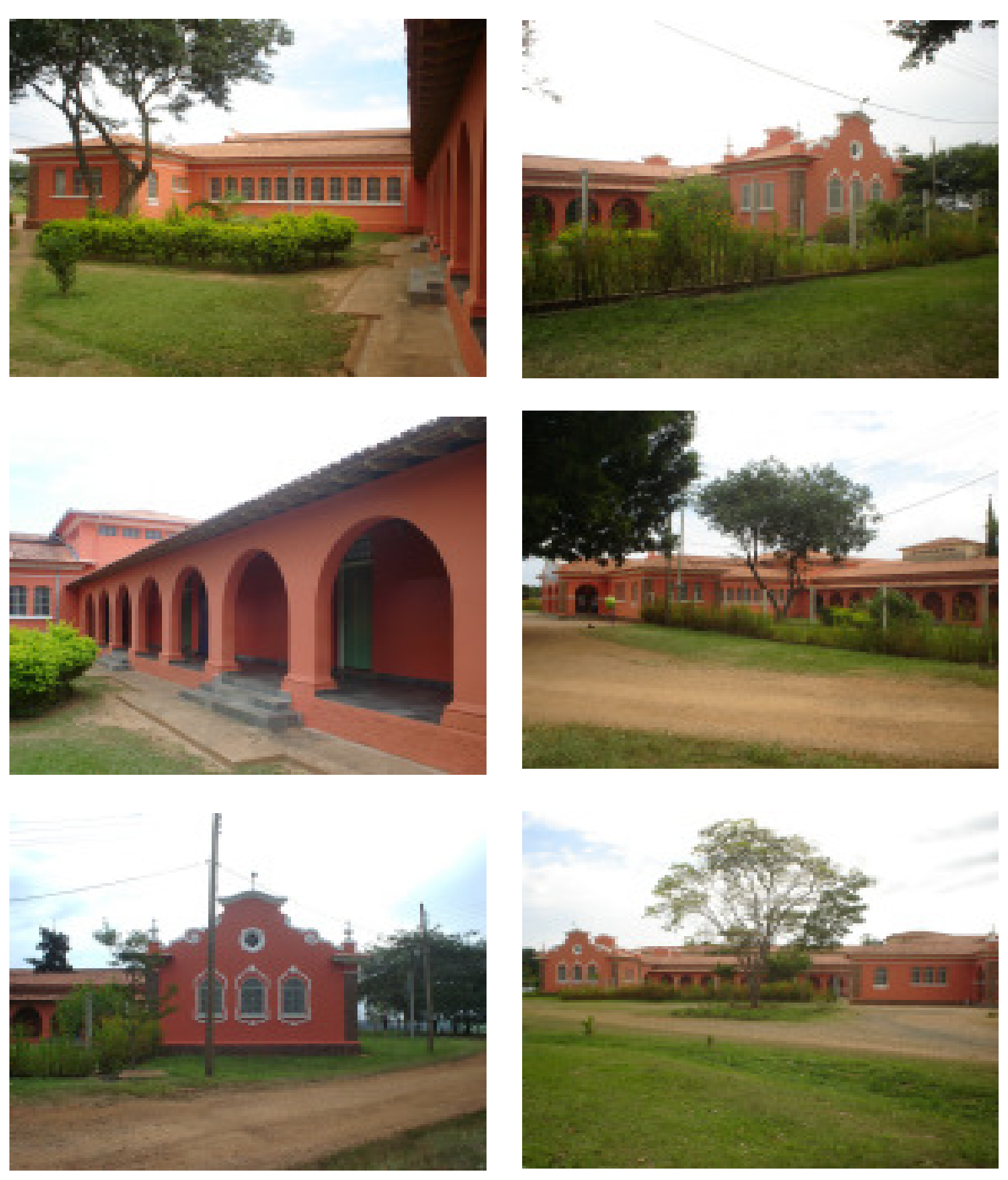

Figura 106 (páginas 330 a 333) - Fotos da Escola Prática de Agricultura "Dr. Carlos Botelho", Itapetininga. Fachada e detalhes externos do prédio principal. Fonte: foto A. F. de Souza, abril de 2007. 

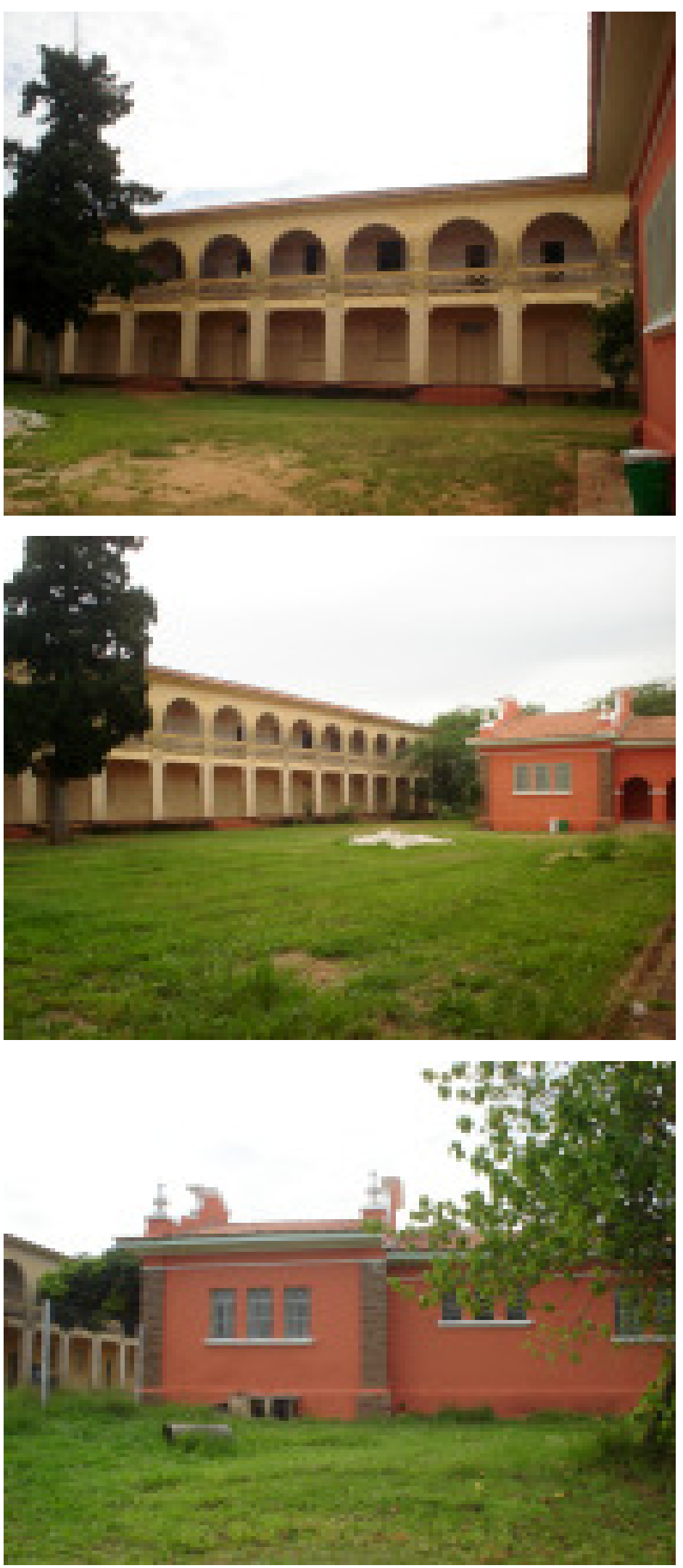

Figura 107 - Arcadas das alas de dois pavimentos da antiga Escola Prática de Agricultura "Dr. Carlos Botelho", Itapetininga. Notar a utilização dos guarda-corpos fechados por meias-luas sobrepostas, tal como em outras escolas analisadas. Nessa caso, essas alas parecem não utilizadas atualmente. Fonte: foto A. F. de Souza, abril de 2007. 


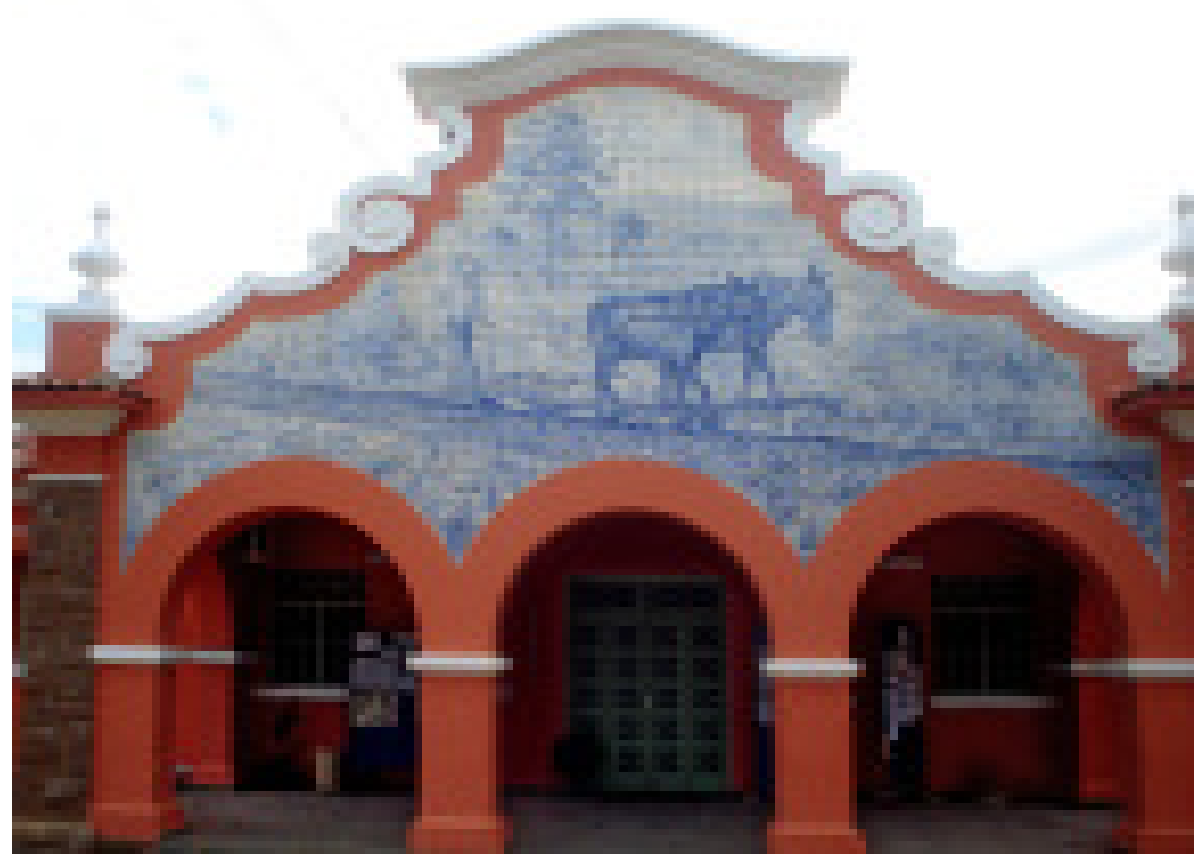

Figura 108 - Frontão do prédio principal com painel de azulejos azul e branco mostrando uma cena agrícola, realizado pelo Liceu de Artes e Ofícios. Fonte: foto A. F. de Souza, abril de 2007.

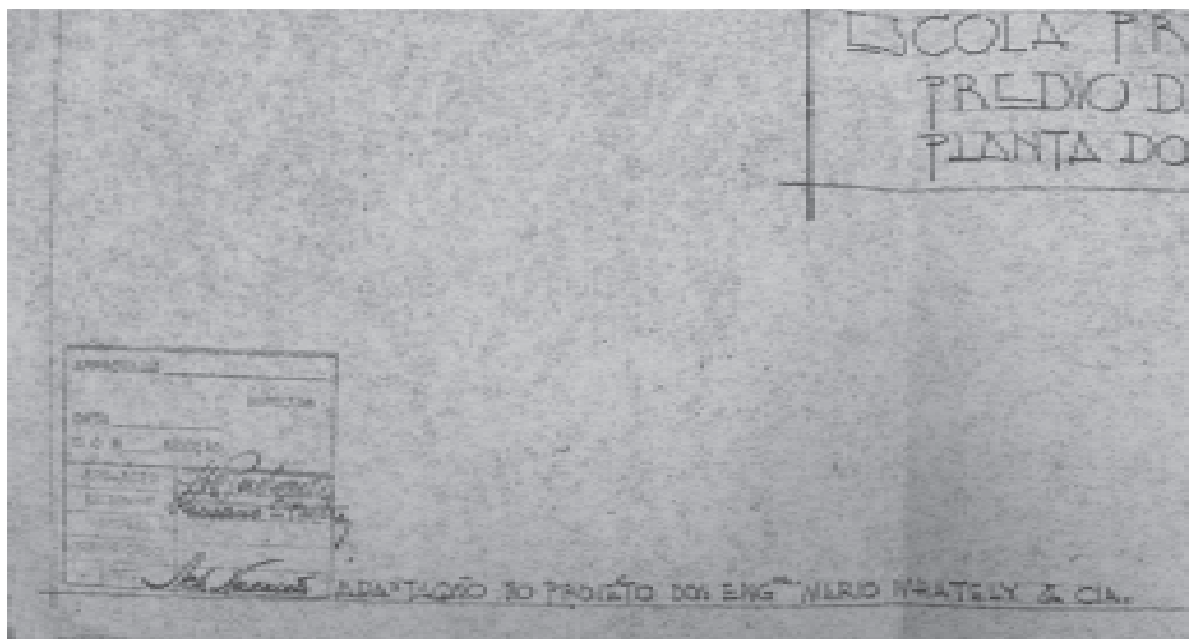

Figura 109 - Observação na prancha de projeto para a Escola Prática de Agricultura de Bauru, cuja autoria é do Hernani do Val Penteado, informando que o mesmo é uma adaptação do projeto dos Engenheiros Mario Whately \& Cia, que acreditamos ser o projeto para a Escola Nacional de Agronomia do Rio de Janeiro. Fonte: Arquivo do Instituto Penal Agrícola "Prof. Noé de Azevedo". 

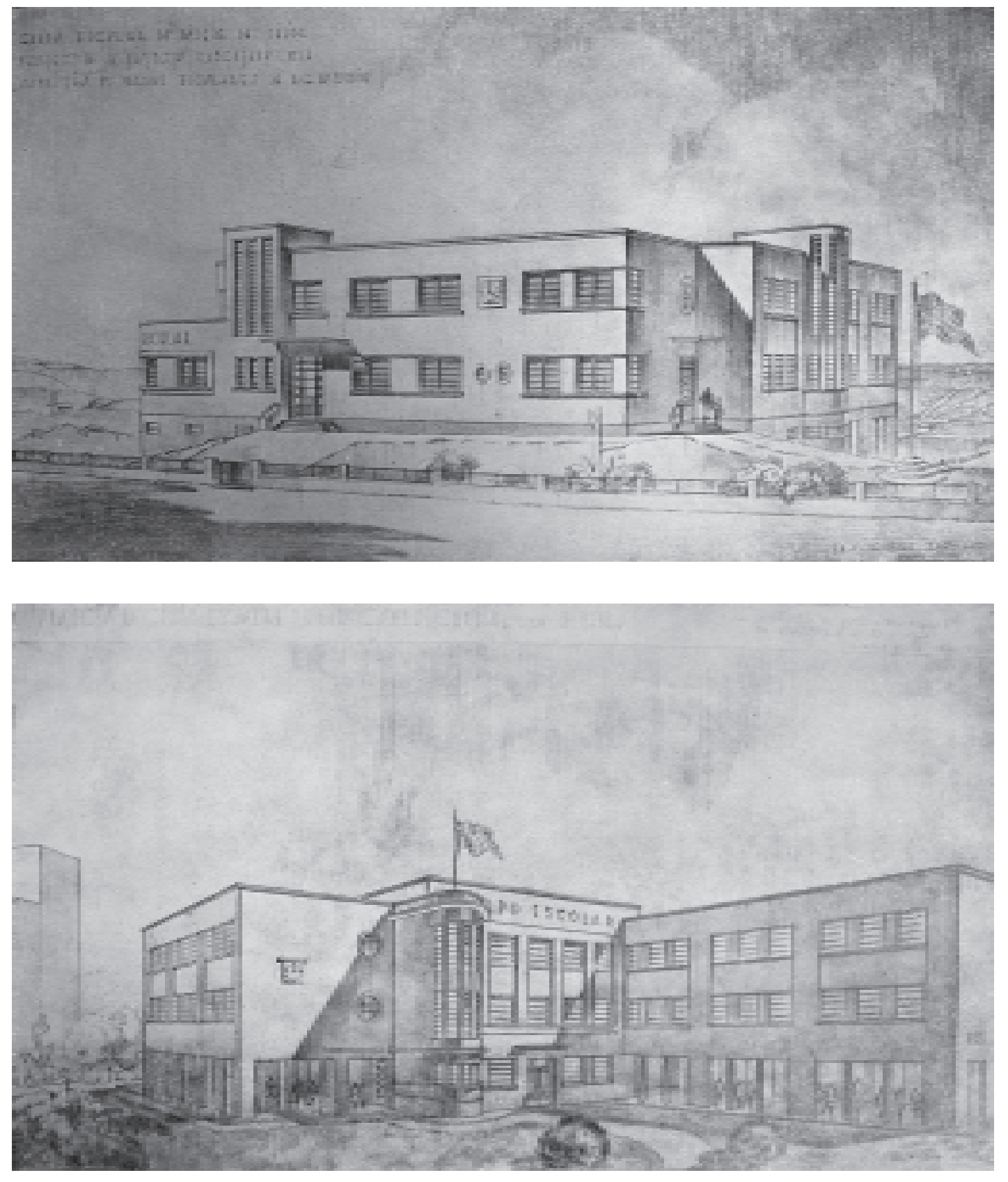

Figura 110 (páginas 336 e 337) - Vários projetos para a Diretoria de Obras Públicas para grupos escolares, de autoria de do arquiteto José Maria da Silva Neves, da década de 1930. Todos de linhas modernistas. Fonte: Secretaria dos Negócios da Educação e Saúde Pública (1937). 

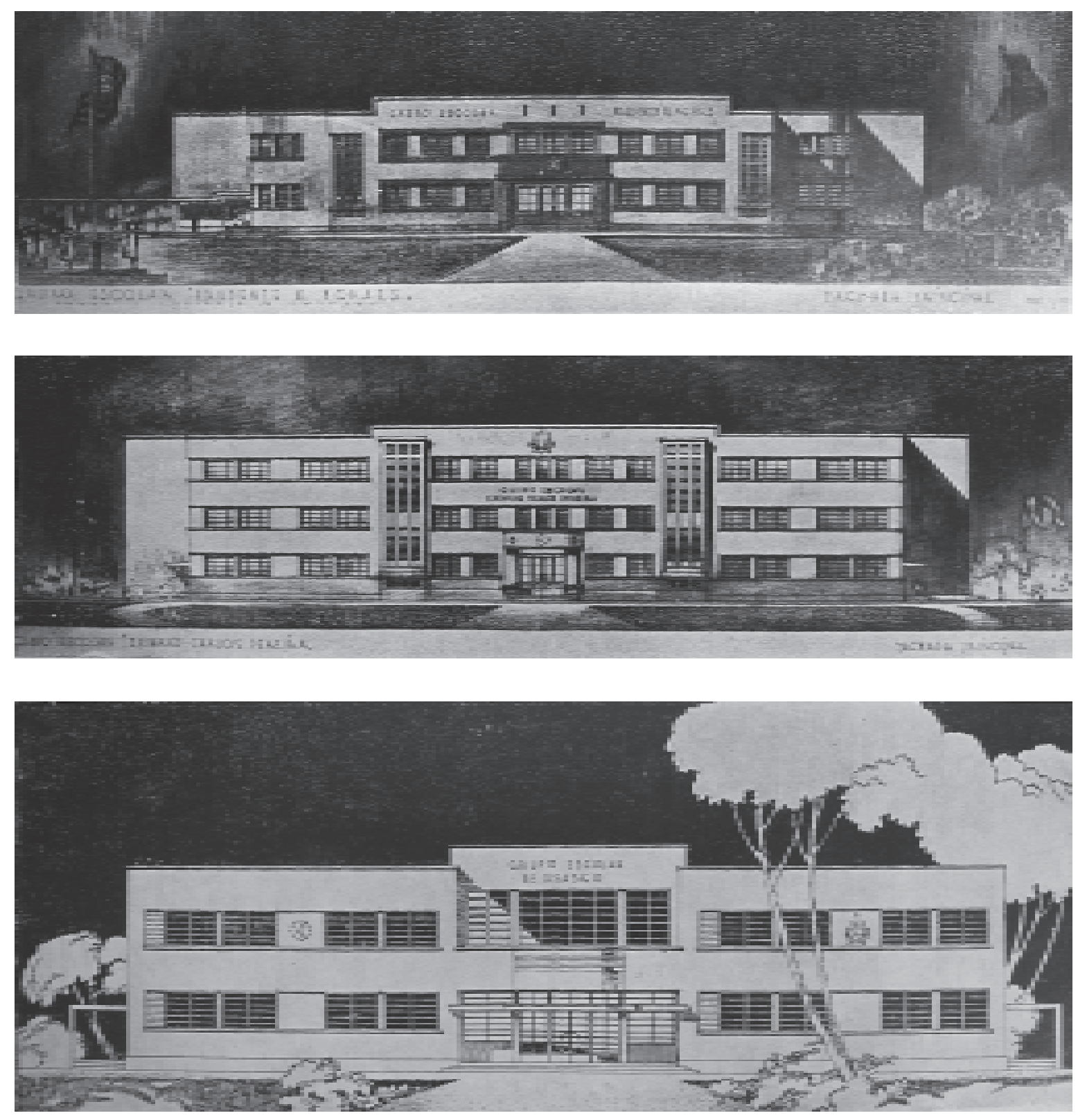

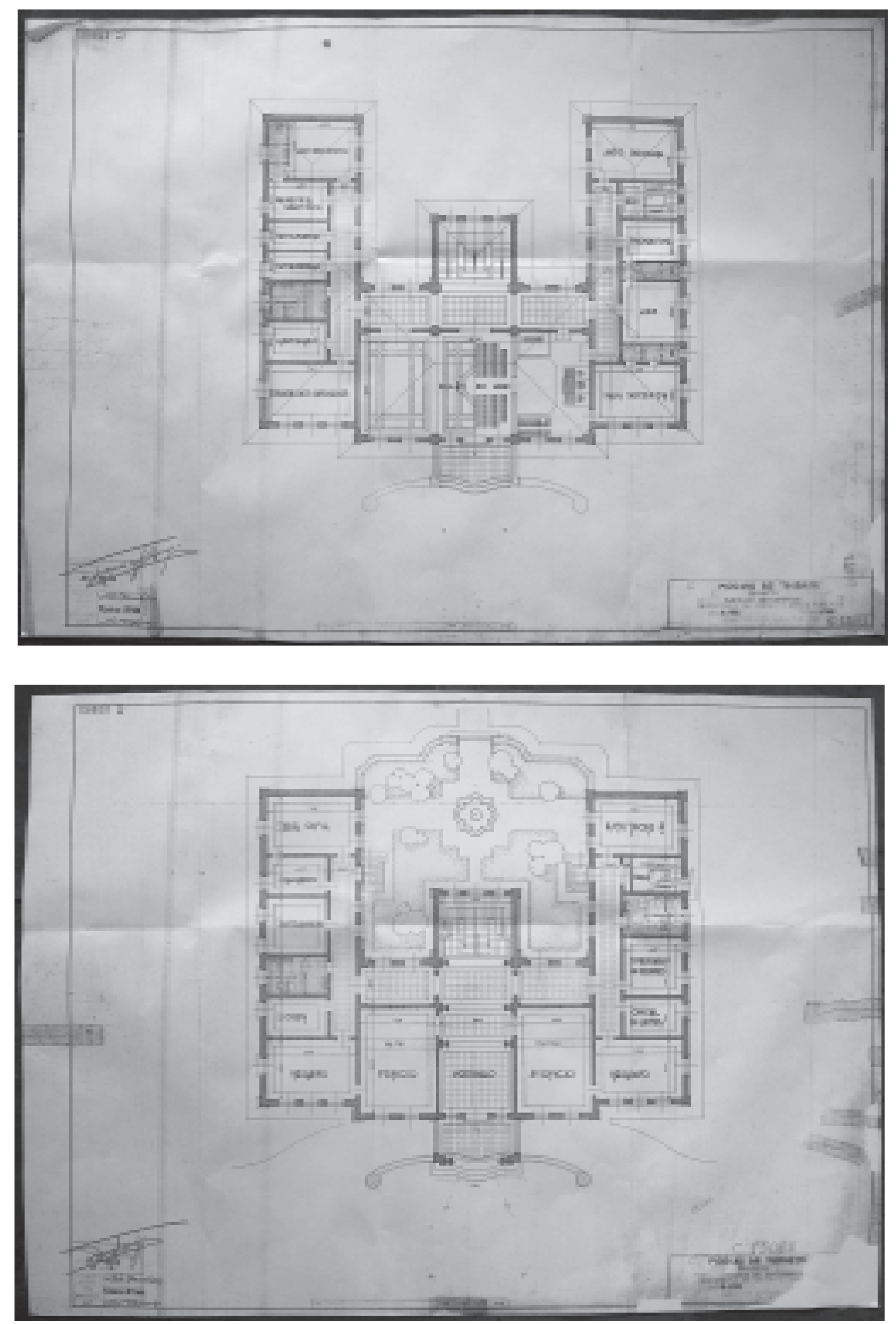

Figura 111 (páginas 338 e 339) - Projeto para o Fórum de Taubaté, de 1944, de autoria do arquiteto Vicente Leme Zammataro. Obra da Diretoria de Obras Públicas. Fonte: Arquivo da C. P. O. S. 

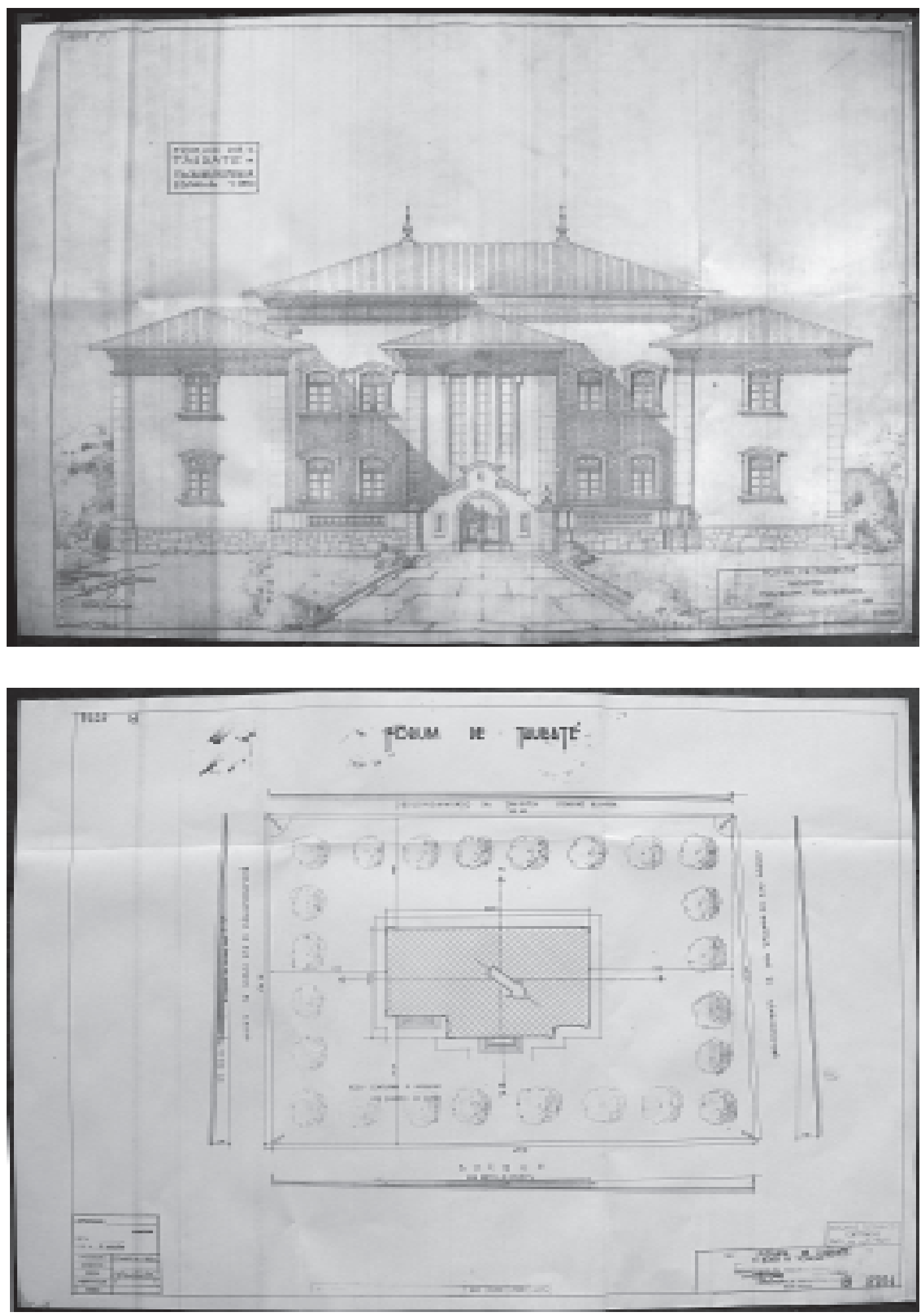

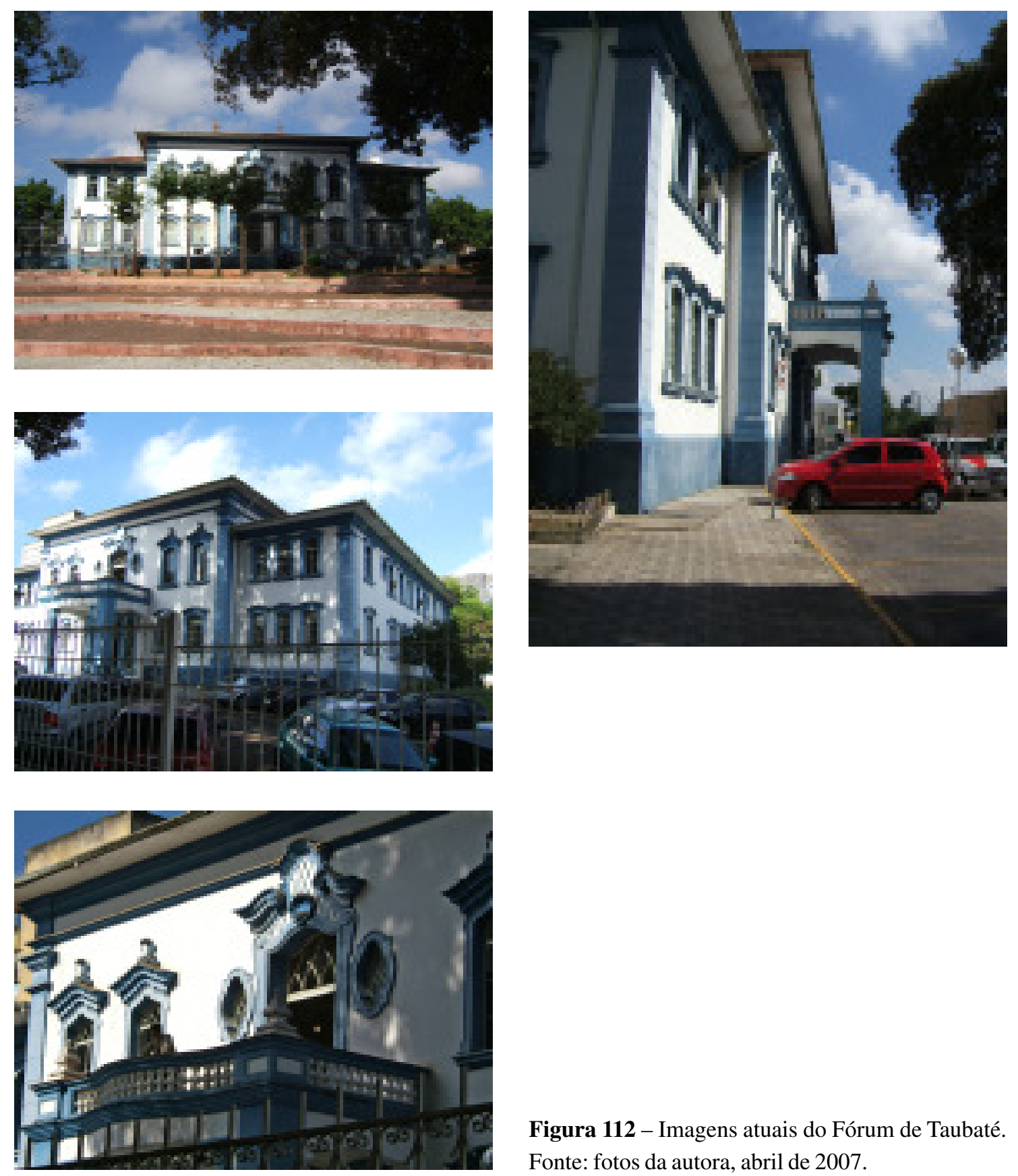

Figura 112 - Imagens atuais do Fórum de Taubaté. Fonte: fotos da autora, abril de 2007. 

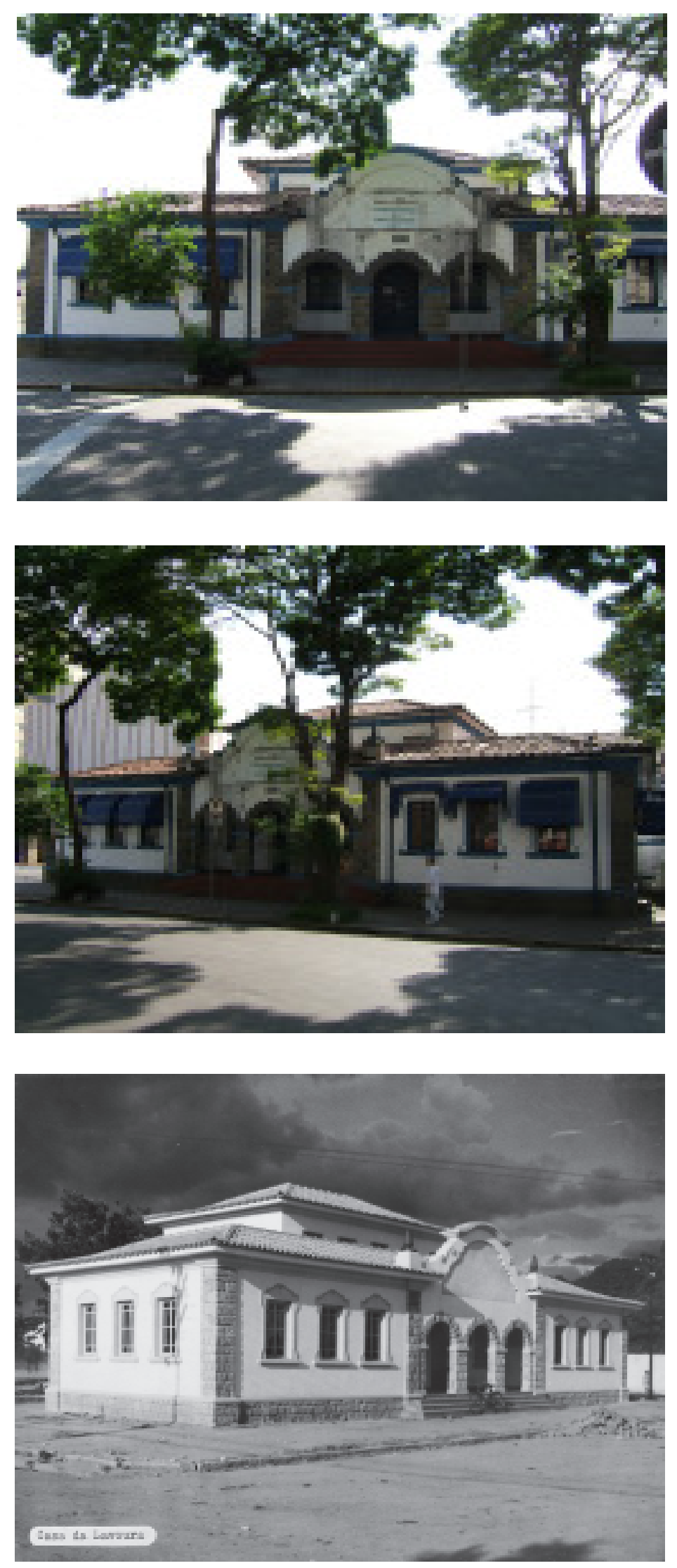

Figura 113 - Imagens da Casa da Lavoura de Taubaté na época de sua inauguração e atuais. Obra da Diretoria de Obras Públicas. Fonte: fotos da autora, abril de 2007. 


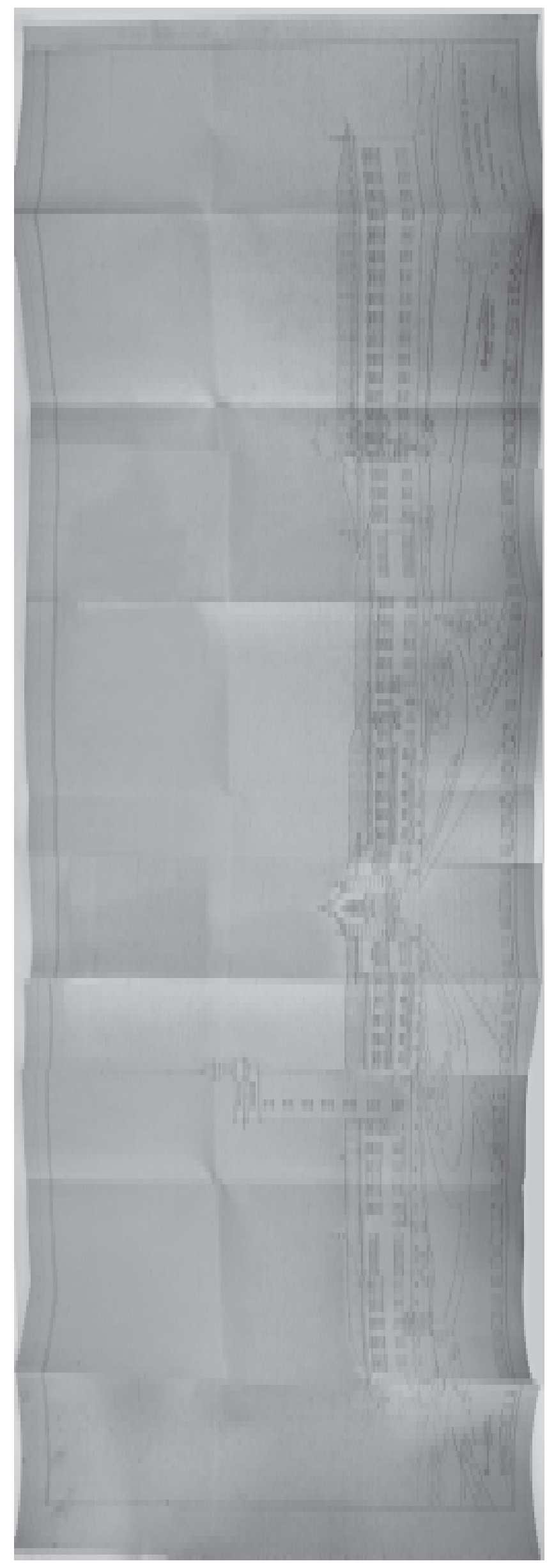

Figura 114 - Projeto da fachada da Escola de Cadetes de Campinas, de autoria de Hernani do Val Penteado. Obra da Diretoria de Obras Públicas. Fonte: Acervo de Projetos FAUUSP. 

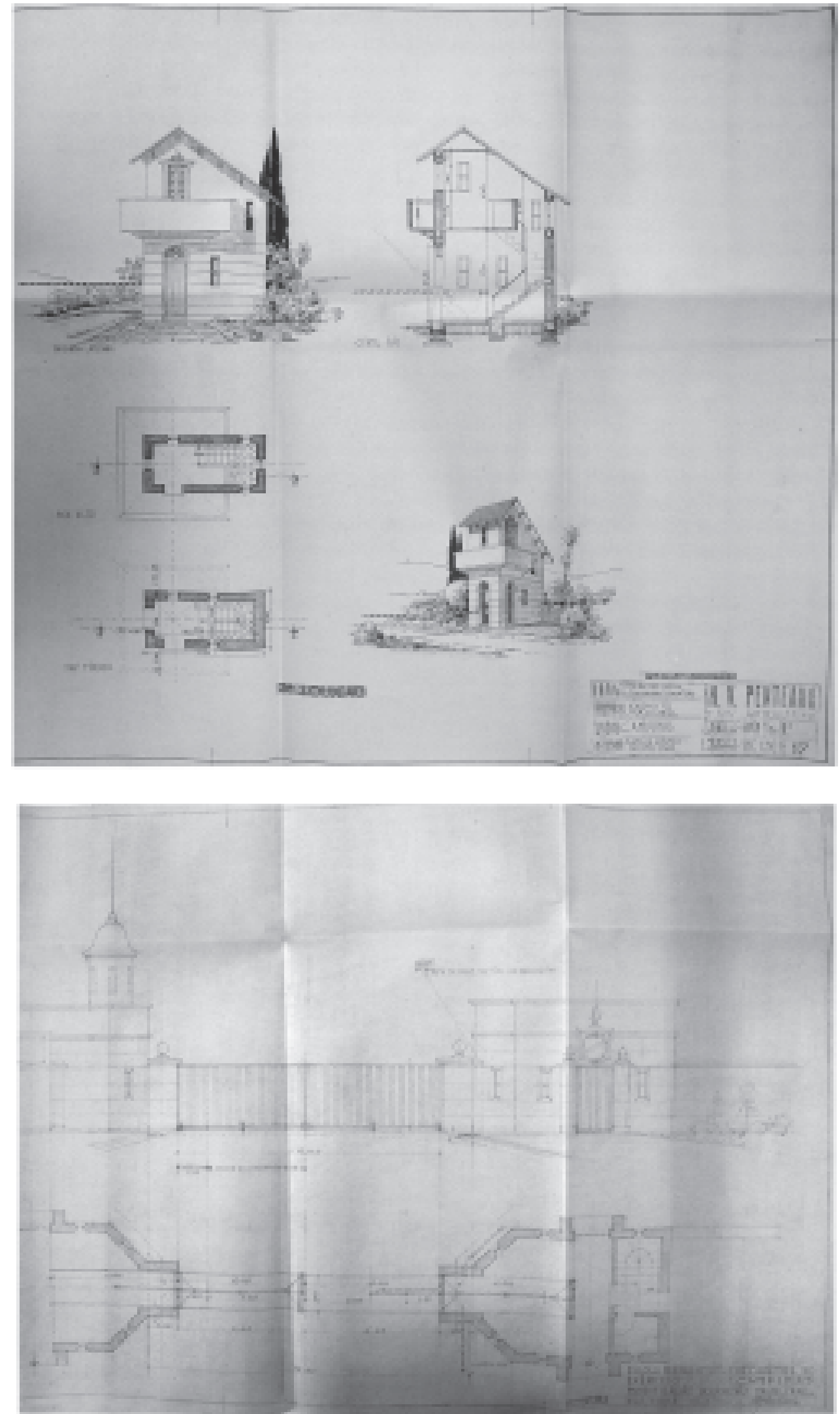

Figura 115 - Projetos para a torre de vigia e para o portão da Escola de Cadetes de Campinas, este último realizado em 1970, por Hernani do Val Penteado. Fonte: Acervo de Projetos FAUUSP. 

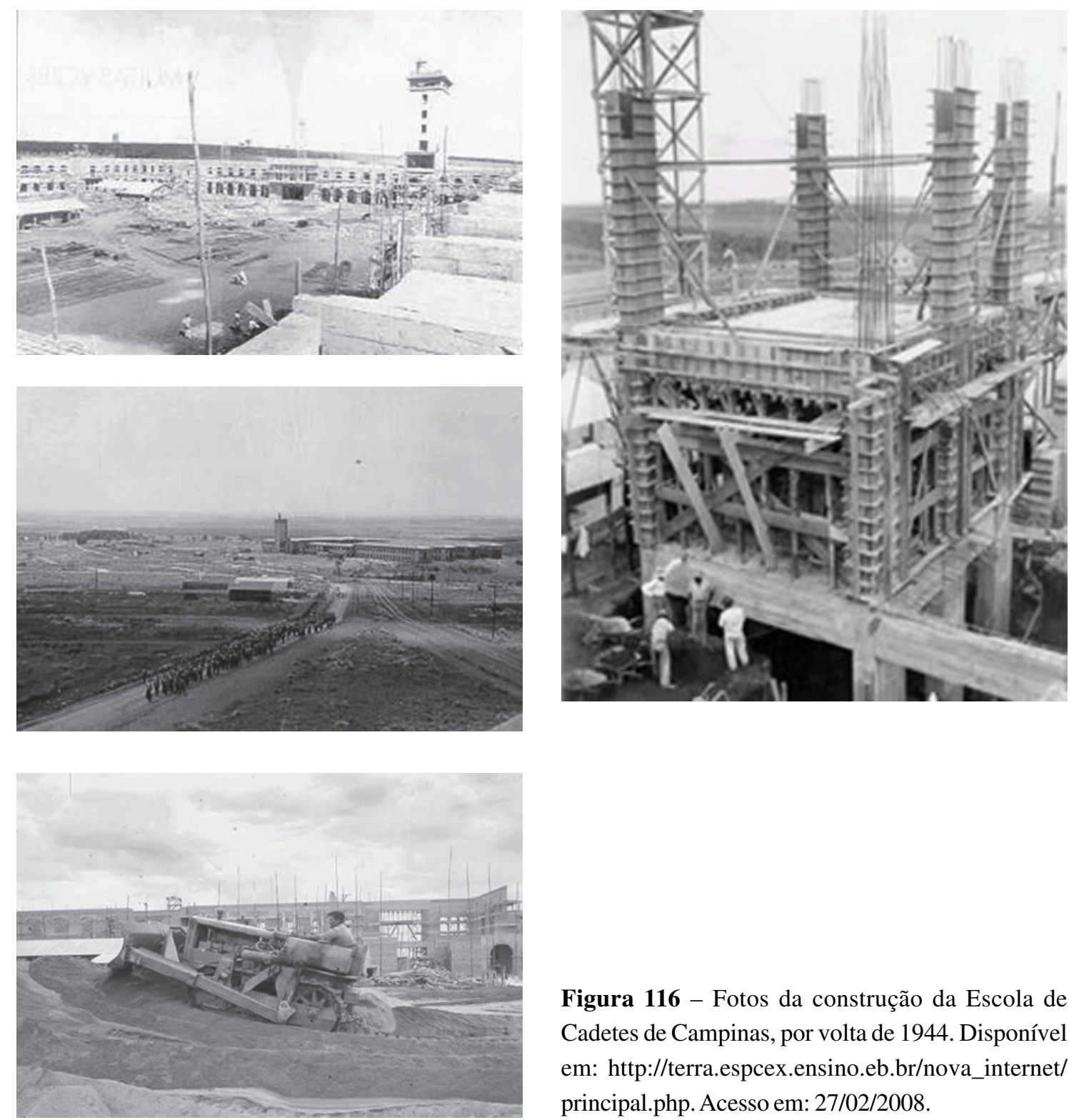

Figura 116 - Fotos da construção da Escola de Cadetes de Campinas, por volta de 1944. Disponível em: http://terra.espcex.ensino.eb.br/nova_internet/ principal.php. Acesso em: 27/02/2008. 

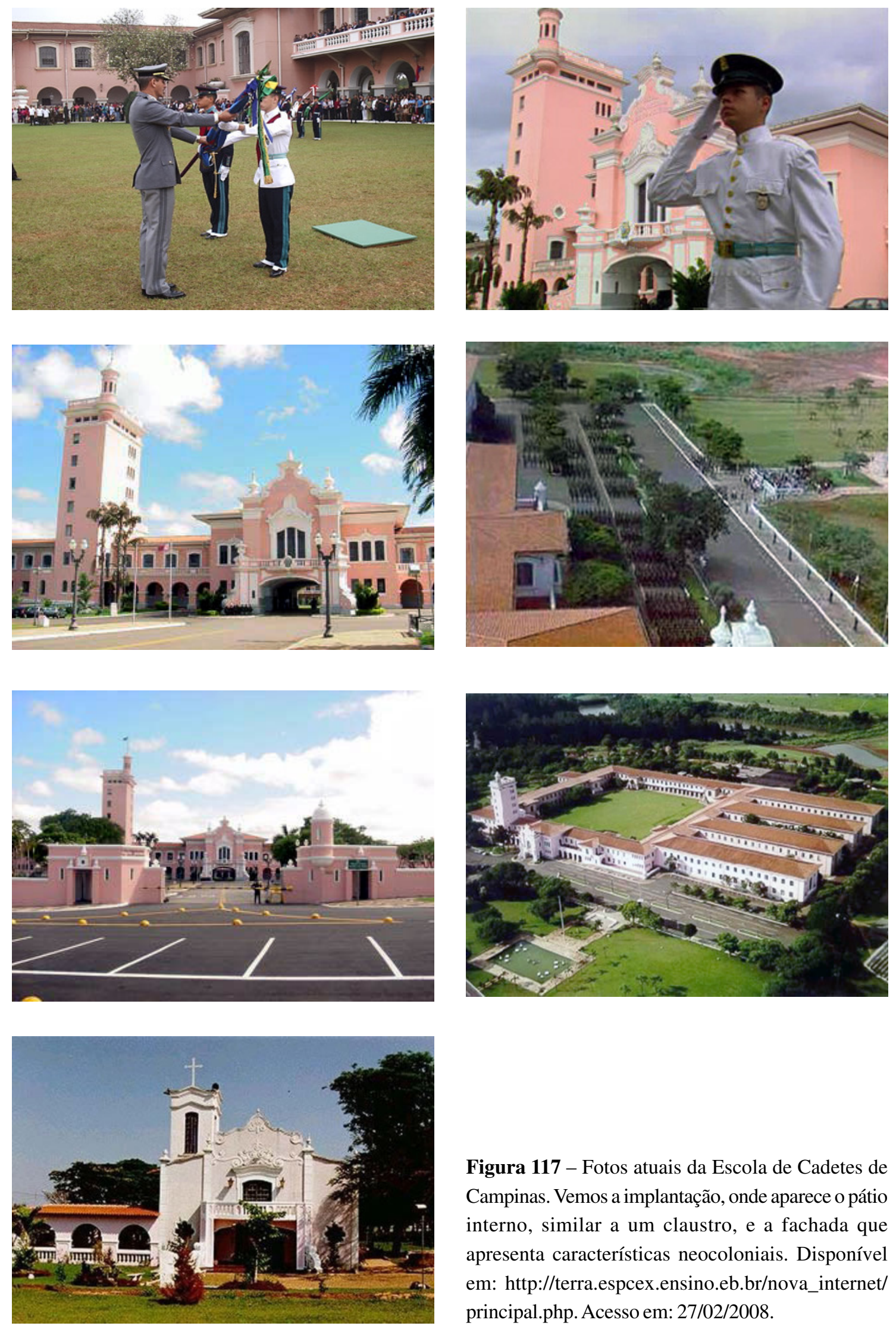

Figura 117 - Fotos atuais da Escola de Cadetes de Campinas. Vemos a implantação, onde aparece o pátio interno, similar a um claustro, e a fachada que apresenta características neocoloniais. Disponível em: http://terra.espcex.ensino.eb.br/nova_internet/ principal.php. Acesso em: 27/02/2008. 


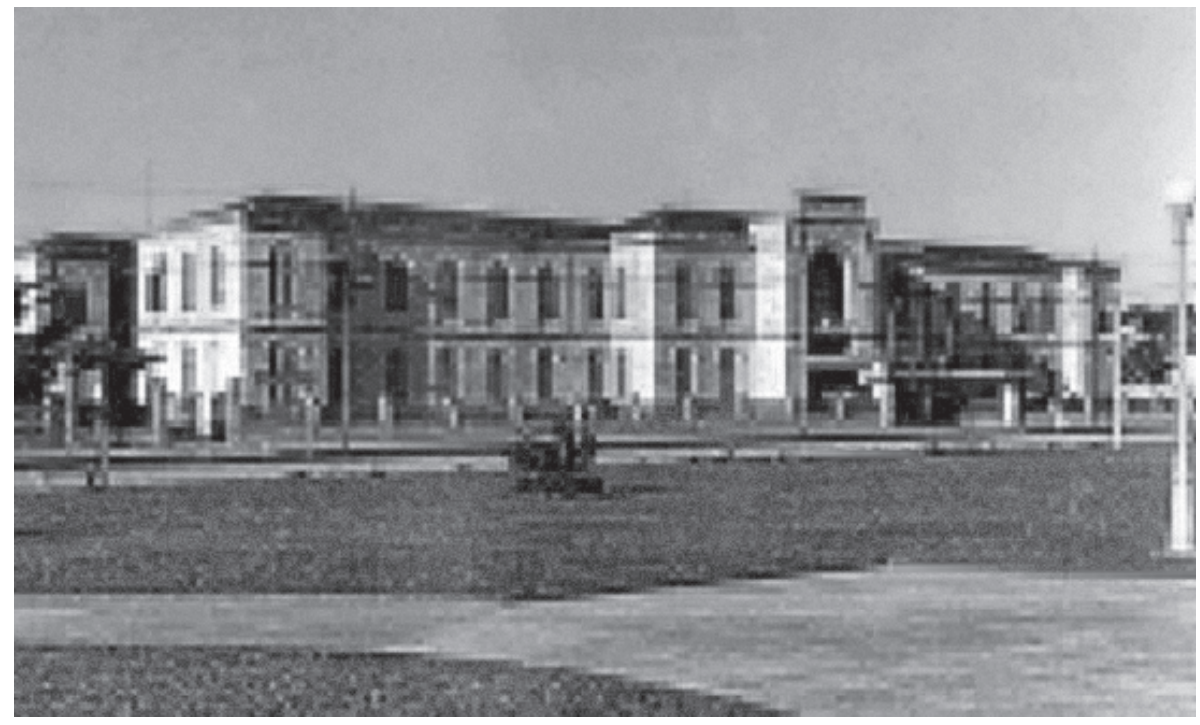

Figura 118 - Edifício antigo da instituição Escolástica Rosa, em Santos, projetada pelo escritório Ramos de Azevedo, de linhas ecléticas. Disponível em: http://www.escolasticarosa.com.br/ fotos\%20pag.htm Acesso em: 15/04/2008.

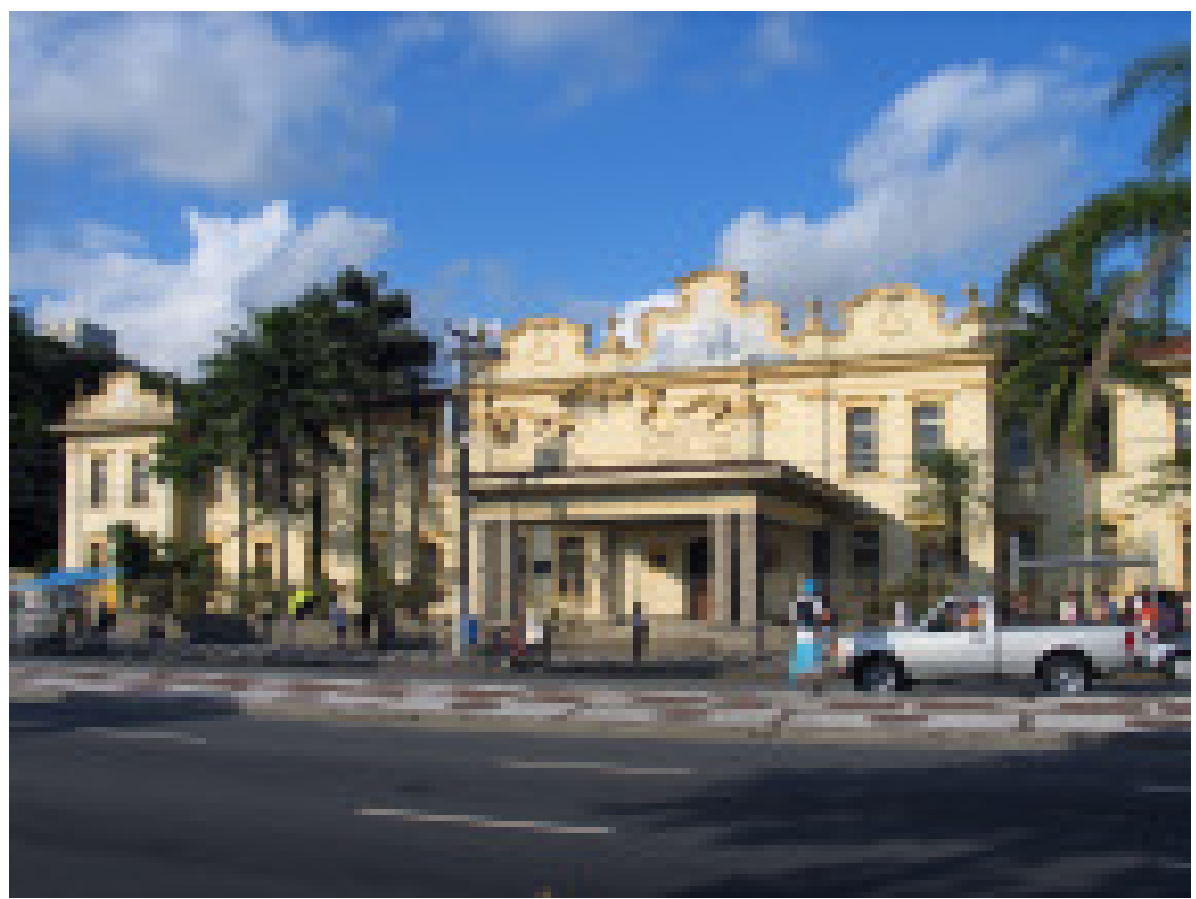

Figura 119 - (páginas 346 e 347) - Fotos atuais da escola Escolástica Rosa, em Santos, depois da reforma que atribuiu a ela o aspecto neocolonial. Fonte: fotos V. Benincasa, fevereiro de 2005. Fotos internas disponíveis em: http://www.escolasticarosa.com.br/ fotos\%20pag.htm. Acesso em: 15/04/2008. 

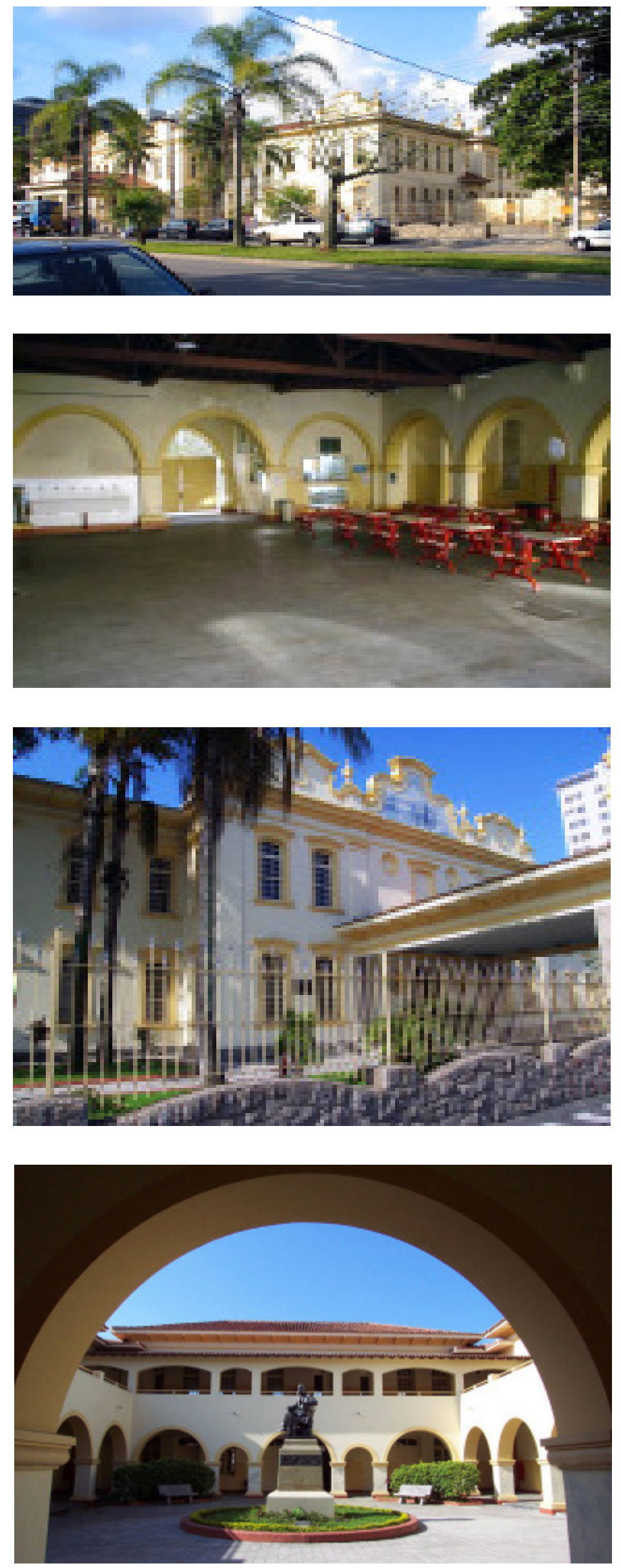

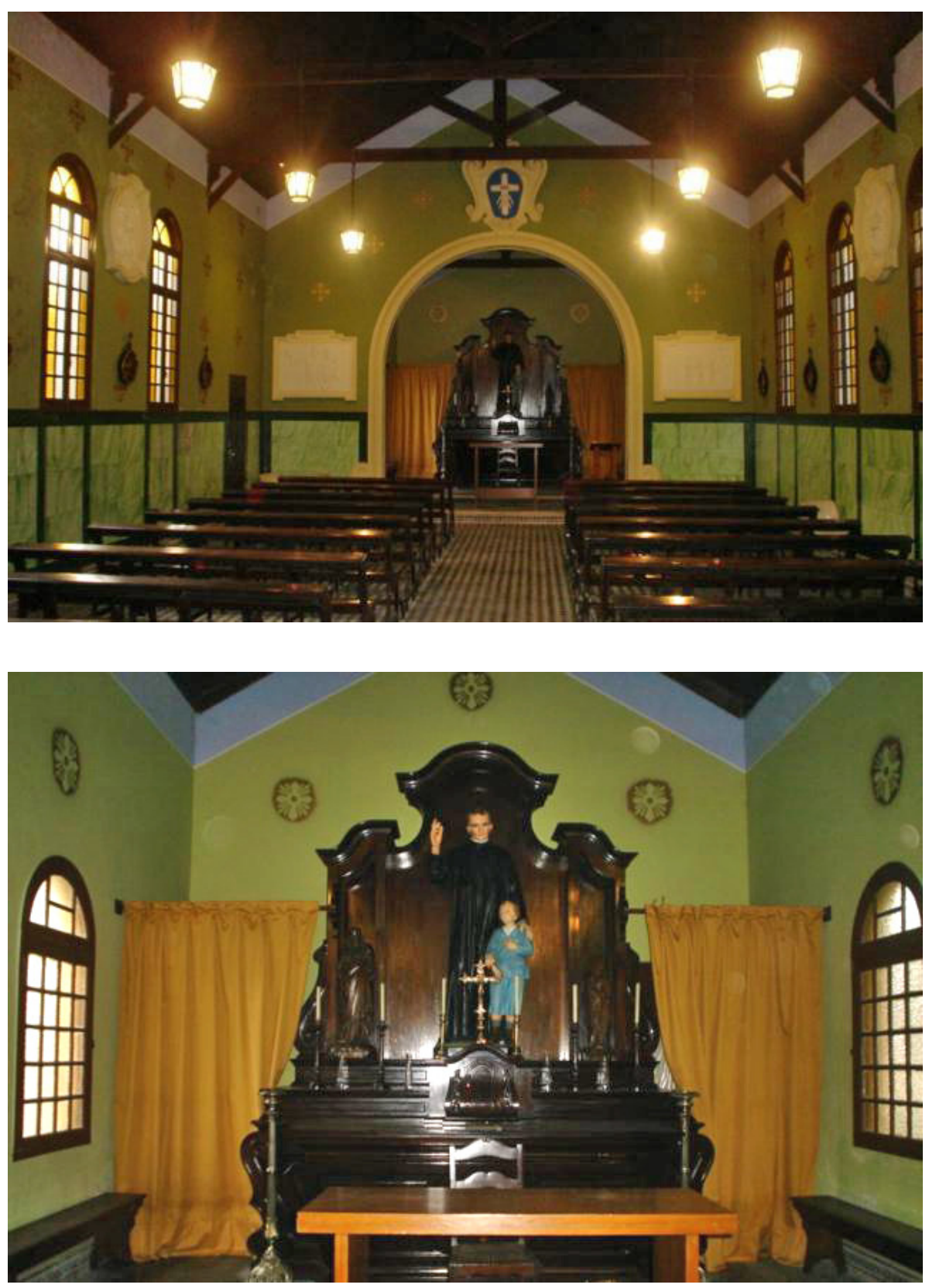

Figura 120 - Vistas do interior da capela da escola Escolástica Rosa, em Santos. A capela foi construída durante as reformas. Notar o retábulo neocolonial. Disponível em: http:// www.escolasticarosa.com.br/fotos\%20pag.htm. Acesso em: 15/04/ 2008. 


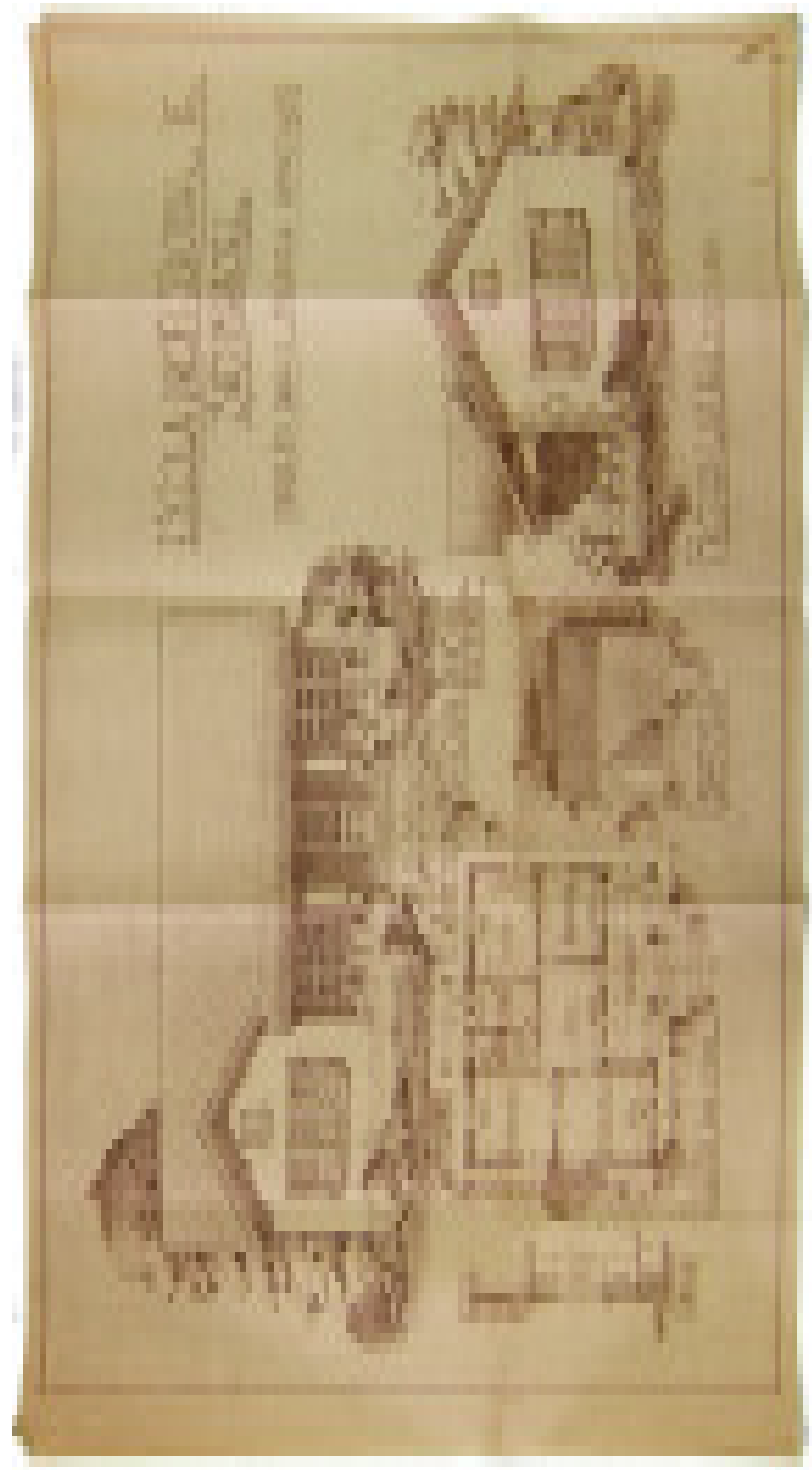

Figura 121 - Projeto para o prédio da administração da Escola de São Manoel, desenvolvido pelo arquiteto Hernani do Val Penteado. Fonte: Acervo de Projetos da FAUUSP. 


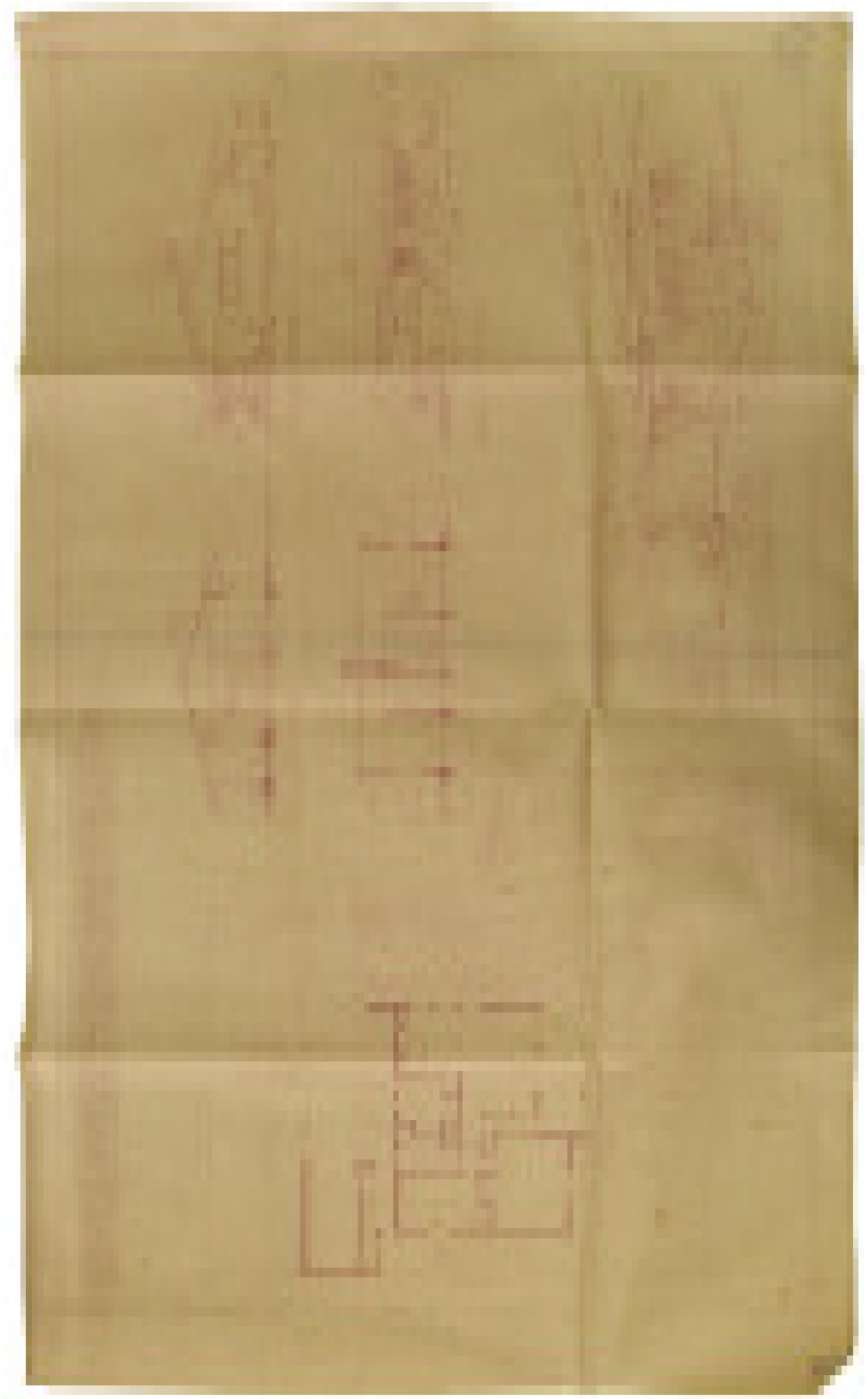

Figura 122 - Projeto do arquiteto Hernani do Val Penteado para sua residência na Praia do Boqueirão, em São Vicente. Ausência de decoração neocolonial, mas manutenção de beirais tradicionalistas. Fonte: Acervo de Projetos da FAUUSP. 


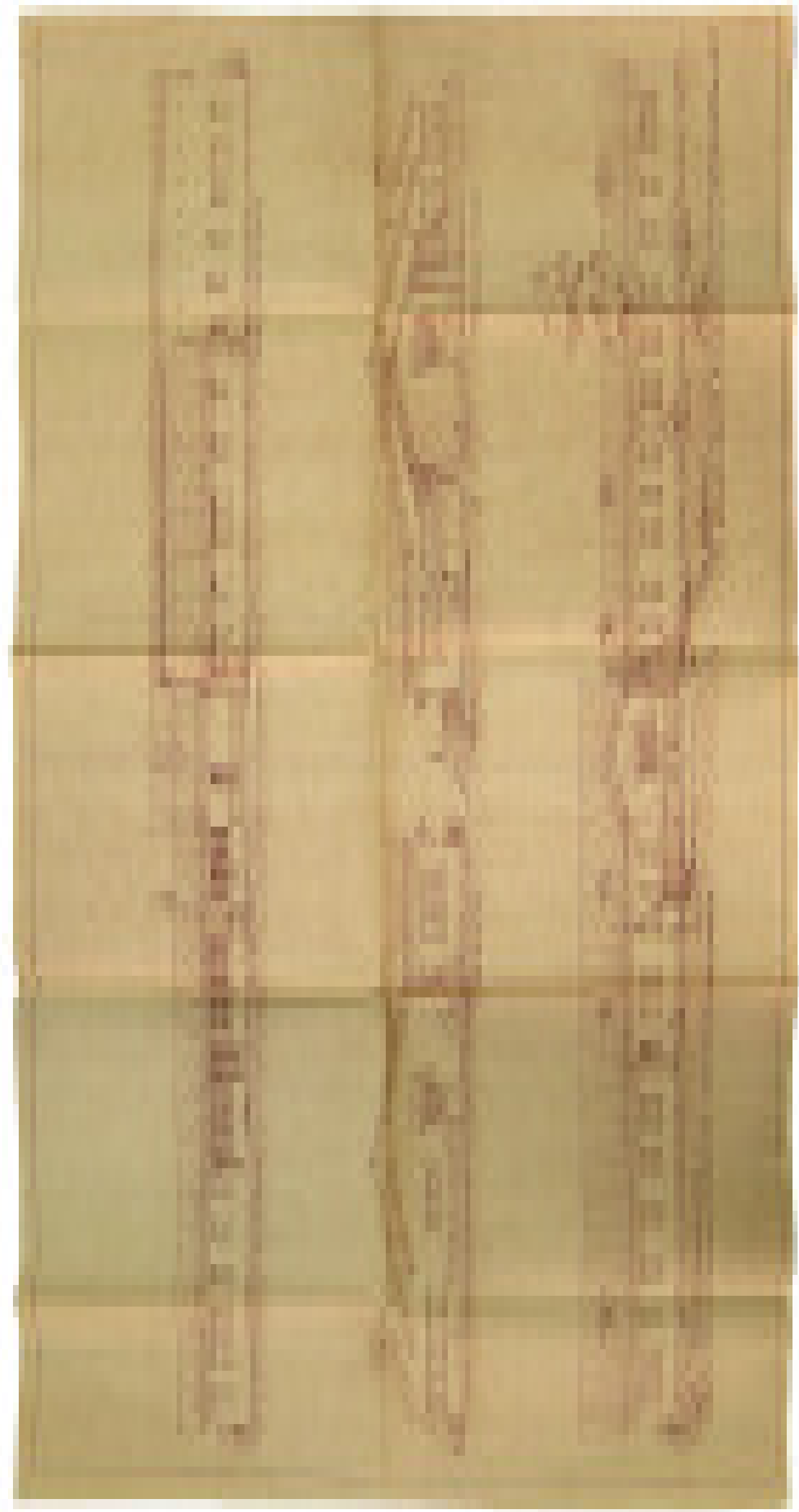

Figura 123 (páginas 351 e 352) - Projeto do arquiteto Hernani do Val Penteado para Hospital de Guarantã. Também mantém os beirais tradicionalistas. Fonte: Acervo de Projetos da FAUUSP. 


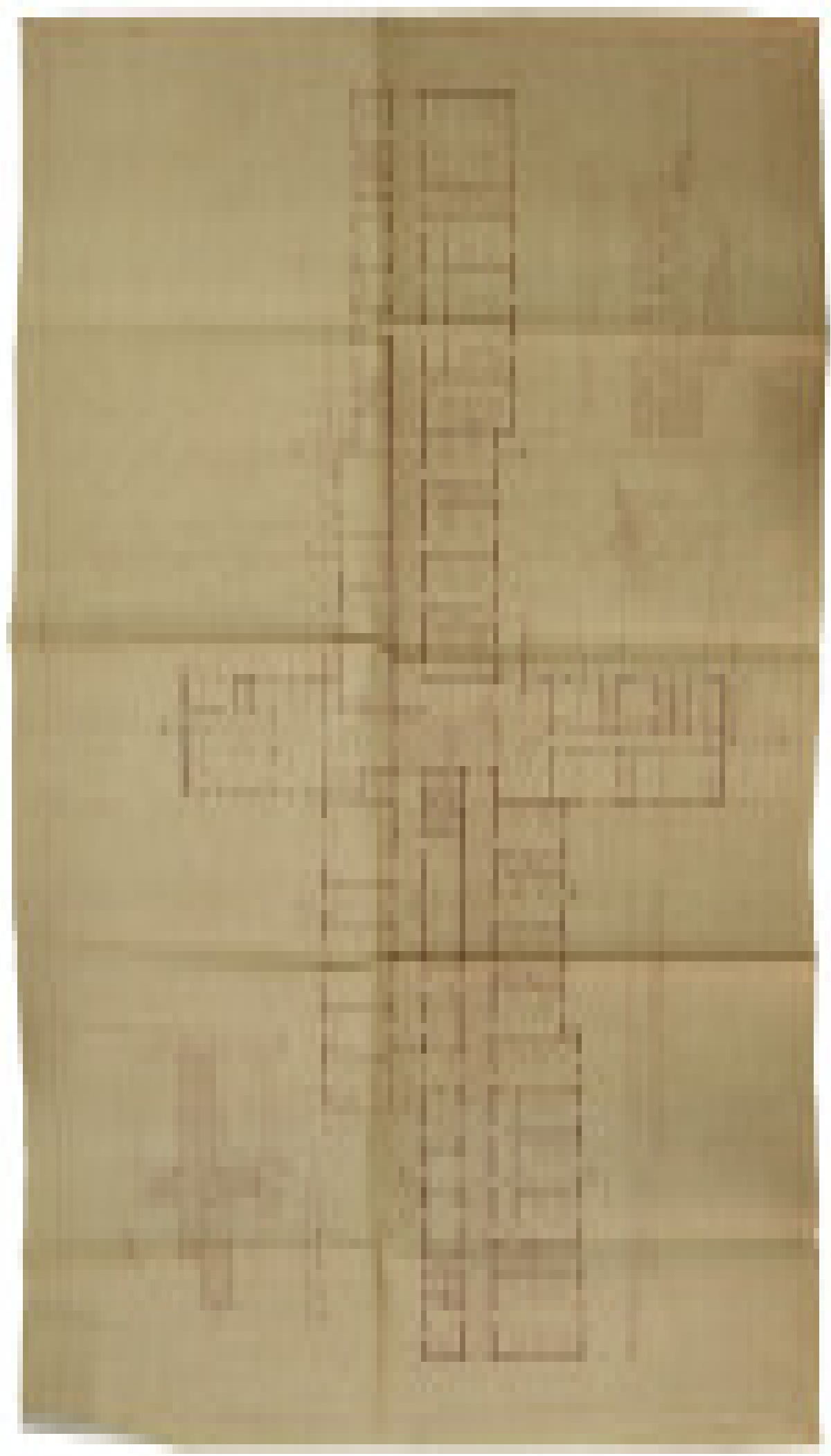

Figura 123 (páginas 351 e 352) - Projeto do arquiteto Hernani do Val Penteado para Hospital de Guarantã. Também mantém os beirais tradicionalistas. Fonte: Acervo de Projetos da FAUUSP. 


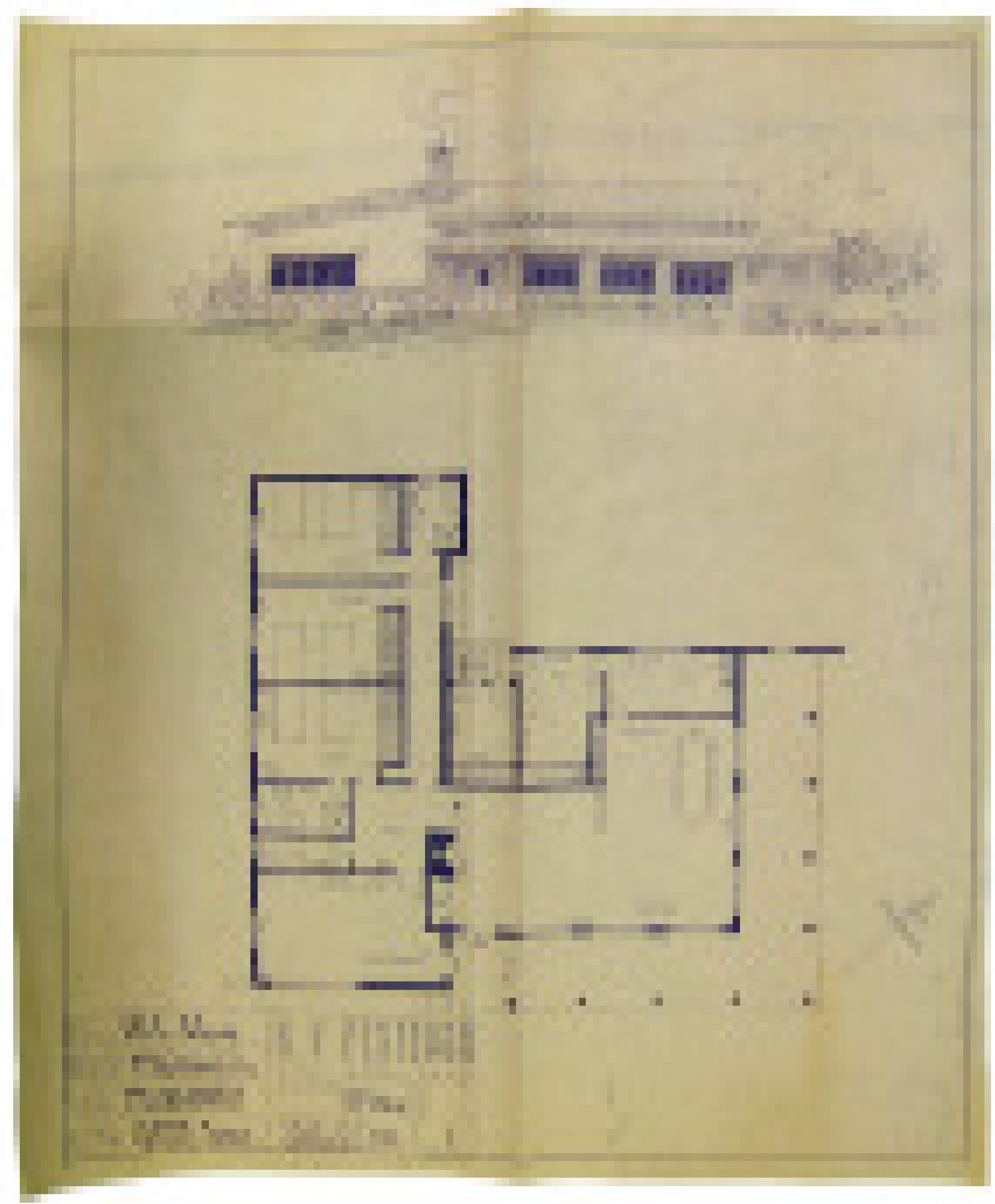

Figura 124 - Casa da administração da Fazenda Santa Helena, em Pindamonhangaba, de 1960, projetada pelo arquiteto Hernani do Val Penteado. Beirais no telhado e pedras no muro e na chaminé marcam a tendência tradicionalista, mas não se encontram estilemas neocoloniais. Fonte: Acervo de Projetos da FAUUSP. 


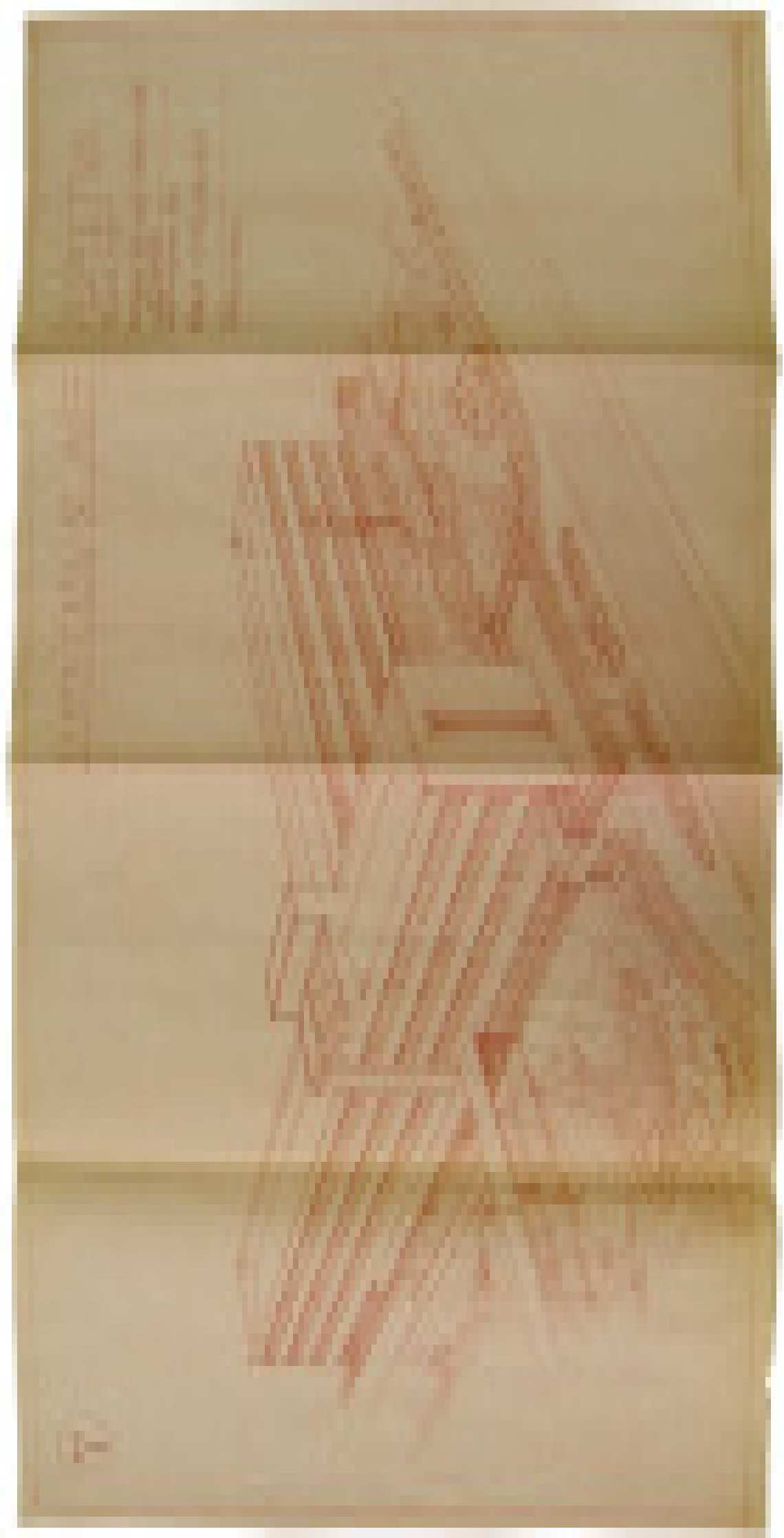

Figura 125 - Perspectiva de Hernani do Val Penteado para o prédio da Santa Casa de Jaú, de características já totalmente modernistas. Fonte: Acervo de Projetos da FAUUSP. 


\section{Capítulo 5}

\section{APROPRIAÇÃO, RECRIAÇÃO E DIFUSÃO DA ARQUITETURA NEOCOLONIAL PAULISTA}




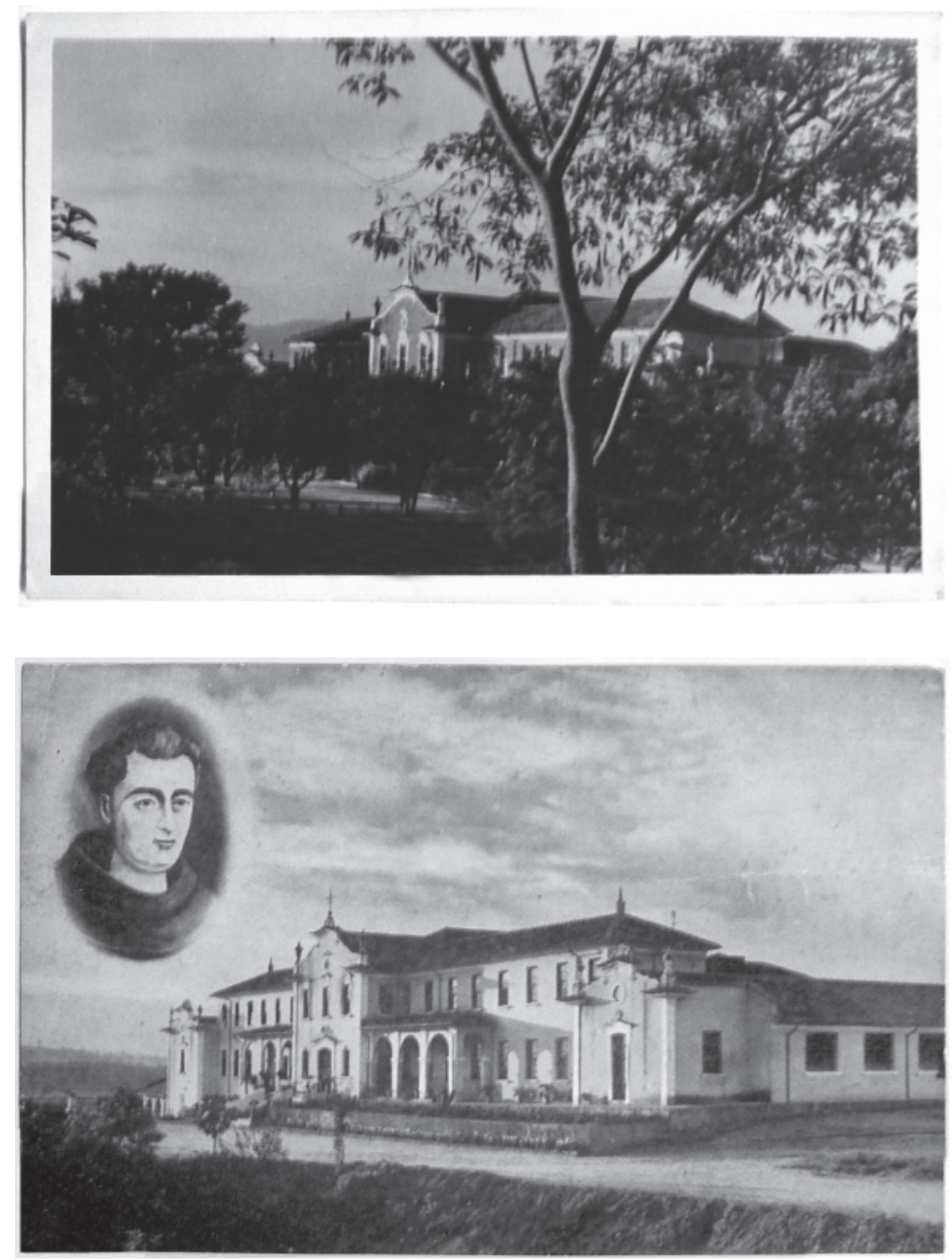

Figura 126 - Fotos antigas do Seminário "Frei Galvão", em Guaratinguetá. Notar, no lado direito do prédio, a ausência do muro em curva já existente nos registros fotográficos atuais. Fonte: Arquivo Municipal de Guaratinguetá. 

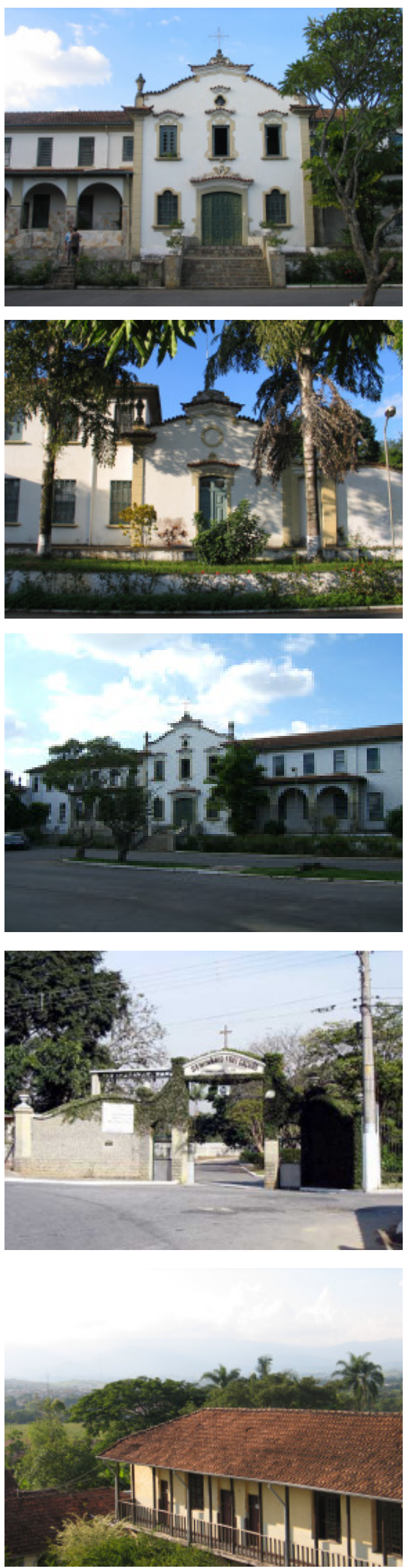
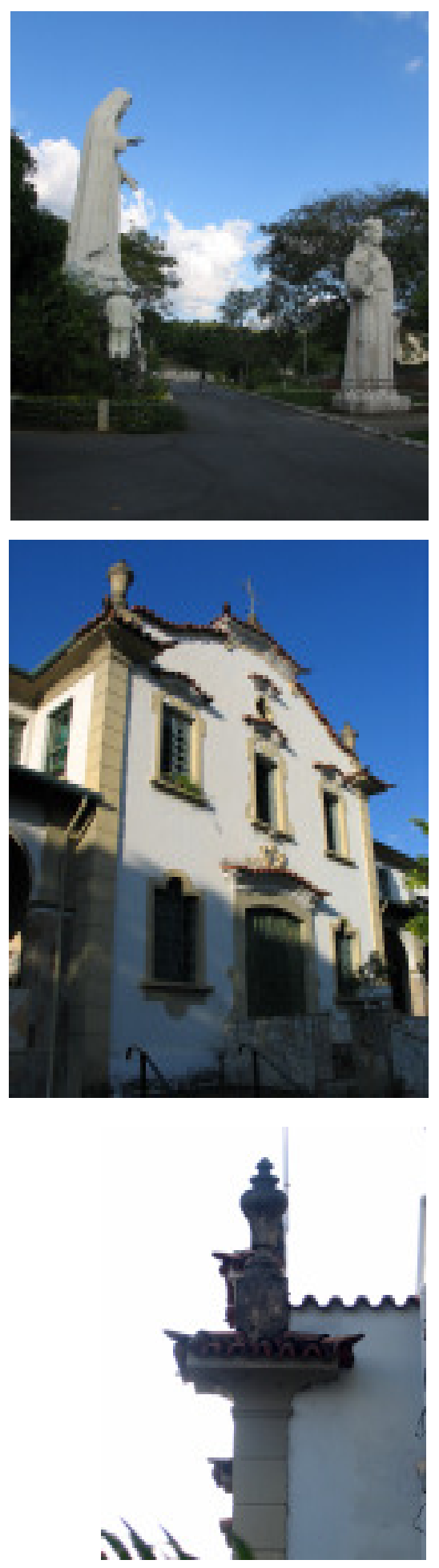

Figura 128 - Vistas do lado externo do Seminário "Frei Galvão", em Guaratinguetá. O portão de entrada também ostenta linhas curvas. Foto do portão disponível em: http://www.franciscanos.org.br/ fraternidades/casas/guara_post/ galeria.php. Acesso em: 13/04/2007. Demais fotos: V. Benincasa, abril de 2007. 

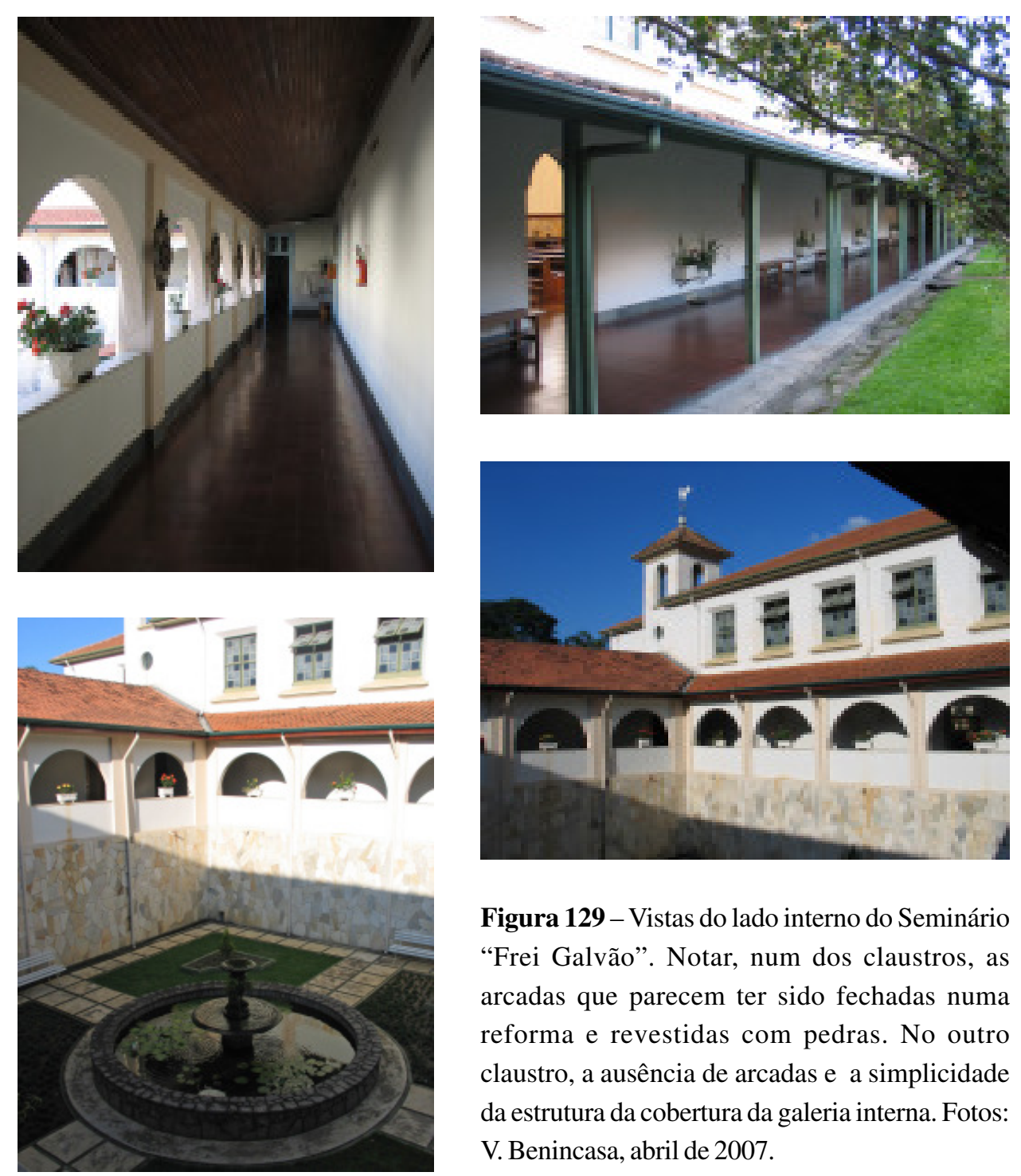

Figura 129 - Vistas do lado interno do Seminário "Frei Galvão". Notar, num dos claustros, as arcadas que parecem ter sido fechadas numa reforma e revestidas com pedras. No outro claustro, a ausência de arcadas e a simplicidade da estrutura da cobertura da galeria interna. Fotos: V. Benincasa, abril de 2007. 

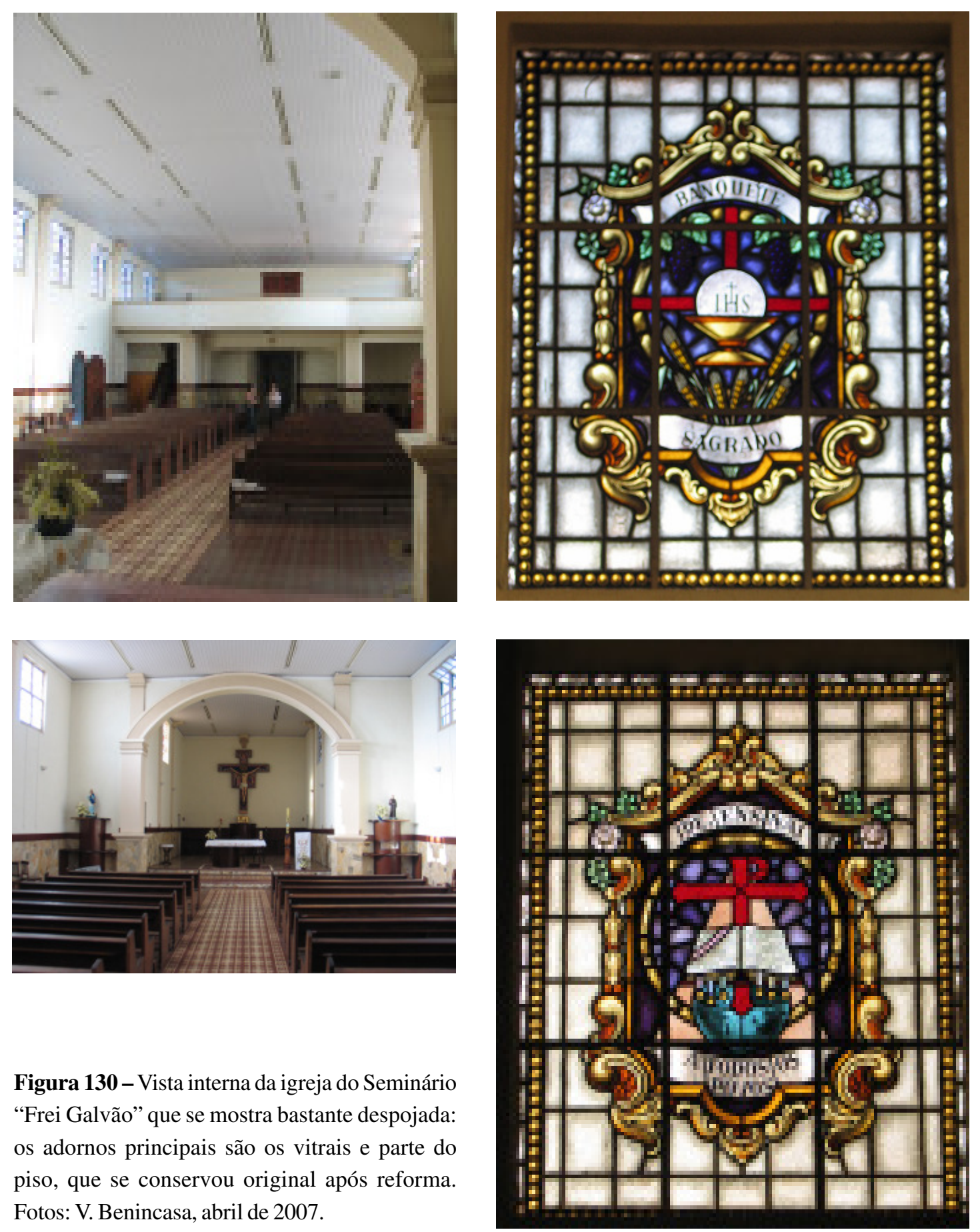

Figura 130 - Vista interna da igreja do Seminário "Frei Galvão" que se mostra bastante despojada: os adornos principais são os vitrais e parte do piso, que se conservou original após reforma. Fotos: V. Benincasa, abril de 2007. 

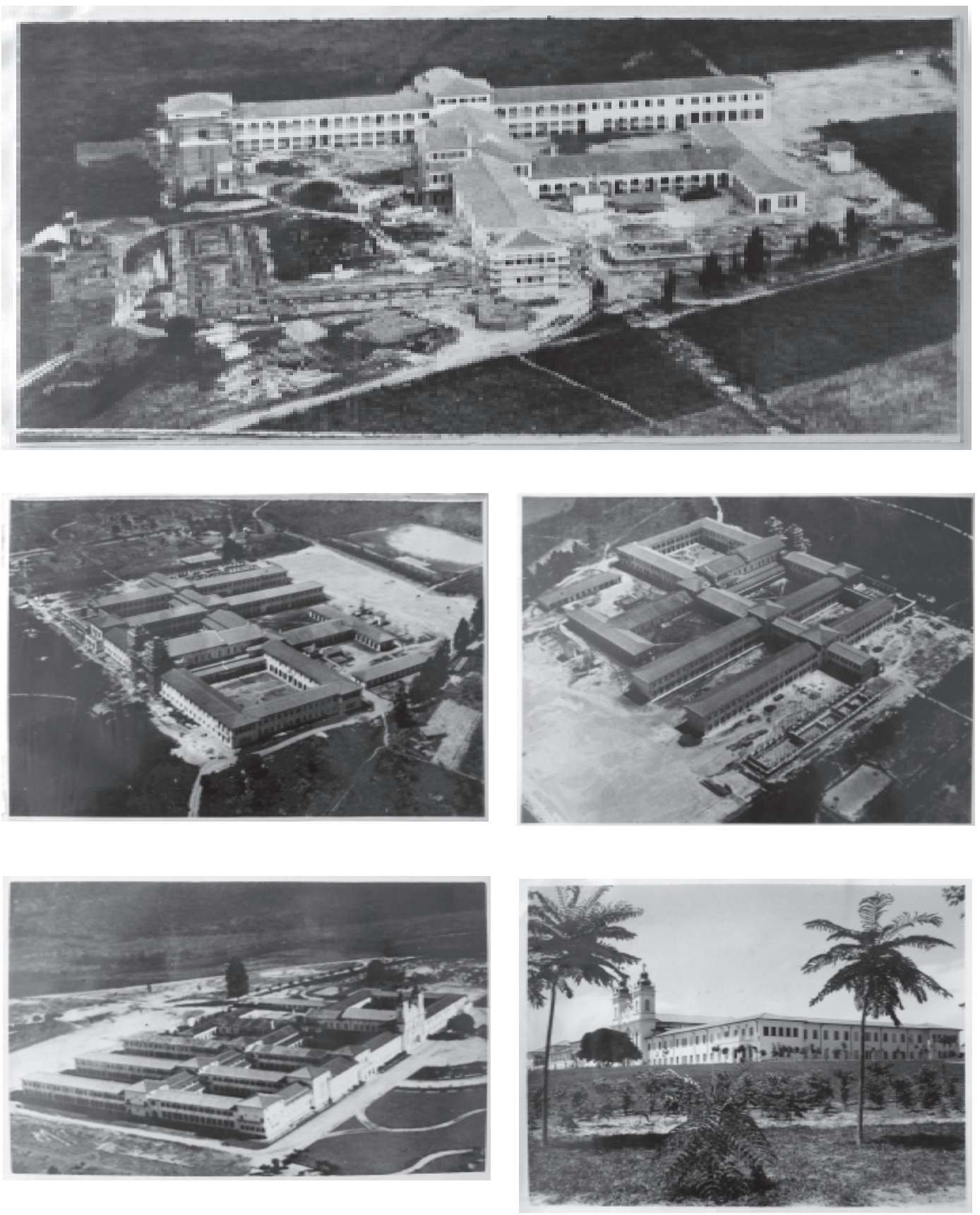

Figura 131 - Fotos da época da construção do Seminário "Santo Antonio", de Agudos. Vemos várias fases de construção: primeiro, as alas posteriores; em seguida, os claustros já fechados e as torres da igreja em construção; e, finalmente, o seminário terminado. Fonte: Museu Histórico "Plínio Machado Cárdia”, Agudos. 


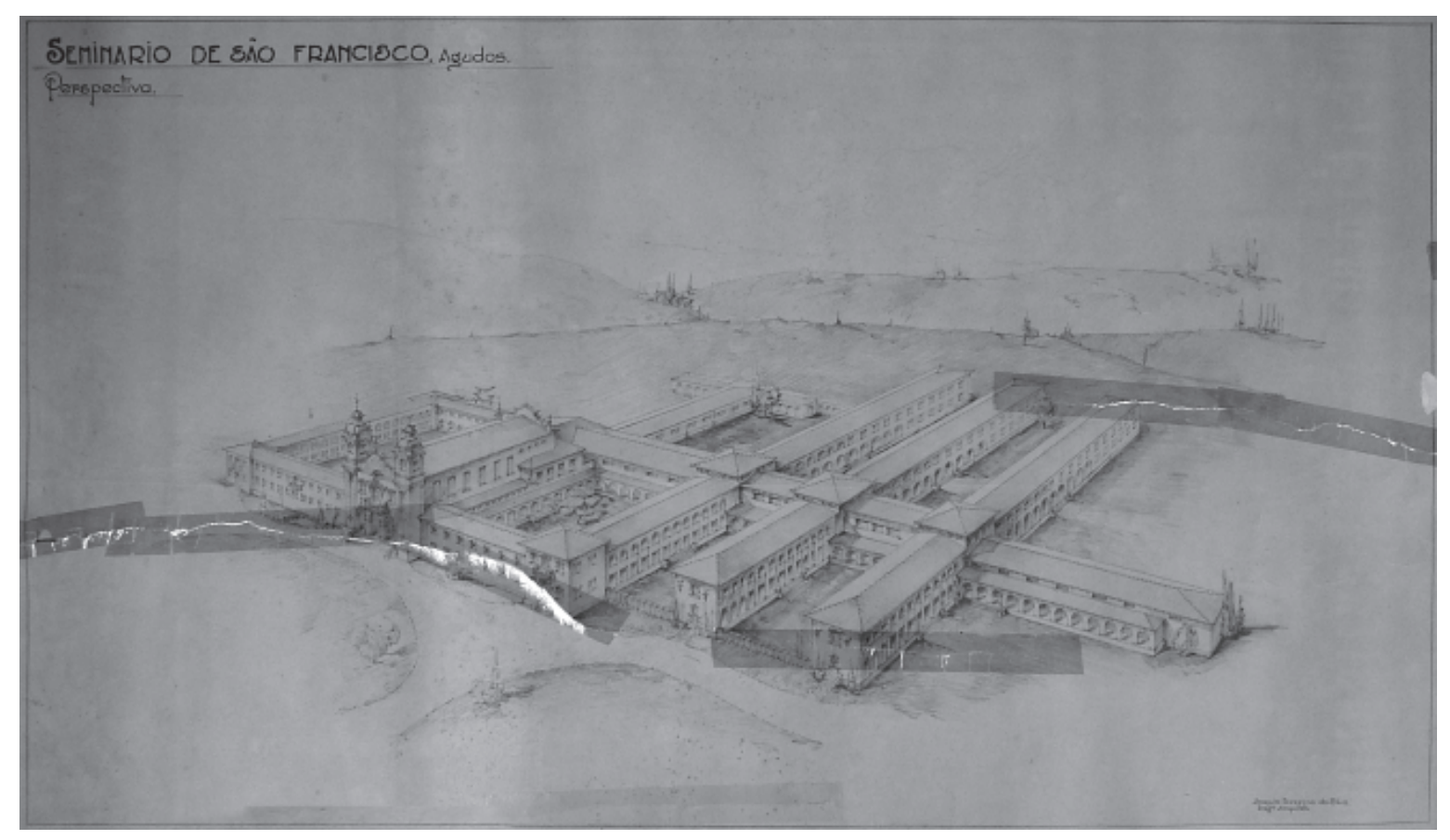

Figura 132 - Perspectiva do arquiteto Joaquim Bezerra da Silva para o prédio do Seminário "Santo Antonio", de Agudos. Vemos no projeto que o nome do seminário está equivocado. Fonte: Arquivo da Sede Provincial da Ordem Franciscana, São Paulo. 

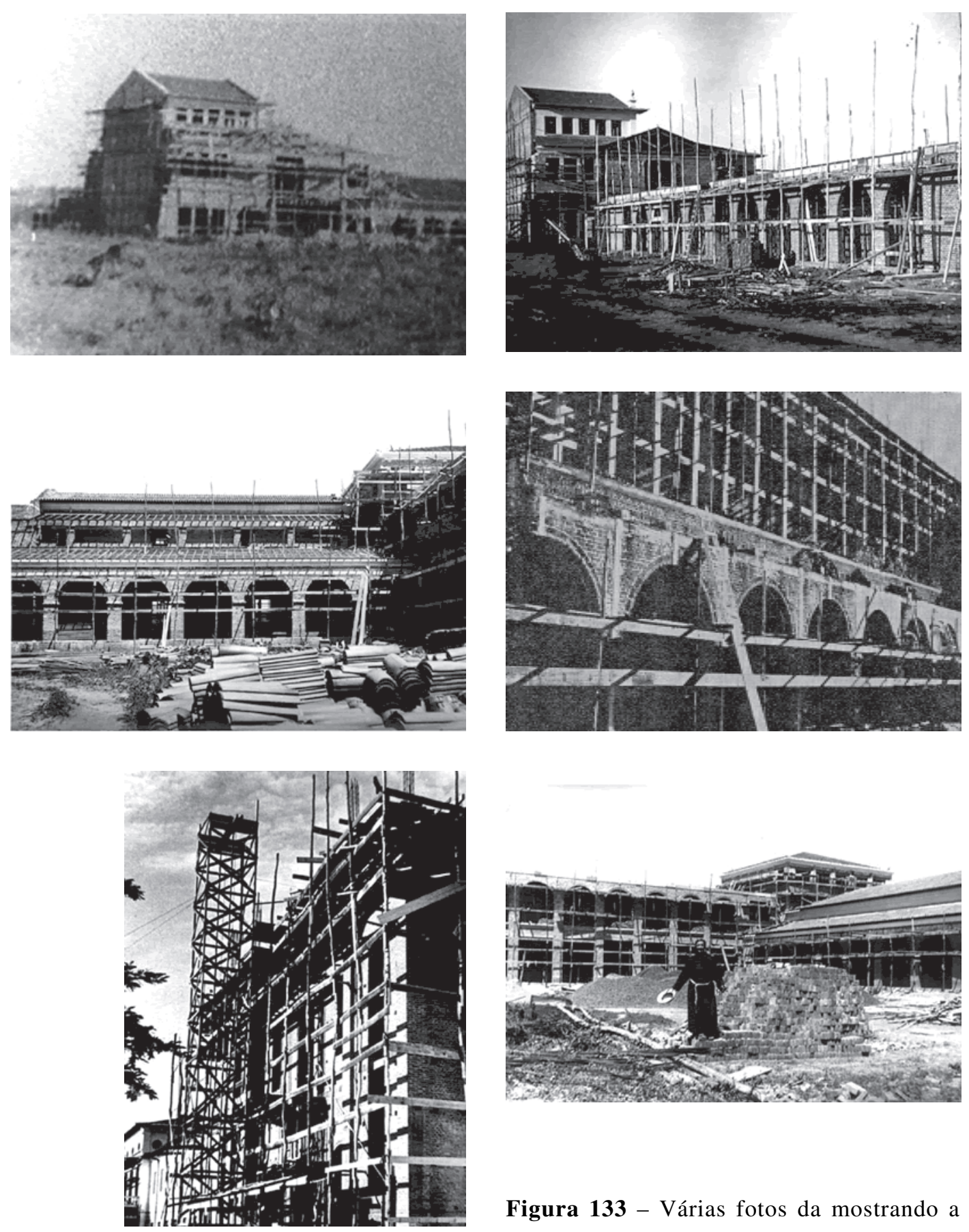

Figura 133 - Várias fotos da mostrando a construção do Seminário "Santo Antonio", de Agudos, mostrando também um pouco dos materiais de construção utilizados. Disponível em: http://www.seminario.org.br/. Acesso em: 15/04/ 2008. 

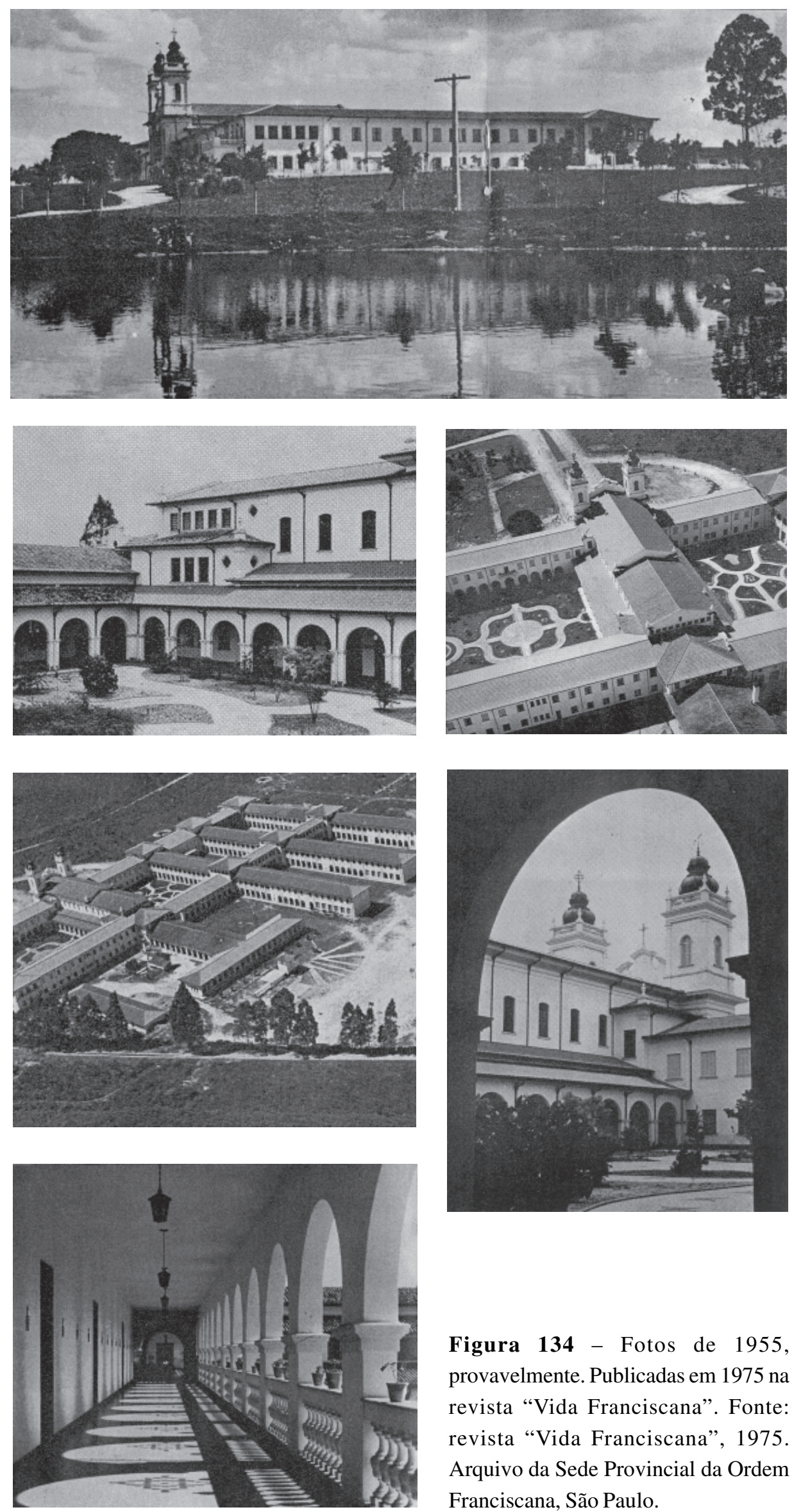

Figura 134 - Fotos de 1955, provavelmente. Publicadas em 1975 na revista "Vida Franciscana". Fonte: revista "Vida Franciscana", 1975. Arquivo da Sede Provincial da Ordem Franciscana, São Paulo. 

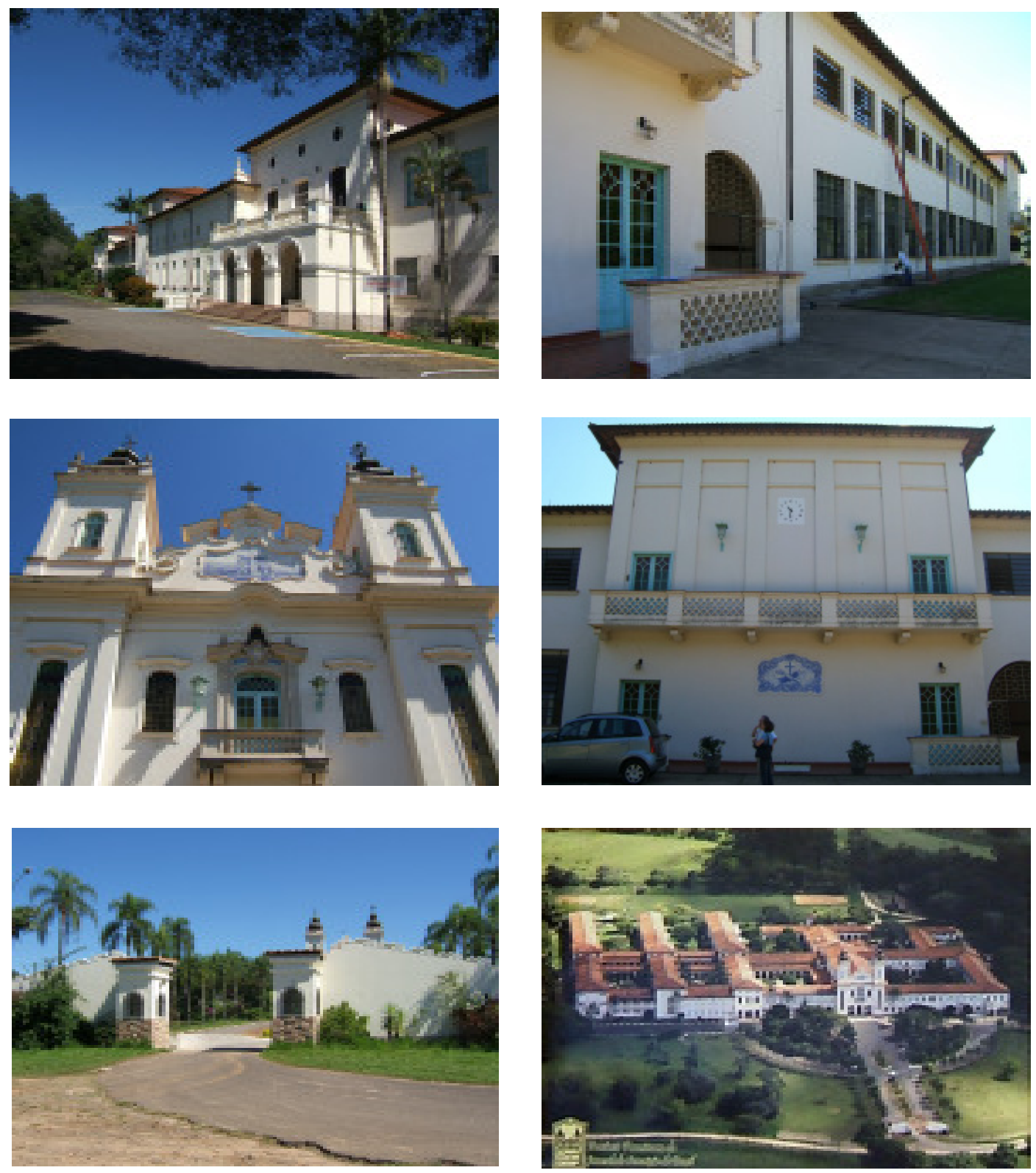

Figura 135 - Aspectos do lado externo do Seminário "Santo Antonio", de Agudos. Destaque para o portão de entrada decorado por várias pequenas volutas e pedras aplicadas aos muros. A igreja no eixo de simetria formado pelo caminho de acesso confere mais imponência ao prédio. Vemos também outros aspectos das fachadas anteriores e posteriores. Fonte: foto da autora, abril de 2007. 

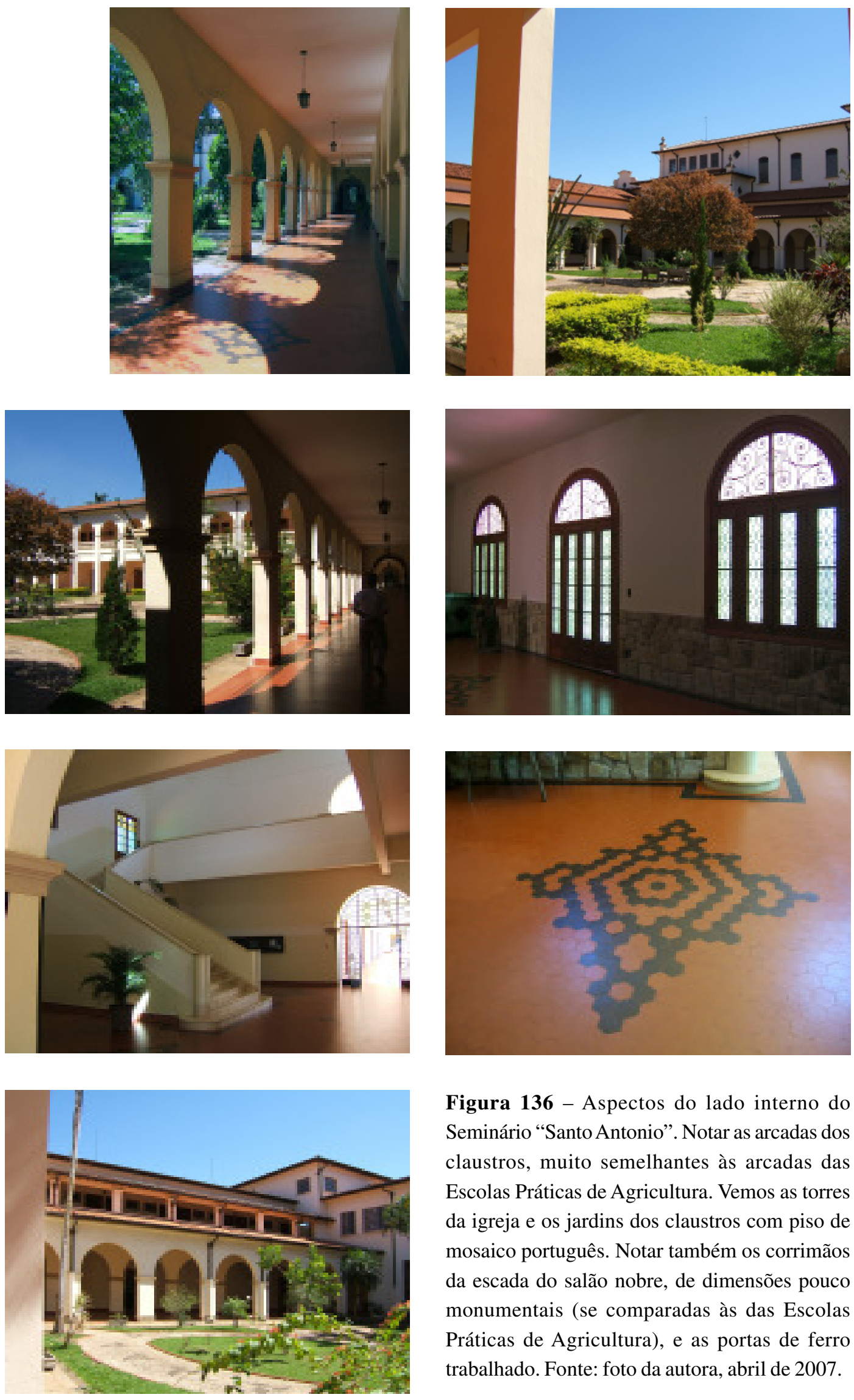

Figura 136 - Aspectos do lado interno do Seminário "Santo Antonio". Notar as arcadas dos claustros, muito semelhantes às arcadas das Escolas Práticas de Agricultura. Vemos as torres da igreja e os jardins dos claustros com piso de mosaico português. Notar também os corrimãos da escada do salão nobre, de dimensões pouco monumentais (se comparadas às das Escolas Práticas de Agricultura), e as portas de ferro trabalhado. Fonte: foto da autora, abril de 2007. 

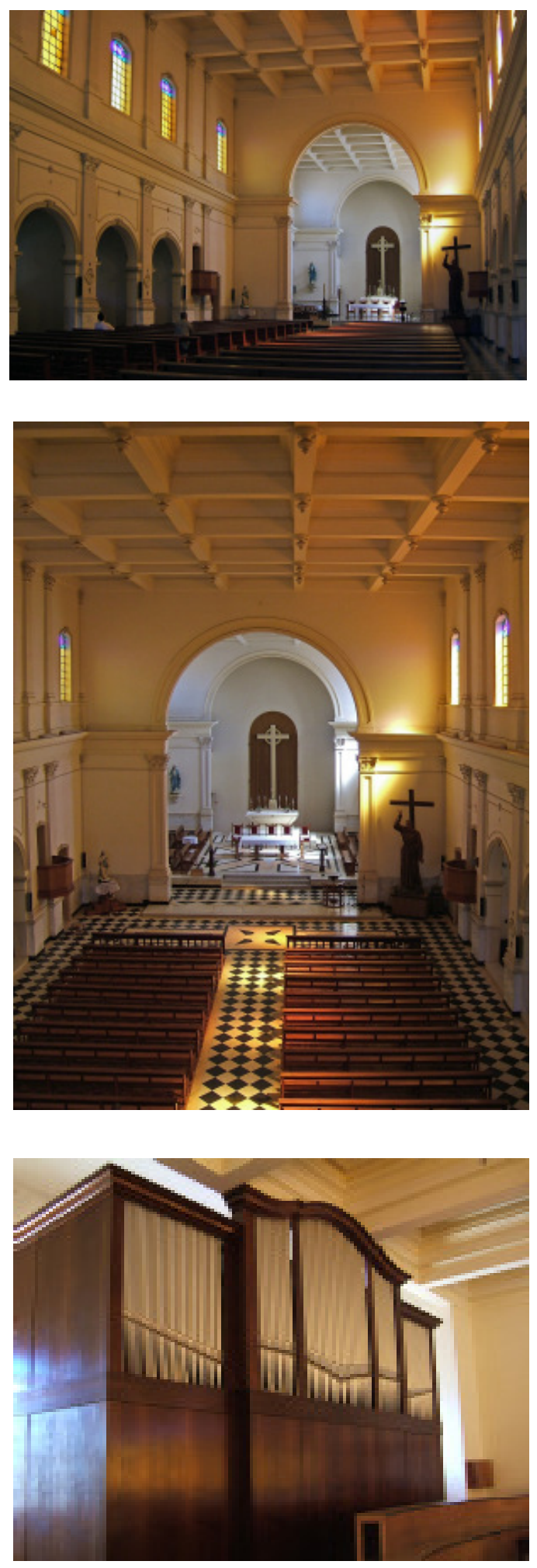

Figura 137 - O interior da igreja do Seminário "Santo Antonio" se apresenta pouco decorado, com janelas de vidros coloridos e piso de mosaico de mármore e granito. Vemos também o órgão construído por um dos freis, na década de 1940. Fonte: foto da autora, abril de 2007. 

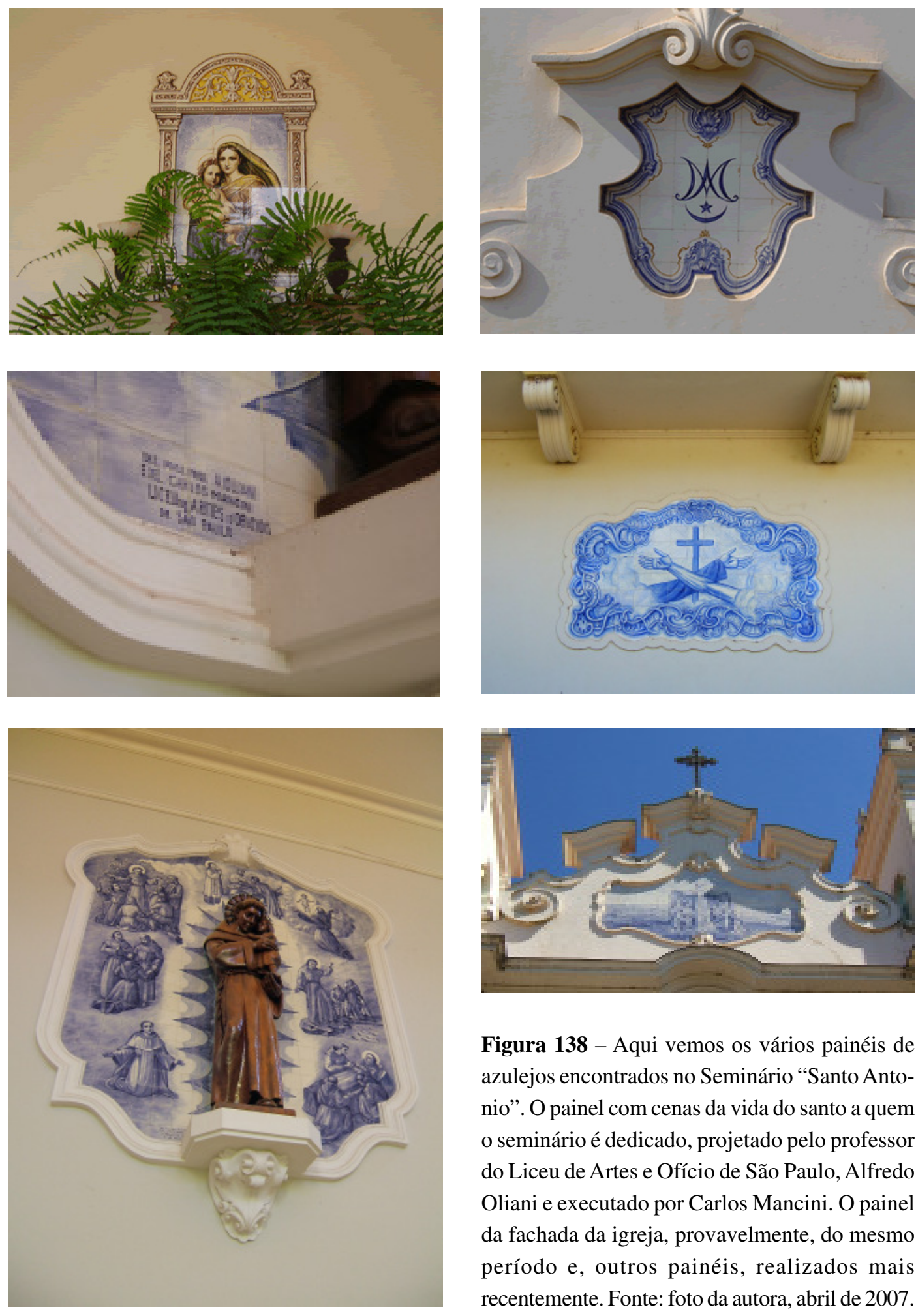

Figura 138 - Aqui vemos os vários painéis de azulejos encontrados no Seminário "Santo Antonio". O painel com cenas da vida do santo a quem o seminário é dedicado, projetado pelo professor do Liceu de Artes e Ofício de São Paulo, Alfredo Oliani e executado por Carlos Mancini. O painel da fachada da igreja, provavelmente, do mesmo período e, outros painéis, realizados mais recentemente. Fonte: foto da autora, abril de 2007. 


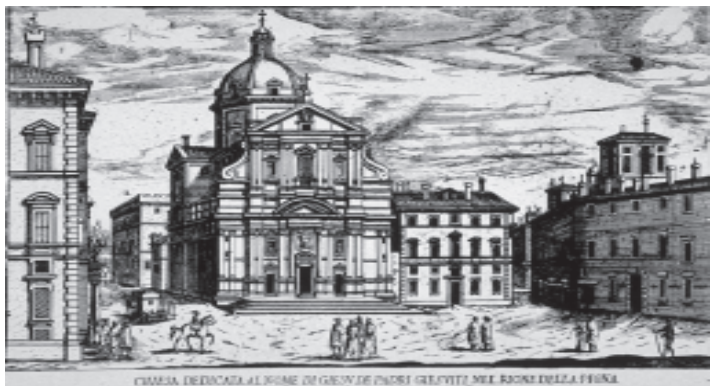

Figura 139 (acima) - Igreja de Jesus, em Roma, que teve parte do projeto realizado por Vignola em fins do século XVI e fachada construída por Giacomo della Porta no mesmo período. Disponível em: h t t p ://www.chies adelgesu.org/ht ml/ img_0006_it.html.Acesso em: 10/04/2008.
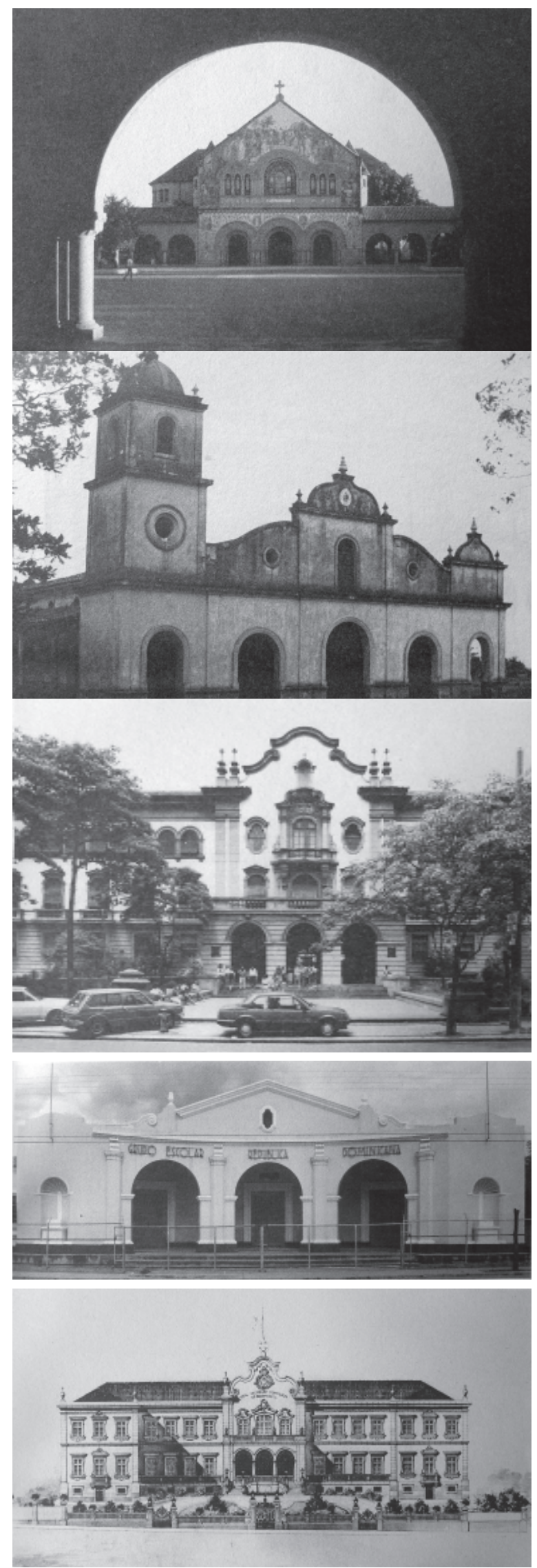

Figura 140 (acima) - Três arcos comuns na arquitetura neocolonial de toda a América Latina. Fonte: Amaral (1994, p. 55, 78, 144, 247, 257). 

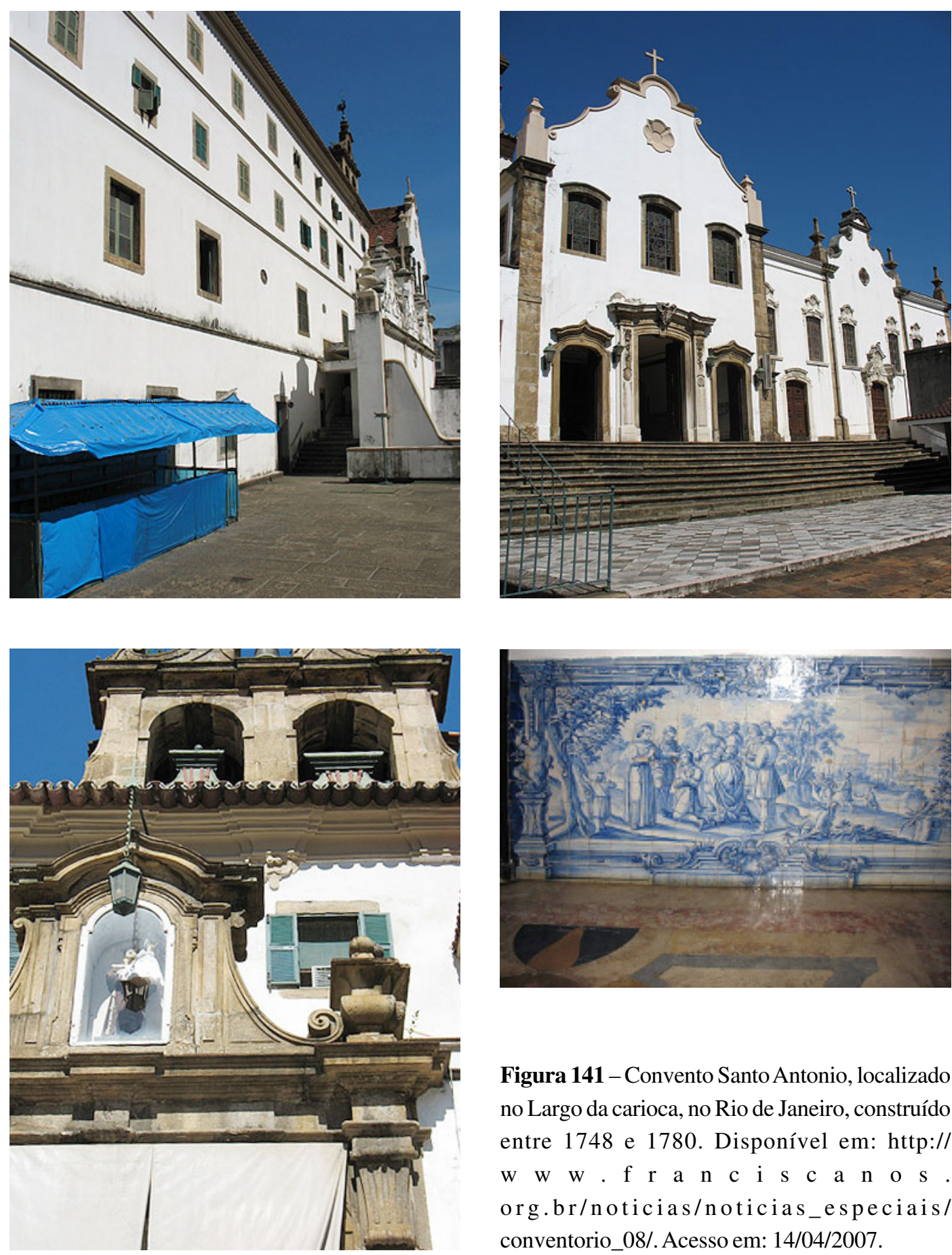

Figura 141 - Convento Santo Antonio, localizado no Largo da carioca, no Rio de Janeiro, construído entre 1748 e 1780. Disponível em: http:// w w w . f $r$ a $n$ c org.br/noticias/noticias_especiais/ conventorio_08/.Acesso em: 14/04/2007. 


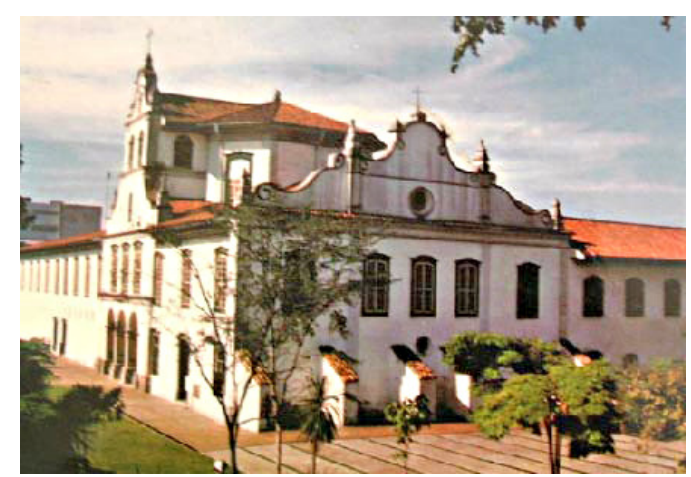

Figura 142 (acima) - Mosteiro da Luz, São Paulo. Disponível em: http://www.saofreigalvao.com.br/ index.php?option=content\&task=view\&id=19. Acesso em: 14/04/2007.

Figura 143 (abaixo e a direita) - Fotos Convento Nossa Senhora do Amparo, São Sebastião, século XVII. Disponível em: http:// www.franciscanos.org.br/fraternidades/casas/ saosebastiao/32.php. Acesso em: 24/06/2007.

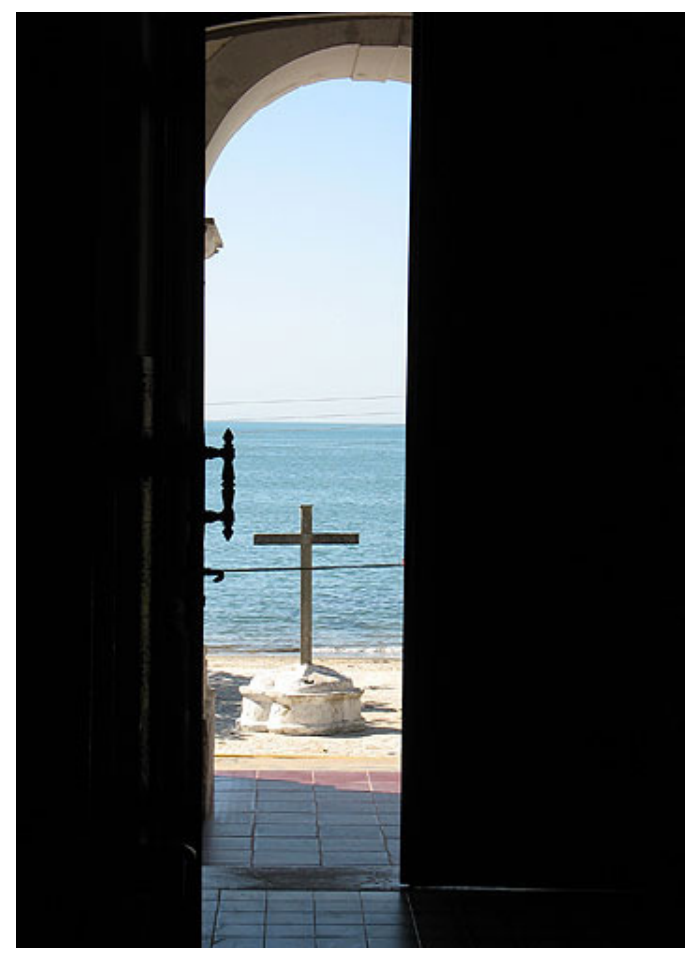

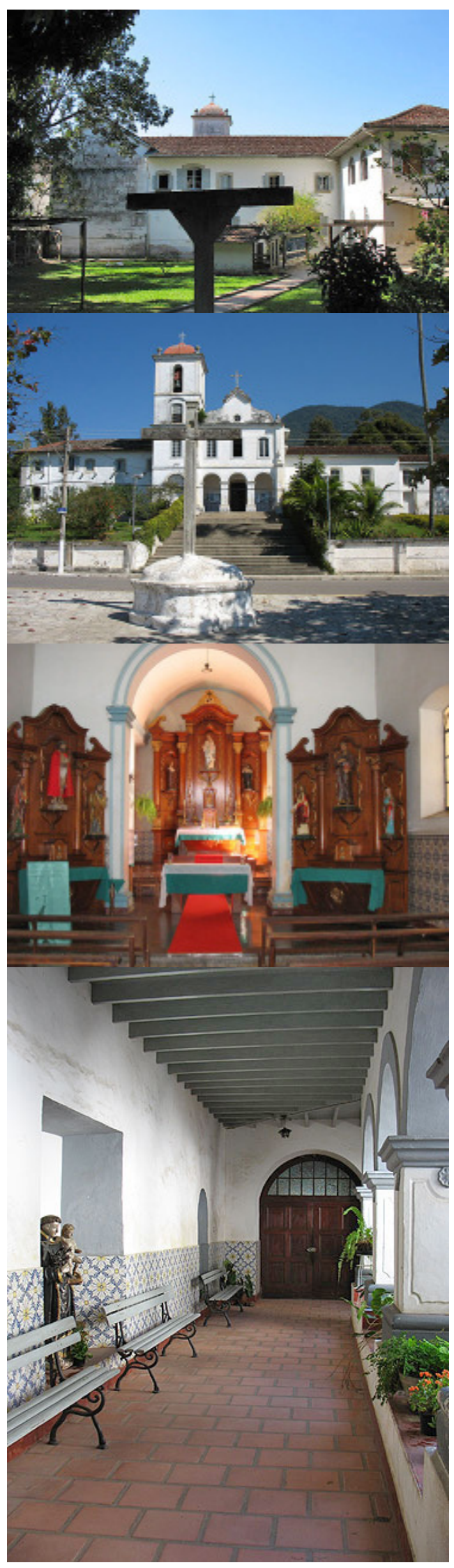



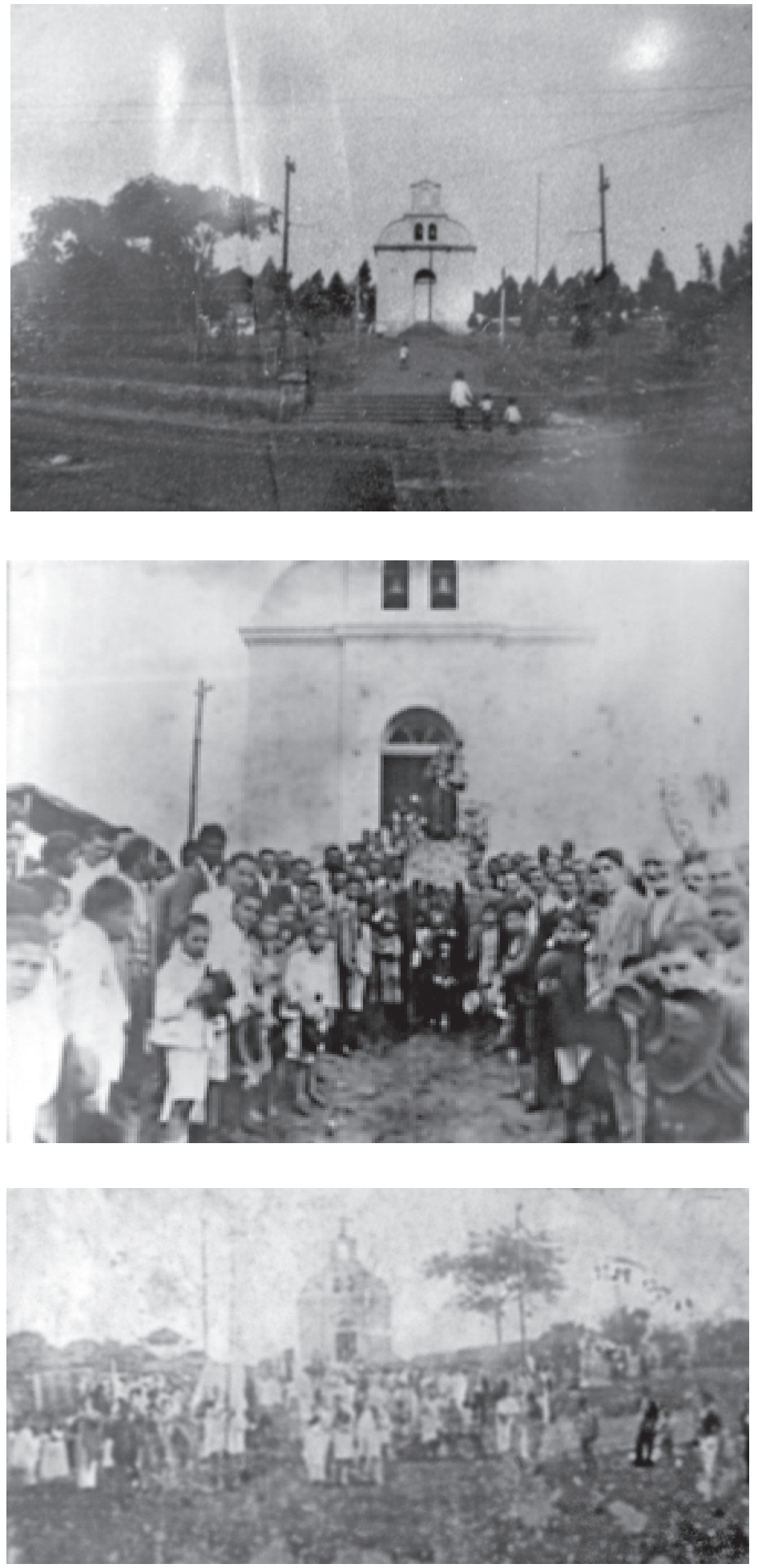

Figura 145 - Antiga capela da paróquia de Santo Antonio em Agudos. Em seu lugar foi construída a atual igreja da paróquia de Santo Antonio (Figura 146). Fonte: Museu Histórico "Plínio Machado Cárdia", Agudos. 

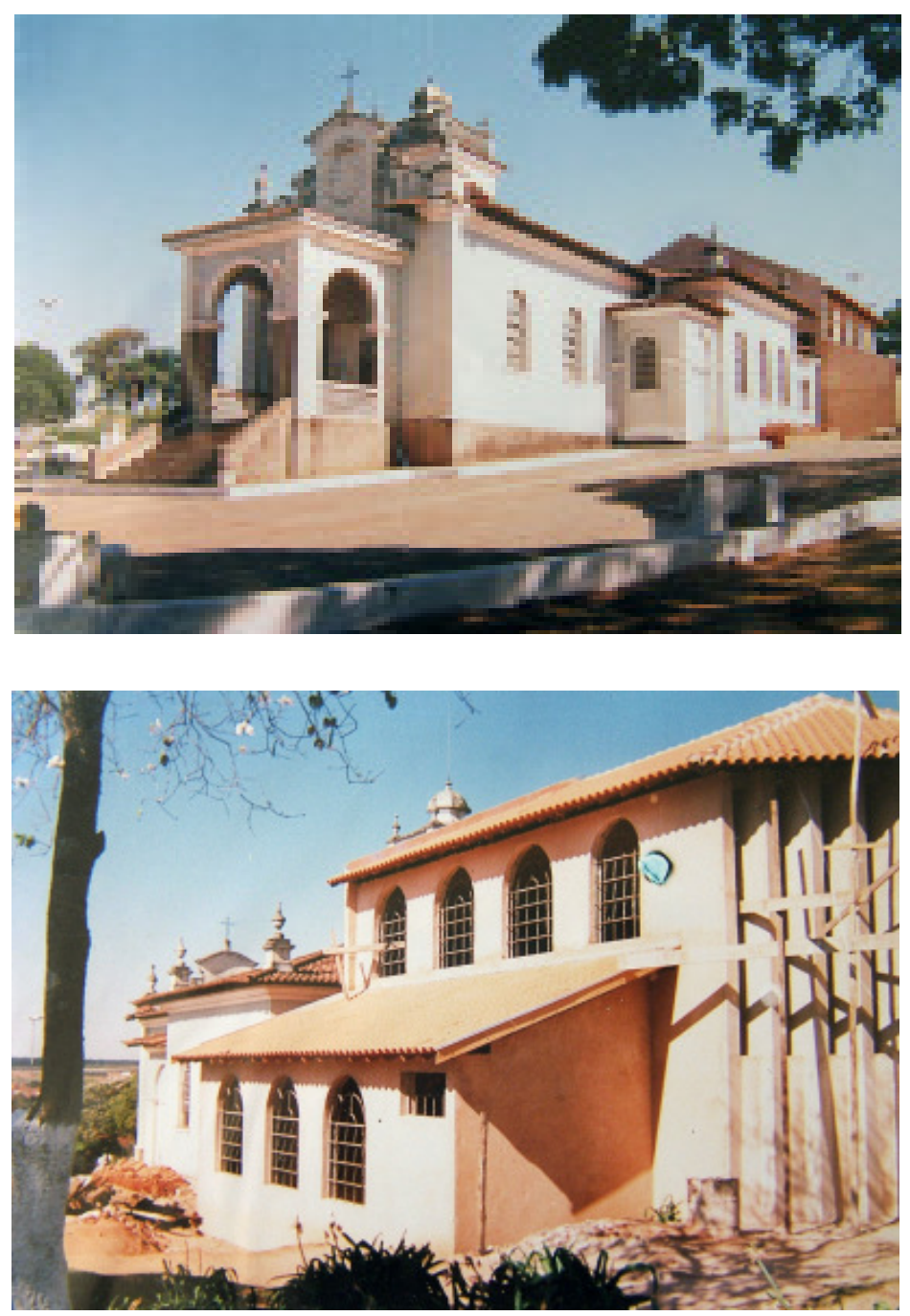

Figura 146 - Construção de um anexo posterior à atual igreja da paróquia de Santo Antonio. Fonte: Museu Histórico "Plínio Machado Cárdia”, Agudos. 

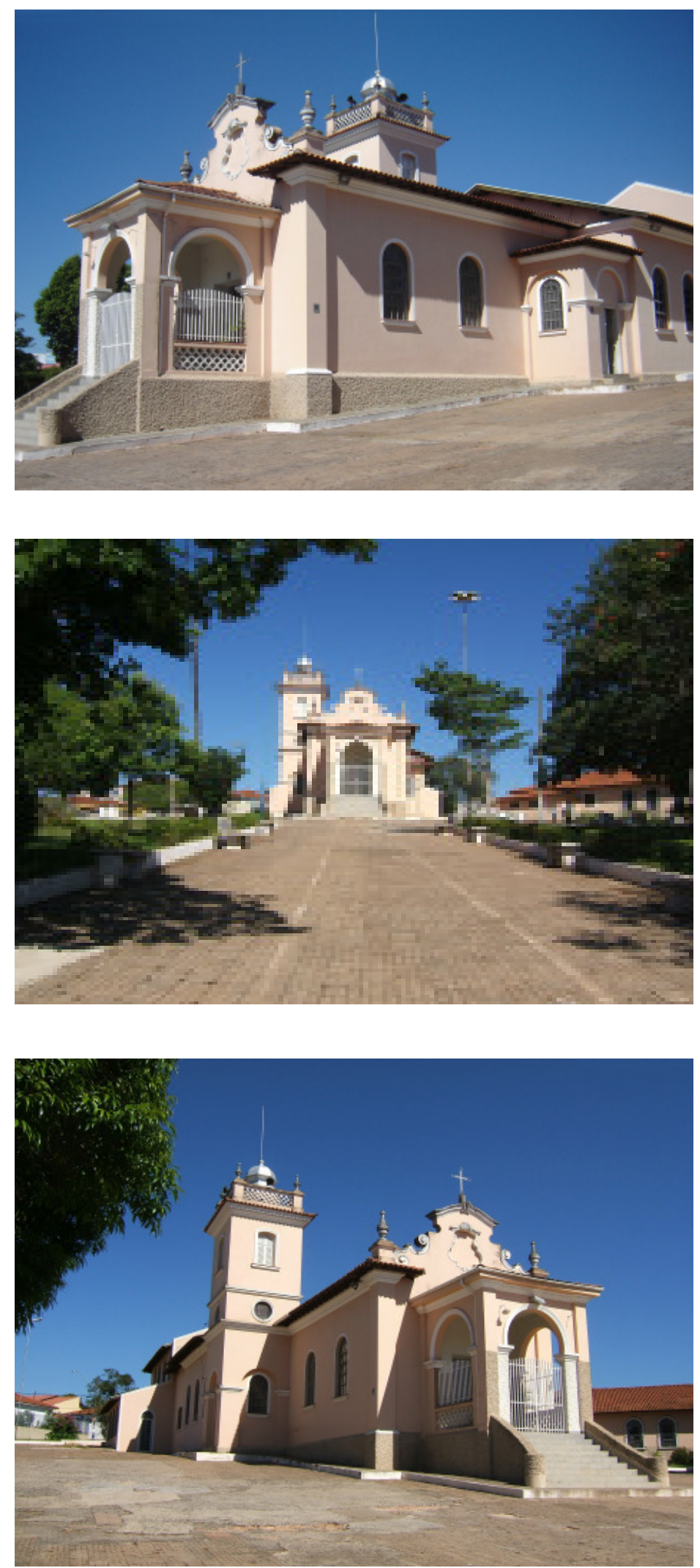

Figura 147 - Fotos atuais da igreja da paróquia de Santo Antonio, em Agudos. Notar semelhança com a igreja do Seminário "Santo Antonio". Fonte: fotos da autora, abril de 2007. Lateral direita, fonte: M. A. Bortolucci, abril de 2007. 

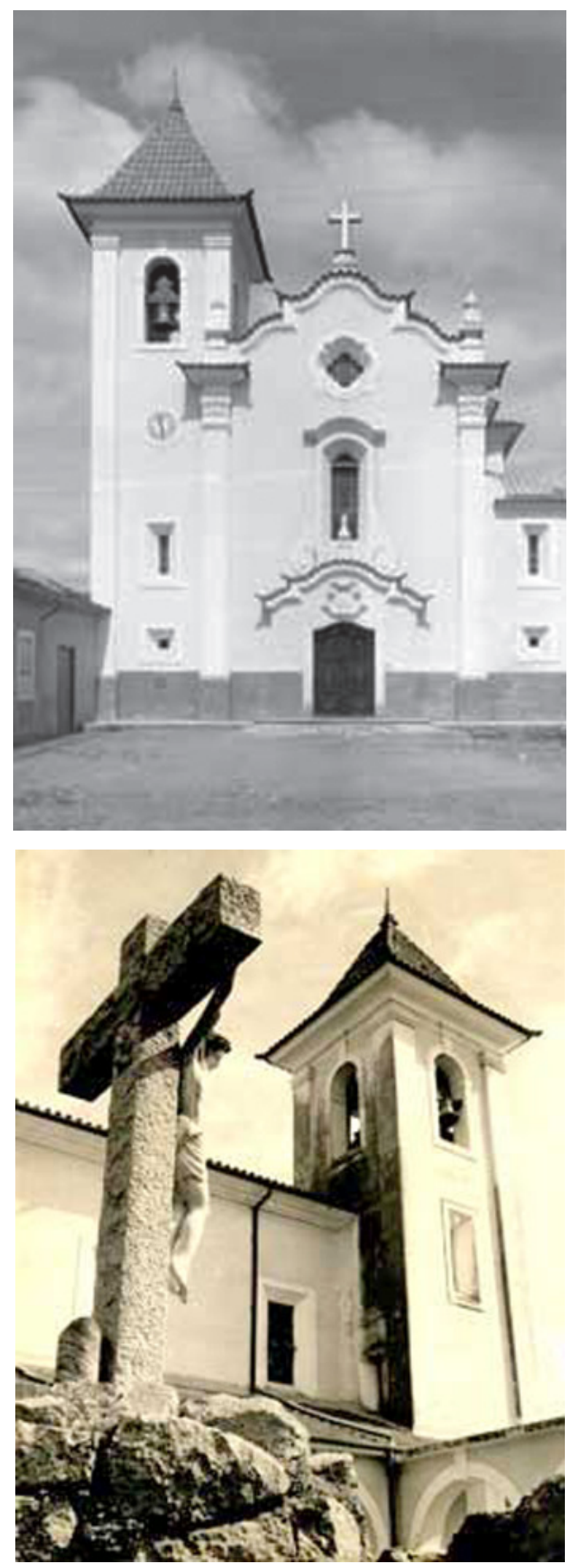

Figura 148 - Fotos antigas da igreja de Nossa Senhora das Graças, de Guaratinguetá. Notar que a torre sineira guarda maior fidelidade com a arquitetura colonial religiosa. Disponível em: http://www.franciscanos.org.br/ fraternidades/casas/gracas/historia.php. Acesso em: 14/ 04/2008. 

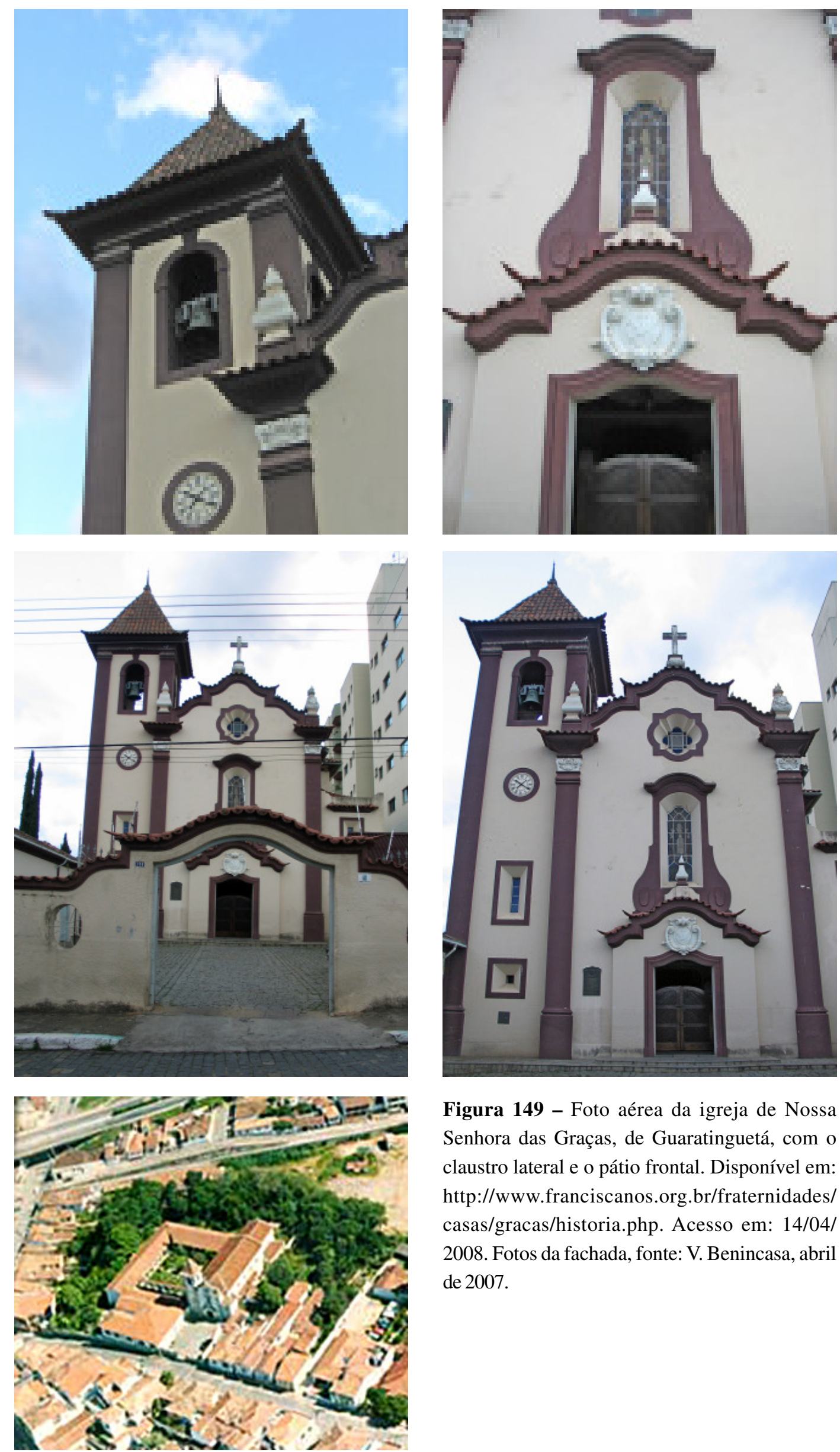

Figura 149 - Foto aérea da igreja de Nossa Senhora das Graças, de Guaratinguetá, com o claustro lateral e o pátio frontal. Disponível em: http://www.franciscanos.org.br/fraternidades/ casas/gracas/historia.php. Acesso em: 14/04/ 2008. Fotos da fachada, fonte: V. Benincasa, abril de 2007. 

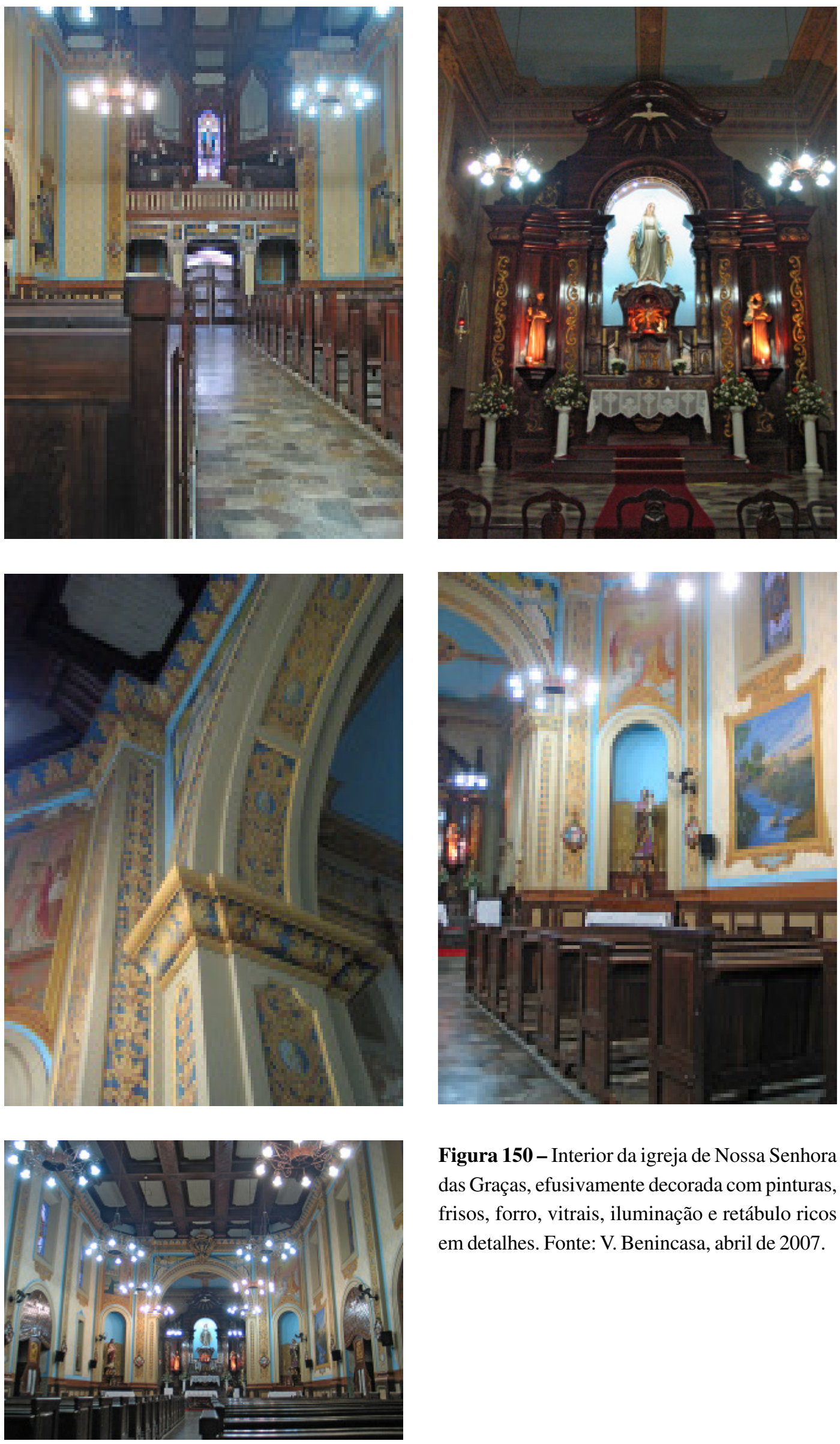

Figura 150 - Interior da igreja de Nossa Senhora das Graças, efusivamente decorada com pinturas, frisos, forro, vitrais, iluminação e retábulo ricos em detalhes. Fonte: V. Benincasa, abril de 2007. 


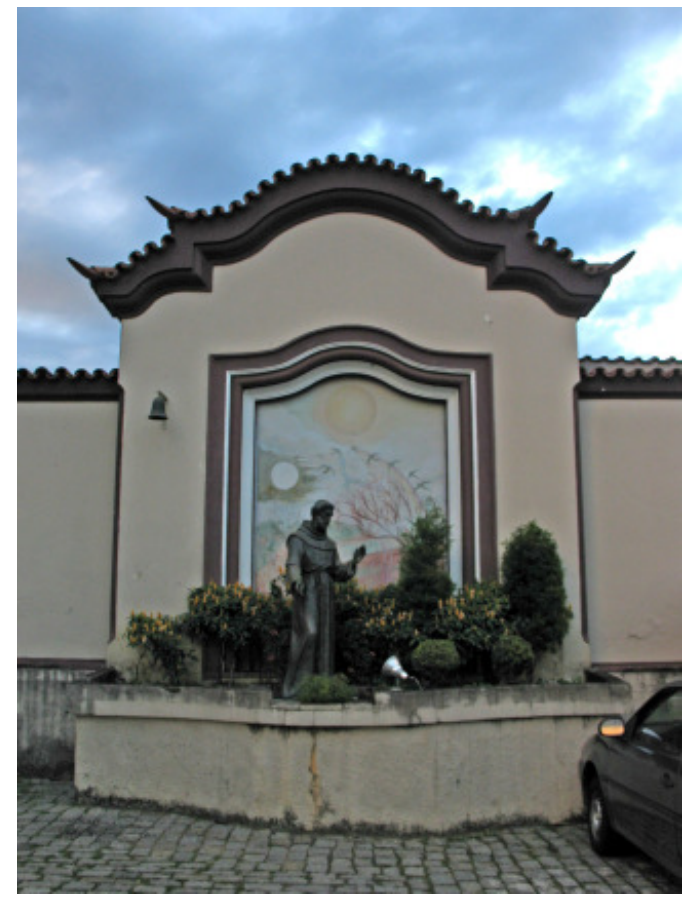

Figura 151 (acima) - Painel pintado por trás da imagem de São Francisco de Assis no pátio frontal da igreja de Nossa Senhora das Graças, Guaratinguetá. Fonte: V. Benincasa, Abril de 2007.

Figura 152 (abaixo e à direita) - Algumas imagens do claustro da igreja de Nossa Senhora das Graças. Disponível em: http://www.franciscanos.org.br/ fraternidades/casas/gracas/historia.php Acesso em: 14/04/2008.

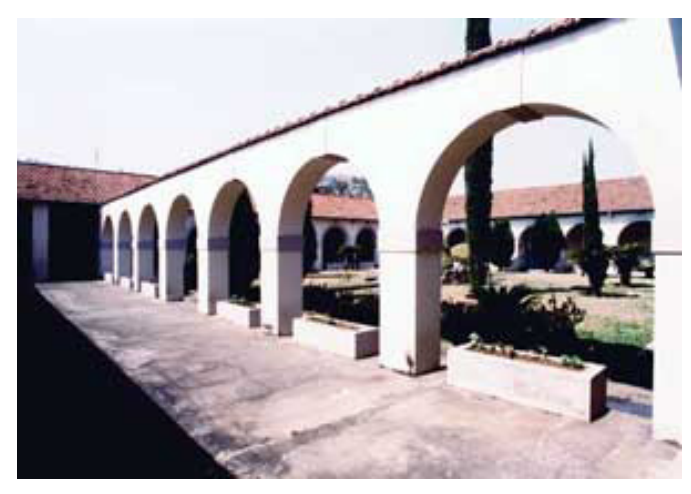

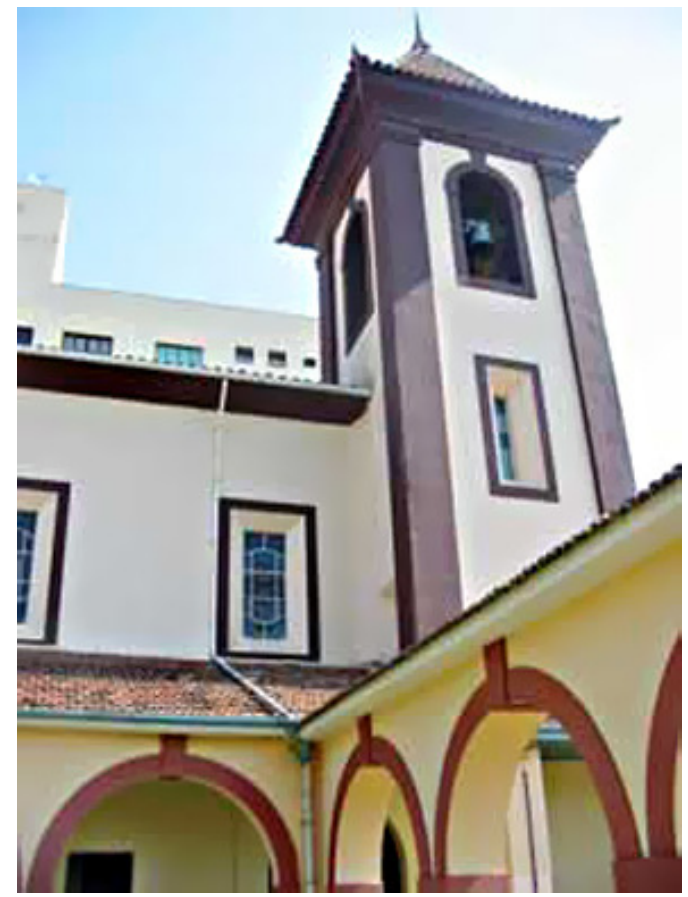
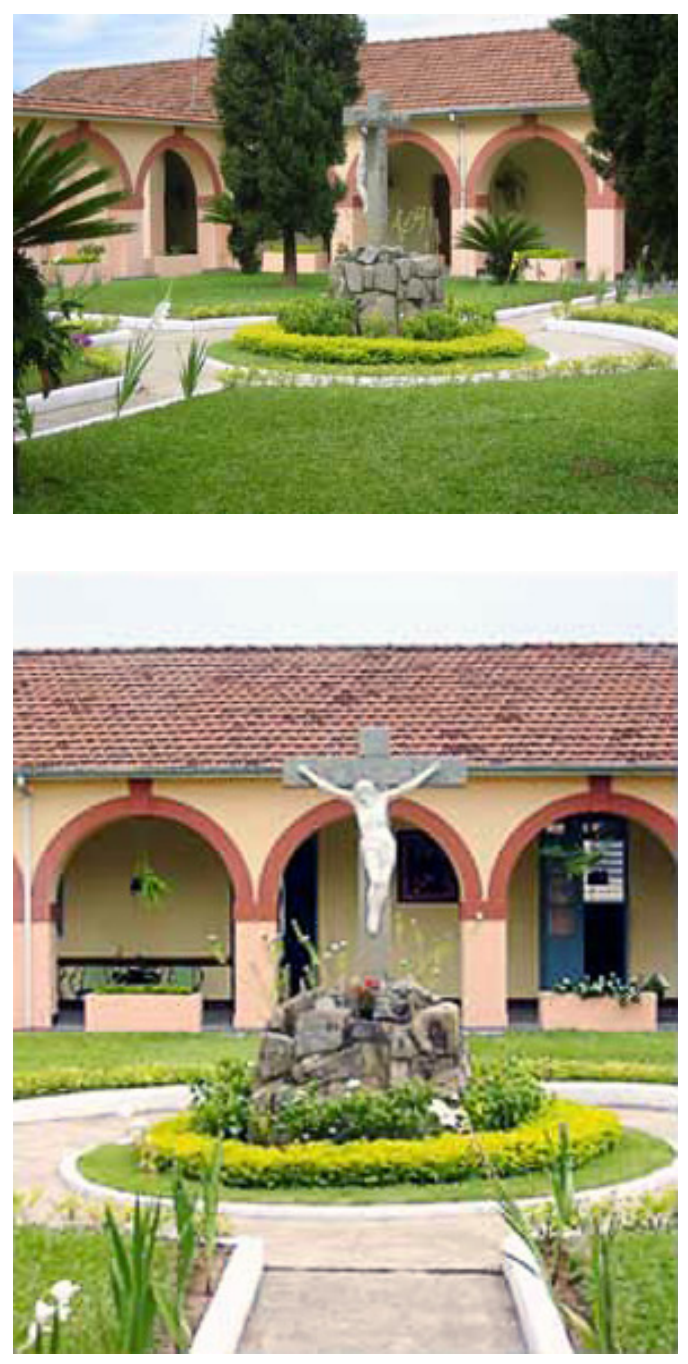

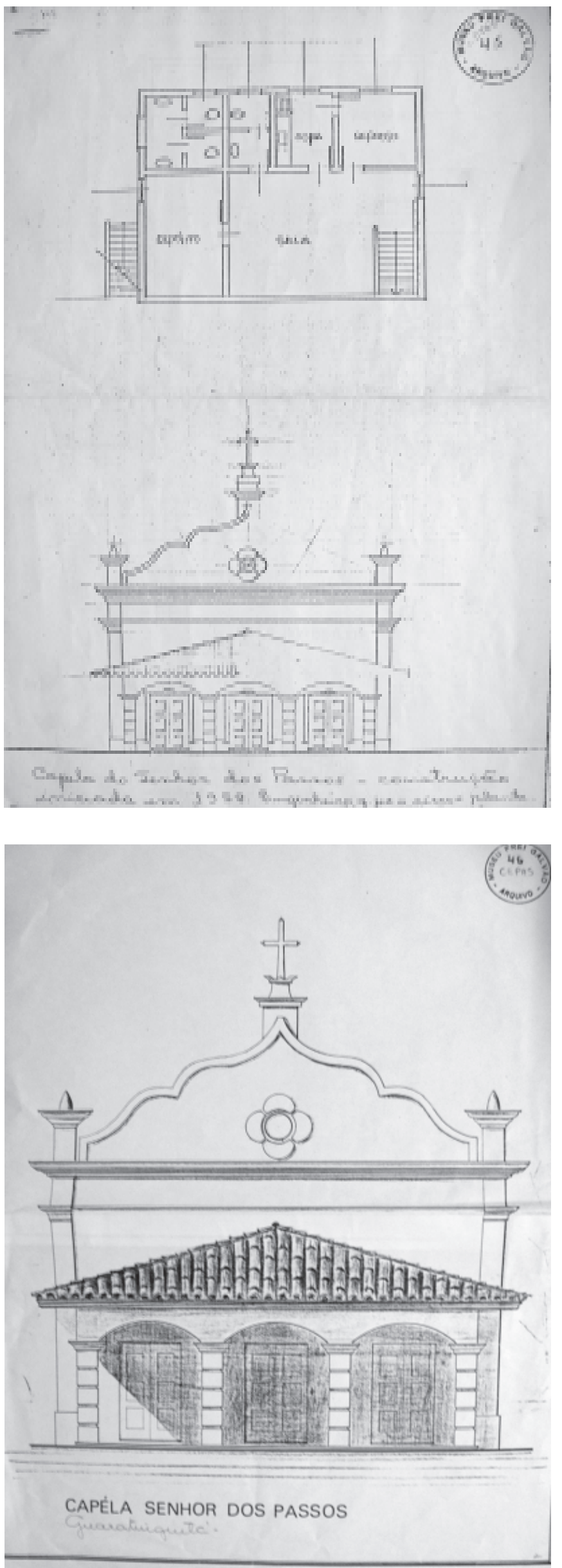

Figura 153 - Projeto do engenheiro João Maurício Sampaio para a capela do Cemitério dos Passos, de Guaratinguetá. Fonte: Arquivo Municipal de Guaratinguetá. 

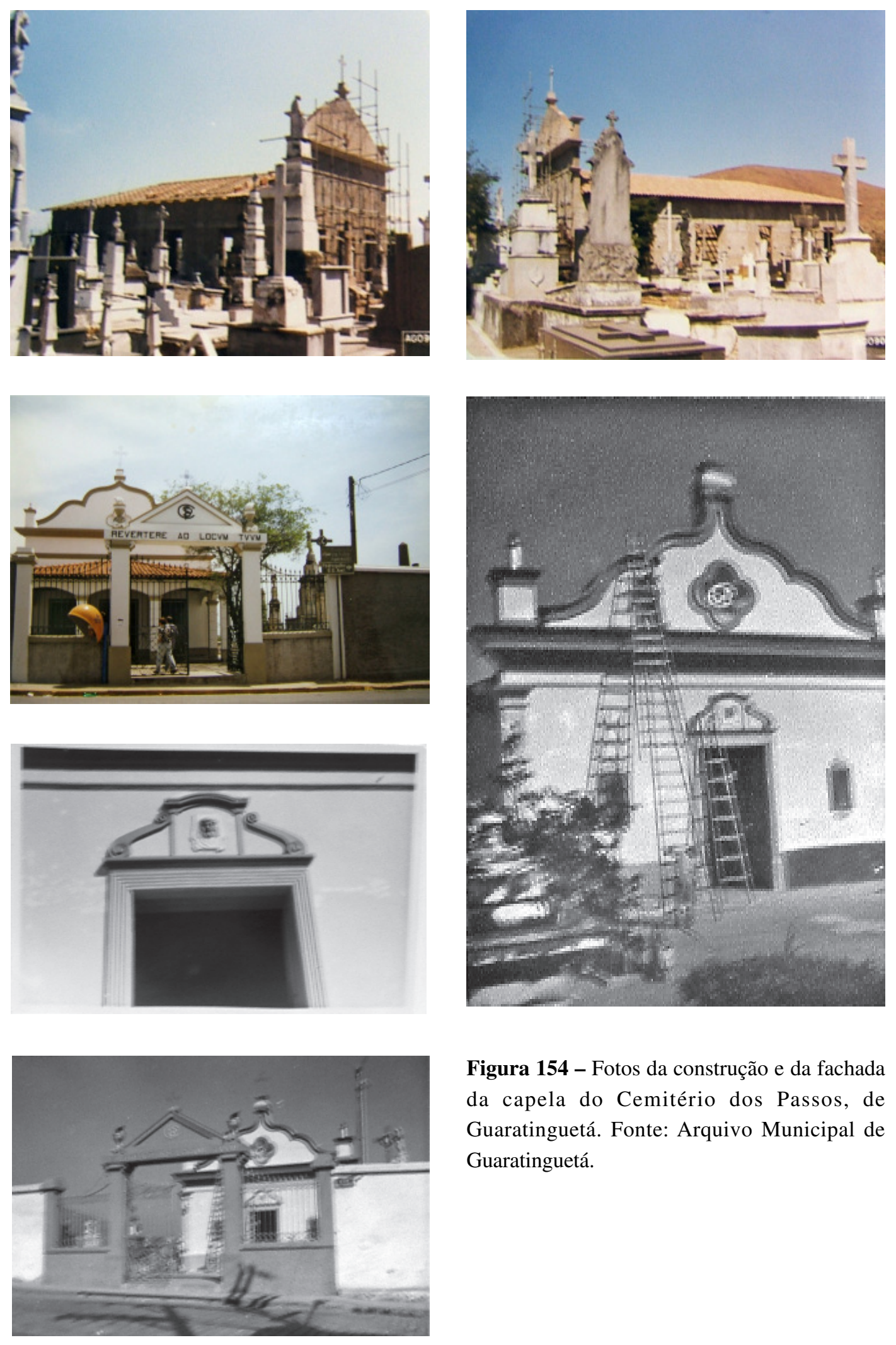

Figura 154 - Fotos da construção e da fachada da capela do Cemitério dos Passos, de Guaratinguetá. Fonte: Arquivo Municipal de Guaratinguetá. 

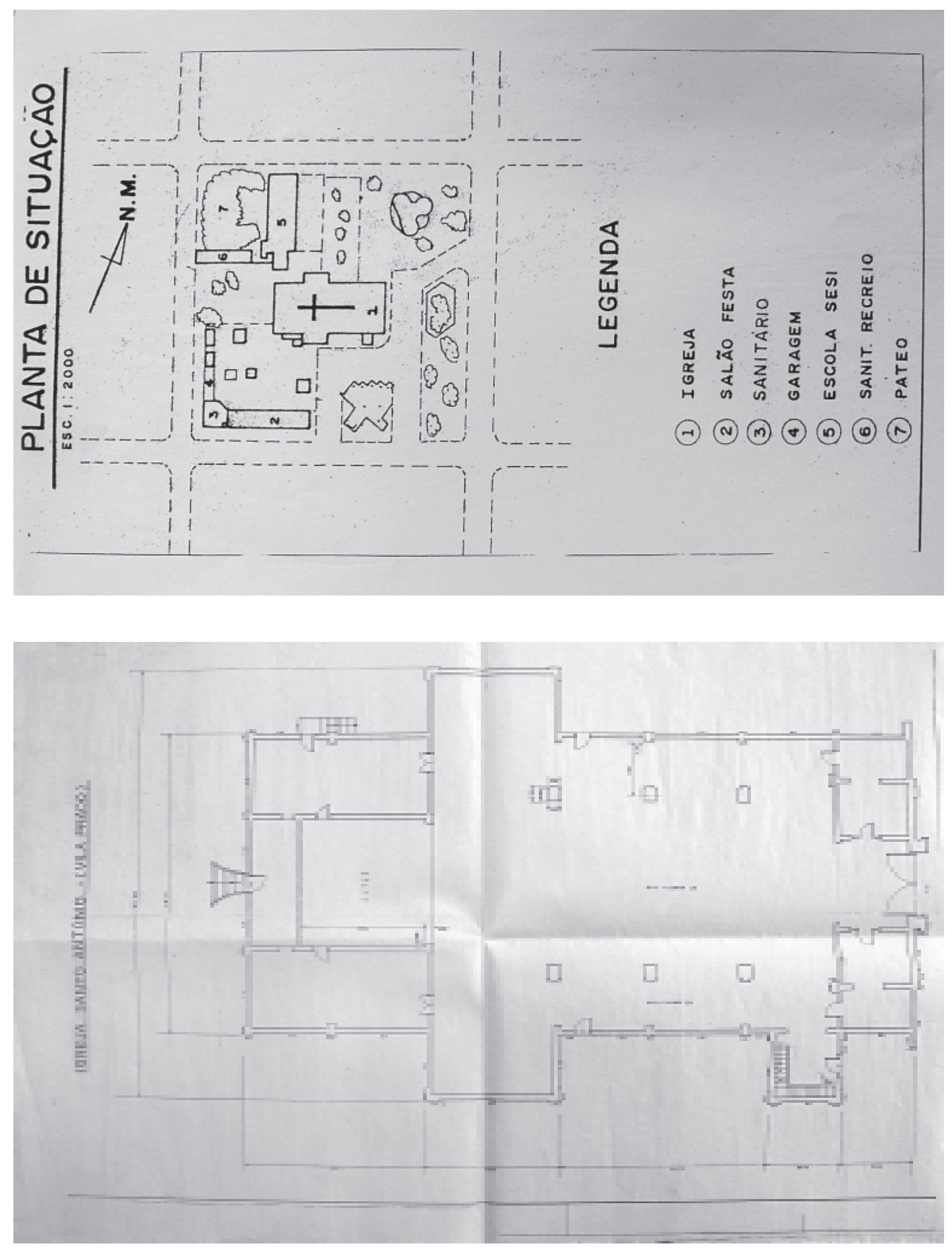

Figura 155 - Levantamento métrico da igreja da Paróquia de Santo António, de São Carlos. Projeto original do engenheiro Durval Duarte, 1943. Fonte: Arquivo Municipal de São Carlos. 

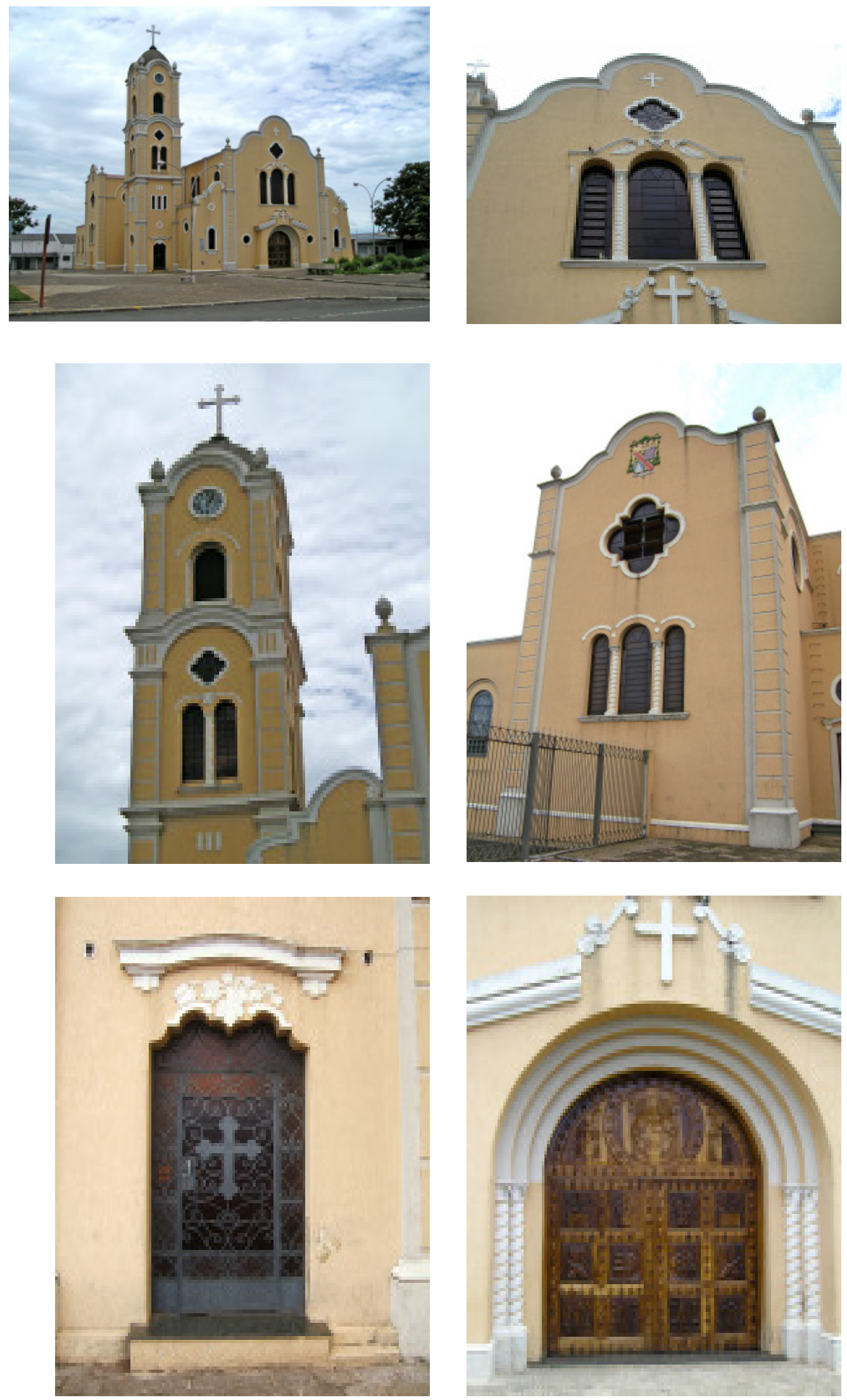

Figura 156 - Igreja da Paróquia de Santo António, São Carlos. Notar características da vertente missões da arquitetura neocolonial e a porta principal, em madeira entalhada. Fonte: fotos da autora, janeiro de 2005. 

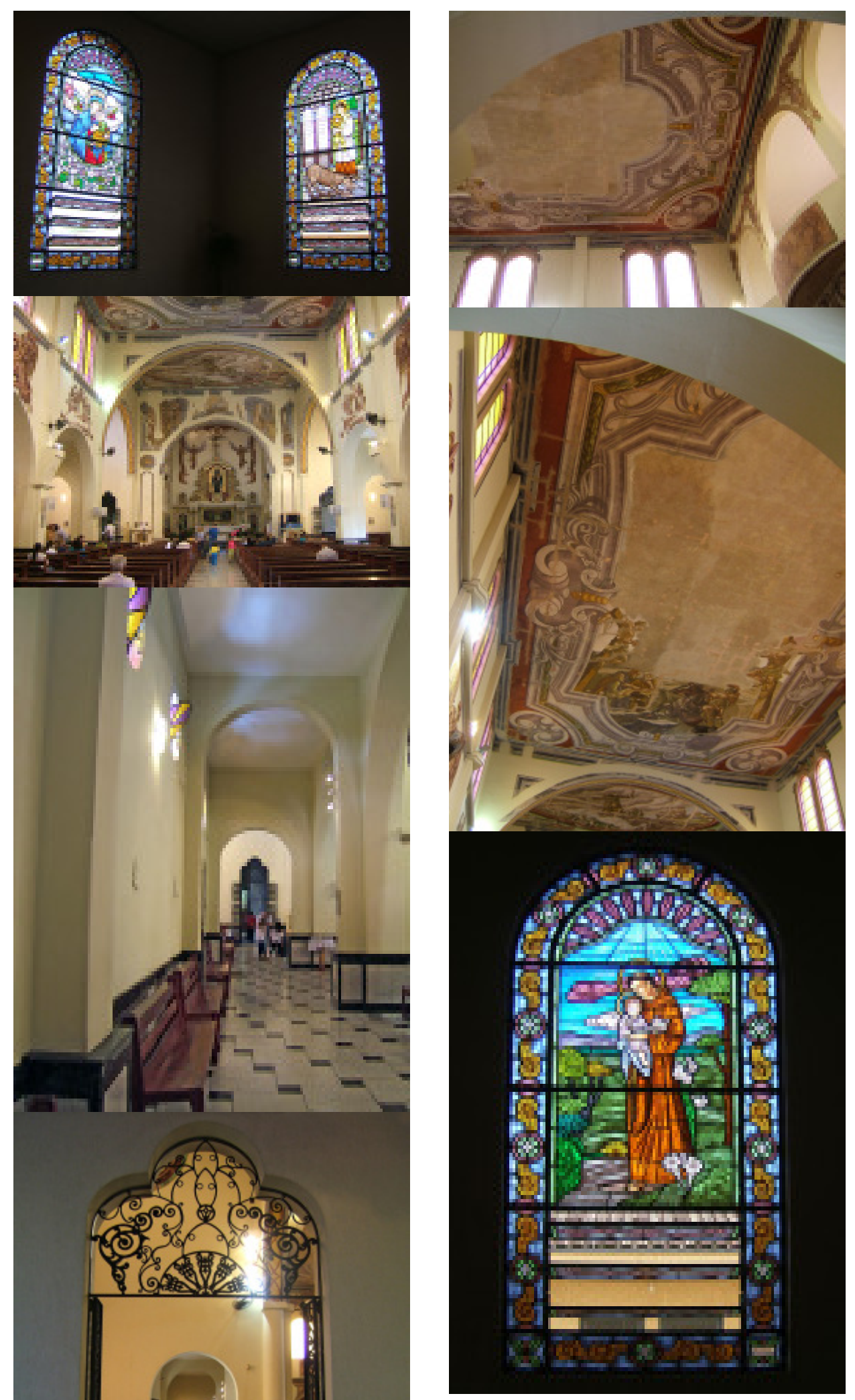

Figura 157 - Aspectos internos da igreja da Paróquia de Santo António. Vemos a antiga pintura exposta, os vitrais, a envazadura da porta de arco trilobado e porta em ferro com motivos decorativos. Fonte: fotos da autora, abril de 2008. 

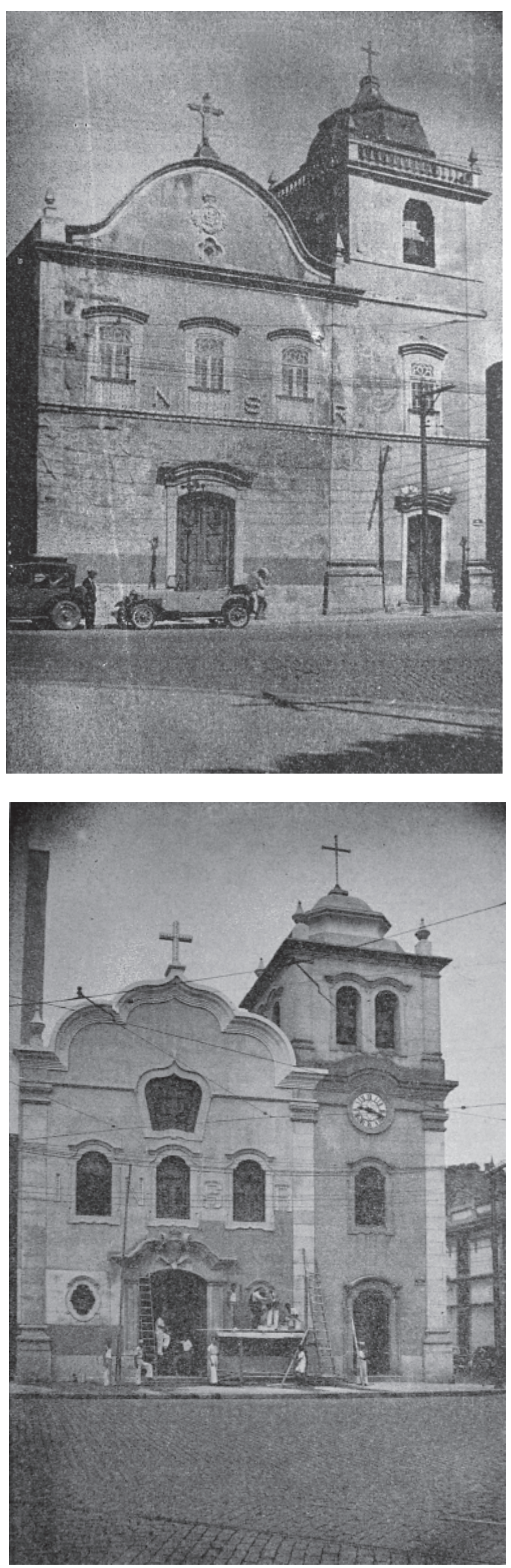

Figura 158 - Igreja do Rosário, de Santos. Primeira foto de 1926, anterior a sua reforma. Segunda foto, outubro de 1930, ano e mês de sua inauguração. Fonte: Franco (s/d, p.85 e 95). 

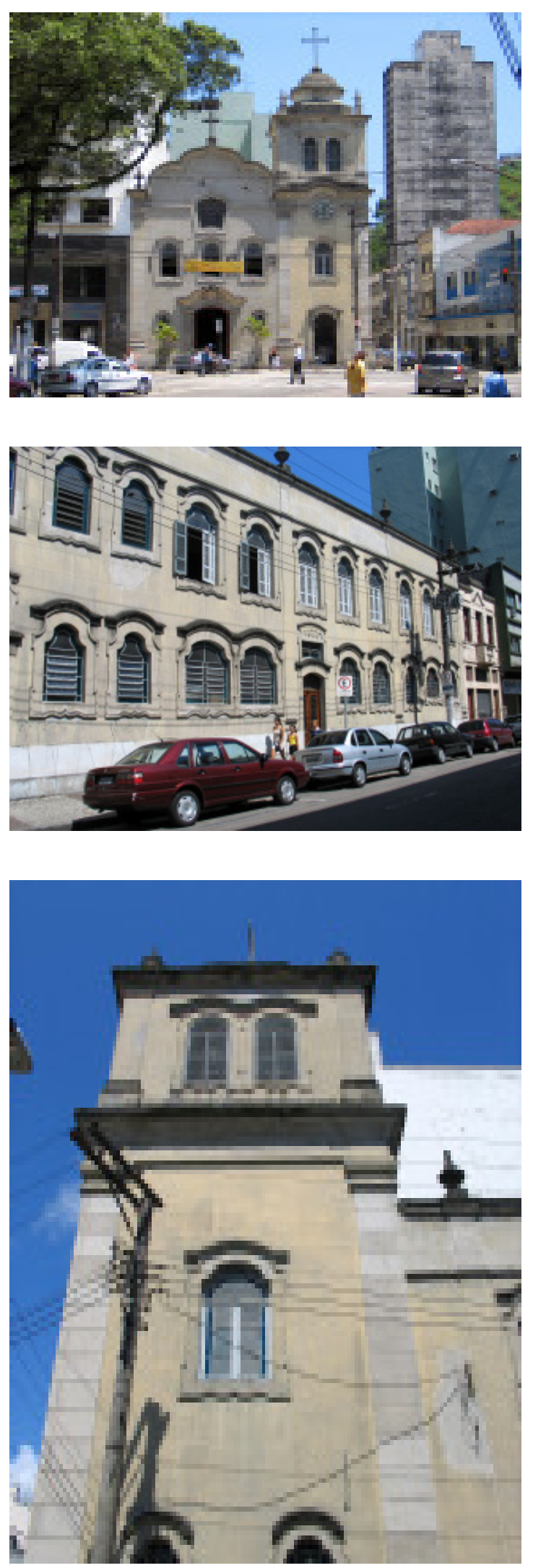

Figura 159 - Registros da Igreja do Rosário de Santos em seu aspecto atual. Fonte: fotos M. A. Bortolucci, fevereiro de 2005. 

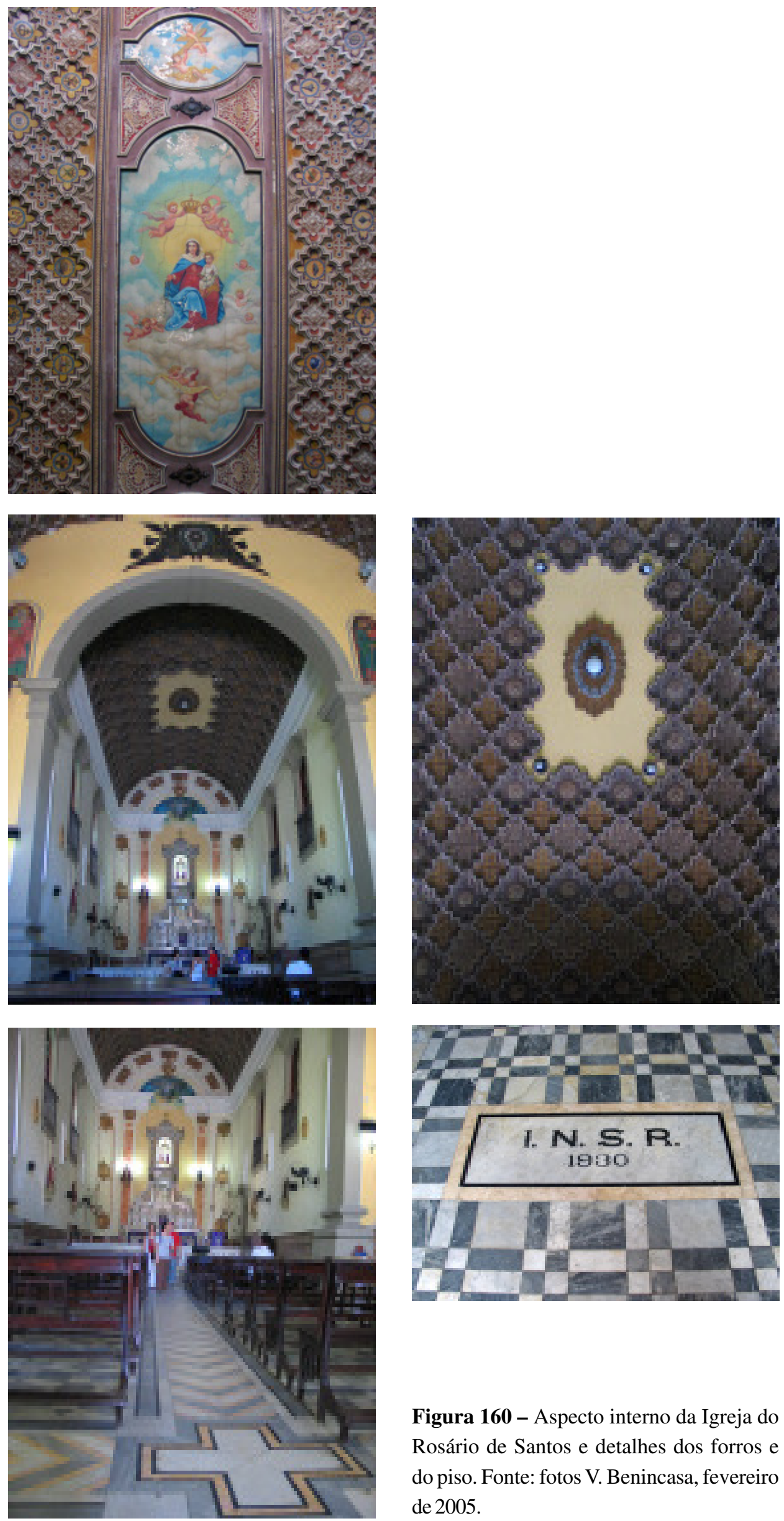

Figura 160 - Aspecto interno da Igreja do Rosário de Santos e detalhes dos forros e do piso. Fonte: fotos V. Benincasa, fevereiro de 2005. 


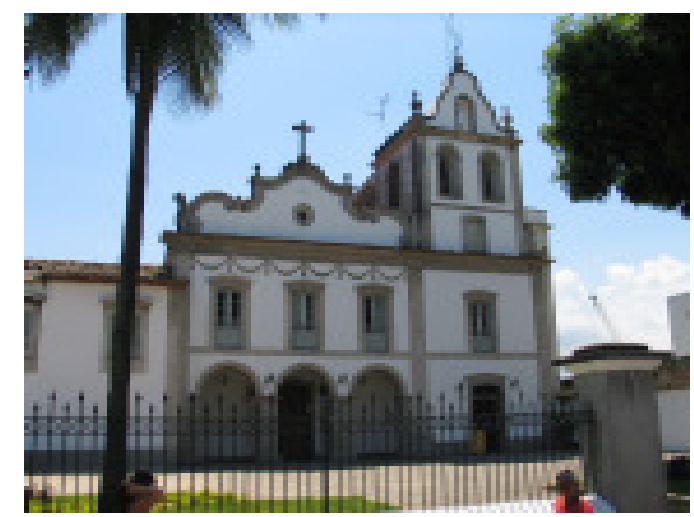

Figura 161 (acima) - Fachada do Santuário de Santo Antonio do Valongo, Santos, século XVII. Fonte: fotos M. A. Bortolucci, fevereiro de 2005.

Figura 162 (abaixo e à direita) - Interior da igreja do Santuário de Santo Antonio do Valongo, com seus retábulos barrocos, pinturas de estêncil e painel de azulejos azul e branco, de 1940, de autoria do pintor Cândido da Silva Júnior. Fonte: fotos V. Benincasa, fevereiro de 2005.

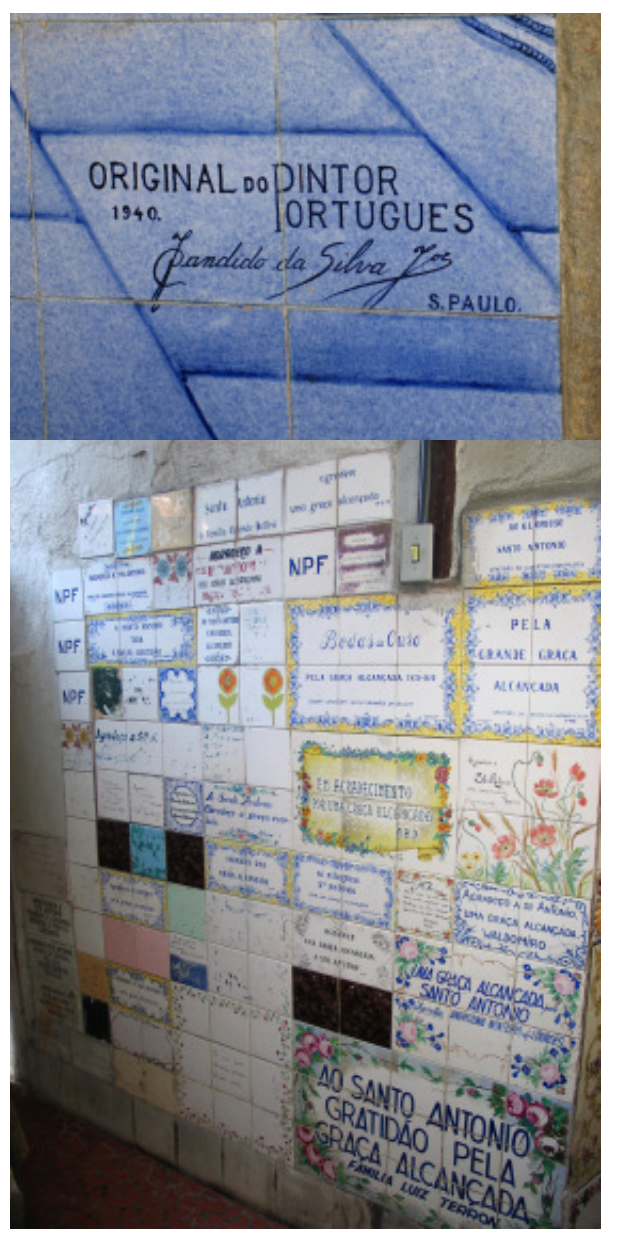

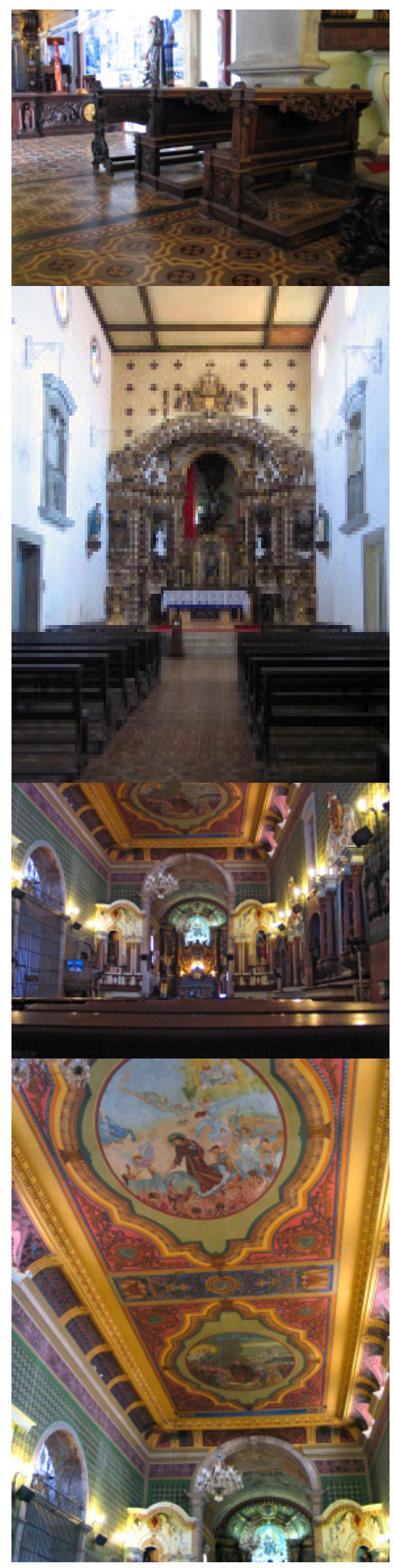



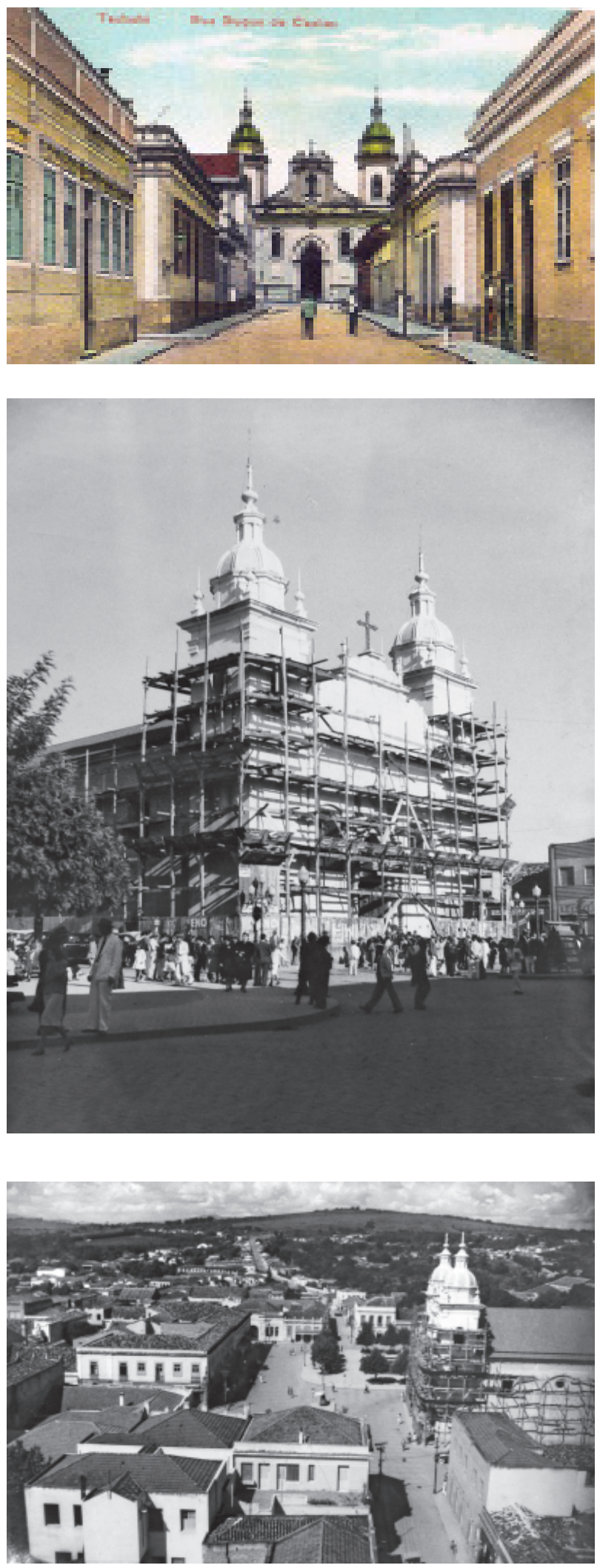

Figura 163 - Uma imagem da antiga Igreja Matriz de Taubaté. Disponível em: http://www.solariseditora.com.br/ sp3_113.htm. Acesso em: 14/04/2007. Obras de reforma, iniciadas em 1942, que transformaram a matriz na Catedral Diocesana de São Francisco das Chagas, em 1950. Fonte: Museu da Imagem e do Som de Taubaté. 

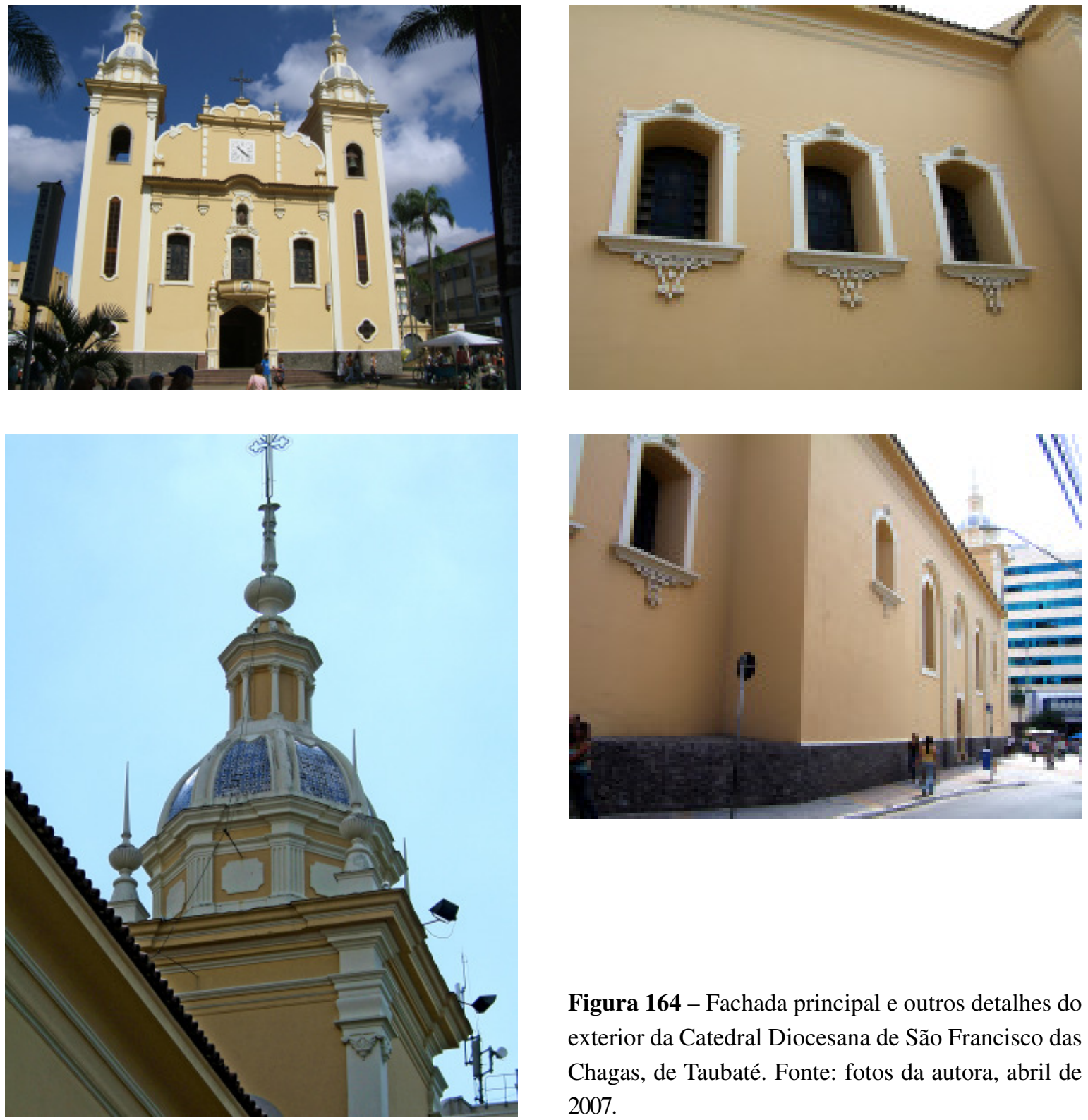

Figura 164 - Fachada principal e outros detalhes do exterior da Catedral Diocesana de São Francisco das Chagas, de Taubaté. Fonte: fotos da autora, abril de 2007. 

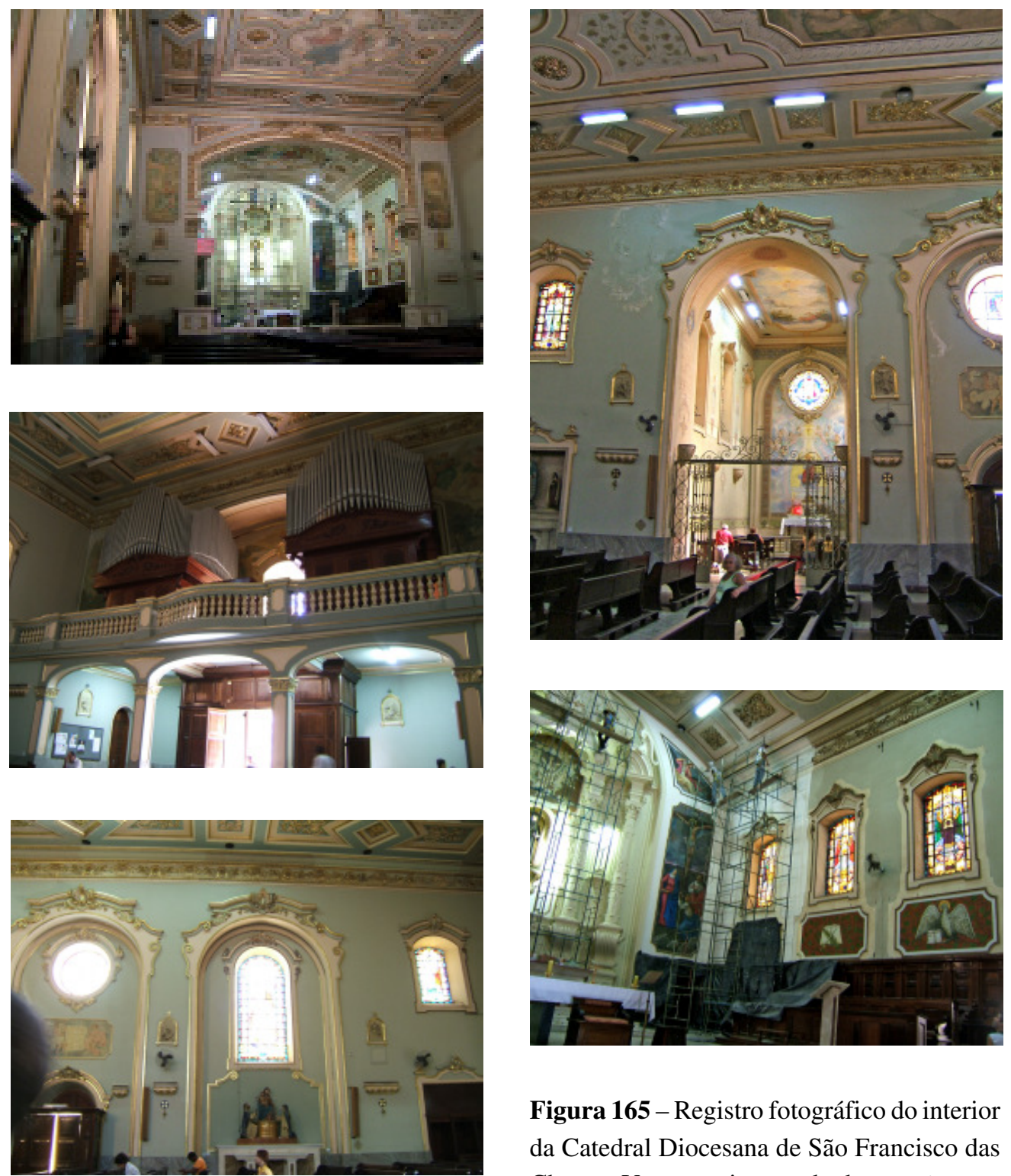

Figura 165 - Registro fotográfico do interior da Catedral Diocesana de São Francisco das Chagas. Vemos a riqueza da decoração neocolonial neste exemplar. Fonte: fotos da autora,

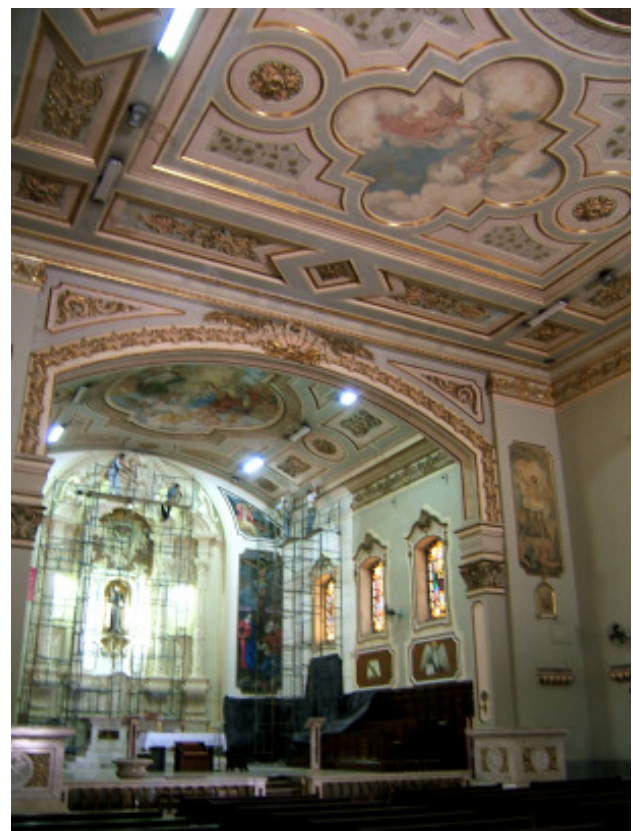
abril de 2007. 


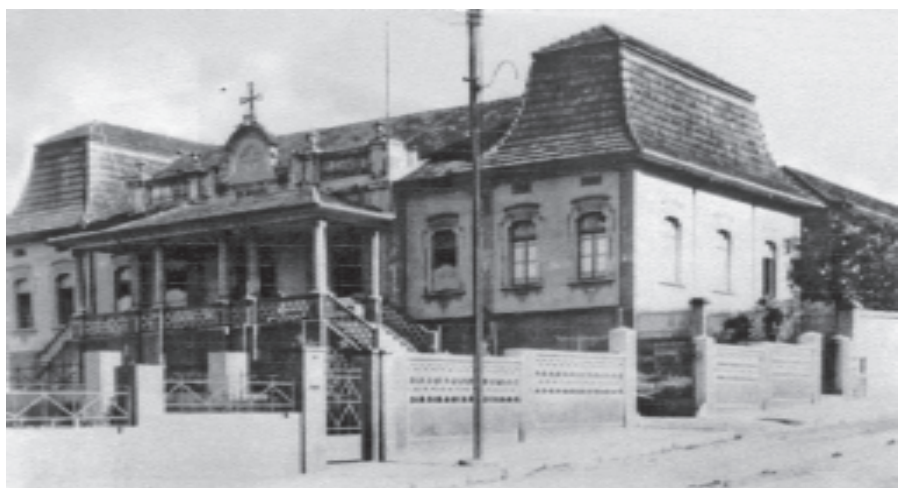

Figura 166 (acima) - Fachada da Sede do Hospital da Beneficência Portuguesa, em Bauru, inaugurado em 1928. Projeto de Ricardo Severo. Notamos elementos vazados no muro e nos corrimãos da escada similares às meias-luas sobrepostas. Apesar desses estilemas comumente encontrados na arquitetura neocolonial, o telhado é diferente do tradicional telhado "à portuguesa". Fonte: Ferraz (2003, p.18).
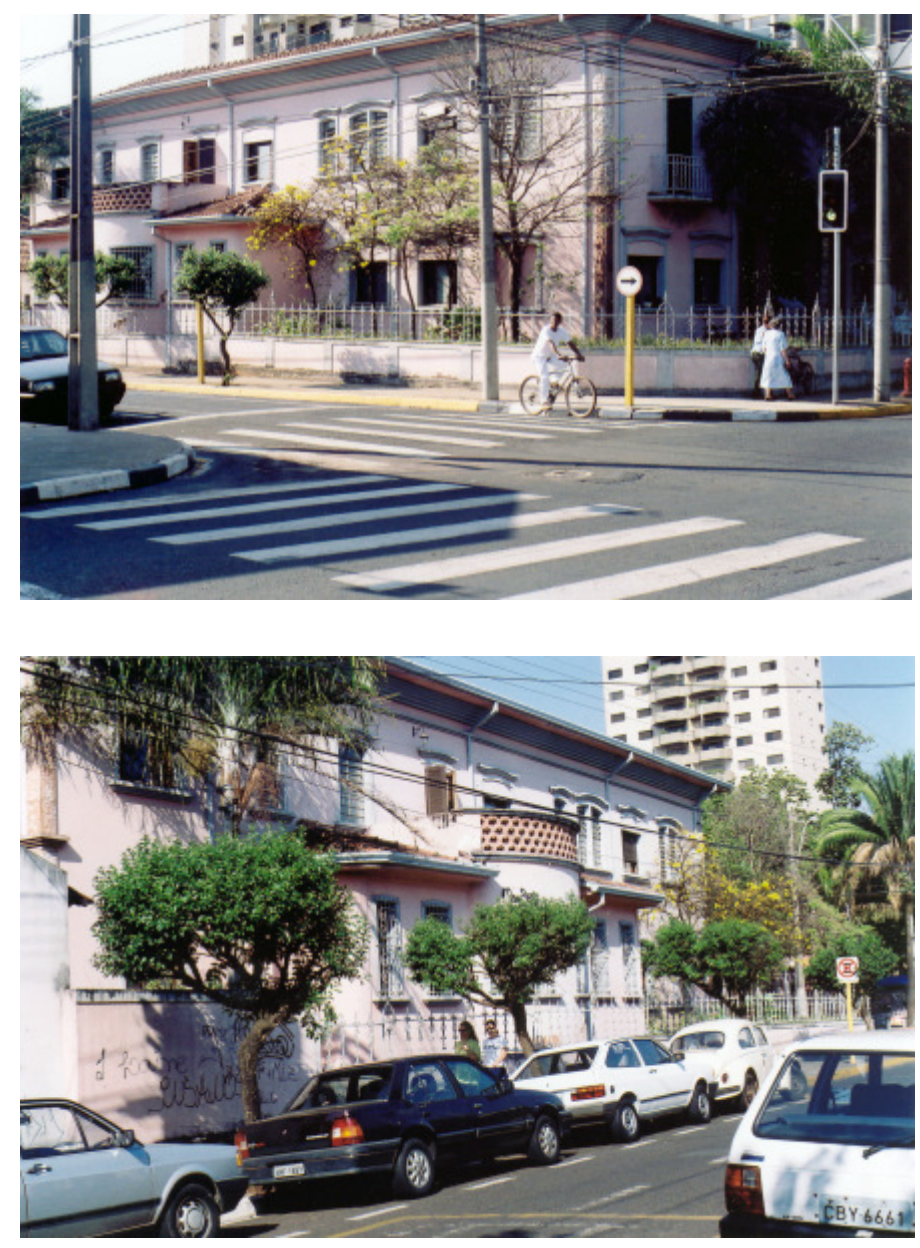

Figura 167 (acima) - Aspectos externos do prédio da Maternidade Gota de Leite, de Araraquara, cujo projeto é atribuído ao arquiteto José Maia da Silva Neves. Vemos algumas estilemas neocoloniais como os telhados, os guarda-corpos com elementos vazados em forma de meias-luas e as janelas de arcos abatidos. Fonte: fotos da autora, outubro de 2004. 

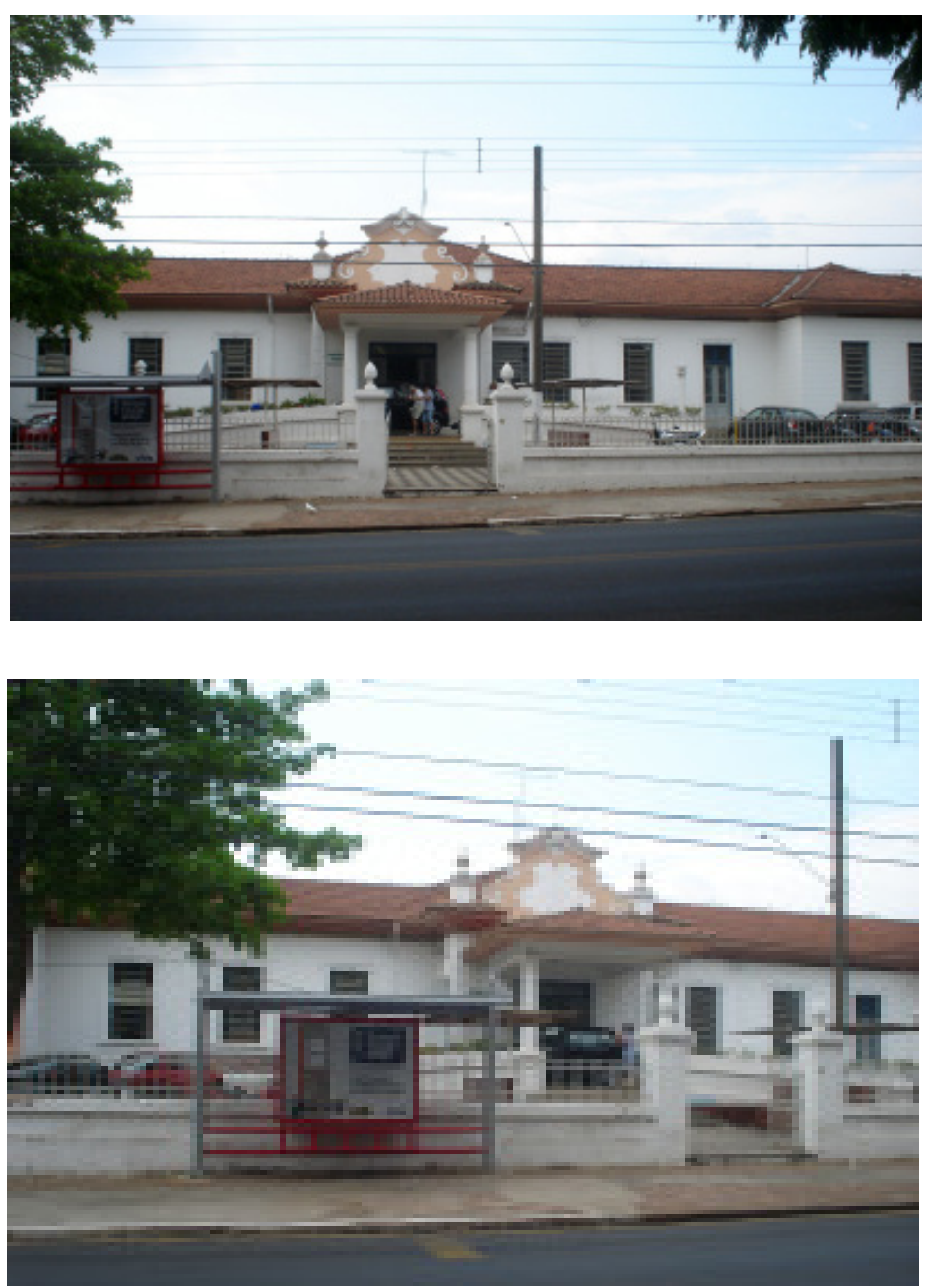

Figura 168 - Fachada do Hospital da Irmandade Santa Casa de Misericórdia, de Itapetininga. Frontão neocolonial sobre a entrada principal. Fonte: fotos A. F. de Souza, outubro de 2007. 


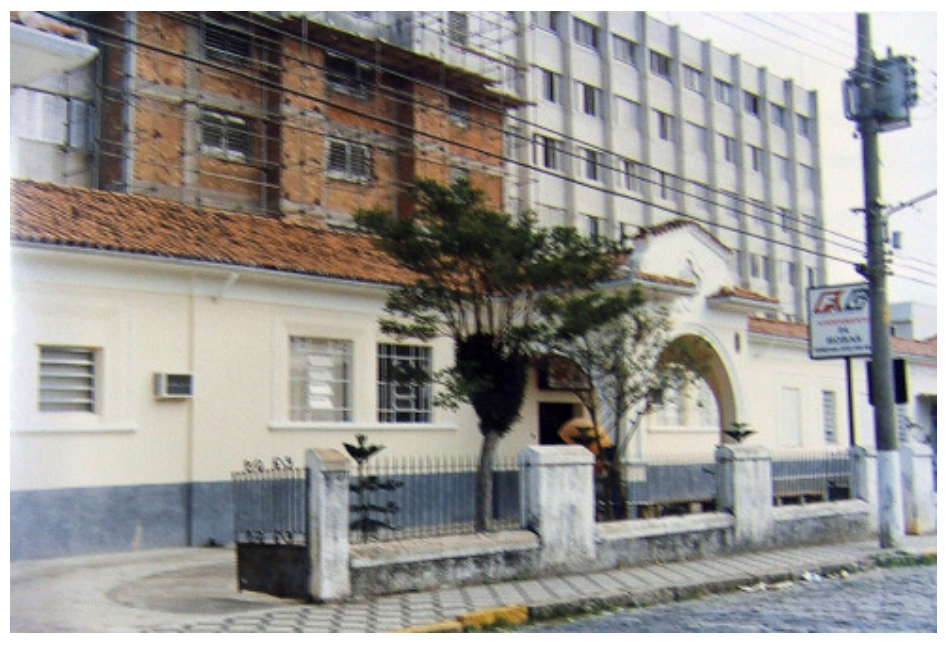

Figura 169 - Fachada do Hospital e Maternidade Frei Galvão, de Guaratinguetá, em 1999. Fonte: Arquivo Municipal de Guaratinguetá.

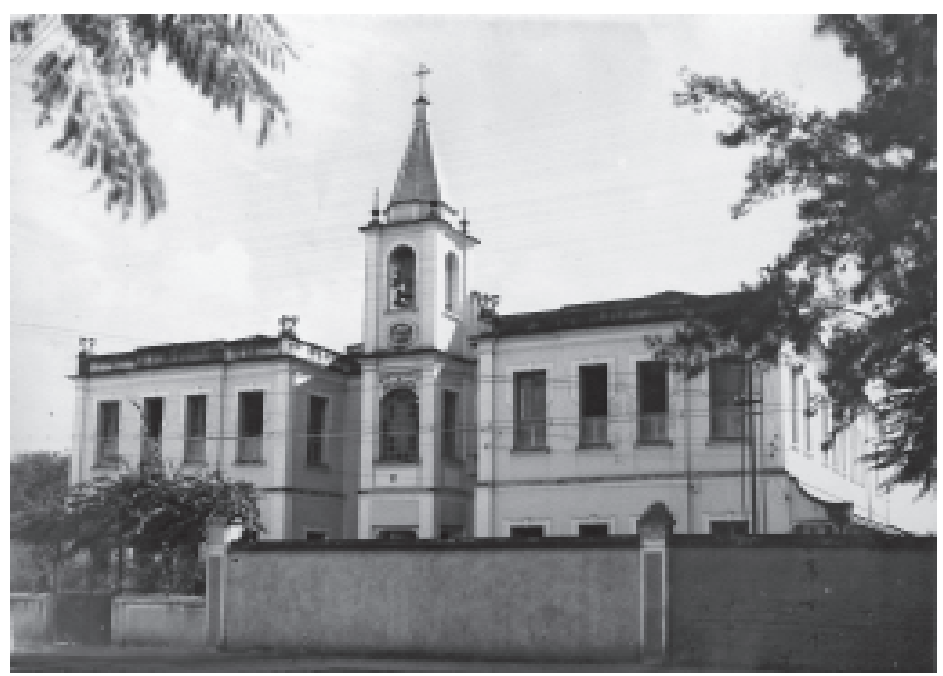

Figura 170 - Imagem do primeiro prédio do Orfanato Santa Verônica, em Taubaté, com sua capela central, inaugurado em 1927. Arquitetura de tendência eclética no final da década de 1920. Fonte: Museu da Imagem e do Som de Taubaté. 

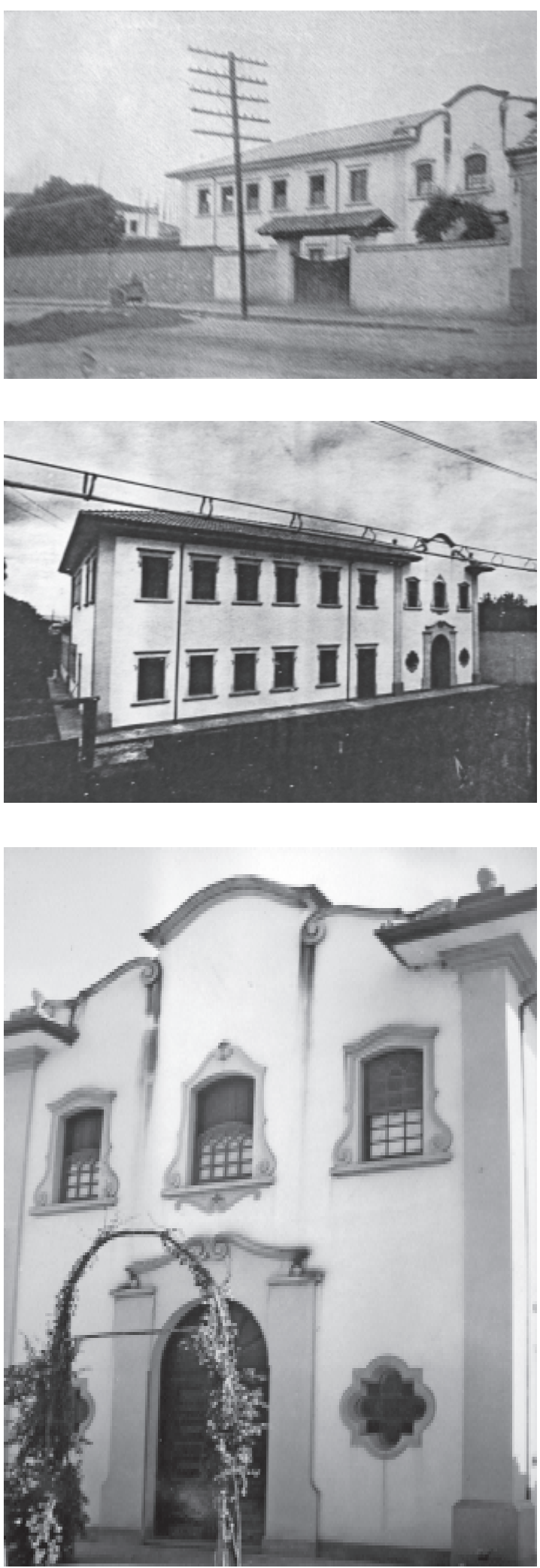

Figura 171 - Fachada do pavilhão "Patronato Cardoso Ribeiro" do Orfanato Santa Verônica, em Taubaté. Inaugurado em 1940 segundo projeto neocolonial realizado pela Companhia Predial de Taubaté. Fonte: Álbum Comemorativo ao Tri-Centenário de Taubaté (1945) e Museu da Imagem e do Som de Taubaté. 


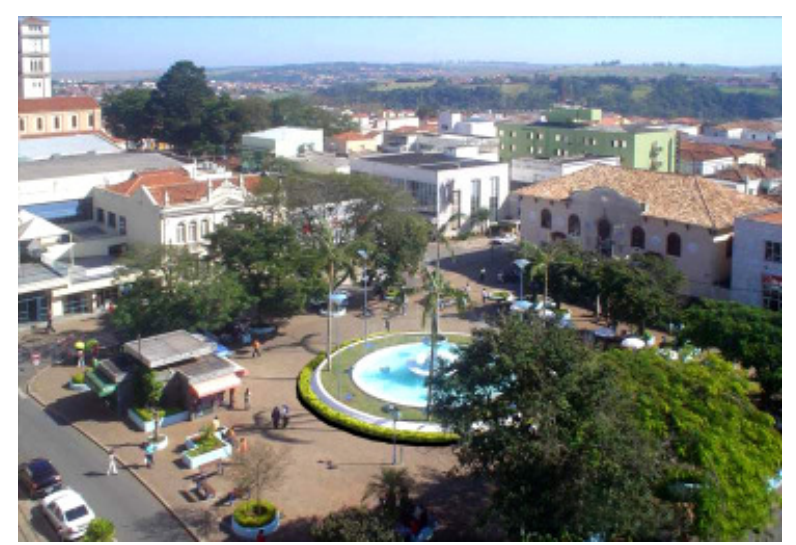

Figura 172 (acima) - Prédio que abriga o Centro Cultural e Histórico de Itapetininga, localizado na Praça Marechal Deodoro da Fonseca, à direita, na esquina. Vemos a volumetria simples, o telhado de quatro águas e o frontão em destaque sobre a entrada principal. Disponível em: http://itapetiningasp.uniblog.com.br/. Acesso em: 23/11/2007.

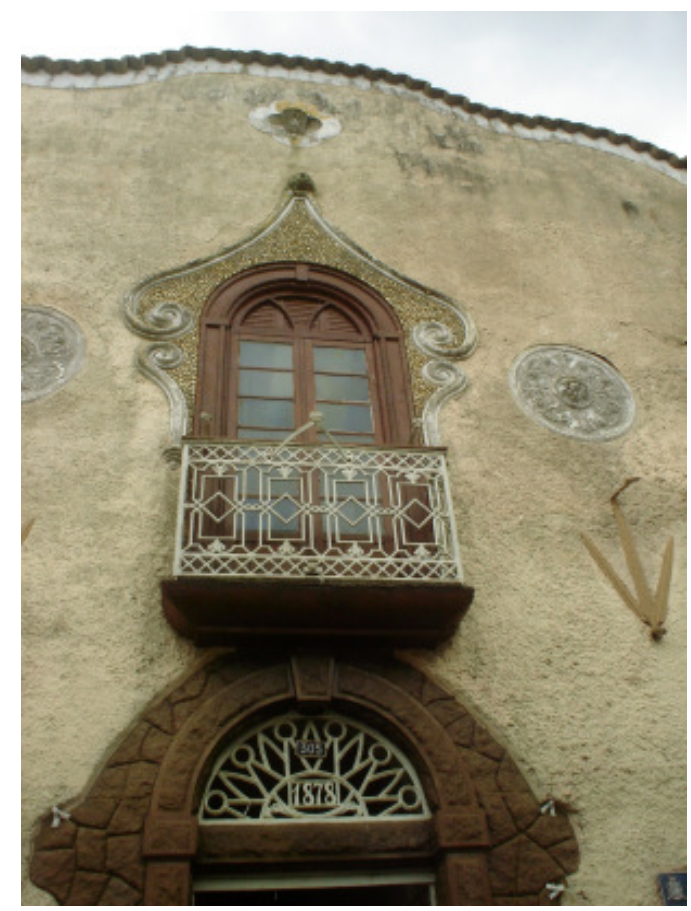

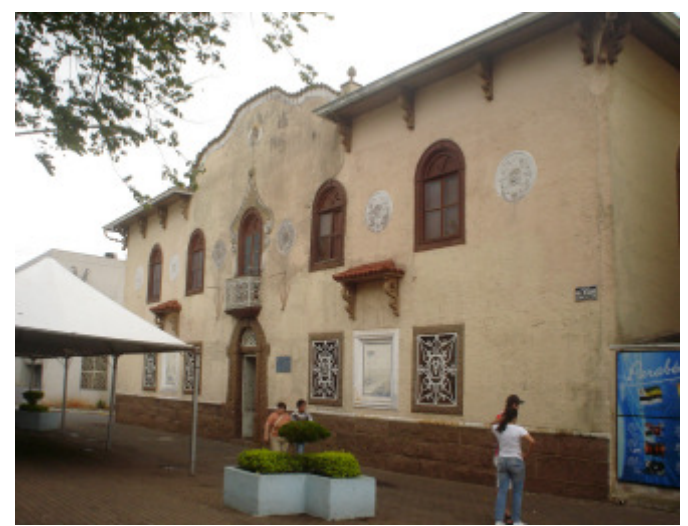
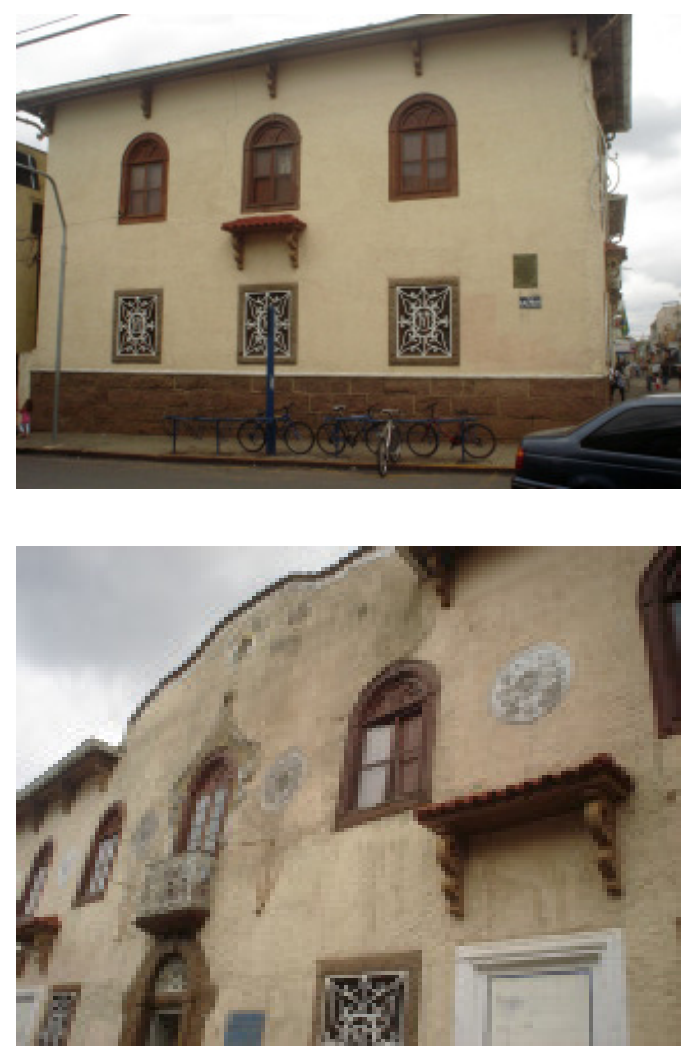

Figura 173 - Exterior do Centro Cultural e Histórico de Itapetininga. Notar os elementos decorativos aplicados à fachada e as paredes revestidas com acabamento de aspecto rústico. Sobre a porta a data de 1878 . Fonte: fotos A. F. de Souza, novembro de 2007. 

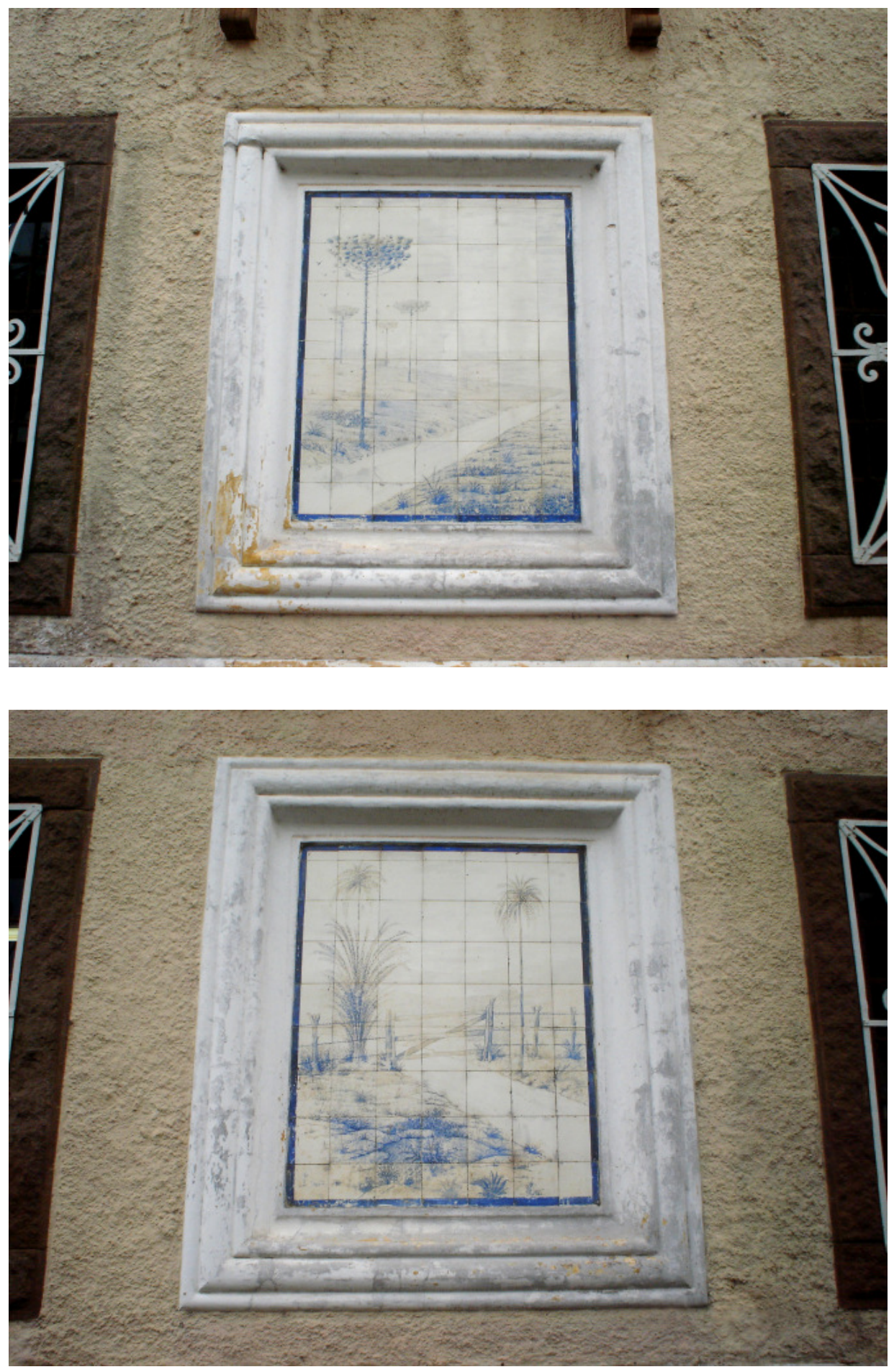

Figura 174 - Painéis de azulejos com motivos pitorescos aplicados à fachada do Centro Cultural e Histórico de Itapetininga. Fonte: fotos A. F. de Souza, novembro de 2007. 

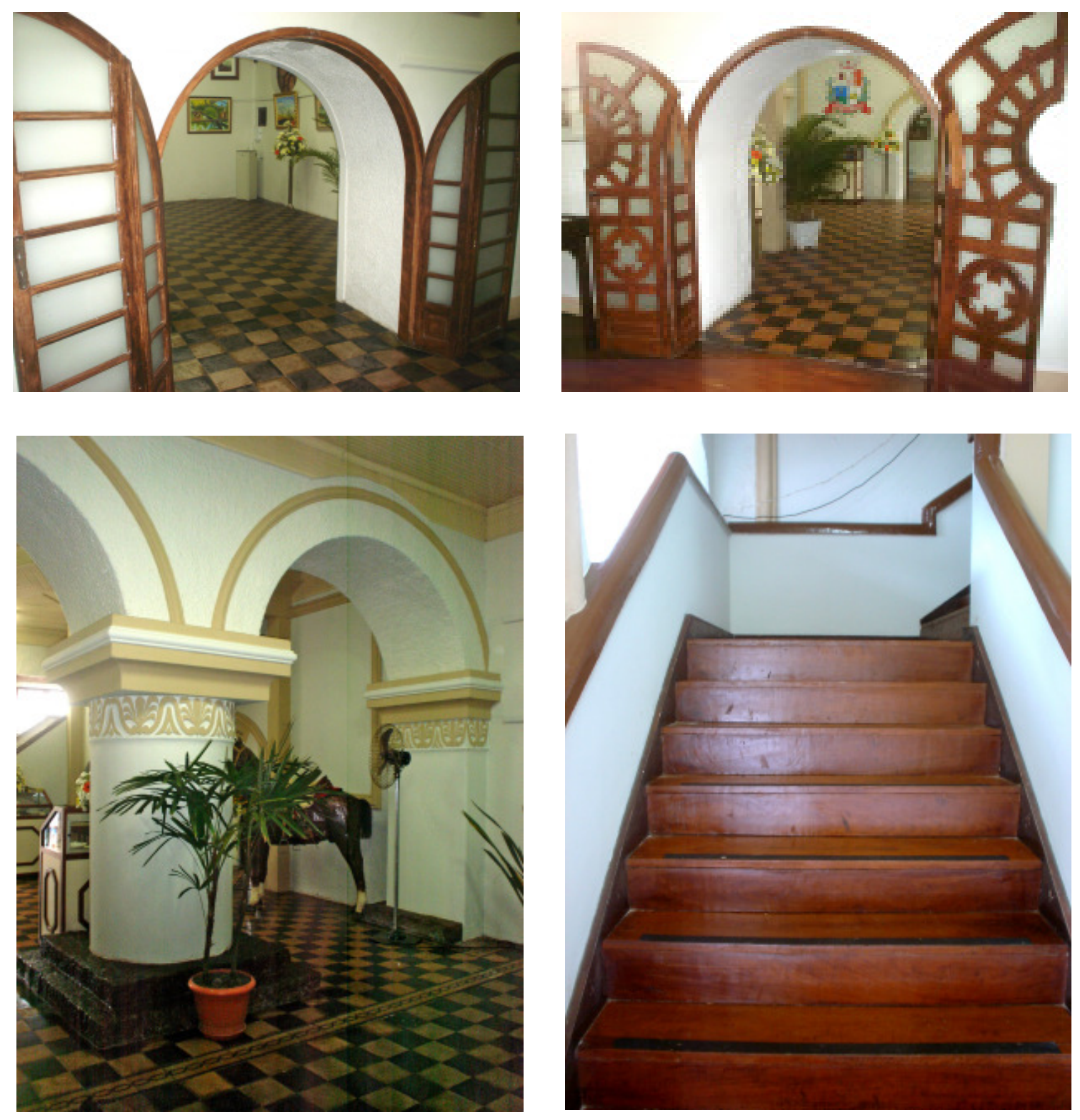

Figura 175 - Interior do Centro Cultural e Histórico de Itapetininga, com suas portas e pilares de proporções exageradas e decoração em madeira. Fonte: fotos A. F. de Souza, novembro de 2007. 

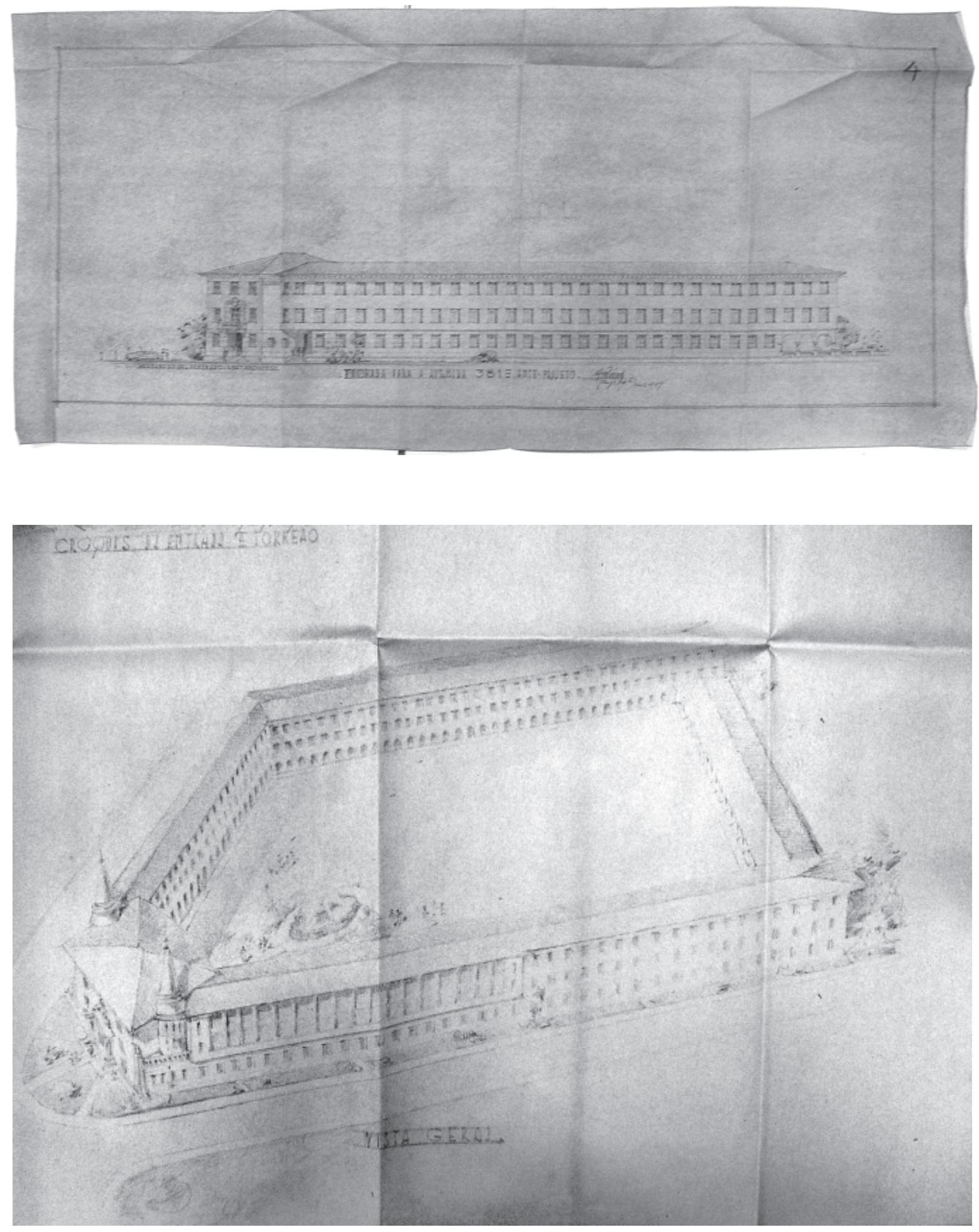

Figura 176 (páginas 398 e 399) - Projeto do arquiteto Hernani do Val Penteado, de 1949, para um Colégio de Freiras, que se localizaria na Ponta da Praia, em Santos. Provavelmente demolido ou não construído. Fonte: Acervo de Projetos FAUUSP. 

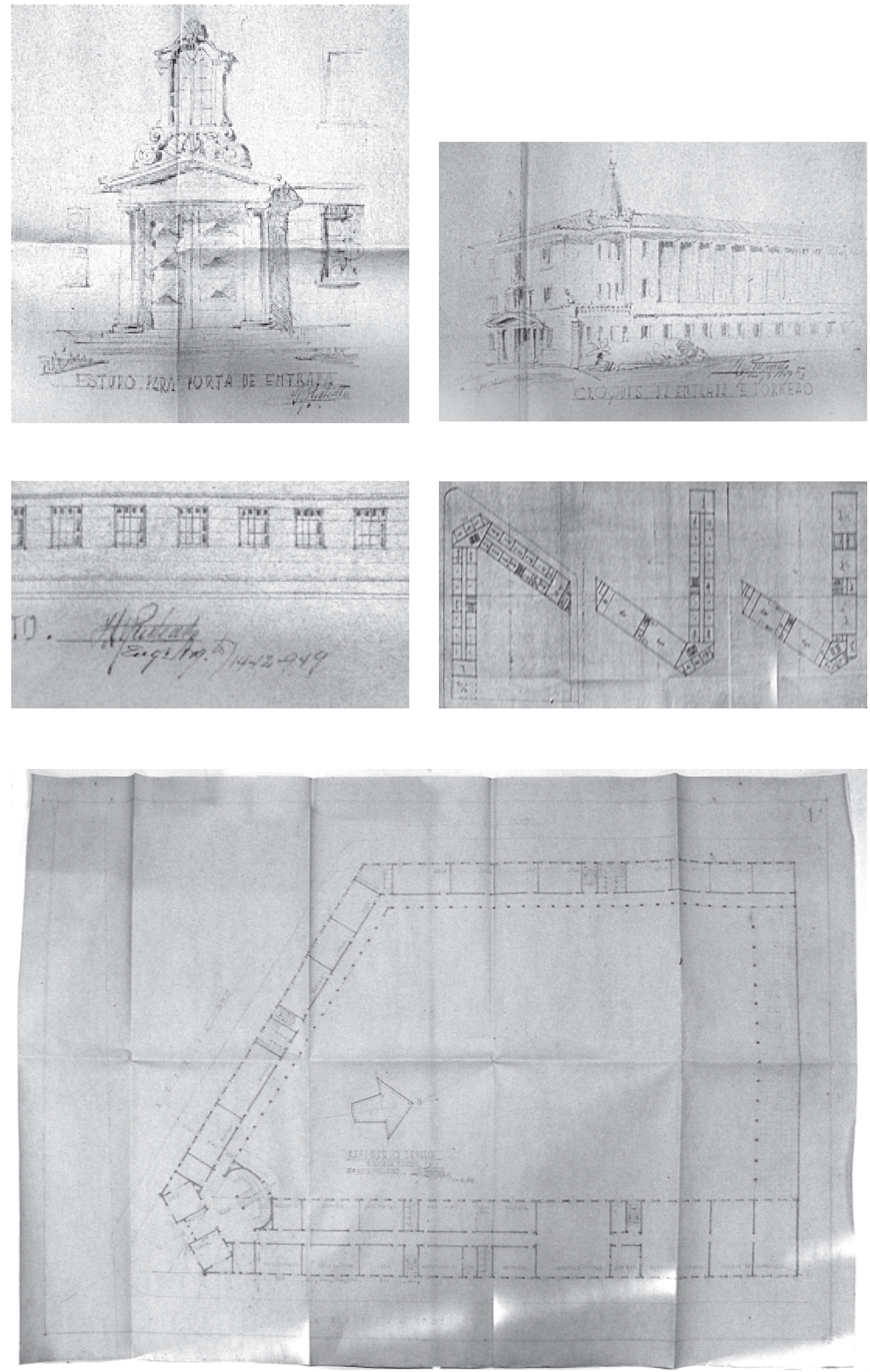

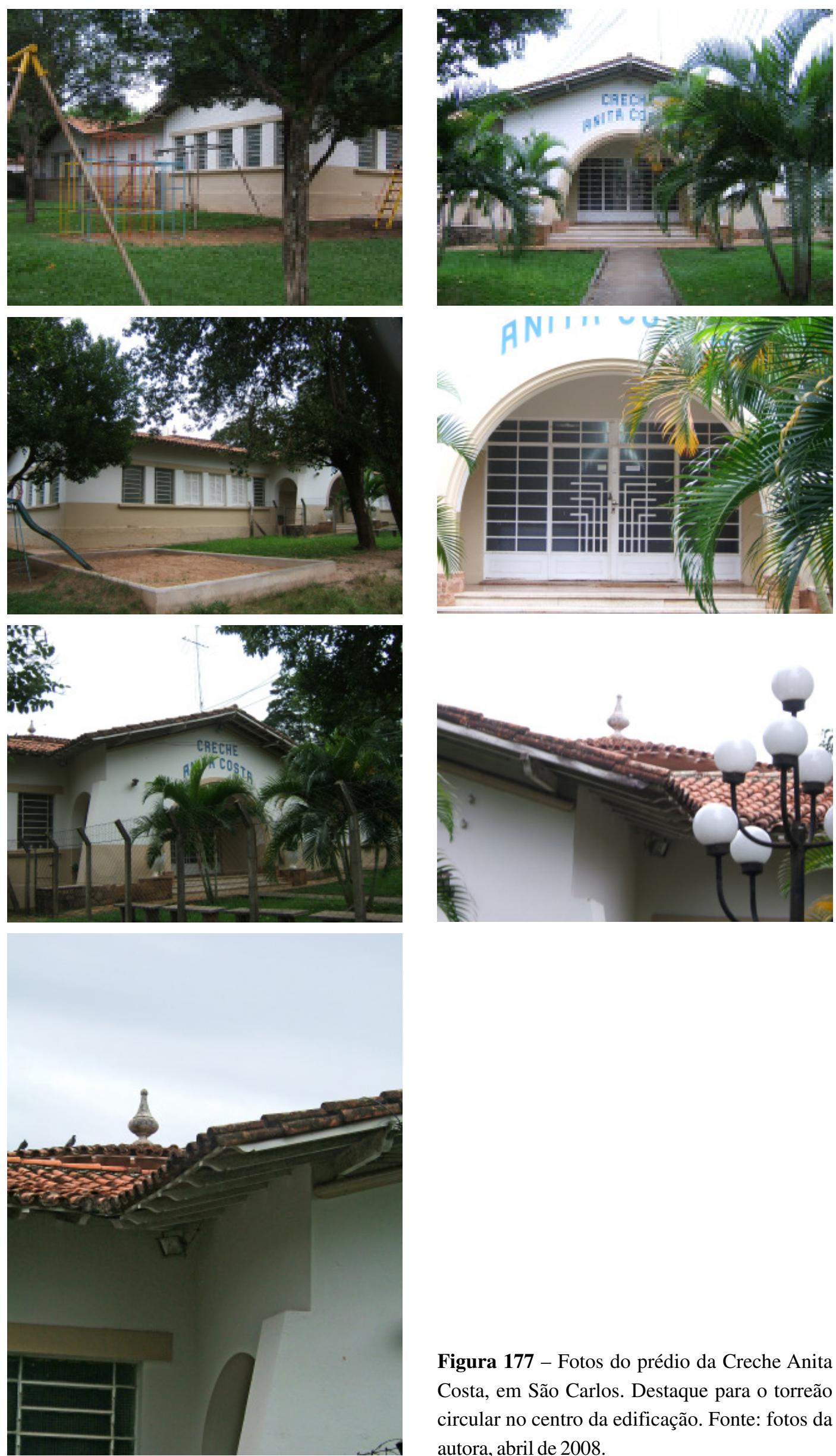

Figura 177 - Fotos do prédio da Creche Anita Costa, em São Carlos. Destaque para o torreão circular no centro da edificação. Fonte: fotos da autora, abril de 2008 

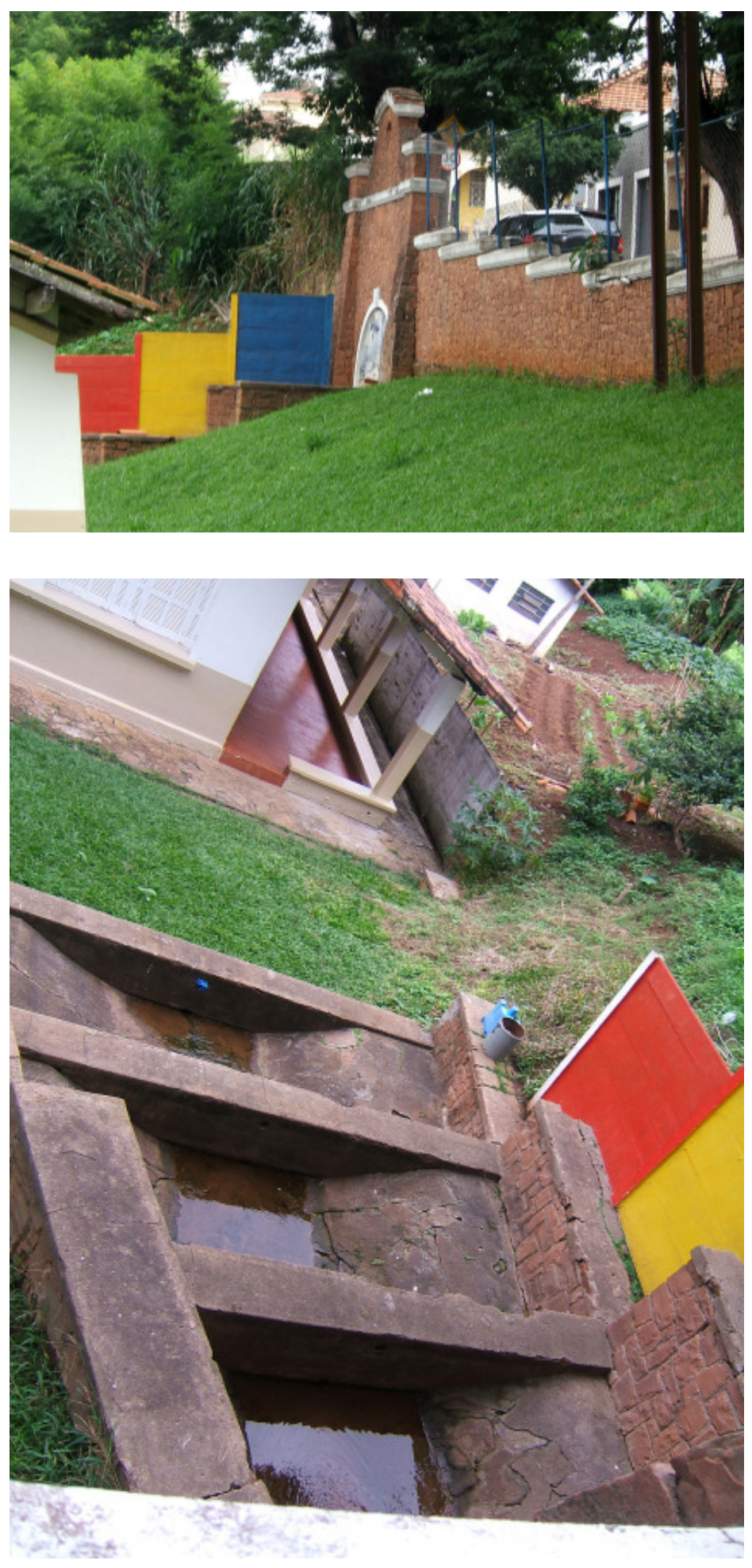

Figura 178 - Fonte com três quedas revestida de pedras e com painel de azulejos azul e branco na Creche Anita Costa. Fonte: fotos da autora, abril de 2008. 

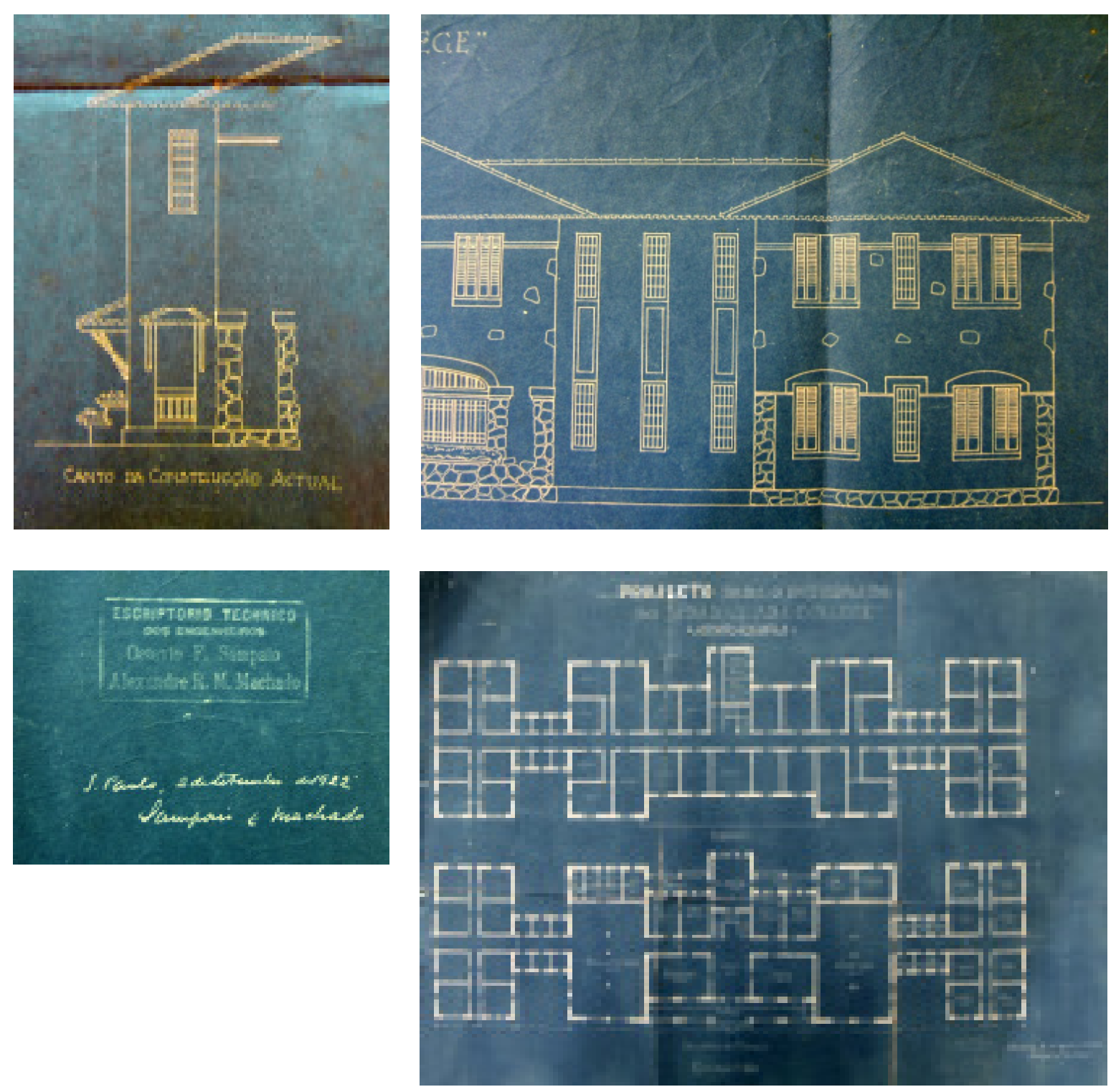

Figura 179 - Projeto, de 1922, do Escritório Técnico "Sampaio \& Machado" para o edifício do Araraquara College. A aplicação de pedras nos cunhais, na base e nas fachadas, de forma esparsa, mostra a influência da tendência neocolonial. Fonte: Arquivo Municipal de Araraquara. 

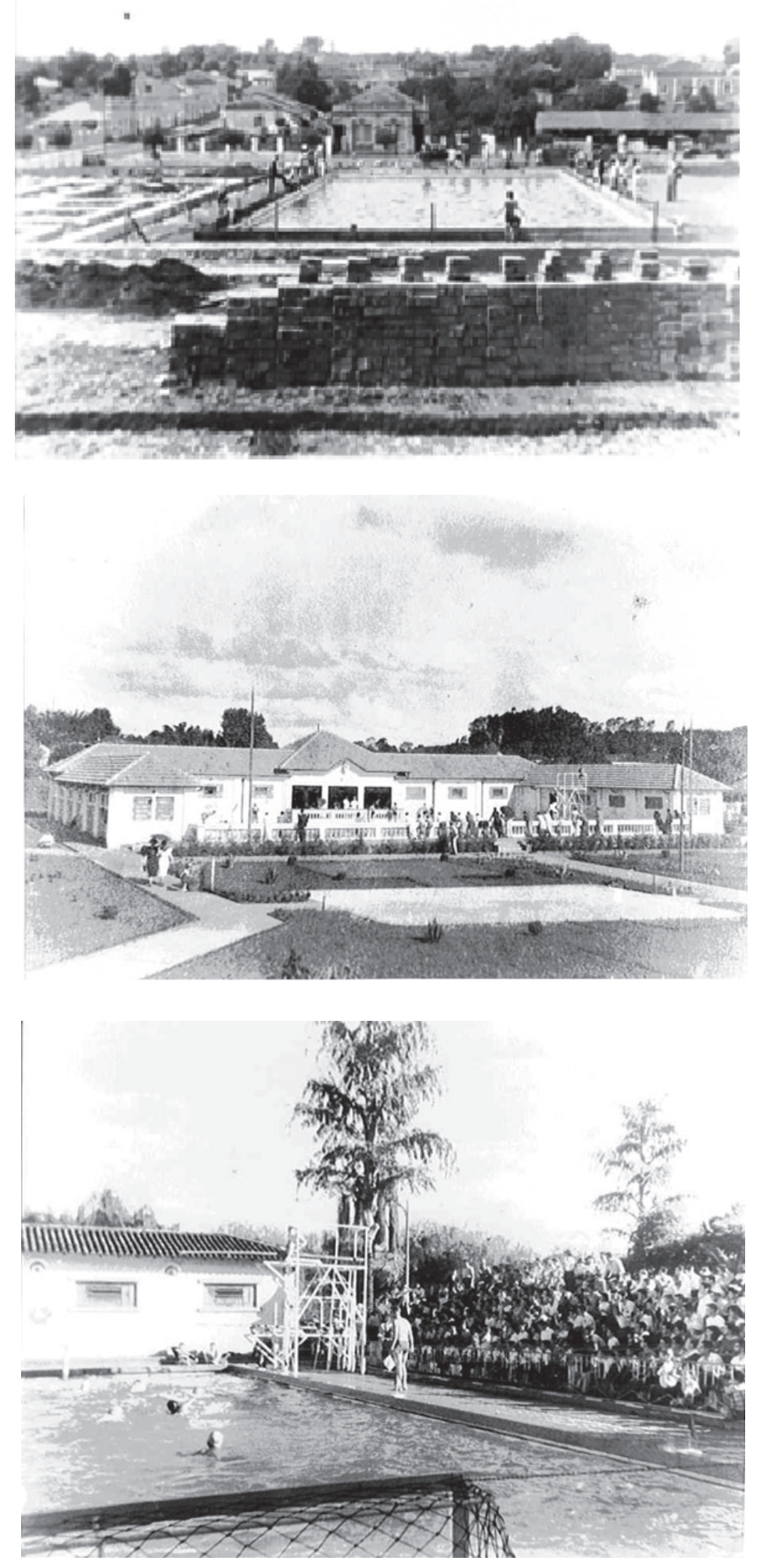

Figura 180 - A primeira foto é de 1934 e mostra a construção da Piscina Municipal de São Carlos; a segunda mostra as instalações já prontas em 1940; e, a terceira, de 1957, mostra que as características do prédio já estão diferentes da foto anterior, indicando que passou por reforma na qual adquiriu feições neocoloniais. Disponível em: http://www.saplei.eesc.usp.br/tgi2005/sites_2003/cintia/fotos.htm. Acesso em: 23/04/2008. 

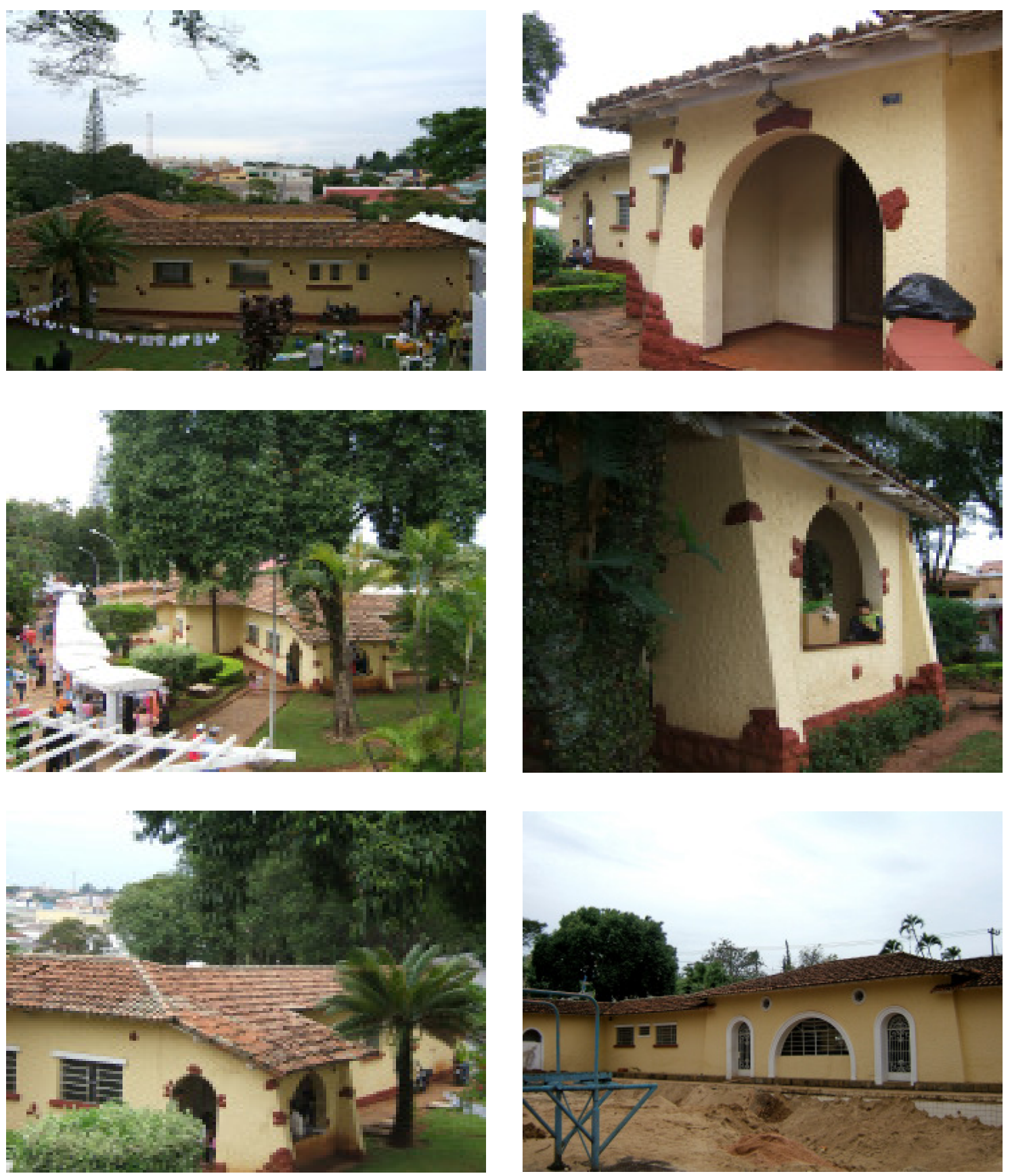

Figura 181 - Aspecto atual da Piscina Municipal de São Carlos. Telhados com beirais e telhas capa e canal, arcos com paredes laterais alargadas na base, pedras esparsas nas fachadas entre outros estilemas remetam à influência da vertente missões nesse prédio. Fonte: fotos da autora, abril de 2008. 

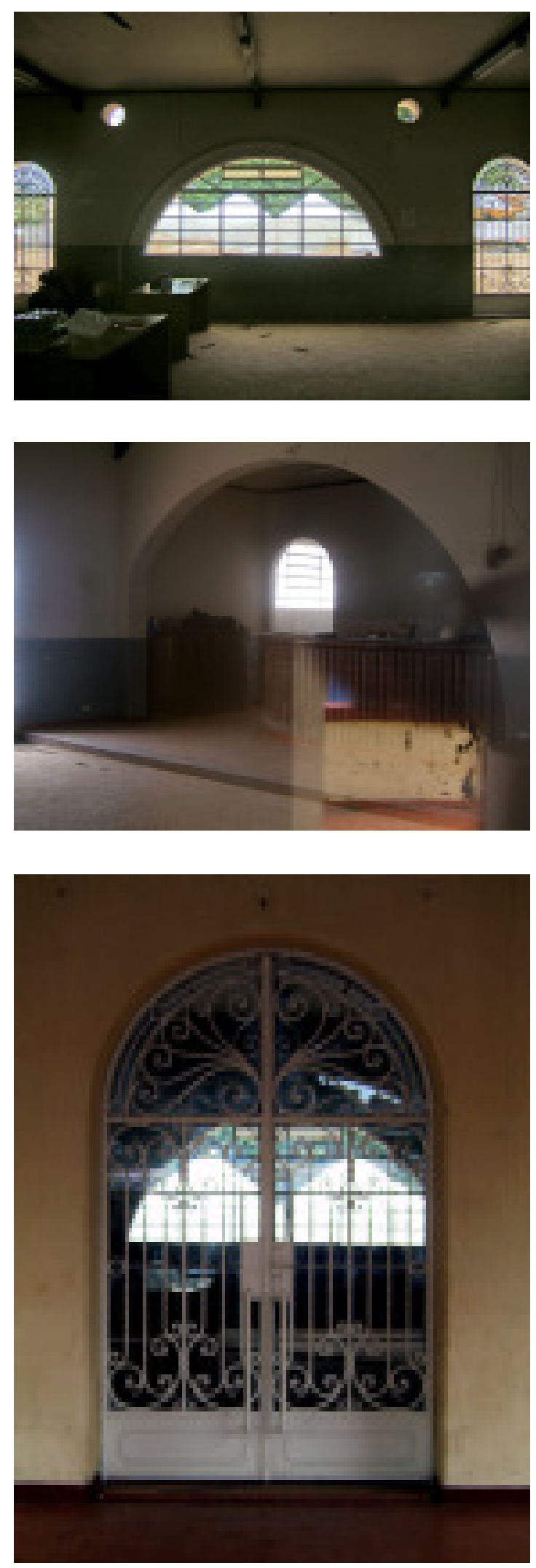

Figura 182 - Alguns detalhes do interior do prédio da Piscina Municipal: aberturas em arco, portas de ferro com motivos decorativos, balcão em madeira. Fonte: fotos da autora, abril de 2008. 

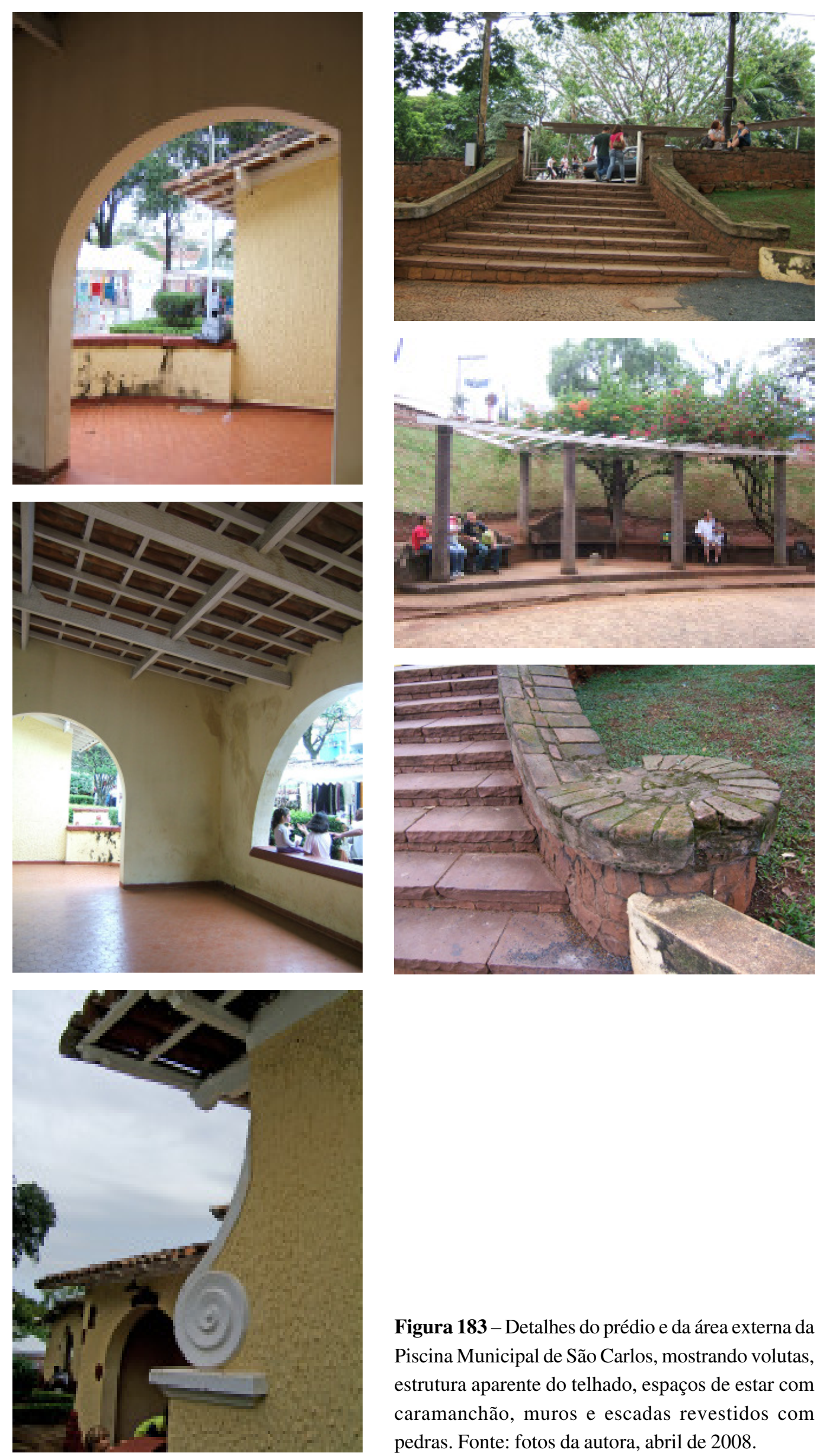

Figura 183 - Detalhes do prédio e da área externa da Piscina Municipal de São Carlos, mostrando volutas, estrutura aparente do telhado, espaços de estar com caramanchão, muros e escadas revestidos com pedras. Fonte: fotos da autora, abril de 2008. 

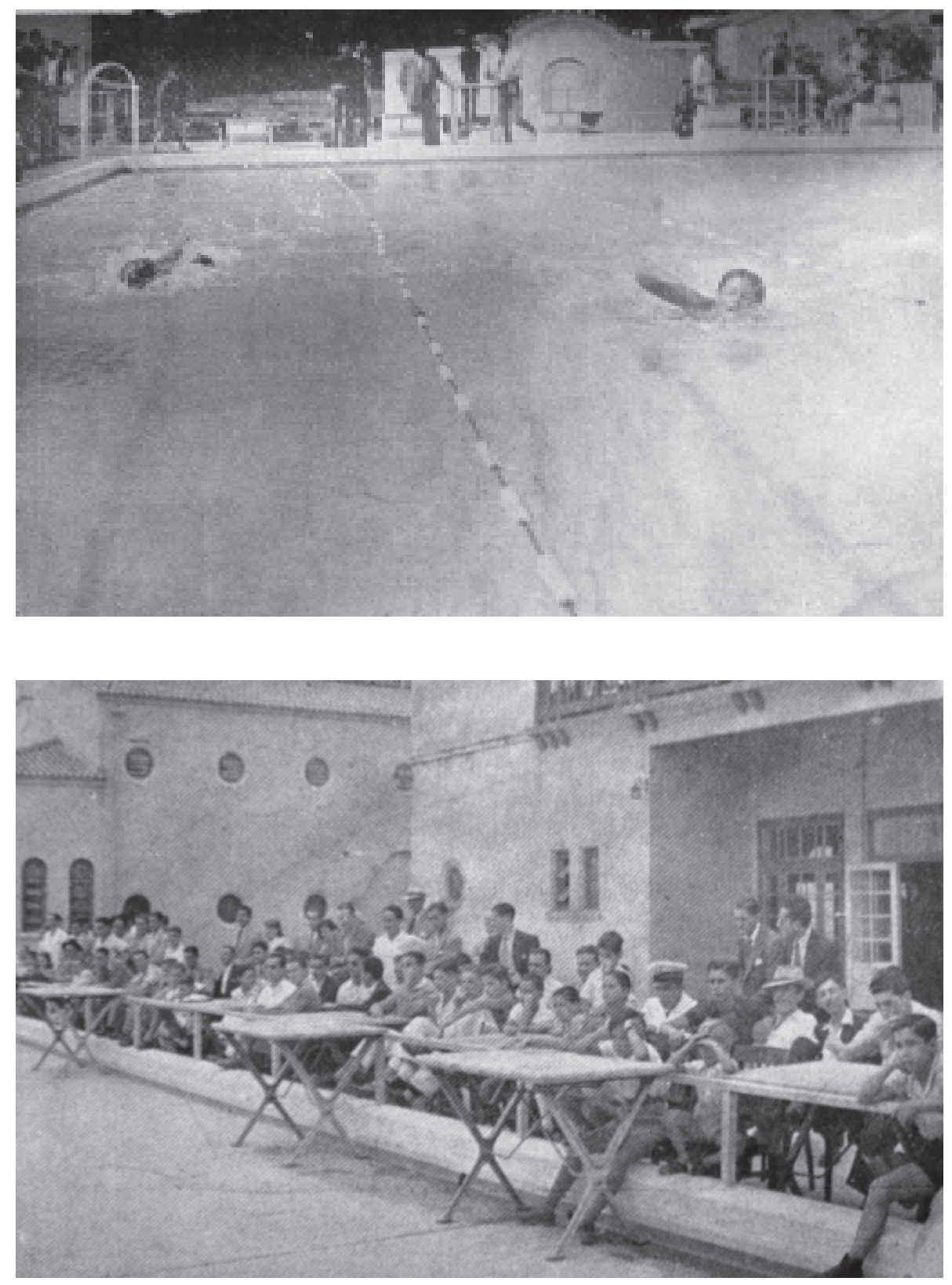

Figura 184 - Imagens de 1945 do Taubaté Country Club. Ao fundo vemos um muro de linhas curvas e telhas capa e canal assentadas no topo como decoração. Vemos também parte do prédio com parte do telhado com beiral, janelas redondas e sacada com mísulas. Fonte: Álbum Comemorativo ao TriCentenário de Taubaté (1945). 

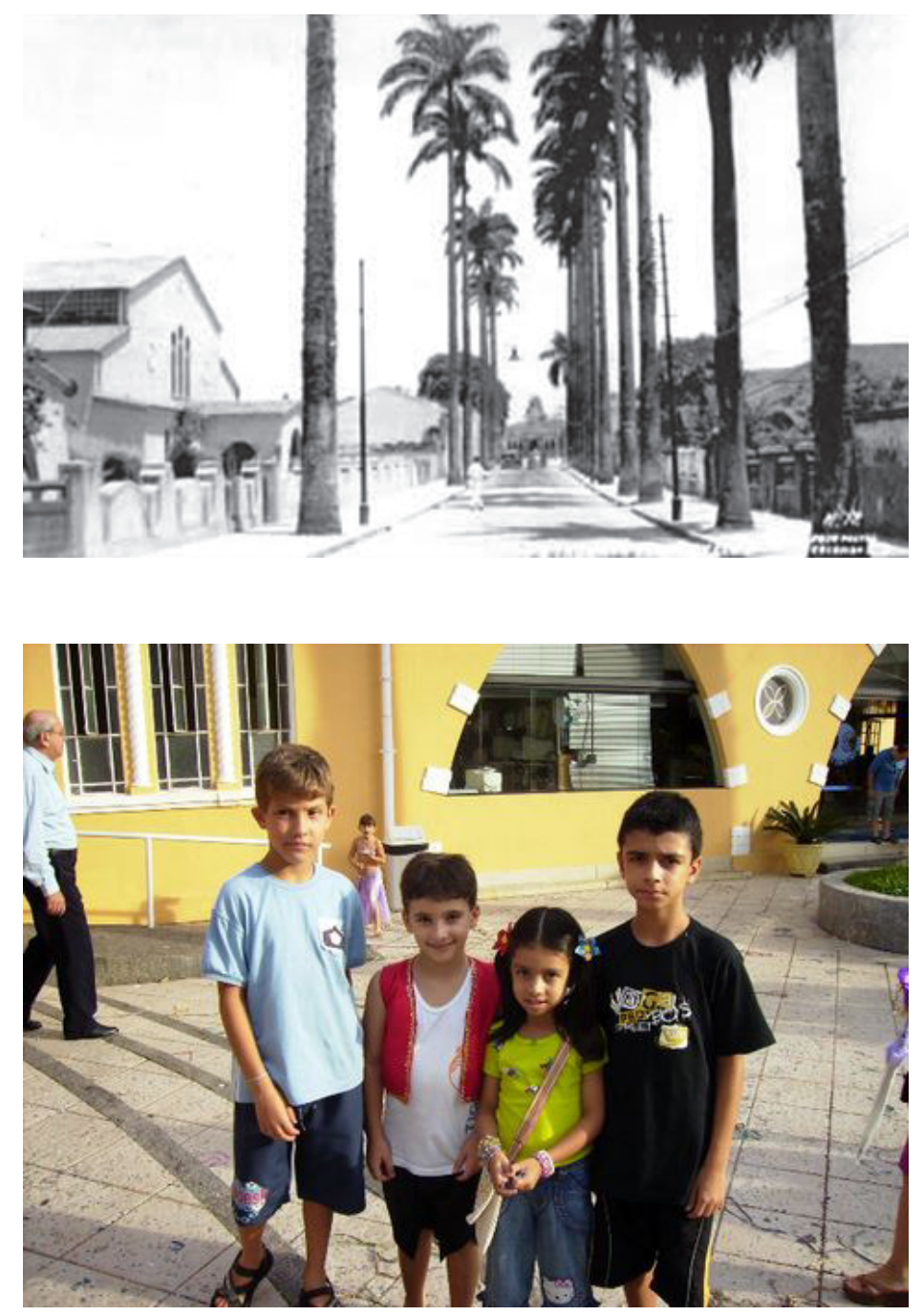

Figura 185 - Vista da fachada do Tubaté Country Club nos anos de 1940 e foto recente do prédio mostrando arco e decoração com pedras na fachada e colunas salomônicas na janela. Disponível em: http:// www.taubate-sp.com.br/art1.htm. Acesso em: 22/04/2007. Disponível em (foto atual): http://www.taubatecountryclub.com.br/ galeriadefotos.php Acesso em 22/04/2007. 

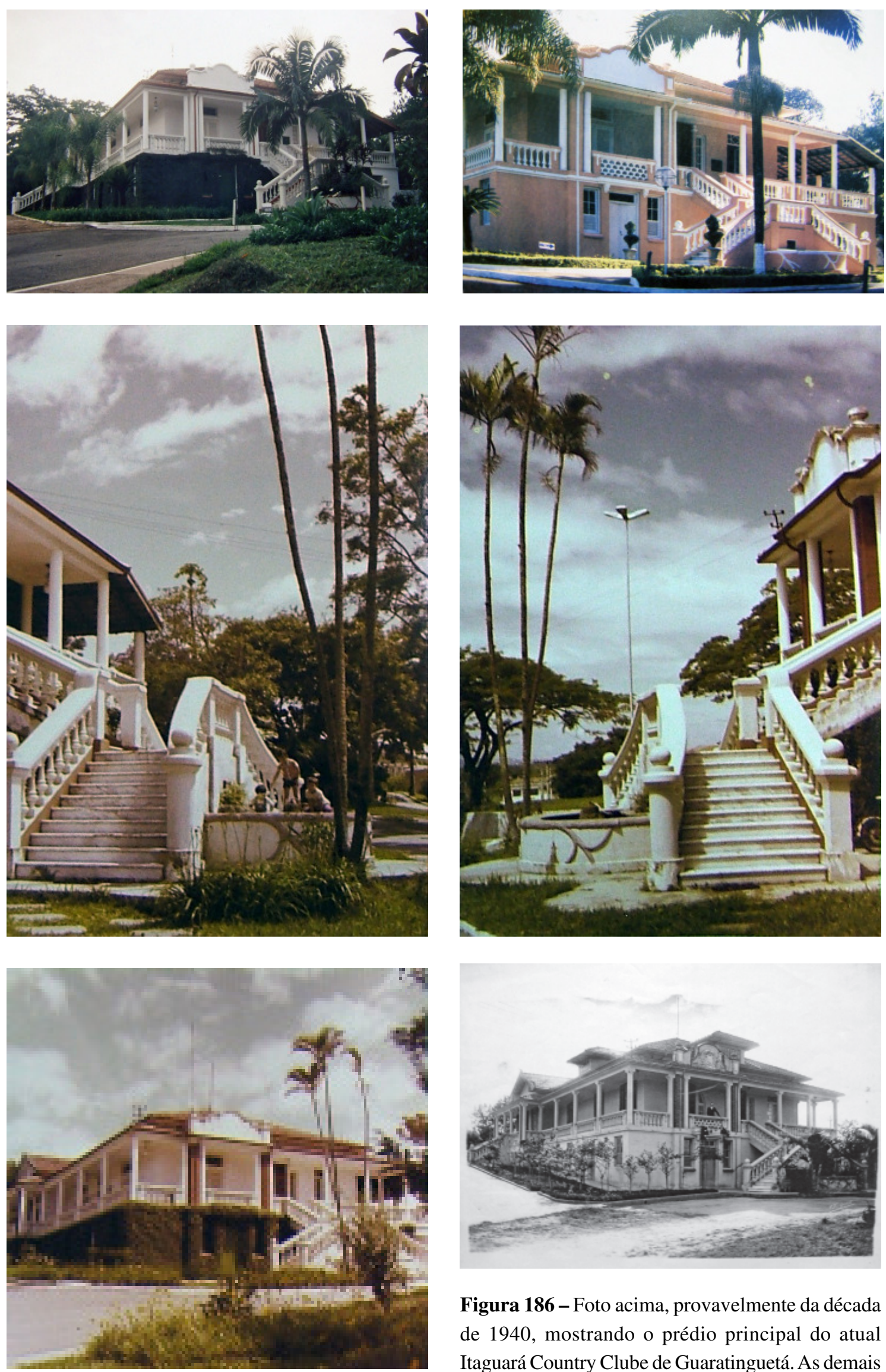

Figura 186 - Foto acima, provavelmente da década de 1940, mostrando o prédio principal do atual Itaguará Country Clube de Guaratinguetá. As demais fotos mostram o mesmo prédio na década de 1990, antes das últimas obras de restauro. Fonte: Arquivo Municipal de Guaratinguetá. 


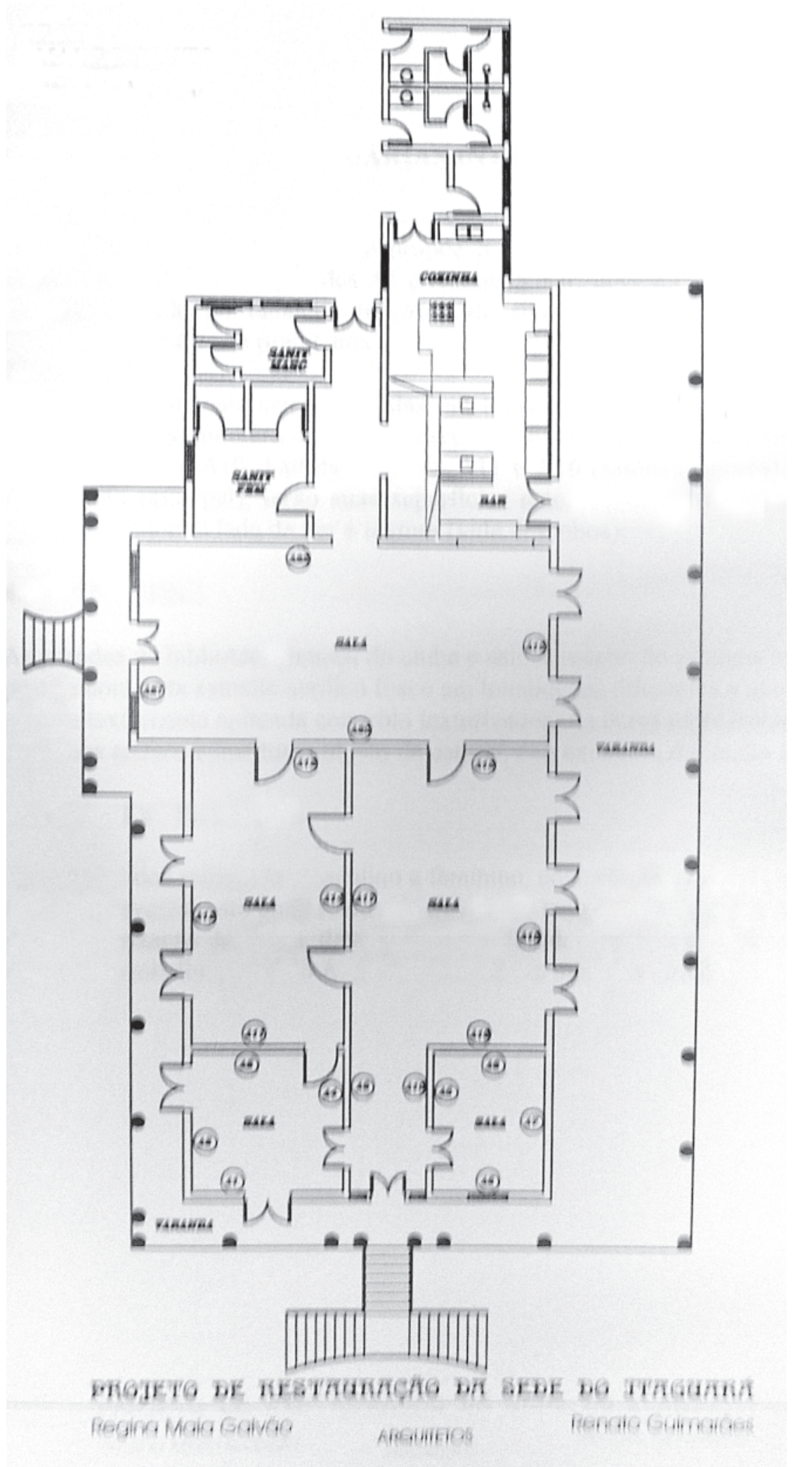

Figura 187 - Levantamento métrico da planta do prédio principal do Itaguará Country Clube de Guaratinguetá realizado pelos arquitetos Regina Maia Galvão e Renato Guimarães para realização de projeto de restauro, na década de 1990. Fonte: Arquivo Municipal de Guaratinguetá. 

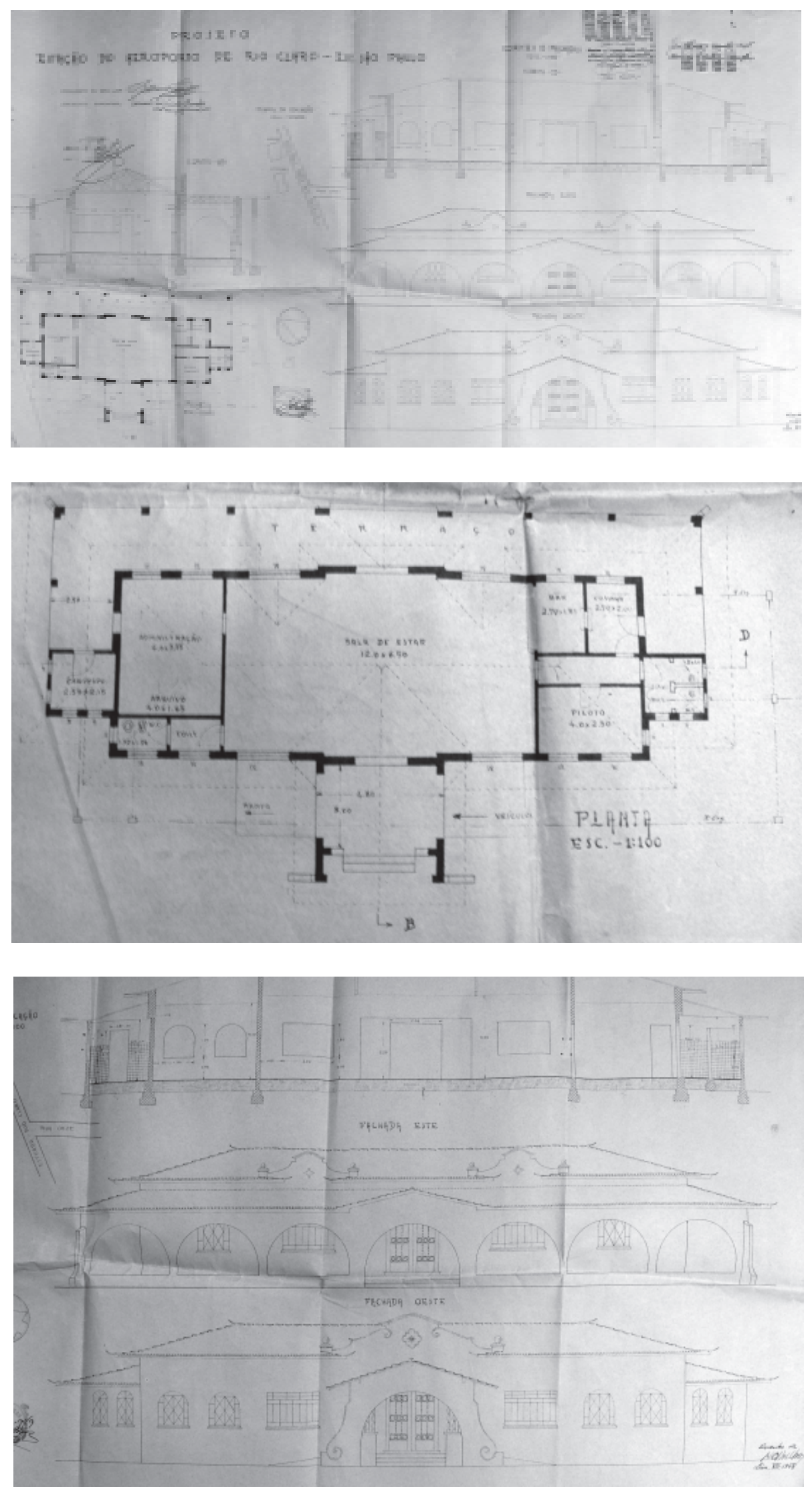

Figura 188 - Projeto para a Estação e Passageiros do Aeroclube de Rio Claro, de 1948, realizado pelo engenheiro Minton Silveira. O desenho é assinado, mas está ilegível. Talvez se deva ao autor do desenho o aspecto neocolonial da construção. Fonte: Arquivo Municipal de Rio Claro. 

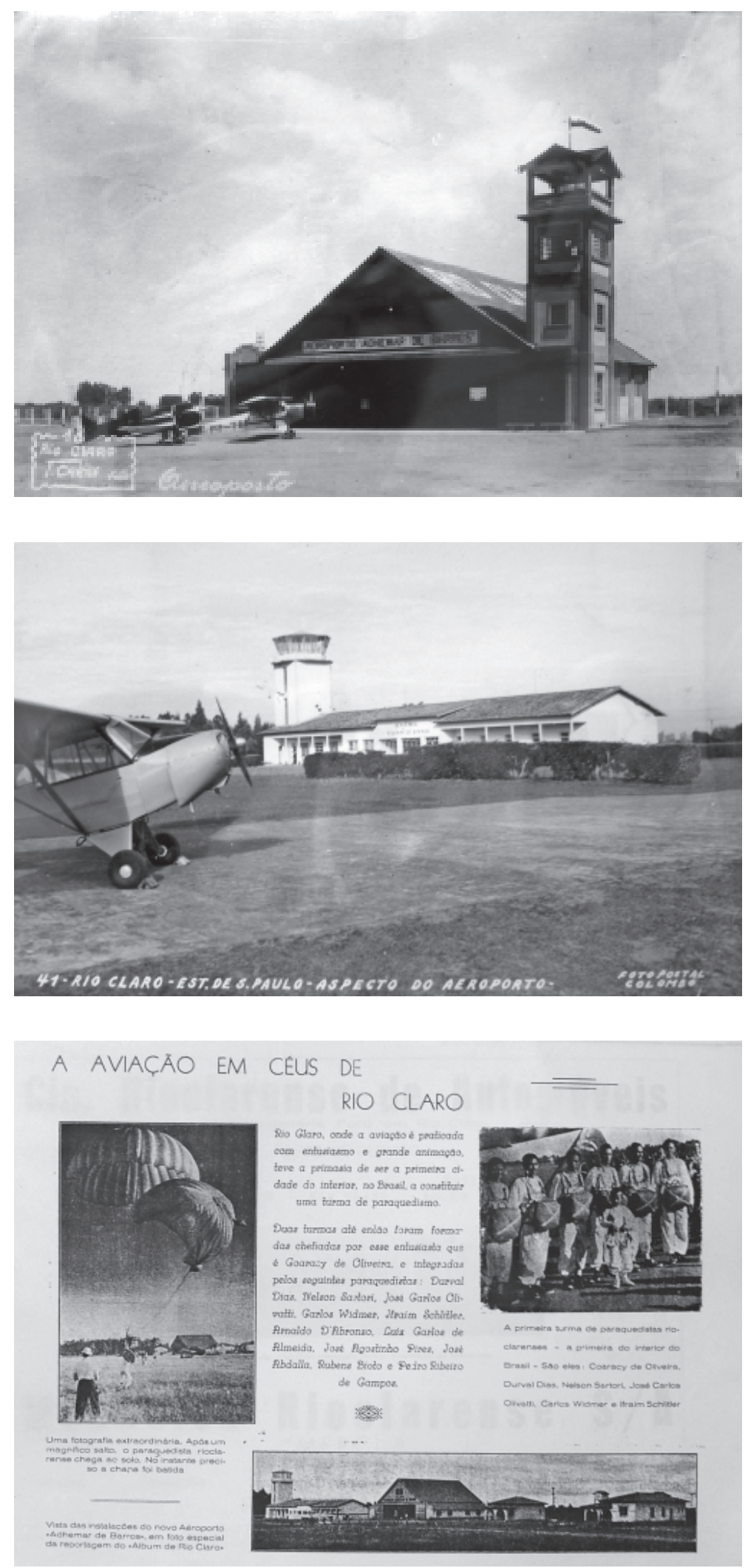

Figura 189 - Imagens de outras instalações do Aeroclube de Rio Claro. Fonte: Álbum de Rio Claro (1951). 

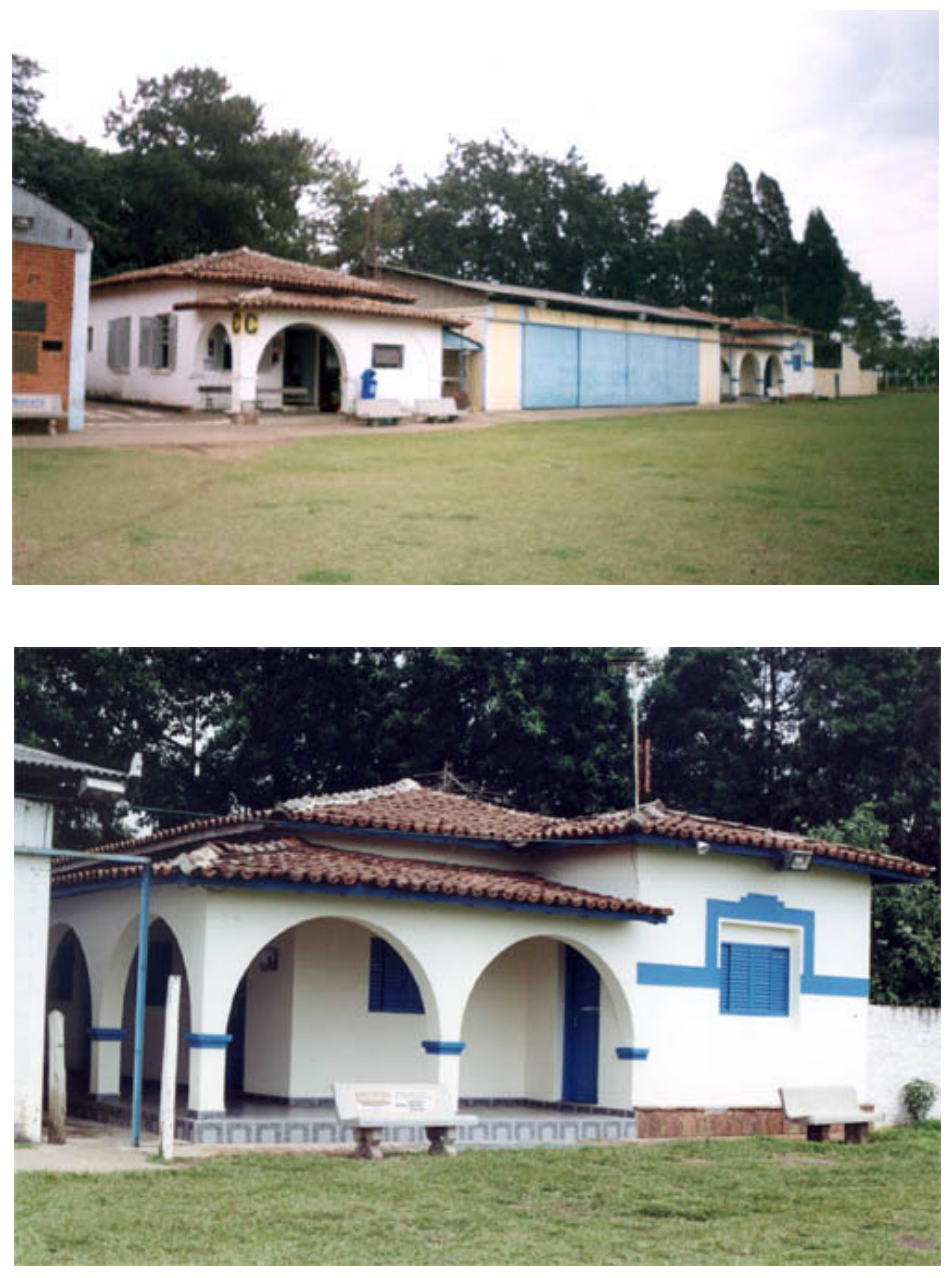

Figura 190 - Vista dos atuais alojamentos do Aeroclube de Rio Claro, provavelmente, utilizados com outro uso nas décadas de 1940 e 1950. Suas linhas neocoloniais sugerem que foram construídas na mesma época em que o foi a Estação de Passgeiros. Disponível em: http://www.aeroclubederioclaro.com.br/alojamentos.asp\# Acesso em: 22/04/2008. 

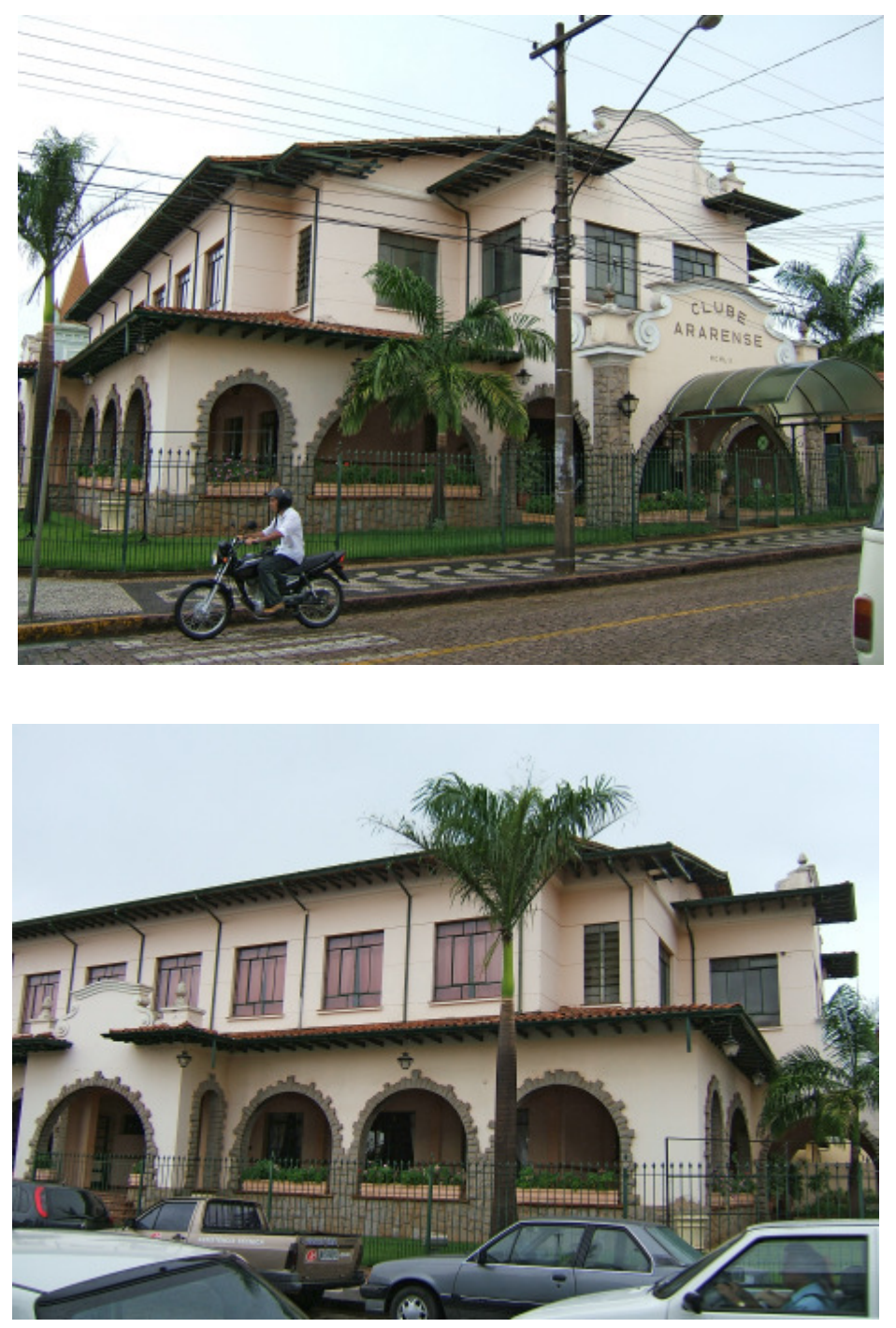

Figura 191 - Fachadas do prédio do Clube Ararense, no centro da cidade de Araras. Exibe traços neocoloniais marcantes. Fonte: fotos da autora, outubro de 2006. 


\section{COMPANHIA PREDIAL}

\section{TAUBATE'}

RUA CONSELHEIRO MOREIRA DE BARROS, 185

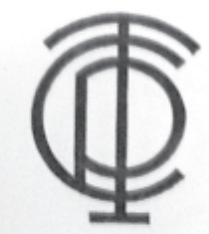

\section{RELATORIO}

$E$

\section{CONTAS}

DE

\section{8}
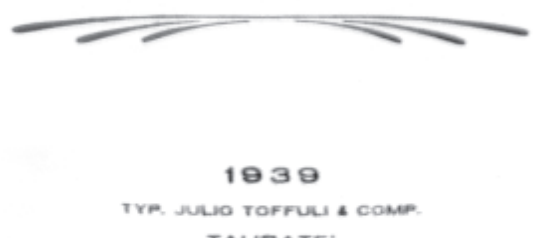

TAUEATE'

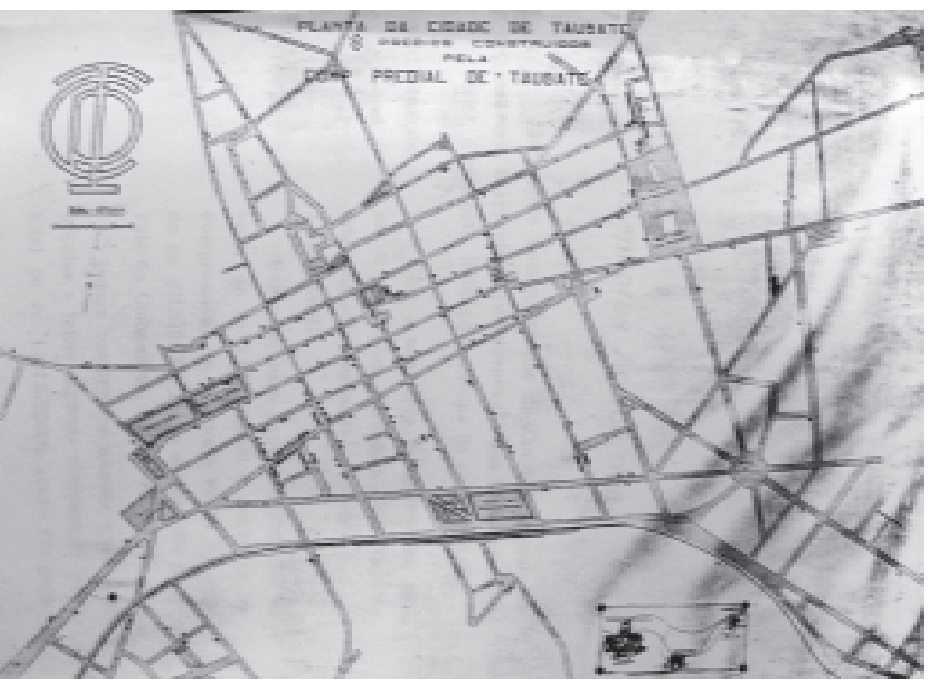

Figura 192 - Mapa de Taubaté publicado no Relatório de Contas da Companhia Predial de Taubaté de 1938 mostrando os prédios construídos pela companhia na cidade até aquele ano. Fonte: Relatório de Contas da Companhia Predial de Taubaté (1938). 

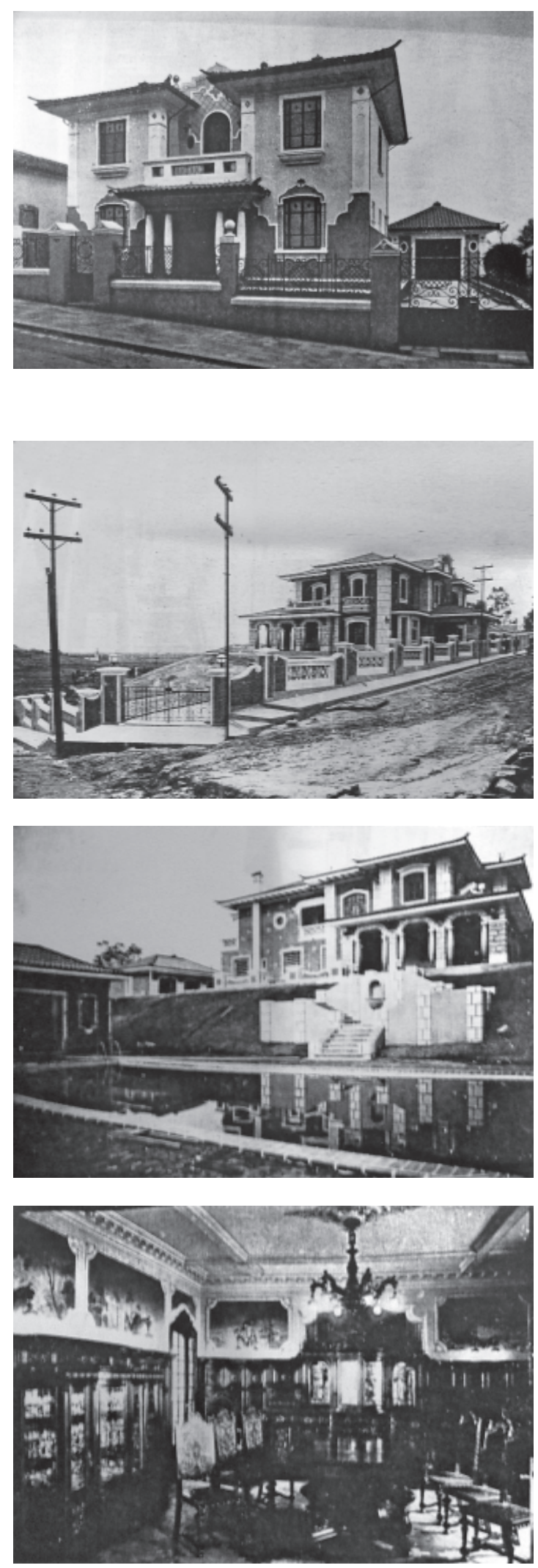

Figura 193 (à esquerda) - A primeira foto mostra a residência de Eleozippo S. Pinto, construída pela Companhia Predial de Taubaté, nessa mesma cidade. A segunda, a residência de Alberto Pedrosa, em Caçapava. Notar como a volumetria das edificações se assemelha à volumetria de algumas obras de Ricardo Severo. Fonte: Relatório de Contas da Companhia Predial de Taubaté (1934 e 1938, respectivamente).

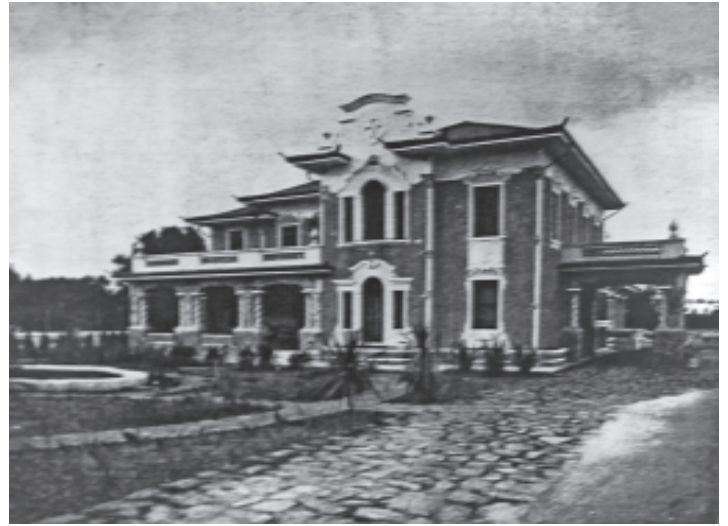

Figura 194 (acima) - Outra residência construída pela Companhia Predial de Taubaté, mas esta com estilemas neocoloniais misturados aos da vertente missões. Fonte: Relatório de Contas da Companhia Predial de Taubaté (1937). 

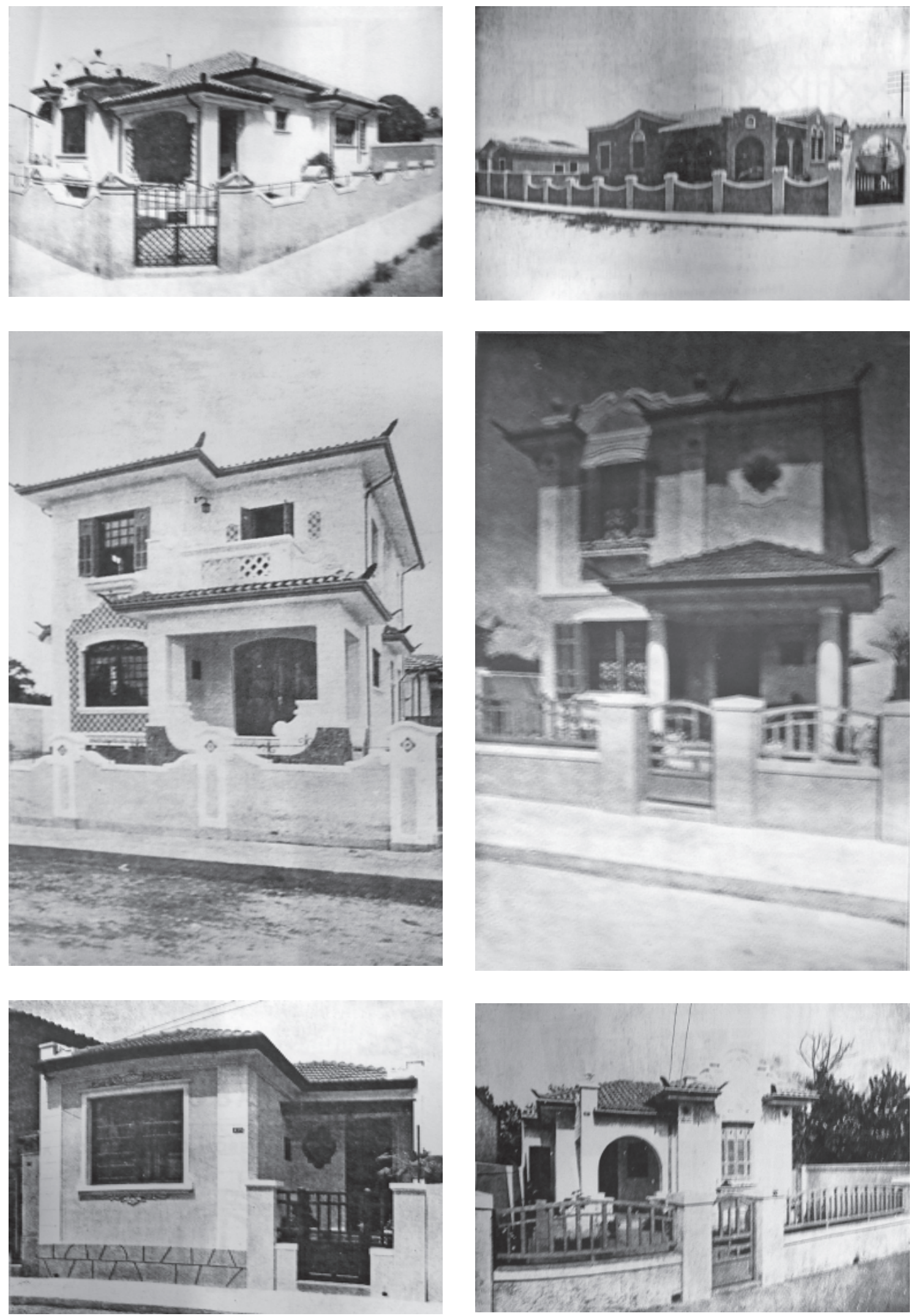

Figura 195 (páginas 417 a 419) - Várias residências construídas pela Companhia Predial de Taubaté nas cidades da região, durante as décadas de 1930 e 1940, segundo tendências neocoloniais. Fonte: Relatório de Contas da Companhia Predial de Taubaté(1932 a 1941). 

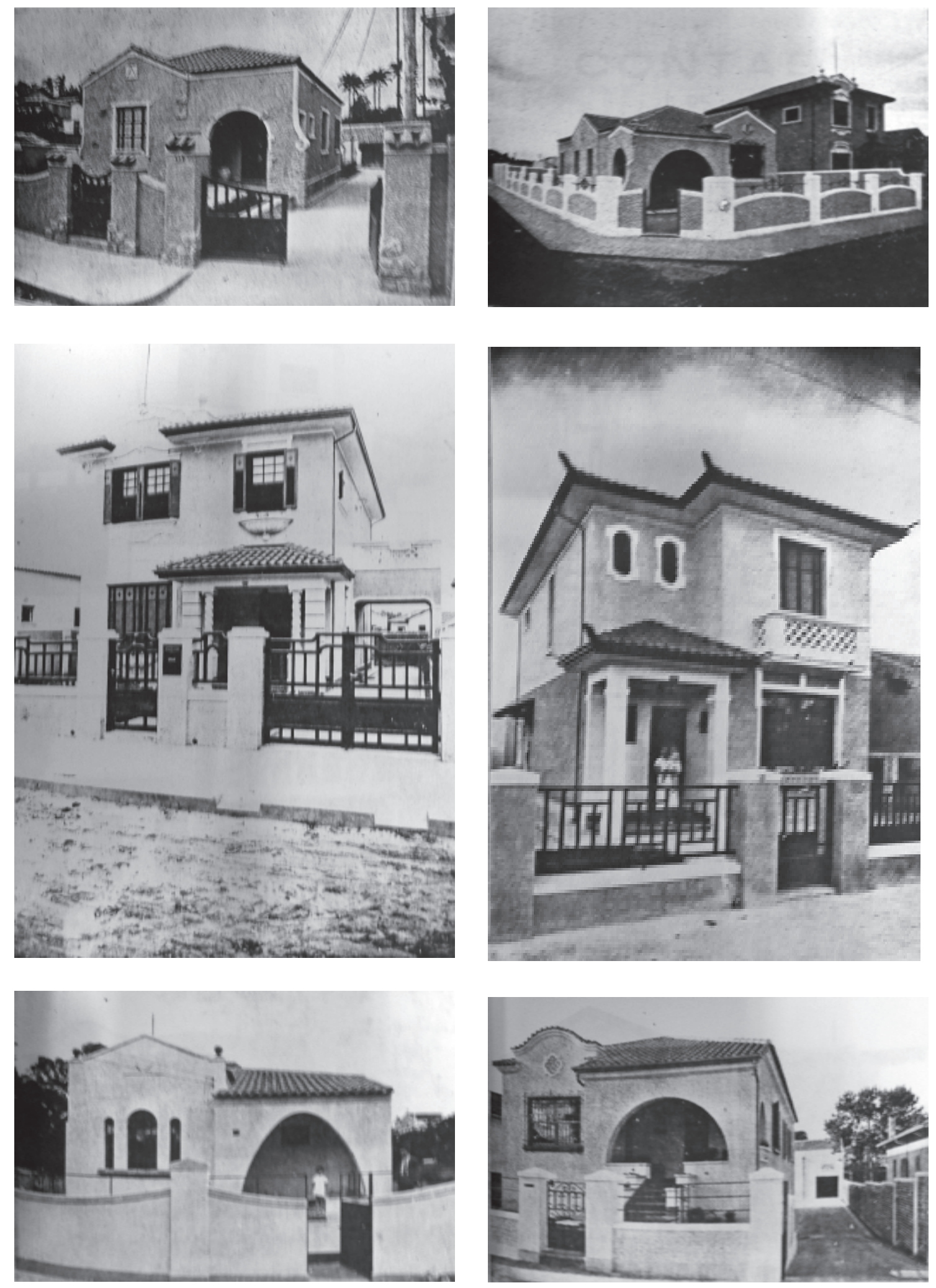

Figura 195 - legenda na página 417. 

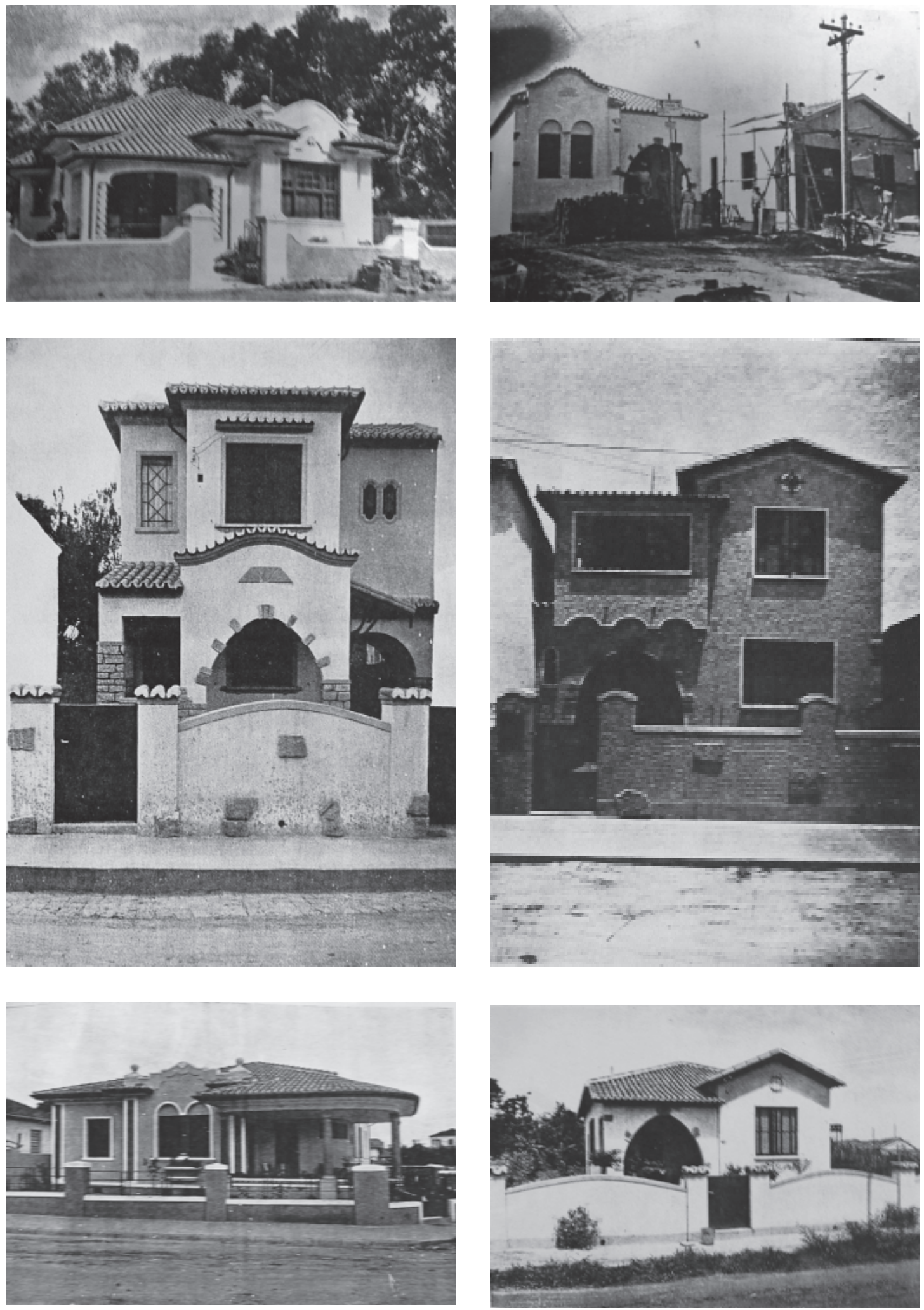

Figura 195 - legenda na página 417. 

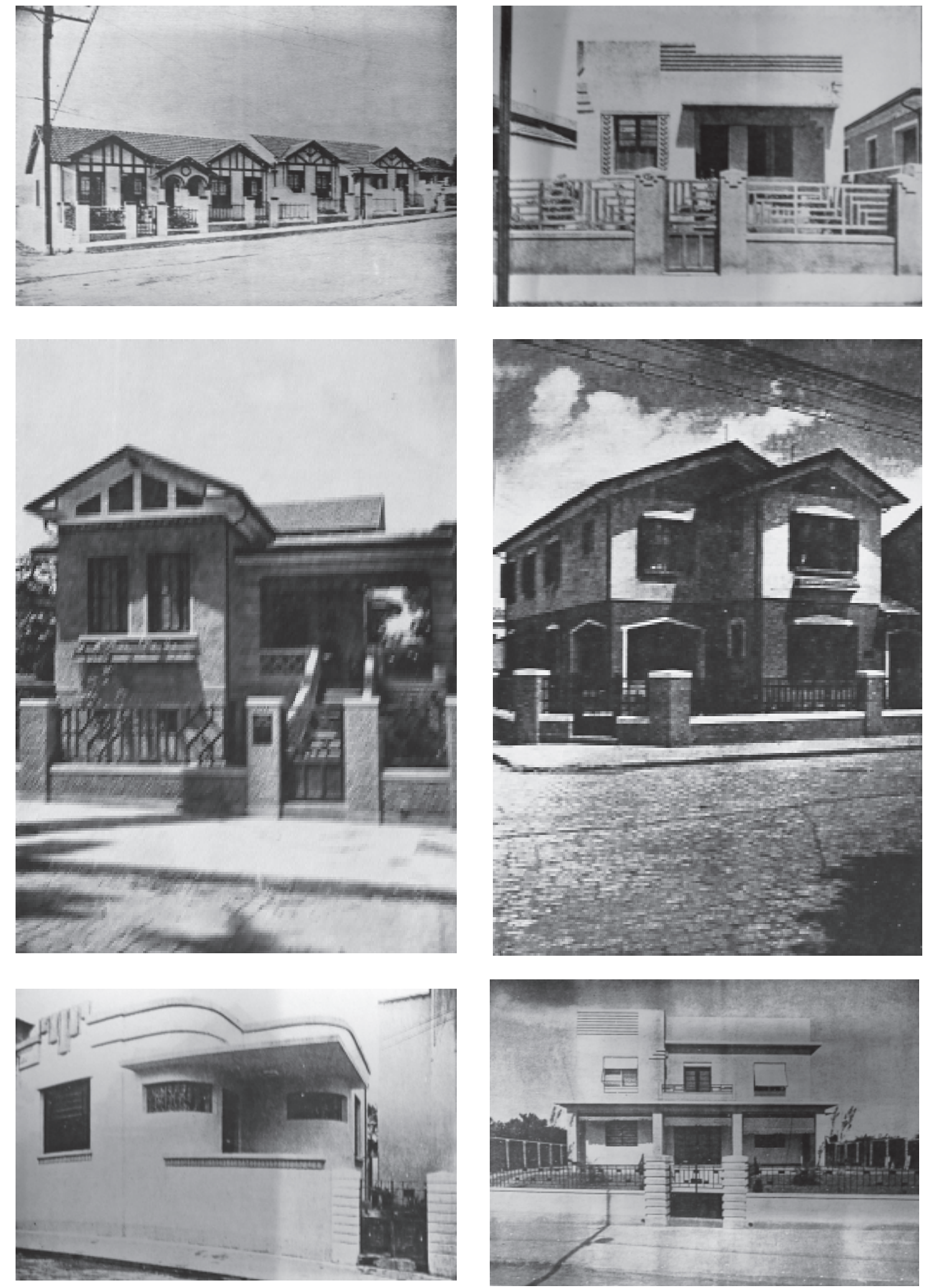

Figura 196 - Várias residências construídas pela Companhia Predial de Taubaté nas cidades da região, durante as décadas de 1930 e 1940, segundo tendências art déco, eclética e modernista. Fonte: Relatório de Contas da Companhia Predial de Taubaté (1932 a 1941). 


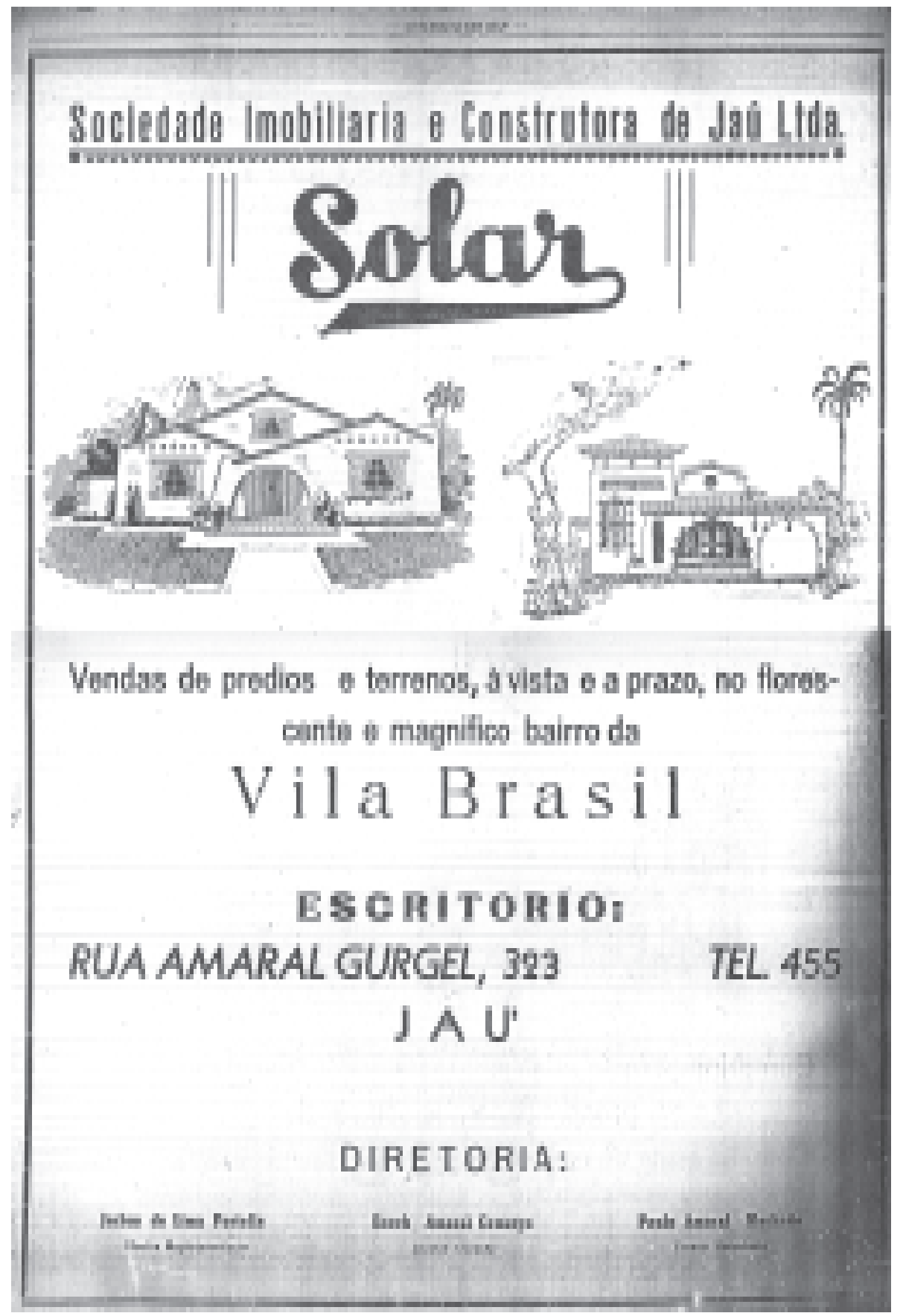

Figura 197 - Anúncio da Vila Brasil no Jornal "O Comércio do Jaú”, de 25 de dezembro de 1947. Notar as características dos modelos de residências anunciados: neocoloniais e missões. Fonte: Arquivo Municipal de Jaú. 

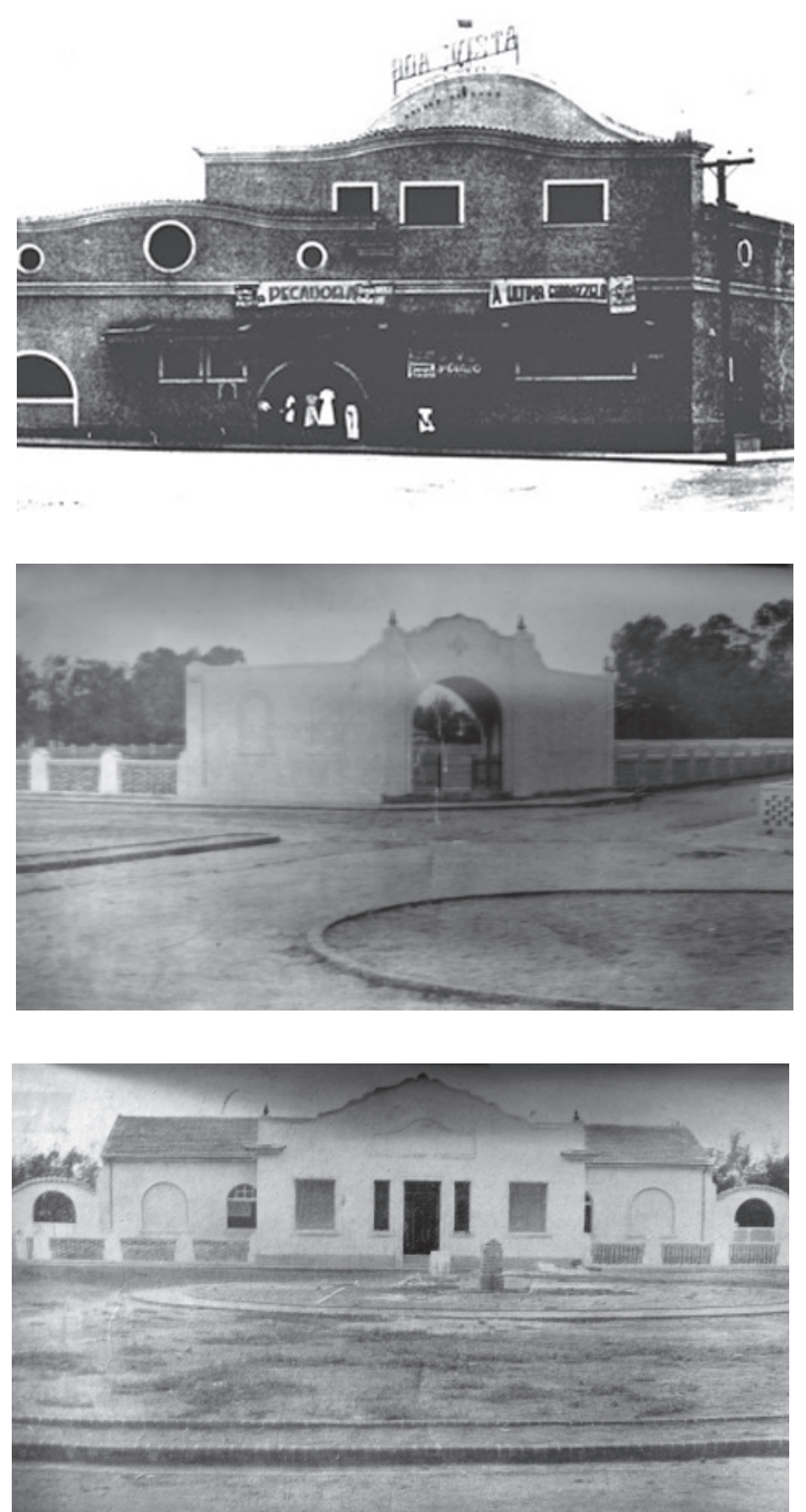

Figura 198 - Imagem do Cine Boa Vista, na vila da Companhia Fabril de Juta. Disponível em: http://www.idesa.com.br/idesagora/ index.php?cod=354\&edicao=25 Acesso em: 25/04/2008. Imagem do Parque Infantil e do Grupo Escolar da vila operária da Companhia Fabril de Juta. Fonte: Álbum Comemorativo do Tri-Centenário de Taubaté (1945). 

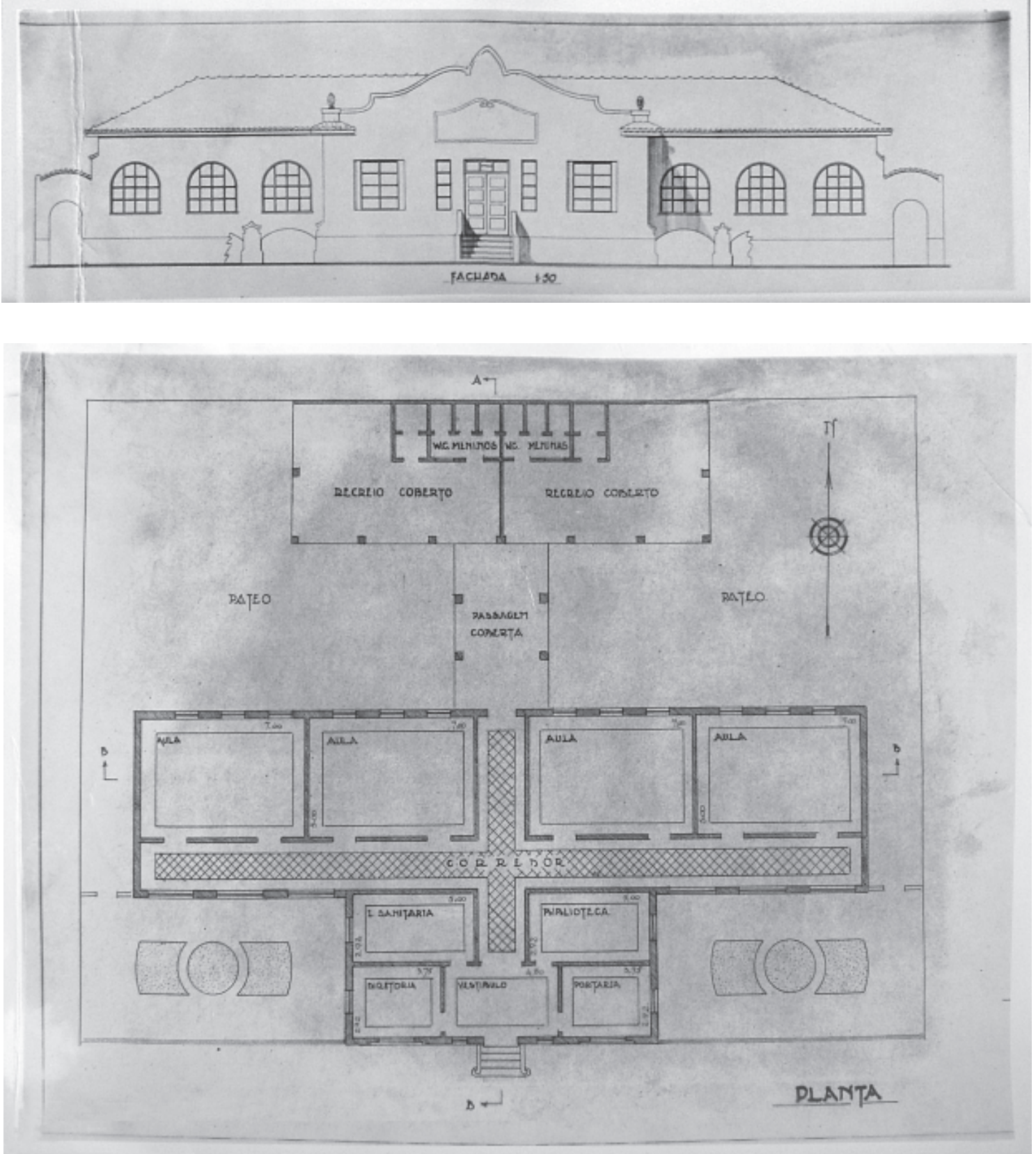

Figura 199 - Projeto do Grupo Escolar na vila da Companhia Fabril de Juta. Fonte: Álbum Comemorativo do Tri-Centenário de Taubaté (1945). 

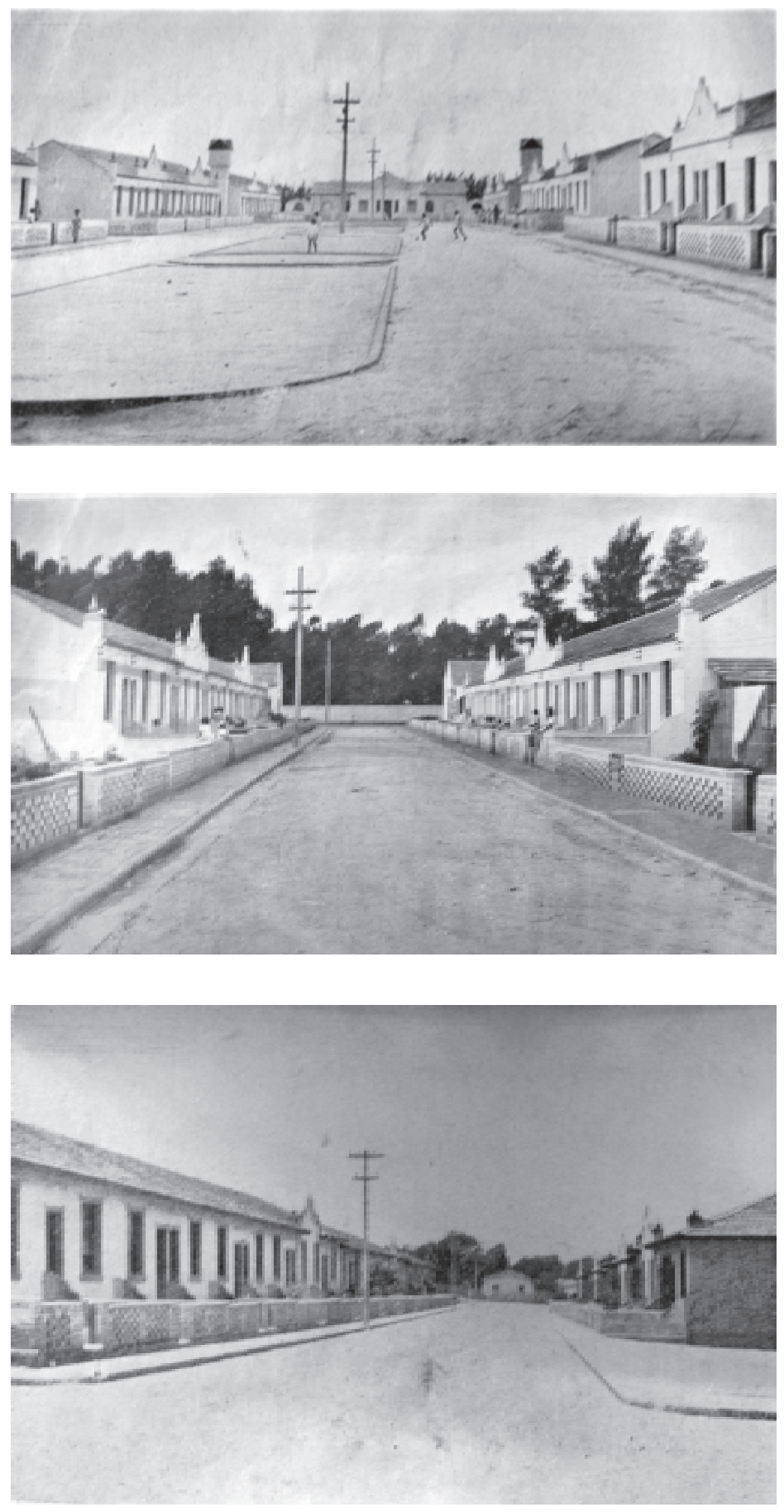

Figura 200 - Residências para os operários da Companhia Fabril de Juta. Fonte: Álbum Comemorativo do Tri-Centenário de Taubaté (1945). 


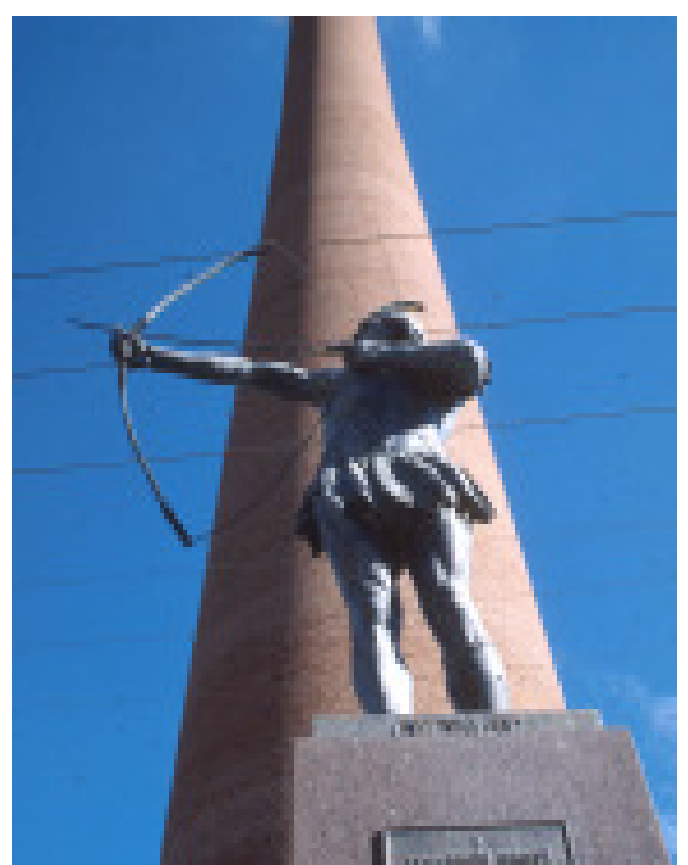

Figura 201 (acima) - Estátua de um índio Tamoio, situada junto à chaminé, na entrada da Usina Tamoio, em Araraquara. Fonte: foto da autora, janeiro de 2001.

Figura 202 (à direita) - Exemplos de painéis de azulejos produzidos durantes as décadas de 1930 e 1940, para a arquitetura neocolonial, retratando motivos indígenas. Fonte do primeiro painel: foto da autora, abril de 2008. Segundo painel, Bica do Bugre, Taubaté. Disponível em: http:// www.ciaux.com/TAUBATEcidade.html Acesso em: 25/04/2008.
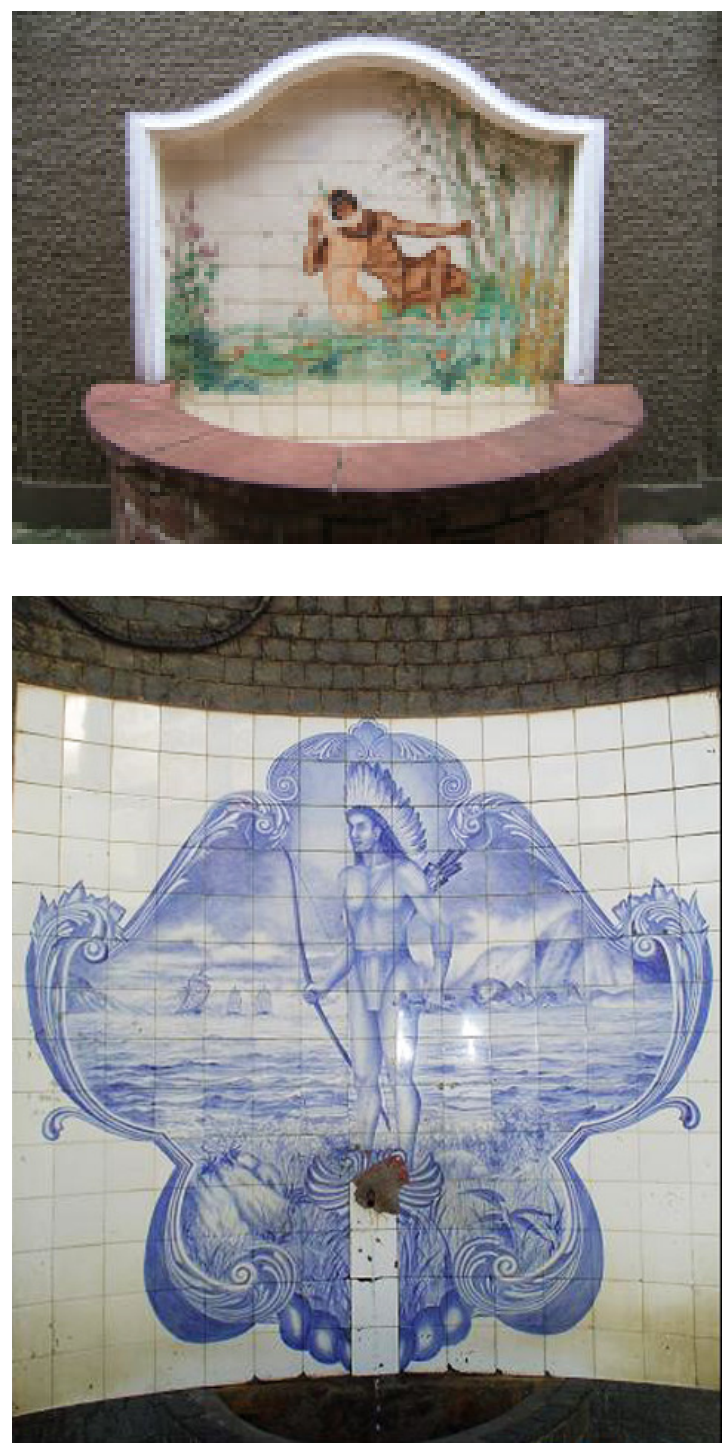

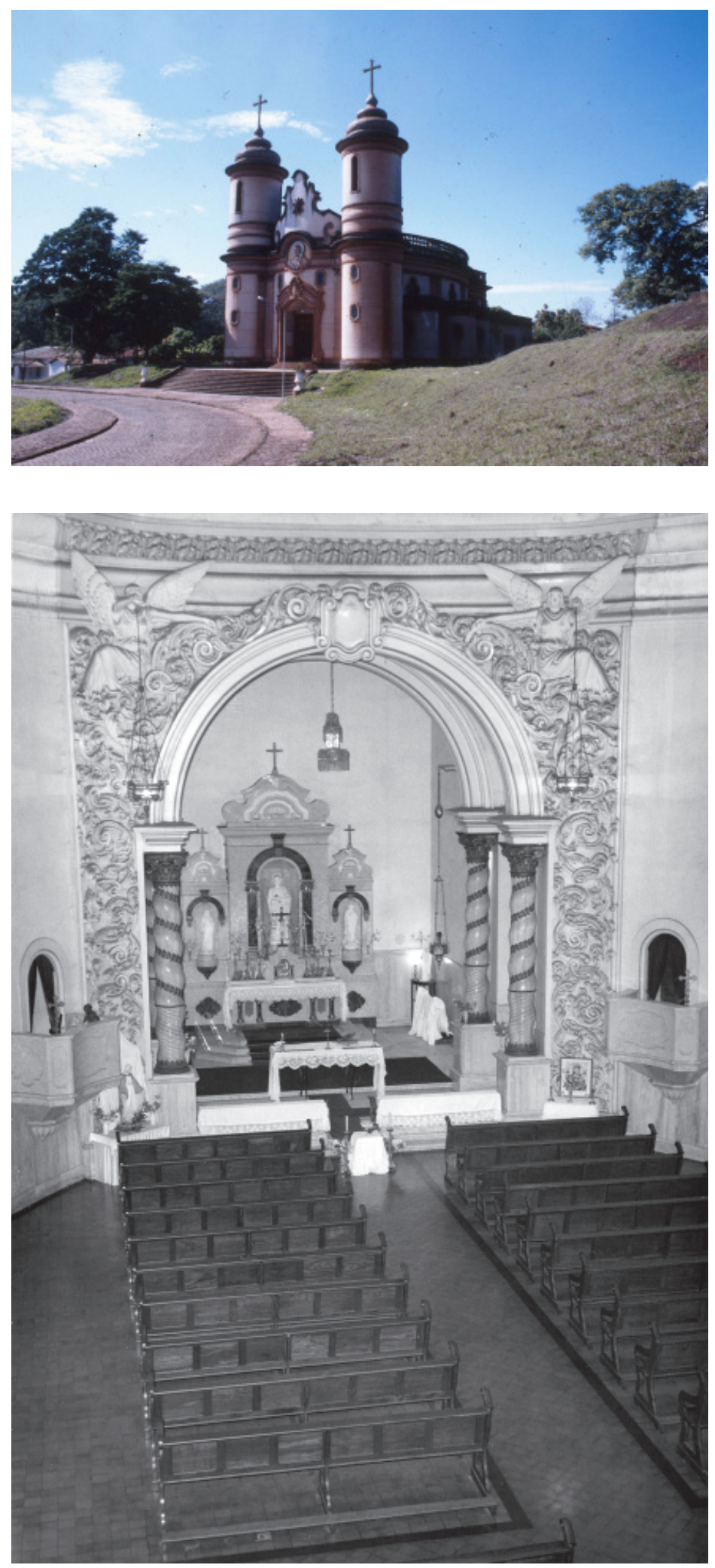

Figura 203 - Templo de São Pedro, construído na vila operária da Usina Tamoio, Araraquara. Fonte: foto externa da autora, janeiro de 2001; Foto interna: E. B. Carneiro (década de 1940). 

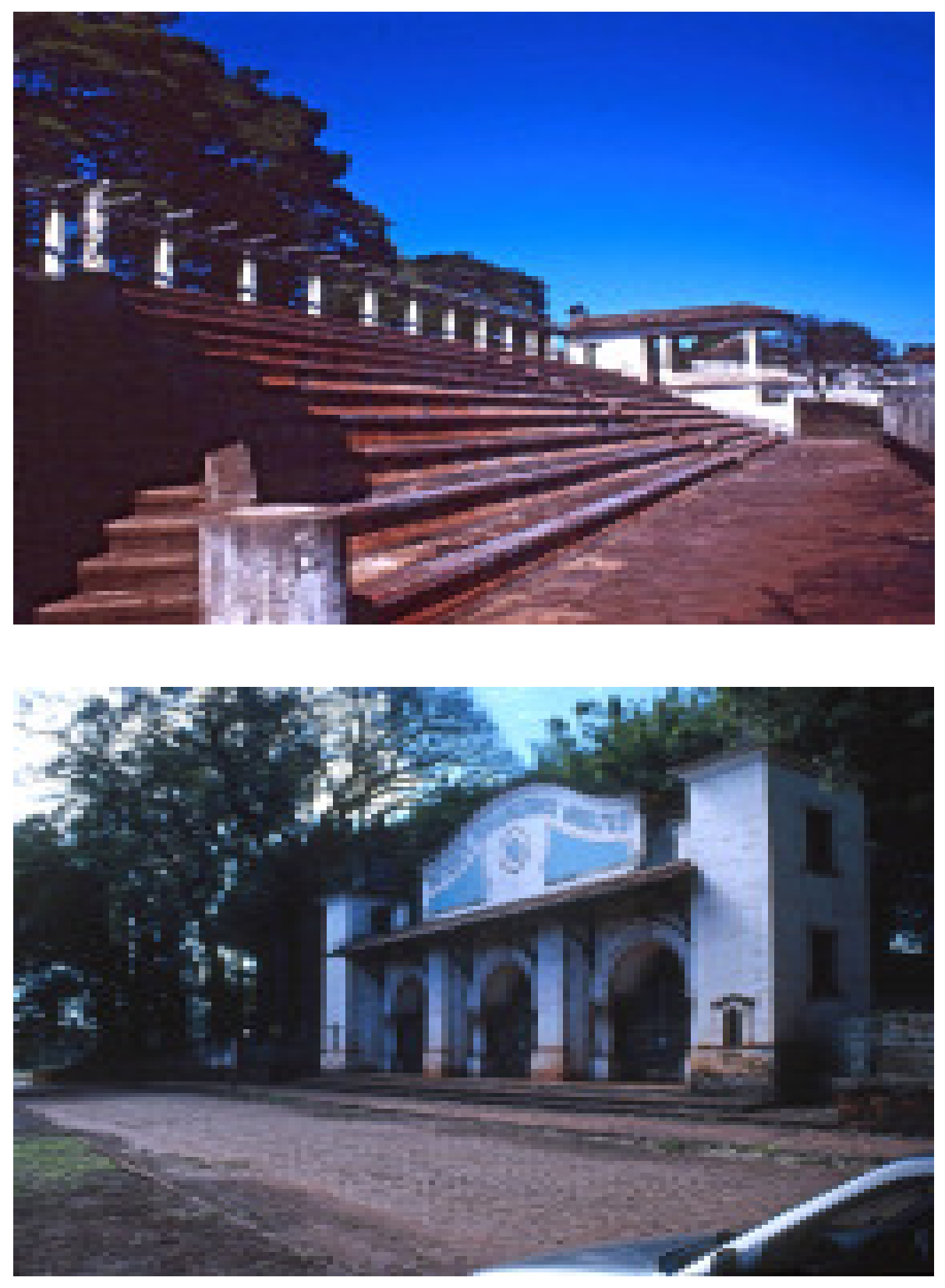

Figura 204 - Fotos do Estádio "Comendador Freitas", na Usina Tamoio. Fonte: foto da autora, janeiro de 2001. 

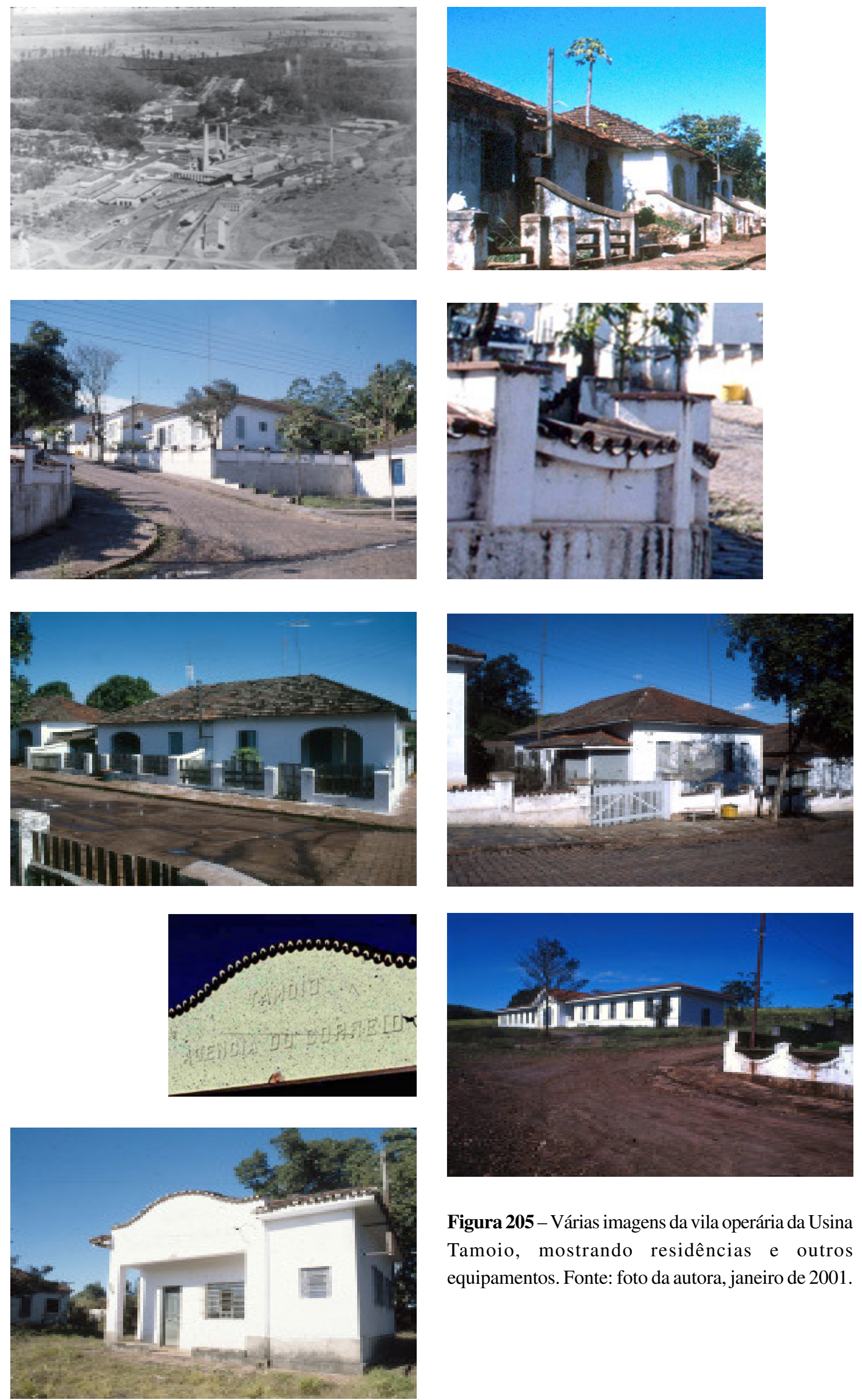

Figura 205 - Várias imagens da vila operária da Usina

Tamoio, mostrando residências e outros equipamentos. Fonte: foto da autora, janeiro de 2001. 


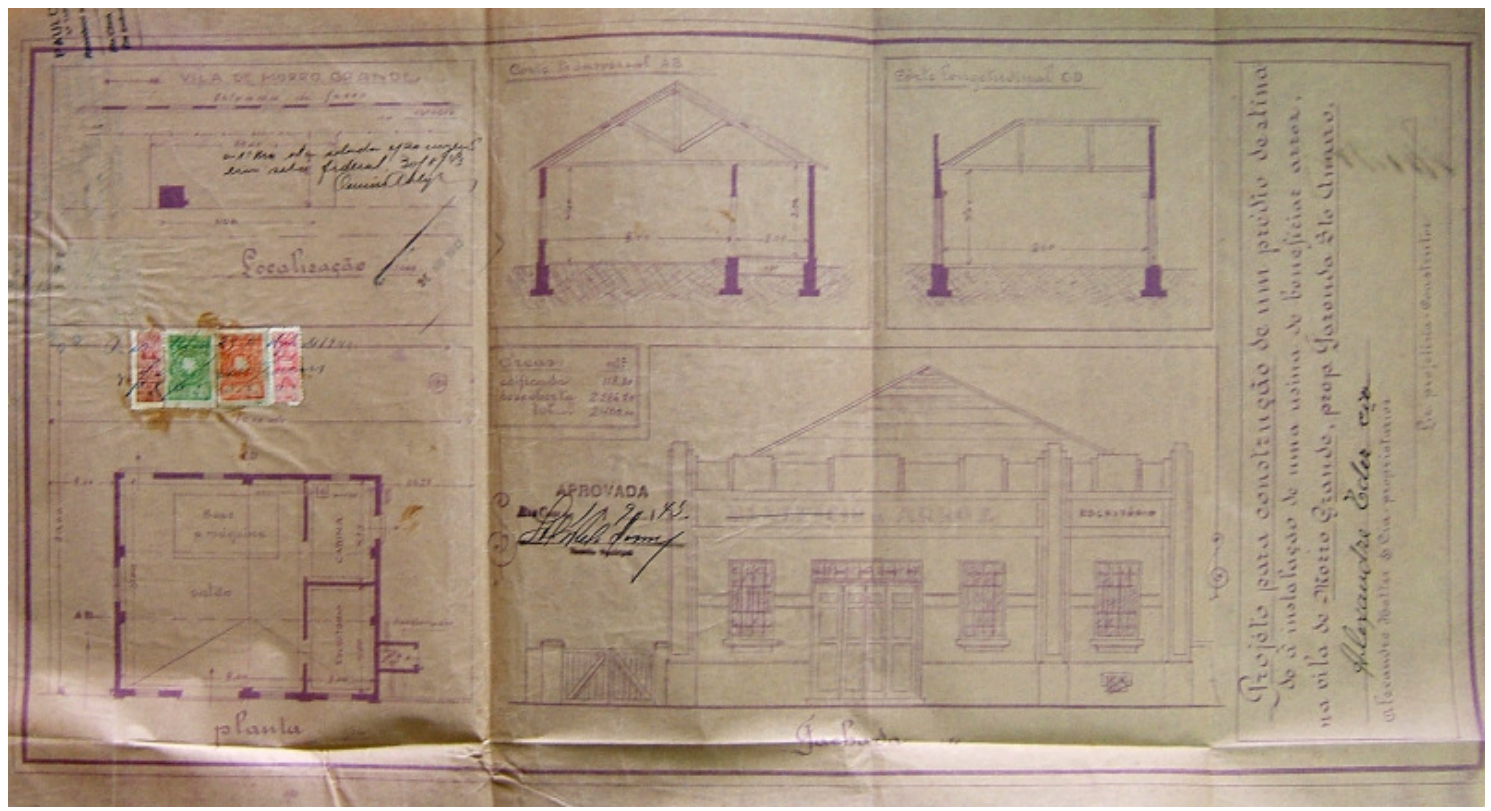

Figura 206 (acima) - Projeto de linhas art déco para uma usina de beneficiar arroz, de autoria do construtor Flávio Santomauro, a ser construído em Rio Claro, em 1943. Fonte: Arquivo Municipal de Rio Claro.

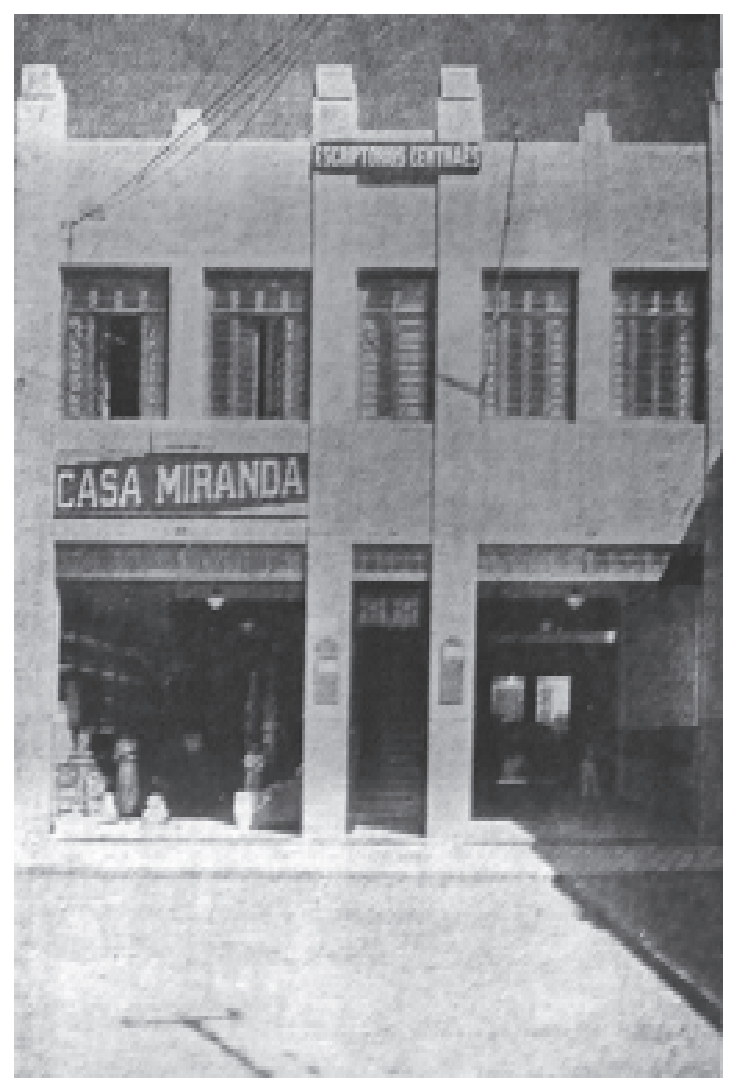

Figura 207 - Em Taubaté, a “Casa Miranda”, também de linhas art déco para um estabelecimento comercial e de serviços. Construída pela Companhia Predial de Taubaté em 1935. Fonte: Relatório de Contas da Companhia Predial de Taubaté (1935). 


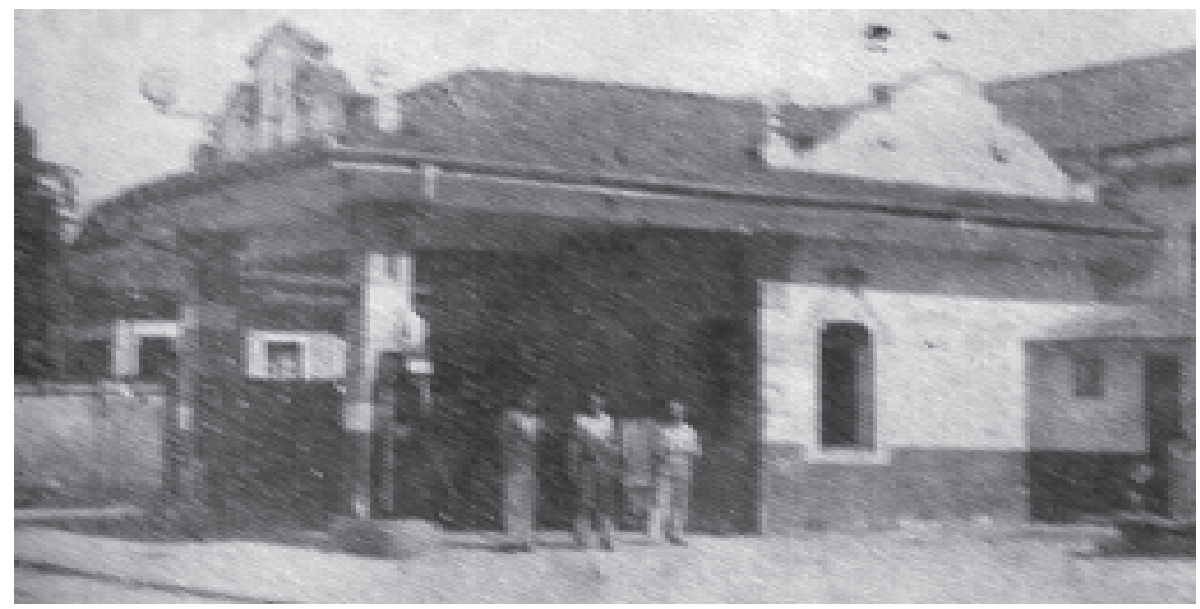

Figura 208 - Posto de gasolina neocolonial, da marca "Atlantic" construído em Taubaté. Fonte: Álbum Comemorativo do TriCentenário de Taubaté (1945).

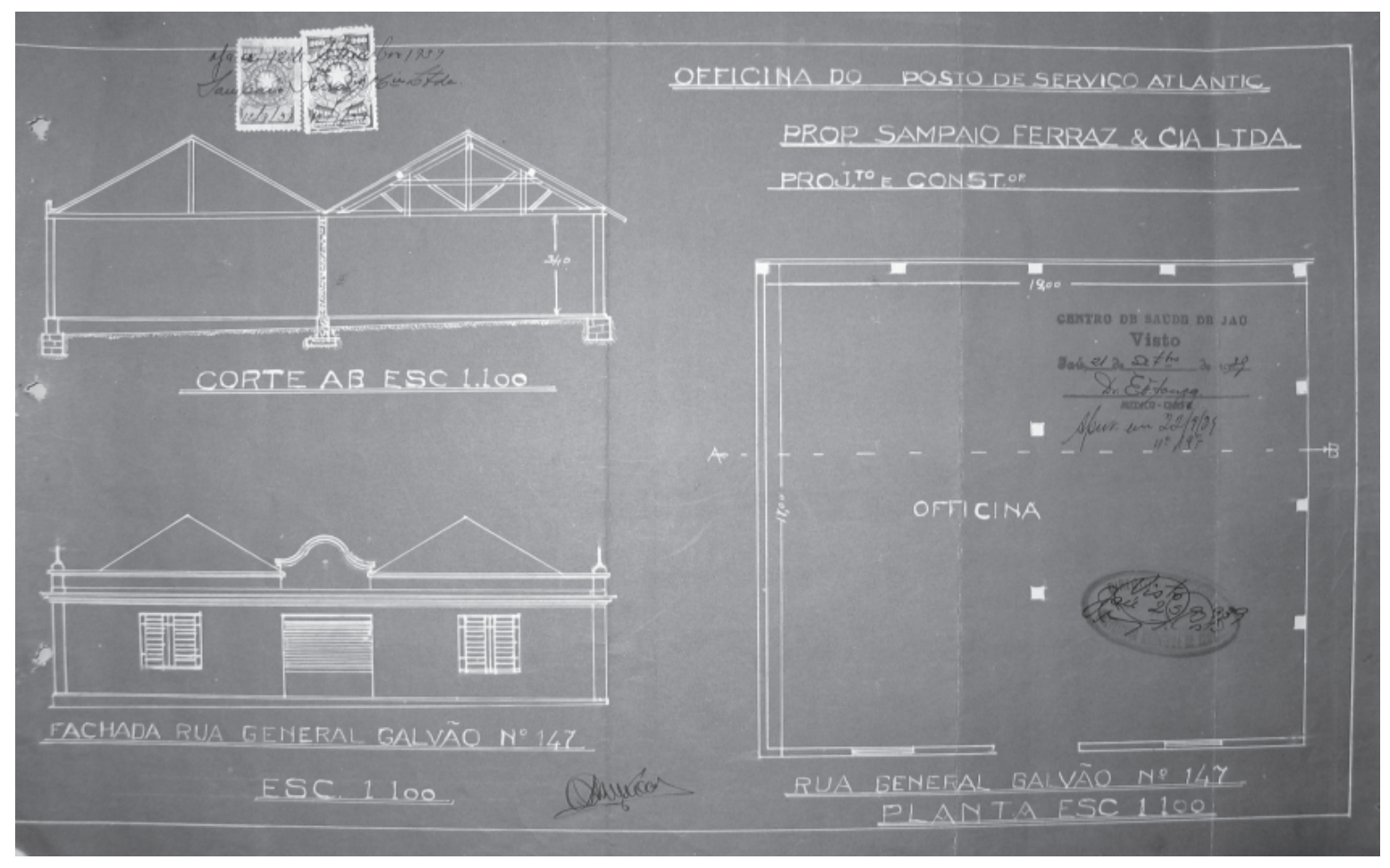

Figura 209 (páginas 430 e 431) - Projeto de autoria do escritório Sampaio \& Ferraz Ltda para um posto de gasolina neocolonial, também da marca "Atlantic", a ser construído na cidade de Jaú, em 1938. Fonte: Arquivo Municipal de Jaú. 

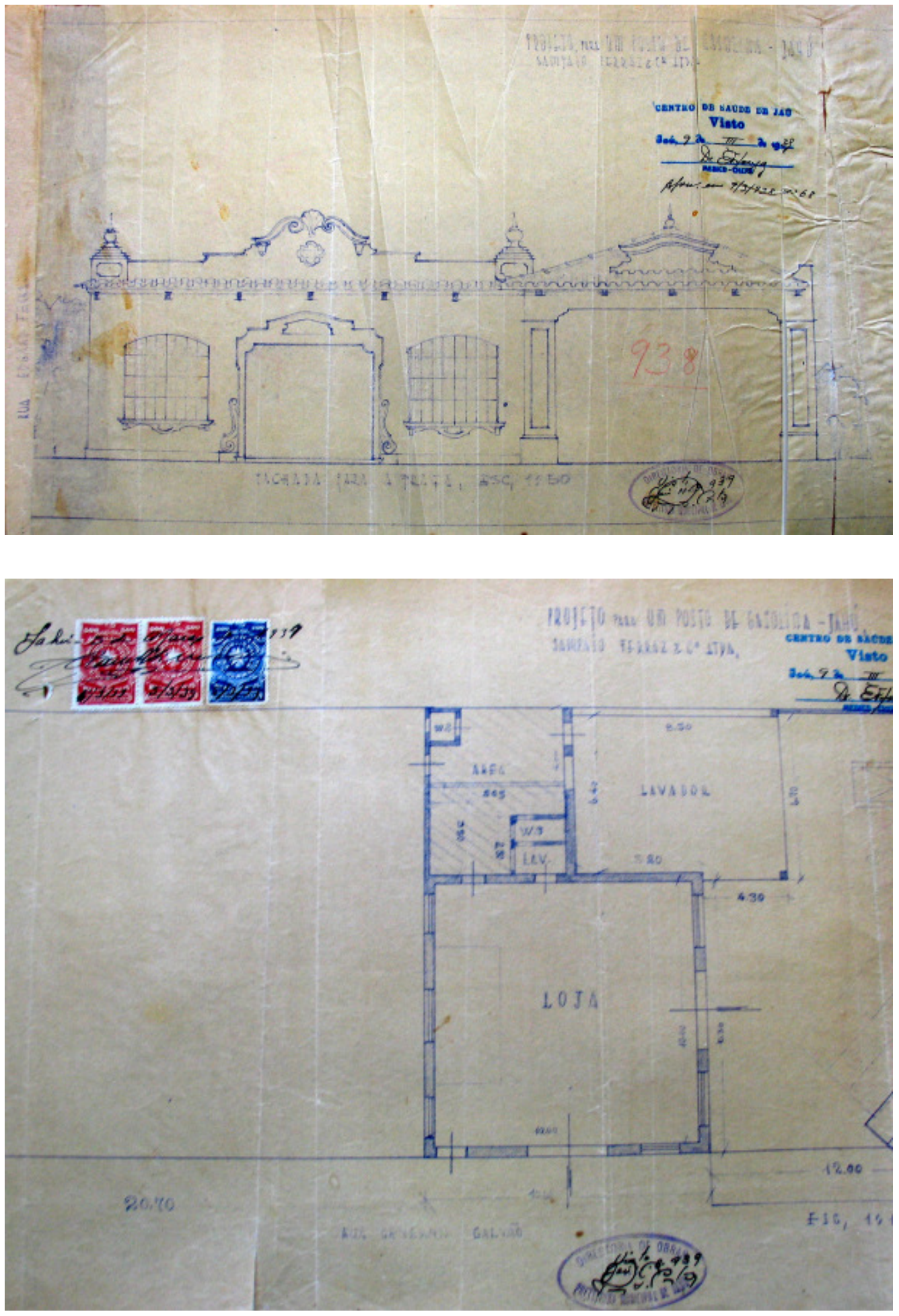

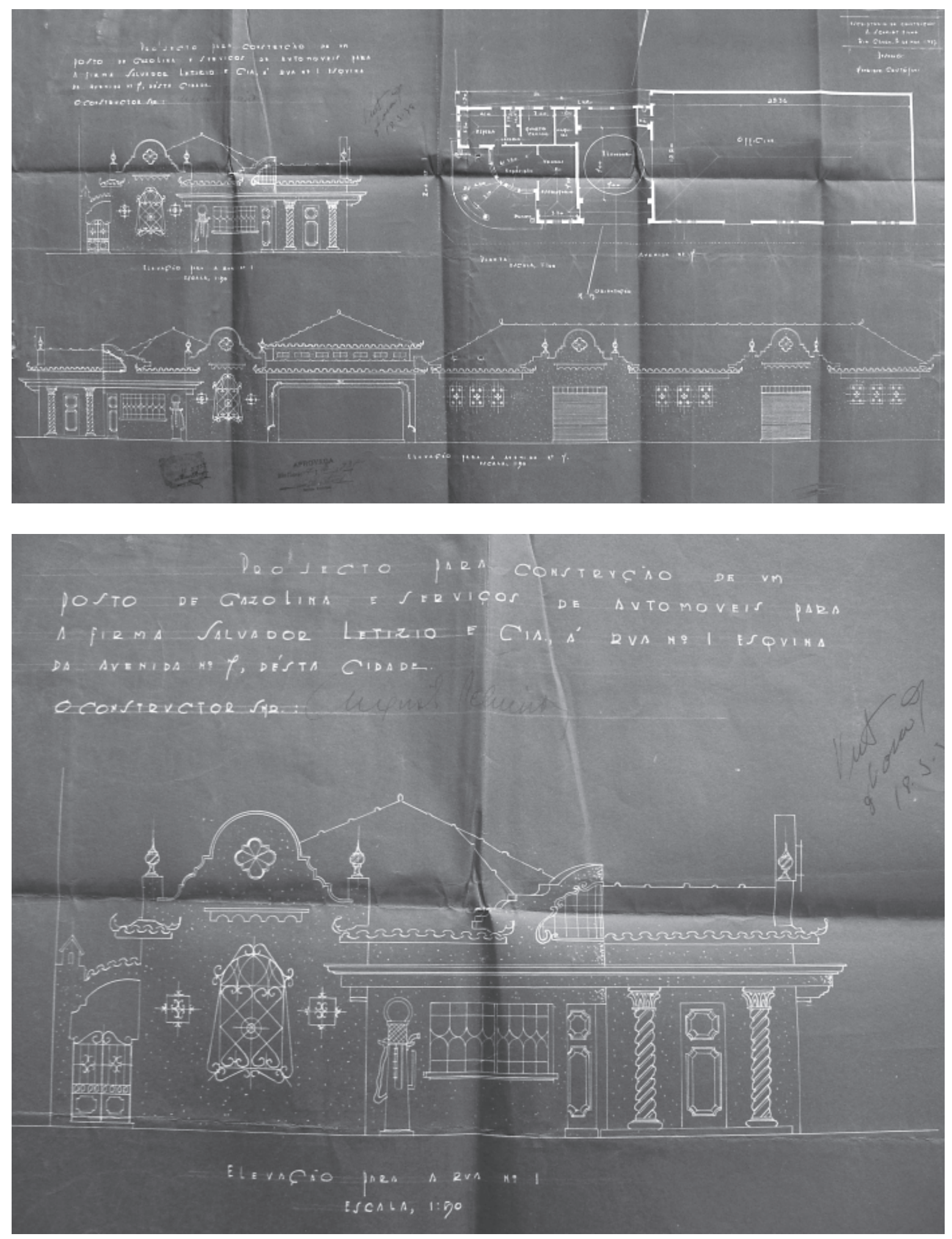

Figura 210 - Projeto para um posto de gasolina em Rio Claro, de autoria do engenheiro Augusto Schmidt Filho e do desenhista Henrique Cristofani, com data de 1937. Fonte: Arquivo Municipal de Rio Claro. 


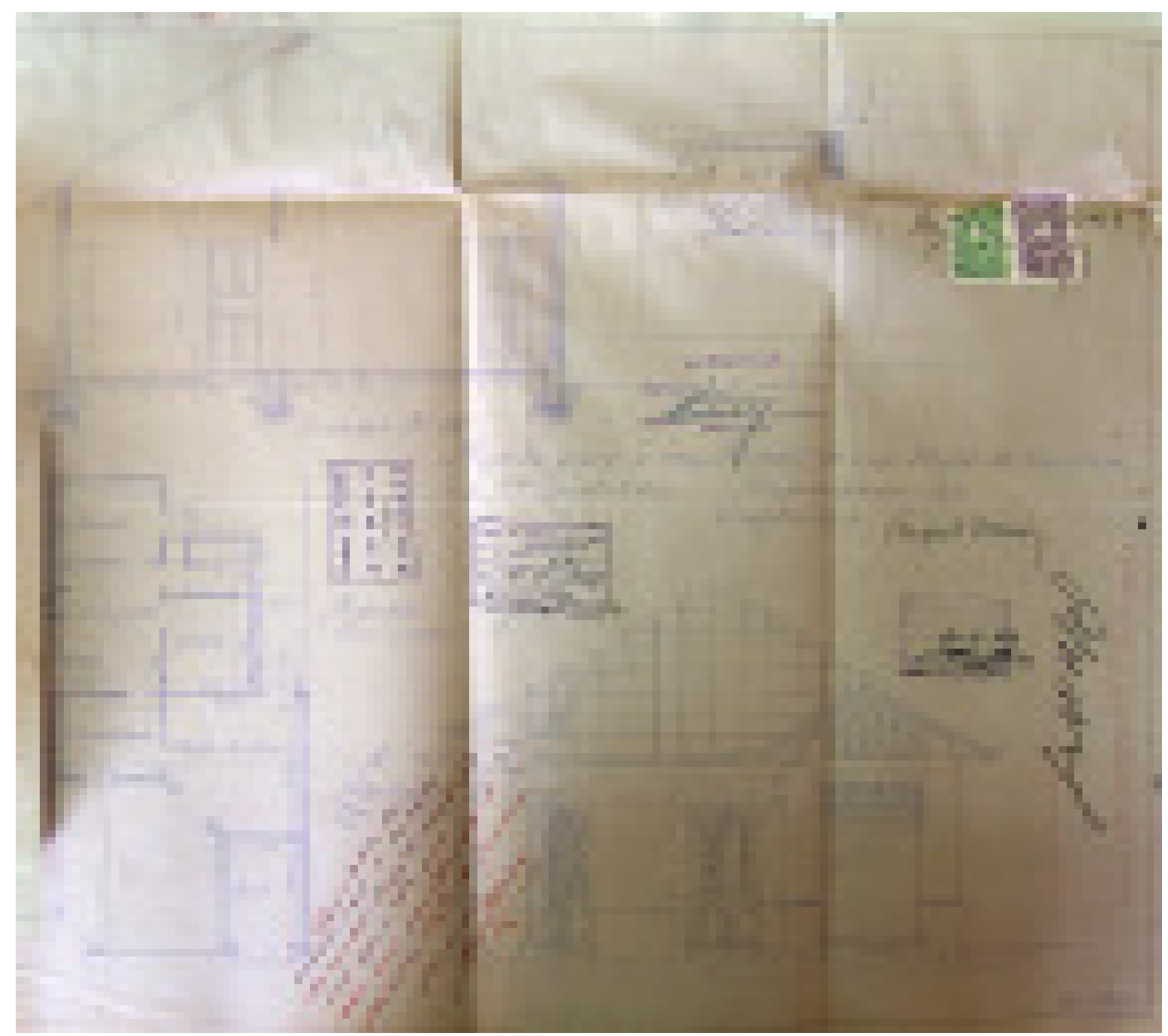

FIGURA 211 - Projeto, de 1939, para um posto de gasolina em Santa Gertrudes, distrito de Rio Claro, também de autoria do engenheiro Augusto Schmidt Filho. Exibe estilemas de não apenas da tendência neocolonial. Fonte: Arquivo Municipal de Rio Claro. 

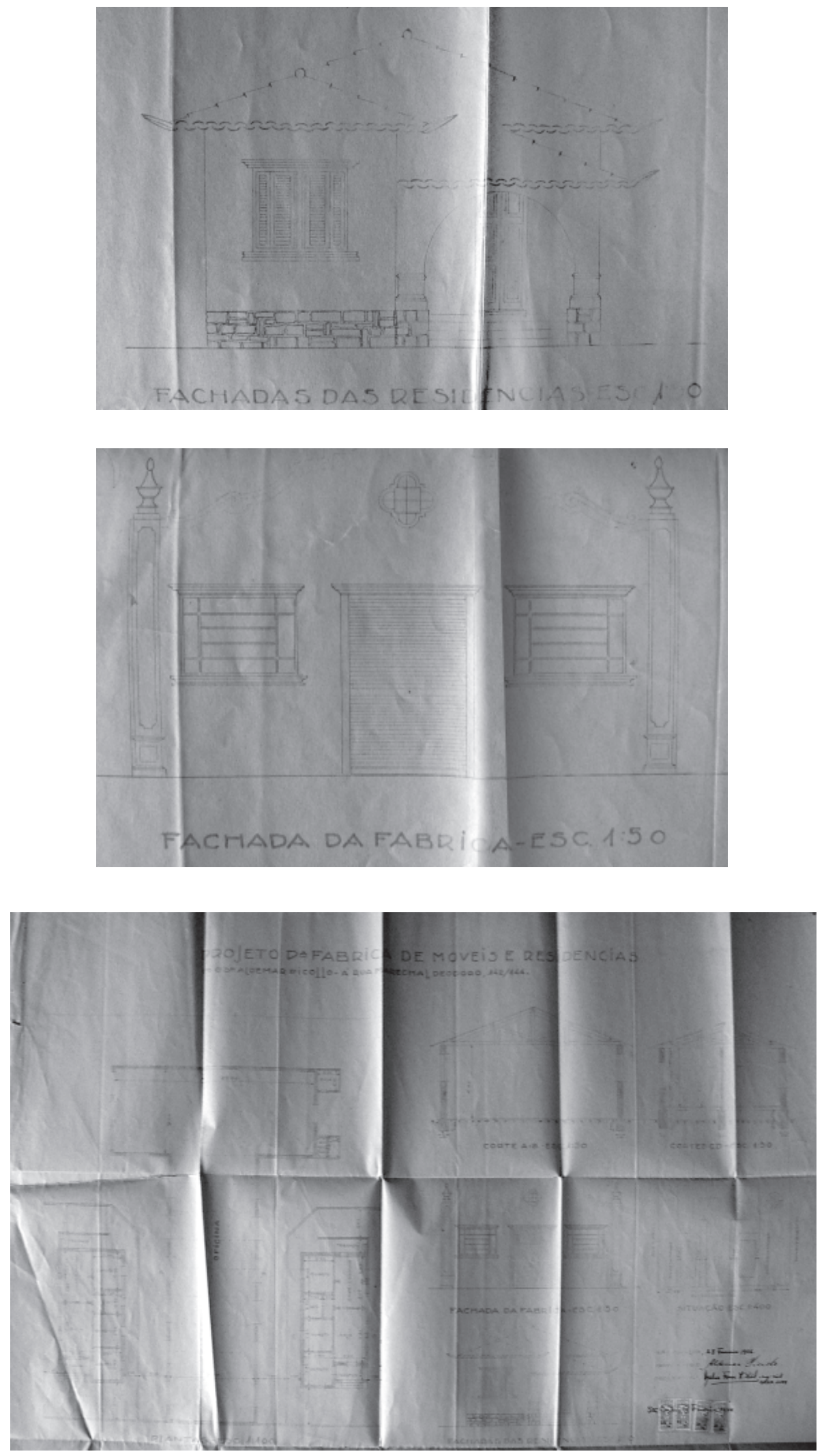

Figura 212 - Projeto para duas residências e uma fábrica de móveis em São Carlos, de autoria do engenheiro civil Djalma Ferraz Kehl, de 1948, retratando um caso de edificação destinado ao uso industrial e de características neocoloniais. Fonte: Arquivo Municipal de São Carlos. 


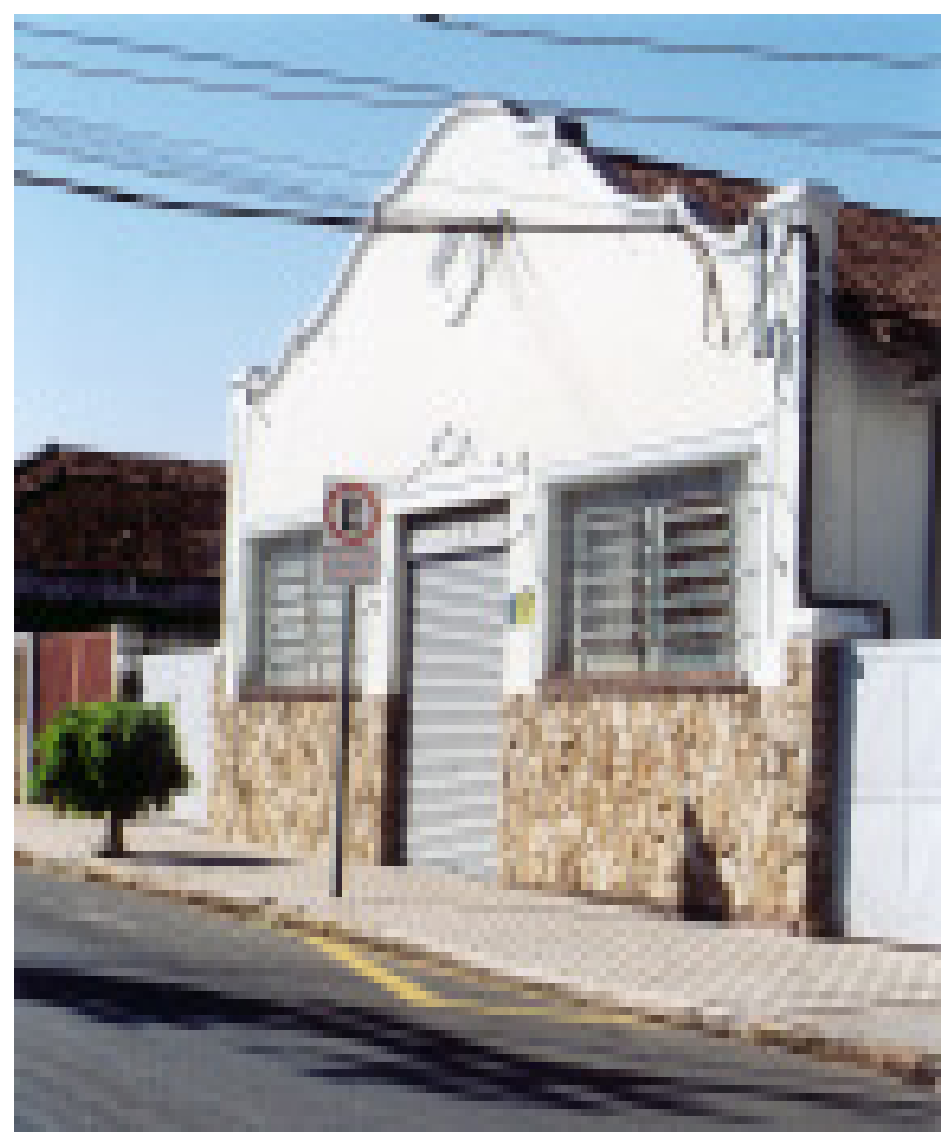

Figura 213 - Foto atual da fábrica de móveis em São Carlos, de autoria do engenheiro civil Djalma Ferraz Kehl. Fonte: foto da autora, outubro de 2004. 

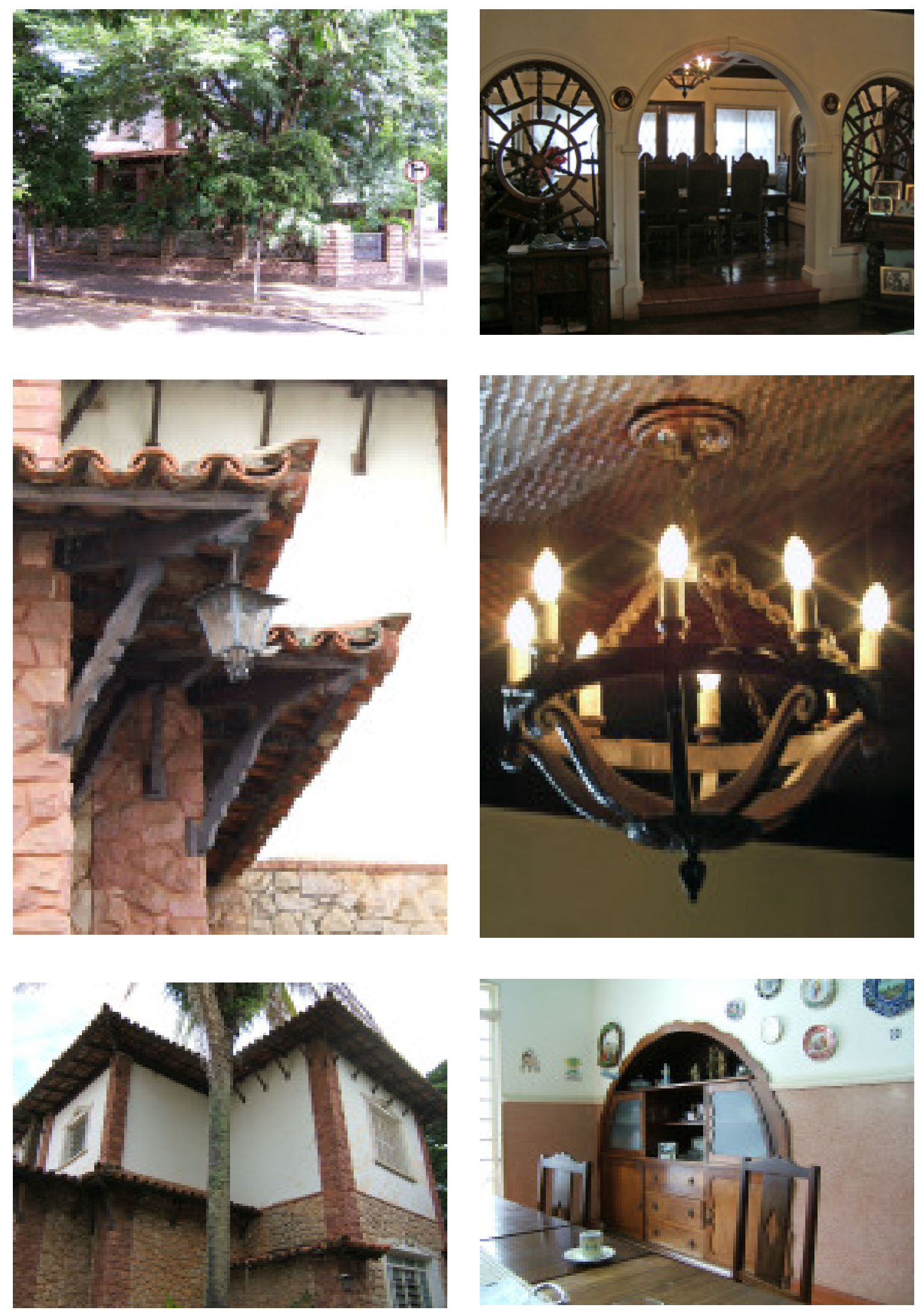

Figura 214 - Residência da senhora Nara Herfer, construída na cidade de Catanduva, a Rua Aracajú esquina com a Rua Ceará, em 1946, pelo construtor Elias Nechar. Notar a presença de armário embutido e decoração em madeira no interior da casa. Fonte: foto da autora, abril de 2007. 

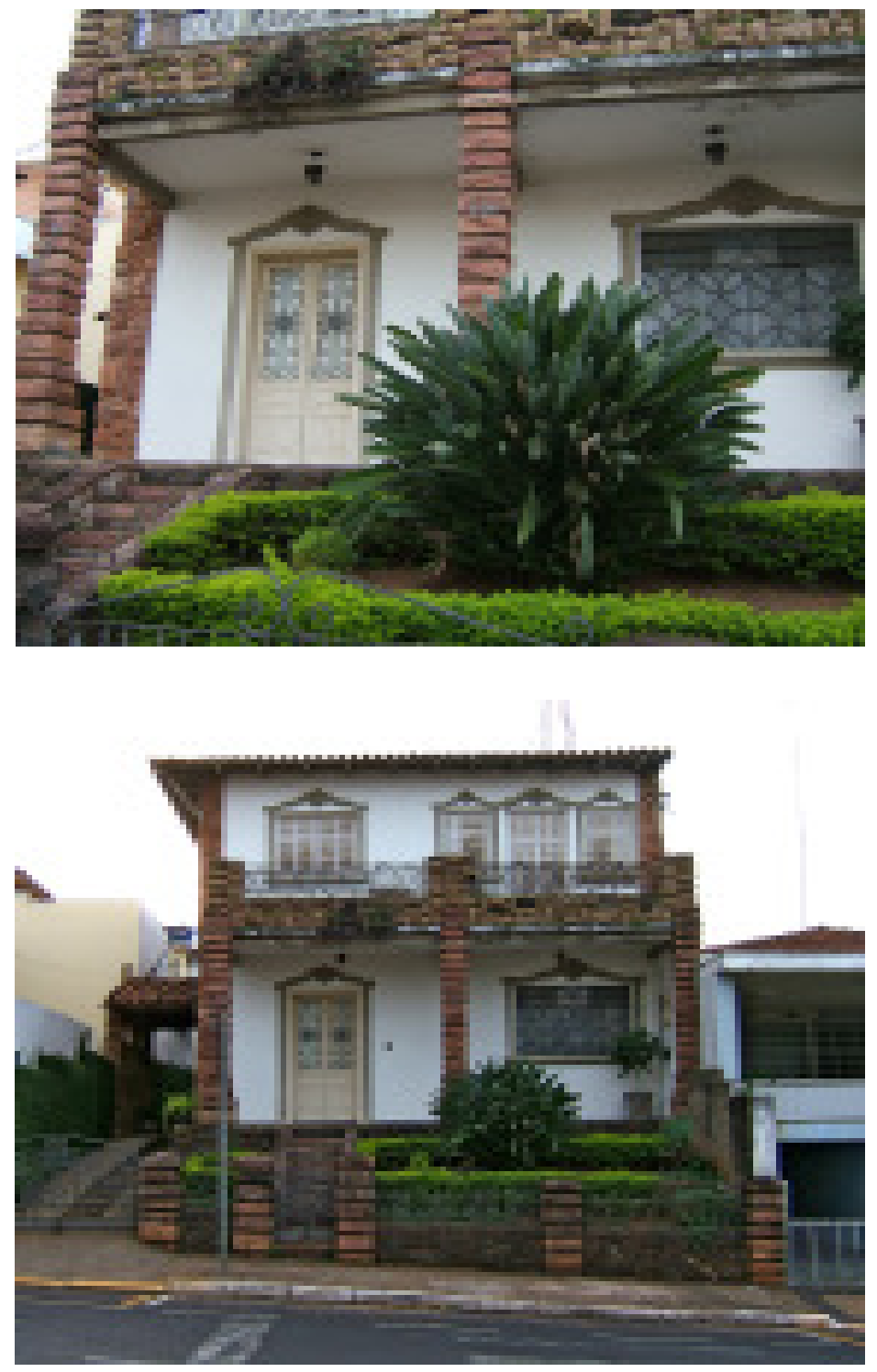

Figura 215 - Residência inspirada na da senhora Nara Herfer, construída pelo mesmo construtor Elias Nechar, em Catanduva. Fonte: foto da autora, abril de 2007. 

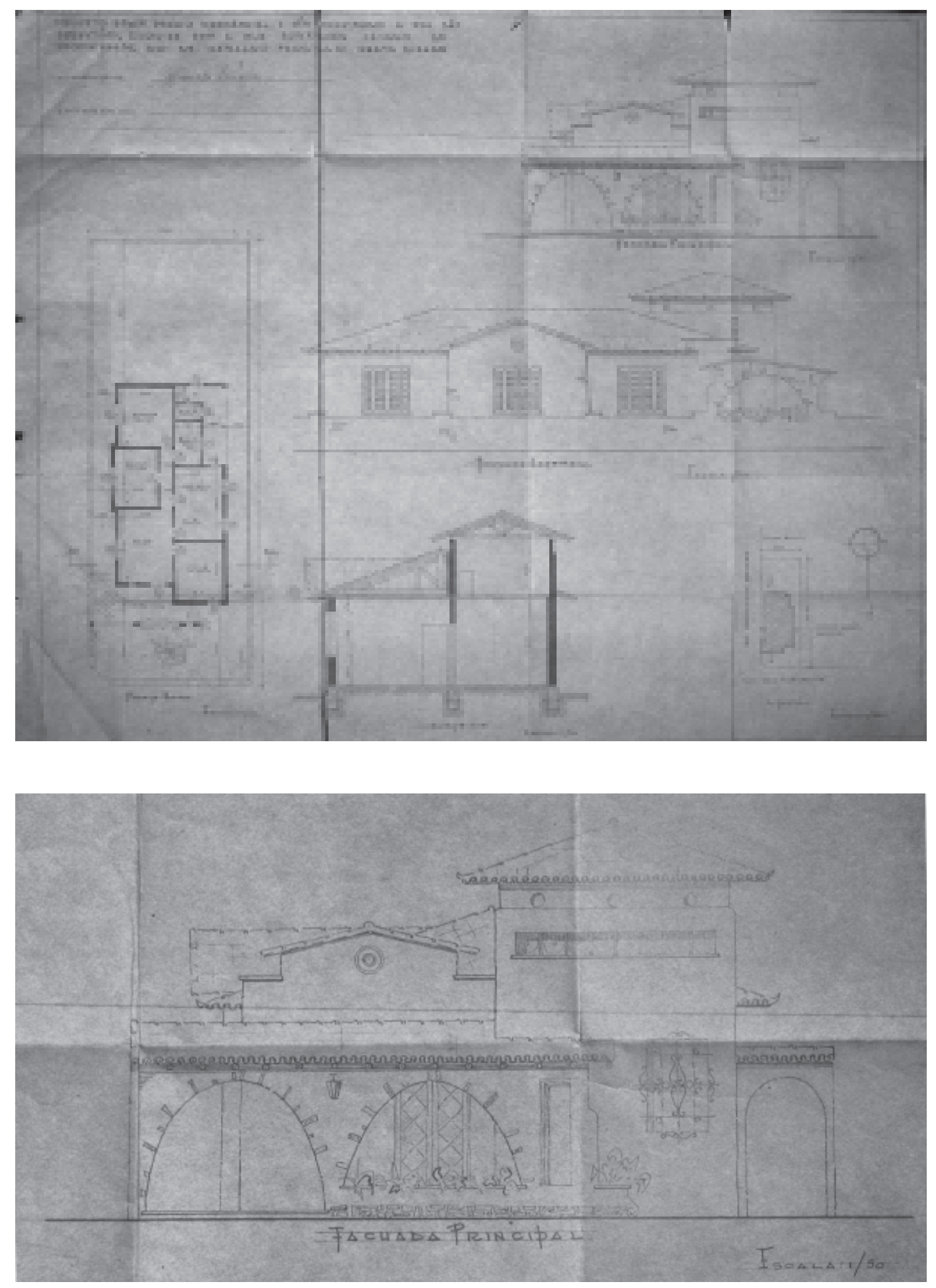

Figura 216 (páginas 438 e 439) - Projeto para a residência do senhor Geraldo Paolillo, construída na Vila Nery, São Carlos. Notar as linhas arquitetônicas da vertente missões. Fonte: Projeto do proprietário fotografado pela autora em outubro de 2004. 

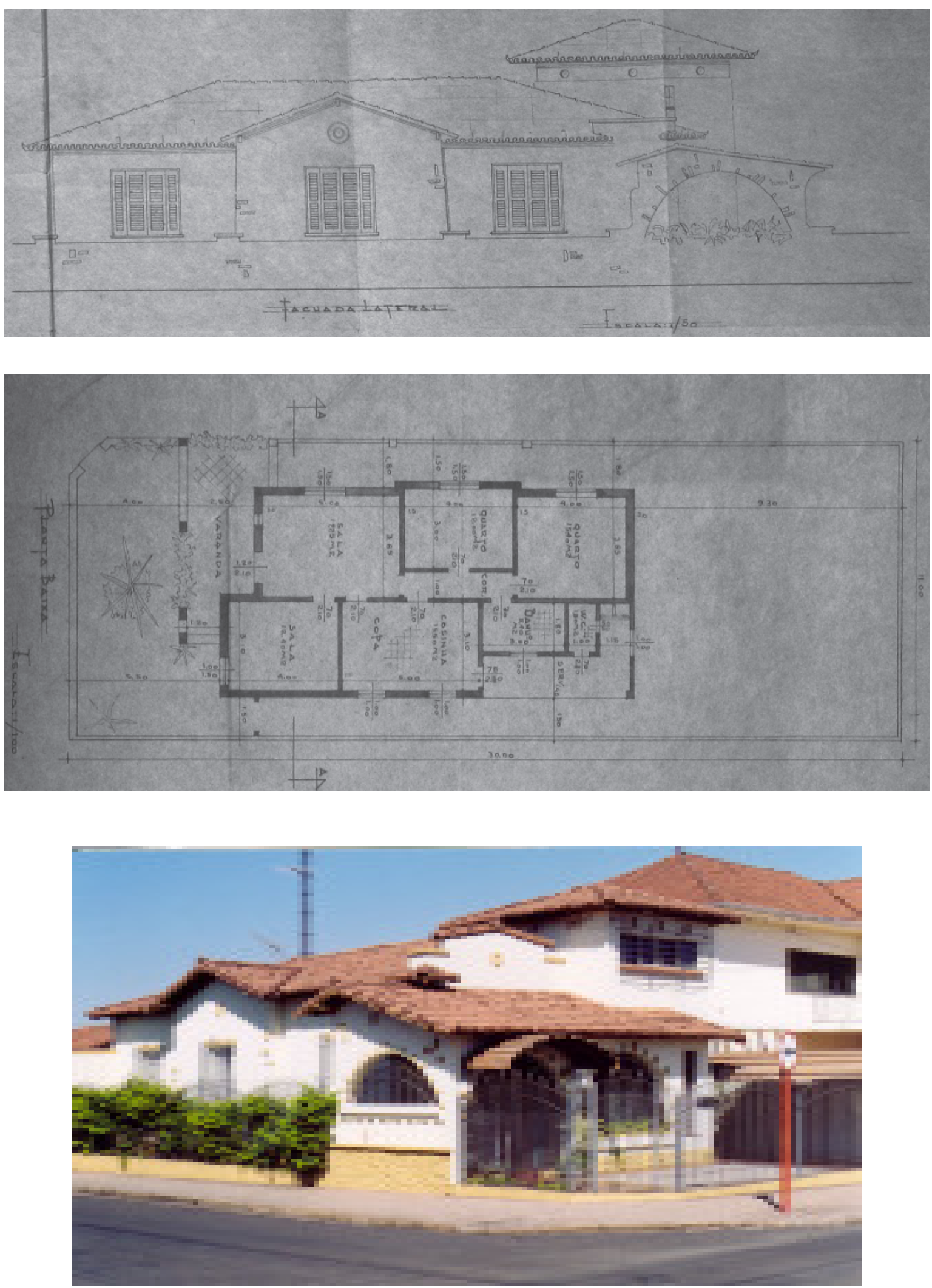

Figura 217 - Foto da residência do senhor Geraldo Paolillo, onde se vê a substituição da torre circular por um ambiente de planta retangular. Fonte: foto da autora, outubro de 2004. 


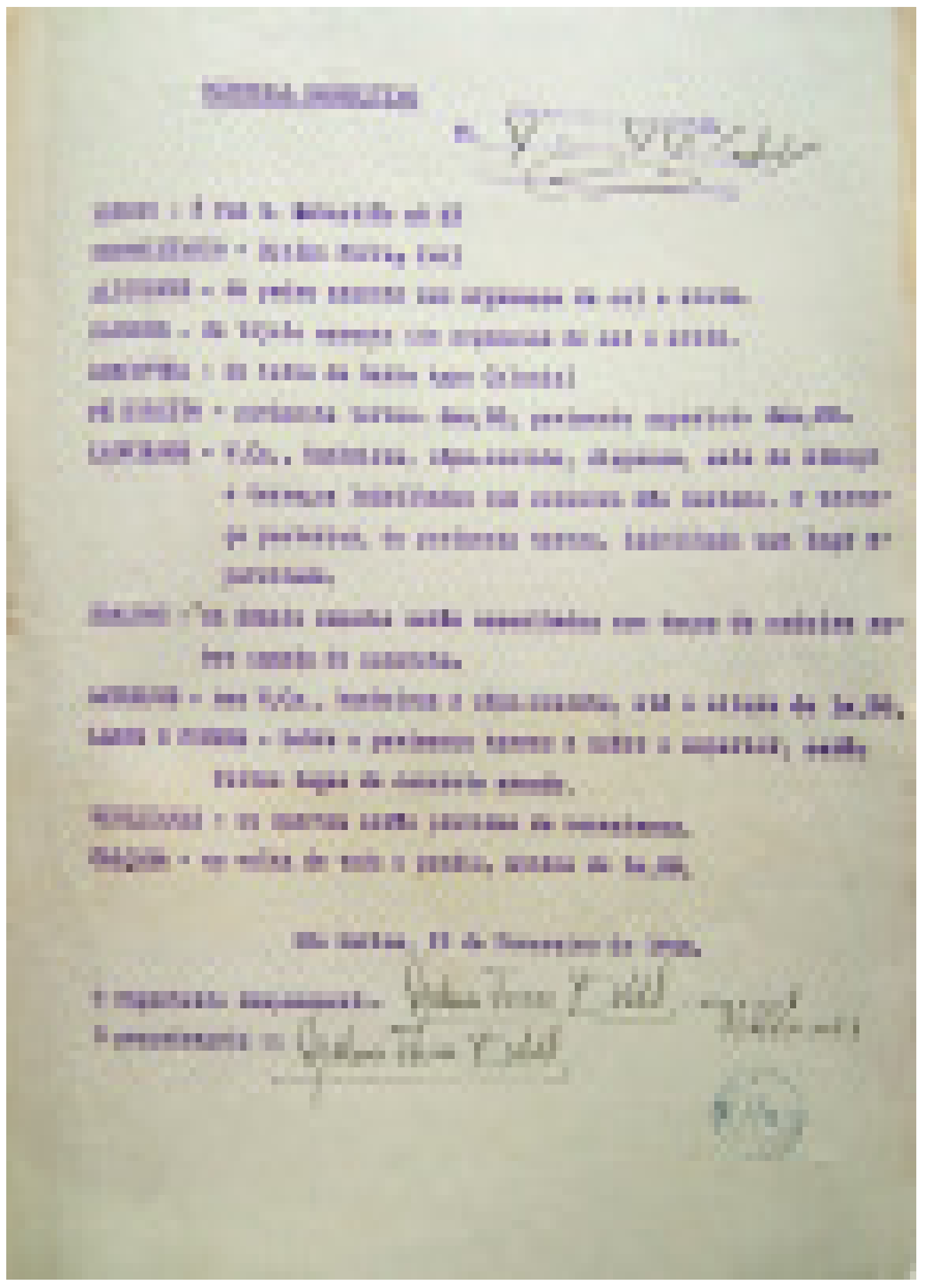

Figura 218 (páginas 440 e 441) - Projeto do arquiteto Ângelo Murgel para a residência do engenheiro Djalma Ferraz Kehl, que data de 1944, situada a Rua São Sebastião, em São Carlos. Fonte: Arquivo Municipal de São Carlos. 


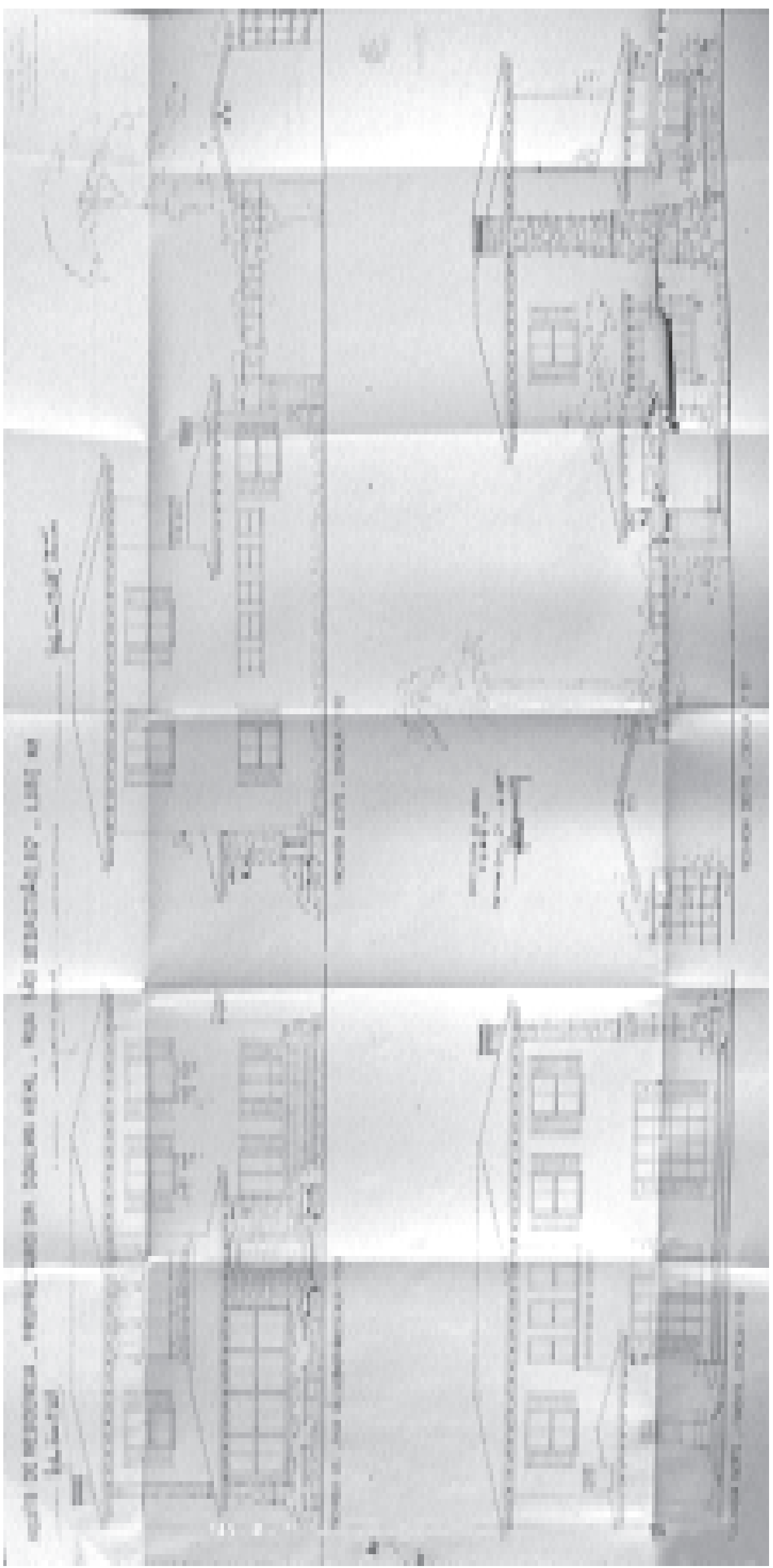



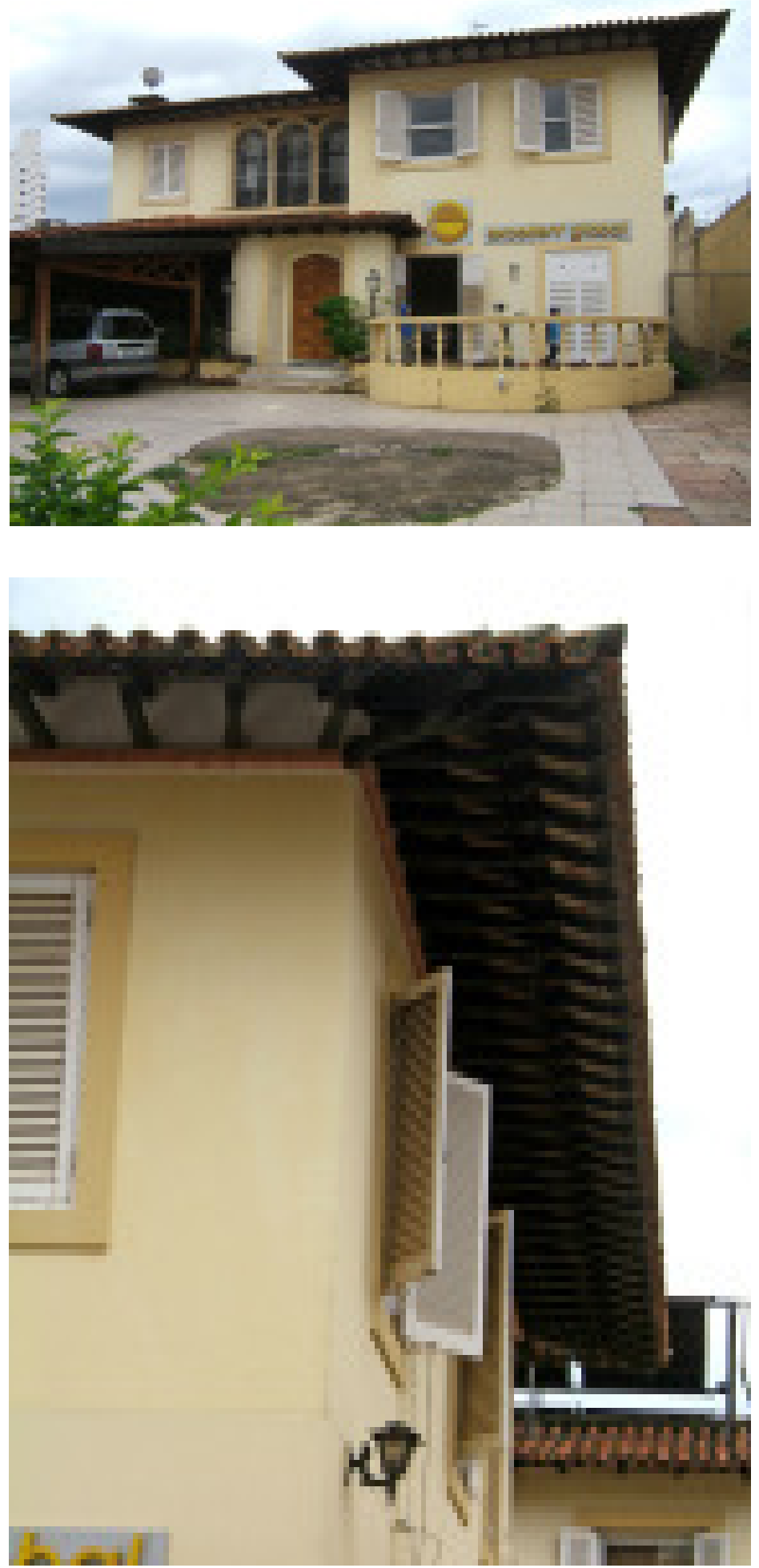

Figura 219 - Fotos atuais da residência do engenheiro Djalma Ferraz Kehl, projetada por Ângelo Murgel. Fonte: fotos da autora, abril de 2008. 


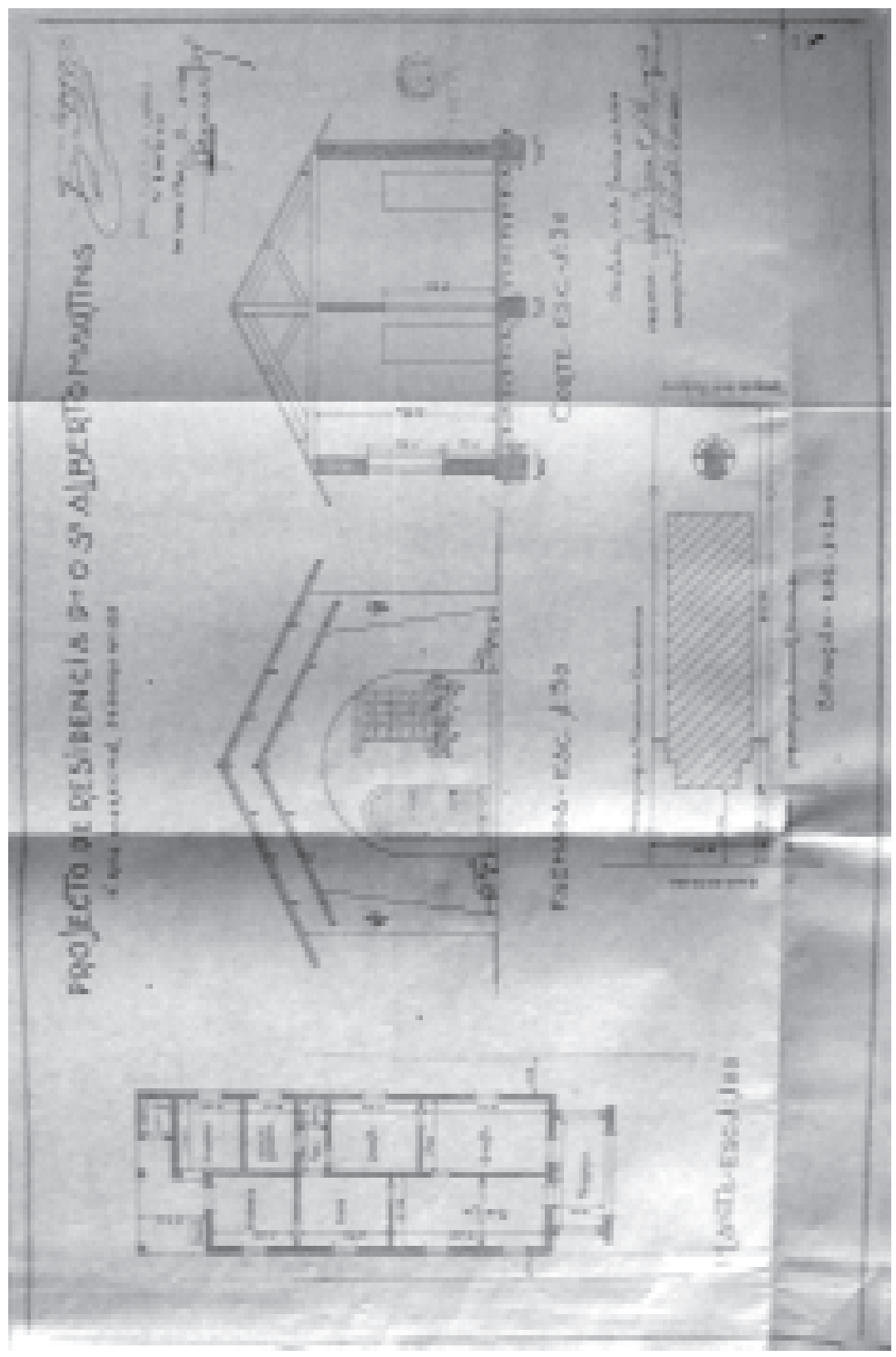

Figura 220 - Projeto, de 1944, do engenheiro Djalma Ferraz Kehl para residência para Alberto Martins, a Rua Marechal Deodoro, em São Carlos. Nesse e nos próximos projetos podemos verificar a influência do arquiteto Ângelo Murgel sobre a produção do engenheiro sãocarlense. Fonte: Arquivo Municipal de São Carlos. 


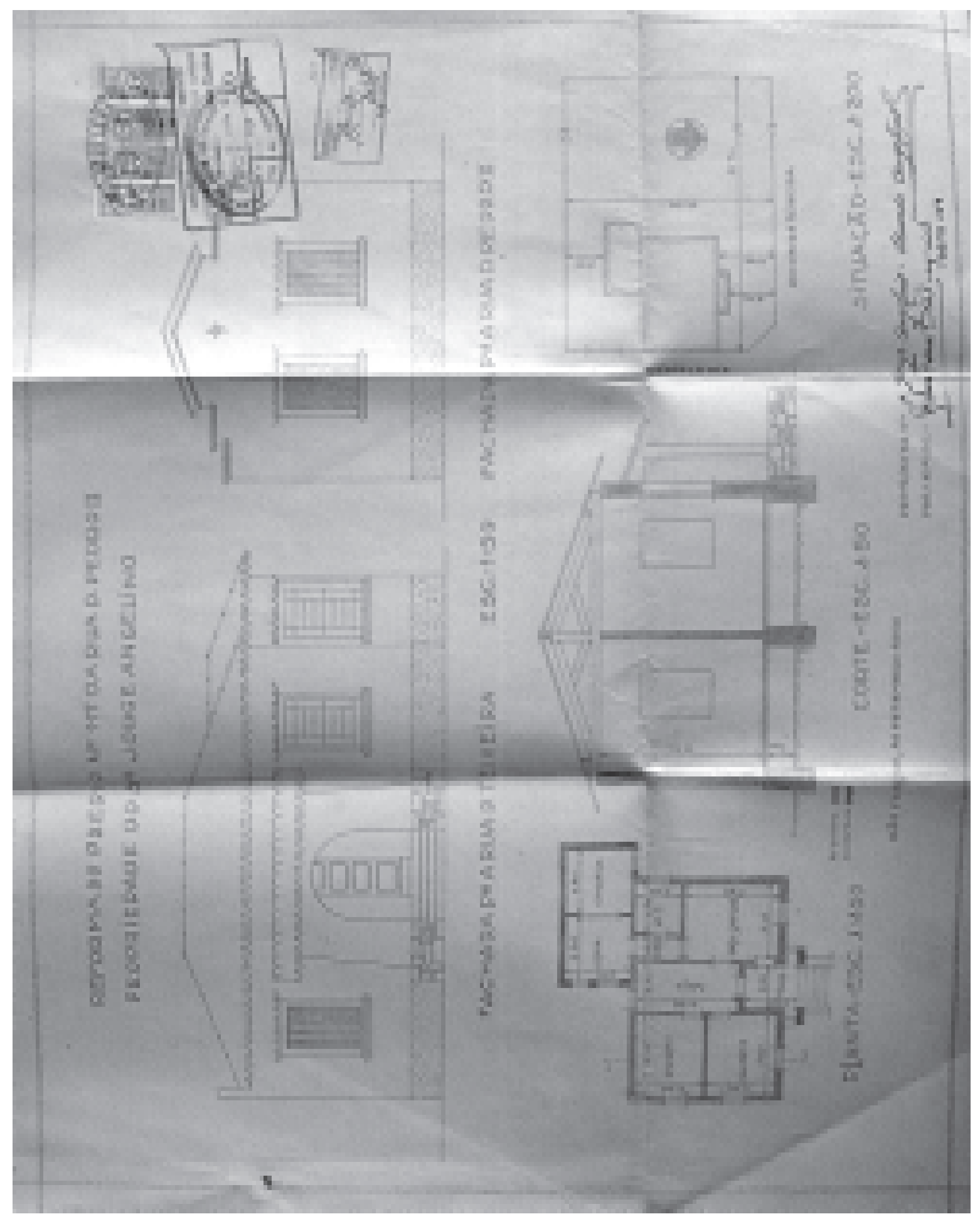

Figura 221 - Projeto de reforma da residência de Jorge Angelino, de 1946, pelo engenheiro Djalma Ferraz Kehl, a rua D. Pedro II, em São Carlos. Adição de estilemas neocoloniais. Fonte: Arquivo Municipal de São Carlos. 


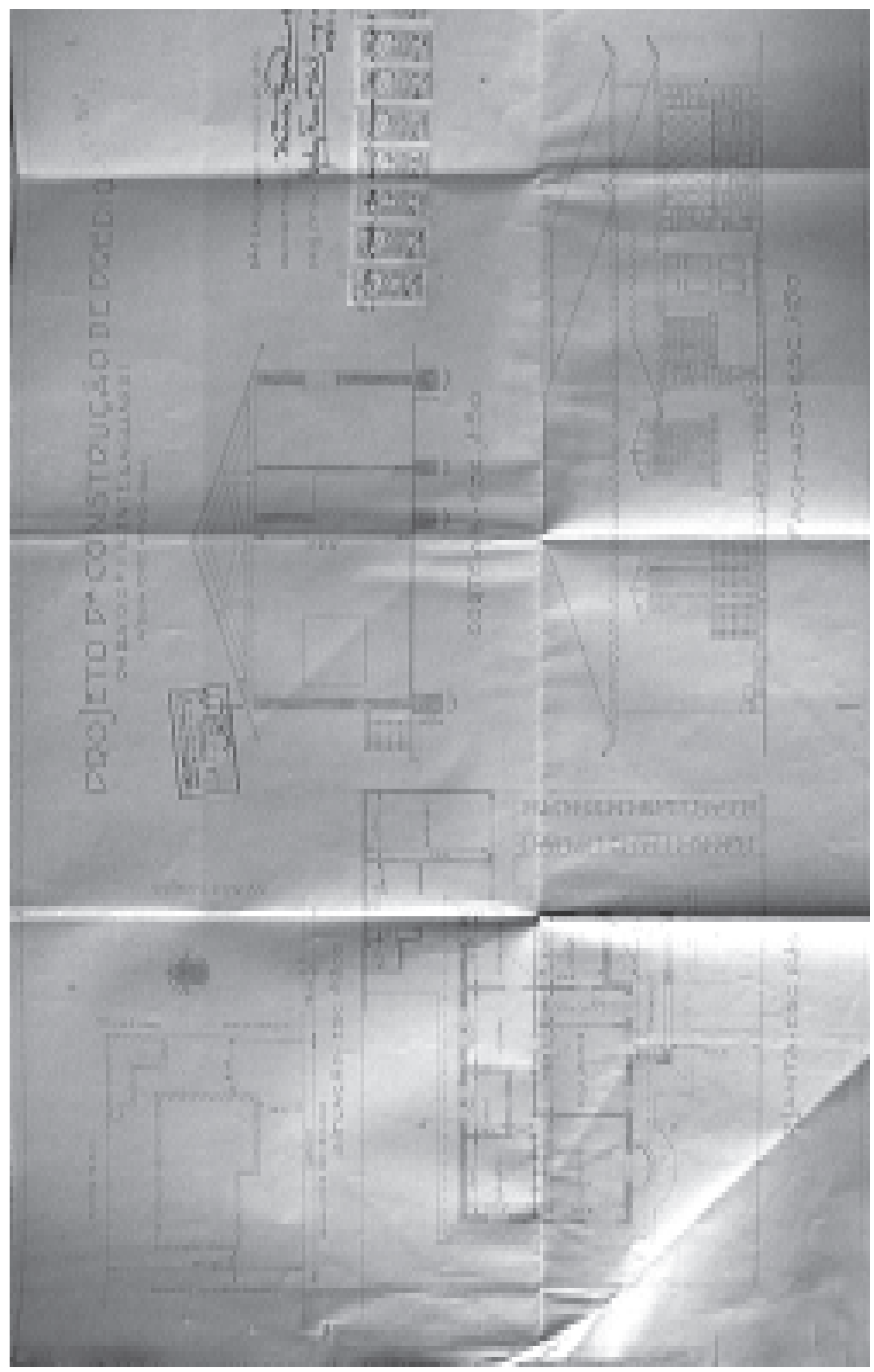

Figura 222 - Projeto para a residência para Vicente Gagliardi, de 1946, a Rua XV de Novembro, São Carlos, de autoria do engenheiro Djalma Ferraz Kehl. Notar semelhança dessa residência com a própria residência do engenheiro. Fonte: Arquivo Municipal de São Carlos. 


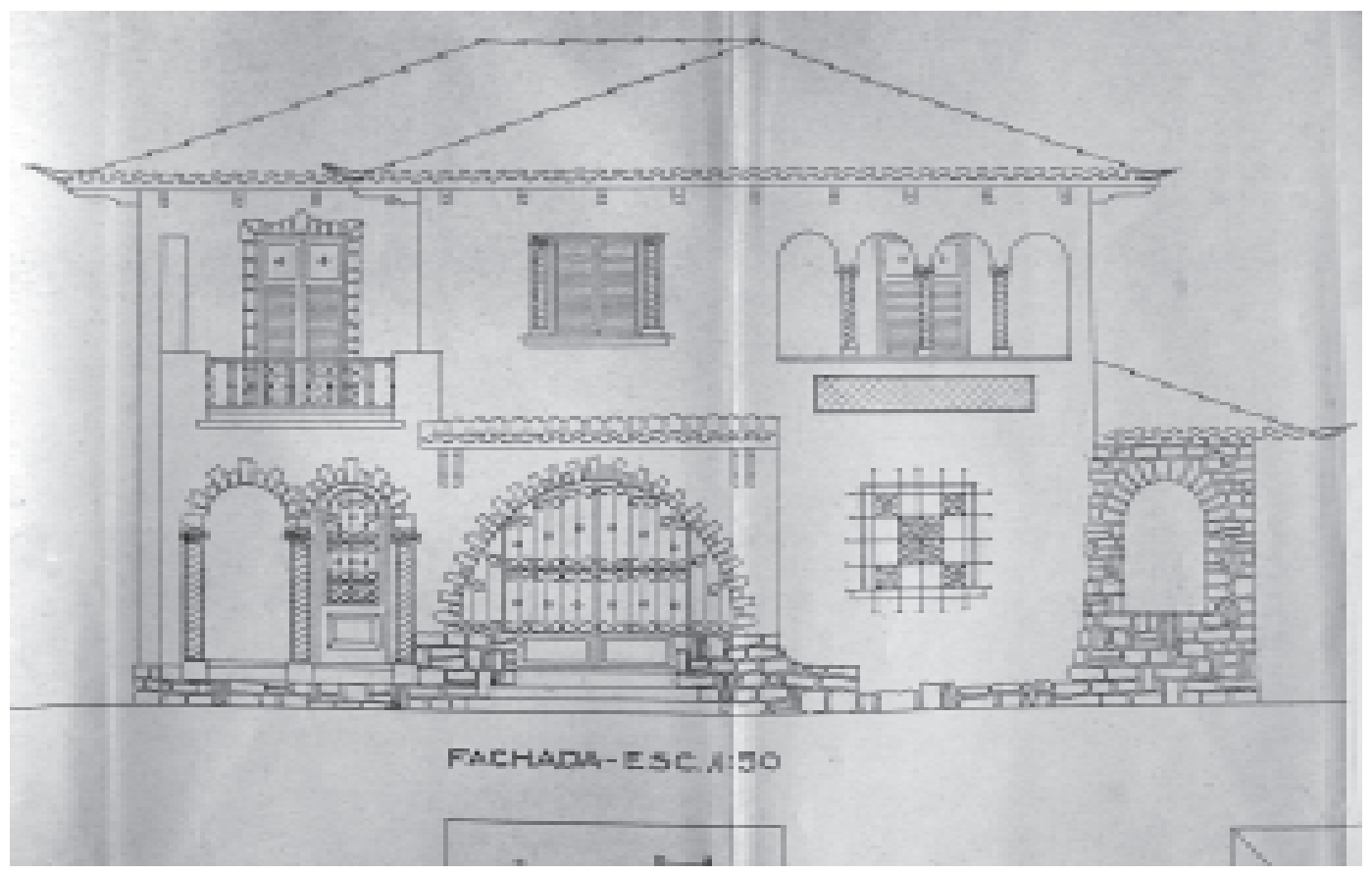

Figura 223 (páginas 446 e 447) - Projeto do engenheiro Djalma Ferraz Kehl, também de 1946, para a residência de Samuel de Oliveira, a Rua 9 de Julho, em São Carlos. Fonte: Arquivo Municipal de São Carlos. 

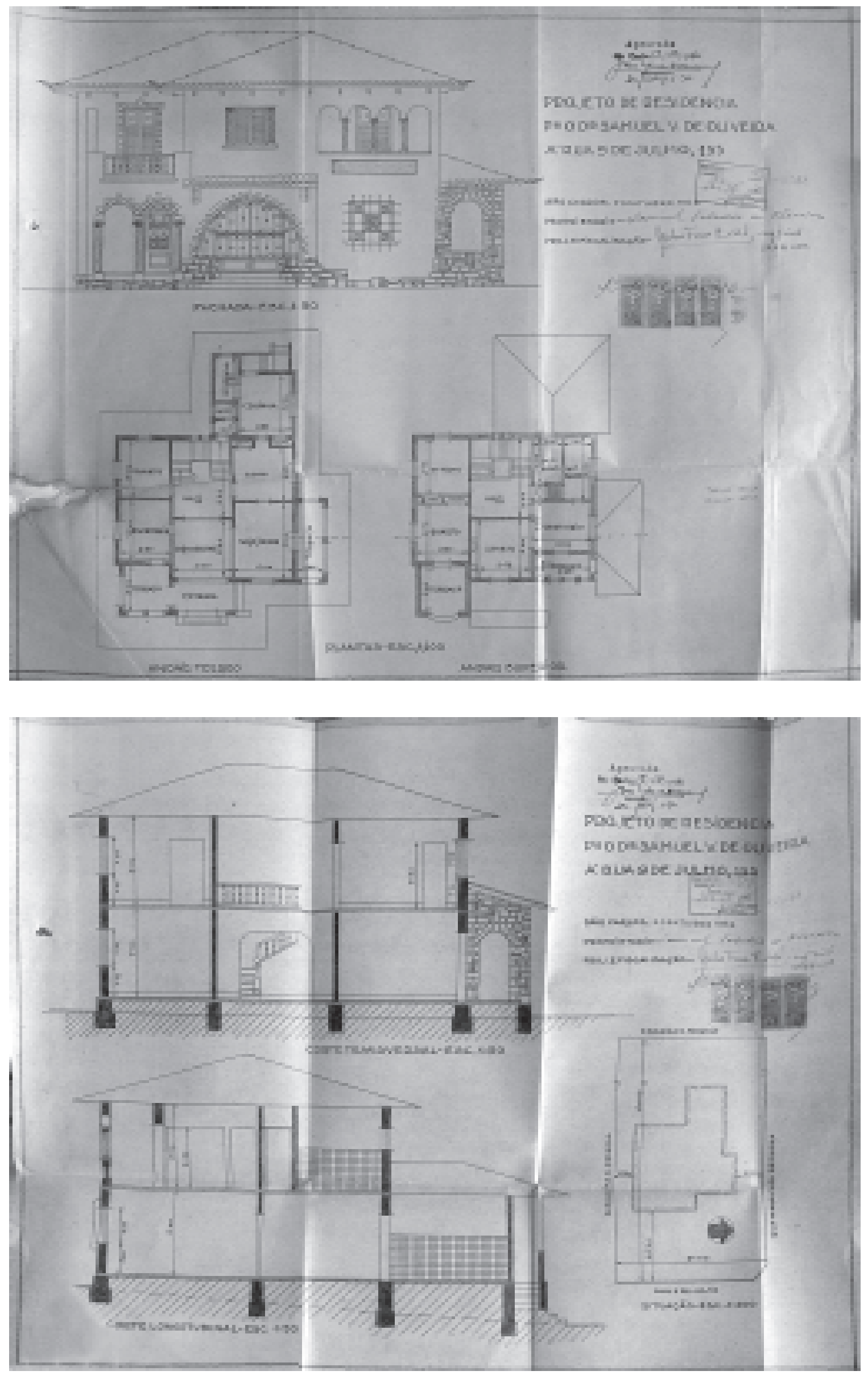

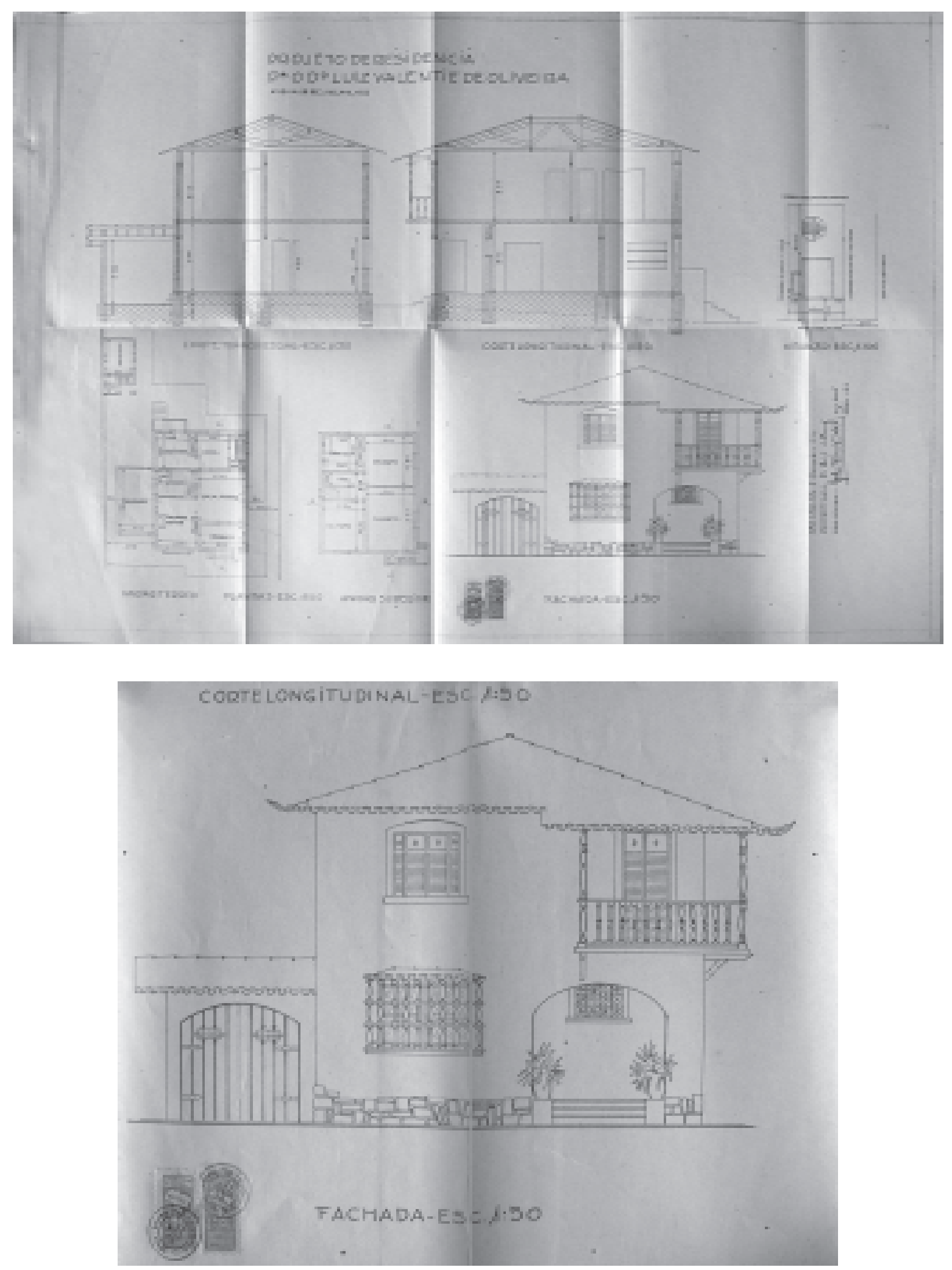

Figura 224 - Mais um projeto de Djalma Ferraz Kehl com características que evidenciam sua adesão à arquitetura neocolonial após a construção de sua própria casa. Trata-se da residência para Luiz Valentie de Oliveira, também a rua 9 de Julho, em São Carlos, que também data de 1946. Fonte: Arquivo Municipal de São Carlos. 


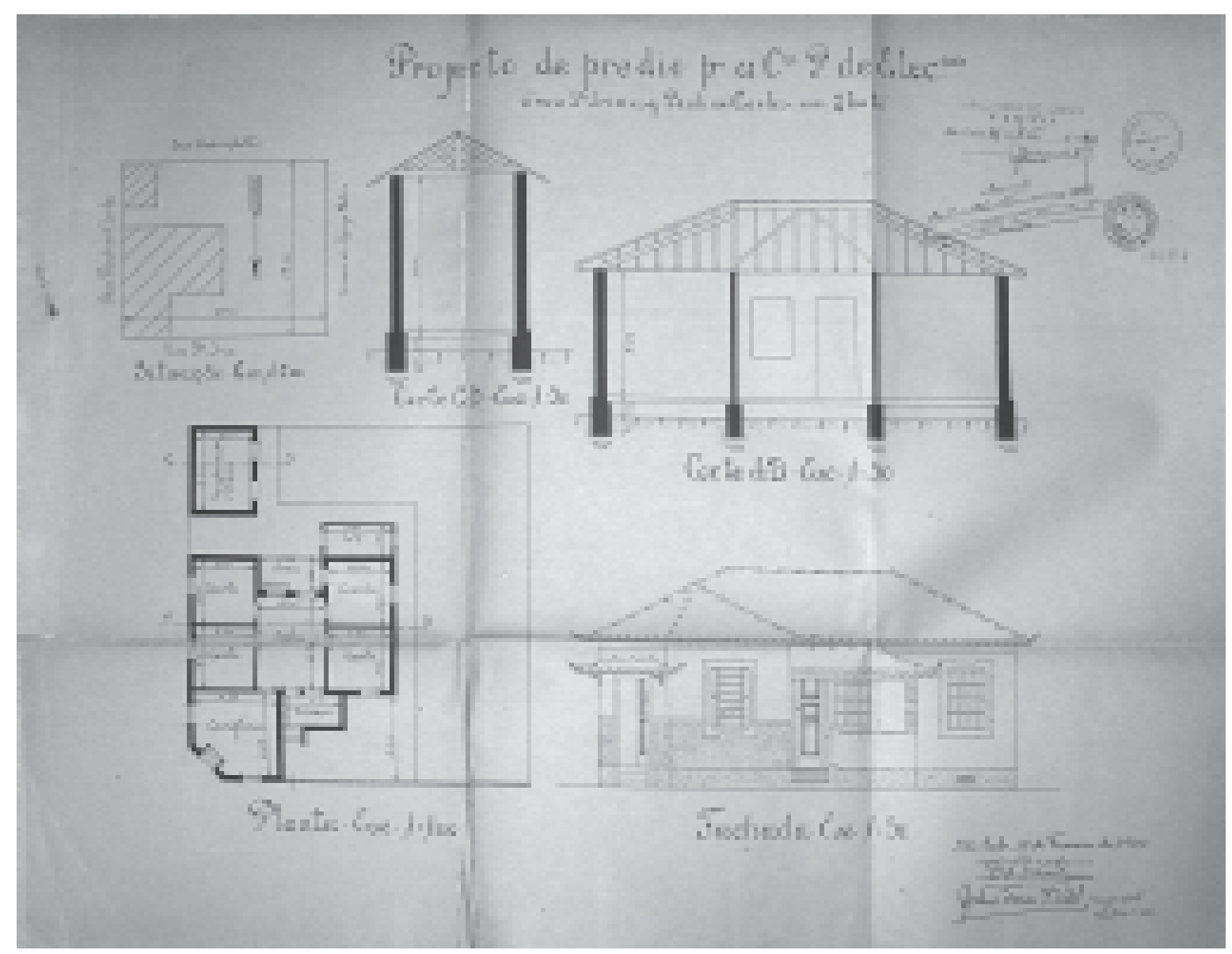

Figura 225 - Projeto do engenheiro Djalma Ferraz Kehl, de 1940, ou seja, anterior à construção de sua casa, mostrando que o profissional já havia tomado conhecimento da tendência neocolonial, possivelmente, antes de se radicar em São Carlos. Fonte: Arquivo Municipal de São Carlos. 

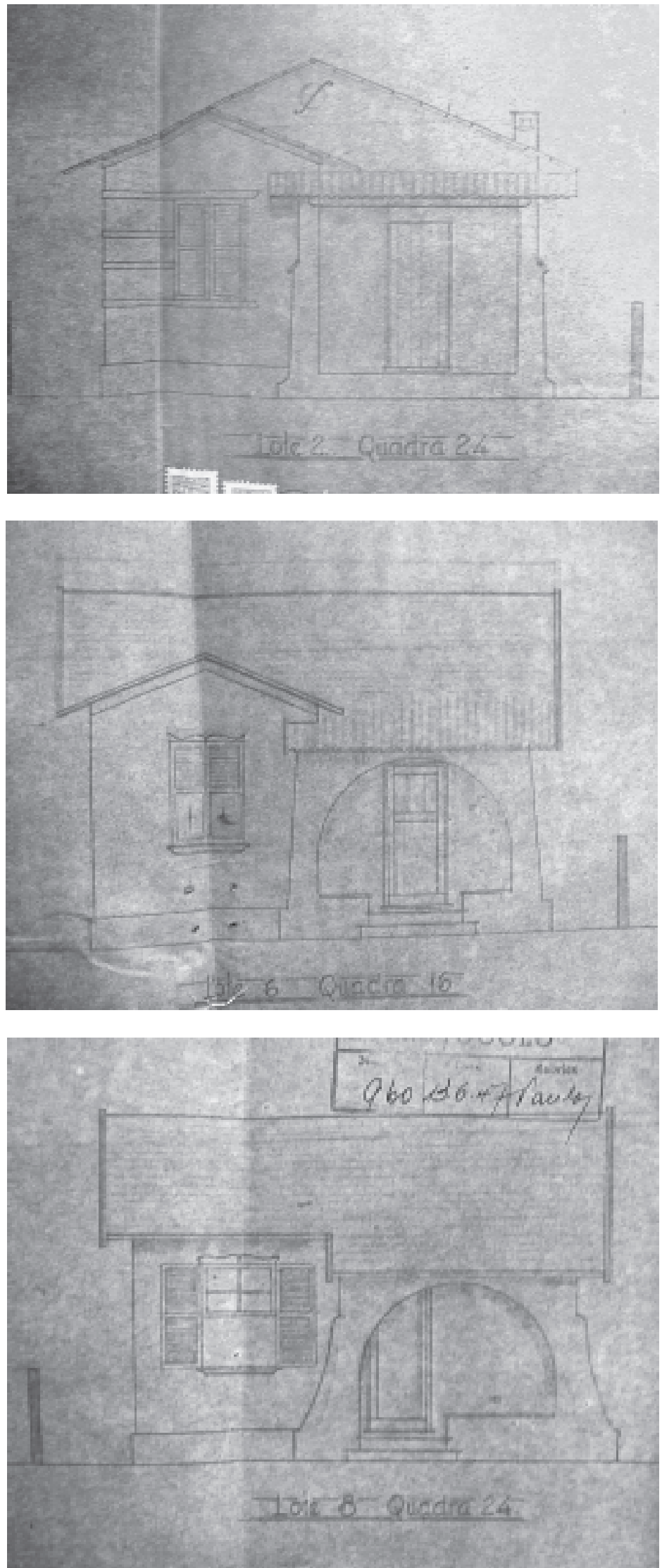

Figura 226 - Algumas fachadas, projetadas pelo engenheiro Augusto Schmidt Filho, em 1947, para um conjunto de sete casas de sua propriedade, situadas em Rio Claro, provavelmente para aluguel. Fonte: Arquivo Municipal de Rio Claro. 

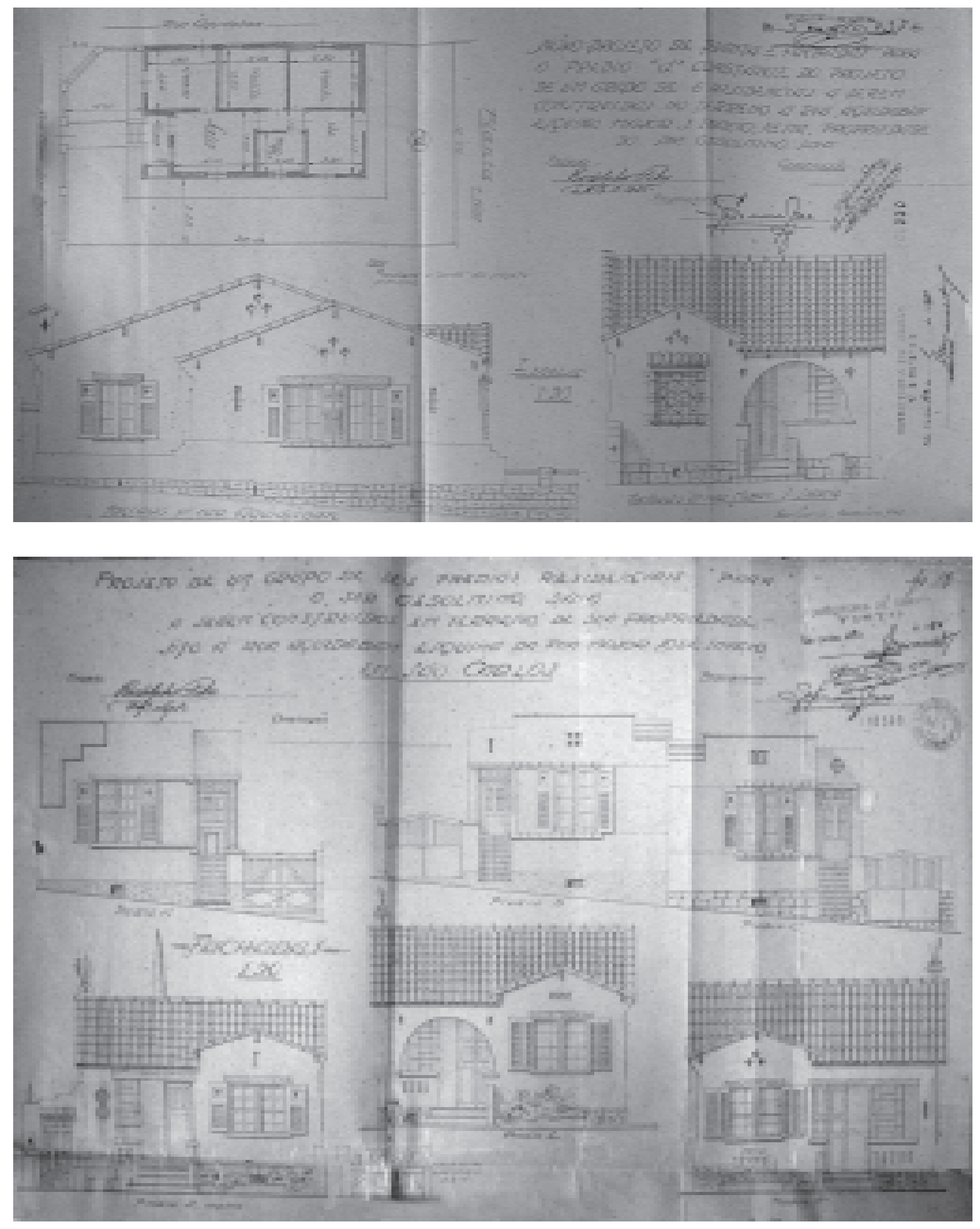

Figura 227 - Projeto para seis residências, de autoria do engenheiro Rodolpho Fehr para o proprietário Gelsomino Saia, em São Carlos, que data de 1940. Três tem fachadas de tendência art déco e três, de tendência neocolonial, demonstrando que as opções eram questão de gosto. São, também, casas para aluguel, provavelmente. Fonte: Arquivo Municipal de São Carlos. 

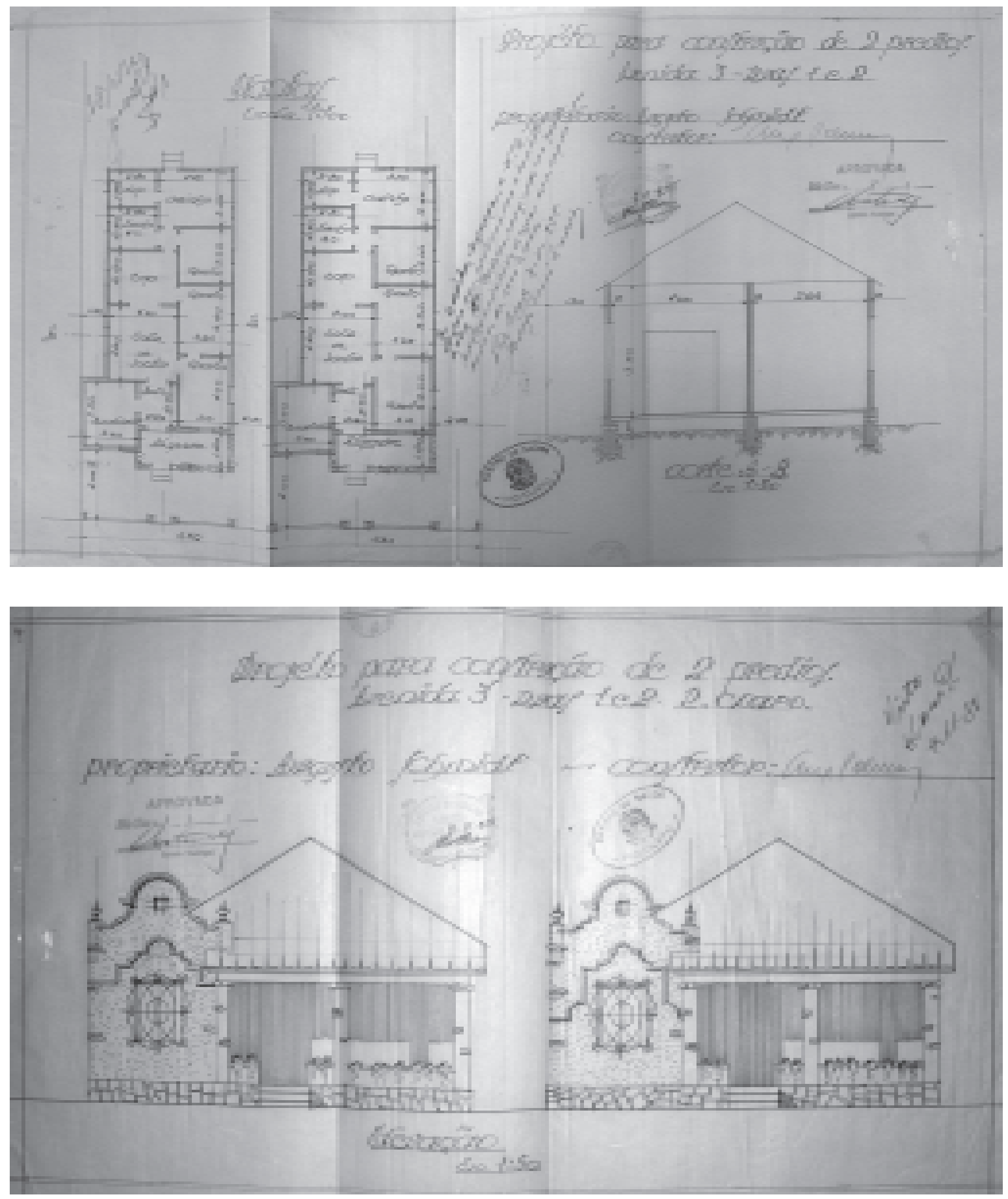

Figura 228 - Projeto para duas casas de padrão médio, de 1938, também de autoria e propriedade do engenheiro Augusto Schmidt Filho, provavelmente para aluguel ou venda, situadas em Rio Claro. Fonte: Arquivo Municipal de Rio Claro. 

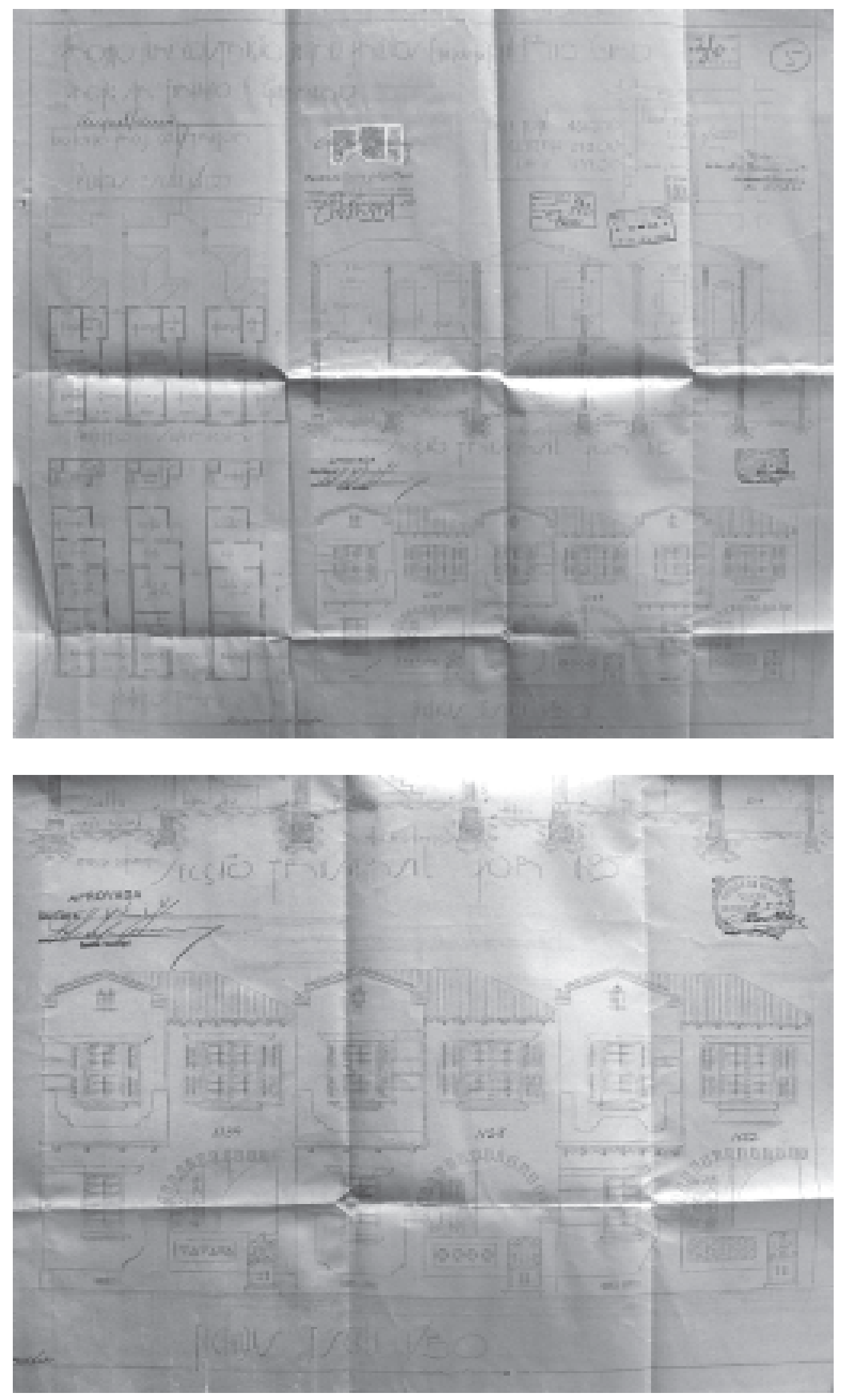

Figura 229 - Conjunto de três casas formando uma pequena vila, de autoria do engenheiro Augusto Schmidt Filho, para o proprietário Fernando Guerreiro, a serem construídas em Rio Claro, em 1941. São residências de médio padrão, provavelmente, destinadas à venda ou aluguel. Fonte: Arquivo Municipal de Rio Claro. 


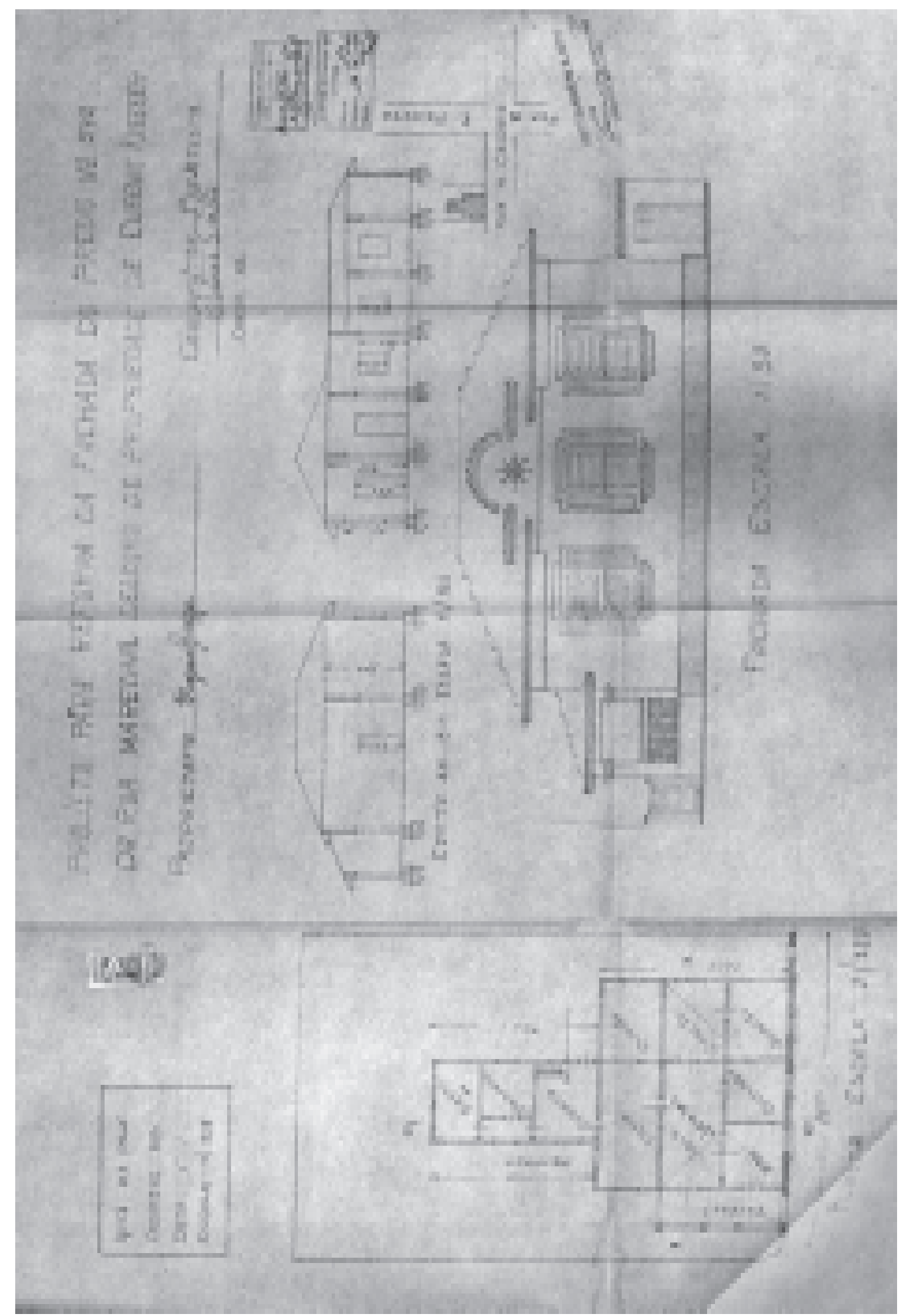

Figura 230 - Projeto de reforma de autoria do construtor Octávio Daltro, que data de 1950, para a fachada da residência de Eugenio Ruegger, na cidade de Araras. Notar o acréscimo de um frontão que evoca a tendência neocolonial. Fonte: Arquivo Municipal de Araras. 


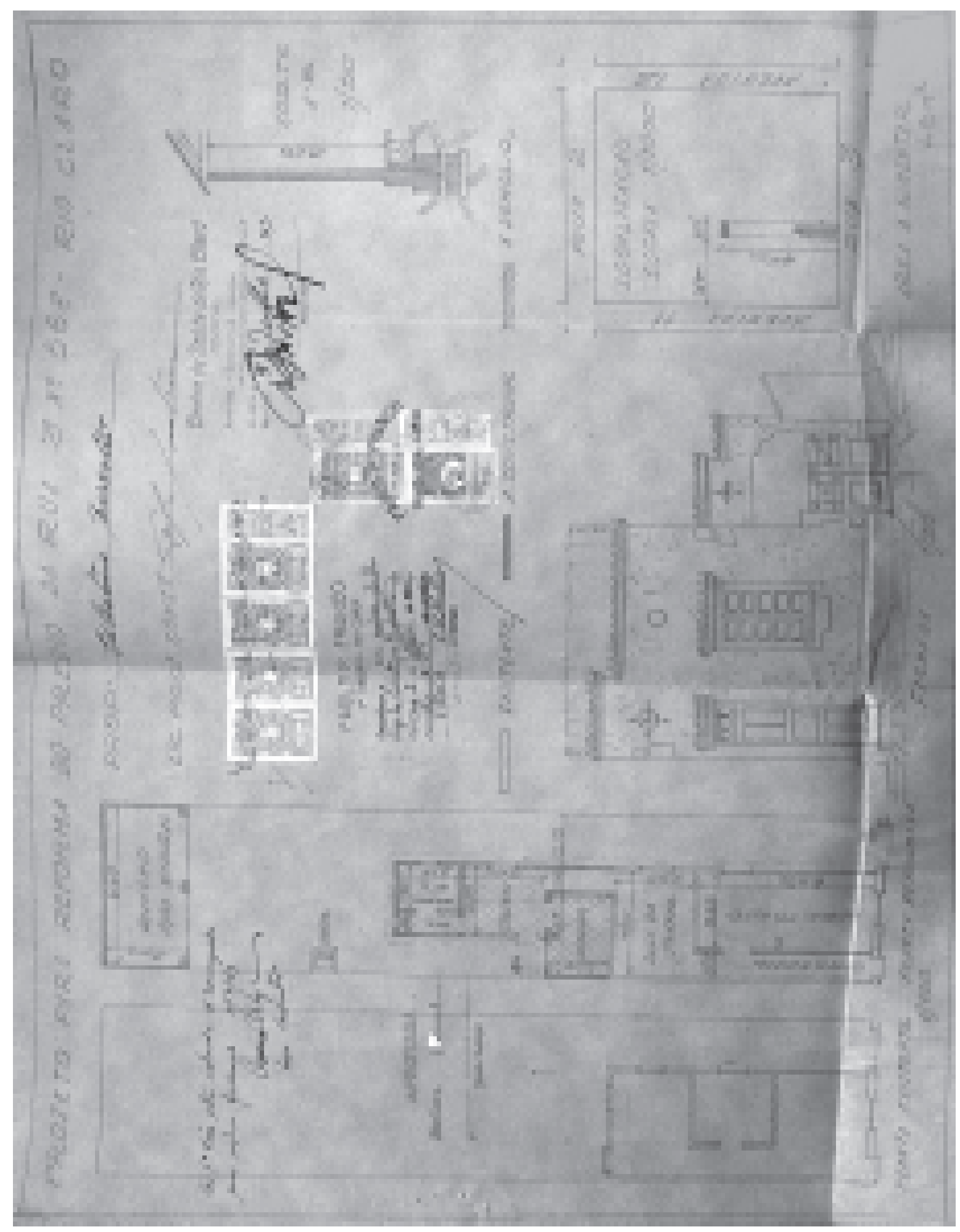

Figura 231 - Projeto de reforma de autoria do construtor Flávio Santomauro, de 1943, para uma residência, em Rio Claro, construída ainda no alinhamento da calçada como a maior parte das edificações ecléticas anteriores aos códigos sanitaristas. Na reforma, foram anexados estilemas neocoloniais. Fonte: Arquivo Municipal de Rio Claro. 

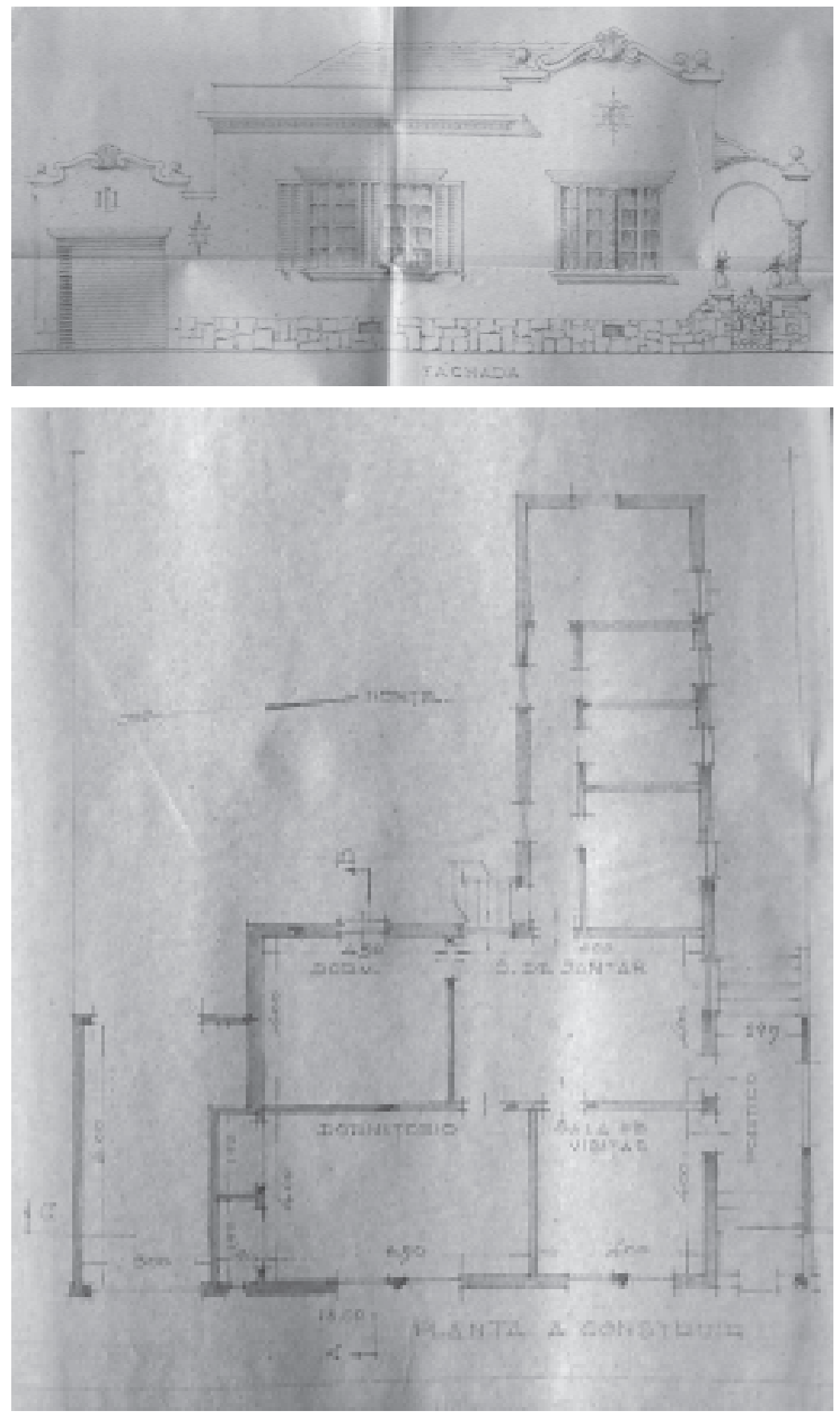

Figura 232 - Projeto de reforma, de 1950, de autoria do engenheiro Abrahão Schevz executado pelo construtor Humberto Sorregotti, em São Carlos. Essa edificação também ganhou frontões e volutas, mostrando mais uma vez que a tendência neocolonial nessas décadas de 1930 e 1940 era bastante usual. Fonte: Arquivo Municipal de São Carlos. 


\section{Tabela 1 - Processos de Aprovação de Obras por Data - Comparação natureza e padrão da obra}

Fizemos uma tabela geral por data do projeto para proporcionar uma visualização por época. Uma organização por cidades seria talvez menos útil, visto que em algumas, os respectivos arquivos não guardavam processos de determinados anos, ou só guardavam processos a partir de uma data, o que gerou um levantamento desigual em número e poderia levar a uma interpretação equivocada do tipo: "quantidade de processos" igual a "importância da ocorrência".

Conforme esclarecemos anteriormente, fizemos uma distinção dos profissionais conforme fossem diplomados ou não, com a finalidade de expor que parte da difusão simplificada da arquitetura neocolonial foi realizada por engenheiros e arquitetos que passaram por uma escola. Consideramos também, nesse contexto, cabível a existência de profissionais autodidatas, a quem se atribui o título de engenheiro ou arquiteto, porém, não pudemos identificá-los.

Para selecionar os projetos segundo o critério "padrão" - alto, médio ou baixo - levamos em consideração as dimensões do terreno (terreno inteiro ou meio terreno); a implantação (geminadas ou isoladas no lote); e, área construída (dimensões do projeto; dimensões dos ambientes; número de quartos; banheiro dentro ou fora da área construída principal). O padrão está associado à classe social.

As indicações referem-se ao número do processo de aprovação de projeto, por ano, nas respectivas Prefeituras Municipais e, é por eles que se localizam cada processo nos respectivos Arquivos Municipais. Indicamos o número da FIGURA dos processos que selecionamos para apresentar ao final do texto. 


\begin{tabular}{|c|c|c|c|c|c|c|c|c|}
\hline & Cidade & Processo* & Endereço & Autor & $\begin{array}{c}\text { Categoria } \\
\text { Profissional }\end{array}$ & $\begin{array}{l}\text { Natureza da } \\
\text { Obra }\end{array}$ & Padrão & Uso \\
\hline$\underset{1}{2}$ & Araraquara & Pasta 02 & - & $\begin{array}{l}\text { Escritório } \\
\text { Sampaio \& } \\
\text { Machado }\end{array}$ & Escritório - SP & Erudito & Alto & $\begin{array}{l}\text { "Internato } \\
\text { Araraquara } \\
\text { College" }\end{array}$ \\
\hline$\stackrel{\infty}{\approx}$ & Araraquara & Pasta 02 & Av. Brasil, s/n & $\begin{array}{l}\text { Celso Siqueira } \\
\text { Cabral }\end{array}$ & Engenheiro Civil & Erudito & Baixo & Residencial \\
\hline \multirow{2}{*}{ ñ } & \multirow{2}{*}{ Araraquara } & Pasta 03 & Av. Feijó, 4B & - & Engenheiro Civil & Erudito & Baixo & Residencial \\
\hline & & Pasta 03 & $\begin{array}{l}\text { Av. Cristóvão } \\
\text { Colombo, } 48 \mathrm{~A}\end{array}$ & - & - & - & Baixo & Residencial \\
\hline \multirow{2}{*}{ ñ } & \multirow{2}{*}{ Araraquara } & \multirow{2}{*}{ Pasta 03} & \multirow{2}{*}{ Av. Portugal, 15A } & $\begin{array}{l}\text { José A. } \\
\text { Kleindienst }\end{array}$ & Arquiteto & \multirow{2}{*}{ Erudito } & \multirow{2}{*}{$\begin{array}{c}\text { Médio } \\
\text { FIGURA } 237\end{array}$} & \multirow{2}{*}{$\begin{array}{l}\text { Comercial - Posto } \\
\text { para Lubrificação } \\
\text { de Automóveis }\end{array}$} \\
\hline & & & & $\begin{array}{l}\text { Celso Siqueira } \\
\text { Cabral }\end{array}$ & Engenheiro Civil & & & \\
\hline \multirow{2}{*}{ å } & \multirow{2}{*}{ Araraquara } & Pasta 04 & $\begin{array}{l}\text { R. Padre Duarte esq. } \\
\text { com Av. Espanha }\end{array}$ & $\begin{array}{l}\text { José A. } \\
\text { Kleindienst }\end{array}$ & Arquiteto & Erudito & $\begin{array}{c}\text { Médio } \\
\text { FIGURA } 238\end{array}$ & Residencial \\
\hline & & Pasta 04 & R. 9 de Julho, 6A & $\begin{array}{c}\text { Celso Siqueira } \\
\text { Cabral }\end{array}$ & Engenheiro Civil & Erudito & Baixo & Residencial \\
\hline
\end{tabular}




\begin{tabular}{|c|c|c|c|c|c|c|c|c|}
\hline & & 971 & - & Bruno Giongo & Construtor & Não Erudito & Baixo & Residencial \\
\hline & & 1099 & Conde do Pinhal, 62 & Rodolpho Fehr & Engenheiro Civil & Erudito & Médio & Residencial \\
\hline \multirow{5}{*}{ ñ } & Jaú & 03 & Rua Edgar Ferraz & Álvaro Botelho & Arquiteto - SP & Erudito & $\begin{array}{c}\text { Alto } \\
\text { FIGURA } 248\end{array}$ & Residencial \\
\hline & \multirow{4}{*}{ Araraquara } & \multirow{2}{*}{ Pasta 04} & \multirow{2}{*}{ Av. Portugal, s/n } & $\begin{array}{l}\text { Celso Siqueira } \\
\text { Cabral }\end{array}$ & Engenheiro Civil & \multirow{2}{*}{ Erudito } & \multirow{2}{*}{ Médio } & \multirow{2}{*}{ Residencial } \\
\hline & & & & Hermínio Tecco & Construtor & & & \\
\hline & & Pasta 04 & Av. D. Pedro II & $\begin{array}{l}\text { Celso Siqueira } \\
\text { Cabral }\end{array}$ & Engenheiro Civil & Erudito & Baixo & Residencial \\
\hline & & Pasta 04 & $\begin{array}{c}\text { R. Carlos Gomes, } \\
117 \mathrm{~B}\end{array}$ & $\begin{array}{l}\text { Celso Siqueira } \\
\text { Cabral }\end{array}$ & Engenheiro Civil & Erudito & Médio & $\begin{array}{c}\text { Residencial / } \\
\text { Consultório }\end{array}$ \\
\hline \multirow{3}{*}{$\stackrel{b}{a}$} & Jaú & 04 & $\begin{array}{c}\text { Rua Campos Salles } \\
\text { esq. com Rua Tenente } \\
\text { Lopes }\end{array}$ & Luciano Terreri & Construtor & Não Erudito & - & Residencial \\
\hline & \multirow[t]{2}{*}{ Araraquara } & Pasta 05 & Av. Barroso, 48 & José Barbugli & Engenheiro Civil & Eruditas & $\begin{array}{c}\text { Baixo } \\
\text { FIGURA } 233\end{array}$ & Residencial \\
\hline & & Pasta 05 & R. Padre Duarte, s/n & $\begin{array}{c}\text { Celso Siqueira } \\
\text { Cabral }\end{array}$ & Engenheiro Civil & Erudito & Médio & Residencial \\
\hline
\end{tabular}




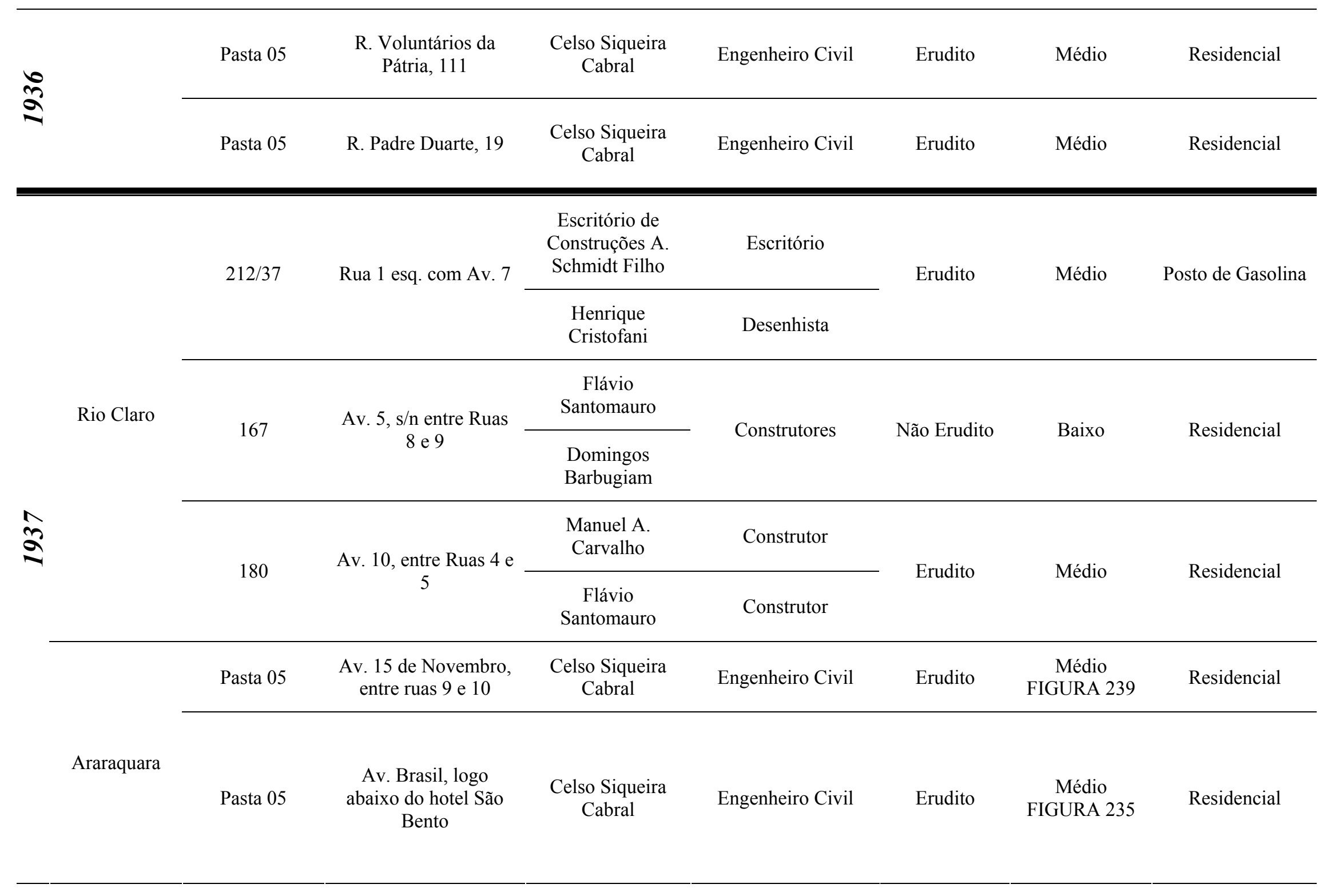




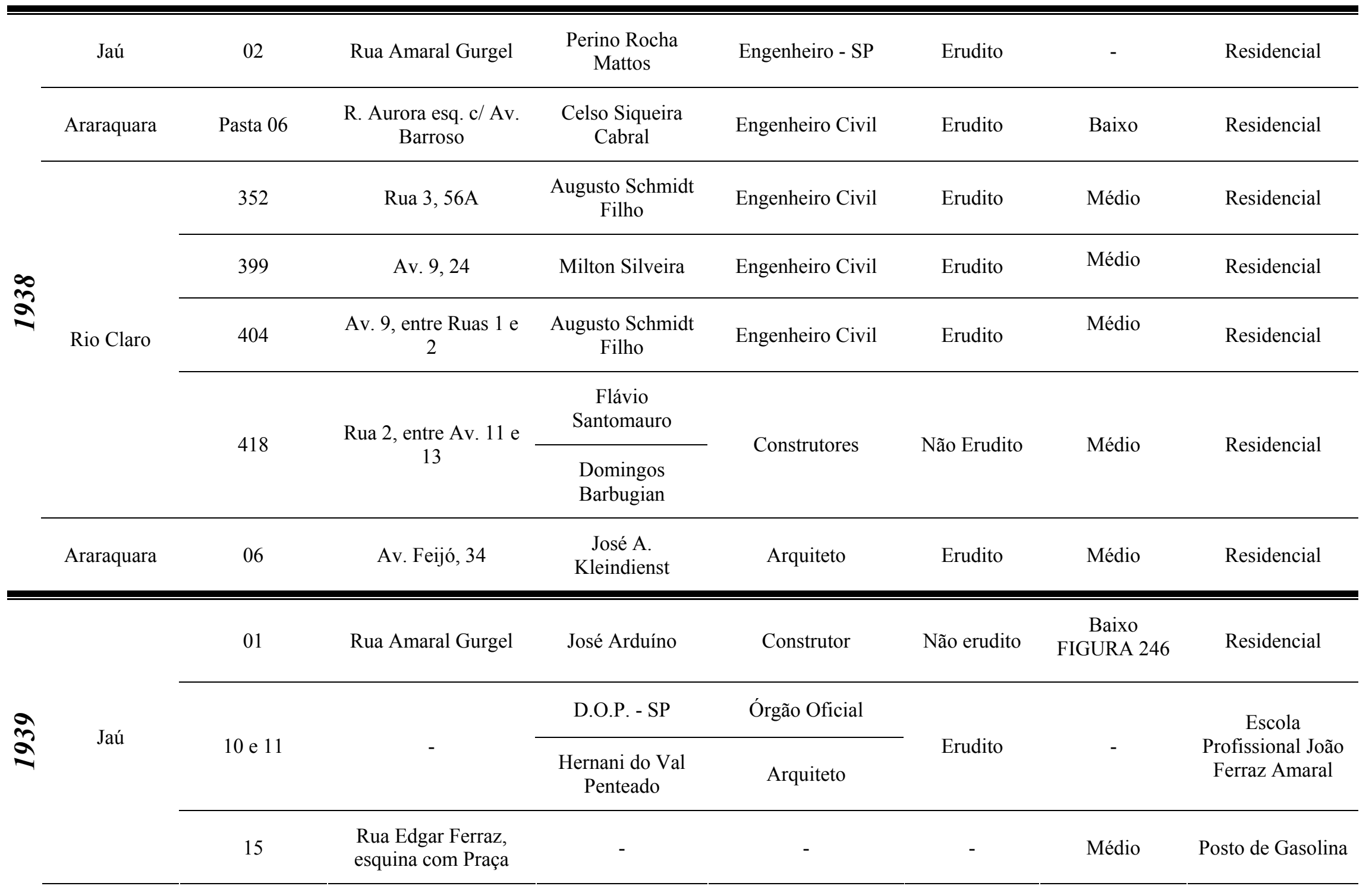




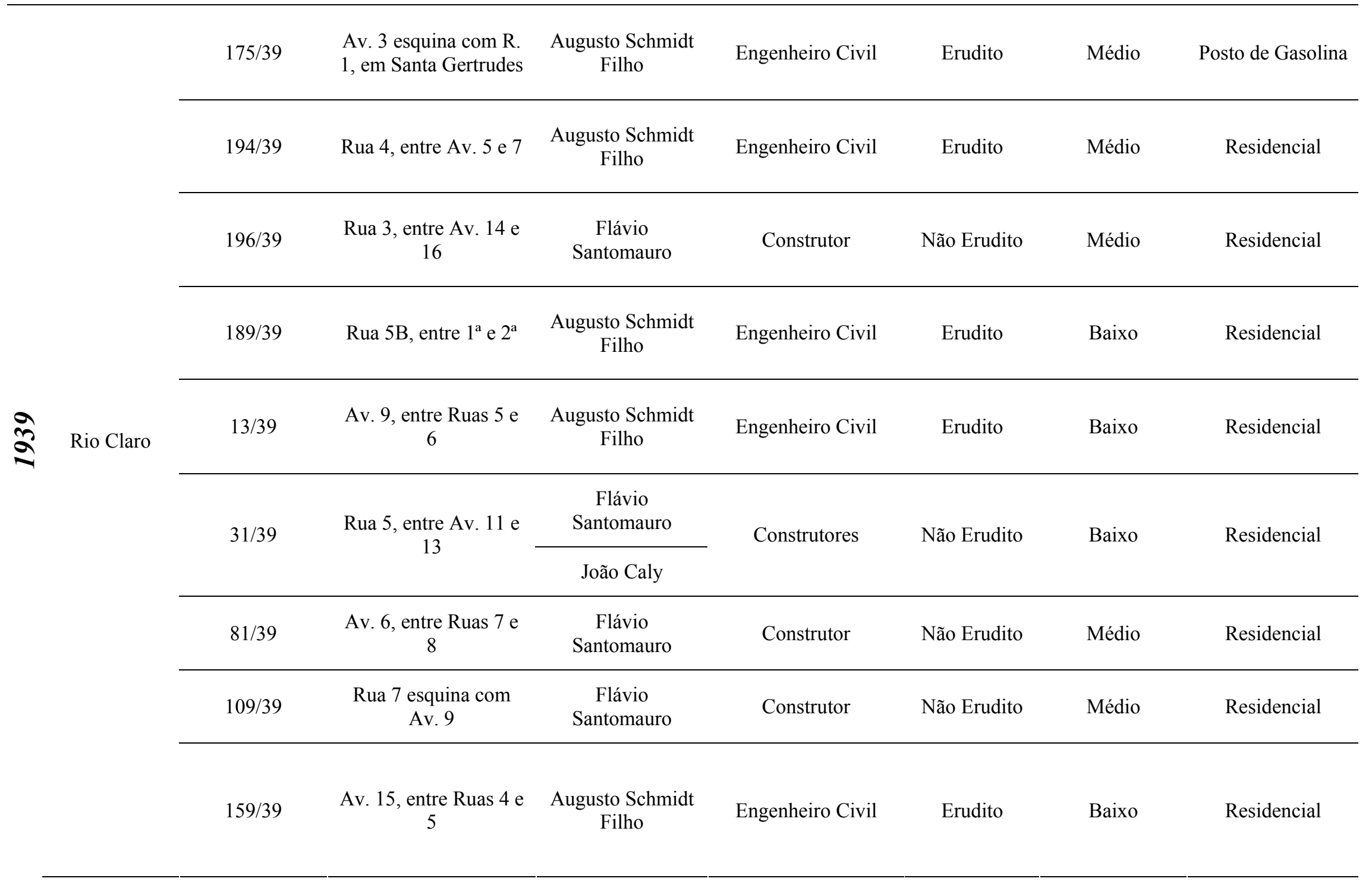




\begin{tabular}{|c|c|c|c|c|c|c|c|c|}
\hline \multirow{2}{*}{$\stackrel{a}{a}$} & \multirow[b]{2}{*}{ Araraquara } & Pasta 06 & Av. Brasil, 27 & $\begin{array}{c}\text { Boaventura } \\
\text { Gravina }\end{array}$ & Engenheiro Civil & Erudito & Médio & Residencial \\
\hline & & Pasta 06 & R. Padre Duarte, 37 & $\begin{array}{c}\text { Celso Siqueira } \\
\text { Cabral }\end{array}$ & Engenheiro Civil & Erudito & Médio & Residencial \\
\hline \multirow{11}{*}{\multicolumn{2}{|c|}{ São Carlos }} & $160 / 40$ & Av. 15,356 & $\begin{array}{l}\text { Augusto Schmidt } \\
\text { Filho }\end{array}$ & Engenheiro Civil & Erudito & Baixo & Residencial \\
\hline & & Pasta 06 & $\begin{array}{l}\text { Av. Brasil, a } 30 \mathrm{~m} \text { da } \\
\text { R. Voluntários da } \\
\text { Pátria }\end{array}$ & Mattos \& Freitas & Escritório - SP & Erudito & $\begin{array}{c}\text { Alto } \\
\text { FIGURA } 234\end{array}$ & Residencial \\
\hline & & Pasta 06 & Av. Portugal, 37 & Mattos \& Freitas & Escritório - SP & Erudito & Médio & Residencial \\
\hline & & Pasta 06 & R. Major Tito, $\mathrm{s} / \mathrm{n}$ & $\begin{array}{c}\text { Boaventura } \\
\text { Gravina }\end{array}$ & Engenheiro Civil & Erudito & Baixo & Residencial \\
\hline & & 3321 & - & Camillo Domicci & Construtor & Não erudito & Baixo & Residencial \\
\hline & & 3421 & - & Rodolpho Fehr & Arquiteto & Erudito & Baixo & Residencial \\
\hline & & \multirow{2}{*}{858} & \multirow{2}{*}{ R. Episcopal, 100} & Rodolpho Fehr & Arquiteto & \multirow{2}{*}{ Erudito } & \multirow{2}{*}{-} & \multirow{2}{*}{ Residencial } \\
\hline & & & & Bruno Giongo & Construtor & & & \\
\hline & & 1123 & $\begin{array}{l}\text { R. Paulino Carlos, em } \\
\text { Ibaté }\end{array}$ & $\begin{array}{c}\text { Djalma Ferraz } \\
\text { Kehl }\end{array}$ & Engenheiro Civil & Erudito & Baixo & Residencial \\
\hline & & 4376 & $\begin{array}{l}\text { R. Major José Inácio } \\
\text { com R. Aquidaban }\end{array}$ & Rodolpho Fehr & Arquiteto & Erudito & Baixo & Residencial \\
\hline & & 4281 & R. 7 de Setembro, 170 & Rodolpho Fehr & Arquiteto & Erudito & Médio & Residencial \\
\hline
\end{tabular}




\begin{tabular}{|c|c|c|c|c|c|c|c|}
\hline \multirow{2}{*}{ a } & 3364 & $\begin{array}{l}\text { R. Riachuelo, entre R. } \\
\text { Geminiano de Arruda } \\
\text { e R. } 13 \text { de Maio }\end{array}$ & Rodolpho Fehr & Arquiteto & Erudito & Baixo & Residencial \\
\hline & 1014 & $\begin{array}{c}\text { Rua aberta entre } \\
\text { Conde do Pinhal e } 13 \\
\text { de Maio }\end{array}$ & Rodolpho Fehr & Arquiteto & Erudito & Baixo & Residencial \\
\hline & 02 & $\begin{array}{l}\text { Rua Lourenço Prado, } \\
\text { esq. com Rua } \\
\text { Marechal Bittencourt }\end{array}$ & José Arduino & Construtor & Não erudito & - & $\begin{array}{c}\text { Banco comercial } \\
\text { do Estado de São } \\
\text { Paulo }\end{array}$ \\
\hline & 07 & Rua Rui Barbosa & Affonso Galindo & Construtor & Não erudito & - & Residencial \\
\hline \multirow[t]{4}{*}{ Rio Claro } & $43 / 41$ & $\begin{array}{c}\text { Rua } 7,1122,1128 \mathrm{e} \\
1143\end{array}$ & $\begin{array}{l}\text { Augusto Schmidt } \\
\text { Filho }\end{array}$ & Engenheiro Civil & Erudito & Médio & Residencial \\
\hline & $122 / 41$ & $\begin{array}{l}\text { Av. } 5 \text { entre Rua } 3 \text { e } \\
\text { 4B (cidade nova) }\end{array}$ & $\begin{array}{c}\text { Flávio } \\
\text { Santomauro } \\
\begin{array}{c}\text { Manuel António } \\
\text { Carvalho }\end{array}\end{array}$ & Construtores & Não Erudito & Baixo & Residencial \\
\hline & $147 / 41$ & $\begin{array}{c}\text { Rua 33 } 3^{\mathrm{a}}, 278-290 \\
\text { (Vila dos Alemães) }\end{array}$ & $\begin{array}{c}\text { Flávio } \\
\text { Santomauro } \\
\begin{array}{c}\text { Manuel António } \\
\text { Carvalho }\end{array}\end{array}$ & Construtores & Não Erudito & Baixo & Residencial \\
\hline & $171 / 41$ & Rua 2, 1491 & $\begin{array}{c}\text { Flávio } \\
\text { Santomauro }\end{array}$ & Construtor & Não Erudito & Baixo & $\begin{array}{l}\text { Residencial / } \\
\text { Comercial }\end{array}$ \\
\hline
\end{tabular}




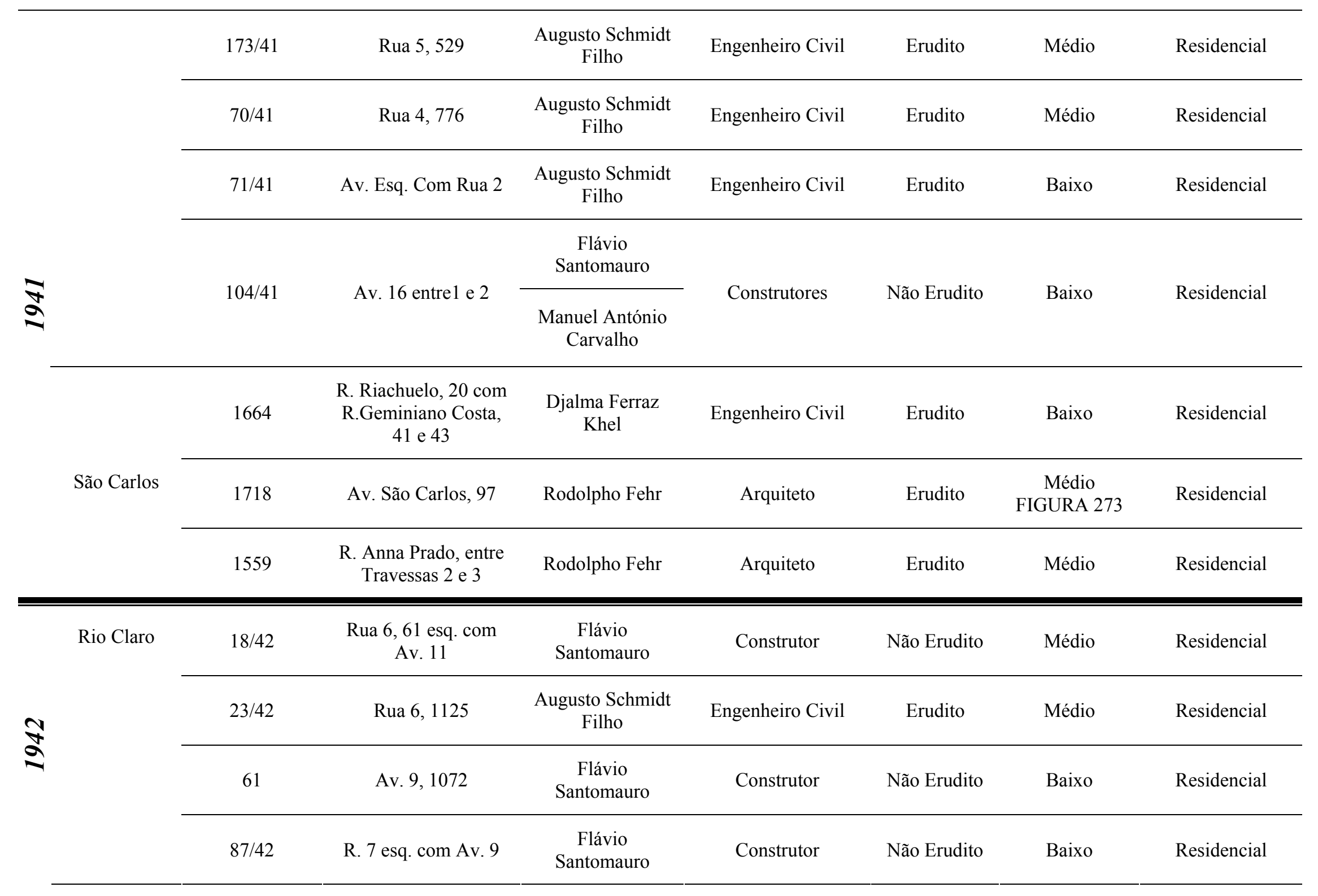




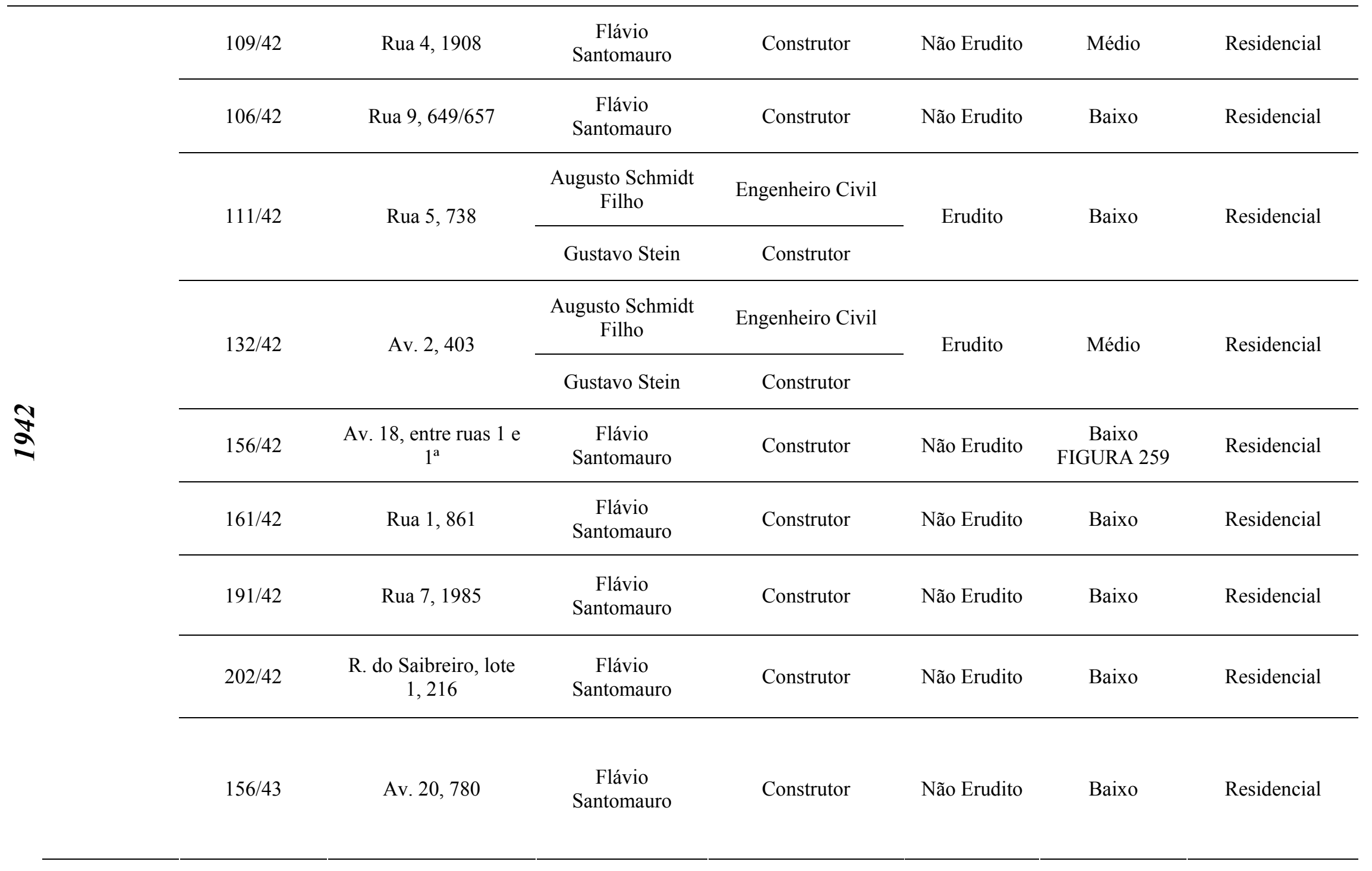




\begin{tabular}{|c|c|c|c|c|c|c|c|}
\hline \multirow{5}{*}{ São Carlos } & 2243 & R. 7 de Setembro, 109 & Rodolpho Fehr & Arquiteto & Erudito & Baixo & Residencial \\
\hline & 2099 & $\begin{array}{l}\text { R. São Joaquim, } 26 \text { e } \\
28\end{array}$ & Rodolpho Fehr & Arquiteto & Erudito & Baixo & Residencial \\
\hline & 3014 & $\begin{array}{l}\text { R. D. Pedro II com M. } \\
\text { J. Inácio e } 7 \text { de set. }\end{array}$ & Rodolpho Fehr & Arquiteto & Erudito & $\begin{array}{l}\text { Baixo } \\
\text { FIGURA } 275\end{array}$ & Residencial \\
\hline & \multirow{2}{*}{1708} & \multirow{2}{*}{$\begin{array}{l}\text { R. Major J. Inácio, } \\
\text { s/n, entre R. Episcopal } \\
\text { e Av. São Carlos }\end{array}$} & Rodolpho Fehr & Arquiteto & \multirow{2}{*}{ Erudito } & \multirow{2}{*}{ Médio } & \multirow{2}{*}{ Residencia } \\
\hline & & & Bruno Giongo & Construtor & & & \\
\hline Jaú & 02 & Rua Riachuelo & José Arduíno & Construtor & Não erudito & Médio & Residencial \\
\hline \multirow[t]{5}{*}{ Rio Claro } & $10 / 43$ & Rua $2^{\text {a }}, 349$ & $\begin{array}{c}\text { Flávio } \\
\text { Santomauro }\end{array}$ & Construtor & Não Erudito & Baixo & Residencial \\
\hline & $16 / 43$ & Av. 3, 532 & $\begin{array}{c}\text { Flávio } \\
\text { Santomauro }\end{array}$ & Construtor & Não Erudito & Médio & Residencial \\
\hline & $22 / 43$ & Rua 6, 1353 & $\begin{array}{c}\text { Flávio } \\
\text { Santomauro }\end{array}$ & Construtor & Não Erudito & Médio & Residencial \\
\hline & $46 / 43$ & Rua 3, 553 & $\begin{array}{c}\text { Flávio } \\
\text { Santomauro }\end{array}$ & Construtor & Não Erudito & $\begin{array}{c}\text { Baixo } \\
\text { FIGURA } 254\end{array}$ & Residencial \\
\hline & $95 / 43$ & Rua 3, 568 & $\begin{array}{c}\text { Flávio } \\
\text { Santomauro }\end{array}$ & Construtor & Não Erudito & Baixo & Residencial \\
\hline
\end{tabular}




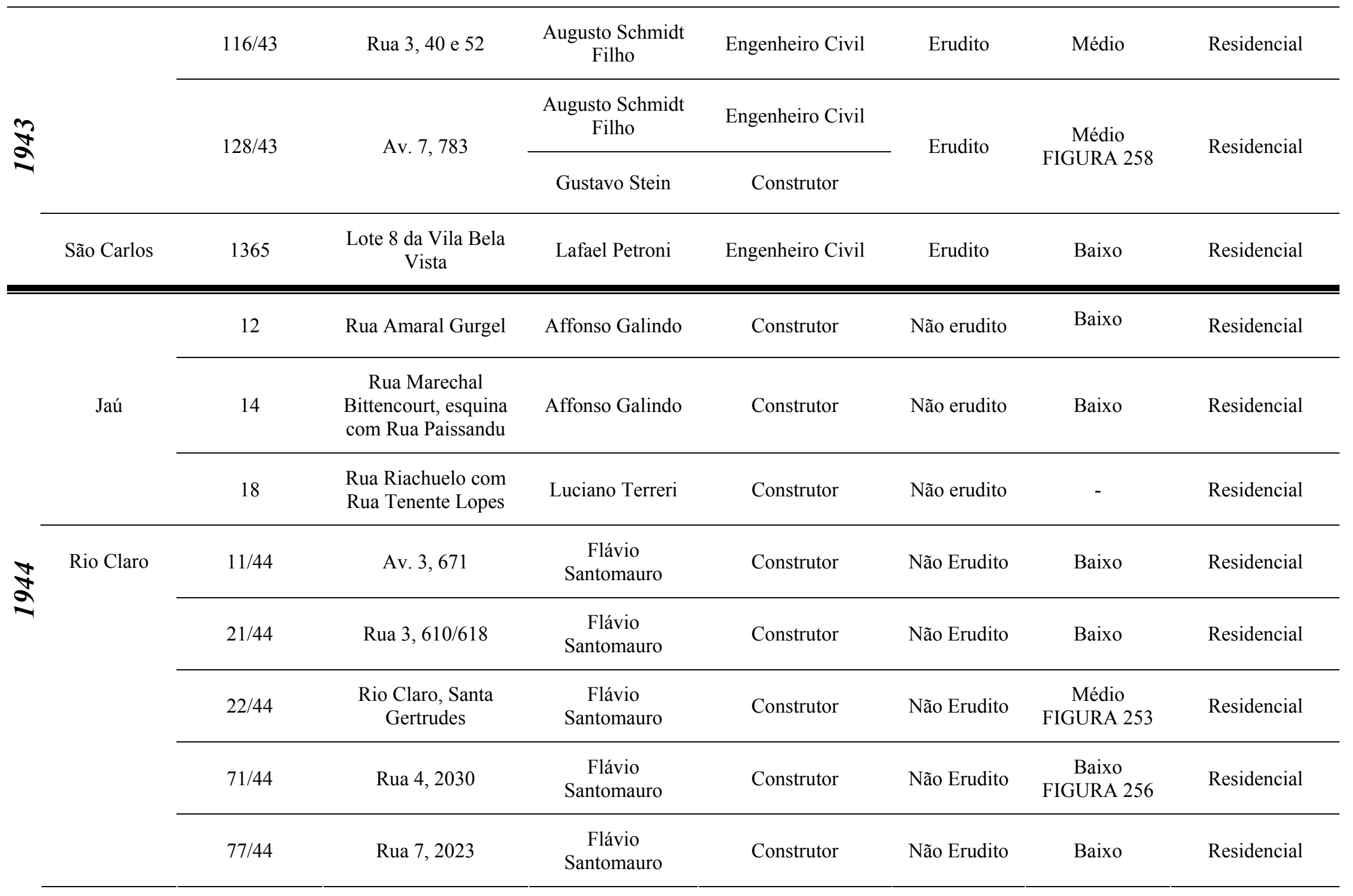




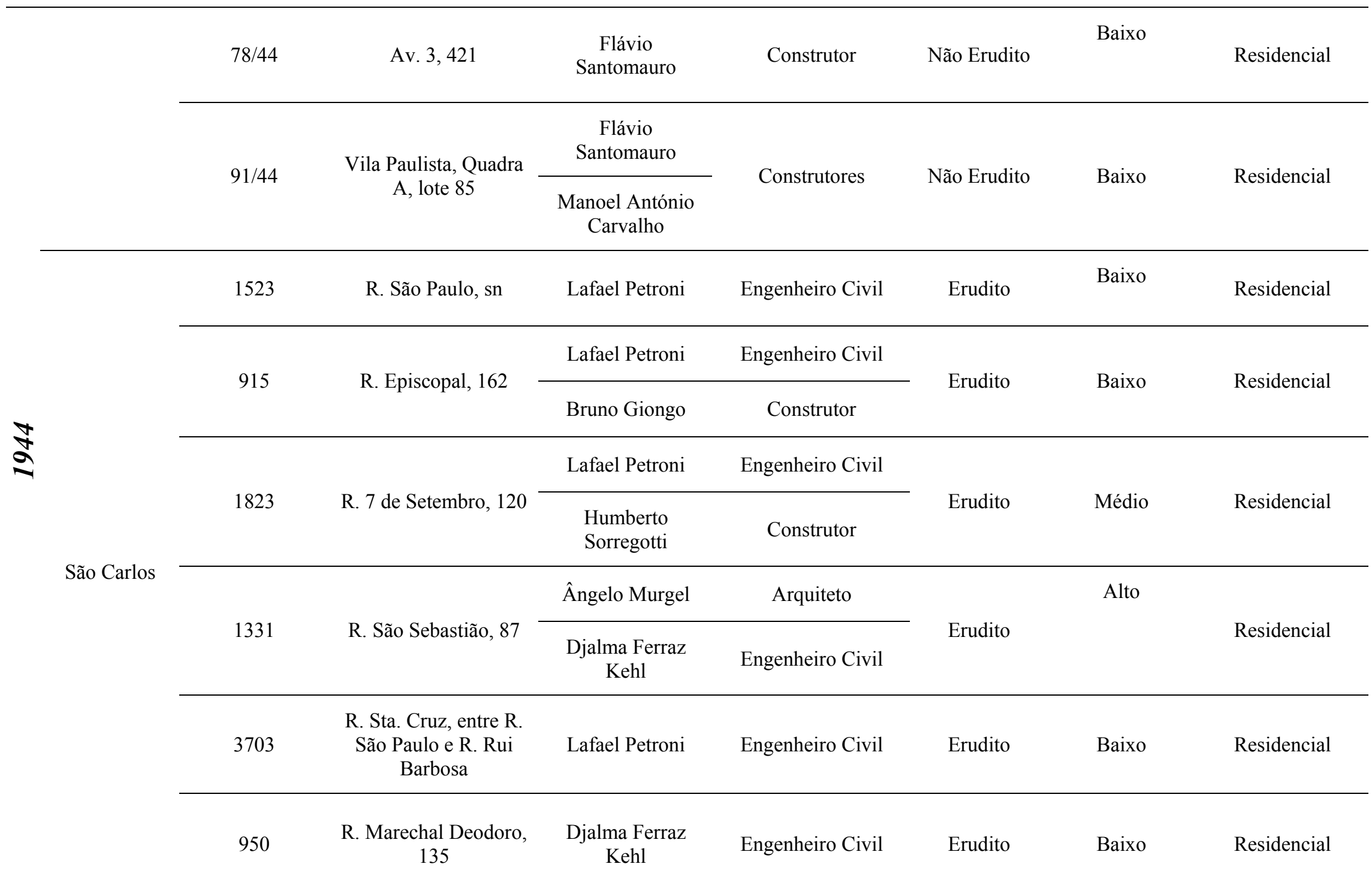




\begin{tabular}{|c|c|c|c|c|c|c|c|}
\hline \multirow{2}{*}{ Jaú } & 16 & Rua General Galvão & José Arduíno & Construtor & Não erudito & - & $\begin{array}{c}\text { Residencial / } \\
\text { Serviços }\end{array}$ \\
\hline & 18 & $\begin{array}{c}\text { Rua Riachuelo com } \\
\text { Rua Visconde do Rio } \\
\text { Branco }\end{array}$ & $\begin{array}{l}\text { Ângelo José } \\
\text { Terreri }\end{array}$ & Construtor & Não erudito & Baixo & Residencial \\
\hline \multirow{3}{*}{ Rio Claro } & $137 / 45$ & Av. 3 & $\begin{array}{c}\text { Flávio } \\
\text { Santomauro }\end{array}$ & Construtor & Não Erudito & Baixo & Residencial \\
\hline & $71 / 45$ & Rua 1, 2279/2287 & $\begin{array}{c}\text { Flávio } \\
\text { Santomauro }\end{array}$ & Construtor & Não Erudito & Baixo & Residencial \\
\hline & $233 / 45$ & $\begin{array}{l}\text { Rua 5, entre Av. } 15 \mathrm{e} \\
17\end{array}$ & $\begin{array}{l}\text { Francisco de } \\
\text { Godoi }\end{array}$ & Engenheiro Civil & Erudito & $\begin{array}{c}\text { Baixo } \\
\text { FIGURA } 261\end{array}$ & Residencial \\
\hline \multirow[t]{7}{*}{ \& Araraquara } & Pasta 07 & $\begin{array}{l}\text { R. Prudente de } \\
\text { Morais, } 796\end{array}$ & Vicente Miceli & Engenheiro Civil & Erudito & Baixo & Residencial \\
\hline & 4634 & $\begin{array}{l}\text { R. Riachuelo com } \\
\text { Geminiano Costa }\end{array}$ & Lafael Petroni & Engenheiro Civil & Erudito & Alto & Residencial \\
\hline & 1470 & $\begin{array}{c}\text { R. Major José Inácio, } \\
126\end{array}$ & Rodolpho Fehr & Arquiteto & Erudito & $\begin{array}{c}\text { Alto } \\
\text { FIGURA 271 }\end{array}$ & Residencial \\
\hline & 1695 & $\begin{array}{l}\text { R. Aquidaban com } \\
\text { Santa Cruz }\end{array}$ & Rodolpho Fehr & Arquiteto & Erudito & $\begin{array}{c}\text { Baixo } \\
\text { FIGURA 272 }\end{array}$ & Residencial \\
\hline & 3246 & $\begin{array}{l}\text { R. Conde do Pinhal, } \\
\text { próximo ao } 71\end{array}$ & Lafael Petroni & Engenheiro Civil & Erudito & Baixo & Residencial \\
\hline & 3937 & $\begin{array}{l}\text { R. } 9 \text { de Julho com } \\
\text { Major J. Inácio }\end{array}$ & Lafael Petroni & Engenheiro Civil & Erudito & Baixo & Residencial \\
\hline & 3940 & R. D. Pedro II, s/n & Lafael Petroni & Engenheiro Civil & Erudito & Baixo & Residencial \\
\hline
\end{tabular}




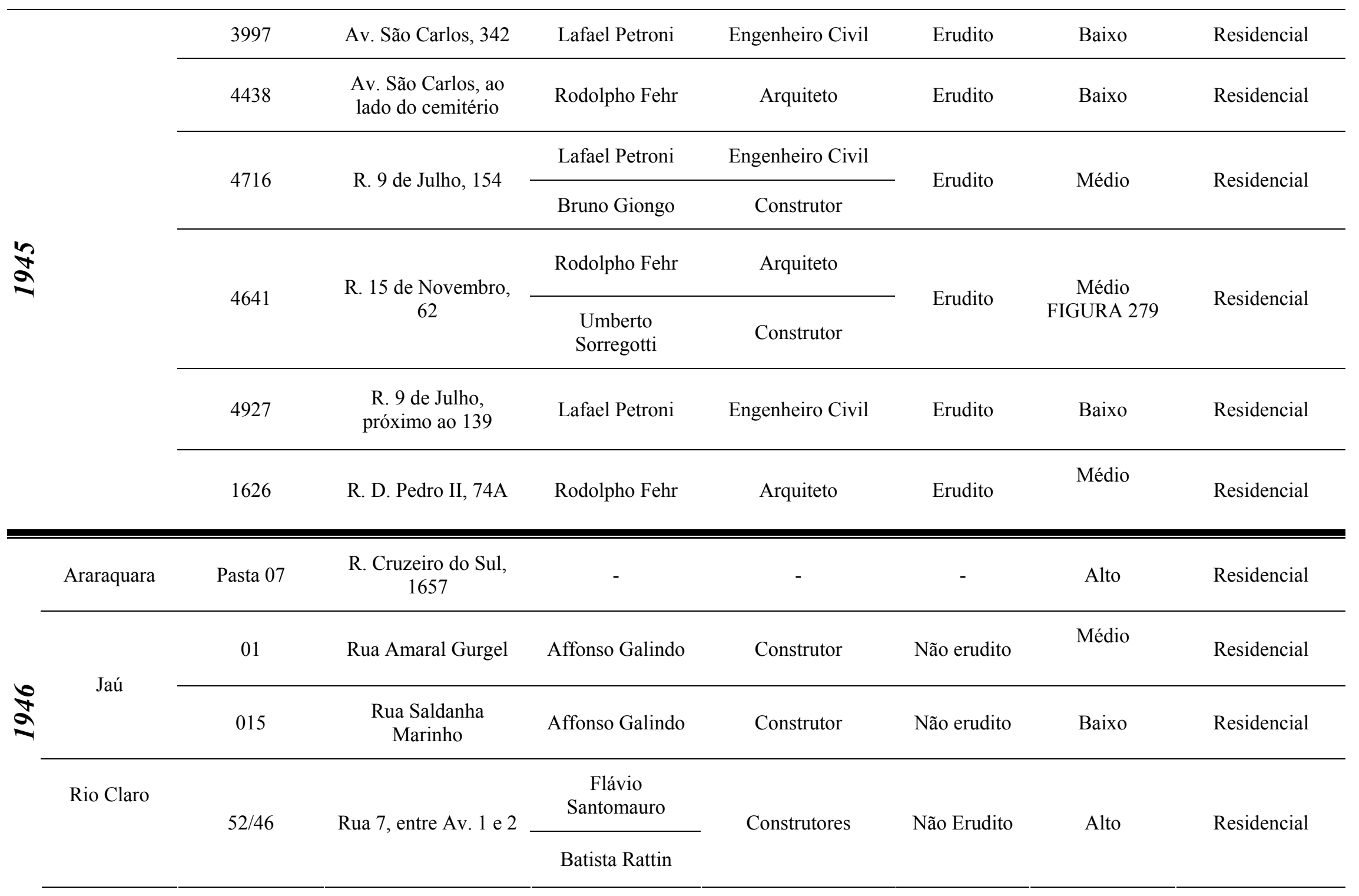




\begin{tabular}{|c|c|c|c|c|c|c|c|}
\hline & $105 / 46$ & $\begin{array}{l}\text { Rua 8, entre Av. } 22 \mathrm{e} \\
24\end{array}$ & $\begin{array}{c}\text { Flávio } \\
\text { Santomauro }\end{array}$ & Construtor & Não Erudito & Médio & Residencial \\
\hline & $180 / 46$ & Rua 4, entre Av. 4 e 6 & $\begin{array}{c}\text { Flávio } \\
\text { Santomauro }\end{array}$ & Construtor & Não Erudito & $\begin{array}{l}\text { Médio } \\
\text { FIGURA } 260\end{array}$ & $\begin{array}{c}\text { Residencial / } \\
\text { Comercial }\end{array}$ \\
\hline \multirow{7}{*}{$\frac{b}{a}$} & $193 / 46$ & Rua 3, esq. da Av. 17 & $\begin{array}{c}\text { Flávio } \\
\text { Santomauro }\end{array}$ & Construtor & Não Erudito & Médio & Residencial \\
\hline & $234 / 46$ & Rua 5, entre Av. 8 e10 & $\begin{array}{c}\text { Flávio } \\
\text { Santomauro }\end{array}$ & Construtor & Não Erudito & Baixo & Residencial \\
\hline & $276 / 46$ & Av. 6 entre Ruas 4 e 5 & $\begin{array}{c}\text { Flávio } \\
\text { Santomauro }\end{array}$ & Construtor & Não Erudito & Baixo & Serviços \\
\hline & $281 / 46$ & Av. 17, entre Ruas $4 \mathrm{e}$ & $\begin{array}{c}\text { Flávio } \\
\text { Santomauro }\end{array}$ & Construtor & Não Erudito & Baixo & Residencial \\
\hline & $321 / 46$ & Rua 8, esq. da Av. 19 & $\begin{array}{c}\text { Flávio } \\
\text { Santomauro }\end{array}$ & Construtor & Não Erudito & Baixo & Residencial \\
\hline & \multirow[t]{2}{*}{$334 / 46$} & \multirow[t]{2}{*}{ Rua 7, entre Av. 1 e 2} & $\begin{array}{c}\text { Flávio } \\
\text { Santomauro }\end{array}$ & \multirow[t]{2}{*}{ Construtores } & \multirow[t]{2}{*}{ Não Erudito } & \multirow[t]{2}{*}{$\begin{array}{c}\text { Alto } \\
\text { FIGURA } 262\end{array}$} & \multirow[t]{2}{*}{ Residencial } \\
\hline & & & Batista Rattin & & & & \\
\hline \multirow[t]{3}{*}{ São Carlos } & 937 & R. 9, de Julho, 86 & Lafael Petroni & Engenheiro Civil & Erudito & Baixo & Residencial \\
\hline & 939 & $\begin{array}{l}\text { R. Padre Teixeira, } \\
\text { entre R. São Paulo e } \\
\text { R. Rui Barbosa }\end{array}$ & Lafael Petroni & Engenheiro Civil & Erudito & Baixo & Residencial \\
\hline & 1546 & $\begin{array}{c}\text { R. Marechal Deodoro, } \\
142 / 144\end{array}$ & $\begin{array}{c}\text { Djalma Ferraz } \\
\text { Kehl }\end{array}$ & Engenheiro Civil & Erudito & Baixo & $\begin{array}{c}\text { Residencial e } \\
\text { Fábrica de } \\
\text { Móveis }\end{array}$ \\
\hline
\end{tabular}




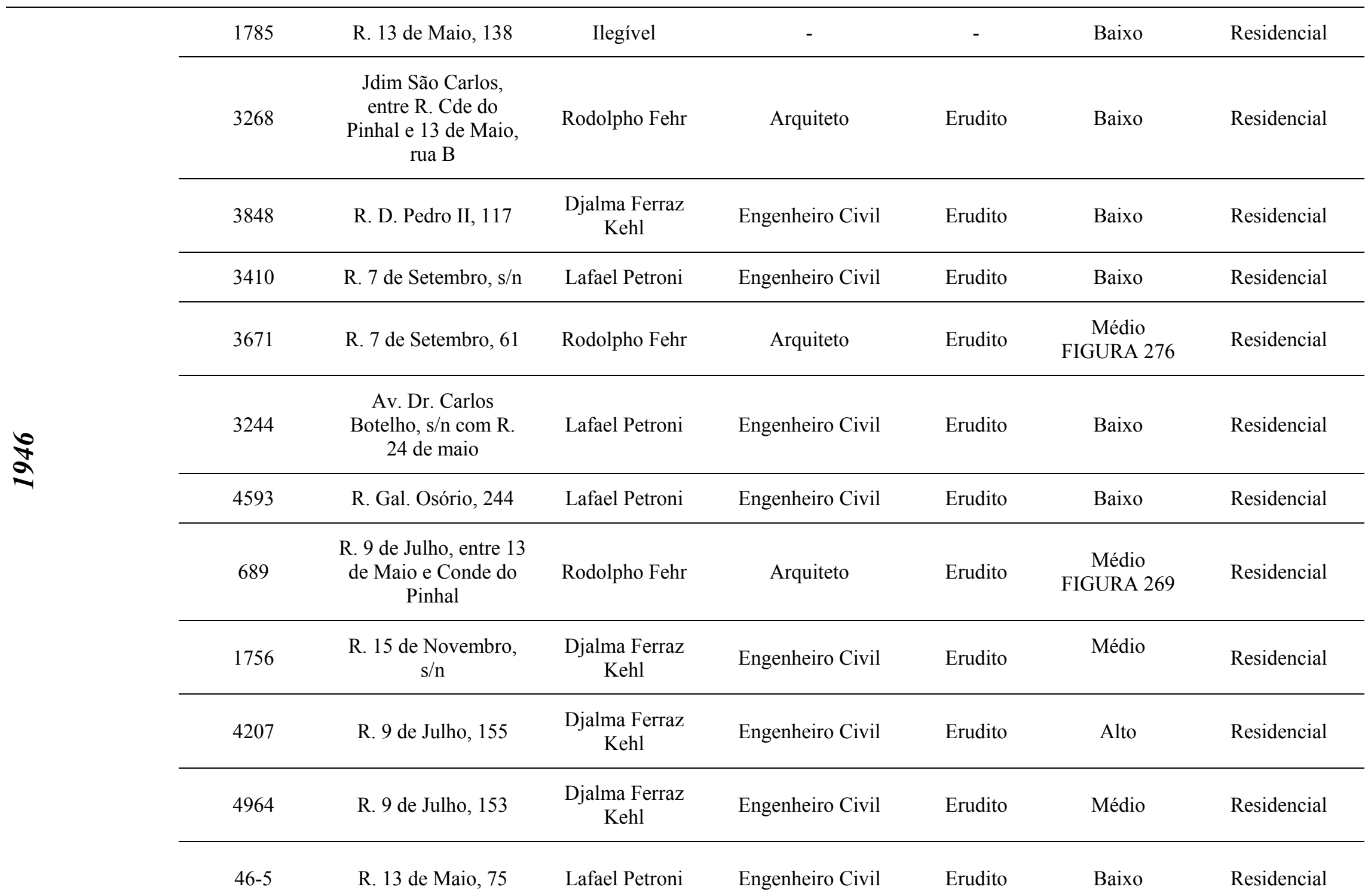




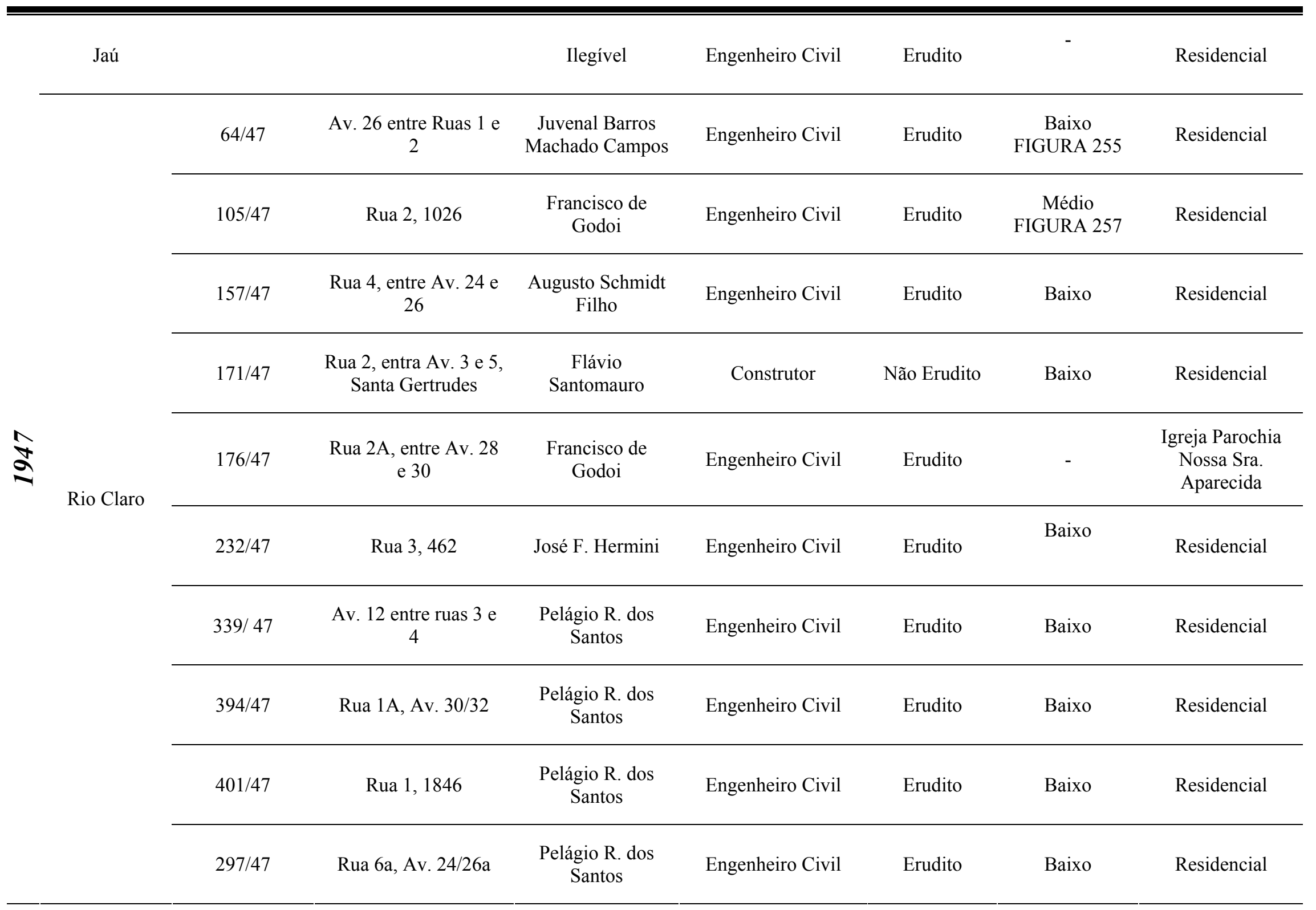




\begin{tabular}{|c|c|c|c|c|c|c|c|c|}
\hline & \multirow{3}{*}{ Araraquara } & Pasta 07 & $\begin{array}{l}\text { Av. Feijó esq. com R. } \\
\text { Carvalho Filho }\end{array}$ & José dos Santos & Engenheiro Civil & Erudito & $\begin{array}{c}\text { Médio } \\
\text { FIGURA } 236\end{array}$ & Residencial \\
\hline \multirow{9}{*}{ à } & & Pasta 07 & R. Carlos Gomes, s/n & Ilegível & - & - & Baixo & Residencial \\
\hline & & Pasta 07 & $\begin{array}{l}\text { R. Cruzeiro do Sul, } \\
\text { entre R. S. Geraldo e } \\
\text { R. C. Colombo }\end{array}$ & Ilegível & - & - & Baixo & Residencial \\
\hline & \multirow{7}{*}{ São Carlos } & 904 & $\begin{array}{l}\text { R. Visconde de } \\
\text { Inhauma, 35A }\end{array}$ & - & - & - & Baixo & Residencial \\
\hline & & 1063 & $\begin{array}{l}\text { Av. Dr. Carlos } \\
\text { Botelho, } 59\end{array}$ & Lafael Petroni & Engenheiro Civil & Erudito & Baixo & Residencial \\
\hline & & \multirow[b]{2}{*}{2155} & \multirow[b]{2}{*}{ R. D. Alexandrina, 26} & Lafael Petroni & Engenheiro Civil & \multirow[b]{2}{*}{ Erudito } & \multirow[b]{2}{*}{ Médio } & \multirow[b]{2}{*}{ Residencia } \\
\hline & & & & $\begin{array}{l}\text { Humberto } \\
\text { Sorregotti }\end{array}$ & Construtor & & & \\
\hline & & & & Lafael Petroni & Engenheiro Civil & \multirow[b]{2}{*}{ Erudito } & \multirow[b]{2}{*}{ Médio } & \multirow[b]{2}{*}{ Residencial } \\
\hline & & 1234 & 63 & $\begin{array}{l}\text { Humberto } \\
\text { Sorregotti }\end{array}$ & Construtor & & & \\
\hline & & 2127 & $\begin{array}{l}\text { R. Carlos Botelho, } \\
103\end{array}$ & Rodolpho Fehr & Arquiteto & Erudito & Médio & Residencial \\
\hline \multirow{3}{*}{$\stackrel{\infty}{a}$} & \multirow[t]{3}{*}{ Jaú } & 01 & $\begin{array}{l}\text { Rua Amaral Gurgel, } \\
\mathrm{s} / \mathrm{n}\end{array}$ & $\begin{array}{l}\text { Ângelo José } \\
\text { Terreri }\end{array}$ & Construtor & Não erudito & Médio & Residencial \\
\hline & & 02 & $\begin{array}{l}\text { Rua Visconde do Rio } \\
\text { Branco }\end{array}$ & - & - & - & Baixo & Residencial \\
\hline & & 03 & $\begin{array}{l}\text { Rua Francisco } \\
\text { Glicério }\end{array}$ & Affonso Galindo & Construtor & Não erudito & $\begin{array}{c}\text { Baixo } \\
\text { FIGURA } 249\end{array}$ & Residencial \\
\hline
\end{tabular}




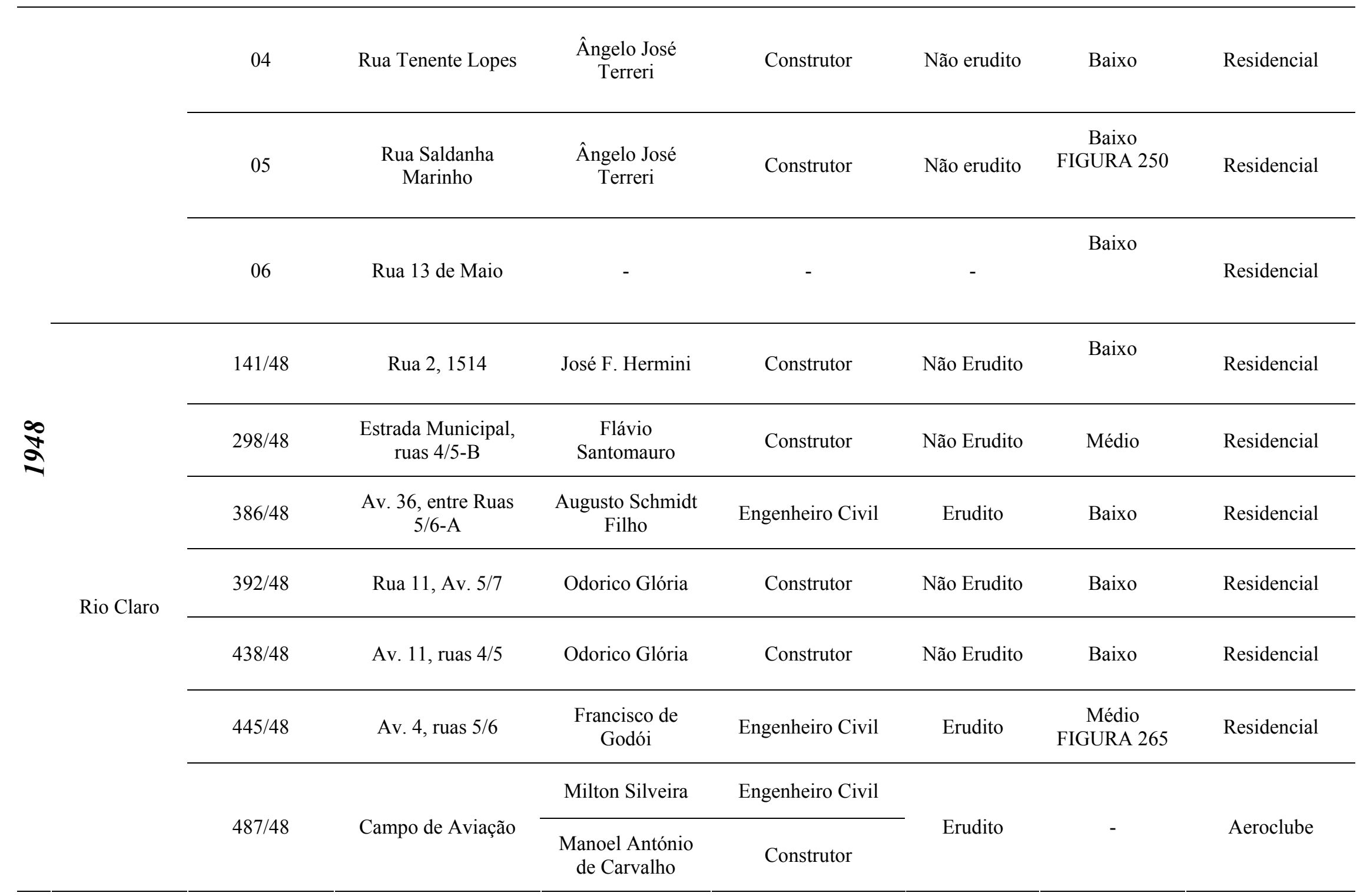




\begin{tabular}{|c|c|c|c|c|c|c|c|c|}
\hline & São Carlos & 1177 & $\begin{array}{l}\text { R. Aquidaban esq. } \\
\text { com R. Major J. } \\
\text { Inácio }\end{array}$ & Lafael Petroni & Engenheiro Civil & Erudito & Baixo & Residencial \\
\hline \multirow{9}{*}{\multicolumn{2}{|c|}{$\underset{7}{\infty}$}} & 1385 & $\begin{array}{l}\text { R. Jesuíno de Arruda } \\
\text { esq. com R. S. } \\
\text { Joaquim }\end{array}$ & Lafael Petroni & Engenheiro Civil & Erudito & Alto & Residencial \\
\hline & & 2492 & R, 7 de Setembro, 139 & Lafael Petroni & Engenheiro Civil & Erudito & Baixo & Residencial \\
\hline & & 2648 & $\begin{array}{l}\text { Av. Dr. Carlos } \\
\text { Botelho, } 119\end{array}$ & Lafael Petroni & Engenheiro Civil & Erudito & Baixo & Residencial \\
\hline & & 2951 & Av. São Carlos, 457 & Theodoro Fehr & Engenheiro Civil & Erudito & $\begin{array}{c}\text { Médio } \\
\text { FIGURA } 274\end{array}$ & Residencial \\
\hline & & 3849 & R. D. Pedro II, s/n & & Engenheiro Civil & Erudito & Baixo & Residencial \\
\hline & & 3870 & $\begin{array}{l}\text { Prolongamento da R. } \\
\text { São Paulo }\end{array}$ & - & Engenheiro Civil & Erudito & Baixo & Residencial \\
\hline & & \multirow[b]{2}{*}{3871} & \multirow{2}{*}{$\begin{array}{l}\text { R. Jesuíno de Arruda, } \\
191\end{array}$} & - & Engenheiro Civil & \multirow[b]{2}{*}{ Erudito } & \multirow[b]{2}{*}{ Médio } & \multirow[b]{2}{*}{ Residencial } \\
\hline & & & & $\begin{array}{l}\text { Humberto } \\
\text { Sorregotti }\end{array}$ & Construtor & & & \\
\hline & & 3903 & $\begin{array}{l}\text { Estrada de Rodagem, } \\
\text { em São Carlos }\end{array}$ & Eng. Enio Perillo & & Erudito & Médio & Residencial \\
\hline
\end{tabular}




\begin{tabular}{|c|c|c|c|c|c|c|c|c|}
\hline & & 4114 & $\begin{array}{c}\text { Jardim São Carlos, } \\
\text { rua A }\end{array}$ & Alfredo Borelli & Engenheiro Civil & Erudito & $\begin{array}{c}\text { Baixo } \\
\text { FIGURA } 278\end{array}$ & Residencia \\
\hline \multirow{7}{*}{\multicolumn{2}{|c|}{$\stackrel{\infty}{a}$}} & 4594 & Av. São Carlos, s/n & $\begin{array}{l}\text { Escritório de } \\
\text { Construções } \\
\text { Gelsomino Saia }\end{array}$ & Escritório & Erudito & Baixo & Residencia \\
\hline & & & & Alfredo Borelli & Engenheiro Civil & & & \\
\hline & & 4086 & R. 9 de Julho, s/n & - & Engenheiro Civil & Erudito & $\begin{array}{c}\text { Baixo } \\
\text { FIGURA } 277\end{array}$ & Residencia \\
\hline & & 1273 & $\begin{array}{l}\text { R. } 9 \text { de Julho esq. } \\
\text { com R. } 15 \text { de } \\
\text { Novembro }\end{array}$ & Theodoro Fehr & Engenheiro Civil & Erudito & $\begin{array}{c}\text { Alto } \\
\text { FIGURA } 270\end{array}$ & Residencia \\
\hline & & 2425 & $\begin{array}{l}\text { R. Padre. Teixeira, } \\
113\end{array}$ & Theodoro Fehr & Engenheiro Civil & Erudito & Médio & Residencia \\
\hline & & 2449 & $\begin{array}{l}\text { Av. Dr. Carlos } \\
\text { Botelho esq. com R. } \\
15 \text { de novembro }\end{array}$ & Lafael. Petroni & Engenheiro Civil & Erudito & Baixo & Residencia \\
\hline & & 897 & $\begin{array}{l}\text { R. } 13 \text { de Maio, junto } \\
\text { ao } 2\end{array}$ & Lafael Petroni & Engenheiro Civil & Erudito & Baixo & Residencia \\
\hline \multirow{3}{*}{ à } & Araras & $128 / 49$ & $\begin{array}{l}\text { Chácara Agrícola, } \\
\text { quadra } 03 \text {, lote } 20\end{array}$ & Octávio Daltro & Construtor & Não erudito & Baixo & Residencia \\
\hline & & $140 / 49$ & $\begin{array}{l}\text { R. Nunes Machado, } \\
\text { entre R. C. Colombo e } \\
\text { R. Carlos Gomes }\end{array}$ & Palmiro Righetti & Construtor & Não erudito & $\begin{array}{c}\text { Médio } \\
\text { FIGURA } 241\end{array}$ & Residencia \\
\hline & & $244 / 49$ & $\begin{array}{l}\text { R. Visconde do Rio } \\
\text { Branco, lote A, } \\
\text { quadra } 2\end{array}$ & José Grandi & Construtor & Não erudito & $\begin{array}{c}\text { Baixo } \\
\text { FIGURA } 242\end{array}$ & Residencia \\
\hline
\end{tabular}




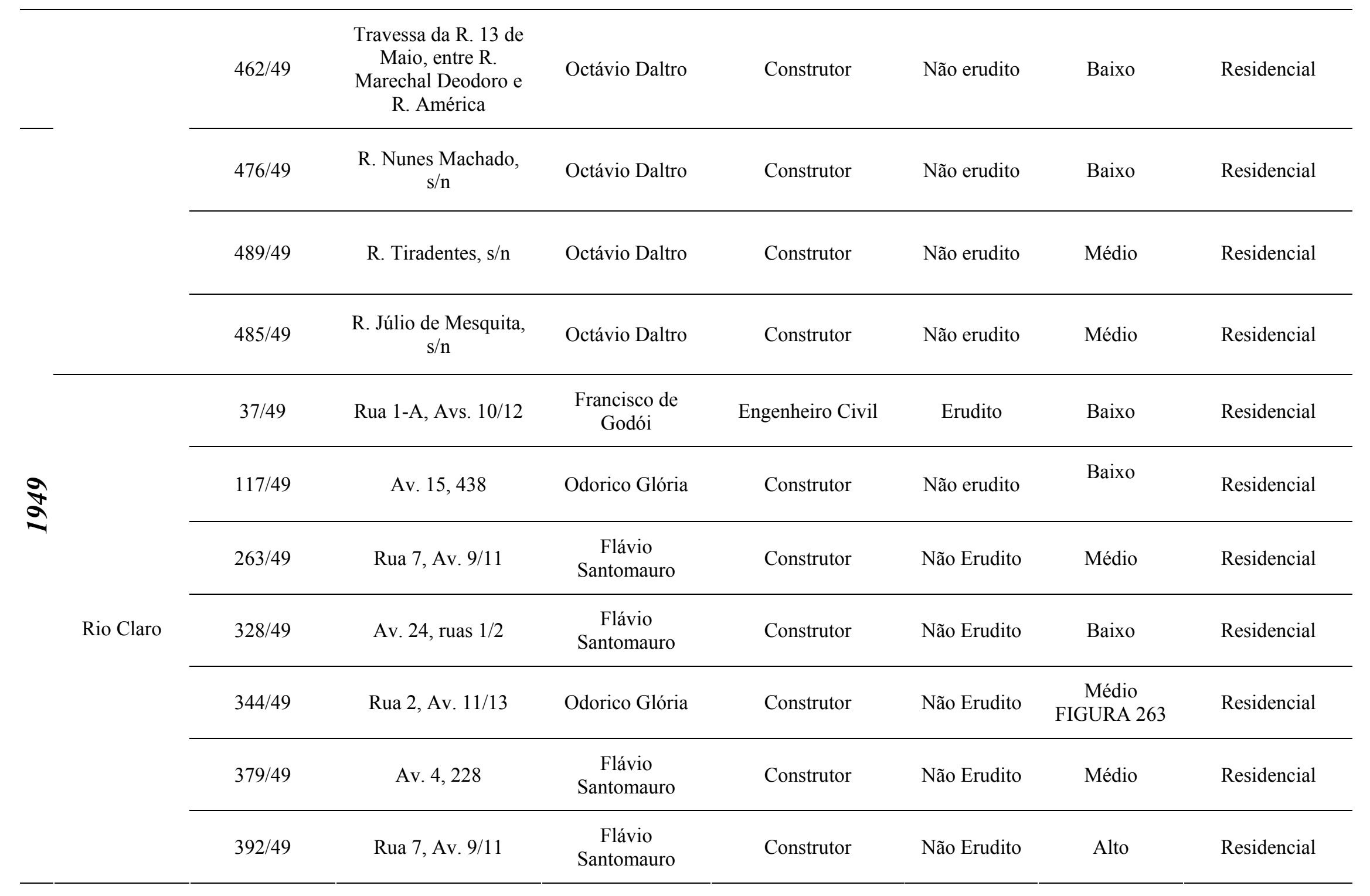




\begin{tabular}{|c|c|c|c|c|c|c|c|c|}
\hline \multirow{3}{*}{ à } & \multirow{2}{*}{ Araraquara } & Pasta 07 & $\begin{array}{c}\text { Av. C. Colombo, } \\
\text { entre S. Bento e Padre } \\
\text { Duarte }\end{array}$ & Walter Logati & Engenheiro Civil & Erudito & Baixo & Residencial \\
\hline & & Pasta 07 & $\begin{array}{l}\text { R. São Bento esquina } \\
\text { com Av. São José }\end{array}$ & - & Arquiteto & Erudito & Médio & Residencial \\
\hline & São Carlos & 06 & R. Episcopal, s/n & - & Engenheiro Civil & Erudito & - & Residencial \\
\hline \multirow{9}{*}{ â } & \multirow{5}{*}{ Araras } & $89 / 50$ & $\begin{array}{l}\text { R. Marechal Deodoro, } \\
542\end{array}$ & Octávio Daltro & Construtor & Não erudito & Médio & Residencial \\
\hline & & $336 / 50$ & $\begin{array}{l}\text { R. do Patrocínio, lote } \\
\text { 2, Chácara Fachini }\end{array}$ & Octávio Daltro & Construtor & Não erudito & Médio & Residencial \\
\hline & & $468 / 50$ & R. J. de Mesquita, & - & Engenheiro Civil & \multirow{2}{*}{ Erudito } & \multirow{2}{*}{$\begin{array}{c}\text { Médio } \\
\text { FIGURA } 243\end{array}$} & \multirow{2}{*}{ Residencial } \\
\hline & & & Chico Pinto & José Grandi & Construtor & & & \\
\hline & & $549 / 50$ & R. 7 de Setembro, s/n & Octávio Daltro & Construtor & Não erudito & $\begin{array}{c}\text { Baixo } \\
\text { FIGURA } 244\end{array}$ & Residencial \\
\hline & \multirow[t]{4}{*}{ Rio Claro } & $58 / 50$ & Av. 6, Ruas 4/5 & $\begin{array}{l}\text { Augusto Schmidt } \\
\text { Filho }\end{array}$ & Engenheiro Civil & Erudito & Médio & Residencial \\
\hline & & $115 / 50$ & Rua 5-A, Av. 28/30-A & $\begin{array}{c}\text { Francisco de } \\
\text { Godói }\end{array}$ & Engenheiro Civil & Erudito & Baixo & Residencial \\
\hline & & $124 / 50$ & Rua 3-B, Av. 2-A & $\begin{array}{c}\text { Flávio } \\
\text { Santomauro }\end{array}$ & Construtor & Não erudito & Baixo & Residencial \\
\hline & & $209 / 50$ & $\begin{array}{c}\text { Av. 26-A, Ruas 9/10- } \\
\text { A }\end{array}$ & $\begin{array}{c}\text { Flávio } \\
\text { Santomauro }\end{array}$ & Construtor & Não erudito & Baixo & Residencial \\
\hline
\end{tabular}




\begin{tabular}{|c|c|c|c|c|c|c|c|c|}
\hline & & $254 / 50$ & Rua 7, Av. 11 & $\begin{array}{c}\text { Flávio } \\
\text { Santomauro }\end{array}$ & Construtor & Não erudito & Baixo & Residencial \\
\hline & & $356 / 50$ & Rua 7, Av. 7/9 & $\begin{array}{c}\text { Flávio } \\
\text { Santomauro }\end{array}$ & Construtor & Não erudito & $\begin{array}{c}\text { Médio } \\
\text { FIGURA } 264\end{array}$ & Residencial \\
\hline & & $511 / 50$ & Rua 9, Av. 1/2 & José F. Hermini & Construtor & Não erudito & Médio & Residencial \\
\hline & Araraquara & Pasta 08 & $\begin{array}{c}\text { R. dos } \\
\text { Expedicionários, } 1159\end{array}$ & Hermínio Tecco & Construtor & Não Erudito & Médio & Residencial \\
\hline \multirow{5}{*}{ â } & \multirow{5}{*}{ São Carlos } & 1135 & $\begin{array}{l}\text { R. Cde. Do Pinhal, } \\
\text { entre R. } 9 \text { de Julho e } \\
\text { R. Episcopal }\end{array}$ & $\begin{array}{l}\text { Henrique } \\
\text { Sorregotti \& } \\
\text { Irmãos }\end{array}$ & Construtor & Não Erudito & Médio & Residencial \\
\hline & & 1205 & $\begin{array}{c}\text { R. Alexandrina entre } \\
\text { Tiradentes e } 28 \mathrm{de} \\
\text { Set. }\end{array}$ & Lafael Petroni & Engenheiro Civil & Erudito & Baixo & Residencial \\
\hline & & 1408 & $\begin{array}{l}\text { R. Marechal Deodoro, } \\
\mathrm{s} / \mathrm{n}\end{array}$ & Lafael Petroni & Engenheiro Civil & Erudito & Baixo & Residencial \\
\hline & & & & Abrahão Schevz & Engenheiro Civil & & & \\
\hline & & 1139 & Av. São Carlos, 95 & $\begin{array}{l}\text { Humberto } \\
\text { Sorregotti }\end{array}$ & Construtor & Erudito & Médio & Residencial \\
\hline
\end{tabular}




\section{Tabela 2 - Profissionais Encontrados, por Cidade.}

Nessa tabela apresentamos um resumo dos profissionais no mercado da construção civil, no período de nossa pesquisa, agrupados por cidade. É preciso notar que algumas vezes não foi possível identificar o profissional, pois seu nome estava ilegível nos processos.

\begin{tabular}{|c|c|c|}
\hline Cidade & Autor & Profissional \\
\hline \multirow{10}{*}{ Araraquara } & Boaventura Gravina & Engenheiro Civil \\
\hline & Celso Siqueira Cabral & Engenheiro Civil \\
\hline & Escritório Sampaio \& Machado & Escritório - SP \\
\hline & Hermínio Tecco & Construtor \\
\hline & José A. Kleindienst & Arquiteto \\
\hline & José Barbugli & Engenheiro Civil \\
\hline & José dos Santos & Engenheiro Civil \\
\hline & Mattos \& Freitas & Escritório - SP \\
\hline & Vicente Miceli & Engenheiro Civil \\
\hline & Walter Logati & Engenheiro Civil \\
\hline \multirow{3}{*}{ São Carlos } & Abrahão Schevz & Engenheiro Civil \\
\hline & Alfredo Borelli & Engenheiro Civil \\
\hline & Ângelo Murgel & Arquiteto \\
\hline
\end{tabular}




\begin{tabular}{|c|c|c|}
\hline \multirow{10}{*}{ São Carlos } & Bruno Giongo & Construtor \\
\hline & Camillo Domicci & Construtor \\
\hline & Djalma Ferraz Kehl & Engenheiro Civil \\
\hline & Enio Perillo & Engenheiro Civil \\
\hline & Escritório de Construções Gelsomino Saia & Escritório \\
\hline & Lafael Petroni & Engenheiro Civil \\
\hline & Henrique Sorregotti \& Irmãos & Construtor \\
\hline & Rodolpho Fehr & Arquiteto \\
\hline & Theodoro Fehr & Arquiteto \\
\hline & Umberto Sorregotti & Construtor \\
\hline \multirow{8}{*}{ Jaú } & Affonso Galindo & Construtor \\
\hline & Álvaro Botelho & Arquiteto - SP \\
\hline & Ângelo José Terreri & Construtor \\
\hline & Diretoria de Obras Públicas - SP & Órgão Oficial \\
\hline & Hernani do Val Penteado & Arquiteto \\
\hline & José Arduíno & Construtor \\
\hline & Luciano Terreri & Construtor \\
\hline & Perino Rocha Mattos & Engenheiro - SP \\
\hline
\end{tabular}




\begin{tabular}{|c|c|c|}
\hline \multirow{14}{*}{ Rio Claro } & Augusto Schmidt Filho & Engenheiro Civil \\
\hline & Batista Rattin & Construtor \\
\hline & Domingos Barbugiam & Construtor \\
\hline & Flávio Santomauro & Construtores \\
\hline & Francisco de Godoi & Engenheiro Civil \\
\hline & Gustavo Stein & Construtor \\
\hline & Henrique Cristofani & Desenhista \\
\hline & João Caly & Construtor \\
\hline & José F. Hermini & Engenheiro Civil \\
\hline & Juvenal Barros Machado Campos & Engenheiro Civil \\
\hline & Manuel Antonio de Carvalho & Construtor \\
\hline & Milton Silveira & Engenheiro Civil \\
\hline & Odorico Glória & Construtor \\
\hline & Pelágio R. dos Santos & Engenheiro Civil \\
\hline \multirow{3}{*}{ Araras } & José Grandi & Construtor \\
\hline & Palmiro Righetti & Construtor \\
\hline & Octávio Daltro & Construtor \\
\hline
\end{tabular}




\section{REFERÊNCIAS}

A CASA do Sr.Albino Caetano da Silva. (1909). A Architetura Portuguesa, Lisboa, ano 2, n.8, p.30-31, ago.

AGRÔNOMOS regionais. Folha da Manhã, São Paulo, jun. 1941.

AGUDOS, no alvorecer. $\quad$ (1999). Disponível em:<http://www.seminario.org.br/foto/discurso_50_anos_de_fr_gregrio.htm>. Acesso em: 18 jan. 2008.

AlbernAZ, Maria Paula; Lima, Cecília Modesto. (2003). Dicionário ilustrado de arquitetura. São Paulo: ProEditores.

ÁLBUM comemorativo do tri-centenário de Taubaté, 1645-1945. (1945). Taubaté: [s.n.], 1945.

ALBUM de Rio de Claro. (1951). Rio Claro: [s.n].

ALVARENGA, Djanira. (1998). Prédio do TCC é patrimônio histórico. O Vale Paraibano, 18 jan. 1998. Disponível em:<http://jornal.valeparaibano.com.br/1998/01/18/social/tombado.html>. Acesso em: 23 abr. 2007.

AMARAL, Aracy A. (Coord.). (1994). Arquitectura neocolonial: América Latina, Caribe, Estados Unidos. São Paulo: Memorial; Fondo de Cultural Econômica.

ANDRADE, Antonio Carlos Argôllo. (1998). A Cia. Predial e Taubaté. Poeira do tempo. Diário de Taubaté, Taubaté, 23 maio.

ANDRADE, Mário de. (1976). Táxi e crônicas no Diário Nacional. Organizado por Telê Porto Ancona Lopez. São Paulo: Duas Cidades; Secretaria da Cultura, Ciência e Tecnologia. p.69-71.

. (1981). Mário de Andrade, cartas de trabalho: correspondência com Rodrigo Mello Franco de Andrade (1936-1945). Brasília: Ministério da Educação e Cultura, Secretaria do Patrimônio Histórico e Artístico Nacional, Fundação Nacional Pró-Memória.

(1985). Carta a Paulo Duarte. In: Duarte, Paulo. Mário de Andrade por ele mesmo. São Paulo: Hucitec.

ARCHITECTURA colonial. (1926). O Estado de São Paulo, São Paulo, 13 abr./29 abr.

AZEVEDO, CARLOS de. (1988). Solares portugueses: introdução ao estudo da casa nobre. 2.ed. Lisboa: Livros Horizonte.

AZEVEDO, Ricardo Marques de. (1994). Las Ideas de Ricardo Severo y la relación con el academicismo. In: Amaral, Aracy. (Coord). Arquitetura neocolonial: América Latina, Caribe, Estados Unidos. São Paulo: Memorial; Fondo de Cultura Econômica. p.249-258.

BACKHEUSER, Luiz Alberto Fresl. (2006). Os "Brasileiros" e a azulejaria exterior portuense do século XIX. Arquitextos, n.69, fev. 2006. Disponível em:<http://www.vitruvius.com.br/arquitextos/arq000/esp351.asp>. Acesso em: 4 abr. 2006.

BENINCASA, Vladimir. (2004). Parecer sobre a Igreja do Santuário de Nossa Senhora da Aparecida da Babilónia para o inventário. São Carlos: Arquivo Municipal.

BORTOLUCCI, Maria Ângela Pereira de Castro e Silva. (1991). Moradias urbanas construídas em São Carlos no período cafeeiro. 2v. Tese (Doutorado) - Faculdade de Arquitetura e Urbanismo, Universidade de São Paulo, São Paulo, 1991.

BOWE, Nicola Gordon. (Ed.). (1993). Art and the national dream. The Search for vernacular expression in turn-of-the century design. Dublin: Irish Academic.

BRASIL. Ministério da Educação. (2007). Banco de Teses / Capes. Disponível em:<http://servicos.capes.gov.br/capesdw/>. Acesso em: 07 dez. 2007; 14 mar. 2008.

BREITEMBACH, Silvia Becher. (2005). A Presença da arquitetura neocolonial na cidade do Salvador. Dissertação (Mestrado) - Universidade Federal da Bahia, Arquitetura e Urbanismo, Salvador, 2005.

BRUAND, Yves. (1981). Arquitetura contemporânea no Brasil. São Paulo: Perspactiva.

BRUNETTA, Mario. (2000). Criação de uma paróquia no século XXI. Agudos: Gráfica Agudos.

CÂMARA MUNICIPAL DE LISBOA. (2007). Prémio Valmor e Municipal de Arquitetura. Disponível em:<http://ulisses.cm-lisboa.pt/data/002/008/index.php?ml=4\&x=03.xml>. Acesso em: 5 maio 2007.

CAPELATO, Maria Helena Rolim. (1998). Multidões em cena: propaganda política no varguismo e no peronismo. Campinas: Papirus. 
CAPORAL, Francisco Roberto. (1991). A Extensão rural e os limites à prática dos extensionistas do serviço público. Dissertação (Mestrado) - Curso de Pós-Graduação em Extensão Rural, Universidade Federal de Santa Maria, Santa Maria, 1991.

CARPEAUX, Otto Maria. (1990). Teatro e estado barroco. Estudos Avançados, São Paulo, v.4, n.10, p.7-36, set./dez.

CATROGA, Fernando. (1991). O Republicanismo em Portugal: da Formação ao 5 de Outubro de 1910. Coimbra: Faculdade de Letras.

CARVALHO, Edis Evandro Teixeira de. (2002). A Arquitetura neocolonial: a arquitetura como afirmação de nacionalidade. Dissertação (Mestrado) - Universidade Federal da Bahia, Arquitetura e Urbanismo, Salvador, 2005 .

CARVALHO, Joaquim Martins Teixeira. (1925a). A Casa moderna. In: Imprensa da Universidade. p.159-175. p.71-77. (1925b). Habitação portuguesa. In: Arte e arqueologia. Coimbra: Imprensa da Universidade.

CASA do Exmo.Sr.Antonio Marques da Silva. (1928). A Arquitectura portuguesa, Lisboa, ano 21, n.1, p.1-3, jan.

REUNIÃO de lavradores na Secretaria da Agricultura. (1941). Diário de São Paulo, São Paulo, jul.

CASTRO, José Liberal de. (1987). Arquitetura eclética no Ceará. In: FABRIS, Annateresa. (Org.). Ecletismo na arquitetura brasileira. São Paulo: Nobel; EDUSP. p.209-255.

CÓDIGO de derecho canônico. (19--?). Disponível em:<http://www.vatican.va/archive/ESL0020/_P4B.HTM>. Acesso em: 16 abr. 2008.

COLÉGIO Pedro II. (2003). Disponível em:<http://pedrosegundo.tripod.com/pedrosegundo/index.html>. Acesso em: 4 dez. 2007.

COLAÇO, Thomaz Ribeiro. (1937). O Exemplo do Brasil. A Arquitectura Portuguesa, Lisboa, ano 29, n.23, p.7-8, fev.

CORRÊA, Maria Elizabeth Peirão et al. (1991). Arquitetura escolar paulista: 1890-1920. São Paulo: FDE.

COSTA, Adriane Lobo. (2001). Extensão rural e meio ambiente. Revista Eletrônica do Mestrado em Educação Ambiental, Rio Grande, v.7, p.1-25, out./dez.

COSTA, Fernando. (1939a). Ministério da Agricultura: trabalhos realizados em 1938. Rio de Janeiro: Oficinas Gráficas do Serviço de Publicidade Agrícola. Relatório apresentado ao Presidente da República dos Estados Unidos do Brasil, Exmo.Sr.Dr.Getúlio Vargas, pelo Ministro de Estado dos Negócios da Agricultura.

(1939b). Atividades agrícolas do Brasil em 1939. Rio de Janeiro: Oficinas Gráficas do Serviço de Publicidade Agrícola. 2v. Relatório apresentado ao Presidente da República dos Estados Unidos do Brasil, Exmo.Sr.Dr.Getúlio Vargas, pelo Ministro de Estado dos Negócios da Agricultura.

(1941). Realizações do presidente Getúlio Vargas no Ministério da Agricultura. Conferência realizada no Palácio Tiradentes, Rio de Janeiro, 1940.

Costa, Lúcio. (1952a). Depoimento de um arquiteto carioca. Os cadernos de cultura, arquitetura brasileira. Rio de Janeiro: Ministério da Educação e Saúde.

(1952b). Considerações sobre arte contemporânea. Rio de Janeiro: Ministério da Educação e Saúde.

(1999). Parecer 30/10/1973. In: Pessoa, José. (Coord.). Lucio Costa: Documentos de Trabalho. Rio de Janeiro: IPHAN. p.283-284.

CUSTÓDIO, Luiz Antônio Bolcato. (2006). Missões jesuíticas: arquitetura e urbanismo. In: CADERNO de História. 21.ed. Porto Alegre: Menorial do Rio Grande do Sul. p.1-22 .

D'ALAMBERT, Clara Correia. (2003). Manifestações da arquitetura residencial paulista entre as grandes guerras. 226p. Tese (Doutorado) - Faculdade de Arquitetura e Urbanismo, Universidade de São Paulo, São Paulo, 2004.

DECRETO perfectae caritatis sobre a convincente renovação da vida religiosa. (1965). Vaticano. Disponível em:<http://www.vatican.va/archive/hist_councils/ii_vatican_council/documents/vat-

ii_decree_19651028_perfectae-caritatis_po.html>. Acesso em: 16 abr. 2008.

DIERBERGER, Reynaldo. (1928). Arte e jardim. São Paulo: Dierberg. 
EL-DAHDAH, Farès. (2004). A Arqueologia da modernidade de Lucio Costa. In: NOBRE, Ana Luiza et al. (2004). Um modo de ser moderno: Lúcio Costa e a crítica contemporânea. Tradução de Luisa Buarque. São Paulo: Cosac \& Naify. p.289-293.

ENCICLOPÉDIA dos municípios brasileiros. (2000). Rio de Janeiro: IBGE. 2 DVD.

FABRIS, Annateresa. (Org.). (1987). Ecletismo na arquitetura brasileira. São Paulo: Nobel; EDUSP.

FERNANDES, José Manuel. (2003). Português suave: arquitecturas do estado novo. Coordenação de Manuel Lacerda; Miguel Soromenho. Lisboa: IPPAR.

FERRAZ, Artemis Rodrigues Fontana. (2003). Marcas do moderno na arquitetura de Bauru. 305p. Dissertação (Mestrado) - Escola de Engenharia de São Carlos, Universidade de São Paulo, São Carlos, 2003.

FICHER, Sylvia (2005). Os arquitetos da Poli: ensino e profissão em São Paulo. São Paulo: EDUSP.

FLORENÇANO, José Carlos Simões; ABUD, Maria José Milharezi. (2002). Histórico das profissões de engenheiro, arquiteto e agrônomo no Brasil. Revista de Ciências Exatas, Taubaté, v.8, n.2, p.97-105.

FRANÇA, José Augusto. (1981). Arte em Portugal no século XIX. Lisboa: Bertrand.

FRANCISCANOS. Província Franciscana da Imaculada Conceição. (2007). Fraternidade Nossa Senhora das Graças. Disponível em:<http://www.franciscanos.org.br/fraternidades/casas/gracas/historia.php>. Acesso em: 25 abr. 2007.

FRANCISCANOS. Paróquia Santo Antonio. (2008). História. Disponível em:<http://www.franciscanos.org.br/fraternidades/casas/santo_antonio_agudos/historia.php > Acesso em: 15 jan. 2008

FRANCO, Jaime. [197-?]. História da Igreja do Rosário de Santos. Santos: A Tribuna.

GHIRARDELlO, Nilson. (1999). À Beira da linha: formações urbanas da Noroeste Paulista. 225p. Tese (Doutorado) - Faculdade de Arquitetura e Urbanismo, Universidade de São Paulo, São Paulo, 1999.

GOODWIN, Philip L. (1943). Brazil builds. Architecture old and new: 1652/1942. New York: MMA.

GUIA oficial da exposição portuguesa em Sevilha. (1929). Lisboa: [s.n.].

HOMEM, Maria Cecília Naclério. (1996). O Palacete paulistano e outras formas de morar da elite cafeeira, 1867-1918. São Paulo: Martins Fontes.

INSTITUTO ANTÔNIO HOUAISS DE LEXICOGRAFIA (2001). Dicionário eletrônico Houaiss da língua portuguesa. São Paulo: Objetiva.

KESSEL, Carlos. (2002). Entre o pastiche e a modernidade: arquitetura neocolonial no Brasil. Tese (Doutorado) - Programa de Pós-Graduação em História Social, Universidade Federal do Rio de Janeiro, Rio de Janeiro, 2002.

KOCH, Wilfried. (1994). Dicionário dos estilos arquitetônicos. São Paulo: Martins Fontes.

LABOURDETTE, Jean-François. (2003). História de Portugal. Lisboa: Dom Quixote.

LEAL, João. (2000). Etnografias portuguesas (1870-1970): cultura popular e identidade nacional. Lisboa: Dom Quixote.

LEMOS, Carlos Alberto Cerqueira. (1979). Arquitetura brasileira. São Paulo: Melhoramentos.

(1985). Alvenaria burguesa: breve história da arquietura residencial de tijolos em São Paulo a partir do ciclo econômico liderado pelo café. São Paulo: Nobel.

(1987). Ecletismo em São Paulo. In: FABRIS, Annateresa. (Org.). Ecletismo na arquitetura brasileira. São Paulo: Nobel; EDUSP. p.60-103.

(1994). El Estilo que nunca existió. In: AMARAL, Aracy. (coord.). Arquitectura neocolonial: América Latina, Caribe, Estados Unidos. São Paulo: Memorial; Fondo de Cultural Econômica. p.147-164.

LIMA, Ana Maria Liner Pereira. (1987). Nosso parque faz 80 anos. Revista ADEALQ, Piracicaba, v.10, n.6, p.20-22.

LIMA, Fábio José Martins de. (2005). Urbanismo em Minas Gerais: as grandes composições e o urbanismo moderno do arquiteto Angelo A. Murgel (1932-1942). In: SEMINÁRIO DOCOMOMO BRASIL, 6., 2005, Niterói. Livro de resumos e anais... Niteróis: UFF. Cd-ROOM.

LIMA, Roberto Pastana Teixeira. (2001). Modelos portugueses e a arquitetura brasileira: catálogo e análise das formas arquiteturais paulistanas e lusitanas nos oitocentos. Tese (Doutorado) - Instituto de Filosofia e Ciências Humanas, Universidade Estadual de Campinas, Campinas, 2001. 
LINO, Raul. (1918). A Nossa Casa: Apontamentos sobre o bom gosto na construção das casas simples. Lisboa: Atlântida, 1920-1930, 2ed. (1929). A casa portuguesa. Lisboa: Imprensa Nacional.

(1933). Casas Portuguesas: alguns apontamentos sobre o arquitectar das casas simples. Lisboa: Valentim de Carvalho.

(1937). Auriverde jornada - recordações de uma viagem ao Brasil. Lisboa: Valentim de Carvalho.

LIVRO de ouro commemorativo do centenário da independência e da exposição internacional. Rio de Janeiro: Annuario do Brasil, 1923.

LÔBO, Margarida Souza. (1995). Planos de urbanização da época de Duarte Pacheco. Porto: FAUP.

LOURENÇO, Maria Cecília França. (Org.). (1999). Bens imóveis tombados ou em processo de tombamento da USP. São Paulo: EDUSP.

MARTINS, Carlos Alberto Ferreira. (1987). Arquitetura e estado no Brasil: elementos para uma investigação sobre a constituição do discurso moderno no Brasil; as obras de Lucio Costa 1924/1952. 225p. Dissertação (Mestrado) - Faculdade de Filosofia Letras e Ciências Humanas, Universidade de São Paulo, São Paulo, 1988.

MASCARO, Luciana Pelaes. (2003). Arquitetura e modo de vida no assentamento rural Bela Vista Chibarro. 247p. Dissertação (Mestrado) - Escola de engenharia de São Carlos, Universidade de São Paulo, São Carlos, 2003.

MATOS, Sérgio Campos. (2002). História e identidade nacional: a formação de Portugal na historiografia contemporânea. Revue de Lusotopie, Paris, n.2, p.123-139.

MECO, José. (1986). O Azulejo em Portugal. Lisboa: Alfa.

MERCADAL, Fernando Garcia. (1949) .Parques y jardines: su historia e sus trazados. Madrid: Afrodisio Aguado, v.4, 299p.

MILHEIRO, Ana Vaz. (2005). A Construção do Brasil: relações com a cultura arquitectónica portuguesa. Porto: FAUP.

MINDLIN, Henrique Ephim. (1956). Modern architecture in Brazil. New York: Reinhold.

MONTEIRO, Miguel. (1991). Fafe dos “brasileiros”- (1860-1930) - perspectiva histórica e patrimonial. Fafe: [s.n.].

NEVES, Henrique das. (1908). A Casa do Conde Armand. A Architetura Portuguesa, Lisboa, ano 1, n.6, p.2224 , jun.

NOBRE, Ana Luiza et al. (2004). Um Modo de ser moderno: Lúcio Costa e a crítica contemporânea. São Paulo: Cosac \& Naify.

NUNES, Ivanil. (2005). Douradense - a agonia de uma ferrovia. São Paulo: Annablume.

PATETTA, Luciano. (1987). Considerações sobre o ecletismo na Europa. In: FABRIS, Annateresa. (Org.). Ecletismo na arquitetura brasileira. São Paulo: Nobel; EDUSP. p.8-27.

PEIXOTO, Rocha António Augusto. (1967). A Casa portuguesa. Póvoa do Varzim: Câmara Municipal de Póvoa de Varzim.

PEREIRA, José Fernandes. (1989). Dicionário da arte barroca em Portugal. Lisboa: Presença.

PEREIRA, Renato Guimarães. (2004). Documentário necessário: contribuição de José Wasth Rodrigues para a arquitetura brasileira entre 1914 e 1944. Dissertação (Mestrado) - Universidade Presbiteriana Mackenzie, Arquitetura e Urbanismo, São Paulo, 2004.

PERICHI, Ciro Caraballo. (1994). Venezuela: la arquitetctura tras la quimera de la historia. In: Amaral, A. Arquitetura neocolonial: América Latina, Caribe, Estados Unidos. São Paulo: Memorial; Fondo de Cultura Econômica.

PEVSNER, N. (1982). Panorama da arquitetura ocidental. São Paulo: Martins Fontes.

PIMENTEL, Diogo Lino. (2006). Diogo Lino Pimentel: entrevista. [jan. 2006]. Entrevistadora: Maria Júlia Brandão Barbosa Lourenço e Luciana Mascaro. Entrevista concedida na Casa do Cipreste em 2006.

PINHEIRO, Maria Lúcia Bressan. (2003). O Neocolonial e o edifício da Faculdade de Direito de São Paulo. In: $3^{\circ}$ ENCORE. Encontro Sobre Conservação e Reabilitação de Edifícios. Lisboa: LNEC, Maio de 2003, p. 165173. 
. (2004). Enigmas de Lucio Costa. In: NOBRE, Ana Luiza et al. (2004). Um Modo de ser moderno: Lúcio Costa e a crítica contemporânea. São Paulo: Cosac \& Naify. p.299-304.

(2005). Neocolonial, modernismo e preservação do patrimônio no debate cultural dos anos 1920 no Brasil. 233p. Tese (Livre-Docência) - Faculdade de Arquitetura e Urbanismo, Universidade de São Paulo, São Paulo, 2005.

PINHEIRO, Maria Lúcia Bressan; D’AGOSTINHO, Mário Henrique Simão. (2004). A Noção de pitoresco no debate cultural das primeiras décadas do século XX no Brasil. Revista Desígnio - revista de história da arquitetura e do urbanismo, São Paulo, n.1, p.119-128, mar.

PINHEIRO, Maria Lúcia Bressan. (2005). Mário de Andrade e o neocolonial. Revista Desígnio - revista de história da arquitetura e do urbanismo, São Paulo, n.4, p.97-104, set.

PRIM, Marino. (1975). Agudos 25 anos depois. Vida Franciscana. São Paulo, ano LII, n.49, dez.

PUPPI, Marcelo. (1998). Por uma história não moderna da arquitetura brasileira. Campinas: Pontes, Associação dos Amigos da História da Arte; Centro de História da Arte e Arqueologia da UNICAMP.

RAMOS, R. (1994). A Segunda Fundação (1890-1926). In: Mattoso, J. (Org.) História de Portugal. Lisboa: Círculo de Leitores.

REBOUÇAS, Márcia Maria. (2006). Pelo resgate da memória documental das ciências e da agricultura: o acervo do Instituto Biológico de São Paulo. In: História, Ciências, Saúde - Manguinhos, Rio de Janeiro, v.13, n.4, p.65, out./dez.

REIS FILHO, Nestor Goulart. Quadro da arquitetura no Brasil. São Paulo: Perspectiva, 1970.

REVISTA ARQUITETURA: revista de arte e construção. (1937). Lisboa, ano 10, n.37, fev./mar.

RIBEIRO, Irene. (1994). Raul Lino, pensador nacionalista da arquitectura. Porto: UP/FAUP.

RICCI, Fabio. (2002). Vilas operárias de Taubaté: contribuição ao estudo da urbanização. Taubaté: UNITAU. Disponível em:<http://www.unitau.br/scripts/prppg/humanas/download/vilasoperarias-N2-2002.pdf $>$. Acesso em: 23 abr. 2007.

RIO-CARVALHO, Manuel. (1986). "Revivalismos e ecletismos”, história da arte em Portugal. Do Romantismo ao fim do século. Lisboa: Alfa. v.11.

RODRIGUES, Eduardo de Jesus. (1985). O Estilo missões: as fachadas na arquitetura paulistana. 1v. Dissertação (Mestrado) - Faculdade de Arquitetura e Urbanismo, Universidade de São Paulo, São Paulo, 1985.

RONZANI, André Henrique Quintanilha. (2004). O Discurso de Ricardo Severo e o neocolonial brasileiro. Dissertação (Mestrado) - Universidade Presbiteriana Mackenzie, São Paulo, 2004.

ROSMANINHO, Nuno. (2003). A Casa Portuguesa e Outras Casas Nacionais. Revista da Universidade de Aveiro. Letras, n. 19-20, p. 225-250.

RUMBELAPAGER, Maria de Lourdes. (2005). Arquitetura neocolonial. Rio de Janeiro: Ed.Universidade Rural.

SALGUEIRO, Heliana Angotti. (1987). O Ecletismo em Minas Gerais: Belo Horizonte, 1894-1930. In: FABRIS, Annateresa. (Org.). Ecletismo na arquitetura brasileira. São Paulo: Nobel; EDUSP. p.105-145.

SALLES, Apolônio. (1943). As Atividades do Ministério da Agricultura em 1942. Rio de Janeiro: Oficinas Gráficas do Serviço de Publicidade Agrícola. 2v. Relatório apresentado ao Presidente da República dos Estados Unidos do Brasil, Exmo.Sr.Dr.Getúlio Vargas pelo Ministro de Estado dos Negócios da Agricultura.

SANSÃO, Juvenal. (1961). O Seminário Frei Galvão em seu vigésimo ano de existência. Vida Franciscana. São Paulo, ano XVIII, n.28, set.

SANTOS, Margaret Ferreira dos. (1999). Por uma sociedade conservacionista: idéias e expoentes da conservação da natureza no Brasil. Tese (Doutorado) - Escola de engenharia de São Carlos, Universidade de São Paulo, São Carlos, 1999.

SANTOS, Paulo. (1981). Quatro séculos de arquitetura. Rio de Janeiro: IAB.

SÃO CARLOS (CIDADE). Prefeitura Municipal de São Carlos. (2006). Prédio da piscina municipal voltará a cor original. Disponível em:<http://ped.linkway.com.br/cpub/body.php?pagcod=657\&pubord=61\&newcod=8622>. Acesso em: 23 abr. 2008.

SÃO PAULO (Estado). (1951). Explicação Pessoal. Diário Oficial do Estado de São Paulo, São Paulo, ano 61, n.265, p.30. 
SÃO PAULO (Estado). Secretaria dos Negócios da Educação e Saúde Pública. Directoria do Ensino. (1936). Novos prédios para grupo escolar: estudos da Directoria do Ensino e da Directoria de Obras Públicas. São Paulo: Secretaria dos Negócios da Educação e Saúde Pública.

SÃO PAULO (ESTADO). Secretaria de Economia e Planejamento (1978). Manifestações da relação estadourbano no estado de São Paulo. Coordenado por C.M.LAMPARELLI. São Paulo: SEP.

SEGAWA, Hugo. (1996). Ao Amor do público: jardins no Brasil. São Paulo: Nobel; FAPESP.

SEGAWA, Hugo. (1997). Arquiteturas no Brasil 1900-1990. São Paulo: EDUSP.

SERRÃO, Vitor; PIMENTEL, Diogo Lino. (2005). Raul Lino em Cascais: Casa de Santa Maria. Cascais: Câmara Municipal de Cascais.

SEVERO, Ricardo. (1916). A Arte tradicional no Brasil. In: SOCIEDADE e cultura artística - Conferências 1914-1915. São Paulo: Levi.

(1922). Da Arquitetura colonial no Brasil. Arqueologia e arte. O Estado de São Paulo, São Paulo, 7 set.

SILVA, Joana Mello de Carvalho e. (2005). Nacionalismo e arquitetura em Ricardo Severo : Porto 1869 - São Paulo 1940. Dissertação (Mestrado) - Escola de Engenharia de São Carlos, USP.

SOLAR. Sociedade Imobiliária e Construtora de Jaú Ltda. (1947). O Comércio do Jaú. Jaú, 25 dez.

SUTIL, Marcelo Saldanha. (1996). O Espelho e a miragem: ecletismo, moradia e modernidade na Curitiba no início do século. Dissertação (Mestrado) - Universidade Federal do Paraná, Curitiba, 1996.

(2003). Beirais e platibandas; arquitetura de Curitiba da primeira metade do século XX. Tese (Doutorado) - Universidade Federal do Paraná, Curitiba, 2003.

TOLEDO, Benedito Lima de. de. (2007). Frei Galvão: arquiteto. Cotia: Ateliê.

TOSTÕES, Ana Cristina dos Santos. (2002). Cultura e tecnologia na arquitectura moderna portuguesa. Tese (Doutorado) - Instituto Superior Técnico, Universidade Técnica de Lisboa, Lisboa, 2002.

(2006). Sob o signo do inquérito. In: IAPXX inquérito à arquitectura portuguesa do século XX em Portugal. Lisboa: Ordem dos Arquitectos. p.18.

UM GRANDE problema artístico: quem é o autor do pavilhão da rotunda? (1932). O Notícias Ilustrado, Lisboa, 9 out.

VARGAS, Getulio Dornelles. (1937). Mensagem apresentada ao poder legislativo em 3 de maio de 1937 pelo presidente da república Getulio Dornelles Vargas. Rio de Janeiro: Imprensa Nacional.

VEIGA, José Eli da. (2003). Cidades imaginárias: o Brasil é menos urbano do que se calcula. Campinas; São Paulo: Autores Associados.

VIEIRA, Mário Sérgio Costa. (2005). Aplicação do método IDEA como recurso didático-pedagógico para avaliação da sustentabilidade de propriedades agrícolas no município de Rio Pomba- MG. Dissertação (Mestrado) - Instituto de Agronomia, Universidade Federal do Rio de Janeiro, Rio de Janeiro, 2005.

VITERBO, Sousa. (1912). A Casa portugueza. In: Boletim da Associação dos Archeologos Portuguezes, Lisboa, tomo $12,5^{\text {a }}$ série, n. 12 .

VOGLIAZZO, M. (1988). Due ipotesi minoritarie nell'architettura del novecento: "a nossa casa" di Raul Lino e "das englische haus" di Hermann Muthesius. Estudos Italianos em Portugal, Lisboa, n.51/53, p.15-31.

WOLFF, Silvia Ferreira Santos. (1998). Jardim América: o primeiro bairro jardim de São Paulo e sua arquitetura. 255p. Tese (Doutorado) - Faculdade de Arquitetura e Urbanismo, Universidade de São Paulo, São Paulo, 1998.

WILTGEN, Vitor. (1950). Seminário de Santo Antonio em Agudos, Estado de São Paulo. Vida Franciscana. São Paulo, ano IX, n.13, abr.

WOLFF, Silvia Ferreira Santos. (2001). Jardim América: o primeiro bairro jardim de São Paulo e sua arquitetura. São Paulo: EDUSP; FAPESP; Imprensa Oficial.

ZAMBOM, Marisangela de Cássia. (2007). Clube de mães - creche Anita Costa: primeira creche do município de São Carlos - SP. In: CONGRESSO DE PÓS-GRADUAÇÃO. 4., 2007, São Carlos. Anais... São Carlos: UFSCar. v.3, p.1525-1526. 


\section{Anexos}


ANEXOS 


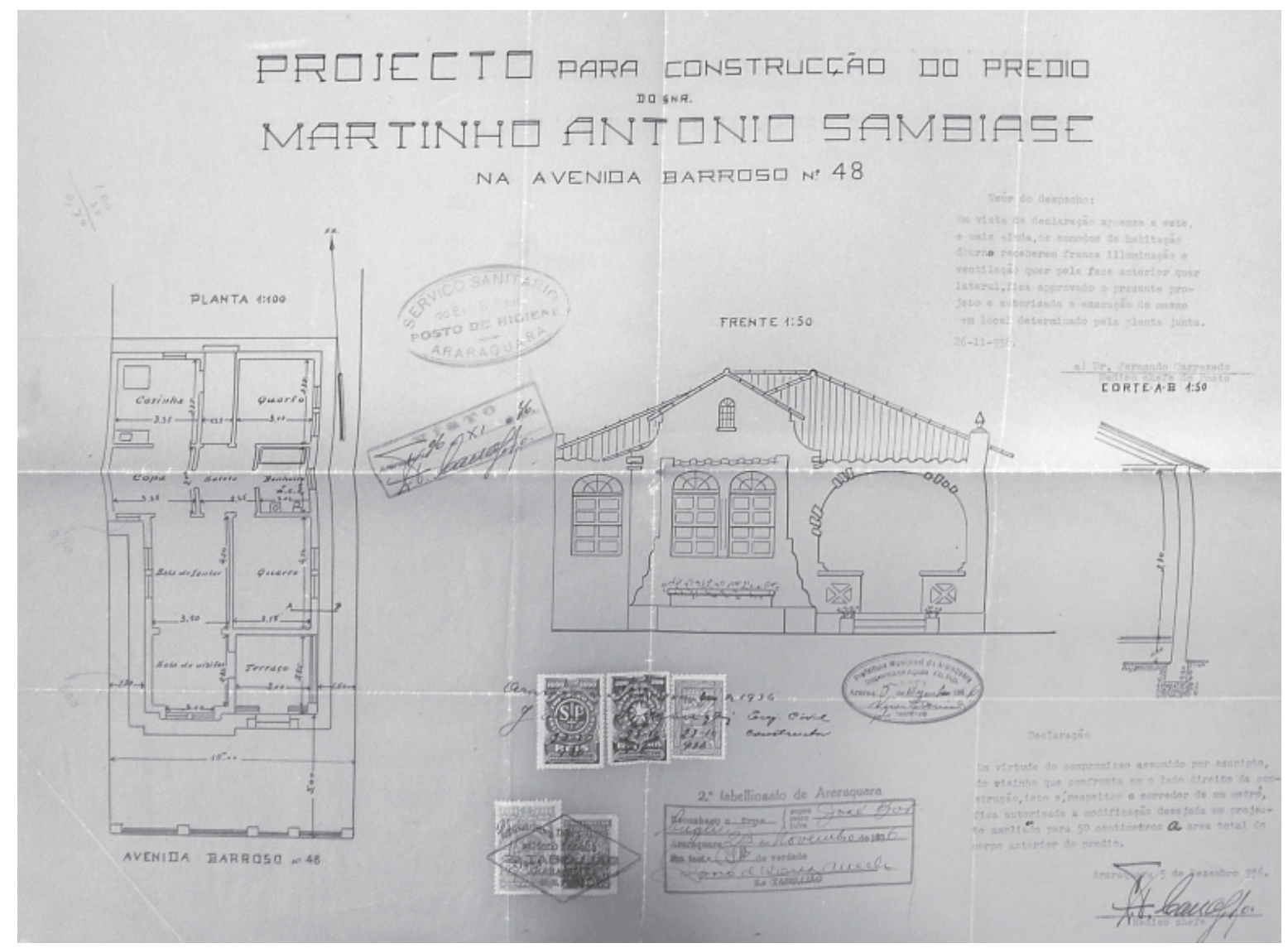

Figura 233 - Projeto do engenheiro José Barbugli para a residência de Martinho Antonio Sambiase, à Avenida Barroso, 48, em Araraquara, no ano de 1936. Fonte: Arquivo Municipal de Araraquara. 


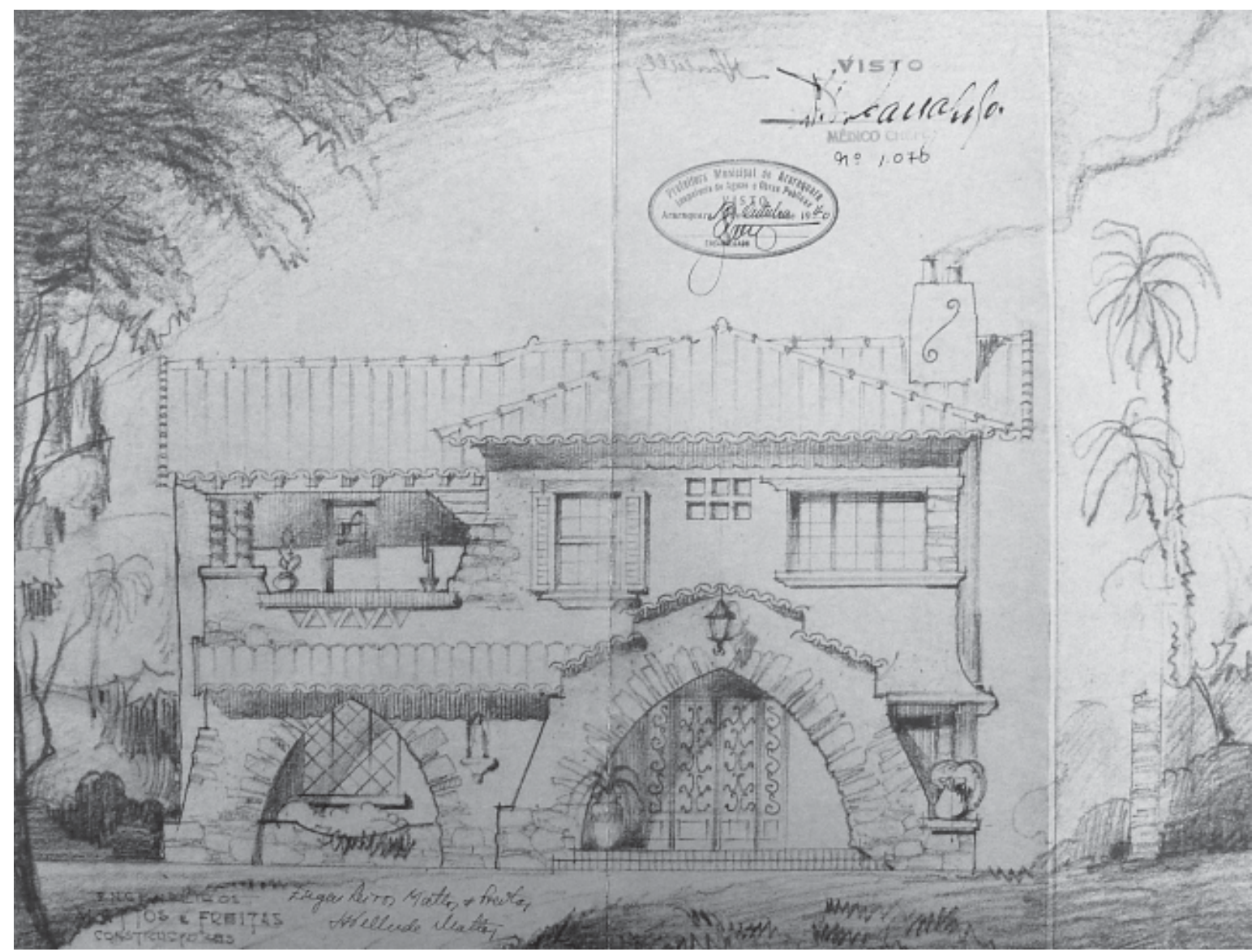

Figura 234 - Projeto de residência realizado pelo Escritório Mattos \& Freitas para Jader Lessa Cezar, à Av. Brasil, em Araraquara, em 1940. Misturas de vários estilemas neocoloniais e da vertente missões, com presença de um nicho para imagem de santo na fachada. Fonte: Arquivo Municipal de Araraquara. 


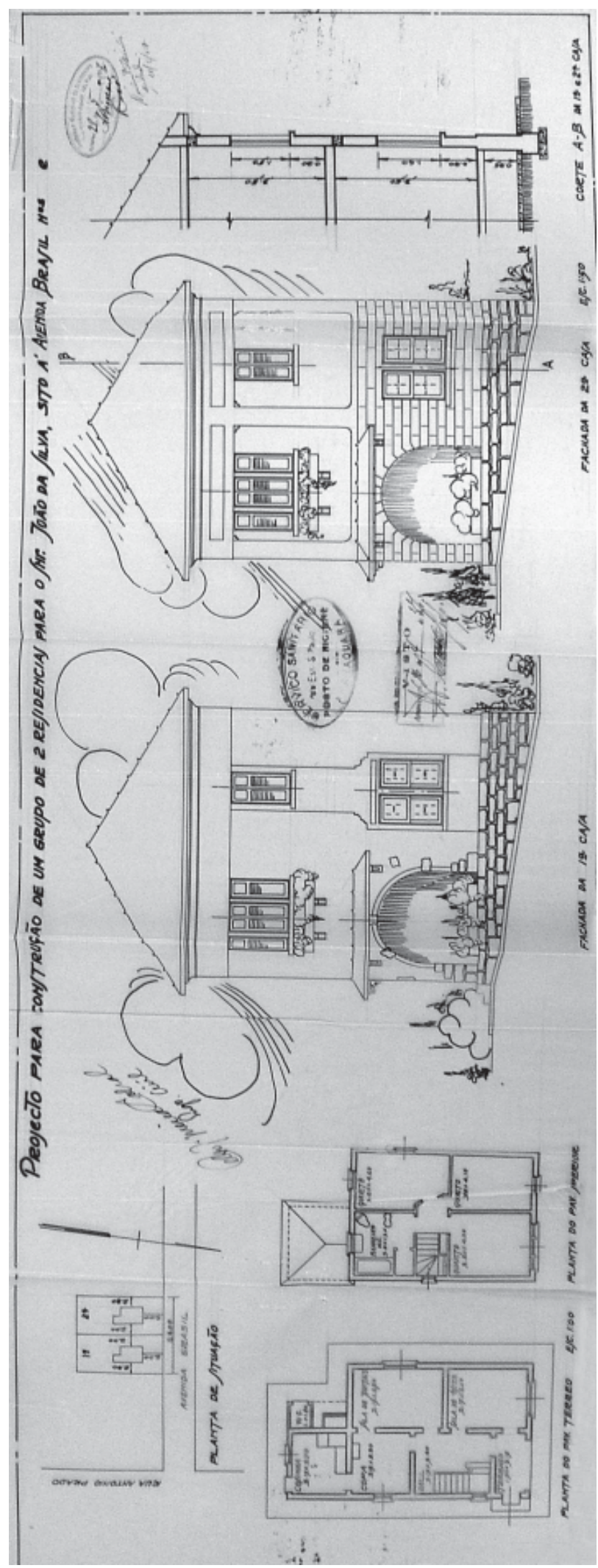

Figura 235 - Projeto do engenheiro Celso Siqueira Cabral para duas casas de João da Silva, de 1937, à Av. Brasil, logo abaixo do hotel São Bento, em Araraquara. Provavelmente, casas para aluguel ou venda. Fonte: Arquivo Municipal de Araraquara. 


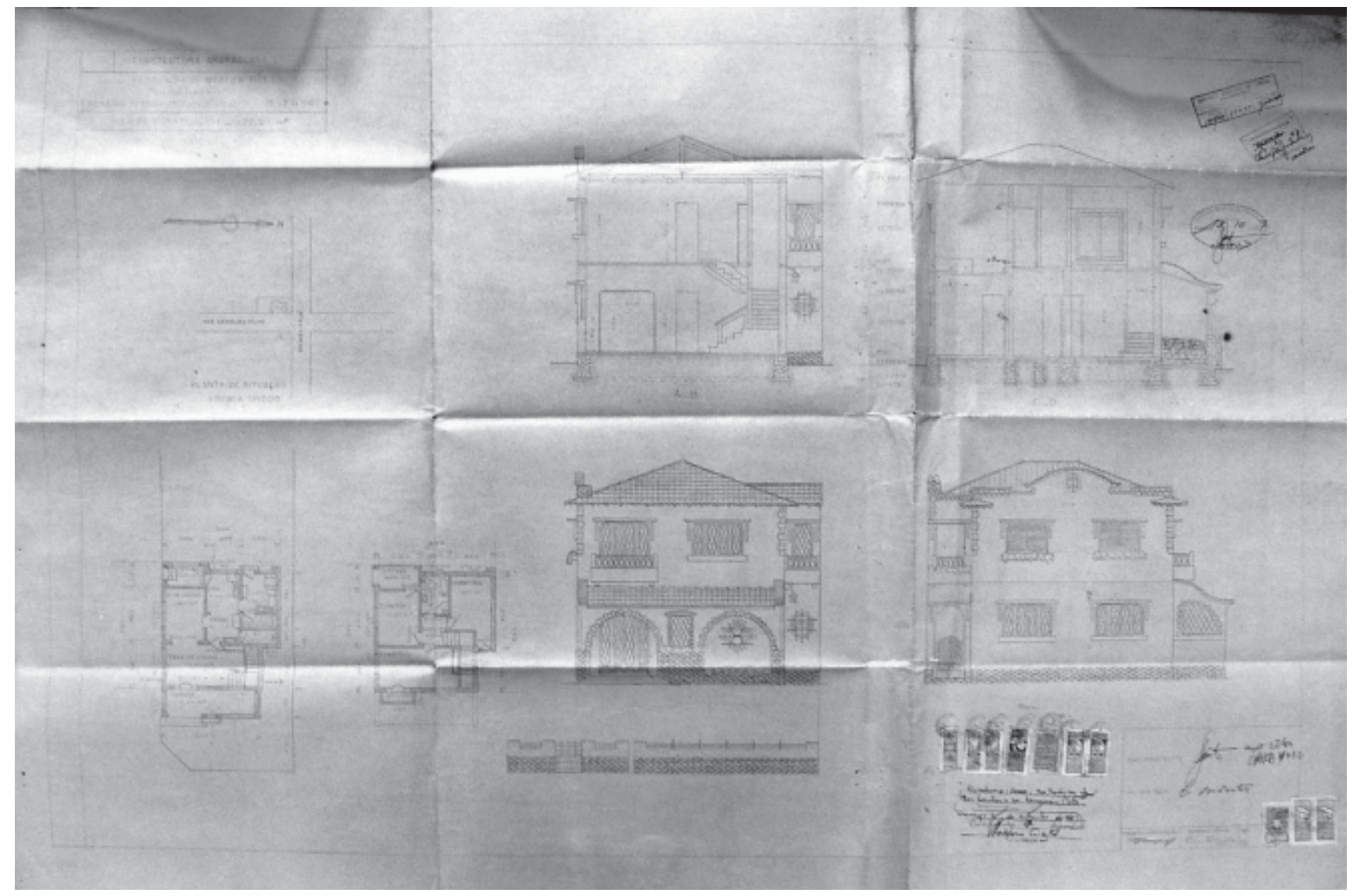

Figura 236 - Projeto construído em 1947 à Av. Feijó esq. com R. Carvalho Filho, de autoria do engenheiro José dos Santos. Fonte: Arquivo Municipal de Araraquara. 

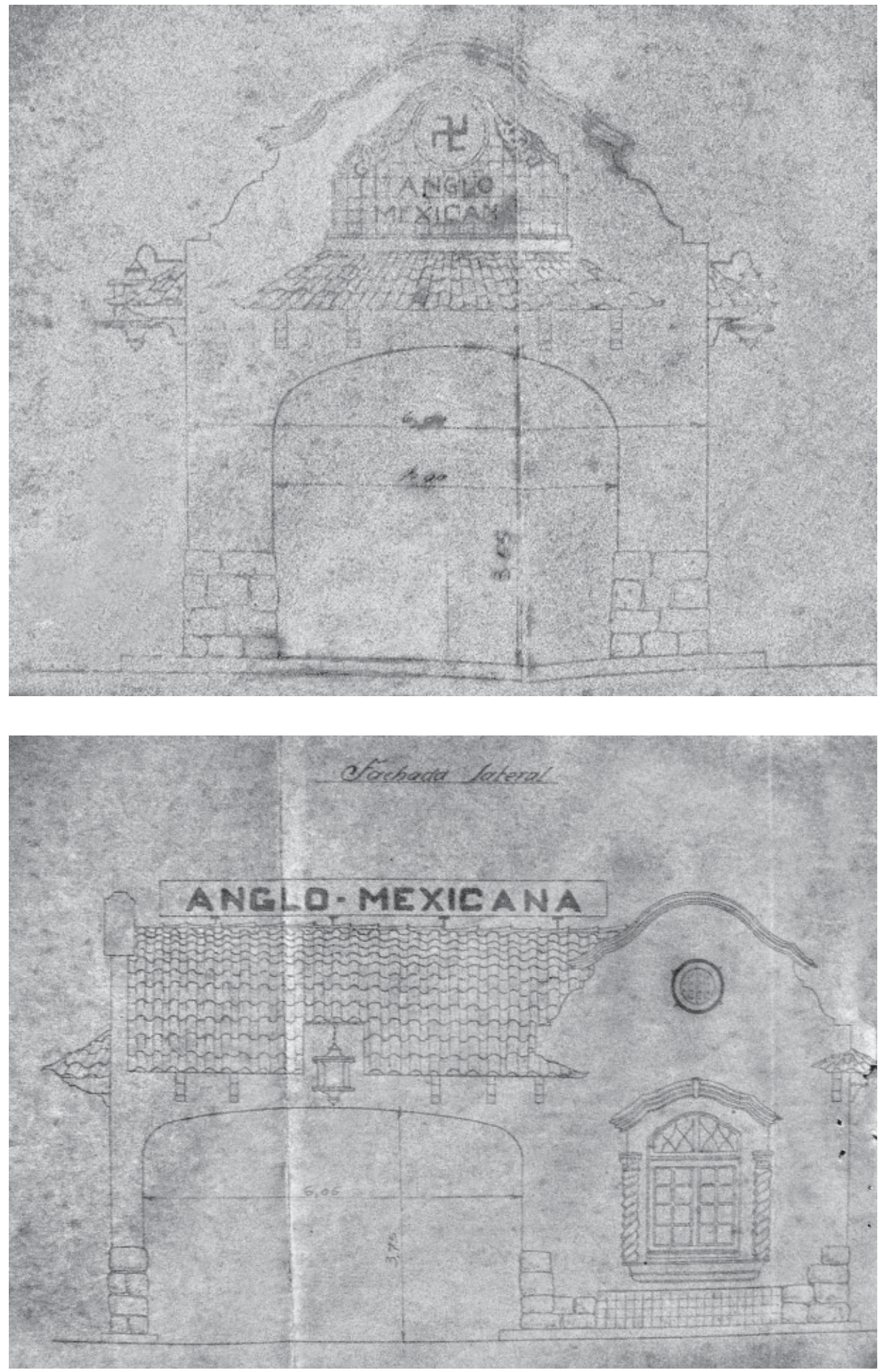

Figura 237 - Projeto do arquiteto José A. Kleindienst construído pelo engenheiro Celso Siqueira Cabral, à Av. Portugal, 15ª em Araraquara, no ano de 1931. Trata-se de mais um posto de gasolina da marca "Anglo-Mexicana”. $\mathrm{O}$ nome sugere que, talvez, a influência da vertente missões na arquitetura desse exemplar tenha se dado através da ligação com um elemento hispano-americano - o nome do posto. Fonte: Arquivo Municipal de Araraquara. 


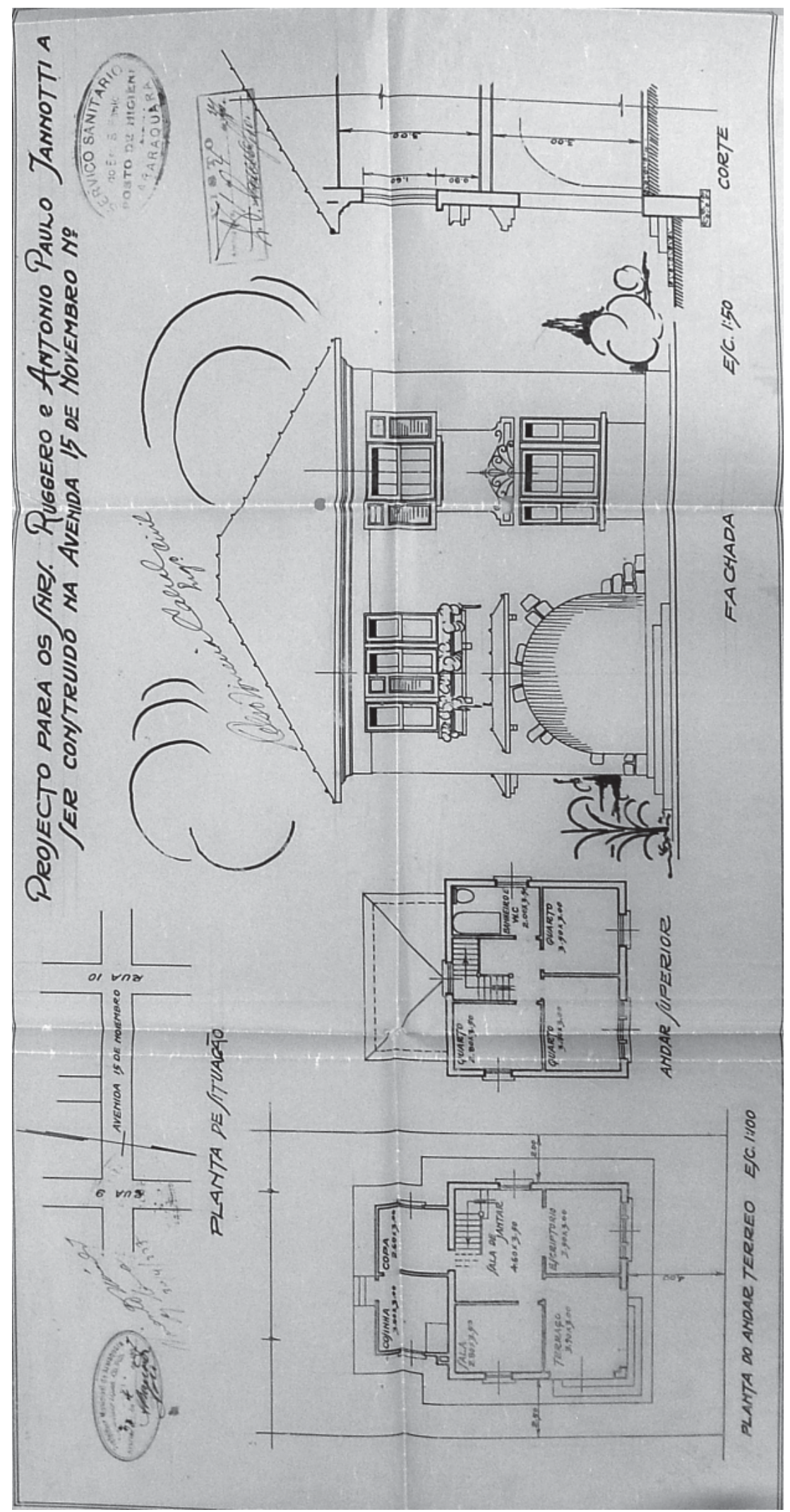

Figura 238 - Projeto do engenheiro Celso Siqueira Cabral para Ruggero e Antonio Paulo Jannotti, construído à Av. 15 de Novembro, entre ruas 9 e 10, em Araraquara. Fonte: Arquivo Municipal de Araraquara. 

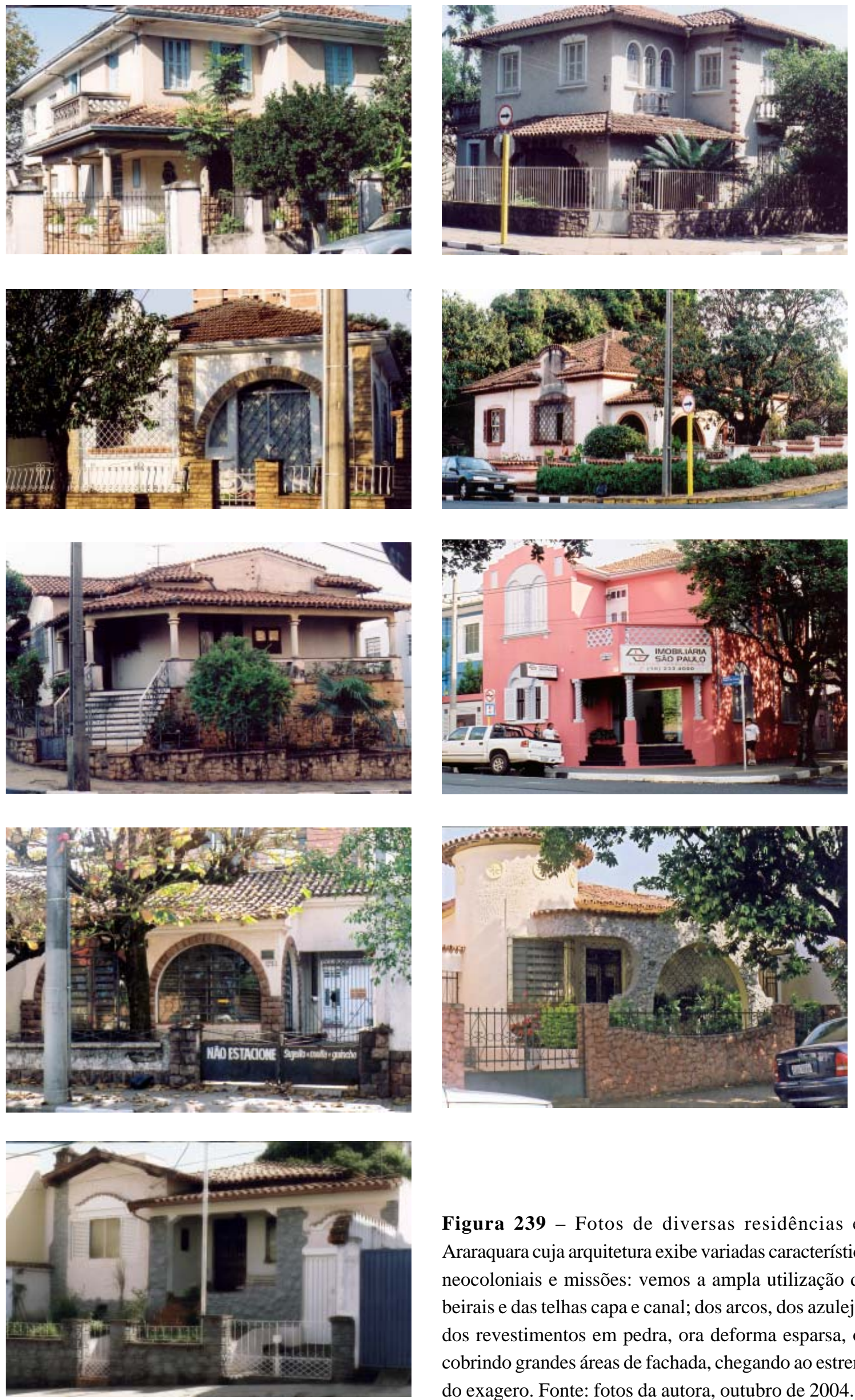

Figura 239 - Fotos de diversas residências em Araraquara cuja arquitetura exibe variadas características neocoloniais e missões: vemos a ampla utilização dos beirais e das telhas capa e canal; dos arcos, dos azulejos; dos revestimentos em pedra, ora deforma esparsa, ora cobrindo grandes áreas de fachada, chegando ao estremo do exagero. Fonte: fotos da autora, outubro de 2004. 


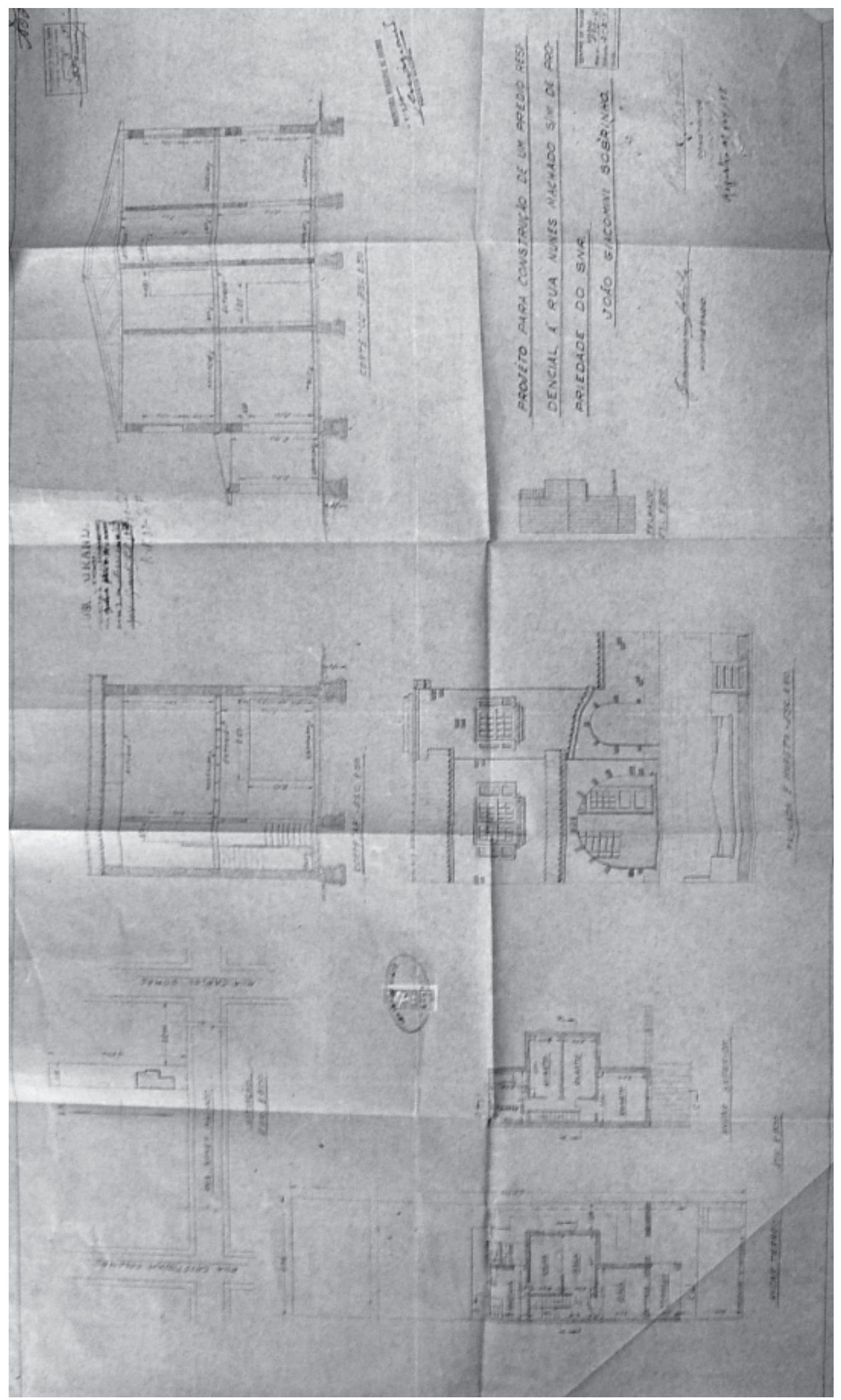

Figura 240 - Projeto de 1949, do construtor Palmiro Righetti, situado à Rua Nunes Machado, entre Rua Cristóvão Colombo e Rua Carlos Gomes, em Araras, para a residência de Jaão Giacomini Sobrinho. Fonte: Arquivo Municipal de Araras. 


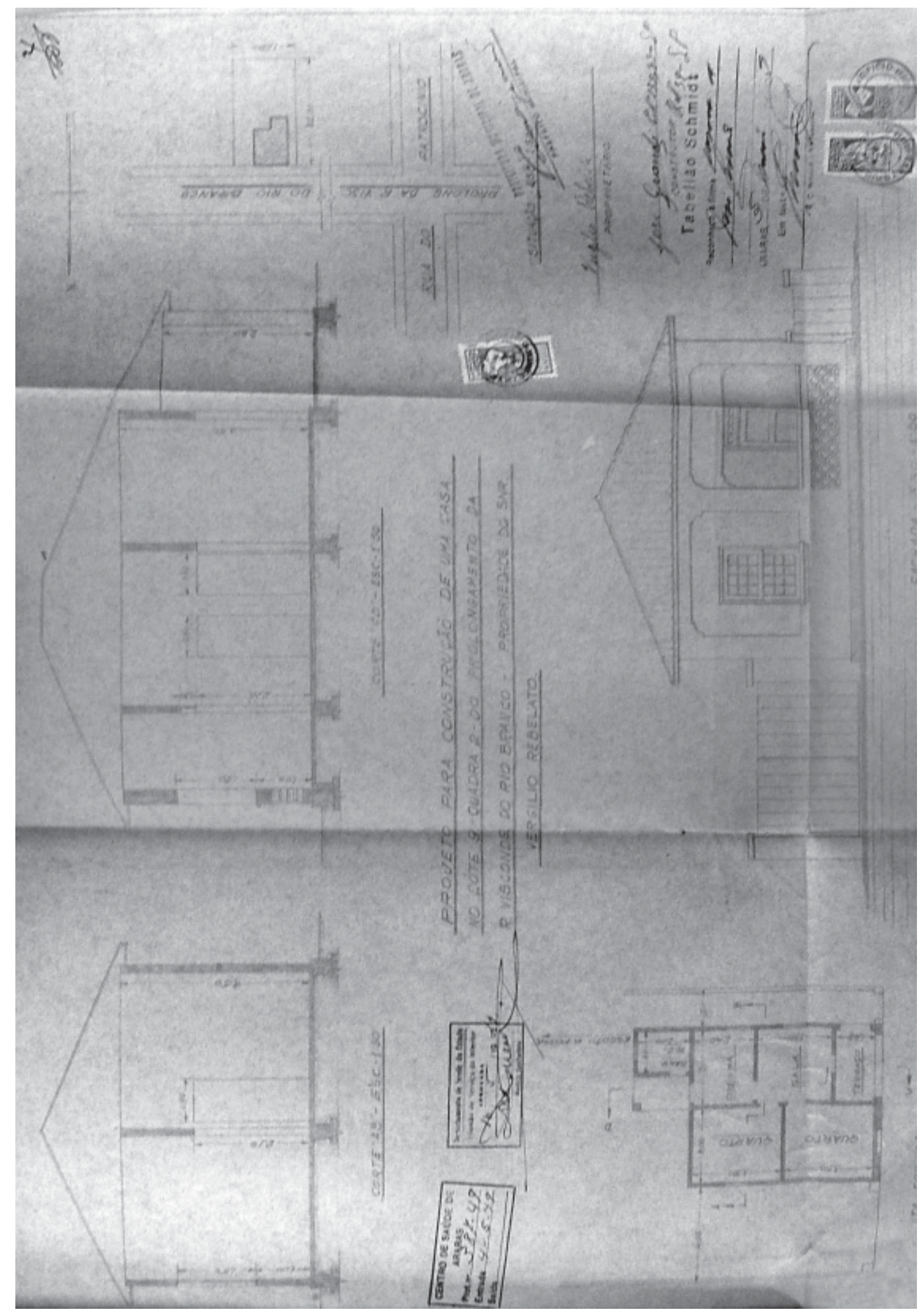

Figura 241 - Projeto do construtor José Grandi para Vergílio Rebelato, à Rua Visconde do Rio Branco, lote A, quadra 2, em Araras. Ano de 1949. Edificação despojada de ornamentos, mas com guarda-corpo de meias-luas sobrepostas. Fonte: Arquivo Municipal de Araras. 


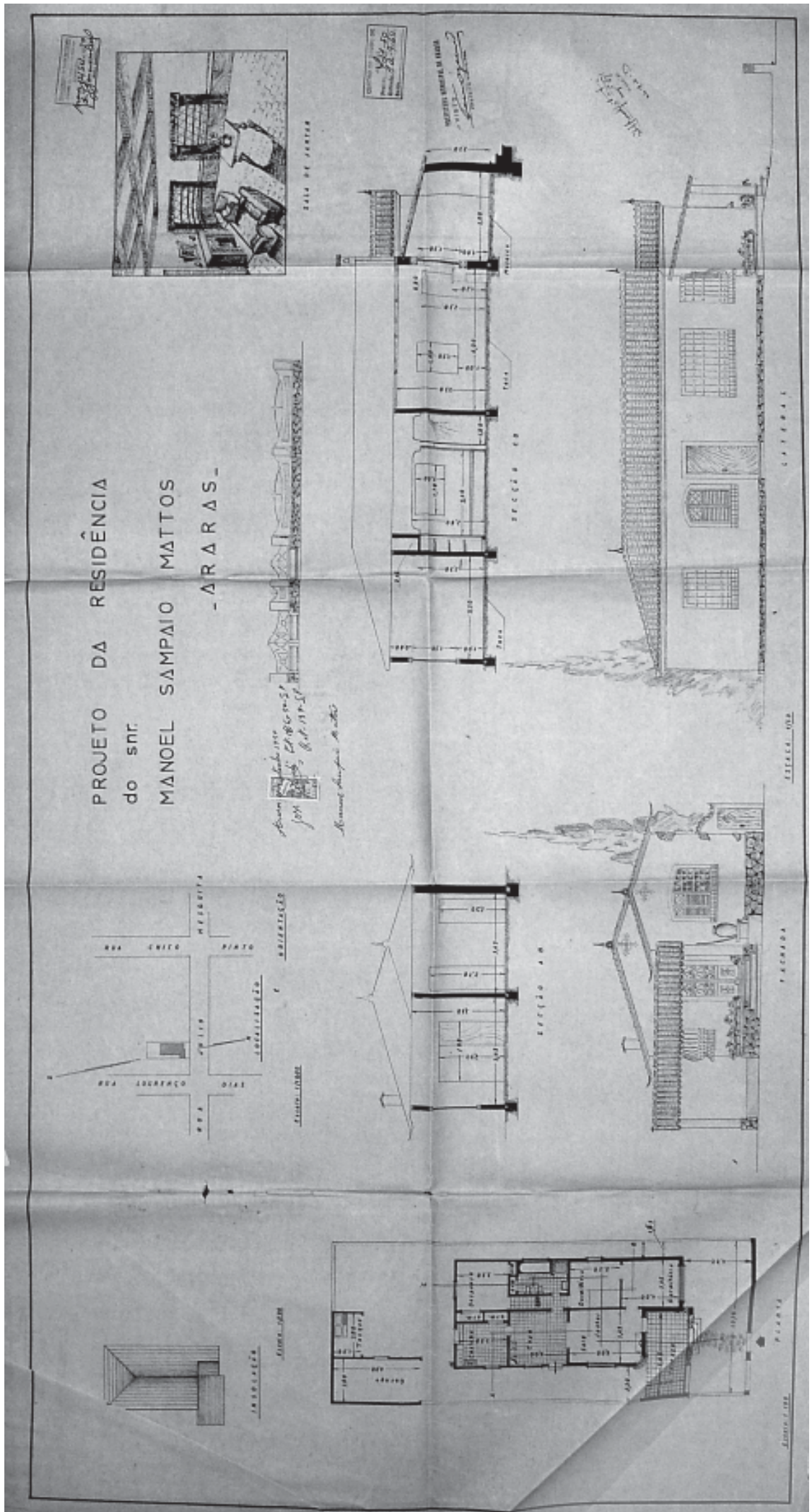

Figura 242 - Projeto de um engenheiro não identificado e do construtor José Grandi, de 1950, para a residência de Manoel Sampaio Mattos, à Rua Júlio de Mesquita, entre Rua L. Dias e Rua Chico Pinto, em Araras. Fonte: Arquivo Municipal de Araras. 


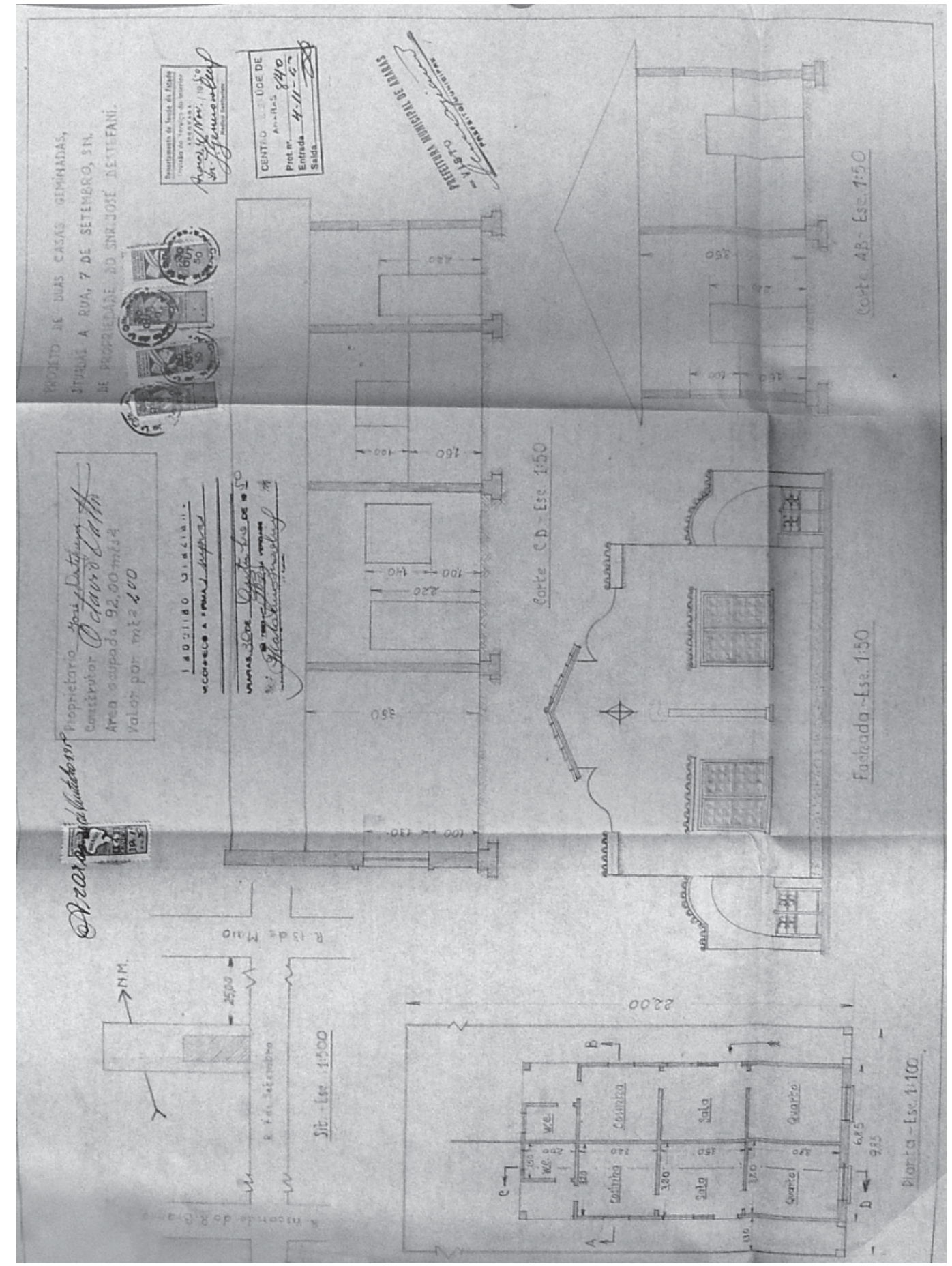

Figura 243 - Projeto para duas casas geminadas do construtor Octávio Daltro, de 1950, para José Destefani, à Rua 7 de Setembro, s/n, em Araras. Fonte: Arquivo Municipal de Araras. 

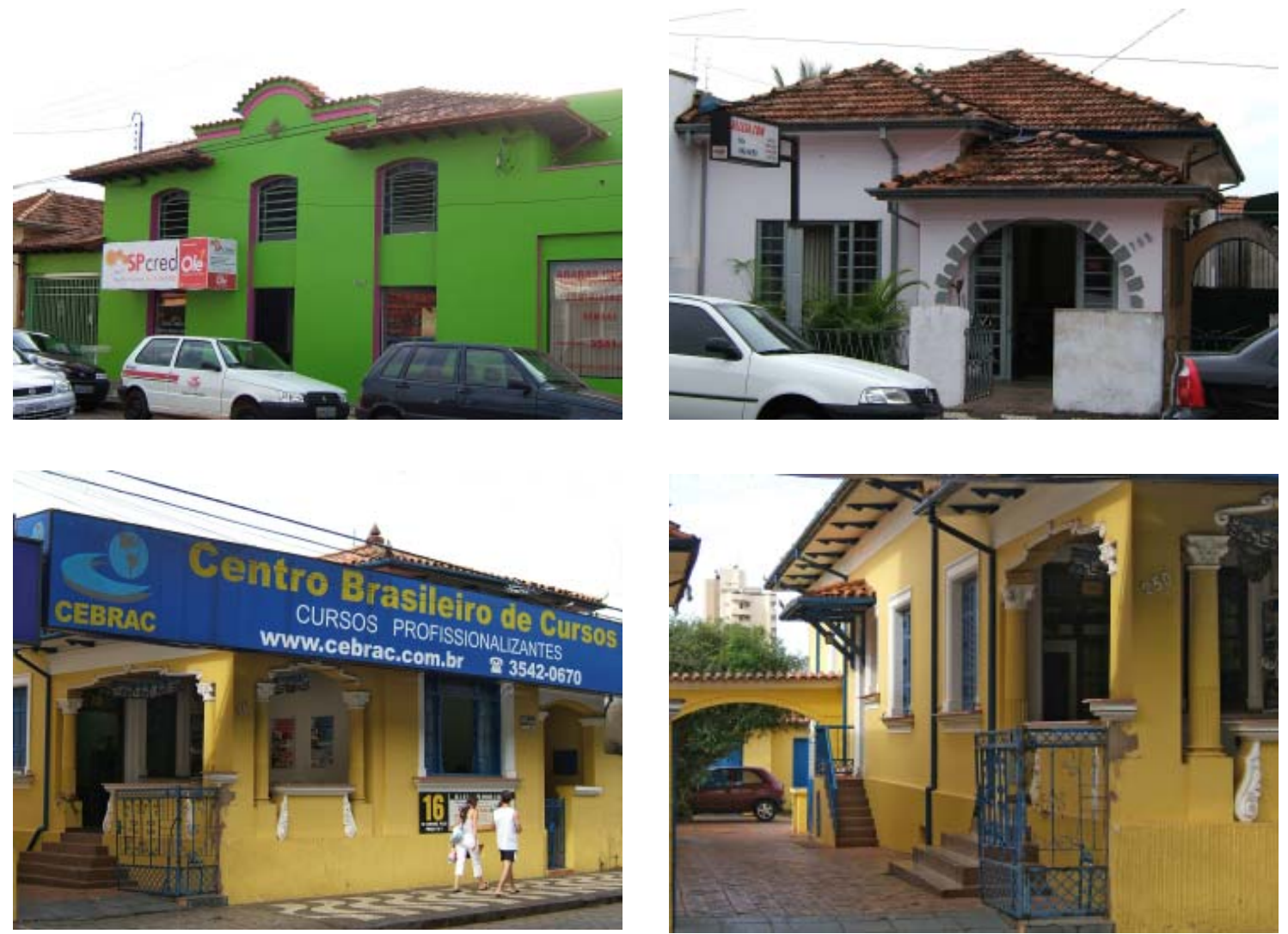

Figura 243 - Fotos de algumas edificações de tendência neocolonial em Araras. Fotos da autora, outubro de 2006. 


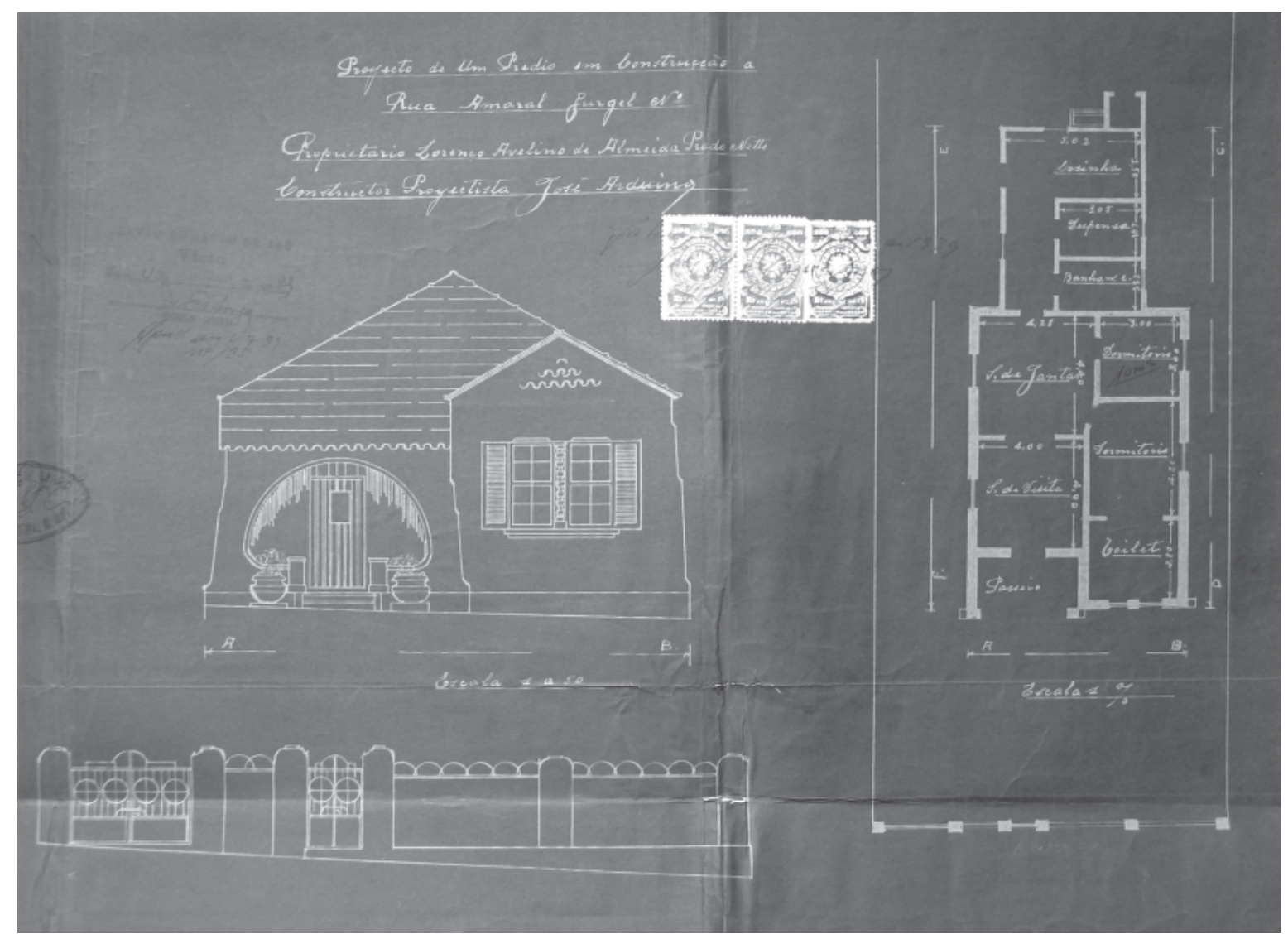

Figura 244 - Projeto do construtor José Arduíno à Rua Amaral Gurgel, em Jaú, para Lorenço A. A. Prado Netto, de 1939. Arco com paredes laterais alargadas na base evocam a vertente missões da tendência neocolonial. Fonte: Arquivo Municipal de Jaú. 


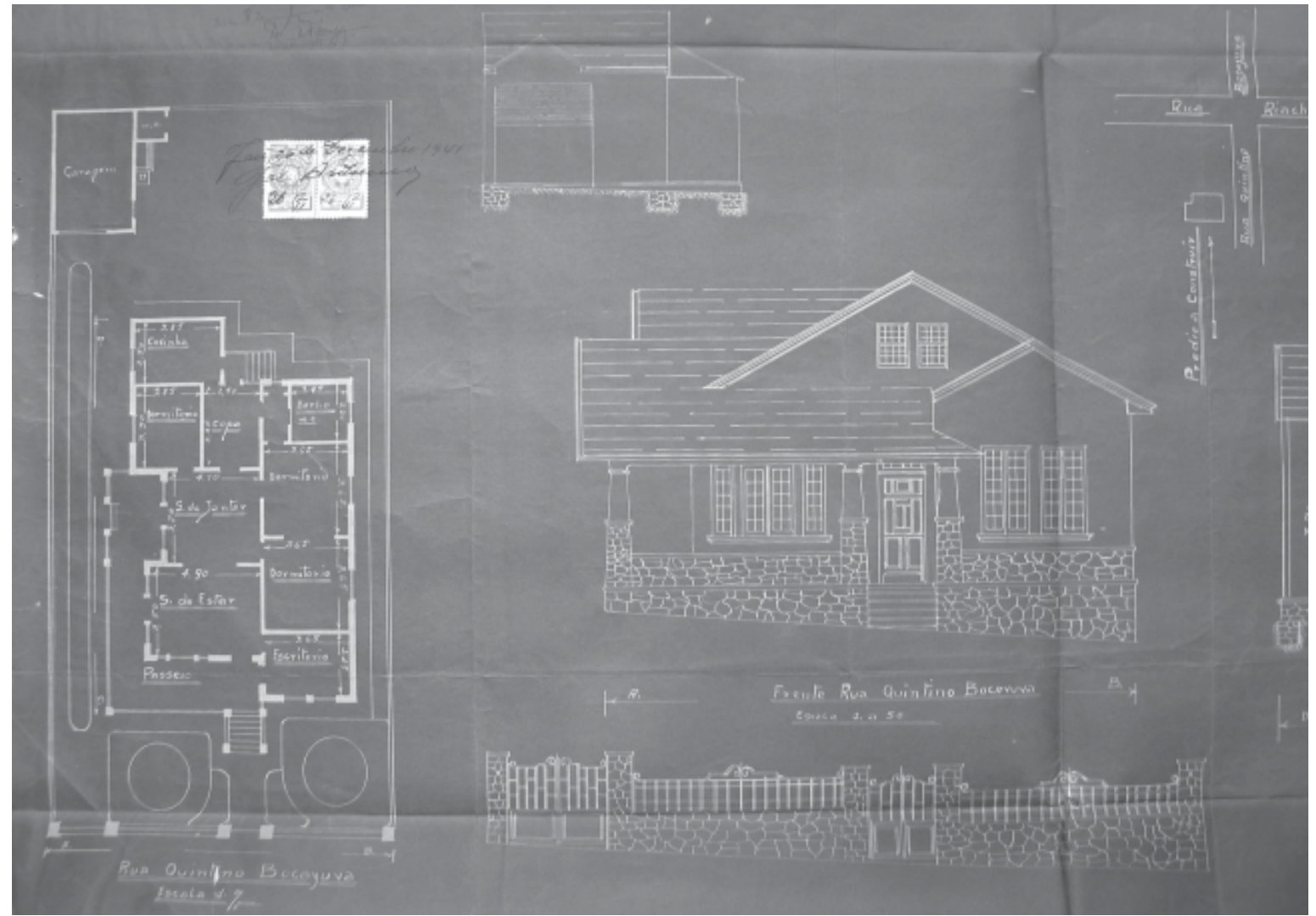

Figura 245 - Projeto do construtor José Arduíno à Rua Quintino Bocaiúva, em Jaú, de 1941. Fonte: Arquivo Municipal de Jaú. 


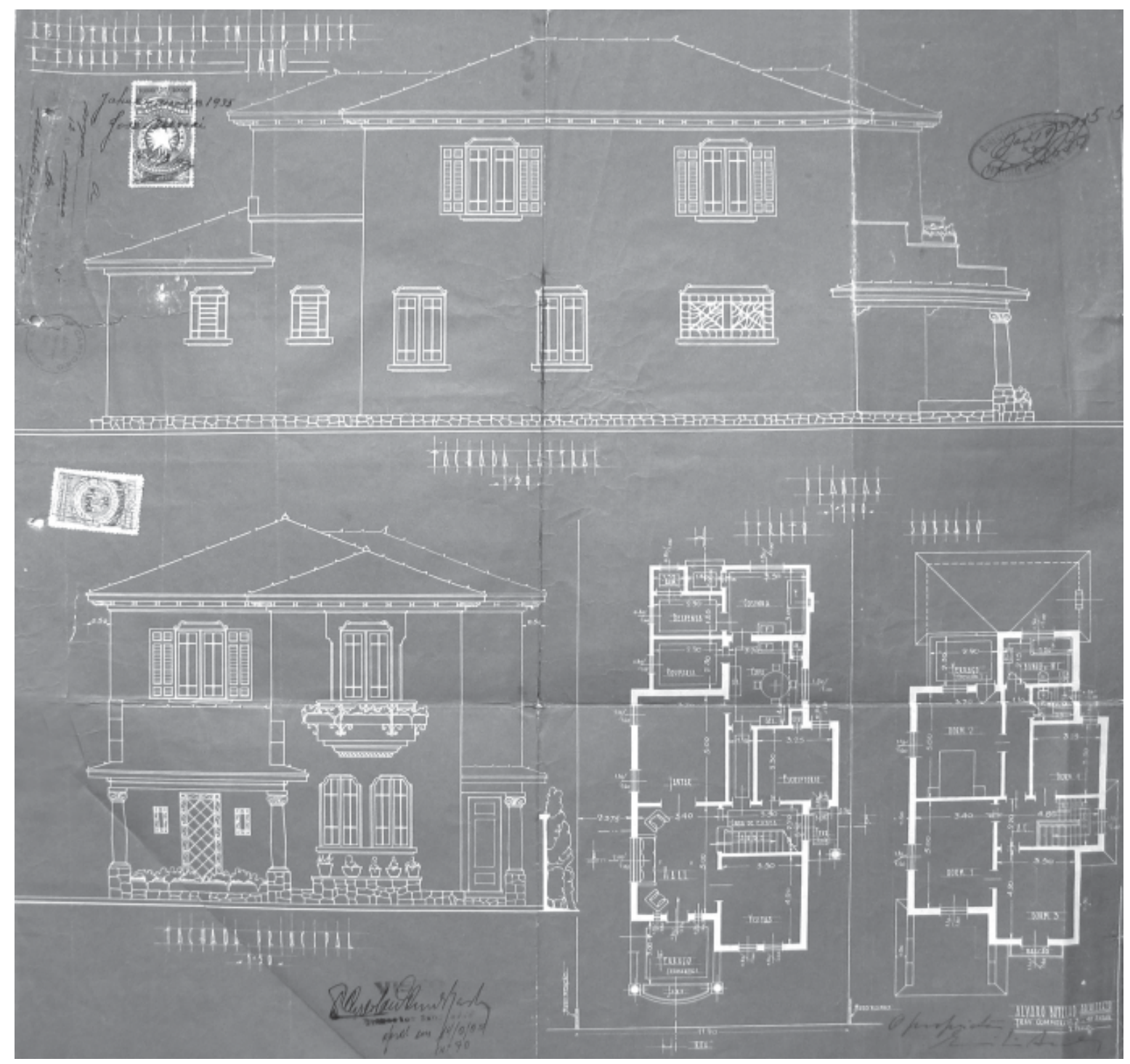

Figura 246 - Projeto do arquiteto Álvaro Botelho, de 1935, para Emílio A., à Rua Edgar Ferraz, em Jaú. Fonte: Arquivo Municipal de Jaú. 


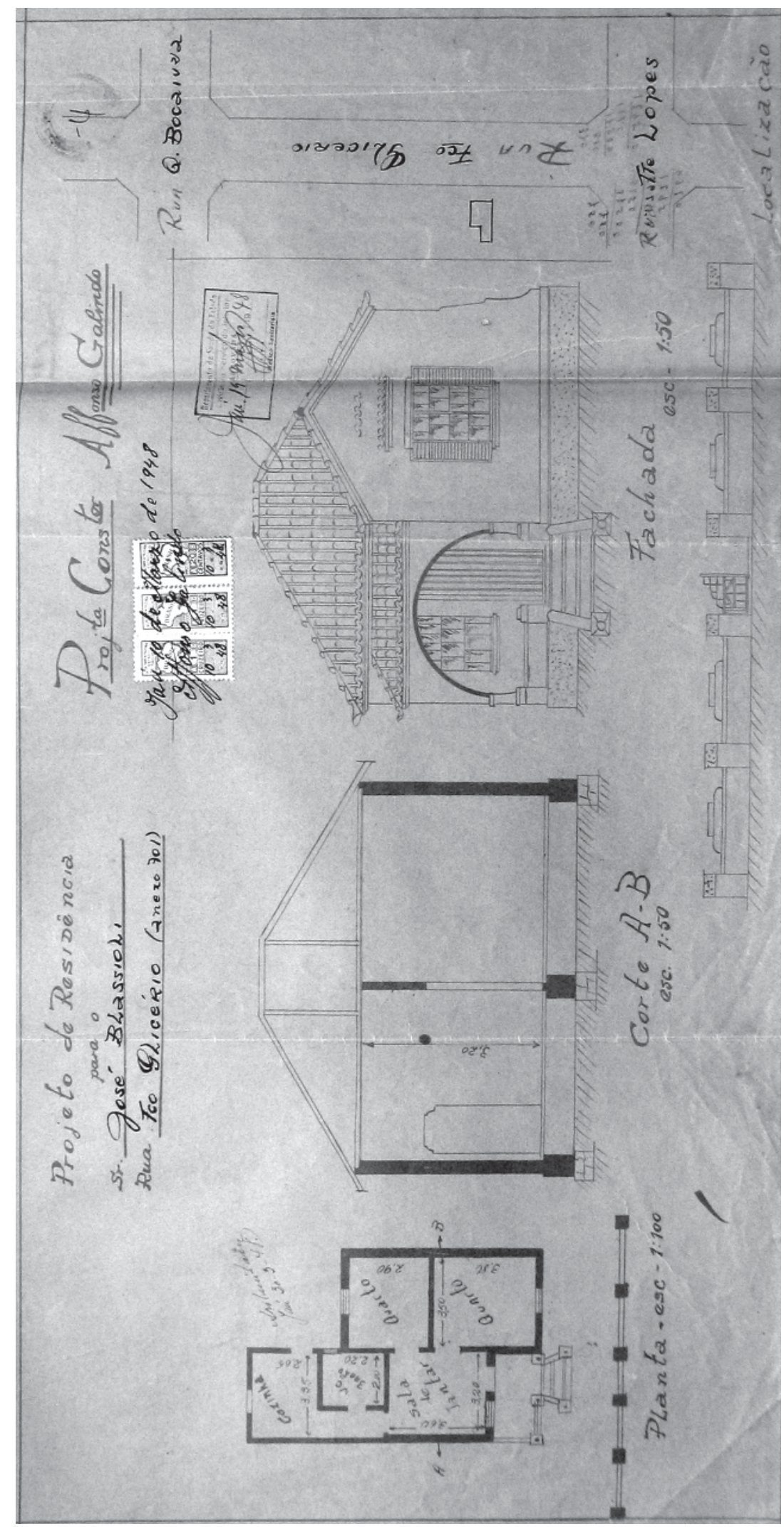

Figura 247 - Projeto do construtor Affonso Galindo à Rua Francisco Glicério, em Jaú, de 1948, para José Blassioli. Fonte: Arquivo Municipal de Jaú. 


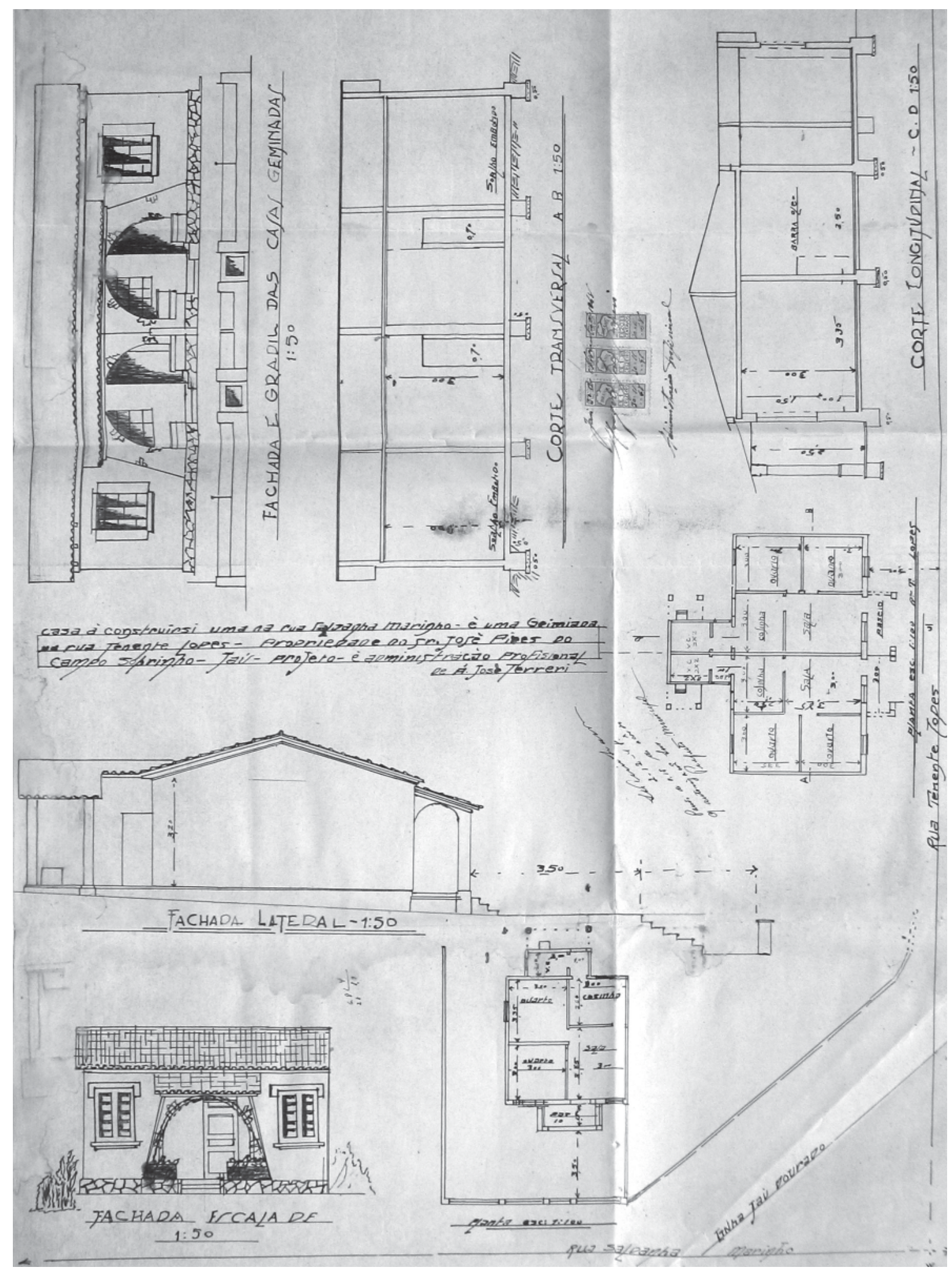

Figura 248 - Projeto de duas casas geminadas do construtor Ângelo José Terreri, de 1948, em Jaú, à Rua Saldanha Marinho, para José P. do Campos Sobrinho. Pedras esparsas na fachada e arcos. Fonte: Arquivo Municipal de Jaú. 


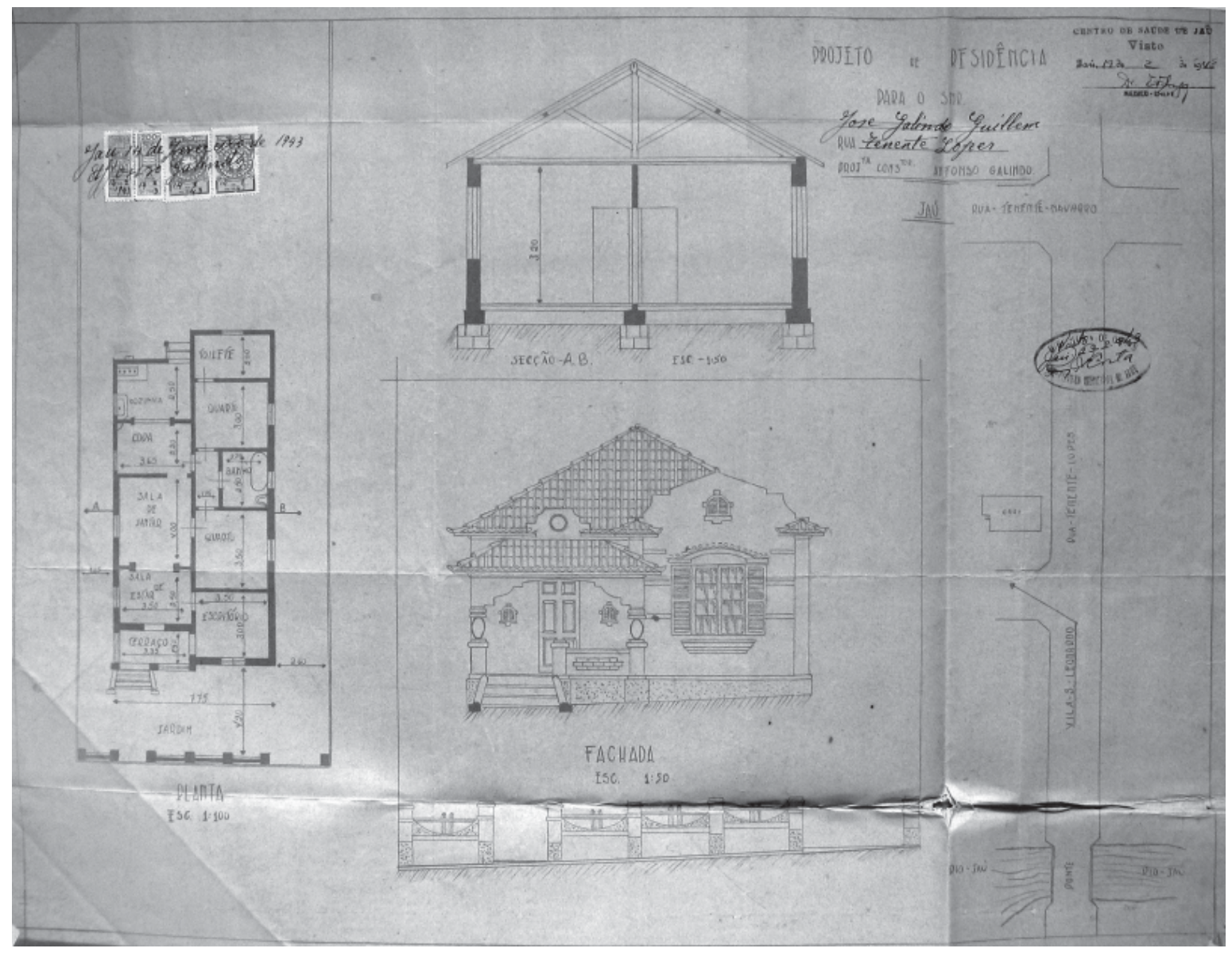

Figura 249 - Projeto de Affonso Galindo para a residência de José Galindo Guillem, de 1943, situada à Rua Tenente Lopez, em Jaú. Fonte: Arquivo Municipal de Jaú. 

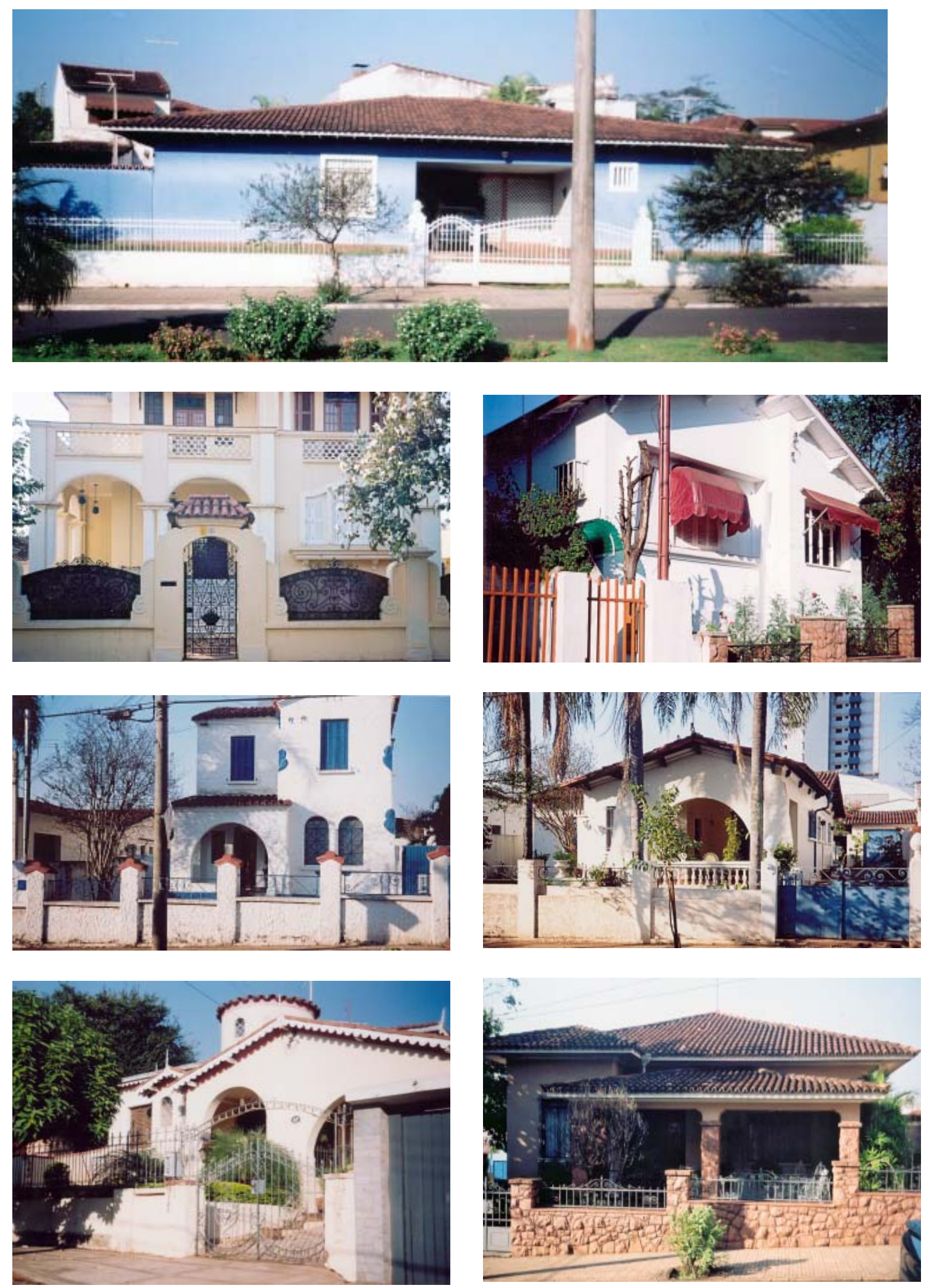

Figura 250 - Fotos de várias edificações de tendência neocolonial na cidade de Jaú. Notar os diferentes estilemas empregados nos prédios que seguem a vertente missões e nos que seguem influência mais associada à arquitetura portuguesa. Notar, também, uma residência com grande telhados de quatro águas, varanda entalada e janela fechada por peças de madeira numa clara referência às casas bandeiristas. Fotos da autora, outubro de 2004. 


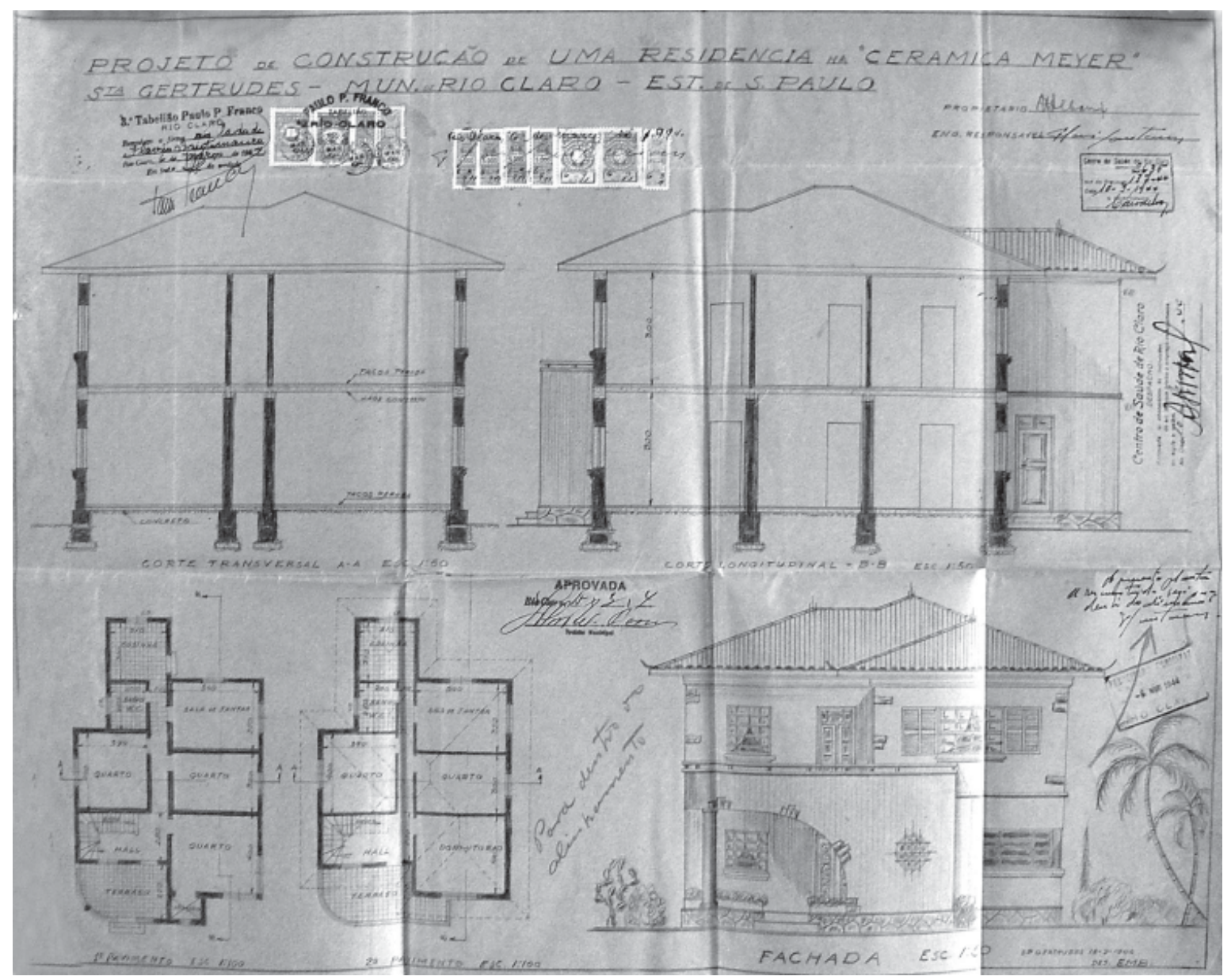

Figura 251 - Projeto de Flávio Santomauro, construtor, para uma residência na Cerâmica Meyer, em Santa Gertrudes, distrito de Rio Claro, em 1944. O desenho da, no entanto, consta como sendo de BEM. Trata-se de duas residências, uma em cada piso e, sem o ambiente destinado a sala de estar, apenas com dormitórios, sala de jantar, cozinha e banheiro. Exterior neocolonial. Fonte: Arquivo Municipal de Rio Claro. 


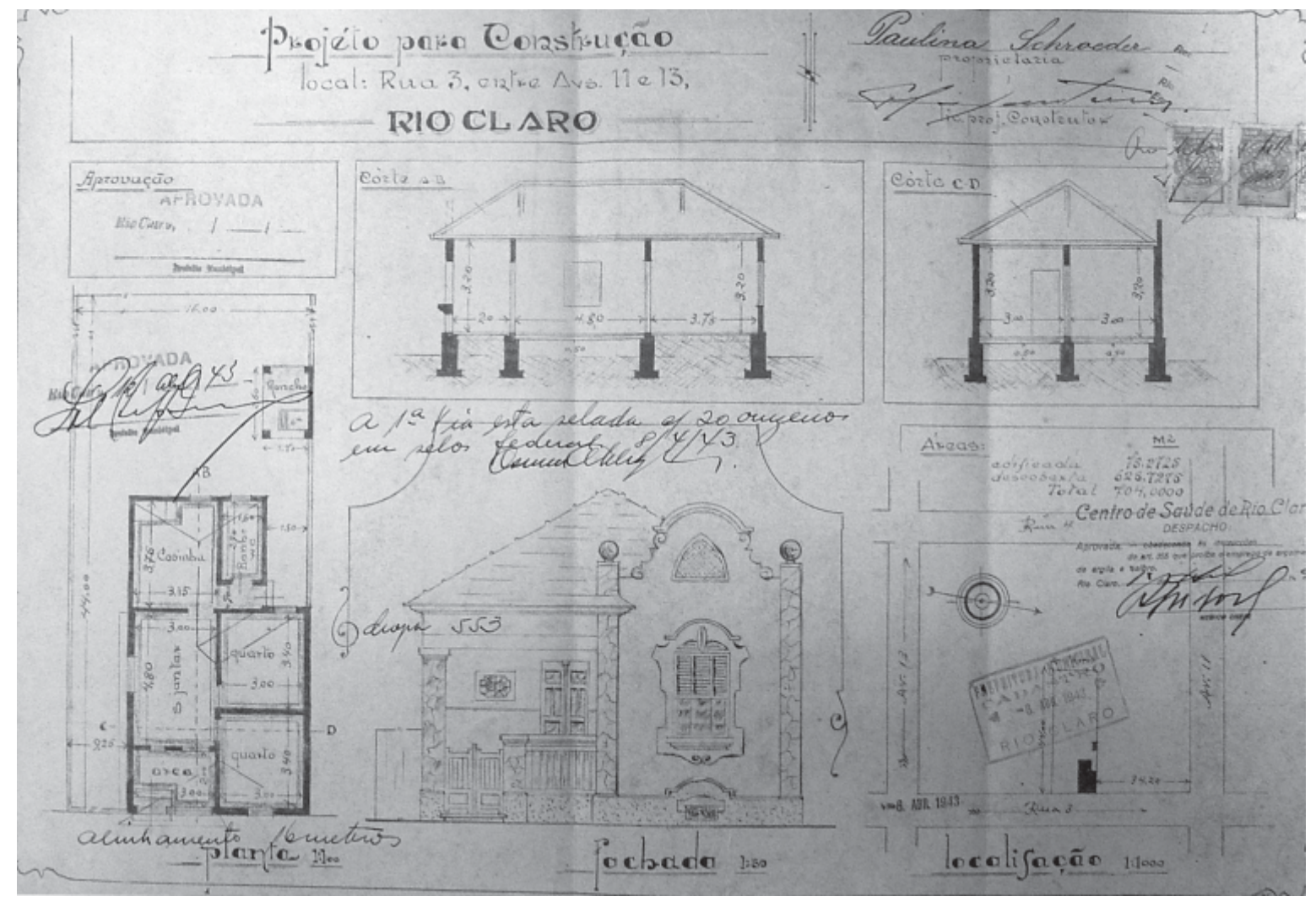

Figura 252 - Projeto de residência à Rua 3, entre Avs. 11 e 13, em Rio Claro, de responsabilidade do construtor Flávio Santomauro, em 1943, para Paulina Schroeder. Fonte: Arquivo Municipal de Rio Claro. 


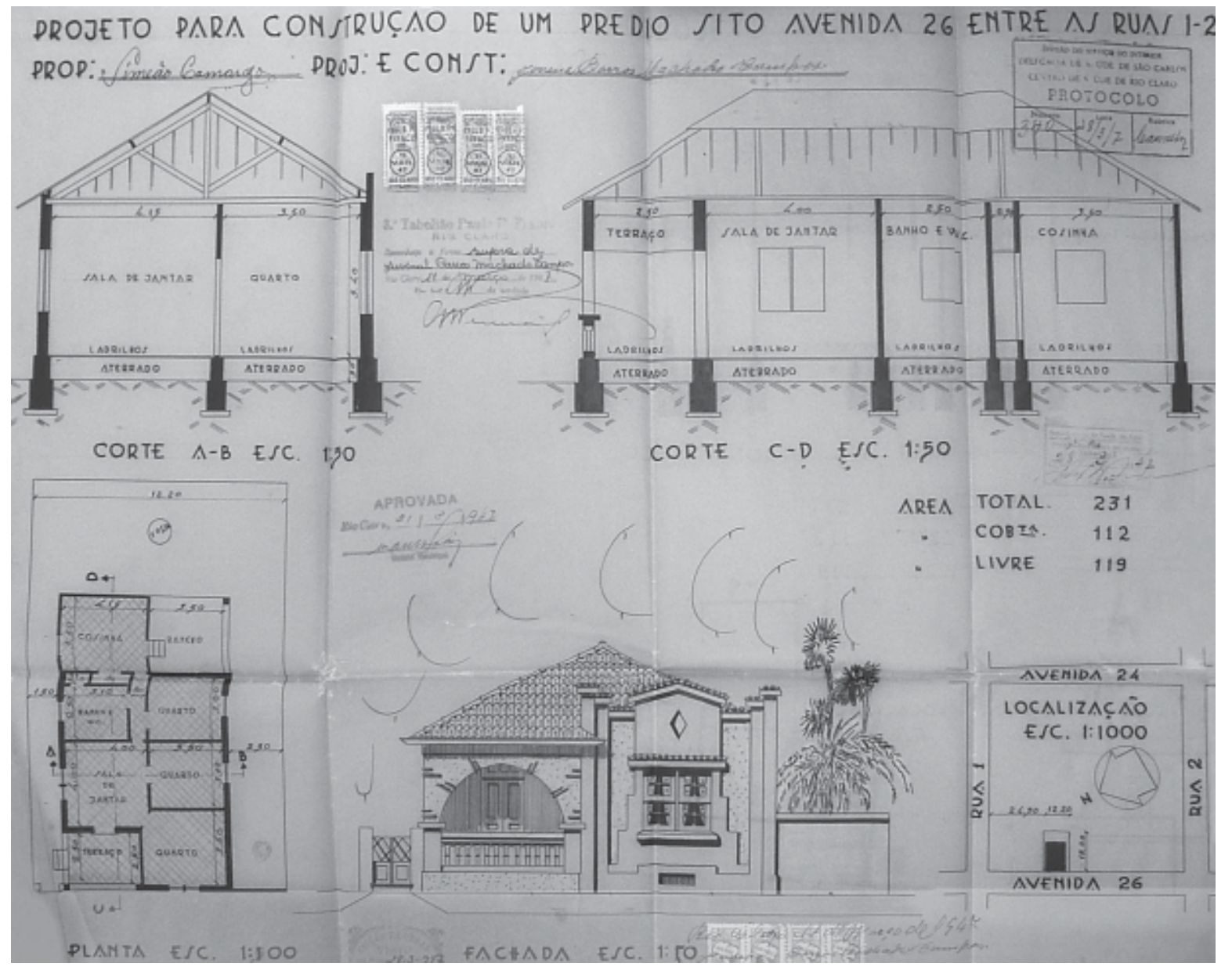

Figura 253 - Projeto do engenheiro Juvenal Barros Machado Campos para a residência de Simão Camargo, à Av. 26, entre ruas 1 e 2, em Rio Claro, no ano de 1947. Esta edificação é um híbrido, misturando linhas neocoloniais e art déco na mesma fachada. Fonte: Arquivo Municipal de Rio Claro. 


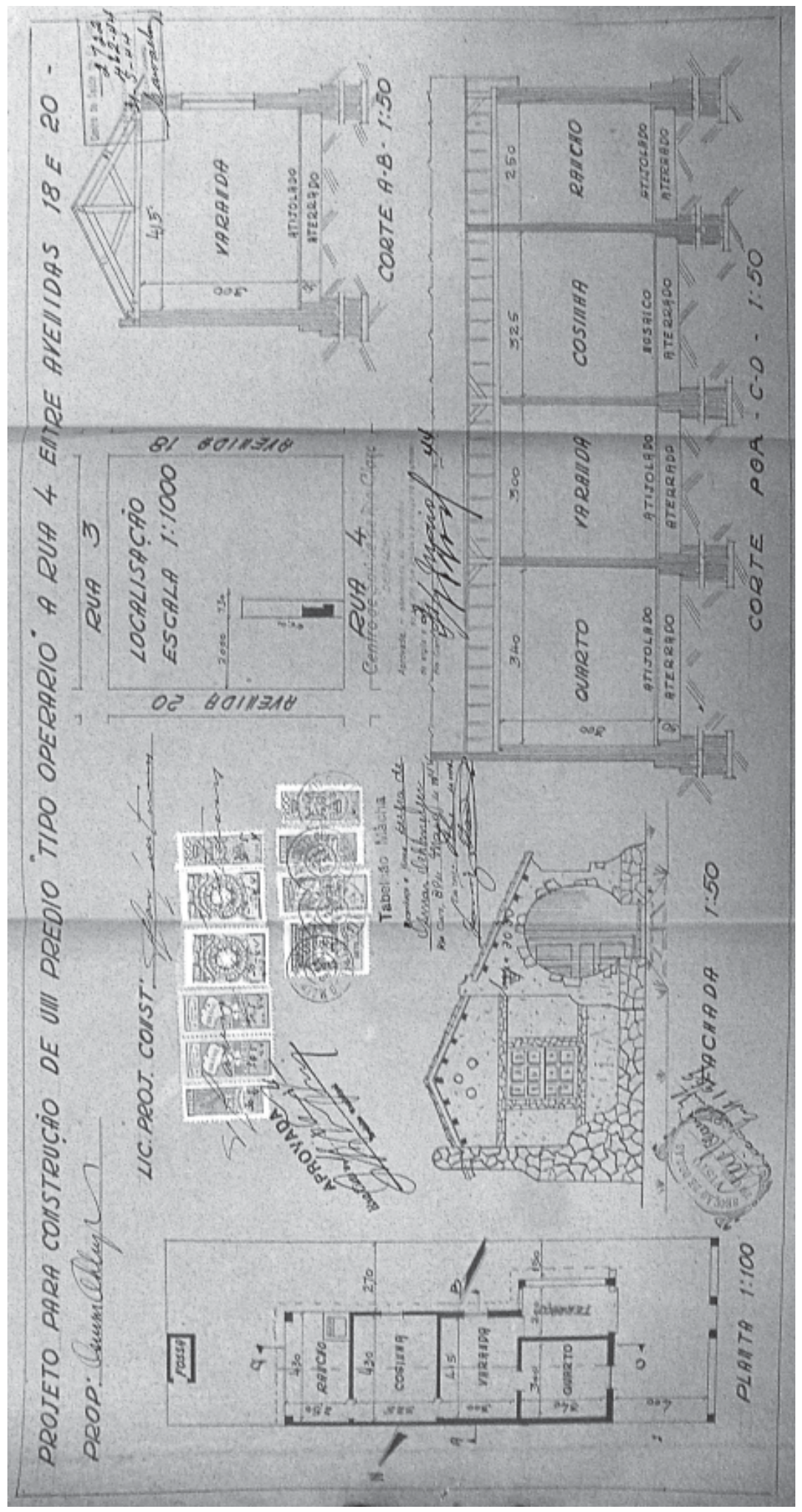

Figura 254 - Projeto de um prédio “tipo operário”, como consta na prancha de desenho, destinado ao uso residencial, de responsabilidade do construtor Flávio Santomauro a ser construído à Rua 4, entre av. 18 e 20, em Rico Claro. Exagero na utilização das pedras na fachada. Fonte: Arquivo Municipal de Rio Claro. 


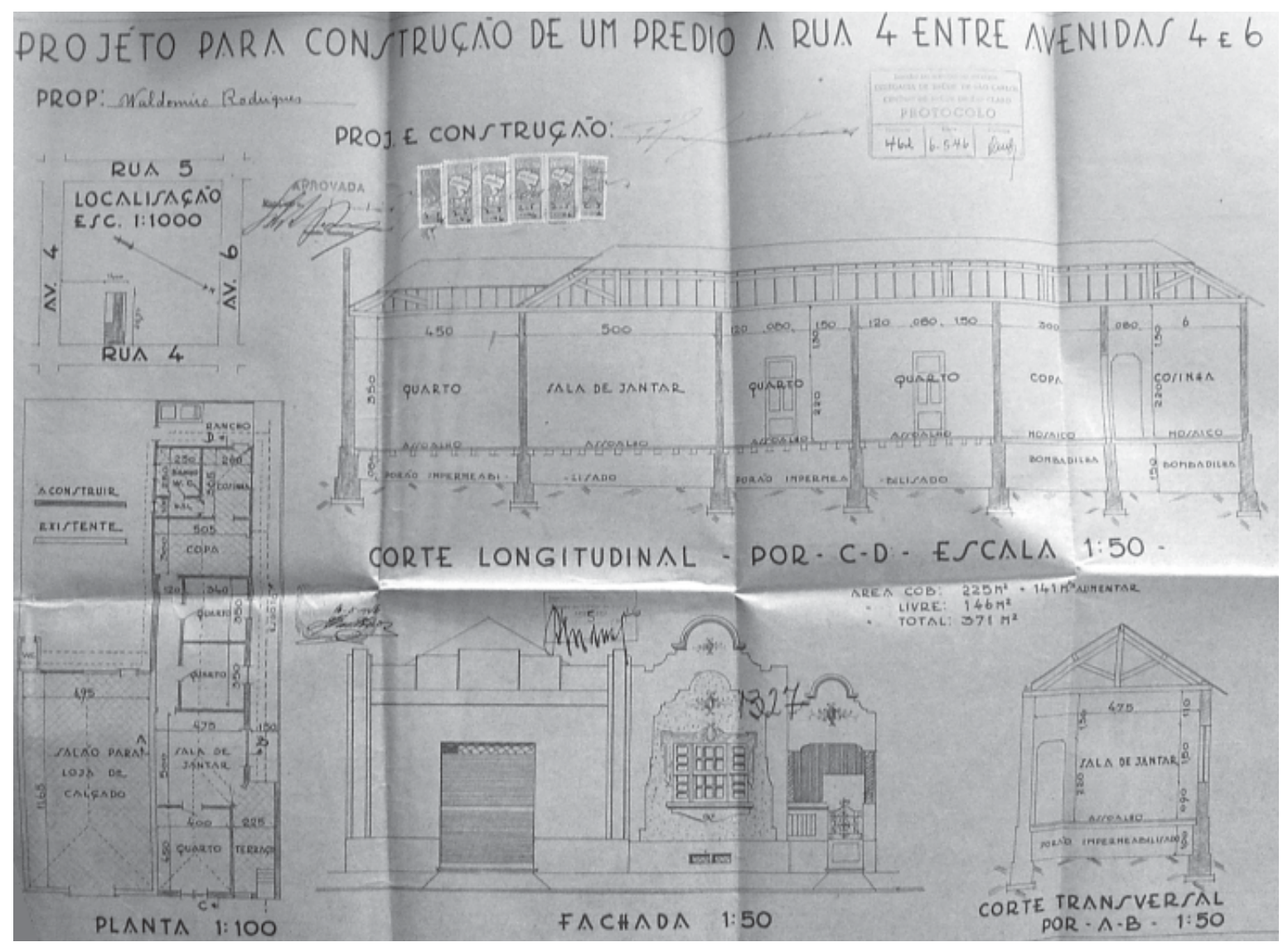

Figura 255 - Edifício de uso misto para Waldormiro Rodrigues, siatuado à Rua 4, entre Av. 5 e 6, em Rio Claro, projetado pelo construtor Flávio Santomauro, em 1946. Esse exemplar mostra a preferência da utilização de linhas neocoloniais para a residências e de linhas art déco para o prédio comercial. Fonte: Arquivo Municipal de Rio Claro. 


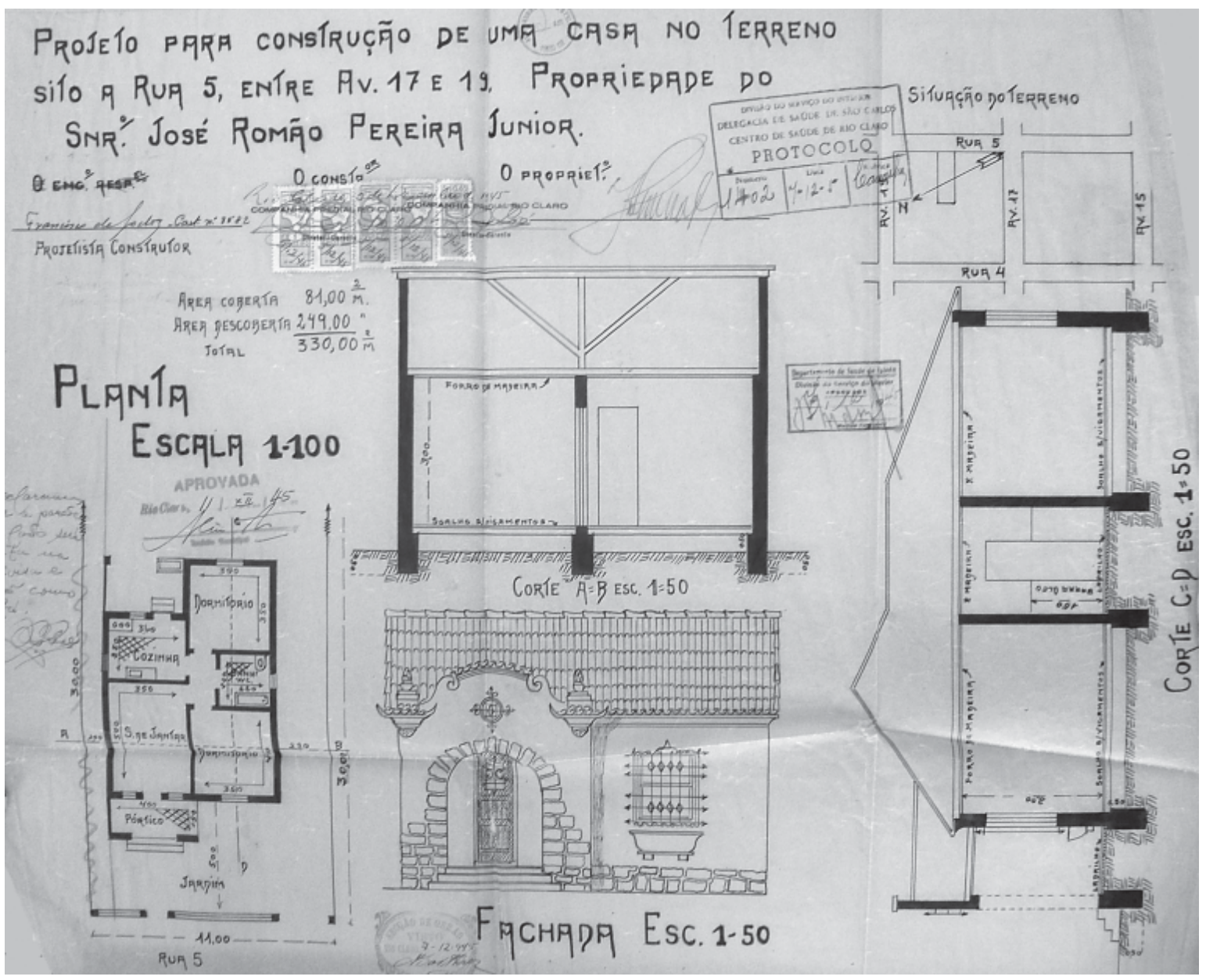

Figura 256 - Projeto de uma casa para José Romão P. Júnior situada à Rua 5, entre as ruas 15 e 17, em Rio Claro. Data de 1945 e é de responsabilidade do engenheiro Francisco de Godói. Apesar de ser uma residência de baixo padrão, exibe decoração marcadamente neocolonial. Fonte: Arquivo Municipal de Rio Claro. 


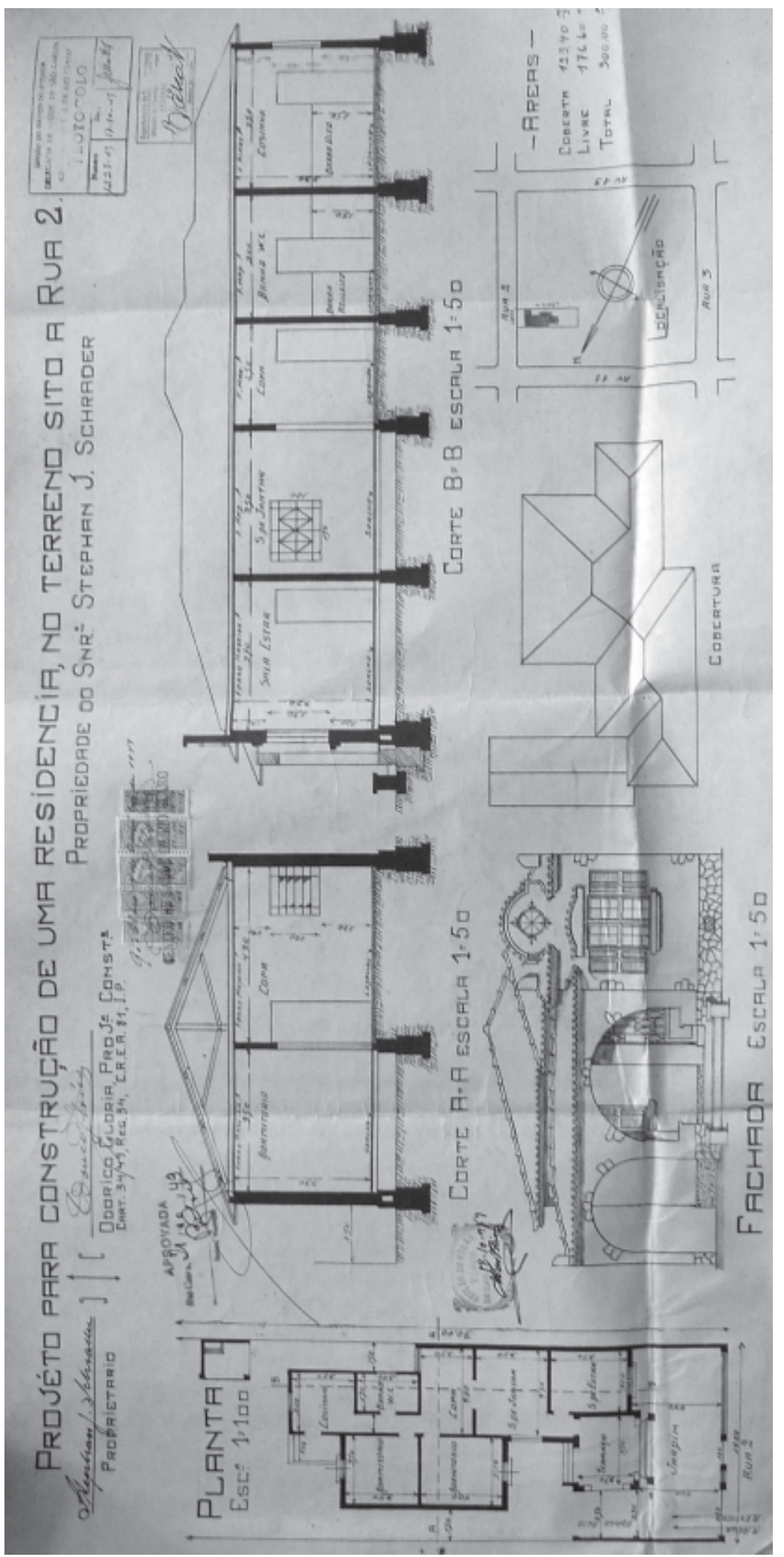

Figura 257 - Projeto do construtor Odorico Glória para uma residência à Rua 2, entre av. 11 e 13, em Rio Claro, para Stephan J. Schrader, realizado em 1949. Fonte: Arquivo Municipal de Rio Claro. 


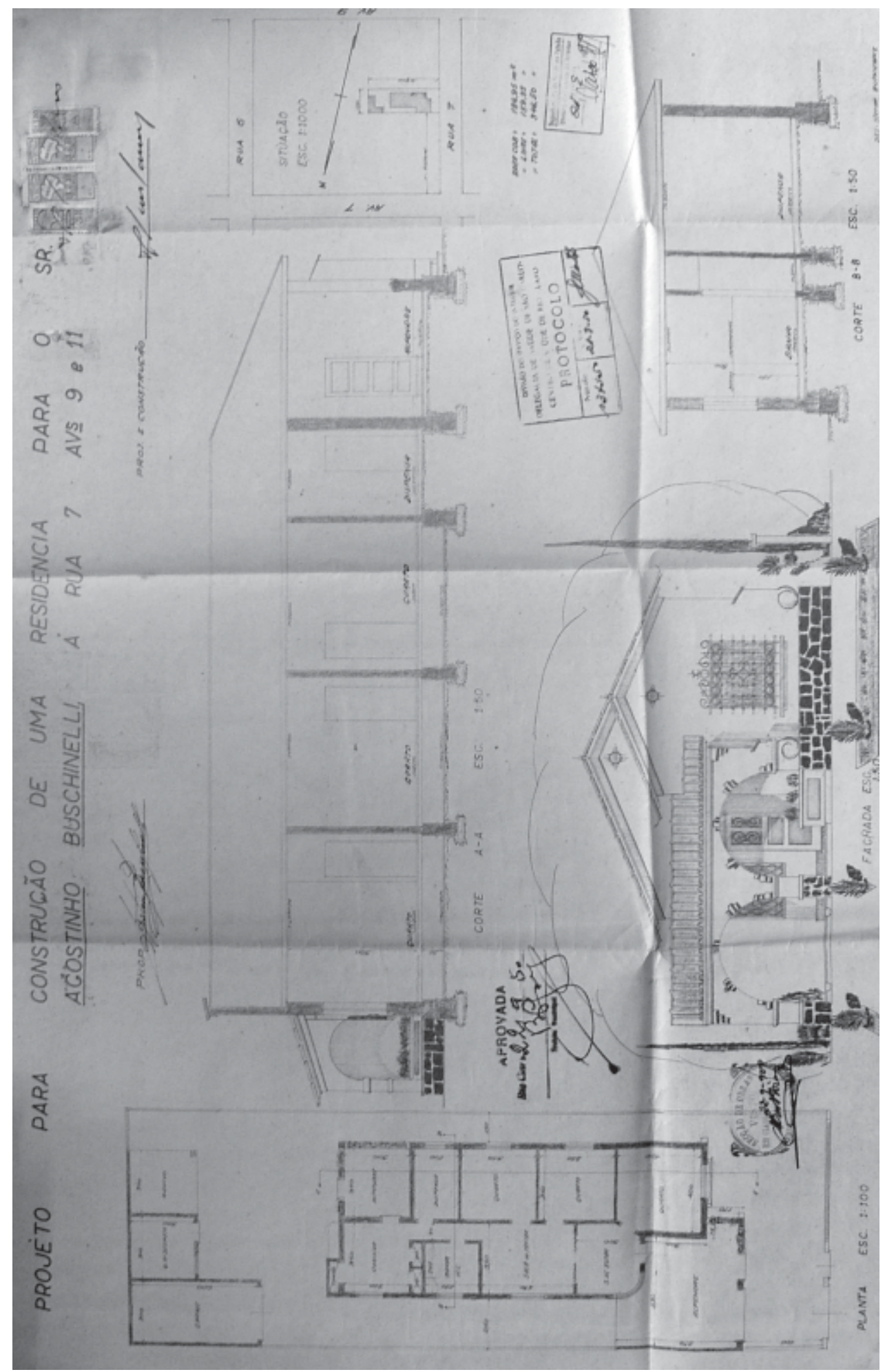

Figura 258 - Residência para Agostinho Buschinelli, situada à Rua 7, entreva v. 9 e 11, em Rio Claro, projetada pelo construtor Flávio Santomauro em 1950. Fonte: Arquivo Municipal de Rio Claro. 


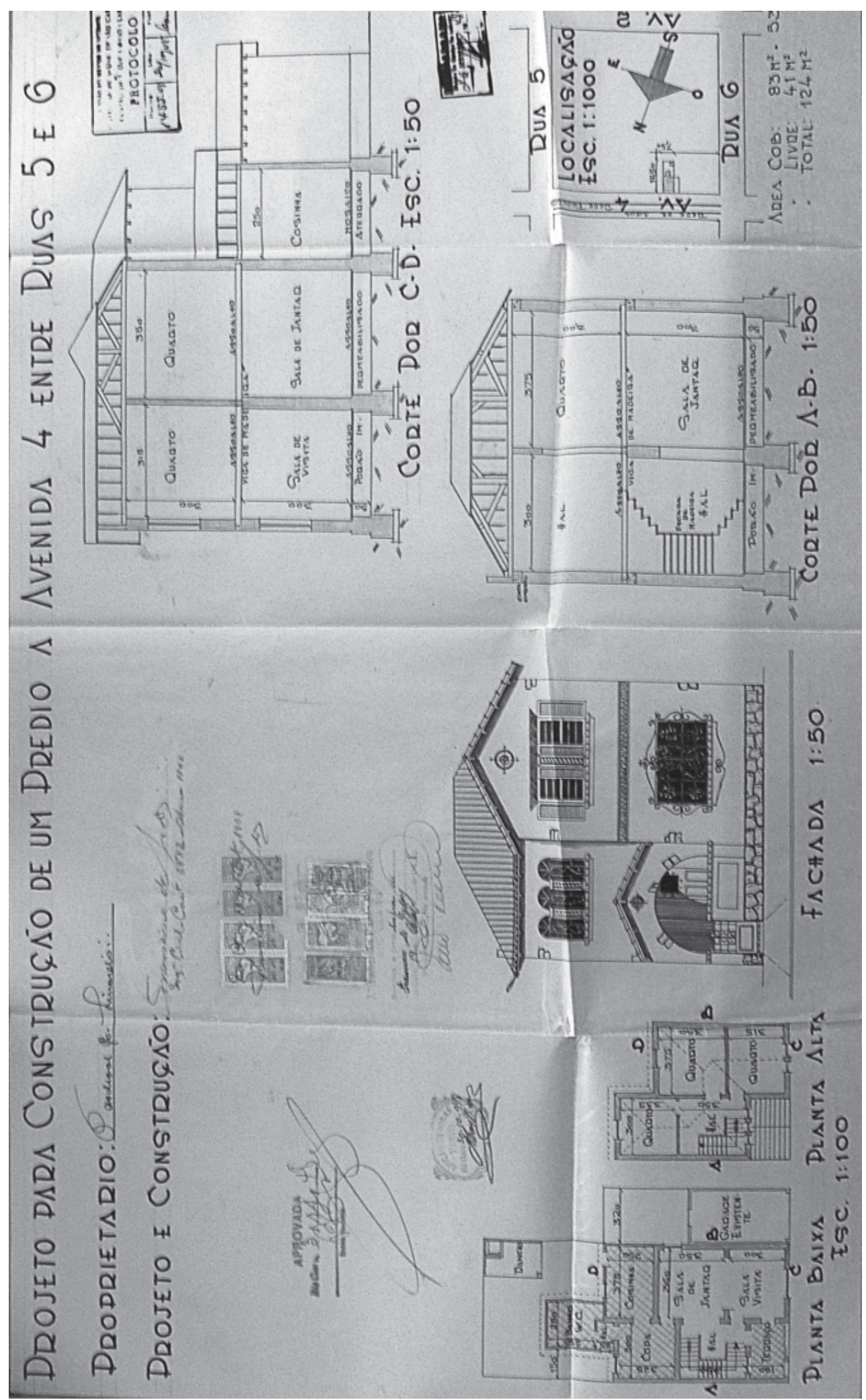

Figura 259 - Sobrado situada à Av. 4, entre ruas 5 e 6, em Rio Claro, projetada pelo engenheiro Francisco de Godói, em 1948. Colunas salomônicas e outras características missões. Fonte: Arquivo Municipal de Rio Claro. 

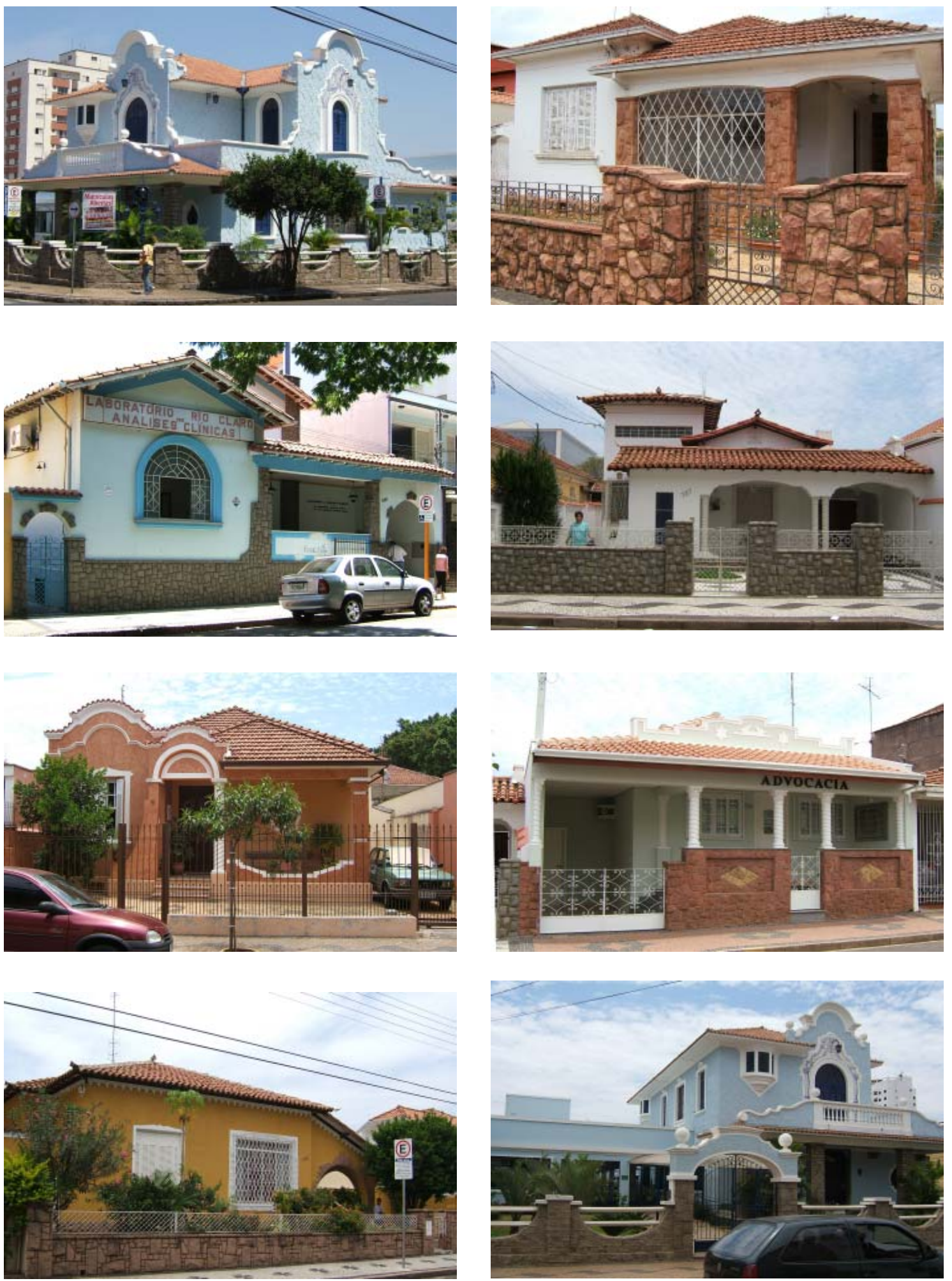

Figura 260 - Fotos de diversas edificações em Rio

Claro, e sua maioria, originalmente, destinadas ao uso residencial. Podemos ver uma grande diversidade de estilemas e características utilizadas em conjunto, num mesmo prédio, caracterizando uma mistura de vertentes arquitetônicas, ou isoladamente, em exemplares mais simplificados. Fonte: fotos da autora, dezembro de 2006. 


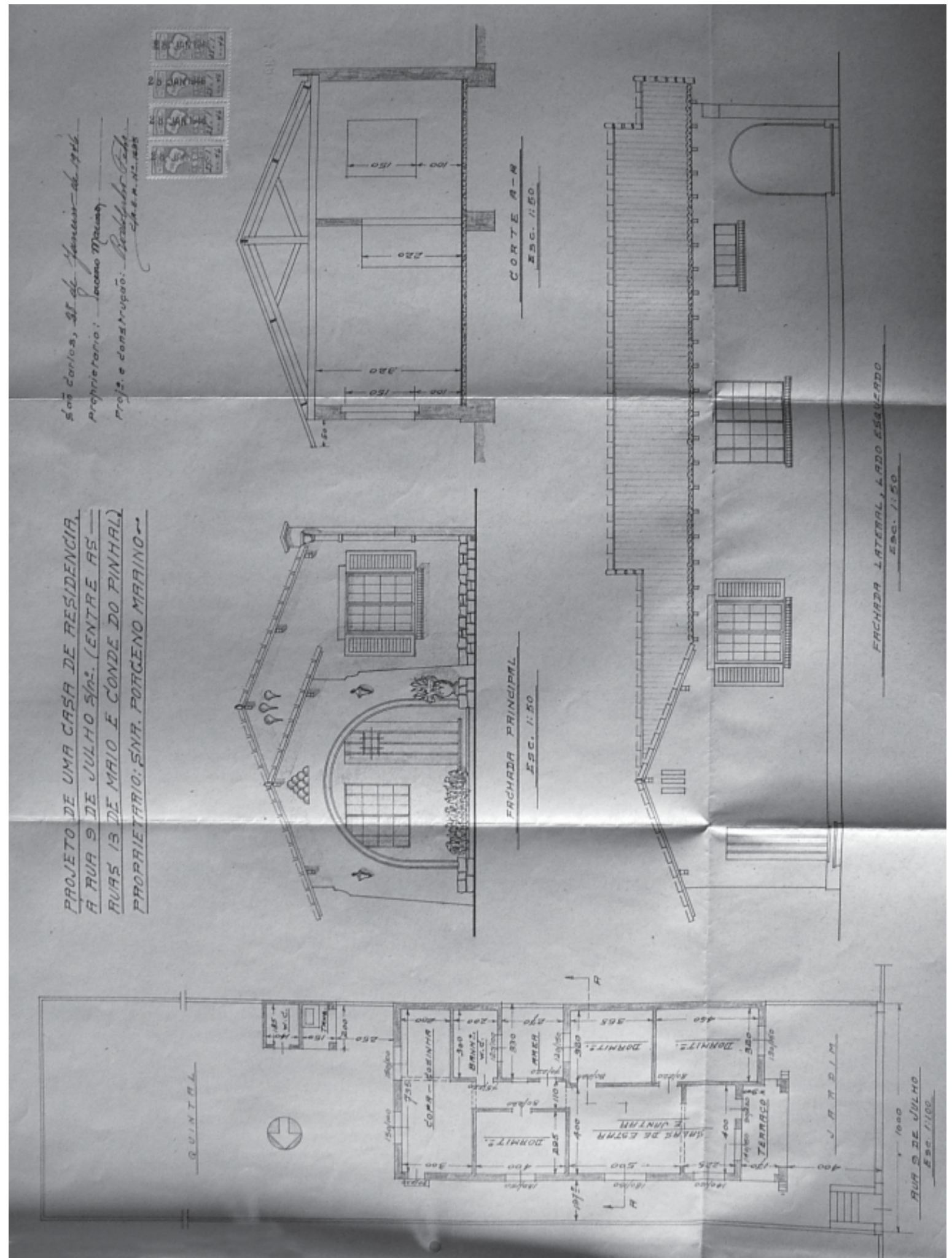

Figura 261 - Residência projetada pelo arquiteto Rodolpho Fehr, em 1946, para Porgeno Marino. Está situada na cidade de São Carlos, à Rua 9 de julho. Fonte: Arquivo Municipal de São Carlos. 


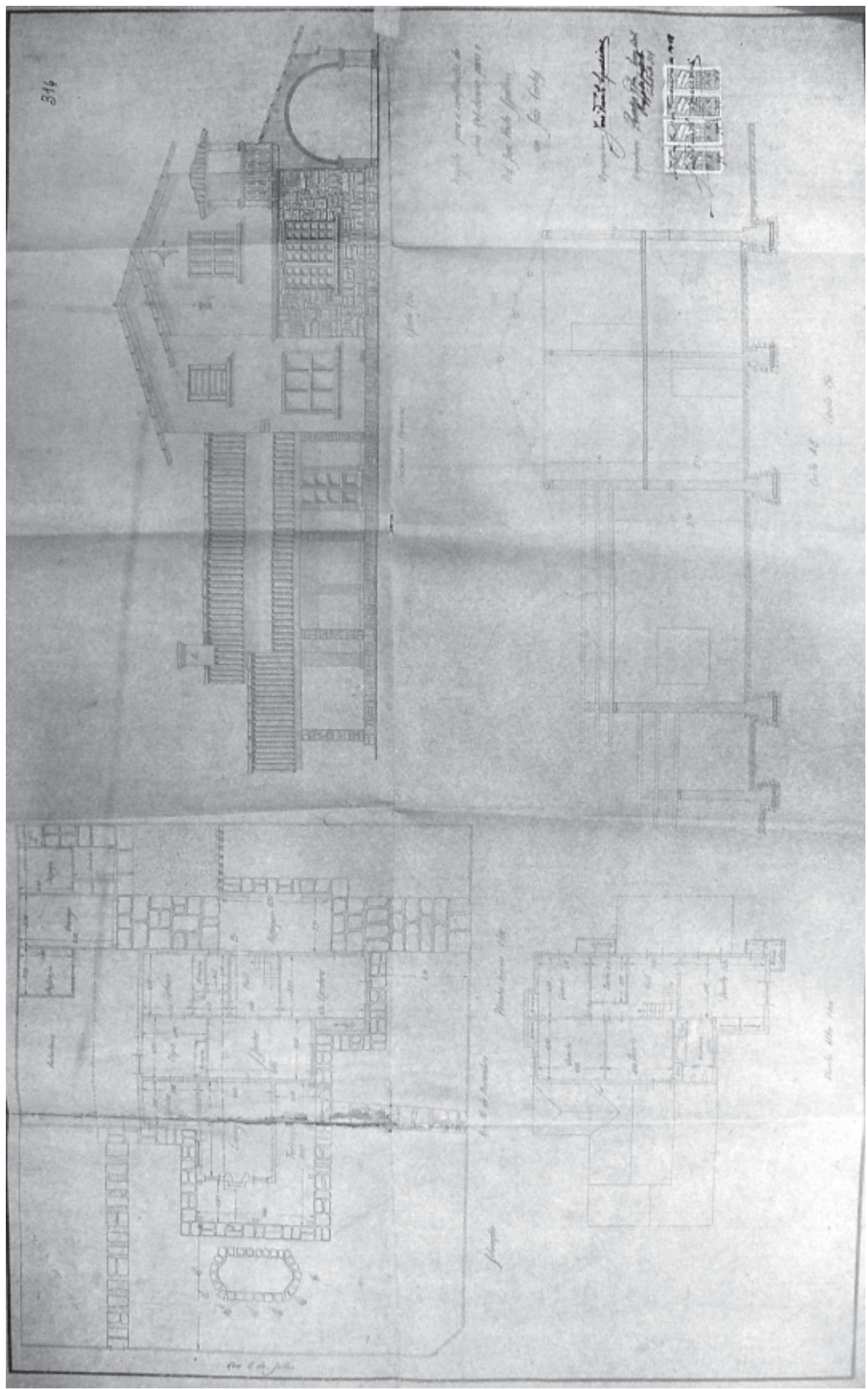

Figura 262 - Projeto de 1948 para uma residência situada à Rua 9 de Julho, esquina com a Rua 15 de Novembro, em São Carlos, de autoria do engenheiro Theodoro Fehr, irmão de Rodolpho Fehr. Fonte: Arquivo Municipal de São Carlos. 

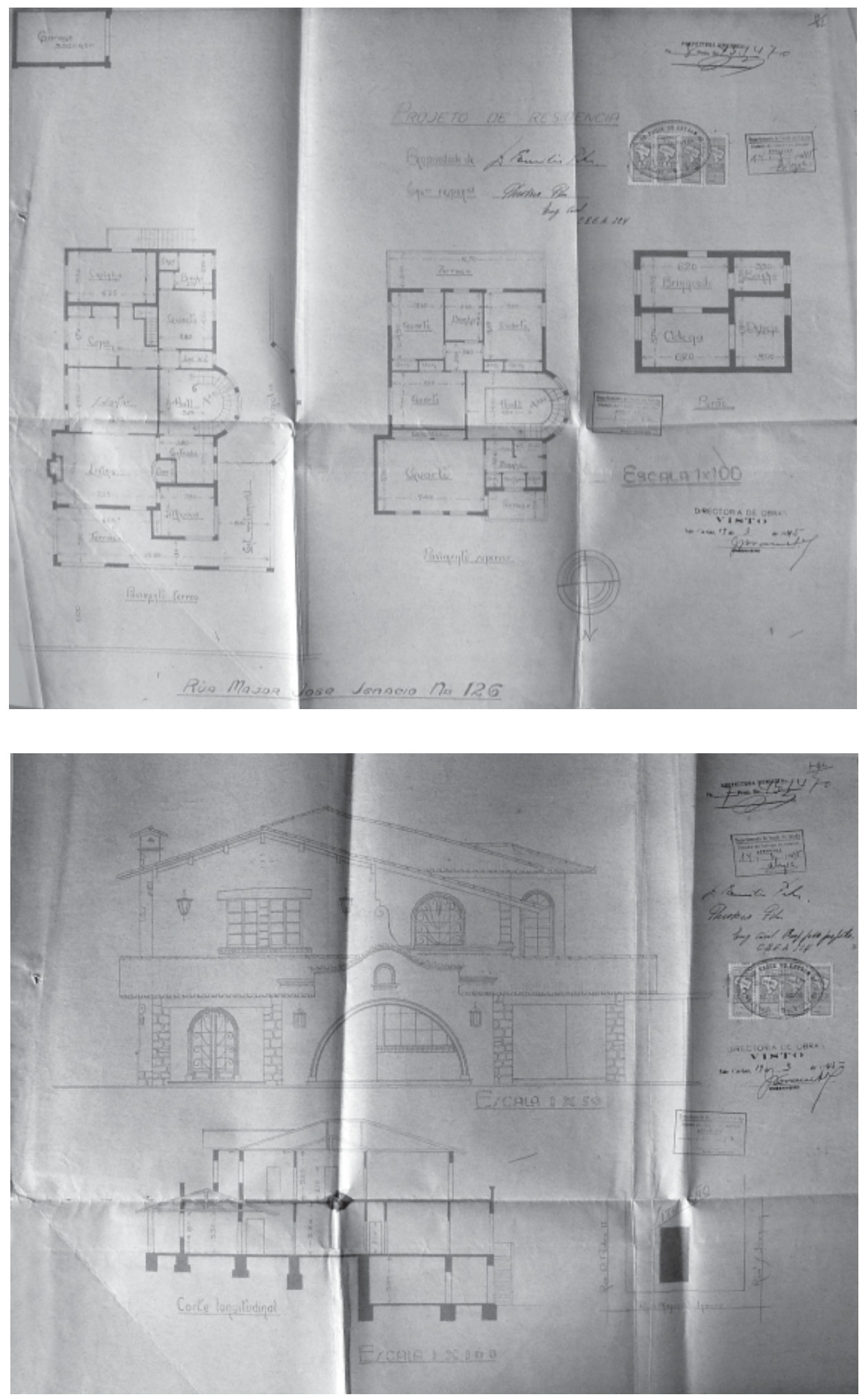

Figura 263 (acima e página seguinte) - Projeto do arquiteto Rodolpho Fehr para a residência de Emílio Fehr situada à Rua Major José Inácio, 126, em São Carlos. O projeto data de 1945 e é um dos exemplares neocoloniais mais expressivos encontrados na cidade, como se pode verificar pelas fotos. Fonte: Arquivo Municipal de São Carlos. 


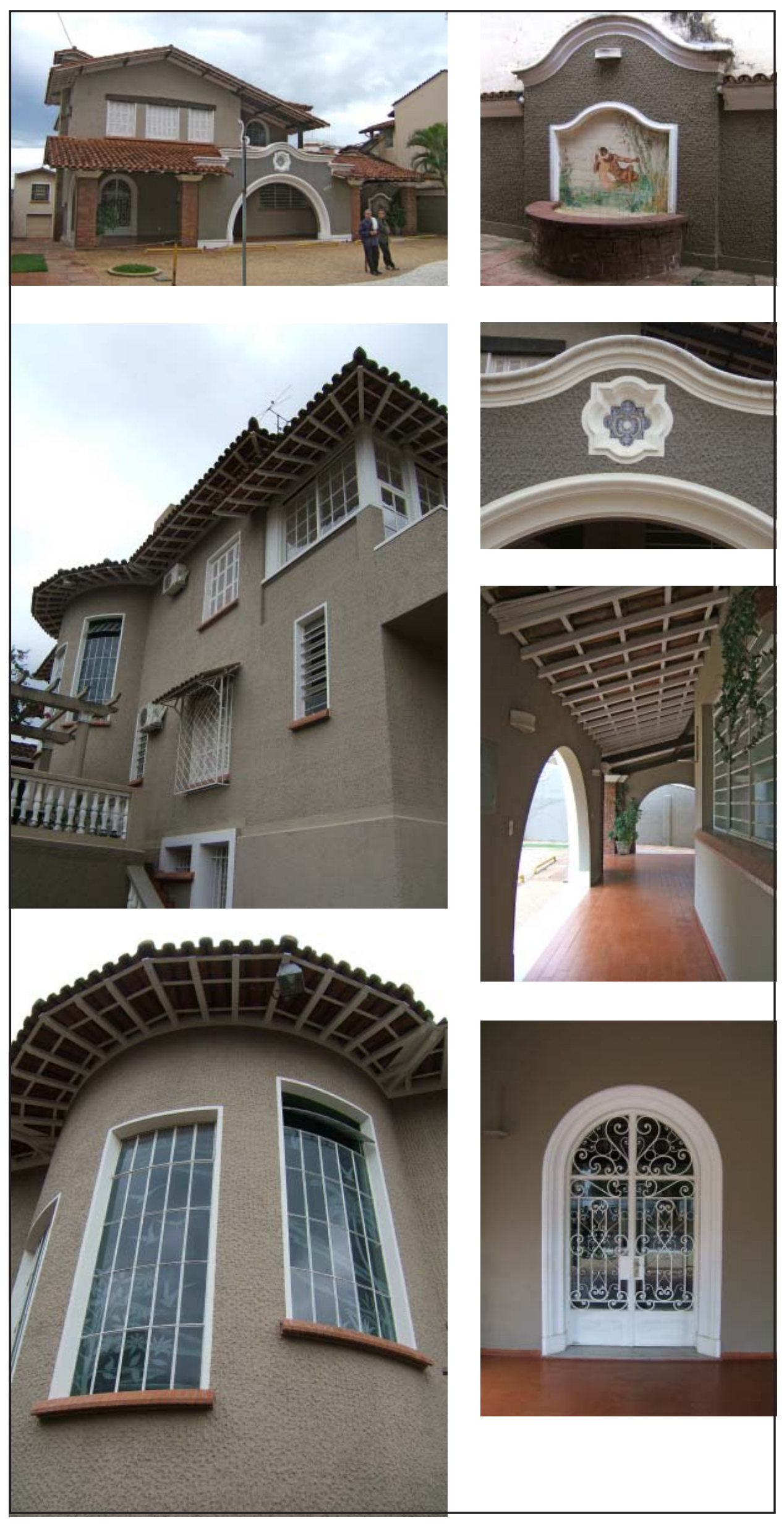




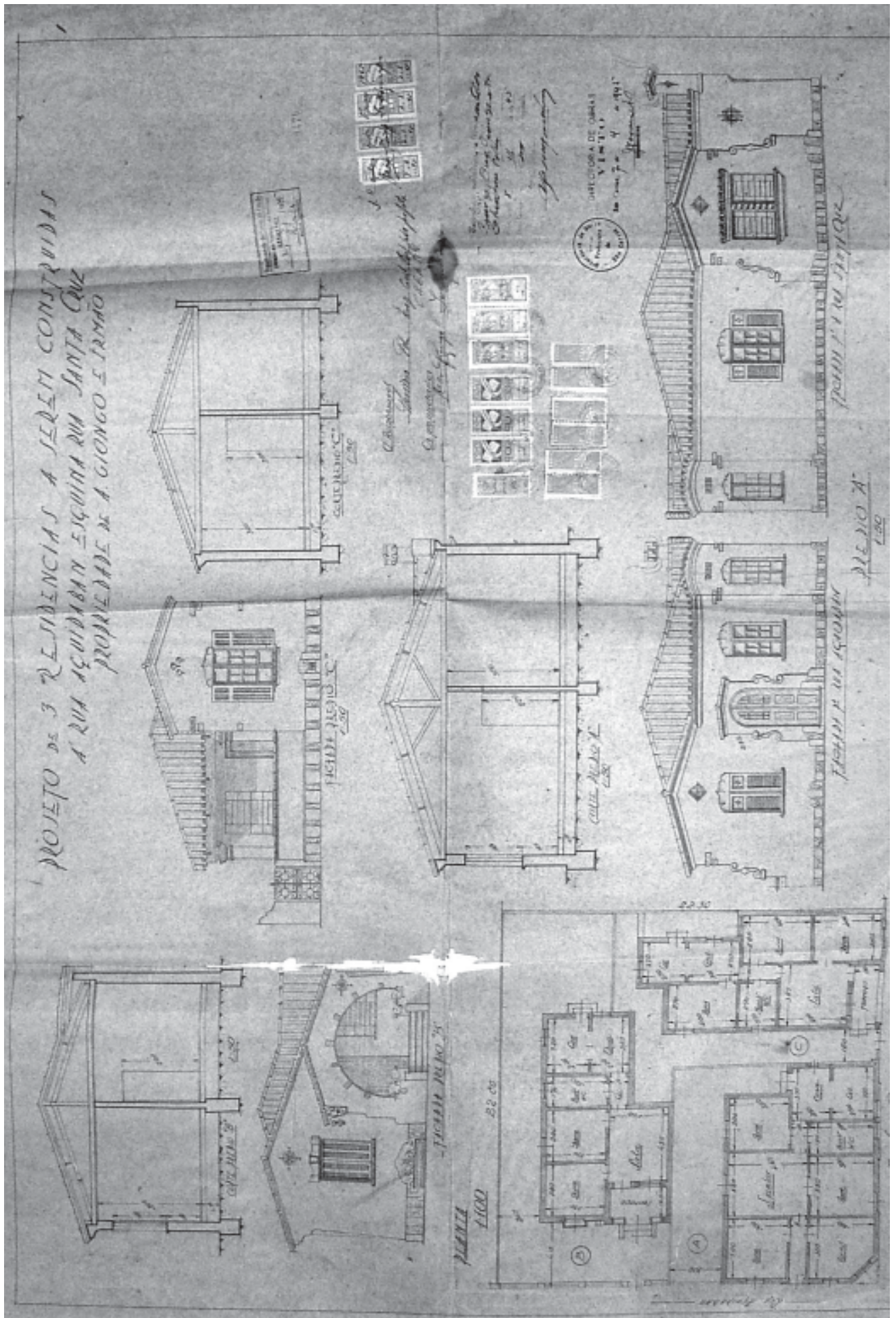

Figura 264 - Projeto para três residências situadas à Rua Aquidaban com Santa Cruz, em São Carlos. A autoria é do arquiteto Rodolpho Fehr para A. Giongo e Irmão, com vários estilemas neocoloniais, e data de 1945. Outro exemplo de casas destinadas à vendo ou aluguel, provavelmente. Fonte: Arquivo Municipal de São Carlos. 


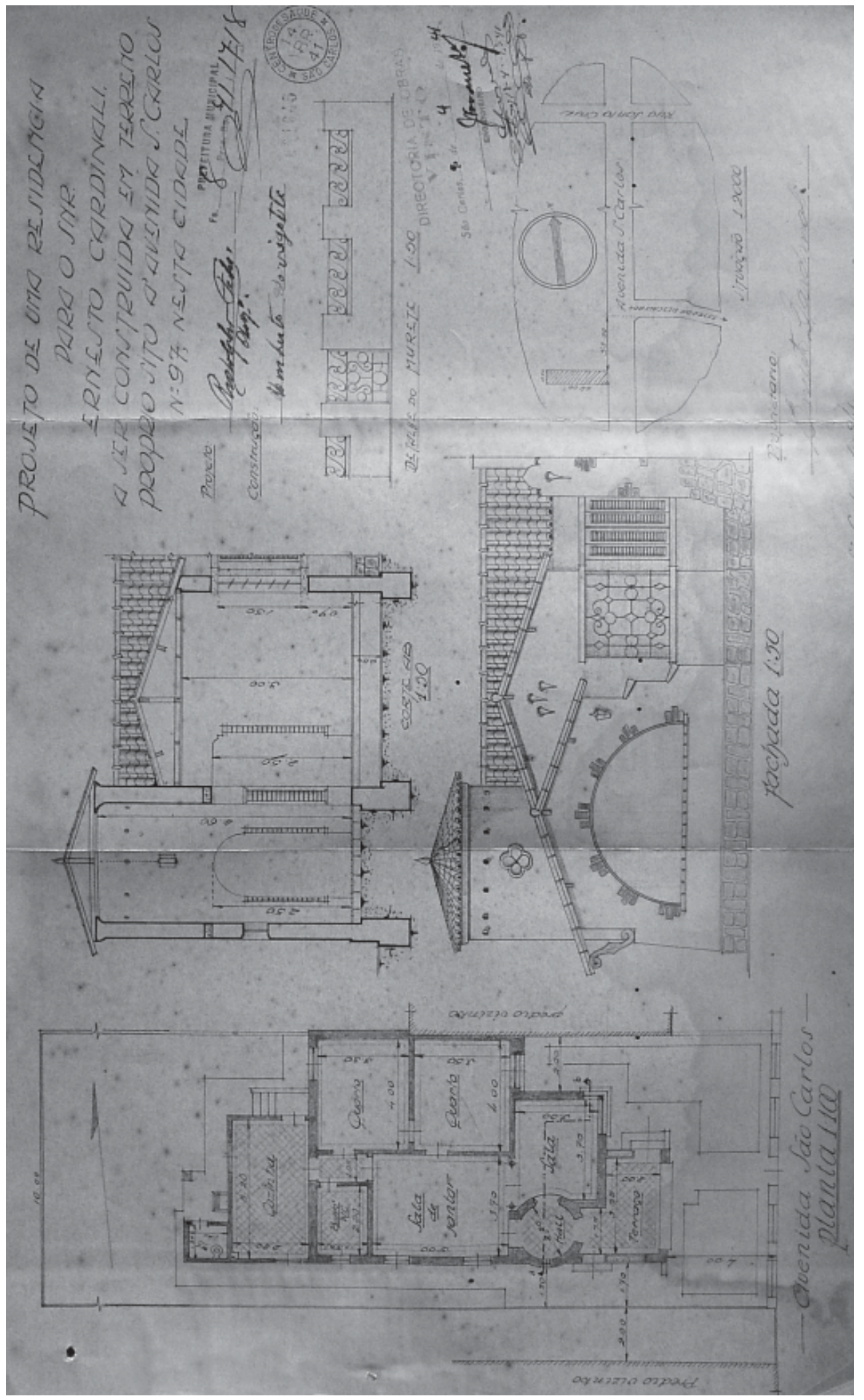

Figura 265 - Mais um projeto de Rodolpho Fehr, realizado em 1941. Residência situada à Av. São Carlos, 97, em São Carlos, de propriedade de Ernesto Cardinali. Nesse exemplar vê-se o torreão circular com telhado cônico. Fonte: Arquivo Municipal de São Carlos. 


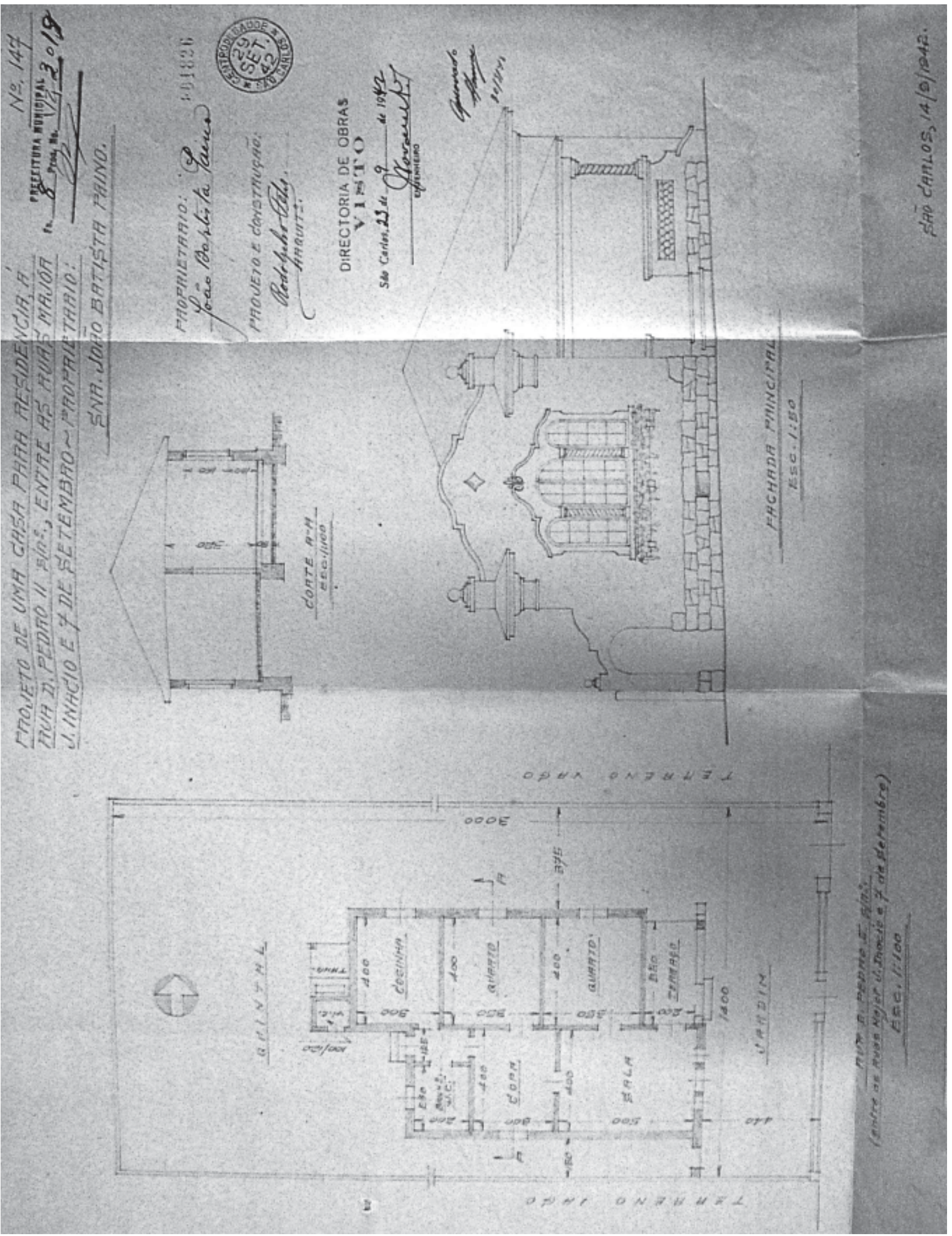

Figura 266 - Residência situada à Rua D. Pedro II, em São Carlos, projetada pelo arquiteto Rodolpho Fehr, em 1942, para João Batista Paino. Notar o exagero nas proporções de alguns detalhes decorativos da fachada. Fonte: Arquivo Municipal de São Carlos. 


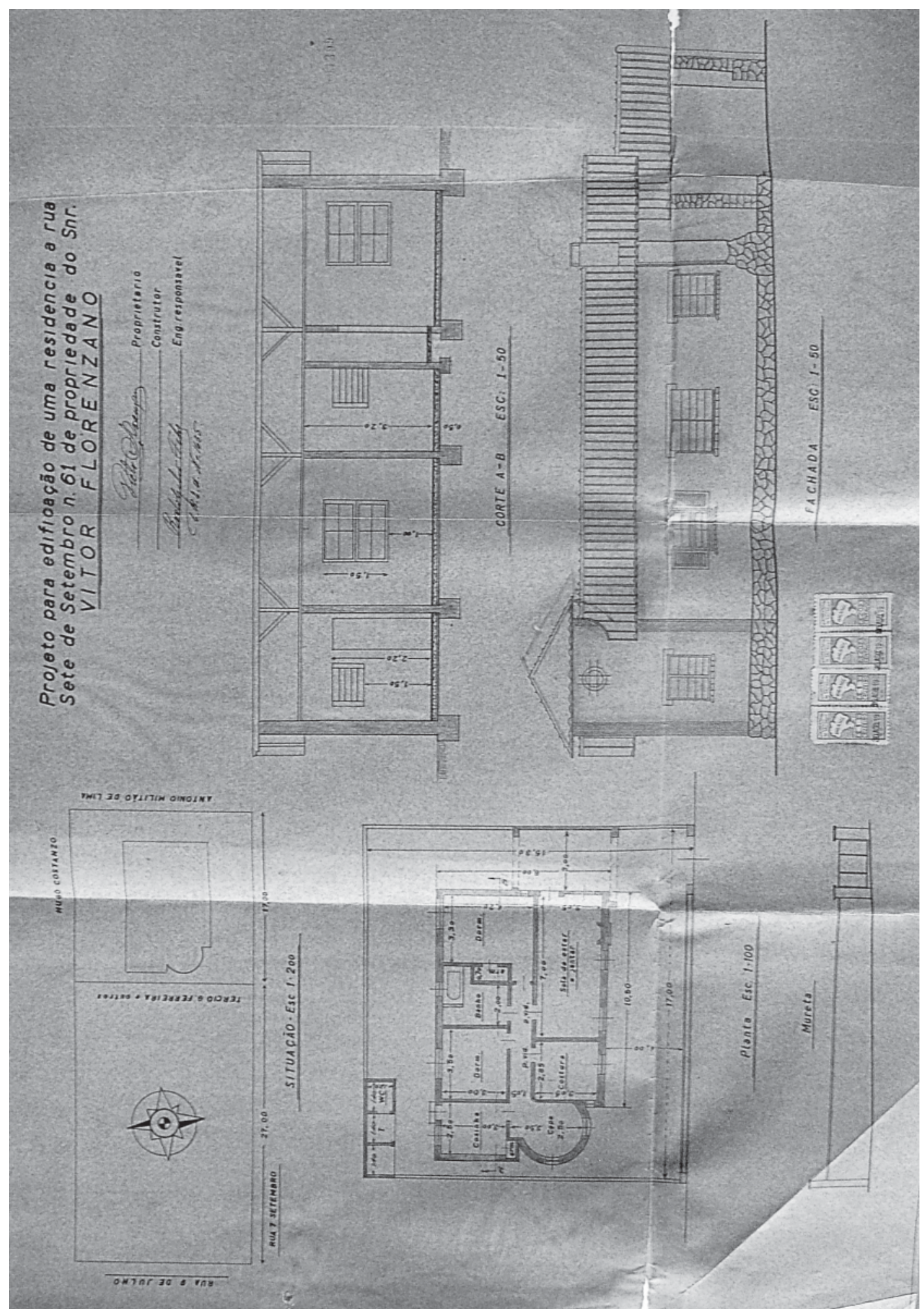

Figura 267 - Projeto do arquiteto Rodolpho Fehr para a residência de Vitor Florenzano, à Rua 7 de Setembro, 61, em São Carlos, datada de 1948. Este exemplar é marcado por um grande torreão circular situado no canto da construção. Fonte: Arquivo Municipal de São Carlos. 


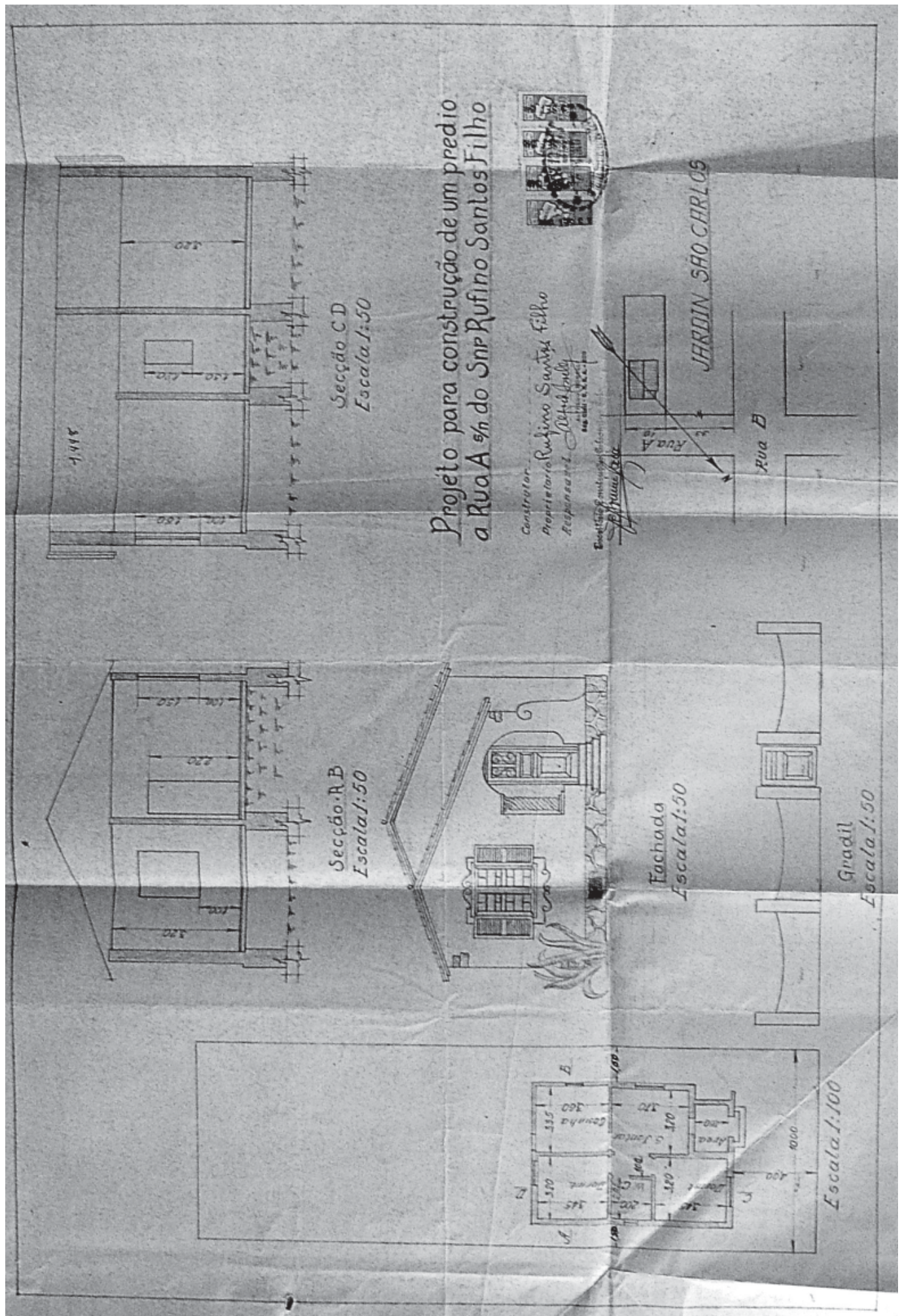

Figura 268 - Residência situada no Jardim São Carlos, rua A, de autoria do engenheiro Alfredo Borelli para Rufino Santos Filho, projetada em 1948. Fonte: Arquivo Municipal de São Carlos. 


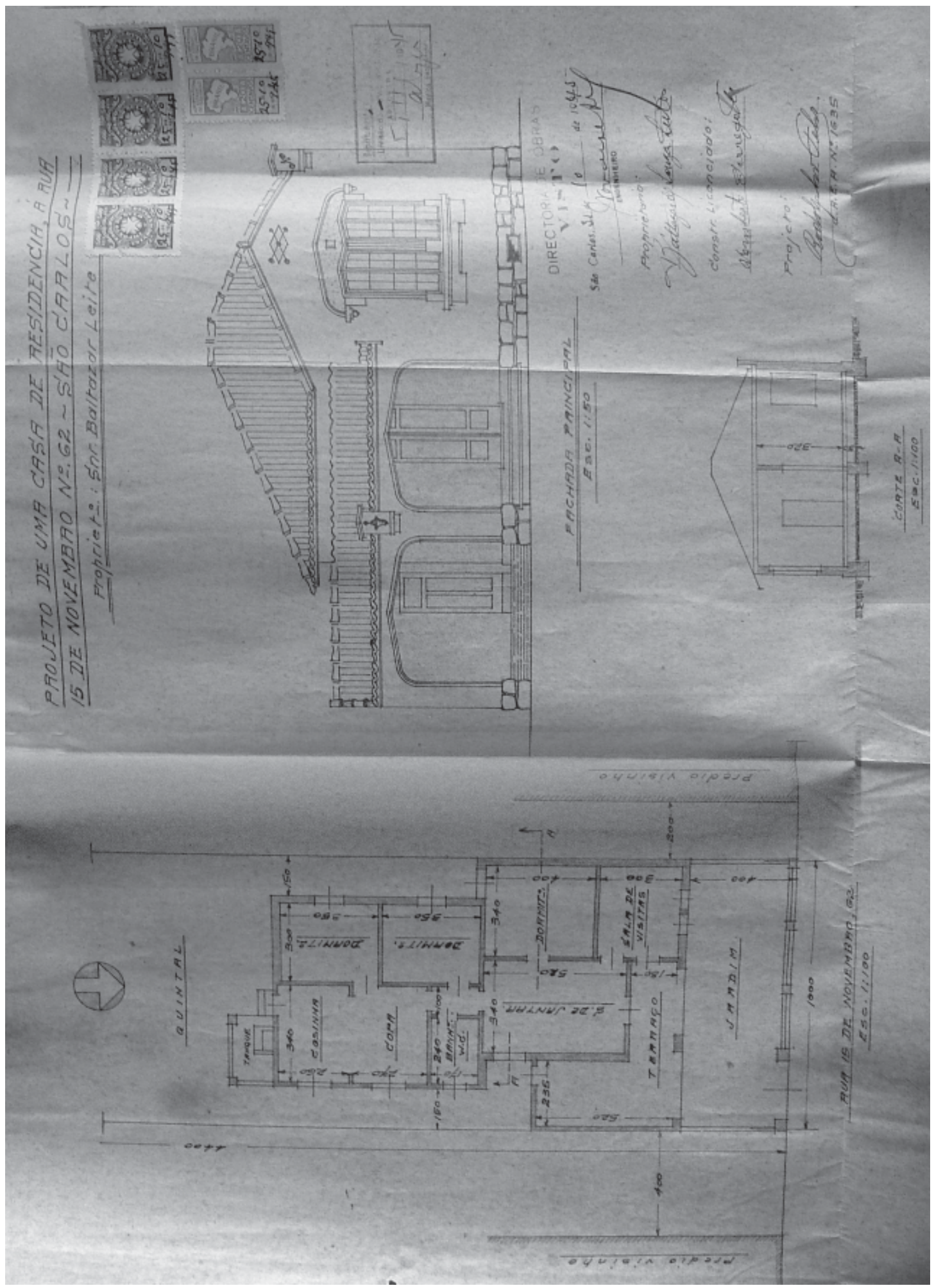

Figura 269 - Casa de Baltazar Leite, situada à Rua XV de Novembro, 62, projetada pelo arquiteto Rodolpho Fehr e edificada pelo construtor Umberto Sorregotti, em 1945. Fonte: Arquivo Municipal de São Carlos. 

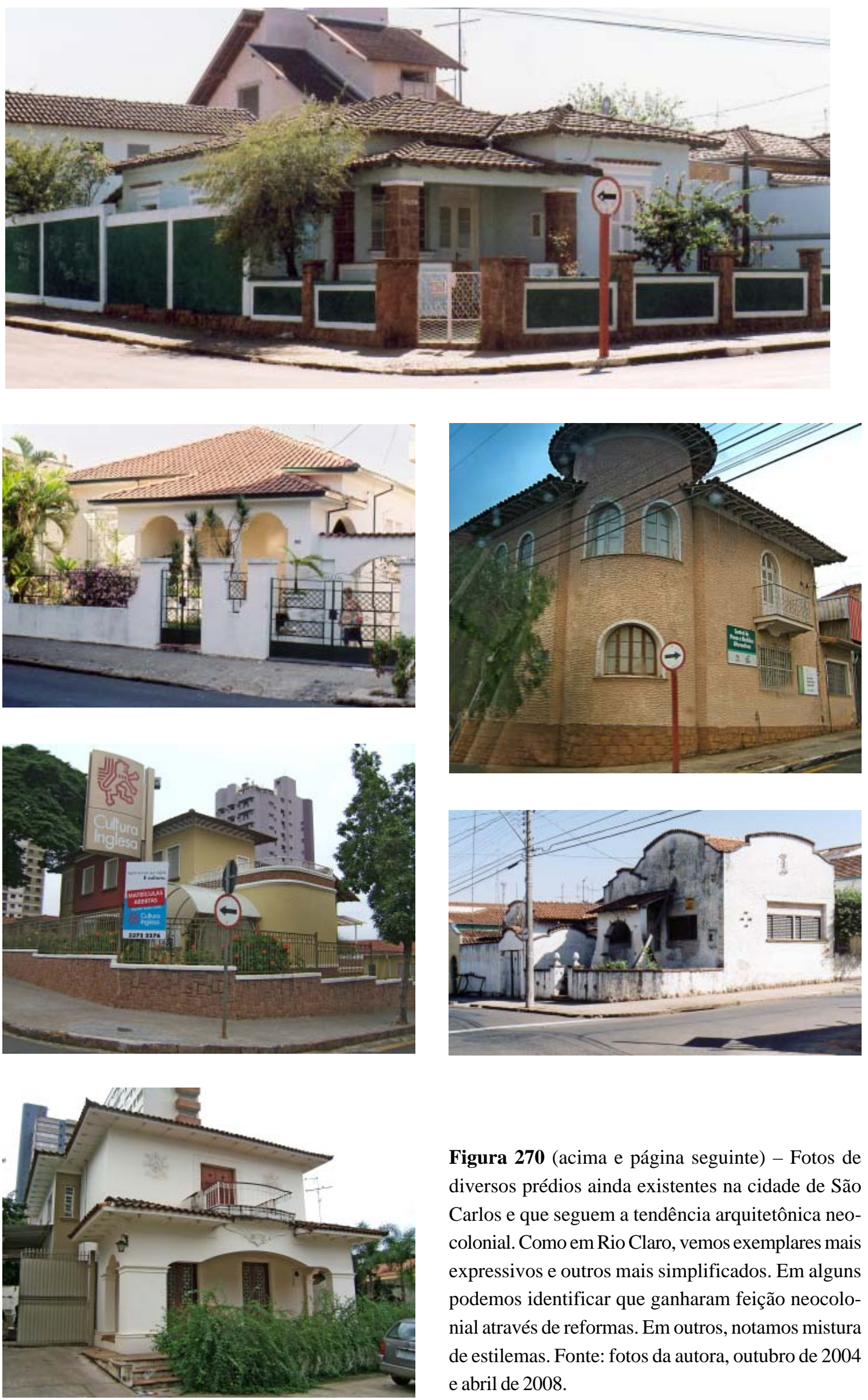

Figura 270 (acima e página seguinte) - Fotos de diversos prédios ainda existentes na cidade de São Carlos e que seguem a tendência arquitetônica neocolonial. Como em Rio Claro, vemos exemplares mais expressivos e outros mais simplificados. Em alguns podemos identificar que ganharam feição neocolonial através de reformas. Em outros, notamos mistura de estilemas. Fonte: fotos da autora, outubro de 2004 e abril de 2008. 

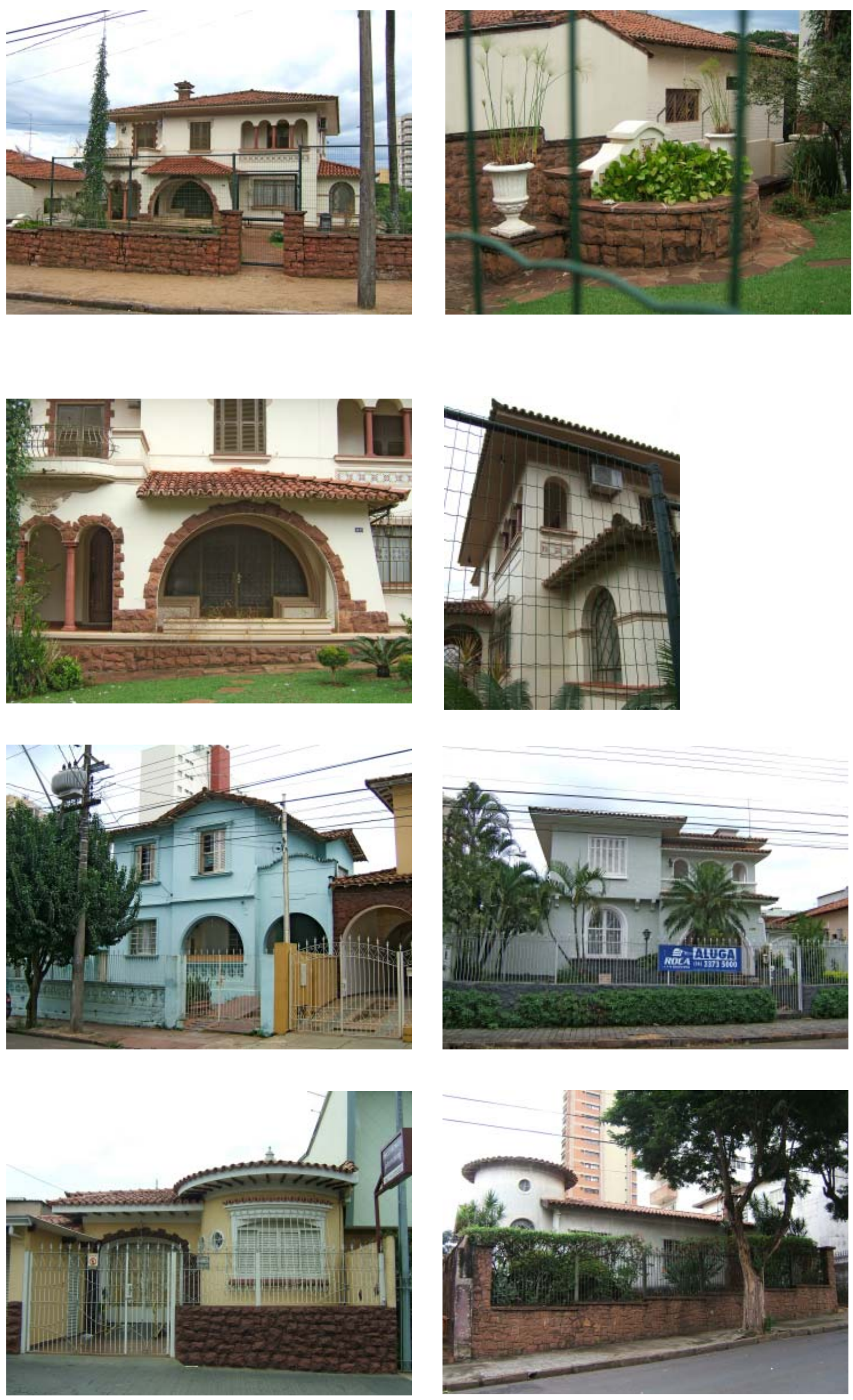

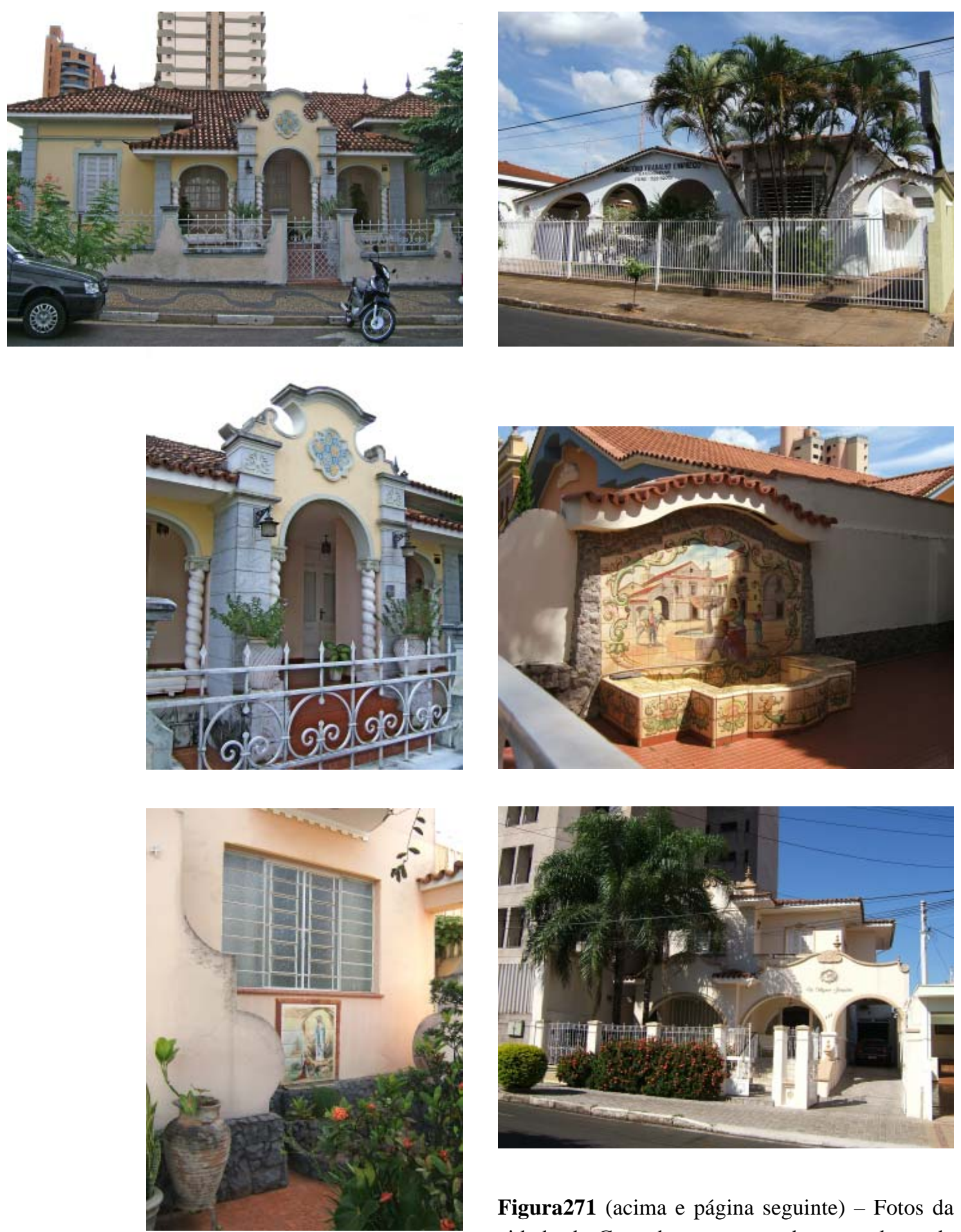

Figura271 (acima e página seguinte) - Fotos da cidade de Catanduva, mostrando exemplares de tendência neocolonial. Também nessa cidade podemos encontrar edificações que exibem as características mais comuns do neocolonial e do missões, como arcos, frontões, decorações com azulejos, beirais, telhados de telha capa e canal, revestimento de fachadas com pedras, etc. Vemos também alguns exemplares (não só nesta cidade) onde podemos identificar linhas que tendem à arquitetura modernista, evidenciando mais um tipo de hibridismo. Fonte: fotos da autora, abril de 2007. 

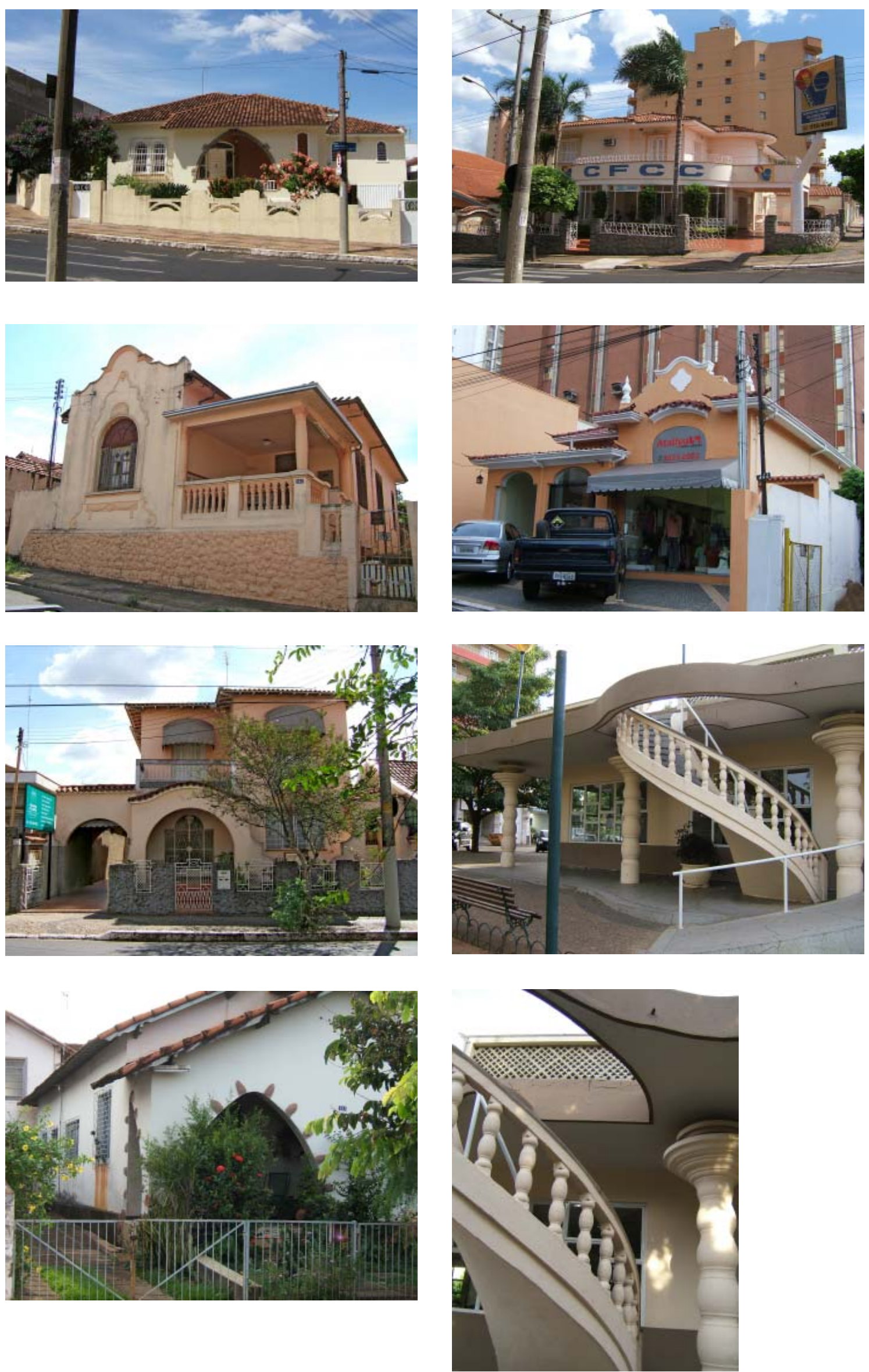

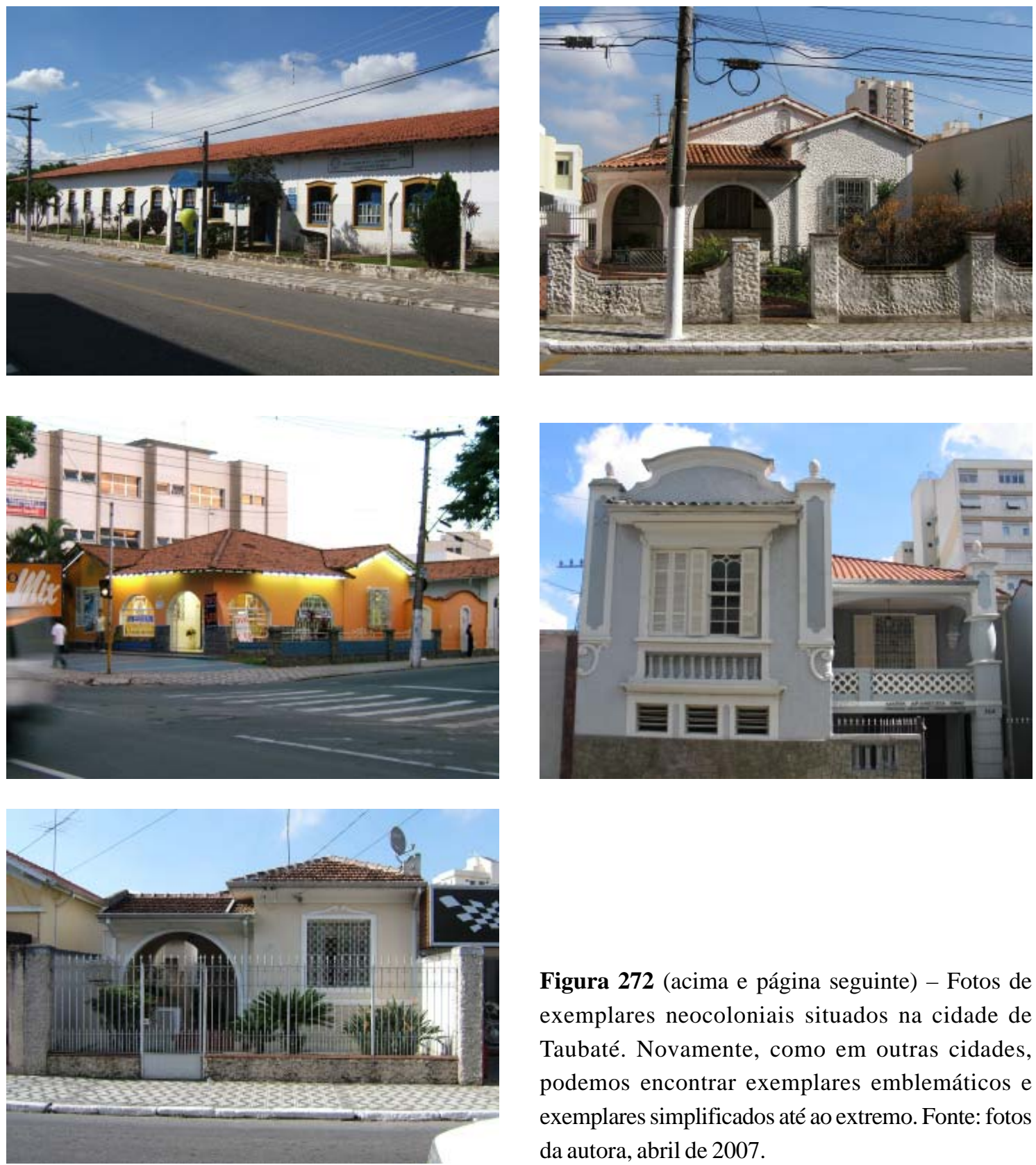

Figura 272 (acima e página seguinte) - Fotos de exemplares neocoloniais situados na cidade de Taubaté. Novamente, como em outras cidades, podemos encontrar exemplares emblemáticos e exemplares simplificados até ao extremo. Fonte: fotos da autora, abril de 2007. 

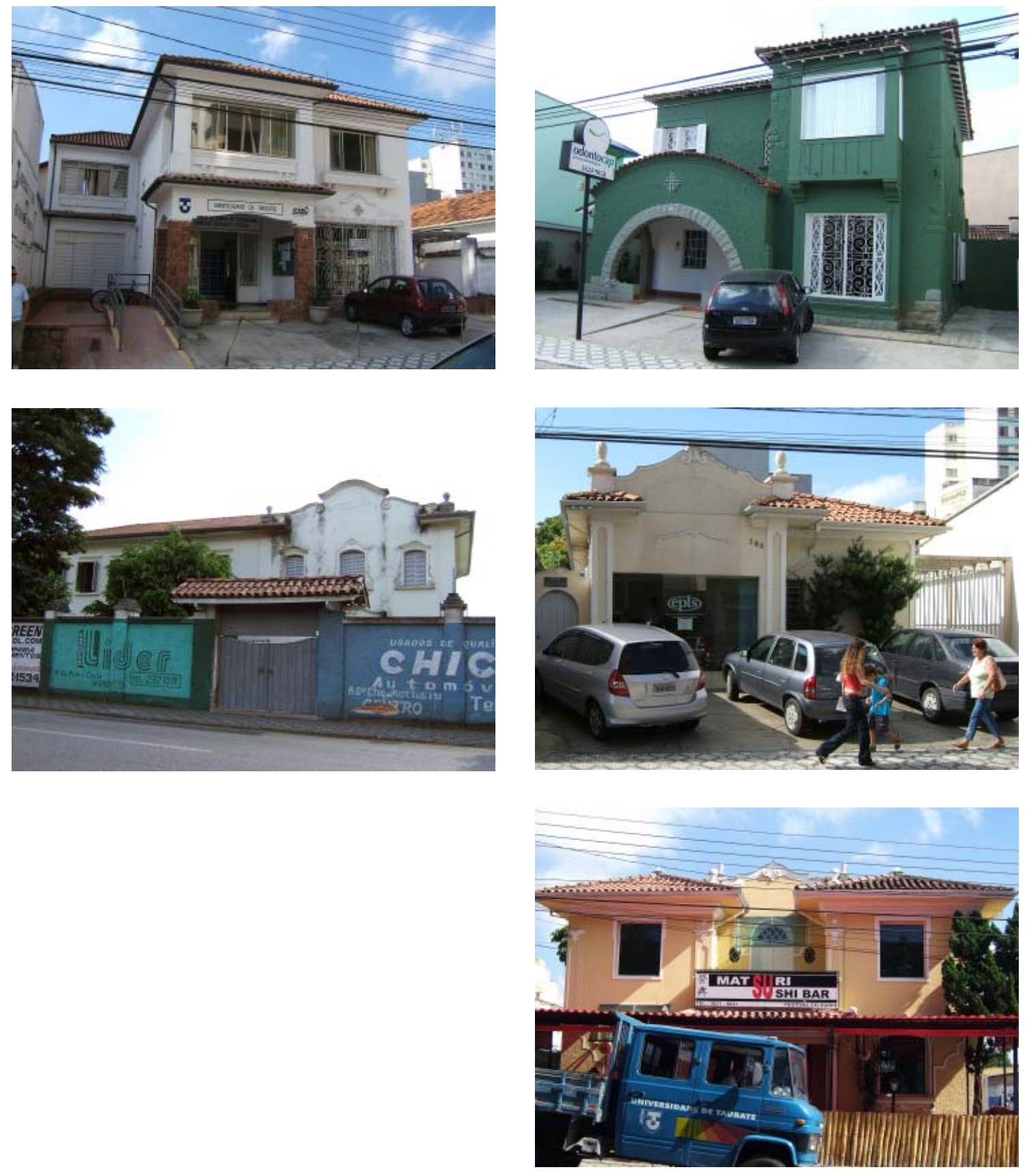

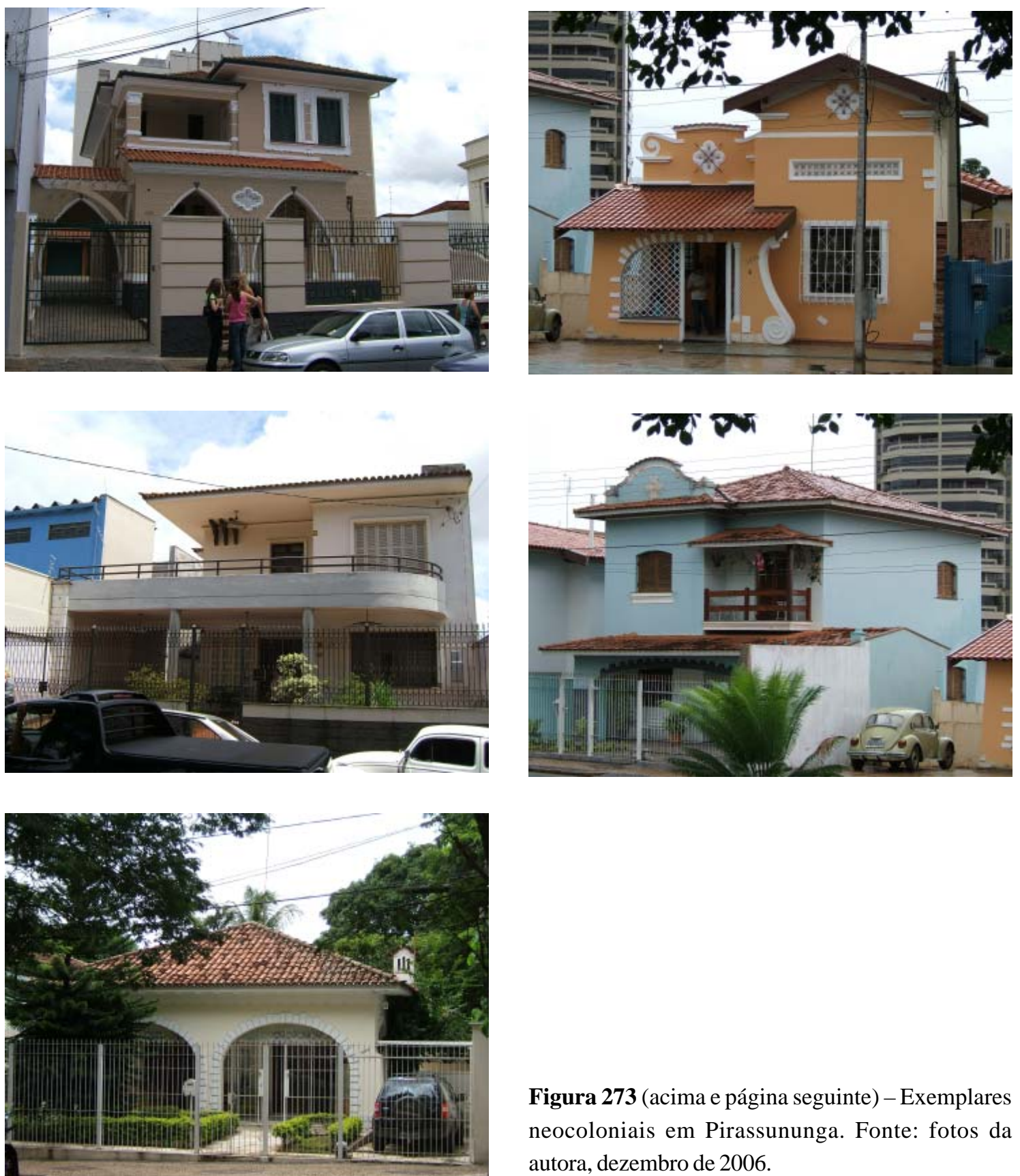

Figura 273 (acima e página seguinte) - Exemplares neocoloniais em Pirassununga. Fonte: fotos da autora, dezembro de 2006. 

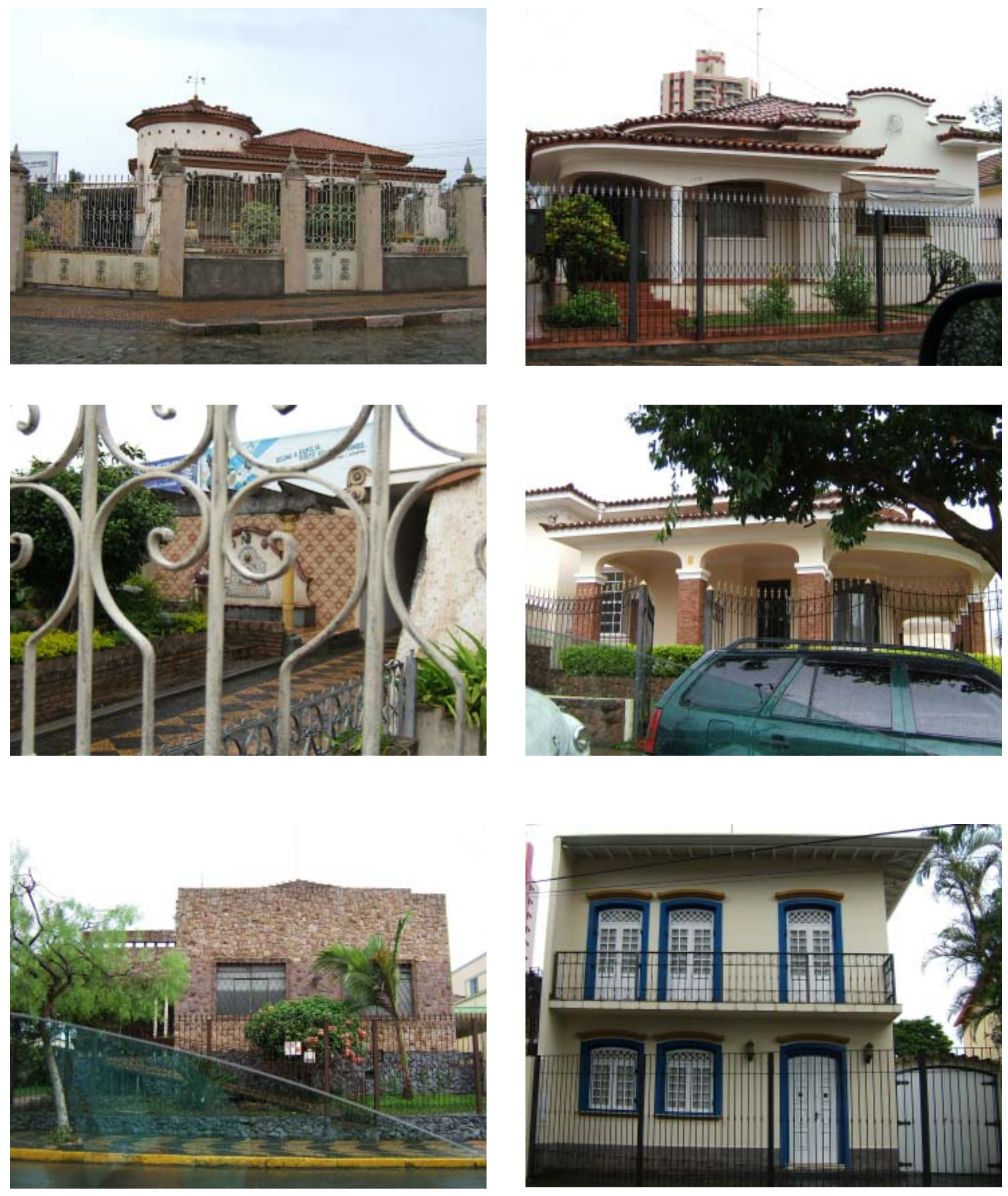

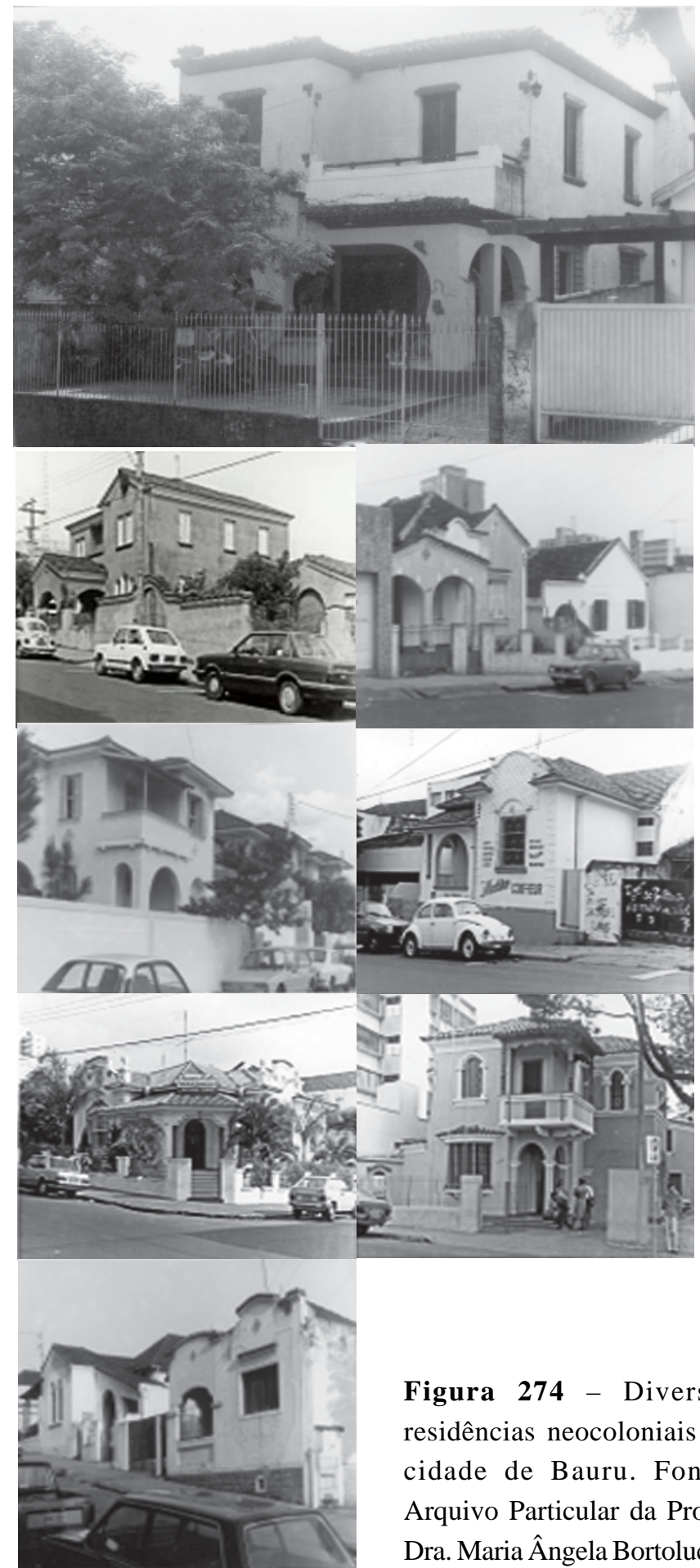

Figura 274 - Diversas

residências neocoloniais na cidade de Bauru. Fonte: Arquivo Particular da Profa. Dra. Maria Ângela Bortolucci. 

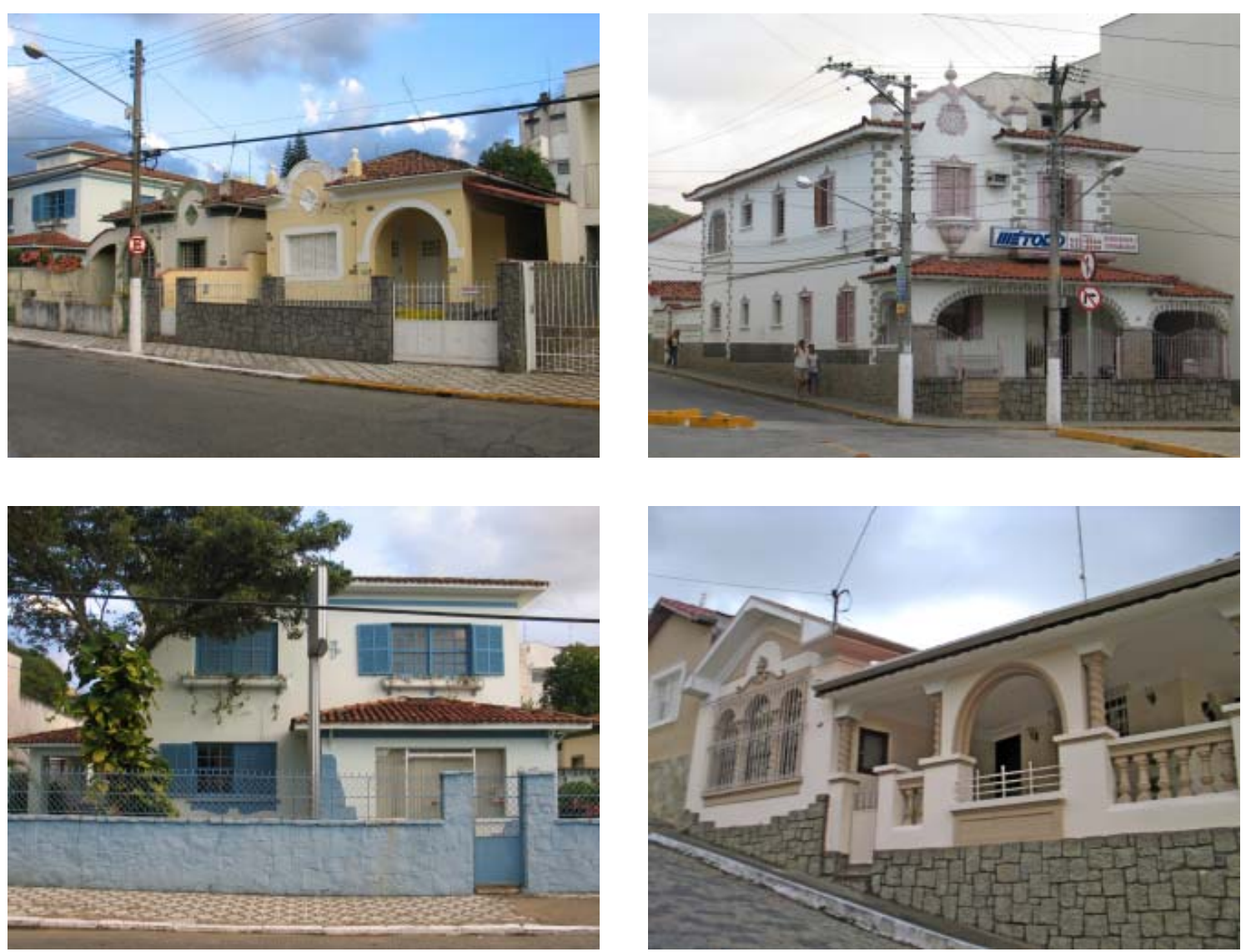

Figura 276 - Algumas edificações neocoloniais em Guaratinguetá. Fote: fotos V. Benincasa, abril de 2007.

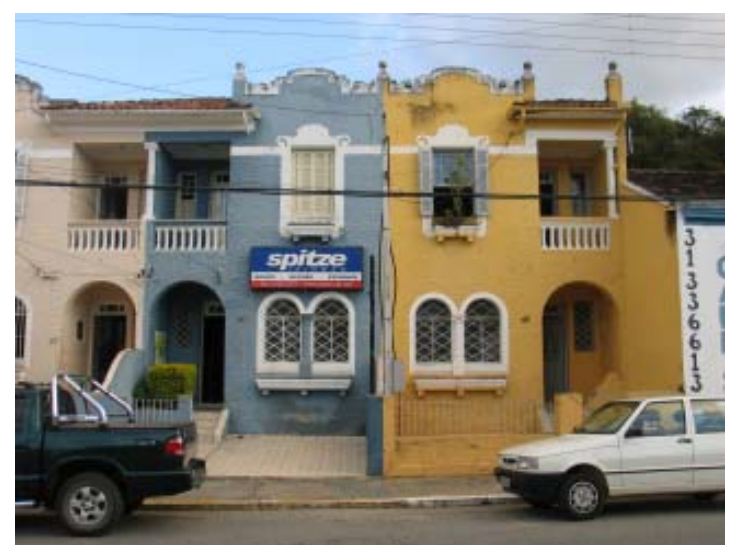



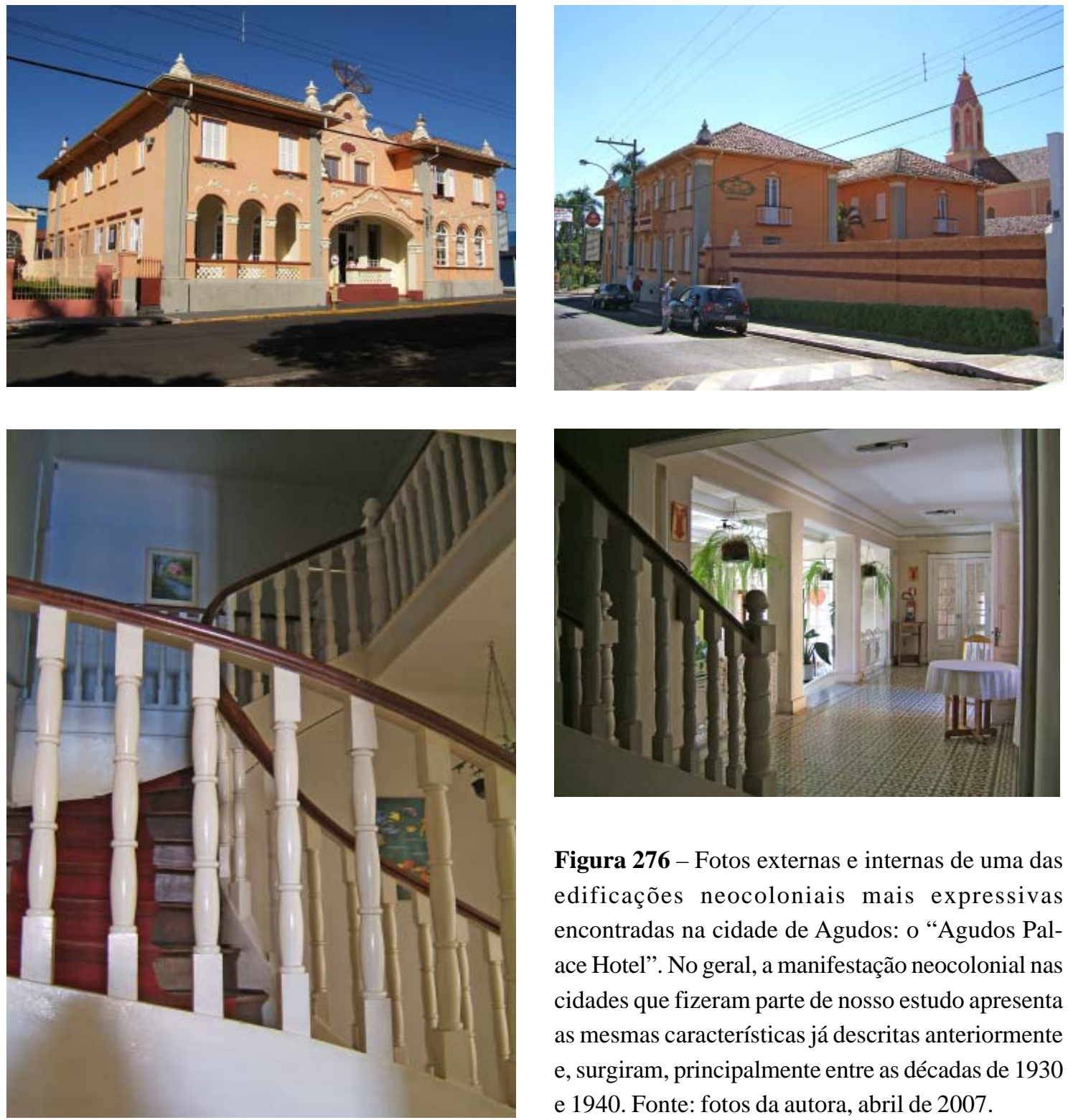

Figura 276 - Fotos externas e internas de uma das edificações neocoloniais mais expressivas encontradas na cidade de Agudos: o "Agudos Palace Hotel”. No geral, a manifestação neocolonial nas cidades que fizeram parte de nosso estudo apresenta as mesmas características já descritas anteriormente e, surgiram, principalmente entre as décadas de 1930 e 1940. Fonte: fotos da autora, abril de 2007. 